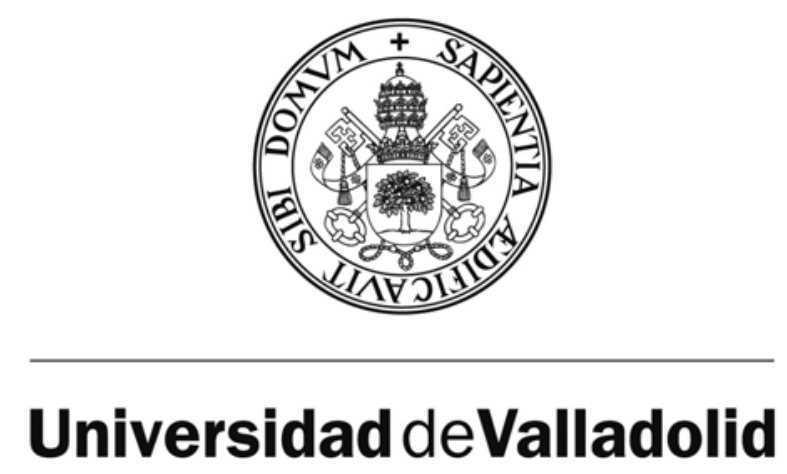

FACULTAD DE CIENCIAS ECONÓMICAS Y EMPRESARIALES

DEPARTAMENTO DE SOCIOLOGÍA Y TRABAJO SOCIAL

TESIS DOCTORAL:

\title{
¿DE LA MUERTE (DE)NEGADA A LA MUERTE REIVINDICADA? ANÁLISIS DE LA MUERTE EN LA SOCIEDAD ESPAÑOLA ACTUAL: MUERTE SUFRIDA, MUERTE VIVIDA Y DISCURSOS SOBRE LA MUERTE
}

Presentada por Ricardo Jiménez Aboitiz para optar al grado de Doctor por la Universidad de Valladolid

Dirigida por:

DR. D. RICARDO MONTORO ROMERO DRA. Da . ROSA GÓMEZ REDONDO 

“Mínima alma mía, tierna y flotante, huésped y compañera de mi cuerpo, descenderás a esos parajes pálidos, rígidos y desnudos, donde habrás de renunciar a los juegos de antaño. Todavía un instante miremos juntos las riberas familiares, los objetos que sin duda no volveremos a ver... Tratemos de entrar en la muerte con los ojos abiertos..."

Marguerite Yourcenar 



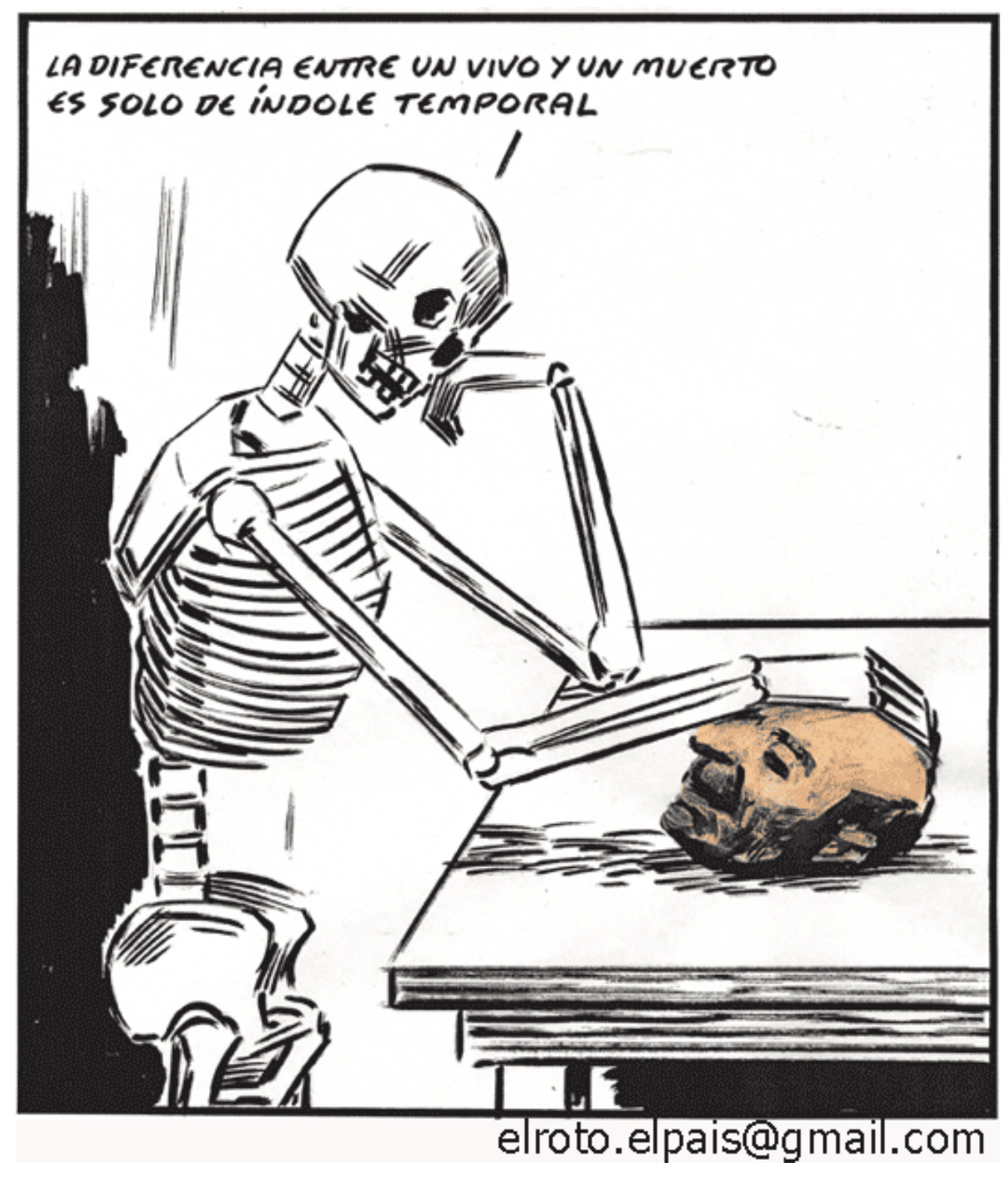





\section{ÍNDICE:}

\section{INTRODUCCIÓN}

Pág.

\section{CAPÍTULO 1.- DELIMITACIÓN PREVIA A UNA CARACTERIZACIÓN DE LA SOCIOLOGÍA DE LA MUERTE Y EL MORIR}

1.1. $<<$ ¿Qué es estar muerto?>>: La muerte, un concepto sin contenido.

1.2. $<<i$ Qué es estar muriendo?>>. Una presencia evidente e inevitable: la

Muerte. sociedad.

1.4. Muerte animal, muerte humana:

1.4.1. ¿Por qué sólo "mueren" los seres humanos?

1.4.2. Muerte sin sentido: Aproximación a la biología de la muerte

1.4.3. ¿Por qué se produce la muerte?:

1.4.3.1. Muerte del organismo y muerte celular.

58

1.4.3.2. Reproducción sexual y muerte.

59

1.4.3.3. Envejecimiento y muerte.

1.4.3.4. El envejecimiento y la muerte en la evolución de las especies por selección natural.

\section{CAPÍTULO 2.- <<SISTEMA DE MUERTE >>: EL CONTEXTO SOCIAL DEL MORIR}

2.1. Concepto de $<<$ Sistema de Muerte $>>$.

2.2. Cambio social y mutaciones en la experiencia de la muerte y el morir:

2.2.1. Modernización demográfica

2.2.2. Pacificación interna de esas sociedades: nacimiento del Estado moderno.

2.2.3. Burocratización.

2.2.4. Desarrollo del conocimiento científico-técnico.

2.2.5. Medicalización de la vida social.

2.2.6. Cambios en las preferencias valorativas.

101

2.2.7. Secularización.

104

107

2.2.8. Nuevos perfiles en el proceso de individualización. 114

2.3. Definición social de la muerte y el morir: 117

2.3.1. Dificultad de definir la muerte: Dificultades en la identificación 121 social de la muerte humana.

2.3.2. La muerte, ¿¿suceso o proceso?: morir- muerte-cadáver. 133

2.3.3. Tipología de definiciones médicas de muerte. Consecuencias. 137

2.3.4. Concepto de muerte en España.

CAPÍTULO 3: DELIMITACIÓN Y CARACTERIZACIÓN DEL(OS) DISCURSO(S) SOBRE LA MUERTE

3.1. Patrones generales sobre el morir y la muerte: 171

3.1.1. La Muerte Domada. 172

3.1.2. La Muerte Propia. $\quad 175$

3.1.3. La Muerte Lejana y Próxima 179

3.1.4. La Muerte del Otro. 181

3.1.5. La Muerte Invertida 185

3.2. Modelos de muerte en la sociedad occidental contemporánea: 194

3.2.1. Muerte Tradicional. 195

3.2.2. Muerte Moderna. 198 
3.2.3. Muerte Neo-moderna. 206

3.3. Discursos sobre la muerte en las sociedades contemporáneas. ¿Es la 217

muerte un tabú?:

3.3.1. Discursos sobre la muerte en las sociedades modernas. 218

3.3.2. Discursos sobre la muerte en las sociedades contemporáneas. 233

3.3.3. ¿Es la muerte un tabú en las sociedades contemporáneas?. 154

\section{CAPÍTULO 4.- CONTABILIDAD DE LA MUERTE: “LA MUERTE
SUFRIDA”}

4.1. Intensidad y calendario en la muerte: 271

4.1.1. Transición Demográfica (Transición de la Mortalidad). 272

4.1.1.1. Transición de la Mortalidad 278

4.1.2. Transición Epidemiológica 287

4.1.3. Transición Sanitaria $\quad 296$

4.2. La Muerte Sufrida en España. 310

4.2.1. Evolución histórica de la mortalidad en España. 312

4.2.2. Mortalidad diferencial: $\quad 320$

4.2.2.1. Mortalidad por causa de muerte en España. 321

4.2.2.2. Relación entre Mortalidad y Morbilidad. 328

4.2.2.3. Estructura etarea de la mortalidad. 334

4.2.2.4. Mortalidad, sexo, género. 346

4.3. Evolución futura de la mortalidad: 377

4.3.1. La transición sanitaria en el futuro: ¿contra-transiciones?. 378

4.3.2. La longevidad humana en el futuro. $\quad 390$

4.3.3. Añadir años a la vida versus añadir vida a los años. 415

CAPÍTULO 5.- LA “MUERTE VIVIDA” CUANDO ESTÁ LEJANA: 437

CREENCIAS, ACTITUDES, VALORES Y COMPORTAMIENTOS ANTE

LA MUERTE Y EL MORIR

5.1. metodología, técnicas, instrumentos y datos para el análisis de la 440

muerte vivida

5.2. Dimensiones axiológicas generales. 457

5.2.1. Transmisión de valores. $\quad 458$

5.2.2. Creencias religiosas. 463

5.3. Muerte y vida cotidiana: 473

5.3.1. Pensar en la muerte. $\quad 474$

5.3.2. Hablar de la muerte. $\quad 482$

5.3.3. Experiencia con la muerte. 487

5.3.4. Saber de la muerte. $\quad 489$

5.4. Planes de vida en relación a la muerte. 494

5.5. Rituales funerarios. $\quad 504$

5.6. Interacción con el ámbito hospitalario: 517

5.6.1. Medicalización de la vida y de la muerte: 519

5.6.1.1. Confianza en la ciencia: eliminación de la muerte; 520

5.6.1.3. Medicalización de la muerte. 528

5.6.1.4. Los hospitales como nidos de muerte. 532

5.6.2. Preferencias ante la propia muerte: <<canon>> de muerte. 540

5.7. Imágenes de la muerte.

5.8. Multidimensionalidad del miedo a la muerte.

5.9. La muerte como dimisión de la vida: 570

5.9.1. La muerte como deserción: Suicidio. 571

5.9.2. La muerte como descanso: Eutanasia. 580 
Índice

CONCLUSIONES

613

BIBLIOGRAFÍA 


\section{ÍNDICE DE CUADROS:}

2.1.: Evolución de los valores materialistas/postmaterialistas entre 1990-2000. España

2.2.: Creencias, opiniones, actitudes y comportamientos de la sociedad española. 2000.

2.3.: Indicadores para evaluar la calidad del proceso de donación. Autoevaluación. 1998-2009

2.4.: Causas de pérdidas durante el proceso de donación. Porcentaje sobre el total de Muertes Encefálicas (ME). 1998-2009.(Pérdidas desagregadas por motivos en 2009)

4.1.: Cambios históricos en el calendario demográfico del ciudadano europeo

4.2.: Evolución de los indicadores de mortalidad en Suecia y España

Pág.

106

114

164

165

283

287

4.3.: Evolución de la esperanza de vida de la población española a lo largo del siglo

XX. (años)

4.4.: Evolución de la mortalidad proporcional por grandes grupos de causas de muerte (\%o). España

4.5.: Principales causas de muerte en España. Tasa de mortalidad ajustada por edad por 100.000 hab. y porcentaje de cambio. España. 1981, 2000 y 2008.

4.6.: Evolución de la edad media de fallecimiento en los principales capítulos de causas de muerte (años). España

4.7.: Evolución de la morbilidad hospitalaria por diagnóstico, 1980-2008

4.8.: Evolución de la mortalidad y de la mortalidad hospitalaria total. España. 1980, 1989, 2000 y 2008

4.9.: Esperanza de vida (años). España

4.10.: Años de $\mathrm{e}(\mathrm{x})$ ganados a cada edad y su distribución por sub-periodos. Total. España, 1970-1998

4.11. Años de vida ganados en la e(0) por grupos de edad. Total. España, 1970-1998

4.12. Supervivientes en los distintos aniversarios. España

4.13.: Diferencias en la esperanza de vida al nacer entre mujeres y hombres (años). 2005-2010

4.14.: Evolución de la razón de sobremortalidad masculina $\left(\mathrm{r}_{\mathrm{x}}\right)$. España

315

323

326

328

331

334

339

340

342

344

351

361

4. 15: Contribuciones por edad a la desigualdad en la $\mathrm{e}(0)$ entre mujeres y hombres.

Años de vida y porcentaje

363

4.16.: Tasas específicas de mortalidad. Tasas estandarizadas de mortalidad. Razón de tasas. Diferencia de tasas. Para capítulos de causas de muerte (por 100.000 hab.). Por sexo. España. 2008.

4.17.: Indicadores de mortalidad en España. 1975, 1980, 1991, 2000 y 2009.

4.18.: Evolución de la población centenaria y de su distribución por sexo. España, 1991-2049

4.19.: Esperanza de vida (e(x)), esperanza de vida en buena salud percibida (EVBS), porcentaje de EVBS/e(x) y diferencias por sexo. España. 1987, 1997 y 2007.

4.20.: Esperanza de vida $(\mathrm{e}(\mathrm{x})$ ), esperanza de vida libre de discapacidad (EVLD), porcentaje de EVLD/e(x) y diferencias por sexo. España. 1986, 1999 y 2007.

4.21.: Esperanza de vida $(\mathrm{e}(\mathrm{x})$ ), esperanza de vida libre discapacidad (EVLD), esperanza de vida libre discapacidad severa (EVLD1), diferencia EVLD1 y EVLD, esperanza con incapacidad (EI) y esperanza con incapacidad severa (EIS) por sexo. España, 1999 y 2008

5.1.: Distribución por sexo y edad de la muestra. (\%)

5.2.: Distribución por edad/nivel de estudios y sexo/nivel de estudios de la muestra.

5.3.: Distribución por edad/religiosidad y sexo/religiosidad de la muestra. (\%)

5.4.: Preferencias valorativas (\%)

5.5.: Preferencias valorativas por edad y nivel de estudios (\%)

5.6.: Creencias religiosas (\%) 
5.8.: Frecuencia con que se piensa en la muerte (\%) 476

5.9.: Grado de preocupación actual por las siguientes situaciones... (\%) 479

5.10.: Principales preocupaciones

481

5.11.: ¿Cuándo se imagina usted que la gente piensa más sobre la muerte? (\%) 482

5.12.: Frecuencia con que se habla de la muerte (\%)

485

5.13.: ¿Cree usted que la gente debería hablar de la muerte? (\%)

486

5.14.: ¿Ha visto usted algún cadáver humano? ¿Ha rechazado usted la posibilidad de ver el cadáver de algún ser querido?, ¿por qué? (\%)

5.15.: Grado de acuerdo/desacuerdo con la idea: “Tener la seguridad de que moriré no afecta a mi conducta en la vida”. ¿Desearía conocer la fecha en que va a morir? (\%)

5.16.: ¿Qué haría si supiera que le quedan seis meses de vida? (\%)

5.17.: Elección entre calidad de vida y cantidad de vida (\%)

5.18.: ¿Cree usted que toda persona debería hacer como previsión a la muerte testamento, seguro de vida, disponer sobre el propio funeral, donar órganos, testamento vital? (\%)

5.19.: ¿ Tiene usted hecho testamento, seguro de vida? (\%)

5.20.: Preferencia por la inhumación o incineración (\%)

5.21.: Utilizaría criogenización y “cementerios virtuales”. (\%)

5.22.: Opiniones y comportamientos respecto a rituales funerarios (\%)

5.23.: Utilizaría "paquetes funerarios" (\%)

5.24.: Grado de acuerdo o desacuerdo respecto a si el ser humano será capaz de eliminar completamente la muerte a través de los avances científicos. ¿Cree usted en la inmortalidad del alma? (\%)

5.25.: Grado de acuerdo o desacuerdo con las siguientes ideas: Selección de enfermos para tratamientos; No dedicación de recursos a quienes realizan actividades de riesgo (\%).

5.26.: Grado de acuerdo o desacuerdo con las siguientes ideas: No dedicar recursos de investigación a mayores; Las personas enfermas deben desaparecer (\%).

5.27.: ¿Cree usted que la muerte ha perdido su carácter natural y es tratada médicamente como si fuese una enfermedad?. ¿Desea usted la medicalización de la muerte? (\%)

5.28.: En lo relativo a las muertes que se producen en los hospitales, grado de acuerdo o desacuerdo con las siguientes ideas: Los hospitales dan seguridad; Los hospitales provocan la alienación de los moribundos (\%)

5.29.: En lo relativo a las muertes que se producen en los hospitales, grado de acuerdo o desacuerdo con las siguientes ideas: Los hospitales deshumanizan; Los hospitales ocultan la muerte (\%)

5.30.: En caso de poder elegir ¿dónde le gustaría morir? ¿Con qué grado de conciencia preferiría morir? ¿Y de dolor? ¿Durante cuánto tiempo? (\%)

5.31.: Proporción de personas que están de acuerdo con las siguientes afirmaciones: Morir es sufrir; La muerte es como un largo sueño; La muerte siempre viene pronto (\%)

5.32.: Proporción de personas que están de acuerdo con las siguientes afirmaciones: el sentido de la vida es obtener lo mejor de ella; La muerte es el descanso natural; Hay situaciones peores que la muerte (\%)

5.33.: Proporción de personas que están de acuerdo con las siguientes afirmaciones: los niños deben de ser protegidos de ver la muerte; La muerte de los ancianos es menos trágica que la de los jóvenes; La muerte de una persona es una pérdida para... (\%)

5.34.: Grado de acuerdo/desacuerdo con la idea: "Me siento preparado para afrontar mi muerte" (\%)

5.35.: Principales preocupaciones 
5.37.: Anovas para edad

5.38.: Anovas para religiosidad

5.39.: Anovas para "Tener la seguridad de que moriré no afecta a mi conducta en la vida"

5.40.: Anovas para "Me siento preparado/a para afrontar mi muerte" 569

5.41.: Derecho a quitarse la vida (\%) 577

5.42.: Cree que hay más suicidios... (\% 580

5.43.: Sinceridad en la transmisión de malas noticias por el personal médico en una enfermedad grave (\%)

594

5.44.: Quién debe tomar las decisiones sobre los cuidados médicos en el final de la vida de una persona enferma (\%)

5.45.: Conformidad o no con que... (\%)

5.46.: Conformidad con que los médicos administren algún producto para poner fin a la vida de un enfermo incurable... (\%)

5.47.: Conformidad o no con que se castigue a los médicos que administren algún producto para poner fin a la vida de un enfermo incurable, si éste se lo pide (\%)

5.48.: Si un familiar con una enfermedad incurable le manifestase su deseo de morir... (\%)

\section{ÍNDICE DE GRÁFICOS:}

1.1.: Dialéctica inadaptación/adaptación a la muerte

Pág. 39

2.1.: Estructura del proceso de donación en muerte encefálica. UC (Unidad de Críticos)

4.1.: Distribución porcentual de muertes por causa en modelos de población seleccionados

4.2.: Evolución de las T.B.M. en España (\%)

4.3.: Esperanza de vida al nacer. España

4.4.: Probabilidad de muerte $\left({ }_{n} q_{x}\right)$. España

4.5.: Mortalidad proporcional por grupos de edad (\%). 1930 y 2000. España

4.6.: Supervivientes por sexo. España 2000 y 2009

4.7.: Sobremortalidad masculina por causas concretas. España. 2008

4.8.: Sobremortalidad masculina por edad y causas de muerte seleccionadas. España. 2008

4.9.: Supervivientes en los distintos aniversarios. España. 1800-2009

4.10.: Distribuciones de las defunciones producidas entre cada dos edades exactas. España. 1985-86, 1990-91, 2000-01 y 2008-09

4.11. EVBS y expectativa de mala salud al nacimiento por sexo. España, 1987, 1997 y 2007

4.12.: EVBS y expectativa de mala salud a los 65 años por sexo. España, 1987, 1997 y 2007

4.13.: EVLD y expectativa de incapacidad al nacimiento por sexo. España, 1986, 1999 y 2007

4.14.: EVLD y expectativa de incapacidad a los 65 años por sexo. España, 1986, 1999 y 2007

9

80

94

99




\section{ÍNDICE DE TABLAS:}

2.1. Definiciones médicas alternativas de muerte

Pág.

143

3.1. Modelos de muerte de Phillippe Ariès 192

3.2. modelos de muerte de Tony Walter 216

5.1. Áreas temáticas objeto de la investigación $\quad 451$

5.2. Conceptos relacionados con la eutanasia 582

5.3. Posiciones ideológicas básicas respecto a la legalización de la eutanasia activa $\quad 610$

\section{ÍNDICE DE ESQUEMAS:}

4.1.: Determinantes de la salud (modelo de Frenk)

304

4.2.: Niveles y determinantes en el análisis de la salud 

INTRODUCCIÓN 



\title{
INTRODUCCIÓN
}

\author{
"Para todos tiene la muerte una mirada. \\ Vendrá la muerte y tendrá tus ojos. \\ Será como dejar un vicio, \\ como ver en el espejo \\ asomar un rostro muerto, \\ como escuchar un labio ya cerrado. \\ Mudos, descenderemos al abismo”
}

C. Pavese

En su reflexión sobre el papel del <<científico>>, recogida en La ciencia como vocación, M. Weber (1998) afirma que la ciencia se ha insertado como fuerza propulsora del proceso, "prolongado durante milenios en la cultura occidental", por el que se ha excluido lo mágico del mundo (desmagificación). Con ella ya no sería necesario recurrir a medios mágicos para controlar a los espíritus, como creían los pueblos primitivos, porque la ciencia niega la existencia de tales espíritus con poderes ocultos e imprevisibles y, sobre todo, porque se asienta en la creencia de que en el momento que se desee saber "todo puede ser dominado mediante el cálculo y la previsión" Weber (1998:201-203). De esta forma, aunque la población general de las sociedades occidentales no sepa explicar fenómenos antaño calificados de mágicos o de milagrosos, sí que sabe, o tiene la posibilidad de saber, que los mismos tienen una explicación racional. Como "hombre de ciencia” que era, Weber se manifiesta claramente partidario de demostrar que la misma tiene un sentido y que merece la pena dedicarse a ella; sin embargo, en su reivindicación de la ciencia se observa cierta decepción por las contrapartidas que conlleva; de un lado, porque su desarrollo implica el desencantamiento del mundo ${ }^{1}$; de otro, porque por su esencia ese proceso de “intelectualización y racionalización crecientes” es ilimitado e inacabable ${ }^{2}$.

En efecto, al analizar el problema del sentido de la ciencia, más allá de lo puramente práctico y técnico, Weber se apoya en la obra de Tolstói, con quien comparte esa decepción, y expone como ejemplo la preocupación de éste centrada en los cambios históricos acaecidos en la percepción de la muerte y en el sentido de la misma. La producción de conocimientos mediante la ciencia habría trasformado sustancialmente el planteamiento vital de los individuos, o al menos el de los individuos cultos. Así, mientras que el campesino de las sociedades tradicionales, insertado en el círculo orgánico de la vida, “moría <<viejo y saciado de vivir>>”, porque entendía que así era la lógica natural de su vida y "porque no quedaba ante él ningún enigma que quisiera descifrar y podía así sentirse $<<$ satisfecho >>,... el hombre civilizado, inmerso en un mundo que constantemente se enriquece con

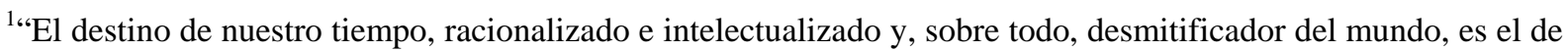
que precisamente los valores últimos y más sublimes han desaparecido de la vida pública y se han retirado, o bien al reino ultraterreno de la vida mística, o bien a la fraternidad de las relaciones inmediatas de los individuos entre sí” (Weber, 1998:231).

2 “¿Por qué preocuparse de algo que, en realidad, no tiene ni puede tener nunca fin?” (Weber, 1998:199).
} 
nuevos saberes, ideas y problemas, puede sentirse <<cansado de vivir $>>$ pero no <<saciado >>”. Como la muerte le impediría colmar una vida individual instalada en el <<progreso >>, continuo y siempre provisional, y en las ansias infinitas de conocimiento, al "hombre civilizado" le resulta un hecho absurdo. De ahí que, según Weber, Tolstói concluyera que "como la muerte carece de sentido, no lo tiene tampoco la cultura en cuanto tal, que es justamente la que con su insensata <<progresividad>> priva de sentido a la muerte" (Weber, 1998:202). Si bien Weber no apoya abiertamente esa conclusión, su defensa de la ciencia en este punto tiene, siguiendo a Aron (1998:20), un "tono patético" por cuanto en la misma se percibe "el eco amortiguado de una nostalgia” por la fe perdida y, conexo a ella, la desilusión por que la ciencia, cuyo sentido es precisamente mostrar que el mundo carece de sentido en sí mismo y no obedece a ningún plan divino ${ }^{3}$, no aporta una cosmovisión del universo y del ser humano como por ejemplo hace la religión: "no tiene respuesta para la únicas cuestiones que nos importan, las de qué debemos hacer y cómo debemos vivir” (Weber, 1998:208209).

Ciertamente, el avance del conocimiento científico ha modificado un escenario social en el que la religión ofrecía una cosmovisión universal y del individuo absoluta, unitaria e integradora de aspectos no racionales, lo que aportaba a los individuos respuestas cerradas a esas cuestiones existenciales "que nos importan”. Motivo principal por el que, en las sociedades tradicionales, la religión jugaba (juega) un papel esencial en la ubicación de los mismos en el mundo, en su actitud ante la vida, y en su enfrentamiento a la muerte. Sin embargo, no han sido sólo las innovaciones científicotécnicas las que han causado el proceso de secularización que ha derivado en una disminución de la relevancia social de la religión en esas sociedades. En efecto, la secularización es un proceso que Berger (1999) vincula al inicio de la individualización con el protestantismo en el siglo XVI, que se potenció a partir de la Ilustración, y que ha estado fuertemente correlacionado con el proceso global de modernización que han vivido las sociedades occidentales en los dos últimos siglos. En el mismo, además de los avances científicos, que con su dinámica regida por "propias normas de autocrítica rigurosa y escepticismo organizado” ha socavado efectivamente las bases dogmáticas de la religión, hay que considerar además la incidencia de otros procesos simultáneos como han sido la racionalización del mundo y de la vida, que con su "énfasis en la lógica puramente instrumental y pragmática, ha desafiado la orientación religiosa de la conducta y fomenta un ethos laico”, y el desarrollo del capitalismo industrial, que en la medida en que ha fomentado el individualismo imperante ha socavado las formas comunitarias de convivencia (Requena, 2008:321-322).

En el caso de la muerte, la contradicción existencial que comporta para los individuos el que, por un lado, sean conscientes de que les llegará y, por otro lado, sean incapaces de tener un

\footnotetext{
3 “Si tales conocimientos (científicos) tienen algún efecto es más bien el de secar de raíz la fe en que existe algo que pueda ser llamado <<sentido>> del mundo” (Weber, 1998:207).
} 
conocimiento cierto sobre lo que es la muerte y lo que les significará, constituye una poderosa y constante amenaza para su seguridad ontológica ${ }^{4}$. Por ello, el carácter disruptor de la muerte y el temor irracional que inspira han sido históricamente mitigados por el papel mediador de la sociedad entre los individuos y su muerte inevitable. Así, e independientemente de que la muerte en sí misma tenga sentido o no, es la sociedad a través del <<sistema de muerte $>>$ la que la da un sentido determinado, un envoltorio social en el que socializa a sus individuos. En el caso de las sociedades tradicionales, la religión ha sido uno de los instrumentos sociales básicos para alcanzar ese objetivo tranquilizador e integrador, una especie de paraguas protector que, sin embargo, se ha debilitado notablemente en las sociedades modernas, aunque sigue `protegiendo' a una parte de la población de éstas. Es obvio que la nueva forma de conocer el mundo a través de la ciencia no puede entrar en el territorio de lo no racional, por lo que en estas sociedades los individuos se enfrentan a la muerte con un paraguas científico que no les cubre desde todos los lados. Además, la disolución señalada de los lazos comunitarios conlleva la consiguiente percepción de que cada uno tiene que adquirir, tener y utilizar su propio paraguas, es decir, de soledad frente a ella. Si para Berger (1999) "toda sociedad es, en última instancia, hombres reunidos frente a la muerte", para Mellor y Shilling (1993:42) "la sociedad moderna es, en último caso, gente sola frente a la muerte”. De esta forma, la mayor vulnerabilidad existencial de la población frente a la muerte en las sociedades avanzadas determina que, a diferencia de la actitud de "aceptación de acercamiento" a la misma dominante en las sociedades tradicionales, en ellas coexistan diversas actitudes ante la muerte entre sus individuos.

En efecto, en el significado de la muerte, tanto para los grupos sociales como para los individuos que los integran, sólo existe un dato común a todos: que sucede. Por lo demás, la valoración de la muerte para un individuo está mediatizada socialmente y no es la misma a lo largo de su vida, ni tampoco es la misma para todos los individuos en un momento determinado. Así, se la puede conceptualizar como "un suceso biológico, un rito de paso, algo inevitable, un suceso natural, un castigo, extinción, el cumplimiento de la ley de Dios, absurda, separación, reunión, un tiempo de juicio. Es una causa razonable para la cólera, depresión, negación, represión, frustración, culpa, alivio, absolución, incremento de la religiosidad, y disminución de la religiosidad” (Kalish, 1985:149). Esta diversidad en la conceptualización de la muerte y el carácter dinámico de la misma, determina inevitablemente que desde una perspectiva sociológica el análisis de la muerte en las sociedades desarrolladas no sea un reflejo estático de categorías sociales cerradas y unitarias. Al contrario, la sucesión de cambios estructurales observados en estas sociedades desde el siglo XIX ha determinado que la construcción social de la muerte en ellas sea desde luego mucho más compleja que cuando en el pasado se cimentaba exclusivamente bajo criterios religiosos.

\footnotetext{
${ }^{4}$ El concepto de seguridad ontológica es un concepto central en la teoría de Giddens (1997:295), al que define como el "sentimiento de continuidad y orden de los sucesos, incluidos aquellos que no caen directamente dentro del entorno perceptivo del individuo". Por tanto, depende de que las personas sean capaces de encontrar sentido en sus vidas.
} 
Los estudios empíricos encaminados a conocer las relaciones entre los individuos y la muerte emplean una gran variedad de técnicas de investigación que van desde los tests proyectivos y medidas de reacciones fisiológicas hasta las encuestas, entrevistas semi-estructuradas o grupos de discusión; desde las técnicas dirigidas tanto a la población en general como a grupos específicos, especialmente niños, ancianos y moribundos, hasta las aplicadas a diferentes colectivos profesionales que trabajan diariamente en ámbitos de muerte (hospitales, geriátricos, tanatorios, etc). El origen de estos estudios se remonta a finales de la década de 1950, principios de la de 1960, y su florecimiento no es ajeno a las transformaciones estructurales señaladas y que, fundamentalmente durante el siglo $\mathrm{XX}$, han alterado las experiencias y expectativas de los individuos ante la muerte. Fruto de esas transformaciones en el enfrentamiento de la muerte y en el proceso de morir, se asiste desde finales de la década de 1950 a un 'redescubrimiento’ de la muerte. En esa época comenzaron a emerger, a ambos lados del Atlántico, diversas preocupaciones sobre las condiciones de muerte de los moribundos y las posibilidades de mejorarlas. Así, mientras que en Gran Bretaña la atención se centraba en el "abandono" médico de los moribundos, una vez que se había "fracasado" y ya "no se podía hacer nada”, en Estados Unidos se reaccionaba contra los tratamientos inútiles cuando la muerte era inevitable, tratamientos que además provocaban todo tipo de dolores y sufrimientos (Clark, 2002:905). Según Clark (2002, 1999), cuatro novedades particulares son paradigmáticas de la nueva forma de enfrentar la muerte que estaba emergiendo en la segunda mitad del siglo XX:

1) Un incremento cuantitativo en la bibliografía sobre cuidados a enfermos terminales, acompañado de un cambio cualitativo de la misma al pasar de recoger la mera anécdota idiosincrásica a ser reflejo de una observación sistemática y analítica.

2) El nacimiento de una visión del morir en la que comienzan a promoverse conceptos como dignidad y sentido, a la par que se reconoce abiertamente las condiciones de los enfermos terminales.

3) Un enfrentamiento más activo que pasivo de los cuidados a moribundos sustituyendo la resignación fatalista (“no hay más que podamos hacer”) por una actitud dirigida a la búsqueda de caminos alternativos e imaginativos que permitieran desarrollar nuevos cuidados aplicables hasta el final de la vida.

4) El creciente reconocimiento de la interdependencia de los dolores físicos y mentales: el "dolor total”, lo que provocó un cambio profundo en el dualismo cuerpo-mente en el que se había movido hasta ese momento la práctica médica. 
Dos ejemplos relevantes de la creciente bibliografía de esa época en la que se critica la forma en que las sociedades occidentales se enfrentaban a la muerte son, por un lado, las denuncias de Ivan Illich sobre la medicalización de la muerte y, por otro lado, un informe coordinado por Claude Veil en Francia. En su ya clásico Némesis médica. La expropiación de la salud, I. Illich (1975) criticó el proceso de morir en las sociedades modernas y afirmó que la medicina moderna había llevado a su fin a la muerte natural. En esencia los aspectos principales de su crítica se sintetizan en cuatro puntos: a) en las sociedades modernas se ha producido una pérdida de la capacidad de aceptar la muerte y el sufrimiento como aspectos significativos de la vida; b) en esas sociedades se está en un estado de "guerra total” contra la muerte en todas las etapas del ciclo vital; c) al debilitamiento de los cuidados personales y familiares se ha añadido una devaluación de los rituales tradicionales alrededor de la muerte y el morir, y; d) se ha creado una forma de control social en la que se rechaza al moribundo como gafe o las personas en duelo son etiquetadas como una forma de desviación.

Con un tono menos radical pero igualmente consistente, un grupo multidisciplinar de trabajo dirigido por el doctor Claude Veil realizó en 1973 un informe a petición del Ministerio de la Salud Pública de Francia cuyo objetivo básico era obtener una visión lo más comprehensiva posible del fenómeno de la muerte en las sociedades desarrolladas. Subyaciendo a este objetivo general, y de forma más específica, el informe perseguía realizar un diagnóstico de las condiciones del morir, especialmente del morir en los hospitales, y proponer recomendaciones para mejorar esas condiciones. El propio encargo del informe indicaba una sensibilización de las autoridades sanitarias hacia una realidad social, la muerte, a la que las instituciones y la opinión pública se enfrentaban con imprecisión, ambivalencia, e incluso incoherencia y que, como se afirmaba en el informe, su conocimiento era de capital importancia para "la política sanitaria de un país o, lo que es lo mismo, para la salud de su sociedad” (Veil et al, 1974:65).

El diagnóstico de ese informe resalta, entre otras cosas, la tendencia de la sociedad occidental a desnaturalizar la muerte ("El desarrollo agobiador de la civilización del <<producir por producir>> trata de empobrecer la muerte y de esconderla, como un desecho industrial”), a no considerarla nunca como real (Veil et al, 1974:65). Fruto de esta dinámica de ocultación el miedo universal a la muerte se había convertido en terror en "la civilización actual”. En el contexto de este proceso se resaltaba el papel esencial desarrollado por el complejo médico-hospitalario, con su aplicación incontestable de tecnología, que provocaba el aislamiento y la alienación de las personas enfermas e impedía “al moribundo preparar y organizar su muerte”, privándole de sus derechos (Veil et al., 1974:79). El informe resaltaba asimismo la paradoja que supone, en ese contexto, el tratamiento de la muerte por parte de los medios de comunicación que "no lo hacen de cualquier manera, sino que presentan una muerte aséptica, limpia, incolora, silenciosa. Imágenes que no corresponden a la muerte ordinaria, a la que nos puede sobrevenir” (Veil et al., 1974:80). De esta forma, "la muerte ha cambiado”, lo que se 
observa claramente en la transformación profunda del tipo de muerte ideal: "Hace algunos años se deseaba una muerte que dejara al moribundo un plazo, un momento de lucidez para prepararse, arrepentirse, poner en orden diversos asuntos... (hoy) ya no se estima buena muerte la muerte consciente, orientada hacia la preparación para la otra vida. Hoy sólo nos fijamos en el acto mismo de morir, en lo inmediato” (Veil et al., 1974:80).

Las conclusiones más importantes de este informe fueron, por un lado, el reconocimiento de que "todo hombre tiene derecho a vivir su propia muerte" y, por otro lado, y a la vez que recomendación básica, la necesidad de realizar un esfuerzo general para evitar ocultar la muerte y devolverla su lugar en la vida, puesto que la "aceptación de la muerte y su reinserción natural en la vida social facilitarían la formación de todos los que deben afrontarla” (Veil et al., 1974:66).

Por otra parte, no es casualidad que la mayoría de los estudios de las relaciones entre los individuos y la muerte se realizaran inicialmente en Estados Unidos. El redescubrimiento de la muerte en ese país viene explicado, por un lado, por el cambio de valores de la cultura estadounidense orientada hacia valores "expresos" tales como "la juventud, como símbolo de la vida; la familia nuclear, como símbolo de la libertad romántica, y la prestación de servicios de asistencia, como símbolo de la liberación de tareas desagradables”, con los que se elude o niega la muerte (Folta y Deck, 1974:54). Por otro lado, asimismo se explica por la convergencia de una serie de circunstancias histórico-sociales concretas en diversos niveles de la experiencia (Fulton, 1974:28-35). Según este autor, esas circunstancias serían, en un nivel <<macro >>, la sustancial disminución del papel que antaño desempeñaban los ancianos. En un nivel <<medio >>, el gran desarrollo de los aspectos científico-técnicos, especialmente en el ámbito médico y su capacidad para alargar la vida, que estaban cambiando no sólo la edad a la que una persona podía sospechar que iba a morir, sino también el lugar donde probablemente se iba a producir esa muerte; además de la creciente secularización de la población estadounidense, que estaba privando a los ancianos de las redes sociales de apoyo tradicionales. Y, en un nivel <<micro >>, la gran movilidad social y espacial de su población, que afectó a las relaciones familiares con el progresivo aislamiento físico, psíquico, económico y social de un creciente número de ancianos que, asimismo, provocó la ruptura de antiguos lazos sociales y la resistencia a crear otros nuevos.

Estas circunstancias motivaban que la actitud social e individual ante la muerte de los estadounidenses difiriera sustancialmente de la europea y presentara una tendencia mayor a negar la realidad de la misma y a que la persona moribunda muriera en mayor soledad. A comienzos de la década de 1970, E. Kubler-Ross (1974:22), conocedora de las sociedades europea y norteamericana, lo expresó de esta forma: “Culturalmente hay diferencias enormes en el modo de morir. En los Estados Unidos los pacientes tienen en general grandes dificultades para encontrar a algún médico o enfermera 
que se preste a escucharles y a participar en sus últimas preocupaciones. El 80\% de la población norteamericana muere en una institución, donde la agonía se convierte en un proceso mecanizado, despersonalizado y, a menudo, deshumanizado. No se permite a los niños que entren en las salas de los hospitales, y por eso raramente asimilan la experiencia de que la muerte es parte intrínseca de la vida”.

Esa tendencia hacia una mayor hospitalización de los enfermos crónicos y de los moribundos motivó que, lentamente y desde diversas perspectivas, se fueran tratando aspectos específicos del complejo fenómeno de la muerte que, poco a poco, se convirtió en un "campo legítimo de investigación" (Folta, 1974:53). Desde entonces, tanto en los Estados Unidos como en la mayoría de los países desarrollados se han venido realizando un número creciente de estudios empíricos sobre este tema desde diversas ciencias. No obstante, y como se ha subrayado en numerosas ocasiones, no ha sido el caso de la Sociología que, más preocupada por los problemas de la vida (la desigualdad social, el poder, las instituciones sociales, etc.), prácticamente ha obviado el análisis sociológico de la muerte ${ }^{5}$. Carencia incomprensible ya que, de acuerdo con Berger (1999), la muerte es un rasgo esencial de la condición humana, por lo que eludir su análisis es ignorar uno de los pocos parámetros universales sobre los que se construye la vida social e individual (Mellor y Shilling, 1993:411). Circunstancia asimismo resaltada por A. de Miguel (1994:261) al afirmar que "no deja de ser chocante que el suceso más cotidiano e ineluctable, como es el de la muerte, se deje ver tan poco como objeto de estudio de los informes sociológicos”.

Por otra parte, resulta asimismo sorprendente ese menosprecio hacia la muerte, para escorarse en exclusiva hacia el lado de la vida, cuando la Sociología tiene en sus efectos cierta equiparación con aquélla, en el sentido de que ambas son torpedos en la línea de flotación del individualismo, y más concretamente del narcisismo, imperante en las sociedades más avanzadas. En efecto, entre las funciones prácticas de la Sociología remarcadas por Giddens (2002:32) está la del “autoconocimiento”, es decir, la de lograr una mayor “comprensión de uno mismo”. En este terreno, frente a las pretensiones de los individuos postmodernos cuando se perciben a sí mismos como seres independientes, como "mónadas sin ventana alguna” (Elias, 1987), la Sociología atraviesa esas presunciones mostrándoles que en realidad son seres estructuralmente sociales, mientras que la muerte, por su parte, les muestra su finitud.

En el caso de España, tampoco existe un número elevado de trabajos sociológicos sobre la muerte, y desde luego ninguno que analice empíricamente de forma integral las relaciones de los españoles ante la muerte. A pesar de esa carencia, y como se recoge en los distintos capítulos de esta

\footnotetext{
${ }^{5}$ Por ejemplo, en un artículo irónicamente titulado “Los sociólogos nunca mueren”, Walter (1993) daba cuenta del volumen comparativamente reducido de estudios sociológicos sobre la muerte en Reino Unido, en relación a los estudios sobre ella desde otras ciencias, o a los estudios sociológicos sobre la muerte desarrollados en EE.UU.
} 
Tesis en donde se los cita $^{6}$ sí que se han realizado estudios sobre aspectos parciales o colaterales (eutanasia, suicidio, mortalidad, salud, personal sanitario, envejecimiento, rituales tanáticos, massmedia, cine, etc.), pero que, en conjunto, no permiten obtener una imagen global de esa relación.

Para ayudar a cubrir esa laguna, y sin entrar en el debate sobre la conveniencia de conformar la sub-especialidad Sociología de la Muerte o de servir al desarrollo de la Sociología General situando a la muerte en el centro de sus debates y estrategias ${ }^{7}$ (Mellor, 1993), el objetivo fundamental de esta Tesis es analizar la construcción social de la Muerte en la sociedad española actual. Para ello, se han examinado desde las perspectivas sociológica, demográfica, antropológica, histórica, psicológica y biológica, las dimensiones más significativas de la organización social y del enfrentamiento individual de la muerte y el morir.

Dado que en las sociedades más desarrolladas coexisten en la actualidad distintos modelos de enfrentamiento a la muerte, se puede observar en ellas diferentes actitudes en las materializaciones concretas de ese enfrentamiento. Actitudes que están mediadas por las características estructurales y culturales de esas sociedades y por la evolución de las mismas (globalización, secularización, individualización, racionalidad, burocratización, etc.). Sobre esta base, la hipótesis central de esta investigación es que el modelo de muerte dominante en la sociedad española actual está caracterizado por la (de)negación de la misma, Modelo Moderno en la terminología elaborada por Walter (1994), y no tanto por la aceptación de acercamiento, Modelo Tradicional, o por la reivindicación de la muerte, Modelo neo-Moderno. Es decir, en un entorno en el que enfrentamiento a la muerte se ha ido vaciando de contenido social desplazándose desde el ámbito público al privado, los individuos más que desarrollar actitudes ante la muerte que la dotan de sentido existencial, bien reduciendo su trascendencia y transformándola en un simple pasaje hacia una sobrevida eterna siguiendo los dogmas religiosos, bien reivindicándola como conclusión lógica de una biografía controlada (pilotada) por el propio individuo que se constituye en la máxima autoridad de sus procesos de morir y de muerte, la actitud dominante en las sociedades occidentales es la de la (de)negación de la muerte. Una negación de la muerte que más que intelectual (los individuos saben que van a morir) es emocional (los

\footnotetext{
${ }^{6}$ No obstante, por su influencia inicial en el desarrollo de esta Tesis es necesario resaltar en este punto los siguientes trabajos: PONCE DE LEÓN, O. (1997): El médico enfermo, Madrid, CIS; DE MIGUEL J. (1995): “<<El último deseo>>: Para una sociología de la muerte en España”, en R.E.I.S., no 71-72, y; ABAD MÁRQUEZ, L. (1994): “La construcción social de la muerte. Muerte y estructura social”, en SISTEMA, n 122. ${ }^{7}$ Frente a la posición de algunos autores que abogan por el desarrollo de una sub-especialidad denominada Sociología de la Muerte, con un nivel de articulación similar al de las sub-especialidades consolidadas incluidas en el listado de la Asociación Internacional de Sociología, como la sociología del género, otros autores, que no desdeñan esa posibilidad, consideran sin embargo que dada la relevancia sociológica de la muerte su análisis no debe realizarse desde "los márgenes de la Sociología", sino que debe de estar localizado en el centro mismo de los debates sociológicos actuales. Justifican su posición argumentando que explicar el enfrentamiento moderno a la muerte es una vía muy adecuada para entender todo lo que significa la modernidad misma. Asimismo, temen que la generación de una sub-especialidad limite el alcance de los análisis, al eliminar su transversalidad, contribuyendo con ello al ocultamiento de la muerte en las sociedades desarrolladas (Mellor, 1993; Bauman, 1992).
} 
individuos se aferran al deseo de no morir). Obviamente, dada la amplitud del tema ha sido preciso acotar la aproximación al mismo, por lo que la estructura central de la investigación ha sido conformada para contrastar las siguientes hipótesis básicas:

a) La muerte es un principio estructurador de la vida social. Es una especie de envoltorio que cubre, define y delimita la estructura social. Así, las relaciones de los individuos con la muerte ponen de manifiesto aspectos básicos y esenciales de la vida social y, a su vez, las relaciones sociales de los individuos están condicionadas por su relación con la muerte. Hipótesis que se coteja en el Capítulo 1.

b) No existen unos conceptos "muerte" y "morir" establecidos a priori y asentados en una única, hegemónica y abstracta cultura de la muerte, sino que cabe hablar de culturas -o, lógicas- de la muerte y el morir, socialmente construidas en relación a, o al margen de, los procesos de interacción inherentes y conexos a las prácticas profesionales y organizativas del continuo salud-enfermar-morirmuerte-cadáver-duelo. Hipótesis que se comprueba en el Capítulo 2.

c) El papel disruptor de la muerte en la vida social se ve potenciado actualmente por las características de la alta modernidad: individualismo, aislamiento, avances tecnocientíficos, reflexividad $^{8}$, riesgo, inseguridad ontológica, etc. Como resultado, y a través de la multiplicación de estrategias de enfrentamiento a la muerte, se ha reforzado la exclusión social de la muerte a la par que ese enfrentamiento se localiza exclusivamente en el ámbito privado. Hipótesis que se constata en el Capítulo 3.

d) El nivel y las estructuras de la mortalidad constituyen elementos orgánicos esenciales en la conformación del enfrentamiento a la muerte. Así, la evolución descendente de la mortalidad ha determinado variaciones en la (pre)vivencia del fenómeno mortal modificándose con ello la conciencia de $<<$ seguridad $>>$ de la muerte, que pasa de ser inminente a ser improbable. Hipótesis que se verifica en el Capítulo 4.

e) La muerte es abstracta mientras que el morir es concreto. La amenaza y la forma de morir condicionan la concepción de la muerte. Es decir, la concepción de la muerte no es la misma cuando el morirse o el morir de los otros está lejano que cuando está próximo en el tiempo. Asimismo varía dependiendo de cuál sea la causa y cómo se desarrolle el proceso de muerte. Hipótesis que se contrasta en el Capítulo 5.

\footnotetext{
${ }^{8}$ La reflexividad es un examen sistemático y crítico por el que se monitorizan y revisan todas las creencias y prácticas a la luz del cambio de circunstancias, es decir, "implica la incorporación rutinaria de conocimientos o información nueva a los entornos de acción, que de ese modo se reorganizan y reconstituyen" (Giddens, 1997:295).
} 
f) Como consecuencia de todo lo anterior, el análisis de las relaciones individuo/sociedad/muerte tiene gran capacidad explicativa para las ciencias sociales en general, y para la Sociología en particular.

La estructura básica de la investigación realizada para contrastar estas hipótesis se asienta en la traslación al ámbito sociológico del esquema propuesto, en Ideologías y Mentalidades, por el historiador de las mentalidades Michel Vovelle (1985) para la realización de una historia "total vertical” de la muerte. Enfoque que permite dilucidar el juego relativo que existe entre las condiciones de existencia de los seres humanos y la manera en que reaccionan respecto de ellas (Vovelle, 1985:92). Para acometerla, Vovelle señala que hay que hacerlo desde una mirada vertical de la muerte que vaya “<<desde el sótano hasta el granero >>”, esto es, se han de examinar los distintos niveles de la experiencia humana, “desde los condicionamientos sociodemográficos hasta las formas más sofisticadas de la expresión artística, pasando por las actitudes y las reacciones de la mayoría” (Vovelle, 1985:96-99). Así, sin suponer de entrada una vinculación de causalidad mecánica entre los tres niveles, propone analizar lo que denomina:

Muerte sufrida: "El hecho bruto de la mortalidad. Se inscribe en las curvas demográficas”. Valorar su peso es apreciar los parámetros, los componentes sociales de la <<sangría >> humana, empezando por las desigualdades entre las diferentes subpoblaciones.

Muerte vivida": "La red de gestos y ritos que acompañan el recorrido de la última enfermedad a la agonía, a la tumba y al más allá”. El envoltorio formal lo constituye el conjunto de "prácticas funerarias, mágicas, religiosas, cívicas, que en todos los tiempos han tratado de domesticar la muerte”. El núcleo esencial es el grado de sensibilidad ante la muerte, las actitudes, los valores y comportamientos ante la muerte, el morir (de los demás) y el morirse (el morir propio).

Discurso(s) sobre la muerte: Imaginarios colectivos, conscientes o inconscientes, que envuelven la vida social relacionada con la muerte. Especie de residuo psicológico irreductiblemente estable, hecho de ideas, conceptos y creencias, comunes a todos los individuos. Según Vovelle, ha evolucionado en el tiempo desde un discurso mágico hasta otro religioso, para posteriormente emerger uno laico, en diferentes formas (filosófica, científica, cívica), y caracterizarse, en la época contemporánea, por la proliferación del discurso literario (bajo múltiples formas).

Siguiendo este planteamiento, el objetivo fundamental de la Tesis, el análisis de la construcción social de la muerte, se ha abordado a partir de una concepción vertical de la misma que ha implicado el desarrollo de cinco objetivos secundarios que operan como escenarios que se 
superponen unos a otros, a la par que se complementan en su explicación. Estos objetivos específicos son:

$1^{\circ}$ ) Identificación de los componentes básicos de la construcción social de la Muerte en el contexto de las sociedades occidentales. A partir de las aportaciones desde diferentes disciplinas, se analiza en el Capítulo 1 el papel jugado por esos componentes en el continuo individuo/sociedad/ muerte. Así, la emergencia de la conciencia de muerte en la especie humana, por ejemplo, constituye uno de los pilares en los que se asentó el salto antropológico por el que se diferenció del resto de las especies animales, constituyendo además un factor determinante en el propio proceso de construcción de las sociedades y culturas humanas. En este capítulo se discute asimismo el hecho de que sean los seres humanos los únicos entre todas las especies animales que saben que han de morir. Finalmente, con el objetivo de matizar los mitos de la contingencia de la muerte, se examinan las aportaciones realizadas desde "las ciencias de la vida" sobre porqué se produce la muerte animal y el carácter inevitable de ésta.

$2^{\circ}$ ) Caracterización del <<Sistema de Muerte $>>$ como construcción social mediadora entre el individuo y su muerte inevitable, así como identificación y evaluación de la incidencia de sus componentes principales en la construcción de las culturas de la muerte y el morir en la misma. Es decir, determinación de las funcionalidades del sistema de muerte que permiten la no deserción de los individuos ante el sinsentido de la muerte. Este análisis se expone en el Capítulo 2, en el que, por su especial relevancia en la construcción del Sistema de Muerte en la sociedad a comienzos del siglo XXI, se resaltan las consecuencias de algunos de los cambios económicos, organizativos, científicostécnicos, y, más ampliamente, culturales (individualización, secularización, desacralización, etc.) que han incidido especialmente en ese proceso de construcción. La complejidad del Sistema de Muerte queda reflejada de forma paradigmática en la propia construcción de la definición social de la muerte y el morir -pura pragmática médica-, aspecto básico que siendo aparentemente sencillo de dilucidar se torna problemático en muchas ocasiones, lo que conlleva importantes consecuencias de todo tipo, tal y como se expone en ese capítulo.

$3^{\circ}$ ) Análisis de las características y de los dominios del(os) Discurso(s) sobre la Muerte, que a modo de imaginario(s) colectivo(s) está(n) presente(s) en la sociedad española actual. Es decir, se examina si existen claves básicas y estables -juicios, conceptos, creencias-, comunes a todos los individuos, en la mentalidad ante la muerte. Tomando como fondo la revisión histórica acometida por P. Ariès (2000, 1983), el estudio se centra en la tipología de la muerte elaborada por T. Walter (1994) que diferencia la sucesión de tres modelos de muerte en las sociedades desarrolladas en los dos últimos siglos: Tradicional, Moderna y Neo-Moderna. El análisis de la muerte en cualquier sociedad desarrollada permite reconocer algunos de los rasgos pertenecientes a diferentes modelos de muerte 
siendo imposible, sin embargo, identificar netamente en ninguna de ellas un único tipo de muerte. Además de otras circunstancias, el mero hecho de que, en la actualidad, las poblaciones de esas sociedades estén constituidas por más de cien cohortes de individuos determina que por el "efecto generación” coexistan en su seno diferentes modelos de muerte. De esta forma, la cultura de la muerte en las sociedades desarrolladas no es tanto el agregado de culturas estancas de la muerte cuanto una cultura transversal de ellas. El análisis, recogido en el Capítulo 3, permite distinguir tres miradas distintas sobre la muerte, con sus respectivos discursos dominantes, que a modo de superestructuras determinan, condicionan o justifican las actitudes de los individuos ante ella. Asimismo, dada la negación de la muerte en la sociedad española actual, en este capítulo se aborda el alcance de la misma y la discusión sobre si esa negación llega a la categoría de tabú, y si éste lo es individual y/o social.

$4^{\circ}$ ) Estudio estático y dinámico del aspecto más básico y visible de la muerte: cuánta gente muere, a qué edades, por qué causas de muerte, qué diferencias existen entre los diversos grupos sociales, etc. Esto es, a partir del análisis demográfico se determina la intensidad, el calendario y las tendencias de la mortalidad española actual: la Muerte Sufrida. Este análisis se recoge en el Capítulo 4 y se realiza tomando como referencia base el marco teórico de la Transición Demográfica, lo que permite contextualizar toda una serie de aspectos relativos a la evolución histórica de la contabilidad de la muerte en España. Asimismo, se utilizan otros modelos teóricos, Transición Epidemiológica y Transición Sanitaria, para explicar la evolución descendente de la mortalidad hasta fechas muy recientes a partir de la evolución de la mortalidad por causas de muerte. Además, como la construcción social de la muerte no sólo se asienta en la evolución de la Muerte Sufrida hasta hoy, sino que también influyen las percepciones sobre su evolución futura, se abordan asimismo distintas hipótesis sobre la evolución futura de la mortalidad.

$5^{\circ}$ ) Por último, se examinan las actitudes, valores y comportamientos de la sociedad española ante la muerte con el objetivo de determinar su grado de sensibilidad ante ella: la Muerte Vivida. Para ello se valora el peso y la influencia que la muerte tiene en la vida cotidiana de los individuos tanto en aquellas situaciones en las que está alejada como cuando está próxima. Esta distinción es fundamental por que, aunque una gran mayoría de individuos puedan alinearse dentro de un mismo modelo de muerte (el Tradicional, el Moderno o el Neo-Moderno), dentro de ese modelo pueden identificarse distintas culturas o lógicas de muerte y morir. En efecto, en su texto clásico Passing on, sobre la organización social del morir, Sudnow (1967) resalta que las categorías "vida”, "muerte", "enfermedad”, “morir”, etc., tal como se viven y se entienden en los hospitales están construidas por las prácticas del personal, en sus interacciones diarias rutinarias y tienen una fundamentación organizacional concreta: "sucesos organizativamente relevantes, concebido su manejo como gobernado por las consideraciones del trabajo prácticamente organizado del personal y la organización social tutelada”. Obviamente, ésta es una cultura de la muerte, la de las personas que están en contacto 
directo y diario con la muerte, que envuelve temporalmente a los moribundos y a sus allegados, pero de la que no está claro que participe la inmensa mayoría de la población, que en su vida diaria no tienen ese contacto directo con el proceso de morir o con experiencias de muerte ${ }^{9}$. Con esta premisa, se optado por enfocar el análisis de la Muerte Vivida cuando la muerte no está próxima físicamente -la muerte propia-, ni en el tiempo -la muerte ajena-, Capítulo 5. En esta circunstancia la construcción social de la muerte está mediatizada por el distanciamiento físico, temporal y mental respecto a ella. La cultura de la muerte así construida y reconstruida, en la que vive la mayoría de la población de las sociedades desarrolladas, no se asienta en el enfrentamiento continuo de los problemas prácticos que envuelven al morir y a la muerte, como hacen algunos de los profesionales que ejercen la medicina/enfermería o los profesionales de la tanatopraxia. Tampoco en la interiorización de la angustia del morir próximo (como hacen las personas moribundas y los familiares y amigos de éstas). No obstante, aunque esa cultura, o esa lógica, tiene otros componentes, entre éstos el componente vicario resulta esencial.

En efecto, se ha señalado arriba que no es lo mismo morir que morirse, y que tampoco es lo mismo la experiencia del morirse de los demás y la del morir propio. De las relaciones con el morir de los demás se aprende que se ha de morir en alguna y única ocasión; de ahí surge lo que Castillo del Pino (1995) denomina "actitud ante la expectativa de nuestra muerte" ineludible y que es un constructo imaginario sobre lo que podrá ser morirnos (“suceso de representación”). Del morir propio surge la "actitud ante la muerte" ("sujeto de presentación”). Las dos actitudes son diferentes; mientras que en el primer caso se considera la muerte como un acontecimiento que se experimentará en el futuro, en el segundo caso, cuando la propia muerte está próxima "todo el tiempo que resta es presente”. Por eso, desde la perspectiva de la vida cotidiana de la mayoría de la población cabe eludir la expectativa de la muerte ya que, aunque pueda mediatizar, no limita la consecución del resto de intereses vitales; sin embargo, la actitud ante la muerte es "apremiante e insoslayable”, todo lo demás queda difuminado. De esta forma, es la expectativa ante la muerte, no lo que es, sino lo que se imaginan que es o va ser la muerte, la que juega mayor importancia durante la vida de los individuos (Castilla del Pino, 1995) -"lo que crea problemas al hombre no es la muerte, sino el saber de la muerte” (Elías, 1987:11) - y la que en principio tiene mayor interés para la Sociología al ser la actitud dominante en términos vitales, de tiempo, de espacio, etc., en el escenario social de las sociedades avanzadas. No obstante, las actitudes ante la muerte, desarrolladas en un microcosmos espacialmente reducido y segregado, temporalmente limitado, pero mucho más denso, complejo y asimétrico que el de la vida cotidiana, están cobrando creciente importancia en la vida social al demandarse una

\footnotetext{
9 “En general, las personas que no están implicadas en los procesos moribundos difícilmente podrán comprender e interpretar el significado real del dolor y del sufrimiento. Es lógico, ¡mueren los otrosi Ya se encargan la sociedad y la cultura reinantes de enmascarar la muerte y de ocultar los trágicos e inhumanos sufrimientos no mitigables fácilmente que muchos pacientes soportan” (Urraca, 1995b:50).
} 
Introducción

solución a la situación, cuando menos paradójica, que regula socialmente el proceso de morir en los últimos momentos de la vida de una persona.

Desde el punto de vista metodológico, esta investigación se ha realizado utilizando cuatro de los métodos característicos de las ciencias sociales señalados por Beltrán (1991): el histórico, el comparativo, el cuantitativo y el cualitativo. Si bien en cada capítulo se explicitan en mayor medida las metodologías y técnicas empleadas en cada caso, cabe resumir los instrumentos aplicados: en que en el Capítulo 1 se ha utilizado metodología histórica y cualitativa, mientras que en el análisis realizado en los Capítulos, 2, 3 y 4 los métodos histórico y comparativo han sido esenciales. En el análisis de la Muerte Sufrida, Capítulo 4, se ha empleado además metodología cuantitativa, especialmente las técnicas más representativas del análisis demográfico clásico aplicadas a diversas fuentes de datos secundarios, sobre todo a las provenientes del INE. Se han utilizado asimismo técnicas cuantitativas en el Capítulo 5; concretamente, se ha realizado una encuesta con el objetivo de caracterizar la Muerte Vivida sobre una muestra de personas que no trabajan/estudian en el sector sanitario y no han vivido un proceso de morir(se) o muerte de otros cercano en el tiempo, es decir, con el objetivo de estimar las actitudes ante las expectativas de muerte ${ }^{10}$. Los detalles de esta encuesta se recogen en el Capítulo 5 y en el Anexo $1^{11}$. Por su parte, en el Anexo $2^{12}$ se recoge la información correspondiente a cuatro entrevistas semi-estructuradas y a un grupo de discusión, con personas de las mismas características que las encuestadas, que se implementaron para obtener información cualitativa complementaria a la cuantitativa proporcionada por la encuesta realizada.

\footnotetext{
${ }^{10}$ La financiación de todo el proceso de encuestación, así como del de las entrevistas y del grupo de discusión, se realizó con fondos provenientes de la Comisión Interministerial de Ciencia y Tecnología (DIGYCIT) para el proyecto (DIGES-PBS96-0362) dirigido por el profesor Dr. Eduardo Fernández Gijón.

${ }^{11}$ El Anexo 1, incluido en el CD adjunto a este documento, contiene el cuestionario utilizado, la ficha técnica de la encuesta y la matriz de datos inicial.

${ }^{12}$ El Anexo 2, incluido asimismo en el CD, contiene las fichas técnicas de las entrevistas y el grupo de discusión así como la trascripción anonimizada de los discursos obtenidos.
} 
CAPÍTULO 1.- DELIMITACIÓN PREVIA A UNA CARACTERIZACIÓN DE LA SOCIOLOGÍA DE LA MUERTE Y EL MORIR 



\section{CAPÍTULO 1.- DELIMITACIÓN PREVIA A UNA CARACTERIZACIÓN DE LA SOCIOLOGÍA DE LA MUERTE Y EL MORIR}

"Nada teme más el hombre que ser tocado por lo desconocido"

E. Canetti

La construcción social de la muerte ha derivado en las sociedades más avanzadas en una paradójica inversión de significados. Mientras que la mayoría de las sociedades tradicionales se han enfrentado a ella recreando culturalmente mediante mitos el inevitable proceso biológico de la mortalidad humana, el proceso analítico de deconstrucción iniciado con la modernidad, con el objetivo de resolver los grandes problemas que plantea la realidad parcelándolos y poder así enfrentarse más eficientemente a pequeños problemas resolubles uno a uno, ha conllevado en su aplicación a la muerte el camuflaje de la mortalidad humana (del proceso puramente biológico) para concentrarse en el carácter puramente cultural de la misma (Bauman, 2007, 1992). Así, como señala este autor, esta estrategia racionalizadora para hacer más llevadera esa “<<alteridad absoluta $>>$ del no ser” que es la muerte, ha transformado a ésta al desplazar la mirada -y los temores-, desde el hecho biológico, universal e irremediable que es la muerte en sí, a las causas específicas de fallecimiento, que técnicamente pueden ser conocidas y controladas.

Con el objetivo general de contextualizar conceptualmente un análisis de la muerte en la sociedad española actual, y con el objetivo concreto de matizar en sus justos términos esta variante del $<<$ mito de la contingencia de la muerte>>, en este capítulo se aborda inicialmente el análisis de la muerte como construcción social y la influencia determinante de ese proceso en la propia construcción de la sociedad. A continuación, se revisa la discusión sobre si la conciencia de la muerte es una característica atribuible sólo a los seres humanos o si está también presente en otras especies animales. Finalmente, se sintetizan las principales aportaciones de distintos autores provenientes de las denominadas "ciencias de la vida" sobre el por qué se produce la muerte, el vínculo entre la reproducción sexual y la muerte y entre el envejecimiento y la muerte, interrelaciones que son enmarcadas en la evolución de las especies por selección natural. Se busca con ello recalcar el carácter natural e inexorable de la muerte animal, y por tanto de la muerte humana.

\section{1. <<¿QUÉ ES ESTAR MUERTO?>>: LA MUERTE, UN CONCEPTO SIN CONTENIDO}

“El hombre puede pensar que existe y también puede pensar un mundo sin su existencia, más no su propia no-existencia: tal es la condición fundamental de su ser”

J. Améry

En Una pena en observación, el escritor y crítico irlandés C. S. Lewis, dos años antes de morir, reflexiona sobre el vacío, la soledad, el sufrimiento, en definitiva, la pena, que le embargaba por la 
pérdida de su mujer, la poetisa americana Helen J. D. Gresham. Cristiano militante, Lewis intenta, por una parte, alcanzar una cierta cordura que le permitiera, si no armonizar, sí al menos compatibilizar la crisis existencial que el sinsentido de la vida humana le provocaba en esos momentos con sus profundas creencias religiosas. Por otra parte, buscaba dar respuesta a los múltiples interrogantes a los que esa muerte concreta le había enfrentado. Impotente en su dolor, concluye que gran parte de esos interrogantes -teológicos, metafísicos, existenciales-, con los que él interpela directamente a Dios, carecen de respuesta y llega a asimilarlos a preguntas disparatadas sin contestación posible: “¿Cuántas horas hay en una milla? ¿El amarillo es cuadrado o redondo?” (Lewis, 1997:95) ${ }^{1}$.

A semejanza de estas preguntas absurdas existen otros interrogantes que carecen de respuesta, no tanto porque haya en su formulación inconsistencias lógicas como porque ocultan fisuras en los presupuestos de partida. Más concretamente, son interrogantes que se refieren a cuestiones nominales, que tienen existencia lingüística pero que su ser no se halla en la realidad extra-lingüística. Un ámbito de reflexión paradigmático a este respecto es el de la muerte. Así, por ejemplo, pueden plantearse cuestiones como “¿qué es estar muerto?” que no admiten respuesta, porque el ser o la existencia de las personas muertas es una condición puramente nominal y no real (Bauman, 2007:46; Arregui, 1992:79; Carse, 1987:17-26; Rosenberg, 1983:24-34) ${ }^{2}$. En efecto, si bien cabe formular múltiples enunciados sobre la vida del ser humano, no cabe plantear ninguno concreto sobre su muerte. De tal forma que cuestiones como la planteada 'ocultan`que las personas no pueden 'vivenciarse` como muertas, no pueden hacerse presente ni anticipar su muerte: "si yo desaparezco como observador de mí mismo y de mi mundo, mi mismidad y mi mundo dejan de serme <<dados>>” (Meyer, 1983:29-30).

Asumiendo que la muerte es la "frontera límite" que al atravesarla la vida se extingue completamente sin continuidad, la grieta absoluta que se abre en ese límite impide cualquier tipo de experiencia en la muerte al no continuar la vida bajo forma alguna. En efecto, al no ser un evento de la vida, no se vive la muerte, es decir, no se experimenta la muerte cuando la vida termina, porque simplemente no se experimenta (Carse, 1987:18). Por tanto, la llegada de la muerte provoca una disrupción total que niega la condición misma de <<vida >> ya que, como señala Savater (2007:67-68) en su crítica a la vida de ultratumba eterna elaborada por la mayoría de las religiones, “en el más allá no tendremos ni cuerpo ni mundo, por lo que difícilmente podremos considerarnos <<vivos $>>$ en ningún sentido inteligible del término”.

\footnotetext{
${ }^{1}$ La relación entre C.S. Lewis y H.J.D. Gresham ha sido llevada al cine por Richard Attemborough (1993) en la película Tierras de penumbra.

${ }^{2}$ El psicólogo estadounidense R. Kastenbaum (1984:13), que ha estudiado los fenómenos fronterizos de la vida y la muerte -comunicación entre vivos y muertos, experiencias extracorporales-, señala que, aunque "algunos positivistas lógicos” puedan aducir que no se trata de verdaderas preguntas, él, por contra, admite la validez de
} 
En su texto clásico El Hombre y la Muerte, E. Morin (1974a) aborda el tema de la muerte considerándolo un fenómeno humano total, reflexionando tanto sobre la muerte en sí misma como sobre el ser humano como sujeto de muerte ${ }^{3}$. En ese texto, Morin (1974a:32) señala que "la idea de la muerte propiamente dicha es una idea sin contenido, o, si se quiere cuyo contenido es el vacío infinito. Es la más vaga de las ideas vacías, pues su contenido no es sino lo impensable, lo inexplorable”. Es por ello por lo que ningún ser humano ha sido capaz de definir y describir en sí misma la muerte. Ésta no es una cuestión técnica ni es susceptible de verificación científica al no poderse tener experiencia directa e inmediata de la misma, ya sea de la propia o de la de los otros. Cuando muere una persona deja de ser persona y se transforma en un cadáver. Pero éste no es la muerte. Esta mutación no lo es de estado sino de tipo de realidad (Rosenberg, 1983:24-34). Tránsito a otra 'realidad', que no tiene duración ${ }^{4}$, con la que no hay continuidad ni posibilidad de comunicación. Así, nada del saber humano acumulado aporta pista alguna sobre la muerte. Al contrario, ésta anula de raíz todo lo que define `la sabiduría de la vida', trasformando en inútiles todos los conocimientos y habilidades frente a ella. "La muerte es la encarnación de <<lo desconocido >>, y entre todos los demás <<desconocidos $>>$ es el único que es plena y realmente incognoscible" (Bauman, 2007:46). No existe, en consecuencia, un conocimiento cierto, racional y radical sobre ella, sobre esa otra realidad.

De ahí la perplejidad con la que los seres humanos se enfrentan a su paradójica 'experiencia` de la muerte: cada individuo sabe que ha de morir pero no puede representarse su propia muerte, es decir, puede representarse la muerte como una realidad que le afecta, como un acontecimiento datable, igual que la muerte de cualquier otro individuo, pero no puede anticipar su muerte como una realidad propia accesible a su experiencia, ya que su muerte en este sentido es el final del tiempo y no el final en el tiempo ${ }^{5}$ (Meyer, 1983:135). En este mismo sentido se manifiesta Bauman cuando resalta que

esos interrogantes tanto por razones psicológicas como sociológicas, porque considera que esos fenómenos son significativos por sí mismos para un gran número de personas.

${ }^{3}$ Su aproximación a la muerte se realiza desde la antropología filosófica, es decir, desde una reflexión filosófica y global de los fundamentos del ser humano, y de la consideración de éste como punto de partida de todo conocimiento sobre sí mismo y sobre el mundo. Análisis en el que no se establecen apriorísticamente las características de una pretendida esencia humana inmutable, sino que, integrando los distintos niveles, desde la realidad biológica hasta la mitológica, incluye simultáneamente un enfoque antropológico, social, lingüístico, psicológico, histórico y biológico, para elaborar una reflexión holística del ser humano en su complejidad (Diccionario electrónico de Filosofía Herder, 1992; López Gil y Regnasco, 1996).

4 "No hay tiempo en la muerte. La muerte no es más que límite, línea de frontera, sin otra dimensión que la momental del punto puro en el tiempo" (Pérez Gálvez, 1997:121).

${ }^{5}$ Distintas corrientes de pensamiento han afirmado la imposibilidad de 'vivir` la propia muerte: epicureismo, kantianos, existencialismo, psicoanálisis, etc. A modo de ejemplo, Kant expone de forma muy diáfana esa imposibilidad: "El pensamiento: no soy, no puede existir; pues si no soy, tampoco puedo ser consciente de que no soy. Puedo, ciertamente, decir que no estoy sano y puedo pensar otros predicados semejantes negándolos de mí mismo (...); pero hablando en primera persona, negar el sujeto mismo, con lo que éste se aniquila a sí mismo, es una contradicción” (Kant, 1991:70). Por su parte, Schopenhauer (1976) lo expresa como sigue: "Intentamos representar con viveza el tiempo, sin duda no muy lejano, en que estaremos muertos. Entonces imaginamos nuestra no existencia y dejamos que el mundo siga existiendo; pronto descubrimos, para nuestra sorpresa, que a pesar de todo nos imaginamos existiendo. Hemos querido representar el mundo sin nosotros; pero en la conciencia el yo es la realidad inmediata que nos hace accesible el mundo, gracias al cual está 
aunque todo el mundo "sabe” muy bien qué es la muerte, nadie responde sin embargo cuando se solicita a cualquier persona un relato preciso sobre cómo define y comprende la muerte. Y no se aportan respuestas sencillamente porque no es posible pensar, y por tanto verbalizar, el no soy ${ }^{6}$ : "la muerte es el otro absoluto del ser, otro inimaginable, que revolotea más allá de lo que alcanza la comunicación; cuando el ser humano habla de ese otro, se encuentra a sí mismo hablando, a través de una metáfora negativa, de sí mismo” (Bauman 1992:2). De ahí la perplejidad y angustia del moribundo Iván Ilich: “<<¿Qué habrá, cuando falte yo?. No habrá nada. Entonces, ¿dónde estaré, cuando ya no sea?>>” (Tolstoi, 1981:59).

En buena medida, la ambigüedad con la que los seres humanos se enfrentan a la muerte se debe, siguiendo a Jankélévitch (2002:18-19), a su carácter desconcertante y vertiginoso, a que sea necesaria e incomprensible, lo que se pone de manifiesto en una paradójica contradicción: la muerte es un secreto indescifrable en un evento cotidiano obvio, un acontecimiento visible y familiar envuelto en “un misterio de dimensiones metaempíricas, es decir, infinitas, o mejor aún sin dimensiones de ninguna clase”. Misterio no revelado positivamente, sin alteridad posible, al contrario, pura y completa extinción. Misterio sin ubicación ni tiempo, sin geografía, sin pasado, sin presente, sin futuro. Misterio en el que no existe la negociación. Misterio que trastorna al mundo, misterio cotidiano y absolutamente democrático, que no supone una alteración anómala y atípica de la lógica del orden natural, sino que es "el destino ecuménico de las criaturas", y que, además, se materializa en un acontecimiento comparativamente inclasificable, singular por excelencia, único en su género, sin relación con todos los demás acontecimientos, desmesurado e inclasificable, y del que, por tanto, no se tienen referencias de garantía sobre cómo afrontarlo. Por eso siempre es una especie de escándalo, por eso "el hombre mortal” no se ha acostumbrado todavía a la muerte y la extraña, como si ocurriese siempre por primera vez: “insólita, y sin embargo tan familiar que el más torpe de los hombres la reconoce instantáneamente, la identifica en el momento en que se topa con ella, -así es esta naturalidad contra natura y así es esta naturaleza sobrenatural de la muerte” (Jankélévitch, 2002:20).

Resumiendo, la ausencia de un conocimiento fehaciente sobre qué es la muerte significa que, en sí misma, es inaprensible para el ser humano en los planos de la percepción, la vivencia y la imaginación (Thomas, 1991:11). Por mucha intencionalidad que se vuelque en ello, la muerte no

presente esa realidad. Este centro de toda existencia, este núcleo de toda realidad debe cesar, pero dejando que el mundo exista; es una idea que puede pensarse en abstracto, mas no puede realizarse... El resultado es esto: llegará un tiempo en el que yo no existiré; ha de llegar alguna vez; pero subjetivamente no puede llegar”.

6 "Sólo la muerte significa que nada ocurrirá a partir de entonces, que nada le ocurrirá a usted, es decir, que nada sucederá que usted pueda ver, oír, tocar, oler, disfrutar o lamentar... Lo único que no podemos (ni podremos jamás) visualizar es un mundo que no nos contenga a nosotros mismos visualizándolo" (Bauman, 2007:46). "Sé que mi mundo seguirá existiendo. Esto significa que el mundo, como mundo común e intersubjetivo, no dejará de existir cuando yo muera. Pero el mundo (y, con él, el tiempo) acaba en tanto que es mi mundo, es decir, el 
puede ser percibida, menos aún visualizada o 'representada`, por que no hay "algo” que sea la muerte. La muerte no es nada, o mejor dicho, es la nada absoluta; es la cesación del "sujeto actor" mismo, y con ello el fin de toda percepción (Bauman, 1992:2). Es un hecho irrefutable que la esencia de ese cambio sustancial que es la muerte escapa a la inteligencia humana. El término “muerte” por tanto no se refiere a nada específico, no designa a ningún objeto, función, categoría o estado concreto. La muerte elude la razón humana. No se puede pensar la muerte, al menos no en sus aspectos esenciales, "no se deja atrapar por el discurso humano; la reflexión rebota en su opacidad, no taladra su ser y nos

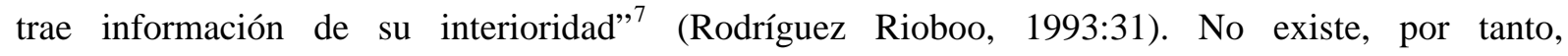
conceptualización alguna de la muerte misma. El ser humano no sabe "qué es estar muerto" o, lo que es lo mismo, la idea de la muerte propiamente dicha es una idea sin contenido. La muerte es inefable.

\section{2. $<<$ ¿QUÉ ES ESTAR MURIENDO?>>. UNA PRESENCIA EVIDENTE E INEVITABLE: LA MUERTE}

\author{
"Sé que un día moriré, \\ que sumido en el vacío \\ y arrojado a la nada \\ me convertiré en polvo"
}

$\mathrm{X}$. Lete

El ser humano sabe de la muerte aunque ésta es incognoscible, inimaginable. A pesar de su inexperiencia en la muerte, el ser humano desde que es tal (históricamente, desde la aparición del homo sapiens; biográficamente, desde que toma conciencia de su individualidad) no ha dejado de interrogarse sobre ese <<no sé qué>>, concebido como <<el mundo de los muertos >>, del que no sabe lo que es pero sí que le horroriza: la muerte. El enfrentamiento a ésta, como fenómeno que pone fin a la vida, ha suscitado en los seres humanos de todas las épocas, como le ocurría a Lewis, "las más graves reflexiones y las más profundas preguntas” (Hispánica. Macropedia, 1990:vol.10:260-261). Fruto de las primeras y en un intento de responder a las segundas, históricamente todos los grupos sociales y sociedades han creado y desarrollado todo tipo de rituales, instituciones, creencias, sistemas filosóficos, etc., para enfrentarse a la muerte. Enfrentamiento que incluso ha conllevado la especialización de algunos individuos en la realización de tareas relativas al manejo y gestión de los

mundo que yo <<poseo>> en cuanto sujeto" (EDWARDS, P. (1967): “My Death”, en EDWARDS, P. (dir): Encyclopedia of Philosophy, Londres, citado en (Meyer, 1983:135)).

${ }^{7}$ Esta incapacidad para penetrar en la muerte fue expuesta de forma sincrética y rotunda por el poeta japonés Toko (1795) poco antes de morir:

"Los poemas a la muerte son un engaño.

La muerte es la muerte” (Hoffmann, 2000:270).

De forma más irónica Fuld (2004:8) la describe como sigue: "por muy bajo que sea el montón de tierra que la cubre, no vemos más allá de la tumba. Ya pueden los filósofos ponerse de puntillas y estirarse todo lo posible: no ven más que nosotros, y el resto es pura creencia”. 
"efectos destructores y desorganizativos" tanto de los fenómenos que conducen a la muerte (enfermedad y envejecimiento), como de la propia irrupción de la misma (Lindesmish et al, 2006:561).

La incapacidad ontológica para dilucidar, definir y conocer en su ser a la muerte no significa que ésta sea un concepto irreal, "metafísico”, ni que el ser humano no haya aprehendido algo sobre ella. De hecho, como resalta Meyer (1983:15), a la muerte hay que atribuirla la "máxima virtualidad” entre todos los ingredientes de la vida de los seres humanos. En efecto, de igual forma que no existe representación alguna de la "nada" y sin embargo se habla constantemente de ella -"sabemos no lo que es la nada sino qué significa que no haya nada” (Sábada, 1991:30)-, aunque la muerte no sea objeto de experimentación directa, ya se trate de la propia o la de otros, no significa que no pueda ser objeto de proyección deductiva. Así, y a pesar de esa vivencia-imposible de la muerte, históricamente ha existido siempre una reflexión teórica sobre ella, como si se hubiera 'rozado`alguna vez la epidermis del <<gusano en el corazón>>, tal como la denominó W. James, que erosiona cualquier pretensión de felicidad en los seres humanos. Derivado de la misma, y a diferencia del interrogante anterior, “¿qué es estar muerto?”, este nuevo interrogante, “¿qué es estar muriendo?”, sí que tiene respuestas.

Indirectamente a través de la muerte del otro, se tenga miedo o no a morir, todos los seres humanos desde que toman conciencia de sí se saben mortales; concluyen que ellos también deberán morir. Y no sólo saben que van a morir, sino que piensan en la muerte y de alguna forma tratan de racionalizarla para controlarla. La muerte ajena es, además de un acontecimiento subjetivo, un evento objetivo que enseña a las personas que lo mismo les debe ocurrir a ellas. Así, la experiencia vicaria permite al ser humano colocarse frente a la muerte (o, al menos, frente a su posibilidad). A través de la analogía y de la concepción de la muerte propia con parámetros de la muerte ajena, el ser humano puede `anticipar' su muerte en la medida en que puede pensar en ella (o en su posibilidad) y en la medida en que puede 'imaginarla'. En cierta forma, señala Ferrater Mora (1986:157), cabe hablar de $<<$ nuestra propia muerte>>, aunque él mismo reconoce que esta actitud ante la muerte es de tipo reflexivo y que por ello no puede considerarse, más que mínimamente, como una auténtica experiencia del posible morir ${ }^{8}$.

En efecto, de acuerdo con Bauman (1992:3), las muertes de los otros son eventos que acontecen en el mundo externo de los objetos, en el "ahí fuera”, que se pueden percibir como cualquier

\footnotetext{
${ }^{8}$ Poco antes de morir, y como consecuencia de la muerte de M. Mújica Láinez, J. L. Borges reflexionaba sobre la muerte señalando "....ahora siento impaciencia; me parece que debo morirme pronto. Que ya he vivido demasiado. Y, además, tengo una gran curiosidad. Creo, pero no estoy seguro, que la muerte tiene que tener cierto sabor; tiene que ser algo peculiar que uno no ha sentido nunca... Que no puede comunicarse, desde luego, ya que uno solo puede comunicar lo compartido por el otro. Las palabras presuponen experiencias compartidas; en el caso de la muerte todavía no".
} 
otro objeto o suceso. Estas muertes forman parte del "mundo inteligente" de los objetos y no rompen la continuidad de la percepción propia. De hecho, la muerte de un otro próximo, a pesar del inconmensurable dolor y de la frustración que pueda acarrear, puede ser relatada; es decir, desde el lado de la persona que sigue viviendo puede ser percibida la "nada particular” (no absoluta), el vacío, que la pérdida crea en ella. Sin embargo, la propia muerte, y sólo la propia muerte, es un evento que no forma parte de ese mundo inteligente externo, que rompe la continuidad de la percepción propia y que, en consecuencia, no puede ser narrada por uno mismo: “cómo expresar un vacío o una amplitud sin mi” ${ }^{\prime}$. En este mismo sentido se manifiesta Castilla del Pino (1995), quien niega siquiera la existencia de una identificación mínima entre la muerte del otro y la muerte propia. Por ello, distingue entre morir y morirse; mientras morir es un acontecimiento biológico que les ocurre a todos los organismos desde que nacen, morirse es la experiencia individual e intransferible de ese acontecimiento por parte del sujeto que, además, sabe lo que le está ocurriendo. No cabe, por tanto, homologación entre ambos.

No obstante, aunque cada muerte constituye el fin de un mundo único, obviamente, la muerte de una $<<$ tercera persona $>>$, de un $<<$ otro $>>$, de un desconocido anónimo y sin rostro ${ }^{10}$, "no transmite la misma potencia de revelación, ilustración e instrucción” que la muerte de un $<<t u ́>>$, la de una persona querida. En el primer caso, esa muerte lejana e indiferente "nos resulta imposible remitirla a nada en particular que podamos estar perdiendo nosotros”, es una muerte dada junto a un sinnúmero de otras cosas dadas en una realidad naturalizada, una muerte amortizada para la propia conciencia sin que llegue a constituir un objeto de comprensión; mientras que, en el segundo caso, la muerte de ser querido constituye una <<sacudida >> que trastoca "la vacuidad de la naturalización de lo social”, una pérdida irreparable de un mundo único que formaba parte del propio: la vida no es eterna, pero la ausencia de ese otro sí se hace eterna (Aguiluz Ibargüen, 2009:315-316; Bauman, 2007:61-62; Jankélévitch, 2002:34-43). Es casi como la muerte propia ${ }^{11}$. En efecto, cualquier persona que haya vivido la muerte de un/a familiar o amigo/a muy cercano conoce que esa muerte se siente como si se

\footnotetext{
${ }^{9}$ En la misma línea, Savater (2007:52-53) señala que los seres humanos aparentemente asumen sin demasiado escándalo "el silogismo fundacional de la lógica de nuestra existencia": " $<<$ todos los hombres son mortales/yo soy hombre/luego yo debo morir >>. Sin embargo, apoyándose en Freud y la escuela psicoanalítica (<<en lo inconsciente todos nosotros estamos convencidos de nuestra inmortalidad $>>$ ), considera que la muerte de los otros forma parte de la realidad subalterna de cada individuo pero ésta no es la realidad misma por antonomasia, el yo, por lo que aunque se asume la muerte en la realidad subalterna, "no nos lo creemos" en el caso de la muerte propia, que no pasa de ser "mucho más que una conjetura, íntimamente poco verosímil”.

10 "La muerte en tercera persona es problemática sin ser misteriológica; es un objeto como cualquier otro, un objeto que se puede describir o analizar médicamente, biológicamente, socialmente, demográficamente, y que representa por tanto el colmo de la objetividad atrágica. El Yo, en este asunto, deviene sujeto anónimo y acéfalo de una muerte indiferente” (Jankélévitch, 2002:35).

${ }^{11}$ En el caso concreto de la muerte de los padres, para Jankélévitch, (2002:39) significa que "Ha llegado mi turno, y ahora le toca a la generación siguiente pensar la muerte a través de mi efectiva muerte. La muerte del padre y de la madre es de este modo para cada hombre el paso de lo mediato a lo inmediato".
} 
hubiera arrancado y destruido -como si se `hubiera muerto’ - una parte del propio ser $^{12}$. Mutilación parcial, difusa e irreparable. Mutilación diáfana, como la descrita por Sádaba (1991:78) al referirse a las sensaciones que experimentó con la muerte de su padre: “radical separación de la persona con la que hasta el momento estabas comunicándote. Es un corte absoluto, sin mediaciones. Algo que no pertenece ya en nada a la vida. La distancia entre vivo y muerto es lo más anticotidiano que puede uno imaginar. Se establece, por hablar de alguna forma, una distancia absoluta. Entre el vivo y el muerto no hay grado alguno". Mediante esta experiencia de la muerte <<en primer grado >> (Bauman, 2007:62-63), por la que cada uno de los seres humanos comprueba que poco a poco y pedazo a pedazo, de forma irreversible e irreparable, que su mundo va desapareciendo sin sustitución de ningún tipo, saben aquéllos que la muerte existe, les afecta, y sobre todo, anticipan que significa la cesación de sus vidas.

Al saber que va a morir, la vida del ser humano queda cualificada por la muerte futura. De esta forma, la muerte "puede habitar” de antemano en la vida sin que ella sea constatable como realidad en cada momento particular, aunque "en todos los momentos particulares de la vida somos los que van a morir” (Simmel, 2001:90). El ser humano en cuanto que vive, todavía no ha muerto, pero ya es mortal: no sólo muere en un momento dado, sino que sabe siempre que es mortal. Como subraya Savater (2007:113), "Mortal no es el que muere, sino quien ve venir la muerte... incesantemente. Hasta el punto de que podríamos definir la muerte humana como el momento en que por fin dejamos de vernos morir”. Es por ello por lo que el segundo de los interrogantes sí que tiene respuestas. El ser humano sabe `qué es estar muriendo` y al enfrentarse a ese morir construye la muerte.

En este sentido, la muerte no es un concepto objetual sino relacional, en tanto que no puede concebirse sin su opuesto, la vida. La muerte para el ser humano significa la última frontera de la vida, la disolución absoluta e irremediable de su conciencia, la extinción completa. La muerte no trasforma al ser humano, lo aniquila; su resultado es lo informe: "no nos cambia nada, sino que nos cambia en nada” (Savater, 1999:12). No tiene rostro, pero disuelve todas y cada una de las caras, es "el final de las apariencias físicas o psicológicas”. Así, Morin (1974a:32) califica a la idea de la muerte como la idea traumática por excelencia. ¿Por qué?, porque la muerte es la negación de toda posibilidad a cualquier sujeto vivo concreto: la muerte trunca todo, constituye la disolución de su existencia

\footnotetext{
${ }^{12}$ En un libro dedicado a su hija Joana, por entonces recientemente fallecida, Joan Margarit (2002) expresa de forma diáfana la mutilación, el desconsuelo y el sentimiento de vacío que siguió a esa pérdida:

"Te vi nacer: después, vivir radiante.

Quizá es porque te estoy viendo morir.

O quizá son más cosas: el aire claro y frío

de las mañanas mientras envejezco

levanta un muro sin ninguna puerta,

un muro al que ilumina

el sol de tu sonrisa ya sin rostro".
} 
personal, de su individualidad, el final de todas las cosas, el final de su mundo, de todo su universo, de su historia, "la inconcebible tragedia de (su) nihilización” (Jankélévitch, 2002:33; Sádaba, 1991:2435). Y porque el ser humano no está `programado’ para asumirla, porque para la conciencia individual, que no envejece, la muerte “no es en absoluto una necesidad” (Roger, 1995:222; Ziegler, 1976:307).

Además, la muerte es inhumana pues no habla, no responde, "repudia todo coloquio”, y las palabras sobran. Cualquier intento de comunicación con los muertos es un monólogo estéril. La célebre máxima de Epicuro en su Epístola a Meneceo, que describe de forma diáfana la grieta absoluta entre la vida y la muerte, expresa esa incapacidad total para <<narrar >> la muerte (propia): “el mal que más pone los pelos de punta, la muerte, no va nada con nosotros, justamente porque cuando existimos nosotros la muerte no está presente, y cuando la muerte está presente entonces nosotros no existimos”. Sin embargo, a pesar de su elegancia racional, que anticipa el pensamiento científico moderno sobre la vida y la muerte ${ }^{13}$ (Carse, 1987:53-78), y de su poder de persuasión, la lógica implacable de esta argumentación tranquilizadora de Epicuro "suena y se percibe como fraudulenta” para la mayoría de la gente: como algo remoto que parece pasar por encima de la inquietud real, al no estar realmente relacionada con lo que se cree y se siente sobre la propia muerte, porque es "contradictorio vivir en un nivel de la existencia en que no podamos ser tocados por la muerte” (Bauman, 1992:3, Carse, 1987:78). De esta forma, la 'sabiduría innegable`contenida en este tipo de razonamientos no ha evitado que, generación tras generación, la muerte propia siga horrorizando a los seres humanos. En efecto, el conocimiento racional de la existencia de la muerte y de que se es mortal no contrarresta de ninguna forma el que a la mayoría de los seres humanos, como ya se ha señalado, les cueste creer `en el fondo de su corazón’ en su propia muerte o en la de sus más allegados. Por ello, la muerte casi siempre sobreviene como algo increíble, una desgracia, una escandalosa injusticia (Leep, 1967:45-51). De ahí, que Sádaba (1991:24 y 34), califique de “pueril” el argumento de Epicuro ${ }^{14}$, ya que sólo puede

\footnotetext{
${ }^{13}$ A esta cuestión se hace referencia en el apartado 1.4.

${ }^{14}$ Según Carse (1987), la filosofía de Epicuro no tenía especial interés en conocer la verdad, sino en expulsar los sufrimientos de la mente y en especial los provocados por la muerte. En este sentido, Epicuro consideraba que el futuro, y todo lo que se desea, está amenazado por el azar y la muerte inevitable, por lo que las esperanzas se transforman en ansiedad y el presente se hace miserable. Sin predicar la resignación a esa situación, propone superar la impotencia ante el poder de la muerte eliminando el deseo, no intentado ordenar lo fortuito, dejando que la muerte se adueñe del futuro pero viviendo el presente. Por todo ello, limitar la reflexión sobre la muerte de Epicuro a la cita referida oculta otros aspectos asimismo importantes que hacen al caso. En especial los relativos a la afirmación de la ausencia de un más allá y, en consecuencia, a la disposición a concentrarse en la vida, y más específicamente en una vida de calidad. Quizá en esta invitación se halla el auge del epicureismo en los últimos años (Lledó, 1995), por lo que para ser justos con Epicuro conviene al menos citarle de forma más extensa:

"Acostúmbrate a pensar que la muerte no tiene nada que ver con nosotros, porque todo bien y todo mal radica en la sensación, y la muerte es la privación de sensación. De ahí que la idea correcta de que la muerte no tiene nada que ver con nosotros hace gozosa la mortalidad de la vida, no porque añada un tiempo infinito sino porque quita las ansias de inmortalidad.

Pues no hay nada temible en el hecho de vivir para quien ha comprendido auténticamente que no acontece nada temible en el hecho de no vivir. De modo que es estúpido quien asegura que teme la muerte no porque hará sufrir con su presencia, sino porque hace sufrir con su inminencia. Pues lo que con su presencia no molesta sin
} 
convencer a los que ya se han liberado del terror provocado por la muerte, mientras que para la inmensa mayoría de los individuos restantes, y ya desde que los antepasados fueron conscientes de ella, la muerte es un mal, el "mal de males" al que el ser humano no se puede adaptar. Hasta tal punto que Bauman se pregunta cómo explicar la desconcertante incapacidad de razonar de los seres humanos para aplacar esa angustia.

Desde el plano fenomenológico, y aunque no son términos de la misma realidad, vida y muerte son inseparables ya que ésta supone el fin de aquélla. Esto no sólo significa que la muerte conforma a la vida cuando ésta finaliza sino que, al configurarla en su <<entorno total $>>$, impregna todos sus contenidos ya que no sólo se convierte en un desafío intelectual, sino que desde un punto de vista práctico casi todos los comportamientos de los individuos se realizan con el objetivo de evitarla, aplazarla o conjurarla (Savater, 2007:46). Por ello, Bauman (2007:72) afirma que la muerte es la “ambivalencia encarnada”, porque por una parte su proximidad llena la vida a rebosar de miedos y, por otra parte, actúa como un estimulante de gran potencia: a la vez que despoja a la vida de su significado, la dota de una "enorme significación”. Esta mediatización es descrita metafóricamente por Simmel (2001:92): “Somos como hombres que caminan sobre un barco en la dirección contraria a su marcha: en tanto van hacia el sur, el suelo sobre el que lo hacen es portado con ellos mismos hacia el norte. Y esta doble dirección de su ser-en-movimiento determina su correspondiente posición en el espacio”. Es decir, el viaje vital de los seres humanos, delimitado en su totalidad por la muerte, está conformado simultáneamente por dar pasos para huir de ella (todas sus actuaciones, instintivas o conscientes, en los distintos ámbitos -trabajo, placer, descanso- están dirigidas a la evitación de la muerte), a la par que al dar cada uno de esos pasos se produce un acercamiento temporal a la muerte: "La vida que consumimos para esto, para acercarnos a la muerte, la consumimos para esto, para huir de ella” (Simmel, 2001:90-92).

Así, al imponer la muerte a los individuos la conciencia de la finitud de sus vidas, paradójicamente, es lo que de hecho les `da la vida'. En efecto, junto al abismo existencial en el que sitúa a la conciencia, la muerte, al asignar al campo de lo "vivido y de lo vivible límites precisos, necesarios e irrevocables”, plantea paradójicamente al ser humano la realización de su vida, le empuja a la acción y a la elección entre diferentes posibilidades, es decir, da significado a su vida: al imponer

razón alguna hace sufrir cuando se espera. Así pues, el mal que más pone los pelos de punta, la muerte, no va nada con nosotros, justamente porque cuando existimos nosotros la muerte no está presente, y cuando la muerte está presente entonces nosotros no existimos. Por tanto, la muerte no tiene nada que ver ni con los vivos ni con los muertos, justamente porque con aquellos no tiene nada que ver y éstos ya no existen. Por otro lado, el común de las gentes unas veces huye de la muerte por considerarla la más grande de las calamidades y otras veces la añora como solución a las calamidades de la vida.

Pero el sabio ni rehúsa vivir ni teme no vivir, pues ni le ofende el vivir ni se imagina que es un mal el no vivir. Y de la misma manera que de la comida no prefiere en absoluto la más abundante sino la más agradable, así también disfruta del tiempo no del más largo sino del más agradable” (Epicuro, 1999:88-89). 
un límite a la existencia humana, instaura una discontinuidad, instituye el tiempo, confiere un lugar y un sentido a cada instante de vida, da unicidad a cada acto, lo que en la duración social indistinta "singulariza cada vida y le da su significación. La muerte instaura la libertad". De esta forma, la muerte desempeña en la historia de la conciencia individual el papel "irremplazable y necesario de un órgano-obstáculo" que, al tomar conciencia de él, "transforma la nescencia existencial del ser humano en un destino cargado de sentido”. Sin ese límite el ser humano estaría disuelto en la indiferencia ${ }^{15}$ (Ziegler, 1976:301-308, 328-337).

Asimismo, la muerte, y en especial la muerte del otro, revela otros aspectos fundamentales para la experiencia de los vivos por cuanto abre unas grietas irreparables en la propia vida en tanto que suponen la súbita ruptura de la "frágil red de la existencia” (Carse, 1987:20). En efecto, la muerte tiene la virtualidad inmediata de revelar la interconexión de la vida social, el juego de las dependencias mutuas que mediatiza las elecciones y permite a los individuos construir su identidad, porque con suma potencia muestra no sólo la contingencia de las cosas, sino la de los propios individuos. Así, la muerte revela a éstos que su vida no les pertenece completamente pero que, sin embargo, se vuelve suya en la medida en que la comparten. Revelación paradójica, a la par de dependencia y de libertad: "que obtenemos nuestra personalidad de los otros y que podemos ser personas sólo en tanto que somos libres (para comprometerse)” (Carse, 1987:498). Por todo ello, aunque la muerte no está inscrita en la necesidad de la conciencia aparece para ésta como una necesidad de tipo existencial ${ }^{16}$ : "La conciencia de la muerte es así indisoluble de la voluntad de vida inscrita en la subjetividad esencial de cada hombre” (Ziegler, 1976:331).

\footnotetext{
${ }^{15}$ En este mismo sentido se pronuncia Savater (2007:65-66) cuando afirma que "la vida perdería cualquier sentido -no ya intrínseco, que dudo que tenga en ningún caso, sino ante nuestros propios ojos- porque nos sobraría tiempo para emprenderlo todo, conseguirlo todo y renunciar a todo. La única interpretación inteligible de lo que llamamos <<dar a sentido a la vida > es la administración orientada hacia esto o aquello de la escasez del tiempo de que disponemos. La falta de tiempo -argumento central de nuestra contingencia- es el auténtico significado existencial de la vida, como afirmó a su modo enrevesado pero consistente el Heidegger de Ser y tiempo. Si sobra el tiempo, perdemos cualquier atisbo de sentido y autenticidad en una vida que ya nos sería imposible seguir llamando <<humana >”.

${ }^{16}$ Esta interpretación no es compartida en principio por los filósofos existencialistas para quienes el que la vida acabe en la muerte conduce al absurdo de aquélla y es la causa de la angustia existencial. No obstante, dentro de esta perspectiva filosófica se observan posiciones contradictorias y habría que diferenciar en este ámbito (Diccionario electrónico de Filosofía Herder, 1992), por ejemplo, la perspectiva, más próxima a lo señalado, de Heidegger, quien quiere "desarmar" a la muerte haciéndola consciente para lo que hace coincidir muerte y finitud y considera a aquélla como el fundamento constitutivo de la existencia en su finitud, así, el ser (Dasein) es la libertad hacia la muerte, y lo característico del ser en este mundo es el ser cuando todavía no, como no cosa: "La muerte es una posibilidad de ser que ha de tomar sobre sí en cada caso el <<ser ahí >> mismo. Con la muerte es inminente para el <<ser ahí >> él mismo en su <<poder ser >> más peculiar. En esta posibilidad le va al <<ser ahí > su <<ser en el mundo >> absolutamente” (Heidegger, 1974:273). Por su parte, Sartre, contra Heidegger, señala que ha de separarse muerte y finitud ya que la muerte no es una posibilidad propia ínsita en cada individuo, sino un hecho contingente que pertenece a la facticidad y que por lo tanto no confiere sentido a la existencia, impide que las personas realicen sus propias posibilidades: "Toda tentación de considerarla (a la muerte) como un acorde de resolución al término de una melodía debe ser rigurosamente desechada... En una palabra, no hay ninguna virtud personalizadora que sea particular a mi muerte... la muerte no podría caracterizarse como mi muerte por el hecho de ser muerte y, por consiguiente, su estructura esencial de muerte
} 


\subsection{CONSTRUCCIÓN SOCIAL DE LA MUERTE VERSUS CONSTRUCCIÓN TANÁTICA DE LA SOCIEDAD}

"Los muertos rodean a los vivos. Los vivos son el centro de los muertos.
En este centro se encuentran las dimensiones de espacio y tiempo.
Lo que lo rodea es intemporal”.

J. Berger

Con el paso del tiempo en la vida de las personas se observa una creciente disimetría entre un proceso cierto, el deterioro fisiológico del cuerpo que acaba en su desagregación definitiva, y otro proceso que, salvo contingencias derivadas de accidentes fisiológicos, camina en dirección contraria, el crecimiento de la conciencia que progresivamente acumula las claves fundamentales del posicionamiento del yo y del mundo. Fruto de ese choque disimétrico entre la muerte cierta del propio cuerpo y la muerte incierta de la conciencia, la mayoría de las personas perciben la muerte como un absurdo, un escándalo o una agresión intolerable (Ziegler, 1976:308). En este sentido, Landsberg (1995:30) constata como un fenómeno histórico generalizado que la toma de conciencia de la mortalidad supone un cambio del ser y afirma que de él se desprende una $<<$ regla $>>$ : la conciencia de la muerte acompaña a la individualización humana, entendida ésta como "constitución de individualidades singulares”. Para este autor, no se trataría sólo de que el ser humano, a través de la conciencia de la muerte individual, adquiere "una conciencia más clara y más matizada de la propia singularidad”, sino sobre todo de que, a través de la amenaza misma de la muerte, el "individuo actualiza un contenido propio sólo de él” que necesariamente traspasa "los límites del clan y del renacimiento del clan”: "Sólo a partir de este momento se forma un elemento susceptible de ser amenazado con un verdadero aniquilamiento, es decir, de muerte individual”.17.

En esta misma línea, se sitúa Morin (1974a) para quien en la afirmación de la individualidad está la clave para entender tanto la construcción (desarrollo) histórico de la especie humana y su diferenciación respecto del resto de las especies animales, como las reacciones humanas ante la muerte. En efecto, dada la "fetalización de la especie humana", esto es, su escasa especialización comparativa, fue necesario el desarrollo de mecanismos culturales que propiciaran la adaptación al entorno y compensaran esa carencia. Sin embargo, a diferencia de los designios inexorables de la

no basta para hacer de ella el acaecimiento personalizado y cualificado que puede esperarse.... Siendo así, no podemos decir ya ni siquiera que la muerte confiere a la vida un sentido desde afuera: un sentido no puede provenir sino de la subjetividad misma” (Sartre, 1976: 652-660). En el fondo, para Sastre, "la muerte reduce la propia existencia a lo que realmente es: una <<pasión inútil>>, nada”, por lo que la reflexión sobre la muerte en realidad es la reflexión sobre la falta de significado de la existencia (Torcer, 1997:21). En Carse (1987) puede consultarse una extensa exposición sobre cómo han abordado las distintas perspectivas filosóficas y las religiosas más relevantes el problema existencial derivado de la muerte.

17 "El efecto de esta evolución explica que las épocas históricas ricas en individualidades singulares estén obsesionadas por el pensamiento de la muerte” (Landsberg (1995:30). 
naturaleza, esos mecanismos culturales se caracterizan por su indeterminación relativa ya que lejos de marcar una línea única de actuación aportaban un abanico de posibilidades que permitieron al ser humano abrir canales por los que iba a fluir la evolución social. Bajo esa potencialidad, Morin añade que toda una serie de constantes humanas -detectadas en todos los seres humanos, de todos los tiempos y de todas las culturas- que aparecen en el estado arcaico con la aurora del pensamiento humano, y que llegan hasta la actualidad, se hallan íntimamente imbricadas a, y se manifiestan con, la afirmación de la individualidad frente a la especie.

De forma paradigmática todo ello precipita en el desarrollo de una práctica que, según Morin, va a diferenciar a la especie humana del resto de las especies animales con un peso específico de similar importancia al de los atributos humanos que habitualmente ${ }^{18}$ se han considerado en esa taxonomía: la construcción de sepulturas. Éstas sedimentarían la toma de conciencia de las limitaciones del <<más acá >> y de la existencia de un límite que se ha de pasar: la muerte. Los enterramientos revelarían, por tanto, que la muerte había fracturado una conciencia que, hasta entonces, no había sido más que instrumental, y que por la brecha abierta se habrían introducido “fuerzas nuevas e inmensas” que transformaron la percepción humana de la vida, de la muerte y del mundo (Ziegler, 1976:145). Así, el ser humano sería tal desde que entierra a sus muertos, es decir, el inicio de esa práctica situaría las fronteras del no man's land antropológico (Morin, 1974a:23). En efecto, simultáneamente a la aparición del ser humano emergieron signos que asociaban a la muerte “unas prácticas totalmente inexistentes entre los antecesores del hombre”. Esas prácticas (rituales ${ }^{19}$ ) son indicativas, por un lado, de que los humanos veían y vivían la muerte de sus congéneres de forma diferente que los no humanos y, por otro lado, que ese diferencial en el enfrentamiento de la muerte se sobrecargaba de “significados peculiares” (Jonas, 1998:51; Tornos, 1990:34-35).

Como se ha mostrado desde distintas ciencias, y en especial desde la Paleoantropología, en el proceso por el que "salimos de la naturaleza y nos hicimos hombres" existe un evento fundamental a modo de "pasaporte" para la humanidad: el surgimiento del "útil”, por el que "el homo faber se

\footnotetext{
${ }^{18}$ Tradicionalmente, la distinción entre el ser humano y el resto de las especies animales se ha centrado en el reconocimiento en aquél de su capacidad de generar ideas a partir de su cerebro (homo sapiens), en la construcción y empleo de todo tipo de utensilios (homo faber) y en la capacidad de comunicación a través del lenguaje (homo loquax) (Morin, 1974a:9). En su análisis de esa distinción, Jonas (1998:cap.2) elige como primeros "artefactos" visibles de la producción humana, y que "no podrían ser obra de ningún animal", a la herramienta, la imagen y la tumba.

${ }^{19}$ Frente a la concepción sociobiológica de ritual (aquélla conducta no comunicativa que en la evolución de una especie se vuelve comunicativa y funciona como una comunicación), se asume la antropológica que denota a aquéllas conductas interactivas más complejas y no necesariamente asentadas en la biología y en la evolución estricta, y que "implican la sobredeterminación de unos sucesos o tiempos ya relevantes de por sí (verbigracia, nacimiento, llegada de la primavera, construcción de una casa) con acciones expresivas más y más evolucionadas y de configuración compartida” (Tornos, 1990:35).
} 
apropia del mundo, lo objetiva, lo transforma, lo humaniza”20. Para Morin, junto a este evento concurre otro "pasaporte" asimismo fundamental que se materializa desde el momento en que el homo sapiens neanderthalensis comienza a enterrar a sus muertos ${ }^{21}$. Con esta práctica, que asimismo refleja un progreso indiscutible del conocimiento objetivo, no sólo se trataba de evitar a los supervivientes los efectos contaminantes de los cadáveres puesto que para ello bastaría, como hacen otras especies animales, abandonarlos en el extrarradio deshabitado para ser consumidos por carroñeros o arrojarlos al agua. Sin embargo, la disposición tendida o fetal de los cadáveres, el que fueran recostados sobre lechos de flores, o recubiertos con almagre, o acompañados de sus armas, trofeos y alimentos, o depositados al resguardo de animales necrófagos o simplemente el que fueran protegidos con piedras, revela algo más que una mera actuación profiláctica. Estos comportamientos para conservar los restos del individuo fallecido perseguían además conservar la identidad del mismo mediante una ofrenda simbólica de lo que se habría de necesitar en un ulterior nacimiento a otra realidad que trasciende la de este mundo físico (Domínguez-Rodrigo, 1997:170). Y, junto al respeto debido, estas actuaciones buscaban algo mucho más prosaico: asegurarse que la desaparición de los muertos fuera definitiva y conjurar así la amenaza de "su indeseable retorno" porque "lo peor de los muertos es que, aun ya muertos... ¡siguen pareciéndose a los vivos!” (Savater, 2007:47-48). Esas prácticas, por tanto, denotan la existencia de una conciencia de la muerte, de creencias en el más allá22, en la supervivencia del individuo muerto bajo forma de "espectro corporal con idénticas necesidades que los vivos”. Así, la

\footnotetext{
${ }^{20}$ Para Jonas (1998:43), la herramienta es "humana precisamente porque en sí misma no tiene que ver con el ser humano, porque no surge de una función orgánica y no está sometida a programación biológica alguna”. A través de ella el "homo faber adapta el mundo al instrumento, instrumentaliza las cosas, y al mismo tiempo por medio del instrumento, se adapta objetivamente al mundo y acabará instrumentalizando el mundo y las relaciones humanas” (Roger, 1995:221).

${ }^{21}$ A pesar de las múltiples controversias científicas que históricamente han animado la discusión sobre el proceso evolutivo de la hominización, actualmente existe un amplio el consenso sobre que los hombres de Neandertal, anteriormente considerados una subespecie de sapiens (Homo sapiens neanderthalensis), en realidad fueron una especie homo independiente de aquélla (Homo neanderthalensis) (SALVAT (2003): La Enciclopedia, vol.10:7727). Este homo vivió desde hace más de 200.000 años hasta hace 35.000 años, cuando desapareció por el empuje colonizador del moderno Homo sapiens cuyas raíces africanas se remontan hasta unos 100.000 a 200.000 años. Aunque, como señala el paleoantropólogo Manuel Domínguez-Rodrigo (1997:cap.8), esa independencia ha motivado que no se admitiera en el ámbito académico "la existencia de enterramientos realizados por homínidos anteriores al H. sapiens sapien", sin embargo, las evidencias disponibles en la actualidad muestran sin ninguna duda que realizaban ritos funerarios. Así, esas evidencias confirman, de momento, que las "preocupaciones religiosas (materializadas en los enterramientos) en el ser humano se remontan a unos 120.000/100.000 años y están asociadas a dos tipos de homínidos: H. sapiens sapiens y $H$. sapiens neanderthalensis", y es muy probable, según este autor, "que el ser humano hace medio millón de años se estuviese asomando ya al umbral de la inmortalidad".

22 "El almagre, símbolo de sangre y vida, que cubre a menudo el cadáver, podría expresar la idea de supervivencia, pero las ofrendas de animales y los objetos de tipo ornamental indican una concepción de la muerte como paso a una vida ultraterrena y un deseo de supervivencia” (F. FACHINI (1990): El origen del hombre. Introducción a la paleontología, Madrid, Aguilar, p.174, citado en Roger (1995:224)). En este mismo sentido, Sádaba (1991:18-24) señala que la construcción de sepulturas ya no es magia (entendida como una aproximación a una técnica, un acto ligado a la supervivencia, a la vida: un "intento rudimentario por dominar el mundo"), sino que indica que el hombre "comienza a ser religioso" (entendida la religión como un acto ligado a la vida pero sobre todo a la muerte: "expresión simbólica de profundas necesidades humanas... En cuanto libera angustias, protege contra el desorden mental y hace del límite algo más llevadero que un abismo mortal... Por eso muerte y religión van siempre juntas”).
} 
irrupción de la muerte entre los antepasados del ser humano conllevó el desarrollo de una "capacidad autoconsciente de reflexión” sobre la vida, y de lo que se oculta tras su materialidad, generando con ello "una serie de modificaciones antropológicas que permitieron y provocaron tal irrupción” (Morin, 1974b:114; Domínguez-Rodrigo, 1997:170). Capacidad de reflexión que no se limitó a la meditación sobre su relación con el mundo, sino que se extendió a su relación consigo mismo, es decir, que le llevó a reflexionar sobre sí mismo, ya que, para Jonas (1998:51-52), lo que en última instancia cristaliza en las tumbas es la pregunta: “¿De dónde vengo, a dónde voy? Y, finalmente: ¿Qué soy más allá de lo que hago y experimento?”23.

En esencia, según Morin, las realidades antropológicas de la muerte se moverían entre dos polos contrarios: la $<<$ conciencia humana de la muerte $>>$ y el $<<$ riesgo de muerte $>{ }^{24}$. El primero de esos polos, la conciencia humana de la muerte, está integrado por tres constantes humanas inseparables que coexisten originariamente de forma dialéctica, "la triple constante antropológica" -decadencia de la especie (instinto de conservación) versus afirmación del individuo-: la <<conciencia de la muerte>>, el $<<$ horror a la muerte $>>$ y la $<<$ creencia en la inmortalidad $>>$.

La <<conciencia de muerte>> es la conciencia “objetiva” de la muerte: se reconoce la mortalidad. El ser humano es objeto de muerte en tanto se acepta el hecho de la muerte como tal. A partir de lo cual "se reconocerá la ley de una muerte" futura ineludible que se puede presentar en cualquier momento.

Junto a esta conciencia realista de la muerte emerge una conciencia traumática: el <<horror a la muerte>>. Es la conciencia “temporal” de la muerte por la que, en última instancia, el ser humano se reconoce sujeto de (a) la misma, es consciente de su finitud. Conciencia de sí mismo que se enfrenta obligatoriamente a una idea de tipo particular, la "idea” cuyo contenido es su destrucción, el vacío de una nada provocado por la pérdida irremediable de la identidad. El horror a la muerte engloba al conjunto de realidades heterogéneas que provocan sentimientos traumáticos en el ser humano.

\footnotetext{
23 "Con el conocimiento de su mortalidad no puede vivir como ser humano sin una comprensión de sí mismo, que no es en absoluto algo que se <<comprende por sí mismo»>, sino que es el resultado vacilante de especulaciones interrogativas. Desde el yo singular estas especulaciones se extienden necesariamente a la totalidad de lo existente dentro del cual se ve situado. De esta manera, de las tumbas se levanta la metafísica. Pero también lo hace la historia, entendida como recuerdo de lo pasado, como lo muestra primero el culto a los antepasados. La conservación del vínculo con ellos amplía el ahora pasajero de la propia existencia convirtiéndola en la continuidad de la sucesión de las generaciones, y la memoria de lo temporal se vuelve tan suprapersonal como la meditación sobre lo eterno" (Jonas, 1998:51-52).

${ }^{24} \mathrm{El}<<$ riesgo de muerte > es otra constante fundamental y constituye la paradoja suprema del hombre ante la muerte, puesto que "contradice total y radicalmente el horror a aquélla". Morin (1974a:72-78), menciona, por ejemplo, los valores como motivo para arriesgar la vida. ¿Por qué? porque son fundamentales para el individuo, que los reconoce y son reconocidos "como superiores a la vida: dominan el tiempo y el mundo, son inmortales". Con ellos "el individuo se afirma y afirmándose, se sobrepasa, se olvida, da su vida por $<<$ su $>>$ verdad, <<su > justicia, <<su >> honor, <<sus $>>$ derechos, $<<$ su $>>$ libertad".
} 
Sentimientos que en su concreción tiene un claro carácter discriminatorio, como ya se ha mencionado: no es la muerte en abstracto ni la muerte de cualquier individuo la que preocupa y abruma, sino la de las personas más cercanas, la de los miembros del grupo: “cuanto más próximo, íntimo, familiar, amado o respetado, es decir <<único>> era el muerto, más violento es el dolor; sin embargo, poca o ninguna perturbación se produce con ocasión de la muerte del ser anónimo, que no era <<irremplazable>>” (Morin, 1974a:30-31). Entre esas realidades se incluyen: a) el temor a la descomposición del cadáver por su impureza y capacidad de contagio; temor centrado en los más cercanos mientras que produce indiferencia o simple malestar si el cadáver no está personalizado. Este temor determinará el tratamiento funerario del cadáver ${ }^{25}$; b) el dolor en los funerales ${ }^{26}$, asimismo más intenso cuanto mayor es la proximidad respecto a quien fallece, a la par que no produce emoción sino indiferencia ante la muerte anónima, desconocida, cosificada, y; c) la obsesión por la muerte, como generadora de un sentimiento de ruptura, de desastre, de un vacío donde antes había estado la plenitud individual (Morin, 1974a:25-37).

La emergencia de la conciencia humana de la muerte supuso un salto cualitativo en el conocimiento consciente del homo sapiens, que vino acompañado de un creciente grado de la complejidad del mismo. Al tomar conciencia de la muerte, ésta es algo más que un mero hecho -“tal como sucede entre los animales"-, o una pérdida o un perjuicio irreparables, supuso tomar plena conciencia de que, además, la muerte significaba el tránsito de una realidad a otra (Morin, 1974b:114). Esta conciencia realista de transformación conectó, por un lado, con una conciencia del tiempo ${ }^{27}$ manifestada en que el pensamiento del hombre de Neanderthal no se limita a lo inmediato del acto -en ello "podemos descubrir la presencia del tiempo en el seno de su conciencia”. Por otro lado, provocó la emergencia de nuevas formas de percepción de la realidad -lo imaginario- y que se desarrollaran nuevas visiones del mundo -el mito-, que "se convertirán a un mismo tiempo en productos y coproductores del destino humano”28 (Morin, 1974b:115). Es decir, por primera vez en la historia coexistía en el pensamiento de los antepasados del homo sapiens sapiens la dualidad objeto/sujeto, fruto de la brecha abierta en su conciencia por la muerte. Brecha antropológica indicativa de que desde

\footnotetext{
25 "De este horror han surgido todas las prácticas a las que ha recurrido el hombre, ya desde la prehistoria, para apresurar la descomposición (cremación y endo-canibalismo), para evitarla (embalsamamiento), o para alejarla (cuerpo transportado a un lugar alejado o huida de los vivos)" (Morin, 1974a:26).

26 "Como muy bien ha puesto de relieve R. Hertz, el periodo de duelo corresponde a la duración de la descomposición del cadáver. La putrefacción del muerto es su <<impureza >>, y el tabú de impureza, que afecta a los parientes, obligados por ello a cubrirse con un signo distintivo o a esconderse, es el propio duelo, es decir la cuarentena a la que se somete la familia en la que reina la muerte contagiosa” (Morin, 1974a:27).

27 "El encuentro entre la consciencia de sí y la conciencia del tiempo determina la consciencia de vivir en el tiempo y de tener que experimentar la muerte” (E. Morin (1986): La Méthode, vol. 3, p.196, citado en (Roger, 1995:226).

${ }^{28}$ En el homo sapiens aparece "todo un aparato mitológico-mágico que se moviliza con el objeto de afrontar la muerte". A modo de ejemplo, "las exequias son ritos que contribuyen a que se efectúe de forma adecuada el paso a la otra vida, protegiendo a los vivos tanto de las iras del muerto (de donde tal vez tome su origen el culto
} 
ese estadio el homo sapiens se disocia de su destino natural ${ }^{29}$, la especie, y de que entra en un nuevo desarrollo de la individualidad caracterizado por el impulso de la autoconciencia y el fortalecimiento de las relaciones sociales como respuesta a la propia mortalidad ${ }^{30}$ (Morin, 1974b:116-117). Brecha que “será colmada de mitos y ritos de supervivencia que acabarán integrando la idea de la muerte”, es decir, que permitirán una adaptación mágica, por tanto social, a aquello para lo que cada individuo está incapacitado racionalmente: la asunción de la muerte propia. Lo que lleva a Bauman (2007:47) a afirmar: "Todas las culturas humanas pueden interpretarse como artefactos ingeniosos calculados para hacer llevadero el vivir con la conciencia de la mortalidad”. Es decir, la muerte humana va a dimanar de la cultura tanto como de la naturaleza ${ }^{31}$.

La tercera de las constantes antropológicas de la muerte, la <<creencia en la inmortalidad $>>$, fruto lógico e inmediato de las otras dos constantes (conciencia realista y conciencia traumática de la muerte), es la conciencia "subjetiva” de la muerte: la que crea "imágenes que asimilan la muerte a realidades de la vida"; la que "la recusa, la supera y la resuelve a través del mito y de la magia" (Morin, 1974a:32). El individuo reacciona frente a la muerte que provoca su disolución afirmándose contra ella como ser superviviente. La prueba más tangible de esta afirmación es el desarrollo de la idea de la inmortalidad como "réplica a la podredumbre”, como afirmación individual más allá de la muerte, como negación del carácter definitivo de ésta: "La muerte es vista como un especie de vida que prolonga, de una u otra forma, la vida individual” (Morin, 1974a:24). De esta forma, la muerte que es inexorable, irreversible, irremediable, el fin de todo, y que, por tanto, no es contingente, es concebida sin embargo como tal. Ya no sería una finalización, sino una expiración, el tránsito de un mundo a otro (Bauman, 2007:47).

Además de la prueba irrefutable que de ello constituye la construcción de las sepulturas, Morin lo ejemplifica con otros tipos de construcciones socio-culturales; concretamente, con la existencia de dos mitos fundamentales y universales que, ante "la imposibilidad de pensar en el no ser

a los muertos) y de su descomposición (posiblemente derive ya de ahí el luto que aísla a los allegados del difunto)" (Morin, 1974b:115).

${ }^{29}$ Lo que le permite afirmar a Morin (1974a:13) que "contrariamente a lo que sostiene el sociologísmo y el culturalismo reinantes, no existe una muralla entre naturaleza y cultura, sino un engranaje de continuidades y discontinuidades".

30 "Se hace necesario que exista una fuerte presencia personal para que la individualidad de un muerto sobreviva entre los que ha abandonado; se hace necesario que los vínculos afectivos e intersubjetivos sean realmente intensos para que sigan ejerciendo su influencia aún más allá de la muerte. Para percatarse plenamente de la brecha mortal, confluencia entre la afirmación objetiva de la muerte y la afirmación subjetiva de la amortalidad individual, es necesario que se desarrolle este nuevo epicentro que es la conciencia de sí mismo" (Morin, 1974b:117)

${ }^{31}$ Análisis asumido también por M.A. Durán (1985:102-103) para quien el homo sapiens en su capacidad para generar ideas introduce la "idea y el miedo a la muerte" -reflejado en los enterramientos-, "el mito y los ritos y la conciencia de la individualidad. Tras esta brecha antropológica no nace el hombre solamente al simbolismo y al arte, sino que nace también a la risa y a la magia, a las lágrimas y al desorden, al error y a la sinrazón. Por ellas llega el hombre a su último nacimiento: el de la sociedad histórica, a través del umbral de la cultura”. 
de uno lleva a concebir el ser superviviente, el ser uno otro", buscan "llenar" la muerte propia de un sentimiento de vida afirmativo ante un "todo mundano transindividual que sigue inalteradamente su curso”, en expresión de Torno (1990:37): el mito de la muerte-renacimiento ${ }^{32}$ y el del doble ${ }^{33}$. Estas creencias, mezcladas o diferenciadas, se encuentran en todas las sociedades arcaicas conocidas y constituyen el germen del que han brotado todas las creencias históricas sobre la muerte (Morin, 1994a:187-294). Por tanto, para el homo sapiens la toma de conciencia de la muerte conlleva la pérdida de conciencia de la misma (homo demens): "la lucidez sobre el hecho de la muerte le ciega y le transporta a la creación de toda una noosfera en la que el aire se a va a llenar de fantasmas, dobles, ángeles, dioses...” en su intento de negarla como paso a la nada (Roger, 1995:222 y 235).

Este proceso `neurótico', por el que los seres humanos desarrollaron creencias sobre lo invisible extramundano -en el más allá, en Dios, etc.- para hacer frente a la más prosaica de las realidades visibles, implicó “dejar de creer realmente en la muerte (como aniquilación final, es decir, como verdadera muerte)”, lo que a su vez conllevó, paradójicamente, la desvalorización de la vida terrenal (Savater, 2007:115-116). En efecto, los intentos de adaptación por parte del ser humano a lo inadaptable supusieron "resolver la contradicción entre una vida dotada de sentido" -derivada de la conciencia inexorable de la muerte- “y una vida eterna” -emanada de la negación del carácter definitivo de la muerte. Este dilema fue resuelto en muchas culturas diferenciando entre cuerpo y alma, distinción que quedó definida por la naturaleza temporal del primero y el carácter imperecedero de la segunda ${ }^{34}$. Así, la existencia corpórea del ser humano que muere se interrumpe (o queda suspendida o se reencarna), mientras que su alma se libera de su envoltorio corporal trasladándose a 'otro mundo`. Además, para poder hacer frente y superar la contingencia del cuerpo, el dilema se conformó identificando la verdadera vida con la vida eterna del alma, mientras que la vida terrenal, con sus luces y sombras, sus sufrimientos y recompensas, no sería más que un ensayo -o un

\footnotetext{
${ }^{32}$ El "mito de la muerte-renacimiento" es una metáfora del ciclo biológico. Si, al caer sobre la tierra, la semilla renace brotando de ella una vida más pródiga, lo mismo puede ocurrir con el cuerpo: "En las conciencias arcaicas, cuyas experiencias elementales del mundo se identifican con las metamorfosis, desapariciones y reapariciones, transmutaciones..., toda muerte anuncia un nacimiento, todo nacimiento procede de una muerte, todo cambio es análogo a una muerte-renacimiento y el ciclo de la vida humana se inscribe en los ciclos naturales de la muerte-renacimiento (Morin, 1974a:115).

${ }^{33}$ El "doble", metáfora de la reproducción, es un mito universal que refleja la creencia en la supervivencia personal bajo forma de espectro (Morin, 1974a:141-165). Browker (1996:6), afirma que en este ámbito la imaginación humana ha sido muy prolífica ilustrándolo con una serie de ejemplos concretos ("todos los cuales inciden al menos en una determinada imaginación religiosa acerca del modo en que pueda ser posible la vida mas allá de la muerte”): “... si el aliento mismo (que finalmente regresa al aire en el instante de la muerte) es el aire que, después de haberlo respirado yo, podría inhalar otra persona por su parte, quizá también lo que yo he sido en vida pueda insuflarse en otra vida distinta; si el humo que desprende el fuego puede transportarse más allá de todo discernimiento hacia el cielo, quizá el humo del cuerpo al incinerarse pueda transportar la realidad de esa persona más allá de nuestro discernimiento presente;... si la serpiente se desprende de la piel y sigue viva a pesar de haber dejado atrás sus escamas muertas e inservibles, quizás también podamos nosotros despojarnos de este cuerpo y vivir en una nueva encarnadura”.
} 
espejismo- "para la auténtica existencia que llegará después” (Savater, 2007: 65-67; Bauman, 2007:cap.1).

Obviamente, este imaginario de la inmortalidad conllevaba el riesgo de desafección y desprecio hacia la vida terrenal, lo que podría derivar en sentimientos de alienación y en el abandono de las tareas diarias, ¿para qué realizarlas? ${ }^{35}$ Estas incertidumbres existenciales incapacitantes fueron eliminadas o, en todo caso, minimizadas, por el desarrollo de creencias mágicas, y sobre todo por los posteriores dogmas religiosos ${ }^{36}$, que condicionaron la calidad de la vida futura del alma a lo vivido antes de morir. Con ello, no sólo se restituía el valor a la vida terrenal, sino que incluso se la añadía un plus de inmenso valor -ya que no hay <<segundas oportunidades >>- al convertirla en la llave con la que se abrían distintas puertas de acceso a la eternidad: "la gloria sin fin” o la pesadilla del "tormento eterno". Paradójicamente, esta nueva concepción del destino "universal y no negociable” de la vida después de la muerte, restablecía asimismo la preocupación por ésta aunque con el importante matiz, como señala Bauman (2007:50), de que ese temor pasó a "representar un deber universal (y redentor)”, lo que posteriormente quedaría sintetizado en la admonición memento mori (<<recuerda que vas a morir >>). Es decir, si la proclamación de la “eternidad de la vida” facilitaba poder mirar a la cara a la muerte, el enlace cualitativo entre vida terrenal y vida eterna instaba a que esa mirada se mantuviera continuamente durante las veinticuatro horas del día, para que en ningún momento se olvidara que según cuál fuera el desarrollo de la vida terrenal sería posible alcanzar, o no, la felicidad en la vida después de la muerte ${ }^{37}$. Bauman (2007:49-50) califica de “auténtica jugada maestra” esta inversión en la concepción de la muerte ya que, al transformar "la más aborrecible de las caídas en la más gloriosa de las ascensiones”, reconcilió a los mortales con su mortalidad y, sobre todo, realzó a la vida al dotarla de "un sentido, un propósito y un valor”: “enganchó el caballo de la muerte al carro de la vida.

\footnotetext{
34 “Si no pasase una temporada ligada al cuerpo y padeciendo sus urgencias, no tendría sentido decir que el alma es $<<$ inmortal $>>$... Casi podríamos decir que el alma brota del temor a la muerte del cuerpo, o sea que no es precisamente sino el deseo mismo de inmortalidad de éste” (Savater, 2007:66-67).

${ }^{35}$ Con el objetivo de anular el poder 'anomígeno' de la muerte, todas las sociedades han elaborado su Sistema de Muerte, tal y como se analiza en el Capítulo 2 de esta Tesis.

${ }^{36}$ La religión, "fenómeno histórico surgido del desarrollo institucional y mitológico de la magia”, es para Morin (1974a: 83-84) una especie de placebo social para calmar la angustia de los individuos ante la muerte: "es una adaptación social que expresa la inadaptación humana a la muerte, una inadaptación que encuentra su adaptación”.

${ }^{37}$ A modo de ejemplo, Bauman (2007:49) resalta que el "concepto cristiano de pecado original hereditario fue un invento particularmente oportuno: aumentó aún más el valor de la vida terrenal y magnificó su significación... los herederos del pecado original se vieron impelidos a adoptar una actitud positiva ante sus tareas vitales: como nadie nace siendo inocente, sino que desde el primer momento soporta la carga de un pecado heredado, los mortales necesitan redoblar sus esfuerzos y su celo en el ejercicio de su efímero poder para ganarse la salvación. Alejarse de las malas obras no basta: además de buenas obras (tantas como sea posible), también hacen falta el sacrificio, la inmolación y el sufrimiento expiatorio autoadminstrado para lavar el estigma del pecado original, que, de permanecer, tardaría luego toda una eternidad en ser consumido por el fuego del infierno".
} 
Puso la eternidad al alcance de lo transitorio y puso a los autorreconocidos como mortales al cargo del cuadro de mandos de la inmortalidad” 38 .

Por todo ello, la emergencia de la conciencia humana de la muerte, de la que brota antropológicamente la conciencia, constituye según Morin un 'pasaporte` para la humanidad tan válido, por lo menos, como el surgimiento del útil. Se puede afirmar, por tanto, que la muerte humana, como "hecho dotado de propiedades semióticas especiales y necesitado de una consideración social que abarca sus proyecciones significativas" ${ }^{39}$, no ha sido nunca "sólo cosa de uno mismo ni sólo corpórea, sería además idea y signo importante para la sociedad” (Tornos, 1990:34-35). En efecto, además de estar en el origen de la humanidad, la conciencia humana de la muerte se constituyó en uno de los principios activos clave en el propio proceso de la construcción histórica de la sociedad, al estar éste íntimamente ligada con el desarrollo de la individualidad (Gráfico 1.1): “en la muerte, el hombre identifica al hombre como tal y se identifica a sí mismo como ser humano. La muerte une en humanidad” (Sádaba, 1991:23). Si para el homo sapiens la presencia de la muerte se convierte en un problema vivo, es decir, “que modela su vida” (Morin, 1974b:116), la inadaptación individual a la muerte sólo puede superarse, parcialmente, en sociedad, ya que ésta se constituye en el único refugio frente a la misma. Arrogándose la mayoría de los atributos de la especie, a modo de <<segunda naturaleza >>, la sociedad adapta al individuo a la muerte. Esa dialéctica inadaptación/adaptación se libera a partir de la inadaptación a la especie, lo que hace posible las adaptaciones humanas (Morin, 1974a:80-84). Sean estas adaptaciones mágicas, religiosas o de otro tipo, como la que caracteriza a las sociedades modernas: la deconstrucción de la mortalidad ${ }^{40}$. O dicho de otro modo, la sociedad es continuamente conformada por la muerte. Ejemplos paradigmáticos de ello lo constituyen los funerales y el duelo: "el duelo es la expresión social de la inadaptación del hombre a la muerte, pero al mismo tiempo es también el proceso social de adaptación tendente a restañar la herida de los individuos supervivientes” (Morin, 1974a:82).

\footnotetext{
${ }^{38}$ Desde una perspectiva cristiana, Landsberg (1995:48) señala lo siguiente sobre la necesidad que el ser humano siente de una supervivencia después de la muerte: "La muerte interpretada como definitiva, la muerte física interpretada como negación universal de nuestra existencia, no es más que el reflejo de la descreencia desesperada, una negación de sí misma por la propia persona. Si la naturaleza humana tiene necesidad de supervivencia no es ni por egoísmo ni por capricho, ni tampoco por algún atavismo histórico. Esta necesidad atestigua una estructura ontológica fundamental: la conciencia imita el ser profundo. Si no hubiera ninguna posibilidad verdadera que correspondiera a esta tendencia, la entera existencia humana se abismaría en la nada”. O, como espeta el personaje de dostoievskiano: $<<$ Si Dios no existe, todo está permitido >>.

39 "Las celebraciones funerarias primitivas... expresan una clase de reacciones vividas ante la muerte humana, las cuales solamente se explican si esa muerte daba lugar a experiencias elementales muy vivas, muy compartidas y muy diferentes de las que la incidencia de la muerte producían en otros animales superiores” (Tornos, 1990:36).

${ }^{40}$ Como se ha señalado al inicio de este capítulo, esta estrategia racionalizadora de la muerte desplaza la mirada desde el hecho biológico, universal e irremediable que es la muerte en sí, a las causas específicas de fallecimiento, que técnicamente pueden ser conocidas y controladas. Este moderno mito de la contingencia de la muerte se desarrolla en los Capítulos 2 y 3 de esta Tesis.
} 


\section{GRÁFICO 1.1. DIALÉCTICA INADAPTACIÓN/ADAPTACIÓN A LA MUERTE}

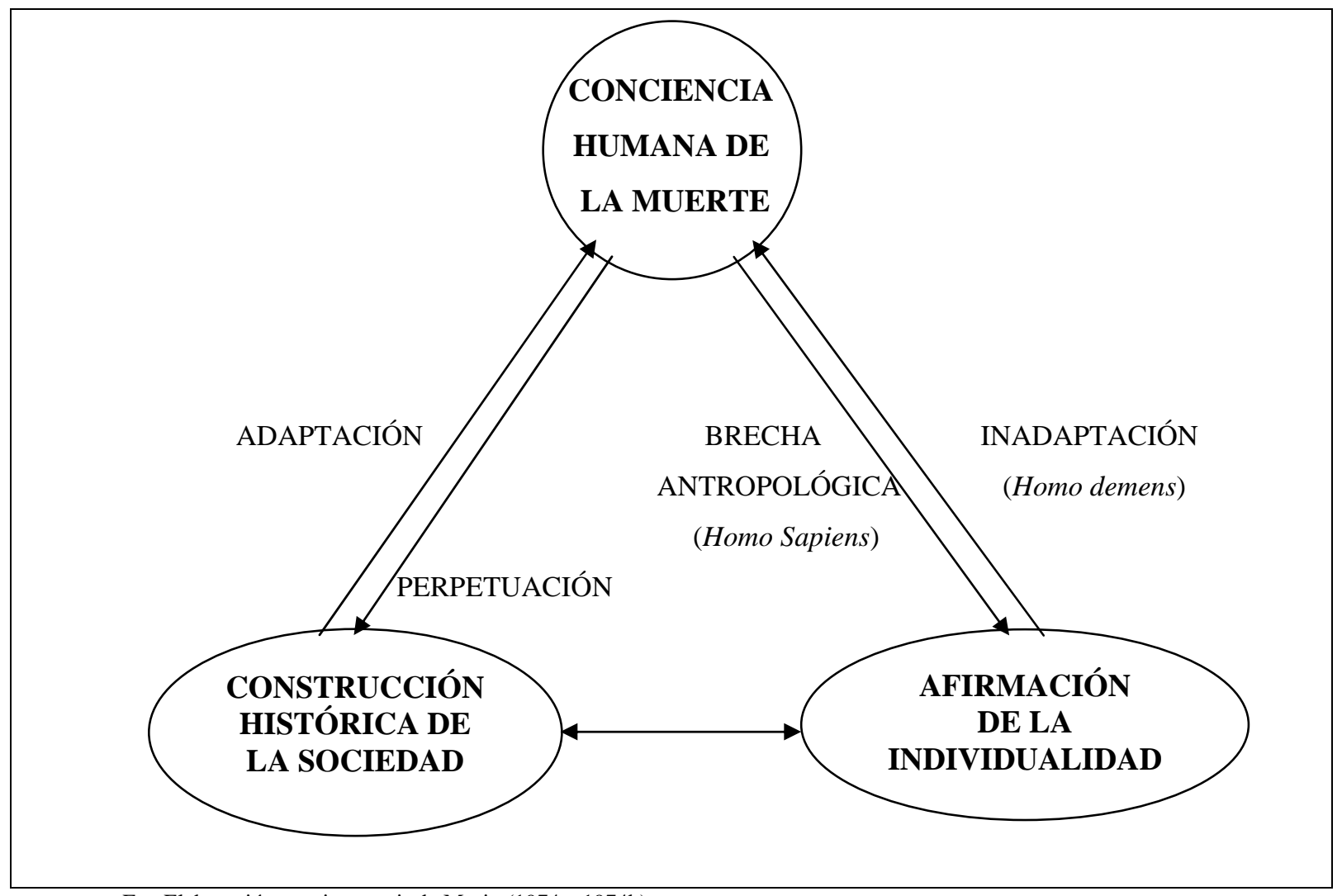

Fte: Elaboración propia a partir de Morin (1974a; 1974b).

Además de las funciones sociales adaptativas de las construcciones mágico-rituales y de sus secuelas religiosas y filosóficas, la dialéctica individuo/grupo en el enfrentamiento de la muerte juega un papel clave en el propio devenir social. En palabras de Morin (1974a:34-40): "El horror a la muerte se disipa desde el instante en que empieza a debilitarse el músculo de la afirmación de uno mismo”. Dado que la afirmación de la individualidad “choca” con la afirmación del grupo social, en las sociedades en las que existe una "presencia imperativa del grupo" se "aniquila, rechaza, inhibe o adormece la conciencia y el horror de la muerte" ${ }^{41}$. Inversamente, en las sociedades en las que el individuo se afirma sobre el grupo la angustia ante la muerte sería máxima. En el extremo, “cuando la individualidad se desprende de todo vínculo, allí donde aparece solitaria y radiante, solitaria y radiante también se alza, como un sol, la muerte”42 (Morin, 1974a:50).

Insistiendo en ese carácter esencial de la relación conciencia de muerte/individuo/sociedad, Pierre Bourdieu (2002:55-56) subraya al final de su Lección sobre la lección que la Sociología sólo

\footnotetext{
${ }^{41}$ El ejemplo universal y contemporáneo de la disolución de la presencia de la muerte por la preeminencia de lo social sobre lo individual es el estado de guerra. Éste provoca una regresión general de la conciencia y, "en el paroxismo de esta regresión, se produce la desaparición total de la conciencia de muerte” (Morin, 1974a: 41-45). ${ }^{42}$ Para Morin (1974a: 49-50), el suicidio sería el paradigma de este extremo: “todo deseo de participación huye del individuo solitario, al que ya nada retiene a una vida destinada a la desaparición. Así es como, con la propia deificación, nace la angustia extrema de la muerte, puerta abierta a la extrema tentación: el suicidio...”.
} 
podrá comprender la esencia del juego social si tiene en cuenta "algunas de las características universales de la existencia corporal”. Entre ellas destaca, precisamente, el saberse mortal. En efecto, la “corporeización” contiene ínsita un problema clave como es el hecho de que los cuerpos mueren. Problema que desde el punto de vista sociológico repercute en dos niveles: la estabilidad de las estructuras sociales, y el sostenimiento de los significados individuales que sustentan la seguridad ontológica (Seale, 1998:50). Así, en el análisis que Bourdieu (1999:cap.6) realiza sobre la justificación del sentido de la existencia humana en sus Meditaciones pascalianas, donde aborda la cuestión de la legitimidad de la existencia individual ("derecho de un individuo a sentirse justificado de existir como existe") en las sociedades modernas, establece un vínculo necesario entre "tres hechos antropológicos indiscutibles e indisociables”. Los dos primeros coinciden con los señalados por Morin: el ser humano es y se sabe mortal y el pensamiento de que va a morir le resulta insoportable o imposible. El tercero, sin embargo, obvia la rebelión-proyección transmundana de Morin, el "mito de la contingencia de la muerte”. Supone la cruda asunción del desamparo y la soledad metafísica individual y, en consecuencia, la búsqueda de sentido en el más acá, en la propia <<sociedad>>: “condenado a la muerte, fin (en el sentido de término) que no puede ser tomada como fin (en el sentido de objetivo), puesto que representa, según la sentencia de Heidegger, <<la posibilidad de la imposibilidad>>, es un ser sin razón de ser, poseído por la necesidad de justificación, legitimación, reconocimiento. Pero, como sugiere Pascal, en esa búsqueda de justificaciones para existir, lo que llamamos $<<$ el mundo $>>$, o <<la sociedad >> es la única instancia capaz de rivalizar con el recurso a Dios” (Bourdieu, 1999:316).

Sin nada a lo que asirse por arriba y desplazado del centro de sí mismo, el ser humano busca refugio en la <<sociedad>>, es producto de la exterioridad (Rodríguez López, 2002:111-112). Ser que sólo es un ser social, y eso en tanto que únicamente la sociedad justifica el sentido de su "singular particularidad” ${ }^{43}$, a través de "su relación distintiva y jerárquica respecto al resto de los individuos y de los grupos en los que vive”. No es extraño, por tanto, que Bourdieu finalizase su Lección sobre la lección afirmando que "es la sociedad, y sólo ella, quien dispensa, en grados diferentes, las justificaciones y las razones de existir... a fin de cuentas, Dios no es otra cosa que la sociedad. Lo que se espera de Dios sólo se consigue de la sociedad, que es la única que tiene poder de consagrar, de salvar de la facticidad, de la contingencia, de la absurdidad..."44.

\footnotetext{
${ }^{43}$ Tomando como referencia a Joseph K., protagonista de la novela de Kafka, El Proceso, Bourdieu (1999:cap.6) analiza la incertidumbre respecto al porvenir cuando se desvanece el ser social, la identidad.

${ }^{44}$ En este mismo sentido se expresa Savater (2007:40-41) cuando señala que conocer "nuestra mortalidad no consiste meramente en anticipar nuestro cese, así como el de todos y todo lo que apreciamos: sabernos mortales es ante todo sabernos abocados a la perdición. Lo más grave no es precisamente no durar, sino que todo se pierda como si jamás hubiera sido... sólo el amor en lo personal y el reconocimiento público en lo social mantienen la ilusión de que no estamos perdidos del todo: más tarde llega la muerte e intuimos que nadie volverá a recogernos jamás”.
} 
Haciendo abstracción de cuáles sean las funciones adaptativas frente a la muerte socialmente dominantes, si es que no coexisten varias como ocurre en las sociedades desarrolladas, y al margen de otras críticas $^{45}$ al mismo, el esquema elaborado por Morin tiene la virtualidad de destacar la continua retroalimentación entre la conciencia humana de la muerte y el propio desarrollo social. En este sentido, y como resaltan Huntington y Metcalf (1979), la vida social llega a ser transparente sobre el fondo de la muerte. Ésta revela la mayoría de los procesos sociales y los valores culturales; es un catalizador que, cuando entra en contacto con cualquier orden cultural, precipita las expectativas, preocupaciones y creencias básicas de las personas (Kearl, 1995:5). La muerte, por tanto, es un principio estructurador de la vida social ${ }^{46}$. Una suerte de "bóveda" que cubre, define y limita la estructura social (Marías, 1993:381). Asimismo, a la par que se produce esa "realización” vital y social, de modo circular actúa otro proceso de retroalimentación por el que múltiples factores que condicionan la vida de los individuos en sociedad determinan los de su enfermar y morir.

\subsection{MUERTE ANIMAL, MUERTE HUMANA}

“La evolución de la vida ya no es un fenómeno natural” C. Venter

\footnotetext{
${ }^{45}$ Para Morin, como se ha señalado, en el horror a la muerte estriba tanto el origen mismo como el poder de toda empresa religiosa. La religión con su capacidad para generar imágenes persuasivas ofrece paraísos compensatorios a quienes no pueden afrontar su condición de realidad efímera. Este análisis, compartido por muchos autores, entre ellos Marx y Freud, no se corresponde, según Bowker (1996), con la realidad. Para abordar esta cuestión Bowker (1996:27) se pregunta “¿en qué creían nuestros más remotos antepasados?” y, a partir de la poca evidencia empírica existente, se responde a la par que extrae diversas conclusiones: a) de los mismos datos arqueológicos pueden extraerse inferencias opuestas. De hecho, poco puede decirse de lo que pensaban nuestros antepasados sobre la muerte, aunque sí se puede decir mucho sobre qué hacían respecto a ella (p.28); b) no existió uniformidad sino una diversidad extrema en los modos en que los individuos y las comunidades afrontaron el hecho de la muerte (desde la derrota y el castigo hasta la liberación y la oportunidad) y, por tanto, no cabe la generalización: no es posible hallar una única y sencilla conexión entre la muerte y los orígenes de las religiones aplicable, por ejemplo, a las sociedades de las cuales no existan datos concretos (p.2834); c) "los comportamientos de los hombres están controlados, en lo que a su resultado atañe, por constricciones múltiples, y no por teorías abstractas. El hecho fundamental es bien claro: cuando tenemos acceso a las reflexiones sobre la naturaleza de la muerte y sobre la posibilidad de una existencia más allá de la muerte, resulta que... abrumadoramente, la muerte era considerada como algo que era preciso posponer tanto como fuese posible, ya que nada hay después de la muerte que se pueda desear, en tanto en cuanto pueda ser un lugar de compensación o de bienaventuranza. Para nuestros antepasados, no existía ningún futuro, definitivamente, en el hecho de la muerte” (p.46); d) de los datos disponibles sobre la más temprana imaginación religiosa se sigue que "es la vida la que resulta de todo punto natural y la muerte de todo punto antinatural, en el sentido de que tronza y quiebra lo que de otro modo habría sido la circunstancia natural y continuada de la vida” (p.47); y e) las exploraciones religiosas más antiguas se centraban sobre todo en el "desorden y en la disrupción de la muerte, en cómo mantener el orden a despecho del caos y de la malevolencia y del deliberado deseo del mal” (p.58).

${ }^{46}$ Aunque permanezca oculto, es el caso de las sociedades más desarrolladas, tal y como se interroga retóricamente Basterra (2006:23): “¿Qué hace, sino negar la muerte, aquel que se pasa la vida acumulando riquezas mucho más allá de lo que podría disfrutar realmente? Cuando una persona se pasa la vida labrando ascéticamente una contabilidad moral, ¿qué hace sino presentar un balance para la otra vida o de cara al final
} 
En una de sus sentencias más conocidas Séneca afirma que “después de la muerte todo acaba, hasta la muerte”. En un sentido literal, no metafórico, esto significa que la muerte es el final de la vida; es decir, que sólo los seres vivos mueren. En efecto, en la utilización cotidiana de metáforas es habitual expresar que todo lo que acaba (real o imaginariamente) muere. Así, se habla de la "muerte del rock”, de la “muerte de la novela”, de la "muerte de las ideologías”, etc. Siguiendo a Ferrater Mora (1986:10-11), lo correcto sería referirse a que "todas las realidades, incluyendo las orgánicas y la humana, dejan de existir o cesan, y que las realidades orgánicas y la humana, dejan de vivir o mueren”. Este autor señala la existencia de un gradiente en el que sus <<conceptos-límites >> serían la “pura cesación” y en el otro extremo la "muerte humana”. Gradiente caracterizado por que "toda muerte es cesación, pero no toda cesación merece llamarse <<muerte>>”. En este epígrafe se aborda primero el interrogante de si la conciencia de muerte es una característica exclusiva de los seres humanos o si también está presente en otros seres vivos; posteriormente se realiza una aproximación a la biología de la muerte con el objetivo de responder exclusivamente al por qué de la muerte biológica. Obviamente, este último análisis es en sí mismo insuficiente al no abordarse un "aspecto crucial de la cuestión” y que es anterior a la muerte biológica: la muerte física, la muerte de la naturaleza inorgánica ${ }^{47}$.

\title{
1.4.1. ¿POR QUÉ SÓLO “MUEREN” LOS SERES HUMANOS? ${ }^{48}$
}

\author{
"Que la vida iba en serio \\ uno lo empieza a comprender más \\ tarde \\ -como todos los jóvenes, yo vine \\ a llevarme la vida por delante. \\ Dejar huella quería \\ y marcharme entre aplausos \\ -envejecer, morir, eran tan sólo \\ las dimensiones del teatro. \\ Pero ha pasado el tiempo \\ y la verdad desagradable asoma: \\ envejecer, morir, \\ es el único argumento de la obra” \\ J. Gil de Biedma
}

Desde la dimensión existencial la especie humana es un caso especial entre las especies animales. En ella se puede percibir "algo <<transanimal >> y ver en ello su esencia propia” (Jonas,

ecuánime de ésta? Los que se pasan su vida demostrando que existe una vida más allá de la muerte o los que pretenden lo contrario, ¿qué hacen si no servir a la muerte?”.

${ }^{47}$ Un análisis de esta cuestión se aborda por ejemplo en Thomas (1983:19-33) y en Ferrater Mora (1986:23-67).

${ }^{48}$ En Thomas (1983:82-119) se analiza de forma extensa las diferencias entre la muerte animal y la muerte humana, incluyendo las perspectivas etológica y antropológica. 
1998:39). Entre las propiedades en las que se asienta esa distinción está el que sus miembros son los únicos seres vivos potencialmente conscientes de que la muerte les aguarda, los únicos con capacidad para saber que tienen que morir y, en consecuencia, los únicos que pueden desarrollar "una vida propia dentro de unos límites temporales determinados"; de hecho, "sólo nosotros hemos puesto nombre a la muerte” ${ }^{49}$ (Bauman, 2007:70; Sádaba, 1991:31). Conocimiento de la muerte que es fruto de la reflexión, pero sobre todo, según Voltaire, lo es por la experiencia ${ }^{50} 51$.

Este conocimiento aprehendido determina que para los seres humanos la muerte rebase el ámbito objetivo de lo biológico y se transforme en un fenómeno bio-social que les plantea inquietantes interrogantes a los que ni la Biología ni la Fisiología por sí solas pueden responder. Conviene recordar en este sentido, con Baudrillard (1980:185-192), que ya muchas culturas ancestrales, que no han dispuesto de los conocimientos aportados por la ciencia moderna (objetividad e irreversibilidad de la muerte biológica), "afirman que la muerte comienza antes de la muerte, que la vida continúa después de la vida y que es imposible discriminar la vida de la muerte”. Es decir, sin un concepto biológico de la muerte, ésta es para esas culturas exclusivamente una relación social con un agente externo: "toda muerte es social, pública, colectiva, y es siempre la consecuencia de una voluntad adversa que debe ser absorbida por el grupo”. Por su parte, el resto de las especies animales al no ser conscientes de la determinación biológica, y social, de la muerte viven como si ésta no existiera. Así, aunque mueren, viven como si fueran inmortales.

No obstante, algunos autores no comparten esta afirmación y han resaltado que la doble dimensión de la muerte (biológica y social) no es privativa de la especie humana. Esta discrepancia hay que enmarcarla en el contexto más amplio y profundo de una impugnación general a las características tradicionalmente empleadas en la identificación de lo que hace "especial” al ser humano respecto al resto de las especies animales, las fronteras del no man's land antropológico, y que entronan el especieismo ${ }^{52}$. Impugnación que por otra parte ha recibido un fuerte empuje en los últimos

\footnotetext{
${ }^{49}$ Citando a Maurice Blanchot, Bauman (2007:46-47) sugiere que "del mismo modo que el hombre sabe de la existencia de la muerte sólo por el hecho de ser hombre, sólo es hombre porque es una muerte en proceso de materialización”.

${ }^{50}$ La conocida sentencia de Voltaire recogida en su Dictionnaire philosophique dice exactamente: "La especie humana es la única que sabe que ha de morir, y lo sabe sólo por la experiencia”. Morin (1974:62-63) niega la posibilidad de que ese conocimiento sea aprehendido por el ser humano a través de la <<experiencia>>, entendida ésta como algo interno al propio individuo, sino que la muerte humana es una adquisición del individuo, en el sentido de un saber que le viene del exterior. Otra revisión crítica de la sentencia de Voltaire puede verse en Landsberg (1995).

${ }^{51}$ Voltaire añade: "Un niño criado solo y llevado a una isla desierta no tendría mayor noción de esto (la muerte) que una planta o un gato".

52 Término acuñado por Richard Ryder en 1970, recogido por el Oxford English Dictionary, para designar la "discriminación o explotación de ciertas especies animales por los seres humanos, basada en una presunción de superioridad del género humano”, citado en Singer (1997:173). Según este autor, la mayoría de los seres humanos son especieistas y las dos formas principales de especieismo en las sociedades contemporáneas son la experimentación con animales y el consumo de carne (Singer, 2003:cap.5).
} 
años al constatarse, gracias a los avances de la Genética, la escurridiza naturaleza de la frontera biológica que separa a los seres humanos de los otros grandes simios: el animal humano es un pariente genético muy próximo de los chimpancés, con los que comparte el 98,4\% de ADN, y de los gorilas y los orangutanes, con los que el porcentaje de ADN común es un poco menor (Singer ${ }^{53}$, 2003:181). En efecto, comprobada mediante observación la capacidad que tienen algunas especies animales no sólo para utilizar sino también para construir los útiles necesarios para alcanzar sus objetivos ${ }^{54}$ racionalidad de primer grado-, lo que diluye la distinción atribuida al homo faber y cuestiona en cierta medida al homo sapiens, y rebatida empíricamente también la exclusividad de la capacidad de comunicación a través del lenguaje de los seres humanos ${ }^{55}$, homo loquax, no cabe ya mantener, según Singer (1997:cap.8), unas fronteras de conformación religiosa, que construidas sobre unas diferencias limitadas entre los seres humanos y otras especies se han materializado sin embargo en una separación absoluta "entre $<<$ nosotros $>>$ y $<<$ ellos $>>$ ".

Es cierto desde Darwin que el análisis científico de la historia evolutiva ha mostrado que las diferencias entre los seres humanos y otros animales no humanos son diferencias de grado, no de clase. Es cierto asimismo que algunos de estos animales no humanos son conscientes de su propia existencia ${ }^{56}$ y pueden razonar. Sin embargo, quedan al menos otras dos características diferenciadoras de los seres humanos más difíciles de objetar. Por un lado, al hilo de ser los únicos que se percatan conscientemente de sus propios procesos de pensamiento y de que poseen "intereses críticos" -los conectados con las convicciones más profundas acerca del modelo de vida que se considera más valioso-, los seres humanos tienen la capacidad de hacer proyectos alternativos de futuro y escoger entre ellos, es decir, de prever las consecuencias de sus propias decisiones -racionalidad de segundo

\footnotetext{
${ }^{53}$ Apoyándose en Darwin (El origen del hombre) y en los trabajos más recientes de Richard Dawkins, Singer (2003; 1997) llega a afirmar que existe una continuidad evolutiva incontestable entre los humanos y los otros grandes simios, integrantes todos ellos de la misma familia y del mismo género, continuidad rota por la muerte de los tipos intermedios entre ellos, por lo que "no se puede descartar la posibilidad de que los humanos y los chimpancés se crucen” (Singer, 1997:176-179).

${ }^{54}$ Son paradigmáticos de esta evidencia empírica los trabajos de Dian Fossey (1988) con gorilas en los Montes Virunga, en la frontera entre Zaire, Ruanda y Uganda, y sobre todo los de Jane Goodall (1986) con chimpancés en la región selvática próxima al lago Tanganika. Esta etóloga, por ejemplo, no sólo comprobó que los chimpancés utilizaban herramientas, palos, para capturar termitas dentro de un hormiguero, sino que incluso las fabricaban dando forma a los palos para conseguir mejor sus objetivos.

${ }^{55}$ Singer (1997:cap.8) señala que la incapacidad física de chimpancés o de gorilas para producir palabras, al no disponer de las cuerdas vocales necesarias, no les impide sin embargo aprender, comprender y utilizar un gran número de signos que les permite comunicarse. Cita varios ejemplos para demostrarlo y entre ellos destaca el caso de la chimpancé Washoe que, educada desde cría con el lenguaje americano de signos, lo utilizaba para comunicarse con sus cuidadores, con otros chimpancés e, incluso, para sí misma cuando no había nadie alrededor.

${ }^{56}$ En Desacralizar la vida humana, Singer (2003) hace referencia a toda una serie de ejemplos que muestran cómo distintas capacidades, como la de sentir dolor, la de actuar intencionadamente, la de resolver problemas, la de comunicarse y relacionarse con otros seres, y diferentes características, como la autoconciencia, el sentido de la propia existencia a lo largo del tiempo, la curiosidad, y el tener interés por otros seres, no son privativas de los seres humanos. Por su parte, la primatóloga C. Maté (2005:137) señala que el escepticismo con el que se tiende
} 
grado- (Puigpelat, 1998:2), lo que mantiene cualitativamente en vigor la distinción atribuida al homo sapiens.

Por otro lado, y en estrecha relación con la característica anterior, los seres humanos se enfrentan a la triple constante antropológica de la muerte ligada al desarrollo de la individualidad (conciencia de muerte, horror a la muerte y creencia en la inmortalidad), que, retomando a Morin (1979b), supone un salto cualitativo en el conocimiento realista del homo sapiens al rebasar la percepción de la muerte como un mero hecho, como les sucede al resto de los animales, y tomar plena conciencia de que supone el tránsito de una realidad a otra, lo que enlaza con la presencia del tiempo en su conciencia y la emergencia de nuevas formas de percepción de la realidad. Centrando el análisis en esta segunda característica, es cierto que se ha observado que en otras especies animales también existen presentimientos de la muerte propia y que los miembros de algunas de ellas, incluso, manifiestan dolor y desarrollan cierta ritualización ante la muerte de un pariente y/o congénere ${ }^{57}$, lo que ha llevado a algunos autores a concluir que la dimensión social de la muerte, “contrariamente a lo que se ha sostenido durante siglos, no es ni mucho menos, una prueba de <<humanidad >>" (Rodríguez, 2002:58 $)^{58}$. Sin embargo, esas reacciones ante la muerte ¿significan realmente que los animales no humanos tienen conciencia de la proximidad de la muerte?, ¿que saben que la muerte es inevitable, es

a reconocer la vida emocional de otros animales viene determinado porque "lógicamente esto también conlleva una reivindicación de su conciencia moral”.

${ }^{57}$ C. Maté (2005) relata las reacciones de distintos mamíferos ante la muerte de alguno de sus compañeros de grupo. Describe especialmente el caso del gorila Koko, que aprendió a utilizar más de 1.000 palabras del lenguaje americano de signos, $\mathrm{y}$, sobre la base de fragmentos transcritos de $<<$ conversaciones $>>$ con KoKo, afirma que éste "también ha adquirido la habilidad de comunicar pensamientos y sentimientos acerca de la muerte”. Por su parte, Mosterín (1995:70-71) refiere el caso de los elefantes y cita literalmente las descripciones realizadas por Cyntia Moss, quien pasó 30 años observándolos: "Cuando un elefante muere, toda la manada se preocupa. Si se trata de una cría, su madre permanece junto al cadáver varios días e incluso trata de transportarla consigo con ayuda de su trompa y sus colmillos. El resto de la manada permanece a su lado o reduce el paso. Cuando muere un adulto, los otros elefantes tratan de levantarlo y no se separan de él hasta que sus restos entran en putrefacción. A veces velan el cadáver, ahuyentando a los carroñeros, e incluso medio lo entierran con hojarasca. La muerte de la matriarca de la familia causa general consternación y puede conducir a la disgregación del grupo entero (Mosterín, 1995:71) [MOSS, Cynthia (1992): Los elefantes, Barcelona, Plaza y Janés).

${ }^{58}$ En su análisis sobre la muerte humana/muerte animal, este autor (Rodríguez, 2.002:cap.2), basándose en estudios sobre elefantes, lobos y chimpancés asume que algunos mamíferos (incluso algunas aves sociales) "disponen de un sistema de referencias y valores que les hace reaccionar mediante gamas emocionales diversas -idénticas a las nuestras- debajo de las cuales subyacen, necesariamente, ideas, conceptos y sentimientos equivalentes a los nuestros" (p.59). Con estas premisas, afirma que esas especies animales son especialmente "sensibles" a la muertes "ilógicas" (las que no se producen por edad avanzada) (pp.62-72). Estrechamente relacionado con esto, señala que "no tiene por qué haber una relación directa entre el hecho de tener conciencia de la muerte, enterrar a los fallecidos y practicar algún ritual o religión propiamente dicha... (porque)... cada especie, ante la muerte de sus congéneres, parece comportarse en función no sólo de su complejidad cerebral sino, particularmente, de su estructura de organización social (que determina qué destino puede tener el cadáver) y de los estímulos ambientales y/o socioculturales que señalan como <<natural $>>$ o no determinadas circunstancias de muerte (y, por ello, predeterminan gran parte de la reacción emocional que se desata ante esa eventualidad)" (p.74). A la exposición de Rodríguez se puede contraponer la de Zuckermann, recogida por Morin (1983:98), quien sobre la base de observaciones a animales similares a las descritas por aquél, concluye 
decir, que van a morir?, ¿que saben que ellos deben morir? Resulta arriesgado responder de forma afirmativa a los tres interrogantes, toda vez que, como alerta Thomas (1983:97), no existe una evidencia empírica amplia, obtenida sistemáticamente, que aporte una luz concluyente en ese sentido. Por ello, se asume, con Toynbee (1989:9-10), que si bien algunas especies no humanas lloran la pérdida de un compañero, sólo los seres humanos pueden ser conscientes de su finitud, de que la muerte ya "arrastró" a innumerables generaciones anteriores y de que inevitablemente arrastrará a las generaciones futuras.

En efecto, asumiendo la existencia de actividad psíquica en los animales se debe evitar, sin embargo, caer en el error de realizar interpretaciones antropocéntricas asimilando el comportamiento de los animales a lo que se conoce de la psicología humana (Leep, 1967:31). De esta forma, por ejemplo, la muerte de una de sus crías, y "la presencia de su cadáver aún tibio”, provoca en algunas hembras de mamíferos comportamientos similares a los del duelo de una madre humana; sin embargo, los mismos no demuestran en absoluto que esa percepción inmediata de la muerte constituya un saber propiamente dicho sobre ella, y mucho menos un saber de su necesidad (Landsberg, 1995:22). Según afirman los especialistas en psicología animal, los animales, incluidos los psíquicamente más desarrollados, únicamente perciben el presente, carecen por completo de la noción de futuro y, por tanto, de lo contingente, y mucho menos tienen cualquier capacidad de abstracción. Ferrater Mora (1986:173) añade que los animales son ciegos a la muerte, porque ésta es una forma simbólica, y son incapaces de simbolización ya que para ello su inteligencia se debería liberar de su "servidumbre biológica”. Es decir, los comportamientos de los animales se han de explicar de otra forma ${ }^{59}$ porque sus "supuestos" presentimientos de la muerte no son tal cosa. Por instinto, los animales perciben claramente los peligros inminentes que les acechan, incluido el de la proximidad de la muerte; sin embargo, están psicológicamente incapacitados para abstraer de la muerte de sus congéneres que la muerte está en la esencia de su naturaleza (de su especie), y que, tarde o temprano, han de, y tienen que, morir.

Aunque enmarcada dentro de las posiciones del darwinismo clásico, resulta sugerente en este punto el matiz (la hipótesis) aportado por Morin (1974a:57-66) para quien "la vida animal no implica tanto una verdadera ignorancia de la muerte, (...) como una adaptación a la misma, es decir, una adaptación a la especie”. Es ésta quien de verdad conoce a la muerte y no tanto el individuo, que es ciego a ella. La “clarividencia” de la especie es la condición necesaria para su propia supervivencia, y

que "los monos y los antropoides no reconocen a la muerte, puesto que se comportan con sus compañeros muertos como si éstos estuvieran vivos pero pasivos”.

59 “El animal es sólo especie, y son los hombres quienes, por vía de la proyección antropomórfica ven en él también al individuo” (Leep, 1967:31). 
se asienta en "el instinto" 60 , que permite superar las contingencias ambientales, y en la muerte $<<$ natural $>>$ ínsita ${ }^{61}$ de sus individuos, que permite el rejuvenecimiento constante de la especie. De esta forma, "la ley de la especie que se defiende contra la muerte no sufre cambio por la muerte de los individuos, antes bien continúa inmutable, y precisamente para defenderse contra ella” (Morin, 1974a:62). Esta afirmación de la especie sobre el individuo determina que la individualidad animal no tenga sentido en sí misma, no se pueda oponer a la especie, sino que la confirme en todo momento. Así, la ceguera del individuo (animal) ante la muerte sólo puede entenderse sobre el marco de fondo que constituyen las relaciones individuo/especie, y la ausencia de conciencia de la muerte no sería más que el corolario de la adaptación del individuo a la especie. Dado que "la conciencia sólo puede ser individual y supone una ruptura entre la inteligencia específica, es decir, el instinto, y el individuo”, éste sólo ejecuta las operaciones que resultan posibles dentro de su especie, es decir, sólo puede tener la conciencia que ésta le "permite”. Al no ser consciente de su individualidad, un animal no puede ser consciente de su propia muerte. Esto no significa que se pueda hablar de que haya ignorancia animal de la muerte. La especie "sabe" de la muerte y por eso dota a cada uno de sus individuos (conducta prefijada filogenéticamente) de un instinto <<lúcido >> ante el peligro inmediato de muerte, aunque sean ciegos a su propia muerte o a la de otros.

Se ha diferenciado más arriba entre cesar, o dejar de existir, y morir, o dejar de vivir, y se ha señalado que las realidades orgánicas y los seres humanos además de cesar dejan de vivir o mueren. La ausencia de conciencia de muerte por parte de los animales determina que su vivir ${ }^{62}$ no esté tamizado por la (su) muerte; su óbito es un mero proceso biológico y, por tanto, en sentido estricto no se puede hablar de que mueren, sino de que dejan de vivir (Arregui, 1992:88). Por el contrario, la muerte de los seres humanos ${ }^{63}$, aquellos que además de vivir "hacen su propia vida” ${ }^{64}$, es el cesar inorgánico y el

\footnotetext{
${ }^{60}$ Los instintos constituyen el sistema rector de la vida de los animales determinando sus comportamientos. "Es un sistema de desarrollo y de vida. Es también un formidable sistema de protección ante cualquier peligro mortal”. Protege de la muerte-agresión, de la muerte-peligro (Morin, 1974a:58).

61 "Cuando la especie procura la muerte natural de sus individuos, se está protegiendo a sí misma” (Morin, 1974a:58).

${ }^{62}$ Ferrater Mora (1986:110-114), siguiendo a Zubiri, diferencia entre los seres vivientes que <<están viviendo>> y los seres humanos que además <<están haciendo su vida >>. Refiriéndose a los seres vivientes señala que lo que hacen no es $<<$ su vida $>>$, sino parte de la vida de la especie a la que pertenecen. Para hacer su propia vida sería necesario que no se limitaran a girar entorno al círculo del hierro de su especie, que la especie se convirtiera en comunidad, y ésta en sociedad. Ello supondría una relación entre individuo y la especie que, además, de $<<$ natural $>>$ fuera asimismo <<cultural >>. De aquí deriva que la sociedad humana es menos "específica" que el resto de las especies.

${ }^{63}$ Frente a las corrientes (dualistas) de pensamiento que defienden que en el ser humano, a diferencia del resto de animales, hay un <<principio >> fundamentalmente distinto del cuerpo, se asume como planteamiento de fondo en esta cuestión lo propugnado por Ferrater Mora (1986:106-109): "el ser humano no tiene, propiamente hablando, un cuerpo, porque es más bien un cuerpo -su propio cuerpo-. (Es decir) el hombre es un modo de ser cuerpo -lo que incluye las relaciones entre este cuerpo y el mundo circundante-. Así, si el hombre se distingue de otros seres biológicos no es porque, a diferencia de ellos, posea alguna realidad además del cuerpo: es por el modo como el cuerpo, su propio cuerpo, es y funciona... El ser humano no es una realidad, o conjunto de realidades, unificadas por cierto elemento o principio existente $<<$ más allá $>0<<$ más acá >> de él”.
} 
dejar de vivir biológico ya que el ser humano no muere aparte de su materia y de su cuerpo, pero simultáneamente es algo más (Ferrater Mora, 1986:169). Como gráficamente apunta Arregui (1992:88), la narración de una muerte humana no es una necropsia, ya que la muerte no es una mera cesación del vivir ajena a éste y cerrada sobre sí misma. Reconocer, en todas sus consecuencias, esa "peculiar” dimensión de la muerte humana es básico al analizar su significado, como alertaba Feifel (1959:128) al denunciar la profunda equivocación que constituía considerar la muerte humana sólo un acontecimiento puramente biológico, ya que "las actitudes relacionadas con ella y el significado que le da el sujeto puede servir como un principio organizador importante para determinar cómo se comporta en la vida”.

En efecto, enfocar toda la atención en los aspectos puramente biológicos de la muerte significaría excluir los factores que hacen que el deceso de un ser humano sea una muerte y no un mero dejar de vivir (Arregui, 1992:cap. 2). En la construcción de este matiz diferencial tiene una importancia determinante, como subraya Thomas (1983:12), la dimensión social que lo rodea: las creencias en el más allá, los mitos sobre la supervivencia y renacimiento de los difuntos, los ritos y símbolos funerarios, etc., hacen que, entre todas las especies animales vivas, sólo para la especie humana la muerte esté omnipresente a lo largo de toda la vida. La especie humana es la única especie animal para la que la muerte como hecho de la cultura predomina sobre el hecho natural de la muerte biológica.

Todo ser humano vive y muere en el cruce de un substrato biológico, más o menos determinado, y un entorno social, más o menos cambiante. Sobre este juego de fuerzas que le mediatizan el individuo concreto construye su vida y su muerte. Las fuerzas biológicas internas le hacen naturalmente ciego a la muerte, pero la aprehensión de la misma desde el exterior le hacen consciente de su existencia, y las fuerzas sociales, a modo de amortiguadores, “calman” ese conocimiento adaptándole a la vida. El saber de la muerte ${ }^{65}$ traumatiza al ser humano individual que puede anticipar su muerte futura y queda horrorizado ante la disolución de la propia individualidad. Esto le obliga a "reasumirla sin cesar" y a actuar frente a su posibilidad, a tenerla presente ya, como

José Luis Sampedro se refiere asimismo a la "unidad” del ser humano de forma mucho más poética: "Mi piel es la frontera: afuera queda el mundo, que existe según lo interpreto. Todo cuanto soy llena este recinto, a la vez defensivo y permeable, con millones de sensores advirtiendo el dolor y abriéndome al placer. La vista o el oído pueden perderse, pero mi piel envejecerá conmigo hasta el fin, dándome la fiesta de los roces, el tacto febril de los encuentros, el éxtasis de las caricias...”

${ }^{64}$ A diferencia del resto de las especies, "se incorporan a un proceso histórico en el curso del cual sobrevienen cambios que, aunque apoyados en realidades naturales no obedecen -o no obedecen solamente- a las leyes de la Naturaleza... (De esta forma) hacer la propia vida significa sacrificar las posibles conveniencias e intereses de la especie a las exigencias de la realidad objetiva”.

${ }^{65}$ En ese saber de la muerte, Arregui (1992:88-96) analiza las diferentes posiciones de autores que consideran que existe una diferencia esencial entre la muerte impersonal de otro y la propia muerte. Mientras que la primera 
una sombra en todas sus actividades diarias. Según Morin (1974a:63), esta reacción ha sido común a todos los seres humanos de todos los tiempos y de todas las culturas y "se nos impone como un hecho psicológico y sociológico". Por tanto, en esa dialéctica resulta ineludible considerar además "la perspectiva biográfica $^{66}$, que es la específicamente humana” (Arregui, 1992:87). Siguiendo a este autor, "un animal se limita a vivir y a morir, pero no tiene que asumir ni su vida ni su muerte. En la medida que un animal ni conoce ni asume su término, vive en verdad como si fuera inmortal, pues no se relaciona con su propia muerte. En consecuencia, la vida animal no es propiamente hablando mortal, no es una vida que se sabe limitada en el tiempo, sino que el animal vive su vida como si fuera inmortal. Por el contrario, el hombre tiene que establecer una relación con su propia muerte, adoptar una conducta respecto de ella, o sea, ha de asumir en su existencia su propia muerte... De ese modo, el hecho del deceso futuro es asumido ya por la vida humana. Por eso, la muerte animal y la humana son esencialmente distintas: un animal se limita a morir, y su óbito es un puro suceso biológico, mientras que el hombre sabe que muere y se relaciona con su propia muerte, por lo que ésta adquiere una dimensión biográfica” (Arregui, 1992:87-88).

En consecuencia, al ser los únicos en saber, pensar, sentir, y prever que existe la muerte, los seres humanos son los únicos que de verdad mueren. Su vida queda permanentemente calificada por la muerte: los seres humanos no sólo mueren en un momento determinado, sino que son siempre mortales. De acuerdo con Morin, Arregui (1992:55) resalta que éste es precisamente el exponente máximo de la condición humana y, retomando la definición que los griegos aplicaban para diferenciar a los hombres de los dioses y los animales, señala que en este sentido, los seres humanos pueden definirse a sí mismos como "nosotros, los mortales".

En los Capítulos 2 y 3 de esta Tesis se examinan las distintas estrategias `neuróticas' de adaptación derivadas de la conciencia humana de la muerte que conviven en las sociedades más desarrolladas, con sus correspondientes mitos de la contingencia de la muerte. No obstante, cabe adelantar que en una de esas estrategias, la correspondiente al <<modelo moderno de muerte>>, dominante en la actualidad en esas sociedades, la muerte, como hecho inevitable de la naturaleza, ha sido deconstruida en diferentes procesos contingentes de muerte privada, cada uno con su propia causa evitable. De esta forma, la muerte deja de ser considerada inherente a la naturaleza humana y pasa a

es "perfectamente comprensible" desde las leyes biológicas de la especie, la otra (la propia o la de una persona amada), vista desde la biografía y la relación personal, es inasimilable.

66 "El ser humano es un ser biográfico, un sujeto no sólo porque posee una autoconciencia intelectual sino también porque puede ser objeto de la propia conducta. Conocerse y tomarse como objeto de la propia conducta implican un alto grado de reflexividad y por eso se dice que una existencia subjetiva es una existencia reflexiva. Ahora bien,... una existencia es reflexiva cuando mantiene una relación consigo misma, cuando no se agota en ser lo que es, sino que ha de asumirse a sí misma. Un animal, por el contrario, se limita a ser lo que es y a realizar las conductas que realiza, pero no mantiene una relación consigo mismo y con su conducta" (Arregui, 1992:87). 
ser percibida como algo que viene de fuera, un ente ajeno con vida propia. Además de esta neutralización como hecho natural, los grandes avances científico-técnicos han conformado un concepción no aleatoria de la misma, ya que en última instancia se trataría de enfrentarse a un problema resoluble técnicamente. Para comprobar si esto es así, resulta inevitable abordar en primer lugar los planteamientos teóricos de los científicos de la vida -"la manera biológica de pensamiento", para constatar qué hay de verdad, como afirman éstos, en que la muerte es una catástrofe biológica ineludible y necesaria. Es decir, ¿cuánto de razón tenía en el texto de P. Weiss (2000:57-58) el personaje libertino en lo privado y conservador en lo público, el Marqués de Sade, cuando afirmaba lo siguiente al personaje revolucionario en lo social pero conservador en lo particular, J-P. Marat?:

"Marat: Yo leí una vez en Sade/ (en uno de sus escritos inmortales)/ que el principio de toda vida está en la muerte.

Sade: Y esa muerte sólo existe en la imaginación;/ somos nosotros los que tenemos esa idea./ La Naturaleza no la conoce./ Hasta la más cruel de todas las muertes o catástrofes/ se borra en la indiferencia absoluta de la Naturaleza./ Sólo nosotros damos a esta vida cierta importancia./ La Naturaleza podrá asistir sin inmutarse/ al exterminio de la raza humana./”.

\subsubsection{MUERTE SIN SENTIDO: APROXIMACIÓN A LA BIOLOGÍA DE LA MUERTE}

"La Naturaleza es objetiva y no proyectiva" J. Monod

En su análisis del epicureísmo como precursor del pensamiento científico moderno, y en especial de los teóricos de la Biología, Carse (1987:53-78) resalta una serie de presupuestos similares entre ambos que pueden ser tomados inicialmente como referentes de fondo a la hora de examinar la “manera biológica” del pensamiento sobre la vida y la muerte: a) asunción del principio de que $<<$ nada nace de la nada>>, de lo contrario el universo sería caótico y podría dejar de existir en cualquier momento; b) rechazo de cualquier tipo de discontinuidad dentro de la naturaleza física del universo, aunque los átomos que la componen tienen un comportamiento impredecible y son los que introducen la variabilidad en el universo material; c) visión del universo en la que aparece la vida sin necesidad de recurrir a explicaciones sobrenaturales; d) la vida es accidental, apareció por azar, no existe por una razón determinada, no tiene fin alguno; e) el agente de la muerte no es algo externo a la materia, que la dirija de una forma u otra, es la naturaleza misma de la materia, y; f) la muerte sólo puede consistir en la dispersión y redistribución de los átomos' que han compuesto el organismo, todos ellos continúan 
indefinidamente. A este marco de fondo cabe añadirle, siguiendo a Monod (1970), que todo fenómeno está sujeto simultáneamente al ciego azar y a la necesidad, y que la diferencia entre la vida y lo inerte arranca por puro azar, originándose unos organismos que se autoconstruyen, "máquinas químicas", con la propiedad (necesidad) de reproducirse, incorporando en ese proceso nuevos efectos del azar.

El extraordinario desarrollo de las ciencias de la vida durante la segunda mitad del siglo XX ha permitido incrementar además el conocimiento sobre la biología de la muerte. Así, la investigación teórica y experimental sobre la biología del envejecimiento, por ejemplo en la búsqueda y control de los genes cuya "expresión" aboca al deterioro de los cuerpos, ha favorecido indirectamente una mejor comprensión de los procesos biológicos que llevan a la extinción de aquéllos. La gran complejidad de la biología de la muerte determina que el conocimiento sobre la misma sea aún “frágil” y presente numerosos puntos de controversia. No obstante, en los últimos años la discusión de alguno de esos puntos se ha ido perfilando hasta alcanzar un consenso tan amplio sobre determinados procesos que prácticamente son asumidos por unanimidad en el ámbito de la Biología (Klarsfeld y Revah, 2002). En su análisis de la biología de la muerte estos dos neurobiólogos realizan un repaso histórico, desde el siglo XIX hasta hoy, de las principales aportaciones teóricas y experimentales sobre ese proceso. A efectos del presente trabajo resulta especialmente significativo mencionar, con el objetivo de explicitar la construcción social subyacente, por un lado, algunos de los condicionantes histórico-estructurales e ideológicos ${ }^{67}$ que han mediatizado la evolución del conocimiento científico de la biología de la muerte; por otro lado, procede subrayar algunas de los escasas “certezas” que según estos autores son asumidas mayoritariamente por la comunidad científica biológica en la actualidad y, sobre la base de las mismas, describir las principales aportaciones teóricas de esa rama de la ciencia sobre el por qué de la muerte.

En lo relativo al primero de los ámbitos, el contexto estructural e ideológico en el que se produce el conocimiento sobre la naturaleza de la muerte, Klarsfeld y Revah (2002:228-241) resaltan

\footnotetext{
${ }^{67}$ Mediatización que puede frenar, desviar, confundir e, incluso, clausurar la evolución del conocimiento científico. Sin necesidad de retrotraerse a Galileo, la prohibición en algunos de países de la investigación con "células madre" es paradigmática en este sentido. En Watson y Berry (2003) se describen las múltiples influencias de todo tipo que han condicionado la investigación en Biología y Genética desde que se descubriera la estructura del ADN en 1953 hasta hoy. El propio Darwin lastró la teoría de la selección natural con "una presunción a la vez innecesaria y probablemente falsa”, no sustentada por el registro geológico, como es la de considerarla como un proceso gradual -con "infinitos eslabones transicionales"-, lento y ordenado (Gould, 2004a:63-68). Para este autor, esa elección de Darwin hay que enmarcarla en que "al ir cayendo las monarquías y finalizar el siglo XVIII con una era de revolución, los científicos empezaron a considerar el cambio como una parte normal del orden universal, y no como algo aberrante y excepcional. Los estudiosos transfirieron a la naturaleza el programa liberal de cambio lento y ordenado que postulaban para la transformación social en la sociedad. Para muchos científicos, un cataclismo natural resultaba tan amenazador como el reino de terror que se había llevado a su gran colega Lavoisier”.
} 
dos tipos de obstáculos que han frenado el desarrollo del mismo ${ }^{68}$. El primer tipo corresponde a los obstáculos conceptuales ligados tanto a que la muerte es la materia de estudio que entraña mayor carga afectiva, lo que ha retardado su consideración como objeto de análisis favoreciendo la ignorancia científica sobre "un fantasma al que no nos atrevemos a mirar a la cara", como sobre todo a la necesidad de obtener respuestas con "sentido" (un porqué) con que desde la sociedad se demanda continuamente a la ciencia, ya que, como apuntó Monod (1970), el ser humano piensa inevitablemente en términos de fines y proyectos. Afrontado desde finales del siglo XIX el primero de estos obstáculos conceptuales, la superación del segundo ha requerido sin embargo un "esfuerzo inmenso" dado que la aprehensión que provoca la muerte, la toma de conciencia íntima sobre ella, es, como se ha señalado, uno de los pilares esenciales sobre los que se asienta la brecha antropológica de la que despega la humanización. De esta forma, la investigación sobre materia tan sensible ha tenido que hacer frente en mayor medida aún a lo apuntado de forma genérica por Bachelard: “Ante lo real, lo que creemos saber claramente ofusca lo que deberíamos saber” ${ }^{29}$.

Según Klarsfeld y Revah (2002:14 y 239), la necesidad, tanto individual como social, de dotar de un sentido a la muerte no sólo ha frenado históricamente la construcción de unos cimientos intelectuales objetivos con los que mirar la realidad del proceso biológico del morir y la muerte. Por el contrario, lejos de facilitarse esa reflexión positivista rigurosa, evitando toda tentación moralizadora, se han dispuesto los elementos científicos, incluidas las propias prácticas científicas de recopilación de datos, "al servicio de una conclusión a menudo reconfortante y las más de las veces preestablecida”, buscando más justificaciones que explicaciones, e ignorando o rechazando las aportaciones más modernas de las teorías evolucionistas ${ }^{70}$. A modo de ejemplos, Klarsfeld y Revah (2002:236-237)

\footnotetext{
${ }^{68}$ Además de los obstáculos que se mencionan, no se han de obviar los que introduce la propia dinámica de unas prácticas científicas condicionadas por el paradigma dominante en cada momento histórico. Un ejemplo claro en este ámbito es la poderosa influencia del concepto <<inmortalidad celular >> instaurado a principios del siglo XX por A. Carrel, Premio Nobel de Medicina y Fisiología en 1912, y que se convirtió en un "auténtico dogma” no cuestionado hasta la década de 1960. Dogma que impidió el desarrollo de otras líneas de pensamiento, cronológicamente anteriores o contemporáneas a las de Carrel, como las del biólogo alemán August Weismann, y que hoy están de plena actualidad (Klarsfeld y Revah, 2002:127-133). En este texto y en (Haylick, 1999:cap. 8) se describe cómo se desmontó el dogma de Carrel, asentado en un experimento erróneo. Otro ejemplo diáfano resaltado por Klarsfeld y Revah (2002:cap.VI) es la tardanza en reconocer, por parte de la comunidad científica y a pesar de los "numerosos indicios experimentales", la importancia de la muerte celular (la embriogénesis en el desarrollo del feto y la apoptosis a lo largo de toda la vida) para la propia vida de los individuos. Ignorancia asentada en el falso presupuesto de que las células son la unidad básica de la vida y, por tanto, sólo pueden estar relacionadas con la vida, no con la muerte.

${ }^{69}$ BACHELARD, G. (1986): La formation de l'esprit scientifique, París, Vrin, pp.14, (v.o. 1938), citado en Klarsfeld y Revah (2002:229).

${ }^{70}$ Resulta paradójica esta queja y reivindicación positivista de una visión exclusivamente biologicista de la muerte cuando desde de las ciencias sociales se denuncia, simultáneamente, el unilateralismo dominante del enfoque positivista. El reduccionismo conceptual y la fragmentación de la realidad, conexos a las interpretaciones mecanicistas de los fenómenos biológicos, choca con la reivindicación desde las ciencias sociales de una visión interdisciplinar de la salud, la enfermedad y la muerte como medio para conocer de forma holística esos fenómenos. Así, desde una perspectiva holística, Vandana Shiva (2001:cap.II), por ejemplo, critica el reduccionismo biologicista denunciando dos de las múltiples facetas del mismo. La primera, a la que
} 
señalan que ese esfuerzo por dar sentido a la muerte, obviando las últimas aportaciones de la biología, se hace diáfano al revisar los trabajos de reputados científicos sociales, pero sobre todo de eminentes representantes de las ciencias de la vida. Entre estos últimos citan al Premio Nobel de Medicina en 1965, François Jacob, quien escribía que la muerte es una “condición necesaria para la posibilidad en sí de una evolución..., como una necesidad impuesta, desde el huevo, por el propio programa genético... (para permitir) la desaparición de la generación que ha cumplido su función en la reproducción”. Asimismo mencionan al biólogo M. Marois, presidente entre 1971 y 1987 de la <<Société de Thanatologie>>, para quien "la muerte encuentra su lugar en la economía de la vida: está al servicio de la vida al darle nuevas oportunidades para nuevas pruebas y nuevas expresiones del protoplasma”. Más ilustrativas aún de esa mezcla teleológica entre biología y moral son las conclusiones expuestas en 1975 por O. Thibalut: "la muerte, que nos parece tan atroz e intolerable, es, no obstante, vista desde la escala de la Evolución, una novedad, una ventaja selectiva y, en cierto modo, un <<avance>>. (...) la muerte de los individuos garantiza no sólo la perennidad de la especie, sino su rejuvenecimiento; por lo que no sólo es una necesidad, sino también un bien. Y, al menos en esto, encontramos un sentido biológico a la muerte (ajeno a todo sentido metafísico), sin el cual es evidente que la muerte no sería más que un verdadero escándalo”.

Superar desde la perspectiva de la Biología esta ofuscación conceptual obliga a enfrentarse al segundo tipo de escollos: los epistemológicos. Klarsfeld y Revah (2002:229-235) identifican el origen de estos obstáculos epistemológicos con la experiencia previa “indebidamente sobrevalorada siempre” (también en el caso de la muerte). Concretamente mencionan dos aspectos esenciales que, a su juicio, han perturbado el enfoque científico de la muerte natural. Por un lado, la concepción determinista de la misma como una fatalidad impuesta, involuntaria, sumamente arbitraria, e inevitable. Injusticia última que paradójicamente se percibe en mayor grado aún en las sociedades desarrolladas, dominadas en sus relaciones sociales por la individualización y la elevada esperanza de vida, en las que los avances científico-técnicos han generado la ilusión del control sobre la muerte llegando a concebirla como la "última enfermedad por vencer". A esto se añade, por otro lado, el que a la muerte se la considera un absurdo, "sin duda el más insoportable de todos".

La influencia de estos dos aspectos esenciales se ha manifestado reiteradamente en una serie de "presupuestos implícitos" que han mediatizado hasta hoy toda reflexión, también la reflexión biológica, sobre la muerte natural. Cabe destacar dos de estos principios: el primero, y más antiguo, es

denomina "reduccionismo de primer orden”, actúa a nivel de especie, "otorga valor únicamente a una especie el ser humano- y confiere un valor utilitario a todas las demás”. La segunda, que cada día cobra más peso, a la que denomina "reduccionismo de segundo orden o genético", "reduce el comportamiento de los organismos biológicos, incluyendo el ser humano, a genes". El reduccionismo biologicista conlleva un reduccionismo cultural al devaluarse "muchas formas de saber y muchos sistemas éticos" y actuar "con total indiferencia por sus consecuencias sociales y ecológicas". 
el que afirma que la muerte natural es una característica intrínseca del ser vivo, que se halla inscrita en su propia constitución y, por tanto, le llega desde su interior. En la versión arcaica de este presupuesto se concebía a la muerte como un castigo divino; en la más moderna, desde el nacimiento de la Termodinámica, se invoca la necesidad del cumplimiento de las leyes físico-químicas. Según este último planteamiento, la vida orgánica se rige por las mismas leyes que gobiernan al mundo inanimado. Por ello, y aunque aparentemente la evolución de las especies, cada vez más ordenada, compleja y diferenciada, choca con el Segundo Principio de la Termodinámica, que apunta hacia el aumento de la entropía ${ }^{71}$, la muerte es la disolución inevitable del orden elaborado ${ }^{72}$. Esta explicación entrópica de la muerte, sin embargo, sólo es válida al ser aplicada a sistemas cerrados pero es insuficiente, como han resaltado diversos autores ${ }^{73}$ (Klarsfeld y Revah, 2002: 230; Kirkwood, 2000:65-67; Hayflick, 1999:335-337) para explicar la muerte de los seres vivos, que son sistemas abiertos por los que fluye constantemente materia y energía, además de ser sistemas inestables afectados por miles de factores ambientales.

El segundo presupuesto está estrechamente relacionado con la necesidad de que la muerte posea un sentido (un porqué) y, por tanto, deba tener una utilidad (un para qué). Sin embargo, como resaltan Klarsfeld y Revah, esta función oculta de la muerte, real o ficticia, no sería más que una especie de placebo que aporta consuelo y permite soportar una situación en la que se es imponente

\footnotetext{
${ }^{71}$ La entropía mide la calidad de la energía almacenada, en el sentido de que cuanta más alta es la calidad de la energía, más baja es la entropía. Así, la entropía es una medida del desorden, que crece al aumentar éste. Dado que, según lo postulado por el Segundo Principio de la Termodinámica, "la dirección natural del cambio es hacia el desorden cada vez mayor", derivado de la desestructuración de la materia ordenada y de la decadencia y dispersión de la energía localizada, al caer en una homogeneidad sin estructura en la que nada puede ocurrir, el resorte del Universo tal como lo desvela ese Principio consiste en su degradación imparable (Atkins, 2003: cap.4).

${ }^{72}$ La resolución de esta paradoja se explica cuando se considera a "la evolución como segregación de entropía". Es decir, "como la construcción de pequeñas islas de orden y complejidad a costa de más desorden en otros lugares", o lo que es lo mismo, que hay que pagar un precio por cualquier organización de la energía, dado que ésta no se obtiene de la nada. De esta forma, el mayor orden de las estructuras vitales no entra en contradicción con el Segundo Principio de la Termodinámica (Diccionario de la Naturaleza, Madrid, Espasa-Calpe, 2003:221; Boulding, 1978). En la misma línea lo refiere Lupasco: "Pasado un tiempo de desgaste más o menos largo, todo el universo tiende hacia la muerte. Pero esta muerte no es sino <<estadística probabilística >>. No indica más que un devenir asintótico. El caos es el estado natural de la materia. Todo tiene que dejarse llevar por el desorden. Abandonada a sí misma, la materia se desintegra hasta el estado de equilibrio, la condición natural, es decir, la distribución azarosa del caos. El orden más sencillo -como la molécula, partícula de materia- es contrario a la naturaleza. La vida de un organismo humano (como toda vida) formado de materia altamente organizada es un acontecimiento sin razón de ser ocurrido gracias a unos encuentros fortuitos,... La muerte no es la ausencia de vida, es la vida la que es ausencia de muerte” (LUPASCO, Stéphane (1960): Les trois matiéres, Julliard, París, citado en Rodríguez Rioboo (1993:43).

${ }^{73}$ Kirkwood (2000:65-67), por ejemplo, señala que la explicación entrópica de la muerte es puro fatalismo encubierto: "No hay ninguna razón por la cual un ser vivo tenga que obedecer al segundo principio de la termodinámica, en el sentido de hacerse viejo y morir por no ser capaz de seguir adelante. Además, si fuese así, ninguno de nosotros estaría aquí: las primeras células aparecieron hace millones de años. Las células se reproducen por división, y todo el material que constituye las nuevas células procede, en principio, de sus antecesoras... Los ingredientes celulares, que han sido renovados y sustituidos muchas veces a lo largo de ese proceso, no pueden haber ido acumulando componentes de <<usar y tirar $>>$, pues hubieran muerto hace ya mucho tiempo".
} 
para satisfacer la necesidad de buscar una razón a la propia existencia. Las interpretaciones del para qué ocurre la muerte han variado con el tiempo y, en concreto, las interpretaciones evolucionistas se centraron inicialmente en las ventajas selectivas que se derivarían de la existencia del envejecimiento y la muerte. Éstos serían, bien procesos que impedirían que la evolución se parara en seco -<<teoría del bien de la especie >> (Austad, 1998:70-83)-, o bien, mecanismos de control demográfico que permitirían evitar la superpoblación y la destrucción del medio ambiente. Así, desde Darwin hasta la segunda mitad del siglo XX se ha asumido de forma casi generalizada -darwinismo ortodoxo clásicoque la mortalidad individual era una condición necesaria para la perpetuación de la especie ya que la supervivencia de ésta constituía el objetivo principal de la evolución ${ }^{74}$ (Olshansky y Carnes, 2001:63). Las opiniones de Jacob, Marois y Thibalut recogidas arriba serían representativas de esta perspectiva.

En efecto, una vida potencialmente eterna tendría consecuencias "potencialmente monstruosas” para las especies, como sería por ejemplo la multiplicación infinita de organismos, lo que entrañaría su extinción ${ }^{75}$. Por otro lado, dado que, como señala el paleontólogo S.J. Gould (2004a:105), “la imperfección de la naturaleza pone de relieve la evolución”76, el envejecimiento y la muerte se hicieron inevitables porque en otro caso la evolución de los seres vivos se habría detenido tras la aparición de sus primeros representantes, que serían `perfectos' en grado absoluto. Cosa que obviamente no ha ocurrido. Al contrario, los entornos constantemente cambiantes conllevaron la aparición de nuevos organismos cada vez mejor adaptados; organismos surgidos de mutaciones que sólo pudieron aparecer y sobrevivir cuando una generación muere y es sustituida por otra: "Sin

\footnotetext{
${ }^{74}$ Inicialmente, Darwin (1983) señala en El Origen de las especies a la selección natural como principal fuerza creadora del cambio evolutivo. Influido por el Ensayo sobre el principio de la población de T.R. Malthus después de leerlo escribe Darwin: "se me ocurrió de pronto que bajo estas circunstancias las variaciones favorables tenderán a conservarse, y que se destruirían las desfavorables” (Atkins, 2003:30)-, y “fascinado" por las ideas de A. Smith, concretamente por el laisez faire -dejar a los individuos maximizar su beneficio personal sin restricciones era la mejor vía para la optimización general de la economía-, Darwin identificó al individuo como el nivel único en el que se producía la selección natural. Así, la <<selección organísmica >> se produce por la lucha entre los individuos que, interactuando causalmente con el entorno, buscan el éxito reproductivo personal, es decir, persiguen "influir en la representación relativa de su aportación hereditaria de las generaciones futuras” (Gould, 2004b:625-627). Sin embargo, como resalta Gould, aunque los individuos son unidades de selección, no evolucionan y tan sólo pueden crecer, reproducirse y morir. Por ello, y a pesar de todos los esfuerzos que Darwin realizó para "acomodar" todas las formas evolutivas (incluidas múltiples excepciones) "bajo el paraguas de la selección organísmica", finalmente "fracasó" y tuvo que invocar a una selección a un nivel superior. De aquí, del hecho de que el cambio evolutivo se produjese en grupos de organismos interactivos, que el darwinismo ortodoxo clásico considerara a las especies como la unidad de evolución (Gould, 1994:74).

${ }^{75}$ Chauchard (1960) ofrece una estimación de lo que ocurriría si diversas especies se reprodujesen sin que exista algún tipo de límite que lo impida: "Bastarán menos de dos días para que los descendientes de una única bacteria cubriesen la superficie de la tierra si todos sobrevivieren, un infusorio necesitaría cuarenta y dos días; una mosca dos años; un bacalao, cuatro años; una rata, ocho años; el trébol, once años; el elefante, más de un siglo".

${ }^{76}$ Precisamente éste es uno de los tres argumentos principales utilizados por Gould (2004a:101-109), agnóstico declarado, para reivindicar la evolución como hecho, además de como teoría, frente a los partidarios del $<<$ creacionismo científico $>$.
} 
muerte, no hay evolución y, sin evolución, no hay creación de nuevas especies”77 (Volk, 2011:42). Es decir, existe la evolución porque los organismos envejecen y pueden morir. Así, al margen de la muerte llegada desde el exterior, el incremento de la vulnerabilidad ligado al envejecimiento y al deterioro, que conducen a la muerte, cumpliría la función ecológica de lograr una más adecuada distribución de los recursos escasos en un entorno competitivo eliminando a los individuos ancianos y a los más débiles, que nada aportan ya a la especie y sí, por el contrario, detraen recursos necesarios para los individuos sanos. De acuerdo a este criterio y durante el periodo de tiempo señalado, por tanto, la idea dominante entre los evolucionistas, también en la reflexión biológica, mantenía que los individuos eran mortales mientras que las poblaciones (las especies) eran `inmortales ${ }^{-78}$.

Sin embargo, y a pesar de la buena acogida ${ }^{79}$ que tuvo durante mucho tiempo, la hipótesis de la inmortalidad de las especies presenta unas limitaciones insalvables. De forma general, como se puede comprobar en los registros fósiles, las especies también se extinguen, por lo que es imposible demostrar científicamente la inmortalidad de una especie (Kirkwood, 2000:49). De forma más concreta, dado que los organismos actúan egoístamente movidos por su impulso reproductor, no entienden de altruismo, es decir, no hacen nada en nombre de la especie. Lo que puede ser ventajoso para el individuo, puede perjudicar al grupo. Es por ello por lo que no cabe plantear la mortalidad individual como un mecanismo buscado por los propios individuos para garantizar la pervivencia de las especies. Como se comenta a continuación, en biología no hay razones para hacer algo, todo es prueba y error. Finalmente, es una hipótesis circular, ya que presupone dado el declive ligado al envejecimiento y al deterioro físico que conducen a la muerte, que es precisamente lo que se ha de explicar (Klarsfeld y Revah, 2002:121).

Por estas razones, y por los avances en la Biología Molecular y en la Genética entre otras disciplinas, en la segunda mitad del siglo XX se ha ido conformando otro criterio evolutivo ortodoxo, el neodarwinismo contemporáneo, al que se denomina $<<$ teoría sintética de la evolución $>>^{80}$, en el que

\footnotetext{
${ }^{77}$ En Cosmos, el astrónomo C. Sagan (2000:18) vincula la muerte con el proceso de evolución al señalar que "los secretos de la evolución son la muerte y el tiempo, la muerte de una extraordinaria cantidad de formas de vida imperfectamente adaptadas a su medio y el tiempo para la larga sucesión de pequeñas mutaciones que fueron azarosamente adaptativas, el tiempo para la lenta acumulación de pautas de mutaciones favorables”.

78 "Una especie animal típica perdura unos dos millones de años” (Atkins, 2003:40).

${ }^{79}$ Dawkins (1994:10-14) atribuye el apoyo que recibió la teoría de selección de especies (de grupos) a que "ejerce una gran atracción intuitiva” al estar "en completa armonía con los ideales morales y políticos que la mayoría de nosotros compartimos”. Es decir, no se la asumía por haber sido contrastada empíricamente, sino por motivaciones políticas, ideológicas y culturales, ya que "es posible que, con cierta frecuencia, nos comportemos egoístamente como individuos, pero en nuestros momentos más idealistas, honramos y admiramos a aquellos que ponen en primer lugar el bienestar de los demás”.

${ }^{80}$ El neodarwinismo contemporáneo comenzó a forjarse en la década de 1930, "cuando se vio que teorías relativas a la genética respaldaban las relativas a la historia natural observatoria. De hecho, no se aceptó plenamente la selección natural hasta los años treinta del siglo XX, con el establecimiento de la síntesis moderna" (Atkins, 2003:32). En el mismo se unen las emergentes teorías de la genética de poblaciones con las
} 
se reformulan algunos de los postulados más característicos de Darwin (Gould, 1994:cap.18). Así, se asume con Darwin que la Naturaleza no tiene un plan, carece de causa <<superior>>, no lleva necesariamente a una mayor sofisticación, no se dirige en ninguna dirección ni piensa en un meta concreta, no efectúa elecciones conscientes y deliberadas. Está centrada sólo y por completo en el presente y carece en absoluto de previsión. El mecanismo base de la evolución natural, la selección natural, "no puede prever si está conduciendo a una especie a un callejón sin salida. De hecho, no puede prever nada. Es el carpe diem total” (Atkins, 2003:33). Por tanto, el equilibrio que pudiera darse en la naturaleza no es sino una consecuencia no buscada de la lucha despiadada entre individuos que persiguen sus propios intereses (Gould, 1994:74). En palabras de J. Monod (1970:17): "la Naturaleza es objetiva y no proyectiva". Un mundo sin sentido en el que a la evolución le resulta totalmente indiferente si la especie sobrevive o no, y en el que el factor azar juega un papel esencial en la historia de la vida, hasta el punto de que muchas especies muy bien adaptadas han desaparecido por catástrofes naturales u otras contingencias mientras que otras, peor adaptadas, han sobrevivido a las mismas simplemente por azar.

El neodarwinismo contemporáneo ha reformulado asimismo la idea de la selección natural ${ }^{81}$ ${ }^{82}$ desplazando el foco de atención hacia los genes ${ }^{83}$, los planos de los organismos. En efecto, dado que las mutaciones sólo se producen en los genes, éstos son el motivo último de variación, y dado que ésta es un requisito necesario para la evolución, se considera a los genes como los verdaderos protagonistas de la selección natural: "El gen es la unidad de la herencia” (Dawkins, 1994:14). Según

aportaciones clásicas de "la morfología, la sistemática, la embriología, la biogeografía y la paleontología" (Gould, 1994:159).

${ }^{81}$ En esencia, la selección natural, en la versión clásica elaborada por Darwin que presupone una continuidad sin interrupción en el proceso evolutivo desde la aparición de la vida en la Tierra, sostiene que la diversidad de las especies se asienta en la "lentísima acumulación de ínfimas variaciones aleatorias, cada una de las cuales se va imponiendo porque supone, por mero azar, una pequeñísima ventaja para su portador” (Sampedro, 2001:31). Este $<$ gradualismo $>$, que afecta a los individuos, es replanteado por el neodarwinismo ortodoxo en el sentido de que consideran que existe una estricta continuidad entre la micro y la macroevolución en la que ésta no sería más que una microevolución extendida: <<gradualismo filético〉>, (Atkins, 3003:25; Gould, 1994:159-160). Una vez inscrito en la estructura del ADN, ese accidente singular e imprevisible es mecánicamente replicado y, por tanto, multiplicado a millones de ejemplares ya que "sacado del reino del puro azar, entra en el de la necesidad, de las certidumbres más implacables. Porque es a escala macroscópica, la del organismo, a la que opera la selección” (Monod, 1970:119).

${ }^{82}$ Existen algunas lagunas de la evolución no explicadas por la teoría de la selección natural que hacen que no todos los evolucionistas compartan el gradualismo del (neo)darwinismo ortodoxo. Así, la llamada "explosión cámbrica", salto brusco que se detecta en los registros fósiles de hace 540 millones de años con la aparición repentina de "casi todos los tipos generales de diseño animal" que existen actualmente en la Tierra (Sampedro, 2002:3). Gould (2004b:cap.9), por ejemplo, propone la Teoría del equilibrio puntuado para explicar ese salto evolutivo. $\mathrm{O}$, por otra parte, la aparición de la célula eucariota, constituyente de las eucariotas (animales y plantas), hace 1500 millones de años como fruto de una "boda simbiótica" -Teoría de la Simbiogénesis- entre otros dos micro-organismos, lo que constituye un mecanismo diferente al del motor de la evolución darwinista (Margulis, 2000:208-210).

83 "Los genes son partes concretas de la molécula de ADN que ordenan la producción de proteínas, que a su vez vienen a ser los ladrillos con que se construye un organismo" (Salomone, 2000:51). "La molécula de ADN es un almacén de información, un mensaje, que se transmite de generación en generación. Dicho mensaje contiene toda la información necesaria para construir y sostener el organismo en el que habita” (Atkins, 2003:78-79). 
plantea este autor en su Teoría del gen egoísta, el efecto de la intensa competencia entre los genes desde el inicio de la vida en la Tierra condujo a que, en un proceso de perfeccionamiento acumulativo y para superar la selección, construyeran "máquinas de supervivencia" -organismos- para vivir en ellas. Máquinas cada vez más complejas y que ahora son "gigantescos y lerdos robots” en los que los genes están a salvo, "protegidos del mundo exterior, comunicándose con él por medio de rutas indirectas y tortuosas, manipulándolo por control remoto” (Dawkins, 2004; 1994:cap.II). Así, sobre la base de que los genes controlan indirectamente la fabricación de los cuerpos, el criterio dominante hoy día no es el de que los individuos son importantes en sí mismos, sino que su trascendencia en la evolución se deriva de que, desde hace aproximadamente 3.500 millones de años en que empezaron a ser creados (Schopf, 2002:56), su fin es el de transportar el "inmortal libro del código genético de la vida”. Los individuos no son más que meros "vehículos de transporte... desechables” cuya carga, el gen, es la unidad básica de la evolución. En la preservación de los genes, que no se vuelven seniles y son los potencialmente inmortales, está la razón última de la existencia de los organismos, incluidos los seres humanos ${ }^{84}$ (Atkins $^{85}$, 2003:42-44; Olshansky y Carnes, 2001:54-64, Dawkins, 2004; 1994:25). Esta es una de las escasas certezas que manejan los biólogos y sobre la que, según Klarsfeld y Revah, cada vez cabe menos discusión. En las bases de esta certeza se hallan las aportaciones más modernas de la Biología Molecular y la Genética relativas al porqué de la muerte. No obstante, el $<<$ seleccionismo génico $>>$ no es asumido por la totalidad de los evolucionistas. De hecho, algunos autores lo consideran una visión radical, e igualmente teleológica, del darwinismo, un fundamentalismo que "ha inspirado un seguimiento ferviente de naturaleza cuasirreligiosa": el $<<$ ultradarwinismo >> (Gould, 2004b:644) ${ }^{86}$.

\subsection{3. ¿POR QUÉ SE PRODUCE LA MUERTE BIOLÓGICA?}

“En mi principio está mi fin”

T.S. Elliot

\footnotetext{
84 "Los cuerpos humanos... funcionan a modo de vehículos de transporte genético. Los genes han viajado en esos vehículos haciendo dedo a lo largo de los tiempos. No pueden sobrevivir los unos sin los otros. Los seres humanos y otros organismos vivos están destinados a crecer, desarrollarse y reproducirse a fin de que los genes que hacen autostop dentro de nosotros puedan trasladarse a la siguiente generación” (Olshansky y Carnes, 2001:55).

${ }^{85}$ Este autor incluso va más allá y afirma que, como el gen, como entidad física, no es inmortal y debe reconstruirse una y otra vez, en realidad la unidad de selección es la información cifrada en el ADN: "El componente verdaderamente importante de la vida no es el gen físico, sino la información abstracta que contiene. La información es inmortal, y despiadadamente egoísta. La información genética es con toda probabilidad la unidad última de selección, siendo el ADN su plasmación, y el cuerpo, su recipiente sumiso desechable” (Atkins, 2003:44).

${ }^{86}$ En (Gould, 2004b:cap.8 y 1994:cap.8) pueden verse las críticas que este autor realiza a la teoría del gen egoísta así como el desarrollo de su propuesta alternativa, el <<seleccionismo jerárquico >> la competencia se puede producir a veces entre genes, ocasionalmente entre individuos, esporádicamente entre poblaciones y de vez en cuando entre especies -Teoría jerárquica de la selección.
} 
Desde la dimensión biológica, la muerte de los seres humanos no difiere, en su esencia, de la del resto de los seres vivos. Los avances científicos, y en especial los provenientes de la Biología, han aportado respuestas cada vez más aquilatadas sobre las razones del porqué de la muerte. Razones que insertan la muerte individual en la evolución por selección natural. De acuerdo con ésta, los seres vivos, sobre todo los más complejos, son mortales no porque estén genéticamente programados para morir, sino porque no están “diseñados” para ser inmortales (Hayflick, 1999:293). Es decir, los seres vivos son perecederos, y lo que es más significativo, son los propios genes los que indirectamente “valúan” tal condición (Kirkwood, 2000:77). Esta característica, la caducidad, es la que hace a los seres vivos vulnerables a la actuación de todo tipo de riesgos -condiciones extremas del medio, depredadores, accidentes-, a las enfermedades y, en última instancia, a ser alcanzados por la muerte.

La mayoría de los biólogos que estudian los procesos de envejecimiento y muerte asumen que la longevidad no viene determinada por una única causa, sino que es un fenómeno multifactorial en el que algunos de los factores operan en interacción constante. A continuación se aborda de forma sintética el análisis del porqué de la muerte en general, y de la muerte humana en particular, a partir de las aportaciones recogidas en textos de divulgación sobre el tema escritos por especialistas de los ámbitos de la Biología y la Genética, y que son resumidas en las siguientes cuatro cuestiones: a) muerte del organismo y muerte celular; b) reproducción sexual y muerte; c) envejecimiento y muerte, y; d) el envejecimiento y la muerte en la evolución de las especies por selección natural.

\subsubsection{MUERTE DEL ORGANISMO Y MUERTE CELULAR}

$$
\text { "Si el tiempo no puede acabar contigo, el azar lo hará” }
$$

S.N. Austad

El análisis de la muerte de los organismos vivos resulta insuficiente si no se consideran los procesos que tienen lugar en las entidades vivas autónomas más pequeñas, las células. De tal forma que, antes de abordar cualquier otra cuestión, cabe preguntarse si existe algún tipo de relación entre el ciclo de vida y la muerte celular, y el ciclo de vida y la muerte de un organismo individual cualquiera. A este respecto, Klarsfeld y Revah (2002:31-32) resaltan la complejidad de esas relaciones, mucho más sutiles de lo que hasta hace poco se pensaba. En efecto, si uno de los sentidos de esa relación es axiomático -la muerte de un organismo conlleva la muerte de sus células, salvo que se utilice algunos de sus órganos en trasplantes-, el sentido contrario es cuando menos incierto -la muerte de un organismo "es un fenómeno global que no reside en el funcionamiento autónomo de las células”, que pueden morir y/o renovarse continuamente. Superado en la década de 1960 el dogma de la 
$<<$ inmortalidad celular $>{ }^{87}$ establecido por Carrel a principios del siglo XX, el descubrimiento en 1959 por Hayflick y Moorhead, del fenómeno conocido como <<senescencia celular $>>{ }^{88}$ abrió las puertas a otras investigaciones en las que se admitía la posibilidad de una muerte celular llegada desde dentro de la propia célula. El desarrollo de esas investigaciones confirmó la existencia de la misma y hoy en día se admite que, fruto de la evolución de la naturaleza orgánica, existen dos clases distintas de muerte celular ${ }^{89}$ :

a) La muerte que llega desde el exterior, a la que se conoce como necrosis o citocidio. Es la más antigua desde el punto de vista evolutivo y equivale, en el ámbito celular, a un asesinato: accidental, rápida, no prevista ni preparada, caótica, evitable y “sucia” ${ }^{90}$. Ocurre cuando la célula sufre un daño grave por una agresión externa como un golpe u otra circunstancia que le priva de la energía necesaria (falta de alimento, desecación u otras carencias).

b) La muerte que llega desde el interior de la propia célula siguiendo instrucciones precisas del propio genoma. Es un tipo de muerte más reciente en términos evolutivos, se la denomina apoptosis ${ }^{91}$ o “muerte celular programada”: muerte natural, ineludible, serena, “estereotipada”, “limpia”, que proviene de una <<desprogramación programada >> inscrita en los complejos mecanismos del ADN ${ }^{92}$.

Si en la necrosis las células son agentes pasivos, meros receptores de ataques que alteran y contaminan su entorno, en la apoptosis las células contribuyen activamente a su autodestrucción en lo

\footnotetext{
${ }^{87}$ Como se ha señalado en la nota 66, el dogma de la inmortalidad celular determinó durante la primera mitad del siglo XX el tipo de mirada dominante sobre el envejecimiento y la muerte: "si células normales sacadas de animales son <<inmortales >> cuando se las cultiva en laboratorio, decía el razonamiento, entonces no puede ser resultado de acontecimientos que ocurran dentro de las células individuales. El envejecimiento ha de ser, por consiguiente, resultado de acontecimientos que ocurren fuera de las células” (Hayflick, 1999:41).

${ }^{88}$ La senescencia celular, "senescencia replicativa" o "senescencia proliferativa", como se la denomina en la actualidad, se manifiesta a través de la limitación intrínseca de la capacidad de división celular. Es el conocido como límite de Hayflick. De manera experimental, Hayflick y Moorhead descubrieron que cuando las células normales de un tejido se extraen del cuerpo y se cultivan en laboratorio crecen y se dividen unas 50 veces -el número varía según el tipo de tejido- y después caen en la senectud. La existencia de dicho límite es un fenómeno intrínseco a cada tipo celular, independiente del medio y de las células circundantes. Además, observaron que el número de divisiones restantes sólo dependía de las efectuadas anteriormente y no del tiempo transcurrido. De ahí, dedujeron que a escala celular se producía una especie de envejecimiento determinado internamente para cada célula, es decir, las células poseían un reloj interno que regulaba el número potencial de divisiones (Klarsfeld y Revah, 2002:129). Hayflick (1999:176-178) señala que eso mismo es exactamente lo que ocurre con las células normales en el propio animal del que han sido extraídas, por lo que en el caso de existir en él algunas poblaciones de células inmortales son "de algún modo anormales y casi siempre se convierten en células cancerosas".

${ }^{89}$ Una descripción de las diferencias morfológicas de ambos tipos de muerte celular se puede ver en (Klarsfeld y Revah, 2002:169-172; Margulis y Sagan, 1998:131-137; Duke et al, 1997).

${ }^{90}$ Determinadas carencias "pueden privar a las células de la energía necesaria para bombear iones de potasio hacia dentro y de sodio hacia fuera, lo que hace que la célula se hinche y acabe reventando" (Margulis y Sagan, 1998:131-133).

${ }^{91}$ El proceso morfológico de la apoptosis fue descrito por primera vez en 1972 por el patólogo J.F.R. Kerr. Tan tardío descubrimiento se debió a que "las células apoptóticas son eliminadas velozmente, por lo que desaparecen sin dejar rastro" (García Barreno, 1998:60).

${ }^{92}$ Como resultado de ese proceso, a la célula le ocurre lo que a "un paciente en coma sin actividad eléctrica cerebral, puede mantenerse con vida algún tiempo, pero las esperanzas de recuperación son nulas” (Margulis y Sagan, 1998:135).
} 
que constituye un proceso esencial de adaptación para el desarrollo normal de los organismos fruto de una diferenciación primordial de funciones. En efecto, la función básica de la apoptosis es el "mantenimiento de la homeostasis del organismo", puesto que establece una "regulación social entre las células”, al controlar su número y eliminar cuando procede células individuales en beneficio del organismo (Ridley, 2001:270-275). El hecho de que continuamente estén muriendo células dentro de un organismo no conlleva en sí la muerte del mismo. Las investigaciones biológicas más recientes no permiten afirmar con certeza que la muerte celular desempeña un papel relevante en el envejecimiento y muerte de los individuos ${ }^{93}$, aunque sí que certifican con rotundidad que la muerte celular desempeña un papel crucial en la vida de los individuos a lo largo de todo su ciclo vital ${ }^{94}$. De hecho, la ausencia de dicha muerte celular, o una regulación aberrante de la misma, puede originar graves patologías en el organismo, desde el cáncer ${ }^{95}$ hasta el SIDA o la enfermedad de Alzheimer (Cacabelos, 2001; Duke et al, 1997:44). Por ello, y aunque a efectos prácticos es indistinguible de la senescencia replicativa, se suele distinguir de ésta la denominada senescencia prematura que "ocurre en células jóvenes, células en las que se ha detectado un daño importante en el ADN que puede dar lugar, por ejemplo, a la activación de un oncogén” y a las que “se obliga” a envejecer rápidamente (Macip, 2008:250).

La inexistencia de una relación directa y esencial entre muerte celular y muerte del organismo no excluye, sin embargo, algo que es fundamental: la existencia de otro tipo de relaciones como son las que se derivan de las transformaciones celulares. En efecto, tanto el hecho de que la capacidad de multiplicación de las células de un cuerpo no sea ilimitada, como los cambios que se producen en las mismas antes de dividirse, cada vez más lentos e insuficientes, o la acumulación al azar de errores, sí que se considera que influyen en el proceso de envejecimiento y muerte del organismo. Y ello no tanto porque exista una relación directa entre ambos procesos, sino por cuanto esas transformaciones impiden una renovación "ad infinitum” de los tejidos deteriorados. Inevitablemente, esto provoca a su

\footnotetext{
${ }^{93}$ La mayoría de las células de un organismo son mucho más jóvenes que él. Así, por ejemplo, el biólogo J. Frisen ha estimado que la edad media de todas las células de un cuerpo adulto puede ser de entre 7 y 10 años. Utilizando el carbono 14, Frisen ha desarrollado un método para estimar el tiempo de vida de las células del cuerpo humano. Con este método ha comprobado que cada tipo de tejido tiene su tiempo de regeneración dependiendo del volumen de trabajo que soportan las células que lo forman: las células que recubren el estómago duran 3 días; los glóbulos rojos, 120 días; las células de la epidermis, 2 semanas; las de un hígado adulto, entre 300-500 días; todo el esqueleto humano se renueva aproximadamente cada 10 años en los adultos. Por el contrario, las neuronas de la corteza cerebral, las células de la lente interna ocular y, tal vez, las células musculares del corazón duran toda la vida (The New York Times-El País, 21/09/05:31).

${ }^{94}$ Casi todos los tejidos portan células apoptósicas en algún momento, siendo las más significativas las del ojo (el cristalino), intestino, piel, útero, y timo (Volk, 2011:cap. 6; Duke et al, 1997). "En torno a diecisiete mil millones de células de nuestro cuerpo mueren cada minuto de nuestra existencia para posibilitar que el organismo complejo que somos siga viviendo en las mejores condiciones posibles. La muerte es el motor imprescindible para la generación de la vida. Nuestra existencia se construye sobre el morir permanente y programado de una infinitud de billones de células que fuimos nosotros mismos” (Rodríguez, 2002:34).

${ }^{95}$ La apoptosis es "el arma contra el cáncer más importante del cuerpo, la última línea de fuego". Si falla, por ejemplo al no expresarse el gen TP53, se desarrolla el cáncer. El gen TP53 es el encargado de activar a la proteína p53, el <<Guardián del Genoma >, que, a través de la activación de otros genes, "le dice a la célula
} 
vez un "desgaste irreparable" de los órganos de los que forman parte que, finalmente, hace que el cuerpo entero sea más vulnerable a las enfermedades en la edad madura. Así, "se cree que la acumulación de células senescentes con la edad es uno de los factores que determinan nuestro envejecimiento como organismo” (Macip ${ }^{96}$, 2008:251), hasta el punto de que, incluso, se puede producir la muerte del mismo antes de que las células hayan agotado su capacidad de reproducción (Klarsfeld y Revah, 2002:126; Hayflich, 1999:190).

\subsubsection{REPRODUCCIÓN SEXUAL Y MUERTE}

“¿Podría yo vivir plenamente esta pequeña muerte sino como una anticipación de la muerte definitiva?”

G. Bataille

Como se ha señalado, existen numerosos puntos de controversia entre los propios biólogos a la hora de explicar determinados procesos relativos a la evolución. Uno de los procesos que provocan mayor desconcierto es el de la aparición de la reproducción sexual, fundamentalmente porque en términos de selección natural, según Atkins (2003:44-45), aparentemente y a primera vista, "el sexo es innecesario", "inestable” y "tremendamente complejo”. Perplejidad no compartida por otros autores que resaltan precisamente el papel central del sexo en la evolución, al ser el generador de la multiplicación de variantes genéticas que permiten mayor capacidad de adaptación, como se comenta más abajo, lo que ha dado lugar a una intensa polémica en el ámbito de la biología de la muerte cuando se plantea la existencia, o no, de ligazón entre el sexo y la muerte. Más concretamente, cuando, como sostienen diversos autores, se afirma que la evolución biológica de la especie humana, como la de otros seres vivos, es fruto de un largo proceso en el que la muerte se insertó como una respuesta ineluctable en aquellos organismos que comenzaron a reproducirse mediante relaciones sexuales (Olshansky y Carnes, 2001:Cap.2; Margulis y Sagan, 1998:124-147).

En esencia, según esta hipótesis, la historia evolutiva de la vida y la aparición de la conexión sexo/muerte es como sigue: desde el comienzo de la condensación del planeta Tierra, hace 4.600 millones de años, hasta la emergencia de las primeras trazas de actividad orgánica registradas pasaron alrededor de 1.000 millones años; durante los siguientes 3.000 millones de años de la vida en la Tierra, el único tipo de reproducción existente era la uniparental sin sexo; hace aproximadamente 700 millones de años, surgió la reproducción sexual (Ispisúa, Rasskin y Raya, 2002a:12). Es decir, desde hace 3.600 millones de años en que se empezó a crear vida los organismos, todos ellos unicelulares, se

(tumoral) que haga una de dos: o bien que detenga la proliferación, deje de replicar su ADN y haga una pausa hasta que esté reparada, o bien se suicide” (Ridley, 2001:270-271).

${ }^{96}$ Este investigador biomédico resalta que la senescencia celular es "uno de los fenómenos más sorprendentes y misteriosos del cuerpo humano", ya que habiendo aparecido como mecanismo de seguridad para evitar las consecuencias del envejecimiento celular, el cáncer y otros problemas, "tiene una consecuencia negativa totalmente opuesta a su función original de protegernos”: el envejecimiento del organismo (Masip, 2008:252). 
reproducen por fisión, de modo asexuado el progenitor se divide en dos vástagos aproximadamente iguales -mitosis ${ }^{97}$ - transmitiéndoles intacto todo su libro del código genético: duplicación del ADN y replicación continua del mismo modelo ${ }^{98}$. La reproducción por fisión (con transmisión en serie de mutaciones ventajosas) era y sigue siendo hoy día la forma mayoritaria de reproducirse de la materia viva. Obviamente, esta multiplicación por división celular supone, en un entorno favorable, una proliferación infinita de organismos potencialmente inmortales ${ }^{99}$ (<<inmortalidad protoplasmática >> pueden morirse de hambre, accidente, calor o frío, pero no de viejos).

De esta forma, desde los albores de la vida, y durante millones de años, el envejecimiento y la muerte no constituyeron cualidades inherentes de la materia viva. Por sus propias características la reproducción por fisión impide que las células envejezcan, aunque no puede evitar la existencia de la muerte que llega desde el exterior -necrosis o citocidio.

La estrategia vital acumulativa derivada de la fisión, sin embargo, se "refrenó y perfeccionó”, de manera fortuita, hace unos setecientos millones de años con la innovación de la reproducción sexual mediante la cual, en la formación de los gametos -meiosis-, bien a través de los óvulos o bien a través de los espermatozoides, los individuos únicamente aportan la mitad de su libro del código genético a cada uno de sus descendientes (con transmisión en paralelo de las mutaciones ventajosas de los dos progenitores). Este tipo de reproducción, en el que sólo se transmite la mitad de la carga genética individual, podría parecer en términos evolutivos más ineficiente que la reproducción por fisión en la que se transmite íntegramente la carga genética. Sin embargo, la ineficiencia relativa de la reproducción sexual sólo sería manifiesta en un entorno estático donde la transmisión de la "misma vieja carga” genética es la solución más adecuada para la evolución (Atkins, 2003:44-47; Olshansky y Carnes, 2001:58-59). Por el contrario, en un entorno medioambiental muy inestable y amenazador para la supervivencia, como es el que alberga la evolución de la vida orgánica, la reproducción sexual introdujo la "flexibilidad biológica" necesaria para subsistir y prosperar en él. Este tipo de reproducción, a través de nuevas combinaciones genéticas en las que se `barajan’ periódicamente los genes reordenándolos, ha remodelado el libro del código genético en cada nueva generación al seleccionar naturalmente a los individuos mejor adaptados ${ }^{100}$. De esta forma, ha permitido que se

\footnotetext{
${ }^{97}$ La mitosis es la "división celular en la que se conserva el número de cromosomas, como la que da lugar a dos células descendientes genéticamente similares a partir de una célula progenitora” (Margulis y Sagan, 1998:247).

98 "La fisión... es el hecho fundamental de la ciencia evolutiva: el impulso irresistible de crecer y reproducirse es nuestro legado microbiano absoluto" (Margulis y Sagan, 1998:126). Este "modus operandi asexual de la vida primigenia”, por el que las células actúan como células inmortales que se reproducen ilimitadamente, es, de hecho, el mismo que hoy muestran el tumor canceroso o la infección bacteriana (Margulis y Sagan, 1998:130). ${ }^{99}$ Morin (1974:330) prefiere denominar a la aptitud biológica de vivir indefinidamente, pero que siempre puede ser truncada por un accidente, con la expresión amortalidad, y dejar la expresión inmortalidad a la noción religiosa de indestructibilidad.

100 "La reproducción sexual permite evitar la acumulación de mutaciones deletéreas en el patrimonio genético de la especie generación tras generación. La formación de las células sexuales después de su fusión entraña
} 
incrementaran las posibilidades de producir alguna descendencia con la carga genética adecuada para subsistir, a la par que se encarga de deshacerse de las mutaciones perjudiciales (Ispisúa, Rasskin y Raya, 2002:13): la diversidad genética que emergió con el salto evolutivo de la reproducción sexual capacitó a algunos seres vivos ${ }^{101}$ para ser “supervivientes flexibles” en un mundo que cambiaba constantemente.

El sexo de fusión permitió a esos seres sobrevivir y reproducirse en entornos hostiles (calor y frío, humedad y sequedad) ligados a los ciclos de las estaciones o a otras contingencias. Esta nueva alternativa reproductora constituyó la ruptura del dique de contención ecológico que hasta ese momento establecían los ciclos estacionales y que habían impedido, de hecho, la multiplicación infinita de organismos. En estas condiciones, según Margulis y Sagan, la muerte, llegada desde el interior, se hizo necesaria e inevitable. Al margen de los aspectos puramente físicos de esta evolución, la fusión conllevó una redundancia en partes de las células, que se habían duplicado, y eran innecesarias. Los procesos evolutivos seleccionaron algunas de esos componentes asegurando la supervivencia de las nuevas células de fusión ${ }^{102}$. Por estas razones Margulis y Sagan (1998) definen la reproducción sexual como un "pacto con el diablo", en el sentido de que "la naturaleza conservadora de la evolución ligó el sexo con la muerte” desde sus inicios unicelulares: el estado fusionado sólo podía ser transitorio y para ello se limitaba temporalmente la existencia de los individuos discretos. Este pacto con el diablo supuso, por tanto, la aparición de una nueva forma de muerte celular, la apoptosis o muerte celular programada. Sólo era posible llegar a la vida por la vía de la muerte.

La existencia de estos vínculos forzosos entre sexualidad y muerte ha tenido y sigue teniendo gran aceptación incluso fuera del ámbito de la Biología. Así, ha sido utilizada en el ámbito de las ciencias sociales por destacados científicos sociales en sus explicaciones sobre la muerte. Es el caso, por ejemplo, de Morin (1974a:333) al referirse a la "muerte-renacimiento" como "la fuente de juventud perpetua del verdadero ser amortal: la especie”. O el de J. Ruffié (1986) que en Le sexe et la mort destaca "la notoria ventaja selectiva (de la muerte), no tanto a nivel individual como de la especie", ya que "la sexualidad y la muerte que la acompañan garantizan el cambio". Además de Thomas (1983:46-52) para quien, "la vida vive de la vida, por lo tanto de la muerte” y ésta "encuentra su lugar en la economía de la vida" abriendo nuevas posibilidades de desarrollo a aquélla: "la sexualidad permite una verdadera resurrección”.

innumerables intercambios y renovaciones cromosómicas, en lo que comúnmente se conoce como la lotería hereditaria... Gracias al sexo, el patrimonio genético de una especie no envejece” (Klarsfeld y Revah, 2002:87).

101 Es el caso de algunos protoctistas como los ciliados (microbios unicelulares sexuales), sucesores de las bacterias y antepasados de los mamíferos.

${ }^{102}$ Se desarrollaron "trayectorias de autodestrucción o crecimiento preferente que regulaban el número de cromosomas, cloroplastos y mitocondrias por célula” (Margulis y Sagan, 1998:130). 
No obstante, aún admitiendo la mayor flexibilidad biológica introducida por la reproducción sexual, algunos biólogos rechazan, por considerarlos simplistas, los argumentos mencionados sobre el vínculo del sexo con la muerte. Así, por ejemplo, Klarsfeld y Revah, (2002) discuten tanto la existencia de los vínculos forzosos entre sexo y muerte como la universalidad de una muerte natural inherente inexorablemente en la naturaleza de los seres vivos. A través de distintos ejemplos, en especial el de la levadura, estos autores afirman que también los organismos simples asexuados envejecen y mueren de <<viejos>>, lo que demostraría que no existe tal vínculo positivo entre el sexo y la muerte. Esto, a su vez, les permite cuestionar la premisa mayor sobre la que se asienta la relación sexo/muerte y extraer como conclusión principal "la ausencia de una fatalidad última de la muerte”, es decir, a pesar de que todo organismo ha de morir por una u otra razón, "no existe ninguna ley superior que condene inexorablemente a todo ser vivo al envejecimiento y a la muerte" (Klarsfeld y Revah, 2002:91).

Desde otra perspectiva, el sexo de fusión constituyó un salto cualitativo fundamental en la evolución al iniciar una nueva fase de la misma en la que la reproducción sexual abrió las puertas al desarrollo de cuerpos pluricelulares cada vez más complejos. A partir de la conformación de estos seres pluricelulares, los biólogos actuales, desde la aportación seminal del biólogo alemán Weismann en el siglo XIX, distinguen entre dos grandes clases de células: las células <<germinales >>, directamente implicadas en la reproducción (óvulos y espermatozoides), y las células <<somáticas>>, el resto de las células (“el cuerpo que uno ve reflejado en el espejo”) ${ }^{103}$. Esta distinción es básica a la hora de determinar, en términos evolutivos, los porqués del envejecimiento y de la muerte. En efecto, mientras que ninguno de los seres unicelulares que se reproducen por fisión puede perder su capacidad ilimitada de reproducción, de lo contrario se extinguirían, en los organismos pluricelulares no es necesario que tal capacidad esté inscrita en la totalidad de las células que los componen. Así, sólo se considera esencial para garantizar la sucesión de las generaciones la "inmortalidad" de las células germinales ${ }^{104}$, al mismo tiempo que la inmortalidad del soma resulta irrelevante. De esta forma, el cuerpo de los seres pluricelulares no sería más que un "apéndice accesorio de los verdaderos portadores de la vida, las células de reproducción”. Cuerpo desechable al ser innecesario su mantenimiento una vez transmitidas las células germinales que permiten la continuidad del linaje (Klarsfeld y Revah, 2002:29-30).

103 "Las células germinales contiene una única copia de la principal receta para la vida: el ácido desoxirribonucleico (ADN). Las células somáticas contienen dos copias de ADN, una de cada progenitor" (Olshansky y Carnes, 2001:54).

104 “La inmortalidad potencial de las células reproductoras es un término muy preciso en la biología moderna, no designa la supervivencia eterna, sino la capacidad de división celular un número ilimitado de veces... Esta inmortalidad es sólo potencial, y parcial. Potencial porque ningún individuo de ninguna especie tiene garantizado el alcanzar la edad de reproducción, el encontrar una pareja sexual, ni, por último, el dejar descendencia viable y que alcance, por su parte, la madurez reproductiva. Parcial porque en cada generación se mezclan una línea materna y una línea paterna” (Klarsfeld y Revah, 2002:31). 


\subsubsection{ENVEJECIMIENTO Y MUERTE}

\author{
“Cuando éramos niños \\ los viejos tenían como treinta \\ un charco era un océano \\ la muerte lisa y llana no existía \\ luego cuando muchachos \\ los viejos eran gente de cuarenta \\ un estanque era un océano \\ la muerte a lo más \\ una palabra \\ ya cuando nos casamos \\ los ancianos estaban en cincuenta \\ un lago era un océano \\ la muerte era la muerte de otros \\ ahora veteranos \\ ya le dimos alcance a la verdad \\ el océano es el océano \\ pero la muerte empieza a ser \\ la nuestra”
}

M. Benedetti

Los avances en el conocimiento de la biología de la muerte se están derivando en buena medida de los avances en el conocimiento de la biología del envejecimiento. En primera instancia, sin embargo, no cabe relacionar directa y exclusivamente la muerte con el envejecimiento, como se observa en las muertes de infantes y jóvenes por enfermedad o accidente. De hecho, lo único cierto de las relaciones entre envejecimiento y muerte es que al aumentar la edad de un ser vivo se incrementan sus probabilidades de fallecimiento. Para profundizar en esas relaciones, como resalta Hayflick (1999:53-54), conviene diferenciar entre los fenómenos que caracterizan la finitud de la vida: la longevidad, la duración de vida y la muerte. Fenómenos a los que este autor define como sigue: a) "La longevidad es el periodo de tiempo que puede esperarse que un animal viva, supuestas las mejores condiciones”. La cuestión primordial a resolver acerca de la longevidad es “¿por qué vivimos el tiempo que vivimos?”; b) En la etapa final del ciclo vital -duración potencial entre la concepción y la muerte- "el envejecimiento representa pérdidas en las funciones (corporales) normales, cosa que ocurre tras la maduración sexual y que continúa por todo el tiempo de longevidad máxima para los miembros de una especie” ${ }^{105}$. En este caso, el interrogante fundamental a desvelar es “¿por qué nos hacemos viejos?”; c) “La muerte es el evento final con que acaba la vida”. La cuestión esencial sobre la muerte es “¿por qué morimos?”.

La longevidad, concepto que puede aplicarse a individuos, a poblaciones y a especies, es la facultad de desarrollar ciclos vitales largos (Bernis, 2004:4). En el caso de los individuos, hace

\footnotetext{
${ }^{105}$ Cabe añadir a esta descripción que el envejecimiento es un proceso multifactorial, que afecta a la capacidad funcional de todos los tejidos y órganos del cuerpo, y que está mediatizado por la interacción con el entorno, lo que se traduce en una disminución de la habilidad para ajustarse a estímulos ambientales (Bernis, 2004:1).
} 
referencia a la capacidad de aquéllos que se aproximan más que otros de su especie a la duración máxima de vida fijada para la misma, se mide por la edad de muerte. En relación a las poblaciones, la longevidad se determina por la proporción de sus individuos longevos. En este sentido, resulta crucial no confundir el promedio de longevidad de una población (medido por la esperanza de vida o por la edad mediana de muerte) y la longevidad máxima de la especie (duración máxima de la vida). Así, mientras que la esperanza de vida de un ser humano recién nacido ha aumentado, especialmente durante el siglo XX, y se sitúa hoy en los países más desarrollados alrededor de los 80 años ${ }^{106}$, la longevidad máxima de la vida humana apenas ha variado desde hace cien mil años y se estima, según Hayflick $^{107}$ (1999; 1997), en unos 115 años para todos los seres humanos, independientemente de su género, etnia o localización espacial. Es decir, como ocurre con todas las especies, aunque existan diferencias importantes en las tasas de mortalidad entre distintas poblaciones (bien entre países, o entre hombres y mujeres), el tiempo de envejecimiento de la especie humana es una característica propia de ella prácticamente independiente de las condiciones de vida (Klarsfeld y Revah, 2002:48). De esta forma, ante la cuestión esencial de la longevidad -“¿por qué vivimos el tiempo que vivimos?” -, cabe preguntarse, en consecuencia, si la longevidad se halla inscrita en la herencia genética. Dado que las características que un individuo adquiere a lo largo de su vida no pueden ser transmitidas a sus descendientes, resulta imposible transferir hereditariamente la última de esas características: morir a una edad determinada ${ }^{108}$.

El envejecimiento, por su parte, es un fenómeno oculto en la naturaleza que emerge con la civilización y la domesticación ${ }^{109}$. La rápida evolución social y cultural de los dos últimos siglos "ha dejado atrás a la evolución biológica” al eliminar o reducir sustantivamente los peligros extrínsecos que antaño asolaban a la especie humana aflorando de esta forma con total nitidez, y como nunca antes había ocurrido para ningún ser vivo, su <<mortalidad intrínseca >> Kirkwood (2000:81-93). Es un fenómeno difícil de definir "debido tanto a la ausencia de sincronía en el inicio y velocidad de los

\footnotetext{
${ }^{106}$ Según el Informe de Desarrollo Humano 2010 del PNUD (2010:166), la e(0) media de los países con un Índice de Desarrollo Humano muy alto, en 2010, era de 80,3 años.

107 "Aunque creemos que el ciclo de vida humana ha permanecido fijo a lo largo de los últimos cien mil años, en realidad no hay manera de probar que no haya cambiado algo desde entonces... La mayoría de los gerontólogos no aceptan una duración máxima de la vida humana que exceda de los ciento quince años” (Haylick, 1999:143). Con esta duración máxima, en torno a los $100 \pm 15$ años, se considera longeva a una persona que sobrepase los 85-90 años (Bernis, 2004:4). Lo que sí ha cambiado es la esperanza de vida global, al lograr que un número mayor de personas se acerque al límite máximo de vida. Pero, "incluso si se eliminaran las principales causas de muerte, la duración (media) de la vida humana se mantendría en unos noventa o cien años” (Haylick, 1997:64).

${ }^{108}$ Ya a finales del siglo XIX Weismann señaló al respecto: "No alcanzo a explicarme cómo esa muerte (...) podría comunicarse a las células germinativas de modo que éstas diesen origen, en la generación siguiente (...), a un organismo cuyas células somáticas se deteriorasen espontáneamente al llegar el momento en que sucumbieron sus ancestros”, citado en (Klarsfeld y Revah, 2002:95).

${ }^{109}$ Según todos los registros disponibles, hasta mediados del siglo XVIII fueron muy pocas las personas que vivieron lo suficiente como para experimentar las consecuencias del envejecimiento. De forma más general, los individuos de la mayoría de las especies en estado salvaje suelen morir víctimas de agresiones externas antes de "alcanzar el término <<normal >> de su existencia por efecto del envejecimiento" (Klarsfeld y Revah, 2002:93).
} 
procesos involutivos entre los diferentes tejidos y órganos corporales, como a la enorme variabilidad individual y poblacional que existe en estos aspectos” (Bernis, 2004:3). Implica una reducción de la eficacia en el funcionamiento del organismo entero comprometiéndose, al aumentar la edad, el equilibrio homeostático del mismo. Como se ha señalado, las transformaciones celulares que ocurren con el paso del tiempo en un cuerpo -senescencia, deterioro, mutaciones-, conllevan un aumento de la vulnerabilidad frente a agresiones de todo tipo, y en especial un incremento de la probabilidad de enfermar. De esta forma, por ejemplo, la reducción con la edad de la eficacia del sistema inmunitario del organismo socava sus defensas ante enfermedades como los cánceres, las cerebro-vasculares, el Alzheimer, etc. Enfermedades que afectan con mayor probabilidad a un organismo a medida que envejece tanto porque forman parte del proceso normal de envejecimiento en sí mismo como porque con la edad se reduce la capacidad de rechazarlas (Hayflick, 1999:88-89).

La cuestión esencial relativa al envejecimiento, “¿por qué nos hacemos viejos?”, no tiene una respuesta única y concluyente desde la Biología. La constatación de que el envejecimiento conlleva un incremento de las tasas de mortalidad con la edad no es más que una constatación estadística que describe lo que ocurre pero no por qué ocurre. Por su parte, las investigaciones experimentales que analizan los mecanismos bioquímicos concretos del envejecimiento no han aportado una respuesta unánime al respecto, pudiéndose distinguir entre dos grandes grupos de teorías derivadas de las mismas $^{110}$ (Volk, 2011; Macip, 2008; Bernis, 2004; Klarsfeld y Revah, 2002:cap. V; Le Bourg, 2001; Hayflick, 1999:cap. 14 y15; Austad, 1998): a) Teorías que consideran que el envejecimiento está programado desde el desarrollo embrionario según un plan maestro preexistente. Estas teorías han sido asumidas mayoritariamente hasta finales de la década de 1970 y, en la actualidad, las más representativas de ellas se basan en la hipotética existencia de un $<<$ reloj biológico $>>$ que controla todo el proceso de envejecimiento ${ }^{111}$, y; b) Teorías del <<envejecimiento evolutivo $>>$, basadas en la acumulación aleatoria de errores, por lo que lo consideran inevitable a pesar de la gran capacidad de auto-reparación de los organismos; combinan necesidad y azar ${ }^{112}$.

\footnotetext{
${ }^{110}$ En 1990, Z. Medvedev censó más de 300 teorías del envejecimiento. Para un exposición detallada de las teorías biológicas del envejecimiento se pueden consultar (Bernis, 2004; Klarsfeld y Revah, 2002; Olashansky y Carnes, 2001; Kirkwood , 2000; Hayflick, 1999; Austad, 1998).

${ }^{111}$ Entre las teorías basadas en la existencia de un reloj biológico destaca la teoría endocrina, que considera a la puesta en marcha de unas secreciones hormonales por el hipotálamo o la glándula pituitaria como los determinantes de los cambios derivados con la edad (Hayflick, 1999:303-308).

${ }^{112}$ Se incluye entre estas teorías la de los radicales libres, que son "compuestos intermedios o subproductos de metabolismos oxidativos que se producen de forma natural en las células. Especialmente inestables, tienden a reaccionar con todas las moléculas que se encuentran en su entorno inmediato... pueden producir desgastes irreversibles en el ADN,... así como alterar el patrimonio genético de la célula y perturbar el metabolismo celular en su conjunto" (Klarsfeld y Revah, 2002:124). Ver también (Bernis, 2004:5-6). Asimismo, caben entre estas teorías las interpretaciones modernas derivadas de la secuenciación del genoma, considerado éste como el programa de la vida de los organismos. Por ejemplo, las teorías de errores y reparaciones basadas, por un lado, en la acumulación de fallos en diversas moléculas (ADN, proteínas) y, por otro lado, en la imposibilidad de tener procesos de reparación perfectos, que hacen que sistemas <<perfectos >> en principio, envejezcan y mueran. En 1972, J. Watson descubrió de forma fortuita que al copiarse el ADN las copias no podían comenzar por el
} 
Al margen de esta disparidad teórica, la mayoría de los biólogos admiten en la actualidad, por una parte, que el origen del envejecimiento se halla en una multiplicidad de causas y, por otra, que nada puede frenar ni retrasar los procesos naturales que llevan a la merma de las capacidades fisiológicas de los individuos puesto que el envejecimiento es un "efecto ineludible, pero secundario, del modo de actuar de la selección natural” (Klarsfeld y Revah, 2002; Rose ${ }^{113}$, 2000).

Otro tanto ocurre con la muerte. En la explicación biológica de ambos, envejecimiento y muerte, resultó fundamental el descubrimiento en 1953, por James Watson y Francis Crirk, de la estructura de doble hélice del ácido desoxirribonucleico, ADN. En efecto, este descubrimiento permitía comprender los mecanismos moleculares de la herencia (la reproducción y transmisión del material genético y los cambios y daños que éste podía sufrir), además de que abría las puertas a nuevos horizontes en la comprensión de la evolución y diversidad de las especies. Como resultado del mismo, y como se ha señalado, los biólogos desplazaron su foco de atención hacia el gen ${ }^{114}$, la “molécula maestra”, provocando un desarrollo acelerado de la Biología Molecular, la Bioquímica y la Genética, cuyas aportaciones han supuesto un enorme salto cualitativo en el conocimiento de la biología de la vida, que posteriores descubrimientos han ayudado a profundizar ${ }^{115}$. En sintonía con estas investigaciones, que toman al gen como la unidad básica de la evolución, se produjo una reorientación en el examen de la biología de la muerte. De esta forma, las interpretaciones modernas

extremo del filamento de ADN, por lo que el "texto" se acortaba un poco cada vez que se duplicaba el ADN. Se observó además que en los extremos del cromosoma existe un fragmento de texto "sin sentido" -el telómeroque se repite unas dos mil veces y cuya misión es estabilizar al cromosoma durante la mitosis, evitando que se pierdan secuencias básicas, por lo que el ADN se copia sin cortar nada del texto que tenga sentido. "Después de algunos cientos de copias, el extremo del cromosoma se acorta tanto que hay peligro de perder genes significativos. En nuestro cuerpo los telómeros se acortan a un ritmo de más de treinta y una $<<$ letras $>$ al año, más en ciertos tejidos". Para contrarrestar este proceso algunos genes generan telomerasa; la falta de esta <<enzima mítica>> parece ser la razón por la que las células envejecen, dejan de desarrollarse más allá de una determinada edad y mueren. También puede ser la razón por la que los cuerpos envejecen (Blasco, 2008; Ridley, 2001:225-226).

${ }^{113}$ Michael Rose $(2000,1998)$, biólogo evolutivo que con sus experimentos trata determinar si se puede retrasar el envejecimiento, señala que el envejecimiento es un proceso multifactorial cuya modificación -retraso-, "va a necesitar, a buen seguro, la manipulación de varias vías bioquímicas, muchas quizá”. Ve de momento imposible tal retraso, aunque no lo descarta teóricamente si "descubrimos cómo activar los genes antienvejecimiento en los jóvenes o cómo preparar cócteles de fármacos con los mismo efectos que la ingeniería genética. Se ignoran las líneas fundamentales de tales intervenciones y si podremos acertar”.

${ }^{114}$ Arthur Kornberg, premio Nobel de Medicina en 1953 por la síntesis in vitro del ADN, explica de forma muy gráfica este cambio de orientación en los estudios biológicos: "De 1900 a 1920 dominaron los cazadores de microbios, de 1920 a 1940 los cazadores de vitaminas y de 1940 a 1970 los de enzimas. Desde 1970 los que mandan son los cazadores de genes, con la derivación de la ingeniería genética y la biotecnología” (EL PAÎ́S, 12/02/03:32).

${ }^{115}$ Descubrimientos esenciales para el conocimiento de la biología de la vida, de las enfermedades, del envejecimiento y de la muerte. Así, el desarrollo en 1972 de la técnica del $<<A D N$ recombinante $>$, que, cortando y pegando trozos de ADN, permite editarlo, es decir, crear moléculas de ADN "que nunca se habían visto antes en la naturaleza", lo que permitía “<<jugar a ser Dios >> con la infraestructura molecular de la vida"; la secuenciación del ADN, en 1977; o el desciframiento completo del genoma humano en abril de 2003 (Watson y Berry, 2003). 
del envejecimiento y de la muerte, derivadas de la secuenciación del genoma como programa de la vida de los organismos, se enfrentan a la disyuntiva de considerarlos como un desenlace o como un deterioro de dicho programa: “ ¿avanza el organismo hacia la muerte siguiendo un designio inscrito expresamente en los genes o se desliza de forma inexorable hacia su fin en un marco general fijado también por los genes, pero sin que la muerte esté inscrita de forma explícita en su genoma?” (Klarsfeld y Revah, 2002:123-125). De la elección de una u otra opción depende la respuesta a “¿por qué morimos?”. El examen de esta cuestión se aborda desde las perspectivas teóricas del $<<e n v e j e c i m i e n t o$ evolutivo >> que relacionan envejecimiento y muerte con la selección natural de genes y con los efectos positivos o negativos que dicha selección puede conllevar. Si bien hasta el momento estas teorías no están totalmente validadas por los datos disponibles y no explican esos procesos en su totalidad, son "probablemente" las mejores teorías disponibles en la actualidad (Le Bourg, 2001:21-23; Austad, 1998:cap.7).

\subsubsection{EL ENVEJECIMIENTO Y LA MUERTE EN LA EVOLUCIÓN DE LAS ESPECIES POR SELECCIÓN NATURAL ${ }^{116}$}

"El Proyecto Genoma Humano ha demostrado que Darwin tenía más razón de la que él mismo se hubiera atrevido a soñar”

J.D. Watson y A. Berry

El análisis comparativo entre especies muestra la existencia de diferencias notables entre ellas en lo que se refiere a longevidad, envejecimiento y muerte ${ }^{117}$. Estas diferencias parecen certificar que, de alguna forma, esos límites vitales están inscritos en el patrimonio hereditario de cada individuo. Por otra parte, en estado salvaje existe un punto común entre prácticamente todas las especies animales: sus miembros fallecen antes de alcanzar su longevidad máxima. Si bien esta coincidencia se puede explicar por la acción directa de entornos hostiles, de depredadores o de enfermedades que pueden afectar indistintamente con similar intensidad a las especies, no es menos cierto que esos factores inciden con mayor virulencia entre aquellos individuos que han sufrido mermas en sus capacidades

\footnotetext{
${ }^{116}$ En este apartado se hace referencia a las aportaciones que analizan el envejecimiento y la muerte desde la perspectiva exclusiva del Genoma. Dado que el deterioro de los cuerpos depende tanto de la robustez con que están construidos como del medio ambiente en que viven, en los últimos años ha surgido toda un área de investigación, Ambioma, que analiza la expresión de los genes y sus cambios o mutaciones bajo la influencia del medio ambiente. Desde esta perspectiva, Mora (2003:48) afirma que "los mismos genes se expresan de modo diferente según el medio ambiente que interactúa con ellos”, y cifra, por ejemplo, en más del $70 \%$ del desarrollo del cerebro humano como resultado del contacto con el medio ambiente. En éste no sólo incluye "sol y aire, física y química, sino también medio ambiente emocional, personal y social”. De esta forma, el envejecimiento y la muerte-, se torna en un proceso no programado por los genes, sino fuertemente mediatizado por el medio ambiente y por el propio estilo de vida de los individuos. Cada individuo tiene la oportunidad de empezar "un programa nuevo, un programa distinto, único en la historia de la biología” (Mora, 2003:49).

${ }^{117}$ En Hayflick (1999:70-75) se recoge una muestra de esas diferencias al comparar la longevidad máxima estimada, en cautividad, para un amplio grupo de especies seleccionadas. Así, por ejemplo, la longevidad estimada de 115 años de los seres humanos, una de las más elevadas entre todas las especies, es notablemente mayor que los 46 años de los caballos, los 21 del búho, los 56 del cocodrilo, los 50 de la carpa, los 6 de la lombriz de tierra o los 5 años de la abeja reina.
} 
funcionales fruto del envejecimiento. Estos hechos -longevidades diferentes y desiguales ritmos de envejecimiento entre especies-, constituyen indicios de que en el fondo sí existe algún tipo de programación genética de los límites vitales en las especies animales, pero no certifican que la misma los designe expresamente. Siendo esto así, y teniendo en cuenta que el envejecimiento y la muerte no favorecen en ningún caso a los individuos concretos, cabe preguntarse, con Klarsfeld y Revah (2002:97), y con Ridley (2001:223), que si el genoma es inmortal, ¿por qué la selección natural ha dado lugar a organismos que envejecen hasta morir? ${ }^{118}$. La respuesta a este interrogante pasa por recordar cuál es el “objetivo” de la evolución por selección natural, y qué relación mantienen con el mismo el envejecimiento y la muerte.

Afirman Olshansky y Carnes (2001:190-191) que “ni la crueldad ni la benevolencia dirigen la trayectoria de la evolución”. Sintetizan con esta expresión el papel neutral, o todo lo más de filtro pasivo, que las teorías evolucionistas otorgan a la Naturaleza en la propagación de los genes a lo largo del tiempo: la naturaleza no altera, ni condiciona, ni dirige, el depósito de genes hacia ninguna meta concreta. Sobre esta base, la fuerza que empuja a la selección natural es la continuación de la línea germinal; esto es, garantizar la inmortalidad de los genes. La eficacia en el cumplimiento de esta tarea es el principal criterio de la selección natural, de tal forma que $<<$ triunfan $>>$ aquellos individuos de cada especie que consiguen la transmisión de los genes que portan. Para ello necesitan sobrevivir y procrear puesto que en caso contrario se extinguirían. En efecto, la continuidad del linaje germinal de una especie depende de que un número suficiente de miembros de la misma alcance la maduración sexual y tengan un número suficiente de crías que, a su vez, se independicen y repitan el ciclo reproductor. La selección natural "favorece” a aquellos individuos que tienen más posibilidades de alcanzar esta meta (Kirkwood, 2000; Hayflick, 1999).

Según las teorías evolucionistas, por tanto, el objetivo de la evolución por selección natural es el éxito reproductor y todo lo demás tendría una importancia secundaria ${ }^{119}$. De esta forma, esas mismas teorías consideran que los individuos son desechables una vez cumplido su papel reproductivo y, por ello, que en los organismos pluricelulares no existe "programación activa y deliberada” del

\footnotetext{
${ }^{118}$ Es lo que Austad (1998:17) denomina <<Paradoja del envejecimiento>>, ya que según él no haría falta infringir ninguna ley de la física para diseñar un animal que no envejeciera, por lo que no encuentra razón alguna para que sea así.

${ }^{119}$ Se ha relacionado la elevada longevidad de la especie humana con la singularidad que la caracteriza: el tamaño y la complejidad estructural de su cerebro. Al ser éste un órgano intensivo en la utilización de energía nutricional, la competencia con otros órganos por ésta ha determinado que la evolución del mismo haya requerido "tanto de importantes cambios anatómicos, fisiológicos y de comportamiento, como cambios en el número y duración de las etapas del ciclo vital”: la encefalización ha mediatizado las características del ciclo vital. En efecto, "el elevado coste energético derivado del mantenimiento del cerebro humano (entre un 25-40\% de la Tasa Metabólica Basal) requiere un metabolismo más lento, al que se ajustan todos los sistemas y órganos del cuerpo", lo que ha retrasado la maduración sexual en la especie humana y, en consecuencia, su proceso de envejecimiento y muerte respecto a otras especies (Bernis, 2004: 6-7).
} 
envejecimiento y la muerte natural, a pesar de que estos procesos están de una u otra forma inscritos en los genes. Para comprender esta paradoja se puede recurrir a una situación hipotética, como la planteada por Klarsfeld y Revah (2002:113-114): ¿tiene sentido en términos evolutivos una especie cuyos individuos gozaran de una longevidad teóricamente infinita, no envejeciesen, ni conociesen la muerte natural? No, porque todos los organismos vivos son perecederos y, en consecuencia, la <<amortalidad >> no puede figurar entre las prioridades de la evolución. En efecto, dado que, de una u otra forma, y en un periodo de tiempo más o menos dilatado, todos y cada uno de los individuos de esa especie irían desapareciendo fruto de las agresiones provenientes del entorno donde viven, desde el punto de vista evolutivo esa especie sería totalmente "inestable" por cuanto, al no tener garantizada en absoluto su eternidad, la selección natural no podría preservar su inmortalidad potencial.

Siendo la prioridad de todo organismo vivo conseguir el éxito reproductivo, la mediatización por un contexto en el que la muerte extrínseca es estadísticamente inevitable determina que los organismos impliquen todos sus recursos y esfuerzos en la consumación de su función reproductora antes que en asegurarse su propia supervivencia individual. La premura a la que se hallan sometidos por unos plazos reproductivos limitados por amenazas de muerte ciertas e indeterminadas los condiciona a protegerse al máximo hasta triunfar en su tarea reproductora. El 'mandato' que la selección natural impone a los organismos vivos es sobrevivir hasta reproducirse y criar una prole independiente, no sobrevivir sin más. De esta forma, los cuerpos de los organismos pluricelulares no fueron "diseñados” para funcionar después de conseguir su objetivo reproductor, mucho menos para ser inmortales. Obviamente, eso no significa que la evolución haya <<programado >> la muerte natural, ni que ésta tenga una utilidad en sí para ella, sino que intentar evitar la muerte eternamente no resulta nada rentable en términos evolutivos. Se pasa así "de una concepción utilitaria de la muerte a una concepción de alguna manera <<inutilitaria >> de la misma (Klarsfeld y Revah, 2002:100 y 228-233; Hayflick, 1999:289-293).

Distintas teorías evolucionistas profundizan específicamente en esta interpretación de la longevidad, el envejecimiento y la muerte como resultado indirecto de la selección natural, a la que se denomina como $<<$ Hipótesis de la Optimización del Ciclo de Vida $>{ }^{120}$. Entre esas teorías se encuentra la Teoría del soma desechable, propuesta en 1977 por Kirkwood y que es un caso especial de pleiotropía antagónica. Según Kirkwood (2000), los organismos deben siempre dividir su energía fisiológica entre la reproducción sexual y el mantenimiento del soma o cuerpo y sugiere que "la

\footnotetext{
${ }^{120}$ Es el caso de la Teoría de la pleiotropía antagónica propuesta en 1957 por George C. Williams, según la cual en todo organismo existen genes que son pleiotrópicos, es decir, están implicados en múltiples procesos biológicos. Algunos de estos genes confieren ventajas para la supervivencia en las etapas anteriores a la reproducción pero, una vez alcanzado el éxito reproductivo, ejercen efectos fisiológicos deletéreos. En Wick et al (2002) se utiliza esta teoría para analizar la aparición de enfermedades como el Alzheimer o el cáncer de próstata.
} 
mayoría de los animales no ha adquirido, a través de la evolución, sistemas de mantenimiento que aseguren su inmortalidad, porque se hubiera derrochado una energía que se invertiría mejor en la reproducción: al existir la probabilidad del riesgo de muerte violenta, la especie haría bien en invertir en sistemas de protección que garanticen el vigor juvenil durante ese periodo, pero no más allá de él. El resto del suministro energético puede dirigirse hacia la promoción de una fertilidad óptima..., serían las células somáticas, las células no reproductivas, las que en último término serían las prescindibles. Por contraste, una fracción de las células germinales deben conservar la capacidad de auto-repararse perfectamente, ya que de otro modo la especie se extinguiría”. Por tanto, la senescencia, consecuencia inevitable de la acumulación de defectos no reparados en las células y tejidos, es el precio que se paga por la reproducción sexual.

Lo que sucede una vez conseguido el éxito reproductor no tiene importancia para la selección natural. Del arbitraje entre esa prioridad y una muerte externa inevitable nacen el envejecimiento y la muerte natural como efecto secundario de la propia selección natural ${ }^{121}$. La muerte y el envejecimiento son "el precio que pagamos por la inmortalidad de nuestros genes” (Olshansky y Carnes, 2001:60). La selección natural dota a los organismos de las reservas fisiológicas necesarias para que cumplan con su función reproductora. De la misma forma que ha evitado el despilfarro de programarles con unos recursos ilimitados que les permitiera hacer frente al gasto energético infinito necesario para ser <<amortales >>, tampoco ha construido un mecanismo específico de autodestrucción para acabar con ellos en el momento mismo de consumar su éxito reproductivo. Así, los organismos vivos seleccionados por la evolución tienen un exceso de reserva fisiológica, que los biólogos denominan $<<$ capacidad redundante $>>{ }^{122}$, que les permite superar el objetivo crítico de criar a su progenie hasta la independencia para, posteriormente, deslizarse "pendiente abajo" por un tiempo hasta que mueren. La selección natural, por tanto, determina indirectamente la longevidad y la muerte de los individuos (Hayflick, 1999:290-293).

No existe una programación genética activa de la muerte en los organismos pluricelulares como no existe una programación genética de su envejecimiento ${ }^{123}$. En sí mismo, tampoco éste tiene

\footnotetext{
121،La interpretación moderna que sostiene que el ADN de cada una de nuestras células aporta el programa también del proceso de envejecimiento es seductoramente simple, porque descansa en el dogma admitido según el cual el ADN y el aparato genético desempeñan el monopolio virtual de determinar casi todo lo que nos sucede... Sin embargo, nunca hubo miembros de una especie suficientemente viejos, y ciertamente ninguno lo fue por suficiente tiempo, como para que fuera posible que la evolución los seleccionara directamente para los procesos de envejecimiento" (Hayflick, 1999:305).

${ }^{122}$ Los seres humanos tienen una capacidad redundante muy notable en muchos de sus órganos. Por ejemplo, "poseemos una dotación magnífica por el hecho de disponer de dos riñones cuando con uno bastaría perfectamente. Podemos también sobrevivir con parte de nuestro hígado, estómago o intestinos” (Hayflick, 1999:289).

${ }_{123}$ "La evolución no puede crear genes con el propósito de matar a la gente (genes de la muerte)... los genes que causan las dolencia, las enfermedades y la muerte son un subproducto involuntario de un descuido evolutivo, no
} 
utilidad para la selección natural. La neutralidad de ésta no compensa completamente las continuas pérdidas de recursos y energía que se producen en la reserva fisiológica de los organismos, por lo que se generan desequilibrios moleculares -errores o mutaciones moleculares-, que alteran el orden molecular inicial. Son estos cambios moleculares, precisamente, los que hacen que los fallos sean cada vez más probables dando lugar a pérdidas fisiológicas que aumentan la vulnerabilidad e inician, con ello, el envejecimiento ${ }^{124}$ (Hayflick, 1999:339).

No obstante, la selección natural no tolera que estas "limitaciones en el diseño de los organismos” actúen, y se transmitan, cuando los mismos no han alcanzado aún su maduración sexual (mutaciones que podrían reducir el número de descendientes o su capacidad reproductiva). En efecto, los caracteres heredables persisten y se transmiten en una población si son útiles para la consecución del objetivo de la reproducción, pero se tornan escasos si perjudican la supervivencia de los jóvenes. En este caso, la selección actúa en su contra, ya que sus portadores suelen ser eliminados antes de reproducirse. Por el contrario, se muestra permisiva si esas deficiencias se manifiestan más allá de la maduración sexual, cuando el número de individuos se va reduciendo y su contribución relativa a la generación siguiente es menor. Fuera del periodo <<protegido>> por la selección natural, las mutaciones genéticas somáticas que afectan a los individuos de edad avanzada se acumulan en el genoma al transmitirlas los portadores a la generación siguiente sin que sus efectos perniciosos impidan la reproducción. De hecho, cuanto más tarden en manifestarse esos efectos, más se propagarán esos genes al tener más tiempo sus portadores para reproducirse. En palabras de Rose (2000:62), la selección natural, "el cancerbero que protege los caracteres promotores del vigor juvenil”, se adormece con la edad lo que permite que furtivamente se grabe el envejecimiento en las especies pluricelulares. La inutilidad biológica de los sistemas de reparación para impedirlo facilita, de esta forma, la emergencia de la muerte natural, y del envejecimiento, como un fracaso inevitable de la selección natural (Klarsfeld y Revah, 2002:228; Ridley, 2001:229; Kirkwood, 2000:93; Autad, 1998:cap.7).

A esta interpretación del envejecimiento y la muerte se la denomina "Hipótesis del lastre mutacional”. En la misma subyace que poco importa si aquéllos están o no inscritos en los genes con tal de que no se manifiesten demasiado pronto, dado que esto es lo único relevante en términos de la

el producto final de un designio evolutivo... una vez que ha sido alcanzada la madurez sexual, los programas genéticos destinados a favorecer la vida empiezan a operar con menos eficiencia... esa ampliación de la supervivencia demuestra a las claras que, desde una perspectiva evolucionista, los seres humanos están hiperdiseñados, pues sobreviven más tiempo del que es necesario para producir la descendencia portadora de sus genes. No es necesario mejorar el diseño de un cuerpo que ya está hiperdiseñado" (Olshansky y Carnes, 2001:84-85).

124 "Yo tengo la certeza de que no envejecemos por causa de una muerte masiva de células, pero los complejos cambios moleculares que precedan a la muerte celular bien podrán ser la causa de los cambios relacionados con la edad y de la muerte animal mucho antes de que las células mismas mueran” (Hayflick, 1999: 305). 
evolución de la especie. Explica, además, la aparición de las enfermedades ligadas al envejecimiento $^{125}$. En este sentido, Peter B. Medawar ${ }^{126}$, premio Nobel de Medicina y Fisiología en 1952, fue uno de los primeros en alertar sobre las consecuencias para la supervivencia específica de los seres humanos de los avances científico-técnicos aplicados al ámbito médico-sanitario. El creciente número de personas que lograban sobrevivir hasta el periodo post-reproductivo estaba permitiendo que las enfermedades del basurero genético “tuvieran oportunidad de revelarse, o de actuar”, cada vez con mayor frecuencia (Olshansky y Carnes, 2001:64-66). De esta forma, y a pesar de que el envejecimiento se inicia desde el inicio de la pubertad ${ }^{127}$, sus consecuencias no se hacen evidentes hasta la quinta década de la vida. Es a partir de los cuarenta años cuando "la máquina del cuerpo humano” comienza a deteriorarse -el riesgo de enfermar ${ }^{128}$ y morir aumenta-, porque no ha sido “diseñada para durar por mucho tiempo"129 y ha acabado su "periodo de garantía” (Olshansky y Carnes, 2001:69-70; Olshansky et al, 2001:45).

A la luz de los conocimientos biológicos actuales se puede concluir, respondiendo de forma genérica a la cuestión del por qué de la muerte natural, que la ausencia de muerte sólo es concebible en un universo enteramente estático, mientras que en un universo en continua evolución la muerte es inexorable. Ésta es un fenómeno biológico objetivo que afecta a todos los seres vivos, fruto del azar y

\footnotetext{
125 "Las mutaciones que causan efectos dañinos tarde en la vida se han ido acumulando en el genoma humano a lo largo de cientos de miles de generaciones. Y como las mutaciones se dan en todo el genoma, esta <<acumulación de mutaciones>> debería desembocar en daños no sólo en uno o dos órganos sino en todo el cuerpo" (Austad, 1998:115).

${ }^{126}$ Medawar denominó <<basurero genético >> al periodo post-reproductivo de la vida, un tiempo en el que los genes perjudiciales o deletéreos para la supervivencia y la reproducción, que habían sido <<empujados>> por la selección natural hasta las edades más avanzadas, podían actuar sin perjudicar al éxito reproductivo (Olshansky y Carnes, 2001:64).

${ }^{127}$ Aunque habitualmente se suele afirmar que los seres humanos comienzan a envejecer, y a morir, desde su nacimiento, Austad (1998:23-24) sitúa el inicio de los mismos a los “11-12 años”, justificando su afirmación en la distribución de las Tasas de Mortalidad por Edad. Como se describe en el Capítulo 4 de esta Tesis, las probabilidades de fallecer son relativamente altas en el nacimiento y primer año de vida, posteriormente caen hasta un mínimo -10 a 14 años- e inician un crecimiento ininterrumpido hasta el final del ciclo vital. Este crecimiento constante de las probabilidades de fallecer reflejan, según Austad, el debilitamiento propio del envejecimiento.

${ }^{128}$ En su análisis del <<Cromosoma 17>>, en el que se encuentra el gen TP53 que previene el cáncer, Ridley (2001:263-275) concluye que "ahora está claro por qué el cáncer es una enfermedad cuya frecuencia se duplica cada década de nuestra vida y es principalmente una enfermedad de los mayores... Cuanto más vivamos, más errores acumulamos en nuestros genes y mayor es la posibilidad de que un oncogen (gen que provoca la división y el crecimiento celular) pueda ser activado y tres genes supresores de tumores (como el TP53) inactivados en la misma célula. Las posibilidades de que esto ocurra son casi inconcebiblemente pequeñas, pero, claro está, la cantidad de células que fabricamos a lo largo de nuestra vida es casi inconcebiblemente grande”.

${ }^{129}$ Olshansky et al (2001) emplean la perspectiva de la ingeniería mecánica para analizar la anatomía humana como si de una máquina se tratara. Constatan que si el cuerpo humano hubiera sido diseñado para durar más tiempo tendría muchos menos errores de los que tiene, y plantean algunas de las modificaciones que habría tenido que incluir si su objetivo hubiera sido una longevidad dilatada con salud perpetua. Por otra parte, las deficiencias en el diseño del cuerpo humano les sirven para criticar a aquellas posiciones teóricas, como las del Ambioma, que responsabilizan personalmente a cada individuo de las consecuencias de su envejecimiento: es "tremendamente injusto" que se les achaque las consecuencias para su salud de procesos que derivan de la
} 
la necesidad en una evolución de alcance cósmico. Durante millones de años la muerte no estuvo integrada en la vida orgánica, y sólo cabía una muerte accidental venida desde el exterior. Sin embargo, la muerte natural emergió en la evolución por selección natural no como una propiedad intrínseca de los seres vivos, ya que para ellos no tiene ninguna utilidad, sino para limitar los daños que una muerte extrínseca inevitable podía infligir en el objetivo principal de la selección natural, la reproducción. De esta forma, la muerte constituye un fracaso de la selección natural, al menos en la misma medida que un producto de la misma (Klarsfeld y Revah, 2002). En el ámbito biológico, por tanto, la muerte de todos los seres pluricelulares es un proceso irremediable, incondicional y "natural" -inherente biológicamente a su existencia ${ }^{130}$.

Sin embargo, como ocurre con la filosofía de Epicuro, el problema que plantea la muerte a los seres humanos recibe luz pero no queda resuelto con las racionalizaciones aportadas por la ciencia. Porque para aquéllos, por ejemplo, el saber que la vida es un "extraordinario equilibrio entre el azar y la necesidad” no es una guía útil para su vida cotidiana. Como gráficamente lo describe Carse (1987:77): "Uno no puede manejar sus asuntos conformándose pasivamente al incesante transcurrir del fenómeno atómico”. Es decir, para los seres humanos es importante cuánto tiempo van a vivir en sus cuerpos, pero más importante aún cómo de bien van a vivir en esos cuerpos y cuán significativas y saludables van a ser sus vidas. Y en este punto, "el problema de la muerte no es el problema de una existencia física accidental; es un problema que puede ser entendido sólo en la medida en que, intencionalmente, vivamos nuestra existencia física con otros” (Carse, 1987:77-78). De ahí, la construcción de mitos de contingencia de la muerte, como el más reciente de ellos, el de la deconstrucción de la mortalidad.

\footnotetext{
herencia de un "cuerpo que no dispone de perfectos sistemas de mantenimiento y de reparación, ni fue construido para usarlo largo tiempo o para una salud perpetua".

${ }^{130}$ Los importantes avances realizados en laboratorio durante los últimos años han hecho emerger un nuevo paradigma científico según el cual, dado que el envejecimiento y la muerte no son imperativos de la evolución, son entonces procesos tratables, alterables y que por tanto se pueden posponer durante décadas. En el subapartado 4.3.2. de esta Tesis se examinan las dos grandes líneas actuales de pensamiento -la "tradicional" y la "prolongevista" - sobre la evolución futura del envejecimiento y la muerte.
} 
CAPÍTULO 2.- <<SISTEMA DE MUERTE >>:

EL CONTEXTO SOCIAL DEL MORIR 



\title{
CAPÍTULO 2.- <<SISTEMA DE MUERTE >>: EL CONTEXTO SOCIAL DEL MORIR
}

\begin{abstract}
"Llamamos <<cultura >> al género de actividad humana que a fin de cuentas consiste en volver sólido lo volátil, en unir lo finito a lo infinito y, por lo demás, en construir puentes que unan la vida mortal con unos valores inmunes a la erosión producida por el tiempo”.
\end{abstract}

Z. Bauman

La concepción de la muerte en una sociedad compromete globalmente a todo su sistema cultural. La gestión del proceso de morir, el tratamiento de los muertos o el desarrollo de los rituales relacionados con la muerte conforman una mirada concreta sobre ésta, pero también informan sobre la realidad social en su conjunto y sobre la relación de esa sociedad con el mundo. En efecto, como resalta Carmona (2005:473), un axioma básico en Sociología es que "la realidad social no es transparente y los hechos sociales se descubren más allá del saber de la ilusión del saber inmediato y se reconstruyen con la ayuda de la teoría y de la historia”. En esta línea, el tratamiento de la muerte en una sociedad no es estático, no está osificado, sino que interacciona constantemente y de forma estrecha con el resto de ideas-fuerza que dinamizan a la sociedad. Tampoco es tan diáfano como se observa a primera vista, sino que bajo ese tratamiento subyace la complejidad de la vida social en la que se pueden mezclar toda una batería de intereses, desde los más prosaicos -los relacionados con el poder y el control social-, hasta los más heroicos -los relacionados con la supervivencia del grupo. En este capítulo se define en primer lugar el concepto de Sistema de Muerte, que permite delimitar los vínculos entre la mirada de la muerte y la vida social en cualquier sociedad. Centrándose en las sociedades más desarrolladas, se examinan a continuación algunos de los factores del escenario macro-social que han incidido en el proceso de modernización iniciado hace dos siglos, provocando un cambio social global respecto a las sociedades tradicionales pretéritas, y que asimismo han mutado las experiencias y las percepciones de la muerte en esas sociedades. Posteriormente, y como ejemplo de las singularidades que caracterizan la construcción social de la muerte en las mismas, se analiza extensamente y de forma detallada la evolución seguida hasta la actual definición de muerte en las sociedades desarrolladas. Definición pragmática estrechamente vinculada a las ideas-fuerza de la civilización técnica y que, paradójicamente, a pesar de la utilización de tecnologías cada vez más sofisticadas, lejos de identificar de forma taxativa y neutra cuándo se produce la muerte ha creado una nebulosa de criterios que han desembocado en que la toma de decisiones sobre esta trascendental cuestión se halle cautiva de los sucesivos avances técnicos, es decir, sea dependiente, incompleta e inestable. Definición que además no se limita a la función tradicional de identificar la aparición del cadáver, es decir, que no tiene como motivo central sólo el de identificar el cambio de estado de la persona que muere, sino que, en una dinámica al servicio del pragmatismo reinante, se utiliza para satisfacer 
intereses externos a ella, a la que para ello se ubica en el "reino de la pura cosificación"; dinámica tecnomédica que Hans Jonas (1997:156) resumió con impotencia como sigue: "El esplendor y la miseria de nuestro tiempo habitan en esa marea incesante”.

\subsection{CONCEPTO DE <<SISTEMA DE MUERTE $>>$}

"Mostrarme la manera en que una nación se ocupa de sus muertos y yo os diré, con una razonable certeza,

los sentimientos delicados de su pueblo y su fidelidad para con un ideal avanzado”

Gladstone

El ser humano, naturalmente ciego a la muerte, toma conciencia de ella no como un saber específico, sino individual; no de forma innata, sino como el producto de una conciencia que aprehende la realidad (Morin, 1974a:62). Éste es un aprendizaje individual sobre un saber que le llega desde el exterior y que, como se ha señalado, está mediatizado culturalmente, socialmente. No se trata, por tanto, de una aprehensión genética, unívoca, absoluta. Tampoco depende sólo del libre albedrío de cada individuo. Es relativa y viene condicionada por el entorno social, por tanto, no es contingente ${ }^{1}$. En suma, es una síntesis de aspectos “micro” y “macro", fruto de la interacción, en un contexto específico, entre el actor/agente y el <<sistema de muerte>>. Este concepto fue definido por Kanstenbaum y Aisenberg (1972:191-192) como "la esfera total de pensamientos, sentimientos, y comportamientos que está relacionada directa o indirectamente con la muerte”. Con el mismo se busca describir la manera en que la gente vive su morir, su pena y su duelo, y está constituido por la suma total de personas, lugares, tradiciones, actos, omisiones, emociones, y manifestaciones por las que el ser humano conoce, siente y actúa sobre la muerte, el morir y la aflicción en un momento dado. El sistema de muerte, por tanto, actúa como mediador entre el individuo y la muerte conformando la canalización de las aproximaciones personal, social, religiosa, filosófica y psicosocial en el manejo de aquélla (Morgan, 1995:27).

Así, por ejemplo, aunque se vive a nivel individual, el duelo es "sobre todo y ante todo, una realidad colectiva, social y cultural” (Luzón, 2004:20), que comprende al conjunto de fenómenos que se ponen en marcha tras la pérdida de una persona allegada. Estos fenómenos pueden ser psicológicos (los <<procesos de duelo>>: cambios psicológicos y psicosociales,

\footnotetext{
${ }^{1}$ Frente a la contingencia corporal y los designios deterministas de la transmisión genética de la especie "Ser sencillamente un animal significa proseguir la línea irremediable de la especie"-, las creaciones culturales, según Savater (2007:58), "aspiran a identificarnos según lo sublime... La cultura se reclama como mejor que la vida por tanto como relativamente invulnerable ante la muerte... El objetivo de la cultura... es ascendernos a padres de nosotros mismos, autoengendrados por nuestro espíritu y no fabricados en serie por la naturaleza: llegar a ser $<<$ causa de nosotros mismos $>>$, originarios y originales sin sumisión al diseño biológico previo... invulnerables a la asechanza programada del desgaste físico”.
} 
fundamentalmente emocionales por los que se elabora internamente la pérdida; conjunto de emociones, representaciones mentales y conductas vinculadas con la pérdida afectiva, la frustración o el dolor -pena, tristeza, aflicción, angustia, molestias somáticas, etc.), y sociales (el <<luto>>: conjunto de manifestaciones externas, culturales y sociales, antropológicas e incluso económicas, que ayudan o reglamentan la reacomodación social y psicosocial tras la pérdida) (Luzón, 2004:cap.1).

Dado que el conocimiento de la muerte no puede ser evitado por ninguna sociedad, y como "la muerte es el principal desafío a todas las definiciones de la realidad socialmente objetivadas, tanto del mundo, como de los demás, como de uno mismo..., las legitimaciones de la realidad social cara a la muerte se convierten en exigencias necesarias para cualquier sociedad” (Berger, 1999:72). Por ello, porque la amenaza de la muerte cuestiona cualquier significado social y transforma en precaria, en dudosa, la existencia misma de la sociedad, todas las culturas conocidas han elaborado mecanismos (creencias, instituciones, ritos, etc.) para enfrentarla mediante un proceso de sublimación de lo ignoto, en un intento de integrar lo desconocido e intranquilizador en una lógica verosímil (no necesariamente racional, como la religión) y controlada. Siguiendo a Kearl (1995:5-8), este proceso integrador que busca minimizar el potencial `anomígeno’ de la muerte es tanto más eficaz, es decir, logra un mayor control, cuanto mejor se cubren las siguientes cuatro dimensiones:

a) 'dar significado al acontecimiento de la muerte`: siguiendo a Becker (2003:17), la idea de la muerte, el miedo que inspira, “un universal de la condición humana”, es la causa principal de la actividad humana, que es diseñada en su mayor parte para evitarla, "para superarla negando de algún modo que es el destino final de la persona”. En efecto, como la muerte da la verdadera medida de la vida puede llevar a los individuos a cuestionar el sentido de la misma y a desvalorizar los esfuerzos para la consecución de los objetivos sociales, es decir, a poner en cuestionamiento la seguridad ontológica de aquéllos, a los que socava en su significación social (Basterra, 2006:37; Giddens, 1993). Es por ello por lo que sin duda la tarea central de cualquier sistema cultural (sistema de muerte) es la de proporcionar un orden simbólico y un significado a la mortalidad humana fuertes que eviten a los individuos la percepción de su insignificancia social y con ello, como se analiza más abajo, lograr la predisposición favorable de los mismos hacia su participación activa en la vida social, es decir, garantizar el funcionamiento de la sociedad y evitar un orden social vulnerable. Dado que, según Ziegler (1976:144), apenas existen áreas relacionadas con los seres humanos (conductas, productos, normas, instituciones, incluidos los sueños) que no estén conformadas de una u otra forma por la experiencia de la muerte, esa mediatización social ha de ser tan intensa como para determinar, canalizándolas, las 
conductas concretas de los individuos en prácticamente todos los ámbitos de su vida ${ }^{2}$. En este sentido, por ejemplo, distintas investigaciones empíricas ${ }^{3}$ han comprobado la validez de las tesis relativas a que la ansiedad ante la muerte intensifica la lealtad y obediencia a los códigos morales del grupo propio. Así, para canalizar estas energías hacia diferentes fines (religiosos, políticos, sociales, militares), todos los sistemas de muerte siempre han tratado de

b) 'recordar a los individuos su mortalidad': no se trataría tanto de desarrollar un recordatorio de lo obvio -que van a morir-, cuanto de aprovechar el papel disruptor de la muerte, su potencial desintegrador, para favorecer la demanda de adaptaciones que conlleven mayores niveles de cohesión y continuidad social. Se ha comprobado empíricamente, por ejemplo, que el aumento de la conciencia de muerte intensifica la solidaridad intra-grupo a la par que se incrementan los prejuicios hacia los otros y se refuerzan "los extremismos religiosos” (Kearl, 1995:5). Esta reversión paradójica del temor a la muerte en fortalecimiento de la vida se asienta en parte, como apuntó Canetti (2000) al analizar la figura del superviviente, en que "el espanto ante la visión de la muerte se disuelve en satisfacción pues no es uno mismo el muerto". Sentimiento mórbido que es canalizado socialmente en la mayoría de las culturas hacia el deseo de tener una larga vida (Canetti, 2000:262). Así, dado que "el momento de sobrevivir es el momento del poder", los sistemas de muerte se preocupan de

c) 'ayudar a los individuos a sobrevivir a sus contemporáneos': porque esa experiencia, ese sentimiento de satisfacción que permanece oculto bajo las convenciones sociales, a la par que sacia implícitamente los deseos humanos de inmortalidad - “El hombre no sólo quiere estar siempre; él quiere estar cuando los otros ya no estén” (Canetti, 2000:239)-, permite a los supervivientes tomar la porción de poder de los muertos necesaria para consolidar su propia vida y su dominio ${ }^{4}$. En el extremo, cuando otros ponen en peligro la propia supervivencia, ese sentimiento de satisfacción, por el contrario, no sólo aflora sino que incluso puede llegar a ser socialmente alentado y justificado. Es el caso de las guerras, potlatchs de muerte en las que está legitimado matar para limitar el número de víctimas propias: "La declaración de guerra

\footnotetext{
${ }^{2}$ Kearl (1995:5) señala entre otros los siguientes ámbitos: "la militancia de la gente y la tasa de suicidio, su buena voluntad para asumir riesgos, sus miedos o esperanzas de reencarnación y resurrección, su predisposición para recibir trasplantes de órganos o suscribir seguros de vida, su preferencia por la inhumación o la incineración, sus actitudes hacia la pena capital y el aborto, o su conceptualización de la buena muerte".

${ }^{3}$ Kearl (1995:5) cita, entre otros, los experimentos de Rosenblatt et al (1989) en los que, mediante tests, comprobaron que cuando la gente recordaba su mortalidad reaccionaban más severamente hacia los transgresores de la moral y se mostraban dispuestos más favorablemente hacia aquellas personas que actuaban de acuerdo a los valores socialmente legitimados.

4 "Entre estos montones de caídos el superviviente se yergue como afortunado y preferido... Indefensos yacen los muertos, entre ellos está erguido él, de pie, y es como si la batalla se hubiese librado para que él sobreviva. Ha desviado de él la muerte, sobre los otros. No es que haya evitado el peligro. En medio de sus amigos, encaró a la muerte. Ellos han caído. Él está de pie y triunfa” (Canetti, 2000:240).
} 
significa la suspensión de la culpabilidad y la vergüenza que el deseo de sobrevivir engendra en tiempos <<normales >>” (Bauman, 1992:34). En tiempos de guerra o en tiempos de paz los sistemas de muerte deben, además,

d) 'proporcionar a los individuos oportunidades para trascender sobre la muerte': para que crean que su vida se halla inserta en algo eterno, que el significado de la misma está unido a una sociedad que existió antes de su nacimiento y que continuará después de su muerte, que lo que hacen las personas tiene un valor y significado duraderos que sobrevivirá a su muerte y descomposición ${ }^{5}$. En palabras de E. Bloch ${ }^{6}$, “cuando morimos, querámoslo o no, debemos entregarnos, es decir, entregar nuestro 'yo` a los otros, a los supervivientes, a aquellos, y son billones, que vienen después de nosotros, porque ellos y sólo ellos pueden acabar nuestra vida no concluida”. Deseos de trascendencia que según Bauman (2001:13) desencadena el conocimiento de la mortalidad, y que la sociedad alimenta proporcionando "objetos creíbles de satisfacción” para sus dos versiones -la de dejar huellas duraderas o la de vivir experiencias <<más fuertes que la muerte>>- capitalizando y canalizando la energía que ambas conllevan para que esos esfuerzos sean lo suficientemente intensos como "para llenar la duración de la vida y (sean) lo suficientemente variados como para ser ambicionados”. Así, en ese entorno social, en el que se suelen fijar unos modelos sociales de comportamiento sujetos a determinadas constricciones sociales, los individuos viven y aquellos que son capaces de destacar por encima de esos estándares tienen la posibilidad de ser recordados por ello como héroes. De esta forma, los roles individuales suelen estar definidos por "estándares culturales en los que biografía y sociedad pueden ser fusionados, llegando a ser inmortalizados en epónimos, leyendas, arte, estadísticas y edificios públicos de fama” (Kearl, 1995:8).

Es decir, todo sistema cultural no es más que un sistema de acción simbólico que vive de la invención y propagación del "mito del significado de la vida humana”, mientras que todo orden social vive de la manipulación del apremio a la trascendencia (Bauman, 2001:15). Esto es, "provocadora creación de sentido" cuya función es amortiguar la conciencia de vulnerabilidad y mortalidad de los individuos, sumergirles en el "ciego olvido”, a través de estructuras de estatus y roles, costumbres y normas "diseñadas para servir de vehículo al heroísmo terrenal”, independientemente del cuál sea el carácter de éste (mágico, religioso, científico,...). Sistema codificado de héroes que prometen la inmortalidad <<simbólica >> a través de la identificación con el sistema, y en algunos casos la inmortalidad $<<$ real $>>$ a través de la religión, a cambio de un único requisito: cumplir las reglas del sistema y vivir siguiendo

\footnotetext{
${ }^{5}$ Kearl (1995:8) señala que "los orígenes de la civilización empezaron cuando, por ejemplo, los padres empezaron a ser conscientes de que sus hijos les sucedían y descubrieron sus obligaciones para la supervivencia del orden sociocultural”.

${ }^{6}$ Citado en Ziegler (1976:17).
} 
los patrones culturales establecidos por el mismo; criterios a los que los individuos se someten en última instancia para adquirir un "sentimiento de valor primordial”, de utilidad (Becker, 2003:32-37).

Por tanto, la muerte llega a los individuos bajo una máscara con la que la cubre la sociedad en la que aquéllos construyen sus biografías. Es decir, la forma en la que los individuos conocen, piensan, anticipan o se enfrentan a la muerte está mediatizada socialmente, es una creación social: "no es nuestra conciencia cándida la que recibe la muerte, es nuestra conciencia construida” (Ziegler, 1976:144). Por ello, cada individuo 'vive` su morir de forma diferente ya que cada sociedad socializa a sus miembros con un ideario sobre la muerte, les provee de teorías sobre su destino después de muertos, les inculca normas que regulan actitudes y prescriben comportamientos en relación con el morir y la muerte (duelo, funeral, luto, herencia, etc.). Todos esos mecanismos, además, han sido diferentes entre las diversas sociedades dependiendo de sus condiciones de existencia y de la conceptualización dominante sobre la muerte ${ }^{7}$. En efecto, los sistemas de muerte son productos socioculturales y, por tanto, cambian, y además lo hacen, según Kanstenbaum y Aisenberg (1972), como factores claves del cambio cultural. En un proceso dialéctico, de interacción simbiótica, el sistema de muerte cambia las actitudes de los individuos hacia otros objetos, entidades u organismos y las actitudes hacia estos otros cambian al sistema de muerte. Un ejemplo diáfano de las consecuencias de esa mutua influencia es el cambio producido en la segunda mitad del siglo XX en las actitudes prevalentes hacia las personas consumidoras de tabaco. Si hasta hace no muchas décadas la actitud social dominante hacia las mismas era la de tolerancia, una vez conocidos los peligros que para la salud entraña fumar, esa actitud ha mutado hacia un creciente rechazo del consumo de tabaco en espacios públicos, sancionado incluso por ley, y la expulsión de los mismos de las personas que fuman ${ }^{8}$.

Según Kanstenbaum y Aisenberg (1972), dos categorías de factores moldean a los sistemas de muerte y explican las diferencias entre ellos: "factores realidad" (factual factors) y "factores teóricos" (theoretical factors). Los primeros son la "exposición a la muerte" y la "esperanza de vida"; los segundos son el "control percibido sobre las fuerzas de la naturaleza" y la "percepción de qué significa ser persona". El primer factor real que influye en la comprensión de la muerte es la exposición a ella, que puede producirse bien directamente por

\footnotetext{
7 "La enorme variedad de modos de considerar la muerte y lidiar con ella sólo nos muestra que nuestras arraigadas costumbres no vienen dadas por la Naturaleza, que podríamos cambiarlas si quisiéramos” (Barley, 2000:12).

${ }^{8}$ Morgan (1995:34) resalta otro ejemplo claro en este sentido: el incremento del número de incineraciones de cadáveres en las sociedades occidentales. Aumento que a su vez "reformará en unos pocos años el sistema de muerte occidental”.
} 
edad, por enfermedad grave, o por las consecuencias del enfrentamiento, voluntario o involuntario, con algún tipo de riesgo para la propia vida, o bien indirectamente por la pérdida de una persona muy allegada. Siendo evidentes los efectos de las experiencias cercanas a la muerte (exposición directa) en el cambio de actitudes que llevan a la participación plena en el sistema de muerte, algunos autores consideran que "si una persona no ha experimentado la pérdida de un otro significativo (exposición indirecta), sus actitudes hacia la muerte estarán limitadas” y que, por tanto, al no haber vivido nunca un duelo esa persona no participa plenamente en el sistema de muerte (Morgan, 1995:27).

Como se analiza extensamente en el Capítulo 4 de esta Tesis, la exposición a la muerte está estrechamente relacionada con el nivel de la esperanza de vida, segundo factor "real" que influye en la comprensión de la muerte. En efecto, el incremento de la esperanza de vida significa entre otras cosas que cada vez más individuos viven hasta edades más avanzadas y que la muerte es más frecuentemente inevitable que accidental, lo que conlleva una reducción de la exposición a la muerte en las primeras fases de la vida, al disminuir los riesgos de muerte ordinaria y retrasarse la experiencia de la pérdida de un otro significativo, a la par que, por el contrario, un exceso de exposición a la muerte entre los de edades avanzadas derivado de la multitud de pérdidas y duelos previos y complicados a los que han sobrevivido ${ }^{9}$. Este cambio en las condiciones demográficas de la muerte, que mutan profundamente las condiciones de la vida, puede desembocar finalmente en una cierta banalización de la muerte, como ocurre entre los jóvenes de las sociedades desarrolladas en los que se observa una reducción de la conciencia y el respeto a la muerte al diluirse su comprensión de la fragilidad de la vida. Entre los mayores, por su parte, el envejecimiento de la población junto con la disminución del tamaño de las familias, además de la incidencia de otros cambios socio-culturales, ha desembocado en una aminoración de su estatus y poder social, lo que ha conllevado a su vez múltiples consecuencias en la conformación de la conciencia de la muerte cada vez más próxima: aislamiento y soledad en las últimas etapas de la vida, dificultades para rehacer la identidad -la mismidad (el self)-, dificultades para reajustar los roles, “concentración de duelos” en muy pocos años, preocupación acerca de la eutanasia, enfrentamiento de la muerte sin compañía (Tizón, 2004:728-741).

\footnotetext{
${ }^{9}$ La multiplicidad de pérdidas y duelos acumulados con la edad abarca tanto los fallecimientos de familiares y allegados y amigos, en especial los que suponen "pérdidas de relaciones (biopsicosociales) de profunda interdependencia”, como el declive y/o pérdida de capacidades corporales (fuerza y salud) o cognitivas, además de "ideales, recursos económicos, domicilio, autonomía, etc., a lo que hay que añadir el importante duelo que suele suponer la jubilación: camaradería, relaciones sociales, estructuración diaria, medios económicos y sociales” (Tizón, 2004:731-734).
} 
El primero de los factores teóricos, el control percibido sobre las fuerzas de la naturaleza, hace referencia a que las actitudes ante la muerte están modeladas por la visión que tienen los individuos del mundo y del lugar que ocupan en él. No es lo mismo, en este sentido, creer que se es una parte integral de la naturaleza con el deber de respetarla, que tener una percepción de impotencia ante el determinismo de las leyes de la naturaleza o, por el contrario, creer que se está protegido de la naturaleza sobre la que no sólo se tiene un control significativo pudiéndose resolver todos los problemas que plantee, sino que se la percibe como algo conquistado que ha sido transformado en una fuente de recursos a disposición total. En expresión de Morgan (1995:28, 40), “la raíz material de nuestros sueños”. Así, sobre una base común de miedo a la muerte en todas las sociedades, en el primero de los contextos señalados las actitudes ante la muerte socialmente dominantes probablemente sean la de la aceptación natural de la misma ${ }^{10}$, al considerarla un muro totalmente engarzado con la vida, o la de la aceptación neutral de su facticidad como barrera extrínseca inevitable de la vida; ambas actitudes están íntimamente conectadas a actitudes vitales activas que animan sobre todo a vivir la vida, que es única y finita. En el segundo de los supuestos, la percepción fatalista que domina la vida cotidiana genera actitudes vitales de pasividad frente a unas fuerzas ante las que los individuos se sienten inermes, percepción que alimenta actitudes de rendición incondicional y previa ante la muerte o, en su versión extrema, lo que se denomina la aceptación de escape, por la que se considera que existen situaciones peores que la muerte y que ésta puede ser una buena salida para una vida sin esperanza ${ }^{11}$. El tercero de los contextos mencionados corresponde a las sociedades desarrolladas occidentales y en la esencia del mismo subyace desde su origen, como señaló Lynn White Jr. ${ }^{12}$ (1967) al analizar las raíces históricas de la crisis ecológica, el carácter marcadamente antropocéntrico del cristianismo que ha justificado las actitudes humanas de

\footnotetext{
${ }^{10}$ Una muestra diáfana de la visión de integración humana en la naturaleza la ofreció el Gran Jefe Seattle (1885) en su carta al Presidente de los Estados Unidos como respuesta a la petición de comprarle las tierras por parte de los colonos. En un párrafo de la carta se dice: “... ¿Cómo podéis comprar o vender el cielo o el calor de la tierra? Esta idea nos resulta extraña. Ni el frescor del aire ni el brillo del agua son nuestros. ¿Cómo podrían ser comprados? Tenéis que saber que cada trozo de esta tierra es sagrado para mi pueblo. La hoja verde, la playa arenosa, la niebla del bosque, el amanecer entre los árboles, los pardos insectos son sagradas experiencias y memorias de mi pueblo. Los muertos del hombre blanco olvidan su tierra cuando comienzan el viaje a través de las estrellas. Nuestros muertos nunca se alejan de la tierra que es la madre. Somos una parte de ella y la flor perfumada, el ciervo, el caballo y el águila majestuosa son nuestros hermanos... (el subrayado es nuestro)".

11 "El hombre del México antiguo por ejemplo no parecía temerle a la muerte sino a la vida, que le resultaba difícil, azarosa y llena de incertidumbres... Mientras que, para los cristianos, la resurrección a un goce o a un sufrimiento eterno depende de haber llevado o no una vida piadosa, el mito mexicano, por el contrario, no aplaza el castigo para después de la muerte sino que expone al hombre la angustia durante su vida terrena. Este sentimiento, asociado a la vida, hacía que los mexicas llamaran a niño recién nacido "prisionero de la vida". La muerte ponía, por tanto, fin a una situación de dolor en la vida, concebida como una sucesión de catástrofes. La religión prometía una felicidad: la de morir para servir a los dioses; en consecuencia, la muerte era para ellos el principio de la existencia verdadera y Tláloc, dios de la lluvia, recibía en el paraíso terrenal a los que habían sufrido durante su vida. Ahí renacían, transformados en otros” (Blanck-Cereijido y Cereijido, 1996:61).

${ }^{12}$ WHITE Jr., L. (1967): “The Historical Roots of Our Ecological Crisis”, en Science, vol.155, pp.1.2031.207, citado en Singer (1997:173).
} 
dominio sobre la naturaleza y alentado el especieísmo. En efecto, a diferencia de otras culturas, sobre todo las orientales, que han defendido una integración humana armónica con la naturaleza y el carácter sagrado de todas las vidas, incluidas las de los animales no humanos, la hegemonía del cristianismo en Occidente ha fomentado desde sus orígenes ${ }^{13}$ el carácter especial y único de los seres humanos hechos a imagen de Dios; singularidad que además incluía una concesión divina de poder sobre todos los demás seres vivos (Singer, 2003:caps. 5, 7, 9 y 15; 1997:cap.8). Sobre esta base, los avances científicos de los dos últimos siglos no han hecho más que amplificar la creencia de ser amos de la naturaleza que la tradición occidental otorga en exclusiva a los seres humanos, y las aplicaciones tecnológicas derivadas, por su parte, han transformado inevitable y profundamente las relaciones entre los seres humanos y la naturaleza. Todo ello ha sedimentado en el ámbito de las actitudes ante la muerte en, por una parte, una aceptación de acercamiento de la muerte, de raíz religiosa, por la que no se la considera un muro sino una puerta hacia la inmortalidad o, por otra parte y sobre todo, en una negación de la muerte en los niveles consciente y conativo, evitando preocuparse/relacionarse por/con ella, y una denegación de la muerte a nivel inconsciente. Esta actitud de disociación, como se analiza más adelante, está estrechamente relacionada con algunas de las dimensiones que han conformado el proceso de modernización de las sociedades desarrolladas durante los dos últimos siglos: secularización, individualismo, racionalización, privatización, avances del conocimiento científico-técnico, profesionalización, etc.

Así, por ejemplo, la institucionalización y la medicalización de la muerte han conllevado una menor visibilidad de la misma al estar recluida en ámbitos espaciales especializados -hospitales, unidades de cuidados paliativos, geriátricos, etc.-, lo que ha dificultado la socialización en cómo enfrentarse a ella. Proceso de desocialización que se ha visto potenciado por una profesionalización del proceso de morir, a través del personal médico, de enfermería o de los servicios funerarios, que no sólo reduce los contactos con la muerte de los individuos en general, sino que enajena el propio proceso de morir a quienes están próximos a ella. De ahí, las dificultades para hablar en público de la muerte en general o con los niños en particular; los mecanismos de protección que se crean sobre éstos para que no vean o entren en

${ }^{13}$ En el primero de los libros de la Biblia -Génesis- se relata los orígenes del mundo y se traza una clasificación de los seres creados siguiendo un plan lógico. En este plan se sitúa al ser humano en la cúspide de dicha clasificación como sigue: "Y dijo Dios: <<Hagamos al ser humano a nuestra imagen, como semejanza nuestra, y manden en los peces del mar y en las aves de los cielos, y en las bestias y en todas las alimañas terrestres, $\mathrm{y}$ en todas las sierpes que serpentean por la tierra>>.

Creó, pues, Dios al ser humano a imagen suya, a imagen de Dios le creó, macho y hembra los creó. Y bendijo los Dios, y díjoles Dios: $<<$ Sed fecundos y multiplicaos y henchid, la tierra y sometedla; mandad en los peces del mar y en las aves de los cielos y en todo animal que serpea sobre la tierra >>.

Dijo Dios: $<<$ Ved que os he dado toda hierba de semilla que existe sobre la haz de toda la tierra, así como todo árbol que lleva fruto de semilla; para vosotros será de alimento. Y a todo animal terrestre, y a toda ave de los cielos y a toda sierpe de sobre la tierra, animada de vida, toda la hierba verde les doy de alimento>>. Y así fue” (Biblia de Jerusalén, Bilbao, Desclée de Brouwer, p. 26). 
contacto con la muerte real; el no saber qué hacer o decir cuando se asiste a un funeral; la desaparición en la práctica buena parte de los componentes del luto; etc. ${ }^{14}$ `Profesionalización' de la muerte que además, y de forma mucho más relevante, ha influido en la propia definición de qué es estar muerto, con todas las consecuencias que ello entraña a la hora de materializar el 'derecho` individual a morir ${ }^{15}$.

El debate actual sobre este 'derecho', o mejor dicho sobre su ausencia, es un ejemplo paradigmático de cómo condiciona el segundo factor teórico, la percepción de qué significa ser persona, la comprensión de la muerte. Sin entrar a considerar la reivindicación que desde algunas posiciones filosóficas se realiza para aplicar el concepto persona también a algunas especies animales no humanas ${ }^{16}$, y centrando el análisis exclusivamente en la equiparación funcional que la tradición occidental ha hecho de persona como sinónimo de ser humano, durante siglos la cultura occidental ha considerado, con amplio consenso, que lo específico del ser humano, la esencia diferencial de la persona, es su racionalidad, compuesta de inteligencia, sentimiento y voluntad ${ }^{17}$. Sin la misma, podría existir un cuerpo humano vivo pero no un auténtico ser humano. Concepción de persona que históricamente ha servido de coartada y justificación al sexismo, al racismo, al especieismo, y que en la actualidad, concretamente desde la segunda mitad del siglo XX, es una de las piezas clave en el debate sobre la definición, identificación y comprensión de la muerte humana en las sociedades desarrolladas. En efecto, la acepción de persona como ser racional, con conciencia de sí misma -racionalidad de "primer

14 Refiriéndose específicamente al caso de Estados Unidos, en los que el pragmatismo, la movilidad espacial de la población y la conexa soledad y aislamiento de los mayores son características definitorias de su sociedad, Morgan (1995:37, 39) describe gráficamente la percepción dominante de la muerte en ese país: "la muerte parece ser no un proceso gradual sino una llamada de teléfono en la noche. La muerte es vista en las funerarias, pero no se ve el morir”. Alejamiento de la muerte cuyo epitome pragmático se muestra en una funeraria de California en la que se puede ver el cadáver y firmar en el libro de firmas sin bajarse del coche.

${ }^{15}$ Como se desarrolla en el último sub-apartado del Capítulo 5 de esta Tesis, al analizar la percepción de la eutanasia entre la población encuestada para este trabajo, el <<derecho a morir $>>$ constituye, según H. Jonas (1997:cap.11) una extraña combinación de palabras ya que históricamente, en todo discurso, siempre se había hecho referencia al derecho a vivir, derecho originario de todos los demás. En ese texto, Jonas muestra que la moderna tecnología médica ha creado un nuevo problema "al retrasar de múltiples maneras el final más allá del punto en el que la vida así prolongada le merece la pena al paciente mismo”, por lo que concluye que "es en última instancia el concepto de vida, no el de muerte, el que rige la cuestión del <<derecho a morir >>”.

${ }^{16}$ En Singer (2003) se exponen los argumentos a favor de tratar los intereses de los animales en pie de igualdad con los de los seres humanos (capítulo 7: "Matar seres humanos y matar animales”), se afirma que la categoría persona tal como es aplicada a los humanos puede ser empleada con pleno sentido a los grandes simios no humanos (capítulo 9: "El Proyecto $<<$ Gran Simio $>>$ ”), y se refuerza esta afirmación al comparar las capacidades de los adultos de estas especies no humanas con los miembros de la especie humana que nacen con discapacidades profundas: "algunos de estos seres no humanos superan a cualquier cosa que algún pequeño humano pudiera eventualmente alcanzar mediante una educación y una asistencia intensivas” (capítulo 15: “Desacralizar la vida humana”).

17 Es paradigmática de esta tradición occidental la concepción funcional de persona establecida en la definición clásica que el filósofo inglés Locke propuso en 1690 (Ensayo sobre el entendimiento humano, libro II, Cap. 9, párr.29) sobre la misma: "un ser pensante inteligente que razona y reflexiona y que se puede considerar a sí mismo como sí mismo, el mismo ser pensante, en diferentes momentos y lugares”. 
grado"-, y capaz de hacer proyectos de futuro y de escoger entre ellos -racionalidad de "segundo grado"-, se traduce actualmente de forma operativa admitiendo como humanos a aquellos seres capaces de realizar determinadas actuaciones, de relacionarse o comunicarse intelectiva o afectivamente y de prever las consecuencias de sus propias decisiones y proyectos. Paradójicamente, la necesidad de poseer estas capacidades vacía de contenido la identificación de aquellos seres que carecen de ellas, lo que implica que un animal humano no pueda ser considerado un ser humano cuando no tiene esas capacidades, es decir, cuando ha perdido total e irreversiblemente la aptitud humana para vincularse con el medio (Gracia, 1996:23-24). En ese caso, se plantea el complejo problema de determinar cuál es el estatus social de ese ser.

Por otra parte, y en relación asimismo con el segundo factor teórico, no es lo mismo vivir en una sociedad comunitaria en la que los individuos son parte de un todo, sea un todo religioso o un todo político, y están socializados en los principios de reciprocidad, codependencia y co-responsabilidad, que vivir en una sociedad societaria centrada en la individualización y en la que prima la diferencia, la independencia y la auto-responsabilidad. En el primer caso, cada persona tendría un estatus especial dentro de un, por ejemplo, hipotético proyecto divino y su vida sería un don inviolable que no le pertenece sino que dispone de ella en usufructo hasta llegar, de forma 'natural', la muerte -<<santidad de la vida >>; en el segundo caso, cada individuo sería el constructor principal de su mismidad (self), que no sólo protagoniza su vida sino que la pilota, como pilota la muerte que cierra su vida y culmina su biografía, por lo que, demandando la forma de morir que considera más adecuada para sí mismo, "hace su camino" hasta que muere $-<<$ calidad de vida $>>$. La influencia del tipo de organización de la sociedad, sociedades “socio-céntricas” versus sociedades “individuocéntricas”, no sólo mediatiza el enfrentamiento de cada individuo con su propia muerte, sino que también condiciona la forma en la que se ha de entender y enfrentar la muerte de los otros, es decir, el duelo ${ }^{18}$.

La interrelación entre estos cuatro factores ha modelado históricamente las dimensiones esenciales de los sistemas de muerte a los que se han añadido en cada caso y en cada momento peculiaridades culturales específicas. Al margen de las divergencias estructurales o coyunturales, los distintos sistemas de muerte se han enfrentado a dos tipos de problemas cruciales a los que debían de aportar alguna solución: los referentes a la muerte propia y los que están relacionados con las consecuencias y las obligaciones especiales que de la muerte de alguien se derivan a los sobrevivientes (Riley, 1979:275). El primer grupo de problemas remite al hecho de que la muerte humana es algo más que los procesos fisiológicos que hacen aparecer

\footnotetext{
${ }^{18}$ Puede consultarse un análisis de esta cuestión en (Tizón, 2004:cap.3).
} 
el cadáver -incluidos los de la descomposición del mismo-, ya que a aquéllos se les sobreañade un conjunto complejo de procesos sociales que le dan un carácter propio. Para la "conciencia social” la muerte constituye un objeto de representación colectiva que remite, por tanto, a la creación de significados específicos con que la han dotado los seres humanos y que son necesarios "para captar la comprensión diferencial de la muerte propia" (Torno, 1990:36). Históricamente esta representación colectiva es muy diversa, compleja, dinámica y cambiante, aunque en esencia estos significados han venido caracterizados por una triple dimensión: a) social: cada muerte trasciende a quien muere y se hace relevante para toda la comunidad, como se puede constatar con la construcción colectiva de monumentos funerarios; b) biográfica: la muerte no se localiza en un hecho y en un momento puntual, sino que se distiende temporalmente hacia antes y después de ocurrir; c) religiosa o mágica: la muerte es considerada como un "acontecimiento relacionado con los límites del mundo y no como uno más entre los hechos del mundo” ${ }^{19}$ (Torno, 1990:36-37).

Así, por ejemplo, en sus análisis sobre la muerte en las sociedades más primitivas Robert Hertz concluyó que, a diferencia de lo que ocurre en las sociedades más desarrolladas, aquéllas no consideraban la muerte como algo instantáneo, como la destrucción total e inmediata de la vida humana, “un hecho único sin análogos”. Por el contrario, Hertz (1990:94) afirma que la muerte era un caso particular de un fenómeno general: la concepción de la vida de un individuo como una "sucesión de fases heterogéneas, con contornos determinados, a cada una de las cuales corresponde una clase social definida, más o menos organizada”. En este proceso continuado los individuos morían a una fase y nacían a otra, desarrollándose durante cada periodo intermedio en el que ocurrían los procesos de tránsito toda una serie de ritos de paso. Cuando morían físicamente, en el último de los tránsitos, las sociedades también desarrollaban costumbres funerarias de una etapa liminar cuyos objetivos eran, por una parte, ayudar a la persona muerta a atravesar el limen y a alcanzar el mundo de los ancestros; y, por

\footnotetext{
19 "El significado que la mayor parte de las culturas ha dado a la muerte incluye creencias en algún tipo de existencia posterior a ella; casi todos los pueblos, excepción hecha de los iliteratos, han alimentado teorías de salvación personal; la religión, la filosofía y la ideología política han ofrecido también respuestas a la preocupación humana sobre el sentido de la muerte... (por su parte, en los pueblos iliteratos) la creencia de un mundo habitado por espíritus es prácticamente universal” (Riley, 1979a:275).
} 
otra parte, proteger a la sociedad del "carácter contagioso" de la muerte ${ }^{20}$ durante ese periodo de tránsito, que coincidía con el tiempo de putrefacción del cadáver ${ }^{21}$.

El segundo tipo de problemas, las obligaciones sociales derivadas de la muerte de una persona, se han resuelto con diferentes normas sociales que abarcan toda una batería de aspectos para hacer frente a las consecuencias, al desorden provocado por la disrupción de la muerte. Entre estas consecuencias, y las correspondientes obligaciones sociales derivadas, cabe diferenciar: a) consecuencias para todas las personas que, aún alejadas de la muerte, se saben mortales, lo que genera en ellas actitudes de todo tipo (negación, huída, abatimiento, rechazo, indiferencia, etc.); b) consecuencias para las personas moribundas que, además de "vivir" las de un proceso de morir tecnológicamente determinado, dependerán de la socialización en la que han estado inmersas; por ejemplo, la trascendencia metafísica con que se enfrentan a la muerte que puede suponer el final de todo o el principio de la "vida eterna”; c) consecuencias para los grupos sociales más próximos a quien fallece, que se han modificado al quebrarse determinadas relaciones sociales por la pérdida sufrida y en los que se inicia un proceso de duelo para superar la misma y recomponer aquéllas: además de hacer frente a toda una batería de consecuencias administrativas derivadas del deceso (cuidado y tratamiento del cadáver; disposición, gestión y distribución de sus propiedades, etc.), internamente deben abordar asimismo la reasignación de roles, derechos y responsabilidades imprescindibles para la integración y cohesión del grupo (dotación de un nuevo estatus a los muertos; sustitución por otras personas que ejerzan los roles vacantes; reafirmación de la solidaridad del grupo; aportación de apoyo y consuelo a los allegados; etc.), y; d) consecuencias para el conjunto de la sociedad porque la muerte constituye una amenaza omnipresente para el sistema de interacción social en el que las personas canalizan sus comportamientos en sus relaciones mutuas.

La intensidad y el alcance de esos problemas no han sido homogéneos en las diferentes sociedades, lo que históricamente ha generado una muy variada casuística de soluciones culturales para enfrentarlos; respuestas que han dependido, y dependen, del juego de fuerzas

\footnotetext{
${ }^{20}$ Según Hertz (1990:30-54), había que dar a la muerte lo que pertenecía a la muerte para evitar que los estragos continuaran en el interior del grupo. En este sentido adquiría especial importancia el papel que se hacía jugar, forzosamente, a la familia de la persona fallecida: "Mientras la muerte esté actuando (durante la putrefacción), la familia inmediata del difunto se verá expuesta a la <<acción tenebrosa de las potencias hostiles>>. Su propia integridad física está empañada, y apenas se distingue su cuerpo del cadáver... Son con toda propiedad <<gente de muerte>>, viven en las tinieblas y están muertos desde el punto de vista social, ya que toda participación activa en la vida colectiva no haría mas que propagar la maldición que llevan consigo" (Hertz, 1990:51-52).

${ }^{21}$ Una práctica confirmatoria de la existencia de una fase de transición (liminaridad) dotada de autonomía entre estar vivo y estar muerto en algunas sociedades, es el segundo enterramiento: "(Éste) elimina, no sólo el cadáver ya descompuesto, sino también el alma del muerto, que en la etapa de transición ha vivido `sin estar ni aquí ni allí', en los márgenes de la población humana, capaz de malevolencia debido a su incomodidad, a menos que su hostilidad y su envidia sean desviadas por medio de particulares ritos o acciones” (Bowker, 1996:32-33).
} 
individuo (actor)/sociedad (sistema de muerte), del balance inadaptación individual/adaptación social. De los problemas mencionados, resulta interesante detenerse en el último de ellos, el papel disruptor de la muerte, y en las respuestas sociales elaboradas en las sociedades occidentales para enfrentarlo. La necesidad social de hacer frente a la muerte determina que, como se ha señalado, el activo principal de cualquier cultura sea su capacidad para construir un orden simbólico y dar un significado a la mortalidad humana.

En este sentido, y centrándose en las sociedades desarrolladas, un aspecto clave de su sistema de muerte, en el que se percibe de forma diáfana la interrelación dialéctica entre los cuatro factores citados, es la construcción histórica de las definiciones de la muerte y el morir dominantes en las mismas. En el tercer apartado de este capítulo se realiza un análisis de esta construcción social, análisis en el que se describen los avatares y se examinan los pros y contras en la evolución de una dimensión social especialmente sensible como es la de la identificación social de la muerte. Dada la trascendencia de esta cuestión se realiza un análisis pormenorizado de la misma con el afán de mostrar cómo en un ámbito delegado socialmente al dominio aparentemente neutral del conocimiento técnico experto (médico) se concitan, sin embargo, toda una serie de intereses que van mucho más allá, o se quedan mucho más acá según algunos autores, de los resultados objetivos que ese conocimiento puede aportar a día de hoy. La fuerza preponderante e innegable del estamento médico en esta parcela de la vida social, capaz de imponer desde su génesis una nueva concepción de la muerte y, por tanto, de modificar los criterios que establecen cómo y cuándo se define a una persona como muerta, se halla mediatizada por toda una serie de condicionantes -culturales, ideológicos, tecnológicos, organizativos, políticos, de mercado, etc.-, igualmente relevantes, cuya evolución e incidencia se aborda en el siguiente apartado.

\subsection{CAMBIO SOCIAL Y MUTACIONES EN LA EXPERIENCIA DE LA MUERTE Y EL MORIR}

"Por lo tanto decimos que hombre es proceso, y, precisamente, el proceso de sus acciones”

A. Gramsci

Previo al examen de la construcción social de la definición de muerte en las sociedades desarrolladas, se hace necesario describir sintéticamente los cambios estructurales más importantes que han mediatizado el devenir de la misma, y más ampliamente el del discurso sobre la muerte, desde que hace dos siglos se iniciara el proceso de modernización conformado por la influencia de las tres revoluciones desarrolladas en los ámbitos del conocimiento 
(Ilustración), de la política (Revolución Francesa) y de la economía (Revolución Industrial). Por su especial incidencia en la experiencia y percepción del morir y de la muerte en estas sociedades, cabe destacar las siguientes transformaciones sociales, algunas de las cuales serán desarrolladas más ampliamente en los siguientes Capítulos de esta Tesis.

\title{
2.2.1. MODERNIZACIÓN DEMOGRÁFICA
}

\author{
"Ha muerto mi madre \\ extenuada por el trabajo. \\ Se ha muerto \\ por amor al trabajo, \\ sin llegar a saber \\ para qué sirve la vida. \\ La tía ha muerto también. \\ De la misma manera \\ ha muerto la tía”
}

Las sociedades desarrolladas, caracterizadas por su dinamismo y creciente complejidad, han experimentado profundas mutaciones en sus estructuras económicas y sociales a lo largo de los tres últimos siglos. Durante este periodo de tiempo, y en simbiosis con las anteriores, se han producido asimismo transformaciones en el ámbito demográfico dentro de un proceso general de modernización socioeconómica. En esencia, cinco transformaciones demográficas conforman, con diferente peso, los pilares sobre los que se ha asentado el proceso de modernización demográfica en los países desarrollados ${ }^{22}$. Las mismas han supuesto una metamorfosis de profundo calado en la infraestructura demográfica de las sociedades avanzadas, hasta el punto de ser calificadas como $<<$ terremotos $>>$ por sus consecuencias decisivas "para los modos de producción material de la vida, para la dinámica de la desigualdad, para el conflicto y la integración social, para los valores, las normas y los símbolos, para la política y los movimientos sociales” (Beltrán, 2002; 1992). También para la muerte; en especial a través de los cambios acaecidos en las tres dimensiones demográficas siguientes:

A) Reducción de la mortalidad e incremento de la esperanza de vida. Este cambio demográfico, incluido en la Transición Demográfica y denominado globalmente transición de la mortalidad ${ }^{23}$, ha desembocado en un sistema demográfico más eficiente (Livi-Bacci, 1990). Como resultado del mismo se ha producido una progresiva rectangularización de las curvas de

${ }^{22}$ Estas transformaciones demográficas son: “1) Transición demográfica; 2) Transformación del ciclo vital anual; 3) Transformación del modelo matrimonial; 4) Creciente grado de urbanización; y 5) Transformación de la estructura de la ocupación” (Pérez Moreda, 1987:25-62).

${ }^{23}$ En el Capítulo 4 de esta Tesis se analiza ampliamente la transición de la mortalidad y las consecuencias sociales de la misma sobre la construcción social de la muerte (postergación en el tiempo de la idea de la muerte, normalización de la muerte en la vejez como la “muerte natural”, fase final del ciclo vital, etc.). 
supervivencia y, por tanto, una creciente concentración de decesos en las edades más avanzadas. De esta forma, las poblaciones de los países desarrollados en la actualidad mueren más viejas (progresivo aumento de la edad media de fallecimiento) y además mueren más envejecidas (progresiva disminución de la varianza en la distribución de los decesos por edad). Es decir, a lo largo del siglo XX se ha ido conformando lo que Caselli y Egidi (1995) denominan "una nueva edad de la muerte” ubicada en la vejez. Esto a su vez ha conllevado múltiples consecuencias sociales, entre ellas por ejemplo una profunda modificación de la valoración social de la muerte y más específicamente de las muertes según la edad de las personas fallecidas (Blauner, 1966:378-394). Según este autor, el impacto social de una muerte en una sociedad es más reducido cuanto menor es la importancia social de quien fallece. En efecto, la muerte constituye una gran amenaza para el orden social si alcanza a las personas que desarrollan las actividades principales sobre las que se asienta el sistema social y, en este sentido, todas las sociedades se han organizado, también mentalmente, para minimizar la disrupción provocada por la muerte. Tomando la edad como criterio de discriminación social, se aprecia que de igual forma que en las sociedades tradicionales las muertes de infantes resultaban comparativamente menos traumáticas (Hertz, 1990:98-99) ${ }^{24}$, otro tanto ocurre en las sociedades modernas con las muertes de ancianos que son consideradas mucho menos trágicas que las de personas jóvenes. De hecho, mientras en las sociedades tradicionales el nacimiento físico era anterior al nacimiento social ${ }^{25}$ y la muerte física y la social coincidían, en las sociedades modernas ocurre justo al contrario, el nacimiento físico y el social coinciden pero la muerte social, al menos la de los ancianos, acaece antes que su muerte física (Walter, 1994:51).

Esta muerte social anticipada a la muerte física está relacionada con el desplazamiento de la mayoría de las muertes hasta edades muy avanzadas, afectando a personas jubiladas, que reducen su participación en la vida social activa, con cuerpos envejecidos y cuyos proyectos de auto-identidad avanzan hacia su conclusión (Seale, 1998:50-52). Según este autor, la “devaluación general de lo viejo” y la extensión de su estigmatización, junto con la segregación física de ancianos y moribundos en marcos institucionales especializados, que están gestionados por expertos en vejez y/o en salud, ha contribuido a "secuestrar" el problema social de la muerte

${ }^{24}$ Refiriéndose específicamente a las muertes de niños en sociedades primitivas Hertz (1990:98-99) señala que las mismas provocaban una reacción social muy débil "que se apaga casi inmediatamente. Todo ocurre como si en este caso no existiera conciencia colectiva de una muerte verdadera... La muerte de un recién nacido es, en última instancia, un fenómeno infrasocial. Al no haber puesto nada de ella en el niño, la sociedad no se siente concernida por su desaparición y permanece indiferente". Visión que contrasta con la valoración de la niñez en las sociedades modernas cuya "vida" puede ser apreciada incluso antes de su nacimiento, como puede comprobarse en una lápida de un cementerio madrileño: "Al feto González, tus padres no te olvidan”.

${ }^{25}$ En las sociedades tradicionales los recién nacidos muertos no recibían funerales, marcando el bautismo la entrada en sociedad más que el nacimiento mismo. En las sociedades modernas el nacimiento social coincide con el físico o aún lo precede. La edad en la que se reconoce un duelo infantil está cayendo hasta el punto que se organizan funerales para fetos abortados (Walter, 1994:50). 
desplazándolo hasta ámbitos etareos, espaciales e institucionales muy concretos con la consiguiente invisibilización de la misma fuera de los mismos.

B) Regulación y ordenación del ciclo vital. Este segundo cambio demográfico, estrechamente relacionado con el anterior (de hecho se deriva de él) ha facilitado representar a la muerte como la estación final de un proceso natural. La construcción del ciclo vital moderno constituye una auténtica revolución y se halla en la base misma del propio proceso de modernización. La implementación de cualquier tipo de proyecto personal o grupal que acarree un compromiso con "otros”, más allá del de la mera supervivencia, hace imprescindible vislumbrar que, con suficientes garantías, los actores del mismo vivirán hasta alcanzar un horizonte temporal determinado. El nivel de mortalidad establece la naturaleza de gran parte de la sociedad, así con una mortalidad elevada las personas mantienen una condición social en la que no hacen ningún esfuerzo por avanzar. El elevado riesgo de fallecimiento en todas las edades confiere gran incertidumbre, además de precariedad, a cualquier plan a medio y largo plazo centrado en una persona concreta cuya existencia es insegura e insignificante. Inherente a la elevada mortalidad, además, se añade otro elemento igualmente aleatorio como es la elevada probabilidad de desorden generacional (una hija muerta antes que su madre, un nieto antes que su abuelo), es decir, de la "subversión del orden natural y cronológico de la muerte conexo a la edad" (LiviBacci, 1990:108-119).

En estas circunstancias de inseguridad y desorden generacional, características de las sociedades tradicionales, los factores primordiales para potenciar el desarrollo como son la innovación, el progreso técnico e intelectual, el ahorro y la inversión, se hallan extremadamente constreñidos. La reducción de la mortalidad con el proceso modernizador ha constituido la base sobre la que se ha asentado y ordenado el ciclo vital del individuo. Así, las relaciones humanas se han hecho potencialmente predecibles en términos temporales, creándose las condiciones para que el desarrollo científico y técnico tuviera continuidad, a la par que se reducen las incertidumbres de todo tipo que rodeaban a la invalidez y la muerte. Al producirse la mayoría de las muertes entre las personas de edad el resto de la población, "está libre para concentrarse en los problemas de vivir, sin necesidad de considerar los requerimientos de la muerte” (Seale, 1998:52).

C) Urbanización. La concepción de la muerte y del morir en las sociedades desarrolladas se ha visto asimismo influida por la progresiva concentración espacial de la población en ciudades y por los cambios de todo tipo acaecidos en la propia organización social derivados de la misma. El tipo de civilización urbana dominante, sobre todo en las grandes urbes, se caracteriza por no dejar lugar para los muertos y por la carencia de tiempo para ocuparse de ellos (Thomas, 
1985:41-43). En efecto, las exigencias impuestas por el modelo de producción capitalista dominante en Occidente determinan que el ritmo de la vida cotidiana de sus habitantes gire en torno a los horarios impuestos por las necesidades de la producción o gestión de los bienes y servicios; es decir, "en exclusivo interés de los vivos”. Por otra parte, las mutaciones morfológicas derivadas del crecimiento de las ciudades mediatizan cada vez más tanto la movilidad espacial de la población como las condiciones de habitabilidad de sus viviendas ${ }^{26}$. En el primer caso, el 'habitante hipersedentarizado' de las ciudades se ha convertido no obstante en un ser 'itinerante' con continuos y dilatados desplazamientos a su centro de trabajo o para la satisfacción de sus necesidades de ocio. En el ámbito de la enfermedad, del morir y de la muerte, estos desplazamientos pueden suponer un largo circuito hacia el hospital-el tanatorio-la iglesia-el cementerio, lo que unido a las cada vez mayores dificultades de circulación determinan la ruptura del ritual tradicional del cortejo funerario al optarse por la asistencia durante los funerales a un lugar único de los cuatro mencionados. En el segundo de los casos, la construcción vertical de viviendas en inmuebles colectivos junto con el pequeño tamaño de las mismas no sólo dificulta la convivencia intergeneracional familiar en un mismo hogar, sino que hace cada vez más inviable el modelo tradicional de muerte en casa. El pequeño tamaño de las habitaciones, la inclinación de las escaleras y las limitaciones de los ascensores hacen problemático el desplazamiento del ataúd y constriñen espacialmente la reunión de personas en una velada fúnebre. Además, el desarrollo de organizaciones secundarias expertas, como se comenta más adelante en el apartado de burocratización, ha derivado hacia ellas funciones que antes tenían asignados los grupos primarios, de tal forma que la mayoría de las personas de las sociedades desarrolladas mueren bajo el cobijo de ese tipo de organizaciones (hospitales, geriátricos, etc.) siendo cada vez más reducido el número de personas que fallecen en casa ${ }^{27}$. Asimismo, el amortajamiento del cadáver, antaño función de las mujeres de las familias, es ahora realizado por personal experto en tanatopraxia. Por lo que, incluso aunque el fallecimiento se produjera en casa, los velatorios caseros prácticamente han desaparecido, desplazándolos a los tanatorios, o, como mucho, han quedado reducidos a la participación del circulo de familiares y amigos más cercanos.

\footnotetext{
${ }^{26}$ Asimismo, factores psicológicos y la carestía del suelo en las ciudades han planteado problemas derivados de la utilización y ubicación de los cementerios en las mismas, por lo que los nuevos cementerios han quedado confinados en las afueras de las ciudades, muy alejados de donde se desarrolla la vida cotidiana. Entre los primeros, la resistencia a "tener una necrópolis debajo de la ventana”, rechazo que se amplia incluso la ubicación de tanatorios, como se ha observado en distintas poblaciones españolas en los últimos años, 'por los humos contaminantes` de la incineración de cadáveres. Respecto al segundo factor, el elevado coste de los terrenos urbanos ha impedido extender las necrópolis tradicionales, en muchos casos situadas casi en el centro de las ciudades, provocando su saturación. Así, la imposibilidad de ampliarlas, junto con el mantenimiento de las preferencias de los enterramientos en concesión, a pesar de que en las últimas décadas se ha producido un lento desplazamiento en las preferencias desde la inhumación hasta la incineración, ha hecho inevitable "el desplazamiento de los muertos" hacia la periferia de las ciudades (Thomas, 1993:424-427).

${ }^{27}$ En el Capítulo 4 de esta Tesis se muestran datos de esta evolución para el caso de España.
} 
Además de los aspectos estructurales mencionados, el proceso de urbanización ha conllevado el desarrollo de la cultura urbana que difunde sistemas de valores, actitudes y comportamientos propios alejados de la cultura tradicional (Cortés Alcalá, 1998:807). Las instituciones características de ésta pierden fuerza como elementos de control social ante el pluralismo, heterogeneidad y transversalidad del melting-pot cultural urbano; hibridación que hace dudar de la universalidad y del valor absoluto de cada una de las culturas presentes, y por tanto de la propia, facilitando el desarrollo de nuevas concepciones sobre la vida y la muerte (Thomas, 1985:41). Así, esta mutación subyace como uno de los elementos conformantes de los procesos de secularización e individualización que se analizan más adelante. Por otra parte, la concentración espacial de individuos, junto con la pérdida de funciones de los grupos primarios, ha provocado la ruptura de las solidaridades tradicionales y el desarrollo de roles -productores y consumidores- alienantes, originando procesos de despersonalización y anomia. El anonimato y el aislamiento consiguiente se manifiestan negativamente en el elevado coste -personal, familiar, económico, sentimental- para hacer frente al cuidado del gran número de personas ancianas que viven solas y de los enfermos, sobre todo de los enfermos terminales; asimismo, se muestran "en la participación irrisoria en los funerales”, que ya no convocan a la totalidad del grupo sino sólo a los más allegados a la persona fallecida (Thomas, 1985:43).

\subsubsection{PACIFICACIÓN INTERNA DE LAS SOCIEDADES DESARROLLADAS: NACIMIENTO DEL ESTADO MODERNO}

"El hombre es mortal por sus temores, e inmortal por sus deseos” Pitágoras

Un aspecto clave en el desarrollo del proceso de modernización fue la diferenciación estructural de las distintas instituciones sociales, por la que se produjo la separación primero de la política de la religión y, más tarde, de la economía de la política. Esta diferenciación estructural de esferas culturales y funcionales, larvada desde la baja Edad Media y materializada en los siglos XIX y XX, supuso, al menos en la Europa occidental, la ruptura del statu quo tradicional por el que la institución religiosa, que "coronaba el edificio cultural y daba sentido sagrado a las demás instituciones sociales”, perdiera su control y tutelaje sobre éstas, que comenzaron a actuar autónomamente sin sentirse comprometidas por las demandas de la institución religiosa, que pasa a ser un subsistema más entre otros y con un campo de actuación cada vez más circunscrito al ámbito privado de las personas (secularización de las instituciones) (Carmona, 2005:494; Bericat, 2003b:275). 
Fruto de este proceso nació la empresa económica moderna, cuyo crecimiento futuro se construirá sobre las bases de las innovaciones técnicas y las nuevas formas de organización. Asimismo, en el ámbito de la regulación de las relaciones sociales, la imperiosa necesidad de generar un clima social de confianza que garantizase en todos los órdenes de la vida social unas reglas del juego claras, eficaces y flexibles y eliminara los obstáculos heredados del pasado, contribuyó al nacimiento y desarrollo del Estado moderno, "con su consiguiente razón de Estado", independiente de la tutela religiosa. La capacidad normativa y disuasoria de éste, que asume el monopolio del ejercicio de la violencia, lentamente se constituyó en un elemento esencial de estabilidad social al reducir notablemente los diversos focos de incertidumbre y pacificar internamente las sociedades, generando así un mayor grado de confianza en las relaciones y una conciencia de seguridad de los ciudadanos en todos los ámbitos de la vida (Tezanos, 2001; Elias, 1987). Este incremento de la seguridad y la reducción de los peligros en la vida de las personas en las sociedades desarrolladas, entre ellos el peligro de muerte, tuvo como consecuencia el que esas personas, a diferencia de épocas pretéritas o de lo que ocurre en otras partes del mundo en la actualidad, perciban como lo normal "una forma muy determinada de morir..., pacífica, en la cama producida por la enfermedad y los achaques de la vejez”. Colateralmente, esa dinámica de menores riesgos y mayor seguridad proporcionada por las instituciones atemperó la necesidad de "poderes protectores sobrenaturales” (Elias, 1987:15 y 61-66).

Además, el desarrollo de un sistema de autoridad legal-racional en el que se promulgaron reglas comunes que garantizaban la igualdad de trato favoreció la iniciativa individual, la motivación del logro y el desarrollo de valores que quebraron el control social tradicional basado en la adscripción y en el que se primaba lo comunitario sobre lo individual (Inglehart, 1998). En este orto de valores modernos se sitúa el inicio o la potenciación de algunos de los procesos sociales relevantes al caso: por ejemplo, el proceso de secularización o el proceso de individualización, en cuya vertiente de la individualización moral se asienta el debate actual sobre la santidad de vida/calidad de vida.

\subsubsection{BUROCRATIZACIÓN}

"Nosotros no recordamos días, sino momentos"

C. Pavese

Una de las características que distinguen a las sociedades modernas es su creciente densidad organizativa y el incremento de la complejidad de sus organizaciones. La necesidad de alcanzar mayores cotas de eficiencia en la utilización de recursos escasos (racionalidad 
instrumental $^{28}$ ) ha favorecido el auge imparable de un tipo especial de organización, la burocrática, que, como señaló Weber, era la más adecuada para lograrlo ${ }^{29}$. De esta forma, muchas de las funciones que los grupos primarios desarrollaban en las sociedades tradicionales pasaron a manos de estas organizaciones acelerando la transformación de aquéllos, que quedaron sobre todo como refugio de la dimensión socio-afectiva de los individuos, lo que provocó el desvanecimiento de las formas de vida tradicional, que pasaron a tener cada vez más carácter residual. Así, al igual que en otros ámbitos de la vida social moderna -nacimiento, educación, salud-, también la gestión de los procesos de morir, muerte, aflicción y duelo han sido asumidos por organizaciones burocráticas especializadas, muy localizadas tanto espacialmente como en el imaginario colectivo -el hospital como espacio de enfermedad, dolor, sufrimiento y muerte; el geriátrico como reserva para ancianos; el tanatorio como el escenario de la despedida pública-, siendo implementados rutinariamente a través de procesos estandarizados. En efecto, el predominio de los procedimientos burocráticos en la gestión de los procesos de muerte se hace patente en la organización jerárquica de la autoridad y el trabajo, en la especialización de los que trabajan en ella, en la impersonalidad de las relaciones que están basadas en los roles ocupacionales y son fragmentarias, frías, utilitarias e instrumentales y en la repetición de procedimientos de actuación previamente establecidos, que son explícitos, fijos y abstractos y a los que todos deben atenerse (protocolos para los tratamientos de las enfermedades, declaración de fallecimiento, regulación de la utilización de cadáveres para transplantes, disposiciones sobre inhumación y cremación, normativas sobre comercialización de productos funerarios, etc.).

Por otra parte, el proceso acelerado por el que la mayor parte de los fallecimientos en las sociedades modernas se producen en entornos especializados (hospitales, clínicas, geriátricos) ha conllevado, ideológicamente, la “desimplicación” e invisibilidad de la muerte. Es decir, se han sentado las bases para una nueva comprensión social de la muerte por la que "se aprende a vivir distanciado de la muerte y a aceptarla más como un suceso biotécnico que ligada sustancialmente a la experiencia existencial” (Cordero y Díez, 1988:109-113).

\footnotetext{
${ }^{28}$ La racionalidad instrumental o formal "es aquella que se adecua del mejor modo posible a los fines que persigue sin atender ni a principios ni a consecuencias nocivas o efectos perversos", es decir, aquella en la que el fin justifica los medios. A diferencia de la racionalidad substancial que es "aquella que responde a ciertos principios o convicciones morales y se legitima a través de ellos así como mediante una consideración ética de los riesgos y consecuencias que acarrea” (Giner, 1998:625).

${ }^{29}$ En el último tercio del siglo XX han surgido otros tipos de organización más eficaces ligadas a nuevas formas de organización y/o al desarrollo de la sociedad red (Castells, 1997). No obstante, las organizaciones burocráticas siguen siendo mayoritarias en Occidente y, dominantes en el entorno complejo pero estable en el que se desarrolla el proceso enfermedad-morir-enterramiento-muerte.
} 


\subsubsection{DESARROLLO DEL CONOCIMIENTO CIENTÍFICO-TÉCNICO}

"Los jueces de la normalidad están presentes por todas partes. Estamos en la sociedad del profesor-juez, del doctor-juez, el trabajador socialjuez; en ellos se basa el reino universal de la normalidad; y a cada sujeto, donde pueda encontrarse, le condicionan su cuerpo, sus gestos, sus comportamientos, sus aptitudes, sus logros”

M. Foucault

Las soluciones aportadas por la ciencia y la tecnología a los problemas de la vida social durante los dos últimos siglos han incrementado el nivel de bienestar y la calidad de vida en las sociedades más desarrolladas. Así, el avance del conocimiento científico-técnico se ha conformado como una de las dimensiones básicas del proceso de modernización, una de sus señas de identidad cuyas consecuencias atraviesan prácticamente todas las esferas de la vida social. También la de la muerte. En efecto, ciencia y tecnología juegan un doble papel en las sociedades contemporáneas; por un lado, como producto social, ambas desarrollan un papel conservador del orden social en el que están insertas y las configura, ya que "ni la ciencia ni sus aplicaciones tecnológicas, ni los científicos o expertos actúan en el vacío social”. Por otro lado, junto a esa función de cristalización de las relaciones sociales, y como proceso social, son una de las puntas de lanza del cambio social por su potencia transformadora de todos los aspectos de la vida humana (Juan y Rodríguez, 1994). También en el ámbito intangible de las creencias, actitudes y valores, como resaltan estos dos autores al analizar las consecuencias sociales, y de identidad individual, de las nuevas tecnologías de reproducción asistida y de trasplante de órganos que han redefinido el significado del cuerpo al modificar las condiciones biológicas que definen el principio y final de la vida humana ${ }^{30}$.

De forma general, entre las primeras contribuciones logradas por el conocimiento científico resulta especialmente relevante al caso el desarrollo del concepto matemático de "probabilidad” a finales del siglo XVII. La búsqueda de regularidades en distintos ámbitos de la vida social, mediante el empleo de las leyes de probabilidad, generó desde los primeros resultados positivos una percepción social de que en esos ámbitos subyacía un orden distinto al que aportaba la visión sobrenatural del universo. De esta forma, se fue abandonando la concepción existencial determinista, hegemónica en las sociedades tradicionales, y progresivamente el mundo "fue haciéndose pensable" a través de las estadísticas y las

\footnotetext{
${ }^{30}$ Por ejemplo, en el caso concreto de la tecnología de trasplante de órganos "la radical trasformación de creencias acerca de la vida y el cuerpo que implica" ha chocado con la "reticencia social histórica en la donación de material orgánico personal”, que no propiciaba una actitud social de donación espontánea. Para superar esa barrera y reducir progresivamente las reticencias ha sido necesaria una actuación social conjunta que, sobre la base del papel esencial de la medicina, garantizase la "necesidad, bondad, eficacia y altruismo" de todo el proceso, además del uso aceptable de los órganos a trasplantar (Juan y Rodríguez, 1994:185-186).
} 
experiencias vitales interpretadas en términos probabilísticos (Seale, 1998:82). Lentamente la racionalidad estadística colonizó las actitudes en todos los ámbitos sociales contribuyendo, entre otras cosas, a la construcción social de lo "normal” como el "más frecuente de los comportamientos”. Así, vivos y muertos pasan por el tamiz de la normalidad establecido según el juicio de los expertos.

En el caso concreto del proceso de muerte, el concepto de probabilidad permitió calcular las tablas de mortalidad, desplazando la muerte desde el ámbito religioso, del pecado y el destino, hasta al ámbito de la razón, midiéndola en términos de probabilidad estadística. La concepción de una muerte caprichosa e invencible que podía llevarse a cualquiera en cualquier momento y en cualquier lugar, actuando bajo los designios inescrutables de Dios, se transformó en un enemigo abatible para lo que bastaba identificar primero las causas de la mortalidad y su correlación con los factores determinantes de las mismas (entorno, nutrición, higiene, ingresos, trabajo, etc.), actuando a continuación en el control y eliminación de las mismas, todo ello inscrito en el marco de la razón. De está forma, se ha llegado a la situación actual en la que "la ley moderna no puede permitir que una muerte no esté racionalizada”, primando si es necesario la identificación científica de las causas de muerte a través de patólogos, médicos forenses o jueces de instrucción sobre la sensibilidad de los supervivientes o sobre los intereses de éstos por la pronta puesta en marcha de los ritos funerarios (Walter, 1994:9-10). Lógica de racionalización que se ha extendido incluso hasta al proceso psicológico del enfrentamiento a una muerte por parte de los supervivientes, identificándose el duelo normal con una secuencia de etapas (negación, ira, pacto, depresión, aceptación) por las que deberían de transitar los afligidos para no caer en un duelo patológico (Kübler-Ross, 1989).

\title{
2.2.5. MEDICALIZACIÓN DE LA VIDA SOCIAL
}

\begin{abstract}
“Cosificado, reducido a una suma orgánica de síntomas, difunto ya en el sentido etimológico del término (privado de función), al moribundo ya no se le escucha como a un ser racional, tan sólo se le observa como sujeto clínico, aislado cuando ello es posible, como un mal ejemplo y se lo trata como a un niño irresponsable cuya palabra no tiene sentido ni autoridad. Los moribundos ya no tienen estatus y por lo tanto, tampoco tienen dignidad. Son seres clandestinos"
\end{abstract}

P. Ariès

De forma más concreta, los importantes avances científico-técnicos aplicados en el ámbito médico-sanitario, además de cumplir con su principal finalidad -aportar diagnósticos, soluciones y medios técnicos para enfrentarse a los efectos de la naturaleza y los problemas derivados de la “corporeización” humana-, han contribuido, simultáneamente, a la construcción de la mentalidad moderna sobre la vida y la muerte. El discurso médico moderno ha 
conformado, en efecto, los pensamientos y sentimientos de los individuos en una comprensión de la vida y la muerte alejadas de certidumbres sobrenaturales, transformando la percepción de la invasión desordenada de la naturaleza caótica en una experiencia científica, racional, ordenada y sobretodo susceptible de ser controlada ${ }^{31}$ (Seale, 1998:4 y 78). De esta forma, desde que los médicos sustituyeron, a finales del siglo XVIII, a los sacerdotes en el lecho de los moribundos, la muerte dejó de ser un pasaje espiritual y comenzó a ser un proceso natural supervisado médicamente ${ }^{32}$ (Walter, 1994:12). Frente a la práctica médica medieval, los primeros pasos del proceso de racionalización abordado en las representaciones médicas modernas de la muerte consistieron, como se ha señalado arriba, en asumir por un lado que toda muerte tiene su causa, que ha de ser identificada para que aquélla pueda ser racionalizada y, por otro lado, en localizar dentro del mismo cuerpo las causas de muerte ${ }^{33}$ (Seale, 1998:76). Así, la muerte dejó de ser percibida como una fatalidad inevitable que se llevaba dentro de sí, una especie de alien autodestructivo, y pasó a convertirse en una agresión externa a evitar o a minimizar en sus consecuencias. Bauman (2007:cap.1; 1992:10-15 y 130-140) considera esta deconstrucción de la mortalidad como la característica más importante del tipo moderno de muerte porque representa a ésta, que es la única certeza de la existencia humana, como una anormalidad -la muerte no sería más que un caso extremo de enfermedad-, y la disuelve en una exhaustiva colección de condiciones contingentes, pero no-inevitables, condiciones que pueden ser cambiadas: "Yo no puedo oponer nada a la muerte. Pero yo puedo hacer bastante para evitar un cáncer de pulmón” (Bauman, 1992:138).

La influencia del discurso médico moderno se ha extendido, asimismo, a todo lo concerniente con el propio gobierno de las sociedades modernas en las que se ha asistido a la sustitución de dicotomías sociales básicas para la gestión del vivir y el morir: lo moral/inmoral fue remplazado por lo normal/patológico, sano/enfermo, saludable/no saludable (Seale, 1998:75). El discurso médico ha logrado extender una "conciencia general de la vida como negocio de riesgo" y de la muerte como producto del mismo, relacionando el riesgo de muerte con elementos de la estructura social y del estilo de vida y, por tanto, haciendo posible su

\footnotetext{
${ }^{31}$ Thomas (1985:37-41) subraya la incidencia del “imperialismo"de la Ciencia y de la Técnica en la crisis y el declive de los rituales de muerte: "El cambio de las mentalidades que resulta del impacto del saber científico implica el abandono progresivo de conductas simbólicas juzgadas irrisorias o gratuitas. El saber racional tiende a sustituir a cualquier tipo de reflexión y la omnipresencia de la máquina hace olvidar la eficacia de los símbolos".

${ }^{32}$ El desarrollo de la Medicina, junto con los seguros de vida, han redibujado "las fronteras tradicionales entre lo sagrado y lo profano, haciendo posible el cálculo del valor de la vida humana y el asalto de la santidad de las fronteras corporales (por ejemplo, a través de los transplantes de órganos)” (Seale, 1998:4).

${ }^{33}$ Ambos pasos quedan simbolizados por los Certificados Médicos de Defunción, "práctica uniforme que encierra una visión unificada de qué causas de muerte existieron,... afirmación pura del contenido corporal de la muerte, identificación ritualizada de los trabajos de la enfermedad natural dentro del cuerpo" (Seale, 1998:79).
} 
control por la actividad de promoción de la salud (Seale, 1998:82). Sin embargo, esta promoción de la salud con el tiempo se ha ido orientando fundamentalmente hacia el desarrollo de políticas de supervivencia centradas en el auto-cuidado que, en última instancia, ha desembocado en una construcción social de la muerte como un asunto individual. De esta forma, la salud individual queda en manos de los propios individuos, a los que corresponde reducir riesgos haciendo ejercicio, siguiendo una dieta equilibrada, no fumando ni tomando bebidas alcohólicas, etc. Como señala Bauman (1992:130-160), todas estas "incontables pequeñas prescripciones diarias y prohibiciones”, que son factibles de realizar, redefinen el "problema inmanejable de la muerte", ante el que no cabe hacer nada, como una serie de “problemas absolutamente manejables” sobre los que sí se puede hacer algo. Como resultado de todo este proceso de "des-metafisicación" de la muerte, ésta ha sido localizada en espacios segregados y 'humanizada' a través de esos problemas solubles, ante los que "uno puede hacer algo razonable y útil”.

Por otra parte, no es extraño, como afirma Thomas (1985:38), que las esperanzas y las angustias de los individuos se hayan polarizado sobre los nuevos descubrimientos y la sofisticación creciente del equipamiento médico desarrollándose, no obstante, sentimientos de ambigüedad en situaciones extremas. Las consecuencias negativas del desarrollo tecnológico han conllevado, como han mostrado empíricamente numerosas investigaciones, que en la actualidad la ciencia haya perdido "hasta cierto punto el apoyo y la ingenua legitimidad que obtuvo en la época moderna”, abriéndose una grieta entre el discurso del experto (médico) y los procedimientos burocráticos asociados, por un lado, y la satisfacción de las necesidades perentorias de los profanos, por otro. Como ocurre, por ejemplo, en el caso de la aplicación de los criterios de muerte en la definición de muerte, o como ha sucedido de forma más visible socialmente con el perfeccionamiento de las técnicas de reanimación que pueden salvar una vida pero también pueden dilatarla forzando el tratamiento hasta caer en la denominada “obstinación terapéutica" ${ }^{34}$. Situación reflejada de forma diáfana por P. Ariès ${ }^{35}$ : "La muerte del paciente en el hospital, cubierto de tubos, se ha hecho una imagen popular, más aterradora que la del esqueleto de la retórica macabra”. En efecto, se ha llegado a un "conflicto doloroso"

\footnotetext{
${ }^{34}$ En un documento interno elaborado por la Organización Médica Colegial, titulado Atención médica al final de la vida. Conceptos, se define la obstinación terapéutica como "la aplicación de medidas no indicadas, desproporcionadas o extraordinarias con el objetivo de alargar la vida innecesariamente. Estas medidas pueden llamarse también tratamientos inútiles o fútiles". Se reconoce que su aplicación por parte de los médicos "son una mala práctica y una falla deontológica". Se citan como causas, entre otras, las dificultades para aceptar el proceso de morir, la falta de formación, la demanda por parte del enfermo y familia, o la presión para usar tecnología diagnóstica o terapéutica. Se reconoce la frustración que ello puede provocar en enfermos, familiares y en los propios profesionales. Curiosamente, al final del mismo se propone evitar el término habitualmente utilizado para definir ese proceso, encarnizamiento terapéutico, por considerar que "presupone una cierta intencionalidad negativa por parte de quien lo efectúa".
}

${ }^{35}$ ARIÈS. P. (1981): The Tour of Our Death, Londres, Allen Lane, pp.614, citado en Walter (1994:22). 
Capítulo 2.- <<Sistema de Muerte>>: el contexto social del morir

en el enfrentamiento a la muerte derivado de los éxitos alcanzados en la domesticación de la misma a través de los procesos de burocratización y medicalización, por un lado, y el creciente individualismo en las sociedades modernas por otro, como será analizado más adelante (Walter, 1994:22).

\subsubsection{CAMBIOS EN LAS PREFERENCIAS VALORATIVAS}

"Soy un fue, y un será, y un es cansado"

F. de Quevedo

A la par que se producían las transformaciones estructurales mencionadas, las sociedades desarrolladas han experimentado una profunda metamorfosis en su universo valorativo. En este proceso se pueden diferenciar dos fases, a las que se ha hecho un lugar común denominarlas modernización y postmodernización:

Modernización: Implantación de nuevos valores inspirados en los principios de racionalidad y cálculo. El proceso de modernización iniciado hace dos siglos supuso un cambio global respecto a las sociedades tradicionales pretéritas de carácter comunitario en las que los intereses del grupo siempre prevalecían sobre los de los individuos y dominaban los valores $<<$ materialistas $>>$ (sobre todo la supervivencia, el orden, la seguridad física y económica) (Inglehart, 1998). Siguiendo a Tezanos (2006), ese cambio fue fruto de la interrelación de tres revoluciones que supusieron la ruptura total con el orden social anterior. La Ilustración, revolución en lo cultural y en el conocimiento, propició un cambio en la forma de conocer la realidad, incluida la realidad social. La explicación científica sustituyó a la tradición (explicaciones teológicas o metafísicas), que queda como residuo de superstición e ignorancia, y la generación de ideas pasó a ser fuente de transformación, en especial la idea de "progreso" que buscaba materializar un nuevo ideal: la Naturaleza dominada por la razón. Por su parte, la Revolución Francesa, revolución en lo político social (cambio de élites), mostró que el statu quo no era inmutable, lo que se tradujo en, por un lado, la disolución de las formas de organización social seculares y, por otro lado, el cambio de mentalidades al acabar con la pasividad derivada de la concepción teológica del poder y del determinismo social, lo que en última instancia generó un nuevo clima político en el se reconocía la importancia del individuo y sus intereses. Finalmente, de la Revolución Industrial, revolución en lo económico, emergió una nueva economía industrial (basada en la producción fabril), asentada en nuevas relaciones de producción (cambios en el trabajo: división del trabajo; burocratización, asalarización), nuevas relaciones laborales, que se desarrolló en simbiosis con el proceso de urbanización y que supuso el ascenso de la burguesía como nueva clase económica dominante. De hecho, la burguesía pasó a dominar todas las esferas de la vida social, por lo que sus valores, caracterizados por la 
supremacía social de la dimensión económica -asentada en los principios de racionalidad y cálculo-, se extendieron al conjunto de la sociedad influyendo decisivamente en el comportamiento de los ciudadanos. De esta forma, en las sociedades modernas además de la ruptura con las tradiciones, en especial la materialización del proceso de secularización, se interiorizaron valores individualistas como responsabilidad, racionalidad instrumental, cálculo, previsión, rentabilidad, aspiración de éxito, competencia, esfuerzo, disciplina, aplicación y dedicación (Tezanos, 2001). Así, los vínculos entre las personas dejan de forjarse bajo el paraguas comunitario y pasan a tener un carácter societario, y los valores señalados se asentaron tanto en la vida diaria como en la gestión del proceso de morir, muerte y duelo ${ }^{36}$.

Postmodernización: Maximización del bienestar subjetivo. El rápido desarrollo económico y la expansión del Estado de Bienestar tras la segunda Guerra Mundial, experimentado por la mayoría de los países actualmente desarrollados, determinó que las experiencias formativas de las cohortes más jóvenes de esas sociedades industriales difirieran en lo esencial de las que tuvieron las viejas cohortes, de tal modo que aquéllas acabaron desarrollado prioridades valorativas distintas a las de éstas (teoría del cambio intergeneracional de valores). Ese cambio en la visión del mundo y en las motivaciones nace del hecho de que hay una diferencia fundamental entre crecer con una conciencia de que la supervivencia es precaria y crecer con la sensación de que la supervivencia de uno se da por supuesta (sentimiento de seguridad existencial) (Inglehart, 1998). De esta forma, si con el proceso de modernización aumentó la importancia concedida al logro económico, con el inicio de la postmodernización la importancia relativa de ese valor disminuye siendo sustituido en las preferencias valorativas por la maximización del bienestar subjetivo (Inglehart, 1998:46). Así, uno de los elementos centrales de ese tránsito ha sido la perdida de importancia de la prosaica racionalidad instrumental de las sociedades modernas, por la que se equiparaba sobre todo al "crecimiento económico con lo bueno”, a favor de la más poética racionalidad valorativa, que persigue la felicidad humana en sí más que los medios económicos para alcanzarla (Inglehart, 1998:106). La plasmación valorativa de estos cambios se ha sustanciado en las prioridades <<postmaterialistas $>>$ (sobre todo la autorrealización personal -las personas pueden hacer bastante por cambiar el rumbo de

\footnotetext{
${ }^{36}$ Este proceso fue analizado por Thomas (1993) en su obra clásica Antropología de la muerte donde comparó el tratamiento de la ancianidad y de la muerte en las sociedades negro-africanas y en las sociedades occidentales. En las primeras, el individuo está completamente integrado en sus grupos sociales donde es identificado, estructurado, protegido, no siendo nada fuera de ellos, y cuando fallece su muerte atañe no sólo a la familia en sentido amplio (linaje, clan), sino también al poblado. Además, no es vivida como un mal supremo, como una ruptura definitiva, sino más bien como un "accidente del recorrido del grupo" que es superado a través de complicados ritos que unen a vivos y muertos y que buscan la integración del difunto en el mundo de los ancestros para asegurarse además su participación en la continuidad del grupo. En las sociedades occidentales, el individualismo corta los lazos comunitarios desvaneciendo los lazos de solidaridad y los ritos de épocas pretéritas; cualquier fallecimiento es un fallecimiento privado que no concierne más que a los más allegados y, además, es vivido como algo insoportable pues anuncia, como un signo premonitorio, el aniquilamiento futuro de la persona.
} 
sus vidas-, la autoexpresión personal -la vida tiene el sentido que le dé cada uno, el derecho a ser diferente-, la autonomía personal -cada individuo es el constructor de su vida, de su identidad $^{37}$-, la satisfacción intelectual y estética, el tener relaciones personales significativas, la conciencia medioambiental y la calidad de vida, etc.). De esta forma, en las sociedades postmodernas los vínculos societarios de la modernidad mutan ya que, frente a la autoridad religiosa de las sociedades tradicionales, o la legal-racional (política) de las sociedades modernas, la subjetividad dominante en las mismas cuestiona todo tipo de autoridad heterónoma e identifica al individuo mismo como autoridad central (Inglehart y Welter, 2006; Inglehart, 1998).

El incremento de los valores postmaterialistas no constituye una inversión de polaridades, sino un cambio de prioridades - del énfasis en la supervivencia se ha pasado a la maximización de bienestar subjetivo-, lo que no significa que esa evolución sea definitiva. En efecto, el colapso de la seguridad derivado de una crisis socioeconómica podría conducir a un regreso gradual a las prioridades materialistas (Inglehart, 1998). En el Cuadro 2.1. se recoge la evolución de los valores materialistas/postmaterialistas entre la población española. En el mismo se observa cómo, según los criterios analíticos empleados en las Encuestas Mundiales de Valores y en los Estudios Europeos de Valores, en el año 2000, un cuarto de la población española mantenía valores materialistas mientras que casi un quinto por tenía valores postmaterialistas. A la par, más de la mitad de la población tenía valores mixtos, mezcla de los dos anteriores.

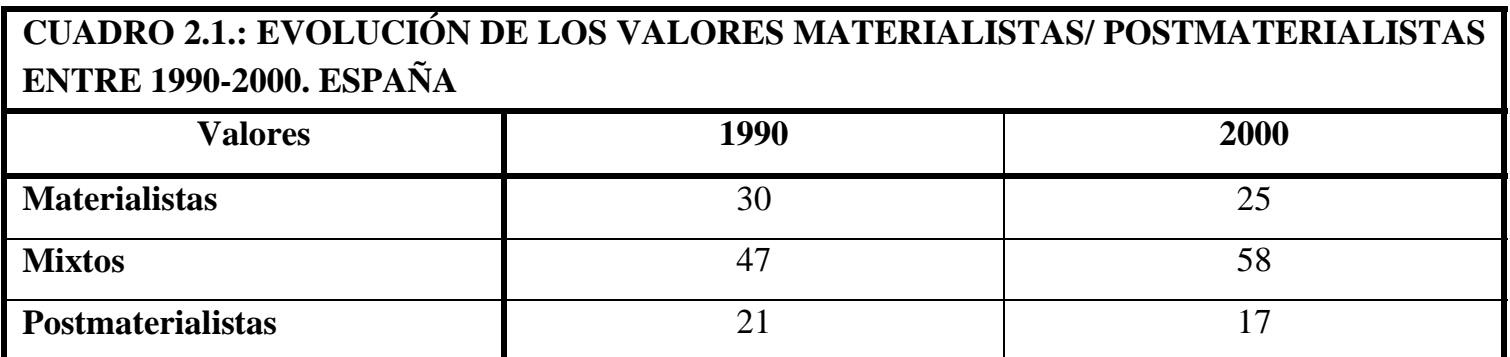

Fte: Inglehart et al (2004:383-384).

Por otra parte, los resultados de la investigación científica y sus aplicaciones tecnológicas se han convertido en uno de los principales campos de batalla cultural en la actualidad: enfrentamiento entre el optimismo y determinismo tecnológico heredero de la época moderna con el desarrollo de un cierto escepticismo y la necesidad de regulación y control de la

\footnotetext{
${ }^{37}$ La emergencia de los valores de seguridad en las sociedades más avanzadas, y la consiguiente menor necesidad psicológica de garantías absolutas ofrecidas por los sistemas de creencias tradicionales, es, según Inglehart (1998:106), la causa de la continuación y reforzamiento del proceso de secularización en las sociedades postmaterialistas.
} 
actividad científico-técnica ${ }^{38}$ (Bericat, 2003a:12). Según los análisis empíricos realizados por este autor, en la actualidad y a juicio de los españoles, se ha producido una pérdida de la legitimidad de la ciencia, que ya no es absoluta, por lo que la cosmovisión científica "sólo puede ofrecer explicaciones específicas y parciales del mundo". Esto ha abierto "la posibilidad del reconocimiento de lo incognoscible, de lo numinoso, de lo sobrenatural, de lo místico, del pensamiento mítico y, en suma, de toda la espiritualidad y modos de pensamiento ajenos a la racionalidad científica”. Así, en la postmodernidad no se excluye la posibilidad de una "bifurcación epistémica”, es decir, no se puede descartar "el hecho de que un mismo individuo mantenga al mismo tiempo sólidas creencias sobre la verdad y utilidad de la explicación científico-racional del mundo”, y aplique "otros modos de explicación o comprensión en aquellos ámbitos más complejos e incognoscibles de la vida y del mundo, ámbitos en los que el paradigma científico-racional no aporta apenas información relevante” (Bericat 2003b:294). En esta mutación valorativa, por la que se produce un alejamiento de la racionalidad instrumental, incapaz como afirmó Weber de dar respuestas a las preguntas existenciales últimas, a la par que se abraza la racionalidad substancial, se encuentra la base del proceso de desecularización (Berger, 2001) que se analiza a continuación.

Obviamente, el avance de los valores postmaterialistas que protagonizan este nuevo y profundo cambio cultural, tiene, y sobre todo tendrá en el futuro, una importancia clave en las decisiones individuales sobre el pilotaje de las últimas fases de la propia vida. Manifestada, por ejemplo, en la creciente sensibilización de los individuos sobre los riesgos que les afectan en el proceso de morir, y su deseo de, además de controlar las condiciones que les afectan en su vida, decidir sobre las de su muerte.

\subsubsection{SECULARIZACIÓN}

"Y sin el infierno, la muerte perdió cualquier riesgo espiritual,
$\begin{aligned} & \text { y se hizo un asunto médico y psicológico" } \\ & \text { T. Walter }\end{aligned}$

Si hay un ámbito privilegiado de la vida social en el que se observa ese cambio en la matriz de valores dominantes, primero en la modernidad y más tarde en la postmodernidad, ése

\footnotetext{
${ }^{38}$ En su análisis empírico sobre los consensos -grandes acuerdos- y los disensos -grandes desacuerdos-, en términos valorativos, que caracterizarían a las relaciones sociales de los españoles en la actualidad, Bericat (2003a:25) resalta dos consensos aparentemente contradictorios: "la visión muy positiva del quehacer científico" y "la ambivalencia hacia la ciencia”. Para este autor, esta hibridación define el nuevo tránsito cultural hacia la época postmoderna que está viviendo la sociedad española actual por el que los españoles se alejan "tanto de la cultura tradicional, caracterizada por la resistencia a creer que la ciencia pudiera traernos grandes beneficios, como de la cultura moderna, caracterizada por una incapacidad para ver que la actividad científica también podía comportar evidentes riesgos o graves consecuencias negativas sobre nuestras vidas, culturas y sociedades”.
} 
es precisamente el del hecho social religioso. Como se ha señalado más arriba, para Morin (1974a:83-84) la religión es un factor de mediación social, heredero de las creencias mágicas, cuya función es adaptar socialmente a los individuos calmando la angustia que les produce su muerte inevitable. Para ello actúa desde un ámbito, el mundo de lo no racional -punto 'intermedio' entre lo racional y lo irracional-, desde el que por ejemplo la ciencia, por las características del método científico, no puede entrar y que, por el contrario, ha hecho que la religión sea la representación colectiva, verosímil (no en sentido racional), consolidada, unánime y estable más utilizada frente al poder `anomígeno’ de la muerte (Basterra, 2006:215). En efecto, las creencias religiosas pertenecen al género de las creencias básicas y esenciales del individuo y están presentes en todas las sociedades conocidas, hasta tal punto de que no puede comprenderse la historia de la humanidad si se prescinde de la religión ${ }^{39}$ (Carmona, 2005:473). La diversidad de manifestaciones religiosas dificulta la elaboración de una definición universal de religión ${ }^{40}$, lo que no es obstáculo para: a) reconocer que es "el más importante recurso de religación social y cultural de entre todos los que están al alcance del ser humano"41 (Bericat, 2003b:269); b) identificar sus elementos -"las creencias, los ritos, la comunidad, la moral, los mitos, la visión transempírica de la realidad”- y; c) resaltar sobre todo sus funciones sociales: "legitimaciones últimas, devoción y respeto absoluto, respuesta a problemas últimos de sentido, movilización para causas que pueden exigir la entrega de la vida, cohesión social y autocomprensión desde una realidad intocable e incuestionable” (Díaz Salazar, 1998:645). Funciones que, sustanciadas en lo sagrado que se constituye en el centro del orden social y cultural -como dosel sagrado (Berger, 1999)-, mantienen integrado el mundo social al ofrecer a los individuos, por un lado, una “una visión totalizante de la realidad”, una cosmovisión asentada en un absoluto que reduce la incertidumbre, los defiende del caos y el sin sentido y, por otro lado, un ethos (el deber ser), "una forma de sentir y actuar en coherencia con esa

\footnotetext{
${ }^{39}$ En el ámbito teórico de la Sociología, sin sus estudios sobre la religión tampoco serían comprensibles las obras de Durkheim, para quien "la religión es consustancial con la sociedad”, y de Weber, cuya crítica a "la razón instrumental y a la jaula de hierro no es sino una forma de expresar el final de la racionalidad sustantiva y de la religión como su matriz cultural” (Carmona, 2005:492-493).

${ }^{40}$ No obstante, cabe asumir la definición de religión aportada por Geertz como "un sistema de símbolos que expresan una concepción general de la existencia que armoniza las acciones humanas con el orden total y proyecta imágenes de ese mismo orden en el plano de la experiencia humana”, citado en Carmona (2005:476). Definición más amplia que la de religiosidad que, ante todo es una práctica simbólica: "es una experiencia personal y colectiva de religación con algo sagrado que posee diversas dimensiones: la fe, las prácticas, las vivencias, la comunidad, la moral” (Díaz Salazar, 1998:646).

${ }^{41}$ "Las ligaduras societarias más cerradas, los vínculos sociales más íntimos, la clausura más hermética e impermeable y la identidad más sólida se logran siempre con el concurso de la dimensión sagrada... En los ritos sacrificiales, el yo profano e individual se funde en la sacralidad del grupo prestando atención a un mismo foco, valorando idénticamente un mismo hecho, y sintiendo colectivamente una misma emoción” (Bericat, 2003b:269). Sacralidad que no se limita a lo trascendente (religiones sobrenaturales), sino que puede ser también inmanente (religiones laicas) -nacionalismos, ideologías políticas, personas, instituciones, etc. (Díaz Salazar, 1998:645).
} 
visión de la realidad", lo que da sentido a la vida social y la legitima "como un camino válido”42 (Carmona, 2005:477).

Legitimación de importancia esencial para la admisión social de la muerte, ya que la religión integra las situaciones marginales -la muerte es la situación marginal por excelenciaen términos de una realidad sacra: "Ello permite al individuo que pasa por estas situaciones continuar $<<$ existiendo $>>$ en el mundo de su sociedad - no $<<$ como si nada hubiera ocurrido $>>-$, lo cual en las situaciones marginales sería psicológicamente demasiado difícil, sino en el convencimiento de que aun estos sucesos o experiencias ocupan un lugar en un universo que tiene sentido" (Berger, 1999:72). Esa capacidad de cierre social y cultural de la religión, generadora de orden y sentido, es la que la convierte, según Bericat (2003b:270) en una herramienta especialmente idónea para generar identidades, lo que es especialmente relevante en la evolución del proceso de secularización en la actualidad.

La secularización es un proceso que hunde sus raíces en el Medioevo ${ }^{43}$ y que, sobre todo a partir de la Ilustración, pone en cuestión las legitimaciones religiosas del mundo en la Europa occidental $^{44}$. Díaz Salazar (1998:673) la define como "un proceso socio-histórico a través del cual se establece, por un lado, una separación entre el factor religioso y los sistemas políticos, sociales y culturales y, por otro lado, crecientes sectores de la sociedad se alejan de los universos simbólicos religiosos”. Es decir, el concepto de secularización opera en tres ámbitos (Herrera Ponce, 2007:153-154): a) el organizacional, que es el componente principal de la misma, ya mencionado al hablar de la secularización de las instituciones desde el inicio del proceso de modernización; b) el cultural, inducido del anterior, por el que queda cercenada la secular posición hegemónica de la cosmovisión religiosa del mundo como única vía de conocimiento capaz de interpretarlo totalmente. De tal forma, que la religión deja de ser la

\footnotetext{
${ }^{42}$ Carmona (2005:477) concluye que "la función de la religión en una cultura humana es la de dar las claves explicativas últimas y aportar sentido y significado a todas las acciones del hombre... la religión armoniza las acciones humanas con un orden total, proyecta imágenes de ese orden en el plano de la experiencia humana y hace posible que el creyente viva ambos mundos como reales".

${ }^{43}$ En su análisis histórico del proceso de secularización, Berger (1999:cap.5) sostiene que en una parte de la propia tradición religiosa occidental, el protestantismo, está la semilla de dicho proceso: "el protestantismo puede ser descrito en términos de una inmensa contracción respecto al alcance de los sagrado en la realidad, al menos comparado con su adversario el catolicismo. El aparato sacramental se reduce al mínimo... El protestantismo cesa de rezar por los muertos... el protestantismo se despojó tanto como pudo de las tres concomitancias de lo sagrado más antiguas: el misterio, el milagro y la magia. Este proceso ha sido correctamente expresado con la frase $<<$ desencantamiento del mundo $>$... (el protestantismo) cortó el cordón umbilical entre el cielo y la tierra, y obligó al hombre a enfrentarse consigo mismo de un modo que históricamente no tenía precedentes” (Berger, 1999:161-163).

${ }^{44}$ Berger renombra al proceso de secularización como <<eurosecularización >> ya que, según él, se circunscribe a Europa y a los países influidos por ella. Esta "excepcionalidad europea" no es una característica mundial, ni siquiera puede aplicarse a países desarrollados como EE.UU. y Japón (BERGER, P. (2002): "Globalization and Religión", en The Hedgehog Review, vol. 4, 2, pps. 7-21, citado en (Mardones, 2004:400).
} 
constructora última del sentido personal y social convirtiéndose en un tipo más de orientación de los valores sociales en competencia con otros -el conocimiento científico y la razón, por ejemplo-, y; c) personal, derivado de los dos anteriores, la influencia del factor religioso queda reservada al reducto de las conciencias personales, se privatiza: secularización de las conciencias $^{45}$. Esta `privatización' de la religión no sólo conlleva que ésta se convierta en un asunto de preferencias personales, sino que, a diferencia de los grandes sistemas religiosos, ya no pueda cumplir las funciones institucionales señaladas arriba. Así, se constata empíricamente que para un número creciente de individuos la religiosidad pierde importancia en sus vidas personales y colectivas, que pasan a ser interpretadas "sin referencia a cosmovisiones religiosas” (Díaz Salazar, 1998:673). Esta secularización de las conciencias se asienta en la racionalización -“incremento de la legitimidad de la ciencia y de la racionalidad instrumental” - y en la "mundanización” o “desacralización” del mundo -“la religiosidad se desencanta y abandona su universo sobrenatural”, con lo que se contempla el mundo de forma natural buscando explicaciones causales a lo observado empíricamente (Bericat, 2003b:276). Es evidente que este proceso se encuentra en la raíz del proceso de deconstrucción de la mortalidad mencionado. Es evidente asimismo que el proceso de secularización trastoca el enfoque tradicional de la enfermedad y del sufrimiento, que se viene abajo como instrumento de redención, y que por tanto cambian las valoraciones de la salud y del cuerpo: "Cuando se pierde la fe en otra vida después de la muerte, la salud pasa a adquirir un significado nuevo y un valor superior... sin ella, todo lo demás es nada” (Beck y Beck-Gernsheim, 2003:250-251).

La implosión de la matriz religiosa ha sido comprobada en numerosas investigaciones empíricas que han mostrado cómo la religión ha perdido prestigio social, como "dosel sagrado", en la jerarquía de valores de las sociedades europeas occidentales. Para el caso de España, el proceso de secularización, iniciado con retraso en la década de $1960^{46}$, ha sido "fulgurante" al producirse en ella en una sola generación lo que en el resto de Europa ha durado un siglo

\footnotetext{
45 "La diferenciación sistémica llega a la vida del individuo por medio de los diversos roles de los que éste es portador. Al haber desaparecido del nivel macroestructural una institución rectora que armonice las diferentes instituciones y establezca una jerarquía de prioridades entre las diferentes obligaciones sociales, las demandas de cada uno de sus roles aparecen ante su conciencia como parcelas independientes y con demandas contradictorias. La tarea unificadora queda bajo la responsabilidad del individuo, que ha de realizarla <<por libre>> y en el seno de su propia conciencia" (Carmona, 2005:494495).

${ }^{46}$ Tardanza relacionada con el retraso de su atípico proceso de modernización, en el que "el desarrollo económico hizo posible la transformación de nuestra economía... esto trajo consigo unos cambios drásticos en las formas de asentamiento de la población y una transformación histórica de la estructura de clases de la sociedad española. La mesocratización de la estratificación española repercutió en los niveles de consumo, en el acceso masivo a la educación, en la mejora de la salud, en las demandas de mejores condiciones de trabajo y de calidad de vida en general, y en una reorientación ideológica de la vida política que se hace realidad con la Transición y en una plena vinculación con Europa. Pero estos cambios también repercuten en el proyecto y modelo de persona. Surge un español más autónomo, más permisivo, más lúcido y con formas diferentes de entender la moral en lo individual y lo social” (Carmona 2005:497).
} 
(Pérez-Agote y Santiago García, 2005:8). Proceso de secularización de la sociedad española que, de acuerdo a la tesis de la secularización, no sólo ha estado relacionado con el de la modernización, sino que, como prevé esa tesis para las sociedades de gran homogeneidad religiosa y en las que existe una estrecha interdependencia entre la Iglesia y el Estado, ha experimentado un declive rápido tanto de la religión organizada como de los niveles de afiliación y práctica religiosa a medida que el proceso de modernización avanzaba (Requena, 2008:320). Esta evolución puede ser observada de forma diáfana, entre otras fuentes, en las series temporales del CIS en las que se constata cómo la religión, junto con la política, han perdido paulatinamente importancia en las preferencias axiológicas hasta ocupar las dos últimas posiciones en la jerarquía de valores de la sociedad española actual ${ }^{47}$ (Pérez-Agote y Santiago García, 2005; Carmona, 2005; Comas Arnau, 2004; Mardones, 2004; Arroyo Méndez, 2004; Bericat, 2003).

No obstante, los evidentes procesos de “desdogmatización”, “desritualización”, “despolitización” y “desnacionalización” de la religión que caracterizan la dinámica secularizadora de las sociedades occidentales no implican, sin embargo, que se haya producido el vaciado o el desecamiento total de la dimensión religiosa en ellas. El declive del compromiso con las instituciones religiosas no conlleva, sin embargo, el de las preocupaciones espirituales; así, en las sociedades más desarrolladas permanece vigente todavía una reserva de creencias religiosas básicas, que si bien no determinan la totalidad de la vida de los individuos, sí constituye un referente de buena parte de sus valores y actitudes centrales. Hecho que desmiente la tesis de la secularización, que aventuraba un reforzamiento del proceso secularizador hasta la inevitable desaparición de la religión del ámbito público, y que ha reabierto el debate sobre el papel de la religión en las sociedades postmodernas: "una secularización en la que Dios no muere” (Arroyo, 2004). De hecho, como rectifica uno de los defensores de esa tesis, Berger (2001:15), “la idea según la cual vivimos en un mundo secularizado es falsa. El mundo hoy, con algunas excepciones... es tan furiosamente religioso como siempre ha sido; e incluso más en ciertos sentidos” ${ }^{48}$. En efecto, el retorno de la religión a la esfera pública, la aparición de nuevas formas de religión, de expresión de la espiritualidad y de sacralidad, etc., constituyen nuevos procesos de desecularización que atraviesan a las sociedades postmodernas (Pérez-Agote y

\footnotetext{
${ }^{47}$ Este cambio de valores es el resultado de una progresiva diferenciación de los ámbitos de vida en los que participan los individuos, diferenciación marcada, además, por la primacía de los intereses personales más cercanos y/o inmediatos sobre cualquier otra consideración. Véase al respecto el análisis diacrónico sobre las series temporales del CIS realizado por Comas Arnau (2004), o el trabajo de Pérez-Agote y Santiago García (2005:17-18) quienes comprueban, al comparar la importancia de la religión para los españoles entre los años 1987 y 2002, que la religión no sólo ocupa el antepenúltimo lugar en el ranking de las preocupaciones en ambas fechas, sólo por delante de la política, sino que además la valoración de la misma continúa descendiendo: 6’11 de media, en 1987; 5’34, en 2002.

${ }^{48}$ BERGER, P. (2001): "La désécularisation du monde: un point de vue global”, en BERGER, P. (dir.): Le réenchantement du monde, París, Bayard, citado en Pérez-Agote y Santiago García, 2005:7.
} 
Santiago García, 2005:7). De esta forma, en estas sociedades el proceso de secularización continúa en lo que se refiere a la "crisis" de la-religiosidad institucionalizada-, pero no afecta al sentido espiritual de la vida -religiosidad experiencial-, al contrario: "podemos encontrar también una sólida tendencia a través de las diferentes naciones a pasar más tiempo pensando sobre el significado y el propósito de la vida. El predominio de la racionalidad instrumental está dando paso a una mayor preocupación por los fines últimos” (Inglehart, 1998:59). Afirmación que ha sido corroborada empíricamente no sólo en los diferentes estudios nacionales e internacionales realizados bajo el paraguas de la periódica Encuesta Mundial de Valores, y que, para el caso de España, confirman asimismo otros estudios en los que se constata cómo a pesar de su alejamiento de las instituciones religiosas las personas encuestadas, con distinta intensidad, mantienen un alto grado de creencias espirituales abstractas ${ }^{49}$. Bericat (2003b:270) relaciona este retorno de la religión en las sociedades postmodernas con, por un lado, su capacidad para generar identidades comunitarias e individuales y, por otro lado, con la profunda ansiedad provocada por el "miedo al vacío" en esas sociedades: "es precisamente por esto que en nuestras sociedades hiperdesarrolladas y posmodernas, sociedades en las que $<<$ todo lo sólido parece desvanecerse en el aire>>, y en las que el ser humano está expuesto a un alto grado de apertura, de pluralidad, de incertidumbre, de movilidad, de contingencia y de relativismo, los problemas de identidad vuelven a ocupar un lugar preeminente en la escena social y cultural contemporánea” ${ }^{50}$.

En el Cuadro 2.2. se exponen datos extraídos de la Encuesta Mundial de Valores y del Estudio Europeo de Valores para el caso de España en el año 2000. En el mismo sólo se recogen el total de las respuestas afirmativas a los ítems seleccionados y la distribución de esas respuestas según la ubicación de la población en valores modernos, postmodernos y mixtos ${ }^{51}$. Se constata lo afirmado más arriba sobre las divergencias entre la religiosidad espiritual y la religiosidad institucionalizada, ya que si bien una buena parte de la población encuestada hace explícita su auto-identificación como persona religiosa a través de sus actitudes y de algunas de sus creencias, fundamentalmente en Dios y en la existencia del alma, simultáneamente se pone

\footnotetext{
${ }^{49}$ En el apartado 5.2. de esta Tesis se exponen datos sobre esta cuestión extraídos de estudios empíricos sobre la religiosidad en la sociedad española actual.

${ }^{50}$ Algunos autores, como Comas (2004), observan este proceso con más escepticismo y consideran que, al menos en el caso español, esos datos sobre creencias religiosas no reflejan más que un cierto "catolicismo cultural", es decir, una identificación con la cultura católica pero no con la religión católica. Así, en el ámbito de la religión "la mayoría de los españoles se sitúa en tierra de nadie, fuera de la iglesia católica, pero también al margen de otras creencias religiosas y muy lejos del laicismo positivo. Por este motivo sus referencias religiosas son tan contradictorias y confusas". Por su parte, Arroyo (2004:414) desarrolla la idea de <<bricolaje religioso >> según la cual al desvincularse la población de la Iglesia, se han desarrollado formas individualizadas y light de religiosidad, "en la medida que se seleccionan "a la carta” aquellos fragmentos que son válidos para cada creyente".

${ }^{51}$ Aunque en el Cuadro 2.2. no se aporta información sobre las distribuciones por género y edad, numerosos estudios, como se comenta en el apartado 5.2. de esta Tesis, han mostrado que, con carácter general, la religiosidad es relativamente mayor entre las mujeres y entre las generaciones de más edad.
} 
de manifiesto que no se comparten con tanta intensidad algunas de las creencias dogmáticas de la Iglesia Católica, fundamentalmente la creencia en el infierno, y sobre todo no se la reconoce, y se duda de, la propia capacidad de las iglesias para cumplir con algunas de las funciones que tradicionalmente las justificaban, en especial, ser referentes morales y ejercer de guía en la vida familiar. Las prevenciones hacia las iglesias se incrementan a la hora de plantear su papel en la vida social, rechazándose mayoritariamente que la religión pueda ejercer algún tipo de influencia en el desarrollo de la vida pública. El alejamiento hacia las iglesias se confirma, además, a partir de los comportamientos declarados que, en este caso, se concreta en que, en claro contraste con la religiosidad manifestada, "sólo" una de cada tres personas encuestadas visita regularmente la iglesia. Por otro lado, y como es obvio, el cambio valorativo señalado en el sub-apartado anterior se refleja en la menor religiosidad y en el mayor rechazo hacia las iglesias por parte de las personas que declararon valores potmaterialistas. 
CUADRO 2.2.: CREENCIAS, OPINIONES, ACTITUDES Y COMPORTAMIENTOS DE LA SOCIEDAD ESPAÑOLA. 2000.

\begin{tabular}{|c|c|c|c|c|}
\hline & \multirow[b]{2}{*}{ Total } & \multicolumn{3}{|c|}{ Valores } \\
\hline & & Materialist. & Mixtos & Postmater. \\
\hline \multicolumn{5}{|l|}{ Actitudes: } \\
\hline Pensar en el significado de la vida & 22 & 19 & 22 & 29 \\
\hline Completa confianza en las Iglesias & 42 & 52 & 42 & 23 \\
\hline Se considera una persona religiosa & 61 & 74 & 61 & 43 \\
\hline Importancia de Dios en su vida & 46 & 54 & 45 & 34 \\
\hline Encuentra confort y fuerza en la religión & 54 & 65 & 55 & 32 \\
\hline \multicolumn{5}{|l|}{ Creencias en } \\
\hline Dios & 85 & 92 & 84 & 72 \\
\hline Un Dios personal & 49 & 54 & 45 & 34 \\
\hline El alma & 72 & 75 & 66 & 70 \\
\hline El pecado & 51 & 69 & 49 & 31 \\
\hline El cielo & 51 & 62 & 50 & 33 \\
\hline Vida después de la muerte & 53 & 61 & 51 & 44 \\
\hline El infierno & 37 & 45 & 36 & 22 \\
\hline La reencarnación & 20 & 23 & 20 & 18 \\
\hline \multicolumn{5}{|l|}{ Opiniones: } \\
\hline $\begin{array}{l}\text { Las iglesias dan respuesta adecuada a las } \\
\text { necesidades espirituales de la gente }\end{array}$ & 55 & 63 & 55 & 39 \\
\hline $\begin{array}{l}\text { Las iglesias dan respuesta adecuada a los } \\
\text { problemas morales de los individuos }\end{array}$ & 41 & 53 & 40 & 20 \\
\hline $\begin{array}{l}\text { Las iglesias dan respuesta adecuada a los } \\
\text { problemas de la vida familiar }\end{array}$ & 37 & 48 & 35 & 21 \\
\hline $\begin{array}{l}\text { Las iglesias dan respuesta adecuada a los } \\
\text { problemas sociales de cada día }\end{array}$ & 31 & 41 & 30 & 15 \\
\hline $\begin{array}{l}\text { Desacuerdo con que los líderes que no creen en } \\
\text { Dios están incapacitados para la tarea pública }\end{array}$ & 69 & 57 & 71 & 81 \\
\hline $\begin{array}{l}\text { Acuerdo con que los líderes religiosos no deben } \\
\text { influir en el Gobierno }\end{array}$ & 69 & 59 & 70 & 82 \\
\hline \multicolumn{5}{|l|}{ Comportamientos } \\
\hline $\begin{array}{l}\text { Al margen de actos religiosos-sociales (bodas, } \\
\text { entierros, etc.), acude una vez al mes o más a la } \\
\text { iglesia }\end{array}$ & 36 & 47 & 35 & 18 \\
\hline
\end{tabular}

Fte: (Inglehart et al, 2004)

\subsubsection{NUEVOS PERFILES EN EL PROCESO DE INDIVIDUALIZACIÓN}

"Los rituales públicos alrededor de la muerte se han marchitado y se han contraído de modo que, como acontecimiento social, la muerte ha `muerto'”

T. Walter

El proceso de modernización socioeconómica ha constituido el sustrato social sobre el que se ha construido un nuevo tipo de personalidad individualista orientada hacia intereses concretos e inexistentes antaño. Siguiendo a H. Béjar (1989), “el fenómeno del individualismo ${ }^{52}$

52 Tocqueville (1984:89, Tomo II) diferencia entre egoísmo e individualismo. Mientras que el primero, de larga data en las sociedades occidentales, se centra exclusivamente en el propio yo ("el egoísmo es un amor apasionado y exagerado hacia la propia persona que induce al hombre a no referir nada sino a uno 
conforma un marco de referencia general que ayuda a comprender las características de la moderna interacción y de algunas de sus quiebras”; marco de referencia definido por el desplazamiento de intereses desde lo público (“alude a lo visible, a lo común; su esfera será la de los intereses colectivos, la de los asuntos políticos”) a lo privado ${ }^{53}$ (“se refiere a lo oculto, a lo propio, y apunta al ámbito de las cuestiones domésticas, al dominio de las relaciones personales y de los afectos”) ${ }^{54}$. Es decir, es un proceso en el que la autonomía y la toma de decisiones individual adquieren creciente importancia. Si bien el individualismo, y la $\operatorname{privacidad}^{55}$, son ideas latentes a lo largo de la historia de la cultura occidental, no van a desarrollarse en su sentido moderno hasta el siglo XIX (Bejar, 1989:52). En buena medida por el proceso de secularización y por el desarrollo del espíritu competitivo y mercantil característico de las nacientes sociedades industriales en ese siglo que alentaron sentimientos exacerbados del yo para contrapesar el anonimato, la despersonalización, la homogeneización fomentadas por la sociedad de consumo de masas y el proceso de urbanización (Thomas, 1985:42-45).

Uno de los principales rasgos de este proceso es la progresiva asunción como valor básico (en los ámbitos personal y familiar) de la individualización ética, por la que se exige el derecho a una mayor libertad personal, es decir, a que sea la propia conciencia moral del individuo la que en último término decida. Una evolución hacia lo que Kerhofs (1994) denomina <<ética de la situación>>. En efecto, el proceso de secularización conllevó un menor condicionamiento por el entorno (por el qué dirán), una ruptura de la imposición obligatoria de los valores religiosos que nivelaban y homogeneizaban las conciencias, permitiendo mayor

mismo y a preferirse en todo”), el segundo, de nuevo cuño, incluye en el círculo de interés propio a los más cercanos ("El individualismo es un sentimiento reflexivo y apacible que induce a cada ciudadano a aislarse de la masa de sus semejantes y a mantenerse aparte con su familia y sus amigos; de suerte que después de formar una pequeña sociedad para su uso particular, abandona a sí misma a la grande”).

${ }^{53}$ Bejar (1989:52) define la privacidad como "una esfera de soberanía individual libre de interferencias externas”.

${ }^{54}$ En su análisis cualitativo sobre la percepción de los elementos esenciales del individualismo en la sociedad española, Béjar (1989), siguiendo a H. Arendt, considera además una tercera categoría, "la esfera de lo social", concepto <<negativo >>, que no es ni público ni privado, que está adquiriendo "una importancia progresiva al hilo del emborronamiento y la intrusión recíproca de actividades que pertenecen a las esferas de competencia referenciales, esto es pública y privada”. Toma como núcleo de referencia de esta esfera al trabajo.

55 “El dominio de lo privado, lugar de autodesarrollo (la dimensión expresiva de la persona), autenticidad (el lugar de creación y por tanto el origen de la vida social... lo privado se opone a un exterior amenazante, potencialmente hostil cuando no abiertamente agresivo, en el cual sólo cabe la convención, el disimulo, el disfraz. Fuera de la esfera privada se corre el peligro de ser vulnerado), seguridad (afectiva,... la intimidad,... el universo significativo que confiere al individuo una fuerte sensación de arraigo, permanencia, sentido y certeza) e intensidad (el escenario de la generosidad y la entrega sin reservas. Los amigos son el engarce fundamental con el mundo exterior, $<<$ recipientes $>>$ del relato de nuestra actividad y, a la vez, <<contraste $>>$ de la misma... Al compartir experiencias y sentimientos, los amigos constituyen un círculo definido tanto externamente (por oposición a lo público) como internamente (como referencia de mí mismo, destinatario inmediato de mi actividad), es el recinto de la libertad, de los sentimientos y de la propia naturaleza” (Béjar, 1989:64). 
libertad en la moralidad individual, lo que implicó una tolerancia cada vez más amplia hacia valores antagónicos en lo que atañe a la moralidad personal y familiar. Este pluralismo ético favoreció a su vez la extensión del relativismo social y moral y la posibilidad de eludir los códigos prescriptivos. Como contrapartida, en el ámbito del enfrentamiento con la muerte, el temor a ésta se desplazó desde el temor por la muerte del grupo, es decir, por cómo incidiría una muerte individual sobre la supervivencia del grupo en las sociedades comunitarias, en las que la identidad personal está atada en buena medida al grupo, hasta el temor por la pérdida de la propia identidad, del yo mismo (self), en las sociedades modernas, convirtiéndose esto en el talón de Aquiles del individualismo (Walter, 1994:16).

Además, el individualismo, con su búsqueda prioritaria del confort y el bienestar subjetivo, refuerza el proceso de traslación de funciones desde los grupos primarios a las organizaciones burocráticas. Por todo ello, el creciente individualismo en las sociedades desarrolladas se ha constituido como fuente de asocialización y de insolidaridad a la par que ha minado las respuestas tradicionales comunitarias dominantes en las sociedades rurales al trasladar al ámbito de lo privado muchos de los procesos que anteriormente eran esencialmente públicos, entre ellos prácticamente todos los relacionados con la muerte (Thomas, 1985:43). Así, necesidades como el cuidado de los moribundos, la atención a los familiares más mayores, el amortajamiento de los cadáveres, la organización del funeral o la mera contratación de una esquela, se cubren ahora de acuerdo a la lógica del beneficio en un mercado en el que se concitan una oferta 'fría', caracterizada por la profesionalización y comercialización de productos y servicios similar a la del resto de mercados, y una demanda ‘caliente', apremiada por responder satisfactoriamente a las situaciones traumáticas sensibles que se viven en la intimidad.

Esta fragmentación cultural derivada del individualismo se refuerza en otras “quiebras” en la esfera privada (Béjar, 1989). Concretamente, lo hace como el envés de la privacidad: la soledad. Y si bien ésta, como "búsqueda voluntaria de aislamiento", puede ser valorada positivamente al relacionarla con un deseo de independencia, esfera de construcción de un yo ideal, de una soberanía libre de interferencias externas (la soledad como elección), esa elección puede mutar negativamente en carencia, en miedo a la soledad, como "ausencia de compañía deseada" y, por tanto, convertirse en marco de necesidad (la soledad como destino). "El protagonista de tan desolado paisaje es un tipo humano (<<un ermitaño >>, <<un anacoreta >) 
caracterizado por una negatividad en relación a lo social”, abandonado por los demás, hastiado y rodeado por el silencio, la amargura y la muerte (Béjar, 1989:65-69) ${ }^{56}$.

No obstante, y tal como se desarrolla en el Capítulo 3 de esta Tesis, algunos autores matizan el proceso de individualización descrito y consideran que lo que realmente se está produciendo en este momento no es tanto el reemplazo de la comunidad por el individuo aislado, sino por el individuo comunicado con un(os) otro(s) de confianza, lo que en el ámbito concreto del enfrentamiento a la muerte es de suma importancia (Walter, 1994).

La actuación sinérgica de los cambios mencionados, junto a otros como las transformaciones en la institución familiar, el desarrollo de la sociedad de consumo de masas, las innovaciones en las formas de organización de la producción, las nuevas tecnologías, el proceso de globalización, la revolución en los instrumentos de comunicación (INTERNET) ${ }^{57}$, y la expansión de los medios de comunicación de masas con su enorme poder sobre la configuración del imaginario colectivo, mediatizan la construcción social de la muerte en las sociedades desarrolladas. Lo que antes se daba por descontado -por influjo de la tradición o de la propia naturaleza-, ahora se muestra difuso ampliándose el escenario social con nuevas posibilidades de elección. Así, constantes de la existencia humana, como por ejemplo la constitución biológica, pasan a ser variables sobre las que cabe decidir a muy diversos niveles. Es el caso de los nuevos interrogantes generados por los avances médicos, tanto los referidos a la medicina reproductiva como la medicina intensiva: ¿qué es la vida humana?, ¿dónde empieza?, ¿dónde se sitúa su final?, ¿cuánta cirugía invasiva utilizar?, ¿cuánta alimentación y respiración artificiales? Dilemas que en casos extremos "requieren decisiones médicas en las que entra en juego no sólo la vida de las personas, sino también la misma definición de la vida y la muerte” (Beck y Beck-Gernsheim, 2003:243-244).

\subsection{DEFINICIÓN SOCIAL DE LA MUERTE Y EL MORIR}

\footnotetext{
${ }^{56}$ Del análisis de los discursos relativos a la relación individualismo/soledad, Béjar (1989:69) concluye que "la soledad pasa de ser una situación objetiva -un modo de vida en un hogar unipersonal- para transformarse en un rasgo subjetivo... se produce un desplazamiento de sentido de la soledad, que pasa de la denotación (<<vivir solo >>) a la connotación (<<estar solo >>) para acabar imprimiendo carácter (<<ser un solitario $>>)$ ".

${ }^{57}$ En el apartado tercero del Capítulo 3 de esta Tesis se desarrolla de forma pormenorizada cómo inciden algunos de estos cambios estructurales en el sistema capitalista actual sobre el enfrentamiento de los individuos ante la muerte.
} 
"La muerte pone radicalmente en duda la actitud generalmente aceptada de que <<todo sigue igual $>>$, actitud con la que se vive la vida cotidiana”

P. Berger

La imposibilidad de conocer directamente la inmanencia de la muerte no ha impedido, como se ha señalado, que históricamente se la haya abordado de forma indirecta y que desde distintas perspectivas se hayan afrontado las diversas vertientes de la misma para lograr un mejor funcionamiento de la vida humana en sociedad. Entre estas cuestiones existe una que resulta esencial e ineludible: identificar y concretar la definición social de la muerte. Es decir, en un contexto histórico determinado ¿qué significa desde el punto de vista social estar muerto/a?, ¿qué caracteriza a la muerte humana?, o más específicamente, ¿cuándo la sociedad considera a una persona como muerta?

La muerte humana, en principio, es un fenómeno bidimensional. Por una parte, es un proceso natural inevitable ligado a la biología de los seres vivos y, por otra parte, es un proceso social derivado de la pérdida total e irreversible de la capacidad para conectar con el entorno. Como se ha mostrado arriba, es esta segunda dimensión, la específicamente humana, la más relevante desde un punto de vista sociológico porque es en la que se constata que la muerte es ante todo una construcción social, un concepto. Concepto que, como todo producto históricosocial, es dinámico y en su caso muy complejo, ya que en su conformación intervienen aspectos médicos, filosóficos, éticos, religiosos, legales, etc. En esencia, esa complejidad, que se observa sobre todo en la noción de muerte de las sociedades más desarrolladas, remite a la existencia de tres dimensiones básicas interrelacionadas a la hora de definir socialmente la muerte de un ser humano: la filosófica, la médica y la psico-sociológica.

La dimensión filosófica se sustenta en el concepto abstracto de finalidad: la muerte como límite final y absoluto de la vida. Esta dimensión se refiere por tanto a cuestiones del tipo qué es la vida y qué es la muerte, aplicables a todos los seres vivos y que, en última instancia, llevan a preguntarse sobre qué características definen en esencia la naturaleza de un ser vivo y cuáles las de un ser muerto (Gracia, 1996:23). En el caso concreto de la muerte de los seres humanos esas cuestiones se hacen más complejas ante la necesidad de testar los rasgos que denotan específicamente humanidad -ser persona. Es por ello por lo que la reflexión filosófica busca delimitar aquellas características o rasgos muy generales que parecen afectar siempre a la muerte humana para así poder identificar las condiciones bajo las cuales esa muerte es “verdaderamente humana y no inhumana o extrahumana” (Tornos, 1990:33). En definitiva, y siguiendo a este autor, el análisis filosófico se afana en deslindar "las características que separan 
el morir humano de un morir que ya no pudiera reconocerse como humano”; sin embargo, para la mayoría de los autores esa identificación/distinción es por ahora un ideal inalcanzable.

La dimensión médica, por su parte, tiene un marcado carácter empírico y pragmático y en principio se centra en la dimensión biológica de la muerte, orientando sus esfuerzos prioritariamente hacia la comprensión y la resolución técnica del proceso de envejecimiento, del proceso de morir y la agonía y, sobre todo, al diagnóstico de la "muerte clínica”58 que reconoce el nuevo estado de muerte, lo que compromete la dimensión real del sujeto que pasa a ser un cadáver. No obstante, las posibilidades abiertas con los avances logrados en el ámbito de los trasplantes de órganos, que han hecho que en alguna medida la muerte de un individuo no sea su "fin terrenal" al vivir sus órganos en otros individuos a los que dan vida, ha provocado inevitablemente la emergencia de un debate público sobre la definición de la vida, la muerte y el cuerpo humano que desborda la dimensión médica en la que se inicia. En efecto, el salto conceptual provocado por esa tecnología, ha supuesto que en algunos casos la identificación de la muerte no coincida, como ocurría hasta los años sesenta del siglo pasado, con el final total de la vida de una persona. Al ser el cuerpo-cadáver fuente potencial de vida para otros, y para poder materializar esa función se ha necesitado, como se analiza más adelante, una redefinición social de la muerte lo que a su vez ha conllevado "cambios sociales y de valores importantes acerca de la esencia del ser humano, de la identidad del cuerpo ${ }^{59}$ y de sus partes y de la esencia de la existencia” (Juan y Rodríguez, 1994:174 y 188).

Finalmente, la dimensión psico-sociológica, de perfiles poliédricos, abarca un amplio espectro de cuestiones que van desde la asunción de una definición pública de muerte hasta las consecuencias sociales de la misma, que determinan una gran diversidad de reacciones individuales y sociales ante la muerte. Una muestra de esa diversidad de reacciones ante la cercanía de la muerte queda reflejada, por ejemplo, en los $<<$ Patrones de Muerte $>>$ de Pattison $(1977)^{60}$. Este autor distingue entre: a) muerte fisiológica: la terminación de las funciones de todos los órganos vitales; b) muerte clínica o biológica: la terminación de toda la actividad cerebral, indicada por la ausencia de ondas cerebrales; c) muerte sociológica: el abandono y

\footnotetext{
${ }^{58}$ El neurólogo J.L. Trueba (2007:58) define la "muerte clínica” como "la actualidad presencial de la realidad de la muerte en quien yace, postrado clínicamente, ante un médico, que tiene que afrontarlo, verificando y atestiguando mediante un juicio diagnóstico el <<estado de muerte irreversible >>”.

${ }^{59}$ El trasplante de órganos ha conllevado una profunda trasformación del significado del cuerpo humano que "se ha ido troceando y perdiendo su identidad holística, para convertirse en material medicalizable. En la aplicación de la nueva tecnología el cuerpo es un conjunto de partes en funcionamiento. Las partes no encarnan la vida, aunque son necesarias para la vida del cuerpo. Las partes no encarnan a la esencia de la persona. Ni incluso el conjunto de sus partes. La esencia de la vida, y por tanto de la persona, pasa a residir, según la ciencia, en el cerebro” (Juan y Rodríguez, 1994:188).

${ }^{60}$ Citado en Rice (1997:648-650).
} 
alejamiento de la gente cuando considera que la persona está muriendo ${ }^{61}$; y d) muerte psíquica: la aceptación de la muerte y regresión al yo por parte de la persona que muere. Sobre esta base, Pattison describe cinco patrones posibles de muerte: 1) Proximidad ideal: a partir de un momento dado la persona 'tocada' por la muerte se da por vencida y entonces empieza la fase terminal. Aunque existe alguna esperanza de vivir más tiempo, la gente empieza a alejarse (muerte sociológica), la propia persona acepta ya su muerte (muerte psíquica), el cerebro deja de funcionar (muerte clínica) y finalmente el cuerpo muere (muerte fisiológica); 2) Rechazo social del paciente: mucho antes de que ocurra el fallecimiento las otras personas rechazan al moribundo (muerte sociológica). De ésta se deriva la muerte psíquica, que al final conduce a la muerte clínica y la muerte fisiológica; 3) Rechazo social y del paciente de la muerte: en este patrón el moribundo y los familiares y amigos que le rodean se niegan a aceptar la inminencia de la muerte, por lo que cuando llega produce una gran conmoción; 4) Rechazo de la vida por parte del paciente: éste rechaza la vida y enferma psíquicamente (muerte psíquica), aunque los que le rodean traten de motivarlo para que siga viviendo; 5) Rechazo social de la muerte por medio del mantenimiento artificial: cuando existe una negación social del hecho que ya se ha producido la muerte psíquica y la muerte clínica de la persona.

Es evidente que cuando una persona es etiquetada como muerta, toda una serie de procesos sociales, culturales, políticos, económicos y éticos entran en juego alrededor de ella. Por un lado, familiares y amigos inician el proceso de duelo en un intento de reconstruir su realidad superando la pérdida; eligen entre inhumación o incineración; si es el caso, se tramitan la herencia y los seguros; etc. Por otro lado, se ponen en marcha alrededor del cadáver de la persona muerta toda una batería de procedimientos médicos y administrativos: unos tratamientos médicos se paralizan sólo cuando es declarada muerta; otros se activan si el cuerpo muerto va a ser empleado en investigación, docencia o trasplantes de órganos. Estos procesos médicos requieren procedimientos administrativos (permisos, certificados, etc.) establecidos de acuerdo a la legalidad vigente.

\footnotetext{
${ }^{61}$ Mulkay (1993:32-33) considera la muerte social como una respuesta contingente a los cambios demográficos de los dos últimos siglos, y en especial al notable incremento de la esperanza de vida producido durante ese periodo de tiempo. Para él, la muerte social significa que una persona pasa a ser "no-persona", es decir, cesa como agente social activo en la vida de los otros, lo que no significa que sea así para todos los otros, pudiendo haber muerto para unas personas pero no para otras. Por otra parte, Mulkay analiza la relación de la muerte social con la edad y resalta cómo se produce sobre todo entre las personas ancianas. La constatación de ello es clara si se compara, por un lado, la muerte social de las personas ancianas, iniciada con la jubilación y sobre todo al abandonar la actividad cotidiana, emisaria de la muerte esperada por previsible y cercana, muerte social en buena medida aceptada por la sociedad que en general está preparada para afrontarla y, por otro lado, la muerte súbita, imprevista, traumática, accidental en muchos casos, de las personas más jóvenes.
} 
En definitiva, desde el mismo momento en que se etiqueta como "muerto" a un ser humano se activa una batería de procesos sociales que rebasan el ámbito de lo personal, no sólo porque son los "otros" los que etiquetan, sino sobre todo por las dimensiones sociales de sus consecuencias. Desde la perspectiva sociológica, por tanto, resulta esencial responder a diversas cuestiones relativas a la definición pública de muerte que permite identificar a una persona como muerta. Así, cuando esto ocurre, ¿qué criterio o criterios se emplean para sustentar esa adscripción?, ¿existe un único criterio?, si no es así, ¿por qué razones se admite socialmente uno de ellos en detrimento de otros?. Por otra parte, la fijación de un criterio de muerte socialmente admitido ¿se basa en razones de política pública o es una cuestión meramente científicotécnica?, es decir, ¿qué ámbitos, organismos e instituciones sociales tienen capacidad para fijar la adscripción de una persona como muerta?, ¿quiénes para aplicar el(los) criterio(s)?, ¿cómo se formalizan legalmente la definición "estar muerto/a” y los criterios de muerte?, ¿ existe la objeción de conciencia en este punto?, etc.

\title{
2.3.1. DIFICULTAD DE DEFINIR LA MUERTE: DIFICULTADES EN LA IDENTIFICACIÓN SOCIAL DE LA MUERTE HUMANA
}

\begin{abstract}
"La muerte se ha vuelto silenciosa y reclama silencio, y le damos de buena gana el gusto de callar, la matamos con nuestro silencio. Y no porque no sepamos nada de ella sabido es que ése no es un motivo para callar-, no, es sencillamente porque, como es siempre negativa, una aguafiestas, una auténtica perturbadora, con esa clase de gente no queremos tratarnos”
\end{abstract}

P. Süskind

La tipología de muerte de Pattison es un ejemplo diáfano de las dificultades que entraña definir la muerte, o al menos la muerte humana. Al igual que el concepto de persona, y el de vida, el concepto de muerte no está uniformemente establecido y aceptado. En efecto, si bien la mayoría de los diccionarios remiten a la raíz latina mors, mortis, cesación de la vida, al abordar la voz Muerte ${ }^{62}$, algunos autores resaltan la insuficiencia de esta definición. Aplicada a todos los seres vivos la definición de muerte debe expresar cuál es su naturaleza, su esencia, y qué es lo que la distingue de otros fenómenos. Para Quintana (1997:46-50), por ejemplo, esa definición

\footnotetext{
62 “Cesación o terminación de la vida” (Real Academia Española (1984:935): Diccionario de la Lengua Española, Madrid, Espasa-Calpe, 20ª ed.); “Cesación completa y definitiva de la vida: La muerte es el punto a partir del cual se hacen irreversibles los procesos degenerativos de un organismo. A partir de este punto se liberan en el citoplasma celular gran cantidad de catalasas y otros enzimas líticos, este proceso es local, se denomina necrosis“(cesación de vida). Fenómeno biológico natural que implica el fin irreversible de las funciones vitales" (Gran Enciclopedia Larouse (1976), vol.7:480); "La total cesación de los procesos de vida que eventualmente ocurren en todos los organismos vivos" (Enciclopedia Británica. Micromedia (1987), vol. 3:941); “Cesación de la vida” (María Moliner (1984:470): Diccionario de uso del Español, vol.2, Madrid, Gredos; "Fenómeno biológico natural que implica el fin irreversible de las funciones vitales” (Diccionario electrónico de Filosofía Herder).
} 
debería cumplir una condición inexcusable: no tener contraejemplos o excepciones porque en caso contrario cambiaría su propia naturaleza. Así, definir la muerte como terminación de la vida conlleva tener que definir lo que es "vida", concepto igualmente opaco por la variedad de acepciones que tiene y por lo difícil de precisar "al no haber una característica específica de los seres vivos que no tenga excepciones”. Según este autor, aplicada al caso de los seres humanos existirían además dos razones para justificar que la tesis de la extinción o terminación de la vida no sirve para entender ni conceptualizar la muerte. La primera de esas razones, más bien retórica, es que la tesis de la cesación “va contra las intuiciones más elementales”, ya que la muerte de una persona implica que ésta deja de existir, lo que a su vez implicaría que no habría que asistir al entierro de la misma porque ya no se entierra a esa persona: "los cadáveres han dejado de existir”. La segunda de las razones tiene mayor calado en las circunstancias actuales en las que la utilización de determinados criterios para establecer legalmente la muerte puede suponer que una persona esté muerta en términos humanos (la "persona psicológica" al morir deja inmediatamente de existir), pero no en términos animales (la "persona biológica deja de existir progresivamente”), lo que da lugar a la situación paradójica de que la vida supone existencia, mientras que la muerte humana puede, simultáneamente, ser existencia y no existencia.

Así, la resolución técnica de un problema aparentemente sencillo, cómo y cuándo sucede la muerte, se enturbia sobremanera en el caso de los seres humanos haciéndose necesario dilucidar los dos tipos de muerte que acaecen a los mismos. Una, más básica, la muerte biológica como ser animal; otra, más específica, la muerte como ser humano propiamente dicho (como persona). La primera de las muertes conlleva la segunda, pero no ocurre siempre lo contrario. Desde la década de 1950, las constantes innovaciones científico-técnicas aplicadas al campo de las ciencias de la salud han conducido a un creciente número de seres humanos hacia una situación en la que, con ayuda mecánica o no, mantienen sus constantes vitales -están vivos biológicamente-, pero han perdido de forma irreversible, al tener su cerebro muy dañado, toda capacidad de relación humana -están muertos humanamente. De esta forma, las sociedades desarrolladas se enfrentan actualmente al dilema de definir qué son y qué hacer con aquellos individuos que pueden estar vivos pero no son personas (Veatch, 1995:408-409). Dilema que, como se ha podido comprobar en los últimos años, por ejemplo en el caso de Terri Schiavo, ha dado lugar a un vivo y agrio debate, muy mediatizado ideológicamente, sobre la identificación social de quién está vivo y quién está muerto y sobre la conexa salvaguarda de los derechos, y la 
capacidad legal para tomar decisiones en su nombre, de los individuos que estando vivos biológicamente están muertos humanamente ${ }^{63}$.

El 25 de febrero de 1990, la estadounidense de 26 años María Theresa Schiavo, que se estaba sometiendo a una dieta de adelgazamiento, tuvo un desequilibrio en los niveles de potasio de su organismo que la produjo una parada cardiaca por la que entró en "coma prolongado", es decir, en estado vegetativo permanente con muerte de la conciencia o incapacidad para desarrollar vida en relación ${ }^{64}$. Alimentada con sonda nasogástrica, podía respirar sin ayuda externa, abrir los ojos, responder automáticamente a las caricias, pero no mostraba ninguna evidencia de consciencia. Aunque esta situación no provocó inicialmente grandes problemas entre el marido de Terri Schiavo y los familiares directos de ella, ya que todos estaban de acuerdo en tratar de rehabilitarla, el conflicto emergió una vez que el marido obtuvo en 1997, de la clínica de adelgazamiento que asesoraba a Terri Schiavo, una cuantiosa indemnización para que cuidara de ésta y solicitó, en mayo de 1998, la retirada de la sonda nasogástrica para así cumplir con los deseos que, según él, le había expresado oralmente Terri Schiavo de que nunca le mantuviera viva artificialmente si tenía un accidente. A partir de ese momento se inició una disputa legal en los tribunales del Estado de Florida para conseguir la desconexión de la sonda según los deseos de Terri Schiavo, por parte del marido, y para obtener la custodia legal de Terri Schiavo, por parte del padre y de la madre de ésta. Éstos argumentaron que Terri, católica ferviente como ellos, creía que la vida la da y la quita Dios y, por tanto, nunca habría estado de acuerdo en que le retiraran la sonda; además, presentaron el testimonio de nueve neurólogos que afirmaban que Terri Schiavo tenía cierto grado de consciencia y que, por tanto, existía la posibilidad de rehabilitación con la terapia adecuada. Al margen de la disputa entre ambas ramas familiares, o de los diagnósticos contradictorios de los médicos que examinaron a Terri Schiavo ${ }^{65}$, lo relevante de este caso fueron las sucesivas intervenciones de

\footnotetext{
${ }^{63}$ Más recientemente se han producido otros casos similares en los que asimismo se han generado agrios debates públicos. Es el caso de Eluana Englaro, en Italia, que estando en coma desde 1992 fue desconectada el 09/02/09. Es el caso asimismo, aunque con mucha menos polémica, de Ramona Estevez, en estado vegetativo desde el 26/07/11, y “desenchufada” el 6/09/11 (EL PAÍS, 07/09/11:34). De forma más amplia, en Cuenca (2006) se recoge una breve descripción de diferentes casos que, desde la década de 1970, han provocado la emergencia recurrente en los medios de comunicación de los debates sobre la eutanasia y el suicidio asistido y su relación con los avances de la tecnología médica (Baby Doe, Karen A. Quinlan, Nancy Cruzan,Vicent Humberto, etc.).

${ }^{64}$ En el próximo sub-apartado se desarrolla una tipología sobre las características de los distintos estados en los que puede encontrarse una persona que ha perdido su consciencia.

${ }^{65}$ George Greer, el juez del Estado de Florida que presidió desde el principio el “caso Terri Schiavo”, argumentó su decisión de desconectar la sonda de alimentación sobre la base de: a) Michael Schiavo, el marido de Terri, era el guardián legal de los intereses de ella; b) consideraba probado el testamento oral realizado por Terri Schiavo a su marido; y c) dio por válido el diagnóstico realizado por algunos médicos según el cual Terri Schiavo se encontraba en estado vegetativo permanente sin posibilidad de recuperación (EL PAÍS, 22/03/05:25).
} 
destacados políticos que transformaron, como señaló el congresista demócrata Henry Waxman, una “tragedia personal en una farsa política nacional” (EL PAÍS, 19/03/05:28).

En efecto, en su afán por paralizar la orden, ya efectiva, de desconexión de la sonda nasogástrica el Congreso del Estado de Florida aprobó por vía de urgencia el 21 de octubre de 2003 una ley ${ }^{66}$ que permitía al gobernador de ese Estado, Jeb Bush, ordenar a los médicos que alimentaran a Terri Schiavo. Se procedió a la realimentación de ésta, pero en septiembre de 2004 el Tribunal Supremo de Florida declaró inconstitucional esa ley al considerar que suponía una intromisión en la vida privada y violaba la separación de poderes del Estado. Posteriormente, y en una intervención política urgente el Senado, primero, y el Congreso de EE.UU., después, aprobaron el 20 y el 21 de marzo de 2005 respectivamente una ley ad hoc, refrendada inmediatamente, por la noche, por el presidente de EE.UU., George W. Bush, por la que se otorgaba la jurisdicción del "caso Schiavo” a los tribunales federales y se paralizaba la decisión del juez del Estado de Florida de retirar la sonda de alimentación, en base a una “posible violación de los derechos constitucionales” de Terri Schiavo por parte de los Tribunales de Florida que no habrían cumplido con todas las garantías procesales. Esta intervención además de sorprendente -los poderes ejecutivo y legislativo interfiriendo en el ámbito judicial a favor de una de las partes en una disputa familiar-, y esperpéntica ${ }^{67}$, reflejaba asimismo las luchas ideológicas y de poder $^{68}$ subyacentes en la sociedad estadounidense $\mathrm{y}$, sobre todo, la necesidad de los sectores más conservadores del Partido Republicano -“la derecha religiosa" - de imponer sus tesis sobre lo que es, y lo que debe ser, la vida en sociedad. Baste como ejemplo de ello las dos razones aducidas por el jefe de la mayoría republicana, Tom DeLay, para justificar esa intervención: "la santidad de la vida está por encima de la santidad del matrimonio (aludiendo a los derechos que reclama el marido)" y "dejar morir a una persona

\footnotetext{
${ }^{66}$ Esta ley fue denominada "ley Terri", porque fue elaborada sólo para aquellos casos en los que el paciente no había expresado su voluntad por escrito, se encontraba en estado vegetativo permanente y un familiar se oponía a que le retirasen las sondas de alimentación. Exactamente el caso de Terri Schiavo, que no había hecho testamento previamente y sus padre y madre se oponían a la retirada de la sonda nasogástrica (EL PAÍS, 24/09/04:32).

${ }^{67}$ Haciendo caso omiso sobre el estado de inconsciencia de Terri Schiavo, tanto el Senado como el Congreso de EE.UU. "la citaron a comparecer en persona a fines de mes junto a su marido. El Senado ha citado a Terri a comparecer ante el comité de asuntos sanitarios con el pretexto de revisar los cuidados a los pacientes que no se pueden manejar por sí mismos, implícitamente ignorando las evaluaciones médicas sobre el supuesto <<estado vegetativo permanente>> de Terri. La Cámara de Representantes, por su parte, ha ido más allá abriendo una investigación, para lo cual enviaron ayer cinco citaciones de urgencia a Terri, su marido y la directora y el equipo médico del hospital en el que vive, con el fin de realizar la investigación in situ. Quien impida el cumplimiento de las citaciones, en desacato al Congreso, se arriesga a que le imputen cargos criminales..." (EL PAÍS, 19/03/05:28).

${ }^{68}$ Con independencia de la larga disputa familiar, todo parece indicar que Terri Schiavo "cayó atrapada en una lucha de poderes” que no necesariamente respondía sólo a la confrontación ideológica izquierda/derecha (todos los senadores demócratas y 47 congresistas demócratas apoyaron la ley de urgencia) o las disputas entre sectores moderados o fundamentalistas de los cristianos (el líder religioso de izquierda Jesse Jackson también apoyo la ley de urgencia). "Más bien, lo que ha funcionado han sido subcorrientes de intereses, que sólo el tiempo sacará a la superficie” (EL PAÍS, 01/04/05:24).
} 
de hambre y sed es un salvajismo que equivaldría a condonar el asesinato” (EL PAÍS, 21/03/05:24). Ambos argumentos son falacias que no se corresponden siquiera con lo que había sido hasta ese momento la propia actuación de las distintas instituciones públicas en casos similares, ya que, como se analiza más adelante, desde la década de 1970 se consideraba como una práctica médica éticamente aceptable y legalmente posible en muchos países, también en EE.UU., la limitación del esfuerzo terapéutico, que no eutanasia, en pacientes en estado vegetativo permanente si ellos lo habían solicitado previamente. Así, si Terri Schiavo hubiera manifestado por escrito su deseo de no ser mantenida artificialmente con vida, el argumento de la santidad de vida, el principal de todos los empleados, se habría diluido por inconsistente con lo que era la práctica médica habitual hasta ese momento y no habría existido el "caso Schiavo": si realmente era la "vida” de Terri Schiavo en sí misma lo que se quería salvaguardar, por ser sagrada, eso se tendría que hacer en todos los casos independientemente de los deseos de ella. Es decir, posiblemente la "santidad de vida está por encima de la santidad del matrimonio”, pero no está por encima de la "santidad” del individuo, de sus derechos y deseos. En lo relativo al segundo de los argumentos, la supresión de la alimentación viene acompañada siempre de todos los cuidados necesarios para que esos pacientes, que por otra parte no sienten dolor, vayan apagándose como las personas que fallecen de muerte natural y no comen ni beben en los días u horas previos a su óbito.

La batalla legal iniciada en 1998 se resolvió finalmente 7 años después cuando tanto el juez federal nombrado para implementar la norma especial aprobada en el Congreso como el Tribunal Federal de Apelaciones se negaron a intervenir en la decisión del juez del Estado de Florida, que había fijado la fecha del 18 de marzo de 2005 para que le fuera retirada la sonda a Terri Schiavo. En su dictamen, el juez Stanley F.Birch, del Tribunal Federal de Apelaciones de Atlanta, declaró inconstitucional la intervención del presidente G.W. Bush y del Congreso en este caso ${ }^{69}$.

Como reflejaron todos los medios de comunicación españoles, el debate sobre el "caso Terri Schiavo", que había perturbado profundamente a la sociedad estadounidense, se trasladó asimismo a España durante el primer cuatrimestre de 2005. En el caso de la sociedad española ese debate tuvo además otros matices al coincidir en el tiempo con otros acontecimientos relativos también al ámbito de las relaciones vida/muerte que la afectaban más o menos directamente, coincidencia de debates entre los que en algún momento hubo confusión de argumentos: la crisis político-social desatada por la denuncia anónima sobre la sedación a

69 "Es hora de ejecutar desapasionadamente nuestras responsabilidades. A pesar de la sincera y altruista motivación, las ramas ejecutiva y legislativa han actuado de manera obvia contra la guía de gobierno de nuestros Padres Fundadores para la gobernabilidad de la gente libre: nuestra Constitución” (EL PAÍs, 01/04/05:24-25). 
pacientes terminales aplicada en el Hospital Severo Ochoa de Leganés (Madrid), la rápida decadencia física, agonía y muerte de Juan Pablo II retransmitida en tiempo real por televisión, y la lenta agonía y fallecimiento de Rainiero de Mónaco asimismo recogida diariamente por todos los medios de comunicación.

Dado que el concepto de muerte dominante en una sociedad se asienta en principio en la muerte "biológica", la que hace aparecer el cadáver, es imprescindible identificar a ésta ya que es a partir de ella que se construye básicamente la realidad social de la muerte humana. Esa realidad $^{70}$ que el conocimiento del "hombre de la calle" da por sentado y que sin embargo no es idéntica en todas las sociedades, ni tampoco permanece inmutable en el tiempo para una misma sociedad. Es más, puede ocurrir que en algunas sociedades, como en las desarrolladas, ni tan siquiera exista una única realidad social de la muerte humana, observándose una gran variabilidad en las reacciones de los individuos y los grupos ante ella y en la aceptación de la concepción de muerte socialmente dominante. El caso de Terri Schiavo es paradigmático en este sentido: basta comparar para ello los argumentos sostenidos por la familia, por los dirigentes del Partido Republicano, o por el portavoz del Vaticano, Joaquín Navarro Valls, quien señaló al respecto que "una existencia fue interrumpida. Una muerte fue arbitrariamente acelerada" (EL PAÍS, 01/04/05:24), con un editorial de este periódico titulado “Murió hace 15 años”, en el que se afirmaba: "El cuerpo de Terri Schiavo dejó de vivir ayer, tras casi dos semanas desenchufado de la sonda que lo alimentaba. La persona había dejado de vivir 15 años atrás”. (EL PAÍS, 01/04/05:10).

Por razones pragmáticas, dado que el ser humano muere cuando muere su cuerpo, para el propósito de buscar una definición pública de muerte la cuestión filosófica de la personalidad históricamente ha tenido un papel meramente subsidiario. En efecto, hasta fechas recientes, el objetivo de identificar el momento en el que aplicar de forma apropiada la condición de muerta a cada persona cuando finalizaba su vida se alcanzaba de forma relativamente sencilla por cuanto la muerte biológica y la muerte de la personalidad se sucedían en un breve lapso de tiempo. Esta situación, no obstante, se ha modificado profundamente en las últimas décadas al hilo del progreso del conocimiento experto que, como se examina a continuación, ha oscurecido y difuminado la identificación de la muerte al escindir de la muerte biológica la muerte de la personalidad, pasando ésta a ser el foco de atención en el debate público de la definición de muerte humana. Transformación que ha sido reforzada asimismo por la incidencia de algunas de las características de las sociedades desarrolladas, en especial la secularización de las mismas, el

\footnotetext{
${ }^{70}$ Siguiendo a Berger y Luckmann (1972:13-14), se emplea el concepto realidad "como una cualidad propia de los fenómenos que reconocemos como independientes de nuestra volición (no podemos "hacerlos desaparecer")".
} 
aumento del individualismo y la consiguiente reclusión de los aspectos existenciales de la muerte y el morir en la esfera de lo privado. Cambios de valores que han reemplazado en el tiempo la percepción de la muerte como fenómeno sobrenatural por la percepción de la muerte como natural y, más tarde, como algo que podía ser conquistado por el ingenio humano; cambios que han conllevado una pérdida de socialización ante la muerte al reducirse la experiencia directa de la gente con los procesos de morir y muerte, con el consiguiente déficit de aprendizaje sobre cómo controlarse en esas situaciones (Quint Benoliel y Degner, 1995:119).

En estas circunstancias, la dimensión médica ${ }^{71}$ de la muerte humana ha cobrado una importancia creciente desde la década de 1950, al producirse un claro proceso de medicalización y tecnificación en la identificación social de aquélla. Esta dinámica se ha cimentado en la combinación de cinco elementos: a) función tradicional de testar la muerte: sólo el estamento médico está facultado socialmente para certificar la defunción de las personas ${ }^{72}$; b) creciente tecnologización de la muerte que permite determinarla legalmente sin que se haya producido la muerte biológica: en esas circunstancias sólo el personal médico está capacitado técnicamente para decidir si seres humanos en estado de coma están vivos o están clínicamente muertos; c) identificación de la muerte clínica que permite desconectar a los que han sido diagnosticados como muertos; d) identificación de la muerte clínica que permite el trasplante de órganos: práctica que ha supuesto un impulso esencial en la lucha por la vida y en la lucha contra la muerte al permitir que la muerte de una persona se convierta en fuente de vida para otra(s). Para ser eficaz precisa de una compleja estructura organizativa gestionada por un sistema de expertos en tecnología y de profesionales de la medicina, siendo estos últimos la pieza clave de dicho sistema ya que, además de realizar el trasplante, seleccionan a los donantes y a los receptores, y redistribuyen los órganos de acuerdo a sus criterios especializados. Representa el éxito del paradigma clásico intervencionista y reparador del cuerpo de la medicina más ortodoxa (Juan y Rodríguez, 1994), y; e) percepción social de la muerte y el morir: en el contexto histórico actual el debate público sobre la muerte no gira tanto en torno a ella, que es una abstracción inaccesible directamente en su inmanencia, sino que se concentra sobre el proceso de morir y en el diagnóstico de la muerte, fase de transición entre el ser y el no ser, parte conclusiva de la

\footnotetext{
${ }^{71}$ En 1957, el Papa Pío XII declaró que "le corresponde al médico dar una definición clara y precisa de la muerte y del momento de la muerte de un paciente que fallece en estado de inconciencia... En lo referente a la comprobación del hecho, la respuesta no se puede deducir de ningún principio religioso y moral, y por esa razón escapa a la competencia de la Iglesia.” (Thomas, 1993:33)

${ }^{72}$ No siempre ha sido el médico el que ha diagnosticado la muerte. Hasta finales del siglo XVIII y principios del XIX, el médico "acompañaba al paciente mientras "había algo que hacer”, pero a partir de dicho momento procedía al "desahucio" del paciente que quedaba en manos de familiares, y de los miembros sociales y religiosos,... El diagnóstico propiamente dicho de "muerte clínica” basado en la intervención de un médico para emitir un certificado legal para poder enterrar no se implantó hasta principios del siglo XIX , ligado al nacimiento de los criterios científicos de la medicina moderna, y a razones de salubridad pública” (Trueba, 2007:60).
} 
vida, que es todavía vida, es decir, es un proceso concreto accesible en el que sí que cabe algún tipo de actuación humana, precisamente aquella que compete a la profesión médica. Así, ésta ha pasado a convertirse en "garante de la existencia personal con una obligaciones testimoniales de la mayor trascendencia... alguien que dé fidelidad y testimonio de la muerte de una persona... El médico que testifica el diagnóstico de muerte clínica no es un mero evaluador, sino un testigo veraz, capaz de dar fe pública de quién y cuándo está muerto” (Trueba, 2007:60).

El establecimiento de una definición que identifique la muerte ha constituido históricamente una necesidad social básica que se torna perentoria desde la segunda mitad del siglo XX. Esta necesidad social obedece a dos tipos de inquietudes (Thomas, 1991:41). Por un lado, una preocupación secular, el propio interés de delimitar el objeto muerto. Para cualquier persona viva resulta clave no ser identificada con su cadáver, por lo que siempre ha sido fundamental que socialmente se determine con claridad y precisión cuándo alguien está vivo o muerto. Por otro lado, otra preocupación asimismo secular y a la que la aparición y desarrollo de nuevos hechos y fenómenos ligados al cambio social durante la segunda mitad del siglo XX ha incrementado de intensidad, la exigencia práctica de permitir que se pongan en marcha los procesos sociales conexos a la muerte anteriormente mencionados. La inaplazable urgencia para posibilitar la extracción de órganos o para proceder a la inhumación o incineración ha acelerado la fijación de una definición legal de la muerte (Thomas, 1991:22).

En efecto, históricamente toda una serie de interrogantes han atribulado al ser humano en el oscuro territorio de la muerte. Junto a la irresoluble cuestión ¿qué es la muerte?, se han formulado otras preguntas relativas al morir asimismo arduas de responder: ¿cuándo muere un ser humano?, ¿es la muerte la pérdida irreversible de funciones de la totalidad del organismo, es decir, de todos y cada uno de sus componentes?, o ¿es la pérdida de función del organismo como un todo, a saber, como una unidad biológica que tiene sentido e independencia?, etc. (Enciclopedia Británica. Macropedia, vol.16, 1987:1031). Estos interrogantes seculares son buena muestra de que la determinación de la muerte humana nunca ha sido fácil y siempre ha estado rodeada de incertidumbre. Incertidumbre históricamente ligada al miedo a ser enterrado vivo $^{73}$ como consecuencia de las llamadas $<<$ muertes aparentes $>>{ }^{74}$, y que con otros perfiles se

\footnotetext{
${ }^{73}$ Existen numerosos estudios históricos que hacen referencia a exhumaciones en las que se encontraron rasgadas por dentro - prueba de haber sido arañadas- las tapas de los ataúdes que contenían a los cadáveres. Humphry y Wickett (1989:363-364) citan, por ejemplo, al médico parisiense Jean Bruhier, quien durante el siglo XVIII recopiló relatos sobre veinticinco personas supuestamente enterradas vivas, y de setenta y dos cuya muerte se certificó por error en París. Señalan, también, que "en el siglo XIX se registraron cuarenta y seis casos de personas que volvieron a la vida mientras esperaban ser inhumadas". Por su parte, la Enciclopedia Británica (Macropedia, vol.16, 1987:1031) señala que muchos de esos enterramientos de vivos - "secretos desagradables que miran desde el subsuelo"- se produjeron en momentos de histeria colectiva generados por epidemias de peste, cólera y viruela, que llenaban hospitales y funerarias, y en los que existía un auténtico pánico al contagio de la infección.
} 
ha incrementado notablemente en la segunda mitad del siglo XX cuando, fruto del desarrollo científico-tecnológico, la esencia de la vida humana (de la persona) ha pasado a estar ubicada en el cerebro. Como resalta Veatch (1995:407), hasta la década de 1960 prácticamente no había existido ningún tipo de debate de política pública sobre cuándo identificar a una persona como muerta. Durante siglos ha sido suficiente con tomar el pulso de una persona y/o colocarle un espejo o una pluma frente a su boca para, si no daba señales de vida -pulso y respiración-, diagnosticar su defunción. Existía una única definición (criterio) de muerte y cuando ésta se producía, en un espacio de tiempo muy breve, se ponían en marcha todos los procesos sociales ligados a la misma, sucediéndose rápidamente en el tiempo, sin que prácticamente existieran conductas contingentes. En estas circunstancias era poco lo que estaba en juego desde el punto de vista del debate público. Así, "la muerte no necesitaba definición legal ninguna porque su realidad era <<evidente >>” (Camps, 2002:96).

Desde la década de 1960, sin embargo, la situación ha cambiado sustancialmente fruto de la incidencia de dos fenómenos ya mencionados. Por una parte, los avances científicotecnológicos que han permitido un incremento sustancial en los índices de supervivencia de la población ante accidentes o enfermedades que antaño resultaban letales ${ }^{75}$ han añadido simultáneamente, junto a esta evolución positiva y deseable, otras consecuencias que han generado una gran confusión en la identificación de la muerte. En efecto, si anteriormente una rápida sucesión de sucesos corporales enlazados inevitablemente (parada cardiaca, parada respiratoria, o muerte del cerebro) llevaban a la muerte, esos avances han ampliado "la capacidad para prolongar el proceso de morir”, prorrogando con ello el tiempo hasta que se produce el deceso. Junto a ello, la propia dinámica de la investigación científica ha buscado persistentemente delimitar qué parte del cuerpo humano (órgano o función) es irremplazable y sin la cual el individuo puede considerarse irremediablemente muerto. Así, se han establecido varios indicadores (criterios) potenciales que marcan, fijan, la muerte de un individuo como un todo. La confusión surge cuando, en un proceso de morir cada vez más dilatado en el tiempo, los diferentes indicadores establecen momentos de no retorno distintos y separados en el tiempo. De esta forma, a medida que el conocimiento científico de la muerte progresa y se

\footnotetext{
${ }^{74}$ La muerte aparente o relativa, es denominada así porque el sujeto puede volver a la vida recobrando su conciencia de forma instantánea (persona que se ha electrocutado o ha sufrido un proceso de ahogamiento), de forma controlada (yogui), o con ayuda de procedimientos tecnomédicos de reanimación. Esta fase se caracteriza por ser una "especie de síncope", con insensibilidad, bajo tono muscular, cese de respiración, ausencia de pulso (Thomas, 1991:30-31). Precisamente para evitar enterramientos de individuos que pasan por la muerte aparente las legislaciones de la mayoría de los países han impuesto un plazo de 24 horas antes de enterrar un cadáver.

${ }^{75}$ Una innovación clave en este sentido fue la invención en Dinamarca, en la década de 1950, de un mecanismo tan sencillo como el respirador o ventilador que permitía bombear aire continuamente a los niños afectados por la epidemia de polio, evitando su muerte. Tras la automatización del respirador con una bomba mecánica, "pronto hubo respiradores en todos los hospitales, que salvaron la vida a muchas personas” (Singer, 1997:36).
} 
acrecienta su complejidad, se requieren en mayor medida pruebas científicas mucho más específicas para determinar la muerte. Es decir, los avances del conocimiento científico-técnico aplicados a la identificación de la muerte han llevado a la situación paradójica de que cuanto mayor es ese conocimiento "menor es la posibilidad de precisar cuándo y cómo se produce la muerte” ${ }^{76}$ (Thomas, 1991:22). En definitiva, durante la segunda mitad del siglo XX, el debate público sobre la muerte y el establecimiento de una definición legal de la misma se ha vuelto más complejo, más técnico y más especializado, hallándose lejos de alcanzar la unanimidad de posiciones en el mismo.

Un segundo fenómeno social ha propiciado asimismo el desarrollo de un profundo debate sobre la identificación de la muerte humana: la utilización de cadáveres humanos en la investigación, en la docencia $\mathrm{y}$, sobre todo, para trasplantes de órganos ${ }^{77}$, ha hecho absolutamente necesario fijar legalmente la definición de muerte para que el personal médico pueda determinarla con precisión sin actuar contra la legalidad vigente. En este sentido, la existencia de diferentes criterios médicos de muerte para identificarla genera confusión al establecer cada uno de ellos diferentes grados de restricción. Así, si socialmente se autorizase la aplicación de los menos restrictivos esto podría favorecer la consecución de un número mayor de órganos para trasplantes que, además, serían de mayor calidad. Sin embargo, simultáneamente, podrían generarse dudas en la población sobre si el criterio de muerte

\footnotetext{
${ }^{76}$ De forma descriptiva, y clarificadora, Quintana (1997:50-51), muestra esta confusión en una situación cada vez más habitual en la vida cotidiana: "Supongamos que se trata de una persona joven que ha sufrido un accidente de tráfico y ha quedado tendida en la carretera. Casualmente se encuentra en el lugar del accidente un médico que, inmediatamente, se acerca al accidentado para prestarle auxilio y comprueba que no tiene pulso y que no respira. Desde siempre, cuando a una persona deja de latirle el corazón y, naturalmente, no respira, se considera que ha muerto. El médico, no obstante, empieza maniobras de reanimación elementales hasta que llega poco después una Unidad de Vigilancia Intensiva (UVI) móvil, con personal especializado, que intuba al accidentado y lo conecta a un respirador. Se le traslada rápidamente al hospital más cercano donde ingresa en la UVI. En la UVI se comprueba que el corazón late, respira con ayuda de un respirador, tiene reflejos, pero no responde a las órdenes más elementales y no responde al dolor. El electroencefalograma demuestra actividad cerebral muy lenta y atenuada. Pasan unas semanas y la situación permanece estable sin mejorar ni empeorar. La opinión de los médicos es que no recobrará la conciencia más y, por tanto, tampoco la capacidad de relacionarse, pero que puede permanecer en esta situación un tiempo indeterminado, que puede ser largo. La familia discute con los médicos y, tras varias conversaciones deciden que para ellos está muerto aunque siga vivo: <<sigue vivo como un vegetal, pero no como una persona y por tanto ya lo hemos perdido, ya está muerto>>. Mientras debaten la actitud a tomar, el paciente empeora, le baja la tensión arterial, el pulso se hace lento y luego se recupera. Se repite el encefalograma y se comprueba que es plano, es decir, no hay actividad cerebral. Está en muerte cerebral y por tanto se considera que ha muerto.

Este paciente ha pasado por tres situaciones distintas en las que, para observadores con distintos puntos de vista, el paciente estaba muerto. No es que el paciente haya muerto tres veces, sino que se utilizaron criterios distintos. El primero, el de parada cardiorespiratoria, es el que puede denominarse clásico. El segundo, el de la familia en nuestro ejemplo, es el de la falta de funciones cerebrales superiores, es decir, capacidad de relacionarse, de comunicarse, ya que ni siquiera tiene las de los animales superiores, como son las de sentir dolor y placer. El último es el criterio de muerte cerebral, que es el aceptado por la mayoría de países”.

${ }_{77}$ Una síntesis de la evolución histórica de los trasplantes de órganos, en sus vertientes técnica y ética, puede verse en Gracia (2004:cap. 19; 1996).
} 
empleado es el más adecuado para determinarla. De hecho, desde su aparición muchos de los críticos de los nuevos criterios de determinación de la muerte han sugerido que podían existir médicos que "tuvieran interés en certificar la muerte de un donante antes de hacer todo lo posible por reanimarle” (Humphry y Wickett, 1989:364). Al margen de que no todas las personas vivas o todos los pacientes en muerte cerebral pueden ser donantes de órganos quedan excluidos los de edad avanzada, los que tienen lesiones en los órganos, sepsis, neoplasias, enfermedades infecciosas o pertenecen a algún grupo de riesgo del VIH- (Valero et al, 1992:34), es importante resaltar en este punto que el trasplante de determinados órganos es más viable, esto es, tiene mayores posibilidades de éxito, cuanto antes se realiza su extracción. La extracción de algunos órganos, como los riñones, puede realizarse sin problemas cuando el corazón del donante ha dejado de latir; sin embargo, el trasplante de corazón, pulmones o hígado requiere que el corazón no haya dejado de latir. Esta circunstancia plantea dos tipos de problemas: por un lado, si el mantenimiento de la actividad cardiaca se ha conseguido por procedimientos mecánicos puede producirse un cierto deterioro de esos órganos del donante hasta hacerlos inservibles para el receptor; por otro lado, y sobre todo, la extracción de órganos de pacientes en estado de muerte clínica, pero en los que el corazón continúa latiendo, pone a prueba a los profesionales que realizan la extracción de órganos al generar un profundo malestar entre algunos de ellos que tienen la percepción de que en realidad lo que están practicando es una vivisección. Así, por ejemplo, en el año 2000 un editorial de la revista inglesa Anesthesia se hacía eco del intenso debate existente en el mundo médico sobre la necesidad de anestesiar a todos los donantes con certificado oficial de haber fallecido antes de extraerles los órganos dado que al hacer esto los cuerpos se mueven y retuercen y “cuando utilizas el bisturí el pulso y la presión sanguínea se disparan. Las enfermeras están realmente disgustadas y nadie niega que es incómodo" (El Norte de Castilla, 21/08/00:37).

Los dos fenómenos sociales descritos son fruto del papel fundamental de la ciencia y de la tecnología como "definidores de la existencia humana” y de su papel transformador como poderosas fuentes de cambio social (Juan y Rodríguez, 1994:188-191). Siguiendo a estos autores, una de las consecuencias del desarrollo científico-técnico es la emergencia de una “nueva racionalidad acerca del cuerpo y de la vida” que, sobre todo en el caso de la donación de órganos, exige a todos los actores una "creencia (absoluta) en las afirmaciones de la ciencia y del colectivo médico”. Este acto de fe choca, sin embargo, con la visión tradicional de la vida, la muerte y el cuerpo, lo que provoca importantes tensiones entre los diversos actores implicados al confrontar esas visiones ya que "las emociones que genera el poder dar y recibir órganos son muy complejas y trascienden la racionalidad científica”. En efecto, afirmaciones que centran la esencia del ser humano en el cerebro, como si éste fuera "la base y el límite de la humanidad", mientras que "el resto del cuerpo puede ser intercambiable sin que ello signifique intercambiar 
una parte de la personalidad", conforman una "visión científica del cuerpo como un conjunto de órganos sin identidad propia”, una mera herramienta útil para el cerebro, que contradice la visión tradicional asentada en la "creencia en la integridad personal del cuerpo" o en la creencia tradicional que sitúa la esencia del ser en el corazón. En este sentido, H. Jonas (1997:155) señala críticamente que ese proceso es un "extraño retorno” del viejo dualismo cuerpo/alma en una nueva forma de dualismo cuerpo/cerebro: "si el cerebro muere es como si el alma se escapara: lo que queda son los <<restos mortales >>", y reivindica que la identidad de un individuo es "la identidad de todo el organismo completamente individual, aunque las funciones superiores de la personalidad tengan su sede en el cerebro" ${ }^{78}$. Un hecho que evidencia la importancia de estas tensiones es la exigencia de una "estricta confidencialidad", de donantes y receptores, recogida en la normativa que regula los trasplantes de órganos ${ }^{79}$. Para Juan y Rodríguez (1994:191) esta imposición del anonimato indica, entre otras cosas, que muchas personas, familiares de donantes y receptores, “otorgan a los órganos un significado más trascendente que el de simple materia orgánica” y de que, “a pesar de la muerte, un ser querido vive en otras personas” ${ }^{80}$.

Veatch (1995), por su parte, resalta la importancia de otra contradicción: la disfunción existente entre las consecuencias de los avances tecnológicos -la ampliación del proceso de morir- y la persistencia de una mentalidad social dominante que considera la muerte como un suceso. La mayoría de la población tiene asimilada la percepción tradicional dicotómica (vivo/muerto) según la cual existe un único "punto simple definible” en el tiempo hasta el que una persona está viva. Una vez rebasado ese punto la persona pasa a estar muerta ${ }^{81}$. Obviamente, la utilización, por ejemplo, de los criterios de muerte menos restrictivos, en los que

\footnotetext{
78 “El cuerpo es tan únicamente el cuerpo de ese cerebro y de ningún otro como el cerebro es únicamente el cerebro de ese cuerpo y de ningún otro... ¿De qué otro modo podría un hombre amar a una mujer, y no sólo a su cerebro? ¿De qué otro modo podríamos perdernos a la vista de un rostro?” (Jonas, 1997:155).

${ }^{79}$ En el caso de España ese anonimato está recogido en el Capítulo II, artículo 5 del Real Decreto 2070/1999 de 30 de diciembre por el que se regulan las actividades de obtención y utilización clínica de órganos humanos y la coordinación territorial en materia de donación y trasplante de órganos” (B.O.E., $4 / 01 / 00)$.

$\overline{80}$ Juan y Rodríguez (1994:190-191) señalan como principal motivo de la exigencia normativa del anonimato "evitar la posible dependencia entre el enfermo <<salvado >> gracias al órgano y los familiares del donante muerto. La dependencia puede surgir al considerar que los órganos transmiten parte de la humanidad de la persona muerta, de tal forma que los familiares de un donante vean en el receptor una continuidad del familiar que acaba de morir. Otro aspecto de la dependencia puede crearla el agradecimiento del receptor hacia los familiares del muerto, quienes pueden convertir los actos de agradecimiento en actos de recuerdo de la desgracia. Con el anonimato se pretende reforzar la idea de que el donante está muerto, ha desaparecido y, tras la etapa de duelo, los familiares deben asumir su total ausencia”. Estos autores critican que la exigencia de anonimato implica también "una actitud paternalista de los profesionales al considerar a los receptores y a los familiares de los donantes incapaces de compartir órganos sin por ello generar una relación problemática”.

${ }^{81}$ Baudrillard (1980:185-187) relaciona la concepción digital de la idea de muerte con el dominio en las sociedades modernas del sistema de representación de la máquina y el funcionamiento: "una máquina anda o no anda. Del mismo modo, la máquina biológica está muerta o viva”.
} 
una persona pasa al estado de muerta cuando pierde de forma irreversible las características que definen su identidad personal, aunque su cuerpo siga vivo, choca con la óptica tradicional dicotómica. Esto introduce en el debate público la necesidad de un cambio de mirada que supere la conceptualización de la muerte como un suceso que tiene lugar en un instante concreto para ser considerada como un proceso ${ }^{82}$.

\subsubsection{LA MUERTE, ¿SUCESO O PROCESO?: MORIR-MUERTE-CADÁVER}

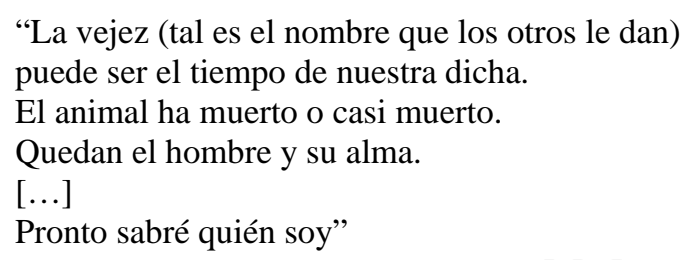

En su dimensión biológica, la muerte humana es el dejar de vivir y, como en todos los seres vivos de organización compleja, se pueden diferenciar, en principio, tres expresiones de muerte (Larousse, vol. 7, 1976:525). En primer lugar, la que se produce de forma aislada en alguna parte del organismo: muerte celular o muerte parcial de algún tejido. En segundo lugar, la muerte del organismo como un todo por fallo de las funciones de integración vital, aunque durante horas puedan persistir fenómenos vitales aislados, no integrados ya en la vida global: contractibilidad muscular, movimientos de leucocitos, etc. Por último, después de muchas horas se produce la muerte absoluta de todos los tejidos y células, aunque en el cadáver continúe produciéndose numerosos procesos físicos, químicos y metabólicos que conducen a su putrefacción. Cuando socialmente se adscribe a un ser humano la condición de muerto, ¿̇a cuál de los tres tipos de muerte se hace referencia?, ¿a la pérdida irreversible de funcionalidad de una parte del mismo?, ¿a la pérdida irreversible de función del organismo como un todo?, o, ¿̇a la pérdida irreversible de función de la totalidad de las partes componentes del organismo? Obviamente, la acepción que suele emplearse es la segunda: la muerte del organismo como un todo. El ser humano es mientras es y no se le considera proyectado en las células (vivas) que le suceden después de muerto, ni tampoco en aquellos órganos suyos que puedan vivir en otro ser humano. Sin embargo, los tres tipos de muerte conjuntamente conforman un proceso de evolución relativamente lento en el que los órganos y funciones vitales van "cayendo cada uno a un ritmo propio" ${ }^{83}$.

\footnotetext{
${ }^{82}$ De cara al futuro, Veatch (1995:402) considera poco probable que esta asimilación cambie a corto y medio plazo, pero no descarta que finalmente acabe imponiéndose la identificación de la muerte y el morir como procesos, gracias al avance tecnológico y la reflexividad, como ha ocurrido en otros ámbitos de la vida social.

${ }^{83}$ Un símil, utilizado por la Enciclopedia Británica (Macropedia, vol. 16, 1987:1031), permite observar claramente la diferencia entre los distintos tipos de muerte, a la par que simultáneamente denotan un
} 
La muerte biológica es un proceso y la mejor ilustración del mismo lo proporcionan las muertes “ordinarias”84 (Enciclopedia Británica. Macropedia, vol. 16, 1987:1031) ${ }^{85}$ : "varios minutos después el corazón ha dejado de latir, un mini-electrocardiograma puede registrarlo, si se prueba con señales desde dentro de la cavidad cardiaca. Tres horas más tarde, las pupilas aún responden por contracción, y los músculos golpeados repetidamente pueden aún contraerse mecánicamente. Un injerto de piel viable puede obtenerse a las $24 \mathrm{~h}$. de fallecimiento desde que el corazón se ha parado, un injerto de hueso hasta las 48 h. después, y un injerto arterial viable como muy tarde 72 h. después de una parada cardiaca”. La razón de este proceso asincrónico está en que las células de los distintos órganos y tejidos difieren ampliamente en su capacidad para aguantar la privación de oxígeno (anoxia) que sigue a la parada de circulación sanguínea.

Desde un punto de vista biológico el cambio radical que supone pasar de estar vivo a estar muerto no tiene carácter digital, no se produce en un instante, sino que es un proceso que se prolonga en el tiempo. La muerte biológica no es un fenómeno reducible a un momento concreto, aunque eso no significa que en el proceso no exista un punto de no retorno. Sólo para "el médico que está obligado a extender un certificado autorizando la incineración o la inhumación, y para el médico forense, que debe determinar en qué momento dejó de vivir un sujeto”, la muerte se produce en un instante preciso ${ }^{86}$ (Thomas, 1991:24). De hecho, bajo el común denominador de la pérdida de conciencia, al dañarse el cerebro por una agresión aguda fuerte traumatismo o por una grave intoxicación- o por un proceso crónico, una persona se puede encontrar clínicamente en situaciones muy diversas que conviene diferenciar en su grado de aproximación a la muerte biológica (BIOÈTICA \& DEBAT, 2005a y 2005b):

a) Coma: estado clínico "caracterizado por la pérdida de la conciencia, de la motilidad voluntaria y de la sensibilidad, ausencia de actividad verbal, de respuestas a órdenes y estímulos, imposibilidad de abrir los ojos..., conservando, sin embargo, la respiración, la circulación de la sangre y la diuresis”. Hasta hace relativamente pocos años los individuos en

proceso, en este caso histórico: "las civilizaciones caen pero sus sociedades componentes viven; las sociedades se desintegran pero sus ciudadanos sobreviven; los individuos mueren mientras sus células, perversamente, metabolizan; finalmente, las células pueden ser desorganizadas pero las enzimas pueden permanecer muy activas”.

${ }^{84}$ Se denominan muertes ordinarias a todas las que no se producen por accidente y/o violencia.

85 Una descripción similar puede verse en (Sotto y Oberto, 1986:49, citados en Rodríguez Rioboo, 1993:37), cuando se preguntan “¿En qué momento se detiene la vida?. ¿Cuándo comienza la muerte?. ¿Dónde se sitúa el punto de ruptura que define el final del organismo?”, y describen que "los ganglios espinales del ojo experimentan la muerte celular, mientras que el pelo y las uñas siguen creciendo. La sangre puede permanecer viva cuarenta y ocho horas en los vasos. Las células reproductoras son las que conservan su vitalidad durante más tiempo. Los espermatozoides mantienen su movilidad durante días, incluso semanas".

${ }^{86}$ En este sentido, Thomas (1993:8) señala la posición ambigua que ocupa la muerte en el pensamiento occidental a la que, por un lado, se le concede demasiado ya que ella "nadifica" al ser, pero por otro lado, "no se le otorga bastante" al identificarla con un acontecimiento reducido a un punto. 
este estado evolucionaban con gran probabilidad hacia su fallecimiento; sin embargo, los avances tecnológicos de las últimas décadas han alterado esa dinámica secular permitiendo que muchos de ellos recuperen total o parcialmente sus funciones después de un tiempo variable. No obstante, una de las posibles evoluciones de este estado clínico es el agravamiento hacia el estado vegetativo.

b) Síndrome "locked-in" (encerrado en sí mismo, o del cautiverio): "se produce al lesionarse el tronco encefálico alterándose el control voluntario pero estando preservada la activación y el contenido de la conciencia. Los pacientes en esta situación se pueden comunicar utilizando movimientos de los ojos o de los párpados pero son incapaces de moverse o de hablar”.

c) Estado de Mínima Conciencia (EMC): “condición neurológica con grave alteración de la conciencia, con mínima pero definida evidencia de conducta propia o percepción del entorno, que se puede demostrar". Se llega a este estado "evolucionando desde el coma al recuperar algunas de las funciones neurológicas con diversas respuestas” ${ }^{87}$.

d) Estado Vegetativo Persistente (EVPs): se produce al haber "perdido las funciones superiores cerebrales, es decir, de la corteza cerebral (hemisferios cerebrales), mientras permanecen, de manera completa o parcial, las funciones sujetas al control del tronco encefálico que no necesitan ninguna regulación cerebral”. Un individuo en este estado clínico puede respirar sin ayuda mecánica y puede permanecer despierto pero no tiene conciencia de sí mismo ni de su entorno, por lo que no padece dolor ni sufrimiento; al haber perdido las funciones voluntarias carece, por ejemplo, de la habilidad para masticar o para tragar que requieren hemisferios cerebrales intactos ${ }^{88}$.

e) Estado Vegetativo Permanente (EVP): estado clínico de inconsciencia al que se llega cuando se hace crónico el EVPs y que "puede ser diagnosticado de irreversible, con un alto grado de certidumbre clínica, transcurridos tres meses en esa situación, después de una lesión no traumática, o un año después de una lesión traumática”. A este estado se le conoce como "coma prolongado" o muerte para la conciencia o para la vida en relación. Pasado un año las

\footnotetext{
${ }^{87}$ Las personas que se encuentran en ese estado clínico son capaces de: 1) obedecer órdenes sencillas; 2) responder afirmativa o negativamente, con aparente sentido, a una estimulación verbal; 3) movimientos intencionales, no reflejos, en relación con estímulos del entorno; 4) reír o llorar frente a un estímulo auditivo o visual con significado emocional; 5) seguimiento o fijación de la mirada como respuesta al movimiento de un objeto, incluso, intentar tocarlo (BIOĖTICA \& DEBAT, 2005b:3).

${ }^{88}$ Según la Academia Americana de Neurología se requieren siete criterios clínicos para diagnosticar EVPs: "1) Ausencia de conciencia de sí mismo y del entorno e incapacidad para interactuar con otros; 2) La respuesta a estímulos visuales, auditivos y dolorosos no posee carácter reproducible, propósito o conducta voluntaria; 3) Ausencia total de lenguaje expresivo o comprensivo; 4) Estado de vigilia intermitente manifestado por la existencia de ritmo vigilia/sueño; 5) Preservación de actividad hipotalámica y de tronco-encefálico que permita sobrevivir con atención médica; 6) Incontinencia de esfínteres; 7) Variable preservación de reflejos en nervios craneales y espinales" (BIOĖTICA \& DEBAT, 2005b:2).
} 
posibilidades de reversión son escasas ${ }^{89}$, pudiéndose prolongar durante varios años, es decir, “constituye una condición severa y debilitante pero no terminal”. Como en el citado caso de Terri Schiavo, los individuos en este estado no son enfermos terminales ni moribundos, pueden sobrevivir sin ayuda mecánica sofisticada pero no sin los cuidados de quienes los rodean, ya que no pueden alimentarse ni hidratarse por sí mismos. Son los "vivos muertos”, en expresión de Thomas (1991:39).

f) Muerte Cerebral: es el estado clínico irreversible en el que dejan de existir las funciones de la corteza y del tronco cerebrales, con lo que se anulan totalmente la conciencia y la vigilancia al destruirse las funciones de vida vegetativa. A este estado se le conoce como "coma sobrepasado”, y conlleva toda una serie de alteraciones orgánicas, en especial la pérdida irreversible del automatismo respiratorio, que conducen inevitablemente a la parada cardiaca en un plazo de tiempo variable, en general inferior a las 72 horas, si no se aplica mantenimiento externo. Es decir, los individuos que se encuentran en ese estado sólo pueden sobrevivir con ayuda de maquinaria sofisticada (Pera, 2003:244-245). Son los “muertos vivos” (Thomas, 1991:40).

La muerte biológica de una persona, por tanto, es un proceso concreto pero no simple. $\mathrm{Al}$ contrario, es un proceso complejo y poliédrico con múltiples perfiles algunos de los cuales no están completamente definidos hasta el momento. No obstante, como se ha señalado, esto no es asumido así socialmente puesto que mayoritariamente se la sigue considerando como un suceso que tiene lugar en un momento dado. En todo caso, en la actualidad coexisten diversas definiciones y criterios alternativos de muerte que marcan, fijan, diferentes puntos posibles de no retorno para etiquetar a un individuo como ya muerto. Definiciones de muerte que se han sucedido en el tiempo y en las que progresivamente se ha ido asimilando la ontología del enfoque médico de carácter meramente pragmático. En efecto, como se expone más abajo, las distintas definiciones médicas de muerte en realidad lo único que dejan claro es qué es estar muerto (y qué es estar vivo), pero no permiten deducir cuándo exactamente se cambia a ese nuevo estado. A la cuestión “cuándo morimos” se responde, según la definición médica de muerte empleada, cuando hemos dejado de respirar, o, cuando el cerebro ha muerto, o, cuando el tronco cerebral ha muerto, o, cuando la corteza cerebral ha muerto; se traslada de lugar la muerte del individuo a la muerte de alguno de sus órganos y se deja sin resolver la cuestión planteada: no determinan la muerte, sino que determinan el haber muerto (Jonas, 1997; Arregui, 1992:71-82). El problema esencial de fondo, como resalta este último autor, es que, por definición, no se puede decir cuándo muere alguien sino sólo que ya ha fallecido. No se puede

\footnotetext{
89 "Hasta el momento, no existe ningún tratamiento activo específico que haya demostrado, de manera concluyente, un aumento en la probabilidad de recuperación de la conciencia en un estado vegetativo" (BIOĖTICA \& DEBAT, 2005b:4).
} 
determinar el momento exacto de morir simplemente porque ese momento no existe: "no hay un acto instantáneo que sea el morir, en que alguien pase de la vida a la muerte, simplemente porque no hay paso. Vida y muerte son discontinuas”90 (Arregui, 1992:77). Vida y muerte son opuestos que se excluyen mutuamente, o se está vivo o se está muerto.

Por otra parte, siguiendo a Sádaba (1991:26), se asume que fijar con toda precisión el momento exacto de la muerte, independientemente de que eso sea factible o no, es un "tanto irrelevante" ${ }^{91}$ para este trabajo. No interesa tanto determinar en sí mismo el momento exacto en el que llega la muerte, que en todo caso es una cuestión meramente empírica, como analizar los procesos sociales en los que se asienta, se justifica y se certifica que la vida humana se ha extinguido.

\subsubsection{TIPOLOGÍA DE DEFINICIONES MÉDICAS DE MUERTE}

"En cierto sentido, no hay muerte; sólo existe el moribundo o el cadáver, y por extensión, todo lo que mata o es destruido"

L-V Thomas

Ciertamente, el inicio de la putrefacción corporal es el único signo irrefutable de que una persona ha muerto: es la muerte total del organismo, cuando ya no quedan células vivas del mismo (Thomas, 1991:31). Sin embargo, este hecho biológico nunca ha sido culturalmente asumido con facilidad como identificador de la muerte, por lo que se han buscado "signos premonitorios” de la descomposición orgánica (Gracia, 1990:14). En la antigua Grecia, por ejemplo, se pensaba que la muerte podía originarse en la cabeza, en los pulmones o en el corazón, pero la vida únicamente se asentaba en éste; sólo cuando el corazón dejaba de latir llegaba la muerte. En la tradición judía, por su parte, la vida se manifestaba en la respiración; si no había signos de ella la persona estaba muerta (Escalante, 1996:54). Históricamente los interrogantes planteados en este ámbito se han sucedido en el tiempo a medida que se ampliaba el conocimiento humano. Así, por ejemplo, la necesidad de diferenciar entre la muerte del organismo <<como un todo >> de la muerte de sus componentes, cuestión de tanta trascendencia en el debate actual, tiene su origen en el desarrollo de la "teoría de los tejidos" a finales del

\footnotetext{
90 "No puede existir tal cosa como un instante que sea el punto de sutura entre el estar vivo y el estar muerto... No puede haber un acto instantáneo de morir, porque no hay ningún instante en que se esté vivo y muerto a la vez. El presunto acto instantáneo de morir no puede existir, porque no hay término medio entre estar muriéndose (o sea, estar agonizando, o sea, estar todavía vivo) y estar ya muerto” (Arregui, 1992:77).

${ }^{91}$ Sádaba (1991:26), por ejemplo, cita a Wittgenstein cuando éste afirmaba que no es más preciso quien preguntado por la hora que es, responde con obsesión dándola en milisegundos.
} 
siglo XVIII ${ }^{92}$. En esas fechas, además, se identifica al sistema nervioso central como el responsable fundamental de que el organismo humano funcione articuladamente como un todo, y se inicia asimismo el debate sobre si la muerte llegaba al descomponerse las neuronas o si había que esperar a la muerte de la totalidad de las células del organismo. La respuesta dada a ese dilema es la que ha dominado hasta mediados del siglo XX como criterio de muerte: el deterioro de todas las estructuras del cuerpo humano, incluido el sistema nervioso central, se produce con celeridad cuando cesa de forma irreversible la actividad cardiaca y respiratoria. Durante todo ese tiempo, el cese de las funciones cardiaca y respiratoria -la muerte cardiorrespiratoria (<<el último latido >>; <<el último aliento >>)- fue considerado como el “determinante de la pérdida permanente del funcionamiento del organismo <<como un todo>>, tomándose, por tanto, como el <<criterio de muerte >> del individuo” (Escalante, 1996:55).

A partir de la década de 1960 surge una nueva cultura de la muerte, o más precisamente, del morir (Gracia, 1990:13) ligada al proceso de medicalización y tecnologización de la muerte -aparición de las Unidades de Cuidados Intensivos (U.C.I.), desarrollo de técnicas de soporte vital, mejoras en las técnicas de transplantes, etc. Antes de la introducción de las mismas, los pacientes con lesiones cerebrales graves fallecían inmediatamente por infarto cerebral si la lesión provocaba un edema cerebral y aumentaba la presión intracraneal hasta impedir el riego sanguíneo del cerebro; la muerte de éste destruía las funciones de vida vegetativa desembocando inevitablemente en una parada cardiorrespiratoria. Sin embargo, como "subproducto macabro" de la moderna tecnología se rompe esa lógica al disociarse el ritmo de muerte entre los distintos componentes orgánicos ya que el más importante de ellos, el cerebro, muere antes sin provocar con ello el cese de otras funciones corporales como la circulatoria ${ }^{93}$ (Enciclopedia Británica. Macropedia, 1987, vol. 16:1032). Como consecuencia, la frontera que separa la vida de la muerte se difumina y surgen dudas sobre dónde se halla situada.

En efecto, gracias a innovaciones tecnológicas como el respirador que permite ventilar, los mecanismos de bombeo para las funciones circulatorias, la alimentación intravenosa, con

\footnotetext{
${ }^{92}$ Para una revisión histórica amplia de los diferentes diagnósticos de muerte ver Escalante (1996), Veatch (1995), Rodríguez del Pozo (1993).

${ }^{93}$ De forma pedagógica, en la página web del Banco Nacional de Órganos y Tejidos se explica en qué consiste la muerte cerebral: a consecuencia, por ejemplo, de "un traumatismo grave de la cabeza se puede producir una inflamación del tejido cerebral, lo que conduce a un aumento de la presión dentro del cráneo. Si la presión alcanza a cifras límites los vasos son comprimidos y disminuye la circulación; si la presión dentro del cráneo es mayor que la de la sangre la circulación cerebral se detiene y con ella el transporte de oxígeno al tejido cerebral, transcurridos 10 minutos el funcionamiento del cerebro se detiene, la función cerebral se pierde, el paciente pierde el conocimiento y cesa la respiración espontánea. En esta situación ninguna actuación médica da resultado, aún cuando se apliquen todas las medidas de cuidados intensivos disponibles, el paciente no tiene la más mínima posibilidad de sobrevivir (si el paciente es sometido a respiración artificial, el corazón puede seguir latiendo por sí mismo, así el resto de los órganos reciben sangre oxigenada y pueden seguir funcionando)”.
} 
sonda nasogástrica o con tubo de gastrostomía, la diálisis para depurar productos inútiles del metabolismo, un creciente número de individuos lograban sobrevivir manteniendo, con ayuda mecánica, la actividad cardiorrespiratoria a pesar de tener el cerebro irreversiblemente dañado: estaban inconscientes y continuarían así. Es decir, las innovaciones técnicas habían generado una situación social sin precedentes para la que se carecía de respuestas sociales y que además conllevaba efectos negativos importantes en todo el continuo individuo/sociedad: reportaba "un beneficio muy dudoso" a los propios pacientes (efectos personales), a sus familiares y amigos (efectos grupales), y a los centros hospitalarios (efectos sociales), en los que "comenzaron a abarrrotarse salas" con pacientes en coma irreversible, cada uno de los cuales comportaba un coste económico elevado en términos de recursos materiales y humanos (cama, respirador, medicación, asistencia médica especializada, etc.) ${ }^{94}$ (Singer, 1997:36). Para eliminar y/o minimizar estos efectos perniciosos se hizo imprescindible, por tanto, establecer unos criterios claros que evitasen, por ejemplo, que pacientes vivos fueran tratados como muertos (falsos positivos), o que el personal sanitario tratara como vivos a pacientes que estaban "muertos". Así, en el aumento de las posibilidades tecnológicas de mantenimiento artificial de la vida humana está el origen del debate médico moderno de la muerte y de la necesidad de una nueva definición de la misma que permitiera enfrentar las nuevas circunstancias sociales emergentes.

Por otra parte, a finales de 1967 se produjo un hecho clave que cambió la percepción que se tenía sobre ese nuevo tipo de pacientes irrecuperables. En Sudáfrica, el doctor Christiaan Barnard trasplantó por primera vez un corazón humano lo que, según Singer (1997:35), desató un “nuevo furor” por los trasplantes de corazón. Furor que sólo se podía atemperar con órganos donados que permitieran realizar los trasplantes. Singer (1997:35-40) señala que esa situación propició que se afrontara el problema generado en la década anterior buscando una solución a la cuestión que hasta entonces no tenía respuesta: ¿ ¿hasta cuándo es razonable mantener conectado a un respirador a un paciente en coma irreversible?. Esa solución, según Singer, consistió en un cambio de mirada hacia los "miles de pacientes" en ese estado que pasaron de ser vistos como “una carga cada vez más intolerable para los recursos del hospital”, que en un contexto de recursos limitados detraían además los necesarios a pacientes que sí podían recuperarse, a ser considerados "un medio para salvar la vida de otros pacientes", como potenciales donantes de corazón y otros órganos. Sin embargo, existía una "barrera aparentemente infranqueable” para poder disponer de los órganos de los pacientes en la situación descrita: legalmente la extracción de órganos de los mismos, es decir, de pacientes vivos, era considerada asesinato. Como señala Quintana (1997:53), el debate fue inevitable, ya que los profesionales (de la medicina)

\footnotetext{
${ }^{94}$ Según estimaciones de la neurocirujana María Elena Kusak Lambea a comienzos del año 2001 el coste de una cama en una UVI española rondaba las 200.000 pts diarias (La Muerte Cerebral y sus implicaciones sociales, conferencia impartida el 6/03/01 en el Ateneo de Valladolid).
} 
precisaban con premura unos criterios claros para poder trabajar, y en especial todos los que estaban implicados en la extracción de órganos para trasplantes ${ }^{95}$.

Ante esta necesidad, desde finales de la década de 1960 sucesivas reuniones médicas, comités de expertos e investigadores a título particular propusieron nuevas definiciones de la muerte humana. En este sentido, dos acontecimientos ocurridos en 1968 son de especial relevancia al caso. Por un lado, en la XXII Reunión Médica Mundial celebrada en Sydney, la asamblea estableció que "la muerte es un proceso gradual a nivel celular con tejidos que reaccionan de forma diversa ante la falta de oxígeno. Pero el interés clínico no reside en el mantenimiento de células aisladas, sino en el de la persona. El momento de la muerte de diferentes células y órganos no es tan importante como la certeza de que ese proceso se ha vuelto irreversible a pesar de que cualquier técnica de reanimación pueda ser empleada” (Gilder, 1968:493-494) ${ }^{96}$. Esta declaración tuvo un impacto definitivo en la práctica médica puesto que, a partir de ese momento, "la pérdida irreversible de función del organismo como un todo”,97 empezó a ser aceptado como el criterio clínico de muerte ${ }^{98}$ (Enciclopedia Británica. Macropedia, 1987:vol.16:1032).

El otro acontecimiento significativo celebrado en 1968 fue la publicación de $\underline{\text { Una }}$ Definición de Coma Irreversible. Informe del Comité Especial de la Escuela de Medicina de Harvard Para Examinar la Definición de Muerte Cerebral. En el preámbulo del mismo se señala: "Nuestro principal propósito es definir el coma irreversible como un nuevo criterio de muerte. Hay dos razones por las que es necesaria una definición: $1^{\text {a }}$ ) Las mejoras ocurridas en los métodos de supervivencia han conducido a aumentar los esfuerzos con miras a salvar a las personas gravemente heridas y cuyo estado es desesperado; esos esfuerzos a veces no son coronados más que por éxitos parciales, pues el corazón continúa latiendo en tanto que el cerebro está irremediablemente perdido y la carga que representan esas personas es pesada para

\footnotetext{
95 "El cerebro se muere por etapas, empezando con la corteza cerebral, siguiendo luego por el cerebro medio y luego por el tallo cerebral. Le sigue la muerte de las células: los órganos y tejidos permanecen vivos por un breve tiempo después. Es esta secuencia de muerte quien hace posible el transplante de órganos vivos de personas que acaban de morir” (Rudikoff, 1981:303, citado en Rodríguez Rioboo, 1993:36).

${ }^{96}$ Citado en Escalante (1996:56).

${ }^{97}$ Trasladado al ámbito jurídico se materializa en que sólo la persona es sujeto de derecho. Es decir, "los miembros considerados en sí mismos, no tienen ningún derecho unos frente a otros, ni respecto a las demás personas; quien mutila injustamente a un hombre, no atenta contra el miembro mutilado, sino contra la persona. Ni siquiera el cuerpo considerado en su totalidad, es el sujeto de derecho" (Pérez Gálvez, 1997:158).

${ }^{98}$ Por otro lado, en el dilema planteado con la aplicación de las nuevas tecnologías sobre cuál es el órgano o la función esencial para el mantenimiento del organismo humano como un todo, las ejecuciones por decapitación proporcionaron el ejemplo que hizo inclinar finalmente el debate hacia la proposición de que la muerte del cerebro es la condición necesaria y suficiente para la muerte de una persona (Enciclopedia Británica. Macropedia, 1987:vol. 16:1032).
} 
sus familiares y para los hospitales, esos pacientes comatosos ocupan camas y reciben cuidados de los que otros enfermos tendrían necesidad. $2^{a}$ ) Los criterios obsoletos de la definición de muerte conducen a una controversia cuando se aborda la cuestión de la extracción de órganos destinados al transplante: no tratamos aquí más que del caso de los comatosos que no tienen actividad descubierta del sistema nervioso central. Si las características de ese estado pudieran ser definidas en términos satisfactorios, muchos problemas desaparecerían o podrían ser resueltos a corto plazo” (JAMA, 1968:205) ${ }^{99}$. En este Informe el citado Comité establece una serie de criterios (“Criterios Harvard” de muerte cerebral) ${ }^{100}$ para identificar cuándo una persona entra en una situación de “coma irreversible (coma dépassé)". Con ellos, trataron de fijar las características del cese permanente de la función cerebral y basándose en esa nueva situación, propusieron actualizar el criterio de muerte (Escalante, 1996:56).

La presunción que alentaba al Comité para identificar como sinónimos al coma irreversible y la muerte cerebral se comprueba hoy día, sin embargo, que no era acertada: las nuevas tecnologías que describen en qué zonas del cerebro circula sangre y en cuáles no, como la tomografía de emisión o la angiografía de tres vasos, permiten diagnosticar con seguridad que un individuo puede estar en un coma irreversible y no tener completamente muerto el cerebro. En cierta forma, y tal como anticipaba el nombre del Comité y el título del informe, el objetivo final del mismo al adoptar una nueva definición de muerte, describiendo la medición empírica de un cerebro destruido, fue simplificar la certificación de la muerte a efectos de política pública, práctica clínica e inicio de los comportamientos y ritos tanáticos (Veatch, 1995:410), y no tanto un auténtico interés científico por identificar en sí misma la llegada de la muerte. Tampoco se perseguía, como resaltan Jonas (1997) y Singer (1997:38), la búsqueda de una solución razonable al número creciente de pacientes que estaban humanamente muertos pero no biológicamente muertos, por lo que no lo estaban legalmente y debían seguir conectados a respiradores. Al contrario, como ha mostrado Singer (2002 y 1997) en su análisis de las deliberaciones del Comité, las razones que movieron al mismo a plantear una redefinición de la muerte fueron mucho más prosaicas y, esencialmente, estaban dirigidas a facilitar la disposición

${ }^{99}$ Citado en Rodríguez Rioboo (1993:33).

$100<<$ Criterios Harward >> de muerte cerebral:

1.- Falta de receptividad y respuesta. Ausencia total de reacción a estímulos internos y externos por intensos que sean.

2.- Ausencia de movimientos (observado por una hora).

3.- Apnea (tres minutos sin el respirador).

4.- Ausencia de reflejos (tronco encefálico y espirales).

5.- Electroencefalograma isoeléctrico (<<gran valor confirmatorio >>).

6.- Excluir hipotermia (menos de $32^{\prime} 2^{\circ} \mathrm{C}$ ) y depresores del sistema Nervioso Central.

7.- Todos los test deben ser repetidos veinticuatro horas después.

Fte: JAMA (1968):337-340, citado en Escalante (1996:57). 
masiva de órganos para trasplantes ${ }^{101}$. Entre la documentación empleada por este autor para corroborar esa afirmación es esclarecedora del contexto en el que la nueva definición nace el siguiente párrafo del discurso pronunciado en 1971 por Robert Ebert, decano del Consejo, al dirigirse a la Asociación Americana para el Avance de la Ciencia: “en la nueva definición hay un potencial de salvar vidas por lo que, cuando se acepte, habrá una mayor disponibilidad de órganos esenciales en condiciones viables para trasplantes y por tanto se salvarán innumerables vidas que ahora se pierden inevitablemente... Cualquier nivel que elijamos para denominar la muerte es una decisión arbitraria. ¿Muerte del corazón? El pelo sigue creciendo. ¿'Muerte del cerebro? El corazón puede seguir latiendo. Es necesario elegir un estado irreversible en el que el cerebro ya no funcione. Es mejor elegir un nivel donde, aunque el cerebro esté muerto, todavía esté presente la utilidad de otros órganos. Hemos intentado dejar claro esto en lo que hemos llamado nueva definición de muerte”102.

Desde entonces se han propuesto sucesivas actualizaciones de la definición de muerte humana al hilo de las nuevas aportaciones producidas por el conocimiento científico-técnico. Entre ellas destaca la realizada por un grupo de expertos que propusieron, en 1981, la adopción de la denominada $<<$ Acta uniforme sobre la determinación de la muerte $>>$, en la que se dice que "un individuo está muerto cuando le ha sobrevenido bien el cese irreversible de las funciones respiratoria y circulatoria, o bien, el cese irreversible de todas las funciones cerebrales incluyendo el tronco cerebral. La determinación de la muerte debe realizarse de acuerdo con los estándares médicos aceptados” (Escalante, 1996:58). Esta definición de muerte, conocida como “Informe de la Comisión Presidencial”, fue adoptada sin mucha oposición en múltiples países, incluido España. Al margen de que la misma contuviera dos definiciones, la tradicional y la de muerte cerebral, sin especificar qué tipo de relación existe entre ambas, la inclusión de la muerte cerebral en la definición de muerte constituyó en realidad, según Singer (2002:209), una “ficción” práctica interesada cuyo propósito era exclusivamente salvar órganos para trasplante que de otro modo se perderían y suprimir tratamientos médicos cuando no producen ningún beneficio. Esa ficción ha acompañado asimismo a las sucesivas redefiniciones propuestas desde entonces.

\footnotetext{
${ }^{101}$ Opinión compartida por Gracia (2004:447), para quien el objetivo directo que perseguía el anestesista H.K. Beecher, presidente del Comité de Harvard, "no fue definir la muerte, sino resolver algunos problemas prácticos cada vez más frecuentes en las unidades de cuidados intensivos y, en especial, evitar el despilfarro de recursos en ese tipo de pacientes". Como consecuencias colaterales: "la posibilidad de extraer órganos para trasplante y la utilización de los cuerpos en coma irreversible o de sus órganos para experimentación".

${ }^{102}$ BEECHER, H. (1971): “The New Definition of Death, Some Opposing Viewpoints”, en International Journal of Clinic Pharmacology, vol. 5, pp. 120-121, citado en Singer (1997:39).
} 
Sobre la base de una concepción de la muerte humana como el cese del funcionamiento del organismo como un todo, en la actualidad se manejan cuatro definiciones médicas alternativas de muerte (Tabla 2.1.). La tradicional, basada en el cese del flujo de los fluidos corporales vitales $^{103}$, y otras tres elaboradas desde finales de la década de 1960, cuando se reconoce que las funciones o estructuras del encéfalo son básicas en la articulación, organización e integración del ser humano. La pérdida de éstas supondría la muerte del individuo como un todo: el cese permanente de las funciones integradoras del organismo como un todo; el cese irreversible de las funciones integradoras del encéfalo como un todo; y la pérdida irreversible de la conciencia y de la cognición (Escalante, 1996:60-71). El carácter abstracto de las cuatro definiciones médicas de muerte no aporta soluciones prácticas para el diagnóstico de la muerte individual concreta. Para dotarlas de utilidad en la práctica clínica, cada definición lleva asociada un criterio de muerte instrumental -estándar objetivo- que se emplea en cada caso. Estos criterios, a su vez, se materializan en la realización de unas pruebas y procedimientos diagnósticos específicos. Aunque no ayudan a entender el significado de la muerte, los criterios de muerte permiten situar aproximadamente el momento en que ésta se produce; además, no tienen carácter absoluto e inamovible, ya que la aparición de nuevos descubrimientos tecnológicos, que permitan ajustar con mayor precisión el momento de la muerte, pueden dejar obsoletos los criterios anteriormente utilizados.

\section{TABLA 2.1. DEFINICIONES MÉDICAS ALTERNATIVAS DE MUERTE}

\begin{tabular}{|l|l|l|}
\hline \multicolumn{1}{|c|}{ Definición } & Criterio de muerte asociado & \multicolumn{1}{|c|}{ Pruebas asociadas } \\
\hline $\begin{array}{l}\text { Cese permanente del flujo de los } \\
\text { fluidos corporales vitales }\end{array}$ & $\begin{array}{l}\text { Cesación de la función cardiaca y } \\
\text { pulmonar }\end{array}$ & $\begin{array}{l}\text { Ausencia de pulso y esfuerzos } \\
\text { respiratorios. Línea isoeléctrica en } \\
\text { E.G.G. }\end{array}$ \\
\hline $\begin{array}{l}\text { Cese permanente de las funciones } \\
\text { integradoras del organismo como } \\
\text { un todo }\end{array}$ & Cese de función del cerebro entero & $\begin{array}{l}\text { Criterios Harvard. Informe } \\
\text { Comisión Presidencial }\end{array}$ \\
\hline $\begin{array}{l}\text { Cese irreversible de las funciones } \\
\text { integradoras del encéfalo como un } \\
\text { todo }\end{array}$ & Cese de función del tronco cerebral & $\begin{array}{l}\text { Criterios Minesota. Código del } \\
\text { Reino Unido }\end{array}$ \\
\hline $\begin{array}{l}\text { Pérdida irreversible de la } \\
\text { conciencia y de la cognición }\end{array}$ & $\begin{array}{l}\text { Cese de función de la neocorteza } \\
\text { cerebral }\end{array}$ & $\begin{array}{l}\text { No existen pruebas efectivas en este } \\
\text { momento }\end{array}$ \\
\hline
\end{tabular}

Fte: Escalante (1996:61).

Tanto las definiciones de muerte como los criterios de muerte y los procedimientos de diagnóstico son convenciones culturales que deben ser sancionadas desde la política pública. La necesidad imperiosa de establecer una definición de muerte, con sus criterios y procedimientos

\footnotetext{
103 Supone que todos los seres vivos poseen algún tipo de fluido corporal (sangre, savia, u otra cosa).
} Cuando éste deja de fluir los seres vivos mueren. 
de diagnóstico correspondientes, ha obligado "al legislador y al médico a conformarse con una posición convencional, aunque realista, menos precisa de la que cabría esperar de una ciencia rigurosa”, de tal forma que todas las definiciones de muerte están mediatizadas ideológicamente (Thomas, 1991:41-43). Condicionamiento que además, como resalta este autor, una vez que la muerte ha entrado en los dominios aparentemente neutrales de la ciencia su confirmación se debe ajustar a la identificación por criterios técnicos cada vez más sofisticados, hasta el punto de que progresivamente las definiciones de muerte se ajustan más a dichos criterios, "aunque de este modo no se diga nada sobre la esencia del fenómeno”.

Dada la especificidad de los criterios de muerte y de los procedimientos de diagnóstico su determinación pertenece al "mundo de los expertos", al campo científico-técnico. Las decisiones tomadas por éstos, en principio neutrales y objetivas, están sin embargo mediatizadas por intereses de todo tipo entre los que destacan dos: la ideología religiosa y el poder del estamento médico. Esto implica que los criterios propuestos por los expertos no pueden ser empleados arbitrariamente, sino que asimismo deban ser debatidos públicamente y regulados por ley. En este sentido, lo más relevante para el debate público actual sobre la determinación de la muerte es que los cuatro criterios médicos alternativos no son apodícticos en el diagnóstico de la muerte ${ }^{104} \mathrm{y}$, en consecuencia, son susceptibles de crítica. Ésta es diáfana en el primero de ellos, la "muerte cardiopulmonar", por cuanto la misma se puede superar a través de diferentes procedimientos de reanimación sin que se produzca la muerte cerebral, con lo que en rigor no es un diagnóstico de muerte real en sentido estricto (Trueba, 2007:62; Gracia, 1996:24-25). Además, su utilización como único criterio de muerte presenta el problema práctico de que podría eliminar virtualmente la obtención de órganos de calidad para trasplantes. Por ello, el número de defensores de este criterio parece haber descendido significativamente desde finales de los años sesenta (Veatch, 1995:418).

De esta forma, la definición basada en el cese permanente del flujo de los fluidos corporales vitales, incuestionable hasta hace unas pocas décadas, resulta insuficiente para identificar toda la casuística posible en la actualidad. La incidencia de los avances tecnológicos ha quebrado el rápido proceso de morir tradicional dejándola obsoleta, por incapacidad, a la hora de definir el estado de los seres en coma sobrepasado o en coma profundo. A la inconsistencia del criterio médico en que se sustenta hay que añadir además la conceptualización naturalista ${ }^{105} \mathrm{y}$, por tanto, parcial de la muerte que subyace en la misma. En

\footnotetext{
104 "Probablemente no hay ningún sistema que sea 100\% fiable para diagnosticar el momento exacto de la muerte” (Quintana, 1997: 53)

${ }^{105}$ Una muestra de esta posición se puede ver en Pardo (1998:8): “un ser vivo se caracteriza porque mantiene la homeostasis. Este proceso es activo porque el medio externo le supone obstáculos que deben ser superados activamente y de manera continua. Cuando estas dificultades desbordan la capacidad del
} 
efecto, considera al ser humano como meramente un conjunto de fuerzas físico-químicas ignorando los procesos mentales que le caracterizan: cualquier individuo que tuviera capacidad para el fluir de la sangre y el aliento debería ser tratado como vivo, aunque esas capacidades sólo se pudieran mantener con ayuda externa (Veatch, 1995:417-418).

Los otros tres criterios de muerte asumen que sólo el cerebro, por su papel patrocinador de la conciencia e integrador somático, puede dirigir al organismo entero. La muerte del mismo (muerte encefálica) supone -condición necesaria y suficiente- la muerte del ser humano como un todo, ya que, por ejemplo, después de un infarto cerebral total el cuerpo tiende espontáneamente a la desintegración. Los tres criterios se diferencian entre sí en la identificación de la porción del encéfalo cuya pérdida irreversible conlleva la muerte clínica.

El segundo de los criterios, el "cese de función del cerebro entero" o muerte cerebral, hace referencia a la muerte encefálica como la pérdida funcional irreversible de todas las estructuras craneales y lleva implícita las muertes de la corteza cerebral y del tronco cerebral. Implica, por tanto, la pérdida irreversible de todas capacidades que definen a una persona y también el cese irreversible de la función cardiorrespiratoria espontánea, que es mantenida temporalmente con ayuda artificial. En expresión de Pera (2003:244), es realmente un estado de decapitación fisiológica. Es el criterio médico dominante en la mayoría de los países, incluido España ${ }^{106}$. Este criterio ha sido criticado de ser teóricamente débil e incoherente, de ser confuso en su aplicación práctica ${ }^{107}$ y de que el único fin de su existencia es establecer un concepto lo más ampliamente consensuado que facilite la obtención de órganos para trasplantes (Singer, 2002 y 1997; Truog, 1999; Pardo, 1998; Jonas, 1997; Youngner, 1992). En este sentido, se señala que para que un concepto sea coherente, debe ser consistente internamente en todos los niveles de análisis y entre los distintos niveles, de tal forma que "los individuos que satisfacen los tests deben cumplir el criterio, y aquellos que satisfacen el criterio deben satisfacer también la definición” (Truog, 1999:44-45). Sin embargo, existe evidencia empírica ${ }^{108}$ de que hay una

organismo para contrarrestarlas, el ser viviente muere; pierde entonces la identidad del medio interno, cuyas condiciones se igualan con las del medio exterior: se igualan sus temperaturas, se descomponen las proteínas, se disuelven y homogeneizan los diversos compartimentos orgánicos y el contenido de éstos con el medio externo, etc... El mantenimiento observable de la vida (la homeostasis) se deriva de una actividad integrada de los órganos del viviente... Como es obvio, todos los pacientes en que sustituimos alguna función orgánica están vivos mientras mantengan su homeostasis... De lo afirmado se sigue... que los pacientes en estado de muerte cerebral están vivos, aunque estén gravemente enfermos”.

${ }^{106}$ En Escudero (2008) se desarrolla todo el proceso técnico de identificación de este tipo de muerte.

107 Truog (1999:46) menciona diversos estudios realizados en hospitales de Estados Unidos en los que se pudo comprobar que un alto porcentaje del personal sanitario (médico y enfermería), en algunos casos el $65 \%$, no identificaban correctamente los criterios médicos y legales para la determinación de la muerte.

108 Se refiere a la inconsistencia práctica detectada en pacientes que habiendo sido diagnosticados fallecidos por una muerte encefálica, varios días después de haberles declarados muertos mantenían aún funciones cerebrales residuales, con lo que no se cumplía el precepto del cese de "todas las funciones del cerebro entero" (Escalante, 1996:62-65). Truog (1999:45), por su parte, hace referencia a diversos 
disparidad significativa entre los tests estándar para hacer el diagnóstico de muerte y el criterio de muerte en el que se enmarcan.

Asimismo, se aprecian inconsistencias entre el criterio y la definición. En efecto, aunque se reconoce que la relación entre ambos, por la que se asumía que "el cerebro es el responsable del mantenimiento de la homeostasis del cuerpo, y que sin función cerebral el organismo rápidamente se desintegra”, tenía sentido en el pasado, gracias a los avances tecnológicos se ha quebrado en la actualidad (Truog, 1999:45). Según este autor, hoy día ya no es cierto que "el cerebro sea el órgano principal del cuerpo, el órgano <<integrador >> cuyas funciones no pueden ser reemplazadas por otro órgano o por medios artificiales”. En el mismo sentido, Singer (1997:43) constata que desde $1986^{109}$ existen diversas técnicas que permitirían "mantener indefinidamente" a pacientes con muerte cerebral, lo que significa que "las fuerzas coordinadas de la medicina de cuidados intensivos moderna han reemplazado el papel del cerebro a la hora de regular el cuerpo". Se mencionan como ejemplos de esta transformación, por un lado, el caso habitual de pacientes con muerte cerebral a los que se les mantiene en esa situación hasta que se donan sus órganos; por otro lado, el caso extremo de mujeres embarazadas y muertas cerebralmente a las que se prolonga su situación hasta dar a luz ${ }^{110}$. A diferencia de la consistencia definición/criterio de la primera de las definiciones, estos casos, además de un creciente número de casos clínicos en los que la "supervivencia del fallecido" se prolonga meses o incluso años, provocan fisuras que impiden construir una unidad homogénea entre el criterio médico y la definición pública de muerte como ponen en evidencia los nuevos

estudios en los que se había observado series de pacientes entre los que alrededor del $20 \%$ de los mismos cumplían totalmente los tests de muerte cerebral y sin embargo continuaban mostrando algún tipo de actividad en sus electroencefalogramas.

${ }^{109}$ Desde el año 1986, en el que un equipo de médicos japoneses suministró una hormona antidiurética a pacientes cuyo cerebro había muerto y consiguió retardar su muerte definitiva manteniendo sus funciones corporales durante una media de veintitrés días, se han ido introduciendo nuevas técnicas que han permitido progresivamente ampliar ese periodo sin control cerebral sobre las funciones corporales (Singer, 1997:43).

${ }^{110}$ El 7/05/05, en EE.UU., Susan Torres, embarazada de 15 semanas, entró en coma irreversible como consecuencia de un melanoma cerebral con metástasis. De acuerdo con la familia, el equipo médico decidió mantenerla artificialmente con vida para permitir el desarrollo del feto hasta que, a finales de julio, se detectó una infección que podía afectar a la placenta y se decidió adelantar el parto. Después de dar a luz el 02/08/05 se la desconectó de la máquina que la mantenía artificialmente con vida muriendo el 04/08/05 (EL PAÏS, 05/08/05:22). Un caso similar se produjo en España en el año 1999. El 31/12/99 nació mediante cesárea en el hospital de Cabueñes (Gijón) un varón sietemesino hijo de Milagros L.M. Esta mujer, de 34 años, entró en estado de muerte cerebral el 14/11/99 a causa de una hemorragia cerebral masiva derivada de una septicemia. Una vez diagnosticado ese estado, y a petición previa expresa de ella misma y de su familia, los servicios médicos del hospital decidieron mantenerla artificialmente con vida hasta el nacimiento del niño. Para ello, como se recoge en EL PAÍS (2/01/00:32), "se la sometió a ventilación mecánica continua, uso de medicamentos vasoactivos, nutrición parenteral (por vena) y tratamiento hormonal, con el suministro periódico de medicamentos de hipófisis y de tiroides. Desde entonces, la mujer sólo mantuvo actividad medular”. Una vez producido el parto, se certificó su defunción y fue enterrada al día siguiente. En Singer (1997:23-32) se puede consultar las circunstancias de dos casos más, el de Trisha Marshall (EE.UU., 1993) y el de Marion Ploch (Alemania, 1992), así como un examen comparativo de los debates públicos suscitados por los mismos. 
problemas éticos, filosóficos y antropológicos de profundo calado que han generado: si estos pacientes (los “muertos vivos”) están muertos, ¿̇es lógico que un cadáver pueda permanecer tanto tiempo sin descomponerse?, ¿¿se pueden mantener cadáveres con vida?; si el paciente comatoso está muerto ya no es un paciente, sino un cadáver, por lo que la "prolongación del estado intermedio" del mismo, que no es vida, ¿es una <<simulación de vida>>? (Jonas, 1997:153); si mantienen, aunque sea con ayuda, algún tipo de actividad órganica integrada, es decir, si son seres vivos y no son seres humanos, ¿̇a qué especie pertenecen? (Pardo ${ }^{111}$, 1998:5); si respecto a otras especies animales se sabe cuándo están vivas y cuándo muertas, ¿̇por qué no en los seres humanos?, ¿por qué sólo se utiliza la definición de muerte cerebral con los seres humanos?, etc. Disparidades e interrogantes que abruman incluso a los propios profesionales de la medicina entre quienes hay algunos que, aunque racionalmente puedan asumir que pacientes cuyos corazones laten están muertos cerebralmente, sin embargo, "tienen dificultades para reconciliar esto con sus sentimientos y su forma de pensar personales”" ${ }^{\text {,12. }}$

Desde otra perspectiva, los detractores más radicales de este segundo criterio, partidarios de otros criterios más específicos en la localización fisiólogica y, por tanto, menos restrictivos, llevan el precepto del cese de todas las funciones cerebrales hasta el extremo y preguntan, con cierta ironía, si la actividad de la médula espinal debe ser tomada también como signo de vida, dado que proporciona actividad del sistema nervioso integrado no distinguible de la del tronco cerebral (Veatch, 1995:420). En todo caso, y a pesar de sus limitaciones lógicas y debilidades empíricas, este criterio ha permitido, a nivel empírico, delinear unas fronteras éticas y legales del diagnóstico de la muerte encefálica que, independientemente de los motivos de

\footnotetext{
${ }^{111}$ Además de esas críticas teórico-prácticas, Pardo (1998:5 y 10) plantea un argumento filosófico que considera decisivo para mostrar la insostenibilidad de la muerte cerebral: admitir ésta como equivalente a la muerte humana supone admitir algún tipo de dualismo: "si puede haber muerte del hombre (es decir, cese de la actividad vital de un cuerpo), sin que de hecho se manifieste el cese de muchas de las actividades vitales del cuerpo, en el fondo parece que se está admitiendo que el vivir humano es algo extraño al vivir corpóreo. El alma, la personalidad (personhood) o la autoconciencia (self), serían algo añadido al cuerpo, que, además, conectan con él mediante un órgano concreto, el cerebro. La persona sería realmente su alma (o espíritu o self). El fracaso del órgano de conexión a causa del infarto cerebral total separaría el alma del cuerpo". Independientemente de la potencia de esta argumentación, ya expuesta por Jonas (1997), que Pardo resume de la siguiente forma: "aunque podamos distinguir aspectos materiales, psicológicos y espirituales, el hombre es una realidad unitaria”, resulta paradójico que a renglón seguido añada: "el hombre es cuerpo, alma (actividad corpórea) y espíritu (actividad incorpórea), que forman una unidad. Esos "componentes" guardan una relación jerárquica, en la que el cuerpo y su actividad están al servicio de la actividad espiritual... (porque)... Lo que merece respeto en y por sí mismo es la persona por su actividad espiritual... El cuerpo humano no es por sí mismo un valor máximo, sino que lo es por ser el cuerpo de una persona, ser espiritual, original e irrepetible” (Pardo, 1998:12).

${ }^{112}$ Singer (1997:45-46), menciona, entre otros ejemplos, que a comienzos de la década de 1990 un tercio del personal sanitario de los hospitales de Cleveland, Ohio, que trabajaban con pacientes con muerte cerebral, "pensaban que a las personas cuyos cerebros estaban muertos, se les podía calificar de muertos porque estaban <<muriendo irreversiblemente >> o porque tenían una <<calidad de vida inaceptable >>, es decir, "los médicos y las enfermeras más íntimamente implicados" no aceptaban la definición de muerte cerebral.
} 
fondo que las animan, han sido ampliamente aceptadas en la medicina occidental (Escalante, 1996:71).

El tercero de los criterios, el cese de función del tronco cerebral, se diferencia del anterior en que hace una selección de las funciones cerebrales esenciales y las localiza en el tronco encefálico. Ésta es la parte que une el cerebro con la médula espinal, y en ella se regulan todas las funciones que se realizan de forma inconsciente como la respiración, la regulación de la presión y del ritmo cardiaco, la presión muscular de las paredes de los vasos sanguíneos, el control de la temperatura corporal, etc. Más importante aún, si cabe, es que contiene el $<<$ sistema de activación reticular ascendente >> (SRAA) que juega un papel determinante en el mantenimiento de la vigilancia, es decir, en la generación de la capacidad para la conciencia, que es una precondición esencial del contenido de la conciencia ${ }^{113}$. Si no funciona el tronco cerebral, además de ausencias de las funciones no voluntarias, no hay capacidad para generar vida cognitiva o afectiva, ni pensamientos o sentimientos, ni interacción social con el medio ambiente, "nada que pueda legitimar el adjetivo sappiens al sustantivo Homo" (Enciclopedia Británica. Macropedia, vol.16, 1987:1033). El daño irreversible en el tronco cerebral, por tanto, constituye el punto de no retorno. Desde el punto de vista clínico, no se trataría de probar que todas las células intracraneales están muertas, cosa por otra parte imposible de realizar, sino de establecer la pérdida irreversible de la función del tronco cerebral (Enciclopedia Británica. Macropedia, vol.16, 1987:1034). La muerte encefálica sería así la muerte del tronco encefálico exclusivamente, dado que la misma equivale a apnea irreversible y a pérdida irreversible de la capacidad de conciencia. De esta forma, y a diferencia del criterio anterior, se admite la existencia de funciones cerebrales residuales, pero que no "plantean problemas conceptuales ya que la actividad de los hemisferios cerebrales queda expresamente fuera" de la definición de muerte (Escalante, 1996:66).

Este criterio goza de una amplia aceptación desde el punto de vista clínico, a pesar de la cual no está normalizado en la mayoría de los países ${ }^{114}$. Las críticas más importantes al mismo son, por una parte, el que la perdida de la capacidad para ventilar espontáneamente puede ser compensada artificialmente con ayuda mecánica; de esta forma, "la respiración (y más particularmente la ventilación) no es tan esencial para la naturaleza humana que su pérdida

113 "Dos componentes fisiológicos rigen la conducta consciente del ser humano: la $<<$ capacidad $>>$ para la conciencia $0<<$ despertar $>>$ y el $<<$ contenido de la conciencia $>>$. El $<<$ contenido $>>$ de la conciencia representa la suma de las funciones mentales cognitivas, afectivas y otras funciones corticales superiores, mientras que la <<capacidad >> está estrechamente vinculada a la aparición de la vigilia” (Escalante, 1996:67).

${ }^{114}$ En el año 1976, la $<<$ Conference of Medical Royal Colleges and their Faculties in the United Kingdom>> determinó los criterios de muerte cerebral conocidos como "Código del Reino Unido". En este Código se establece que la muerte funcional permanente del tronco cerebral equivale a la muerte del encéfalo (Escalante, 1996: 56-57, 66). 
signifique la muerte”. Por otra parte, distintos autores han demostrado, tanto clínicamente como experimentalmente, que al estimular un SRAA cabe reproducir un $<<$ despertar $>>$, lo que asimismo sería indicativo de que "la capacidad para la conciencia no es tan esencial para la vida que su pérdida sea sinónimo de muerte” (Escalante, 1996:66-67).

Las definiciones de muerte asociadas a los criterios segundo y tercero, a pesar de las diferencias de diagnóstico que las sustentan, están bastante próximas entre sí. De hecho, clínicamente la tercera de las definiciones, el cese irreversible de las funciones integradoras del encéfalo como un todo, conlleva la segunda, el cese permanente de las funciones integradoras del organismo como un todo. A diferencia de ésta se asume que puedan persistir actividades corticales residuales, pero son actividades incoordinadas, sin función, que "desaparecen en horas o días y que no conllevan ninguna interacción clínica aparente con el medio” (Escalante, 1996:70). Si bien ambas definiciones se sustentan en pruebas y criterios que son "prudentes, muy seguros” y están avalados por la ciencia, no son indubitables, no diagnostican la muerte sin ningún género de dudas (Gracia, 1996:24-25). Así, por las razones históricas arriba señaladas, en la mayoría de los países del mundo se admite como muerte cerebral la definición basada en el criterio “conservador” del cese de función del cerebro entero.

El último de los criterios, el cese de función de la neocorteza cerebral, supone una identificación aún más concreta de la parte del encéfalo en la que se localizarían las funciones esenciales cuya pérdida supondría la muerte humana. Situada en la parte superior del cerebro, en la corteza cerebral se localizan las funciones que desarrollan el contenido de la conciencia: la inteligencia, el pensamiento abstracto, el lenguaje, el control voluntario de movimientos, la integración sensorial..., es decir, las funciones que permiten ver, oir y sentir; aquéllas por las que se experimenta dolor o placer; o las que facultan para tener objetivos, intenciones o deseos. De esta forma, si no hay flujo sanguíneo en la corteza cerebral se está incapacitado para desarrollar todas esas funciones o, lo que es lo mismo, no se puede llenar de contenido la conciencia; siendo irrelevantes para la vida del ser humano y, por tanto, para la determinación de su muerte, el resto de las estructuras encefálicas, que controlan las funciones vegetativas ${ }^{115}$ (Escalante, 1996:67). Este criterio correlaciona muy bien con las opiniones de los que en este ámbito, en el del tránsito ente la vida y la muerte, reivindican la identidad personal ${ }^{116}$ frente a la

115 Citando a Truog y Flacker (1992), Escalante (1996:67-68) explica gráficamente este criterio: "la terapia intensiva moderna puede sustituir todas las funciones vegetativas del encéfalo, pero una sustitución tecnológica de la conciencia (de su contenido) de una persona es conceptualmente absurdo... El contenido de la conciencia es tan esencial para caracterizar al ser humano, que no puede ser sustituido tecnológicamente, y, por tanto, su pérdida significa la muerte del individuo".

${ }^{116}$ Se suele justificar la idoneidad de ese criterio señalando, por una parte, que la actividad celular no es equivalente a función. Por otra parte, para ilustrar que las personas se identifican a sí mismas con la experiencia de su conciencia, se utiliza el ejemplo hipotético de un persona que se somete a un trasplante 
unidimensionalidad de lo biológico-corporal, es decir, con aquellas opiniones que consideran que "la idea de vida no se concibe por separado de la idea de una persona viva"117. En efecto, si la esencia humana de un individuo, construida en tanto que ser social, es su personalidad, "su vida consciente, su carácter único, su capacidad para recordar, juzgar, razonar, actuar, disfrutar, preocuparse, etc.” (Beecher, 1970:39) ${ }^{118}$, la pérdida irreversible de la capacidad de dotar de contenido a la conciencia le inhabilita para crear, o engancharse a, cualquier proyecto vital humano: está humanamente muerto.

Entre las críticas más significativas a este criterio destaca la relativa a que con el mismo se asume que la definición de muerte se refiere a la persona y no al organismo, con lo que no se tiene en cuenta lo que es común a la muerte de todos los organismos, "sean humanos, ranas, o árboles”119 (Botkin y Post, 1993:129-138). No obstante, la mayor objeción a este criterio es la de que con el mismo se trata como muertos a pacientes que respiran sin ayuda externa. En efecto, este criterio presenta problemas de implementación práctica importantes, y en concreto se mencionan los casos de los anencéfalos ${ }^{120}$ y los pacientes en estado vegetativo persistente (EVP), que según este criterio serían diagnosticados como muertos, mientras que según los dos criterios anteriores estarían vivos. En el segundo de los casos, entre los pacientes en EVP, resulta muy difícil determinar de forma precisa la irreversibilidad de la muerte funcional de la neocorteza cerebral ${ }^{121}$ (Gracia, 1996:24-25), ya que, hasta ahora, no se ha conseguido establecer con certeza cuál es la ubicación morfológica exacta de la función denominada <<contenido de la conciencia>>, por lo que el riesgo de tener falsos positivos, dando como muerto cerebral a un paciente que no se encuentre en ese estado, es de momento elevado. Aunque algunos autores vaticinan que con el tiempo no se verá en ese tipo de pacientes más que los “restos vivos” de las

de cerebro, y se interroga: ¿qué aspectos de su antigua existencia residirían en el nuevo cuerpo? (Truog, 1999:47; Veatch, 1989).

${ }^{117}$ Opinión manifestada por el juez Stevens, del Tribunal Supremo de Estados Unidos, en su voto particular en el caso de Nancy Cruzan. Ésta mujer llevaba varios años inconsciente y sus tutores pretendían que se le retirara el tubo de alimentación. La posición del juez Stevens no ha pasado a formar parte del derecho de Estados Unidos, al no ser secundada por el resto de los miembros del Tribunal Supremo. No obstante, como resalta Singer (1997:59), su discrepancia respecto a la opinión dominante constituye una señal anticipatoria de lo que pueden ser opiniones mayoritarias en el futuro.

${ }^{118}$ Citado en Singer (1997:58).

${ }^{119}$ Los partidarios de este criterio consideran esencial definir la muerte en el contexto del sujeto específico a que se refiere.

120 "La <<anencefalia>> se define como la ausencia congénita de cráneo, del cuero cabelludo y de los hemisferios cerebrales, debido a un defecto del desarrollo neural en el primer mes de gestación. El tronco cerebral puede ser desde relativamente normal hasta estar totalmente ausente" (Escalante, 1996:68). Hasta hace dos o tres décadas, este tipo de niños fallecían poco después de nacer. La tecnología médica moderna ha permitido, sin embargo, mantenerlos vivos.

${ }^{121}$ No obstante, en los últimos años se ha desarrollado toda una batería de procedimientos técnicos (angiografía de tres vasos, angiografía de sustracción digital, tomografía computerizada dinámica y tomografía de emisión) que permiten establecer de forma cada vez más clara en qué partes del cerebro circula sangre y en cuáles no. Así, si no circula sangre por la corteza cerebral, aunque se mantengan las funciones del tronco cerebral, y el paciente pueda respirar, está corticalmente muerto y no recobrará nunca la conciencia (Singer, 1997:54). 
personas que fueron (los “vivos muertos"), lo cierto es que en la actualidad para la mayoría de las personas, y para una buena parte del personal sanitario, resulta "contraintuitivo" percibir a los pacientes en esa situación como muertos (Troug, 1999:47). Así, en mayor medida aún que con el criterio de muerte de todo el cerebro, "podrían surgir problemas prácticos con respecto a las prácticas necrológicas en <<pacientes >> fallecidos que todavía respiran, tienen latido cardiaco, pueden tener naúseas, tos y que parpadean” (Escalante, 1996:69). Paradojas que Singer (1997:28, 31 y 60) describe de forma más gráfica aún: "si estás muerto cuando tu cerebro está muerto, ¿cuándo mueres si nunca has tenido cerebro?”, como ocurre con los bebés anencéfalos; “¿cómo se le podría <<permitir morir>>, ya fuera con dignidad o sin ella, (a alguién que ya esta muerto)?”; “¿quién iba a enterrar a un <<cadáver>> que todavía respirara mientras se clavaba la tapa del ataúd?”.

Por ello, la definición de muerte ligada a este criterio, la pérdida irreversible de la conciencia y de la cognición, no ha sido adoptada aún por ningún país. En esa definición, como señala Thomas (1991:43), se produce la "curiosa paradoja” de que empleando el criterio médico que más la delimita científicamente, la definición "no tiene nada de científica”. Definir la muerte de un ser humano atendiendo al momento en que ha muerto la conciencia ciertamente tiene dos ventajas: la imposición de un límite a la obstinación terapéutica y la necesidad de respetar al moribundo mientras manifieste algún destello de conciencia (Thomas, 1991:46), pero no deja de ser una "definición metafísica", inadecuada a "la medicina, a la biología y a la ciencia” 122 (Schwartzenberg, 1985). Así, a los problemas tecno-médicos implícitos en la definición se añade, en consecuencia, que la misma requeriría un cambio radical del concepto muerte ya que ampliaría su visión fisiológica hasta considerar funciones psicológicas en el mismo (Escalante, 1996:69). Además, siendo por naturaleza el contenido de la conciencia una experiencia subjetiva, este autor se pregunta “¿cómo podemos estar seguros de que esta función está preservada o ausente?”.

Esta revisión de los pros y contras de los distintos criterios médicos de muerte ha permitido identificar los aspectos claves que intervienen en el debate de la definición pública de la muerte. En este sentido, Veatch (1995:414) señala que lograr algún tipo de resolución que permita definir qué cambios se deben producir en las estructuras o funciones corporales para identificar a una persona como muerta es "lógicamente prioritario" e independiente de qué tipo de criterio, tests o medidas deben emplearse para certificar aquellos cambios. Es decir, desde el punto de vista social existe la necesidad perentoria de establecer una definición de la muerte

122 "Se define la muerte de un ser humano atendiendo al momento en que ha muerto su conciencia. Se le declara muerto no porque sus órganos hayan dejado de funcionar, sino porque ha muerto para la especie humana. Se establece una diferencia entre la especie humana y todas las demás especies vivientes. Esta diferencia se llama conciencia” (Schwartzenberg, 1985, citado en Thomas (1991:44)). 
que, al margen de los aspectos teológicos, filosóficos o fisiológicos, pueda ser empleada como convención cultural para determinar cuándo un ser humano debe ser identificado como muerto. Se trata, por tanto, de un problema de política pública, es decir, social: determinar la separación entre la vida y la muerte, resoluble a través de un acuerdo general, articulado sobre principios sociales a través de la legislación, y sin que haya necesidad de resolver todos los problemas filosóficos, o de otro tipo, sobre los que pueda haber desacuerdos en el más alto nivel conceptual (Veatch, 1995:414). Máxime cuando los propios médicos reconocen que la muerte es un proceso en el que la "ciencia médica no puede descubrir el momento en que se dice que se produce la muerte, sino que más bien lo debe elegir” (Shann, 1991) ${ }^{123}$.

En esta dirección, Gracia (2004:430) critica por falta de sentido la obsesión por determinar el momento preciso en el que finaliza la vida y relativiza la importancia de esa determinación, ya que "ni es posible conocer esos momentos con exactitud matemática, ni tiene sentido plantear así las cosas... Hay un momento de morir, porque el argumento de la vida se ha plenificado ya”. Crítica que aprovecha el neurólogo J.L. Trueba (2007) para reivindicar la muerte encefálica como la muerte clínica a pesar de sus limitaciones. En efecto, partiendo de que el concepto de muerte es un constructo cultural en el que, para su identificación, se requieren conocimientos especializados, reconoce que determinar el momento de la muerte es "la cruz del asunto" porque el diagnóstico de muerte es un ejercicio de puro juicio práctico, esencialmente basado en hechos de experiencia, y que como tal nunca puede dar certidumbre absoluta. Como todo conocimiento empírico, por muchos argumentos razonados y prudentes que se empleen, apoyados en valoraciones de los hechos lo más objetivas posibles, y sustentados en procedimientos sofisticados, nunca habrá certeza absoluta sobre el juicio emitido, por lo que cualquier diagnóstico de muerte siempre será un problema ético que obligará a tomar decisiónes desde la imprecisión y la incertidumbre: “Todo proceso orgánico o biológico encierra un componente de incertidumbre que nos obliga a descubrir y asumir cierta dosis de relativismo científico y práctico para nuestras tomas de decisión. Esto puede resultar incómodo pero no es posible establecer un criterio absolutamente absoluto para poder certificar la muerte, pero ello no invalida la posibilidad de un diagnóstico testimonial, razonable y responsable” (Trueba, 2007:66).

Desde distintas perspectivas ideológicas, otros autores sin embargo, reconociendo la necesidad obvia de una definición pública de muerte, discrepan de la lógica de hechos iniciada desde la publicación del Informe del Comité Especial de la Escuela de Medicina de Harvard Para Examinar la Definición de Muerte Cerebral, que consideran viciada en su base, y subrayan

\footnotetext{
${ }^{123}$ Citado en Singer (1997:53).
} 
los riesgos de haber legalizado una definición de muerte que declara como muertos a los muertos cerebrales: es una definición de muerte rehén del progreso tecnológico; paradójicamente, está alejada de su objeto de definición, la muerte, y; se separa de la práctica médica actual (Singer, 2002 y 1997; Truog, 1999; Pardo, 1998; Jonas, 1997).

Así, por ejemplo, Singer (2002, 1997), tenaz opositor al criterio de muerte cerebral y partidario de retornar al criterio de parada cardiorrespiratoria como único identificador de la muerte humana, plantea que una vez que se ha admitido el criterio de muerte cerebral resulta absurdo limitarlo al criterio de muerte de todo el encéfalo, o como mucho al de la muerte del tronco cerebral, y ve inevitable que iniciada esa dinámica se llegue a asumir finalmente el criterio del cese definitivo de la corteza cerebral. Sustenta su posición en las consecuencias de los continuos avances científico-técnicos sobre una lógica de hechos pervertida desde su nacimiento: a) aunque las razones aducidas por el Comité para redefinir la muerte podrían aplicarse a todos los pacientes en coma irreversible, tanto los que estaban en coma profundo (EVP) como los que estaban en coma sobrepasado, el Comité centró su atención en los segundos mientras que seguía considerando como pacientes vivos a los pacientes en EVP, ¿por qué?. Según Singer (2002:208-212), las razones de esta discriminación fueron, por una parte, que en aquel momento, año 1968, no existía la tecnología que permite determinar la irreversibilidad de un coma sino sólo la que permitía observar daños cerebrales masivos sin actividad cerebral alguna, es decir, no era posible diagnosticar fiablemente "la destrucción irreversible de las partes del cerebro asociadas con la conciencia... si el tronco cerebral seguía vivo”. Por otra parte, que como los pacientes en EVP respiran sin ayuda mecánica era contraintuitivo en aquella época, y actualmente, tratar como muertos a pacientes que respiran; b) los avances tecnológicos están dejando obsoleta la primera de esas razones por cuanto ya permiten obtener imágenes de tejidos blandos dentro del cuerpo y describir en qué partes del cerebro circula sangre y en cuáles no, lo que en un futuro cercano permitirá establecer fiablemente cuándo se ha destruido la corteza cerebral, es decir, cuándo se ha perdido irreversiblemente la conciencia. Así, progresivamente se está diluyendo el obstáculo médico más importante de todos, y cabe suponer que "pronto desaparecerá del todo", incrementándose "la presión a favor de que la práctica médica se acerque a una definición de muerte basada en la muerte del cerebro superior”, y; c) en lo relativo a la segunda de las razones, se ha resaltado arriba la sustitución del cerebro por las actuaciones de la medicina intensiva en la función de regular el cuerpo, siendo esto así, ¿por qué elegir la muerte del cerebro como único determinante de la muerte y no la muerte de otros órganos como los riñones, el hígado, o el corazón?. Porque en el fondo, según Singer (1997:43), "no son realmente las funciones $<<$ integradoras $>>0<$ c coordinadoras $>>$ del cerebro las que hacen que su muerte sea el final de todo lo que valoramos, sino más bien su asociación con la conciencia y la personalidad”. Son 
esas funciones cerebrales, las relacionadas con la conciencia, es decir, las que están relacionadas más con la persona que con el organismo, las que realmente importan. Por lo que, en la senda de la dinámica iniciada el criterio de muerte encefálica lógico no es el del cese definitivo del funcionamiento de todo el cerebro sino el de la corteza cerebral (Singer, 2002:211).

En resumen, los rápidos avances científico-técnicos han enfrentado a las sociedades desarrolladas con nuevos retos que nunca antes habían tenido que abordar. La necesidad de dar una respuesta rápida y adecuada a los mismos, regulando las nuevas situaciones creadas cada vez más complejas, ha determinado que en el debate público se adopten decisiones que son cautivas de dichos avances. Decisiones que, por tanto, son incompletas, inestables, dependientes e inducidas. En el caso concreto de la muerte, en la segunda mitad del siglo XX se han elaborado tres nuevas definiciones médicas de muerte que se han añadido a la existente hasta mediados de siglo. Todas ellas, y los criterios de muerte que llevan asociados, presentan fisuras, tienen problemas conceptuales y de implementación práctica. En esta situación, la necesidad de identificar cuándo una persona está muerta obliga a tomar decisiones; decisiones que, hoy por hoy, están excesivamente mediatizadas por el poder del estamento médico en un doble sentido. Para algunos autores, y en especial para Singer (2002, 1997) y Jonas (1997), surgen dudas razonables sobre si con las definiciones de muerte cerebral lo que realmente se ha querido ha sido regular un fenómeno tan complejo como la muerte, o si, por el contrario, lo que se ha buscado ha sido una definición de muerte ad hoc tamizada por la necesidad de conseguir órganos para trasplantes. Para otros autores, al centrar el debate en el componente orgánico cuyo cese funcional produce la muerte, componente que sólo el personal médico puede identificar, se olvida que determinar esa localización orgánica exacta, ese dato técnico, no es lo fundamental para las cuestiones de la definición pública de muerte (Veatch, 1995:406). No hay que olvidar que a menos que la muerte esté definida en su contorno, la decisión de que una persona está "muerta” no puede ser verificada por ninguna cantidad de investigación científica, ya que los datos técnicos nunca pueden ser la respuesta a las cuestiones puramente conceptuales (Enciclopedia Británica. Macropedia, vol.16, 1987:1033).

Ante estas incertidumbres, diversos autores han propuesto soluciones alternativas, aunque no muy dispares entre sí, para superar las dificultades y limitaciones que conlleva la definición de muerte cerebral establecida en la mayoría de los países del mundo. Así, ya en el mismo año 1968, en el que la comisión de la Harvard Medical School propuso la nueva definición de la muerte cerebral, H. Jonas (1997:146-147) se mostró, por una parte, favorable a la primera parte de esa definición, esto es, a la utilización de la muerte cerebral si de lo que se trataba era de identificar el coma irreversible y se decidía "éticamente dejar de oponer resistencia al morir”, es decir, se suspendía la prolongación artificial de ciertas funciones y se 
permitía al paciente "morir en toda su integridad, hasta que se detenga toda función orgánica". Sin embargo, se mostró muy crítico con la segunda parte de la definición rechazándola porque “cuándo este proceso (de morir) ha de contemplarse como agotado en sí mismo y por tanto ha de verse al cuerpo como cadáver, con el que se puede hacer lo que para cualquier cuerpo viviente sería tortura y muerte" ${ }^{124}$.

Por su parte, Truog (1999) señala que la definición de muerte cerebral no equivale a la muerte de la persona y propone, por un lado, un retorno a la definición tradicional basada en el criterio cardio-respiratorio, que además podría representar un “común denominador” en la definición de muerte, virtualmente aceptable por todos los grupos culturales y religiosos y, por otro lado, propone crear otro criterio ${ }^{125}$ diferente alejado de la comprensión de la muerte que permita obtener órganos para trasplantes. En este sentido, Escalante (1996) propone un diseño amplio de la cuestión, sin limitarlo a una única definición de muerte, sino que con un planteamiento más pragmático se dé respuesta a los interrogantes que se presenten en cada caso. Así, a la cuestión de cuándo deben suspenderse los cuidados médicos de atención, responde, con el criterio cortical de la muerte, una vez constatado el cese permanente de la función consciente; en lo relativo a cuándo se podría realizar la extracción de órganos, señala que cuando se reuniesen los requisitos clínicos estándar de muerte encefálica (todo el encéfalo); finalmente, el enterramiento sólo se podría realizar cuando se hubiera producido el cese irreversible de las funciones cardiorrespiratorias.

En una línea similar se manifiesta Singer (2002, 1997), para quien es básico eliminar la escisión existente entre la definición vigente de muerte cerebral y la práctica médica. En este sentido, y por diversas razones ${ }^{126}$, no considera conveniente hacer coincidir la práctica médica

\footnotetext{
124 "Para lo segundo tenemos que conocer la línea con absoluta seguridad; y emplear una definición de muerte menos que máxima para cometer en un estado posiblemente penúltimo lo que sólo el último permitiría significa arrogarse un conocimiento que (creo yo), no podemos tener. Como no conocemos la línea exacta que separa la vida de la muerte, no nos basta con nada que sea menos que la "definición" máxima (o mejor: determinación característica) de la muerte -muerte cerebral más muerte cardiaca más cualquier otra indicación que pueda ser de interés- antes de que pueda tener lugar una violencia definitiva" (Jonas, 1997:147).

${ }^{125}$ Propone cambiar las políticas de trasplante en el sentido de que sólo se podría permitir la extracción de órganos con el consentimiento de la persona donante o de personas cercanas a ella y sólo cuando al hacerlo aquélla no sufriera ningún tipo de daño. Los individuos que podrían no ser dañados por el procedimiento serían aquellos con muerte cerebral de todo el cerebro que "están inconscientes permanente e irreversiblemente (pacientes en EVP o recién nacidos con anencefalia) y aquellos que van a morir inminente e irreversiblemente” (Truog, 1999:49).

126 "Sería posible hacer coincidir la práctica de la medicina con la de la definición de muerte cerebral. Los médicos tendrían entonces que hacer pruebas de todas las funciones cerebrales, incluidas las funciones hormonales, antes de declarar a alguien muerto. Esto supondría que a algunas personas a las que ahora se declararía en estado de muerte cerebral, se las consideraría vivas y, por tanto, se las tendría que continuar manteniendo en un respirador con un coste importante tanto desde el punto de vista económico como de sufrimiento de la familia. Como realizar las pruebas es caro y laborioso, sería necesario seguir manteniéndolos durante el periodo que duraran éstas, incluso aunque al final los resultados mostraran que
} 
con la definición, como se intenta en la situación actual, sino que lo que habría que hacer es lo contrario, la definición de muerte cerebral debería ajustarse con la práctica médica actual. Para ello, y es en este punto en el que se diferencia del resto de autores, propone abordar los problemas de la definición de la muerte humana sin las ataduras intelectuales heredadas del pasado. Más concretamente, abandonado la ética de la "santidad de vida" y rechazando, en consecuencia, la "creencia tradicional de que toda vida humana es de igual valor" (Singer, 2002:213). La no asunción de la vida como un don absoluto recibido de un ente superior, sino como un bien dinámico concreto que cada individuo gestiona según su criterio, al que puede rehusar cuando ya no obtenga de ella ningún beneficio (ética de la "calidad de vida”), además de que los avances técnicos han hecho que esa creencia tradicional sea todavía más insostenible en la actualidad, clarifica la cuestión en tanto que, como "la vida sin conciencia no vale la pena en absoluto" ${ }^{127}$, permite distinguir entre tres interrogantes que "frecuentemente embarullados en las discusiones sobre la muerte cerebral” como una única pregunta, deben plantearse separadamente (Singer, 2002:219-220; 1997:63-65):

1. “¿Cuándo muere un ser humano?”: “cuando la circulación de la sangre se detiene definitivamente con el consiguiente cese de la respiración, pulso y demás”.

2. “¿Cuándo es lícito dejar de intentar mantener vivo a un ser humano?”: cuando se encuentra en un proceso irreversible de muerte y la persistencia de su vida no le supone ningún beneficio, es decir, cuando está inconsciente irreversiblemente. En ese estado, no es significativo que perviva alguna función hormonal en el cerebro o que, incluso, se mantengan las funciones del tronco encefálico, ya que no pueden beneficiar al paciente si ha perdido la conciencia irrevocablemente.

3. “¿Cuándo es lícito extraer órganos de un ser humano con el fin de trasplantarlos a otro ser humano?”: idéntica respuesta que en la pregunta anterior.

Según Singer (1997: 188-190), este enfoque hace menos relevante a la pregunta ¿cuándo muere un ser humano?, con lo que se podría abandonar la redifinición de muerte que tantos problemas ha dado, volviendo a la concepción tradicional de muerte en términos del cese

la persona no tenía ninguna función cerebral. Además, durante este periodo, los órganos de la persona se deteriorarían y quizá no fueran válidos para un trasplante. No habría beneficios que compensaran estas serias desventajas. Ninguna persona a la que se mantuviera en un respirador para hacerle las pruebas del funcionamiento hormonal del cerebro recobraría nunca el conocimiento” (Singer, 1997:48).

${ }^{127}$ En los textos de Singer $(2002,1997)$ se analizan toda una serie de ejemplos que muestran cómo en la práctica la creencia tradicional de que toda vida humana tiene igual valor no es más que una expresión retórica, por lo que subraya, entre otras cosas, que "si fuéramos a tomarnos en serio la idea de que toda vida humana, sin considerar su capacidad para tener conciencia, merece la misma atención y apoyo, tendríamos que suprimir de la medicina no sólo las opiniones francas sobre la calidad de vida, sino también las encubiertas", o, que "si de verdad fuéramos sinceros con nosotros mismos, tendríamos que intentar prolongar la vida de aquellos que ahora clasificamos como muertos porque sus cerebros han dejado de funcionar por completo. Porque si toda vida humana posee el mismo valor, tenga o no capacidad para la conciencia, ¿Por qué nos fijamos en la muerte del cerebro en vez de en la muerte del cuerpo como un todo?” (Singer, 1997:188). 
irreversible de la circulación de la sangre, a la par que se podría beneficiar al paciente, al retirarle el sustento vital, a otras personas, al disponer de órganos que necesitan para salvar sus vidas, y al sistema sanitario, ya que no se puede "ignorar los límites que establece el carácter finito de los recursos médicos”.

\subsubsection{CONCEPTO DE MUERTE EN ESPAÑA}

"Las propiedades que comúnmente atribuimos a los objetos son, en último término, nombres de sus conductas”

R. Herrick

En el régimen jurídico español no existe una Ley General que recoja todos los aspectos relativos al proceso de morir-muerte-cadáver, es decir, que regule globalmente y homogeneice espacialmente las relaciones de cada ciudadano con la muerte. Además, aunque existen diferentes leyes que normalizan algunos aspectos parciales del fenómeno ${ }^{128}$, es asimismo muy significativo que entre las mismas tampoco exista una ley exclusivamente dedicada a definir como tal a la muerte "aplicable a cualquier individuo en cualquier centro hospitalario independientemente del destino del cadáver (si va a ser donante o no es aleatorio)” (Zarranz, 1994:39).

En efecto, resulta muy sintomático del estado de la cuestión identificar el contexto en el que se regula la definición de muerte en España. En ausencia de una ley en exclusiva que defina la muerte para ser aplicada en todos los ámbitos que fuera necesario, se la define de forma subsidiaria, es decir, como elemento instrumental al servicio de un ámbito social específico que se quiere regular, concretamente, el de los trasplantes de órganos. De esta forma, la aproximación del legislador español a la regulación de la definición de muerte se dirige únicamente a especificar los criterios médicos de comprobación y certificación de la misma, la muerte clínica como "estado yatrógeno” (Tarongí et al, 2003), por lo que no es extraño que en su vertiente jurídica algunos juristas interpreten que la misma es insatisfactoria por la indeterminación que supone su delimitación concreta ajena al Derecho. Así, en la legislación española actual se asume el concepto "muerte" como un vocablo normativo "que se incorpora como supuesto de hecho de una norma”, y se limita a "dar eficacia a la lex artis del momento, de modo que permita, según criterio razonable de los técnicos y expertos, estimar producida la

\footnotetext{
${ }^{128}$ En Pérez Pérez et al (2006) y Tarongí et al (2003) puede consultarse una revisión de la legislación española sobre el diagnóstico de muerte y el trasplante de órganos. Un análisis pormenorizado de la legislación sobre todo el sistema funerario español puede consultarse en (Pérez Gálvez, 1997). En este texto se abordan las consecuencias jurídicas de la muerte, además de la normativa sobre empresas de servicios funerarios, cementerios, inhumación, incineración, etc.
} 
muerte, dentro de los límites y marco fijados por la finalidad y garantías establecidas por la Ley”129 (Pérez Gálvez, 1997:126; Romeo Casabona, 1993:6127-6128).

En cualquier caso, y al igual que ha ocurrido en otros países desarrollados, en el caso de España se ha producido una evolución de la norma en la que se han ido admitiendo nuevos criterios para determinar la muerte de una persona al hilo de la acumulación de conocimientos derivados de los avances científico-técnicos. Evolución que para algunos juristas, como Romeo Casabona (1996:111), ha sido muy positiva ya que ha permitido que la determinación de la muerte de una persona no se tenga que centrar siempre en la paralización de ciertas funciones vitales, como la actividad circulatoria o respiratoria, "las cuales pueden ser asistidas y mantenidas casi indefinidamente por procedimientos artificiales”, y se admita alternativamente “la apreciación de lesiones cerebrales que han de ser irreversibles e incompatibles con la vida”.

Frente al inmovilismo de los tiempos del positivismo jurídico, cuando no existía definición legal alguna de muerte al ser ésta evidente, la evolución reciente de la norma que delimita el diagnóstico de muerte ha sido relativamente rápida. Incluso, la norma española más reciente contempla la necesidad de su propia actualización a medida que se sucedan "avances en la materia”. En efecto, por primera vez en España, la Ley 30/1979 ${ }^{130}$ de 27 de Octubre reguló <<sobre Extracción y Trasplantes de Órganos>>, y estableció “que la extracción de órganos u otras piezas anatómicas de fallecidos podrá hacerse previa comprobación de la muerte”. El Real Decreto 426/1980 art.10, de 22 de febrero, por su parte, desarrollaba dicha Ley y en el mismo se establecían las condiciones necesarias para determinar la muerte cerebral de una persona y así poder extraer de su cadáver los órganos viables para trasplante. Sin embargo, en el contenido de este Real Decreto no se contemplaba la posibilidad de obtención de órganos viables para transplante cuando la muerte se producía por parada cardiorrespiratoria, por lo que "había disparidad entre la realidad clínica y la regulación legal” (Pérez Pérez et al, 2006:708). Posteriormente, un nuevo Real Decreto (2070/1999) ${ }^{131}$ actualizó al anterior y en la introducción del mismo se justificaba su aparición, por un lado, por la necesidad de incorporar a la legislación la donación de órganos provenientes de muertes por parada cardiorrespiratoria y, por otro lado, porque aquél había quedado obsoleto por "los progresos científico-técnicos de los

\footnotetext{
129 "Ello quiere decir que siendo un concepto jurídico indeterminado, sólo cabe una sola solución justa en cada caso concreto, sólo que únicamente la prefigura la Ley mediante asignación de una teleología y el cumplimiento de unos trámites y garantías” (Pérez Gálvez, 1997:126; Romero Casabona, 1993:61276128).

${ }^{130}$ Esta Ley “tiene su origen en la Ley de la Jefatura del Estado de 18 de diciembre de 1950, que reguló la obtención de piezas anatómicas procedentes de cadáveres para injertos (BOE 19 de diciembre de 1950, nº 353) (Pérez Gálvez, 1997:149).

131 "Real Decreto 2070/1999, de 30 de diciembre, por el que se regulan las actividades de obtención y utilización clínica de órganos humanos y la coordinación territorial en materia de donación y trasplante de órganos” (B.O.E., 04/01/00, nº 3: 179-190).
} 
últimos años en el campo de la Medicina y de la Biología y, concretamente, en lo relativo al diagnóstico de muerte encefálica” (BOE, 2000, nº 3:179).

En este nuevo Real Decreto se reconoce como prioritaria la necesidad de obtener órganos viables para donaciones con técnicas que, empleándolas de forma rápida, minimicen los riesgos de deterioro de los órganos desde el diagnóstico de muerte. Para ello, se hace preciso articular "un mecanismo eficaz y de suficiente agilidad que permita la inmediata autorización para la obtención de los órganos en los casos en que ésta sea necesaria”. Así, además de resaltar la necesidad de actualizar todas las disposiciones relativas a la organización, transporte, competencias, procedimientos, administración, evaluación y supervisión, etc., en materia de donación y trasplante, se modifican los criterios de donación ampliándolos. De esta forma, se regula la donación a corazón parado ${ }^{132}$ y se incluyen nuevos procedimientos más modernos, eficaces y seguros de diagnóstico de la muerte encefálica, aparecidos desde la aprobación del Real Decreto 426/1980 y que, como es obvio, éste no podía incorporar.

En el artículo 3.4. del Real Decreto 2070/1999 se define el diagnóstico de muerte como sigue: "el diagnóstico y certificación de la muerte de una persona se basará en el cese irreversible de las funciones cardiorrespiratorias o de las funciones encefálicas, conforme establece el artículo 10" (BOE, 2000, n 3:180). En éste artículo se regula la "Extracción de órganos de fallecidos” y se determinan las condiciones y requisitos para poder realizar dicha extracción de órganos. Así, se establecen de forma genérica cuáles son los criterios de muerte a aplicar por profesionales cualificados, y se remite a los protocolos del Anexo I del Real Decreto en los que de forma pormenorizada se explicitan las condiciones diagnósticas específicas de la muerte encefálica, caso de que la persona se encuentre en “coma sobrepasado” (Anexo I.2.) ${ }^{133}$,

\footnotetext{
${ }^{132}$ Los donantes a corazón parado fueron los primeros donantes de la historia de los trasplantes. Cuando en la década de 1940 se iniciaron éstos, las fuentes de órganos eran personas fallecidas por parada cardiaca. Sin embargo, los malos resultados obtenidos junto con la aparición y regulación de la muerte cerebral en la década de 1960 hizo que se abandonara a los donantes a corazón parado para tal fin. La escasez de donantes ha hecho que en los últimos años se retorne a ellos de nuevo. En este retorno han tenido mucho que ver los avances técnicos que permiten controlar el gran problema en este tipo de donación: la rápida degradación de los órganos tras la parada cardiaca (Álvarez y del Barrio, 1999).

${ }^{133}$ Entre los "criterios diagnósticos de muerte encefálica" recogidos en ese Anexo 1.2. cabe mencionar: $1^{\circ}$ ) “Condiciones diagnósticas: Coma de etiología conocida y de carácter irreversible...”, 2º)"Los tres hallazgos fundamentales en la exploración neurológica son los siguientes: a) Coma arreactivo, sin ningún tipo de respuestas motoras o vegetativas al estímulo algésico producidas en el territorio de los nervios craneales..; b) Ausencia de reflejos troncoencefálicos... y; c) Apnea, demostrada mediante <<test de anpnea >> comprobando que no existen movimientos respiratorios torácicos ni abdominales durante el tiempo de desconexión del respirador..”. Además, se examinan las condiciones que pueden dificultar el diagnóstico clínico de muerte encefálica, se determinan las pruebas a realizar y se especifican los periodos de observación antes de certificar la muerte encefálica dependiendo de las causas que hayan provocado la lesión cerebral (BOE, 2000, nº 3:188-189).
} 
y de la muerte por parada cardiorrespiratoria (Anexo I.3.) ${ }^{134}$. En este sentido, cabe resaltar el reconocimiento implícito que en el citado artículo se realiza de la mayor dificultad de diagnóstico de la muerte encefálica por cuanto la certificación de la misma exige "la existencia de un certificado médico firmado por tres médicos, entre los que debe figurar un neurólogo o neurocirujano y el Jefe de Servicio de la unidad médica donde (el paciente) se encuentre ingresado, o su sustituto", mientras que en el caso del cese de las funciones cardiorrespiratorias se exige que el certificado de defunción sea extendido por un solo médico. Es asimismo reseñable que por razones de seguridad, y se supone que para evitar abusos y/o eliminar de raíz cualquier tipo de suspicacia en las certificaciones de defunción, en ambos casos los facultativos que certifiquen la defunción no pueden formar parte del "equipo extractor o trasplantador de los órganos” que se extraigan.

En el caso de España, por tanto, la norma vigente hace buena la sentencia de Pallis ${ }^{135}$ quien afirma que "puede haber varias formas de morir pero sólo hay una forma de estar muerto”. En efecto, siguiendo la terminología de Escalante (1996), Tabla 2.1., se establecen dos definiciones de muerte sin explicar la relación que existe entre ambas: cese permanente del flujo de los fluidos corporales vitales (criterio: “cese de la función cardiaca y pulmonar”) y cese permanente de las funciones integradoras del organismo como un todo ${ }^{136}$ (criterio: “cese de función del cerebro entero”). Trueba (2007:64) matiza que esta doble definición no significa que existan "dos clases de muerte ni dos formas de morir, sino simplemente dos modos de llegar al diagnóstico de muerte clínica”, y que la utilización de ambas responde a "la necesidad de tener que tomar decisiones éticas ante la incertidumbre clínica de determinadas situaciones producidas por la medicina tecnológica y los medios artificiales de soporte cardiopulmonar”. Por otra parte, no se puede descartar una modificación en el futuro de la definición de muerte cerebral como el propio Real Decreto 2070/1999 contempla en su articulado. Concretamente, en la "Disposición final tercera" se asume el carácter inestable del diagnóstico de muerte regulado y se establece que "el Ministerio de Sanidad y Consumo actualizará los protocolos de diagnóstico y certificación de la muerte para la extracción de órganos de donantes fallecidos... según el avance de los conocimientos científico-técnicos en la materia, previo dictamen de la

${ }^{134}$ El "diagnóstico de muerte por parada cardiorrespiratoria" recogido en el Anexo 1.3. se basa "en la constatación de forma inequívoca de ausencia de latido cardíaco, demostrado por la ausencia de pulso central o por trazado electrocardiográfico, y de ausencia de respiración espontánea, ambas cosas durante un periodo no inferior a cinco minutos"

135 PALLIS, C. (1983): “ABC of brain stem death. Prognostic significance of a dead brain stem”, en B.M.J., 286:123-124, citado en Escalante (1996:69).

${ }^{136}$ Criterio conservador en lo que se refiere a la muerte encefálica, motivado en la necesidad de evitar "falsos positivos", es decir, que se diagnostique una muerte clínica a un paciente que está vivo. Situación que específicamente se recoge en el Anexo I del Real Decreto referida a "aquellas condiciones clínicas en las que existen circunstancias que dificultan o complican el diagnóstico clínico", como etiología traumática o hemorragia masiva "en la que no haya lesión destructiva cerebral demostrable por evidencia clínica o por neuroimagen”. 
Comisión Permanente de Trasplantes del Consejo Interterritorial del Sistema Nacional de Salud” (BOE, 2000, nº 3: 188).

Es ya un lugar común la afirmación de que `España es líder en la donación de órganos` a nivel mundial. En su afán por incrementar los índices de las mismas, la Organización Nacional de Trasplantes (ONT) ha impulsado el Plan Donación 40 (ONT, 2011) para desarrollar una estrategia que permita "identificar, difundir e implementar mejores prácticas aplicadas al proceso de donación en muerte encefálica”. En el Gráfico 2.1 se recoge la estructura del proceso:

\section{GRÁFICO 2.1.: ESTRUCTURA DEL PROCESO DE DONACIÓN EN MUERTE ENCEFÁLICA. UC (UNIDAD DE CRÍTICOS)}

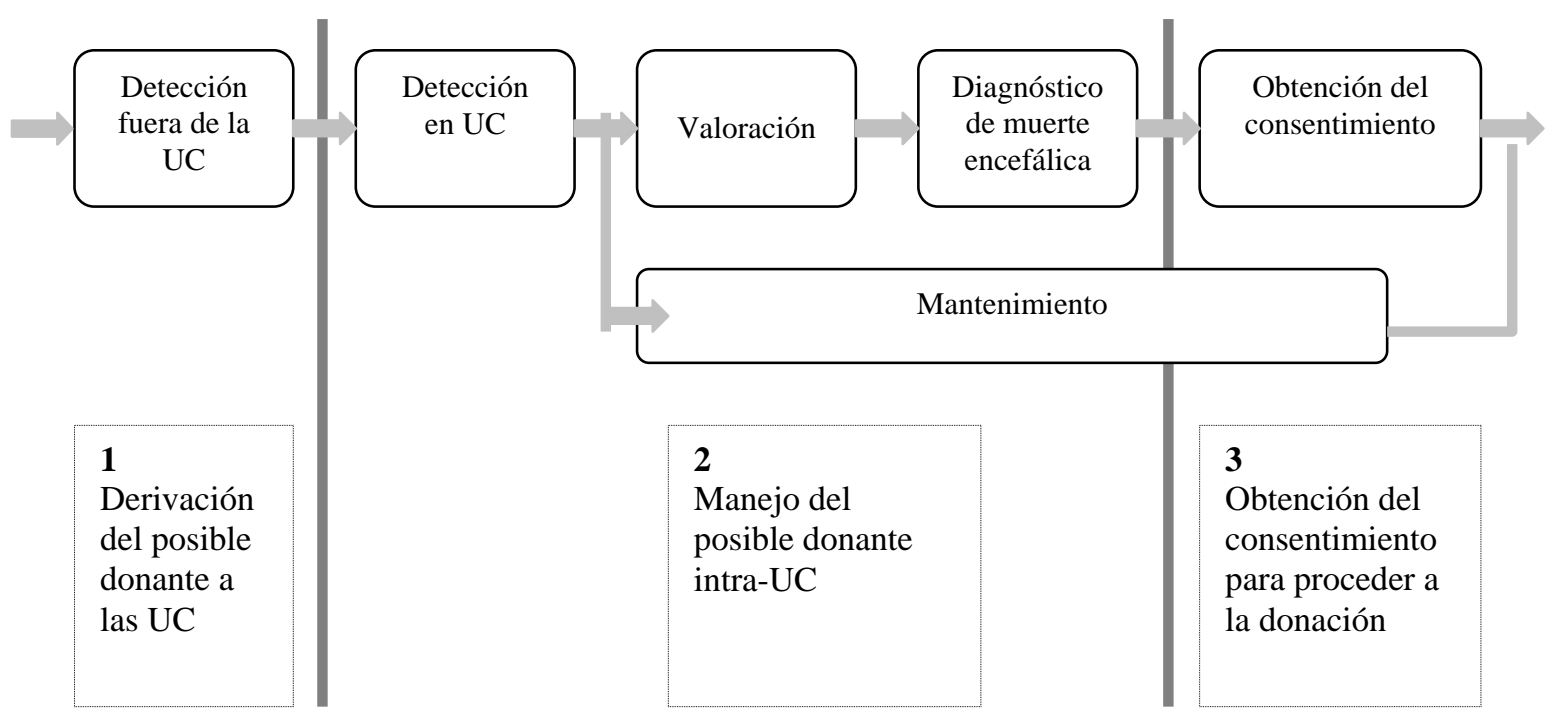

Fte: (ONT, 2011:10)

Como justificación de la dinámica interna del proceso propuesto se identifican en el mismo los tres sub-procesos siguientes (el subrayado es nuestro):

“1. Derivación del posible donante a las unidades de críticos (UC):

La detección de posibles donantes fuera de las UC no ha representado un área de trabajo habitual en nuestro ámbito, al menos de forma generalizada. Sin embargo, la detección precoz y posterior derivación a las UC de posibles donantes puede determinar importantes diferencias en el potencial de donación en muerte encefálica y, por tanto, en el resultado final del proceso. El posible donante se definió como la persona con daño cerebral grave y posible evolución a muerte encefálica en un plazo breve de tiempo. El indicador utilizado para evaluar la efectividad en esta fase del proceso de donación fue el porcentaje que fallece en las UC del total de fallecidos en un hospital con al menos uno de una serie de códigos CIE-9 entre sus diagnósticos primarios o secundarios. Tal serie de códigos representa la etiología del 95\% de las muertes encefálicas en nuestro país. 


\section{Manejo del posible donante en las UC:}

Se trata de un subproceso que, a su vez, comprende una serie de fases, en particular, la detección del posible donante intra-UC, la evaluación clínica y el mantenimiento de una persona en situación de muerte encefálica, así como el diagnóstico de la misma. Como indicador de efectividad en este subproceso, se calculó el porcentaje de donantes aptos para la extracción (pendientes del consentimiento familiar) del total de personas con exploración clínica compatible con muerte encefálica dentro de las UC.

\section{Obtención del consentimiento para proceder a la donación:}

La efectividad en esta fase se evaluó a través del porcentaje de consentimientos a la donación obtenidos del total de donantes aptos para la extracción, pendientes del consentimiento.” (ONT, 2011:11).

En una línea de actuación idéntica se sitúan las recomendaciones sobre las decisiones clínicas tras el diagnóstico de la muerte encefálica realizadas por la Red/Consejo Iberoamericano de Donación y Trasplantes en 2008, con el objetivo de armonizar las actuaciones en este ámbito en los países latinoamericanos (Escudero et al, 2009). En el documento que recoge esas recomendaciones se reconoce que el diagnóstico de muerte encefálica (ME) es independiente de si existe o no donación de los órganos para trasplantes. Si bien, una vez confirmado ese diagnóstico, "el médico responsable debe considerar siempre la posibilidad de donación de los órganos e iniciar las medidas oportunas de mantenimiento... Las obligaciones asistenciales del médico encargado no terminan en el momento de diagnosticarse la ME, sino que deben continuar en el tiempo y trabajar activamente en el mantenimiento del donante para garantizar el buen funcionamiento de los órganos y los tejidos que se van a trasplantar”. Sin embargo, en el caso de que, por la razón que sea, no quepa la donación de órganos, "se procederá a la retirada inmediata de todas las medidas de soporte, incluida la ventilación mecánica... La decisión de retirar todas las medidas de soporte al paciente fallecido en $\mathrm{ME}$ que no es donante de órganos es la única decisión consecuente con el diagnóstico clinicolegal, y diferentes sociedades científicas y bioéticas la apoyan... Mantener las medidas de soporte cuando se ha diagnosticado la ME, y por tanto, ya se está legalmente fallecido, supone una mala práctica clínica, una inexcusable contradicción con el diagnóstico científico y legal establecido, una futilidad terapéutica y un consumo innecesario de recursos... No existe ninguna justificación ética que recomiende mantener artificialmente a una persona ya fallecida y, por tanto, este tipo de práctica clínica está claramente desaconsejada” (Escudero et al, 2009:3-4). La utilización de este doble criterio científico-médico, aunque sea por tiempo muy limitado, fue anticipada y criticada en 1968 por H. Jonas (1997:147): si las medidas de soporte vital ya no son útiles porque el paciente está muerto, retírense y "déjesele morir en toda su integridad”, pero, bajo el paraguas de la misma definición de muerte cerebral, no se mantengan esas medidas que se ha dicho que ya no valen para que "el cuerpo pueda servir como banco de órganos”. 
En la actualidad, más del 95\% de los trasplantes que se realizan en España se hacen con órganos procedentes de donantes en muerte encefálica (Escudero, 2008:122). Datos similares a los de muchos otros países, y que según este médico intensivista demuestran la importancia de la muerte encefálica "como entidad generadora de órganos para trasplante y la convierten en una de las piezas indispensables del proceso donación-trasplante”. Resulta difícil estimar el número exacto de muertes cerebrales -encefálicas (ME)- producidas en España a partir de la información aportada por el INE, ya que son muy numerosas las causas que pueden llevar a ese desenlace $^{137}$. Como una aproximación de mínimos, en el Cuadro 2.3. se recoge la información facilitada por la Organización Nacional de Trasplantes (ONT, 2010) a partir del Programa de Garantía de Calidad en el Proceso de Donación ${ }^{138}$, establecido en 1998, y al que se han ido sumando los hospitales que están autorizados para la donación en España. En la evolución mostrada en el Cuadro 2.3. se aprecia que se ha más que triplicado el número de hospitales participantes en el Programa de Calidad entre 1998 y 2009, hasta alcanzar los 131 hospitales en este último año, constituyendo el $85 \%$ de los hospitales autorizados y alrededor del $95 \%$ del total de donantes de ese año. Obviamente, al incorporarse hospitales al programa aumentan tanto el número absoluto de muertes en hospital, en unidades de críticos (UC) y de muertes encefálicas recogidas en el cuadro. Lo relevante de la información recogida en éste es que la “capacidad generadora”, medida a través del porcentaje de muertes encefálicas entre el total de muertes hospitalarias o entre las que se producen en las UC, ha permanecido aproximadamente constante durante el periodo considerado: de media, las muertes encefálicas han sido el 2,4\% de todas las muertes en los hospitales adscritos al Programa de Calidad y el 12,7\% de las muertes producidas en las UC de los mismos. Es decir, de media, en el periodo 1998-2009, han sido declarados fallecidos por muerte encefálica en los hospitales monitorizados 2.075 personas al año. Por su parte, el indicador de "efectividad global" del proceso, medido a través del porcentaje de fallecidos en muerte encefálica que llegan a convertirse en donantes, se ha incrementado notablemente hasta alcanzar el $60,1 \%$ en 2009 ; incremento que en términos absolutos supone que el número de donantes en muerte encefálica casi se ha cuadruplicado entre 1998 y 2009. De media, en ese periodo, el valor del indicador de efectividad global es 53,4\%, es decir, 1.108 donantes al año ${ }^{139}$.

\footnotetext{
${ }^{137}$ Una exposición de las mismas puede consultarse en Cuende et al (2004).

${ }^{138}$ Programa que nació con tres objetivos específicos: "1.- Definir la Capacidad Teórica de Donación de órganos según el tipo de hospital; 2.- Detectar los escapes y analizar las causas de pérdidas de potenciales donantes de órganos como herramienta para la identificación de posibles puntos de mejora, y; 3.Describir los factores hospitalarios que tienen impacto sobre el proceso de donación” (ONT, 2010).

${ }^{139}$ Según estimaciones de Cuende y De la Rosa (2008:157), sobre los mismos datos recogidos en el Cuadro 2.3., y para el periodo 1998 a 2006, el número medio de muertes encefálicas en UC fue de 2.250 y el de donantes de 1.240.
} 
CUADRO 2.3.: INDICADORES PARA EVALUAR LA CALIDAD DEL PROCESO DE DONACIÓN. AUTOEVALUACIÓN. 1998-2009

\begin{tabular}{|c|c|c|c|c|c|}
\hline & 1998 & 2000 & 2003 & 2005 & 2009 \\
\hline \multicolumn{6}{|l|}{ DATOS GENERALES } \\
\hline Hospitales & 42 & 68 & 107 & 109 & 131 \\
\hline Exitus en hospital & 35.964 & 59.198 & 99.194 & 98.560 & 112.826 \\
\hline Exitus en UC & 6.230 & 13.012 & 19.633 & 17.360 & 19.894 \\
\hline Muertes encefálicas & 783 & 1.571 & 2.220 & 2.304 & 2.409 \\
\hline Donantes reales & 365 & 722 & 1.185 & 1.267 & 1.447 \\
\hline \multicolumn{6}{|c|}{ CAPACIDAD GENERADORA DE MUERTES CEREBRALES (ME) } \\
\hline \% ME / Exitus hospital & 2,2 & 2,7 & 2,2 & 2,3 & 2,14 \\
\hline \% ME / Exitus en UC & 12,5 & 12,1 & 11,3 & 13,3 & 12,1 \\
\hline \multicolumn{6}{|l|}{ EFECTIVIDAD GLOBAL } \\
\hline \% Donantes/ ME & 46,6 & 45,9 & 53,4 & 55,1 & 60,1 \\
\hline
\end{tabular}

Fte: (ONT, 2010)

Igual de relevante para este trabajo es el análisis de las "causas de pérdida" durante el proceso de donación. Análisis que la misma ONT reconoce como fundamental para identificar los posibles puntos de mejora con el propósito de diseñar e implementar acciones para alcanzar ese objetivo. En el Cuadro 2.4. se recogen datos porcentuales sobre las distintas causas agregadas que han provocado la pérdida de donaciones de ME; los mayores porcentajes de pérdidas de donantes se producen por “contraindicaciones médicas” (infección bacteriana; enfermedad tumoral maligna; fallo multiorgánico inevitable; etc.) y "negativas familiares" (negativa previa del donante; dudas sobre la muerte cerebral; dudas sobre la integridad del cuerpo; causas religiosas, problemas con el personal sanitario; etc.). La cuantía de ambas se ha reducido durante el periodo de referencia así como la de las ME por “escape”, es decir, por no haber sido comunicadas a la coordinación de trasplantes pese a no presentar contraindicaciones. De las 2.409 muertes encefálicas producidas en los hospitales adscritos al programa durante el año 2009 se pudo iniciar la extracción de órganos en 1.447 donantes mientras que se “perdieron” 962 donantes. Al margen de las contraindicaciones médicas y las pérdidas por escape, no se pudo iniciar la extracción en $400 \mathrm{ME}$, de las que en 311 casos fue por negativa familiar (entre otras razones: 130 por negativa previa del donante; 8 por dudas muerte cerebral; 13 por dudas integridad del cuerpo; 14 por causas religiosas). 


\begin{tabular}{|l|c|c|c|c|c|}
\hline $\begin{array}{l}\text { CUADRO 2.4. CAUSAS DE PÉRDIDAS DURANTE EL PROCESO DE DONACIÓN. Porcentaje } \\
\text { sobre el total de muertes encefálicas (ME). 1998-2009. (PÉRDIDAS DESAGREGADAS POR } \\
\text { MOTIVOS EN 2009) }\end{array}$ \\
\hline \multicolumn{1}{|c|}{ por escape } & $\mathbf{1 9 9 8}$ & $\mathbf{2 0 0 0}$ & $\mathbf{2 0 0 3}$ & $\mathbf{2 0 0 5}$ & $\begin{array}{c}\mathbf{2 0 0 9} \\
(962)\end{array}$ \\
\hline ME no Comunicadas & 4 & 3 & 2,5 & 4,2 & $\begin{array}{c}1,1 \\
(27)\end{array}$ \\
\hline & 29,1 & 30,2 & 29,3 & 27 & $\begin{array}{c}22,5 \\
(535)\end{array}$ \\
\hline $\begin{array}{l}\text { Contraindicaciones médicas } \\
\text { (incluye no comunicadas) }\end{array}$ & 5,5 & 3,7 & 3,2 & 3,1 & $\begin{array}{c}2,3 \\
(47)\end{array}$ \\
\hline $\begin{array}{l}\text { Problemas mantenimiento } \\
\text { (incluye no comunicadas) }\end{array}$ & 13,1 & 16,6 & 11,7 & 11,4 & $\begin{array}{c}12,9 \\
(311)\end{array}$ \\
\hline Negativas familiares & 0,1 & 0,4 & 0,3 & 0,1 & $\begin{array}{c}0,1 \\
(3)\end{array}$ \\
\hline Negativas judiciales & 1,1 & 0,2 & 0,2 & 0,1 & $\begin{array}{c}0,1 \\
(2)\end{array}$ \\
\hline $\begin{array}{l}\text { No confirmada defunción legal } \\
\text { por ME }\end{array}$ & 0,4 & 0,5 & 0,5 & 1,1 & $\begin{array}{c}0,8 \\
(20)\end{array}$ \\
\hline Ausencia de receptor adecuado & - & 0,6 & 0,4 & 0,4 & $\begin{array}{c}0,4 \\
(10)\end{array}$ \\
\hline Problemas organizativos & & & & & 1,7 \\
\hline
\end{tabular}

Fte: (ONT, 2010)

Obviamente, una de las causas en las que más está trabajando la ONT para reducir su impacto y así poder incrementar el número de donantes es la negativa familiar. Frente a las dudas que por razones contraintuitivas conlleva la muerte encefálica, la ONT ha construido una estrategia de actuación protocolorizada mediante entrevista para comunicar la muerte cerebral a las familias y posteriormente solicitarles que accedan a la donación de los órganos de su familiar fallecido (Gómez y De Santiago, 2008). Estrategia denominada modelo Alicante en la que se explica de forma minuciosa al personal médico encargado de conseguir donaciones las actitudes y comportamientos a desarrollar en ese tipo de entrevistas. Entre los argumentos utilizados en ese protocolo cabe destacar por ejemplo (el subrayado es nuestro):

"Los profesionales sanitarios debemos ayudar a estas familias a aceptar y entender la muerte encefálica de igual manera que a los familiares de los pacientes que fallecen en asistolia. Muerte sólo hay una, lo que cambia es la forma de llegar a ella. Dar falsas esperanzas por ver que su corazón todavía se mueve y respira gracias a un respirador impide que inicien su proceso de duelo de una manera normal...

Nosotros sólo utilizaremos la palabra «muerte» ante la evidencia de que no entienden, no quieren y no pueden comprender y la utilizaremos en tono bajo y grave pues es una palabra de gran contenido emocional. Debemos de ser cautos para no confundir a los familiares con términos como "prácticamente muerto», «diferentes formas de morir», "es como si estuviera muerto», etc. Sin embargo se deben utilizar frases como «esto es el final», «su cerebro ya no vive», etc. «Ya no podemos hacer nada más por él»...

Explicación de la muerte:

- Iniciar la explicación desde sentimientos propios de dolor.

Ej.: «Siento tener que informarle de que las pruebas realizadas...».

- Introducir suavemente el concepto de muerte mediante expresiones que los conduzcan a evidenciarla. 
Ej.: «Desgraciadamente no han dado el resultado esperado» (pausa)...

Evitaremos adjetivar la muerte con «cerebral», pues esto induce a confusión de los familiares. Hablaremos de muerte. Posteriormente, cuando deseen verlo, les explicaremos que lo van a ver igual que en anteriores visitas, contestando a las preguntas/dudas que les surjan..." (Gómez y De Santiago, 2008).

Se ha señalado más arriba que la definición de muerte, propuesta en el Informe de la Comisión Presidencial, fue adoptada sin oposición en múltiples países, entre ellos, como se ha visto, España. Singer (2002:209) vincula esa aceptación pacífica de la redefinición de muerte asentada también en la muerte cerebral a que, en principio, la opinión pública percibía que un cerebro irreversiblemente dañado no podía recuperar la conciencia, por lo que no tenía sentido mantener el cuerpo. De lo que se deducía que, con la nueva definición de muerte, no se perjudicaba a los pacientes con muerte cerebral y se "beneficiaba a todos los demás: a sus familias, los hospitales, los cirujanos de trasplantes, los que necesitaban uno, a los que temían que pudieran un día ser conectados a un respirador después de que su cerebro hubiera muerto, a los contribuyentes y al gobierno”. Estrategia puramente pragmática, soportada en una rutina mecánica, al servicio de los vivos quienes, como afirma Berger, son el centro de los muertos. Estrategia que sin embargo comporta un coste, no es neutra ni gratuita, ya que, siguiendo a Jonas (1997:158), aunque no es muy elevado el número de personas que cada año es declarada en muerte encefálica, constituye un ejemplo paradigmático de cómo los seres humanos se han convertido en rehenes incondicionales de los avances cientifico-técnicos: "Ejemplifica la colaboración de todos esos factores que nos inclinan a dejar seguir su curso a los nuevos logros de la técnica debido a sus beneficios palpables, a doblegarnos al dictado tecnológico de la cosificación de nosotros mismos, incluso a adaptar nuestro sentimiento irracional, nuestras sensibilidades profundas, a lo que en un momento se ha vuelto posible”. 


\section{CAPÍTULO 3.- DELIMITACIÓN Y CARACTERIZACIÓN DEL(OS) DISCURSO(S) SOBRE LA MUERTE}





\title{
CAPÍTULO 3: DELIMITACIÓN Y CARACTERIZACIÓN DEL(OS) DISCURSO(S)
} SOBRE LA MUERTE

\begin{abstract}
“No entres dócilmente en esa noche quieta. La vejez debería delirar y arder al final del día; furia, furia contra la agonía de la luz”
\end{abstract}

D. Thomas

Al ser la idea de la muerte un producto cultural de la sociedad, el entorno circundante conforma inevitablemente los perfiles de la experiencia de la muerte humana. El sistema de muerte imperante mediatiza dicha experiencia. En efecto, dado que en su mayor parte el comportamiento humano es un producto de las normas y los valores culturales, de las estructuras sociales y de la interacción con otros miembros de la sociedad concreta en la que se vive, el morir y la muerte humana quedan definidos por el tiempo y el lugar específicos en el que ocurren. En este sentido, y como ya se ha comentado, las experiencias de morir y de muerte difieren notablemente entre una persona moribunda que se encuentra en su hogar, rodeada del calor de sus seres queridos, sintiendo la explosión de sentimientos que la acompañan, y otra que muere sola en un espacio aislado de un hospital, escoltada únicamente por la fría maquinaria médica y sus ritmos mecánicos de control. Tampoco es la misma experiencia morir en una sociedad en la que se niega la muerte que en otra en la que se la acepta como una parte natural de la vida. En términos generales, por tanto, "el modo en que uno muere es un reflejo del camino en que uno vive” (Moller, 1996:4), es decir, las formas de morir y de enfrentar la muerte en una sociedad en un momento histórico dado no sólo muestran el papel de los muertos en ella, sino que también revelan a su 'negativo`complementario, la forma de vida que la caracteriza.

No obstante, algunos autores consideran que por debajo de la particular implementación social de las experiencias del morir y de la muerte que caracterizaría a cada contexto histórico concreto, subyacen a lo largo de la historia concepciones de largo recorrido temporal sobre cómo vivir y morir que se retroalimentarían con aquéllas. Así, no sólo las condiciones sociales específicas determinarían las formas de vivir y morir, sino que, más ampliamente, éstas se verían mediatizadas también por otras formas de vivir y morir de larga data que las envolverían. De esta forma, el que el modo de vida condicione el modo de morir, y viceversa, sería válido tanto para los individuos concretos como para la sociedad como un todo histórico.

Efectivamente, estudios antropológicos e históricos muestran cómo entre las diversas sociedades, y en una misma sociedad en momentos distintos, los mecanismos de respuesta para enfrentarse a la muerte, combatiéndola o deseándola, han sido diferentes dependiendo de sus 
condiciones de existencia y de la conceptualización de la misma, y que, además, esos mecanismos no han permanecido inmutables en el tiempo para cada una de ellas. Sin embargo, historiadores de las mentalidades ${ }^{1}$ como Vovelle (1985) y Ariès $(2000,1983)$, han demostrado la existencia de esos patrones duraderos de morir y muerte que subyacen en las formas históricas concretas de vivir y morir retroalimentándose con ellas. Con una perspectiva de larga duración, rastreando datos cuantitativos y cualitativos desde múltiples fuentes, algunas de ellas poco convencionales -además del recurso tradicional a los testamentos, también se han utilizado símbolos, representaciones iconográficas, devocionarios populares, lápidas, exvotos, altares, etc. -, han buscado a lo largo de la historia de Occidente identificar en las distintas épocas la mentalidad que da sentido al mundo, esto es, la cosmovisión "que da forma y organiza el destino de los grupos humanos más allá de niveles de producción, tecnología, población y comercio” (Reséndez, 2007:6). En el caso de la muerte, Vovelle (1985:104) denomina a esas representaciones permanentes de la misma $<<$ discursos sobre la muerte $>>$, que son como una especie de residuo psicológico irreductiblemente estable, conformado por ideas, juicios, conceptos y creencias, compartidos por todos los individuos de la sociedad. Discursos colectivos, por tanto, en gran parte inconscientes, que se expresan a través de la repetición de prácticas rituales concretas muchas de las cuales se cumplen involuntariamente. Con cierta ironía este autor resume la evolución histórica de los discursos sobre la muerte como un proceso dominado inicialmente por el discurso mágico que con el tiempo sería sustituido por el discurso religioso, hegemónico e incluso único durante un periodo dilatado del tiempo. En ambos se otorgaba primacía al componente metafísico de la muerte: ésta quedaba explicada por el más allá. Posteriormente, se afianzó un discurso laico en "diferentes formas: filosófica, científica, cívica”, hasta llegar a la época contemporánea, que estaría marcada por la "proliferación del discurso literario, en libertad, sobre la muerte”. Esta proliferación de los discursos sobre la muerte en las sociedades contemporáneas no sería más que el resultado de su propia complejidad, además de que en las mismas coexistirían la mentalidad característica dominante con los restos heredados de mentalidades anteriores (Bouthoul, 1971:10).

En este capítulo se aborda inicialmente la aportación de Ariès sobre la evolución de los sucesivos patrones generales de morir y muerte subyacentes en la sociedad occidental. A pesar de las insuficiencias metodológicas y las críticas recibidas, que se exponen más adelante, el modelo propuesto por Ariès es el más conocido y utilizado para enmarcar históricamente las actitudes generales ante la muerte. Sobre esa base histórica, a continuación se desarrolla la tipología de Walter sobre los modelos de muerte presentes en la sociedad occidental

\footnotetext{
${ }^{1}$ La historia de las mentalidades es una manera de abordar la forma de hacer historia tanto como un tema dentro del campo de la historia. Vovelle (1985:19) la define como "el estudio de las meditaciones y de la
} 
contemporánea. Al hilo de la misma, y de los cambios estructurales y culturales acaecidos durante los dos últimos siglos, en especial los relativos a las mutaciones en el sistema capitalista, se examinan finalmente los discursos dominantes en las sociedades desarrolladas en la actualidad, se profundiza en el papel jugado por el sistema de muerte como instrumento de control social, y se exponen los argumentos utilizados en el debate sobre si la muerte es o no un tabú en esas sociedades.

\subsection{PATRONES GENERALES SOBRE EL MORIR Y LA MUERTE}

"Sólo me restan los huesos, un esqueleto parezco, descarnado, demacrado, sin pulpa.

Mi cuerpo desciende adonde todo se descoyunta"

P. de Ronsard

Utilizando como hilo conductor central de su trabajo la propuesta de Morin (1974a), examinada en el Capítulo 1 de esta Tesis, sobre la existencia de una relación entre la actitud ante la muerte y las variaciones de la conciencia de uno mismo -el sentido del destino individual o del destino colectivo-, Ariès ${ }^{2}$ (1983) construye un itinerario sobre la evolución de la idea de la muerte en las culturas cristianas occidentales desde la temprana Edad Media, siglo V, hasta la segunda mitad del siglo XX. Tomando como referencia cuatro elementos psicológicos -la conciencia de sí mismo; los otros como defensa de la sociedad contra la naturaleza salvaje; la creencia en la sobrevida, y; la creencia en la existencia del mal-, Ariès plantea la existencia durante ese periodo de cinco modelos de muerte sucesivos en las sociedades occidentales: la Muerte Domada, la Muerte Propia, la Muerte Lejana y Próxima, La Muerte del Otro, y la Muerte Invertida (Cuadro 3.1.).

En líneas generales, del siglo $\mathrm{V}$ al XIX, periodo en el que se insertan los cuatro primeros modelos de muerte, la población europea se enfrentaba abiertamente a la muerte de forma habitual, defendiéndose de su amenaza por medio de fuerzas sociales tradicionales como la comunidad, la espiritualidad y el ritual. En el siglo XIX emerge un nuevo modelo general de

relación dialéctica entre las condiciones objetivas de la vida de los hombres y la manera en que la cuentan y aun en que la viven".

${ }_{2}^{2}$ A diferencia de los análisis cuantitativos de otros historiadores de las mentalidades, como Vovelle, el análisis de Ariès (2000:9-19) se basa, como él mismo reconoce, en una multiplicidad heterogénea de documentos de todo tipo en los que intenta descifrar, "más allá de la voluntad de los escritores o artistas, la expresión inconsciente de una sensibilidad colectiva”. En el origen de su interés por estudiar las actitudes ante la muerte se encuentra, como en sus estudios sobre la familia, el contrastar si las manifestaciones contemporáneas del sentimiento que la rodeaba, en las décadas de 1950 y 1960, por ejemplo, las visitas a los cementerios en el mes de Noviembre, la piedad por los muertos o la veneración por las tumbas, eran antiguas o si, por el contrario, se incurría en el hábito de atribuir orígenes lejanos a sentimientos que en realidad eran recientes en el tiempo, lo que, paradójicamente, supondría reconocer que se habían creado mitos en la época del progreso científico. 
enfrentamiento de la muerte, la Muerte Invertida, que está en la base de la multiplicidad de actitudes ante la muerte características de las sociedades occidentales en la actualidad. A continuación se realiza una síntesis de los modelos de muerte propuestos por Ariès en la que, obviamente, se presta especial atención al que predomina en la actualidad pero en la que también se fija la mirada en algunas características de los modelos anteriores que han persistido hasta hoy. Síntesis que permite contrastar la profundidad de los cambios acaecidos en este ámbito esencial de la vida humana.

\subsubsection{LA MUERTE DOMADA}

\author{
"Toda luna, todo año, \\ todo día, todo viento, \\ camina y pasa también. \\ También toda sangre llega \\ al lugar de su quietud”
}

Ch. Balam

Este modelo de muerte se inicia en la temprana Edad Media, siglo V, y se extiende por más de un milenio, aunque a partir del siglo XI comienzan a surgir mutaciones de las que se derivan los modelos siguientes. Durante ese tiempo la muerte se muestra “acrónica”, es decir, parece inalterada. A partir de los cuatro parámetros psicológicos señalados, se pueden resumir las características básicas de este modelo de muerte como sigue:

La muerte era algo natural para las gentes de la época, que estaban constantemente esposados a ella; no era una posibilidad remota en el futuro, sino la verdadera dominante de la vida cotidiana ${ }^{3}$. Los que morían estaban advertidos, sabían lo que les iba a pasar, era un reconocimiento espontáneo que les venía dado por signos naturales más que por una premonición sobrenatural o mágica. Esta conciencia de la proximidad del fin les permitía prepararse espiritualmente para ese momento y activaba la repetición de gestos rituales sencillos, dictados por antiguas costumbres ${ }^{4}$, a modo de defensa contra los miedos por el morir y la muerte ya que ofrecían un significado, una racionalización, para un suceso inexplicable de otra manera. Eran ritos civiles en los que la Iglesia sólo intervenía para absolver (Ariès, 1983:139). En ellos la persona moribunda, en su lecho de muerte, jugaba un papel muy activo

\footnotetext{
3 “El hombre de aquellos tiempos estaba inmediata y profundamente socializado... la socialización no separaba al hombre de la naturaleza, sobre la cual él no podía intervenir sino por el milagro. La familiaridad con la muerte es una forma de aceptación del orden de la naturaleza... El hombre experimentaba en la muerte una de las grandes leyes de la especie y no procuraba ni escapar de ella ni exaltarla" (Ariès, 2000:43-44).

4 "En el cristianismo primitivo, el muerto era representado con los brazos extendidos en la actitud del orante. Se espera la muerte echado, yacente. Esta actitud ritual viene prescrita por los liturgistas del siglo XIII. <<El moribundo -dice el obispo Guillaume Durand de Mende-, debe estar echado de espaldas para que su rostro mire siempre al cielo >>. Esta actitud no es la misma que la de los judíos, conocida por las descripciones del Antiguo Testamento: los judíos se volvían hacia la pared para morir” (Ariès, 2000:29).
} 
tomando sus disposiciones últimas en una ceremonia organizada por ella misma, que presidía y seguía según un procedimiento socialmente tasado y sin desviarse de él ${ }^{5}$. Porque la muerte, como la vida, era ante todo un acto social ${ }^{6}$. La pérdida de un individuo constituía una amenaza para el grupo, que se debilitaba, por lo que era necesario reparar esa pérdida para así recomponer la unidad y constitución del grupo, lo que se hacía mediante esa ceremonia ritual de tránsito. Ceremonia pública que se desarrollaba en la habitación de la persona moribunda, convertida en lugar público con acceso libre a familiares, amigos y vecinos, cuya función era resaltar la fusión/inmersión del individuo con/en su grupo y la centralidad de éste en la vida social. Con la misma se expresaba "la convicción" de que la vida de cualquier miembro del grupo no constituía un destino individual para sí mismo, sino que aquél formaba parte de una cadena ininterrumpida por la que se aseguraba la continuidad del grupo. Así, el individuo que moría, y los vivos que lo rodeaban, asistían a un ritual solidario que los enlazaba comunitariamente entre el pasado y el futuro. Rituales de muerte de los que Ariès destaca su simplicidad y el que fueran aceptados y celebrados sin dramatismo, sin gran impacto emocional. Durante "siglos o milenios" la actitud tradicional ante la muerte fue a la vez familiar, próxima e indiferente, de ahí que Ariès (2000:32-34) la denominara `muerte domada'. No era por tanto "un drama personal, sino la prueba de la comunidad encargada de mantener la continuidad de la especie” (Ariès, 1983:500). Por ello, sólo la muerte súbita e inesperada provocaba espanto y era considerada una maldición ya que no permitía el arrepentimiento y sobre todo privaba al individuo de su muerte, además de poner en peligro la capacidad de readaptación de la comunidad ante la pérdida. Ese tipo de muerte era considerada fuente de vergüenza social, ya que se la percibía como un signo del descontento de Dios, no debiéndose hablar sobre ella cuando se producía.

La muerte de un componente del grupo era temida no sólo porque lo debilitaba, sino sobre todo porque "abría una brecha en el sistema de protección alzado contra la naturaleza y su salvajismo”. Según Ariès (1983:500), la precariedad de la vida diaria y la necesidad de un control social que permitiera la supervivencia del grupo, asegurando "la organización del trabajo”, el mantenimiento del orden y la moralidad, y evitando los ataques ciegos de la

\footnotetext{
${ }^{5}$ La persona moribunda, yaciendo en el lecho de muerte y arropada por su comunidad, realizaba en primer lugar un lamento por la vida evocando a los seres y cosas amados, a continuación reconocía y pedía perdón a sus familiares, compañeros, etc., a la par que éstos le correspondían en la misma dirección; finalizada esa especie de catarsis era el momento "de olvidar el mundo y de pensar en Dios”. Por último, el sacerdote daba la absolución y esperaba serenamente a la muerte (Ariès, 2000:31-32).

${ }^{6}$ A propósito de la `muerte domada', Verdú (“La muerte a los cien”, en EL PAÍS, 19/02/98), comenta: "Era tremendo morir, pero carecía de esa trágica condición que ha hecho a la muerte personalmente horrenda. Antes de tomar conciencia individual, la muerte carecía también de intencionalidad personal. No venía a ensañarse con nosotros, sino que existía como una fatalidad global, flotando en medio de la impiedad de las plagas, las hecatombes o las guerras. No moría uno, sino que quedaba muerto. No se le
} 
naturaleza, determinó que desde épocas muy primitivas, anteriores al cristianismo, los seres humanos no aceptaran al sexo y a la muerte como meros "datos brutos de la naturaleza”. Las potencias disruptoras que ambos comportan constituían los puntos más débiles de la arquitectura social que era necesario controlar, para lo que mediante una estrategia tranquilizadora primero se les asimilaba a las fuerzas descontroladas de la naturaleza, para después atemperar "los delirios pasionales” y “los desgarramientos de la muerte” canalizándolos mediante los procesos de ritualización mencionados, buscando controlar su desmesura. Así, por ejemplo, aunque la muerte era familiar y próxima, el mundo de los vivos debía estar separado del de los muertos porque se los temía, y también su proximidad. Para ello se situaba a los cementerios fuera de las ciudades y uno de los objetivos de los cultos funerarios era precisamente proteger a los vivos de la contaminación por los muertos, que no retornaran y les importunaran (Ariès, 2000:34). No obstante, esta situación cambió a partir del siglo VI cuando se empezó a instalar la creencia, de origen africano, del culto a los mártires y santos, y la gente buscó la protección de éstos frente a los malos espíritus. Se extendió la idea de asociar los propios cuerpos a los huesos de los mártires y santos, por lo que el miedo a estar cerca de un cadáver declinó y el cementerio mismo comenzó a ser definido como un lugar sagrado, desapareciendo poco a poco la distinción entre los suburbios, donde se enterraba a los muertos, y la ciudad. En algún momento del siglo VIII, los cementerios fueron movidos al interior de las ciudades y los muertos entran en ellas, de las que habían estado alejados durante milenios, siendo enterrados dentro de las iglesias o en los patios de las mismas ${ }^{7}$ (Ariès, 2000:35-36). Los cementerios se convirtieron en el centro de la vida social, un lugar de encuentro y de reunión para comerciar, danzar, jugar o simplemente compartir una velada como en una plaza pública. Eran algo similar a los grandes centros comerciales de la actualidad, y con su bulliciosa atmósfera pública cumplían la importante función social de regularizar y normalizar la presencia de la muerte entre los vivos (Moller, 1996:6).

Según las distintas religiones de salvación, con la muerte física no finalizaba la vida de los individuos ya que ésta se extendería más allá de la vida terrenal; de hecho, se extendería hasta la eternidad. En el caso del cristianismo occidental, durante ese periodo de tiempo se creía que esa sobrevida sería un sueño pacífico en el que los muertos esperarían el verdadero fin de la

daba muerte especial, sino que participaba, como era común, de una circunstancia letal. Pensando así, lo fatal era psicológicamente más soportable”.

${ }^{7}$ Aunque las personas adineradas “compraban” la proximidad de ser enterradas junto a los restos de santos y mártires, y la mayoría de la población era enterrada en grandes $<<$ fosas de pobres $>>$, con el tiempo los restos de unos y otros eran removidos y trasladados a osarios. No existía por tanto el concepto moderno de nicho en propiedad, los difuntos no tenían un espacio propio. "En la Edad Media, y todavía en los siglos XVI y XVII, poco importaba la destinación exacta de los huesos con tal que se quedaran cerca de los santos o en la iglesia, cerca del altar de la Virgen o del Santo Sacramento. El cuerpo era confiado a la Iglesia. Poco importaba lo que la Iglesia hiciera de él, con tal de que lo conservase en su recinto sagrado" (Ariès, 2000:40). 
vida al final del mundo, cuando los cuerpos resucitarían para unirse al alma, resurrección en la gloria, alcanzando la vida eterna ${ }^{8}$. En consonancia con el resto de los elementos de la vida social en los que la atención se centraba casi enteramente en este mundo y en sus actividades actividades de una vida responsable en una comunidad llamada a servir a Dios (Morgan, 1995:31)-, existía una imagen de destino colectivo para toda la humanidad -el mismo para la muerte de todas las personas-, en la que no había sitio para juzgar la responsabilidad individual, por lo que todos serían salvados teniendo asegurada la supervivencia gloriosa y no había ningún miedo al castigo. Excepto para "los malvados, los que no pertenecían a la Iglesia”, los que morían de repente y en privado, "que no sobrevivirían a su muerte, no se despertarían y serían abandonados al no ser” (Ariès, 2000:45).

A pesar de su ritualización para domesticarla, la muerte en ningún momento era percibida como un fenómeno neutro, siempre constituía una desgracia cuyo origen estaba, según el cristianismo, en el pecado original. Como señala Ariès (1983:501-502), éste constituye uno de los mitos con raíces más profundas en las mentalidades populares que "respondía a un sentimiento general de la presencia constante del mal” inseparable del ser humano.

\title{
3.1.2. LA MUERTE PROPIA
}

\author{
“¡Señor, Señor, la muerte! \\ Se me cuaja la boca al pronunciarla, \\ se me amarga la lengua, se me nublan los ojos... \\ Nadie la puede ver de frente, por fortuna, \\ cuando llega a buscarnos. \\ Es lo mismo que el sueño. \\ La muerte es superior a nuestras fuerzas. \\ ¡Si no estuvieras Tú!”
}

\section{J. M. Valverde}

La imagen general y predominante de la muerte del modelo Muerte Domada prevaleció hasta el siglo XVIII. No obstante, durante la baja Edad Media, a partir de los siglos XI y XII, surgieron modificaciones en dos de los parámetros psicológicos de referencia (en la conciencia de sí mismo y en la creencia en la sobrevida) que provocaran la emergencia de un nuevo modelo de muerte asentado en el tradicional, la Muerte Propia, en el que, poco a poco, la idea de destino colectivo fue desapareciendo surgiendo la preocupación por el sentido del destino individual, que aportó un cariz dramático y personal al enfrentamiento con la muerte. Los otros dos parámetros (la defensa contra la naturaleza y el sentido del $\mathrm{mal}^{9}$ ) se modificaron más

\footnotetext{
8 “Esta concepción de la sobrevida como un reposo o un sueño pacífico duró mucho más tiempo de lo que podría pensarse. Es sin duda una de las formas más tenaces de las viejas mentalidades” (Ariès, 1983:501).

9 Elemento capital en el mantenimiento del sistema tradicional, Ariès (1983:503) destaca que era "necesario para la economía del testamento y para el mantenimiento de un amor por la vida, fundado en parte en la conciencia de su fragilidad”.
} 
sutilmente, en menor medida el segundo, asegurando la estabilidad secular del modelo tradicional evitando un cambio brusco en el mismo (Ariès, 1983: 502-504).

Inicialmente reservada a la élite poderosa, adinerada e ilustrada, además de a los monjes y canónigos, desde mediados de la Edad Media comenzó a emerger una relación desconocida entre la muerte de cada cual y la conciencia de su individualidad por la que los individuos se reconocían a sí mismos en su muerte: descubrían la propia muerte (Ariès, 2000:61). Este cambio, que está estrechamente relacionado con la transformación de la creencia en el Juicio Final que se comenta más abajo, llevó a tomar conciencia del yo individual desligado del destino colectivo de la humanidad. Emergencia de un individualismo en el que los actos de los individuos podrían ser evaluados como buenos o malos según fueran sus elecciones entre el bien y el mal. Es decir, se desarrolló la idea de una distinción social entre el bien y el mal aplicada a los actos individuales cuyo balance final conformaba una biografía unificada, que era evaluada en el lecho de muerte, momento excepcional en que la individualidad recibía su forma definitiva (Moller, 1996:7). Evaluación en la que el testamento se convirtió en el instrumento esencial para tener una buena muerte al "asegurar la continuidad entre el más acá y el más allá,... para salvar el amor de la tierra y para invertir en el cielo” (Ariès, 1983:502). Era, ante todo, un acto religioso impuesto por la Iglesia, incluso a los que menos tenían, bajo pena de excomunión ${ }^{10}$. Algunos episcopados españoles, por ejemplo, negaban la extremaunción a quien no hubiera hecho su testamento e, incluso, al no recibir los sacramentos se les podía negar la asistencia médica ${ }^{11}$ (Lorenzo Pinar, 1991:23). Además del reparto de la herencia, el testamento recogía opiniones personales sobre sus seres amados y su apego a las cosas, cláusulas piadosas -declaraciones de fe-, y disposiciones para asegurar la salvación del alma y el descanso del cuerpo, entre otras, puesto que también era "un permiso para <<pasar por la tierra >>. En este sentido, legitimaba y autorizaba el goce de los bienes adquiridos durante la vida” ${ }^{12}$ (Ariès, 1983:163). Otra muestra de la desaparición de la idea de destino colectivo fue la evolución

\footnotetext{
10 "Considerado como un sacramental, como el agua bendita, la Iglesia impuso su uso, lo hizo obligatorio so pena de excomunión: el que moría intestato no podía ser enterrado, en principio, en la iglesia ni en el cementerio. El redactor, el conservador de los testamentos era tanto el cura como el notario. Sólo en el siglo XVI prevaleció definitivamente el notario: durante mucho tiempo los asuntos de testamentos dependieron de tribunales eclesiásticos” (Ariès, 1983:161).

${ }_{11}$ "Algunos sínodos (salmantino y zamorano, por ejemplo), daban un plazo de dos días para cumplir con estos deberes pasado el cual no eran atendidos por el médico... El Papa Pío V puso especial hincapié en este aspecto, otorgando un plazo de tres días para la confesión del enfermo bajo la amenaza de negarle el auxilio de la ciencia médica” (Lorenzo Pinar, 1991: 39-40, citado en Gómez Sancho, 2006:70).

${ }^{12}$ A cambio de la reconciliación del pecador, la Iglesia "coge de su herencia un diezmo del muerto, que alimenta a la vez su riqueza material y su tesoro espiritual” (Ariès, 1983:161). Además del reparto de la herencia, el testamento recogía cláusulas piadosas -declaraciones de fe-, y entre otras, el orden y composición del séquito en el entierro, en el que se procuraba incluir abundante representación de sacerdotes, la disposición de misas y servicios eclesiásticos para el día del enterramiento y posteriores. "Lo más habitual era prever, 30, 100, 1.000 misas" (Ariès, 1983:150). También se hacía grabar en la
} 
producida en la construcción de las sepulturas que, siendo anónimas a partir del siglo V en Occidente, progresivamente se individualizaron desde el siglo XII al XVII, así como en el desarrollo del arte funerario, con el que se buscaba sacar del anonimato a la persona fallecida y conservar su identidad después de muerta mediante la personalización de la sepultura (Ariès, 2000:56-59).

Este cambio hacia una conciencia de destino individual está estrechamente ligado al cambio que se produjo en las creencias en la sobrevida, especialmente en las transformaciones de las creencias sobre el Juicio Final. Persistía la idea de que el fin de una persona no se producía con su muerte física, pero ya no se creía que su alma inmortal permaneciese a la espera en un sueño como en el modelo tradicional. La voluntad del individuo por afirmarse y salir del anonimato se trasladó también al más allá y el momento y lugar decisivos para actuar sobre ello eran los instantes finales en el lecho de muerte. A partir del siglo XII se produjeron cambios en la representación del Juicio Final que, según Ariès, reforzaron el proceso de individualización señalado. Por una parte, comienzan a aparecer representados juicios ante tribunales en los que se hacía el balance de la vida de los individuos, contrapesando sus acciones buenas y malas, lo que traduciría la creencia de que la persona moribunda veía recapitulada su vida entera en el momento de morir. Si el balance era favorable al bien, la persona se salvaba, en caso contrario, era condenada. Por otra parte, se suprime el tiempo escatológico entre la muerte y el final de los tiempos, con lo que el Juicio Final se traslada del segundo advenimiento al final del mundo a la habitación de la persona moribunda. En ésta se desarrolla un ritual tranquilizador similar al del modelo tradicional pero con algunas modificaciones sustantivas. Por un lado, se refuerza el protagonismo de la persona moribunda en la ceremonia de su muerte ya que se desarrolló la creencia de que, por otro lado, en la cabecera del lecho de muerte y junto a ella, que es la única que lo puede percibir aunque de manera inconsciente, se encuentran seres sobrenaturales del bien ( la Trinidad, la Virgen y toda la corte celestial) y del mal (Satán y su ejército de demonios) que, luchando por el alma de la persona moribunda, van a tratar de incidir en su última actuación. En un juicio particular en el que nadie conoce su suerte en el más allá antes de que el Juez le hubiera juzgado se decide el destino individual último. De ahí la extraordinaria difusión del Ars moriendi ${ }^{13}$. Estas creencias, asentadas en los siglos XIV y XV y que durarían hasta el siglo XIX, reflejaban que esa actitud en el momento de la muerte daba a una biografía su

iglesia, sobre piedra o metal, las decisiones testamentarias que financiaban los servicios religiosos en su memoria, a modo de defensa contra el olvido (Ariès, 2000:69).

${ }^{13}$ En el siglo XV se escribió en latín el Ars moriendi ("El arte de morir”), publicación ampliamente difundida en varios idiomas con consejos sobre los protocolos a seguir para lograr una buena muerte y morir bien. "No era un libro de preparación remota para la muerte a través de una vida virtuosa... Era un libro de “cómo hacer” en el sentido moderno, una guía completa para el negocio de morir, un método que habría de aprenderse mientras estaba uno en buena salud y saberse al dedillo para utilizarlo en esa hora ineludible” (Gómez Sancho, 2006:28). 
sentido definitivo, su conclusión. Es decir, la salvación del alma de una persona se determinaba según su actuación en la batalla espiritual entre el bien y el mal del acto final de su muerte más que por los actos de su vida. Así, el morir de una muerte buena, de carácter totalmente religioso, se hizo la llave de la salvación y, sobre todo, la posibilidad de una muerte individual mala era ahora posible. La condena y el castigo eterno se hicieron fuentes privilegiadas de terror, lo que dotó a ese enfrentamiento de un dramatismo y una carga emocional que no tenía anteriormente.

Como se ha comentado arriba, el parámetro psicológico defensa contra la naturaleza se modificó más sutilmente que la conciencia de sí mismo y la creencia en la sobrevida, no obstante, las variaciones en éstos lo afectaron. El deseo de afirmar la identidad individual y el asentamiento de la creencia de que no era necesario vivir virtuosamente puesto que una buena muerte redimía de todas las faltas cometidas en vida, según Ariés (1983:503), deberían de haber conducido a una muerte más turbadora y solitaria, alejada del ritual apaciguador del modelo tradicional. "La muerte habría podido convertirse entonces en salvaje, incluso desesperada, a fuerza de patetismo y de miedo al Infierno". No ocurrió, las disposiciones testamentarias en la dirección adecuada y un ceremonial nuevo compensaron los efectos del individualismo y las angustias que le acompañaban en el lecho de muerte. Ariès (1983:142-145) destaca en este sentido la transformación del ritual del adiós de civil a religioso; así, "el velatorio, el duelo y el cortejo se convirtieron en ceremonias de Iglesia, organizadas y dirigidas por hombres de la Iglesia” ${ }^{14}$. Por otra parte, resalta el auge de lo macabro tanto en la poesía, el teatro, la pintura y las artes gráficas, como en las miniaturas de los libros de horas, con representaciones de imágenes de carne corrompida o de esqueletos tendidos en el suelo sobre los que cabalga la muerte representada con una iconografía agresiva (esqueleto, portando arcos, flechas, redes, guadañas, relojes de arena), como enemiga de los seres humanos, simbolizando no sólo la corrupción interna de los cuerpos, sino buscando además dejar constancia, por ejemplo en la Danza de los Muertos $^{15}$, de que la muerte estaba en todas las partes, que nadie sabía cuándo y a

\footnotetext{
14 "Alrededor del muerto ya no hay tanto sitio para las grandes y largas deploraciones de antaño; ya nadie declama con voz fuerte los lamentos ni los elogios de antes. La familia, los amigos, ahora silenciosos y tranquilos, han dejado de ser los principales actores de una acción desdramatizada. En adelante, los primeros papeles están reservados a los sacerdotes, y en particular a los monjes mendicantes... Desde el último suspiro, el muerto no pertenece ya ni a sus iguales o compañeros, ni a su familia, sólo a la Iglesia.”. Otra ceremonia, el cortejo, se convirtió, a partir del siglo XII, en imagen simbólica de la muerte y de los funerales (Ariès, 1983:142-143).

15 "La danza macabra hace pensar en la muerte a los que viven despreocupados, sin pensar en su salvación, entregados al juego de las pasiones terrenales; les hace pensar en la muerte repentina, que puede sacarles inesperadamente de su existencia espléndida, su posición poderosa, de su actividades y placeres... En la danza de la muerte participan todos: papa y emperador, caballero y villano, mendigo y vagabundo, hidalga y ramera, representantes de todas las capas sociales y todas las edades. Alterna siempre un eclesiástico con una persona mundana. A cada uno lo saca a bailar un esqueleto; todos aceptan la invitación y cogidos de la mano, se incorporan al corro macabro" (Gómez Sancho, 2006:30). Un ejemplo de la omnipresencia y "democratización" de la muerte se percibe en la siguiente Danza de la Muerte recogida por Meyer (1983:141-142): “A morir voy./ Nada más cierto que la muerte cierta,/ nadie
} 
quién escogería para bailar; en definitiva, que todos eran iguales ante la muerte (Moller, 1996:9). Asimismo, y a la par de lo anterior, se desarrolló un movimiento compensatorio de defensa contra la naturaleza salvaje de la muerte por el que se la disimulaba más todavía ocultando el cadáver envuelto en un sudario cosido dentro de un ataúd, para así escamotear los rasgos de la persona muerta, cuya visión daba miedo y se volvió insostenible (Ariès, 1983:504).

\subsubsection{LA MUERTE LEJANA Y PRÓXIMA}

"El desenfreno y la muerte son dos gentiles muchachas, y la caja y la alcoba en blasfemias fecundas. Te ofrecen por turno, cual dos buenas hermanas, terribles placeres y horribles dulzuras”

Baudelaire

A partir del siglo XVI se introdujeron algunas modificaciones de profundo calado en el imaginario colectivo sobre la muerte. Los momentos cruciales y dramáticos del morir en el lecho de muerte perdieron su aura mágica y mística y se comenzó a ver a la muerte más que como un fenómeno espiritual como el cese de la vida (Moller, 1996:10). Incluso los sufrimientos emocionales de la agonía se volvieron sospechosos (Ariès, 1983:250). A esta desacralización y devaluación de la buena muerte ayudaron también los moralistas reformadores que a partir del siglo XVII lucharon contra la creencia de que no era necesario esforzarse por vivir virtuosamente puesto que para salvar el alma bastaba con tener una buena muerte (Ariès, 1983:251-255). Así, el arte de morir fue sustituido por el arte de vivir, y la llave de la salvación del alma se desplazó desde la buena muerte al ideal de llevar una vida virtuosa, "no importa cuál”, que preparara para hacer frente a una muerte que podía llegar en cualquier momento. La emergencia de un sentimiento melancólico por la brevedad de la vida, unido a que la muerte se diluía a lo largo de la duración de toda la vida y el vacío creado en ésta al llegar la muerte -la anti-vida-, incitó “a la razón” a no apegarse a la muerte. En definitiva, ya que una buena vida aseguraba una buena muerte, la preocupación por esta última se hizo más remota.

Este proceso de inversión en la sensibilidad ante la muerte constituye, según Ariés (1983:504), “un anuncio lejano e imperfecto de la gran inversión de hoy”. El control sobre la muerte ejercido hasta ese momento, domesticándola con rituales cada vez más solemnes, como la ocultación del cuerpo muerto, saltó por los aires al variar el segundo de los parámetros psicológicos, la defensa contra la naturaleza salvaje. Los diques de contención pacientemente levantados en la arquitectura social desde hacía milenios para contener a la naturaleza se

sabe el momento y hora./ A morir voy// A morir voy./ Polvo, reducido a polvo:/ la misma ley que existir me hizo/ A morir voy.// A morir voy./ A otros sigo, otros me siguen.// Ni el primero soy ni seré el 
agrietaron en los dos puntos más débiles de la misma, abriéndose la "brecha del amor" y la "brecha de la muerte”. Por ésta, en un movimiento irregular, desacompasado y discontinuo retornó a la vida social, en la época moderna, la muerte en estado salvaje. La muerte, “en lo que entonces tenía de lejano, fue acercada y fascinó, provocó las mismas curiosidades extrañas, las mismas imaginaciones y las mismas desviaciones perversas que el sexo y el erotismo. Por eso hemos llamado a este modelo diferente de los otros, la muerte lejana y próxima” (Ariés, 1983:504).

Este modelo de muerte, en el que se había atemperado la inquietud espiritual ante ella ${ }^{16}$, no implicaba sin embargo que se hubiera aminorado la preocupación por la muerte física misma, al contrario, supuso un énfasis en su materialidad inmediata y, sobre todo, fue el sustrato en el que florecieron sentimientos indefinidos y ambiguos respecto al cuerpo muerto, en contraste al miedo al mismo característico de los dos modelos anteriores. En efecto, Ariès (1983:504) resalta como ejemplo de la preocupación por la muerte física el gran miedo que “aparece entonces y sólo entonces: el miedo a ser enterrado vivo, que implica la convicción de que existía un estado mixto y reversible, hecho de vida y de muerte” ${ }^{17}$. No es que hasta el siglo XVII no se hubiera temido a la muerte aparente, al contrario, la preocupación venía de mucho tiempo atrás como atestigua la abundante literatura especializada sobre el tema o que se conocieran algunas prácticas para evitar enterramientos de vivos. Lo que ocurrió fue que todas esas "prácticas habían sido abandonadas bajo presión de la Iglesia” y la imprudencia con la que el clero que administraba hasta entonces el funeral y las sepulturas, con enterramientos que se producían antes de las veinticuatro horas después del deceso, habían derivado en "dramas bien conocidos". La Iglesia por primera vez tuvo que hacer frente a "la acusación de desenvoltura respecto a los cuerpos muertos” y la inquietud y desconfianza ante la posibilidad de ser enterrado vivo se manifestó hasta en los testamentos, en los que se incluían disposiciones para evitarlo $^{18}$. El miedo a la muerte aparente fue "la primera forma confesada y aceptable del

\footnotetext{
postrero./ A morir voy.”

${ }^{16}$ Una buena muestra de ello son los cambios producidos en los funerales y en los testamentos marcados por una decidida voluntad de sencillez en las cosas de la muerte desde finales del siglo XVII. Como también, la impersonalidad del duelo, la sencillez de las tumbas y la "innovación más sorprendente de esta época en el dominio de las sepulturas es (abandonando los enterramientos en la iglesia) el retorno al cementerio al aire libre (Ariés, 1983:269-293).

${ }^{17}$ No va a ser hasta finales del siglo XIX cuando los médicos rechazan la superstición de que la muerte aparente constituía un tiempo de muerte mixto, mezcla de vida y muerte. "Para los médicos (de los siglos XVII y XVIII), el tiempo de muerte era, por el contrario, un estado que participaba a la vez de la vida y de la muerte. La muerte no era real y absoluta hasta más tarde, hasta el momento de la descomposición. Por eso, al retardar la descomposición, se retardaba la muerte absoluta. El embalsamamiento, la conservación permitían alargar ese tiempo de la muerte-estado en el que subsistía algo de la vida.” (Ariès, 1983:335).

${ }^{18}$ Estas disposiciones aparecen por primera vez en los testamentos a mediados del siglo XVII. En el más antiguo de los consultados por Ariès (1983:332), de 1662, se recoge: “<<Que mi cuerpo sea sepultado
} 
miedo a la muerte”, y el germen del gran miedo a la muerte posterior (Ariès, 2000:151; Ariès, 1983:329-337).

Por su parte, como ejemplos de la ambigüedad con la que se llega a percibir al cuerpo muerto Ariès (1983:307-310) señala, por un lado, el que se le transformara en fuente de erotismo macabro, convirtiéndolo en objeto de deseo -necrofilia ${ }^{19}$; mito de la erección del ahorcado- y, por otro, el que se convirtiera en un medio para desvelar los secretos de la vida y de la salud ${ }^{20}$. Esta última función, que ayuda a matizar en cierta medida la sorpresa que provoca que este `asalvajamiento` de la muerte se produce precisamente en el momento de "la invención de la ciencia y de sus aplicaciones técnicas, de la fe en el progreso y su triunfo sobre la naturaleza” (Ariès, 1983:504), fue desarrollada por los médicos que reemplazaron a los hombres de la Iglesia en el tratamiento del cadáver. En una sociedad próxima a la Revolución Industrial y cada día más secularizada, se instaló la idea de que el cadáver contenía los secretos de la vida y que el conocimiento de su anatomía era básico para la comprensión de la misma. Idea que se hizo tan popular en el siglo XVII que las lecciones de anatomía se convirtieron en "una gran ceremonia social donde toda la ciudad se congregaba, con máscaras, refrescos y diversiones” (Ariès, 1983:304). Incluso, las disecciones se convirtieron en un arte de moda, siendo realizadas fuera del ámbito médico por personas adineradas en sus gabinetes privados de anatomía, lo que provocó escasez de cadáveres para los médicos, el asalto a las tumbas en los cementerios y el surgimiento de un mercado negro para cubrir la creciente demanda de cadáveres (Ariès, 1983:305-307).

\subsubsection{LA MUERTE DEL OTRO}

“Transida en la tierra, y sobre ti ese montón de nieve profunda... Lejos, lejos de todo alcance y transida en la sombría tumba, la única alegría que tuve en mi vida me ha venido de tu querida vida, la única alegría que tuve en mi vida está sepultada contigo.

E. Brontë

treinta y seis horas después de mi muerte y no antes>>. En otro de 1696 se recoge otra precaución frecuente: $<<$ Que me den antes dos cortes de navaja bajo la planta de los pies >>.

${ }^{19} \mathrm{Si}$ bien es imposible contrastar si los relatos de necrofilia de la época eran fantasía o realidad, lo cierto es que se hizo popular la idea de gustar a los muertos porque "los signos primeros de la muerte no inspirarán ya el horror y la huída, sino el amor y el deseo” (Ariès, 1983:311). Así, en buena parte de la literatura popular y en la tradición oral de la época se recogían escenas de sensualidad y deseo, protagonizadas por vivos que hacían el amor con muertos (Ariès, 1983:311-316).

20 "La muerte y el cuerpo muerto constituyen en sí mismos objetos de estudio científico, independientemente de las causas de muerte: es decir que se estudia la muerte antes de conocer sus causas, y no sólo para descubrirlas. Se mira al muerto como más tarde se miró al enfermo en su cama. Es una actitud extraña a la medicina actual, en la que la muerte no es separable de la enfermedad, de la que es uno de los dos fines, siendo el otro la curación” (Ariès, 1983:295). 
Ariès (1983:505) señala que una serie de reacciones psicológicas recorrieron Europa a lo largo del siglo XIX alterando estructuralmente los cuatro parámetros psicológicos de referencia, lo que condujo a dar un sentido nuevo a la muerte, de exaltación, de fascinación, a la par que de descontrol. La muerte dará miedo verdaderamente y dejará de ser representada a lo largo de ese siglo (Ariès, 2000:150). Si, como se ha indicado, desde finales del siglo XVI los dos puntos más débiles de la arquitectura social, sexo y muerte, habían iniciado un proceso de maridaje hasta llegar a crear a finales del siglo XVIII "un auténtico corpus de erotismo macabro", se produjo una mutación significativa en ese proceso al mezclarse con otros elementos nuevos aparecidos durante el siglo XIX. En efecto, ese cambio se originó por la conjunción, por una parte y como secuela del proceso anterior, de que se otorgara a la muerte un papel trasgresor similar al del sexo en cuanto a que "arranca al hombre de su vida cotidiana, de su sociedad razonable, de su trabajo monótono, para someterlo a un paroxismo y arrojarlo a un mundo irracional, violento y cruel” (Ariès, 2000:64). Y, por otra parte, del desarrollo del Romanticismo con el ideal de construcción de una sociedad basada en la restricción, la cortesía, la etiqueta apropiada y el decoro (Moller, 1996:12), además de una revolución del sentimiento por la que la afectividad domina al comportamiento y, sobre todo, se concentra en un número mucho más limitado de personas, en aquellas que se vuelven excepcionales, irreemplazables e inseparables (Ariès, 1983:392). El papel disruptor otorgado al sexo y la muerte amenazaba el seguimiento diario de esos ideales, y por tanto al orden que se pretendía alcanzar, por lo que emergió una "sensibilidad de pasiones sin límites ni razón” caracterizada por un "miedo cultural” hacia el sexo, el placer y, en última instancia, la muerte (Ariès, 1983:505). Ésta fue retirada de la esfera de lo erótico, sus rasgos sublimados y reducidos a la Belleza, y definida como sentimental más que como sensual. La persona muerta no será ya deseable, pero sí será admirable por su belleza personal (Ariés, 2000:65; Moller, 1996:12). De esta forma se modifica el segundo de los parámetros, la defensa contra la naturaleza salvaje, "la muerte no es ya familiar y domada, como en las sociedades tradicionales, pero tampoco absolutamente salvaje, es patética y bella”, como la naturaleza humanizada (Ariès, 1983:505).

Pero el elemento determinante del cambio de modelo se sitúa en el primero de los parámetros, la conciencia de sí mismo. Si hasta ese momento las orientaciones frente a la muerte habían evolucionado desde una percepción de la muerte como un destino universal y comunitario hasta la visión de la muerte como cierre de una biografía personal y específica, en esta época ambas perspectivas se debilitan a favor de una tercera: el sentido del Otro. No importa qué Otro, pero sobre él/ella se concentrará una afectividad sin límites, su ausencia no se soportará y su pérdida desencadenará una crisis dramática: la muerte del otro (Ariès, 1983:505). En efecto, la sustitución de la colectividad o del individuo por la familia nuclear como depositaria de un valor social cada vez más apreciado -la privacidad-, modificó el sentido y el 
objeto del miedo a la muerte. Éste permanecía pero se desvió de la muerte propia a la del ser amado. Los supervivientes no se apenaban tanto por el hecho de morir cuanto por la separación física de la persona amada, lo que llevó a que se percibiera a la muerte como el último acto de una relación única. Por ello, conmueve a la par que fascina, convirtiéndose esta mezcla en uno de los rasgos característicos del Romanticismo: la complacencia con la idea de la muerte (Ariés, 2000:66). Este nuevo modelo se materializó de forma objetiva en los cambios observados en los rituales e instrumentos de despida, que reflejan precisamente las transformaciones en las relaciones entre la persona moribunda y su familia. Así, la prosaica, formalizada y concurrida ceremonia tradicional de despida en el lecho de muerte fue desritualizada y reconstruida con una explosión espontánea de pasiones, gritos, lloros y rezos en una ceremonia generalmente limitada a los más allegados; excesos -hoy denominados duelos histéricos- que pueden ser vistos como una compensación intensiva de su dolor por una separación que les parecía intolerable. El testamento, instrumento hasta ese momento de reafirmación personal y de muestra de desconfianza hacia todos los demás, sobre todo hacia la propia familia, se laicizó y redujo para limitarse al acto legal de distribución de los bienes, constatándose un giro pro-familia en la delegación de poderes ${ }^{21}$. La nostalgia y el recuerdo, por su parte, se harán explícitamente visibles con la exageración del luto ${ }^{22}$ y en la emergencia de un nuevo culto a las tumbas y los cementerios. En este caso, y por diversas circunstancias ${ }^{23}$, emerge un nuevo "fenómeno

\footnotetext{
${ }^{21}$ Durante la segunda mitad del siglo XVIII se modificó profundamente la redacción de los testamentos en el Occidente cristiano, desapareciendo de los mismos las cláusulas de contenido religioso (los mandatos de misas y servicios religiosos y las limosnas). Esta laicización de los testamentos según Vovelle constituía uno de los signos de la descristianización de la sociedad, mientras que para Ariès testimoniaba simplemente la nueva naturaleza de los sentimientos entre la persona que testaba y sus herederos, que se habían vueltos confiados. "Relaciones de cariño han sustituido a relaciones de derecho. Parecía intolerable volver contractuales los intercambios entre seres vinculados por un afecto mutuo en una y otra vida”, por lo que sólo se consignaba en el testamento la distribución de la fortuna mientras que el resto de los apartados (opiniones, deseos, etc.) se comunicaban oralmente (Ariès, 1983:389-391).

${ }^{22}$ La doble funcionalidad del luto desde finales de la Edad Media hasta el siglo XVIII (obligando a la familia de la persona muerta a manifestar temporalmente su pena, aunque no fuera sentida; protegiendo a los que sí sentían la pena de los excesos de sufrimiento imponiéndoles un régimen temporal de vida social a cumplir hasta liberar la pena) estaba tasada socialmente y esos límites se rompieron en el siglo XIX: "el luto se desplegó con ostentación más allá de lo que se estilaba”, lo que indicaba que a la gente le costaba más que antaño aceptar la muerte (Ariès, 2000:71-72).

${ }^{23}$ Si hasta el siglo XVIII "las civilizaciones” occidentales no eran "civilizaciones de cementerio", ya que no concedieron a los muertos ni espacio ni mobiliario", desde principios del siglo XIX, "el cementerio vuelve a la topografía” (Ariès, 1983:395). Razones de salud pública, derivadas de los hedores desprendidos por los cadáveres acumulados en la iglesias y en los patios de las mismas, por una parte, y el reproche realizado a la Iglesia acusándola de "haber hecho todo por el alma y nada por el cuerpo, coger el dinero de las misas y desinteresarse de las tumbas”, por otro, habían provocado una desafección hacia los cementerios algunos de los cuales, como los parisinos, fueron cerrados a finales del siglo XVIII. En el resurgir del interés por visitar los cementerios se conjugaron tres influencias: "Los positivistas, por una parte, preconizaron el culto de los muertos como un elemento de civismo: $<<$ la tumba desarrolla el sentimiento de continuidad en la familia, y el cementerio, el sentimiento de la continuidad en la ciudad y en la humanidad>>, escribe Pierre Laffitte en 1874. Por otra parte, los católicos adoptan el culto de los muertos y lo defienden como si lo hubieran practicado siempre. Actitud paradójica, porque, un siglo antes, la Iglesia había sido en parte responsable del desafecto hacia los cementerios... Finalmente, la ciencia no dejó de manifestar su punto de vista: se demuestra que no hay ningún peligro en el hecho de
} 
religioso propio de la época contemporánea”, sin parangón en etapas anteriores en las que no se producían las visitas piadosas o melancólicas a la tumba de un ser querido. Desde la segunda mitad del siglo XVIII esto cambia y se hacen habituales esas visitas en las que se exterioriza el dolor y la pena por las personas muertas como una forma que tienen los vivos de testimoniar su veneración por ellas, porque al recordarlas se las confiere algún tipo de inmortalidad. En el culto romántico del siglo XIX está por tanto el origen de las visitas a los cementerios a principios del mes de Noviembre, la piedad por los muertos o la veneración por las tumbas. Obviamente, para ello era necesario que la tumba estuviera individualizada e identificada en un lugar exacto. Es así como comienza la concesión de sepulturas, que acabaría convirtiéndose en una forma de propiedad (Ariès, 2000:73-77).

Por otra parte, "la muerte no habría podido aparecer ligada” a la Belleza si no se hubiera modificado el cuarto de los parámetros, la creencia en la existencia del mal, al descomponerse la antigua relación que asimilaba la muerte, la enfermedad, el sufrimiento moral y el pecado, y que, como se ha señalado más arriba, se consideraba inseparable de la propia naturaleza del ser humano. Así, por influencia del pensamiento ilustrado, del incipiente proceso de secularización, se objeta la existencia del "Maligno" abandonándose poco a poco la creencia en él y en el Infierno, lo que hará desaparecer la creencia que vinculaba la muerte y el Mal y que se diluyan “todas las variedades del mal espiritual y moral” (Ariès, 1983:508). El Infierno queda reducido a una mera retórica en las conversaciones ordinarias, en algo que para "el hombre piadoso del siglo XIX, es un dogma que se aprende en el catecismo, pero que es extraño a su sensibilidad” (Ariès, 1983:393).

La desaparición del temor al Infierno transforma la percepción del Cielo, con lo que simultáneamente se modifica el tercero de los parámetros, la creencia en la sobrevida. Ariès (1983:392) resalta que, al margen de divergencias en las creencias sobre la relación entre la vida futura y la fe religiosa, y enmarcada en la revolución sentimental señalada, durante el siglo XIX imperaba una creencia común: era "como si todo el mundo creyera en la continuación, tras la muerte, de las amistades de la vida”. Así, el más allá se transforma en un <<paraíso antropomorfo>>, según expresión de Jankélévitch; ya no era tanto el hogar celestial, sino un lugar de reunión similar a las casas de la tierra en el que se reunirían aquellos a los que la muerte había separado, en el que reconstituirían los sentimiento de la tierra y estarían liberados del tiempo y de sus miserias terrestres para la eternidad. Respuesta sentimental ante la imposibilidad de aceptar la muerte del Otro que inicia el ocultamiento de la muerte: al no ser el fin del ser querido, la muerte ya no es la muerte, sino una ilusión (Ariès, 1983:393).

que los vivos habiten en las proximidades de un cementerio y que las influencias mefíticas denunciadas 


\subsubsection{LA MUERTE INVERTIDA}

"Esta palabra se ha convertido para ti en un candado con el que lo
cierras todo. Dices $<<$ muerte >>, y con ello crees haberlo dicho todo." E. Canetti

Los cambios estructurales en las actitudes ante la muerte desde el siglo XII que, como se ha relatado, modificaron sucesivamente el modelo de la muerte domada, no afectaron sin embargo al mantenimiento de un elemento básico de ese modelo tradicional de partida que subsistió hasta finales del siglo XIX: la percepción de la muerte como hecho social y público. El fallecimiento de un individuo no sólo suponía su desaparición personal, sino que alteraba las dimensiones espaciales y temporales de su grupo social, de su aldea, etc., lo que obligaba a una reestructuración del colectivo para cubrir la pérdida y retomar el funcionamiento cotidiano. Por su parte, y como se ha comentado, los rituales funerarios constituían acontecimientos públicos con los que se intentaba racionalizar/controlar a la muerte salvaje. Sin embargo, a lo largo del siglo XIX irá emergiendo, hasta cristalizar en el siglo XX, un nuevo modelo de morir y muerte que modificará incluso ese rasgo milenario. Es un nuevo modelo caracterizado por su oposición a todo lo anterior, de ahí que Ariès (1983) lo denomine la Muerte Invertida ${ }^{24}$. El morir y la muerte dejan de ser experiencias personales y sociales importantes, que dotan de sentido a la vida conformando la identidad, y pasan a ser meros sucesos personales, dramáticos y dolorosos para quien muere y sus allegados, pero que sobre todo absorben el tiempo y la energía de los demás frenando el discurrir de la vida social. La familiaridad y el enfrentamiento abierto y público de la muerte dejan paso a las actitudes vergonzantes, de ocultación y silencio características de los tabúes. Es por ello por lo que la muerte debía ser evitada, negada y, a ser posible, conquistada (Moller, 1996:15). Y así ocurrió. La necesidad de seguir viviendo sin cortapisas una vida cada vez más compleja, en una sociedad cada vez más atomizada, conllevó que aunque la desaparición de un individuo alterara profundamente a su entorno más íntimo no afectara ya a la continuidad social. A ello ayudaron sobremanera los avances científico-técnicos, que en el caso de la muerte condujeron a su medicalización, lo que, como se desarrolla más adelante, consolidó la `indiferencia’ social por la pérdida de uno de los miembros del grupo y la percepción de que el enfrentamiento a la muerte era más un problema personal que social. Paradójicamente, la muerte invertida reforzó las consecuencias de algunos de los cambios estructurales del siglo XIX, de la muerte del otro, en especial de las derivadas del afianzamiento del sentimiento de privacidad y de la progresiva focalización del mismo en el círculo aún más

\footnotetext{
un siglo antes no son más que supersticiones” (Martin-Fugier, 1992:233).

${ }^{24}$ El propio Ariès utiliza otras denominaciones para este modelo de actitudes ante la muerte: muerte negada o muerte vedada.
} 
restringido de la familia nuclear. Ariès (1983:466) resalta además la rapidez y "brutalidad” con la que se ha producido ese cambio de modelo, que en algunas zonas habría supuesto la inversión completa de las costumbres en menos de una generación.

Al igual que Weber, Ariès (1983:466-477) hace referencia a la obra de Tolstói para ilustrar en su caso la transición desde los últimos coletazos de la muerte como hecho público, en la segunda mitad del siglo XIX, hasta la muerte privada y oculta, en el primer tercio del siglo XX. Ariès se centra en la mirada profética que Tolstói vierte en La Muerte de Iván Ilich, editada por primera vez en 1886, en la que se describe la agonía y muerte de un funcionario de la burocracia zarista, Iván Ilich, justo cuando por fin había hecho realidad sus sueños profesionales y, a la par, alcanzado la posición social deseada junto a la aristocracia. Con gran carga simbólica, cuando Iván Ilich estaba en lo más alto de una escalera colocando unas cortinas en la nueva casa acorde con su posición social ideal, se cae y se golpea en un costado sintiendo un dolor interno que irá en aumento hasta convertirse en un "martirio" en los días previos a su muerte. Tolstói narra en la segunda parte de la novela ese proceso mórbido de declive, en el que la muerte social se anticipa a la muerte física, y reflexiona a través de Iván Ilich sobre cómo el sinsentido del morir y la muerte en la sociedad moderna está estrechamente vinculado al nuevo tipo de vida social que la caracteriza. Así, la soledad, el terror y la perplejidad por la carencia de significado con que Iván Ilich ${ }^{25}$ se enfrenta a su muerte no sería más que el reflejo de la cultura moderna y 'desmagificada' en la que vivía: materialismo, individualismo, carencia de vínculos familiares más allá de su familia nuclear, ausencia de relaciones comunitarias, ignorancia de la tradición y debilitamiento del sentimiento religioso. Para Tolstói, esas características de la sociedad moderna habrían propiciado la pérdida de los anclajes sociales que dotaban de sentido a la vida y a la muerte en la sociedad tradicional ${ }^{26}$; en el caso concreto de la muerte, los valores e instituciones sociales modernos no conformaban ya un sistema de apoyo y consuelo como el que aportaban los rituales comunitarios ${ }^{27}$. En última instancia, la búsqueda del interés propio y el esfuerzo por ascender socialmente tenían como contrapartida el precio de la soledad, y ésta se

\footnotetext{
25 "En lo más hondo de su alma se daba perfectamente cuenta de que se moría, pero él no estaba acostumbrado a ello; además, no lo comprendía, no podía comprenderlo... No lo podía comprender y se esforzaba por alejar de sí este pensamiento falso, erróneo, morboso y sustituirlo por otros pensamientos justos y saludables. Pero aquél no era sólo un pensamiento; parecía realidad; se presentaba de nuevo y se detenía ante él.” (Tolstói, 1981:61-62).

${ }^{26}$ Tolstói utiliza en su relato como contrapunto representativo de la sociedad tradicional a Guerásim, un joven criado mujik que atenderá en todo momento a Iván Ilich en su enfermedad y agonía. De hecho, será a la única persona a quien Iván Ilich tolerará cerca precisamente por no mentirle sobre su situación y por afrontarla con naturalidad: "Guerásim era el único que no mentía; en todo se veía que era el único en comprender de qué se trataba sin considerar necesario disimularlo; sencillamente, tenía compasión del señor desmedrado y débil. Incluso una vez dijo sin tapujos, cuando Iván Ilich le mandaba retirarse:

Todos moriremos. ¿Por qué, pues, no dar una mano?” (Tolstói, 1981:70).

27 "No cabía engaño: algo se producía en él, terrible, nuevo y tan importante como nunca lo había sido nada en su vida. Lo sabía él y nadie más. Quienes le rodeaban, o bien no lo comprendían, o no querían comprenderlo y pensaban que todo seguía, como antes, su curso normal.” (Tolstói, 1981:52).
} 
hacía inconmensurable en el proceso de la muerte: "Bajó los pies, se acostó de lado, sobre el brazo, y sintió lástima de sí mismo. Esperó sólo a que Guerásim saliera a la habitación contigua y no se contuvo más: se puso a llorar como un niño. Lloró por su impotencia, por su terrible soledad, por la crueldad de las personas, por la crueldad de Dios, por la ausencia de Dios.

$<<$ ¿Por qué has hecho todo esto? ¿Por qué me trajiste aquí? ¿Por qué, por qué me torturas tan espantosamente?...>>

No esperaba respuesta y lloraba de que no la hubiera ni pudiera haberla.” (Tolstói, 1981:82).

Si Tolstói describe de forma poderosa el colapso psicológico de Iván Ilich en la segunda parte de la novela, en la primera parte retrata de forma magistral las actitudes de la burguesía de la época que, poco a poco, fue tomando conciencia de los inconvenientes que el morir y la muerte románticos suponían como freno de la vida social, incluida la de los más allegados a la persona moribunda. Asimismo, expone la aversión y repugnancia que en éstos produce la contemplación directa de los estragos físicos causados por la enfermedad terminal en la persona moribunda, actitudes muy alejadas de la resignación y compasión con que se enfrentaban a ello en épocas pretéritas (Ariès, 1983:475). Si, hasta entonces, los burgueses morían en casa, ya que consideraban al hospital un "<<lugar horroroso>>” en el que morían quienes no tenían dinero ni familia, el creciente proceso de urbanización y la reducción del tamaño de las casas hizo "penosa la proximidad de la muerte, tanto más cuanto que, después de los descubrimientos de Pasteur, se ha impuesto la obsesión de la higiene. La muerte, que hasta entonces, se hallaba de alguna manera integrada en la vida, empieza a verse como una putrefacción” (Martin-Fugier, 1992:263). Así, Tolstói refleja la diversidad de sentimientos que embargan a los sobrevivientes durante la enfermedad y el fallecimiento de Iván Ilich: a) incredulidad, sufrimiento, pavor e impotencia por la experiencia vicaria del morir y muerte en alguno de los pocos muy cercanos $^{28}$; b) incomodidad por la obligación social y pública de asistir al funeral y entierro en muchos de sus conocidos ${ }^{29}$; c) frustración por la interrupción de actividades sociales o por la

\footnotetext{
${ }^{28}$ Si bien algunos de los familiares más próximos de Iván Ilich sufren realmente su enfermedad y muerte pensando en lo que ello suponía para él, como es caso de su hijo, en otros esos sentimientos eran más contradictorios y se mezclaban con las cuentas pendientes de la vida pasada en común y sobre todo con las incertidumbres que se abrían de cara al futuro en la posición social alcanzada. Así, por ejemplo, Praskovia Fiódorowna, su mujer, empezó "a desear que él muriese, pero no podía desearlo, pues en este caso habría faltado el sueldo, lo cual aún la irritaba más contra Iván Ilich.” (Tolstói, 1981:45).

29 "En cuanto a los conocidos más próximos, los llamados amigos de Iván Ilich, pensaban también, involuntariamente, que debían pagar el aburrido tributo a las conveniencias sociales asistiendo a los funerales y haciendo una visita de condolencia a la viuda” (Tolstói, 1981:9). "Piotr Ivánovich (el amigo más íntimo de Iván Ilich) entró, como suele ocurrir siempre, sin saber qué debía hacer allí... Luego, cuando le pareció que llevaba ya bastante rato santiguándose, se detuvo y se puso a contemplar al difunto... Algo le produjo una sensación desagradable, por lo que se santiguó otra vez apresuradamente y, según le pareció, con excesiva premura, incompatible con las buenas maneras, se volvió encaminándose hacia la puerta” (Tolstói, 1981:11-12).
} 
ruptura de planes de diversión ${ }^{30}$ en allegados y amigos íntimos, y; d) ilusión y esperanza por la potencial promoción profesional para cubrir su puesto en el organigrama del Ministerio entre sus compañeros de trabajo ${ }^{31}$. Pero sobre todo, y anticipándose a Canetti, Tolstói resalta la satisfacción de todos los sobrevivientes por seguir ellos vivos ${ }^{32}$. En definitiva, en lo relativo a las actitudes de los sobrevivientes, Tolstói ilustra de forma diáfana algunas de las actitudes ante la muerte emergentes en la segunda mitad del siglo XIX que se asentarán en el primer tercio del siglo XX: el malestar difuso o explícito, cuando no la repugnancia, que provoca el morir y la muerte de una persona más o menos próxima que desemboca en la consiguiente ruptura de comunicación con ella. A la par, el creciente dominio de los sentimientos e intereses privados que acaban imponiéndose sobre las costumbres sociales y públicas de acompañamiento, derivando en una menor implicación conjunta en el enfrentamiento del proceso de morir y muerte ajeno, lo que llevará al aislamiento físico y moral de las personas moribundas en su último aliento. Tolstói vislumbra además el creciente poder de la profesión médica en este ámbito $^{33}$, anticipando el proceso de medicalización de la muerte que caracterizará el nuevo modelo de muerte durante el siglo XX.

Ariès relaciona los cambios en las actitudes ante el morir y la muerte novelados por Tolstói con los cuatro parámetros psicológicos de referencia para así caracterizar la emergencia de la muerte invertida en el tránsito del siglo XIX al siglo XX y su asentamiento definitivo durante este último. En lo relativo al primero de esos parámetros, la conciencia de sí mismo, la 'dimisión' de la comunidad ante la muerte de uno de sus miembros, por un lado, y la focalización del sentimiento de privacidad en un conjunto de personas aún más reducido, por

\footnotetext{
30 “Comprendió éste (Piotr Ivánovich) que Schwarz estaba por encima de aquello y que no se dejaba turbar por impresiones deprimentes. Su aspecto ya lo decía: los funerales de Iván Ilich de ningún modo podían constituir motivo suficiente para considerar alterado el orden de la sesión, o sea, que nada podía impedir que aquella misma noche abrieran una nueva baraja y la hicieran crujir al tiempo que un lacayo colocara cuatro velas nuevas. En una palabra, no había razón para suponer que aquel incidente iba a impedirles pasar agradablemente la velada de aquel día.” (Tolstói, 1981:12-13).

31 "Al oír hablar del óbito de Iván Ilich, el primer pensamiento de cada uno de los señores reunidos en el gabinete fue el de las repercusiones que podría tener aquella muerte para el traslado o el ascenso de sí mismo o de sus conocidos” (Tolstói, 1981:8).

32 “...el hecho en sí del fallecimiento de una persona muy conocida despertaba en todos, como siempre, un sentimiento de alegría, pues resulta que <<ha muerto otro y no yo >> (Tolstói, 1981:9). "<<Tres días y tres noches de espantosos sufrimientos, y la muerte. Ahora, en cualquier momento puede ocurrirme a mí lo mismo >, pensó, y por un instante tuvo miedo, Pero en seguida, sin saber cómo, acudió en su ayuda la socorrida idea de que esto le había sucedido a Iván Ilich y no a él, y que a él esto no le debe ni le puede suceder... Hecho este razonamiento, Piotr Ivánovich se serenó y empezó a preguntar con sumo interés por los detalles del fallecimiento de Iván Illich, como si morir fuese una aventura exclusiva de éste y que nada tuviera que ver con él.” (Tolstoi, 1981:17).

${ }^{33}$ Apremiado por su mujer, Iván Ilich acude a un "médico famoso" para que le diagnostique el mal que le aquejaba: "Todo ocurrió como se imaginaba. Las cosas pasaron como siempre. La espera, la afectada gravedad doctoral,...; el aspecto imponente, como si insinuara: no se preocupe, confíe en nosotros, que todo lo arreglaremos, pues nosotros sabemos sin duda alguna cómo las cosas se arreglan de manera especial para cada individuo, quienquiera que sea” (Tosltói, 1981:46).
} 
otro, conllevará que la afectividad y la confianza depositada en éstas sean casi absolutas delegando en ellas la toma de decisiones cuando a una persona le asalta la enfermedad. Si bien esto ya estaba presente en la muerte romántica, el rasgo diferencial moderno es que, justificándose en razones de afectividad, la familia más próxima no sólo se ocupa de la gestión diaria del proceso de enfermedad, sino que busca proteger psicológicamente a la persona enferma grave y/o a la moribunda ocultándole o mintiéndole sobre su estado. Mentira de amor que, para evitarle sufrimientos, suprime "el gran privilegio del moribundo" que era "la última comunión con Dios y los otros”, vaciando de contenido la ceremonia del adiós al impedirle expresar su arrepentimiento y últimas voluntades y encargos (Ariès (1983:507).

De esta forma, los individuos dejan de ser los dueños de su muerte, al no ser conscientes de su proximidad, y la familia enajena "el sentido del individuo y de su identidad" que tradicionalmente se terminaban de conformar en el "momento excepcional" del enfrentamiento con la muerte ya que, hasta es época, se era dueño de la propia vida si se era el amo de la propia muerte. Alienación total de la persona moribunda a la que se infantiliza despojándola del derecho a preparar la propia muerte privándola de información vital, lo que la impide actuar con libertad en los últimos días de su vida. Manipulación que la despersonaliza y la aísla de la vida diaria y cuyo objetivo latente, además del manifiesto de protección a la persona enferma, era sin embargo evitar la intromisión cada vez más insoportable e intolerable de la muerte en el orden de la vida cotidiana de los sobrevivientes. Se buscaba conscientemente separar la muerte de la vida, y la persona moribunda se transformó en un rehén de esa estrategia. Así, Ariès (2000:231) afirma que la ocultación de la muerte, que constituyó una extraordinaria inversión de sentimientos primero, y de ideas después, no fue sólo un "hábito puesto ingenuamente en uso, sino que se convirtió en una regla moral” para contribuir a la felicidad colectiva, y que conllevaba la obligación social de evitar a los demás emociones desagradables como las que podían provocar la enfermedad y la agonía. Es decir, además de la retórica de la protección, el escamoteo y disimulo de la muerte a las personas moribundas no sólo reflejaba una simple falta de coraje para comunicar malas noticias, sino que también era un síntoma de algo más profundo y que Ariès (2000:84) identifica como una característica de la modernidad: el enfrentamiento a la verdad plantea problemas. De ahí que, por un lado, si la persona moribunda, y a pesar de la ruptura de la comunicación, adivinaba la farsa se prestara a ella para no decepcionar: "La muerte de antaño era una tragedia -a menudo cómica- en la que uno representaba el papel del que va a morir. La muerte de hoy en día es una comedia -siempre dramática- donde uno representa el papel del que no sabe que va a morirse” (Ariès, 2000:234). Por otro lado, el ocultamiento de la muerte se extiende a los propios allegados que deberán asimismo evitar la expresión pública de su duelo, ya que están obligados a continuar con sus ocupaciones sin 
emociones ni obstáculos, y la discreción se convirtió en la forma moderna de dignidad ${ }^{34}$.

La tendencia colectiva a mantener a la muerte en un "profundo congelador de silencio" (Moller, 1996:21) pone de manifiesto que ésta rompió los diques tradicionales que la contenían y se transformó en una fuerza salvaje e incomprensible (Ariès, 2000:288). Si bien esto es así, lo cierto es que la extensión del silencio sobre la muerte no se asentó únicamente en las actitudes elusivas de la familia, sino que necesitó de otro componente esencial que neutralizó los efectos de esa transformación de la muerte: los progresos científicos y técnicos en el ámbito de la medicina. Y no tanto porque éstos fueran en aquella época -finales del siglo XIX/principios del siglo $\mathrm{XX}$-, sustantivos en términos reales, sino porque contribuyeron a un cambio mental fundamental en las actitudes ante la muerte: una persona enferma ya no se enfrentaba con su angustia existencial inerme e inerte ante la muerte, como hasta entonces, sino que luchaba contra la enfermedad que la aquejaba con ayuda del personal médico. La intervención de éste cambia el foco amenazador desde la muerte a la enfermedad transformándose el diagnóstico en lo realmente importante mientras que aquélla se hizo cada día más invisible. Es decir, la tecnología, en especial la médica, se convirtió en el nuevo instrumento para domesticar la mortalidad, la nueva defensa contra la naturaleza salvaje. En efecto, la `humanización’ de la muerte por el progreso médico no sólo ayudó a controlar lo relativo al malestar físico sino que sobre todo disminuyó el sufrimiento psicológico de los enfermos y de sus allegados. En el caso de los primeros, al menos en los momentos iniciales del descubrimiento de la enfermedad por las perspectivas optimistas que se abrían ante ellos al luchar contra una enfermedad y no contra la muerte. En los segundos, porque, desaparecida la fascinación de la muerte del modelo anterior, sólo les quedaba a los sobrevivientes asumir el horror por los estragos de la enfermedad y la repugnancia por tener que prestar cuidados entre olores nauseabundos y estertores, inconvenientes que los profesionales de la medicina les ahorraban al sustituirles en esas tareas. Así, el nuevo ritual humano en el lecho de muerte se organiza alrededor de la tecnología; por lo que en la vida cotidiana del hogar ya no era necesario defenderse de la muerte salvaje, incomprensible y sucia, sino que al quedar ésta bajo control médico se la excluía de la vida diaria recluyéndola en hospitales y más tarde también en geriátricos. Y es ahí donde la muerte se mostrará salvaje “erizada de tubos,..., más terrorífica que el transido o el esqueleto de las retóricas macabras” (Ariès, 1983:508). Parece lógico considerar, por otra parte, que la

\footnotetext{
${ }^{34}$ Si hasta finales del siglo XIX el dolor por la muerte de un ser querido era la "más violenta expresión de los más espontáneos sentimientos”, y el duelo era una manifestación legítima y necesaria de ese dolor, desde principios del siglo XX "una pena demasiado visible no inspira ya piedad, sino repugnancia, inconveniencia; es un signo de desequilibrio mental o de mala educación; es mórbido... Sólo se tiene derecho al llanto si nadie lo ve ni lo oye: el duelo solitario y retraído es el único recurso como una suerte de masturbación” (Ariès, 2000:87 y 240).
} 
'dimisión' de la comunidad y la eliminación de los rituales públicos de despedida están en buena medida relacionadas con este proceso de medicalización de la muerte, que quedó encerrada entre las paredes de un laboratorio o en las de un hospital donde las emociones debían ser desterradas (Ariès, 2000:294).

En lo relativo al tercero de los parámetros psicológicos, la creencia en la sobrevida, se diluyó al acentuarse el proceso de secularización y declinar con él el apoyo a las creencias religiosas de salvación. Incluso, la creencia desarrollada en la muerte romántica por la que se rechazaba la separación definitiva, creándose una especie de vínculo entre la persona viva y la muerta sin participación de lo sobrenatural, desaparece. Para Ariès (2000:249-251), el incremento de la incineración frente a la inhumación en algunos países occidentales es un ejemplo radical de este proceso de modernización, racionalización y rechazo de la supervivencia en el más allá, en el que no sólo se abandona a la persona moribunda en el hospital, sino que, cuando muere, también se hace desaparecer todo lo que quede de su cuerpo eliminando el culto de los cementerios y el peregrinaje a las tumbas. Aunque, obviamente, ello no significa indiferencia ante la persona muerta, sino que es la materialización lógica de un modelo de muerte que aboga por la ocultación y privatización del duelo señalada arriba.

Finalmente, en lo que se refiere al cuarto de los parámetros psicológicos, la creencia en la existencia del mal, a la par de lo ocurrido con el parámetro anterior se agudiza la tendencia iniciada en la muerte del otro de abandono de la creencia en el Diablo llegándose a "la retirada definitiva del mal”, al menos tal y como había sido difundido por las religiones, en especial por el cristianismo. Persiste la creencia en el mal pero no que estuviera inserto en el ser humano, sino fuera de él en el ámbito de las relaciones sociales. 
TABLA 3.1. MODELOS DE MUERTE DE PHILLIPPE ARIÈS

\begin{tabular}{|c|c|c|c|c|c|}
\hline \multirow{2}{*}{$\begin{array}{l}\text { ELEMENTOS } \\
\text { PSICOLÓGICOS }\end{array}$} & 1) MUERTE DOMADA & 2) MUERTE PROPIA & $\begin{array}{l}\text { 3) MUERTE LEJANA } \\
\text { Y PRÓXIMA }\end{array}$ & 4) MUERTE AJENA & 5) MUERTE INVERTIDA \\
\hline & Hasta el siglo XI & Siglos XI-XVIII & Siglo XVI... & Siglo XIX... & Siglo XX \\
\hline $\begin{array}{l}\text { a) La conciencia de } \\
\text { sí }\end{array}$ & $\begin{array}{l}\text { La vida del ser humano no es un destino } \\
\text { individual, sino continuidad biológica de } \\
\text { una estirpe, de una familia, del grupo. } \\
\text { La muerte de un individuo compromete a } \\
\text { todo el grupo, que ha de recomponerse. } \\
\text { Por ello, la muerte es un acto social, que } \\
\text { incluye una ceremonia más o menos } \\
\text { solemne. Tres momentos clave: } \\
\text { a) aceptación del moribundo de su } \\
\text { papel activo. } \\
\text { b) escena de los adioses. } \\
\text { c) escena del duelo. }\end{array}$ & \multicolumn{2}{|c|}{$\begin{array}{l}\text { Desplazamiento desde la idea de destino colectivo hacia la de } \\
\text { destino del individuo. Éste se reconoce en su muerte. } \\
\text { Se invierte la relación entre uno mismo y los otros: el sentido de la } \\
\text { identidad prevalece sobre la sumisión al destino colectivo. } \\
\text { El balance de la biografía se realiza en el lecho de muerte. } \\
\text { Instrumento esencial para asegurar la continuidad con el más allá: el } \\
\text { testamento. } \\
\qquad \begin{array}{ll}\text { Los testamentos se hacen } \\
\text { más sencillos. Incluyen } \\
\text { disposiciones para evitar ser } \\
\text { enterrado vivo. }\end{array}\end{array}$} & $\begin{array}{l}\text { Se desarrolla el sentido del Otro. } \\
\text { Vida privada, familia nuclear, } \\
\text { remodelada para su nueva función } \\
\text { de afectividad absoluta. } \\
\text { El miedo a la muerte fue desviado } \\
\text { de uno mismo hacia el ser amado. } \\
\text { Romanticismo: complacencia con } \\
\text { la idea de la muerte. } \\
\text { Las ceremonias se desritualizan y } \\
\text { son reinventadas como expresión } \\
\text { espontánea de la pena de los } \\
\text { sobrevivientes. }\end{array}$ & $\begin{array}{l}\text { Menor implicación de la } \\
\text { comunidad en la muerte de uno de } \\
\text { los suyos. } \\
\text { Acentuación de la afectividad, que } \\
\text { conllevará la delegación de respon- } \\
\text { sabilidades frente a la enfermedad y } \\
\text { la muerte. } \\
\text { Alienación del moribundo: se le } \\
\text { oculta la gravedad de su estado. } \\
\text { Dejan de ser dueños de su muerte. } \\
\text { Para el resto de la población, la } \\
\text { vida debe seguir. }\end{array}$ \\
\hline $\begin{array}{l}\text { b) Los otros como } \\
\text { defensa de la } \\
\text { sociedad contra la } \\
\text { naturaleza salvaje }\end{array}$ & $\begin{array}{l}\text { El potencial disruptor de la muerte, y del } \\
\text { sexo, abría una brecha en el sistema de } \\
\text { protección alzado contra la naturaleza y } \\
\text { su salvajismo. Para evitarlo se desarrolló } \\
\text { una estrategia que canalizaba las fuerzas } \\
\text { desconocidas y formidables de la } \\
\text { naturaleza. } \\
\text { Estrategia por la que la muerte no era } \\
\text { abandonada a sí misma, sino aprisionada } \\
\text { en unas ceremonias rituales, transfor- } \\
\text { mada en espectáculo público. }\end{array}$ & $\begin{array}{l}\text { Ceremonial nuevo que vino a } \\
\text { compensar lo que la afirmación de la } \\
\text { identidad había amenazado: } \\
\text { transformación del ritual civil a } \\
\text { religioso. } \\
\text { Todo el proceso de morir y muerte } \\
\text { pasa a ser controlado por "hombres } \\
\text { de la Iglesia". } \\
\text { Danza de la Muerte como símbolo de } \\
\text { igualdad de todos ante ella. } \\
\text { Se cubre le rostro, se oculta el cuerpo } \\
\text { del cadáver. }\end{array}$ & $\begin{array}{l}\text { Retorno al estado salvaje. } \\
\text { Críticas a la gestión tanática } \\
\text { de la Iglesia } \\
\text { Desarrollo de la ciencia y la } \\
\text { técnica. } \\
\text { El gran miedo a la muerte } \\
\text { aparece entonces y sólo } \\
\text { entonces: el miedo a ser } \\
\text { enterrado vivo, que implica } \\
\text { la convicción de que existía } \\
\text { un estado mixto y reversible } \\
\text { hecho de vida y muerte. }\end{array}$ & $\begin{array}{l}\text { La muerte ya no es familiar y } \\
\text { domada, y tampoco absolutamente } \\
\text { salvaje, pasa a ser "patética y } \\
\text { bella". La muerte en sí misma ha } \\
\text { dejado de ser triste. }\end{array}$ & $\begin{array}{l}\text { No se piensa que sea necesario } \\
\text { defenderse de la naturaleza salvaje, } \\
\text { humanizada (domesticada) de una } \\
\text { vez por todas por el progreso de las } \\
\text { técnicas médicas. } \\
\text { El foco de la amenaza se desplaza } \\
\text { desde la muerte a la enfermedad. } \\
\text { Ambas se vuelven sucias. Por ello, } \\
\text { se medicalizan y se las recluye en } \\
\text { hospitales. }\end{array}$ \\
\hline $\begin{array}{l}\text { c) La creencia en la } \\
\text { sobrevida }\end{array}$ & $\begin{array}{l}\text { Concepción de la sobrevida como un } \\
\text { sueño o reposo pacífico. La sobrevida es } \\
\text { esencialmente una espera en la paz y el } \\
\text { reposo. Allí los muertos esperan, según } \\
\text { la promesa de la Iglesia, lo que será el } \\
\text { verdadero fin de la vida. } \\
\text { Los vivos toleran bien la familiaridad de } \\
\text { los muertos en las iglesias, a condición } \\
\text { de que reposen. }\end{array}$ & \multicolumn{2}{|c|}{\begin{tabular}{|l|} 
Transformación de la creencia sobre el Juicio final. \\
Idea de un alma inmortal, sede del individuo. \\
El alma no se contentaba ya con dormir el sueño de la espera. Su \\
existencia traducía la voluntad del individuo de afirmar su identidad \\
creadora en uno y otro mundo.
\end{tabular}} & $\begin{array}{l}\text { El percepción sobre el Cielo } \\
\text { cambia, se convierte en un lugar de } \\
\text { encuentro entre aquéllos a quienes } \\
\text { la muerte ha separado y que no } \\
\text { aceptan esa separación. } \\
\text { Lugar para la reconstrucción de los } \\
\text { sentimientos, libres de las miserias } \\
\text { terrestres para la eternidad. }\end{array}$ & $\begin{array}{l}\text { Declinación de todas las creencias } \\
\text { religiosas de salvación. Provocan } \\
\text { cambios profundos en los rituales } \\
\text { tanáticos, que se acentúan con los } \\
\text { derivados de las transformaciones } \\
\text { estructurales. }\end{array}$ \\
\hline $\begin{array}{l}\text { d) La creencia en la } \\
\text { existencia del mal }\end{array}$ & $\begin{array}{l}\text { La muerte jamás es sentida como un } \\
\text { fenómeno neutro. Sigue siendo una } \\
\text { desgracia. En origen no había más que } \\
\text { un mal cuyos aspectos variaban: el } \\
\text { sufrimiento, el pecado, la muerte } \\
\text { El cristianismo lo explicaba de golpe y } \\
\text { todo junto: el pecado original. Mito que } \\
\text { respondía a un sentimiento general de la } \\
\text { presencia constante del mal. Resignación }\end{array}$ & $\begin{array}{l}\text { Necesaria para la economía del } \\
\text { testamento, y para el manteni- } \\
\text { miento de un amor a la vida, } \\
\text { fundado en parte en la conciencia } \\
\text { de su fragilidad. }\end{array}$ & & $\begin{array}{l}\text { La antiquísima relación de } \\
\text { identidad entre la muerte, el mal } \\
\text { físico, la pena moral, comienza a } \\
\text { dislocarse. } \\
\text { Empiezan a perder fuerza la idea } \\
\text { del Infierno y la del vínculo entre } \\
\text { la muerte y el pecado (el Mal). }\end{array}$ & $\begin{array}{l}\text { Más que horror a la muerte se } \\
\text { siente vergüenza de ella, y se hace } \\
\text { como que no existe. } \\
\text { Esta vergüenza es la consecuencia } \\
\text { directa de la retirada definitiva del } \\
\text { mal. }\end{array}$ \\
\hline
\end{tabular}


Al hilo de todos estos cambios, Ariès (1983:508) se pregunta: si ya no existe "el mal", ¿qué hacer con la muerte?, y señala que la sociedad ha ofrecido dos respuestas a esa cuestión. Por un lado, la respuesta “común” que acabará siendo la mayoritaria durante el siglo XX, la del tabú, la del silencio, la indiferencia y la suficiencia como si se tuviera controlada a la muerte salvaje en un reducto aislado, respuesta que implica un reconocimiento de impotencia ante un horror que no puede evitarse. Por otro lado, la respuesta "aristocrática” que propugna "humanizarla”, pero no en el sentido tecnológico imperante, sino aceptarla y reconciliarla con la vida, como "un paso biológico, sin significación, sin pena ni sufrimiento, y finalmente sin angustia”. Respuestas que materializan las actitudes de (de)negación de la muerte, en el primer caso, y de reivindicación de la misma, en el segundo, y que corresponden a dos de los tres modelos de muerte que, según Tony Walter (1996), en coexisten en la actualidad: los modelos moderno y neo-moderno de muerte, respectivamente.

Antes de abordar en el siguiente epígrafe estos modelos de muerte contemporáneos, procede resumir algunas de las críticas vertidas por diferentes autores sobre la tipología histórica de la muerte elaborada por P. Ariès. Así por ejemplo, A. Di Nola (2006:7-9) realiza una enmienda a la totalidad del trabajo de Ariès en la que mezcla consideraciones conceptuales, ideológicas, y también personales ${ }^{35}$. Enmienda que se asienta en la inconveniencia de realizar, para las sociedades occidentales, una historia evolutiva de la noción de muerte regida por teorías preconcebidas que delinean una evolución desde la " $<<$ muerte dominada $>>$ a sucesivos periodos de muerte <<personalizada>> hasta la visión fragmentaria e incierta actual”. Para Di Nola, no existen "periodizaciones" por épocas en el enfrentamiento a la muerte puesto que ésta "suscita constantemente, en todos los contextos culturales, las mismas formas de reacción”.

Cabe destacar asimismo las críticas metodológicas, conceptuales y de contenido realizadas por M. Vovelle (1985) desde su concepción holística de la historia. Para este autor, como se ha señalado en la Introducción de esta Tesis, la historia ha de ser "total vertical”, en consecuencia reprocha a Ariès la parcialidad e insuficiencia de su enfoque de la historia de las mentalidades ya que amputa en sus dos extremos la "historia total de los hombres frente a la muerte” al obviar, por un lado, los condicionantes estructurales, y diluir, por otro, la ideología en su discurso. En efecto, el análisis de Ariès ignora todo lo relativo a los condicionantes demográficos, epidemiológicos, del modo de producción y de las jerarquías sociales, es decir, construye una "historia sin raíces". Asimismo, al centrarse en la interpretación de las actitudes

\footnotetext{
${ }^{35}$ Según Di Nola (2006:7-8), Ariès "refleja la teoría de una historia de la condición humana en progresiva decadencia, apelando a una sociedad protohistórica o metahistórica caracterizada por un equilibrio y perfección primordiales, una idea sobre la decadencia del tiempo típica de cierta pseudocultura nazifascista a la que pertenecía por vocación y profesión Ariés, diputado de extrema derecha francés y de oficio director de los servicios de importación franceses de frutas exóticas”.
} 
como reflejo de un sistema inconsciente de representaciones colectivas, a lo que denomina <<inconsciente colectivo >>, elabora una historia en la que desaparece "la transmisión vertical de los modelos culturales dominantes y las resistencias de otras culturas”, minimizando la incidencia de las tensiones y los enfrentamientos sociales. Historia aparentemente neutra desde el punto de vista ideológico, pero en la que, según critica Vovelle, lo que en realidad se hace siempre es seleccionar entre la profusión de fuentes utilizadas el discurso de las élites, que se extrapola como si fuera el discurso del conjunto de la sociedad. Es decir, se privilegian las actitudes de los "grupos dominantes" en detrimento de las "actitudes colectivas de las masas", con lo que no sólo no se consideran todos los discursos ideológicos en presencia sino que tampoco se incluye en el análisis la totalidad de la Muerte Vivida de cada época (Vovelle, 1985:40, 96-99).

Por su parte, N. Elias (1987), reconociendo también el extraordinario volumen de información manejado por Ariès, manifiesta asimismo objeciones metodológicas, conceptuales y de contenido a su trabajo. Al igual que Di Nola, le reprocha el manejar una teoría preconcebida sobre la evolución de la historia de la muerte, aunque en este caso esa predisposición a seleccionar hechos históricos esté animada por el espíritu romántico con que describe la forma de morir en las sociedades medievales, que se produciría con mayor calma y serenidad después de haber cerrado todos los asuntos pendientes. Mirada romántica que Elias rechaza ya que, admitiendo que en la Edad Media el morir era para todos "algo menos oculto, más familiar, omnipresente”, eso no significa que se muriese en calma, sin dolor, ni sufrimiento. Todo lo contrario. Comparándolo con el siglo XX, en conjunto, "la vida en la sociedad medieval era más breve; los peligros, menos controlables; la muerte, muchas veces más dolorosa; el sentido de culpa y el miedo al castigo tras la muerte, eran doctrina oficial” (Elias, 1987:24-25).

\subsection{MODELOS DE MUERTE EN LAS SOCIEDADES OCCIDENTALES CONTEMPORÁNEAS}

"La muerte es una vida vivida. La vida es una muerte que viene” J.L. Borges

Cómo una sociedad se organiza para afrontar la muerte depende de las características de los procesos de morir y de las condiciones estructurales de la propia sociedad. En este sentido, distintos autores han propuesto tipologías sobre la muerte para analizarla en la sociedad actual. De especial interés para este trabajo es la tipología elaborada por Tony Walter ${ }^{36}$ (1994), por cuanto la

\footnotetext{
${ }^{36}$ La tipología propuesta por Walter (1994:cap.4) corresponde a unos tipos ideales tal y como se maneja este concepto en Sociología. Es decir, no son ideales en el sentido de tipos deseables, tampoco lo son en el sentido estadístico, no existen en la vida social en la forma pura en la que se exponen, sino que simplemente
} 
claridad y sencillez de los tipos empleados la hace idónea para su contraste en la práctica, razón por la que se la ha utilizado en el análisis empírico de la muerte en la sociedad española actual, tal y como se muestra en los Capítulos 4 y 5 de esta Tesis. Además, tiene la ventaja de que permite la continuidad en el discurso desarrollado hasta ahora, ya que es una tipología que se asienta en la “variedad de sedimentos históricos”, presentes en el siglo XX, de la tipología propuesta por Ariès (Walter, 1994:60). En efecto, este autor parte de la idea de que la abundancia actual de discursos sobre la muerte en las sociedades contemporáneas no es más que el resultado de la complejidad de las mismas y de la coexistencia en ellas de varias mentalidades supervivientes y de otra que ha emergido durante las últimas décadas del siglo XX. Sobre esa base, propone tres tipos ideales de muerte -Muerte Tradicional, Muerte Moderna y Muerte Neo-Moderna-, que tienen además carácter histórico por cuanto, aunque coexisten, son modelos que se van sucediendo unos a otros. En la Tabla 3.2. se muestra la caracterización realizada por Walter de los tres tipos de muerte a partir de 25 variables agrupadas en seis grandes apartados -Contexto Corporal, Contexto Social, Autoridad, Enfrentamiento a una muerte, "el Viaje" ${ }^{37}$ y Valores-, lo que permite realizar una comparativa al objeto de delimitarlos y de contrastar la consistencia existente entre ellos.

\subsubsection{MUERTE TRADICIONAL}

"Bueno es morir si hay Dios, pues si no lo hubiera sería triste vivir.
Morir no es otra cosa que cambiar de residencia”

Marco Aurelio

Walter denomina Muerte Tradicional al primero de sus tipos de muerte, y que es la herencia de la muerte domada, y posteriores mutaciones, analizadas por P. Ariès. Modelo hegemónico hasta bien entrado el siglo XIX, se hallaba mediatizado por una concepción religiosa sobre la naturaleza y esencia del mundo en la que "las cuestiones del significado de la vida y de la muerte no surgen; el mundo es como es” (Seale, 1998:75), y de la que, inevitablemente, se derivaba una visión determinista y de impotencia absoluta frente a la muerte, ante la que nada cabía hacer.

a) Contexto corporal: Las principales causas de muerte eran las enfermedades infecciosas y su portador arquetipo era la plaga por la que aquellas podían extenderse rápidamente sobre la totalidad de la población. La inexistencia de cualquier tipo de tecnologías terapéuticas o paliativas eficaces conllevaba una trayectoria del morir rápida, dolorosa y consciente. La elevada intensidad

son categorías sociales elaboradas por el investigador para analizar la realidad social. Construcciones simplificadas de ésta, dotadas internamente de coherencia lógica, que permiten identificar temas e iluminar las diferencias y, si es el caso, las contradicciones entre los variados elementos que componen las mismas.

${ }^{37}$ Walter, siguiendo una tradición iniciada en el antiguo Egipto, utiliza en su tipología como representación simbólica de la muerte la metáfora de la muerte como un viaje. 
de la mortalidad ordinaria de la época, y aún más la de la extraordinaria, determinaba una baja esperanza de vida (alrededor de los 40 años, en el mejor de los casos), y que la muerte fuera un suceso común y relativamente impredecible que ocurría en todas las edades, aunque afectaba especialmente a los más pequeños. La elevada mortalidad infantil característica de las sociedades tradicionales implicaba que la importancia social de los niños fuera baja y por tanto que su nacimiento social fuera posterior al nacimiento físico, una vez de que se tenían algunas garantías de que el recién nacido podría sobrevivir a los primeros días de su vida. Por otra parte, la disrupción que la muerte implicaba en la comunidad determinaba que toda muerte fuera un ataque a ella, por lo que se desarrollaron instrumentos para superar todos esos ataques y calmar a los muertos, conformándose instituciones como el segundo entierro descrito por Hertz (1990), que implicaba que la muerte social seguía a la muerte física. Esto conducía asimismo a una visión frecuente de la muerte de los otros, lo que determinaba que uno de los parámetros identificadores de la condición humana fuera el vivir con la muerte, su familiaridad. A la par, la agudeza del ataque de las enfermedades infecciosas conllevaba que la confrontación con la propia muerte no fuera más que "un mero encuentro" (Lofland, 1978:26). Con una mortalidad tan elevada, y la consiguiente baja esperanza de vida, las posibilidades de supervivencia hasta edades avanzadas eran reducidas, por lo que sólo una proporción baja de la población llegaba a anciana, motivo por el que la podía corresponder cierta veneración al haber sido capaz de sortear la muerte hasta edades avanzadas.

b) Contexto social: La muerte de un individuo tenía un potente efecto disruptivo en el orden social de unas comunidades con una organización social simple y que, por razones geográficas, estaban conformadas como una densa red de interacción social. Como ya resaltara Tönnies (1979), en las sociedades comunitarias las relaciones sociales dominantes eran las de comunidad de sangre (parentesco), comunidad de espíritu (confraternidad) y comunidad de lugar (buena vecindad), lo que identificaba a un individuo en el orden social por su pertenencia a las mismas. Así, una muerte era una pérdida social, afectaba a toda la comunidad alterando su estructura de roles por lo que implicaba tareas posteriores de reconstrucción y de reintegración de los mismos que se producían con ritos de tránsito y funerales organizados comunitariamente. El duelo $^{38}$ y su manifestación externa, el luto, cumplían esa misión de reintegración de los supervivientes a la comunidad: "Si lloran en común, es que siguen teniéndose unos a otros, de modo que la colectividad no ha quedado dañada, a pesar del golpe sufrido. Es cierto que entonces

\footnotetext{
${ }^{38}$ El duelo es una construcción social vinculada a la muerte que abarca tres procesos: a) el "estar en duelo" (bereavement), que denota el estatus de las personas que han perdido a un/a allegado/a; b) el "hacer su duelo" (grief), conjunto de estados afectivos que conforman el proceso de tránsito psicológico hasta que los 'enlutados' asumen la pérdida, recuperan el tono vital y se reincorporan plenamente a la vida social, y; c) el luto (mourning), la exteriorización de la pérdida, la marca de haber sido tocado por la muerte (Thomas, 1985:71).
} 
sólo se ponen en juego emociones tristes, pero comulgar en la tristeza sigue siendo comulgar, y cualquier comunión de las conciencias..., reconstituye la vitalidad social” (Durkheim, 1993:630).

c) Autoridad: En esa situación, en la que por razones de supervivencia primaba lo comunitario sobre lo particular, Dios y la Tradición conformaban el vértice superior del sistema de autoridad. El discurso dominante era el religioso, que se concretaba en la idea fuente de que las muertes se producían por voluntad de Dios. Discurso que proveía de significados y de normas de comportamiento ineludibles que, legitimadas mediante la religión, eran materializadas a través de la Iglesia, la familia extensa y la aldea, siendo muy difícil sustraerse a su influencia.

d) Enfrentamiento a una muerte: De forma más específica, a la hora del enfrentamiento individual a la muerte esas normas de comportamiento recomendaban la oración, como fuente de fuerza, y el desarrollo de rituales, como escenificación de la de despedida social. Entre el atrezzo de esos rituales, alrededor del lecho de muerte, figuraban familiares y vecinos, mientras que el sacerdote vigilaba "el estado del alma del moribundo", a la vez que los vecinos aseguraban un “comportamiento correcto" del propio moribundo y de su familia según las normas sociales (religiosas) dadas.

e) El "Viaje": De acuerdo al omnipresente discurso religioso dominante, la muerte quedaba explicada por el más allá, siendo su causa inicial el Pecado Original y la consiguiente expulsión de Adán y Eva del Paraíso. Maldición que acompaña a los seres humanos desde su nacimiento y que sólo puede ser mitigada mediante la fe, las oraciones y los rituales prescritos. Discurso que se asentaba en la creencia de una vida después de la muerte, pero sólo para el alma, por lo que las oraciones se dirigían a evitar el castigo y la condena eterna resultante del pecado y con ello garantizar un buen destino al alma de la persona moribunda ya muerta, un final feliz en su viaje de sobrevida. Estas ideas, y la gestión sobrenatural de las mismas, es decir, la distribución social de las garantías de inmortalidad por parte de la Iglesia católica constituyó un poderosísimo instrumento de control social ${ }^{39}$ (Bauman, 1992:53). Desde el inicio de la tradición cristiana, el rito oficial de paso lo constituye un funeral en el que el entierro es la norma: "periodo de descomposición en la tierra, en el que la corrupción corporal es transformada en huesos blancos y limpios, modela la purificación del alma Católica u Ortodoxa, y la pena de los supervivientes” (Walter, 1994).

\footnotetext{
${ }^{39}$ Por ejemplo, F. Martínez Gil (1993) muestra cómo empleando "métodos persuasivos y tranquilizadores" o a través "de la intimidación y el terror de las conciencias", durante los siglos XVI y XVII, la muerte fue utilizada por la Iglesia católica como punta de lanza en su lucha contra la Reforma protestante.
} 
f) Valores: Los valores ejemplares del modelo tradicional de muerte son el respeto por el difunto y la familia, pero también por las tradiciones sociales que los envuelven. Así, la incredulidad, por un lado, y el incumplimiento de las normas y la realización de rituales incorrectos (y por ello ineficaces), por otro, constituían los pecados arquetipos de este modelo. La oportunidad de despedirse de la familia y allegados y la necesidad de ponerse a bien con Dios, requerían tiempo y consciencia, por lo que éstas eran dos de las características que definen la buena muerte en esa tipología.

\subsubsection{MUERTE MODERNA}

\author{
"Era yo el único, \\ el escogido entre todos, \\ que sabía que ibas a morir. \\ Esquivabas mis miradas, \\ que angustiosamente sorprendías. \\ Los dos estábamos en el secreto. \\ Yo oía el rumor de la muerte \\ que lentamente trabajaba dentro de ti, \\ cuando guardabas silencio en aquellas \\ tertulias inolvidables. \\ Procurábamos siempre \\ no quedar solos jamás. \\ Me ocultabas tus manos \\ con una angustiosa torpeza: \\ quizá creyeses que era allí \\ donde yo leía tu muerte.
}

\author{
Y no era en tus manos \\ ni en tu frente ni en tus ojos \\ ni en tu nuca, \\ que es por donde la muerte \\ nos empuja suavemente. \\ Yo no podía saber cómo había llegado \\ esta noticia a mi alma... \\ Una tarde lenta de provincias, \\ te vi más solitario que nadie. \\ En torno tuyo, se hizo \\ como una niebla de ausencia, \\ como un purísimo silencio de estrellas. \\ Por todo eso sabía \\ que me odiabas y me amabas. \\ Pero, cuando llegó aquella \\ hora única y solitaria, \\ me llamaste.”
}

El tipo de muerte dominante en las sociedades desarrolladas durante el siglo XX es el que Walter denomina Muerte Moderna (muerte invertida en la terminología de Ariès). Este modelo de muerte se ha ido conformando lentamente y es fruto de los cambios estructurales ligados al proceso de modernización de los dos últimos siglos descritos en el capítulo anterior de esta Tesis; en especial, del desarrollo del conocimiento científico-técnico y de su aplicación al ámbito médico-sanitario. Como se ha señalado más arriba, los avances científicos han generado un cambio esencial en la mentalidad de los individuos de las sociedades desarrolladas: ya no valen las verdades incuestionables que explicaban la naturaleza del mundo sobre la base de fuerzas sobrenaturales, sino que el mundo pasa a ser sujeto de control humano, está regido por leyes internas que pueden ser descubiertas y, sobre esa base, actuar sobre él ${ }^{41}$. En este sentido, los éxitos conseguidos con el avance de la Medicina en su lucha contra la muerte no han evitado que se la perciba de forma contradictoria porque, por un lado, para la mayoría de los individuos la Medicina representa la mayor esperanza de victoria frente a la enfermedad, la decadencia corporal

\footnotetext{
${ }^{40}$ Poema <<El amigo>> de Luis Pimentel, médico lucense (1895-1958), citado en Simón (2004:105).
} 
y el desplazamiento de la muerte, pero, por otro lado, para otra parte significativa de la población resulta menos satisfactoria que la religión por cuanto su discurso no contiene la promesa de una sobrevida.

a) Contexto corporal: Controladas las enfermedades infecciosas, la muerte arquetipo es la causada a edades avanzadas por el cáncer o las enfermedades coronarias. Se produce fundamentalmente en recintos especializados aislados, por lo que permanece oculta a la vista y se procura no hablar de ella en otros espacios públicos. El control médico experto fragmenta deconstrucción de la mortalidad- el proceso de muerte enajenado a los individuos que la viven alienados sin apenas control sobre ella, hasta el punto de que pueden serles ocultados sus diagnósticos/pronósticos y no saber que están muriendo. Ocultamiento que hace que los individuos tengan menos oportunidades que en épocas pretéritas de ver la muerte de los otros, y en consecuencia de ser socializados sobre cómo comportarse frente a ella. La aplicación masiva de tecnología médica en los procesos de enfermar y de morir hace que se llegue a la muerte de forma lenta, indolora e inconsciente. La baja mortalidad y la elevada esperanza de vida -70 años-, que desplazan las muertes hasta la vejez, conllevan que, como un dato básico de la condición humana en las sociedades modernas, los individuos perciban que la muerte está controlada y que cabe enfrentarse a ella.

Esta ruptura con el fatalismo milenarista, que también se manifiesta en la pérdida de protagonismo de los valores religiosos en la vida cotidiana y la paralela emergencia del proceso de secularización, se puede apreciar singularmente en la diferente valoración social de las muertes según la edad de las personas fallecidas. Proposición central de Blauner (1966), ya comentada más arriba al resaltar la casi nula incidencia de las muertes infantiles en el discurrir de la vida cotidiana de las sociedades tradicionales, y, como un reflejo inverso en el espejo del tiempo, la anticipación de la muerte social de las personas ancianas a su muerte física en las sociedades desarrolladas. Este autor señala que en la época premoderna, con altas tasas de mortalidad, la gran mayoría de los adultos moría en la flor de la vida, dejando tras de sí un "hueco enorme” en lo social, lo económico y lo psicológico, especialmente para la familia. Por el contrario, en las sociedades modernas, con bajas tasas de mortalidad, las probabilidades que tiene un recién nacido de llegar a adulto o a anciano son muy elevadas y, dado que la mayoría de las muertes se producen a edades muy avanzadas, el hueco que deja una persona de edad que fallece está ampliamente colmado, pudiendo ser rellenado en muchos de sus aspectos, echándosela en falta en menor medida que en épocas anteriores. Como consecuencia, en líneas generales la muerte pierde

\footnotetext{
${ }^{41}$ Giddens (1997:14) resalta como rasgo central de la estructuración de la identidad del yo en las sociedades modernas la planificación de la vida, "organizada de forma refleja”, y en la que se ponderan los riesgos bajo el filtro del conocimiento de los expertos.
} 
peso en y frente a la vida y, simplemente, es ignorada, o, como mucho, se la considera si, “inoportuna”, aparece antes de tiempo.

Si, como concluye la bibliografía antropológica, para los individuos de las sociedades tribales la muerte no era algo natural, sino relacional, y si, como se ha señalado más arriba, en las sociedades tradicionales, al menos en las europeas occidentales, la muerte era un designio divino, la regulación y ordenación del ciclo vital, derivada de la reducción de la mortalidad, ha facilitado representar a la muerte como la estación final de un proceso natural. El papel activo jugado por el conocimiento científico-médico en ese proceso ha sido clave ya que ha permitido la construcción de una nueva visión estandarizada sobre la muerte: la muerte "natural” que ocurre al final de una larga vida, como resultado de alguna de las enfermedades descritas en los protocolos clínicos (Seale, 1998:54). Cambio de mentalidad fundamental, asentado en la capacidad de la Medicina para prevenir y controlar las muertes prematuras, para predecir el tiempo aproximado de vida restante, para aliviar el dolor físico del morir, en definitiva, para reducir incertidumbres y asentar seguridades que permiten mirar con más esperanza el futuro. La construcción y asentamiento del ciclo vital moderno ha sido clave en este sentido ya que, al eliminar la aleatoriedad e indeterminación temporal de la aparición de la muerte que la condicionaba, conllevó la ruptura y deconstrucción de la concepción del destino siempre potencialmente inmediato y preestablecido que aguardaba a las personas en las sociedades tradicionales. La posibilidad real de vivir una vida biológicamente completa -infancia, adolescencia, madurez y vejez-, permite a la mayoría de la población rechazar ese destino ubicuo y dado y vivir sus vidas cotidianas libres de las mediatizaciones que imponía la continua proximidad de la muerte. Por ello, la transferencia, parcial, de la preocupación por morir a la preocupación por sobrevivir es especialmente cierta en el ámbito de la economía doméstica en la que, como señala Benjamín (1987:182), se ha pasado “de la protección contra la penuria económica derivada de la muerte a la protección contra las dificultades económicas que se experimentan durante la vida: la protección y el aumento del ahorro (para los periodos de mayor gasto durante la vida), la pérdida de los ingresos por enfermedad durante la vida activa y la pérdida de ingresos por jubilación”. Así, en las sociedades modernas la vida y la muerte son mucho más que el resultado del azar o de una gracia divina. La muerte, aún siendo inevitable, ya no aparece pegada a la vida, no es el complemento simultáneo y arbitrario de ella. Es por esta separación, cada vez más dilatada en términos temporales, por lo que la muerte escandaliza cuando inoportuna aparece antes de tiempo, cuando la vida finaliza en una parada anterior a la que socialmente se considera que es la estación final. Posiblemente, es también por esta razón por la que las personas que han viajado su vida despreocupadas por su mortalidad se sientan más angustiadas al percatarse, cuando está cercana la última estación, de que su viaje está acabando. El enfrentamiento inevitable a este principio de la realidad que antaño 
se realizaba en todo momento de la vida, ahora se concentra mayoritariamente en las edades provectas.

b) Contexto social: A diferencia de las sociedades comunitarias tradicionales, las sociedades societarias modernas están constituidas por dos esferas de relaciones sociales separadas: la vida pública (asentada en hechos; movida por la razón; cuyo referente de actuación es la ciencia; dominada por el principio de la objetividad; centrada en el trabajo, y; orientada a la producción) y la vida privada (sentimientos/significados; emoción; moralidad; subjetividad; casa; elección del consumidor) (Berger et al, 1974). Por ello, la mayoría de las relaciones sociales de los individuos de estas sociedades, que se producen en la esfera pública, se conforman básicamente alrededor del intercambio y el cálculo racional, son en consecuencia impersonales, formales, fragmentarias y utilitarias; mientras, sus relaciones afectivas, personales e íntimas, que comprometen a las personas holísticamente, se recluyen en el ámbito más íntimo de la esfera privada, esencialmente la familia nuclear. Si hay un ámbito de actuación en el que esta hendidura entre lo público y lo privado se expresa de forma más diáfana es en el de la muerte moderna (Walter, 1994:52). Grieta que comporta que ésta sea percibida entre la población con cierta ambigüedad, al ser el resultado de una mezcla contradictoria, por un lado, de la certeza racional, médica, secular y burocrática que caracteriza la lucha contra la muerte en el espacios públicos creados al efecto y, por otro lado, de la soledad emocional con que se vive el fin de la propia vida en esos espacios o, recluida en el espacio privado, la pérdida personal e íntima deriva de un deceso. Actitudes de duelo que tampoco es conveniente exteriorizarlas públicamente, no sólo en esas instituciones específicas de enfermedad y muerte, sino, más ampliamente, en ningún escenario público.

En el ámbito de la personalidad se observa asimismo esa grieta entre lo público y lo privado ya que en el orden social moderno no se considera al individuo en su integridad como persona, sino como sujeto de derechos y deberes, por lo que es fundamentalmente en el ámbito más íntimo de la familia en el que aquél descubre, construye y recrea su identidad. Así, salvo en el caso de personajes públicos, la muerte de un individuo, es una pérdida para sí mismo pero sobre todo para los familiares y amigos, y en mucha menor medida para la sociedad. Por otra parte, dado que la mayoría de los fallecimientos en las sociedades desarrolladas se producen en el contexto hospitalario, en el que priman las rutinas institucionales, la persona moribunda pierde su identidad al pasar a estar controlada médicamente como un objeto, como un "solar de enfermedad” (Walter, 1994:39).

La reconstrucción después del deceso corresponde en exclusiva a la familia más directa que no ha perdido tanto su lugar social como parte de su identidad; además, ha de hacerlo no a 
través de rituales sociales prescritos y cerrados, que aunque persisten ya no tienen la funcionalidad del pasado, son más flexibles y están profesionalizados, sino en solitario a través del duelo, y más concretamente, en la dimensión interior del mismo: "hacer el duelo" (grief), esto es, el trabajo psicológico de recuperación del tono vital para reincorporarse plenamente a la vida social. Asimismo, y puesto que la vida social debe seguir, esta reconstrucción se ha de adaptar a las rutinas de "fabricas y oficinas”, y no al revés, esto significa que las personas `enlutadas' tienen poco tiempo para recuperarse, apenas espacio público para mostrar su desconsuelo y, para facilitar el normal funcionamiento de la sociedad, se espera que guarden sus emociones bajo control.

c) Autoridad: La Medicina, encarnada en el experto médico, detenta la autoridad máxima en la lucha contra la muerte proveyendo de normas de comportamiento -“las órdenes del médico"- para enfrentarse a ella, legitimadas por los avances del conocimiento científico y materializadas a través de instituciones hospitalarias. La íntima correlación existente siempre entre la realidad social objetiva y las reacciones individuales subjetivas inducidas por ella se observa claramente en el gran cambio psico-sociológico propiciado por la transición de la mortalidad $^{42}$ que ha permitido al discurso médico difundir la nueva visión de la muerte "natural" en el siglo XX. En efecto, dado que las actitudes personales son un reflejo de la situación social, a la par que un factor constitutivo de la misma, es decir, son simultáneamente un producto y un proceso social, esas reacciones personales se convierten en ingredientes activos de la realidad social, contribuyendo al clima mental que las envuelve, pudiendo influir en ella y modificarla. La cambiante actitud de los individuos ante "el proceso de modificación del ente humano por el transcurso del tiempo” (Myrdal y Klein, 1973:38), que es función del cambio en la realidad objetiva -reducción de la mortalidad, incremento de la longevidad, regulación y ordenación del ciclo vital-, se ha traducido finalmente en una profunda modificación en la valoración social de la muerte. El contraste en la percepción individual de ésta entre las sociedades tradicionales y las sociedades modernas asentado a lo largo del siglo XX es diáfano. Es el contraste entre, por un lado, una situación en la que la muerte formaba parte del paisaje cotidiano, era "lo normal”, es decir, un contexto en el que se ha naturalizado su atávica presencia como omnipotente, indómita, opaca, aleatoria y caprichosa, una imposición absoluta que amenazaba indiscriminadamente a todos, en todas las edades, a todas las horas y en todos los lugares, y; por otro lado, una situación en la que "lo normal" es su ausencia del paisaje cotidiano, es decir, en la que se ha naturalizado su escondida presencia como sometida, domesticada, extemporánea, discernible y racionalizable, una contingencia relativa que amenaza con discriminación y frente a la que cabe una cierta contención. 
Algunos autores incluso han vinculo esta evolución con que en las sociedades modernas haya menor necesidad de creencias sobre la vida después de la muerte y de ritos de paso. Es el caso de N. Elias (1987:59-60), cuando afirma que la elevada esperanza de vida característica de la muerte "natural" moderna hace comprensibles los casos de las personas que <<olvidan >>, que mantienen alejadas de sí, “durante gran parte de su vida, el pensamiento de la muerte”, dado que ésta se halla a una distancia relativamente lejana, mientras que cuando la esperanza de vida era reducida, "la vida es más corta, la amenaza de la muerte accede insistentemente a la conciencia, el pensamiento de la muerte es más penetrante, y las prácticas mágicas para enfrentarse con esta angustia mayor,... se hallan más extendidas”.

Sin ser el único factor causal, el papel jugado por la Medicina en ese cambio de mentalidad sí que ha sido determinante. Su capacidad para la reducción de riesgos, el control de las enfermedades, el desarrollo de mecanismos de prevención, el alivio del dolor y del sufrimiento, la predicción de las expectativas vitales, etc., ha conllevado que el discurso médico sea el más poderoso en este modelo de muerte. Y no sólo en éste. En efecto, la potencia del discurso médico moderno tiene una influencia decisiva más allá, en el propio discurrir general de la vida social como se ha mostrado, por ejemplo, en el Capitulo 2 de esta Tesis al imponer una definición social de la muerte acorde a la lógica de sus intereses. La profesión médica es la que decide cuándo una persona está muerta. Además, ideológicamente la hospitalización de la muerte significa su objetivación y la desimplicación respecto de ella, la percepción de que se puede vivir distanciado de la muerte y de que ésta es un mero suceso biotecnológico más que una experiencia existencial esencial (Cordero y Diez, 1988). Y así la muerte "se convierte en el punto cero: no es ni más ni menos que el momento en que el control humano sobre la propia existencia encuentra su límite” Giddens (1997:206).

Al ser dominante el discurso científico, y más específicamente el médico, que por su propia esencia racional no puede entrar en cuestiones de significado existencial, esta dimensión concreta se ha diluido de la esfera pública para concentrarse en la privada. Es en este ámbito también en el que el propio individuo decide autónomamente, sin imposición externa, si abraza una religión y a cuál de ellas.

d) Enfrentamiento a una muerte: La brecha público/privado se pone de nuevo de manifiesto en esta dimensión de la muerte moderna. El ocultamiento del diagnóstico y/o del pronóstico a la persona enferma persigue la tranquilidad emocional de la misma, pero también forma parte de una característica implícita de esa separación de ámbitos vitales: no está bien visto

\footnotetext{
${ }^{42}$ Proceso por el que se produce una profunda mutación de los niveles y estructura de la mortalidad y que es
} 
llevar los problemas privados a la esfera pública. Así, si en ésta se ha hecho todo lo que se podía hacer ante la enfermedad, y llegado un momento se ha de admitir el fracaso ineludible, procede como lo más conveniente socialmente que las personas afectadas muestren coraje guardando silencio, no siendo sinceras sobre sus sentimientos de aflicción y no exteriorizándolos para evitar con ello problemas en la interacción con los otros, ya que no se considera adecuado mostrar públicamente esos sentimientos y si se va a llorar, que sea en privado, puesto que la vida misma ya es suficientemente dura para todos. En consecuencia, el peso de la dimensión afectiva de todo ese proceso recae en la familia nuclear, que constituye la principal fuente de apoyo, mientras que los expertos, a través de las rutinas institucionales, se encargan de que todo el proceso corporal esté técnicamente vigilado por el personal médico-sanitario y, posteriormente a la muerte, por los profesionales de las empresas funerarias. A la par, parientes y amigos supervisan que el comportamiento de las personas `enlutadas’ discurra por los cauces sociales normales.

e) El "Viaje": La muerte es la del cuerpo, y es éste el que viaja hacia su descomposición. Viaje en el que es tratado con tecnología médica y farmacológica. Como el cuerpo está sujeto a las leyes de la naturaleza, es en ella en la que hay que buscar precisamente la mayoría de las causas que provocan su muerte (degeneración, infección). La ceremonia de despedida final también ha pasado a ser organizada en su totalidad por expertos y se realiza en el tanatorio, un lugar neutro, que no es la casa ni el hospital. De esta forma, la muerte es transformada en una especie de 'objeto de consumo', y de publicidad, introducido en el circuito económico vía tanatorios - “drugstores de la muerte sonriente y esterilizada” (Baudrillard, 1980:214)- en cuyo espacio se ofrecen servicios ${ }^{43}$ para su metabolización como cualesquiera otros servicios que se prestan a la sociedad y a los particulares; servicio que desde hace años, y por diversos motivos dependiendo de la localidad o del país, además de la inhumación incluye también la posibilidad alternativa de la cremación.

f) Valores: La influencia del discurso médico moderno se ha extendido a todo lo concerniente con el propio gobierno de las sociedades modernas en las que se ha asistido a la sustitución de dicotomías sociales básicas para la gestión del vivir y el morir: lo moral/inmoral fue remplazado por lo normal/patológico, sano/enfermo, saludable/no saludable (Seale, 1998:75). Discurso médico que, junto con el desarrollo de los sistemas de seguros, ha logrado implantar

analizado para el caso de España en el Capítulo 4 de esta Tesis.

${ }^{43}$ Aries (2000) se muestra muy crítico con uno de los servicios ofrecidos por los funeral home de EE.UU: la presentación de los muertos como cuasivivos. "La idea de muerte, a la vez que toda tristeza y todo patetismo, ha sido desterrada de esta ceremonia de adiós... La idea de hacer del muerto un vivo para celebrarlo por última vez puede parecernos pueril y descabellada... Sin embargo, da fe de una adaptación rápida y precisa a condiciones complejas y contradictorias de sensibilidad. Es la primera vez que una sociedad honra de manera general a sus muertos negándoles el estatuto de muertos.” 
entre la población una "conciencia general de la vida como negocio de riesgo" y de la muerte como producto del mismo, relacionando el riesgo de muerte con elementos de la estructura social y del estilo de vida y, por tanto, haciendo posible su control por la actividad de promoción de la salud, que se convierte en un valor esencial, en una especie de "capital corporal” que la medicina preserva e incluso ayuda a acumular (Seale, 1998:82). Sin embargo, esta promoción de la salud con el tiempo se ha ido orientando fundamentalmente hacia el desarrollo de políticas de supervivencia centradas en el auto-cuidado que, en última instancia, ha desembocado en una construcción social de la muerte como un asunto individual (independencia). De esta forma, la salud individual queda en manos de los propios individuos a los que corresponde reducir riesgos haciendo ejercicio, siguiendo una dieta equilibrada, no fumando ni tomando bebidas alcohólicas, etc. (espíritu de lucha). Como señala Bauman (1992:130-160), todas estas "incontables pequeñas prescripciones diarias y prohibiciones”, que son factibles de realizar, redefinen el "problema inmanejable de la muerte", ante el que no cabe hacer nada, como una serie de "problemas absolutamente manejables” sobre los que sí se puede hacer algo. Como resultado de todo este proceso de “des-metafisicación” de la muerte, ésta ha sido localizada en espacios segregados y 'humanizada' a través de esos problemas solubles, ante los que "uno puede hacer algo razonable y útil”. Todo ello, paradójicamente, "ni por un momento" permite a los vivos olvidar la muerte (Bauman, 1992:153).

Como se ha señalado más arriba, el proceso de medicalización de la muerte implica una alienación total de la persona moribunda, que vive de forma pasiva la última fase de su existencia vital insertado en las rutinas de las instituciones hospitalarias. Así, la muerte, padecida en muchos casos en la ignorancia y la pasividad, se convierte en un absurdo, en una falla sin justificación que provoca un temor casi inmanejable ahora que "ya no se cree en la existencia del mal (que le daría sentido) ni en la sobrevivencia del alma (que la anularía)" (Blanck-Cereijido y Cereijido, 1996:63). Al referirse a ello, Giddens (1997:205) habla de "secuestro de la enfermedad y la muerte”. Por ello, desde mediados de la década de 1950 se asiste a un aumento de las demandas sociales reivindicando cambios en la forma en que se produce el proceso de morir en esas instituciones. Entre esas demandas dos han devenido en básicas: dignidad frente a cosificación y privacidad aunque se esté en un espacio público. Muerte digna para el final de una vida humana, que no de un objeto. Privacidad para vivir la explosión de afectos particulares que se concitan en ese momento, que otros, ajenos al proceso de morir, no han de compartir ni tienen porqué contemplar. De esta forma, los pecados arquetipos en este tipo de muerte son la dependencia total por parte de la persona moribunda, y la intrusión en la intimidad de las personas desconsoladas.

Con sus virtudes, las implicaciones de este modelo de muerte no son todas positivas. Si bien Freud afirmó que en el inconsciente todos estamos convencidos de nuestra inmortalidad y 
que la negación es un fenómeno inmemorial y universal, al que califica de convención cultural, ya en el año 1915 alertó sobre las consecuencias negativas que para las sociedades occidentales contemporáneas podía inducir la "patente inclinación a prescindir de la muerte, a eliminarla de la vida” (Freud, 1990:111-123). En las sociedades modernas no se vive la muerte como una salida esperada que se prepara cuando se la `siente próxima', sino que es una ruptura de la vida privada en la que no se quiere pensar y que "se espera remitir indefinidamente por la magia de la ciencia" y, en todo caso, que cuando llegue se desea que lo haga de forma "súbita, inconsciente y discreta" (Thomas, 1985:23). Sin embargo, dada la primacía de las enfermedades crónicas como causas de muerte, este modelo de buena muerte de las sociedades modernas ha devenido en gran medida en un mito (Nuland, 1995:16), ya que la negación de la muerte genera expectativas muy angustiosas frente a ella cuando las barreras médicas de control ya no sirven y la llegada de la muerte no se puede postergar más. Aunque todavía queda un tiempo tasado, que hay que vivirlo. Tiempo de muerte, porque cada vez queda menos y porque sólo cuenta ella, todo lo demás es mera retórica. En consecuencia, los individuos de las sociedades modernas "mueren mal”, y en soledad.

\subsubsection{MUERTE NEO-MODERNA ${ }^{44}$}

“Compartir la soledad puede no ser una cura para el individualismo pero puede ser un primer auxilio muy eficaz”

T. Walter

Fruto de las ambigüedades del modelo moderno de muerte, pero sobre todo de los efectos negativos del mismo sobre la esfera privada de la persona moribunda y de sus allegados (alienación, ocultamiento, desposesión, soledad, dolor no mitigable en algunos procesos de morir, represión, angustia, simulación, desconsuelo, etc.), -cabe recordar en este punto las críticas de Illich (1975) y Veil (Veilet al, 1974) mencionadas en la Introducción de esta Tesis-, se asiste desde el último tercio del siglo XX a un "renacimiento" (revival), también en el campo de la investigación social, del interés por desarrollar nuevos modos de enfrentarse la muerte. En este modelo emergente, denominado por Walter Modelo Neo-moderno (muerte reconciliada o reivindicada), la muerte no está siendo modelada por los dogmas de la religión ni por las rutinas institucionales de la medicina, sino que, como conclusión lógica del individualismo imperante, es controlada (pilotada) por el propio individuo, el yo individual (el self), que se constituye en la

\footnotetext{
${ }^{44}$ Walter (1994) señala que éste es un modelo mixto en el que están "enredados” dos "hilos" que coexisten con tensiones y fricciones en la actualidad: a) el hilo moderno-tardío, en el que el discurso experto maneja y proporciona un lenguaje para articular los sentimientos del morir y del duelo privado. En lo relativo a la muerte, la esfera pública continúa controlando a la privada, pero más sutilmente; lo hace a través del experto en Psicología que sustituye al experto en Medicina; b) el hilo posmoderno, en el que la experiencia privada invade y fragmenta el discurso público al introducir los sentimientos privados en la agenda pública (en la formación médica, en las rutinas del hospital, en los mass media, etc.). En lo relativo a la muerte, la autoridad del propio individuo desafía a la autoridad del experto y se coloca por encima de ella.
} 
autoridad máxima de su proceso de morir, muerte y aflicción: “en una cultura del individualismo en la que vale una única vida vivida únicamente, la buena muerte es ahora la muerte elegida” (Walter, 1994:2). Desde una perspectiva más pragmática, este modelo de muerte ha cristalizado en lo que Thomas denominó "redomesticar" ${ }^{45}$ la muerte, con casos paradigmáticos como los hospices $^{46}$, por un lado, y el creciente e inevitable debate social sobre la legalización de la eutanasia, por otro.

En la emergencia de este modelo de muerte, aún minoritario, han incidido especialmente dos factores. Por un lado, en el ámbito demográfico, las causas de muerte características de la cuarta etapa de la transición epidemiológica ${ }^{47}$. En efecto, las distintas causas de muerte conllevan patrones -estado y síntomas- particulares en los "sucesos corporales" en cada caso que, a su vez, comportan diferentes grados de participación social. La creciente capacidad de la medicina para diagnosticar una enfermedad letal, así como para establecer con bastante aproximación el tiempo de vida restante, ha modificado en profundidad el papel de la persona moribunda en la modernidad tardía ${ }^{48}$. En este sentido, diversos estudios, sobre todo con enfermos con cáncer (Seale, 1998:81), han mostrado cómo los individuos “aprenden” a vivir con su enfermedad mortal, desarrollan toda una serie de actividades que les permiten reparar la seguridad ontológica perdida y mantienen sus propios criterios vitales para lograr que la muerte social coincida con la muerte física.

\footnotetext{
${ }^{45}$ Elisabeth Kübler-Ross y Cicely Saunders son dos personajes claves en el surgimiento de este proceso de reconciliación con la muerte.

${ }^{46}$ El término "hospice" significa literalmente "estación de tránsito" para ayudar a los viajeros en su jornada. Cicely Saunders fundó en 1967 el hospicio de San Cristóbal en Sydenham (Inglaterra) con el objetivo de ayudar a los viajeros (moribundos y sus familiares) que están en el camino a la muerte para evitar un proceso de morir despersonalizado, en solitario y doloroso. Esta primera experiencia fue imitada rápidamente en otros países, especialmente Estados Unidos donde se generalizó a comienzos de la década de los setenta. Los cuidados brindados por el hospicio se pueden realizar en el mismo centro o en el hogar del moribundo, e incluye a un equipo interdisciplinar, con servicios médicos, enfermería, ayuda psicológica, que tratan durante las 24 horas del día al paciente y su familia, controlan los síntomas dolorosos y siguen el duelo familiar después del deceso (Rice, 1997: 651). Este entorno del morir, sustancialmente distinto del existente en los centros hospitalarios, aporta como señala Rice (1997:651) otras ventajas decisivas respecto al de éstos: "los miembros de la familia son bienvenidos y al mantener unidos al paciente agonizante y a su familia se consuela al paciente y disminuye la culpa y la ansiedad de la familia. El hospicio permite que los pacientes y la familia tomen decisiones y tengan control sobre su vida en una atmósfera cálida y atenta. Ellos deciden los asuntos de la familia, la planeación del funeral, el testamento y el dónde, con quién, en qué condiciones y cómo ocurrirá la muerte”.

${ }^{47}$ En el Capítulo 4 de esta Tesis se desarrolla el concepto de "Transición Epidemiológica”, así como su aplicación al caso de la población española. No obstante, cabe anticipar que según algunos autores la sociedad española actual se encuentra en la cuarta fase de la misma, fase a la que se denomina de las "enfermedades degenerativas tardías", y en la que cobra especial importancia la incidencia acumulada del comportamiento, del estilo de vida, en las edades más avanzadas con un mayor peso de las enfermedades degenerativas a esas edades, que no conducen inmediatamente a la muerte.

${ }^{48}$ A. Giddens (1997:81) define a la modernidad reciente (o tardía) como la "fase actual del desarrollo de las instituciones modernas; está marcada por la radicalización y universalización de las características fundamentales de la modernidad".
} 
Por otro lado, este control sobre los sucesos futuros hay que enmarcarlo más ampliamente en el hecho de que la modernidad tardía se caracteriza por una generalización del riesgo “decisivo” en lo vital, de ámbito espacial global, de efectos temporales duraderos, de gran diversidad en sus efectos sociales, auto-engendrado por la propia sociedad y no gestionable con las técnicas usuales de aseguración, generando con todo ello inseguridad, incertidumbre y desprotección en las esferas macro y micro económicas, ambientales, sociales y culturales ${ }^{49}$. Así, en las esferas macro, la incertidumbre reinante está relacionada con la aplicación de la reflexividad a todos los campos de la vida humana, especialmente a los procesos de globalización, especialización y revolución tecno-científica. Esta continua revisión de lo dado “destruye certezas previas, amenaza instituciones y mecanismos históricos de protección y, sobre todo, introduce un signo de interrogación permanente sobre el futuro” (CEPAL, 2002:7). De esta forma, las argamasas que cohesionaban a las sociedades modernas como culturas de riesgo en las que, en su intento de colonizar el futuro, resultaba esencial "valorar hasta dónde es probable que los proyectos difieran de los resultados previstos” a través de la mediación de los expertos (Giddens, 1997:12), se tambalean en las sociedades contemporáneas.

En las esferas micro, por su parte, se asiste a una tensión dialéctica entre la manifestación subjetiva de la complejización y diferenciación social, que lleva a crecientes demandas de autoidentidad -la construcción del Yo (self) como un "monumento" (o individualidad reflexiva) -, y su expresión objetiva (o especialización sistémica), que desvincula "los diversos campos sociales y los aleja de la comprensión de los individuos” (PNUD, 1998). Fruto de esta tensión las personas se perciben a sí mismas solas, "secuestrada la experiencia", y empujadas a controlar continuamente los riesgos que observan, minándose con ello el "salto de fe" (Giddens) sobre el que se asienta su confianza en los expertos. Éstos, cada vez más constreñidos por su creciente especialización, son percibidos, por ello mismo, como cada vez menos capacitados para proteger a todos los individuos de todos los riesgos. Esta crisis de fe ha alcanzado asimismo a los expertos médicos que, cuestionados sobre todo por la distancia y la frialdad que imponen en sus relaciones, en las que cosifican a pacientes y familiares, y porque parecen estar sólo interesados en vencer a las enfermedades, se han visto obligados a desplazar su foco de atención desde éstas hasta los enfermos y a desarrollar nuevas prácticas médicas asentadas en una concepción holística de éstos.

a) Contexto corporal: La evolución de los conocimientos científico-médicos ha favorecido que persistiera la disminución de la mortalidad durante las últimas décadas, con la peculiaridad de que esa reducción se está produciendo en las edades más avanzadas. Fruto de la misma, la esperanza de vida ha seguido aumentando hasta los 80 años. Por otra parte, la capacidad

\footnotetext{
${ }^{49}$ Afectan al propio destino biológico de los seres humanos (Ramos Torre, 1999).
} 
de la Medicina para realizar diagnósticos cada vez más certeros y pronósticos cada vez más aquilatados, que se hacen explícitos, permite a las personas conocer su situación y aproximadamente el tiempo de vida de que disponen. Así, la muerte deja de ser un "mero encuentro", como en el pasado, y se transforma cada vez más en un "asunto prolongado" que puede dilatarse incluso durante décadas desde el primer diagnóstico. Por ello, la muerte arquetipo en el Modelo Neo-Moderno de muerte es la causada en adultos o en la vejez por el cáncer o el SIDA, y no tanto la que tiene su origen en las enfermedades cardiovasculares, pues su desarrollo es menos previsible y puede sajar una vida en cualquier momento. Esa trayectoria prolongada del morir conlleva el que sea difícilmente ocultable, o tabú, transformándose en una sombra tanto para la propia persona interesada, que vive con el morir, como para sus allegados y sus cuidadores, que hasta que se produce el deceso son testigos del morir sin muerte.

Como en el modelo anterior y por los mismos motivos que en él, la muerte atípica es la que se produce entre los jóvenes. Dado que en este modelo la autoridad es el propio individuo, es obvio que para éste resulte esencial el que la muerte social coincida con la muerte física, de ahí que se haya generado una demanda social de servicios que satisfagan esa necesidad. Bajo esta lógica han emergido en las últimas décadas dos organizaciones en las que cristaliza la nueva concepción holística del enfrentamiento a la muerte: por un lado, y como complemento a la labor desarrollada desde el marco institucional público, las Unidades de Cuidados Paliativos (U.P.C.), que pueden desarrollar su trabajo en espacios dentro del propio ámbito hospitalario o en la casa de la persona moribunda, y, por otro lado, desde la iniciativa privada, y con una orientación en sus orígenes fundamentalmente religiosa, los hospices. Por otra parte, Walter (1994) incluye en su análisis de este nuevo modelo de muerte, como otra manifestación práctica del mismo, a la creciente demanda social de la legalización de la eutanasia observada en los países desarrollados; sin embargo, no parece adecuada tal identificación por cuanto, como recuerda Seale (1998), aunque esa actitud pro-eutanasia comparta con el movimiento reivindicador de la muerte la crítica de fondo al modelo moderno de muerte, es una actitud más trasversal en la población ya que también está presente entre partidarios de este modelo de muerte que, sí, son partidarios de la muerte digna, pero que lo que sobre todo quieren es que no se alargue más la agonía ${ }^{50}$. Es decir, no buscan que la muerte física coincida con la muerte social porque, de hecho, esta última ya se ha producido con anterioridad.

\footnotetext{
${ }^{50}$ A partir de su observación sobre el continuo crecimiento en la demanda de eutanasia, Beck y BeckGernsheim (2003:240) se refieren con ironía a que para conseguir una muerte digna no sólo se va a requerir dinero, sino también una gran imaginación política y personal: "los logros de la tecnología médica para hacer que la vida sea más larga,..., se convertirán en un obsequio envenenado que desemboque en un gran vacío social. Lo cual arroja nueva luz sobre una verdad sencilla, a saber, que los aparatos pueden prolongar
} 
b) Contexto social: La grieta emocional entre lo público -afectividad neutral- y lo privado -total afectividad-, que caracteriza a la muerte moderna, se ha ido resquebrajando al expandir la experiencia privada de muerte, que llega a ser públicamente “celebrada” y organizada en casa, U.C.P. u hospices. Espacios en los que, aunque cada persona desarrolla los roles que le corresponden, no lo hace con la rigidez que caracteriza al ámbito hospitalario por lo que la explosión de afectos que rodea a la persona moribunda y allegados, y después del deceso a las 'enlutadas', puede ser también compartida por las personas expertas que las atienden (personal médico, de enfermería, consejeros psicológicos, grupos de apoyo emocional, etc.). Por otra parte, la multiplicidad de relaciones que desarrollan las personas en la modernidad tardía, y el carácter fragmentario y heterogéneo de las mismas, llevan a los individuos a desarrollar múltiples identidades, una para cada escenario de relación. La muerte de un individuo, por tanto, supone la ruptura de esas relaciones y de los lazos que el mismo mantenía en los distintos ámbitos grupales, por lo que después de producirse las diversas personas 'enlutadas' en distinto grado inician un trabajo de aflicción en el que se reconstruyen las diferentes identidades perdidas con ayuda de “compañeros de viaje”, consejeros, grupos de autoayuda y libros (Walter, 1994:53).

c) Autoridad: La base posmoderna de este modelo de muerte se pone de manifiesto cuando se afirma la pérdida de importancia de -crisis de fe en- cualquier autoridad heterónoma (religiosa, científica, médica, política, legal) y se entrona al propio individuo como máxima autoridad. Desde esta orientación, el proyecto societal central consiste en maximizar el bienestar individual, es decir, no está asentado en la satisfacción de las condiciones materiales sino que cada vez más depende de factores subjetivos, los relacionados con la calidad de vida a juicio de los propios individuos (Inglehart, 1998). El carácter cada vez más subjetivo de la experiencia vital se traslada inevitablemente a la experiencia de la muerte, que se vive como un proceso de crecimiento espiritual, es decir, la muerte queda definida más como un proceso psicológico que físico. Así, el significado de la muerte es creado por el propio individuo, pero también por las personas -familiares, allegados íntimos, terapeutas y consejeros-, que él elige como compañía en su último viaje, compartiéndolo y hablando con ellas sobre la muerte que llega y con la que finaliza la narración de su vida: "Yo hice mi camino". Como se ha apuntado arriba, el lugar de fallecimiento es asimismo fruto de la elección personal, no tiene que ser un lugar identificado con la mortificación, sino que debe de ayudar a conseguir la plenitud en ese momento esencial de la experiencia vital; en ese sentido, los espacios preferidos para la ceremonia del último adiós, la propia casa, las U.C.P. y los hospices, constituyen una especie de “anti-institución”.

la vida, pero no pueden atender a las personas. ¿Para qué queremos las $<<$ libertades tardías $>>$ de la vejez si la siguiente fase entraña un aumento de medidas asistenciales?”. 
Además de estos ejemplos en los que institucional y organizativamente se "redomestica" la muerte, existen otros que han florecido en la segunda mitad del siglo XX en los que, asimismo, se aprecia la gran ambivalencia social al enfrentarse a la muerte: ya que no hay más remedio que reconocer que existe, al menos, que ese reconocimiento no sea traumático. Uno de esos ejemplos es el de las experiencias cercanas a la muerte, las denominadas ECM ${ }^{51}$.

d) Enfrentamiento a una muerte: El tener que crear/recrear continuamente su identidad personal en un entorno tan fragmentario explica, según Giddens (2000:60), el "por qué son tan populares las terapias y asesoramientos de todo tipo en los países occidentales”. Tanto en las consultas individuales con expertos, como en las reuniones de los distintos grupos de autoayuda

\footnotetext{
${ }^{51}$ Término acuñado en 1975 por R. Moody -en inglés, Near-death experiences, (NDE)-, en su libro Life after life. Hace referencia a un conjunto de vivencias emocionales muy intensas en personas que, por diversas circunstancias -fallo orgánico grave, agonía o accidente-, "llegan a estar plenamente convencidas de encontrarse en trance de morir”, aunque finalmente han vuelto a la vida (Rodríguez, 2002:319). Con variaciones individuales el relato de estas experiencias ("entre los diversos relatos, ninguno de ellos es idéntico"), no obstante incluye, según Moody (1978:43-109), hasta quince elementos comunes, aunque "no he encontrado a nadie que informe de todos y cada uno de los detalles del modelo": 1) inefabilidad; 2) oír las noticias de que les daban por muertos; 3) sensación de paz y quietud; 4) escuchar inusuales sensaciones auditivas (“el ruido”); 5) sensación de ser empujado por un espacio oscuro (“el túnel oscuro"); 6) ser un espectador del propio cuerpo desde fuera del mismo; 7) encuentro con otros seres que les facilitaban la transición a la muerte o que les indicaban que su tiempo de morir no había llegado; 8) el elemento más común de todos los relatos, el encuentro con una luz muy brillante, "un ser luminoso"; 9) revisión panorámica de su vida; 10) aproximación a una frontera o límite ("que ha tomado la forma de masa de agua, niebla gris, una puerta, un cercado o simplemente una línea”); 11) regreso al propio cuerpo; 12) certeza absoluta sobre la realidad de la experiencia vivida y dificultad para hablar de ella con otros; 13) efectos sutiles sobre sus vidas que "se habían ampliado y que habían profundizado más en ellas"; 14) nuevas visiones de la muerte, nuevas "actitudes ante la muerte física... ya no temen a la muerte”; 15) corroboración de"que han sido testigos de muchos acontecimientos del mundo físico mientras" estaban fuera de sus cuerpos.

Este proceso, que fue descrito por primera vez por Heim en 1892, ha acaparado la atención desde entonces de un buen número de investigadores occidentales en un intento de descifrar las causas fisiológicas y psicológicas del mismo. Un resumen de estas investigaciones puede verse en (Rodríguez, 2002:319-359). Aunque en las mismas se demuestra que todos y cada uno de los elementos de la ECM se producen en situaciones fisiológicas y bioquímicas alteradas, por ejemplo, porque llega poco oxígeno al cerebro (anoxia o hipoxia), desde un punto de vista sociológico lo más relevante de las ECM es que en su proceso se entremezclan aspectos trascendentales, lo que ha conducido a que muchas personas crean que son una demostración de la supervivencia post-mortem (Rodríguez, 2002:321). Esta creencia, basada en la necesidad de creer más que en el conocimiento cierto, ha propiciado una situación paradójica en la que el conocimiento científico testado y riguroso no ha sido funcional para un gran número de personas que, inermes ante la muerte, han preferido ver en las ECM algo que "excede lo humano, que sobrepasa lo fisiológico", que pertenece al lado de la muerte, para de esta forma integrar de forma tranquilizadora la muerte en sus vidas. Una buena muestra de este desajuste social lo constituye el que el libro de Moody se convirtiera en un auténtico best-seller en Occidente, vendiéndose alrededor de 10 millones de ejemplares desde su publicación en 1975.

Resulta también paradójico que, en 1997, Moody reconociera que su libro era un texto "nulo y vacío", "manipulado por su editor", y que no existía ningún tipo de prueba que demostrara la existencia de vida después de la muerte.

Por otra parte, Rodríguez (2002:357) relaciona esa necesidad, más religiosa que científica, de admitir la ECM con la necesidad cultural de "poner en orden la conciencia antes de morir". Apunta como prueba el que sólo se han detectado relatos de ECM en las sociedades más individualistas -los países occidentales, la India o China ("los dominados por concepciones religiosas como la judía, hindú, budista cristiana o musulmana”) -, y no en culturas más primitivas en las que el individuo es secundario respecto al clan o grupo -aborígenes australianos, tribus amazónicas, indios norteamericanos.
} 
(alcohólicos, ludópatas, de duelo, etc.), los individuos buscan revivir y reinterpretar su pasado para enfrentarse a sus miedos y alcanzar una "mayor autonomía para el futuro”. Es decir, seguir adelante reescribiendo el guión de sus vidas. En este sentido, si en el modelo moderno de muerte el coraje en el enfrentamiento a la misma se demostraba con el silencio sobre la batalla que se libraba, en este nuevo modelo la valentía se muestra con el hablar abiertamente sobre ella. Dada la tensión emocional que esas situaciones conllevan se recomienda por los expertos, en este caso los psicólogos, expresar de forma apropiada los sentimientos para evitar situaciones de angustia que potencialmente pudieran desembocar en estados mórbidos. Así, y tal y como si fuera una recuperación de las actitudes románticas ante la muerte, se aboga por la exteriorización de los sentimientos ante la muerte próxima o por la pérdida sufrida. Exteriorización que sin embargo debe ser canalizada por esos mismos expertos para así evitar conflictos en las relaciones derivados de un exceso de sinceridad o de una verbalización inadecuada o a destiempo de los mismos. Es el caso del modelo psicológico de muerte propuesto por E. Kübler-Ross ${ }^{52}$ (1989), según el cual todas las personas afectadas por una enfermedad no curable atraviesan por cinco fases socio-psicológicas desde el momento en que reciben el diagnóstico de la misma: 1) negación (“Esto no me puede estar pasando a mí”); 2) ira, resentimiento, rebelión (“¿Por qué a mí?, ¡no es justo!”); 3) negociación (“Déjame vivir para ver graduarse a mis hijos”); 4) depresión (“Voy a morir, ¿qué sentido tiene?, ¿por qué seguir?”), y; 5) aceptación final (“No puedo luchar, debo prepararme para lo que viene”). Lógica de racionalización que se extiende asimismo hasta al proceso psicológico del enfrentamiento a una muerte por parte de los `enlutados', para los que se identifica cuál y cómo debe de ser el duelo normal con una secuencia de etapas (negación, ira, pacto, depresión, aceptación) por las que deberían de transitar los afligidos para no caer en un duelo patológico. Lógica que ha generado una abundante bibliografía en los últimos años ${ }^{53}$.

\footnotetext{
${ }^{52}$ Modelo psicológico de afrontamiento de la muerte que según Gutiérrez Vega y Martínez Baza (1991:31) quizá pudiera ser aplicado en Estados Unidos pero no tanto en los países europeos occidentales entre los que "no es norma habitual (comunicar) la información sobre el diagnóstico fatal" a la persona interesada.

${ }^{53}$ Como una pequeña muestra de la misma, se pueden consultar los siguientes textos en español: OROZ ECURRA, Ch. (2011): Aspectos psicosociales acerca de la muerte, Pamplona, Eunate; PAYÁS PUIGARNAU, A. (2010): Las tareas del duelo. Psicoterapia de duelo desde un modelo integrativorelacional, Barcelona, Paidós; TIZÓN, J.L. y SFORZA, M.G. (2008): Días de duelo. Encontrando salidas, Barcelona, Alba; HEATH, I. (2008): Ayudar a morir, Buenos Aires, Katz; NOMEN MARTÍN, L. (2007): El duelo y la muerte. El tratamiento de la pérdida, Madrid, Pirámide; BAYÉS, R. (2006): Afrontando la vida, esperando la muerte, Madrid, Alianza; TIZÓN, J.L. (2004): Pérdida, pena, duelo, Barcelona, Paidós; GÓMEZ SANCHO, M. (2004): La pérdida de un ser querido. El duelo y el luto, Madrid, Arán Editores; COUCEIRO, A. (ed.) (2004): Ética en cuidados paliativos, Madrid, Triacastela; BUCAY, J. (2003): El camino de las lágrimas, Barcelona, Grijalbo; POCH, C. y HERRERO, O. (2003): La muerte y el duelo en el contexto educativo. Reflexiones, testimonios y actividades, Barcelona, Paisós; BAYÉS, R. (2001): Psicología del sufrimiento y de la muerte, Barcelona, Martínez Roca; COBO MEDINA, C. (2001): Ars Moriendi. Vivir hasta el final, Madrid, Díaz Santos; FONNEGRA DE JARAMILLO, I. (2001): De cara a la Muerte. Cómo afrontar las penas, el dolor y la muerte para vivir plenamente, Barcelona, Andrés Bello; SOCIEDAD ESPAÑOLA DE MEDICINA DE FAMILIA Y COMUNITARIA (2001): Atención al Paciente Terminal. Curso a distancia. Módulo de Formación Continuada en Atención al Individuo, Hospitalet, SemFYC; DÍAZ HÚDER, J. (2000): Que no te toque a ti. ¿Es cáncer doctor?; Madrid,
} 
Al lado de ese trabajo profesional desarrollado por las personas expertas en Psicología, y como complemento necesario para lograr mayor eficacia en el trabajo psicológico del enfrentamiento a un problema, o de la recuperación cuando el mismo ha estallado con toda su crudeza, se ha asistido durante las últimas décadas en las sociedades desarrolladas a la proliferación de grupos de apoyo, denominados grupos de auto-ayuda, que persiguen, actuando como un espejo, la identificación con iguales que se enfrentan al mismo problema o que ya lo han superado en su fase más crítica. Dinámica que, a diferencia de las conversaciones asimétricas y casi unidireccionales con el personal experto, permite como en las dinámicas de los grupos de discusión compartir inmediatamente sentimientos, intercambiar experiencias, ubicar socialmente discursos y relativizar la propia situación. Estas dinámicas también han proliferado en el ámbito de la salud, en el del enfrentamiento a la muerte y en el del duelo, y si bien, probablemente, la mayoría de ellas son eficaces y cumplen con su función paliativa, no han podido evitar la utilización perversa de las mismas al ser un caldo de cultivo apropiado para la emergencia de comportamientos interesados. Como versión más torticera de esa manipulación, incluso ha crecido una ideología claramente reaccionaria, la Psicología Positiva, que amparada en la legitimación científica de la Psicología, ignora los factores estructurales e individualiza los problemas culpabilizando a los propios individuos de su situación, tal y como ha denunciado B. Ehrenreich (2011). Obviamente el espíritu y los intereses de esta ideología expansionista están muy alejados de la labor de consuelo y apoyo emocional que caracteriza por ejemplo a los grupos de terapia ante la muerte o de duelo; al contrario, dado que con sus prácticas, en su caso multitudinarias, persiguen como aquéllos la aceptación personal del problema que afecta a los individuos implicados, paradójicamente, lo hacen inyectando en ellos una especie de virus de culpabilidad que multiplica las consecuencias negativas para las personas afectadas. Así, éstas, a partir del momento en que entran contacto con sus redes, tienen que enfrentarse a un doble problema: el original que las llevó hasta ellas, y el generado por la asunción de culpa precisamente por tener el problema que las abruma, cuando no las excluye socialmente, por no haber sido suficientemente <<positivas >> en el enfrentamiento al mismo, independientemente de que ese problema sea tener un cáncer, el SIDA, o más ampliamente, estar en el paro, no ser rico, no haber alcanzado un estatus social elevado, etc. Como una muestra suficientemente elocuente del discurso del "optimismo", y de la utilización de referencias a la ciencia como justificación, que caracteriza a este movimiento social cada vez más extendido en EE.UU. se reproduce a continuación un párrafo del artículo online "Breast Cancer Prevention Tips", citado por

Alcántara; GARCÍA-SABELL (1999): Paseo alrededor de la muerte, Madrid, Alianza; LÓPEZ IMEDIO, E. (1998): Enfermería en cuidados paliativos, Madrid, Editorial Médica Panamericana; ANUARIO DE PSICOLOGÍA (1998): Actitudes ante la muerte, Barcelona, Universidad de Barcelona; MITTAG, O. (1996): Asistencia práctica a enfermos terminales, Barcelona, Herder; FERRERO BERLANGA, J. (1993): El afrontamiento de un diagnóstico de cáncer, Valencia, Promolibro. 
Ehrenreich (2011:41): "Se ha descubierto que algo tan simple como la actitud positiva reduce el riesgo de cáncer. Esto le sonará raro a mucha gente, pero bastará con explicar que diversos estudios médicos han demostrado que la actitud positiva se relaciona con un sistema inmunológico más fuerte. La risa y el buen humor han demostrado ser capaces de reforzar las defensas del cuerpo y previenen contra el cáncer y otras enfermedades. Todos hemos oído la frase: ‘La gente feliz no se pone mala’”.

e) El "Viaje": Ese último viaje es un viaje interno que se considera esencial para cerrar la vida, por lo que se asume como aspecto básico de la condición humana la necesidad del vivir con el propio morir. Así, si en el modelo tradicional el viajero es espiritual -el alma-, y en el moderno es físico -el cuerpo-, en el modelo neo-moderno el viajero es emocional -la psique. Viaje psicológico para el que no existen guías que ofrezcan rutas predeterminadas de antemano, pero que sí que está apoyado continuamente en conversaciones y en la expresión de sentimientos con familiares, terapeutas y grupos de apoyo, hasta alcanzar la meta final: la aceptación del final de la propia vida. Frente a los modelos anteriores de muerte en los que existían normas compartidas de cómo morir y cómo afligirse, en éste el individuo que muere "hace su camino”, y eso también queda reflejado en las disposiciones que realiza para la preparación y desarrollo de su funeral, que normalmente se centra en su vida, es decir, es un funeral muy personalizado en el que se homenajea a la persona fallecida. Es el caso, entre otros recientes recogidos por los medios de comunicación, de Pedro Martínez, fallecido en Sevilla a los 34 años de edad el 15/12/11, quien, afectado por esclerosis lateral amiotrófica (ELA), concedió cinco días antes de morir una entrevista a EL PAÍS (22/12/11:40-41) en la que relataba precisamente el enfrentamiento a su muerte y cómo quería que discurrieran los últimos días de su vida. Si bien no sólo los servicios sanitarios públicos que le estaban atendiendo, sino también los profesionales de la asociación Derecho a Morir Dignamente (DMD) que le visitaron, consideraban que todavía faltaban unos meses hasta que muriera, el sufrimiento insoportable que le comportaba la enfermedad y la angustia por la amenaza cada vez más presente de ahogarse al comer o al beber, le llevó a optar por adelantar su muerte mediante sedación -suicidio asistido. Decisión personal sustentada, según declaró, en que "uno debe tener el control de su propia vida... No se trata de morir con dignidad. Se trata de vivir con dignidad hasta el final, llevando el control de lo que se hace”. Control que también ejerció en la ceremonia de su despedida, una fiesta "como una boda” que organizó para dos días antes de la fecha elegida para morir, y a la que asistieron 80 personas; fiesta que sufragó con la última mensualidad de la pensión no contributiva que recibía.

f) Valores: Los valores arquetipos de este modelo de muerte ya han sido desgranados más arriba: emoción, crecimiento personal, autonomía hasta el final, elección informada, comunión de sentimientos, control personal de la situación. Ante ellos, los pecados arquetipo son el aislamiento 
social y/o emocional y la negación psicológica de lo inevitable. La buena muerte en este caso es la que permite culminar de la mejor manera posible una biografía basada en hacer "mi propio camino”, es decir, una muerte que de forma consciente e indolora permita dar por terminado el negocio personal psicológico. 


\begin{tabular}{|c|c|c|c|}
\hline \multicolumn{4}{|c|}{ TABLA 3.2. MODELOS DE MUERTE DE TONY WALTER } \\
\hline & TRADICIONAL & MODERNA & NEO-MODERNA \\
\hline \begin{tabular}{l}
\multicolumn{1}{c}{ CONTEXTO } \\
CORPORAL \\
1.- Muerte arquetipo \\
2.- Trayectoria del morir \\
3.- Esperanza de vida \\
4.- Visón de la muerte de \\
los otros \\
5.- Condición humana \\
6.- Muerte típica \\
7.- Nacimiento social \\
\multicolumn{1}{c}{ Muerte social } \\
8.- Muerte atípica
\end{tabular} & $\begin{array}{c}\text { Plaga } \\
\text { Rápida } \\
40 \text { años } \\
\text { Frecuentemente } \\
\text { Viviendo con la muerte } \\
\text { Niños } \\
\text { Sigue nacimiento físico } \\
\text { Sigue muerte física } \\
\text { Viejo (venerado) }\end{array}$ & $\begin{array}{c}\text { Cáncer//Coronaria } \\
\text { Oculta } \\
70 \text { años } \\
\text { Raramente } \\
\text { Muerte controlada } \\
\text { Ancianos } \\
\text { Al nacimiento físico } \\
\text { Precede muerte física } \\
\text { Joven (sin sentido) }\end{array}$ & $\begin{array}{c}\text { Cáncer//SIDA } \\
\text { Prolongada } \\
80 \text { años } \\
\text { Testigo del morir sin } \\
\text { muerte } \\
\text { Viviendo con el morir } \\
\text { Ancianos } \\
\text { Precede al nacimiento } \\
\text { físico } \\
\text { A la muerte física } \\
\text { Joven (sin sentido) }\end{array}$ \\
\hline $\begin{array}{l}\text { CONTEXTO SOCIAL } \\
\text { 9.- Estructura social } \\
\text { 10.- Envoltorio de la } \\
\text { persona } \\
\text { Fundada en } \\
\text { Muerte= pérdida de } \\
\text { Tarea después de la } \\
\quad \text { muerte } \\
\text { Hacerlo a través de }\end{array}$ & $\begin{array}{c}\text { Comunidad } \\
\text { Pertenencia social } \\
\text { Comunidad } \\
\text { Posición social } \\
\text { Reconstrucción roles } \\
\text { Luto (lamento) } \\
\end{array}$ & $\begin{array}{c}\text { Pública vs privado } \\
\text { Identidad } \\
\text { Familia } \\
\text { Identidad } \\
\text { Reconstrucción identidad } \\
\text { Pena, aflicción } \\
\end{array}$ & $\begin{array}{c}\text { Privado y público } \\
\text { entrelazado } \\
\text { Identidades } \\
\text { Relaciones } \\
\text { Identidades } \\
\text { Reconstrucción } \\
\text { identidades } \\
\text { Trabajo de aflicción } \\
\end{array}$ \\
\hline $\begin{array}{l}\text { AUTORIDAD } \\
\text { 11.- Autoridad } \\
\quad \text { Conocido a través } \\
\text { 12.- Institución } \\
\text { 13.- Significado } \\
\text { 14.- Religión }\end{array}$ & $\begin{array}{c}\text { Dios/Tradición } \\
\text { “La voluntad de Dios” } \\
\text { Clero (hombres) } \\
\text { Iglesia } \\
\text { Dado } \\
\text { Dado }\end{array}$ & $\begin{array}{c}\text { Experto médico } \\
\text { “Órdenes de los doctores” } \\
\text { Doctores (hombres) } \\
\text { Hospital } \\
\text { Abolido (en público) } \\
\text { Elección de iglesia }\end{array}$ & $\begin{array}{c}\text { Uno mismo } \\
\text { “Yo hice mi camino” } \\
\text { Consejeros (mujeres) } \\
\text { Casa/hospicio } \\
\text { Creado } \\
\text { interpersonalmente } \\
\text { Espiritualidad interna }\end{array}$ \\
\hline $\begin{array}{l}\text { ENFRENTANDO UNA } \\
\quad \text { MUERTE } \\
\text { 15.- Valor mostrado en } \\
\text { 16.- Estrategia } \\
\text { 17.- Apoyo laico } \\
\text { 18.- Vigilancia por } \\
\quad \text { Vigilancia de } \\
\end{array}$ & $\begin{array}{l}\text { Oración, súplica } \\
\quad \text { Ritual } \\
\text { Vecinos/pacientes } \\
\text { Sacerdote/vecino } \\
\text { Alma/conducta } \\
\end{array}$ & $\begin{array}{c}\text { Silencio } \\
\text { Soledad emocional } \\
\text { Familia nuclear } \\
\text { Cuerpo/conducta } \\
\text { Cuerpo/conducta } \\
\end{array}$ & $\begin{array}{c}\text { Hablar } \\
\text { Expresada } \\
\text { Grupos de autoayuda } \\
\text { Consejero } \\
\text { Sensaciones } \\
\end{array}$ \\
\hline $\begin{array}{l}\text { EL “VIAJE” } \\
\text { 19.- Viajero } \\
\text { 20.- Muerte } \\
\text { 21.- Modo de transporte } \\
\text { 22.- Funeral } \\
\quad \text { Organizado por }\end{array}$ & $\begin{array}{c}\text { Alma } \\
\text { Resultado del pecado } \\
\text { Acción ritual } \\
\text { Entierro } \\
\text { Comunidad }\end{array}$ & $\begin{array}{c}\text { Cuerpo } \\
\text { Causado naturalmente } \\
\text { Tecnología/drogas } \\
\text { Cremación } \\
\text { Comercio/municipio }\end{array}$ & $\begin{array}{c}\text { Psique } \\
\text { Viaje interno } \\
\text { Hablar } \\
\text { Centrado en la vida } \\
\text { Sociedad memorial }\end{array}$ \\
\hline $\begin{array}{l}\text { VALORES } \\
\text { 23.- Valores } \\
\text { 24.- El peor pecado } \\
\text { 25.- La mejor muerte }\end{array}$ & $\begin{array}{c}\text { Respeto } \\
\text { No creer } \\
\text { Consciente/Listo para } \\
\text { encontrarse con el Creador }\end{array}$ & $\begin{array}{l}\text { Salud/Privacidad/Dignidad/ } \\
\text { Combatividad/Independ. } \\
\text { Intrusión } \\
\text { Inconsciente/Repentina/Sin } \\
\text { molestar a los otros }\end{array}$ & $\begin{array}{c}\text { Emoción/Crecimiento/Ele } \\
\text { cción/Autonomía/Control } \\
\text { Aislamiento/Negación } \\
\text { Consciente/Preciosa/Mi } \\
\text { camino/Fin de negocio }\end{array}$ \\
\hline $\begin{array}{c}\text { DISCURSO } \\
\text { DOMINANTE }\end{array}$ & Religioso & Científico-médico & Psicológico \\
\hline
\end{tabular}

Fte: (Walter, 1994:48). 
Seale (1998), no obstante, señala que el discurso neo-moderno de muerte tiene una aplicación limitada, ya que no todas las personas pueden y/o desean asumirlo. Por ejemplo, no tiene demasiado sentido para aquellos individuos a los que la muerte les sorprende sin margen de tiempo que gestionar. En el lado opuesto, tampoco "sirve" para aquéllas personas con enfermedades degenerativas en las que no sólo la muerte social, sino también la muerte psicológica, se anticipan a la muerte física. Además, como en otras facetas sociales, se percibe en la muerte neo-moderna una cierta "distinción de clase" que refleja las diferencias en la vida material. El propio Walter (1994:60-64) reconoce esas carencias al asumir que su propuesta de tipos ideales no pretende simplificar la realidad sino iluminar la complejidad de la misma, ya que la experiencia real de la gente está caracterizada por una mezcla de los tres tipos de muerte que metaboliza las incertidumbres, contradicciones y conflictos de esa experiencia. Cita como ejemplo de esa mezcla el caso de una persona creyente enferma en fase terminal que vive en su casa y que continúa participando en las actividades de su comunidad local (modelo tradicional); posteriormente es trasladada a un hospital, y aislada (modelo moderno), y; después de su muerte, las personas 'enlutadas' realizan actos memoriales en su homenaje (modelo neo-moderno). Mezcla de modelos de muerte que también ha sido certificada para la población española en el análisis empírico realizado para esta Tesis, tal y como se expone en el Capítulo 5.

\subsection{DISCURSOS SOBRE LA MUERTE EN LAS SOCIEDADES DESARROLLADAS. ¿ES LA MUERTE UN TABÚ?}

"Somos seres discontinuos, individuos que mueren
aisladamente en una aventura ininteligible, pero
tenemos la nostalgia de la continuidad perdida"

G. Bataille

La muerte plantea la "situación marginal” por excelencia al individuo, a la par que, simultáneamente, es la "amenaza más terrible”, por su ominosa presencia y continuo interferir, “a las realidades establecidas de la vida cotidiana” (Berger y Luckmann, 1968:131). Históricamente ha sido capital para cualquier orden institucional, según estos autores, domesticarla e integrarla dentro de la realidad social. Es decir, "legitimarla” para, conocida la muerte de los otros por parte de los individuos y sabiéndose mortales ellos mismos, amortiguar el terror de éstos y evitar la paralización de la vida social cotidiana. De ahí, como se ha señalado en el Capítulo 2 de esta Tesis, la creación de los sistemas de muerte. Los discursos sociales empleados en esa tarea de control social han variado en el tiempo, si bien en la actualidad, y con distinta intensidad en cada uno de ellos, se puede apreciar la coexistencia de tres, el tradicional, de base religiosa, el moderno, cuyo germen se sitúa en el proceso de individualización de las conciencias iniciado con el protestantismo y que se reforzó con los cambios estructurales acaecidos desde el siglo XVIII 
(Ilustración, Revolución Francesa y Revolución Industrial), y, desde la década de 1990, el posmoderno asentado en las críticas al proyecto de modernización y en los cambios estructurales ligados, entre otras causas, al proceso de globalización y al avance científico en todas las áreas de conocimiento y a su aplicación en nuevas tecnologías. En este apartado, se analizan sucesivamente los dos últimos discursos y se finaliza el mismo con una presentación del debate sobre si la muerte es tabú o no en las sociedades occidentales hoy.

\subsubsection{DISCURSOS SOBRE LA MUERTE EN LAS SOCIEDADES MODERNAS}

"Lo que ofrece el sometimiento a la sociedad no es tanto la liberación respecto de unas $<<$ fuerzas físicas irreflexivas $>>$ como la liberación respecto al hecho de pensar en ellas. La libertad se presenta como el exorcismo del espectro de la mortalidad”

Z. Bauman

Dado que el "desafío a la muerte es tristemente ineficaz”, se la acepta no sólo como un hecho natural, sino además como una necesidad -que revela una falta de poder, una incapacidad para cambiar lo que es-, "necesidad que debe ser conquistada no destruyéndola, sino aceptándola” (Marcuse ${ }^{54}$, 1986:153-154). Sin embargo, este autor resalta que esa "inversión ontológica" ${ }^{\text {, }}$ que hace de la necesidad virtud, no tiene en la mayoría de las sociedades desarrolladas -al menos en las de tradición cristiana- un carácter fatalista, ni mucho menos inocente. En efecto, aunque la muerte es inevitable y para una gran mayoría de individuos es un “acontecimiento doloroso, horrible, violento y no bien recibido”, históricamente se acabará convirtiendo en una institución social esencial para el propio funcionamiento de la sociedad. Así, la muerte necesaria biológicamente ha acabado siéndolo también socialmente (Marcuse, 1986:165). Por ello, “el temor a la muerte”, como una necesidad sancionada, y la "represión en la aceptación de la muerte” constituyen factores de cohesión en la organización de la sociedad. En otro caso, por ejemplo, si los individuos aceptaran la muerte sin terror, esta actitud se opondría frontalmente a las instituciones y los valores de civilización implantados. Dicha actitud conduciría, según Marcuse (1986:160), bien a un suicidio en masa, al desaparecer el dique conformado por el temor a la muerte que permite el mantenimiento de la vida cuando ésta

\footnotetext{
${ }^{54}$ En su análisis de la <<Ideología de la Muerte >>, Marcuse (1986) señala que la interpretación de la muerte en el pensamiento occidental se ha movido en una escala cuyos límites son la idea de la muerte como un mero hecho natural y, en el otro extremo, la idea de la muerte como característica distintiva de la existencia humana. Las actitudes hacia la muerte inferidas del primer extremo han sido la "aceptación escéptica o estoica de lo inevitable, o incluso la represión de la idea de muerte durante la vida". En el segundo polo, por su parte, la "glorificación idealista de la muerte que es la que da "significado" a la vida, o la condición previa de la "verdadera" vida del hombre". Es decir, la vida queda trascendida por una muerte que, además de un hecho natural, se convierte en un hecho esencial. Su análisis se centra en esta segunda idea, existencial, de la muerte.

55 “Tendencia a presentar la necesidad empírica como necesidad ontológica” (Marcuse, 1988:154).
} 
constituye para un gran número de personas una carga difícil de sobrellevar ${ }^{56}$, o bien, a "la disolución de toda ley y de todo orden”, al desaparecer, o al menos disminuir, su capacidad disuasoria, el freno que supone el temor a perder la vida como "elemento intrínseco de la moralidad pública y privada”. De ahí que Marcuse afirme que en las sociedades occidentales "la idea tradicional de la muerte es un concepto sociopolítico que convierte unos sórdidos hechos empíricos en una ideología”. Ideología asentada en las características "redentoras e incluso creadoras de la muerte: su necesidad natural y esencial ("la vida no sería vida sin la muerte”)”, y propulsora de comportamientos vitales ligados a toda forma de "ascetismo intramundano". La destrucción de esa ideología de la muerte "equivaldría al derrumbamiento de la civilización establecida" ${ }^{\text {57. }}$.

Marcuse añade que la potenciación de la muerte como categoría existencial, es decir, como un "límite metafísico" contra el que es esencialmente imposible rebelarse y luchar, refuerza el papel de la muerte como institución social reproductora del orden social dominante. Dado que lograr una mayor cohesión social está estrechamente relacionado con una necesaria mayor aceptación por parte de los individuos de la muerte como algo que va más allá de la necesidad natural, para lograr así "su disposición a sacrificarse a sí mismos”, resulta conveniente socialmente "no luchar <<demasiado>>" con ella. Es decir, no habría que valorarla demasiado, desde luego no como al "bien supremo", porque el "orden social exige conformarse a la servidumbre y a la resignación; exige heroísmo y el castigo del pecado” (Marcuse, 1986:169). Es el discurso religioso dominante en el modelo de Muerte Tradicional (Tabla 3.2.).

Admitiendo que la perplejidad que provoca la muerte tiene alcance universal, Baudrillard (1980) resalta que también en las sociedades modernas esa perplejidad se halla socialmente mediatizada, aunque en este caso por la lógica interna de su modelo de desarrollo y del creciente individualismo conexo al mismo. Con una argumentación, en principio, similar a la planteada por Marcuse ("el poder sobre la muerte es también poder sobre la vida” (Death Power)), Baudrillard insiste menos en la dimensión de control ínsita en la muerte como límite metafísico, en la aceptación sancionada de la necesidad (natural y esencial) de la muerte, y se centra en el análisis de unas relaciones con la muerte en las que ésta sigue siendo una institución social básica para el funcionamiento de la sociedad, pero en las que progresivamente ha declinado la importancia de su dimensión existencial respecto a etapas anteriores -la muerte no es ya una puerta hacia otra realidad-, a la par que se han conformado unas relaciones caracterizadas por la exclusión

\footnotetext{
${ }^{56}$ En este mismo sentido se refiere Thomas Szasz (2002) al analizar la construcción social del suicidio en las sociedades desarrolladas.

${ }^{57}$ Ya que supondría una "transvalorización explosiva de los conceptos sociales: la buena consciencia de ser un cobarde, la desglorificación y la desublimación; supondría un nuevo <<principio de realidad > que liberaría el <<principio del placer >> en vez de reprimirlo” Marcuse (1986:164).
} 
intencionada de la misma, se la niega socialmente (modelo tabú de la muerte). Exclusión que precede a todas las demás exclusiones, que está en la base misma de la $<<$ racionalidad $>>$ de la cultura occidental, y que en un proceso evolutivo irreversible desde las sociedades arcaicas hasta las modernas ha derivado en la hipertrofia del discurso relacionado con los vivos y en que "poco a poco los muertos dejan de existir”, pues la muerte interrumpe el proyecto 'prometeico`de unos seres decididos a transformar el mundo y su propio destino. Deriva que constituye la constatación de una impotencia absoluta, la de la imposibilidad de racionalizar la muerte en las sociedades modernas: "sólo la función-muerte no puede ser programada allí, ni localizada. A decir verdad, no saben qué hacer con ella. Porque no es normal estar muerto hoy día, y esto es nuevo”. Por ello, ante tamaña “anomalía impensable”, que asalta y dinamita la lógica reproductiva del sistema capitalista, la única respuesta posible es la de volatilización de los muertos, no dejándoles ni espacio ni tiempo en la vida cotidiana (Baudrillard, 1980:145).

Baudrillard examina esta negación moderna de la muerte contrastándola con el enfrentamiento a la misma por los pueblos primitivos, contraste que este autor sustenta en la concepción de la muerte como una línea de demarcación social que separa a los $<<$ muertos $>>$ de los $\langle<$ vivos $>>$, afectando a unos y otros. El intercambio entre ambos sólo puede ser simbólico, ya que la muerte es la negación de todo supuesto. Al ser productos sociales, la línea de división y el intercambio simbólico necesariamente han evolucionado históricamente. En las culturas primitivas, durante miles de años, no existía un concepto biológico de la muerte, de hecho no tenían siquiera un concepto de muerte, más bien ésta era una $<<$ imagen $>>^{58}$, algo social, público y colectivo que se comparte, y que es socializada por el intercambio (Baudrillard, 1980:194). Es decir, aún no habían <<naturalizado >> a la muerte, sino que simplemente la vivían siempre como una relación social ${ }^{59}$. Como ha resaltado Hertz (1990:89), la muerte no sólo ponía fin a la existencia corporal de un individuo, sino que sobre todo en el mismo golpe destruía "al ser social inserto en la individualidad física”, ente creado por la conciencia colectiva a quien dotaba de importancia y dignidad variable ${ }^{60}$. La destrucción de ese ente equivalía a un sacrilegio, de ahí que

\footnotetext{
${ }^{58}$ Morin (1974a:24) matiza que la muerte no existe en los vocabularios de los pueblos más arcaicos: "se habla de ella como de un sueño, de un viaje, de un nacimiento, de una enfermedad, de un accidente, de un maleficio, de una entrada en la residencia de los antepasados, y con frecuencia de todo ello a la vez".

${ }^{59}$ En la misma línea se manifiesta Riley (1979:275), que señala que en los pueblos iletrados "no existe una teoría clara acerca de la muerte <<natural >>; creen que la muerte es el resultado de la intervención de un agente externo. En todas las culturas existe la idea, implícita o explícita, de una relación (benefactora u hostil) entre los vivos y los muertos. La muerte es vista como una crisis a través de la cual el muerto entra a ocupar un nuevo estatus”. Entre estos pueblos es rara la creencia en una salvación personal, tampoco han creado escatologías de premios y castigos individuales después de la muerte.

60، En el interior de una misma sociedad, la emoción varía extremadamente en intensidad según el carácter social del difunto, e incluso en ciertos casos puede llegar a faltar por completo. A la muerte de un jefe o de un hombre investido de alta dignidad, un verdadero pánico se apodera de todo el grupo.... Sin embargo, la muerte de un extranjero, de un esclavo o de un niño pasará casi desapercibida, sin provocar emoción ni dar lugar a rito alguno. Así pues, no es la extinción de la vida animal lo que provoca en la muerte ese cúmulo de creencias, sentimientos y ritos sociales” (Hertz, 1990:88-89).
} 
los pueblos primitivos no vieran la muerte como un fenómeno natural, sino siempre como fruto de la acción de influencias espirituales con las que había que tratar, a las que había que calmar. Lo que se hacía mediante rituales -sacrificios- para absorber socialmente la muerte, pero sobre todo para reafirmase como colectivo frente a ella ${ }^{61}$. De esta forma, la muerte se integraba en la vida y la vida en la muerte. Los muertos convivían con los vivos en todo momento y, como consecuencia, no existía un corte radical entre ellos y sí un intercambio y circulación constantes.

Frente a este tipo de relación adaptativa de las culturas primitivas con la muerte, el enfrentamiento a la misma ha evolucionado, según Baudrillard (1980:143-166), en una dirección en la que esa relación se ha hecho cada vez más tortuosa, hasta llegar en las sociedades modernas a una situación en la que la línea de demarcación (de separación) con la muerte es absoluta, y el intercambio, en principio, no existe al haber sido expulsada la muerte de la vida. En opinión de este autor, ese extrañamiento de la muerte ha sido intencionado y la impermeabilización de la línea de demarcación ha constituido el instrumento base del control social ${ }^{62}$ en el que se asienta el Death Power, que se instituirá más tarde en todas las otras formas de poder ${ }^{63}$. En efecto, a diferencia del resto de las culturas, desde el siglo XVI, asegura Baudrillard (1980:167-185), toda la cultura occidental ha sido un enorme esfuerzo para disociar la vida de la muerte, beneficiando a la primera (la vida como valor, como acumulación) en detrimento de la segunda (la muerte como vencimiento). El objetivo último perseguido ha sido claro: abolir la muerte. Inicialmente, con una intencionalidad de control existencial de la supervivencia y la eternidad por parte de las religiones; después, con la de fomentar la productividad y la acumulación para la economía por parte de los Estados.

Dado que la Iglesia vive de la eternidad diferida, Baudrillard (1980:168-169) sitúa el origen de la moderna angustia individual ante la muerte en el proceso de individualización de las conciencias iniciado con el protestantismo. La necesidad de lograr la salvación personal disgregó las actitudes grupales enfocando inicialmente esa salvación a través de la fe (convertida en relación personal con Dios), y posteriormente en las obras y méritos en la vida, operación puramente económica de cálculo final y sus equivalencias. Esta mutación de la función social adaptativa a la muerte en las sociedades modernas provocó que la dialéctica inadaptación individual/adaptación social se escorase hacia el primero de los términos por la crisis que la

\footnotetext{
${ }^{61}$ Fantasías colectivas que al estar fuertemente institucionalizadas las dotaba de verosimilitud y hacía prácticamente imposible para los individuos descubrir su auténtica naturaleza fantástica (Elias, 1987).

62 "Romper la unión de los muertos y de los vivos, romper el intercambio de la vida y la muerte, desintrincar la vida de la muerte e imponer a la muerte y a los muertos la prohibición, éste es el primer punto de emergencia del control social. El poder sólo es posible si la muerte no es libre, si los muertos quedan bajo vigilancia, en espera del confinamiento futuro de la vida entera” (Baudrillard, 1980:149-150).

${ }^{63}$ Baudrillard (1980:149) afirma que la represión de la muerte es la represión fundamental. Represión que además es social, es decir, "es ella la que ejecuta el viraje hacia la socialización represiva de la vida”.
} 
ruptura radical en la misma provocó la expulsión social de la muerte, al dejar de ser ésta algo que se comparte, que se socializa mediante el intercambio, a lo que se enfrenta el colectivo para neutralizarla y metabolizarla en la vida social reafirmándose con ello. Desde el momento histórico en el que comienza la afirmación de la individualidad, que con el tiempo se consagrará en las sociedades occidentales como valor absoluto en los distintos planos de la existencia (económico, político y religioso), el individuo se enfrenta en solitario a la muerte. Ya sin soportes existenciales, obligados a enfrentarse cara a cara con su vida y su muerte, "la soledad se hace desesperación y nace una nueva <<conciencia desgraciada>>” (Morin, 1974a). Como este autor expresa de forma diáfana en la extensa cita que sigue, la muerte, o mejor dicho el extrañamiento de la muerte, "roerá a la propia vida, desatando toda clase de angustias, privadas de pronto de toda contención. En este desastre del pensamiento, en esta impotencia de la razón frente a la muerte, la individualidad hará uso de sus últimos recursos: tratará de conocer a la muerte, no ya por vía intelectual, sino rastreándola como una alimaña, a fin de penetrar en su madriguera; tratará de rechazarla recurriendo a las más brutas fuerzas de la vida. Tal enfrentamiento pánico, en un clima de angustia, de neurosis, de nihilismo, adquirirá aspecto de verdadera crisis de la individualidad ante la muerte... El individuo solitario deja de sentirse algo común,... Ya no hay nada universal, nada cultural. El individuo está solo en la irracionalidad. No existe nada, sino él mismo. Entonces, desde el ámbito de lo Único, donde se encierra desesperadamente a sí mismo, se alzará la más formidable angustia de la muerte, y la angustia de la muerte remite a su vez a la ruptura de las participaciones. La soledad acarrea una constante preocupación por la muerte, obsesión ésta que reafirma la soledad” (Morin, 1974a:297-304).

No obstante, como recuerda Baudrillard (1980:198) haciendo referencia a La ética protestante de M. Weber, de ese proceso de interiorización psicológica, que incrementaba notablemente la angustia de cada individuo al dejarle solo ante la muerte, también surgirá "la inmensa empresa moderna de conjuración de la muerte: la ética de la acumulación y de la producción material, la santificación mediante la inversión, el trabajo y la ganancia que comúnmente se denomina <<espíritu del capitalismo>> ${ }^{64}$. De ahí que la obsesión por abolir la muerte mediante la acumulación se convirtiera en el motor fundamental de la racionalidad de la economía política: "economía de la muerte, porque economiza la muerte y la entierra bajo su discurso". Sin embargo, pretender despejar el escenario social para que en el mismo sólo haya

\footnotetext{
${ }^{64}$ Análisis compartido también por Beck y Beck-Gernsheim (2003) y por Bauman (2001:269). Este último resalta la paradoja que comportó: "Como explicó Max Weber, en vez de generar inacción la predestinación calvinista liberó un volumen sin precedentes de energía humana. Si la eternidad administrada por Dios es inmune a las acciones humanas, no hay razón para medir la vida terrenal humana por sus criterios. La religiosidad de la Reforma, nacida del temor, estuvo desde un principio preñada de secularismo humanista: liberó a los seres humanos para que se centraran en cosas que no eran las que se guardaban en los secretos compartimentos de los oficios divinos, en cosas que nosotros, los humanos, somos capaces de comprender y dirigir en nuestro provecho".
} 
vida conlleva que sólo haya muerte. Así, ésta pasa a estar omnipresente en la vida cotidiana y los individuos en su afán de salvación/valoración ven cuestionada su identidad a cada momento, ya que aunque la muerte no tenga finalidad sí cuestiona la finalidad de cada ser individual. Por ello, y para mitigar la angustia individual y también para garantizar el orden social y económico, sólo cabe negarla segregando progresivamente a los muertos, a los que se arrincona física y mentalmente, porque en un sistema donde la vida está regida por el valor y la utilidad no hay sitio para la muerte, que es "anti-reproductiva y antiproductiva”, “un lujo inútil”. De esta forma, la discriminación moderna de los muertos es intencional y busca impedir el intercambio simbólico con ellos desplazando el imaginario -la inmortalidad- hacia la propia vida.

En efecto, el proceso por el que se niega la muerte 'deshumaniza` al ser humano y suprime todo intercambio entre la vida y la muerte. Tiene sin embargo una funcionalidad social y económica evidente. Los individuos han de enfrentarse con inmediatez a los problemas de la vida cotidiana y necesitan hacerlo de forma adecuada. Si quieren ser operativos en su vida diaria, no verse paralizados por la angustia ante la muerte, precisan apartar de su pensamiento la fuente principal de su temor. Así, como señala Castilla del Pino (1995, 1974), si en la realidad social, construida y constituida por los otros, domina una actitud denegadora ${ }^{65}$ de la muerte, se hace posible que el individuo se olvide de que ha de morirse, se sienta inmortal aquí, y actúe aquí y ahora: la expulsión de la muerte de la vida social logra la expulsión de la muerte en los individuos. La denegación de la muerte, y por tanto el no pensar en ella, va a permitir al individuo "salir de sí, dejar de contar con ese ciclo real vivir/morir, para, suprimido el segundo miembro del mismo, entregarse de lleno a vivir lo que en la vida es posible y deseable hacer” (Castilla del Pino, 1995:261). “De esta forma, paradójicamente, la negación de la realidad (de la muerte) sirve al principio de la realidad ${ }^{66}$, que es, como señalaba Marcuse, principio de rendimiento. Sólo los hombres que no piensan en la muerte pueden ser prácticos” (Castilla del Pino, 1974:12). Como reverso a este dominio de la economía política, en las sociedades capitalistas modernas la muerte de un individuo es la de "uno que se larga. No tiene nada que intercambiar. Es ya un residuo antes de morir. Al término de una vida de acumulación, es él quien es restado del total: operación económica. No se vuelve imagen, sino todo lo más de coartada a los vivos, a la superioridad evidente de los vivos sobre los muertos. Es la muerte prosaica,

65 Castilla del Pino (1995:254-255) resalta que esta actitud de denegación (acción de rehusar), prácticamente común a todos en Occidente, es una negación singular ya que "no es una negación intelectual (lógica), sino emocional". Sabemos que vamos a morir, pero "nos aferramos al deseo de no morir, negando/rehusando lo que ha de ser un hecho inevitable".

${ }^{66}$ El principio de realidad es "uno de los dos principios que, según Freud, rigen el funcionamiento mental. Forma pareja con el principio del placer, al cual modifica: en la medida en que logra imponerse como principio regulador, la búsqueda de la satisfacción ya no se efectúa por los caminos más cortos, sino mediante rodeos, y aplaza su resultado en función de las condiciones impuestas por el mundo exterior" (Laplance y Pontalis, 1979:311-314). 
unidimensional, final del recorrido biológico, saldo de un crédito: <<entregar el alma>> como un neumático, recipiente vaciado de su contenido”67 (Baudrillard, 1980:193).

En una línea similar se manifiesta Ziegler (1976:156-175) en su análisis del canibalismo mercantil, definidor de las sociedades occidentales, al examinar las consecuencias sobre las relaciones con la muerte del hecho de que "el hombre de Occidente es en lo sucesivo mercancía", o lo que es lo mismo, que en esas sociedades la mercancía ha pasado a ser el sujeto de la Historia en sustitución del ser humano. Fruto de esa reificación de las relaciones sociales, también el cuerpo humano, vivo o muerto, se convierte en una "mercancía suprema" integrada en el circuito de lo que se puede producir o consumir, es decir, vender, trasplantar, almacenar o comercializar. Fuera de ese circuito, claramente "la sociedad occidental no sabe qué hacer con sus muertos", con esos “extraños contemporáneos”, perfectamente iguales entre sí, que han dejado de producir y de consumir, que no responden a las órdenes ni se dejan influir. Así, cuando los parámetros de referencia son exclusivamente las relaciones con un sistema de producción, de intercambio y de consumo de mercancías, la muerte ya no es un destino sino que se ha convertido en el estado de no-consumo, de no-producción, y "el muerto es lo desaparecido". De esta forma, las sociedades mercantiles de Occidente han transformado la experiencia tanática en un residuo incognoscible: "El canibalismo mercantil mata a la muerte” (Ziegler, 1976:163-164, 168). Si esto es así, si la muerte es negada y los individuos pierden la conciencia de su finitud, del límite que al establecer la temporalidad les da la medida de su existencia al conferirles singularidad, unicidad y destino, ¿¿n qué se convierten?, se pregunta Ziegler: privado de su muerte el ser humano se ve privado de su individualidad, de su libertad, y ya no es capaz de comprenderse a sí mismo porque está oculto para sí mismo: "no atreviéndose ya a nada, renunciando a su calidad de actor principal y autónomo de la historia, el hombre se degrada y degenera en simple célula del proceso reaccional y funcional reificado..., es incapaz de integrar su muerte en otra globalidad que la de la funcionalidad mercantil”68 (Ziegler, 1976:188, 332-334).

\footnotetext{
${ }^{67}$ En su análisis del sistema funerario en el Derecho español, Pérez Gálvez (1997:121-167) destaca entre las modificaciones legislativas habidas en ese ámbito durante la segunda mitad del sigo XX la modificación del “dogma de la intangibilidad del cadáver". Además de a las innovaciones científico-técnicas, achaca esas transformaciones, en la línea de Baudrillard, a que "el sistema sólo admite la muerte manejada de forma técnica; la sociedad actual nos introduce en un engranaje que deja poco lugar a la persona: cuerpo viviente, cuerpo enfermo, cuerpo-cadáver o cadáver-deshecho; su denominador común es el cuerpo-máquina, cuya función es la de producir y consumir. Una vez que se para debe ser eliminado de forma eficiente" (Pérez Gálvez, 1997:160).

68 "Para el hombre de Occidente, sometido al principio estrecho del capitalismo mercantil, al administrador de <<sociedad $>>$ ahorrador, al tecnócrata aseptizado, no hay ni fiesta de la naturaleza pródiga, ni exultación, ni muerte creadora, ni horror, ni cadáver, o más bien el cadáver ausente ya no está, como dice Bataille, ni siquiera marcado con el signo de la nada. La repugnancia misma está prohibida, reforzando el poder de las prohibiciones” (Ziegler, 1976:330).
} 
Argumentos críticos también asumidos por E. Fromm (1980:123-125) quien relaciona la negación moderna de la muerte con el "modo de tener" ${ }^{69}$. Así, si se concibe la vida como posesión, no debe parecer "irracional" tener miedo a la muerte porque supone "perder lo que tenemos: el temor de perder mi cuerpo, mi ego, mis posesiones y mi identidad; de enfrentarme al abismo de la nada, de <<perderme>>”. Fromm señala que no cabe explicación racional alguna que suprima el temor a la muerte, y prescribe como antídoto al mismo el "modo de ser"70: "no aferrarse a la vida ni experimentarla como una posesión”.

Elías (1987:19, 45-46), por su parte, asume asimismo la concepción de la muerte como un tabú que eclosiona con toda su fuerza durante el siglo XX pero cuyo origen, como Baudrillard, considera que "es algo ya muy antiguo", que se ha ido transformando de una manera específica a lo largo del tiempo, según las relaciones de poder existentes en cada momento. En su caso, relaciona el incremento de la <<represión >> de la muerte con el proceso civilizador iniciado hace “400 o 500 años” por el que "todos los aspectos elementales, animales, de la vida humana, que casi sin excepción traen consigo peligros para la vida en común y para la vida del individuo se ven cercados, de un modo más comprehensivo, regular y diferenciado que anteriormente, por reglas sociales, y al mismo tiempo por reglas de conciencia”. Si en las sociedades pretéritas se envolvían esas dimensiones peligrosas de la existencia humana con "fantasías colectivas e institucionalizadas” -que por ejemplo, garantizaban la inmortalidad a sus miembros- como medio para sobreponerse a ellas, con el proceso de civilización esas envolturas han sido sustituidas por "sentimientos de vergüenza y embarazo" que se esconden "detrás de las bambalinas de la vida social pública”. Como consecuencia, para Elías la clave de este proceso es que ha conllevado una reducción de la importancia del otro (de los otros) y, en consecuencia, del sentido "vital” (no el metafísico) que sólo proporciona(n) aquél (aquéllos). En el caso de la muerte, y como consecuencia de la creciente individualización observada en las sociedades desarrolladas, las pretéritas fantasías colectivas de inmortalidad se han transformado en "fantasías de carácter meramente personal y comparativamente privado", es decir, los individuos se perciben a sí mismos aislados y frente al resto del mundo, con su correlato de aislamiento,

\footnotetext{
69 "La naturaleza del modo de existencia de tener surge de la naturaleza de la propiedad privada. En este modo de existencia, lo único importante es adquirir propiedades y el derecho ilimitado de conservar lo adquirido. El modo de tener excluye a los otros; no requiere que yo haga ningún otro esfuerzo por conservar mis propiedades ni que haga un uso productivo de éstas. A este modo de conducta el budismo lo denominó codicia, y las religiones judía y cristiana lo llamaron ambición; esto transforma a todo el mundo y todas las cosas en algo muerto y sometido al poder de otro... En último término, la afirmación "yo (sujeto) tengo $O$ (objeto)" expresa una definición de yo mediante mi posesión de $O$. El sujeto no soy yo, sino que yo soy lo que tengo. Mi propiedad constituye mi yo y mi identidad" (Fromm, 1980:83).

70 "El modo de ser tiene como requisitos previos la independencia, la libertad y la presencia de la razón crítica. Su característica fundamental es estar activo, y no en el sentido de una actividad exterior, de estar ocupado, sino de una actividad interior, el uso productivo de nuestras facultades, el talento, y la riqueza de los dones que tienen (aunque en varios grados) todos los seres humanos... (y que)... no puede expresarse plenamente con palabras" (Fromm, 1980:92).
} 
soledad y contención de todos los impulsos instintivos y emocionales. De ahí deriva el acrecentamiento del miedo a la muerte en estas sociedades, lo que refuerza su negación en las mismas. De ahí la soledad (total) de los moribundos, al ser muy difícil para los individuos el poder identificarse con ellos, ya que están marcados por la muerte e inconscientemente se teme ser contagiado (Mellor y Shilling, 1993:417) ${ }^{71}$. Dificultades también para interaccionar con ellos, cuando se han perdido todos los rituales colectivos de acompañamiento y se reprimen las manifestaciones de emoción forzados como están por el autocontrol impuesto socialmente.

De ahí también que, como han destacado otros autores (Ariès, 2000, 1983), la negación de la muerte esté acompañada de la negación de la vejez, lo que puede explicar cierta tendencia a la marginalización de las personas ancianas que se convierten cada día que pasa en la población en la que se concentra la mortalidad, la poseedora exclusiva de la muerte, casi ausente ésta entre las edades más jóvenes. Así, en el imaginario de las sociedades desarrolladas está asentado firmemente el vínculo muerte/vejez, vínculo que ayuda a conjurar en la vida cotidiana la idea misma de la muerte, y que se refuerza tomando distancia respecto de los que están asociados a ella, las personas ancianas (Loriaux, 1995a:15). Por ello, en esas sociedades existe una “devaluación general de lo viejo” (Seale, 1998) caracterizada por la invisibilidad de las personas ancianas y moribundas, segregadas físicamente en instituciones especializadas entre cuyas funciones esenciales está la función explícita de ayudar a esas personas en su situación de dependencia, pero también la función implícita inconfesable de hacer la muerte más llevadera a los vivos. Por otra parte, el incremento de la esperanza de vida, es decir, el que cada vez más personas le "ganan" terreno a la muerte y llegan en mayor número a edades avanzadas, hace que la vejez pierda el estatuto y prerrogativas que tenía antaño, cuando sólo unas pocas personas llegaban a ella. Liquidación simbólica de la vejez que, como apunta Baudrillard (1980:191), está también asentada en otra razón más prosaica: entra en contradicción con la racionalidad del sistema. Para éste, la vejez se transforma en "un peso muerto considerable en la gestión social... (al) disiparse en ella”, y sin poder darle sentido dentro de la lógica del mismo, una buena parte de la riqueza social (dinero y valores morales): "Un tercio de la sociedad queda de este modo en estado de parasitismo y de segregación. Las tierras conquistadas en esta marcha de la muerte son socialmente desérticas... No es más que un trozo de vida marginal asocial en extremo; un ghetto, una prórroga, una pendiente hacia la muerte”.

\footnotetext{
${ }^{71}$ No obstante, los moribundos, como sustitutos metafóricos de la disolución del cuerpo, junto con marginados sociales, enfermos dependientes con enfermedades incapacitantes, parados, drogadictos, locos, etc., como sustitutos metafóricos de la disolución de la individualidad, cumplen una importante función social: refuerzan el sentimiento de amortalidad de los demás. Al marginarlos, se margina la muerte -la disolución de la individualidad- que representan (Basterra, 2006:159).
} 
Además del desarrollo del sistema capitalista, y del conexo proceso de individualización, la incidencia de otros factores interrelacionados con ellos ha contribuido asimismo a la modificación en la funcionalidad social adaptativa de la muerte al provocar también cambios en el imaginario colectivo sobre la misma. Cambios que han metamorfoseado el determinismo pretérito de las sociedades tradicionales no en un conocimiento cierto tranquilizador entre la población de las sociedades desarrolladas, como cabía esperar, sino en ambigüedad. En efecto, la búsqueda de la verdad intrínseca de la naturaleza, de su lógica causal, por parte de la ciencia, y más específicamente por la Medicina, lejos de atemperar las angustias de los individuos ha desembocado en una paradójica situación: la concepción moderna de la muerte como "natural”, profana e irreversible entra en "contradicción aguda con los principios de la racionalidad burguesa”, al cuestionar la hegemonía de los valores individuales, al reconocer de hecho un límite al progreso ilimitado de la ciencia y, por tanto, a la capacidad real de ésta para dominar la naturaleza (Baudrillard, 1980:187). Concepción científica de la muerte que corresponde a un sistema representado por la máquina y su funcionamiento, y en cuya pieza central, la nueva concepción de la muerte "natural" asentada entre la población por el discurso médico característico del modelo de Muerte Moderna (Tabla 3.2.), está precisamente el origen de esa paradoja.

Como se ha señalado más arriba, la construcción de esa nueva visión estandarizada sobre la muerte, la muerte "natural”, que llega al final de una larga vida, lo que implica la posibilidad real de vivir una vida biológicamente completa -infancia, adolescencia, madurez y vejez-, conformó en el imaginario de los individuos de las sociedades desarrolladas una forma ideal y estándar de muerte, que es la sancionada socialmente. Un proceso <<normal >> al que se llega como final de la vida, límite continuamente ampliado por la Medicina quien controla de forma absoluta todo el proceso. Es decir, en el enfrentamiento a la muerte ya no son los individuos ni los colectivos quienes establecen la forma de neutralizarla y absorberla, sino que entre ellos y la muerte se ha introducido una cuña insalvable, la del personal médico y su conocimiento experto que busca dominarla para exterminarla, por lo que aquéllos ya no entienden la muerte como algo compartido que está dentro del <<orden de las cosas $>>$, sino que al asumir el discurso médico dominante han de denegarla sistemáticamente. Y es que lo que ofrece la Medicina resulta casi imposible de rechazar por parte de los individuos: diagnóstico de enfermedad, identificación de causas, prevención para evitar su incidencia, terapéutica de tratamiento, pronósticos aquilatados y, sobre todo, retraso de la llegada de la muerte.

Así, los individuos de las sociedades modernas ya no perciben a la muerte como una fuerza salvaje de la naturaleza totalmente aleatoria, porque saben que no se reparte con igual probabilidad entre todos los individuos y porque es posible "determinarla”. Esta medicalización 
de la muerte, con su deconstrucción analítica de la mortalidad, y la segregación etárea, espacial e institucional de la misma -muerte en la vejez, aislamiento de los moribundos, muerte en los hospitales- han contribuido a alimentar una "conspiración del silencio" en torno a ella. La muerte, como hecho inevitable de la naturaleza, ha sido deconstruida en diferentes procesos contingentes de muerte privada, cada uno con su propia causa evitable. Con ello, se ha saltado de la cuestión insoluble de la muerte al enfrentamiento de problemas específicos de seguridad y enfermedad que son solubles en principio (Bauman, 2007:cap.1). De esta forma, la muerte ha dejado de ser inherente a la naturaleza humana y se la percibe como extraña a la misma, como algo que adviene de fuera, un ente extrínseco, objetivo, dialéctico con $<<$ mi $>>$ vida y que, paradójicamente, tiene vida propia por su cuenta. Es decir, "uno no muere, uno es asesinado por algo" (Bauman, 1992:138). Y es la Medicina la que tiene las “armas” para detener a la `asesina de las mil caras'. Al no ser la Medicina omnipotente, toda aquella causa que no puede ser 'detenida' se transforma en un desafío al orden social establecido, en algo que no quiere situarse bajo las leyes <<objetivas >> donde se la ha acorralado y que controlan todo. Lo que ha conllevado, y como si de un proceso de regresión histórica se tratara, la paradoja de que "en pleno sistema de la razón” las sociedades desarrolladas se comportan como las primitivas cuando achacaban todo suceso no controlado, y en especial la muerte, a una voluntad hostil (Baudrillard, 1980:189). Proceso que se retroalimenta con otra paradoja señalada por Bauman (2007:59): la deconstrucción de la mortalidad en lugar de reducir la conciencia de mortalidad, ha incrementado "el volumen de terror a la muerte" y "la potencia destructiva" de la misma, haciendo que su presencia en la "vida sea más constante y tenga más repercusión que nunca”. Como un alien espectral diseminado por todos los lados, su recuerdo constante forma parte integral de todas las funciones de la vida y está detrás de todas las decisiones que se toman en ella ${ }^{72}$ (Bauman, 2007:59).

Por otra parte, aunque la ciencia médica busca culminar a nivel simbólico el deseo de revertir la muerte ${ }^{73}$, cuando en el hospital ésta se aproxima, y en la mayoría de las ocasiones la persona moribunda ha perdido la conciencia, el proceso técnico que controla esa muerte la ha dividido en una sucesión de etapas de las cuales, como se ha señalado en el Capítulo 2 de esta Tesis, "no se sabe cuál constituye la muerte auténtica”, por lo que "pequeñas muertes silenciosas han reemplazado y difuminado la gran acción dramática de la muerte, y ya nadie tiene la fuerza o

\footnotetext{
${ }^{72}$ No sólo por los temores a las grandes catástrofes que subyacen en la vida cotidiana, sino también por el miedo a la muerte de un otro especial, a los productos que puedan contener sustancias peligrosas, a los alimentos que puedan envenenar, a conducir con velocidad excesiva, a hacer poco ejercicio, a hacer mucho ejercicio, etc.: "Hoy día no hay un momento para descansar de la muerte” (Bauman, 2007:60). Cosa que los expertos del campo actuarial agradecen.

${ }^{73}$ El hospital no sólo sería un espacio social de ocultamiento de la muerte, sino que simbolizaría la posibilidad de reparación/evitación de la muerte, por lo que no es "nada extraño, por tanto, que la muerte y la agonía se encuentren cada vez más medicalizadas en nuestras sociedades (Basterra, 2006:40).
} 
la paciencia de esperar durante semanas un momento que ha perdido su sentido” (Ariès, 2000). Lo que hace de la muerte una experiencia extraña, naturalizada a la par que cortada del resto de la vida, disecada hasta convertirla en un simulacro de vida, enajenada de cualquier estatus social propio (Basterra, 2006).

Ambivalencias del discurso médico que provoca una percepción social ambigua del control médico de la muerte ${ }^{74}$, lo que paradójicamente ha reforzado la negación moderna de la misma. Así, aunque el ser humano es un ser-para-la-muerte, que desde que nace ya es lo bastante viejo como para morir (Heidegger), es un ser que de forma innata está 'embarazado` de muerte, que, en definitiva, es pura capacidad de muerte, sin embargo, en las sociedades desarrolladas incomprensiblemente ese mejor conocimiento, asentado ahora en la ciencia, de que "yo soy a la vez mi muerte»75 no está en absoluto reflejado en la percepción social existente sobre ella. Al contrario, viene acompañado de una percepción de la misma como "inhumana, irracional, insensata como la naturaleza no domesticada", de tal forma que "no hay muerte buena sino vencida, y sometida a la ley: tal es el ideal de muerte natural” (Baudrillard, 1980:189-190). De esta forma, aunque se asume que la muerte es a la vez que universal, intransferible y única, es decir, todo el mundo tiene que morir y nadie puede traspasar, cambiar o quitar su morir a otro, sin embargo, se la rechaza, se la rehuye, se la quiere suprimir. Como resultado de todo ello, de esa reducción de la muerte a un "hecho natural” vacío de sentido, la muerte se vuelve extemporánea, cada vez más, un escándalo (Baudrillard, 1980:187).

Todo lo anterior no hace más que resaltar el carácter paradójico de las relaciones de los seres humanos, y especialmente los de las sociedades modernas, con la muerte. Bipolarizados entre la racionalidad del homo sapiens y la afectividad del homo demens (Morin), aquéllos saben que la muerte es cotidiana, natural, aleatoria y universal, y, sin embargo, se enfrentan a ella ignorándola, rehusándola. Así, a la cotidianeidad de la muerte se responde con la percepción de

\footnotetext{
${ }^{74}$ Percepción ambigua que asimismo invade el ánimo del propio personal médico, como han mostrado Basterra (2006) y Ponce (1997) en sus análisis de los discursos del personal sanitario: “Ante esta dinámica, el personal sanitario recoge como demanda social implícita hacia su profesión la necesidad de superar las manifestaciones más dramáticas de la proximidad a la muerte. Como consecuencia de esta negación, se favorece una serie de conductas en el personal sanitario inducidas por la sociedad. Así, por ejemplo, el refugio del personal sanitario en el discurso técnico evita el dramatismo social de la muerte, y conecta con los requerimientos de esa demanda social. De esta forma, la muerte ya no es la mera y dramática desaparición de una persona, sino un "problema técnico" insoluble. La muerte ha desaparecido socialmente, y ha inducido, pues, en el personal sanitario una conducta hiperprofesional. De esta manera, el personal sanitario, entrenado en la curación de la enfermedad, no se encuentra preparado para la gestión de enfermos terminales" (Basterra, 2006:31-32).

${ }^{75}$ Rubio (1983) describe de forma gráfica la relación inseparable vida/muerte como sigue: "un coche, un cuchillo, nos <<provocan >> la muerte, no <<son >> la muerte. De nada serviría acuchillar a un <<ángel inmortal $>>$. La muerte no está, pues en la hoja de acero sino en la vida palpitante que esta navaja desgarra". De esta forma, la muerte no es "la" sino que la muerte somos "nosotros".
} 
su alejamiento, especialmente en las etapas tempranas del ciclo vital ${ }^{76}$, de tal forma que algunas personas la 'viven`como si sólo afectara a los otros o, incluso, como si no existiera.

De forma más amplia, la sucesión-acumulación de cambios en la función social adaptativa de la muerte ha llevado a algunos autores, entre ellos los "deterministas tanatológicos"77, a afirmar que la utilización de la muerte como instrumento de control social no sólo ha perseguido favorecer el funcionamiento cotidiano de la vida social, sino que se ha ido más allá y se ha buscado además aprovechar el terror hacia la muerte para acumular poder social -Death Power. Autores como Becker (2003), Kearl (1995), Bauman (1992), Elias (1987), Baudrillard (1980) o Morin (1974a) sostienen que históricamente el poder social se ha concentrado en la institución que ha sido más capaz de explotar ritualmente el poder de la muerte. En los dos últimos siglos, y en especial en las sociedades desarrolladas, los sistemas políticos -los Estados- habrían reemplazando a las religiones en este ámbito convirtiéndose en las más poderosas agencias sociales de la muerte, en el sentido de que han utilizado y modelado creencias y miedos a la muerte para conseguir el control social en los dos sentidos mencionados ${ }^{78}$ (Kearl, 1995). Dado que en los países democráticos no puede ejercerse el control social recurriendo a la amenaza de la utilización de la violencia física, el mismo se ejerce ahora mediatizando cómo piensan sus ciudadanos en este ámbito en el que se sabe, como se ha señalado arriba, que los temores a la muerte incrementan la lealtad al grupo y a la moral dominante. Es por ello por lo que son los Estados a través de sus sistemas de muerte los que en la actualidad:

a) 'dan significado al acontecimiento de la muerte', por ejemplo, a través de la Medicina al institucionalizar la muerte "natural” o al definir cuándo una persona está muerta o no, cuestión esencial que se sitúa en el mismo centro del sistema de muerte y cuyas consecuencias se irradian a todas las dimensiones del mismo ${ }^{79}$, o, al detentar el monopolio de la violencia determinando en qué condiciones es legal o no matar;

\footnotetext{
${ }^{76}$ Rice (1997:665) resume los resultados de diferentes estudios que analizaron las concepciones de la muerte en la infancia y adolescencia: "Los niños menores de cinco años ven a la muerte como algo temporal y reversible; entre las edades de cinco y nueve años gradualmente se van percatando de que la muerte es definitiva y permanente; los niños mayores de nueve años la ven como definitiva, inevitable y universal. Los adolescentes generalmente piensan poco en ella, a menos que hayan sufrido la experiencia personal de la muere de alguien cercano".

${ }_{77}$ Expresión con la que Kearl (1995) denomina a aquellos investigadores de la muerte que como Morin, al que no cita, sostienen que las raíces de la civilización están estrechamente relacionadas con los primeros humanos concientes de su mortalidad.

${ }^{78}$ De forma más específica, y refiriéndose al caso concreto de Estados Unidos, Kearl (1995:4) identifica a lo que denomina complejo médico-industrial-militar como el esqueleto del organismo social controlador.

${ }^{79}$ En el Capítulo 2 se ha analizado la evolución de la construcción social del concepto "muerte” y las importantes implicaciones que se han derivado de la misma.
} 
b) 'recuerdan a los individuos su mortalidad', buscando poner de manifiesto con ello su capacidad ejecutiva para reducir y controlar esa vulnerabilidad mediante la prevención y la protección frente a la enfermedad y la lucha contra las causas evitables que conducen a la muerte. Racionalidad higiénica por la que “matando la suciedad” también se mata la muerte;

c) 'ayudan a los individuos a sobrevivir a sus contemporáneos`, protegiéndoles de las amenazas externas y avalando un marco de estabilidad social en el que los ciudadanos se sientan seguros al desarrollar sus actividades, al tener garantizados sus derechos, y al ser socorridos en caso de necesidad mediante la implementanción de distintos programas asistenciales, $\mathrm{y}$, finalmente;

d) 'proporcionan a los individuos oportunidades para trascender sobre la muerte', trascendencia individual o colectiva que obviamente no tienen ya un carácter religioso, sino marcadamente social al perseguir que la gente ordinaria llegue a sentir que sus vidas se incrustan en un gran todo, ya que si mueren en determinadas circunstancias heroicas su muerte será valiosa para la sociedad y vivirán después de sus muertes en la memoria colectiva como sus héroes muertos, siendo materialmente recordados a través de, por ejemplo, el patrocinio de eventos históricos, museos, bibliotecas, monumentos, etc. Transformación del sino humano de la transitoriedad en el logro cultural de la duración eterna que, a modo de "extensión de la inmortalidad”, también se manifiesta, por ejemplo, a través del control político-legal sobre las normas de herencia, que ayudan a perpetuar los intereses de las familias, y por las que se crea un sentido de continuidad con el pasado y con las generaciones futuras (Giddens, 2001:270; Seale, 1998:56; Kearl, 1995:17).

Así, para Baudrillard (1980), quien considera que en el surgimiento de la supervivencia está el origen del poder, el ejercicio de éste por parte de los Estados no consiste en las sociedades desarrolladas tanto en la capacidad de dar muerte a los individuos, sino en lo contrario, en la capacidad de retrasársela, de darles vida ganada a la muerte, y que al hacerles conocedores de esta circunstancia les convierte en perpetuos deudores de algo que no pueden devolver. Esta sería la "ley profunda" del orden social en esas sociedades: el control progresivo de la vida a través de la institucionalización de la muerte "natural”. En efecto, la postergación efectiva de los límites de la vida ha hecho potencialmente posible la maximización del capital biológico a todos los individuos llegando hasta el tope máximo de su vida, sin muerte precoz y también sin la violencia de épocas pretéritas, que se halla bajo control. Por ello, la reivindicación de una justa duración de vida, como la de un salario justo, se convierte en derecho, en un $<<$ contrato de vida $>>$ implícito con la sociedad, un nuevo contrato social en el que ésta, con su ciencia y técnica al frente, se responsabiliza de la muerte de cada individuo, pero que como contrapartida de ese contrato impone el deber de muerte natural. De esta forma, los individuos tienen el derecho y el deber de 
muerte natural, es decir, la obligación de vivir hasta el final, convirtiendo con ello a toda muerte no natural en un fracaso social intolerable, ya que no se ha habría hecho todo lo que se debía para evitarla. En última instancia, y con la misma funcionalidad que la inmortalidad para las religiones, esto significa que los individuos han sido desposeídos de su muerte, se les prohíbe elegir, pues no pueden morir cuando quieren o como quieren, no siendo ya libres más que para vivir el mayor tiempo posible: control y neutralización de la vida que pierde su dimensión cualitativa y queda reducida a cantidad de vida. En resumen, veto a la muerte $e^{80}$ que los guardianes del mismo, "el poder", utilizan para tener bajo su control las decisiones sobre la extensión de la vida y de la muerte, de igual forma que son los depositarios de la justicia y la venganza.

Por tanto, según Baudrillard (1980:167), “el Estado basa su poder en la administración de la vida como supervivencia objetiva”, sin embargo, sólo consigue dominar verdaderamente a los individuos cuando éstos se identifican con su interés individual y se hacen "contables y capitalistas de su propia vida”. Si esto ocurre, el poder coloniza la conciencia de los individuos de las sociedades desarrolladas, que no sólo aceptan gustosamente el derecho a una muerte "natural" personalizada, sino que alienados en la lógica del sistema -la muerte como bien propio, como si fuera el último objeto de una vida basada en la acumulación- reivindican además que su muerte sea de $<<$ calidad $>>{ }^{81}$. Baudrillard (1980:208) califica a esa petición como un "estrago mental de la apropiación” que impone el sujeto a su propia pérdida. Como reacción a este encorsetamiento vital, a este vaciamiento del contenido que comporta una muerte "natural”, en la que el grupo no tiene parte en ella, ni se comparten duelos colectivos, Baudrillard afirma que la única muerte simbólica posible -social, pública, colectiva- en las sociedades desarrolladas es la muerte “artificial” (accidente ${ }^{82}$, suicidio ${ }^{83}$, violenta ${ }^{84}$ ), ya que, al escapar a lógica de la inversión y de la equivalencia, es anti-reproductiva y antiproductiva para el sistema.

\footnotetext{
${ }^{80}$ Si en el pasado la moral ordenaba $<<$ No matarás $>>$, hoy ordena $<<$ No morirás $>>$ (Baudrillard, 1980:206).

${ }^{81}$ Reivindicación que, según Baudrillard (1980:205), no hace nada más que reforzar el statu quo: "La eutanasia está ya en todas partes, y la ambigüedad de hacer de ella una reivindicación humanista (lo mismo para la <<libertad > del aborto) es evidente: se inserta en la lógica a mediano y largo plazo del sistema. Todo esto va en la dirección de un aumento del control social, porque, detrás de todas las contradicciones aparentes, el objetivo es seguro: asegurar el control sobre toda la extensión de la vida y de la muerte".

${ }^{82}$ Todo aquello que escapa al control hegemónico, que no se somete a las leyes <<objetivas >> que normalizan la muerte "natural" fascina. Las catástrofes, los accidentes, los atentados, rompen el cerco racionalizador impuesto saltando a la plaza pública con lo que, a modo de sacrificios modernos, sólo pueden ser conjurados socialmente (Baudrillard, 1980:189).

${ }^{83}$ El suicidio constituye "un acto de desviación de la muerte institucional y de vuelta contra el sistema que la impone: mediante el suicidio el individuo juzga a la sociedad y la condena a su modo, invirtiendo las instancias, reinstaura la reversibilidad donde había desaparecido completamente y, a la vez, recupera la ventaja... todos (los suicidios) abren una brecha infinitesimal, pero inexpiable, porque constituye una derrota total para un sistema al no poder alcanzar la perfección total: basta con que la menor cosa escape a su racionalidad. La prohibición del suicidio corresponde a la aparición de la ley del valor. Religiosa, moral o económica, es siempre la misma ley que dice: nadie tiene derecho a restar algo del capital o del valor. Ahora bien, cada individuo es una parcela de capital (como cada cristiano es un alma que hay que salvar),
} 
En una de las escenas finales del $\underline{\text { El intercambio }}^{85}$ (Clint Eastwood, 2008), dos guardianes conducen hacia el patíbulo a Gordon S. Northcott, asesino en serie de niños condenado a morir en ejecución pública. Al llegar al final de las escaleras donde estaba la horca, Gordon insulta gravemente a los dos guardianes porque le habían hecho subir dos peldaños de golpe y con ello le habían quitado el tiempo que suponía pisar un peldaño más. Unas décimas de segundo que en cualquier otro momento serían insignificantes, pero que para él, en ese momento, era un tiempo inconmensurable de vida, frente a la nada absoluta a la que le llevaban.

\subsubsection{DISCURSOS SOBRE LA MUERTE EN LAS SOCIEDADES CONTEMPORÁNEAS}

“Duelo: región atroz donde ya no tengo miedo"

R. Barthes

Como se ha señalado arriba, Elias (1987) vincula el nacimiento y desarrollo del modelo tabú de muerte con el proceso de civilización iniciado hace 400 o 500 años. En su análisis de ese proceso menciona la incidencia de diversos factores resaltando entre ellos uno que juega un papel especialmente significativo en la profundización de la denegación de la muerte en las sociedades contemporáneas: el proceso de individualización. En efecto, si, como ocurría en épocas pretéritas, la sociedad institucionaliza la muerte haciéndola continuamente presente, por ejemplo con ritos sagrados de tránsito mediante los que se la absorbe socialmente, proporciona con ello estabilidad psíquica a sus individuos atemperando el miedo que sienten hacia ella. Por el contrario, si, como ocurre en las sociedades modernas, la sociedad oculta la muerte, los individuos se ven privados de ese apoyo socio-emocional en su enfrentamiento a ella, que se transforma en un desafío unipersonal sin anclajes a una adversaria implacable, eclosionando entre ellos el miedo a la muerte en toda su extensión. Orfandad que se ha reforzado en las sociedades más avanzadas al desplazarse aún más los problemas del sentido existencial del espacio público al privado, es decir, al derivar en exclusiva el enfrentamiento a la muerte a áreas privadas de la vida de los individuos, toda vez que los dos principales puentes -Estado-nación y familia- con capacidad para dotar de sentido y de hacer trascender la muerte de los individuos se están desmoronando (Bauman, 2007:275). Esto es, un escenario en el que se abandona a su suerte a los individuos quienes, por un lado, se han de hacer responsables de sí mismos, pero, por otro lado, cada vez son más dependientes de condiciones que no comprenden ni controlan.

no tiene, por lo tanto, derecho a destruirse a sí mismo. Es contra esta ortodoxia del valor que se subleva el suicida, destruyendo la parcela de capital de que dispone” (Baudrillard, 1980:206-207).

84 “Toda la pasión se refugia entonces en la muerte violenta, la única que trasluce algo parecido al sacrificio, es decir, como una transmutación real por voluntad del grupo... A partir del momento en que escapa a la razón <<natural >>, en que es un desafío a la naturaleza, vuelve a ser asunto del grupo, exige una respuesta colectiva y simbólica, en una palabra, suscita la pasión de lo artificial, que es al mismo tiempo, la pasión sacrificial” (Baudrillard, 1980:192).

${ }^{85}$ Película basada en hechos reales ocurridos en Los Ángeles a partir de 1928. 
Si bien las consecuencias generales del proceso de individualización sobre el enfrentamiento a la muerte ya han sido mencionadas en el Capítulo 2 de esta Tesis, cabe profundizar ahora en los nuevos perfiles de ese enfrentamiento en la fase última de la modernidad. Previamente, resulta necesario identificar las características más significativas de esta fase del sistema capitalista mundial y describir sintéticamente el alcance de aquellas con mayor vinculación al objetivo de esta investigación. Al margen de cuál sea la denominación que se otorgue a dicha fase ${ }^{86}$, lo cierto es que en la misma se están produciendo grandes cambios sociales ligados al avance de las nuevas tecnologías, a las nuevas formas de organización de la producción, a la revolución de la comunicación y al proceso de globalización. Cambios que están interrelacionados y que han propiciado una nueva reorganización del tiempo y del espacio tanto en los ámbitos de la vida social como de la privada, provocando profundas mutaciones en las instituciones modernas (trabajo, Estado, familia, pareja, democracia, iglesias, etc.) transformándolas en lo que Giddens (2000:31) denomina instituciones concha, esto es, instituciones que ya no cumplen las funciones para las que estaban destinadas. Mutaciones que se han transmitido asimismo a los individuos transformando de forma rápida e intensa las condiciones materiales, subjetivas e intersubjetivas de su vida cotidiana, impactando e induciendo modificaciones drásticas en "sus estilos de vida, en sus proyectos y políticas de vida ${ }^{87}$; en la configuración de su subjetividad e identidad social; en la forma cómo se relacionan consigo mismo y con los demás, en sus sentidos de vida y de la vida” (Urreiztieta, 2004:459-460). Transformaciones que, según Bauman (2001:21-22), desde el punto de vista de la <<hegemonía ideológica >> y del ejercicio del poder, y a diferencia de épocas anteriores, eliminan la necesidad de cualquier 'lavado de cerebro' para ejercer el control social, ya que la propia inmersión en la dinámica acelerada de la vida cotidiana, determinada por reglas preestablecidas y prescritas sobre las que no se tiene ninguna capacidad de negociación, basta para "mantener a los actores en la línea fijada”.

En este sentido, uno de los cambios más determinantes de las tres últimas décadas, que ha modificado el escenario en el que se mueven los individuos de la mayoría de las sociedades en

\footnotetext{
${ }^{86} \mathrm{Al}$ no existir unanimidad en cuál es el elemento más significativo y distintivo de la misma, entre otras se utilizan las siguientes expresiones para denominarla: modernidad tardía (Giddens, 2000, 1993); modernidad reflexiva (Beck, Giddens y Lash, 1994), modernidad líquida (Bauman, 2003), sociedad del riesgo (Beck, 1994), sociedad global del riesgo (Beck, 2002), posmodernidad (Bauman, 2001, 1996; Jamenson, 1991), sociedad postindustrial (Bell, 1976; Touraine, 1971), sociedad red (Castells et al., 2007; Castells, 1997), sociedad digital (Terceiro, 1996), capitalismo de ficción (Verdú, 2003), sociedad informe (Imbert, 2010).

${ }^{87}$ Giddens (1997:294) define política de vida como "política de la realización del yo en las circunstancias de la dialéctica de lo local y lo mundial y de la aparición de los sistemas internamente referenciales de la modernidad". Siendo referencialidad interna la "circunstancia por la que las relaciones sociales o los aspectos del mundo natural se organizan reflejamente en función de criterios internos” (Giddens, 1997:295).
} 
la actualidad hasta hacerlo en buena parte común, es el derivado del proceso de globalización. Ésta, descrita por Giddens (2000) como un proceso complejo, suma de procesos heterogéneos, supone una creciente interdependencia entre las diferentes regiones y países a medida que las relaciones sociales y económicas se extienden por el mundo. Proceso multidimensional en el que fenómenos que ya existían se relacionan de una nueva forma, modificando las condiciones en que funciona la economía como sistema. Así, aunque cabe hablar de múltiples globalizaciones (cultural, económica, política, demográfica, medioambiental, de seguridad, informativa, militar, de terror, etc.), que operan cada una de ellas con su propia lógica, en la base de todas ellas se encuentra, con mayor o menor grado de determinación, la globalización económica, que se constituye en la dimensión central del proceso. O dicho de forma más prosaica, la globalización supone una nueva configuración espacial para el funcionamiento del capitalismo como sistema y una intensificación y extensión de las relaciones sociales capitalistas. El hecho de que los mercados nacionales se hayan quedado pequeños para el volumen de producción de las grandes empresas, determina que éstas busquen generar una sociedad de consumo de masas internacional, propiciando para ello cierta estandarización a nivel mundial del patrón de consumo como resultado del efecto demostración/imitación internacional y de la globalización comunicacional. Así, en un escenario de mercados mundiales, las empresas y las corporaciones multinacionales juegan un papel central, y desarrollan, entre otras, políticas que tienen importantes consecuencias sobre las condiciones laborales, y por tanto materiales, de la población de los países desarrollados: a) reestructuración general de la producción para eliminar el exceso de capacidad (reconversión); b) flexibilización de las condiciones de trabajo, recortes salariales, subcontratación (precarización), deslocalización, y; c) “adelgazamiento” de las empresas para reforzar las partes del proceso productivo que generan más valor añadido (reingeniería) (Arriola, 2003).

Desde el punto de vista ideológico, es decir, como discurso social dominante, existen diversas ideologías sobre la globalización (globalismos, en la terminología de Safranski), destacando entre todas ellas aquella que ha contribuido a designar, y justificar, los cambios estructurales más recientes arriba mencionados y las tendencias político-sociales dominantes: el neoliberalismo. Ideología hegemónica que ve en la globalización económica el ethos contemporáneo, y usa la globalización como argumento para deshacerse mediante la desregulación de las obligaciones sociales del capital -<<capitalismo sin trabajo, capitalismo sin impuestos >>. Ideología que "pone en práctica la atomización con toda su voluntad política” (Beck y Beck-Gernsheim, 2003:72). En efecto, en su afán por impulsar un mercado mundial que impregne todo y someta a los poderes políticos nacionales e internacionales, el neoliberalismo construye un escenario amenazador para los Estados por el que si no facilitan las cosas pueden verse separados de las corrientes de capital, lo que les fuerza a competir por atraer inversiones y 
puestos de trabajo, implementando medidas que eliminen los impedimentos a las mismas (aspectos sindicales, ecológicos, sociales e impositivos), y medidas que las `ayuden’ a ser más rentables (infraestructuras y subvenciones). Proceso reforzado además con las nuevas definiciones impersonales de la propiedad -“predominio de grandes compañías por acciones, atomización del capital y mayor control e influencia de los conglomerados financieros y los núcleos tecno-gerenciales” (Tezanos, 2001:81)- y por la transversalidad de la misma a la que, al ser planteado el sistema como un capitalismo de masas (millones de pequeños accionistas y poseedores de planes de pensiones de todos los países), sólo cabe alentar. Visión unicausal economicista de la globalización (Beck, 1998) que implica el predominio de los valores del sistema capitalista sobre cualquier otra consideración moral, política o social, y la libertad sin restricciones a los movimientos del capital y a las actividades financieras ${ }^{88}$ : "no pertenecemos a una sociedad, una clase o una nación, en la justa medida en la que nuestra vida es determinada por el mercado mundial” (Barba, 1994:18).

Esta centralización de poder económico y político conexa a la globalización refuerza el carácter plutocrático de los sistemas democráticos: la inmunidad de estos poderes ante la influencia popular provoca el retroceso de la democracia real y la desafección de los ciudadanos hacia sus dirigentes políticos ${ }^{89}$. Nueva lógica del poder por la que el Estado (la política) y la cultura han de servir a la economía. La asimetría de las fuerzas en presencia hace que los Estados-nación, propios de la era industrial, no respondan a la lógica de la nueva economía mundial siendo cada vez más irrelevantes para las "fuerzas que moldean el mundo", por lo que han sido desplazados como instancias de organización de la vida económica, perdiendo su capacidad para promover el bienestar (Ziegler, 2006; Safranski, 2004; Tezanos, 2001; Giddens, 2000; Beck, 1998; Bourdieu, 1998). La ausencia de contrapoderes efectivos frente al poder hegemónico de los mercados ha propiciado la emergencia de problemas de deterioro ecológico y de calidad de vida, al pasar a un segundo plano "valores ecológicos, de equidad social, de atención a las necesidades humanas en la definición de las políticas, etc.” (Tezanos, 2001: 83-84).

Obviamente, si el escenario es amenazador para los Estados, lo es en mucha mayor medida para los individuos de las sociedades desarrolladas que, por un lado, contemplan impotentes el desmantelamiento del Estado de Bienestar y la erradicación de las redes de

\footnotetext{
88 "El globalismo neoliberal pretende que un edificio tan complejo como Alemania -es decir, el Estado, la sociedad, la cultura, la política exterior- debe ser tratado como una empresa” (Beck, 1998).

${ }^{89}$ Es lo que Giddens (2000:85-88) denomina "paradoja de la democracia": a medida que ésta se expande por el mundo, en los países con democracias maduras se observa una "desilusión generalizada con los procesos democráticos”. Además de la corrupción política, en la raíz de este proceso están la revolución de las comunicaciones ligada a la globalización, que produce "ciudadanos más activos y reflexivos”, y la percepción de incapacidad con que éstos perciben a los políticos en la tarea de "controlar las fuerzas que mueven el mundo".
} 
seguridad social, y, por otro, la expansión de un modelo de desarrollo "tercermundista" dualización, desarrollo desigual, exclusión, expulsión-, y el deterioro del mercado laboral -paro masivo; paro estructural de larga duración; corrosión de la negociación colectiva; retroceso de los derechos laborales; división en estratos cada vez más segmentados (fijos y temporales; contratados ilegales; con convenio o sin él, etc.). Así, mientras se favorece la concentración y globalización del capital, "el trabajo se desintegra en su ejecución, se fragmenta en su organización, se diversifica en su existencia y se divide en su organización colectiva. El trabajo pierde su identidad colectiva, se individualiza cada vez más en sus capacidades, condiciones laborales, intereses y proyectos” (Castells et al, 2007; Castells, 1997). Lo que conforma, según Bourdieu (1998), una "máquina infernal” engrasada por la violencia estructural del desempleo, movida un ejercito de reserva de mano de obra docilitada por la precarización y la amenaza permanente de la exclusión. Destrucción de las condiciones existenciales del trabajo nacional local que lleva a Beck (1998) a denunciar que "la clase media se empobrece, los pobres se vuelven pobres de solemnidad, las élites económicas y políticas pierden su legitimación. Se puede hablar de una implosión amenazadora del orden de clases y de la sociedad"90.

Por otro lado, otra fuente de intensos cambios sociales en la modernidad tardía es la derivada de los continuos avances científico-técnicos que están afectando profundamente la forma de organización de la sociedad en todas sus dimensiones, hasta el punto de que Tezanos (2001) denomina a las sociedades de esta fase como sociedades tecnológicas avanzadas. Los nuevos conocimientos, a través de sus aplicaciones prácticas (sobre todo de las nuevas tecnologías de la información y de la comunicación -NTICs), impregnan rápidamente toda la vida social dando lugar a cambios radicales y globales en todas las formas de vida y trabajo. De tal forma que los recursos científico-tecnológicos se han convertido en una variable económica central (Tezanos, 2001:81), lo que implica que la "habilidad técnica" y el conocimiento pasen a ser las bases del poder y la educación el modo de acceso a él, conformándose los denominados por Giddens (2002) "trabajadores del saber" (los que traducen la ciencia especializada en innovaciones generadoras de beneficios), como el grupo privilegiado de la sociedad. Sin discutir la importancia cualitativa de este sector de la población, su importancia cuantitativa, absoluta y relativa, es minoritaria en el conjunto de la población laboral. De hecho, la novedad radical de las NTICs es que, mediante la robotización, permiten incrementar la productividad sin trabajo, con lo que los nuevos descubrimientos conllevan "economizar el uso del factor trabajo sobrepasando el ritmo con el que se pueden encontrar nuevos empleos para el factor trabajo disponible” -paro tecnológico. Esto es, en términos cuantitativos, el papel del ser humano como factor más

\footnotetext{
${ }^{90}$ Según un informe del FMI, la incorporación de China e India al mercado mundial multiplicó por cuatro el número de trabajadores disponibles en el mercado laboral mundial, reduciéndose con ello en 7 puntos, entre 1980 y 2007, los salarios de los trabajadores de los países desarrollados (EL PAÍS, 6/04/07:48).
} 
importante de producción está destinado a disminuir (hipótesis del fin del trabajo de Rifkin (1996) $)^{91}$, aunque de momento lo que sí se percibe es una marcada dualización y segmentación en el mercado laboral. En éste se han conformado dos sub-mercados asimétricos con principios estructurales y reglas de funcionamiento claramente diferenciados: por un lado, un "mercado primario" para las nuevas élites de tecnócratas, gerentes, programadores y especialistas que disponen de credenciales y de la alta cualificación necesaria por el sistema, lo que les permite aspirar a buenas condiciones de trabajo, salarios altos y posibilidades de promoción; por otro lado, un "mercado secundario", el mayoritario, para quienes tienen cualificaciones "obsoletas", desfasadas y menos necesarias, a los que se les ofrece condiciones precarias, bajos salarios y escasa estabilidad, es decir, ven reducida su fuerza de trabajo a la condición de "prescindible” y “sustituible” (Tezanos, 2001:84).

Dualización laboral que, como resalta Tezanos (2001:82), está reconfigurando la estructura social de las sociedades tecnológicas avanzadas no sólo con el incremento de los procesos de exclusión social entre los "grupos sociales postergados” (jóvenes, mujeres, inmigrantes, personas menos cualificadas), sino también con el "declive y desdibujamiento de las clases medias tradicionales” cuyos valores modernos (responsabilidad, cálculo, actuación racional, esfuerzo competitivo, eficacia, disciplina, rigor, puntualidad, implicación, lealtad, sacrificio, etc.) han entrado en crisis. Proceso de corrosión del carácter (Sennett, 2000) que viene acompañado además por el final del mito de la "escalera mecánica”: las familias de clase media no pueden garantizar que, a pesar de los recursos dedicados a la formación de sus vástagos, éstos alcancen un estatus social y un nivel de vida superiores al de sus progenitores.

Junto a estos cambios estructurales propiciados por las nuevas tecnologías, cabe añadir, por las importantes implicaciones socio-psicológicas que comporta, la total implicación de los ciudadanos con las innovaciones tecnológicas, hasta el punto de transformar a la tecnología en un fetiche al que rinden culto. Así, como si de un determinismo se tratara, asimilan sus efectos de una manera "normalizada”, acrítica y casi silenciosa, no se percatan de ellos y en todo caso los perciben como irreversibles. Quizá porque esos efectos son 'solo' una parte del "nuevo gigantismo social”, es decir, de los nuevos escenarios globales en los que los individuos se han

\footnotetext{
${ }^{91}$ Para J. Rifkin (1996) “los avances técnicos y la actual reingeniería de la producción están en la base de un cambio productivo que reduce las necesidades de trabajo para mantener o incrementar el conjunto de bienes y servicios producidos". Hipótesis no compartida por L.E. Alonso (2000) que, observando la experiencia histórica más reciente comprueba que momento no se puede hablar de fin del trabajo sino de empleo turbulento: en un entorno social presidido por la inseguridad a todos los niveles y por la presión para el consumo, el impacto del sistema de relaciones tecnología/empleo no es único, uniforme y homogéneo, sino desigual y heterogéneo: a) en unos espacios hay que trabajar más para conseguir los mismos niveles de bienestar; b) en otros espacios existen degradaciones notables de las condiciones de contratación del trabajo.
} 
visto insertados, cuyas dimensiones perciben como inmanejables, y frente a los que aceptan con total impotencia su desposesión (Tezanos, 2001:84).

En este punto, hay que mencionar necesariamente la incidencia de un nuevo instrumento clave: INTERNET, que está modificando la base material de la sociedad a un ritmo acelerado y conformando una nueva estructura social, denominada por Castells $(2007,1997)$ sociedad red. Siguiendo a este autor, el surgimiento de este nuevo paradigma tecnológico, organizado en torno a nuevas tecnologías de la información más potentes y flexibles, hace posible que la misma información se convierta en el producto del proceso de producción ${ }^{92}$. Como resultado está emergiendo una nueva economía, una nueva forma de gestión, un nuevo sistema de medios de comunicación, una nueva cultura, nuevas instituciones políticas, nuevas formas de organización $^{93}$, debate y acción social, que además tienen alcance global. En efecto, las economías de todo el mundo se han hecho interdependientes a escala global -en un sistema que funciona como una unidad en tiempo real-, introduciendo una nueva forma de relación entre economía, Estado y sociedad en un sistema de geometría variable: red de redes. Con ello, los cimientos materiales de la sociedad, el espacio y el tiempo, se están transformando y organizando en torno al espacio de los flujos, que "no tienen distancia”, y el tiempo atemporal. Las funciones dominantes se organizan en redes pertenecientes al espacio de los flujos, que las enlaza por todo el mundo. Las funciones subordinadas se fragmentan. Así, mientras que el trabajo es local el capital funciona a escala global como una unidad en tiempo real, se realiza, invierte y acumula principalmente en la esfera de la circulación, esto es, como capital financiero. En esa separación se crea un vacío que debilita los procesos de regulación y control que se crearon con la sociedad industrial y, tal como se ha señalado al hablar de globalización, el trabajo pierde su identidad colectiva, individualiza cada vez más sus capacidades, y las condiciones laborales se deterioran.

En definitiva, una combinación de cambios estructurales acelerados, cuando no explosivos, que configuran un escenario ambivalente, incontrolable, caótico, incoherente, inestable e incierto, en el que la realidad social se desmorona en manos de los individuos

\footnotetext{
${ }^{92}$ De forma más amplia, Castells (1997) afirma que este nuevo paradigma tecnológico está transformando la relación entre los dos polos fundamentales de la existencia humana: naturaleza y cultura. Así, si esta relación estuvo caracterizada durante milenios por el dominio de la naturaleza sobre la cultura -"la lucha por la supervivencia bajo el rigor incontrolado de la naturaleza” -, y desde la Revolución Industrial y el triunfo de la razón por el dominio de la naturaleza por la cultura, en el nuevo modelo que está emergiendo la cultura hace referencia directa a la cultura, constituyendo un modelo puramente cultural de interacción y organizaciones sociales: "La información es el ingrediente clave de nuestra organización social, y los flujos de mensajes e imágenes de unas redes a otras constituyen la fibra básica de nuestra estructura social”.

${ }^{93}$ Es el caso de la denominada por Castells (2007) empresa red: "organización a la vez coordinada y descentralizada, fundada en la unidad de proyecto de la empresa y en la flexibilidad y en la autonomía de cada una de sus unidades”. No es una empresa organizada en red interna ni una red de empresas, sino que "se basa en un proyecto de negocio en el que participan distintas empresas y segmentos de empresas con
} 
escapando a su comprensión -modernidad líquida, en expresión de Bauman (2003). Así, la primacía de los valores del mercado, que sustituye las normas sociales y los valores culturales por la libre concurrencia, empuja a que los individuos reemplacen la participación social por la “obsesión de la identidad” (Touraine, 2006). Según este autor, las identidades culturales derivadas de la fragmentación de la vida social se disocian de la racionalidad económica para refugiarse en la vida individual, de tal forma que la sociedad se transforma en un campo de conflicto y de mediación experta entre procesos de racionalización y subjetivación. Lo que lleva a los individuos a encerrarse en el universo de su vida personal y de las relaciones interpersonales para vivir lo que Beck y Beck-Gernsheim (2003) denominan $<<$ vida propia $>{ }^{94}$. Una vida propia que es experimental ${ }^{95}$, ya que los modelos históricos que ofrecían recetas para vivir mejor están devaluados, y reflexiva, esto es, en la que se procesa continuamente "la información contradictoria, el diálogo, la negociación, el compromiso” (Beck y Beck-Gernsheim, 2003:7576).

Abundando en esta idea, en su análisis de la modernidad como "problema sociológico fundamental”, Giddens $(2000,1997)$ plantea asimismo que uno de los rasgos distintivos de la misma en su fase actual es la creciente interconexión entre los "dos <<extremos >> de la extensionalidad y la intencionalidad”, es decir, entre la globalización y las disposiciones personales. Si en el tránsito entre las sociedades tradicionales a las modernas la pérdida de influencia de la tradición y la costumbre afectó a la propia construcción del yo, ya que, al desaparecer la estabilidad de las posiciones sociales que los individuos mantenían en la comunidad, la identidad personal tenía que ser continuamente creada y recreada de acuerdo al estilo de vida que se eligiese; en el mundo desbocado que se ha conformado con la globalización y los cambios estructurales arriba mencionados esa recreación de la identidad se ha hecho mucho más compleja. En efecto, la fragmentación social derivada de unas condiciones sistémicas de “<<apertura>> social” y continuamente cambiantes hace que los individuos construyan su identidad personal, su carácter, no de forma única y unitaria, sino que, forzados a elegir entre la diversidad de estilos de vida alternativos que ofrece la pluralización de ámbitos de acción y la "diversidad de autoridades", aquéllos crean y recrean varias identidades sociales de "carácter microscópico y laxo” adaptadas a las pautas culturales y sistemas de valores de los diferentes

sus recursos y estrategias propias. Es una red que se deshace al final de cada proyecto y que se vuelve a tejer, con otros componentes, con cada nuevo negocio que surge”.

94 "La vida propia es por definición un intento y una tentación para descubrir en uno mismo el fundamento, la fuerza y el sentido de la configuración personal y del mundo” (Beck y Beck-Gernsheim, 2003:267).

$95<<$ Destradicionalización $>>$ que no significa que las tradiciones no tengan importancia, sino que no son impuestas. Así, "las tradiciones deben ser elegidas y a menudo inventadas, y sólo tienen fuerza merced a las decisiones y experiencias de los individuos” (Beck y Beck-Gernsheim, 2003:74). 
escenarios sociales en los que se mueven ${ }^{96}$ (Beck y Beck-Gernsheim, 2003:70; Tezanos, 2001:84, Bauman, 2001:103; Giddens, 1997:14). "Un prestarse a los roles sociales sin entregarse totalmente”, reservando para la esfera íntima lo profundo, lo auténtico, lo más personal (Imbert, 2004:18).

Así, aunque los individuos tienen una libertad de elección sin precedentes históricos para hacer su vida, sin embargo, como no controlan las condiciones de su elección, se ven involucrados en continuos conflictos por las múltiples decisiones que han de tomar, por lo que enfocan la construcción de sus identidades y proyectos de vida con inseguridad, ansiedad, inestabilidad y desconfianza ante el porvenir (Urreiztieta, 2004:465; Bauman, 2001:16-17). Además, a la desposesión derivada de la quiebra de las ataduras tradicionales, la creciente individualización y la fluidez y elusión de las instituciones concha, hay que añadir las consecuencias no previstas de los avances científico-técnicos que hacen que los individuos se tengan que enfrentar a nuevos riesgos vitales ${ }^{97}$-sociedad del riesgo (Beck, 2002, 1994; Giddens, 2000, 1997). En efecto, la emergencia del riesgo manufacturado ${ }^{98}$, el derivado de los avances científico-técnicos, ha roto los intentos de controlar el futuro con los que nació la modernización, volviéndolos contra "nosotros, forzándonos a buscar formas diferentes de ligarlo a la incertidumbre". Esto no significa que "nuestra era” sea más peligrosa que la de generaciones anteriores, sino que el "balance de riesgos y peligros ha cambiado" (Giddens, 2000:34-47). Y lo ha hecho en el sentido de que estos riesgos globales creados por los propios seres humanos superan totalmente la capacidad de respuesta de las instituciones existentes, incluidas también las

\footnotetext{
${ }^{96}$ Bauman (2001:103) describe el proceso de una forma muy gráfica: “Como todo lo demás, las identidades humanas -sus imágenes de sí mismas- se dividen en colecciones de instantáneas, cada una de las cuales tiene que evocar, portar y expresar su propio significado, la mayoría de las veces sin referencia a las demás instantáneas. En lugar de construir uno su identidad gradual y pacientemente, como construye una casa,..., como una serie de <<nuevos comienzos >>, uno experimenta con unas formas reunidas instantáneamente, pero desmanteladas con facilidad, pintadas unas encimas de otras; es una verdadera identidad de palimpsesto. Es el tipo de identidad que se adapta a un mundo en el cual el arte de olvidar es un activo no menos importante, si no más, que el arte de memorizar; en el cual olvidar, más que aprender, es la condición de la adaptación continua; en el cual hasta las cosas y personas nuevas entran y salen del campo de visión de la cámara estacionaria de la atención, y donde la memoria misma es como una cinta de vídeo, siempre preparada para borrarla a fin de admitir nuevas imágenes”.

${ }_{97}$ Giddens (2000:cap. II, 1997) diferencia riesgo de amenaza o peligro, y señala que la noción de "riesgo" es inherente a las sociedades modernas, es decir, a unas sociedades que quieren determinar su futuro sin dejarlo en manos de la tradición, la religión o los dictados de la naturaleza. Así, orientadas al futuro, y como si se tratara de un territorio a conquistar y colonizar, buscan traerlo al presente para regularlo, "normalizarlo" y ponerlo bajo control humano.

${ }^{98}$ Giddens (2000:38-39) distingue entre: a) riesgo externo, el que "se experimenta como viniendo del exterior, de las sujeciones a la tradición o de la naturaleza", y; b) riesgo manufacturado, el "creado por el impacto mismo de nuestro conocimiento creciente sobre el mundo". En este tipo de riesgo se incluyen los vinculados a las consecuencias de la confluencia de cambios ya mencionados más arriba (riesgo ecológico mundial, deterioro medioambiental local, colapso de la economía mundial, proliferación nuclear, etc.). Asimismo, al debilitarse las solidaridades colectivas de épocas pasadas, que aseguraban contra los riesgos, los riesgos manufacturados también penetran en otras áreas de la vida, como la vida familiar o el matrimonio que se afrontan de cara a futuro de una forma mucho más abierta.
} 
científicas, lo que ha agudizado los retos a los que se enfrentan los individuos que ahora no sólo los tienen que afrontar aislados, sino que también lo hacen con menos puntos de apoyo, al producirse una quiebra en su confianza en el conocimiento científico y el papel mediador de los expertos.

Desajustes y desconciertos provocados por la ambivalencia ${ }^{99}$ de la situación que hace que los individuos se sientan incapaces de interpretarla correctamente y elegir entre las alternativas que se les presentan. Incertidumbre que socava la seguridad y confianza personal, provocando frustración, ansiedad y sentimientos de pesimismo y fatalismo que pueden desembocar en actitudes anómicas (Urreiztieta, 2004:462; Tezanos, 2001:84). Es por ello por lo que en su análisis de la dialéctica globalización/disposición personal Giddens (1997:14-17) apunta como una de las cuestiones relevantes de la modernidad tardía ${ }^{100}$, al que califica de "problema psíquico fundamental”, "la insignificancia personal -el sentimiento de que la vida no tiene nada valioso que ofrecer”. Deriva de la precarización vital, como nueva justificación de la sumisión, que Bauman (2001:22-23) asimila a una ‘desfundamentación del ser', y que hace innecesarios "los torpes y costosos medios de <<control directo >>" característicos de las etapas anteriores: "El distanciamiento es hoy día el juego más atractivo y al que más se juega. La velocidad de movimiento, y, sobre todo, la velocidad de escapatoria antes de que haya ocasión de pagar las consecuencias, es hoy la técnica más popular de poder”. Ejercicio de poder desarrollado sobre una estrategia difusa por la que se 'descoloniza' la esfera pública y se desplaza el control a la esfera íntima (privada más individual): se eluden las responsabilidades de las instituciones y se las sitúa en el terreno de las tareas a desarrollar por los individuos como componentes necesarios e imprescindibles para la creación/recreación de sus identidades. Si tienen consecuencias negativas, sólo cabe achacárselas a una inadecuación del yo. Así, el individuo percibe sus fracasos como resultado de su incompetencia o de sus limitaciones, y no por fallos del sistema.

En la fase actual de las sociedades avanzadas, por tanto, el proceso de individualización ${ }^{101}$, ha adquirido nuevos perfiles, ya que las personas se ven obligadas a tener

\footnotetext{
${ }^{99}$ Para algunos autores la ambivalencia es el principal rasgo de la posmodernidad. En este sentido, Imbert (2010:15) señala las consecuencias de la misma: "es cuando uno se mueve en espacios y categorías contrarios sin que sea vivido como contradictorio. El sujeto no opta, no resuelve en términos sintéticos..., sino que vive en la tensión, que puede ser un oscilar entre extremos y desembocar en un desafío a los límites. Cuando hay ambivalencia,..., las fronteras entre principios y categorías se diluyen, se hacen más porosas, se pasa con facilidad de una a otra y la opinión es más maleable.”

${ }^{100}$ Modernidad reciente, tardía o alta es, según Giddens (1997:294), la "fase actual del desarrollo de las instituciones modernas; está marcada por la radicalización y universalización de las características fundamentales de la modernidad”.

${ }^{101}$ Algunos autores prefieren utilizar esa expresión para diferenciarla de individualismo. Así, Beck y BeckGernsheim (2003:39-40), lo entienden en el sentido de un individualismo institucionalizado, o lo que es lo mismo, en el que las instituciones cardinales de la sociedad no están orientadas al grupo sino al individuo. Es decir, como un proceso que no es una "mera $<<$ subjetividad $>>$, una actitud que se niega a ver que $<<$ bajo
} 
que elegir continuamente, convirtiéndose cada vez más en "los legisladores de su propia vida, en los sacerdotes que se perdonan la culpa, en los terapeutas que aflojan y desatan las cadenas del pasado", por lo que su biografía deviene en "una <<biografía electiva>>, en <<biografía reflexiva >>, en <<biografía hágalo usted mismo>>” (Beck y Beck-Gernsheim, 2003:40, Beck, 1998:14-15). Aparentemente, todo es fruto de una elección entre posibilidades: "La vida, la muerte, el género, la corporeidad, la identidad, la religión, el matrimonio, el parentesco, los vínculos sociales, todo ello se está volviendo objeto de decisión <<hasta la letra más pequeña>>; una vez fragmentado en opciones, todo debe decidirse” (Beck y Beck-Gernsheim, 2003:44). Sin embargo, esas decisiones no se toman sin cortapisas ya que otra de las características de la individualización es que "la propia vida -la vida de uno- no es una vida privativa”, sino una vida estandarizada en la que el interés del individuo se interrelaciona con el de la "sociedad racionalizada” (Beck y Beck-Gernsheim, 2003:71). Por ello, los individuos se ven interpelados y exigidos con nuevos requerimientos, controles y limitaciones a los que habrán de enfrentarse porque se les demanda su contribución activa ante los mismos. En efecto, dado que la complejidad de las interacciones sociales provoca que con frecuencia los individuos tomen decisiones sin tener en cuenta los intereses comunes, si no quieren fracasar no sólo deben organizar y planificar sus metas, su vida propia, sino que necesitan coordinarlas e integrarlas con los demás: “A través del mercado laboral, el Estado de bienestar y las instituciones, la gente entra en una red hecha de regulaciones, condiciones, salvedades...”102 (Beck y Beck-Gernsheim, 2003:39). Por lo que la vida propia es una existencia "sumamente socializada”, completamente dependiente de las instituciones en la que éstas, a diferencia de épocas pretéritas, imponen que las regulaciones deban ser “importadas a los individuos mediante sus propias acciones”, es decir, la obtención de cualquier apoyo social hay que ganárselo con esfuerzo activo día a día.

Como consecuencia, y por la estrategia señalada, los errores cometidos al configurar activamente sus propias vidas son apuntados sólo a los individuos, convirtiendo el fracaso en un asunto personal. Así, la <<biografía hágalo usted mismo>> entraña aceptar las responsabilidades de las desgracias personales y de las contingencias que se presenten, es decir, es además una biografía de riesgos y tensiones que se viven de manera cada vez más individual. "Curiosamente, esto no es sólo una percepción individual, sino un modo de atribución culturalmente vinculante”

la superficie de la vida hay una sociedad institucional altamente eficaz y densamente trenzada>>”, sino que significa que "la biografía del ser humano se desliga de los modelos y de las seguridades tradicionales, de los controles ajenos y de las leyes morales generales y, de manera abierta y como tarea, es adjudicada a la acción y a la decisión de cada individuo”. Consideran esta expresión más neutra que la de individualismo que "puede tener un significado peyorativo (individualismo egoísta o utilitarista) o positivo (autoperfeccionamiento individual) (Herrera Ponce, 2007:67, 149; Beck y Beck-Gernsheim, 2003).

102 "Desde el derecho a la pensión hasta la protección que ofrecen las compañías aseguradoras, pasando por las becas de estudios y los tipos impositivos, todas estas cosas son sendos puntos de referencia institucionales que marcan el horizonte dentro del cual deben tener lugar el pensamiento, la planificación y la acción de nuestros días” (Beck y Beck-Gernsheim, 2003:39). 
(Beck y Beck-Gernsheim, 2003:72). Como correlato, los problemas sociales son directamente volcados en los hombros de los individuos mediante disposiciones psicológicas: sentimientos de culpa, ansiedades, conflictos y neurosis. Por ejemplo, los problemas laborales que antes eran sobrellevados como destino colectivo de clase ahora se vivencian como faltas individuales, cuyas responsabilidades deben ser asumidas individualmente (Herrera Ponce, 2007:cap.5).

Es el caso también de la salud: al no ser ya la vida un regalo de Dios, sino una propiedad individual a defender sin cesar, se exige la provisión constante de la salud personal -la prevención- en los modelos biográficos vigentes. Se hace imprescindible evitar todo tipo de comportamiento de riesgo en el ocio, la alimentación, las relaciones sexuales, la vida cotidiana, etc., para soslayar problemas de salud, como también, por ejemplo, es necesario estar en forma para mantenerse en el mercado laboral. Si antes la salud era algo "que nos era dado” y que como mucho requería reparaciones cada cierto tiempo, hoy es "algo que tiene que ser continuamente producido". Nueva moral de la salud precautoria que insta a los individuos a que se preparen de antemano responsabilizándose de su propia salud (Beck y Beck-Gernsheim, 2003:256-258). En su ensayo Sonríe o muere, B. Ehrenreich (2011) realiza un análisis desmitificador de la nueva variante de esta ideología que rápidamente se ha ido extendiendo en todos los ámbitos de la vida social en EE.UU., variante a la que califica como trampa, "la trampa del pensamiento positivo". A partir de su propia experiencia como superviviente de un cáncer de mama, Ehrenreich describe el contraste entre sus percepciones negativas -miedo, ira, pánico, rabia, horror, desolación, soledad- cuando le fue descubierto el cáncer y el entorno "rosa" -lazos rosas, ositos de peluche rosas, páginas webs de las asociaciones de cáncer de mama con fondo rosa, etc.- que rodeaba a la enfermedad enterrándola "bajo una capa cosmética de alegría”, entorno conformado, además, sobre "un mercado considerable para todo tipo de productos relacionados con el cáncer de mama”. Ya no se trataba sólo de la necesidad de desarrollar comportamientos individuales adecuados para evitarse problemas de salud, sino que cuando éstos aparecen resulta imprescindible además mantener una actitud positiva para poder superarlos ${ }^{103}$. Así, la enfermedad se convierte en un "rito de paso", se transforma en un punto crucial de la vida, en un reto por el que luchar y una oportunidad para reinventarse y evolucionar, "no en una injusticia ni una tragedia” contra la que haya que quejarse o rebelarse. En última instancia, si una persona no es feliz es porque no ha puesto suficiente empeño en ello, ha sido negativa. Es la actitud personal, y no el azar o el contexto socio-histórico, la que condiciona el desarrollo de la enfermedad y la superación o no de la misma. Axioma que también debe presidir el enfrentamiento a cualquier otro obstáculo o “problema” vital, laboral, etc. Así, todo, absolutamente todo, depende única y

\footnotetext{
${ }^{103}$ En ese entorno rosa, "los términos "paciente” y "víctima” se consideran políticamente incorrectos por su resonancia de autocompasión y pasividad. En su lugar, se usan sustantivos que indican acción: las que están en tratamiento se llaman "luchadoras" (Ehrenreich, 2011:33).
} 
exclusivamente de la propia persona. Si fracasa en la consecución de sus objetivos, ella sola es responsable, se transforma en victimaria de sí misma. Contra ello, Ehrenreich (2011:53) concluye su análisis de la “cultura del cáncer” manifestando que lo que le dio (el cáncer de mama) no fue ninguna oportunidad para mejorar como persona ni para hacerse más espiritual, sino "la oportunidad de encontrarme cara a cara con una fuerza ideológica y cultural de la que hasta entonces no había sido consciente; una fuerza que nos anima a negar la realidad, a someternos con alegría a los infortunios, y a culparnos solo a nosotros mismos por lo que nos trae el destino”.

En lo relativo a la muerte, y sobre todo el trasfondo reseñado, Beck y Beck-Gernsheim (2003:cap. 11) asumen que el "significado distintivo de la vida propia sólo se podrá entender desde su fin”, esto es, si se tiene en cuenta la importancia existencial de la muerte. Sin embargo, la ausencia de asideros colectivos, junto con las propias peculiaridades que conforman la construcción de la <<vida propia>>, hacen muy difícil a los individuos de las sociedades contemporáneas el enfrentamiento a su muerte. En efecto, ahora ésta no es un tránsito, sino el final absoluto e incognoscible que supone la desaparición del propio yo, único, irremplazable y que, por la disolución de las instituciones concha, ya no puede trascender en nada ni en nadie. Los procesos de secularización e individualización han eliminado todos los puentes sociales entre la vida y la inmortalidad que ayudaban a los individuos a `saltar` la muerte. Ésta queda fuera de toda posibilidad de control, por lo que ante la imposibilidad de abolirla la vida propia se concentra en enfrentarse y metabolizar algo que el yo sí experimenta desde muy pronto: la “amenaza ubicua” que es el morir. Sobre éste sí que se puede actuar, por un lado, desplazándolo hasta que la medicina deja de ser eficaz y, por otro lado, evitando todo pensamiento sobre la muerte. Así, ésta queda enterrada en "las mazmorras más profundas, en las cámaras más recónditas del yo... descansando hasta que se levante por fin para terminar con la vida propia”. Es decir, si, como afirma Baudrillard, la negación simbólica de la muerte era una necesidad inserta en la lógica del sistema de las sociedades modernas, en las sociedades contemporáneas esa necesidad se empotra y torna perentoria para todas y cada una de las lógicas individuales de construcción de la <<vida propia >>. Muerte silenciosa con la que se quiere ocultar el miedo a la nada “después de la trabajosa formación de una identidad demasiado individualizada” (Basterra, 2006:156). De ahí, que la muerte ideal en estas sociedades sea la muerte súbita, como un relámpago: una muerte sin morir.

Por su parte, en su análisis sobre los temores en las sociedades contemporáneas -en la modernidad líquida-, recogido en Miedo líquido, Bauman (2007) examina los efectos de la incertidumbre generalizada instalada en ellas. Incertidumbre que se materializa en miedos, que en el caso de los seres humanos tienen un componente añadido respecto al miedo que puedan sentir 
todo el resto de criaturas vivas, “<<un miedo derivativo $>>{ }^{104}$ que orienta su conducta (tras haber reformado su percepción del mundo y las expectativas que guían su elección de comportamientos)” (Bauman, 2007:11). Entre los miedos que analiza, el primero de ellos es el del terror a la muerte, prototipo o arquetipo de todos los miedos (que "toman prestados (de él) sus significados respectivos”) y que es temible por tener una cualidad distinta a todas las demás: la de “hacer que todas las demás cualidades ya no sean negociables”, esto es, la muerte es irreparable, irremediable, irreversible, irrevocable,..., el fin de todo (Bauman, 2007:45). Ante ella no cabe preparación alguna, porque invalida todo lo aprendido. Si a ello se añade el declive de todo tipo de autoridad (religiosa, ideológica, mitológica) la muerte se muestra entonces desnuda de artificios “en toda su crudeza, injustificada (sin escatología), desvinculada del sentido tanto social como trascendente" (Imbert, 2004:122).

Si bien los seres humanos comparten con el resto de los animales el $<<$ miedo original $>>$ a la muerte (derivado del instinto de supervivencia), sólo ellos tienen conciencia de muerte, por lo que, como ya señaló Elias (1987), sólo ellos se enfrentan además a un <<miedo secundario >> a la misma: "el miedo que rezuma no del hecho de que la muerte llame a nuestra puerta, sino de nuestra certeza de que lo hará, con toda seguridad, tarde o temprano” (Bauman, 2007:47). Esta particularidad específicamente humana determina que el enfrentamiento al miedo a la muerte sólo pueda realizarse con herramientas construidas por los propios seres humanos. De hecho, Bauman considera que es ahí precisamente donde está el origen de todas las culturas humanas, en la construcción de “artefactos ingeniosos”, de mitos de la contingencia de la muerte, con el objetivo de atemperar esos miedos a la muerte haciendo "llevadero el vivir con la conciencia de la mortalidad”. Construcciones que en realidad no son más que meros "subterfugios y paliativos”. Bauman (2007:cap. 1) resume la inventiva humana en ese terreno en tres estrategias, de las cuales las dos primeras, denegación ${ }^{105}$ y deconstrucción ${ }^{106}$ de la muerte, las correspondientes a las sociedades tradicionales y modernas, ya han sido desarrolladas más arriba, por lo que en este punto se presta más atención a la tercera, banalización de la muerte, la propia de la modernidad líquida.

\footnotetext{
${ }^{104}$ Un miedo deducido que es "una especie de temor de <<segundo grado $>$, un miedo $<<$ reciclado $>>$ social y culturalmente..., tanto si hay una amenaza inmediatamente como si no... Miedo equivalente al sentimiento a ser susceptible al peligro, es decir, sensación de inseguridad y de vulnerabilidad" (Bauman, 2007:11).

${ }^{105}$ La negación de la muerte es para Bauman la estrategia más habitual (adopta múltiples versiones) y "aparentemente la más eficaz". Suprime el carácter definitivo de la muerte, que se transforma metafóricamente en un puente entre la vida y la inmortalidad, es decir, la muerte no sería el final de todo sino el comienzo de una nueva vida, por tanto, una expiración temporal. Como ya se ha comentado, para Bauman (2007:47-56) es una estrategia maestra al inventarse la inmortalidad y poner a los "autorreconocidos como mortales al cargo del cuadro de mandos" de la misma.

${ }^{106}$ Estrategia de "naturaleza más cultural", por la que se intenta atemperar los temores a la muerte transformando un acto natural en un acto cultural prosaico: se traslada el foco de atención de la muerte en
} 
Las tres son estratagemas que buscan transformar un hecho natural en un hecho cultural, la primera ignorando la muerte mediante la sustitución de la transitoriedad de la vida por la duración de la eternidad, mientras que las otras dos, renegando de esa estrategia, buscan desactivarla despreocupándose de lo duradero para concentrarse sólo en lo transitorio, en la propia vida. El objetivo de esa marginación de las preocupaciones por la eternidad en la conciencia humana es claro: trasladando el foco de atención del <<más allá >> al presente se desactiva "su poder para dominar, condicionar y racionalizar el curso de la vida individual” (Bauman, 2007:57). Estrategias innovadoras y arriesgadas por cuanto la ruptura de los puentes a la inmortalidad por parte de la deconstrucción y la banalización de la muerte significa que, como ya se ha comentado, la misma se ha transformado en un muro absoluto y estanco. Así, ya no hay nada que esperar después de ella, los individuos viven sin la inmortalidad, y “según parece no les importa”. Esto es, por primera vez en la historia, se ha "llegado a un territorio en el que los seres humanos no han habitado nunca, un territorio que la cultura humana consideró en el pasado inhabitable” (Bauman, 2001:277). Territorio conformado por todos los cambios sociales producidos desde el inicio de la modernidad y que lejos de constituir el paisaje unitario y accesible por igual a todos prometido por ella -"la idea generalizada de que la ciencia y la razón, aplicadas al dominio de la naturaleza y al conocimiento de la vida humana, traerían consigo no sólo el control de las fuerzas naturales, sino también la explicación del mundo, el progreso moral, la justicia en las instituciones y, en último término, la felicidad humana” (Picó López, 1998:590)-, se ha ido transformando hasta convertirse hoy, en la modernidad líquida, en un paisaje con una multiplicidad indefinida y continuamente cambiante de espacios híbridos, cada uno con diferentes sistemas de valores y criterios de legitimación, en el que los individuos que los habitan se han transformado a sí mismos en sus propias 'micro-jaulas de hierro'. Paisaje perturbador que hace que todo el mundo experimente hoy un estado de ansiedad constante, ante la omnipresencia de miedos que pueden filtrarse hasta los lugares más recónditos e íntimos por cualquiera de las múltiples rendijas del mismo.

En efecto, como ya se ha señalado, lejos de conseguir su objetivo tranquilizador, la estrategia de deconstrucción de la muerte, que fragmenta el enfrentamiento a la misma "en incontables preocupaciones sobre incontables amenazas”, paradójicamente, ha saturado de miedo a la muerte a la vida en su conjunto. Gracias a la pulverización de la muerte y al almacenamiento de sus residuos en espacios acotados, sus ubicuas apariciones lo son en pequeñas dosis, poco tóxicas, por lo que "resulta harto improbable que paralice nuestra voluntad de vivir" (Bauman, 2007:57-60). Ausencia de parálisis que sin embargo no impide el condicionamiento continuo de la

sí, ante la que no cabe ninguna actuación, a las causas específicas de la muerte, que sí se que pueden 
vida, pues, como si se tratara de un espectro difuso que lo impregna transversalmente todo, la muerte puede aparecer en cualquier momento en el trabajo, detrás de un viaje, de una comida, de un juguete, de una actividad de ocio, por lo que se requiere no sólo estar continuamente alerta sino además prevenir su futura aparición evitando todo tipo de riesgos. Quizá por ello, al lado de esta estrategia propia de la modernización, y al hilo de la individualización reseñada, se ha desarrollado en la modernidad líquida un “complemento inevitable”, la banalización de la muerte, que también persigue la marginación de la eternidad pero que se diferencia de la deconstrucción en que su concentración en el presente lo es sólo en el corto plazo, en el 'tran tran' cotidiano, un presente continuo asentado en el reciclaje diario de la vida, de la <<vida propia >>.

En este punto es preciso recordar sintéticamente, con Imbert (2010), Roche (2005, 2002) y Maffesoli (2004, 1990), algunas dimensiones de las relaciones sociales características de las sociedades postindustriales con influencia en la estrategia de banalizacion de la muerte:

a) aumento la autoconciencia subjetiva (self), “desplazamiento de la alienación del sujeto hacia su fragmentación”, disolución de las certezas y distanciamiento de la realidad (Roche, 2005:31). Lo que lleva por ejemplo a Maffesoli (2004:475) a resaltar la "significancia que no se proyecta" de algunas prácticas juveniles contemporáneas que tanto llaman la atención y resultan extrañas: "hay que pensar en la profunda significación del no sentido de la vida”;

b) frente a la aspiración por el ser, se apuesta por el devenir, por el ser de un instante: se está siempre en camino, abierto al cambio y a lo posible. Distinción que permite a Maffesoli, y a Imbert, diferenciar entre identidad e identificación: la identidad, perteneciente a la modernidad, es un modo de ser; la identificación, propia de la posmodernidad, es un modo de estar vinculado a un modo de sentir (<<cultura del sentimiento $>>){ }^{107}$;

c) la idea de devenir conduce a que la realidad social se perciba a través de una serie de fragmentos fortuitos, como un estado de flujo incesante, y a que sean los conceptos relacionales la interacción y la asociación- los que mejor definen esa realidad fluida. Así, los nuevos vínculos que se crean "no están basados en los contenidos (ideológicos, axiológicos, morales), sino en una forma de socialidad que se asienta en congregaciones inestables, comunidades informales vinculadas con un compartir el espacio, actividades al margen de la esfera laboral”. Comunidades emocionales conformadas sobre un nuevo tipo de relación en el que los individuos se proyectan más personalmente en actividades improductivas (Imbert, 2010:67; Maffesoli, 2004:471);

combatir y neutralizar (Bauman, 2007:57-60).

${ }^{107}$ La identidad se conforma en la continuidad, en la herencia de modelos: “el yo está determinado por el nacimiento, la formación, la cultura, la clase social,... y se transmite como tal a través de los aparatos de mediación social (familia, escuela, etc.). La identificación es "algo que no está sujeto a un contrato fijo, irreversible, que se puede revocar y sustituir en cualquier momento. La identificación está vinculada a las modas, al culto a las apariencias, a la necesidad de responder a la demanda del mercado, no sólo en términos económicos sino también de imagen, de rol, de acuerdo al contexto” (Imbert, 2010:67). 
d) la experiencia discontinua del espacio y del tiempo, que son relativos, exalta el presente, lo transitorio, lo efímero (Roche, 2005:26). A diferencia de las sociedades tradicionales, orientadas hacia el pasado, y las modernas, orientadas hacia el futuro, en las sociedades posmodernas prima el presente continuo, inmediato (presentismo);

e) así, la experiencia humana se manifiesta en la inmediatez de las relaciones sociales y percibe los acontecimientos como transitorios, fugaces y fortuitos: "El estar-junto no tiene la necesidad de darse una racionalidad lejana, la del progreso social o del paraíso celeste por venir, simplemente se vive el instante” (Maffesoli, 2004:477);

f) eliminada la verdad en la Modernidad sólo cabe, en la Posmodernidad, vivir en la duda. De ahí, que se huya del dogmatismo, del autoritarismo y del absolutismo, y se busque refugio en un relativismo epistemológico en el que todas las teorías son igualmente respetables;

g) la realidad misma es cuestionada en tanto que se desrealiza ${ }^{108}$-al transformar el valor de uso en valor de cambio, el ser queda reducido a valor de cambio-, se desmaterializa -al entrar la economía en una fase de ingravidez y desmaterializarse el dinero con las tarjetas de crédito y las operaciones a través del ordenador-, y se virtualiza -en la economía, cuando los mercados dejan sitio a las redes y el acceso sustituye cada vez más a la propiedad; en la ciencia y en la tecnología, cuando el universo es computable y se abandona la realidad física sustituyéndola por una realidad mental, abstracta, inmaterial y virtual (Roche, 2005:32-34), y; en la cultura, cuando, olvidado el valor de uso y generado el valor de cambio, se materializa la "cultura del simulacro" (Baudrillard).

Por todo ello, siendo la realidad algo que se construye socialmente, 'muertas' las grandes explicaciones sobre la misma, aplicada la reflexividad a todos los campos de la vida humana, teniendo constancia de que las culturas contemporáneas son culturas de riesgo, exacerbada la “cultura del individualismo en la que sólo vale una única vida vivida únicamente”, el individuo $<<$ hace su camino >>, creando y recreando sus pequeñas narrativas. Como señala Verdú (2003:267), la ausencia de autoridades (derivada de la secularización, el fin de las ideologías y la condición apátrida de la globalización) ha traído a los individuos de hoy un regalo paradójico: "la vida pasa a nuestras manos pero despojada de grandeza... Bajo nuestra posesión la vida, antes trascendente, se hace contingente, antes inasible, ahora se hace objeto rendido de nuestro arbitrio... La vida sacralizada pesaba como un muerto, mientras la nueva vida, desprendida de destino, es liviana como un filme. Parece de hecho, una película”.

\footnotetext{
${ }^{108}$ En su análisis del capitalismo de ficción, heredero del capitalismo de producción y del capitalismo de consumo, Verdú (2003:10-11) señala que mientras estos dos últimos se dedicaron a la producción de bienes, el primero, nacido en la década de 1990, pone el énfasis en la importancia teatral de las personas y por ello se encarga de satisfacer las sensaciones, el bienestar psíquico de las mismas: "la representación ha ganado la batalla y lo real se convalida por la realidad del espectáculo”.
} 
Entre las tácticas que permiten banalizar la muerte ${ }^{109}$, la más importante de todas ellas es la de hacerla presente continuamente, a diario, para que, como si se tratara de una vacuna, o de una medicina homeopática, los individuos se inmunicen contra el miedo a la muerte tras su contemplación continua. Saturación por reiteración que lleva a la insensibilización. Una forma de desdramatizar y exorcizar su aterradora presencia sobrecargando el significante para eludir el significado $^{110}$ (Artieda, 1979:67), lo que transforma a la vida en un ensayo perpetuo de la muerte (Bauman, 2007:60). Una forma de acostumbrarse a convivir con ella que tiene una funcionalidad similar a la que en las sociedades tradicionales rurales tenía la contemplación de la muerte de los animales: socializa en el enfrentamiento a la misma devaluando el terror que provoca. Trivialización de la muerte, a través de su continua repetición, que la vulgariza y elimina su carácter sacro por pérdida de misterio, la hace comercial y producto de consumo, como bien cultural, para exorcizarla, expurgándola de su carga simbólica, y transformarla en algo inofensivo (Imbert, 2004:126-127).

Obviamente, además de a la inflación de muerte presente en los medios de comunicación de masas ${ }^{111}$, esas muertes continuas a las que se enfrentan ahora los individuos no constituyen experiencias de la muerte en <<primer grado>>, las de la muerte física de un otro próximo, las únicas accesibles a los seres humanos, sino que tienen un carácter metafórico, es decir, lo son por delegación, muertes de <<segundo grado>>: todas aquellas rupturas de vínculos interhumanos pequeñas muertes- de todo tipo a las que los individuos se enfrentan en su rutina diaria en la construcción/reconstrucción de su <<vida propia>> y que también tienen el sello de lo $<<$ definitivo $>>{ }^{112}$. Bauman achaca la banalización de la muerte a la repetición "hasta el infinito" de estos simulacros de muerte. Simulacros que tienen su caldo de cultivo en las relaciones livianas, “frágiles y provisionales,... (siempre) sencillas de deshacer a voluntad” propias de la modernidad líquida, que se inician y se acaban en ciclos continuos de $<<$ muerte-renacimiento-

\footnotetext{
109 También presente con la estrategia de deconstrucción de la mortalidad, otra de las tácticas, de los “<<caramelos>>", que alivian los temores a la muerte en la modernidad líquida es la de "las nuevas afirmaciones sobre la extensión de la vida biológica (que) enlazan con los antiguos sueños de inmortalidad” (Aguiluz Ibargüen, 2009:306). En el Capítulo 4 de esta Tesis se aborda el análisis de las posiciones contrapuestas existentes sobre las posibilidades reales de tal extensión de la vida humana.

110 "De tanto representar el objeto, se ha perdido conciencia de lo que es el hecho: algo palpitante, fisiológico y, al mismo tiempo, inconcebible, que infunde respeto -es su cariz sagrado-, algo que remite a la cara incontrolable, indecible del poder vivir” (Imbert, 2004:120).

${ }^{111}$ Siguiendo a Bauman, Mellor y Shilling (1993:425) resaltan que las miles de muertes que la gente ve a lo largo de su vida a través de TV, lejos de ser percibidas como una amenaza tienen un efecto tranquilizador. Por un lado, porque son muertes individuales, con causas individuales, es decir, porque por la fragmentación de la muerte anima a tener una visión de la muerte como algo contingente y evitable. Por otro lado, y derivado de lo anterior, porque orientan a la gente a desarrollar estrategias de supervivencia preventivas.

${ }_{112}$ Bauman (2007:63-66) reconoce, no obstante, que en este caso el sello de "definitivo" no es absoluto porque, a diferencia de una muerte real, la relación puede de nuevo renacer y ser recreada, de ahí que la denomine muerte en $<<$ segundo grado $>>$. En este caso, además, el miedo a la muerte metafórica equivale al horror a ser excluido.
} 
muerte>>. Muertes metafóricas que, al no ser irrevocables, incorporan la muerte al flujo de la vida como una parte de ella: banalización por la que "la bestia salvaje deviene una mascota doméstica” (Bauman, 2007:65-66).

Siguiendo el discurso de Bauman, cabría añadir una muerte de $<<$ tercer grado $>>$, la de las relaciones que se mantienen con los objetos. Objetos que el desarrollo de la sociedad de consumo de masas ha hecho más fácilmente accesibles, también los objetos que hasta hace poco eran imposibles de adquirir por la mayoría de la población, y que, mediante "la cultura de las tarjetas de crédito, que han reemplazado a las cuentas de ahorros”, y como si de un milagro se tratara, se pueden traer de un futuro incierto al presente. Rompiendo con ello la noción de tiempo de vida lineal e incorporando la del giro, la de la 'retroalimentación en bucle'. Objetos que, como además llevan incorporada su obsolescencia, no sólo no logran retener los afectos de quienes los poseen, por lo que son fácilmente sustituibles, sino que como no merece la pena que sean reparados, cuando se estropean, se rompen o “están out” van a parar directamente a la cadena del reciclado continuo ${ }^{113}$. Lo que por otra parte es alentado por el sistema de producción con el cambio continuo de modas ${ }^{114}$ (Bauman, 2001:275-277). Así, devenidos esencialmente en consumidores, los individuos consumen relaciones, consumen 'experiencias', consumen productos, todo ello con principio y final integrado, por lo que asisten cotidianamente como espectadores al espectáculo continuo de la muerte propiciada por los medios de comunicación y viven como protagonistas de relatos diarios de muerte. Muerte de $<<$ tercer grado $>>$ que refuerza la banalización de la muerte.

Elias (1987:66-74) recuerda que la imagen que los individuos tienen de la muerte está estrechamente vinculada a la que tienen de sí mismos, a la "del hombre en general, que prevalece en la sociedad en la cual vive”. Dado que, según este autor, en las sociedades desarrolladas los individuos se entienden a sí mismos como seres independientes, “como mónadas sin ventana alguna”, como <<sujetos>> aislados separados del resto de sus congéneres (el <<mundo externo >>) por un muro invisible, son incapaces por ello de crear sentido porque éste sólo es posible como construcción social. Así, este homo clausus que cree vivir como un ser aislado y carente de sentido, morirá también como tal. A ese aislamiento vital hay que sumarle, además, el

\footnotetext{
${ }^{113}$ En una línea similar se expresa Verdú (2003:246): "No asistimos, prácticamente nunca, a las muertes de las cosas, sino tan sólo a su reemplazo... No los arrumbamos (a los objetos) siquiera porque hayan envejecido; sólo quedan obsoletos. Como consecuencia de esta repetida experiencia, la vida se encuentra cada vez menos relacionada con la extinción”.

${ }^{114}$ Los estudios de sociología del cuerpo muestran la importancia simbólica que éste ha alcanzado en las sociedades de consumo actuales, hasta llegar al denominado "culto al cuerpo". Cultura del cuerpo por la que muchas personas buscan expresar su identidad a través de su cuerpo, aunque en algunos casos las prácticas desarrolladas para ello entrañen graves riesgos. Preocupación por el cuerpo que, para Mellor y Shilling (1993), constituye un elemento básico a la hora de analizar el enfrentamiento a la muerte en la modernidad tardía.
} 
que las infinitas posibilidades que se abren ante los individuos en los diversos escenarios en los que construyen su <<vida propia >> les permiten desarrollar un gran abanico de estrategias particulares de afrontamiento de la muerte. Diversidad de opciones que, sin embargo, acaba agrandando el problema ya que, "al no conseguir una forma de actuación globalmente aceptada”, refuerza la incertidumbre y provoca más ansiedad existencial y menos seguridad ontológica: ya que todo vale, nada vale (Basterra, 2006:38; Mellor, 1996).

Si no para evitarlo, y sí para mitigarlo en la medida de lo posible, cualquiera de las tres estrategias ante la muerte señaladas son utilizadas hoy. De hecho, la eliminación de la muerte a través de la negación, el secuestro o la banalización, son una condición aún más necesaria, según Basterra (2006), para la “afirmación hedonista” del individuo tipo -“personalidad narcisista” de unas sociedades posmodernas caracterizadas por su exaltación del individuo, la juventud y el culto al cuerpo. Sociedades en las que priman los "valores materialistas, consumistas, hedonistas, narcisistas, permisivos, de relativismo moral y cultura del instante”, además de una amplia confianza en la tecnología como elemento de poder y de protección humana. La asunción de estos valores avala la hiperexaltación de la vida (del yo como sagrado e `inmortal') y exige, a la vez que refuerza, la eliminación social de la muerte, ya que no hay nada que distorsione e impida más "el hedonismo y el consumo de masas por parte de unas individualidades narcisificadas" que la presencia de la muerte (Basterra, 2006:31-36). Muerte inevitable transformada también en un objeto de consumo masivo, pero dietético, para facilitar su digestión entre la población ${ }^{116}$. La banalización de la muerte favorece el desarrollo de una perspectiva desdramatizada de la misma y, por tanto, la posibilidad de su “comercialización”, lo que a su vez refuerza la propia negación de la muerte. Se establece así una “concausalidad recíproca” que refuerza a la vez la negación de la muerte y su propia comercialización. "Este mecanismo permite la presencia de una muerte banalizada y desnaturalizada en los distintos discursos sociales. Es en realidad una <<no muerte>> discursiva y socialmente” (Basterra, 2006:45).

\footnotetext{
115 "La personalidad narcisista busca cerrarse sobre sí misma fuera de los miedos de la muerte a través de su rechazo e incapacidad para formar relaciones profundas y duraderas con los otros. Cuando no se han formado grandes apegos y uniones a otros, las pérdidas experimentadas no pueden ser grandes” (Mellor y Shilling, 1993:419).

${ }^{116}$ En una replicación de un estudio sobre el $<<$ canon de la muerte $>>$ realizada 10 años antes, al que se hace referencia en el Capítulo 5 de esta Tesis, Marí-Klose et al (2004) interrogaron a un grupo de estudiantes de Sociología sobre cómo les gustaría morir. Si bien en los aspectos esenciales de la percepción de lo que es una "buena muerte" (indolora, rápida, inconsciente, en casa, en la vejez, acompañada), no encontraron diferencias importantes con las personas entrevistadas una década antes, sí que observaron un "tránsito generacional” en la transformación del discurso sobre lo que se consideraba lo deseable o lo indeseable. Para la "generación líquida" entrevistada la muerte, al igual que el amor, es algo líquido. En el cruce de ambos, por ejemplo, algunos varones entrevistados manifestaron que deseaban morir haciendo el amor. Otros de ellos, mientras el Barça mete un gol (Basterra, 2006:263).
} 
Admitiendo que la trivialización de la muerte es la nueva estrategia de expulsión de la misma nacida a finales del siglo pasado y característica de las sociedades posmodernas, Imbert (2004) y Verdú (2003), sin embargo, fijan su mirada en el desarrollo de otras tácticas diferentes a la señalada dentro de esa misma estrategia. En efecto, en sus interesantes análisis sobre la “cultura de lo extremo", el primero enfocando su mirada en tres formas de conductas violentas desarrolladas fundamentalmente por algunos grupos de jóvenes (los rituales festivos vinculados a la cultura bakaladera, los conductores-kamikaze y la violencia de los skinheads) y la representación que hacen los mass media de ellas ${ }^{117}$, el segundo examinando la práctica de deportes de alto riesgo ( $X$-treme), plantean que, aunque minoritarios en número, las actitudes de quienes desarrollan esas conductas, con su búsqueda de llegar al límite incluso rozando la muerte, constituyen otras manifestaciones dentro de la estrategia de banalización de la muerte. Actitudes que en estos casos no devalúan la muerte para así poder consumir sólo vida, sino que, al contrario, la tienen siempre virtualmente presente y, situándose en el borde del precipicio, flirtean constantemente con ella, con la desaparición de la vida, porque así ésta cobra "Valor” de verdad al fortalecerse la verificación de que se existe, de que se domina la situación. Una especie de “test de estar vivo a través del vértigo de morir”. Un fantasma de muerte con el que se coquetea para, "paradójicamente, mantener a raya el miedo, familiarizándose con el objeto de angustia, dándole un rostro". Actitudes que ambos reconocen que traducen un profundo malestar dentro de la cultura actual ${ }^{118}$.

Cuando, disueltas las certezas y alejados de la realidad, lo importante para algunos individuos es el devenir, el presentismo, en el que crean y recrean sus pequeñas narrativas, pero no encuentran límites en los que construir una identidad sólida, sino múltiples identificaciones líquidas, aquéllos pueden correr el riesgo de disolverse y perderse. Horror al vacío que puede transmutarse en comportamientos que son su reverso, "como en un acto de conjuro, consistente en responder a la carencia por el exceso” (Imbert, 2010:177). Así, para este autor las conductas que analiza son conductas de riesgo improductivas que en su provocación buscan transmitir "una no aceptación del sentido social”, un desafío a la Ley: “desafío a la Ley social (económica), desafío a los límites (al poder-hacer social), pero también a la Ley en sentido simbólico, al orden

\footnotetext{
${ }^{117}$ Actitudes violentas que se reflejan en los medios de comunicación contribuyendo a "inastaurar un imaginario en torno a la muerte tanto en el discurso informativo como en la ficción (en particular en el cine), fomentando una verdadera estética de la violencia, que traduce un malestar ante la muerte..., como una manera de adelantarse a ella en representación” (Imbert, 2010:23).

${ }^{118}$ Según Imbert (2004:17) “un mal-estar que procede en gran parte, en términos socioeconómicos, de una incertidumbre hacia el futuro y que, en términos simbólicos, traduce un déficit de identidad, un no sentirse en su sitio; ese malestar se plasma en un repliegue masivo hacia el momento presente (presenteísmo), un vivir al día -una filosofía del <<que me quiten lo bailao >>- que explica esta tendencia a lo efímero pero también una nueva fascinación por la aventura, por todo cuanto permite evadirse del tiempo,..., (entendida la aventura) como un objeto concreto, objetivado,..., que se sitúa en el tiempo vivencial más inmediato; un
} 
de las cosas, al poder ser/no ser, a la vida y a la muerte, manifestando así una tentación de suicidio $^{119 ”, ~(I m b e r t, ~ 2004: 156) . ~ P o r ~ s u ~ p a r t e, ~ V e r d u ́ ~(2003: 251-261), ~ a p o y a ́ n d o s e ~ e n ~ l a ~ p r e s e n c i a ~}$ generalizada de la muerte simbólica a comienzos del siglo XXI, extiende metafóricamente a todos los individuos posmodernos las actitudes de los deportistas de $X$-Treme: "El miedo se une a la cotidianidad y así la cotidianidad adquiere formas de aventura extrema: el miedo a la inseguridad, el miedo bursátil, el miedo a los virus,... el miedo al otro. El pánico ha dejado de ser una emoción reservada a los márgenes y se ha instalado en el centro del sistema... Vivir con miedo, inciertamente, es de carácter posmoderno, y cuanto más amenaza se sienta mayor sensación de vida se recibe”.

\subsection{3. ¿ES LA MUERTE UN TABÚ EN LAS SOCIEDADES CONTEMPORÁNEAS?}

“La muerte me llevó a meditar sobre la vida. Pero ¿qué vida? Me dije que ya
empezaba a ser hora, en una época tan confusa como la nuestra, de
preguntarse qué era lo que realmente entendíamos por vida, es decir, de
preguntarnos de qué hablábamos cuando hablábamos de ella y si no
estábamos en el fondo hablando siempre de la muerte. Seguramente habría
que empezar a matizar la definición de experiencia... Yo también tenía un
recuerdo algo lejano, más bien confuso, de ella. ¿Quién vivía en total
plenitud? ¿Vivía alguien? Y, por cierto, ¿qué clase de vida llevaba la vida?”

El Diccionario de la Lengua Española asimila la palabra tabú a "lo prohibido”, y en su primera acepción lo define como la "condición de las personas, instituciones y cosas a las que no es lícito censurar o mencionar”. Como se ha señalado al exponer los sucesivos modelos de muerte de Ariès, este autor afirma la emergencia en el siglo XIX de un nuevo modelo de actitudes frente a la muerte al que denomina Muerte Invertida. Modelo que se consolida a lo largo del siglo XX y que básicamente está caracterizado por la negación individual y colectiva de la muerte, que deja de ser fuente de experiencias (de sentido) personales y sociales para transformarse en algo vergonzante (modelo tabú). Becker (2003) extiende el alcance de ese modelo a todo tiempo y lugar al argumentar que la negación de la muerte no es una condición sólo moderna, sino que es una condición humana y que, por tanto, todas las sociedades funcionan bajo la premisa de la negación de la muerte. Asimismo, y como también se ha señalado, los cambios estructurales y culturales del proceso de modernización han llevado a que otros muchos científicos sociales asuman en sus análisis el modelo tabú de la muerte (Basterra, 2006; De Miguel, 1995; Elias, 1987; Baudrillard, 1980; Illich, 1975; Gorer, 1965). Basterra (2006:33) matiza que esta negación

tiempo que nos aleja del tiempo social, mediatizado por los ritos y haceres colectivos, y en el que la aventura se vuelve un objeto más de consumo".

${ }^{119}$ Tentación de suicidio que Imbert (2004:120) no equipara a literalmente a un querer morir, sino a "una tentación de muerte, algo sin formular que es más del orden de la representación -la muerte como algo 
social de la muerte no implica que la misma no sea tratada científicamente o no forme parte de la cotidianeidad discursiva. Significa que no forma parte del espacio público tejido por el patrimonio valorativo y de significación de las sociedades contemporáneas en la misma medida que pueda estarlo la vida. De hecho, se asiste desde hace unas décadas a la proliferación de bibliografía académica sobre la muerte y el morir, aunque no en el ámbito de la sociología, junto con la multiplicación de artículos periodísticos relacionados de alguna forma con ella, además de la inflación de muerte contenida en imágenes, canciones, representaciones, etc., en todos los massmedia. Situación paradójica que ha llevado a Mellor (1993:11) a advertir que el análisis sociológico de la muerte debe "reflejar, e intentar explicar, la aparente contradicción que supone la ausencia y la presencia de la muerte en la sociedad contemporánea”. Por ello, cabe preguntarse si efectivamente en esas sociedades la muerte sigue siendo un tabú o no, y si lo es, en qué sentido.

En su análisis de síntesis sobre esta cuestión realizado a principios de la década de 1990, Walter (1991) abordaba esa contradicción para el caso del Reino Unido, contradicción extensible también a España. Aunque desde entonces se han acelerado los cambios estructurales y culturales referidos en el sub-apartado anterior, que han aumentado la incertidumbre (inseguridad ontológica) de los individuos, el diagnóstico y las conclusiones recogidos en dicho análisis no han perdido vigencia, más bien todo lo contrario. En esencia, Walter plantea varias modificaciones y críticas a considerar en el modelo tabú de muerte porque en la actualidad éste no debería ser contemplado como un todo absoluto y cerrado. Con el objetivo de responder al interrogante planteado sobre la vigencia o no del tabú de la muerte, a continuación se reelaboran algunas de las sugerencias realizadas por Walter:

a) hubo efectivamente un tabú de la muerte entre las clases medias durante buena parte del siglo XX, pero ese tabú se fue desintegrando a partir de la década de 1960, con la emergencia de los movimientos contraculturales y su reivindicación de una mayor expresión de los sentimientos y de disipación de las represiones. Actitudes que enlazan con el movimiento reivindicador de la muerte del modelo neo-moderno;

b) el que no exista un tabú de la muerte entre la población en general no implica que no pueda existir entre algunas categorías sociales concretas. Walter resalta en este sentido que, paradójicamente, la muerte puede ser un tabú entre algunos grupos ocupacionales que tienen mucho contacto con ella. Es el caso del personal médico cuyos miembros, sometidos a fuerte estrés y ansiedad en su lucha contra la muerte, pueden percibirla como un fracaso profesional y por ello (de)negarla;

posible, que está ahí sin que necesariamente ocurra- o que es del ámbito de lo virtual, que se manifiesta en 
c) los sistemas sociales contemporáneos deben tanto aceptar la muerte como negarla. Aceptarla, para que sus miembros confronten y asuman el principio de realidad mientras construyen sus vidas; negarla, para facilitar que aquéllos afronten sus "negocios diarios” con algún sentido de compromiso. Paradoja que confunde a los individuos que, al no tener un esquema ritual coherente para enfrentarla, acaban considerando que no tiene sentido social y la perciben simplemente como si de un juego de experiencias personales se tratara. Pura incertidumbre a afrontar en solitario.

d) los cambios demográficos, que han provocado una notable reducción de las probabilidades de fallecer y la elevación de la esperanza de vida, han permitido a la mayoría de los individuos culminar un ciclo de vida dilatado por lo que, en caso de fallecimiento, el nivel de desolación y el ‘hueco socioeconómico' dejado para los sobrevivientes del grupo son menores que en etapas anteriores. Así, la muerte habría perdido importancia en la vida cotidiana, y la mayoría de la gente, excepto los de "los círculos teológicos", cuando hablan sobre ella concentran en gran medida su preocupación más en la enfermedad que en la muerte misma (Giddens, 1997). Por ello, autores como Loriaux (1995a) y Blauner (1966) sostienen que son los factores estructurales, y fundamentalmente las estructuras demográficas, los responsables esenciales de la relación de las sociedades humanas con la vida y con la muerte y de que, en consecuencia, en las sociedades desarrolladas la muerte no sea un tabú, sino que simplemente está “escondida” del espacio público general. Siguiendo esta misma línea de argumentación, Walter (1994:185) afirma que no cabe seguir manteniendo "la pretensión moderna de que la muerte no existe" cuando, por ejemplo, fruto del creciente envejecimiento de la población, cada día aumenta el número de personas que viven con su vida amenazada por ella.

e) estrechamente vinculado con lo anterior, el proceso de medicalización de la muerte y la hospitalización de las personas moribundas han ayudado a extender entre la población la percepción de que la muerte no es tanto un tabú, sino que está recluida en centros especializados. De hecho, ya en el año 1978, T. Parsons planteó límites a la tesis sociológica de la negación de la muerte relacionándolos con el proceso de medicalización de ésta. Concretamente, afirmó que el esfuerzo por parte de las sociedades modernas para controlar las muertes prematuras, evitar las muertes con violencia, o reducir los sufrimientos conexos al morir es incompatible con la negación de la muerte (Seale, 1998:54). En este mismo sentido se manifiesta Giddens al señalar a la medicalización de la muerte como responsable del secuestro de ésta, al pasar a manos de profesionales y transformarla en un asunto técnico de su competencia. Es decir, la ciencia, la tecnología y la especialización juegan un papel esencial en lo que Giddens (1997:cap.5)

forma de riesgo, como potencialidad". 
denomina "experiencia secuestrada" "120. Ésta básicamente consiste en la separación de la vida cotidiana del contacto con experiencias que plantean cuestiones existenciales potencialmente perturbadoras (en especial, experiencias relacionadas con la enfermedad, la locura, la criminalidad, la sexualidad y la muerte). Para muchas personas el `secuestro de la experiencia' implica que su "contacto directo con acontecimientos y situaciones que vinculan la vida individual a cuestiones más amplias de moral y finitud sea escaso y fugaz”. Percepción que está modificándose con la emergencia de las actitudes reivindicadoras de la muerte del modelo neomoderno, orientadas siempre en sentido contrario a cualquier posibilidad de retomar o reforzar el tabú, y también a ’liberarse’ del secuestro de la experiencia.

f) los estudios antropológicos muestran que ante la pregunta de si la muerte es una amenaza para el individuo o para la comunidad, la respuesta depende del tipo de sociedad de que se trate. En las sociedades tradicionales, la amenaza es para el grupo y no tanto para el individuo, mientras que en las modernas ocurre lo contrario, la amenaza es para el individuo pero no para la sociedad.

Estas matizaciones al modelo tabú de la muerte han llevado a otros autores a resaltar la conveniencia de diferenciar en este tema los procesos sociales de los psicológicos (Seale, 1998; Mellor, 1993). En el primero de esos ámbitos, las transformaciones estructurales acaecidas desde el último tercio del siglo XX han provocado mutaciones en las respuestas culturales a la muerte que hacen que en las sociedades contemporáneas sea más apropiado hablar de muerte escondida, ocultada a la vista, en la distancia, que de, propiamente, una negación de la muerte (modelo muerte secuestrada) (Seale, 1998). Si en las sociedades modernas la negación simbólica de la muerte estuvo inducida por las necesidades de la propia lógica del sistema, para que los individuos no pensaran en ella y pudieran concentrarse en ser productivos en la vida (Baudrillard), en las sociedades contemporáneas esa negación responde a una nueva lógica. Ahora, el poder de la sociedad no se manifiesta a través de "maquinarias de control social”, sino en su representación de lo que es real, en su habilidad para “constituir e imponerse como realidad” (Mellor, 1993:14).

\footnotetext{
${ }^{120}$ Giddens resalta como factor determinante en este sentido la creación de un "tiempo de vida internamente referencial". Tiempo de vida que: a) "surge como un segmento de tiempo, distinto del ciclo de vida de las generaciones". De hecho, la ruptura de lazos entre la vida de los individuos y el intercambio de generaciones hace que la idea de $<<$ ciclo de vida $>>$ tenga cada vez menos sentido en la época moderna. Las connotaciones de renovación, asumidas en las sociedades tradicionales, se pierden en la modernidad, "donde las prácticas se repiten sólo en la medida en que sean reflejamente justificables"; b) "se separa de la exterioridad del lugar en tanto que éste es socavado por la expansión de los mecanismos de desenclave”. El aumento de la movilidad permite la recombinación de las actividades locales en relaciones espaciotemporales de ámbitos cada vez más amplios; c) "se libera cada vez más de las referencias externas asociadas a los lazos preestablecidos con otros individuos y grupos". Las ataduras y referentes externos (de lugar, de parentesco) en las vidas de las personas de las sociedades premodernas hoy aparecen difusas, cuando no inexistentes. Esto hace que los individuos concentren todo su tiempo de vida en sí mismos, en sus planes y proyectos; d) "se estructura en torno a <<umbrales de experiencia inciertos >>, más que alrededor de situaciones de paso ritualizadas". El abandono de ritos de tránsito priva a los individuos de apoyo psicológico para superar las principales transiciones de la vida, entre ellas la de la muerte.
} 
Manifestación materializada verbalmente por ejemplo en el mantra contemporáneo $<<$ Esto es lo que hay >>, que inunda transversalmente todos los estratos sociales como expresión de su impotencia para la acción e identificación mental forzosa con la situación social que se vive. En este sentido, el proceso de individualización reseñado arriba ha sido clave al garantizar la predisposición total de los individuos para estar siempre listos cuando se les requiera. Identificación absoluta por la que buena parte de los individuos de las sociedades contemporáneas se han convertido, metafóricamente, en hologramas sociales ${ }^{121}$ : "no mimetizan el todo social, sino que lo constituyen: del mismo modo que el genotipo de un organismo no es una "copia" de su fenotipo, sino su "original", las conciencias de los sujetos individuales no son imitaciones en miniatura de lo que a fin de cuentas es su producto emergente -el "orden social"-, sino causa del mismo" (Navarro, 1997). Por ello, el declive de los valores colectivos, conexo al desarrollo del proceso de individualización, ha desembocado finalmente en la privatización y subjetivación de la experiencia social, de los significados, que están profundamente insertadas en los mecanismos de construcción de las identidades del yo en la modernidad tardía (Mellor, 1993:12).

En lo relativo al enfrentamiento a la muerte, vacía ya de contenido social y eximido el ámbito público de cualquier responsabilidad al respecto, propiamente desde éste no existe interés especial en utilizarla para controlar a la población, por tanto en negarla, aunque sí en recluirla en aquellos espacios públicos donde por intermediación médica pueda ser 'tratada'. En todo caso, y en correspondencia con la nueva lógica, la muerte abandona el ámbito de lo colectivo y queda recluida en el ámbito privado. Así, la muerte aparece como algo propio de los individuos, y son éstos los que tienen que enfrentarse en solitario a ella. Ciertamente se trata también de un tipo de negación social de la muerte, pero no lo es por prohibición (tabú), sino por inhibición y derivación social.

Respecto a los procesos psicológicos, la privatización y subjetivación de los significados torna crecientemente frágil la seguridad ontológica de los individuos, por lo que el abandono del espacio público para quedar forzosamente "secuestrada" en el privado transforma a la muerte en una amenaza intensa y constante para ellos. Esta es la razón por la que Seale (1998), Walter (1993, 1991) y Mellor (1993) consideran innegable, e inevitable, la denegación individual de la muerte como una renuncia necesaria (voluntaria o inconsciente) para el mantenimiento de la seguridad ontológica y para la construcción de un proyecto vital viable. En mucha mayor medida en la actualidad cuando son los propios individuos los únicos responsables de construir su $<<$ vida

121 El modelo de organización holográfico es una forma de organización en la que "las partes que componen una determinada realidad contienen información acerca de la totalidad de la misma y, por ello, son en cierto modo capaces de constituir tal realidad autónomamente, cada una por su cuenta” (Navarro, 1997). 
propia >> y cuando, sin oposición social de ningún tipo, el potencial anómico de la muerte alcanza hasta el fondo de las íntimas profundidades de la identidad de la gente (Mellor, 1993:14). Así, el desplazamiento del enfrentamiento a la muerte exclusivamente al ámbito privado en las sociedades contemporáneas ha reforzado la denegación de la misma por parte de los individuos al quedar ésta reducida al "final completamente privado de ese negocio completamente privado llamado vida” (Bauman, 1992:130). Interiorización del control social que, paradójicamente, impide interiorizar la muerte por ser ésta el final del proyecto reflexivo, el final de la realidad. Límite difícil de aceptar para las personas que están próximos a ella, algunas de las cuales no obstante siguen sin querer asumir su inminencia (denegación por horror). Frontera más o menos difusa para quienes están lejanos a ella, de la que si no es imprescindible y/o inevitable prefieren no saber, hablar, preparar el viaje para atravesarla, ni contactar con los que están próximos a traspasarla, o bien para así centrarse en la vida (denegación moderna), o bien para repudiarla absolutamente porque significa la muerte del yo único e `inmortal’ (denegación por narcisismo), o bien porque intentan exorcizarla consumiéndola virtualmente, incluso compulsivamente, como si con espíritu indomable se la quisiera decir `me vas a acabar ganando, pero antes te voy a ganar yo todas las veces que pueda' (denegación por aventura).

En el ámbito de la historiografía también se han planteado dudas sobre la vigencia del modelo tabú. Así, por ejemplo, Vovelle (1985:45-46) se muestra crítico con la identificación de la muerte como tabú en la caracterización que Ariès hace de la misma durante el siglo XX. Admitiendo los temores que la muerte provoca en una época definida por el creciente individualismo, manifiesta con cierta ironía su desacuerdo con esa caracterización y la relaciona con la parcialidad de la mirada de Ariès y el hecho de que no incluya en sus análisis la totalidad de los discursos presentes en cada momento. Como contraste, resalta la evidencia empírica de que en “compensación catártica a la consigna del silencio (surgida en las sociedades anglosajonas para extenderse por todo Occidente) se ha podido analizar... la omnipresencia de una producción y de una creación de la fantasía alrededor de la muerte, expandida por todos los medios de difusión” durante el siglo XX. Por ello, para analizar el discurso contemporáneo sobre la muerte, Vovelle (1985:111) recomienda utilizar todos los recursos aportados por los mass-media (canciones, televisión, cine, radio, cómic, publicidad, fotonovelas, novelas por entregas, etc.), ya que la multiplicidad de discursos que se transmiten a través de ellos "hacen estallar el marco tradicional dentro del que hasta entonces se había expresado lo imaginario colectivo”.

En este sentido, además de los citados de Imbert (2004) y Verdú (2003), más recientemente se han publicado otros trabajos sociológicos que analizan el tema de la muerte en la línea propuesta por Vovelle y que, efectivamente, muestran que al menos en el ámbito público no existe una prohibición, una ocultación, una negación social de la misma, sino más bien todo lo 
contrario, una proliferación de representaciones de todo tipo sobre la muerte en los mass-media que cuestiona el carácter de tabú que se la atribuye. Trabajos que, junto con los desarrollados desde la Sociología de la Población (Demografía), la Sociología de la Vejez, la Sociología de la Salud, la Sociología del Cuerpo y la Sociología de la Religión ${ }^{122}$, contribuyen a incrementar la escasa $^{123}$ bibliografía española sobre sociología de la muerte. Entre esos trabajos recientes, cabe citar los de Gil Villa (2011) e Imbert (2010), quienes analizan la presentación/representación de la muerte en series de TV, películas ${ }^{124}$, Internet y exposiciones `artísticas` de cuerpos humanos ${ }^{125}$.

En su análisis de la sociedad informe ${ }^{126}$, Imbert (2010:183) resalta como característica central de la misma la necesidad posmoderna de la transparencia total, que afecta a todo, sean objetos o relaciones, y que determina la relación con la realidad produciendo un "cambio axiológico en los valores y principios que regían hasta ahora nuestra representación del mundo y del otro". Derivada de esta <<hipervisibilidad >>, en la que se difuminan las fronteras entre lo público y lo privado, "en la que el dentro y el afuera se confunden”, el escenario público se ha ampliado hasta recoger entre las representaciones sociales que se realizan en el mismo aquellas anteriormente excluidas del discurso público (entre ellas la muerte), que eran "objeto de una actitud reverencial” por su vinculación con lo sagrado. Mirada <<panescópica >> por la que "hoy el intercambio simbólico ha muerto y le sustituye un intercambio icónico, en el que la formaimagen -la iconización de todo- prima sobre los contenidos y fagocita el sentido” (Imbert, 2010:18). En definitiva, banalización de la muerte que Imbert ejemplifica con la transmutación del derecho a saber, el sueño de la transparencia total, en mirada pornográfica que, a pesar del horror que se siente ante el límite supremo, lo quiere ver absolutamente todo con el objetivo de domesticarla. Pornografía del horror alentada por series de TV, películas, vídeos en Internet, o

\footnotetext{
${ }^{122}$ En el Capítulo 2 de esta Tesis se han mencionado las aportaciones recientes en el campo de la Sociología de la Religión; en el Capítulo 4 se menciona la bibliografía española sobre las otras cuatro especialidades reconocidas por la Asociación Internacional de la Sociología.

${ }^{123}$ Escasa sobre todo si se compara con la proliferación de bibliografía proveniente de la Psicología, como se puede comprobar con la muestra de títulos recientes incluidos en la nota a pie $\mathrm{n}^{\circ} 52$ de este Capítulo.

${ }^{124}$ Recientemente Cortina y De la Herrán (2011) ha publicado el interesante texto Pedagogía de la Muerte a través del cine, en el mismo se incluyen numerosas fichas, por niveles educativos, sobre películas en las que directa o indirectamente se trata el tema de la muerte; asimismo, se sugieren orientaciones para la discusión y se incluyen guías para ser trabajadas en clase con el alumnado. Este proyecto es continuador de otro anterior (De la Herrán y Cortina, 2006) con los que se persigue incrementar la formación del profesorado en "Educación para la Muerte".

${ }^{125}$ Un análisis sobre la utilización de cadáveres en las prácticas artísticas contemporáneas puede verse en (Benavente Farías, 2005).

${ }^{126}$ Imbert (2010:10-12) denomina a la sociedad actual la sociedad informe, y la describe como "una sociedad que ha perdido el sentido de los límites, la conciencia de los fines y se vuelca en los imaginarios". Según este autor, las dimensiones de las relaciones sociales que caracterizan a la posmodernidad (crisis de los grandes relatos, distanciamiento de la realidad, etc.), mencionadas más arriba, conllevan que se difuminen los límites entre las grandes categorías simbólicas y se llegue a lo informe: "Lo informe es eso, no sólo la degradación de las formas sociales, sino también la búsqueda de formas nuevas: el intento de construir -o deconstruir- la propia identidad, de relacionarse con el otro, con su propio cuerpo, de
} 
cadáveres plastificados en exposiciones 'artísticas', que han situado a la muerte como tema central y "objeto de una mirada frontal que rompe con el tabú sobre su representación, en especial el que pesa sobre la profanación de la sepultura, la visibilización del proceso necrológico y la <<integridad>> del cadáver”. Transparencia del mal (Baudrillard, 1991) que contamina la representación de la realidad provocando no sólo efectos deshumanizadores, al fragmentar el cuerpo negando con ello la unidad del sujeto, sino que, al utilizar al cadáver como materia narrativa al que se le aplican técnicas científicas avanzadas que permiten adentrarse hasta lo más profundo de él, se le transforma en una mera pieza de un puzzle 'policiaco-científico' por resolver, llegándose con ello hasta la "anulación simbólica del objeto: el cadáver ya no significa nada en términos humanos”. Cosificación que puede llegar hasta la inserción de bromas entre los forenses cuando realizan su tarea de despiece ${ }^{127}$ (Imbert, 2010:110).

Cosificación que, aplicada a seres humanos vivos, es como la que los terroristas utilizan con sus víctimas despojándolas previamente de su humanidad para así poder arrebatarles después sus vidas con indiferencia o con desprecio. Cosificación que, en este mismo orden de cosas, es como la que preside las violaciones, torturas, asesinatos, no ficticios sino reales registrados en los vídeos snuff que proliferan en Internet desde el inicio de este milenio, tal como ha analizado $\mathrm{M}$. Marzano (2010). Deshumanización y desprecio con que miles de espectadores ${ }^{128}$ miran diariamente esos vídeos con indiferencia, o placer, justificándose en la sacralización del $<<$ derecho de ver y de saber $>$, y de que la gente quiere informarse viendo de forma integral y sin intermediación la <<realidad >>, aunque sea macabra (Marzano, 2010:99). Ausencia de pudor, repugnancia y compasión ${ }^{129}$ con la que se conforma una "sociedad de la indiferencia” en la que la muerte se convierte en espectáculo.

replantear el enfoque de objetos complejos -de representación saturada- como el sexo, la violencia, la muerte, de sondear en los abismos sin fondo del horror, para volver a la vida más lúcido y fuerte...”.

${ }^{127}$ Análisis que vale para la mayoría de las series de televisión centradas en hospitales y también para las policíacas que durante la última década han proliferado, con múltiples versiones, en las que el trabajo del personal forense en la sala de autopsias es un elemento clave de la trama. Como contrapunto narrativo a todas estas series, Imbert (2010:111-112) destaca el enfoque de la serie A dos metros bajo tierra en la que la familia protagonista, los Fisher, gestionan un Funeral home situado en el mismo edificio donde tienen su hogar. Imbert destaca la porosidad total entre la vida y la muerte y cómo en este caso se ha domesticado a ésta haciéndola formar parte precisamente del ámbito doméstico. Así, "los muertos ya no dicen nada, no estorban, se han integrado como objetos a la economía doméstica y a la industria funeraria”.

${ }^{128}$ Marzano (2010:12) hace referencia al sitio principal desde el que se podía acceder a ese tipo de vídeos, Ogrish.com, que cerró en 2006 y del que comenta: "se dieron cuenta de que, cada día, más de 200.000 personas miraban aquellas imágenes y de que el número de visitantes superaba los 700.000 cuando se ponía en línea un nuevo vídeo".

${ }^{129}$ Marzano (2010:86) hace referencia a estos tres diques psicológicos propuestos por Freud para " $<<$ estructurar $>>$ a los individuos y permitirles encontrar una especie de equilibrio ante la violencia de sus pulsiones": "El pudor permitiría encauzar la voluntad irreprimible de desvelarlo todo; la repugnancia, restringir la tendencia a sobrevalorar el objeto deseado; la compasión sería esencial para contener la agresividad y la crueldad". 
Por su parte, desde una posición autocalificada como nihilista ${ }^{130}$ y que según él es, junto con la propensión a caer en el "materialismo más pertinaz", la que caracteriza a la mayoría de la población actual de las sociedades de la “alta modernidad”, Gil Villa (2011) sostiene que la perspectiva posmoderna de la muerte, asentada en la estrategia de hacerla transparente, es la antesala al cumplimiento del “sueño más viejo de la humanidad: derrotar a la muerte”. Muerte de la muerte que no obstante, aclara, será sociológica, no biológica, y que se conseguirá al "volverse inconsciente familiar, en el sentido fenomenológico, es decir, al hacerse finalmente una compañera en la que reparamos sólo relativamente” (Gil Villa, 2011:51). Derrota social de la muerte asentada en la estrategia de su banalización por la que, "independientemente de la voluntad de los vivos”, está más presente que nunca a través de los personajes ficticios de moda “convertidos en héroes que habitan la frontera de la vida y de la muerte” (zombis ${ }^{131}$, vampiros ${ }^{132}$, muertos artísticos, según creciente orden de importancia) que inundan todos los mass-media y que le llevan a considerar que las antiguas estrategias de negación de la muerte "dan paso a una revolucionaria y tal vez definitiva reconciliación con la muerte que culmina en su conversión en objeto artístico”. Metáforas de los muertos vivientes o de los no muertos en que se han convertido los supervivientes del individualismo moderno que desarrollan los nuevos tipos de comportamiento adoptados en la época actual, todos ellos caracterizados por la ruptura de normas (Gil Villa, 2011:134). Este autor no se refiere con ellos a los "nihilistas reactivos", que “desgraciadamente" los hay, sino a los individuos que en su reflexividad no creen en tabúes y, “contra todo pronóstico”, incorporan a la muerte como el único anclaje en su vida (Gil Villa, 2011:44). ¿Y cómo lo hacen?, pues con una estrategia “de ataque” consistente en la “instrumentalización artística” de la muerte, en su presentación como una estrella de moda, “sublimándola en la obra de arte, transformándose ellos mismos en objetos artísticos” (Gil Villa, 2011:122): el muerto (el cadáver) artístico como muerto viviente, es decir, como muerto que sigue vivo. Así, para este autor, la construcción social de la muerte ya no sería un proceso de concienciación individual ejecutado en privado, sino un proceso de teatralización y juego

\footnotetext{
130 "Si como nihilistas del siglo XXI no creemos en nada -o creemos en todo, pero de forma superficial-, entonces uno de nuestros principales rasgos debe ser la palidez. Nuestro carácter mortecino no se refleja tanto en nuestro rostro como en nuestro espíritu, al carecer de la melanina de la ilusión. Arrastramos existencias de baja intensidad, más propias de personajes mitológicos como el zombi y el vampiro -ambos pálidos e inmortales- que del ser humano, clásicamente definido por su mortalidad” (Gil Villa, 2011:12).

${ }^{131} \mathrm{El}$ zombi es "una categoría de muertos vivientes representados en los vivos a los que la exclusión social en la modernidad había dejado medio muertos: las personas con discapacidad, sin hogar, inmigrantes, enfermos crónicos. Todos estos grupos sociales son, en realidad, masas de cuerpos a los que el sistema capitalista había dado de baja en la carrera por la productividad y el éxito económico" (Gil Villa, 2011: 133).

${ }^{132}$ El vampiro "forma parte de la categoría de los no muertos, o de los muertos vivos,... el vampiro representa tanto el alter-ego del vivo que habita en la alta modernidad como, en cuanto no muerto, la alteración de la misma muerte, sometida a una operación desustancializadora” (Gil Villa, 2011:72). La misión del mito del vampiro es "mostrar a los humanos cómo es posible vivir en un mundo sin ilusiones, en una especie de pos-historia donde todo, y por tanto nada, funciona. La figura del vampiro simboliza la última ilusión: la ilusión de vivir sin ilusiones” (Gil Villa, 2011:64-65).
} 
colectivo "muchas veces experimentado en diferido". Al margen de los peligros de la inducción ingenua, y de los cambios en las modas, que recomiendan no extrapolar esa tipología de vivosmuertos, o de muertos-vivos, al conjunto de la población, la propuesta de Gil Villa sí que podría ser representativa de alguna de esas "tribus” de prácticas extrañas señaladas por Maffesoli que mueven a "pensar en la profunda significación del no sentido de la vida”. En todo caso, para que la hipótesis de la derrota social de la muerte propuesta por Gil Villa, que sustituye las funciones de expulsión de la muerte, antaño desarrolladas por la religión y después por la ciencia, por la de su incorporación a través de la expresión artística, tenga algún viso de ser cierta quizá habrá que esperar, por un lado, a que se detecte una explosión en la oferta de cuerpos por parte de los nihilistas para someter sus futuros cadáveres al proceso de plastinación ${ }^{133}$ y así poder 'vivir' después de muertos, por otro lado, a que, como si del crucifijo o de la cartilla de la seguridad social se tratara, en buena parte de los hogares posmodernos se adquiera un cadáver artístico, o una parte de un cadáver, o al menos una representación enmarcada, para que forme parte del mobiliario de esos hogares.

${ }^{133}$ El proceso de plastinación que se emplea para “crear” cadáveres artísticos, fue desarrollado desde 1977 por Gunter von Hagens, originario de la antigua RDA, y consiste en "extraer el agua de un cuerpo con acetona fría y luego se sustituye por una solución plástica que se solidifica sin perder su transparencia” (Imbert, 2010:113). 

CAPÍTULO 4.- CONTABILIDAD DE LA MUERTE: “LA MUERTE SUFRIDA" 



\section{CAPÍTULO 4.- CONTABILIDAD DE LA MUERTE: “LA MUERTE SUFRIDA”}

"Probablemente no habría cultura si los seres humanos no fueran conscientes de su mortalidad”

Z. Bauman

En su examen sobre las relaciones entre la Sociología y la Demografía, Shreeniwas (1994:295) afirma que la población es el vehículo humano de la sociedad y que, por tanto, el análisis de una de ellas requiere la comprensión de la otra. No se puede considerar a una población humana como un ente aislado, pasivo, mero receptor de influencias, sino que en realidad es principio y fin de toda actividad social. En efecto, el perfil y la dinámica demográficos de cualquier sociedad son fruto particular de la evolución histórica concreta de los distintos componentes que, actuando en sinergia, conforman su contexto social: el nivel de desarrollo, las condiciones socioeconómicas, los hábitos culturales o las condiciones medioambientales ${ }^{1}$. A la par, y como señaló Stoetzl (1946), "la demografía de una población ordena toda la vida social” ${ }^{2}$, es decir, en un continuo proceso de retroalimentación la evolución de todos esos elementos está profundamente mediatizada por la evolución demográfica: el conocimiento de ésta deriva en una toma de conciencia sobre la realidad social y ayuda a orientar la acción que modifique los elementos indeseables de ella. Esta permanente interacción es la que sitúa al análisis sociodemográfico en un lugar privilegiado para comprender el pasado, el presente y el futuro de una sociedad.

Las características demográficas de una población reflejan la vitalidad o no de la misma sociedad, pudiendo ser consideradas como signos diáfanos que manifiestan mucho más que la mera energía demográfica. Un ámbito paradigmático en este sentido es el de las relaciones Mortalidad/Muerte ${ }^{3}$. En efecto, los datos e indicadores de mortalidad de una sociedad, además de cumplir con su función de contabilización demográfica -permiten estimar el tamaño y estructuras actuales y proyectadas de la población-, son de gran utilidad en la evaluación del estado de salud de la población, en la vigilancia epidemiológica y en la planificación sanitaria ${ }^{4}$. Asimismo, su evolución traza una especie de $<<$ carta del progreso $>>$ en el control de lo que ha

\footnotetext{
${ }^{1}$ Es tal la vinculación de los hechos demográficos con el marco social en el que se inscriben y el sometimiento de los fenómenos demográficos al control social, que "casi se podría decir que no existe el movimiento <<natural >>, sino el movimiento <<sociocultural >>de la población” (Girard, 1986:22).

${ }^{2}$ Stoetzel (1946) concede tanta importancia a la perspectiva demográfica en los estudios sociológicos que llega a afirmar que "todo sociólogo debería ser también un demógrafo".

${ }^{3}$ Para una revisión de las fuentes de datos, técnicas, indicadores y propuestas de análisis relativas a la mortalidad pueden consultarse Goerlich y Pinilla (2009, 2005), Blanes (2007), Gènova (1994), Livi-Bacci (1993:caps. 6-8) y, sobre todo, Pressat (1985).

${ }^{4}$ La información aportada por los datos de mortalidad es imprescindible, por ejemplo, para detectar la mortalidad innecesariamente prematura y sanitariamente evitable, lo que a su vez permite definir estrategias sanitarias más eficaces para aquellas enfermedades que requieren, en cada momento y en cada área geográfica, de un mayor control.
} 
constituido la mayor preocupación de la humanidad desde los tiempos más remotos: la prolongación de la vida y la posibilidad de sortear la muerte prematura ${ }^{5}$.

A estas funciones "tradicionales" de los indicadores de mortalidad se añaden otras igualmente importantes, como por ejemplo la de ser indicadores del nivel de desarrollo socioeconómico de una sociedad ${ }^{6}$. De hecho, como resalta A. Sen (1998; 1993), las estadísticas de mortalidad calibran mejor la calidad de vida y la penuria económica en ciertas naciones, o en grupos concretos dentro de las naciones, que las propias magnitudes de renta y recursos financieros, por lo que incluso aboga abiertamente por una "evaluación de la economía en términos de vida y muerte"7. Según Sen, lo significativo de la información aportada por la mortalidad deviene de una combinación de tres factores: 1) refleja la importancia intrínseca con que la sociedad enfrenta la vida y lucha contra las muertes prematuras: dado que la consecución de la inmortalidad aunque deseable para muchos no es una opción realista, una vida más larga es un fin importante en sí mismo; 2) trasluce el que muchas otras capacidades socialmente valoradas son contingentes con el hecho de estar vivo, que es una condición necesaria para ellas: el incremento de la vida media esperada, por tanto, no es sólo un valor en sí mismo, sino que también lo es por sus consecuencias asociadas, y; 3) muestra, en última instancia, el hecho adicional de que el nivel y las estructuras de la mortalidad, por su ligazón con otras metas sociales, pueden servir, en alguna medida, como aproximación a los éxitos y a los fracasos en la consecución de las mismas (Sen, 1998:4-5). De forma más concreta, el valor añadido de los datos de mortalidad está en que permiten centrar más la atención, comprender y evaluar mejor, así como definir políticas sobre cuestiones insoslayables de la economía política ligadas a las estructuras sociales y a la gestión pública de aspectos cruciales de la desigualdad social, como son "los problemas de las hambrunas, las necesidades sanitarias, la desigualdad entre los sexos,

\footnotetext{
${ }^{5}$ Preocupación que es especialmente cierta en las sociedades modernas cuando se trata de reducir al mínimo posible la mortalidad de los menores de un año ya que, como subraya Salustiano del Campo (1988:211), la Tasa de Mortalidad Infantil -T.M.I.- (fallecidos menores de un año por cada mil nacidos vivos) es un indicador muy importante del "bienestar socioeconómico al no haber objetivo superior para una población que salvar la vida de sus nuevos miembros”.

${ }^{6}$ Aunque en la mortalidad sólo se concitan unas determinadas dimensiones de la muerte, que es un proceso más amplio y en el que, por tanto, cabe detectar un mayor número de desigualdades sociales, en los últimos años se emplean los indicadores de mortalidad, esencialmente la Esperanza de Vida al Nacer -e(0)- y la Tasa de Mortalidad Infantil -TMI-, para medir niveles de desarrollo y bienestar. Es el caso, por ejemplo, del Índice de Desarrollo Humano elaborado por Naciones Unidas para contrastar las diferencias internacionales en éste ámbito. De hecho, la esperanza de vida al nacer, al ser independiente de la estructura por edades de la población permite fácilmente la comparación entre países, por lo que se ha convertido en el segundo indicador de desarrollo más empleado (Sutcliffe, 1999). También es utilizado en los modelos económicos relacionados con la teoría del capital humano y con el concepto "capital salud" (Goerlich y Pinilla, 2009).

${ }^{7}$ Las razones analíticas que justifican la utilización de los indicadores de mortalidad como indicadores socioeconómicos, así como una recusación pormenorizada de las diferentes críticas realizadas a esa utilización, pueden verse en Sen (1998).
} 
así como los de la pobreza y los de la discriminación racial incluso en las naciones ricas” (Sen, 1993:13).

Con esta premisa de fondo, y sobre la base de un análisis histórico-estructural -los niveles, estructuras e instituciones demográficas actuales son el resultado de la evolución pretérita-, en este capítulo se examina de forma estática y dinámica el aspecto más básico y visible de la muerte: la mortalidad. Ésta permite contabilizarla e informar sobre cuánta gente muere, a qué edades -es decir, cuánto tardan en morir-, por qué causas de muerte, qué diferencias existen entre las diversas categorías sociales, etc. El objetivo de este análisis es conocer los niveles, el calendario, las tendencias y los ritmos de la mortalidad: el "hecho bruto de la muerte" inscrito en las curvas demográficas. La "muerte sufrida", en expresión de Vovelle (1985:102).

Es evidente que la muerte, como fenómeno social, no puede reducirse meramente a su componente demográfico; sin embargo, y sin adoptar una posición mecanicista, resulta imposible entenderla sin él. Analizar la mortalidad de una población es conocer los componentes sociales de la "sangría" humana, esto es, de los cimientos sobre los que se asienta la construcción social de la muerte; paso ineludible y complementario por tanto para lograr una comprensión diáfana de la "muerte vivida" y de los "discursos de la muerte" (Vovelle, 1985:103). Y no sólo para entender la muerte. En efecto, el saber que la muerte amortiza toda la liquidez disponible de vida hace que las actitudes individuales y las relaciones interpersonales se adapten y desarrollen no en función del hecho cierto de que en algún momento se ha de morir, sino de la cantidad de vida restante hasta que la muerte llega. De ahí que Julián Marías (1993:365) resalte que el conocimiento de las probabilidades de morir en una sociedad es un "requisito imprescindible" para conocer y entender la propia vida social y los comportamientos humanos que en ella se producen.

El conocimiento de la mortalidad humana aporta, en efecto, parámetros en los que los individuos asientan su seguridad ontológica, y que son básicos para entender la construcción de la cultura y la estabilidad de las estructuras sociales (Seale, 1998). Por ello, a efectos del presente trabajo la actual dinámica demográfica de la población española tiene gran relevancia puesto que, frente a la homogeneidad de épocas pretéritas, anteriores al siglo XX, en las que el riesgo de muerte se caracterizaba por su omnipresencia y transversalidad -estaba presente para todos en todo momento de la vida cotidiana sin distinción de edad, de género o de cualquier otra categorización social-, las transformaciones demográficas del último siglo obviamente no han eliminado el riesgo de muerte -todos los seres humanos mueren por serlo-, pero sí que han templado su intensidad y, sobre todo, han reducido el espectro de las poblaciones de riesgo a 
corto plazo, que ha pasado de ser toda la población indistintamente a unas categorías sociales concretas. De esta forma, los cambios que se han ido produciendo en la estructura de la mortalidad han determinado variaciones en la (pre)vivencia del fenómeno mortal modificándose la conciencia de <<seguridad >> de la muerte. En Occidente, ésta ha dejado de ser “inminente” y ha pasado a ser más lejana, "segura, pero en cada caso y en cada momento improbable; cierta e inevitable, pero en concreto inverosímil” (Marías, 1993:364-365). En sí mismo este cambio ha constituido un salto cualitativo esencial que ha mediatizado y conformado de raíz la vida social de las sociedades industriales avanzadas. La progresiva extensión a un número cada vez más amplio de personas del sentimiento de seguridad existencial ha modificado el diseño de las estrategias vitales de las mismas ya que, retomando a Inglehart (1998:41), existe una "diferencia fundamental entre crecer con una conciencia de que la supervivencia es precaria y crecer con la sensación de que la supervivencia de uno se da por supuesta”. En última instancia, esta diferencia es tan básica que ha propiciado la emergencia de una nueva visión del mundo materializada en un profundo cambio intergeneracional de valores que abarca prácticamente todos los ámbitos de la vida social.

En este sentido, y a pesar de que existe una percepción generalizada de dar por supuesta la supervivencia existencial, la sociedad española actual, como la del resto de las sociedades industriales avanzadas, no es internamente homogénea en su experiencia de mortalidad y de construcción social de la muerte. Esta heterogeneidad viene determinada tanto por los desiguales niveles de riesgo de muerte en el plano individual o entre las diferentes categorías sociales (construidas por el observador según criterios de edad, sexo, hábitat, estado civil, clase social, etc.), como en la propia experiencia histórica de las distintas generaciones que coexisten en la actualidad. En una sociedad 'multigeneracional ` como la española actual "las generaciones no son vagones de un tren que se engancharían unos a otros en un proceso de desplazamiento temporal en la Historia” (Loriaux, 1995:14), es decir, su estratificación de edades no es equiparable a una mera superposición de generaciones divididas en compartimentos estancos destinadas a reproducir en el tiempo lo que han vivido sus generaciones predecesoras. La presencia simultánea hoy día de sucesivas generaciones, encajando unas en otras y sin que exista una separación radical entre ellas, no impide observar una diferenciación suficientemente marcada en sus rasgos derivada de su dispar devenir histórico. En efecto, en la actualidad, la parte alta de la distribución por edad de la población española está constituida por generaciones de individuos que nacieron y vivieron su infancia, juventud y temprana adultez antes y durante la Guerra Civil, o, de las que lo hicieron en los duros años de la posguerra. Son supervivientes de un periodo secular marcado por la escasez crónica y el hambre, en el que estuvieron sujetos a la incidencia de múltiples contingencias desde todos los ámbitos de la vida, y en el que elevados niveles de mortalidad conformaban su conciencia diaria de la vida y de la muerte. Junto a estas 
personas, muy seleccionadas por los filtros de las penurias y las enfermedades, coexisten hoy generaciones de individuos situados en la parte media baja de la distribución por edad, los nacidos en las últimas cuatro décadas del siglo XX, que han crecido en un entorno caracterizado por la seguridad física y económica, y en el que la actuación de fuerzas imprevistas apenas ha influido hasta ahora en su devenir biográfico. Este marcado contraste entre las experiencias vitales de las distintas generaciones ha propiciado, inevitablemente, también un cambio intergeneracional en los modelos de mortalidad/muerte respectivos.

A continuación se delimitan las características de la muerte sufrida teniendo en cuenta que ésta ha experimentado en los tres últimos siglos unos cambios que sin exagerar pueden ser calificados de revolucionarios. Para ello, en primer lugar, se enmarcan las diferentes construcciones teóricas que, a modo de un juego inclusivo de muñecas rusas, tratan de explicar la evolución de la mortalidad: Transición Demográfica (Transición de la Mortalidad), Transición Epidemiológica y Transición Sanitaria. Seguidamente, se aplican esos marcos teóricos generales al caso específico de España con el objetivo de describir muy sintéticamente el panorama sobre el que han transitado las distintas dimensiones de la muerte sufrida en la sociedad española actual. Este análisis histórico pone de manifiesto algunos rasgos peculiares en la evolución demográfica de la población española, destacando entre ellos el retraso en el inicio del proceso de modernización demográfica hasta finales del siglo XIX y la rapidez con que ésta se ha producido, ya que en el caso de la sociedad española ese cambio demográfico revolucionario se ha desarrollado de forma concentrada a lo largo del siglo $\mathrm{XX}^{8}$. Examinada la evolución de la mortalidad hasta el presente, finalmente se aborda la continuación previsible de este cambio demográfico analizando las perspectivas futuras de la misma, con sus luces y sus sombras, a la vista de los conocimientos científicos actuales.

\subsection{INTENSIDAD Y CALENDARIO EN LA MUERTE}

"Mira al frente. ¿Qué hay? Si lo ves tal cual es Nunca errarás”

B. Tokusho

En todo momento los niveles de mortalidad de una población constituyen el resultado de la compleja interacción de muy diversos factores biológicos, económicos, socioculturales, ecológicos, demográficos, médicos, políticos, etc., que afectan en distinto grado a las condiciones de vida y de salud de las personas. Si bien la incidencia de estos elementos no ha permanecido inmutable en el tiempo, por primera vez en la historia de la humanidad la

\footnotetext{
${ }^{8}$ Si bien en el análisis empírico se recogen los datos más actuales, dado que el análisis de la muerte vivida, Capítulo 5, se centra en la información obtenida en una encuesta implementada alrededor del año 2000, interesa por ello enfocar lo más posible la mirada de estudio en la situación demográfica de ese año.
} 
confluencia, a finales del siglo XVIII y principios del siglo XIX, de una sucesión de descubrimientos, innovaciones tecnológicas y transformaciones sociales y económicas provocaron que dichos factores experimentasen intensas e irreversibles modificaciones que, en última instancia, se tradujeron en una paulatina y profunda transformación de las pautas de la mortalidad. Como se ha examinado en el Capítulo 2, entre las profundas mutaciones estructurales que caracterizan al proceso de modernización desarrollado en los últimos tres siglos se incluyen las cinco transformaciones demográficas (<<terremotos $>>)$ que han conformado la modernización demográfica de las sociedades desarrolladas ${ }^{9}$. Centrando el análisis en los aspectos relativos a la mortalidad, en este Capítulo de la Tesis se profundiza en el examen de dos de esas cinco transformaciones demográficas -la reducción de la mortalidad, con el incremento parejo de la longevidad, y la ordenación del ciclo vital- concomitadas en la transición de la mortalidad.

\title{
4.1.1. TRANSICIÓN DEMOGRÁFICA (TRANSICIÓN DE LA MORTALIDAD)
}

\author{
"Aunque terrible es comprenderlo, \\ la vida se hace en borrador, \\ y no nos es dado corregir sus páginas” \\ E. Sábato
}

La transición demográfica da nombre al modelo teórico que analiza la evolución descendente de las tasas vitales de una población y su vinculación causal con el desarrollo socioeconómico. En esencia, consiste en el tránsito desde una situación de Régimen Demográfico Antiguo o Natural, caracterizado por altas tasas de mortalidad $^{10}$ y natalidad, muy

9 Cabe recordar que estas transformaciones demográficas son: “1) Transición demográfica; 2) Transformación del ciclo vital anual; 3) Transformación del modelo matrimonial; 4) Creciente grado de urbanización; y 5) Transformación de la estructura de la ocupación” (Pérez Moreda, 1987:25-62).

${ }^{10}$ Habitualmente, el análisis general de la mortalidad se realiza empleando dos indicadores: la Tasa Bruta de Mortalidad (T.B.M.) y la Esperanza de Vida al Nacer (e(0)). El primero, la T.B.M., contabiliza el número de defunciones por cada 1.000 habitantes de una población durante un periodo de tiempo, generalmente un año. Este indicador es un indicador imperfecto, en el sentido de que, al tratar a todos los individuos de la población de forma homogénea, no considera las diferencias en cuanto al riesgo de deceso según la edad. En consecuencia, mide tanto la incidencia del fenómeno mortalidad como la del factor estructura por edad. Para evitar esta distorsión, el análisis demográfico ha elaborado otros indicadores que permiten medir la mortalidad en estado puro, aislándola del factor riesgo que supone la edad. El instrumento que resume estos indicadores es la Tabla de Mortalidad, que sintetiza toda la información en un solo indicador, el segundo de los mencionados, la e(0). Los datos de este indicador recogidos en este trabajo provienen en todos los casos de las denominadas Tablas de Mortalidad del Momento en las que la e(0) representa la edad media de fallecimiento para un grupo hipotético de personas nacidas en un año determinado y sujetas a lo largo de sus vidas a los riesgos de mortalidad experimentados por los individuos de cada edad a lo largo de ese mismo año. Son, por tanto, valores ficticios aplicados a cohortes ficticias. Es importante tener en cuenta esta consideración básica porque la experiencia histórica reciente muestra que los valores de la e(0) de una generación real concreta, una vez que todos sus miembros han fallecido, siempre han sido mayores que los valores de la e(0) estimados para la cohorte ficticia nacida en el año de esa generación. 
cercanas entre sí, lo que determina un crecimiento natural débil de la población, a un estado de Régimen Demográfico Moderno, con bajas tasas de mortalidad y natalidad, también próximas entre sí y asimismo con escaso crecimiento vegetativo. Este tránsito se ha producido gradualmente a través de una sucesión de cuatro etapas superpuestas entre sí (Nadal, 1976).

Esta profunda mutación de los fenómenos demográficos vitales constituye uno de los rasgos formativos básicos que caracterizan y diferencian a una sociedad moderna, en tanto que con ella se alcanza un control sobre la incidencia de la muerte acompañado con cierto retardo, y de forma "tranquila" y "silenciosa", por el dominio de la reproducción humana con el consiguiente descenso del número medio de hijos por mujer y de las tasas de natalidad. El descenso de la mortalidad y la natalidad supone, por tanto, una racionalización demográfica al conseguirse un rendimiento demográfico más eficaz que en cualquier otra época histórica. Como resultado de esta evolución "el despilfarro de vidas humanas” que conllevaba asegurar la supervivencia del grupo “ya no es necesario”"11 (Chesnais, 1988:129; Livi-Bacci, 1990:107).

Sin entrar a valorar la consistencia y capacidad explicativa y predictiva de la Teoría de la Transición Demográfica, se admite su utilidad en cuanto modelo histórico descriptivo que, huyendo de las explicaciones monocausales y unidireccionales, recoge, integra y sintetiza de forma sensible las regularidades demográficas observadas en el pasado sugiriendo, además, algunas relaciones entre la evolución de las características demográficas y los cambios socioeconómicos ocurridos desde el siglo XVIII (Arango, 1980:173). No obstante las críticas recibidas, y como señala Kirk (1996), sigue siendo una de las generalizaciones mejor documentadas de las ciencias sociales.

En esencia, y centrando la explicación en las transformaciones de la mortalidad, la transición demográfica se ha desarrollado como sigue: hasta hace poco más de dos siglos y medio, la mortalidad constituía el fenómeno demográfico clave en la conformación del tamaño de las poblaciones. Este papel preponderante de la mortalidad en las sociedades agrarias tradicionales de baja productividad y escasos recursos se asocia a la estrecha y compleja interrelación con las condiciones estructurales y a su especial sensibilidad ante cambios en las mismas. La inestabilidad continua de la mortalidad era endémica, siempre a expensas de fuerzas exógenas (Flinn, 1989:74). Esto representaba, en condiciones normales, niveles elevados de mortalidad ordinaria, entre el 45 y el 35 por mil anual, ligados directamente a unas

\footnotetext{
${ }^{11}$ Sirva para ilustrar la situación que, a finales del siglo XX, las tasas de mortalidad en la infancia en los países menos desarrollados decuplicaban a las de los países desarrollados (en 1999, la Tasa de Mortalidad Infantil, T.M.I., fue del 64\% en el conjunto de los países en desarrollo frente al 6\% en los países industrializados (PNUD, 1999:171)). Si la mortalidad de los primeros se redujera a la de los niveles de los segundos, cada año se evitaría la muerte de 11 millones de niños/as.
} 
condiciones de vida cotidianas que hacían de los individuos rehenes de lo que Livi-Bacci (1988:10) denomina “síndrome de atraso”. Éste se caracterizaría por una situación de miseria generalizada, con unas estructuras socioeconómicas que no garantizaban para la población, mayoritariamente rural y agrícola, siquiera los niveles mínimos de subsistencia y mucho menos un excedente que permitiera hacer frente a la variabilidad de las cosechas de un año a otro. A su vez esta precariedad material, con situaciones de hambre total (subnutrición) o carencial (malnutrición), facilitaba el avance de las enfermedades y la condición letal de muchas de ellas en un medio caracterizado, además, por bajas cotas de higiene privada y escaso desarrollo de los conocimientos científicos y técnicos en materias de medicina y sanidad. A esta situación se añadía la actitud fatalista de los individuos sustentada en la idea de considerar la elevada mortandad de la época como un parámetro natural e inevitable, además de un designio de la voluntad divina.

En épocas de crisis (cuando actuaba alguno de los obstáculos <<positivos >> mencionados por Malthus (1983): epidemias, crisis de subsistencia, guerras, etc.), los niveles de mortalidad podían derivar hacia una mortalidad "extraordinaria” o "catastrófica” cercana al 200 por mil o incluso, localmente, del 400 por mil (Pérez Moreda, 1984:60). Esta respuesta demográfica traducía la actuación simultánea de un conjunto de factores que escapaban al control de las sociedades preindustriales (Wrigley, 1985:63-145). Así, por ejemplo, las epidemias de enfermedades infecciosas se producían totalmente al azar y sus ataques imprevisibles resultaban independientes de los ciclos irregulares de las cosechas (Flinn, 1989:74-97).

La incapacidad en la lucha cotidiana contra la muerte unida a la desolación provocada recurrentemente por las mortandades catastróficas desembocaba en que individuos y poblaciones se hallaran inermes e inertes ante la muerte. La mentalidad dominante de rendición incondicional frente a ella se manifestaba de forma diáfana en la ausencia de presión social en la demanda de actuaciones públicas para controlarla y reducirla. De tal forma que, en las sociedades agrarias tradicionales, la lucha contra la muerte, tanto desde una perspectiva individual como colectiva, era ineficaz o ni siquiera se planteaba como posible (Pérez Moreda, 1980:51). En ese contexto de recursos tan limitados, en el que el hambre formaba parte del paisaje cotidiano, a los individuos únicamente les preocupaba sobrevivir, es decir, seguir en el presente, mientras que el futuro, transformado en una quimera, carecía de sentido para ellos. Esta mirada de las sociedades tradicionales centrada sólo en el presente implicaba, como señala Pérez Díaz (2002:55 y 115), que no cabía invertir en futuro, ni siquiera en el de los propios hijos, cuyo porvenir incierto no aseguraba rentabilidad alguna a la inversión realizada en ellos, por lo que las necesidades de los infantes no se podían anteponer a las de los adultos, ya que 
éstos eran los principales actores sociales en los que se asentaba la producción-reproducción de la sociedad. Así, la opción más razonable para las familias era “diversificar los riesgos invirtiendo poco en muchos hijos”. En cualquier caso, la intensa y profunda relación existente entre los distintos fenómenos demográficos determinaba que, en esta primera y dilatada fase de la transición demográfica, ante los elevados niveles de mortalidad ordinaria, y los fortísimos incrementos de la misma en épocas de crisis, los niveles de natalidad (fecundidad) fueran necesariamente altos para poder permitir la reproducción y supervivencia de las poblaciones ${ }^{12}$. Durante esta fase, por tanto, la elevada mortalidad condicionaba la primacía del grupo sobre el individuo y determinaba la necesidad de normas, valores e instituciones pronatalistas.

Distintos autores consideran al siglo XVIII como la "bisagra" que inicia la ruptura del sistema demográfico antiguo y pone en marcha la transición demográfica ${ }^{13}$ (Flinn, 1989:113149; Pressat, 1985:124; Pérez Moreda, 1984:22; Nadal, 1976:9-13). Ésta comienza con una reducción de los índices de mortalidad "levemente anterior y probablemente independiente del nacimiento de la industria” (Livi-Bacci y Del Panta, 1990:17). En efecto, la declinación inicial de la mortalidad se concentró, en primer lugar, en la atenuación de las sobremortalidades catastróficas y en especial de las crisis epidémicas desde la segunda mitad del siglo XVII. No estuvo relacionada, en consecuencia, con los cambios estructurales del proceso de industrialización cuyos efectos inducidos sobre la mortalidad ordinaria no se manifestaron hasta el siglo XIX (Nadal, 1976:10). Se han sugerido diferentes hipótesis explicativas sobre la desaparición gradual de la mortalidad catastrófica en Europa ${ }^{14}$. Entre ellas resulta significativa para el presente trabajo aquélla que, referida a la eliminación de la peste bubónica, considera que pudo haberse debido al triunfo de la organización humana (Flinn, 1989:89-94). La

\footnotetext{
${ }^{12}$ En la época preindustrial, los distintos fenómenos demográficos respondían de forma diversa, tanto en el ritmo como en la intensidad y el sentido, a los cambios económicos y sociales. Así, la nupcialidad, la fecundidad y las migraciones, fenómenos que no atañen a todos los individuos, reaccionaban de forma más rápida, en ambos sentidos, y en general con menores intensidades que la mortalidad ante variaciones coyunturales económicas y sociales. Por su parte, la elevada mortalidad ordinaria se mantenía prácticamente inelástica a las fluctuaciones coyunturales positivas y, por el contrario, su respuesta a fluctuaciones circunstanciales negativas era rápida y de gran intensidad. La escasez y transitoriedad de estados socioeconómicos favorables y la presencia relativamente frecuente de situaciones depresivas daba lugar a que cualquier incremento poblacional fruto de una coyuntura favorable fuera rápidamente limado por la evolución señalada de la mortalidad, con lo que ésta se convertía en el principal determinante de la evolución de las poblaciones en el marco del <<ciclo demográfico antiguo > (Pérez Moreda, 1980:51-54). ${ }^{13}$ Caldwell (1987:35) afirma que "el comienzo de la declinación de la mortalidad suele considerarse el principal determinante de todo cambio demográfico posterior o, por lo menos, la condición sine qua non de un cambio decisivo o constante".

${ }^{14}$ En la actualidad, la mayoría de los historiadores consideran que el retroceso de la peste fue debido a la sustitución de las ratas negras, que cinco siglos antes habían invadido el continente europeo desde la India, por las ratas castañas, que procedentes de Asia habían llegado a Europa en el primer tercio del siglo XVIII y habían relegado a las primeras a los barcos. Según Nadal (1992:230) este relevo tuvo "consecuencias trascendentales" porque la pulga de la rata negra, "destacado vector de la peste", hubo de ceder el lugar a la pulga de la rata castaña, "vector mucho menos eficiente del bacilo pestífero, poco sediento, además, de sangre humana”.
} 
actuación humana no podía eliminar las crisis epidémicas al no disponer de conocimientos sobre las etiologías que las provocaban, pero al menos sí podía limitar su incidencia y, sobre todo, su expansión con algún tipo de control. La creciente eficacia de la administración (primero local, después regional y posterior-mente nacional) y de sus medidas preventivas (cordones sanitarios, cuarentenas) supuso la ruptura del fatalismo que históricamente había caracterizado la lucha contra la muerte.

En una segunda fase de la transición demográfica, iniciada a finales del siglo XVIII y primera mitad del siglo XIX, se produjo el declive de la mortalidad ordinaria causada mayoritariamente por enfermedades infecto-contagiosas ${ }^{15}$. Un amplio debate ha animado la discusión sobre cuál fue la causa originaria del retroceso de las enfermedades infecciosas, debate sintetizado en la disputa avances médicos versus avances nutricionales (Mesle y Vallin, 2006; Tapia, 2005; Bernabeu Mestre y Robles, 2000; Pérez Moreda, 1988; Livi-Bacci, 1988; Mckeown, 2006, 1978; Wriley, 1985). Sin entrar en el mismo, se admite la posición dominante hoy de que ninguna explicación monocausal puede dar cuenta por sí sola de una realidad tan compleja y que han sido muchos los factores, y las combinaciones de los mismos, los causantes de esta reducción. Así, el retroceso de las enfermedades infecciosas se habría producido de forma escalonada fruto de la actuación sinérgica de múltiples factores, aunque, en cada momento, alguno de ellos tuviera un papel determinante (Meslé y Vallin, 2006:253; Vallin, 1995b:98-101). Ante el bajo nivel de desarrollo de los conocimientos y técnicas médicosanitarios de la época, Vallin afirma que en la segunda fase de la transición demográfica las principales causas de la reducción de las enfermedades infecciosas fueron, por un lado, los “progresos de la administración” y sus efectos en el control de las grandes epidemias ${ }^{16}$ y, por otro lado, los cambios económicos estructurales de carácter profundo y duradero que gradualmente alejaron los riesgos extremos de carestías de bienes básicos (Vallin, 1995b:99100). Las revoluciones comercial, agrícola e industrial, en efecto, permitieron el incremento de la productividad del trabajo, el desarrollo de mejores medios de transporte, la intensificación del comercio, la aparición de nuevas tecnologías de almacenamiento, la oferta de un mayor número de productos y en mayor cantidad, etc., que en un primer momento supusieron el aumento del nivel de vida de unos pocos, mejora que lentamente se transmitió al resto de la población. Esto conllevó la disminución del riesgo de contraer enfermedades y el aumento de la resistencia frente a ellas, es decir, el incremento de las posibilidades de supervivencia y la caída de la

\footnotetext{
${ }^{15}$ Este descenso de la mortalidad ordinaria no vino acompañado inmediatamente por el de la natalidad al pervivir las normas, valores e instituciones pronatalistas pretéritos. El diferencial entre una natalidad elevada y una mortalidad descendente dio lugar a la ruptura del equilibrio "homeostático" del régimen demográfico antiguo inaugurando un nuevo tiempo de crecimiento sostenido de la población.

${ }^{16}$ Un ejemplo diáfano de la eficacia de esos controles fue la desaparición de las epidemias de cólera que "terminaron cuando las medidas de salud pública destinadas a garantizar la pureza del agua potable se convirtieron en práctica común” (Reher, 1996:168).
} 
mortandad. Este descenso, además, fue un determinante necesario para la desaparición de las actitudes fatalistas sobre la vida y los dictados de la naturaleza, que a su vez realimentaron la declinación de la mortalidad por cuanto las sociedades desarrollaron comportamientos activos en la búsqueda de nuevas vías que permitieran reducir los riesgos de muerte (Caldwell, 1987:33).

A la actuación de estos factores se sumaron en la segunda mitad del siglo XIX (tercera fase de la transición demográfica ${ }^{17}$ ), el efecto de la revolución pausteriana en las décadas finales de ese siglo y las mejoras en la higiene personal fruto de la generalización de la instrucción pública y en la salud pública -en particular, abastecimiento de agua potable, servicios de saneamiento y reglamentación alimentaria-, con lo que el control de las enfermedades infecciosas tradicionales aumentó y se tradujo en una nueva reducción de los niveles generales de mortalidad.

Este control se aceleró en la cuarta fase de la transición demográfica, desde principios del siglo XX, especialmente por los avances médico-sanitarios: utilización de sulfamidas desde la década de 1930, de los antibióticos después de la segunda Guerra Mundial (Glazer, 1973), además de los efectos de la universalización de la asistencia sanitaria a través del desarrollo de los sistemas de Seguridad Social (Vallin, 1995b:99-100). Pero además de éstos, otros avances han permitido que los peligros reales, los riesgos que amenazan hoy la vida cotidiana de los individuos de las sociedades desarrolladas, sean menores que los que han tenido que afrontar la mayoría de los individuos de épocas anteriores ${ }^{18}$ (Giddens, 1997:148). Paralelamente a esta

\footnotetext{
${ }^{17}$ Fruto de la interrelación entre natalidad y mortalidad, el continuo y sostenido descenso de ésta arrastró con el tiempo a aquélla. Se inició, de esta forma, el descenso de la fecundidad, y de la natalidad, a largo plazo, al reducirse la mortalidad infantil y, por consiguiente, ser menor la necesidad de acumular y reponer descendientes para alcanzar el tamaño de prole deseado. Junto a esta causa demográfica cabe citar otras de tipo económico -como, por ejemplo, el deterioro, hasta volverse negativo, de la relación coste/beneficio de una prole numerosa inducido por los cambios estructurales en la actividad (industrialización) y el abandono del medio rural-, o de tipo social -urbanización, creciente individualismo, reducción de la presión social a favor de una fecundidad alta, mutación de la funcionalidad de la familia, aspiraciones de movilidad social, prohibición del trabajo infantil, efecto demostración, demanda creciente de mayores niveles de formación, etc. Todas estas causas han ayudado a construir la idea de control consciente de la fecundidad en la mentalidad de los individuos. La contracción simultánea y desigual de ambos fenómenos demográficos no impide que las poblaciones sigan creciendo aunque, obviamente, con menor intensidad que en la segunda fase.

${ }^{18}$ En un estudio de Urquhart y Heilmann (1984: Risk Watch, Nueva York, Facts and File, p. 12), citado por Giddens (1997:150-152) en el que se comparaban las condiciones de vida en 1907 con las de 1977 en Estados Unidos, se recoge un listado de las innovaciones de todo tipo que habían permitido reducir a lo largo de ese periodo los riesgos más importantes para la salud: agua potable, servicios de saneamiento de aguas residuales, preparación higiénica de alimentos, leche pasteurizada, refrigeración, calefacción central, amplia aplicación de principios en la nutrición, amplia aplicación de principios de higiene personal, control de roedores e insectos, mejora continua pre y postnatales, mejora continua de los cuidados de bebés y niños, mejora continua en el tratamiento quirúrgico, mejora continua de la anestesia y los cuidados intensivos, amplia aplicación de los principios de inmunización, viabilidad de la trasfusión de sangre, establecimiento de unidades de cuidados intensivos en los hospitales, difusión continua y
} 
evolución descendente de la mortalidad, la fecundidad-natalidad continuó reduciéndose situándose el nivel de ambas tasas vitales alrededor del 10\%. De esta forma, en la última fase de la transición demográfica los bajos niveles de mortalidad y natalidad que caracterizan al ciclo moderno de la población "europea” han derivado en un creciente envejecimiento demográfico desde principios del siglo XX, y en una desaceleración del crecimiento poblacional desde la tercera década del mismo (Nadal, 1976:12-13).

\title{
4.1.1.1. TRANSICIÓN DE LA MORTALIDAD
}

\author{
"Han olvidado cómo morir \\ y de ese modo prolongan su vida asesina. \\ Mi tumor y yo luchamos con todas nuestras fuerzas. \\ Una doble muerte está, espero, descartada. \\ Necesito ver la muerte de mi tumor \\ Un tumor que ha olvidado la forma de morir \\ Y planea sustituir su muerte por la mía. \\ (...) \\ Es posible que las células negras se sequen y mueran \\ o tal vez canten alegremente y se salgan con la suya. \\ Se reproducen tan silenciosamente, día y noche, \\ Que no reparas en ellas, nunca te avisan”.
}

H. Pinter

La evolución hasta lograr los bajos niveles de mortalidad y natalidad que caracterizan el régimen demográfico moderno no se ha realizado de forma autónoma ni aislada, sino que, como se ha señalado anteriormente, constituye un aspecto parcial junto a otros del proceso global de modernización, con los que forma un todo coherente. La mejora de las condiciones de vida de los individuos (de su alimentación, vivienda, trabajo, ocio, relaciones familiares, comunicación, etc.) ha desembocado en cambios en sus niveles de salud que han afectado asimismo a sus experiencias y expectativas ante la muerte. De hecho, el lento control sobre la misma constituye uno de los procesos sociales más destacados, si no el que más, entre los que han tenido lugar a lo largo de los últimos trescientos años. Las victorias conseguidas contra la muerte constituyen para Girard (1986:229) <<la gran revolución>>, a la vez causa y resultado de cambios más visibles, "en cualquier caso símbolo y resumen de todas las demás revoluciones”, y es precisamente en el ámbito demográfico en el que se manifiesta de forma más clara ese control. $\mathrm{Al}$ conjunto de cambios que se han observado en la contabilidad general de la muerte se les denomina, globalmente, <<transición de la mortalidad >> (Haines, 2002; Santow, 1999). Los rasgos básicos que caracterizan a la misma son: a) pronunciado descenso del nivel de la

mejorada de los procedimientos de diagnóstico, mejora continua del tratamiento del cáncer, mejora continua del tratamiento de la oclusión arterial, viabilidad y practicabilidad de la paternidad planificada, mejora y legalización de los métodos de interrupción del embarazo, aceptación amplia de la seguridad en el trabajo, cinturones de seguridad en los coches, reconocimiento de los daños causados a la salud por el tabaco, la obesidad, la hipertensión sanguínea y la vida sedentaria. 
mortalidad; b) reducción de la variabilidad de la misma de un año a otro (Schofield y Reher, 1991); c) notable incremento de la longevidad media. Lo que no significa necesariamente, como se analiza más adelante, que se haya incrementado el límite biológico máximo de la vida humana, sino que un número mayor de personas viven hasta edades avanzadas, de tal forma que, en comparación con las generaciones anteriores, las personas de hoy disponen no de una, sino de dos vidas adultas o, como señalan Rosnay et al (2006), de "una vida extra”; d) alteración sustancial en la distribución relativa de los decesos según las distintas estructuras identificables en una población. Dos estructuras básicas en este sentido son: d1) la estructura por edad, cuya composición relativa se altera por la cúspide conformando, junto al descenso de la fecundidad, la dinámica del envejecimiento demográfico y en la que ha tenido lugar una profunda modificación del calendario de la mortalidad, generándose una <<nueva edad $>>$ de la muerte ubicada en la vejez (Caselli, Meslé y Vallin, 1995:2-20); d2) la estructura por género, en la que, durante todo el siglo XX, se ha producido una creciente divergencia entre las longevidades medias de hombres y mujeres.

Además de los cambios demográficos citados, y los epidemiológicos relativos a las transformaciones en los patrones de salud y de enfermedad precipitados en las causas de muerte que se citarán al describir la transición epidemiológica, Olshansky y Carnes (2001:124-125) añaden un cambio poco visible como ha sido la modificación de la frecuencia de genes dañinos en la reserva genética de las especie humana, que no sólo puede afectar a la evolución futura de la mortalidad, sino que puede incidir en el presente y futuro de costes sociales de todo tipo. Durante miles de años, hasta el inicio de la transición de la mortalidad, las enfermedades infecciosas y parasitarias tenían un efecto sobre los genes que eran transmitidos a la siguiente generación y la selección natural actuaba de criba dejando pasar sólo a aquellos individuos sobre los que no peligrase su supervivencia hasta alcanzar la madurez sexual y su capacidad reproductiva. Las mejoras que han originado la transición de la mortalidad han "burlado a las fuerzas de la selección natural que formaron la reserva de genes de los humanos permitiendo sobrevivir y reproducirse a individuos que en el pasado no hubieran tenido esa oportunidad” ${ }^{19}$.

La transición de la mortalidad es una consecuencia de la dinámica modernizadora, indisociable y constitutiva de un todo coherente con otros procesos sociales del desarrollo con los que ha actuado sinérgicamente en la consolidación del mismo. Puesto que los seres humanos son tanto el medio como el objeto de la mejora de la calidad de vida, el descenso de la mortalidad constituye asimismo un pilar en el que se asienta la modernización socioeconómica, perfilándose como una causa de la misma. De hecho, se trata de una condición sine qua non,

${ }^{19}$ Un análisis de las consecuencias genéticas y biológicas de estos cambios puede verse en Imaizumi (1987). 
aunque obviamente no suficiente, para que el desarrollo moderno haya tenido lugar, como resaltó la División de Población de Naciones Unidas (PNUD, 1987:III) al afirmar que "los cambios en la mortalidad pueden trastornar las relaciones tradicionales y estables de una persona en el hogar y de los hogares en el medio social y económico en el que se desenvuelven. En consecuencia, los cambios en la mortalidad desempeñan una función integral en lo que suele denominarse modernización, proceso que incluso acaso inician”. En efecto, la reducción de la mortalidad, y el conexo incremento de la longevidad, propició el crecimiento de la población, el desarrollo del proceso de urbanización y la generación del excedente de fuerza de trabajo necesario para el despegue de la industrialización (Viciana, 2003:17).

Como se ha señalado en el Capítulo 2 de esta Tesis, la inseguridad y el desorden inherentes a las situaciones de alta mortalidad limitan el desarrollo de la vida social al condicionar en sus aspectos más básicos las relaciones sociales potenciales, las de más allá de la mera supervivencia, e incluso también a éstas. En esta línea, Notestein (1953) ${ }^{20}$ sostenía que el nivel de mortalidad determinaba la naturaleza de gran parte de la sociedad, porque con una mortalidad elevada las personas no hacen ningún esfuerzo de movilidad social y mantienen la condición social con la que nacen ${ }^{21}$. La inseguridad del presente cierra el paso al futuro. Por ello, el retroceso de la muerte se convierte en condición previa para que "desaparezca el fatalismo milenario y aumente la confianza en el futuro" (Chesnais, 1988:30), para que se reduzcan la inseguridad y el desorden (generacional) y con ello se asiente un marco estable en el que emerjan las innovaciones, se conciban proyectos personales de futuro y se aseguren el ahorro y la inversión, pilares del desarrollo económico.

En efecto, la reducción de la mortalidad es la base sobre la que se asienta y ordena el ciclo vital del individuo, permitiéndole reorganizar profundamente su tiempo de vida al conocer aproximadamente cuánto le resta de ella. Por sí mismo este cambio configura un horizonte ampliado de supervivencia y supone una ruptura radical con el pasado al crear un marco de seguridad en el que los individuos pueden, al menos potencialmente, confiar en sobrevivir hasta edades avanzadas. Y esta confianza se torna clave por cuanto el prever que se dispone, con razonable seguridad, de suficiente tiempo de vida permite que las relaciones humanas sean potencialmente predecibles, facilitando lo que Laslett denominó <<la conversación entre generaciones $>>$, mitiga las incertidumbres económicas y culturales conexas a la muerte, y

${ }^{20}$ Notestein, F.W. (1953): “Economics of population change”, en $\underline{8}^{\mathrm{a}}$ International Conference of Agricultural Economics, Londres, Oxford, citado en Caldwell (1987:33-34).

${ }^{21}$ Situación que provoca actitudes nihilistas como las de Pierre Anthon, el protagonista del controvertido cuento juvenil Nada, de Janne TELLER (2011), v.o. 2000, quien, desde lo alto del ciruelo al que se había encaramado para no hacer nada, porque "no merece la pena hacer nada", chillaba a sus compañeros de clase: "Si es tan fácil morir, es porque la muerte no tiene ningún sentido... Y si la muerte no tiene ningún sentido, es porque la vida tampoco lo tiene". 
genera las condiciones para que las innovaciones científico-técnicas tengan continuidad. En definitiva, la disminución de la mortalidad ha permitido a los individuos vivir en un entorno mucho menos heterónomo, lo que ha hecho que mutase la mirada secular sobre el presente en la mirada moderna sobre el futuro, arrastrando y conformando con ello a las actitudes individuales ante la vida, es decir, a la propia vida social: orden que lleva aparejado seguridad, seguridad que ayuda a construir expectativas. Y es que, como resalta Bauman (2002:109), la preocupación acerca del orden -o acerca de una sociedad ordenada y manejable- es el "denominador común” de las principales empresas de la modernidad: industrialismo, capitalismo, democracia.

En el Cuadro 4.1. se recogen distintas estimaciones demográficas, directa o indirectamente relacionadas con la transición de la mortalidad en la Unión Europea, y que por sí solas son lo suficientemente elocuentes de la profundidad de las transformaciones de la vida cotidiana ligadas a la misma. La reducción de la mortalidad ha modificado las edades de la vida, que se han diversificado, y que parece como si se hubiesen multiplicado adquiriendo cada una de ellas importancia y significación en sí mismas²2 (Pérez Díaz, 2005, 2002; Loriaux, 1995; Girard, 1986). No sólo se ha generado una nueva edad de la muerte ubicada en la vejez, sino que "nos hemos inventado" una nueva edad de la vida, desconocida apenas hace dos siglos: la adolescencia $^{23}$. Junto a este "reequilibrio social entre las diferentes edades", el aumento de la esperanza de vida (más que triplicada desde el siglo XVIII hasta finales del siglo XX para un ciudadano europeo medio; un aumento de 30 años sólo durante este último siglo) ha conllevado, además, "una democratización de la supervivencia mínima necesaria para completar la fase de vida adulta”, lo que ha generalizado la posibilidad de formar pareja y tener descendencia. La reducción de la mortalidad infantil (a finales del siglo XX, la TMI era menor del 2,8\% de la del siglo XVIII, e inferior al 4,7\% de la de 1900), fruto de una creciente eficiencia demográfica, ha creado las condiciones para a la larga hacer menos perentorias las responsabilidades reproductivas de los individuos, lo que se ha traducido en un cambio en las estrategias de reproducción que ahora se asientan en una menor descendencia y en una concentración de los

\footnotetext{
${ }^{22}$ En un sugerente ensayo, Julio Pérez Díaz (2002) ha analizado las consecuencias para la sociedad española de la emergencia de una nueva edad de la muerte pero no centrándose en el envejecimiento de la población, sino en otra novedad histórica reciente a la que él denomina $<<$ madurez de las masas $>>$, esto es, en el hecho de que "la mayor parte de los integrantes de una cohorte de nacimientos sobreviva al menos hasta la madurez" (considerando "maduras a las personas que ya han cumplido alrededor de cincuenta años, a efectos estadísticos el límite de la vida fecunda femenina”). Según este autor, en sí mismo el advenimiento de la madurez de masas "ha revolucionado las dinámicas demográficas” por: a) constituir una "transición sin precedentes en la manera de reproducirse", es decir, en la manera de organizar el tiempo de vida, y; b) porque "su mera presencia obliga a reformular todas las relaciones verticales" entre las distintas edades.

${ }^{23}$ En esa "invención" se incluye asimismo la infancia tal como se la entiende hoy, ya que durante todo el régimen demográfico antiguo la supervivencia en las primeras etapas de la vida era tan incierta que la vida social necesariamente estaba supeditada a la vida de los adultos, mientras que el resto de las edades 0 eran invisibles, o eran desechables, o eran "incompletas", o eran "seniles" (Pérez Díaz, 2002:112-118; Ariès, 1987).
} 
nacimientos en el tiempo. La "esperanza de vida” de las uniones conyugales ha aumentado, lo que ha permitido completar la crianza de la prole en pareja y ha retrasado la orfandad garantizando a los infantes que sus progenitores, o incluso sus abuelas y abuelos, vivan hasta que ellos alcancen bien entrada la madurez. La posibilidad de cumplir las bodas de oro matrimoniales no es excepcional, como tampoco lo es que un matrimonio, una vez vacío el nido, pueda vivir veinte años más solo, “uno frente a otro, como el primer día”, lo que inevitablemente ha tenido consecuencias profundas en la naturaleza de las uniones conyugales, en la concepción de las mismas, en la forma de vivirlas y en lo que se espera de ellas (Girard, 1986:120); consecuencias que también se manifiestan a través del incremento del número relativo de rupturas matrimoniales ${ }^{24}$.

Todas estas mutaciones demográficas derivadas directa o indirectamente de la transición de la mortalidad han supuesto asimismo una gran transformación en la estructura etarea de las poblaciones, que ha desembocado necesariamente en una profunda reorganización de las relaciones entre generaciones. Así, mientras que en las sociedades tradicionales las generaciones se sucedían, en las sociedades modernas, además, se superponen pudiendo coexistir simultáneamente, durante un periodo dilatado de tiempo, 3 o 4 generaciones con filiación directa; y si en aquéllas las relaciones entre generaciones eran básicamente horizontales -entre personas de edades similares que competían por los recursos necesarios de cada edad-, en las sociedades más desarrolladas existe una integración vertical entre generaciones -entre individuos de distintas cohortes que compiten por, pero que también comparten, recursos diferentes. Estos cambios en la estructura demográfica por edad constituyen, según Loriaux (1995a:11, 1995), el mayor desafío al que se enfrentan las sociedades que están envejeciendo (como consecuencia de la caída de la mortalidad y el incremento de la longevidad), por los condicionantes que introducen en la cohabitación entre generaciones en la actualidad y cuyos efectos pueden ser "espectaculares" en el futuro, condicionantes que inciden en todos los ámbitos de la vida social ${ }^{25}$.

\footnotetext{
${ }^{24}$ Fourastié (1954) observa en este sentido que, en las sociedades premodernas, los hombres de 25 a 30 años "contraían uniones que sólo eran quebrantadas por la muerte, pero que duraban en promedio menos de veinte años. En la actualidad, hay jóvenes (...) que en principio siguen comprometiéndose para toda la vida; pero esta vez significa para casi cincuenta años”. Según Thomas (1983:177), en esta evolución estaría un posible origen del incremento de las tasas de divorcio, de la evolución hacia un tamaño familiar más reducido (la familia nuclear) y el abandono por parte de las familias de los parientes de edad más avanzada.

${ }^{25}$ En esta línea, Reher (2003:47-49) considera muy probable que los cambios en las distintas estructuras de la población, especialmente en la distribución por edades, se conviertan en frenos importantes para la evolución económica futura e, incluso, para el mero "mantenimiento de los niveles de vida alcanzados hasta ahora". La incidencia en múltiples ámbitos del incremento absoluto y relativo de la población anciana, junto con la reducción en los próximos años de la población en edad laboral, llevan a Reher a afirmar que "la población ha dejado de ser compañero de viaje para la creación de riqueza y comienza a plantearle serios obstáculos. Es posible que en las décadas venideras, la población deje de ser una variable económica importante para convertirse en la variable económica clave”.
} 
CUADRO 4.1.: CAMBIOS HISTÓRICOS EN EL CALENDARIO DEMOGRÁFICO DEL CIUDADANO EUROPEO ${ }^{\mathrm{a}}$

\begin{tabular}{|l|c|c|c|c|}
\hline & S. XVIII & $\begin{array}{c}\text { Hacia } \\
\mathbf{1 9 0 0}\end{array}$ & $\begin{array}{c}\text { Hacia } \\
\mathbf{1 9 4 5}\end{array}$ & $\begin{array}{c}\text { Hacia } \\
\mathbf{1 9 9 2}\end{array}$ \\
\hline Duración media de vida (mujeres) & 25,0 & 50,0 & 65,0 & 80,0 \\
\hline Mortalidad Infantil (por cada mil nacidos vivos) & 250,0 & 150 & 70,0 & 7,0 \\
\hline $\begin{array}{l}\text { Edad media al contraer matrimonio por primera vez } \\
\text { (mujeres) }\end{array}$ & 25,0 & & 24,0 & 25,0 \\
\hline $\begin{array}{l}\text { Número de mujeres que sobreviven a esta edad (por } \\
\text { cada mil nacidos vivos) }\end{array}$ & 450 & 690 & 920 & 980 \\
\hline Número de nacimientos por mujer & 6,5 & 4,5 & 2,5 & 1,8 \\
\hline $\begin{array}{l}\text { Duración media de vida después de contraer } \\
\text { matrimonio (mujeres) }\end{array}$ & 25,0 & 40,0 & 50,0 & 55,0 \\
\hline $\begin{array}{l}\text { Duración mediana de la pareja (no rota por el divorcio) } \\
\text { Edad media en la que el hijo se queda huérfano de al } \\
\text { menos uno de sus padres }\end{array}$ & 17,0 & & 38,0 & 46,0 \\
\hline Porcentaje de matrimonios rotos por el divorcio & 0,0 & 25,0 & 35,0 & 45,0 \\
\hline $\begin{array}{l}\text { Duración media de vida después de la jubilación (60 } \\
\text { años) (hombres) }\end{array}$ & 8,0 & & 10,0 & 20,0 \\
\hline
\end{tabular}

a Edades en años.

Fte: COMISIÓN EUROPEA (1994): La situación demográfica en la Unión Europea. Informe 1994, DGV-COM(94)595., pp.18. Los datos de 1900 se han tomado de Loriaux (1995:12).

En efecto, la prolongación de la vida media derivada del control de la mortalidad, además de las consecuencias más o menos inmediatas sobre el resto de dimensiones y estructuras poblacionales, ha trascendido el ámbito demográfico irrumpiendo en otras dimensiones sociales en las que ha creado asimismo las condiciones necesarias para que afloraran profundas mutaciones. Éstas son diáfanas en los ámbitos de la organización del trabajo, el ocio, la Seguridad Social, las relaciones de poder de todo tipo, los valores culturales, las transmisiones patrimoniales ${ }^{26}$, etc.

Por su relevancia en la vida cotidiana, son paradigmáticas en este sentido las transformaciones concretas observadas en el devenir histórico de la institución familiar. En este ámbito, toda una serie de estrategias familiares se han visto afectadas al generarse nuevos tipos de relaciones sociales derivadas de los cambios en la mortalidad: los roles familiares, las actividades de las mujeres, la duración de la infancia y la juventud, los procesos de socialización, las redes de parentesco, las relaciones de pareja, las restricciones familiares sobre el matrimonio, los comportamientos reproductivos, las prácticas de herencia, las economías familiares, las formas de co-residencia de los ancianos y los adultos jóvenes, los lazos entre la familia conyugal y el grupo familiar amplio, etc. (Meil, 2011; Reher, 2003, 1996; Pérez Díaz, 2005, 2002; Lamo de Espinosa, 1995, Loiraux, 1995a). Por ejemplo, el alargamiento de la

\footnotetext{
${ }^{26}$ Un ejemplo diáfano de esos cambios se ha producido en la institución de la herencia, que ha pasado de ser una cesión constreñida al momento de la muerte, a una estrategia más libre de transmisión patrimonial paterno-filial a lo largo de la vida (Pérez Díaz, 2002:161).
} 
esperanza de vida al nacer de 35 años a casi 80 años ha implicado que, sin crecimiento poblacional, las necesidades sistémicas de reproducción se reduzcan a menos de la mitad, ya que la mayoría de los recién nacidos llegan hasta la madurez. Este incremento en la longevidad media, junto la disponibilidad de métodos anticonceptivos eficaces, ha reducido el número y tamaño de las familias, lo que inevitablemente ha conllevado la entrada en crisis de la institución familiar tradicional como consecuencia de su propio éxito reproductor (Lamo de Espinosa, 1995:51). La "menor necesidad de familia" ha desembocado, a su vez, en nuevas formas de convivencia y nuevos tipos de hogares y, en última instancia, como resalta Lamo de Espinosa, en la sustitución de una sociedad organizada alrededor de redes familiares por otra sociedad que funciona centrada en los individuos ${ }^{27}$.

La incidencia de la transición de la mortalidad sobre las estrategias familiares ha sido especialmente relevante en la modificación de los roles familiares y, sobre todo, en los desarrollados por las mujeres. Sin desdeñar el argumento que deriva la disminución de la fecundidad como resultado de la incorporación de las mujeres al mercado de trabajo, parece más realista sostener el mayor peso de la relación inversa. Es decir, la transición de la mortalidad, que en las primeras fases redujo sobre todo la mortalidad de los infantes, conllevó asimismo una minoración sustantiva del <<tiempo perdido >> por las mujeres y las familias en la crianza ${ }^{28}$ (Reher, 2003:38; Viciana, 2003:17). La desvinculación de las mujeres de la función reproductiva como tarea inevitable y única durante la mayor parte de su biografía ha supuesto una "brutal y liberadora desamortización de su tiempo y de sus energías" (Lamo de Espinosa, 1995:52). Este profundo cambio modificó los comportamientos reproductivos materializados en la disminución de la fecundidad, y ambos procesos crearon las condiciones necesarias para la participación de las mujeres en el mercado de trabajo externo al reducirse el tiempo dedicado a la crianza, pudiendo potencialmente competir con los hombres en ese mercado, alcanzando niveles formativos cada vez más sólidos y, poco a poco, logrando una igualdad de trato mayor, lo que en última instancia derivó en independencia económica y la posibilidad de elegir entre

\footnotetext{
${ }^{27}$ Frente a la tesis clásica conservadora de que una supuesta crisis de valores o ética estaría generando la actual crisis de la familia, Lamo de Espinosa (1995:51) sostiene que, sobre la base de una crisis secular de la misma, es la crisis estructural derivada de la transición demográfica la que constituye el caldo de cultivo de "la llamada <<crisis de valores $>>$, consecuencia y no causa de la crisis de la familia, y que supone otros ethos para regular la vida privada de los individuos, incompatibles con valores vinculados a la reproducción”.

${ }^{28}$ Contrastando el número de embarazos, la crianza, la dependencia filial/materna, de una mujer española media a principios del siglo XX con una de finales del mismo, Reher (2003:38) ha estimado que, mientras la primera invertía alrededor de 25 años de su vida en las tareas reproductivas directas, la segunda dedica entre 8-10 años a esas funciones. Este diferencial, significativo en sí mismo, acrecienta su importancia relativa si se toman en consideración las distintas condiciones estructurales en las que se producen. Así, mientras la primera finalizaba su labor de crianza cerca de los cincuenta años y próxima a la vejez (con lo que la capacidad de ahorrar de las familias sólo era una posibilidad real entre los 50 y 60 años de edad), la segunda, con una longevidad media mucho mayor, aunque inicia más tarde su periodo de crianza lo finaliza antes, con ayudas institucionales, buena salud y muy alejada de la vejez.
} 
otras alternativas distintas a la única e ineludible opción posible en las sociedades tradicionales, la institución matrimonial ${ }^{29}$ (Loiraux, 1995a:15-16). En última instancia, por tanto, lo que para muchos autores constituye uno de los cambios sociales más importantes del siglo XX, la incorporación de las mujeres al mercado de trabajo, tiene sus raíces en la transición de la mortalidad y en la contribución de la misma en términos de reducción de `pérdidas` de tiempo, dinero y recursos en las economías familiares, en la consecuente liberación de recursos desde el trabajo reproductivo ${ }^{30}$ hacia el trabajo productivo, y en el incremento de la productividad sobre todo de las mujeres.

Girard (1986:229), al analizar las consecuencias de la transición demográfica y en especial de la transición de la mortalidad, resume muy gráficamente el alcance social de las mismas: "la condición humana no ha cambiado, el hombre sigue siendo mortal, pero el cortejo de los vivos tiene un aspecto totalmente diferente”. Es una comitiva en la que los individuos ya no se ven embargados por sentimientos de fragilidad y desamparo y necesitan cubrirse con el manto protector del grupo, sino que cada uno de ellos adquiere valor en sí mismo, un carácter específico que no poseía en las sociedades tradicionales. En la que ya no se mimetiza con y en el grupo, sino que adquiere su propia identidad, autonomía y personalidad, independientemente de él. En la que ha germinado el individualismo tal como se manifiesta hoy, fruto, en última instancia, de la transición de la mortalidad.

La transición demográfica (la transición de la mortalidad) no se ha desarrollado de forma homogénea en el espacio y el tiempo para toda la población mundial. Existen diferencias notables entre países, y entre regiones dentro de cada país. La heterogeneidad espacial se observa en el calendario, la duración, el ritmo y el nivel de intensidad del proceso. Tampoco en su origen han estado presentes las mismas causas en todos los lugares. A grandes rasgos, en lo relativo a las diferencias entre países se puede distinguir entre la evolución de los países desarrollados y la del resto de los países. El descenso de la mortalidad en los primeros ha tenido lugar de manera más temprana, lenta y gradual que en los segundos, donde se ha producido de

\footnotetext{
${ }^{29}$ La ruptura de la hegemonía de la institución familiar, desintegrada en múltiples alternativas (cohabitación, unión libre, soltería, familia monoparental o monoparental, etc.), es el fin de la carrera $F$ (Femmes, Foyers, Familla, Fidélié), como vía obligada del ciclo de vida de las mujeres (Loiraux, 1995a:16).

${ }^{30}$ En su análisis sobre "la revolución reproductiva” Garrido (1996) afirma que, de igual manera que con las sucesivas revoluciones tecnológicas, por ejemplo, con la revolución industrial, a la par que se lograba incrementos de la productividad se expulsaba a la mano de obra excedente de los sectores afectados por las innovaciones, la modernización en el ámbito específico de la reproducción de la población conllevó un exceso sobre la "mano de obra" necesaria para "la producción de hijos" en el sector de la reproducción.
} 
forma mucho más tardía, rápida y abrupta ${ }^{31}{ }^{32}$. No obstante, y si bien unas condiciones geográficas o climáticas determinadas generan por sí mismas problemas específicos de salud y desarrollo, es posible identificar a grandes rasgos perfiles comunes en la declinación de la mortalidad.

En el Cuadro 4.2. se recoge la evolución de distintos indicadores de mortalidad que muestran las diferencias de calendario y duración de la transición de la mortalidad entre uno de los países europeos en que antes comenzó y entre los que más ha durado, Suecia, y uno de los países desarrollados en que más tarde se inició y entre los que se ha desarrollado en relativamente menos tiempo, España. Mientras la población sueca modernizó su demografía lentamente a lo largo del siglo XIX, se evidencia por el contrario que la población española durante ese periodo, y a pesar de una caída en la T.B.M. hasta el 28\%, se mantuvo en unos valores característicos del Régimen Demográfico Antiguo. De hecho, los distintos indicadores de mortalidad españoles a principios del siglo XX no sólo muestran una mortalidad superior a la correspondiente a Suecia un siglo antes, sino que incluso certifican que se produjo un empeoramiento relativo durante ese periodo: si en el año 1800 existía una diferencia de diez años entre las e(0) de ambos países, en el año 1900 esta diferencia aumenta hasta los veinte años. Así, las generaciones más mayores de la población española actual nacieron y pasaron su infancia en un entorno de penuria y de determinismo ante la muerte característico de las primeras etapas de la transición demográfica. Desde inicios del siglo XX, el descenso de la mortalidad en España lentamente se acelera y aproxima a los niveles alcanzados por la mortalidad de Suecia; a mediados de siglo las diferencias relativas todavía continúan siendo importantes (9,7 años menos de esperanza de vida; 47,8 puntos de diferencia en la TMI); diferencias que se han reducido sustancialmente a finales del siglo XX. Los datos comparativos de mortalidad a nivel internacional más recientes sitúan a la población española como una de las que tienen indicadores más favorables, hecho que se puede comprobar en el Cuadro 4.2. en el que se observa que la aproximación a Suecia es cada vez más estrecha.

\footnotetext{
${ }^{31}$ Estas diferencias vienen motivadas por las causas que han originado las transiciones de la mortalidad en uno u otro tipo de país. Mientras que en los países desarrollados ha surgido, como se ha descrito arriba, fruto de su evolución interna, en los menos desarrollados -a pesar de que no exista ningún ejemplo histórico de una transición de la mortalidad realizada independientemente de una evolución socioeconómica más general (Chesnais, 1988:128)-, la reducción ha sido fruto casi exclusivamente de intervenciones externas a los propios países. Campañas organizadas por instituciones internacionales para luchar contra determinadas epidemias, transferencias de tecnologías y avances médico-sanitarios (vacunas, antibióticos, insecticidas, etc.). En definitiva, lo que Vallin ha denominado <<trasplante de cultura $>>$ que ha procurado en los países menos desarrollados una transición de la mortalidad rápida y exógena.

${ }^{32}$ Un ejemplo ilustrativo del contraste entre las transiciones de la mortalidad en países desarrollados y menos desarrollados es recogido por Cipolla (1980:116-118), quien señala cómo el empleo de DDT en Ceilán (actual Sri Lanka) para eliminar el mosquito causante de la malaria redujo en un periodo de siete años, los comprendidos entre 1945 y 1952, la T.B.M. de 22 a 12 muertos por cada 1.000 habitantes, mientras que en Inglaterra, para lograr un descenso semejante, se necesitaron más de 70 años.
} 


\begin{tabular}{|c|c|c|c|c|}
\hline \multicolumn{5}{|c|}{$\begin{array}{l}\text { CUADRO 4.2.: EVOLUCIÓN DE LOS INDICADORES DE MORTALIDAD EN } \\
\text { SUECIA Y ESPAÑA }\end{array}$} \\
\hline & & $\begin{array}{l}\text { Tasa Bruta de Mort. } \\
\text { (T.B.M.) (\%o) }\end{array}$ & $\begin{array}{c}\text { Tasa de Mortalidad } \\
\text { Infantil (T.M.I.) (\%o) }\end{array}$ & $\begin{array}{l}\text { Esperanza de Vida al } \\
\text { Nacer }(\mathbf{e}(\mathbf{0})) \text { (Años) } \\
\end{array}$ \\
\hline \multirow{2}{*}{$\bigodot_{\infty}^{\infty}$} & & 26 & 200 & 37,4 \\
\hline & ESPAÑA & 39 & 250 & 27 \\
\hline \multirow{2}{*}{ ஓి } & SUECIA & 16 & 98 & 54,3 \\
\hline & ESPAÑA & 28 & 200 & 34,7 \\
\hline \multirow{2}{*}{ 음 } & & 10 & & 71,8 \\
\hline & ESPAÑA & 10,8 & 69,8 & 62,1 \\
\hline \multirow{2}{*}{ gి } & & 10,7 & 3,4 & 78,8 \\
\hline & ESPAÑA & 9,3 & 4,5 & 78,0 \\
\hline \multirow{2}{*}{ ํㅗㅇ } & SUECIA & 10,2 & 2,4 & 79,8 \\
\hline & ESPAÑA & 8,9 & 3,8 & 79,3 \\
\hline
\end{tabular}

\subsubsection{TRANSICIÓN EPIDEMIOLÓGICA}

"Los muertos se hacen en las sábanas" S. de Beauvoir

Al margen de las diferencias en el calendario, la duración y la intensidad del proceso, el descenso secular de la mortalidad en los países desarrollados no ha sido lineal en el tiempo observándose en todos ellos un estancamiento en la reducción de la fuerza de la mortalidad, medida en términos de e(0), en la década de 1960. Esta estabilización, cuando no retroceso, de la evolución ascendente de la e(0) estuvo motivada por el control efectivo y casi definitivo de la mayoría de las enfermedades infecto-contagiosas tradicionales (Vallin, 1995c:5). Era tal el peso psicológico heredado por la incidencia de estas enfermedades en el pasado que se interpretó la estabilización de la e(0) como que ya no existían mayores posibilidades de reducción de la mortalidad y que se había llegado al final del proceso de modernización en ese ámbito, “al final de una época”, al final de la transición de la mortalidad (Caselli, Meslé y Vallin, 1995:11) ${ }^{33}$.

\footnotetext{
${ }^{33}$ Fue tan intensa la impresión de que la estabilización de la mortalidad en los años sesenta significaba que se "había tocado fondo", que se interpretó como que se habían alcanzado los límites biológicos de la vida humana (Caselli, 1993c:123). Otros autores, por su parte, atribuyeron este estancamiento en la evolución de la e(0) al deterioro progresivo del medio ambiente y a los efectos nocivos de algunos procesos de producción que conjuntamente incrementaban los riesgos de muerte en las edades adultas. En cualquier caso, la asunción de la estabilización definitiva de la e(0) tuvo efectos perversos para los
} 
Sin embargo, desde la década de 1970 hasta hoy se ha producido una recuperación de la tendencia descendente de la mortalidad con el consiguiente, aunque comparativamente menor, incremento de la e(0). La explicación de esta recuperación hay que buscarla, como se desarrolla a continuación, en un cambio profundo en todas las dimensiones de la estrategia sanitaria que ha permitido nuevos progresos en la lucha contra la muerte al modificar la incidencia de las causas directas de muerte. Las consecuencias de esta evolución pueden observarse claramente en las transformaciones de los perfiles epidemiológicos de la mortalidad. Mutación que al hacer aflorar nuevas dimensiones en el enfrentamiento a la muerte, por ejemplo con el alargamiento del tiempo de dependencia o el de la agonía, ha contribuido también a la transformación de la mirada sobre ella.

Más allá del descenso de la intensidad y los cambios de calendario de la muerte, la transición de la mortalidad queda asimismo definida por una profunda reestructuración de las principales causas de fallecimiento. Esta reestructuración del perfil epidemiológico se ha desarrollado según una tendencia general razonablemente discernible que Omran (1971) definió como $<<$ Transición Epidemiológica $>{ }^{34}$, y que transcurre paralela al cambio demográfico descrito por la teoría de la transición demográfica. De hecho, la teoría de la transición epidemiológica analiza los cambios en los patrones de salud y enfermedad sobre la base de sus interacciones -como causa y como efecto-, con los determinantes demográficos y socioeconómicos constituyentes del complejo proceso de modernización. Partiendo de que "la mortalidad es un factor fundamental en la dinámica de la población”, Omran estableció que “durante la transición, se produce un cambio a largo plazo en los patrones de mortalidad y enfermedad por el que las pandemias de infección son gradualmente desplazadas por las enfermedades degenerativas y las producidas por el hombre (“man-made”) como la causa principal de morbilidad y primera causa de muerte”.

En este tránsito se suceden, por sustitución, tres fases identificadas cada una de ellas por el predominio de unas determinadas causas de muerte. En el “modelo clásico u occidental”’3 la

propios estudios sobre la mortalidad: por un lado, al dejar ésta de tener interés, se abandonaron en gran medida; por otro lado, justificó que desde entonces se utilizaran hipótesis de mortalidad estable, tanto en intensidad como en estructura, en las proyecciones de población (Gómez Redondo, 1995:81).

${ }^{34} \mathrm{Al}$ igual que ocurre con la teoría de la transición demográfica, la teoría de la transición epidemiológica es un instrumento útil, ya que permite describir los cambios históricos en la mortalidad por causa, pero que, al adolecer de ciertas limitaciones, ha recibido críticas fundadas. Pueden consultarse resúmenes de las críticas conceptuales, metodológicas, ideológicas y empíricas realizadas a la transición epidemiológica en Gómez (2001); Vera Bolaños (2000); y Bernabeu Mestre y Robles (2000).

${ }^{35}$ Comparando los patrones de mortalidad de diferentes sociedades en distintos momentos del tiempo, Omran diferenció entre tres modelos de transición epidemiológica: a) "el modelo clásico u occidental”, descrito en el texto y correspondiente a la mayoría de los países europeos; b) “el modelo acelerado de 
primera etapa, <<la edad de la pestilencia y el hambre $>>$, corresponde a la época pre-moderna (hasta 1875), está caracterizada por una mortalidad intensa y muy variable y una e(0) baja y oscilante entre los 20 y 40 años, siendo los principales determinantes de la muerte los obstáculos positivos malthusianos: epidemias, hambre y guerras. En la segunda etapa (desde 1875 hasta 1930), a la que denomina <<la edad del retroceso de las pandemias $>>$, la mortalidad declina progresivamente, y aumenta la e(0) hasta los 50 años. Esta reducción de la mortalidad se origina en la progresiva desaparición de las crisis epidémicas durante los siglos XVIII y XIX y en el lento control de las enfermedades infecto-contagiosas y parasitarias que, en todo caso, continúan siendo las causas de muerte más frecuentes. Los determinantes de esta reducción de la mortalidad ordinaria se encuentran principalmente en la interacción de factores “ecobiológicos” -relación entre los agentes de enfermedad, hostilidad del medio y resistencia del huésped- y “socioeconómicos” -mejoras en los hábitos de salud, higiene y nutrición-, mientras que la influencia de los factores médicos no se percibirá hasta más avanzado el siglo XX. La tercera etapa (a partir de 1930), <<la edad de las enfermedades de degeneración y de las enfermedades producidas por el hombre (man-made) ${ }^{36}>>$, es la característica de las sociedades que han alcanzado un nivel bajo y estable de mortalidad; ésta se produce mayoritariamente por enfermedades crónicas y degenerativas, la e(0) excede de los 50 años, y la fecundidad es el factor crucial en el crecimiento de la población. Esta sucesión de etapas, sin embargo, no ha sido (no está siendo) una secuencia lineal de fases estancas, sino que en varios momentos de la transición esas etapas pueden superponerse entre sí, coexistiendo las "patologías pre y postransicionales” en la misma población ${ }^{37}$ (Frenk, 1994: cap.III).

transición clásica”, en el que siguiendo inicialmente el modelo descrito en el texto, la transición de la mortalidad se vio beneficiada por los avances científico-médicos produciéndose en un periodo mucho más corto de tiempo, como ha ocurrido en Japón; y c) "el modelo contemporáneo o retrasado", que caracteriza a la mayoría de los países menos desarrollados después de la Segunda Guerra Mundial, en el que la mortalidad ha decrecido muy rápidamente fruto más de las transferencias tecno-médicas importadas desde las sociedades desarrolladas que de la incidencia de factores socioeconómicos como en el modelo clásico .

${ }^{36}$ En su artículo seminal Omran (1971) no explicó qué significaban las enfermedades producidas por el hombre ("man-made diseases”), sin embargo, posteriormente especificó que en ellas inclúa "daños de radiación, enfermedades mentales, dependencia de drogas, accidentes de tráfico, riesgos laborales" (Omran, 1982).

${ }^{37}$ Frenk et al (1991:34-35; 1989) advierten sobre esta visión lineal y unidireccional de la transición epidemiológica. Por ello, sugieren que en la aplicación de la misma al caso de los países de renta media se tengan en cuenta además cuatro "atributos": a) "la dirección del cambio", ya que es incorrecto asumir que el suave cambio debe ocurrir en una única dirección, y se puede producir la emergencia de nuevas infecciones o el resurgir de otras previamente controladas dando lugar a una pequeña o amplia "contratransición"; b) "la secuencia de etapas", teniendo en cuenta que en la realidad la transición no se produce a través de etapas claramente separadas en las que toda la población pasa de una a otra, sino que mientras unos estratos de la población han podido controlar las enfermedades infecciosas otros estratos puede que no lo hayan hecho y, por tanto, en una misma población se observen simultáneamente etapas superpuestas; c) "el punto de inicio y el ritmo"; y d) "la distribución de los perfiles epidemiológicos" entre los distintos grupos de población ya que la existencia de tasas de mortalidad diferentes entre estratos sociales o regiones de un país genera una "polarización epidemiológica" que produce un empeoramiento de las desigualdades en la salud. 
La transición epidemiológica, por tanto, es un proceso de cambio continuo que desemboca en una situación en la que, a diferencia de las etapas anteriores -en las que el "escenario de la salud" estaba dominado por enfermedades agudas, asociadas a carencias primarias (nutrición, higiene, vivienda, agua), de las que los individuos bien se recuperaban bien sucumbían a ellas, es decir, estaba controlado por la mortalidad-, las enfermedades ligadas a factores genéticos, conductas de riesgo y carencias secundarias (seguridad personal o ambiental, oportunidades de realización), en general, no provocan un desenlace fatal inmediato, con lo que se produce una progresiva separación entre una morbilidad creciente y una mortalidad decreciente y aquélla constituye la fuerza predominante del “escenario de salud”. Esta situación aparentemente paradójica responde, como señalan Frenk (1994) y Verbrugge (1988), a una complejidad de causas: a) el incremento del peso relativo de las enfermedades crónicas, de mayor duración que las enfermedades infecto-contagiosas; b) el menor éxito de los avances médicos a la hora de prevenir las "patologías postransicionales", respecto a lo ocurrido con las "patologías pretansicionales”; c) la mayor disponibilidad de medidas paliativas que dilatan la llegada de la muerte; d) el aumento general de la supervivencia, que facilita la transmisión de enfermedades con una base genética, como la diabetes, incrementándose de esta forma las proporciones de personas con riesgo de sufrir enfermedades en las generaciones siguientes; y, e) el cambio cultural y el incremento del nivel educativo, que amplían la definición de las experiencias que son consideradas como enfermedad. Como resultado de lo anterior se ha producido un incremento en la prevalencia y la duración de las enfermedades crónicas.

Estos cambios, determinados por la mutación radical de las pautas de la morbilidad, conllevaron además una profunda transformación del significado de la enfermedad, de la propia concepción de la salud y, por ende, del enfrentamiento con la muerte. En efecto, el control sobre las enfermedades infecciosas y parasitarias, y la reducción de su incidencia demostró la importancia que los factores sociales tenían en la terapéutica de las mismas: la prevención, que requería la colaboración de toda la sociedad en tareas de higiene y salubridad; la detención del progreso de la enfermedad, además de con fármacos, con aislamientos o cuarentenas. Este cambio en la lucha contra las enfermedades conllevaba asimismo el reconocimiento de la importancia de los factores sociales en su causalidad, lo que de paso debilitó aquellos planteamientos teóricos que, desde la Medicina, asumían sólo criterios orgánicos en la etiología de las mismas. El creciente peso, absoluto y relativo, de las enfermedades degenerativas no hizo más que reforzar la importancia de los factores sociales en el proceso salud/ enfermedad/muerte: la mayoría de estas enfermedades tienen un origen multicausal y son, en gran medida, fruto de la "biografía social" de los individuos. Todo ello, inevitablemente, transformó la mirada sobre la enfermedad en sus diversas vertientes: en su concepción, al reforzarse, frente a la visión 
puramente biológica, la dimensión social de la enfermedad reconociendo la importancia de su íntima relación con el medio ambiente físico y social; en su tratamiento, al ampliar la prevención de la enfermedad más allá de controles ambientales coyunturales hasta una protección que implica a los individuos durante toda su vida; por último, en sus múltiples consecuencias sociales, con especial incidencia en la profunda mutación de las funciones sociales de las personas enfermas derivada de la notable ampliación del tiempo de enfermedad ${ }^{38}$ (Rodríguez, 1987: cap.1).

Estas transformaciones en el significado de la enfermedad, ligadas a la evolución de la morbilidad, afectaron al propio concepto de salud. Entendida la salud como la <<normalidad >> frente a la <<anormalidad $>>$ de la enfermedad, la superación de la concepción puramente organicista de ésta amplió el concepto de salud desde la mera "ausencia de enfermedad” hasta una idea más amplia en la que se incluyen los determinantes psicológicos y sociales ${ }^{39}$ (Rodríguez y García, 1996:354).

Asimismo, la transformación radical en las pautas de morbilidad repercutió en la lucha contra la muerte. De hecho, el perfil cambiante de la mortalidad descrito en la transición epidemiológica refleja los logros históricos alcanzados en ese enfrentamiento. Hasta la década de 1960, el lento control y la eliminación de la mortalidad prematura y evitable provocada por las enfermedades infecto-contagiosas, de carácter exógeno, en todas las edades, pero que diezmaban especialmente en la infancia. Desde entonces, la reducción de una mortalidad más compleja causada fundamentalmente por enfermedades degenerativas difícilmente eludibles. El carácter endógeno de éstas no excluye la incidencia de factores de riesgo externos en su causación, y la identificación de los mismos permitió encontrar los medios para hacer retroceder a estas enfermedades concentrándose su incidencia en edades cada vez más avanzadas (Vallin, 1995c:6).

\footnotetext{
${ }^{38}$ Por su mayor duración, las enfermedades crónicas no sólo conllevan costes económicos más altos al ser los tratamientos más largos, sino que alteran en mayor medida la vida cotidiana de los individuos al tener que ajustar y desajustar continuamente sus roles. Esto implica que "los efectos psico-sociales son más importantes en este tipo de enfermedad que en las enfermedades agudas o contagiosas, debido principalmente a su irreversibilidad que conduce de forma generalmente lenta pero inexorable a la muerte. Así, un enfermo agudo no ve devaluada su posición social por su enfermedad, y su dependencia con respecto a otros es generalmente breve; sin embargo, en los enfermos crónicos el estatus social se devalúa por su prolongada incapacidad para la realización de sus obligaciones, y pasa normalmente a depender de los demás hasta el final de su vida, incrementando esa dependencia gradualmente. Todo ello produce en el enfermo crónico un alto grado de inseguridad e inadaptación” (Rodríguez, 1987:24).

${ }^{39}$ De hecho, fue este tránsito en la percepción de la enfermedad el que indujo la definición de salud como <<el estado de absoluto bienestar físico, mental y social, y no la mera ausencia de enfermedad >>, asumida en el Congreso de Constitución de la Organización Mundial de la Salud de 1948 (Rodríguez y García, 1996:354).
} 
Esta transición en las causas de muerte se plasma en el Gráfico 4.1. a través de la comparación de los modelos de un país desarrollado típico, con su transición demográfica finalizada -bajas natalidad y mortalidad y población envejecida-, y un país menos desarrollado típico al comienzo de su modernización demográfica -altas natalidad y mortalidad y población joven- (Naciones Unidas, 1973). En el gráfico se aprecia el contraste entre dos situaciones dominadas por grupos de causas de muerte diferentes: las enfermedades infecciosas y parasitarias, y las enfermedades respiratorias en los países menos desarrollados provocan por sí solas alrededor del $40 \%$ del total de defunciones, mientras que las enfermedades cardiovasculares, el cáncer y las causas violentas originan aproximadamente el 20\%; por el contrario, la distribución de la mortalidad por causas en los países desarrollados se caracteriza porque estas tres últimas causas -enfermedades crónicas y violencias ${ }^{40}$ - provocan más del $70 \%$ de los decesos, mientras que las dos primeras originan un 10\% como máximo.

\section{GRÁFICO 4.1.: DISTRIBUCIÓN PORCENTUAL DE MUERTES POR CAUSA EN MODELOS DE POBLACIÓN SELECCIONADOS}

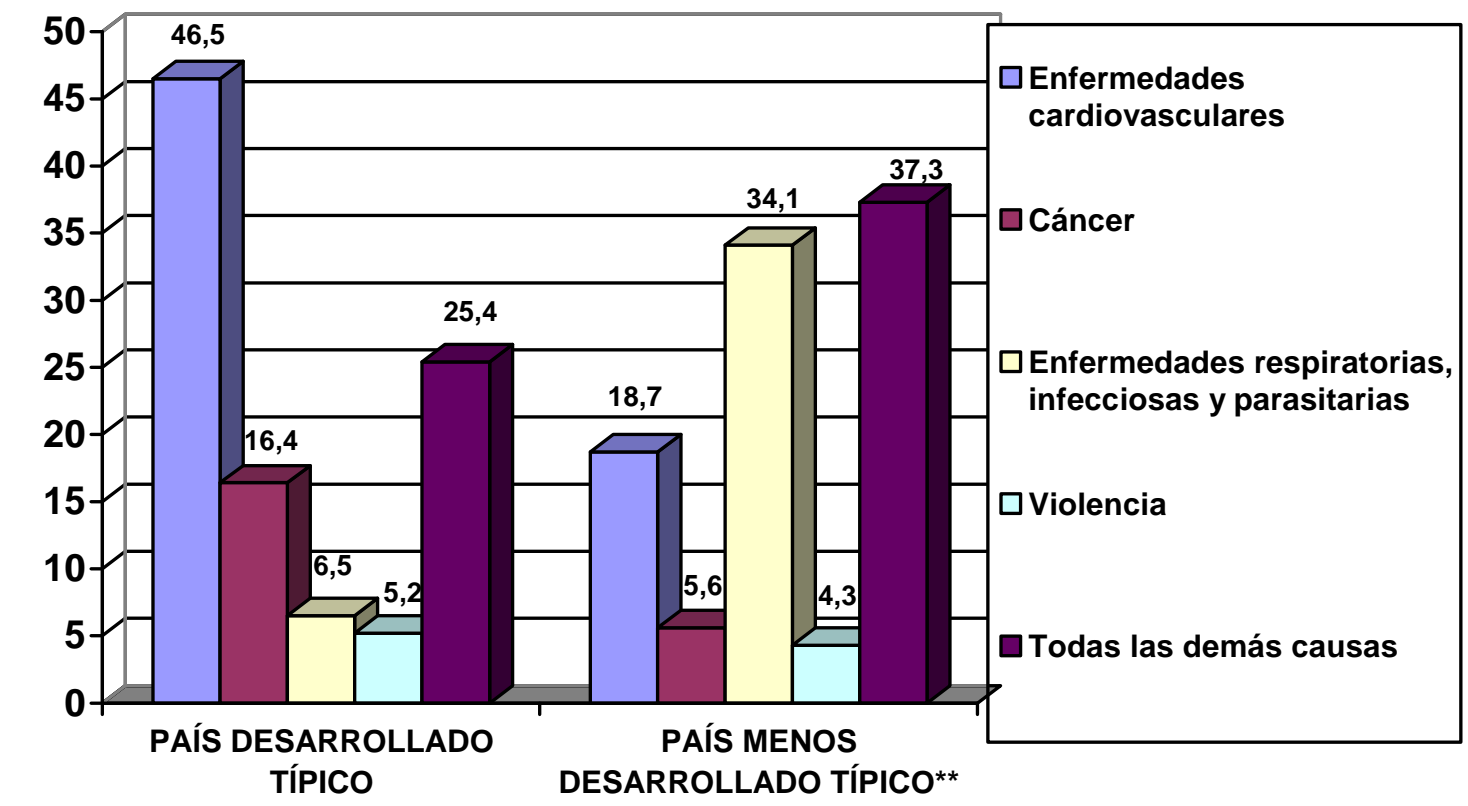

* Modelo de las N.U. en la hipótesis de que EVN= 70 años y la estructura de edades sea "anciana" ** Modelo de las N.U. en la hipótesis de que EVN= 50 años y la estructura de edades sea "joven” Fuente: Boletín de las Naciones Unidas $n^{\circ} 6$ (publicación de Naciones Unidas, $n^{\circ}$ de venta S.62.XIII.2)

La culminación de la transición epidemiológica en una población implica importantes consecuencias demográficas para la misma. Así, supone la reducción de la variabilidad de los niveles de mortalidad de un año a otro, al alcanzarse intensidades bajas y estables en los mismos

\footnotetext{
${ }^{40}$ El término "violencias" incluye un amplio conjunto de diferentes tipos de problemas, cada uno con distintos factores de riesgo, situaciones de riesgo y grupos de riesgo: violencias intencionadas (homicidios, suicidios, guerras) y no intencionadas (accidentes de tráfico, ahogamientos, caídas, envenenamientos, quemaduras, etc.)
} 
(Fogel, 1997). Además, dada la desigual incidencia etaria de las distintas causas de muerte, ante variaciones de la mortalidad el efecto poblacional neto es menor en aquellas sociedades que hayan cubierto su transición epidemiológica ${ }^{41}$.

Algunos autores (Rogers y Hackenberg, 1987; Olshansky y Ault, 1986), admitiendo la capacidad explicativa del esquema teórico elaborado por Omran, consideraron necesario una reformulación del mismo que permitiera explicar los cambios más recientes de la mortalidad y la creciente desconexión entre la morbilidad y la mortalidad. Se considera que estos cambios son consecuencia de la prevención de las enfermedades sociales, por un lado, y de un cierto dominio de las enfermedades endógenas, por otro, y constituían una nueva fase de la transición epidemiológica diferenciada de las anteriores, cuando se perseguía el control de las enfermedades infecciosas. Añadían, en consecuencia, una cuarta fase a dicho esquema en la que resaltaban aquellos aspectos que habían ido emergiendo en los últimos años y quedaban ocultos en él. Así, Rogers y Hackenberg (1987), que denominaron a esta nueva fase como la de las $<<e n f e r m e d a d e s$ híbridas $>>$, subrayaron, por un lado, la creciente importancia relativa de las muertes accidentales y violentas, provocadas en gran medida por “patologías sociales” ligadas a prácticas sociales de riesgo -accidentes, suicidios, homicidios, alcoholismo, drogadicción-, que estaban generando un incremento de la mortalidad entre los jóvenes. Por otro lado, para estos autores la mortalidad se veía afectada asimismo por las consecuencias de estilos de vida potencialmente destructivos - “inactividad física, prácticas dietéticas perniciosas ${ }^{42}$, consumo excesivo de alcohol y tabaco ${ }^{43}$,-, que incrementaban la incidencia de algunas enfermedades

\footnotetext{
${ }^{41} \mathrm{Si}$ bien el efecto letal de las enfermedades infecciosas abarca todas las edades es especialmente relevante entre los infantes, por lo que su incidencia final sobre la evolución de la población es la suma de un efecto directo sobre el tamaño y la estructura por edad (personas que mueren en la infancia, juventud y edades reproductoras) y un efecto indirecto (individuos potenciales que no nacen de gente que muere en esas edades tempranas). Por su parte, las consecuencias letales de las enfermedades degenerativas se concentran en las edades más avanzadas, tienen casi exclusivamente un efecto directo dado que afectan a individuos que están al final de su ciclo vital y han podido formar familias (Santow, 1999:41). Keyfitz (1977), por ejemplo, estimó que para un número similar de muertes por malaria o por enfermedades del corazón, la eliminación de la malaria tenía un efecto sobre el incremento de la población cuatro veces mayor que la eliminación de las enfermedades del corazón.

${ }^{42}$ En la presentación de los resultados de la Encuesta Nacional de Salud 2003, la representante del Ministerio de Sanidad alertaba precisamente sobre la evolución negativa tanto de los datos sobre sedentarismo como los de los hábitos alimentarios y el consiguiente incremento de la obesidad en la población española. Así, por ejemplo, continuando con la tendencia alcista de encuestas anteriores, el 54 `5\% de los encuestados manifestaba no realizar actividad física alguna en su tiempo libre; por otro lado, los lácteos eran el alimento más presente, y en aumento, en la dieta de los españoles (90\%, en 2003; 82\%, en 2001); el 72\% consumían el máximo de carne recomendado -tres veces por semana-, frente al 62\% de 2001; el 34\% de los encuestados consumían diariamente dulces, incluida bollería industrial (el $45 \%$ de los niños menores de 15 años) ( $M^{a}$ de Sanidad y Consumo e INE, 2005). Dulces que, además de incluir azúcar, aportan grasas y entre ellas grasas hidrogenadas (trans) que tienen peores efectos sobre la salud que las grasas saturadas: al acumularse en el abdomen aumentan el riesgo de un accidente cardiovascular o de un infarto (EL PAÍS, 27/06/06:42).

${ }^{43}$ En un estudio sobre una veintena de sustancias adictivas publicado en The Lancet, se midieron nueve parámetros incluidos en tres categorías: daño físico, dependencia y repercusión social. Estimándose el daño máximo posible en un valor de 3, la heroína ocupa la primera posición (28), el alcohol es la quinta
} 
degenerativas (enfermedades del corazón, diabetes, nefritis crónica, cáncer de pulmón, cirrosis y cáncer de hígado) o facilitaban la transmisión de enfermedades infecciosas (por ejemplo, el SIDA).

Olshansky y Ault (1986), por su parte, señalaron que la nueva fase de la transición epidemiológica estaba caracterizada más por una sustitución en las edades de muerte que por la de las causas que la provocaban. Es decir, éstas continuaban siendo las que identificaban a la tercera etapa de la transición epidemiológica -las enfermedades degenerativas y las producidas por el hombre (“man-made”)-, y lo que caracterizaría a la cuarta etapa sería la sustitución de las edades a las que las enfermedades degenerativas tendían a "matar”. Así, la muerte llega en las fases tardías de la vida como precipitado de la influencia del medio a lo largo de un complejo proceso histórico-biográfico. En efecto, dado que la incidencia de las enfermedades degenerativas es el fruto acumulado del estilo de vida y de la actuación de los factores medioambientales, sociales y tecnológicos, la mortalidad por estas causas declina entre los adultos, los jóvenes y los niños y, por el contrario, se desplaza hacia edades cada vez más avanzadas, donde se concentra tanto para los hombres como para las mujeres. De ahí que estos autores denominen a la cuarta fase de la transición epidemiológica como la de las $<<$ enfermedades degenerativas tardías >> . En ese desplazamiento de la mortalidad hacia edades cada vez más avanzadas está, además, el origen de los incrementos no previstos de la e(0) desde la década de $1970^{44}$.

Profundizando sobre las razones de esta nueva dinámica de la mortalidad, Olshansky y Ault (1986:359-361) resaltaron la incidencia de diversas circunstancias históricas cuya contribución relativa, no obstante, era indeterminada. Por un lado, fruto de las etapas anteriores de la transición epidemiológica, aumentaba el número absoluto de personas que sobrevive hasta edades avanzadas produciendo un cambio fundamental en la estructura por edad de la población. Este crecimiento de un "segmento de la población enteramente nuevo”, la población

droga más peligrosa (1'85) y el tabaco es la novena (1'62) (El PAÍS, 24/03/07:33). Por otra parte, a finales del 2007 la multinacional Altadis reconoció que, además de nicotina, alquitrán y monóxido de carbono, el consumo de los cigarrillos de sus marcas (Fortuna, Ducados, Nobel, Gauloises,..) conlleva el de 289 aditivos -sustancias químicas, muchas de ellas tóxicas- cuyo objetivo es aumentar la adicción a la nicotina y disminuir los efectos molestos del tabaco. En El PAÍS (21/10/07:44-45) se puede consultar el listado de los mismos y las funciones para las que se utilizan.

${ }^{44}$ Por este motivo Robine (Robine et al, 2001) denomina a esta cuarta fase de la transición epidemiológica como <<edad de la conquista de la extensión de la vida >>. Incluso, el propio Omran (1998) revisó su propuesta añadiendo dos nuevas etapas: una cuarta etapa a la que denominó <<la edad de la declinación de la mortalidad cardiovascular, el envejecimiento, la modificación de los estilos de vida y la emergencia de enfermedades infecciosas >>, en la que relaciona las variaciones de la mortalidad con los efectos de las innovaciones tecnológicas y los cambios deliberados en los estilos de vida, así como con el rebrote de enfermedades infecciosas tradicionales -malaria, tuberculosis, neumonía-, o la emergencia de nuevas patologías -SIDA-, y; una quinta etapa, proyectando la evolución de la longevidad a mediados del siglo XXI a la que denominó <<la edad de la calidad de vida esperada >>. 
anciana, conllevaba que cada vez más personas se hallasen expuestas a enfermedades notransmisibles y venía acompañado, por tanto, por el aumento de las necesidades y demandas específicas ligadas a las enfermedades degenerativas crónicas y al deterioro psicológico asociado a la edad. Por otro lado, la reducción de la mortalidad infantil y juvenil, que arrastró a la fecundidad/natalidad, determinó un desplazamiento del foco de atención principal de los servicios de salud desde las poblaciones más jóvenes a las de más edad -desde las enfermedades infecciosas a las degenerativas-, liberando recursos de la atención a la infancia y juventud que fueron destinados a la atención de las personas de edad. Asimismo, el desarrollo tecno-médico, por ejemplo de nuevos medicamentos y mejores sistemas de diagnóstico y tratamiento de las enfermedades degenerativas, ayudaba a diferir las muertes por este tipo de enfermedad frenando la progresión de las enfermedades crónicas y reduciendo sus tasas de letalidad. Finalmente, todas estas circunstancias habían venido acompañadas por modificaciones en los estilos de vida relativas a algunos de los principales factores de riesgo que determinan las enfermedades degenerativas: disminución del consumo de tabaco, aumento del ejercicio físico y mejora en los hábitos alimentarios.

El análisis empírico de los cambios en el perfil de la mortalidad por causa en los países desarrollados realizado por G. Caselli (1993a) constata que las enfermedades agudas (esencialmente las infecciosas) eran la principal causa de muerte a principios del siglo XX, representado poco más de un tercio de todas las muertes; si se añaden las enfermedades respiratorias, juntas causaban alrededor de la mitad de los decesos en 1910. En 1930, estos dos grupos de causas de muerte, consideradas también conjuntamente, todavía provocaban el grueso de los decesos, alrededor del 40\%, mientras que las enfermedades del sistema circulatorio causaban entre el $10 \%$ y el $20 \%$ de los fallecimientos y el peso relativo de los cánceres en el total de la mortalidad era mínimo. En la década de 1960, situados estos países en la tercera fase de la transición epidemiológica, el perfil de las causas de muerte cambió sustancialmente respecto a épocas pretéritas. Las enfermedades del aparato circulatorio se erigían en la principal causa de muerte, tanto para hombres como para mujeres, siendo responsables de entre el $30 \% \mathrm{y}$ el $40 \%$ del total de los decesos. Los cánceres eran la segunda causa de muerte y provocaban alrededor del 20\% de las muertes. Por su parte, las enfermedades infecciosas tenían un peso mínimo en el total de la mortalidad. Se asistía ya en los países desarrollados a un proceso de progresiva concentración de los decesos en muy pocas causas de muerte, de tal forma que un número reducido de ellas originaban cerca del $90 \%$ del total de fallecimientos. Además, a diferencia de las enfermedades infecciosas en épocas pretéritas, estas afecciones son crónicas y no conducen de forma inmediata a la muerte. 
Este proceso de concentración ha continuado hasta la actualidad, aunque en los últimos años, y para algunos países, se están produciendo cambios en la jerarquía de las causas de muerte que dominan el perfil de la mortalidad y que sugieren que un nuevo perfil de causa de muerte tiende a emerger (Treas, 1999:78; Caselli, 1993c:4-10). En efecto, la superación de la “crisis” en la evolución de la mortalidad de la década de 1960 y el consiguiente incremento de la esperanza de vida desde los años setenta ha sido relacionado con el inicio de un descenso neto de la mortalidad por enfermedades del sistema circulatorio en las sociedades occidentales. Descenso que ha ido parejo a un incremento neto de los fallecimientos por cánceres de tal forma que esta causa de muerte ha aumentado progresivamente su peso relativo en el total de los decesos de esas poblaciones ${ }^{45}$. No obstante, un análisis más desagregado de la mortalidad por causas pone de manifiesto que esas tendencias varían considerablemente entre países para cada tipo de causa ${ }^{46}$.

\subsubsection{TRANSICIÓN SANITARIA}

"Nunca hallaréis el lugar de mi tumba el lugar exacto de mi tumba que es el poema”.

L.M. Panero

Existe un amplio debate sobre los determinantes subyacentes en este nuevo perfil de la mortalidad por causas de muerte. Este debate ha llevado a que, insistiendo en la misma línea que la transición epidemiológica pero con un planteamiento más amplio, otros autores (Santow, 1999; Caldwell, 1996, 1991, 1986; Vallin, 1995c; Caselli 1993c; Frenk et al., 1991) prefieran

\footnotetext{
${ }^{45}$ Los resultados de distintos estudios epidemiológicos, como los de R. Doll y A. Hill, que en los años cincuenta del pasado siglo demostraron que el riesgo de contraer carcinoma de los bronquios y pulmón era mucho más alto entre fumadores que entre no fumadores (Álvarez, 1999); los de A. Keys, que demostró en el año 1952 la relación entre la presencia de lípidos en la sangre y las enfermedades de las arterias coronarias, y los de J. Morris, que comprobó que la mortalidad por enfermedades de las arterias coronarias era muy inferior en personas cuyas ocupaciones requerían un esfuerzo físico (Florey, 1992), han ejercido una influencia notable en los cambios de actitudes y en los estilos de vida que se han traducido en última instancia en la inversión señalada del perfil de la mortalidad por enfermedades del sistema circulatorio y de algunos tipos de cánceres.

${ }^{46}$ Así, por ejemplo, la mortalidad por enfermedad isquémica del corazón alcanzó su máximo en algunos países, como Francia, al principio de la década de 1960 declinando después, mientras que en otros países, como Portugal o Grecia, esta evolución se produjo mucho más recientemente (Lopez y Cruijsen, 1995). Por otro lado, el aumento del peso relativo del conjunto de la mortalidad por cánceres en los países desarrollados no oculta que en las últimas décadas se haya producido una tendencia descendente en la evolución de algunos tipos de cánceres como por ejemplo los de cuello de útero, colon, recto y testículos en Estados Unidos (Treas, 1999:78), o los de estómago, cuello de útero y mama en el conjunto de la Unión Europea. Incluso, en la evolución creciente del cáncer de pulmón se observan diferencias llamativas entre países: en Finlandia y en Inglaterra alcanzó su tasa de mortalidad máxima alrededor de 1980, descendiendo desde entonces, mientras que en Italia y Francia el máximo no llegó hasta finales de la década de 1990, y se preveía que en Portugal se alcanzará en los primeros años del siglo XXI (Eurostat, 1998:5).
} 
emplear para analizar todo el proceso el marco teórico de la $<<$ Transición sanitaria $>>{ }^{47}$ enunciado por Lerner $^{48}$ en 1973. Desde esta perspectiva -que incluye la transición epidemiológica, la transición de riesgos ${ }^{49}$ y la transición de la asistencia sanitaria ${ }^{50}$-, se asume que la salud y la enfermedad, y en última instancia la muerte, no son consecuencia mecánica y lineal en el tiempo de la influencia de un único factor, sino que constituyen el resultado de un proceso dinámico multicausal en el que intervienen interactuando los entornos social, cultural, económico, político y medioambiental ${ }^{51}$ con el estilo de vida. Horiuchi (1999:57), por ejemplo, relaciona el descenso moderno de la mortalidad por enfermedades cardiovasculares tanto con los avances tecnológicos aplicados a las medicinas curativa e intensiva como con el desarrollo de los sistemas públicos de salud, la elevación de los estándares de vida y los cambios en los estilos de vida ${ }^{52}$.

${ }^{47}$ En Gómez (2001) se revisan los vínculos, semejanzas y diferencias entre la Teoría de la Transición Epidemiológica y la Teoría de la Transición Sanitaria; asimismo, se exponen las críticas metodológicas y sobre todo las ideológicas a ambas teorías, entre ellas su concepción lineal y unidireccional, su trasfondo conservador (legitimador) y su identificación como signo de modernización y progreso.

${ }^{48}$ A la par que Omran acuñaba el término transición epidemiológica, Lerner presentaba "una ponencia al Annual Meeting of the American Public Health Association... y bajo el título de $<<$ Modernization and health: a model of the health transition>> proponía tres etapas en el proceso de transformación de las distintas sociedades: una primera, caracterizada por la baja vitalidad (altas cifras de natalidad y mortalidad); una segunda, donde el rasgo más definitorio sería el aumento del control de la mortalidad; y una tercera, donde la característica más importante sería una conceptualización más amplia de la salud (la lucha contra la mortalidad daría paso a la prevención y la promoción de la salud)” (Bernabeu, 1994:84).

${ }^{49}$ La transición de riesgos describe "los cambios producidos en la exposición a riesgos de la salud ambientales y laborales -desde riesgos "tradicionales" como el agua contaminada o la falta de higiene de los alimentos, a riesgos modernos” como la contaminación atmosférica, el transporte y la modificación y/o aparición de nuevos estilos de vida” (Robles et al., 1995:222). Es decir, su análisis permite identificar los factores de riesgo (estilos de vida, patrones de conducta individuales) que con distinta probabilidad inciden en la pérdida de la salud.

${ }^{50}$ La transición de la atención sanitaria "define la transformación de la forma en que el sistema de salud se organiza para el suministro de servicios y recursos sanitarios” (Robles et al., 1995:222). Describe la evolución de la organización de las respuestas colectivas/individuales a los problemas de salud: beneficencia, hospitalización, medicina preventiva, Sistema Nacional de Salud, etc. (Bernabeu-Mestre).

${ }^{51}$ Manton y colaboradores (Manton et al, 1999), en su análisis de la longevidad humana, afirman que la distinción dominante hasta hoy entre factores endógenos (dotación genética) y exógenos (medio ambiente, en sentido amplio), no es útil para establecer los límites de aquélla, dado que, pueden existir intervenciones externas que muten los mecanismos genéticos considerados inmutables hasta ahora. Así, "el sistema inmunológico puede ser alterado por factores externos y hay evidencia creciente de que infecciones bacterianas y virales pueden ser causas subyacentes de ciertas enfermedades”, como es el caso de los estreptococos malignos como causa de las enfermedades reumáticas del corazón. En este mismo sentido, D. Khayat, copresidente de la Fundación Internacional de Oncología, afirma que "tres tipos de tumores están inducidos en gran medida por agentes infecciosos y que podrían prevenirse"; concretamente, el cáncer de hígado, causado por el virus de la hepatitis B; el cáncer de cérvix, inducido por el papiloma virus; y el cáncer de estómago, en el que está implicada la bacteria Helicobacter pylori (EL PAÍS,24/09/02:34).

${ }^{52}$ Horiuchi cita como ejemplo los problemas de salud derivados de la hipertensión. La prevalencia de ésta estaría reduciéndose parcialmente por el consumo de drogas anti-hipertensión, pero también porque la difusión de refrigeradores ha permitido una gran disponibilidad de alimentos frescos, modificando los patrones de dieta y reduciendo la ingesta de sal. Asimismo, los chequeos médicos permiten detectar en sus primeras fases la hipertensión y los niveles altos de colesterol. Manton, por su parte, resalta el papel jugado por los suplementos vitamínicos y la esterilización de los procesos de producción y distribución de alimentos (Manton et al, 1997). No se puede olvidar, asimismo, la evolución de los medios médicos, preventivos y terapéuticos en la vigilancia y control de la hipertensión, prevención de la angina de pecho 
Según Bauman (2011:87-91), en todas las culturas y lenguas existe un concepto semánticamente equivalente a la palabra <<enfermedad >>. Concepto que designa a ésta como un estado de la persona caracterizado por la ausencia de <<bienestar $>>$, "es decir, una molestia, una incomodidad, una dolencia o aflicción psíquica o física” ${ }^{53}$. Sin embargo, en su uso contemporáneo, el término <<enfermedad >> es utilizado de forma intercambiable con el concepto <<afección médica>>, trasladando con ello la cuestión de la `ausencia de bienestar’a otro registro totalmente diferente, pues pasa de ser un estado para transformarse en una acción, la acción que dicho estado supuestamente requiere y que queda bajo estricto control del sistema sanitario, que es quien determina todas las pautas del reconocimiento de la existencia de enfermedad, del diagnóstico, de su tratamiento y de la prevención para evitarla. Así, entre el conjunto de factores que han acompañado el descenso de la mortalidad y determinado el estado de salud de las poblaciones, además de los económicos ${ }^{54}$, destaca el papel desarrollado por las nuevas estrategias socio-sanitarias que involucran activamente a cada individuo en la lucha contra la enfermedad, modificando comportamientos y estilos de vida y tomando conciencia de que la salud no depende únicamente del sistema sanitario, sino que es fruto de éste más las respuestas sociales e individuales ante la salud y la enfermedad. Por lo que resulta clave el tipo de mediación desarrollada al respecto desde los poderes públicos ya que la salud y la enfermedad además de ser elementos centrales para el buen funcionamiento social determinan

como: el puente coronario (1967), descubrimiento de las propiedades anticoagulantes de la aspirina (1971), etc. (Caselli et al, 1995:38).

${ }^{53}$ Las raíces socioculturales de la salud y la enfermedad se manifiestan de forma diáfana al realizar comparaciones interculturales (Spector, 2003; Cockerham, 2002). Dado que en la mayoría de las sociedades la enfermedad representa una desviación respecto a lo que se considera normal, será lo que se defina como "normal" en una sociedad lo que a su vez defina el fenómeno de la enfermedad y su tratamiento en la misma. Así, en algunas sociedades "la enfermedad es vista como la forma sobrenatural de señalar un acto o intención que es supuestamente disruptor de un determinado orden”: el castigo asociado al pecado, a la ofensa hacia los poderes sobrenaturales, a la ruptura de ciertos tabúes o normas sociales. En las sociedades modernas, por su parte, priman los criterios científicos a la hora de definir la enfermedad y en la búsqueda de la etiología de la misma se asume que puede estar vinculada, aunque no siempre, al desarrollo de determinados comportamientos; la definición de enfermedad, además, se aplica a procesos de origen biológico (cáncer) o de otro tipo (enfermedad mental) (Rodríguez, 1987:46).

${ }^{54}$ En distintos trabajos sobre la relación entre riqueza y mortalidad, Preston $(1975,1976)$ ya había recogido evidencia empírica sobre la correlación existente entre el nivel de ingresos y la e(0), concluyendo que sólo se mantiene hasta cierto nivel: el de la supervivencia. Una vez superado este nivel, ingresos superiores apenas inducen reducciones sustantivas de la mortalidad y funcionan, con más peso, otros factores como determinantes del descenso de la misma. Así, señala que "es probable que los factores exógenos al nivel corriente de ingresos de un país representen entre el 75\% y el 90\% del aumento de la e(0) en todo el mundo entre los decenios de 1930 y 1960. El aumento del ingreso per se representa solamente entre el 10\% y el 25\%" (Preston, 1975:231-248). Dicho de otra forma, "en 1900 la e(0) en Estados Unidos era de alrededor de 49 años y el ingreso per cápita en dólares de 1991 alcanzaba a unos 4800 dólares. En 1990, ese ingreso per cápita se asociaría a una esperanza de vida de alrededor de 71 años, un desplazamiento ascendente que indica que la salud depende de otros factores, además del ingreso" (BM, 1993:36). 
los niveles sociales de bienestar ${ }^{55}$. En efecto, por sus múltiples consecuencias, las enfermedades constituyen, por una parte, una amenaza para la cohesión de los grupos sociales y más ampliamente para la sociedad. La forma en que ésta está estructurada y organizada influye de manera determinante en el tipo y distribución de las enfermedades. Por otra parte, además de ser fuente de dolor, sufrimiento e incomodidad para el individuo que la padece, la enfermedad pasa a ser el centro de su vida, obstaculizando el disfrute de la misma, hasta el punto de que incluso puede suponer la pérdida de control sobre ella, que pasa a manos de expertos. Obviamente, las pérdidas de bienestar varían dependiendo del tipo de enfermedad que se padezca ${ }^{56}$.

Siguiendo a Rodríguez (1987:cap.2), en el proceso salud/enfermedad/muerte los factores sociales discriminan diferencialmente a los individuos según su pertenencia sociocultural: a) las enfermedades no se distribuyen ni aleatoria ni uniformemente entre los miembros de una población, sino que inciden en mayor medida entre los componentes de algunos grupos (o categorías) sociales según su posición en la estructura social o según su tradición cultural o pertenencia étnica; diferencias que desembocan finalmente en mayores tasas de mortalidad y menores e(0) entre las personas de los estratos inferiores de la pirámide social; b) en la percepción de las enfermedades y en el valor y significado dado a las mismas se observan también importantes diferencias socio-culturales ${ }^{57}$; c) una vez reconocida la enfermedad, la respuesta a la misma está asimismo mediatizada por la posición del individuo en la estructura social y/o por su cultura ${ }^{58}$; d) las relaciones salud/enfermedad con la estructura

\footnotetext{
${ }^{55}$ Esta mediatización social trasciende los ámbitos de la salud y la enfermedad y tiene un alcance total para los individuos: como definiciones socio-culturales (la salud y la enfermedad) pasan a "formar parte del conjunto de variables socio-psicológicas que determinan la visión que el individuo tiene del mundo y de la existencia, y por supuesto de su papel de actuación en el mismo. En su interacción con el resto de variables socio-psicológicas el concepto salud se ve influenciado y cambiado a la vez que influencia y cambia otras concepciones. Esa interacción dinámica dará lugar a una visión homogénea de la existencia, en la cual la salud y la enfermedad son piezas claves en la formación de la personalidad y comportamiento del individuo" (Rodríguez, 1988:80).

${ }^{56}$ En este sentido, puede contrastarse el espléndido relato de Argullol (2001) sobre las consecuencias derivas del dolor producido por una enfermedad crónica, pero no letal, con las no menos magnificas exposiciones de Durán (2003) o del informe co-dirigido por Novell (2003) sobre las percepciones individuales y las vivencias personales y familiares en el proceso de enfermar específico de los pacientes oncológicos.

${ }^{57}$ El reconocimiento de la enfermedad no se deriva automáticamente de la aparición de los síntomas de la misma. Se ha demostrado en múltiples investigaciones que "cuando se presentan los síntomas los miembros de las clases inferiores tienden a adoptar actitudes más estoicas y caballerescas. Muchas veces, tales síntomas no son incluso reconocidos como síntomas de enfermedad debido a la falta de $<<$ conocimientos $>>$ científicos y a la preponderancia del <<saber popular $>>$, o debido al hecho de que la experiencia de dolor y malestar derivada de los síntomas es considerada como una componente de experiencias culturalmente aceptadas (dolor y malestar considerados como componentes normales de la vida diaria)" (Rodríguez, 1987:40).

${ }^{58}$ Según Rodríguez (1987:41), varios tipos de factores mediatizan socialmente la respuesta ante la enfermedad: 1) de tipo situacional: los influidos por el poder adquisitivo (coste, disponibilidad de servicios, distancia a recorrer; 2) de tipo socio-cultural: los que condicionan la percepción del sistema médico <<ortodoxo >> como el apropiado para resolver los problemas de salud; 3) las concepciones de la enfermedad: ya que según sean populares o científicas variará la orientación hacia el sistema sanitario
} 
social son circulares y se retroalimentan entre sí; así, los factores sociales predisponen hacia la enfermedad y la incidencia de ésta puede afectar a los factores sociales ${ }^{59}$, y, e) el nivel de salud puede incidir en la orientación médica o en el grado de utilización de los servicios sanitarios a la par que éstos pueden condicionar la salud (conducta sanitaria preventiva) o ayudar o entorpecer la recuperación de la misma. En definitiva, más allá de las desigualdades en las condiciones de vida, en una fase de la transición sanitaria en la que se requiere un papel cada vez más activo por parte de los individuos para luchar contra las enfermedades degenerativas y las enfermedades de la sociedad, las desigualdades sociales en la percepción y en la actitud respecto a la salud, y los comportamientos conexos en cada caso, están contribuyendo a incrementar las diferencias sociales en la salud, la enfermedad y la muerte. Vallin (1995c:13) resume esta situación señalando que "el progreso médico, que ha dado a todos mejores oportunidades de supervivencia, no es por ello menos fuente de agrandamiento de desigualdades”.

Las respuestas individuales ante la salud y frente a la enfermedad, por tanto, están condicionadas socialmente siendo objeto de socialización y aprendizaje en un contexto social concreto. En general, los individuos que padecen una enfermedad biológica no la viven en sí misma y por sí solos, sino a través del tamiz que la sociedad les procura, estableciéndose de esta forma una relación dialéctica entre enfermedad biológica y percepción psico-social de la salud. El contexto social no sólo define, da contenido e interpreta a los propios conceptos de salud y enfermedad, sino que también determina las actitudes y comportamientos "apropiados" de los individuos frente a ellas: promoción de la salud -incremento de hábitos saludables-, prevención de la enfermedad -reducción de conductas de riesgo-, tolerancia o resistencia al dolor, rol de enfermo $^{60}$, “conductas de enfermedad” -reconocimiento y expresión de síntomas, búsqueda de ayuda, cumplimiento de prescripciones terapéuticas, etc.-, acceso y utilización de los servicios

(miedo al sistema médico, confianza en los profesionales de la medicina, respuestas negativas o positivas a los tratamientos y tecnología moderna, etc.); 4) otras barreras: (diferencias culturales entre profesionales médicos y clientes, "vulnerabilidad al asalto del ego" -miedo a ser ridiculizado-, prejuicios de los profesionales sanitarios - preferencia por tratar a determinados grupos sociales-, etc.).

${ }^{59}$ En algunas ocasiones esas relaciones circulares se tornan en un círculo vicioso: las condiciones de vida más desfavorables de las personas situadas en los estratos bajos de la pirámide social les llevan a enfermar con mayor frecuencia e intensidad y a estar más inermes frente a la enfermedad, por lo que, si enferman, trabajan menos e incluso pueden perder en mayor medida sus empleos, y como consecuencia sus ingresos disminuyen sustancialmente y se deterioran aún más sus condiciones de vida (Rodríguez, 1987:40).

${ }^{60}$ El concepto de "rol de enfermo" (sick role) fue elaborado por Parsons, en 1951, enmarcándolo en su concepción funcionalista de la sociedad. Considerando a la enfermedad como una desviación social y al enfermo como una persona que pone en peligro al grupo social y a la sociedad misma, el rol de enfermo incluye los siguientes postulados: 1) la persona enferma no es culpable de su enfermedad, no puede superarla únicamente con su voluntad; 2) la persona enferma está eximida de sus obligaciones y responsabilidades habituales; 3) el estado de enfermo es "indeseable" en sí mismo, por lo que la persona enferma tiene la obligación de sanar; 4) esta obligación pasa por la exigencia de buscar ayuda técnicamente competente, es decir, ayuda médica (Parsons, 1982: 406-407). En Cockerham (2002: cap.8) y Rodríguez (1987:cap.7) se analiza la trascendencia sociológica y médica de este concepto y se exponen las críticas que ha recibido. 
sanitarios, interacción con los profesionales de la salud, estigmatización de enfermedades ${ }^{61}$, desarrollo de nuevas patologías ${ }^{62}$, etc. La salud y la enfermedad no pueden ser definidas, por tanto, como entes biológicos "neutrales”, aislados de los seres humanos y de la sociedad, sino que son fenómenos sociales definidos por el contexto político-social que es quien las otorga significado: los valores sociales imperantes determinan qué procesos son "normales” y cuáles son “patológicos” (Cockerham, 2002; CCEDSSE, 1996; Rodríguez y García, 1996; Rodríguez, 1988, 1987).

El estado de salud -balance entre salud y enfermedad- se expresa a nivel individual, y su agregación define el perfil epidemiológico de una población. La teoría de la transición epidemiológica describe los mecanismos principales que han conducido los cambios de los perfiles epidemiológicos, pero no especifica las transformaciones en los determinantes últimos del estado de salud individual. Esta tarea, además de incluir la transición epidemiológica, es la que realiza la transición sanitaria (Frenk et al, 1991:31). Si la transición de la mortalidad describe la evolución de este fenómeno demográfico, reseñando niveles, tendencias y diferenciales en las tasas de mortalidad, y la transición epidemiológica se ocupa de las

\footnotetext{
${ }^{61}$ En La enfermedad y sus metáforas (1984) y en El SIDA y sus metáforas (1989), Susan Sontag analiza "las fantasías punitivas o sentimentales que se maquinan” alrededor de la enfermedad en Occidente. Más concretamente, repasa históricamente los prejuicios, las fobias y los miedos existentes alrededor de la tuberculosis en el siglo XIX, sustituidos por los generados en relación al cáncer desde comienzos del siglo $\mathrm{XX}$ hasta ahora, y que éstos comparten desde las últimas décadas del siglo XX con los desarrollados en torno al SIDA. En los tres casos, "es casi imposible residir en el reino de las enfermedades sin dejarse influenciar por las siniestras metáforas con que han pintado su paisaje” que, paradójicamente, dificultan su comprensión y, a veces, su cura.

${ }^{62}$ Como se analiza más adelante, el desarrollo de nuevas patologías está relacionado con: A) Las consecuencias objetivas derivadas de los nuevos riesgos surgidos por los procesos de industrialización y desarrollo, y, en especial, de las emanadas de los riesgos ambientales. En Sempere y Riechman (2000:cap.10) se recoge una síntesis de las mismas: 1) crisis ecológica que lleva a organismos debilitados y ecosistemas vulnerables donde se propagan nuevas y viejas enfermedades infecciosas; 2) "tráfico de microbios” en los rápidos movimientos de personas, animales, plantas y mercancías que aumentan la exposición a enfermedades; 3) cáncer inducido por factores ambientales; 4) daños para la salud producidos por productos químicos sintéticos: por ejemplo, residuos tóxicos e insecticidas, y; 5) efectos en la salud del deterioro de la capa de ozono. B) La consideración como patologías a distintos aspectos de la vida de los individuos que anteriormente no estaban contemplados como tal, por ejemplo, la hiperactividad o la calvicie, o por la creciente expropiación de la salud por parte del sistema sanitario cuya injerencia en la vida cotidiana ya fue denunciada por Ivan Illich (1975) en Némesis Médica, y que se materializa, por ejemplo, en el creciente proceso de medicalización de la menopausia, el embarazo o el parto. En sentido contrario, la percepción de determinadas causas de enfermedad como algo "bueno": por ejemplo, el estrés (Rodríguez y García, 1996:352). C) Incluso, la “invención” de nuevas enfermedades por parte de ciertas compañías farmacéuticas, con la complicidad de algunos investigadores y médicos, para crear una demanda de sus productos: Bauman (2011:90), por ejemplo, menciona el caso de la transformación de la timidez en una afección médica grave, el <<tratorno de ansiedad social >>, a partir de que la empresa farmacéutica GlaxoSmithKline, lanzó una multimillonaria campaña de promoción de su producto Paxil indicado para atenuar y/o acabar con esa enfermedad. Estrategia mercantil que Barry Brand, director de producto de Paxil, valoró de la siguiente forma: "El sueño de todo director de marketing es encontrar un mercado no identificado o desconocido y desarrollarlo. Eso es lo que conseguimos con el trastorno de ansiedad social”. Otro ejemplo de invención de enfermedades con gran repercusión en los medios de comunicación ha sido el de la Viagra femenina, producida por la multinacional Pfizer, para tratar "la disfunción sexual femenina” (EL PAÍS, 04/01/03:27)
} 
transformaciones de los perfiles epidemiológicos, identificando las causas de muerte observadas en esa evolución de la mortalidad, la transición sanitaria se centra en los determinantes subyacentes de esos cambios, resaltando la importancia de los factores sociales, culturales y de comportamiento, junto con la incidencia de las intervenciones médico-sanitarias. Es decir, si la transición de la mortalidad pone su énfasis en el "producto final”, la muerte, la transición sanitaria mantiene un enfoque más extenso que abarca a todo el continuo salud-enfermedadmuerte y se asienta en una concepción holística de la salud y el bienestar, identificando factores de riesgo, creencias, actitudes y comportamientos, tanto individuales como sociales. La transición sanitaria supone, por tanto, una conceptualización más amplia de ese continuo que la implícita en la transición epidemiológica, y en ella juegan un papel determinante la prevención y la promoción pública y privada de la salud como estrategia de control de la mortalidad (Bernabeu, 1994:84).

Entre las importantes aportaciones teóricas de esta corriente de análisis resulta especialmente significativa para el presente trabajo el modelo causal propuesto por Frenk et al ${ }^{63}$ (1991) que, a pesar de su complejidad, es uno de los más difundidos en la actualidad, paradójicamente por la sencillez de su utilización e interpretación (Esquema 4.1.). En el mismo se incluyen toda una serie de determinantes del estado de salud individual articulados en una red de relaciones de causalidad perfectamente identificada y jerarquizada. El punto de partida del modelo es la relación que se establece entre la población y su medio ambiente físico ${ }^{64}$, siendo los puentes de la misma la organización social y los factores biológicos. El primero de los puentes incluye a aquellas estructuras que permiten a los seres humanos transformar la naturaleza; en el segundo se ubican las mutaciones acumuladas en la evolución de la especie humana ante los cambios en el medio ambiente. Estos cuatro elementos constituyen los determinantes básicos de la salud.

La organización social, a través de sus cuatro dimensiones más importantes (estructuras económicas, instituciones políticas, ciencia y tecnología, y cultura e ideología) determina el nivel total de riqueza de una sociedad y las reglas de estratificación de los diferentes grupos

\footnotetext{
${ }^{63}$ Como reconocen los propios autores, su modelo es más bien un esquema vivo de la transición sanitaria, que incluye a la transición epidemiológica, que un modelo cerrado y definitivo. Resulta significativo que inician la presentación del mismo con una especie de declaración de intenciones en la que afirman que el mundo había sido testigo en los últimos años de una profunda "declinación de viejas certidumbres", a través de un proceso vasto y rápido de transformación modernizadora que, asimismo, había afectado a todo lo relativo a la salud, y del que la única certeza que cabía esperar "hoy es un crecimiento de la complejidad" (Frenk et al, 1991:22).

${ }^{64}$ Entre los determinantes poblacionales de la salud más importantes destacan el tamaño de la población, la tasa de crecimiento, la estructura por edad y la distribución geográfica. Entre los determinantes medioambientales se incluyen el clima, la altitud, los recursos naturales, y los tipos de parásitos que influyen en enfermedades específicas, además de la calidad del propio entorno urbano creado por el ser humano (Frenk et al, 1991: 24).
} 
sociales; el acceso diferencial a la riqueza de estos grupos está influido por la estratificación ocupacional y distintos mecanismos de redistribución. Estas cuatro dimensiones conjuntamente constituyen los determinantes estructurales de la salud y de los procesos de enfermedad, ya que mediatizan a un conjunto de determinantes próximos de la salud como son las condiciones de trabajo, las condiciones de vida, los estilos de vida y los sistemas de atención sanitaria de la población. Entre estos determinantes próximos destaca la posición central de las condiciones de vida $^{65}$ al materializarse en ellas la incidencia de los factores sociales -básicos y estructurales-, actuando como correa de transmisión de éstos sobre los factores que definen las situaciones individuales concretas. En efecto, las condiciones de vida, a través de la estructura familiar en la que los individuos viven y son socializados, afectan a otro determinante próximo de la salud: los estilos de vida ${ }^{66}$. Éstos no son interpretados en su acepción epidemiológica más común que reduce los comportamientos individuales a conductas de riesgo aisladas limitando o excluyendo la articulación entre las condiciones materiales e ideológicas (Menéndez, 1998:48), sino que son entendidos en su sentido sociológico ${ }^{67}$ como "comportamientos individuales que son compartidos por un grupo social en un contexto específico, representando un puente conceptual entre la cultura y los modelos de comportamiento” (Frenk et al, 1991:28-29).

\footnotetext{
${ }^{65}$ Las condiciones de vida dependen de los "derechos de intercambio" individuales y familiares. Estos derechos pueden ser concedidos por los poderes públicos (Educación y Seguridad Social) o adquiridos en el mercado (Alimentos y Vivienda). Como se observa en el Esquema 4.1., la vivienda hace de puente entre las condiciones de vida y el medioambiente y su papel trascendental en el modelo deriva de que una vivienda buena, frente a una mala, protege contra los riesgos ambientales externos además de suministrar agua corriente y saneamiento, dos recursos que históricamente han sido importantes determinantes de la salud. Por otra parte, en el modelo se destaca el papel del Sistema de Atención Sanitaria, diferenciado del de la Seguridad Social, que puede obtenerse por las dos vías (pública y privada) y tiene influencia en múltiples direcciones (Frenk et al, 1991:28).

${ }^{66}$ Aunque no se recoge en el esquema, Frenk et al (1991:28) señalan que los estilos de vida están asimismo influidos por la cultura y la ideología, por las políticas institucionales a través de leyes, tasas, regulaciones de todos tipo, subsidios, además de las presiones comerciales.

${ }^{67}$ Una discusión sobre las distintas concepciones de los estilos de vida puede verse en Menéndez (1998).
} 
ESQUEMA 4.1.: DETERMINANTES DE LA SALUD (Modelo de Frenk)

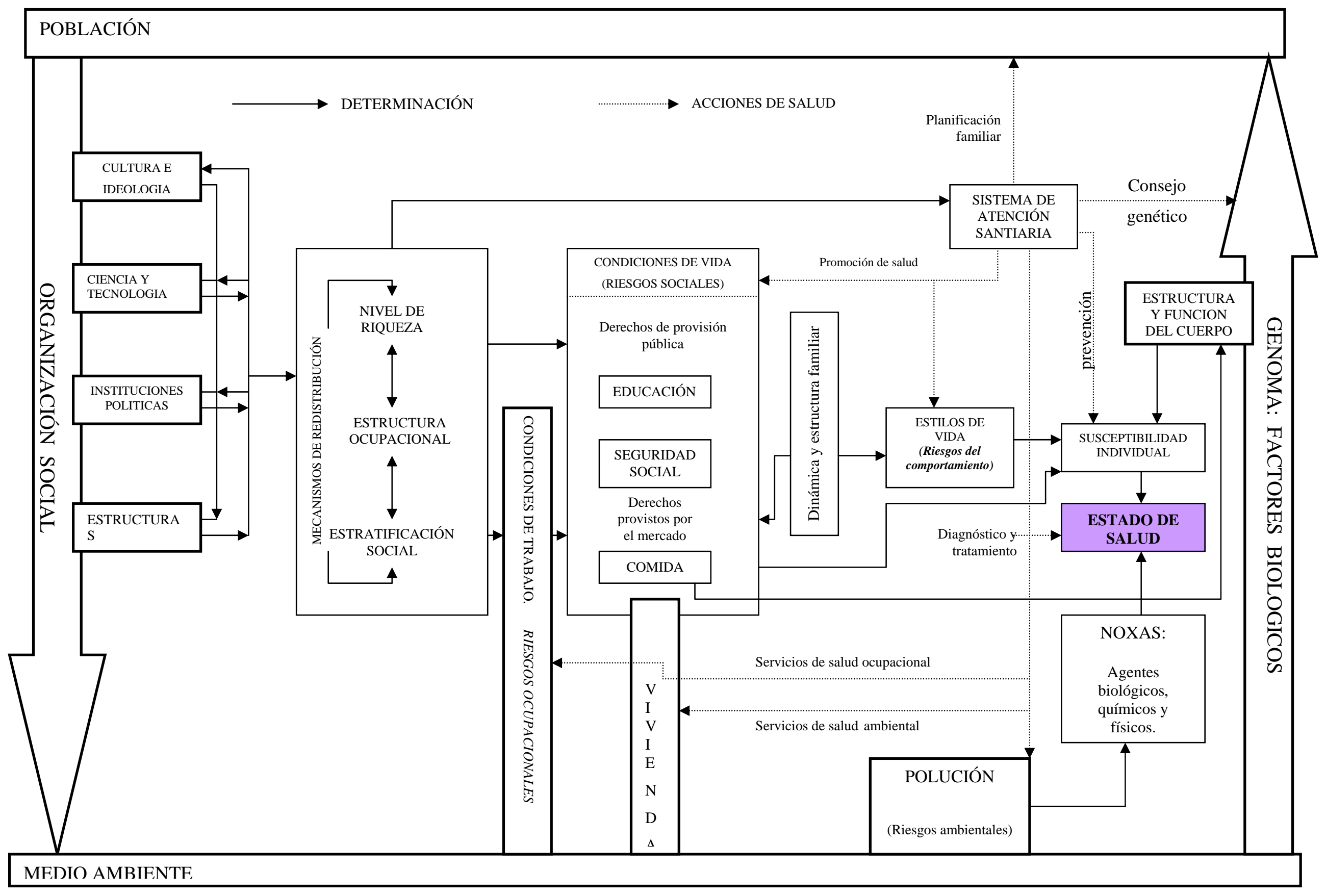


Esta concepción holística del estilo de vida rechaza las explicaciones meramente psicologistas/individualistas o las sólo estructuralistas y no interpreta, por tanto, que el comportamiento individual sea en sí mismo el determinante de los riesgos a los que se enfrentan los individuos. No “culpabiliza” al sujeto responsabilizándole en exclusiva de su situación, ni le “victimiza” exonerándole de toda responsabilidad, sino que lo explica en función de las lógicas de actuación de los grupos, sectores o categorías sociales concretas a los que pertenece. Así, en el modelo de Frenk se resalta la importancia de diferenciar entre las condiciones de vida, que definen la situación material objetiva de los distintos grupos sociales, y los estilos de vida, que representan la forma en que esos grupos sociales trasladan su situación objetiva a los patrones de comportamiento. Mientras las primeras generan los llamados <<riesgos sociales $>>$, los segundos producen los <<riesgos del comportamiento >>, que no se comprenden sin los anteriores; ambos definen la calidad de vida ${ }^{68}$.

Un ejemplo diáfano de esta perspectiva es la interpretación que hace Menéndez (1998:53-57) sobre la evolución diferencial del consumo de tabaco y de bebidas alcohólicas en los países desarrollados y en algunos menos desarrollados para los que existen datos: mientras que los sectores sociales medio y alto de las poblaciones de esos países reducen sus pautas de consumo al acceder a "una nueva cultura de la salud, a una nueva relación con el cuerpo, con la noción de vejez, con una nueva ideología de la <<eterna juventud >>, con la posibilidad consciente de prolongar la esperanza de vida”, las poblaciones de los sectores sociales bajos los mantienen porque forman parte de "su concepción y prácticas de vida”, de su relación con los iguales y con "los otros", y porque "le dan un lugar en el mundo que otros comportamientos no le proporcionan; marcan su diferencia y son parte de su racionalidad de vida”. Estos mecanismos diferenciales de identificación se asientan en que mientras los primeros tienen las condiciones materiales que les permiten construir unas condiciones ideológicas capaces de generar esas modificaciones, es decir, tienen la capacidad de elegir y tienen una cultura del riesgo con una orientación temporal que les permite mirar lejos hacia el futuro -se fijan objetivos a largo plazo, planifican con antelación, se organizan, conciertan citas y toman medidas preventivas, también en lo relativo a su salud-, los segundos, privados de todas esas condiciones y capacidades, tienen una orientación temporal hacia un presente que les agobia y su proyección no puede aspirar más que a mantener la mera supervivencia a corto plazo.

\footnotetext{
${ }^{68}$ Desde esta perspectiva, por ejemplo, "el comportamiento de un alcohólico o de un fumador no debe ser reducido al riesgo en sí, escindido de las condiciones en las que el sujeto produce/reproduce su vida. El estilo del sujeto es su vida, y no sólo un riesgo específico. Escindir los comportamientos de los alcohólicos , y convertirlos en riesgos puede ser eficaz para intervenir en las conductas individuales, pero limita o anula la comprensión del comportamientos en términos de estilo de vida... al dejar de lado aspectos determinantes de los mismos como son, por ejemplo, las condiciones de trabajo y empleo" (Menéndez, 1998:48-49).
} 
La incidencia de todos estos riesgos ${ }^{69}$ sobre la salud de cada individuo, junto con la dotación corporal determinada biológicamente, condicionan la "susceptibilidad individual”"70 ante la enfermedad. De esta forma, el estado de salud individual es el resultado final del balance entre la exposición a agentes de la enfermedad, y la susceptibilidad individual, que resulta de una compleja red de riesgos, producto a su vez de un conjunto articulado de determinantes sociales y biológicos. Esta concepción holística del proceso de salud y, por tanto, del proceso de enfermedad y en última instancia del de la muerte, muestra la insuficiencia de las interpretaciones monocausales al hacer evidente tanto la presencia de múltiples factores en el "escenario de la salud", como la dificultad de aislar la influencia concreta de cada uno de ellos, dada la complejidad de las relaciones que mantienen entre sí $^{71}$. No obstante, el modelo no asume una multicausalidad difusa en la que todo influye en todo, sino que los determinantes están perfectamente jerarquizados en cinco niveles de análisis: sistémico, social, institucional, familiar e individual. Las características particulares que este sistema tiene en cada país o sociedad permiten explicar las diferentes etapas, ritmos, direcciones y modalidades de transiciones sanitarias concretas, así como la comparación entre ellas.

En el Esquema 4.2., se representa sintéticamente esa jerarquización, además de mostrarse que, de arriba abajo, cada nivel de análisis explica o limita la variabilidad de los factores que operan en el nivel inferior; es decir, las explicaciones de los elementos de cada nivel deben realizarse teniendo en cuenta las limitaciones que imponen los factores del nivel inmediatamente superior (Frenk et al, 1991:30). No obstante, esto no significa que los niveles superiores sean intrínsecamente más importantes o complejos que los inferiores; de hecho, se espera que una buena parte de los avances futuros en salud se produzca precisamente por cambios "saludables" en los niveles institucional, familiar e individual. Asimismo, aunque las

\footnotetext{
${ }^{69}$ Se aprecia en el esquema la posición central otorgada a la categoría de riesgo, entendido éste como la probabilidad de que un suceso pueda ocurrir y que Frenk et al (1991:27) aplican a los determinantes básicos, estructurales y próximos de la salud al concebirlos como factores de riesgo: "procesos, atributos o exposiciones que determinan la probabilidad de ocurrencia de una enfermedad u otro resultado de salud”. Obviamente, como matiza Lynge (1984), "ni la ocupación, ni la renta, ni la educación, ni la conducción de coches, etc., son factores de riesgo desde el punto de vista biológico”, por lo que por sí mismos ninguno de esos criterios son adecuados para identificar factores de riesgo específicos, pero sí son apropiados para "señalar la responsabilidad en las desigualdades en salud entre diferentes sociedades".

${ }^{70} \mathrm{La}$ "susceptibilidad individual” es "un fenómeno en el que las condiciones de trabajo, las condiciones de vida, y los estilos de vida, determinados por procesos sociales, convergen con la estructura y función corporal, determinada por procesos biológicos” (Frenk et al, 1991:29).

${ }^{71}$ Una buena muestra de la complejidad de esas relaciones se puede apreciar en la actuación del Sistema de Atención Sanitaria cuya influencia se ejerce sobre: a) los determinantes básicos y estructurales, a través de la planificación familiar, la información y el consejo genético o los sistemas de control medioambiental; b) los determinantes próximos, a través de los servicios de salud laboral o promoción de la salud; c) la susceptibilidad individual, mediante acciones preventivas como la vacunación, y; d) sobre el propio estado de salud, que es determinado a través de diagnósticos y servicios terapéuticos.
} 
flechas continuas del Esquema 4.2. indican una dirección dominante de determinación, las flechas punteadas reflejan la existencia de relaciones de retroalimentación.

ESQUEMA 4.2.: NIVELES Y DETERMINANTES EN EL ANÁLISIS DE LA SALUD

NIVEL

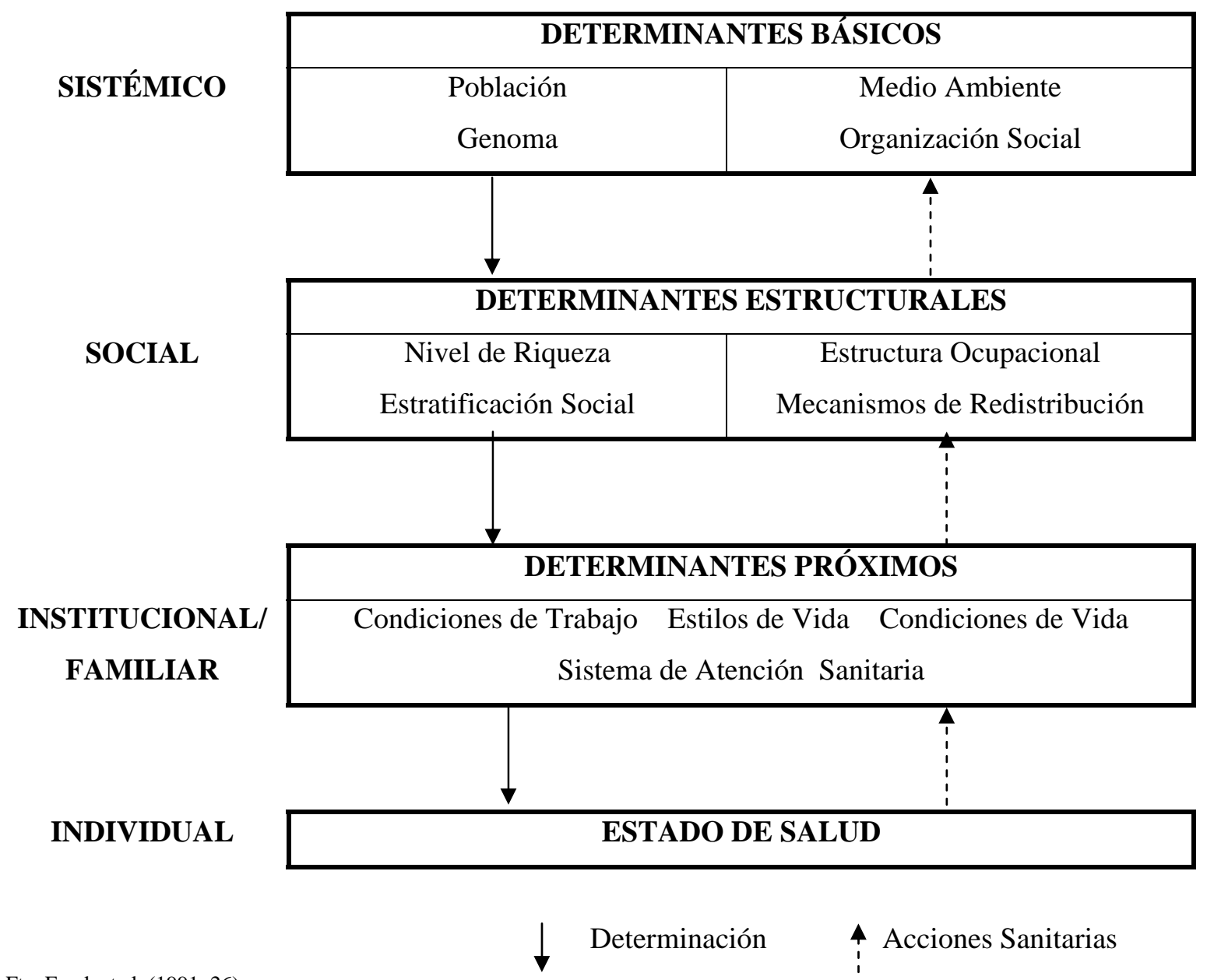

Fte: Frenk et al (1991: 26)

El modelo de transición sanitaria admite implícitamente la existencia de dotaciones genéticas diferenciadas entre los individuos, lo que implica distintos potenciales de supervivencia desde el nacimiento. Además, al otorgar una posición central a las condiciones de vida y a los estilos de vida, como precipitados de las condiciones sociales, asume que la salud, la enfermedad y la muerte no se distribuyen de forma caprichosa y azarosa entre los individuos. De esta forma, en sintonía con las interpretaciones más modernas de la salud, la enfermedad y la muerte, descritas arriba, se dejan al margen las concepciones providencialistas, aleatorias o naturalistas, en las que se obvia toda mediación social y se igualan radicalmente a todos los individuos: "iguales ante Dios, ante el azar o ante la enfermedad" (Durán, 1983:88), o ante la muerte. Asimismo, al no limitar el proceso morbilidad/mortalidad a la actuación exclusiva del sistema de asistencia sanitaria se rechazan los presupuestos subyacentes en las interpretaciones, 
dominantes durante muchos años, del paradigma bio-médico unicausal de la salud que excluye la producción social de la enfermedad: el azar genético o el desorden biológico originan la enfermedad. Su tratamiento y control es competencia exclusiva de los profesionales técnicamente capacitados para ello: el personal médico especializado ${ }^{72}$. El modelo de transición sanitaria, por tanto, impugna también las interpretaciones monocausales del continuo salud/enfermedad/muerte, es decir, las que lo explican de forma determinista, descontextualizada, aséptica en lo social, como mero problema técnico, y que lo fragmentan convirtiéndolo, todo lo más, en objeto de una política específica, la política sanitaria, separándola del resto de la actividad política (Rodríguez, 1988:75).

Asumiendo la importancia de los servicios sanitarios como determinantes de los niveles de salud de la población -como proveedores de salud a través de medidas preventivas (detección precoz, vacunas) y terapéuticas (antibióticos, técnicas quirúrgicas)-, la transición sanitaria, simultáneamente, es heredera de las interpretaciones que correlacionan, de forma más amplia, los niveles de salud con el desarrollo socio-económico general y con la implementación de políticas redistributivas adecuadas -mejoras nutricionales, educativas, higiénicas, reducción del tamaño familiar, viviendas de calidad, infraestructuras de saneamiento, etc. Desde esta perspectiva, la transición sanitaria entronca perfectamente con las demandas de algunos de los nuevos movimientos sociales surgidos en la segunda mitad del siglo XX. Concretamente, con la reivindicación de un papel más activo no sólo en la prevención de la enfermedad, sino en la promoción de la propia salud que caracteriza a las organizaciones de consumidores, ecologistas, feministas y partidarios de la salud integral ${ }^{73}$. De hecho, según Ugalde (1983:57-73), es el auge

\footnotetext{
${ }^{72}$ El dominio ejercido "en las ciencias de la salud por la concepción biomédica de la enfermedad" se ha asentado durante buena parte del siglo XX, especialmente durante el tercer cuarto del mismo, en el "extendido optimismo", conexo a la modernización socioeconómica, y en la presunción de que ésta, a la par de lograr una "mejoría social”, reduciría las desigualdades sociales en salud. Sólo durante los periodos de crisis social y económica, como en las décadas de 1920-1930 y a partir de la recensión económica iniciada a comienzos de la década de 1970, "ha existido una considerable producción de estudios sobre los factores sociales y las desigualdades sociales en salud” (CCEDSSE (1996:30).

${ }^{73}$ Aunque la situación se ha modificado sustancialmente en los últimos treinta años, en parte debido a las denuncias y reclamaciones de esos movimientos, en 1983, Antonio Ugalde (1983:63-70) analizaba el papel de los mismos en el ámbito de la salud como sigue: en el sector de los servicios de salud "el movimiento de consumidores ha facilitado la transformación de la relación médico y paciente al transformar el rol de paciente en el de consumidor, de pasivo receptor de órdenes del médico a un activo agente que exige, compara, y decide como cualquier otro consumidor comprar o no comprar un servicio"; los movimientos feministas con sus críticas a una profesión médica mayoritariamente masculinizada han desarrollado una "variante del movimiento de salud femenino de auto ayuda", especialmente en lo relativo a la exploración ginecológica; los partidarios de la salud integral, con su concepción holística de la salud, en sintonía con la definición de salud propuesta por la OMS, han contribuido al rechazo de "la visión biológica de la vida que reduce al ser humano a una dimensión anatómica y simplista en la que está basada la medicina” y a la reivindicación de unas relaciones en las que al individuo se le considere como <<persona completa y en el contexto del ambiente entero que le rodea >”; los movimientos ecologistas, finalmente, han alertado sobre la relación contaminación ambiental/enfermedad y sobre la necesidad de desarrollar medidas políticas de "prevención social de la enfermedad", es decir, "modificaciones en las actividades de la industria o de los productores que además de bienes producen también enfermedad...
} 
de estos movimientos durante los años sesenta y setenta del siglo XX el que pone fin al dominio del paradigma bio-médico unicausal de la salud.

Como resultado de todo este proceso, postulados básicos de la transición sanitaria forman parte ya de las manifestaciones programáticas de la Salud Pública ${ }^{74}$. Por ejemplo, desde hace años distintos informes de la U.E., antes de la C.E.E., aún reconociendo las mejoras en salud de sus países miembros han alertado sobre los problemas de salud pendientes de resolver y la mortalidad evitable relacionada con ellos. Lo más significativo de estos informes es que se asumía la incapacidad de sus servicios sanitarios -desarrollados y muy especializados-, para resolver en solitario los problemas de salud planteados y los nuevos que estaban emergiendo. De hecho, se admitía que el incremento de la financiación de los servicios sanitarios y la investiga-ción biomédica eran insuficientes si no venían acompañados de acciones económicas, sociales y de modificación de las conductas individuales y del conjunto de la población para prevenir esos problemas de salud (Comisión Europea, 1995:1-2). Asimismo, la aceptación generalizada en la actualidad de esta concepción multicausal de los determinantes de la salud, la enfermedad y la muerte, puede observarse también en los modelos teóricos que analizan específicamente la mortalidad ${ }^{75}$.

(porque)... los obreros no tienen libertad para determinar las condiciones de salud de las fábricas en donde trabajan o los barrios en donde viven".

74 En (García Benavides, 1992) se analizan las relaciones entre todos los cambios señalados, especialmente los derivados de la epidemiología "moderna”, y los objetivos de la "nueva” Salud Pública”. ${ }^{75}$ Es el caso, por ejemplo, del modelo teórico empleado por Eurostat (1998) en el análisis a largo plazo de diferentes escenarios de la mortalidad para los países del Área Económica Europea. Más recientemente, la propia Comisión Europea ha lanzado, desde el año 2000, el proyecto ECHI (European Community Health Indicators) con el objetivo de disponer de un sistema integrado de datos con información comparable entre países tanto sobre la salud, los hábitos de la población relacionados con la salud y las enfermedades, como sobre los sistemas sanitarios. Proyecto al que se sumó el $\mathrm{M}^{\circ}$ de Sanidad y Política Social y que, arrancando en el año 2006, ha cristalizado en una base datos denominada INCLA-SNS construida sobre la siguiente agrupación de indicadores: A) Población (Demografía; Situación socioeconómica); B) Determinantes (Factores biológicos y personales; Comportamiento y salud; condiciones de vida y trabajo), y; C) Sistema Sanitario (Prevención, protección y promoción; Recursos sanitarios; Gasto sanitario; Calidad y resultados de la atención). Los tres grupos de factores inciden en el Estado de salud ( Mortalidad; Morbilidad) ( $M^{\circ}$ de Sanidad y Política Social, 2010:6). 


\subsection{LA MUERTE SUFRIDA EN ESPAÑA}

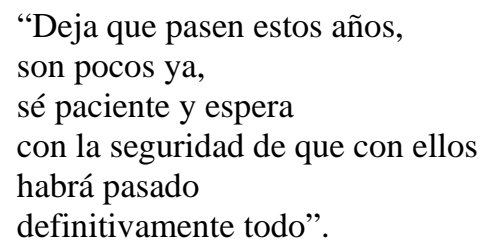

A. González

La utilización del enfoque holístico de la Transición Sanitaria, como el marco de fondo más adecuado para analizar la evolución de la salud, la enfermedad y la mortalidad en los países desarrollados durante las tres últimas décadas del siglo XX, ha desembocado inevitablemente en una modificación de la perspectiva metodológica con la que se aborda empíricamente dicho análisis. El cambio de estrategia sanitaria que caracteriza a las tercera y cuarta fases de la transición sanitaria/transición epidemiológica en las que, además de la provisión suficiente de recursos médico-sanitarios, se requiere un comportamiento activo por parte de los individuos para frenar la incidencia de los factores sociales que mediatizan su salud, ha generado la necesidad de abordar el análisis específico de la mortalidad no sólo a través de los indicadores finales clásicos (probabilidades de muerte y esperanzas de vida) basados en el examen de los sucesos fatales, sino también completando esta perspectiva con el estudio de la salud de las poblaciones. En efecto, en un contexto social concreto, caracterizado por tener bajos niveles de mortalidad y en el que las enfermedades ligadas al comportamiento emergen con una nitidez como nunca antes habían hecho patente, sólo puede lograrse la comprensión global de la mortalidad profundizando en la incidencia del componente social que actúa en las "enfermedades del hombre” y que subyace como caldo de cultivo en el que se desarrolla parte de la biografía de las enfermedades crónicas y degenerativas. Es decir, sobre el fondo de los patrones de respuesta social organizada a las condiciones de salud, estudiando las actitudes y comportamientos de riesgo de los individuos como fuente de información que permiten explicar la situación actual y prever la evolución futura de la relación entre el contexto social en que se produce la mortalidad y el proceso a través del cual se genera un estado de salud y de mortalidad determinado (Gómez Redondo et al, 2002; Gómez Redondo, 2001).

No obstante lo señalado, el análisis empírico de la "muerte sufrida” desarrollado en esta Tesis, y que se expone a continuación, se centra prioritariamente en el examen de la mortalidad. Esta limitación voluntaria de la metodología de análisis se justifica por diversas razones: en primer lugar, porque el principal objetivo que se persigue con este trabajo no es realizar un examen sociodemográfico exhaustivo del continuo salud/ enfermedad/muerte, sino estudiar la dimensión de la "muerte sufrida" en la que se sustenta la construcción social de la muerte, que es el verdadero objetivo de la investigación, y para lo cual se considera que es suficiente un 
análisis descriptivo de la mortalidad; en segundo lugar, porque el no examinar la salud con el mismo detenimiento que la mortalidad no implica en absoluto que se obvie totalmente a aquélla. Los indicadores de mortalidad no sólo sintetizan las consecuencias últimas del hecho de que la muerte representa para cada individuo el "saldo final" de una trayectoria vital en la que, en algún momento, aparece la enfermedad y se comienza a perder salud o se interrumpe bruscamente dicho proceso vital, asimismo, informan sobre los focos de riesgos, lo que permite detectar la mortalidad "innecesariamente prematura y sanitariamente evitable”, y ayudan en la evaluación de las tendencias temporales de distintas enfermedades ${ }^{76}$ (López-Abente, et al., 2002:7). Es decir, los datos e indicadores de mortalidad lo son también de salud y morbilidad aunque, obviamente, no de todas las dimensiones de éstas; en tercer lugar, porque el autor ya ha abordado el análisis de la salud y de las actitudes y comportamientos de riesgo en otros trabajos y los resultados obtenidos en los mismos se harán presentes en la argumentación cuando así se requiera $^{77}$. No obstante, en la parte final de este capítulo, al tratar sobre la evolución futura de la mortalidad, se aborda el intenso debate existente sobre la calidad de vida versus cantidad de vida en las edades más elevadas, en el que inevitablemente los aspectos cualitativos relativos a la salud en esas edades resultan claves.

De esta forma, el análisis empírico de las tres transiciones en España se inicia con una síntesis histórica de la evolución de la mortalidad durante el siglo XX, haciendo referencia en primer lugar al profundo cambio estructural vivido por la sociedad española durante el siglo

\footnotetext{
${ }^{76}$ Además, en su revisión de la utilización de los indicadores de vida y muerte como indicadores de desarrollo y bienestar, A. Sen (1998:17-20) descarta el empleo de indicadores de morbilidad, frente a los de mortalidad, precisamente por la profunda influencia que la sociedad ejerce sobre percepción de la enfermedad y salud entre los individuos. Admitiendo la gran utilidad que tendría una buena información sobre morbilidad, señala sin embargo que en la realidad esa información tiende a ser muy sesgada. Dado que la percepción de la enfermedad varía con el conocimiento de la misma, con la concienciación y convencimiento de que se la puede superar, y con la disponibilidad de asistencia médico-sanitaria, la población más educada y con menores problemas de acceso a servicios médicos tiene menos miedo a la enfermedad, es más consciente del peligro de algunos síntomas, y por tanto es menos propensa a negarla. Esto explica la paradoja de que "en lugares con amplios y buenos servicios médicos, las personas a menudo tienen una mayor percepción de morbilidad, aunque ellas puedan tener mucha mejor salud general... (Así), altas esperanzas de vida y niveles elevados de morbilidad declarada caminan juntas -no en direcciones opuestas".

${ }^{77}$ El autor de esta Tesis ha trabajado durante años en un equipo de investigación dirigido por la profesora Rosa Gómez Redondo. En uno de los proyectos realizados, Factores demográficos y sociales que determinan la supervivencia diferencial de la población española. Perspectivas desde el umbral del siglo XXI (PB96-0154-A), se analizaron en profundidad las Encuestas Nacionales de Salud del $\mathrm{M}^{\mathrm{o}}$ de Sanidad y Consumo/CIS. Distintos trabajos publicados recogen entre otros los resultados obtenidos en el análisis de las desigualdades sociales en: a) "salud percibida": percepción que los individuos tienen sobre su propia salud. A pesar de las críticas recibidas por este indicador es buen predictor de la mortalidad (una salud deficiente predice una mayor mortalidad); b) "salud objetiva o morbilidad declarada": declaración por parte de los individuos de sus problemas reales de salud/enfermedad, enfermedades crónicas diagnosticadas, episodios de dolor, accidentes, las limitaciones de actividad que esas circunstancias han conllevado, así como el consumo de medicamentos conexo; c) "hábitos y estilos de vida": fundamentalmente consumo de tabaco, consumo de bebidas alcohólicas, ejercicio físico, etc. (Gómez Redondo et al, 2002 y 2001; Gómez Redondo 2001; Jiménez Aboitiz et al, 2001).
} 
pasado y al papel que la mortalidad, como causa y como efecto, ha tenido en el mismo. Posteriormente, y al objeto de profundizar en el comportamiento de la mortalidad en las tres últimas décadas, se aborda el análisis de lo que se conoce como Mortalidad Diferencial, centrando dicho análisis en tres variables que finalmente serán cruzadas: causas de muerte, edad y sexo.

\subsubsection{EVOLUCIÓN HISTÓRICA DE LA MORTALIDAD EN ESPAÑA}

"En este país uno no puede siquiera morir en paz"

J. Ortega y Gasset

La sociedad española en su conjunto no conoce el inicio de su transición demográfica hasta finales del siglo XIX. Si bien es muy difícil evaluar los niveles de mortalidad antes de finales del siglo XVIII, Livi-Bacci (1968:90) ha estimado que para el total de la población española la T.B.M. ${ }^{78}$ en los siglos XVIII y XIX se situaría en torno al 38 por mil, y la e $(0)^{79}$ en la época preindustrial alcanzaría los 26,8 años. Como se ha comentado más arriba, los datos comparativos de España y Suecia recogidos en el Cuadro 4.2. reflejan que durante el siglo XIX España quedó rezagada respecto a otros países europeos en la reducción de la mortalidad, haciéndose más explícito aún el carácter arcaico de su estructura demográfica a finales del mismo. Arcaísmo que estaba determinado más por su mortalidad que por su natalidad (Pérez Moreda, 1984:26). Este retraso relativo en el ámbito demográfico del conjunto de la población española ${ }^{80}$ respecto a la evolución seguida en otros países europeos es el reflejo del atraso existente en el ámbito socioeconómico respecto a dichos países (Tortella, 1994:28-35, 207-219). A finales del siglo XIX, España en conjunto era un país rural con la mayoría de sus habitantes adscritos al sector primario y presentaba, según Bustelo (1985:23), "todos los rasgos de lo que hoy llamaríamos subdesarrollo”.

\footnotetext{
${ }^{78}$ Pérez Moreda (1980:133) afirma que "las tasas brutas de mortalidad oscilaban en las poblaciones preindustriales anteriores al proceso de modernización demográfica, y para cualquier lugar, entre los valores 35 y 45 por mil, apenas sin notables modificaciones a corto y medio plazo. (...) Por debajo de aquellos límites, la tasa pone ya en evidencia un descenso de la mortalidad general hacia niveles modernos”.

${ }^{79}$ La mayoría de los autores coinciden en estimar que, durante miles de años, la media de la duración de la vida media humana oscilaba entre los 35 y los 25 años (Kula, 1977:368), aduciéndose para ello que "una sociedad cuya duración media de la vida es inferior a los 25 años estaba condenada a la extinción", al no poder asegurar la tasa mínima de reproducción de sus habitantes. No obstante, otros autores matizan estos cálculos por haber sido realizados sobre poblaciones cerradas, sin considerarse, por tanto, las influencias de los movimientos migratorios, por lo que en núcleos con abundante inmigración resultaron "posibles índices de esperanza de vida al nacimiento inferiores a los veinticinco años e incluso a los veinte, para largas etapas de su historia” (Pérez Moreda, 1980:140).

${ }^{80}$ Pérez Moreda (1987:41-42) señala que "la población española conoció, pues, sólo inicios parciales y muy localizados de la transición demográfica en la segunda mitad del siglo XIX, aunque en Cataluña tal proceso se consumó ya prácticamente a lo largo de esa centuria y de las primeras décadas de la siguiente.... En el último cuarto del siglo pasado (XIX) todavía el 60 por 100 de las provincias españolas mostraban... una tasa de mortalidad situada entre el 30 y el 37 por mil.”
} 
Por tanto, la modernización demográfica del conjunto de la población española se ha realizado a lo largo del siglo XX, convirtiéndose en el factor clave de la misma la reducción de las tasas de mortalidad (Tortella, 1994:210, Nadal, 1976:226). A comienzos del siglo XX, Gráfico 4.2., la TBM era todavía muy elevada, 28\%, y más propia de una situación pretransicional. El declinar de la mortalidad a lo largo del siglo pasado fue además muy irregular de un año a otro, como consecuencia de las intensas fluctuaciones provocadas por la incidencia ordinaria de las enfermedades infecto-contagiosas, lejos aún de estar controladas (Gil Alonso y Cabré, 1997:69). Incidencia que quedó muy patente en la gran mortandad provocada por la epidemia de gripe de 1918. Superada esa adversidad, la mortalidad continuó descendiendo hasta los años de la Guerra Civil y la posguerra, cuando esa nueva fatalidad incrementó de forma notable los valores de la T.B.M. Desde la segunda mitad de la década de 1940 la mortalidad retoma definitivamente la senda descendente, se sitúa por debajo del 10\%o en la primera mitad de la década de 1950 y llega a su mínimo histórico en 1982, 7,5\%o, -poco más de un cuarto de la de principios del siglo XX. A partir de ese momento, y como ha ocurrido con en el resto de los países que finalizaron su transición demográfica, la T.B.M. incrementa su valor fruto del envejecimiento de la población, siendo el mismo de 8,95\%o, en el año 2000, y del 8,43\%, en 2008 (INEbase).

Cabe resaltar que este sustancial descenso de los niveles de mortalidad transcritos por las cifras relativas de la T.B.M. conlleva en sí mismo un cambio fundamental de la experiencia cotidiana de la muerte como es la reducción de la probabilidad individual de entrar en contacto directo con ella. Ese cambio se hace más diáfano al comparar cifras absolutas; así, mientras que la población española ha más que duplicado sus efectivos durante el siglo XX, el número medio de decesos anuales se ha reducido notablemente durante ese periodo de tiempo: 536.716 muertes en una población de 18.594.405 habitantes, en 1900; 360.391 decesos entre 39.927.400 habitantes, en 2000 (INE) ${ }^{81}$.

\footnotetext{
${ }^{81}$ Desde otro punto de vista, Julio Pérez Díaz (1996) ha estimado que si no hubiese habido mejoras en la mortalidad desde 1900, la población española en 1991 habría sido de 21.270 .816 habitantes en lugar de los 38.727.174 efectivamente censados. Es decir, casi 16,5 millones menos de habitantes.
} 
GRÁFICO 4.2.: EVOLUCIÓN DE LAS T.B.M. EN ESPAÑA (\%)

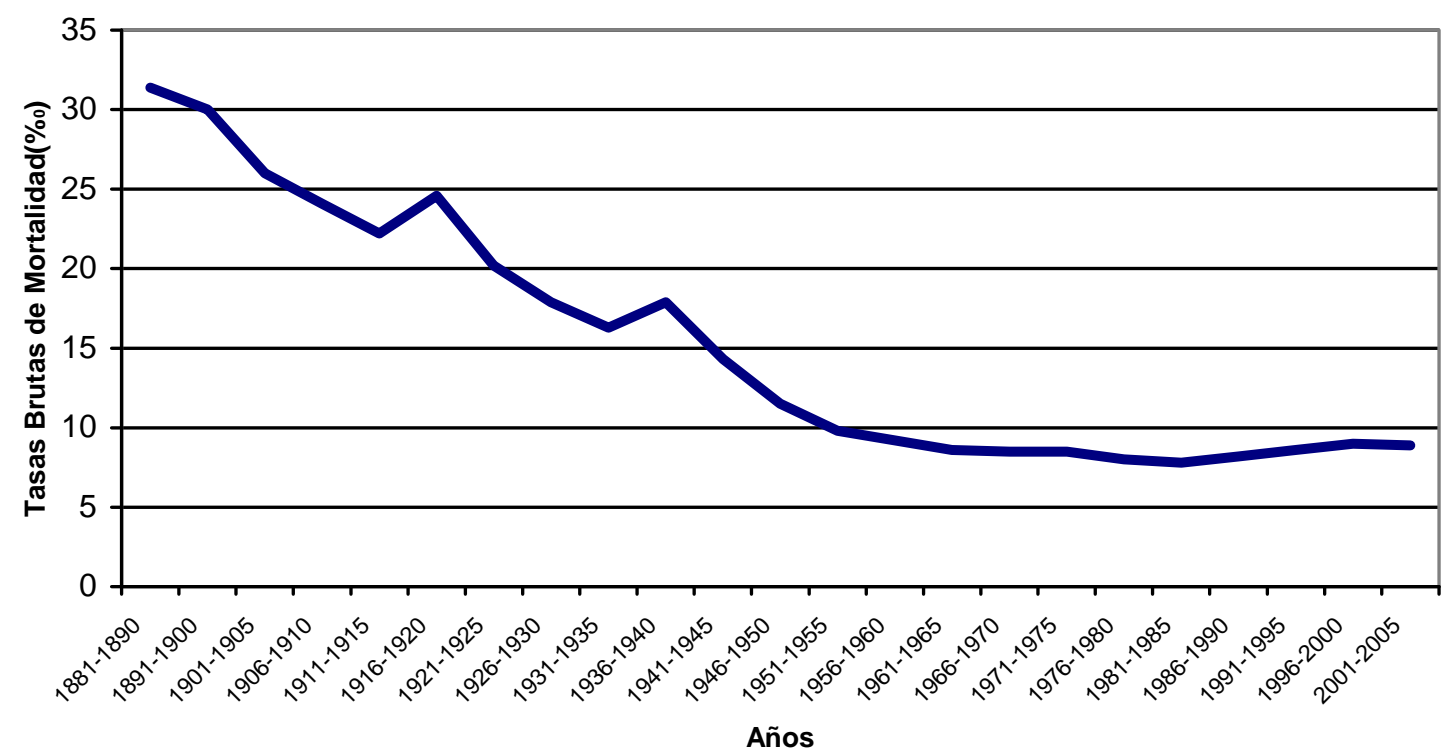

Fte: Hasta 1980 Del Campo y Navarro (1987:34). Desde 1980, elaboración propia a partir de INE: Banco de datos TEMPUS (http//www.ine.es/tempus/cgi-bin/itie).

La modernización demográfica de la población española no sólo ha supuesto la caída de la mortalidad hasta los bajos niveles actuales, sino que se ha traducido además en un notable incremento de su longevidad media -medida en términos de esperanza de vida al nacer-, que se ha más que duplicado a lo largo del siglo XX: con un crecimiento medio de 4,4 meses por año, la e(0) ha crecido desde los 34,76 años de 1900 hasta los 79,05 años de 2000, es decir, es 2,27 veces mayor que un siglo antes. Dado que la e(0) sintetiza la suma de las fuerzas de mortalidad de todas las edades, ese notable incremento de la "vida media" indica que un número creciente de españoles/as viven hasta edades avanzadas, hasta las que hace unas pocas décadas sólo llegaba una minoría de la población (Cuadro 4.3.; Gráfico 4.3.). Esa acelerada mejoría de la longevidad media, que ha continuado en la primera década del siglo XXI, no se ha producido con una trayectoria uniforme, sino con un desenvolvimiento sincopado, en el que se han alternado periodos de intenso crecimiento de la vida media, con otros de estancamiento, y otros, los menos pero significativos, de retroceso derivados de graves crisis coyunturales de la mortalidad. 


\begin{tabular}{|c|c|c|c|c|}
\hline \multicolumn{5}{|c|}{$\begin{array}{l}\text { CUADRO 4.3.: EVOLUCIÓN DE LA ESPERANZA DE VIDA DE LA POBLACIÓN } \\
\text { ESPAÑOLA A LO LARGO DEL SIGLO XX. (Años) }\end{array}$} \\
\hline AÑOS & TOTAL & $\begin{array}{c}\text { VARONES } \\
\text { (a) }\end{array}$ & $\begin{array}{l}\text { MUJERES } \\
\text { (b) } \\
\end{array}$ & $\begin{array}{c}\text { DIFERENCIA } \\
\text { (b-a) }\end{array}$ \\
\hline 1900 & 34,76 & 33,85 & 35,70 & 1,85 \\
\hline 1910 & 41,73 & 40,92 & 42,56 & 1,64 \\
\hline 1920 & 41,15 & 40,26 & 42,05 & 1,79 \\
\hline 1930 & 49,97 & 48,38 & 51,60 & 3,22 \\
\hline 1940 & 50,10 & 47,12 & 53,24 & 6,12 \\
\hline 1950 & 62,10 & 59,81 & 64,32 & 4,51 \\
\hline 1960 & 69,85 & 67,40 & 72,16 & 4,76 \\
\hline 1970 & 71,98 & 69,17 & 74,69 & 5,52 \\
\hline 1980 & 75,62 & 72,52 & 78,61 & 6,09 \\
\hline 1990 & 76,94 & 73,40 & 80,49 & 7,09 \\
\hline 1996 & 78,11 & 74,53 & 81,70 & 7,17 \\
\hline 2000 & 79,05 & 75,64 & 82,46 & 6,82 \\
\hline 2005 & 80,23 & 76,96 & 83,48 & 6,52 \\
\hline 2008 & 81,24 & 78,17 & 84,27 & 6,10 \\
\hline
\end{tabular}

Fuente: Los datos desde 1900 a 1990, INE (1999): Tablas de Mortalidad de la Población Española. 1996-1997, pp. 8; los datos de 1996, 2000 y 2005, INE (2008): Indicadores Demográficos Básicos, www.ine.es.

GRÁFICO 4.3.. ESPERANZA DE VIDA AL NACER. ESPAÑA.

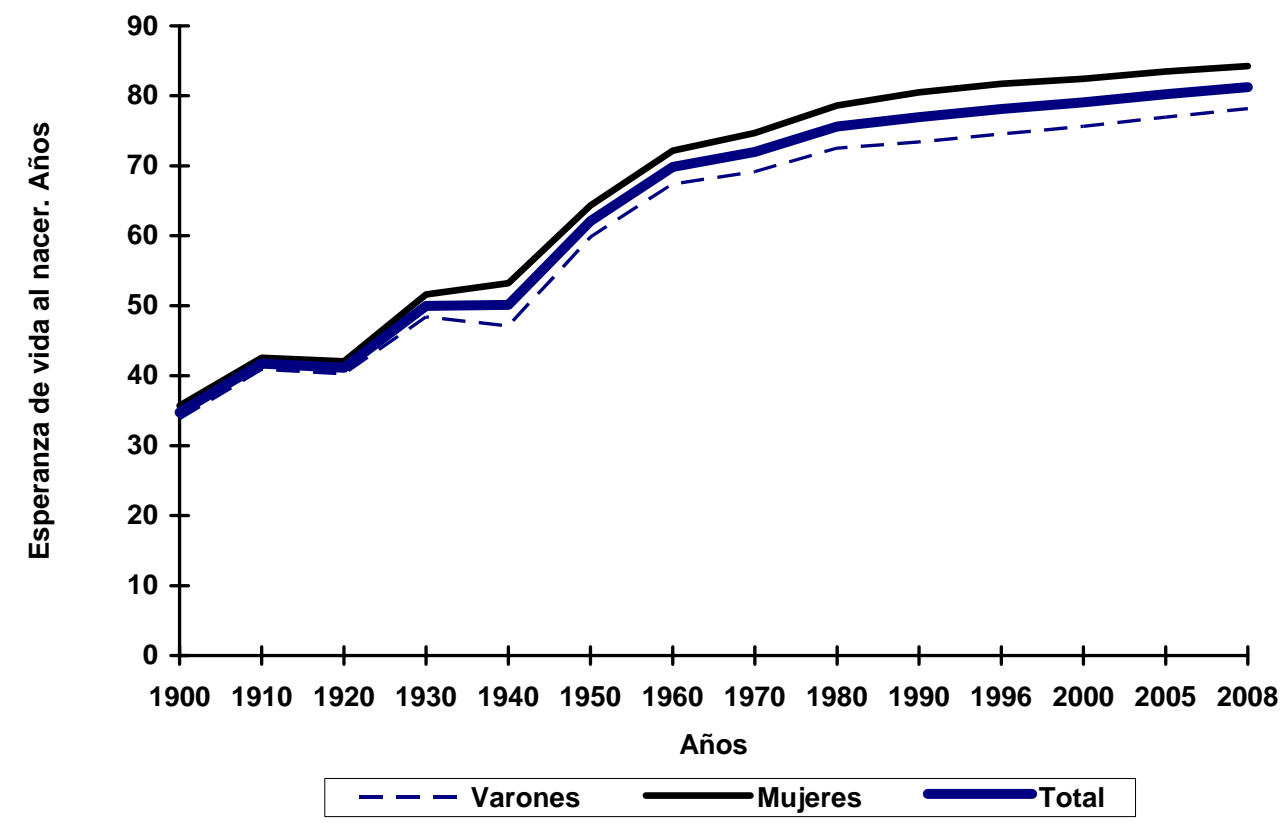

Fuente: Cuadro 4.3.

En los treinta primeros años del siglo XX, la e(0) española aumentó en 15,2 años, lo que significa que si una cohorte ficticia de individuos nacida en 1900 perdía la cuarta parte de sus 
efectivos al año y medio de edad y la mitad de los nacidos no llegaban a cumplir los 33 años, una generación nacida en 1930 no se veía reducida al 75 por ciento hasta los 23 años y no perdía la mitad de sus componentes hasta los 60 años. Este pronunciado descenso de la mortalidad puede imputarse básicamente al control y atenuación de los efectos de las enfermedades infectocontagiosas. La incidencia del desarrollo económico en este proceso se constata al comprobar que los escasos núcleos de incipiente industrialización -Cataluña, País Vasco- presentaban en esa época menores niveles de mortalidad que regiones económicamente más atrasadas, como las dos Castillas, Extremadura o Andalucía $^{82}$ (Tortella, 1994:212). Asimismo, en este descenso inicial de los niveles de mortalidad influyó también la "dignificación en las infraestructuras urbanas (agua corriente, alcantarillado) que tuvo lugar en las décadas de 1920 y 1930” (Arango, 1987:209), y el que se produjeran mejoras cualitativas y cuantitativas en las infraestructuras sanitarias, derivadas de una dotación presupuestaria antes prácticamente inexistente ${ }^{83}$ : "No caben dudas acerca de la relación entre este gran aumento del gasto en Sanidad y el descenso de la tasa de mortalidad” (Tortella, 1994:212).

Además, intervinieron otros factores que también ayudaron a la reducción de la mortalidad durante el primer tercio del siglo XX como los relativos a la legislación sanitaria obligatoriedad desde 1902 de la vacuna antivariólica-, la mejora de la alimentación "que trajo consigo el nuevo ciclo de bonanza” y que provocó el desplome de la mortalidad infantil (A. de Miguel, 1987:150), la mejora del vestido, y la enseñanza y difusión de prácticas higiénicas. Esto último resultó esencial para reducir la elevada mortalidad en la infancia, al lograr que actitudes y prácticas prehigiénicas referidas al cuidado de recién nacidos y de los más pequeños fuesen retrocediendo o incluso erradicándose (J. de Miguel, 1973:210). Sobre esta relación, Leguina (1970:95) sostiene que la disminución de la mortalidad infantil en esta época es deudora más bien del abandono de algunas prácticas tradicionales sobre el cuidado y alimentación de los niños que a la puesta en marcha de instalaciones sanitarias específicas: "en otras palabras, el dejar de destetar a los niños con aguardiente y el abandono de otras prácticas parecidas ha

\footnotetext{
${ }^{82}$ Las diferencias de nivel, ritmo, duración y calendario en la evolución de la mortalidad se observan asimismo dentro de cada país. El análisis realizado por Dopico y Reher (1998) muestra que España es un país paradigmático en este sentido. Según estos autores, "una de las características más relevantes del proceso de transición demográfica español es la notoriedad de los contrastes territoriales, lo que convierte las cifras globales referidas a todo el territorio en indicadores insuficientemente expresivos de la complejidad del cambio demográfico en nuestro país” (Dopico y Reher, 1998:13). En la segunda mitad del siglo XIX y principios del XX España es uno de los países europeos que presenta mayores contrastes regionales en los ámbitos socioeconómico, cultural y demográfico. Contrastes que no son coyunturales sino que "representan tendencias que ya se daban a finales de la Edad Moderna". Así, en el año 1900-01 frente a una e(0) máxima de 44,9 años en Baleares, o de 37,2 años y 36,8 años en Cataluña y País Vasco, respectivamente, las regiones del centro y sur peninsular tienen una longevidad 11 años menor (Castilla la Vieja, 33,1 años; Andalucía, 33,2 años; Extremadura, 31,1 años) (Dopico y Reher, 1998: 43).

83 "Los gastos presupuestarios en Sanidad, casi nulos a principios de siglo, se decuplican en términos reales durante el primer tercio de siglo" (Tortella, 1994:212).
} 
evitado, posiblemente, más muertes infantiles que la introducción -tímida de hecho- en medios rurales de servicios de puericultura adecuados" ${ }^{\prime 4}$.

En la década de $1930^{85}$, y como consecuencia de la Guerra Civil, se frena el incremento de la $\mathrm{e}(0)$ que, de hecho, reduce su nivel en los varones mientras que en las mujeres crece mínimamente. Los efectos de la Guerra Civil no terminaron con ella y las "peculiaridades de la situación social” de la posguerra (represión política, autarquía, control de precios, estancamiento y reducción de las rentas salariales, escasez de alimentos y de bienes esenciales, economía de trueque, dificultades de abastecimiento en un contexto internacional bélico) provocaron el repunte de la mortalidad en la primera mitad de la década de $1940^{86}$. En la segunda mitad de la misma se recuperó la tendencia descendente de la mortalidad de tal forma que la e(0) se incrementó en 12 años en el conjunto de esa década. Incremento que fue más intenso en los hombres que en las mujeres, lo que indica efectivamente que se trata de una recuperación de la tendencia descendente de la mortalidad, ya que son esa década y la primera del siglo XX las únicas en la que la vida media de los varones crece más que la de las mujeres (Tortella, 1994:213).

No deja de ser paradójico que esta evolución favorable de la mortalidad española, que ha continuado hasta hoy, se acelerara precisamente en unas décadas de "penuria económica y de reconstrucción” como son las de 1940 y 1950, en las que se produjeron los mayores avances de la lucha contra la muerte del siglo XX medidos en términos de e(0). Entre 1940 y 1960, ésta aumentó en casi veinte años, alcanzando un valor de 70 años en 1960, valor que duplicaba los

\footnotetext{
${ }^{84}$ Una buena muestra de las actitudes y comportamientos prehigiénicos desarrollados a principios del siglo XX fue recogida por el Ateneo de Madrid en los años 1901 y 1902, a través de diversos corresponsales en las distintas provincias españolas, en una encuesta sobre costumbres tradicionales relacionadas con el nacimiento, el matrimonio y la muerte. En el caso de la provincia de Salamanca, por ejemplo, en el apartado de alumbramientos se dice: "Lo general, fuera de las clases acomodadas, es la asistencia por mujeres no profesionales, llamadas parteras o partoleras: se llama al médico cuando el estado de la parturienta es grave.

Antes de llamarle, la partolera apela a extremos tan serios como el de meter a la parturienta en la boca la trenza de su propio pelo o darle orines del marido para que provoque náuseas y arroje o libre las secundinas, sotenas o pares (delibrar y delibración) o la de hacerla que sople en una botella o colgarla de llares (cadena de la que pende la caldera del hogar) cuando el parto viene recio. También apelan a apretar con los puños los riñones...

(Una vez concluido el parto)... El régimen es de quietud en la cama sudando el parto, con el crío, a quien también es de rigor el sudar, para que no se le quede el sebo que saca a la naciencia con calecío en la piel; nada de mudar la ropa de la parida ni menos la de la cama, aunque, por el buen parecer, se viste a aquélla sobre su camisa un historiada chambra y se echa encima de la cama el mejor cobertor con las mejores sábanas” (Blanco, 1986:17-54).

85 "En vísperas de la guerra civil, España había recorrido aproximadamente la mitad del camino entre una mortalidad propia del antiguo régimen demográfico y otra que la asimilaba, al menos por sus indicadores cuantitativos, con los países más avanzados” (Dopico y Reher, 1998: 30).

${ }^{86}$ Los años de la década de 1940, como describe A. de Miguel (1987:cap. 8), además de oscuros, y aun tenebrosos, por la "cruel represión", fueron "los años del hambre". Tiempos difíciles en los que se produjo la última hambruna de la historia española derivada de las ínfimas cosechas en el bienio 1944-45.
} 
35 años de la e(0) de 1900, y que equiparaba la longevidad española a la de los países más desarrollados. Dado que esta evolución $<<$ contraintuitiva $>{ }^{87}$ de la mortalidad española durante ese periodo de tiempo constituye uno de los primeros ejemplos históricos de ruptura de la hipotética relación unilateral entre crecimiento económico y descenso de la mortalidad, ha existido un especial interés entre los científicos sociales por explicar las razones que dieron lugar a la misma. En este sentido, se ha resaltado que, a diferencia de la mayoría de los países desarrollados que lograron comprimir su mortalidad ordinaria básicamente al reducir los riesgos con el propio proceso de modernización socioeconómica, en el caso de la mortalidad española esa reducción se logró por la actuación conjunta de factores socioeconómicos y de factores médico-sanitarios (Gil y Cabré, 1997:71). Así, se cita entre los primeros, además del efecto acumulado derivado de los factores causales señalados para el primer tercio de siglo, la creciente urbanización, la mejora de las condiciones de vida en las ciudades, la extensión de los servicios médicos estatales (Seguridad Social ${ }^{88}$ ) y la incidencia de otros factores "sociales" como la política higiénica, el incremento de los niveles culturales y de instrucción entre la población (Tortella, 1994:212; Nadal ${ }^{89}$, 1976: 226-233). A la incidencia de los factores socioeconómicos se unió, desde finales de la década de 1940, la utilización de los avances médicos-sanitarios, algunos de muy bajo coste (sulfamidas, antibióticos -penicilina, estreptomicina-, vacunas, nueva quimioterapia), parte de los cuales empezaron a ser fabricados en España (Pérez Díaz, 2002:71). La influencia de éstos realimentó el descenso de la mortalidad y, al controlar especialmente la mortalidad de la población más joven, fue determinante para que se alcanzaran los 70 años de e(0) en $1960^{90}$.

\footnotetext{
${ }^{87}$ Tapia $(2011,2007)$ resalta que distintas investigaciones han mostrado que, a corto plazo, descontando las tendencias seculares, en distintos países industrializados se ha observado una evolución <<contraintuitiva >> de la mortalidad, en el sentido de que ésta tiende a subir en las épocas de expansión y a disminuir en las de recesión. Es el caso de EE.UU (1920-1940), o de España (1960-2000, fijándose especialmente en el quinquenio 1976-80). Por su parte, Goerlich y Pinilla (2006), siguiendo a Sen (1998), asocian lo ocurrido en los años cuarenta y cincuenta en España con una distribución más equitativa, al aplicar procedimientos de racionamiento, frente a épocas de mayor prosperidad económica, como los años sesenta, en las que se redujo la preocupación por las cuestiones distributivas.

88 "En el año 1942 se implantó el Seguro de Enfermedad y en el 1947 el Seguro Obligatorio de Vejez e Invalidez (SOVI)" (Blanes, 2007:119).

${ }^{89}$ Haciendo referencia explícita a esta fase concreta de la evolución de la mortalidad, Nadal (1976:227) señala que "a pesar de un nivel económico insuficiente, a pesar de una producción agrícola muy débil (43,5 millones de quintales métricos de trigo para un censo de 24 millones de habitantes, en 1931-35; sólo 48,1 millones de quintales, para 32 millones de habitantes, en 1963-1967), la mortalidad ha disminuido en un 46 por 100 desde 1935 hasta la fecha (1960)”. Para lo cual, sólo encuentra una explicación de tipo social, "a partir de un nivel mínimo, la mortalidad depende hoy mucho más de factores sociales y sanitarios (política higiénica, educación) que del desarrollo económico propiamente dicho”.

${ }^{90}$ Esta evolución peculiar de la mortalidad española respecto a la de los países desarrollados de su entorno, caracterizada por el retraso en el inicio de la reducción de la mortalidad ordinaria, el rápido descenso de la misma una vez iniciado el proceso, y la reducción de los riesgos provocada por la actuación conjunta de factores socioeconómicos y médico-sanitarios, lleva a Gil y Cabré (1997:70), utilizando el esquema de Omran (1971), a identificar a la sociedad española como un "buen ejemplo" del modelo "acelerado" de transición epidemiológica, más que del modelo "clásico" de la misma.
} 
Como se ha señalado más arriba, en un contexto internacional de estancamiento de la longevidad, durante la década de 1960 la evolución de la e(0) española continuó su marcha ascendente incrementándose durante esa década en 2 años. Este incremento de la e(0) estuvo relacionado con la mejora de las condiciones generales de vida (nutrición, higiene, vivienda) derivada de los cambios estructurales iniciados con el Plan Nacional de Estabilización de 1959 y con la lenta ruptura del aislamiento internacional del régimen franquista: la llegada capitales extranjeros, las remesas de los inmigrantes, las divisas de los turistas (además de su efecto demostración en lo relativo a actitudes y comportamientos), el éxodo rural y los masivos movimientos migratorios internos, el incremento del peso relativo de los sectores secundario y terciario en la economía en detrimento del sector primario, etc., que supusieron la inserción de la sociedad española en el capitalismo de producción y consumo de masas. Por tanto, fue una gran conjunción de cambios económicos y sociales, reforzados entre sí, la que generó por un lado un aumento de la producción y riqueza agregada y, por otro lado, una redistribución de esta riqueza a través de un aumento significativo de los salarios, al menos en las ciudades, lo que en conjunto favoreció la reducción de la mortalidad en la década del “desarrollismo”. Entre esos cambios estructurales hay que destacar, además, por su significativa incidencia en la reducción de la mortalidad infantil desde finales de la década de 1960, el papel jugado por la tecnología médica, la mejora en la atención obstétrica y materno-infantil y el inicio de la construcción de los grandes hospitales maternales de la Seguridad Social, con lo que los nacimientos pasaron a ser atendidos en hospitales y con personal sanitario especializado, abandonándose la práctica antigua de dar a luz en los domicilios particulares con la sola asistencia de parteras y comadronas $^{91}$ (Viciana, 1998:172; del Campo, 1987:38).

La evolución favorable de la e(0) se aceleró aún más en la década de 1970, en la que las nuevas reducciones de la mortalidad derivadas del cambio de estrategia en la lucha contra la muerte se tradujeron en una recuperación de la senda ascendente de la longevidad en casi todos los países cuya transición epidemiológica estaba muy avanzada. Así, entre 1970 y 1980 la e(0) española aumentó en casi cuatro años, incremento que situó a la longevidad española entre las más elevadas del mundo a comienzos de los años ochenta. Los descensos de la mortalidad han continuado desde entonces, aunque los crecimientos intercensales de la longevidad en las

\footnotetext{
${ }^{91}$ En el año 1970, el 55\% de las amas de casa entrevistadas para el II Informe Sociológico sobre la Situación Social de España habían dado a luz su último hijo en un domicilio particular, mientras que el $12 \%$ de los alumbramientos habían sido asistidos por personal no especializado, es decir, en ausencia de médicos y comadronas (J. de Miguel, 1973:212). Como contraste a estos datos, en el año 1975, 820 nacimientos de cada 1000 ya fueron atendidos en centros sanitarios por personal especializado. Esta evolución, que tanto ha redundado en la disminución de la mortalidad infantil, llega a los 918 nacimientos de cada 1000 en 1991. En este control de riesgos relacionados con el parto hay que incluir además la influencia del progresivo cambio de actitudes por parte de las mujeres embarazadas, con revisiones ginecológicas más frecuentes, control de dieta, peso, información sobre enfermedades que pudieran incidir en la salud del feto, etc. (INE, 1994:544-545).
} 
últimas décadas han sido menos intensos. En efecto, una vez controlada casi totalmente la mortalidad infantil y en gran medida la mortalidad juvenil, los principales avances en la lucha contra la muerte, como se expone más adelante, se han estado produciendo en las edades más avanzadas y en éstas son menos los años que se pueden ganar a la muerte.

Una vez controladas casi totalmente las enfermedades infecto-contagiosas, la creciente complejidad en el enfrentamiento de la muerte desde el último tercio del siglo XX hace imprescindible que el análisis de la mortalidad se aborde a través de lo que globalmente se denomina $<<$ Mortalidad Diferencial $>>$.

\subsubsection{MORTALIDAD DIFERENCIAL}

“¿Por qué tengo que desangrarme?”

B. Pasternak

Como se ha señalado, a lo largo de las décadas de 1960 y 1970 se produjeron una serie de acontecimientos relativos a la transición de la mortalidad que impulsaron a los científicos sociales, especialmente a los demógrafos, a reorientar la perspectiva desde la que analizaban dicho fenómeno. En lo que se refiere a los países desarrollados, el estancamiento en el descenso secular de la mortalidad durante la década de 1960 y la recuperación de la tendencia descendente en los años setenta generó la necesidad de conocer el por qué de esta nueva dinámica y cuáles eran los factores de riesgo subyacentes en la misma. De esta forma, comenzó una nueva fase de profundización en el estudio de la mortalidad en la que, sin embargo, no se analizaba a ésta como una totalidad, sino que se la examinaba, estática y dinámicamente, discriminando los efectos de los distintos factores de riesgo ya que éstos no inciden de la misma forma y con la misma intensidad en cada uno de las individuos, ni en cada una de las categorías sociales de análisis. Es lo que se denomina "Mortalidad diferencial", y hace referencia a las desigualdades ante la muerte que se plantean entre las diversas subpoblaciones determinadas según criterios de edad, sexo, estado civil, hábitat, pertenencia social, etc. Desigualdades que se expresan, entre otros, en algunos de los siguientes ámbitos: “1) en el conocimiento y en las actitudes relativas a la salud y su cuidado; 2) en el acceso a las bases de la salud (alimentación, vivienda, trabajo, educación, estilo de vida), y en el riesgo de enfermedad (genérico y de enfermedades específicas); 3) en el grado de cobertura en el acceso a los servicios médicos; 4) en el cuidado no institucional de la salud; 5) en la eficacia en la utilización del sistema sanitario; 6) en el nivel de salud, autopercibida y examinada; 7) en el tratamiento ante una misma enfermedad” (Durán, 1983:180). Desigualdades que, en última instancia, cristalizan en la desigual duración de la vida, en distintos niveles y estructuras de la mortalidad, en la disparidad de las causas de muerte. 
A continuación se aborda el análisis de la mortalidad diferencial según los dos criterios sociodemográficos básicos: la edad y el sexo, aunque previamente se realiza un primer acercamiento muy sintético a la evolución de la mortalidad y a la morbilidad por causas de muerte en España ${ }^{92}$. Los objetivos de esta aproximación son, por un lado, describir a grandes rasgos la evolución de las principales causas de muerte para así fijar temporalmente las distintas fases de la transición epidemiológica en el caso español y, por otro lado, evaluar sucintamente con datos desagregados por causa de enfermedad/muerte la situación paradójica que se observa en las últimas fases de la transición sanitaria en la que se combina una morbilidad creciente con una mortalidad decreciente. Además, como señala Vallin (1988:21), aunque las causas inmediatas o "médicas" de muerte no constituyen los determinantes primarios de la mortalidad, su análisis es un paso intermedio obligado para examinar la relación entre el nivel y las estructuras de la mortalidad con sus determinantes. De esta forma, una vez examinada la mortalidad por causas, el análisis posterior cruzando las causas de muerte con la edad y el sexo permitirá profundizar en los determinantes de la mortalidad española en el último tercio del siglo XX y primera década del siglo XXI.

\subsubsection{MORTALIDAD POR CAUSA DE MUERTE EN ESPAÑA ${ }^{93}$}

“Doctor, ¿tengo los ojos abiertos? No puedo ver nada”

M. Sánchez, Manolete

De forma similar a lo acontecido en el resto de los países desarrollados, la transición de la mortalidad española se ha caracterizado además por una profunda modificación en la distribución de las causas inmediatas de muerte ${ }^{94}$. Por un lado, se ha producido una reducción

\footnotetext{
92 Puede consultarse en Blanes (2007) y en Viciana (2003, 1998) el análisis detallado de la mortalidad por causa en España durante el siglo XX.

${ }^{93}$ En el caso de España, los datos sobre las causas de defunción se inscriben en el Boletín Estadístico de Defunción, en el que se recogen hasta cuatro causas de muerte: inmediata, intermedia e inicial o fundamental y otros procesos. Desde principios del siglo XX el INE sólo codifica las defunciones según la causa fundamental que produjo el deceso. Se entiende por causa inicial la "enfermedad o el traumatismo que han desencadenado la evolución o las circunstancias del accidente o de la violencia que han ocasionado el traumatismo mortal" (Nizard, 1985:107). A ella se hace referencia en este trabajo cuando se habla de causa de muerte.

${ }^{94}$ El análisis de la evolución histórica de la mortalidad por causas en los países desarrollados requiere de ciertas precauciones con el fin de evitar sesgos interpretativos. Así, por ejemplo, el aumento relativo de la mortalidad por una determinada causa de muerte puede tener su origen en un incremento real de la mortalidad por dicha causa, pero también puede responder al perfeccionamiento en la identificación de los casos y en el diagnóstico. Siendo así que casos que en el pasado fueron atribuidos a otras causas se diagnostiquen con mayor precisión y se atribuyan correctamente a aquélla. Es el caso señalado por Meslé (Meslé et al., 1985:38) para el notable incremento de la mortalidad por infarto de miocardio en todos los países desarrollados hasta 1970. Al incremento real derivado del aumento de los factores de riesgo (tabaquismo, sedentarismo, etc.), se añadía el sesgo de observación derivado de diagnósticos médicos imprecisos que atribuían a otras enfermedades lo que en realidad eran muertes por infarto de miocardio.
} 
neta de la mortalidad exógena -resultado del descenso de las enfermedades infecciosas y parasitarias, y la evolución errática de las muertes por causas externas-, incrementándose, en consecuencia, el peso relativo de la mortalidad endógena; por otro lado, esta transformación ha venido acompañada de un proceso de concentración de los fallecimientos en muy pocas causas de muerte.

En efecto, aunque a lo largo del siglo XX se produjeron todavía algunas crisis concretas asociadas a los obstáculos positivos malthusianos, se puede afirmar que a principios del pasado siglo la sociedad española en su conjunto había superado la "edad de la pestilencia y el hambre" y se encontraba en la segunda fase de la transición epidemiológica, la "edad del retroceso de las pandemias”. El conjunto de la enfermedades infecciosas y parasitarias (tuberculosis, gripe, tifus, cólera, disentería, difteria, sarampión, escarlatina, etc.) eran la principal causa de muerte y provocaban casi la mitad de los fallecimientos entre la población española, mientras que las enfermedades del sistema circulatorio y los tumores malignos no causaban más que el $15 \%$ de los decesos ${ }^{95}$, Cuadro 4.4. En el año 1945 se cruzan las tendencias de las mortalidades por enfermedades infecciosas y por enfermedades no infecciosas (Robles et al, 1996:225), y a mediados del siglo XX se aprecia ya con nitidez la profundidad del cambio en el perfil de las causas de muerte; el control de las enfermedades infecto-contagiosas había reducido su peso relativo a menos del $10 \%$, y la mortalidad endógena provocaba el $72 \%$ de las muertes, lo que significa que la población española estaba finalizando la segunda etapa de la transición epidemiológica.

Este hecho se confirmó al comprobarse que el incremento por infarto de miocardio se acompañó con la disminución simultánea de las muertes por "enfermedades mal definidas". A los problemas de diagnóstico hay que añadir el hecho de que la clasificación de las causas de muerte ha evolucionado con el tiempo con distintas revisiones de la nomenclatura que la hacen poco compatible de un periodo a otro (Vallin, 1988:43). En la actualidad, está vigente la Clasificación Internacional de Enfermedades (CIE), $10^{a}$ revisión, adoptada por la OMS en 1992 y empleada en las estadísticas oficiales españolas desde 1999, y que ha sustituido a la 9a revisión, empleada en España entre 1980 y 1998. Un análisis de la evolución de la CIE y de los problemas de comparabilidad puede consultarse en (Nizard, 1985:100-114; Vallin, 1988). Para el examen de la calidad y comparabilidad de las estadísticas por causa de muerte en España puede verse (García Benavides et al, 1991).

${ }^{95}$ El indicador "Mortalidad Proporcional por causa" expresa la contribución relativa de una causa dada a la mortalidad total, o el porcentaje de riesgo global de muerte que cabe atribuir a la enfermedad en cuestión. 
CUADRO 4.4.: EVOLUCIÓN DE LA MORTALIDAD PROPORCIONAL POR GRANDES GRUPOS DE CAUSAS DE MUERTE (\%). ESPAÑA

\begin{tabular}{|l|c|c|c|c|c|}
\hline & $\mathbf{1 9 0 7}$ & $\mathbf{1 9 5 5}$ & $\mathbf{1 9 7 0}$ & $\mathbf{2 0 0 0}$ & $\mathbf{2 0 0 8}$ \\
\hline (1) Enfermedades infecciosas y parasitarias & $485^{\mathrm{a}}$ & 94,1 & 28,24 & 17,4 & 19,9 \\
(2) Accidentes y otras muertes violentas & 18 & 39,3 & 48,2 & 45,9 & 39,6 \\
\hline Total mortalidad exógena (1)+(2) & 503 & 133,4 & 76,5 & 63,3 & 59,5 \\
\hline (3) Tumores & 18 & 109,4 & 164,0 & 263,8 & 269,3 \\
(4) Enfermedades del sistema circulatorio & 130 & 262,5 & 357,3 & 348,8 & 317,8 \\
(5) Otras enfermedades endógenas & & 345,3 & 321,4 & & \\
\hline Total mortalidad endógena (3)+(4)+(5) & 148,0 & 717,2 & 842,7 & & 353,4 \\
\hline Senilidad y mal especificadas & & 159,4 & 80,9 & & \\
Otras & 349 & & & 324,1 & 1000 \\
\hline \multicolumn{1}{|c|}{ Todas las causas } & 1000 & 1000 & 1000 & 1000 & \\
\hline
\end{tabular}

a Incluye las enfermedades de los sistemas respiratorio y digestivo.

Fte: Elaboración propia a partir de los datos de: 1907, (Viciana, 1998:196); 1955 y 1970, (FOESSA, 1976:29); 2000 y 2008, INE:INEbase.

El perfil de mortalidad por causa de 1970, dominado por las enfermedades crónicas y degenerativas (84,3\% de los decesos), confirma que en esa fecha la población española ya se encontraba en la tercera etapa de la transición epidemiológica, la "edad de las enfermedades degeneración y de las enfermedades producidas por el hombre". En un escenario marcado por la mortalidad endógena, la mortalidad exógena estaba provocada en sus dos terceras partes por muertes violentas, mientras que la letalidad de las enfermedades infecto-contagiosas se había reducido sustancialmente respecto a épocas pretéritas. Se observa, además, que muy pocas causas de muerte concentran la mayoría de los fallecimientos: las enfermedades del sistema circulatorio junto con los cánceres provocaron más de la mitad de las muertes de 1970.

Esta tendencia se ha reforzado en el último tercio del siglo XX paralelamente al envejecimiento de la población española, si bien los datos del año 2000 reflejan los cambios producidos durante ese periodo en la jerarquía de las causas de muerte que dominan el perfil de la mortalidad: descenso relativo de la mortalidad por enfermedades cardiovasculares ${ }^{96}$, aunque siguen siendo la principal causa de muerte para el conjunto de la población, unido a un

\footnotetext{
${ }^{96}$ Hay que matizar, no obstante, que en estos datos agregados se compensan las evoluciones opuestas de, por ejemplo, los dos principales componentes de las enfermedades cardiovasculares, que en conjunto causan cerca del $60 \%$ de la mortalidad cardiovascular total: las enfermedades cerebrovasculares, cuya incidencia está declinando, y la enfermedad isquémica del corazón que, por el contrario, evoluciona con creciente intensidad. La elevada prevalencia que los tres factores de riesgo cardiovascular prevenibles más importantes -consumo de tabaco, hipertensión arterial y colesterol alto- tienen en la población española, además del creciente envejecimiento de ésta y la extensión de hábitos de vida insanos (consumo elevado de alimentos elaborados con grasas animales o azúcar entre la población infantil; aumento de la prevalencia del tabaquismo entre las mujeres), hacen prever, según Villar y Banegas (2000), un incremento del riesgo de muerte cardiovascular en los próximos años, a pesar de las mejoras en la atención médica o en la detección y tratamiento de la hipertensión arterial.
} 
incremento constante del peso relativo de las muertes por tumores ${ }^{97}$, segunda causa de muerte. Juntas estas dos causas de muerte provocan, en el año 2000, el 60\% de los decesos. Si se las suman las muertes debidas a enfermedades de los sistemas respiratorio -tercera causa de muerte- y digestivo - cuarta causa de muerte- (ambas endógenas), y los accidentes, envenenamientos y violencias -quinta causa de muerte- (exógenos), el conjunto de estos cinco grupos de causas originan el $83,4 \%$ del total de fallecimientos en ese año. Por su parte, las enfermedades infecciosas y parasitarias, principal causa de muerte a principios del siglo XX, constituyen la undécima causa de muerte por orden de importancia y sólo originan un 1,7\% de los decesos al final del mismo. Estos cambios en el periodo 1970/2000 son indicativos de un cierto control sobre las enfermedades degenerativas e identifican, por tanto, el tránsito de la población española por la cuarta etapa de la transición epidemiológica.

Tránsito que se consolida en la primera década del siglo XXI como constatan los datos de mortalidad proporcional en $2008^{98}$ : reducción del peso relativo de la mortalidad exógena y de la provocada por las enfermedades del sistema circulatorio, mayor importancia absoluta y relativa de la mortalidad por tumores ${ }^{99}$, por enfermedades del sistema nervioso ${ }^{100}$, que desde el

${ }^{97}$ Este crecimiento de la mortalidad por cáncer en España contrasta con la evolución favorable de la mortalidad para este grupo de causas observado en el conjunto de la Unión Europea, desfase que para López-Abente (2000) significa que "nos encontramos en un momento de la epidemia de cáncer todavía bastante anterior que la de otros países del norte de Europa”. Estos países, así como Estados Unidos, arbitraron hace años medidas de prevención primaria (fomento de comportamientos saludables y reducción de los insalubres, por ejemplo, disminución del tabaquismo) y de prevención secundaria (diagnóstico precoz de algunos tumores), que en España se ha implementado con retraso. Retraso que, además, justifica el que se pueda prever un incremento futuro de la mortalidad por esta causa y, en consecuencia, un agrandamiento del diferencial con la media de la UE. El aumento global de la mortalidad por cánceres, no obstante, oculta la evolución favorable por algunos tipos de tumores, como el de estómago entre los hombres y los de estómago y útero entre las mujeres, que no pueden contrarrestar la evolución creciente de los cánceres de laringe, faringe, pulmón, páncreas, próstata, vejiga e intestinos entre los hombres, y mama, ovario, páncreas, intestinos y pulmón entre las mujeres. El consumo de tabaco está relacionado con el crecimiento observado en buena parte de los tumores que afectan a los hombres, y en menor medida hasta ahora en los de las mujeres, aunque entre éstas la situación empeorará en el futuro cuando, como ya ha ocurrido en los países donde las mujeres empezaron a fumar antes, emerjan con fuerza los cánceres relacionados con el tabaquismo y en especial el cáncer de pulmón (López-Abente et al, 2002; López-Abente, 2000; Fernández et al, 2003). La mortalidad por cáncer de pulmón entre las mujeres españolas, siendo siempre reducida, presenta crecientes tasas desde 1995 que "pueden estar mostrando el inicio de la epidemia de cáncer de pulmón en mujeres en nuestro país" (López-Abente, 2000).

${ }^{98}$ Para un análisis detallado de la evolución de la mortalidad tanto por capítulos como por las principales causas específicas de muerte en España pueden consultarse (Regidor et al, 2011, 2009).

${ }^{99}$ La mayor importancia absoluta de los tumores se debe a que el número absoluto de decesos por ellos no ha dejado de aumentar en las últimas décadas; así, en 1980-82, fallecieron por esta causa 59.863 personas en España, en el año 2000, 94.836, y en el 2008, 103.810. No obstante, las tasas de mortalidad por esta causa se encuentran en un ligero descenso desde la década de los noventa, por lo que su mayor importancia relativa se debe a la redistribución de los pesos relativos con otras causas de muerte que se han reducido con mayor intensidad.

${ }^{100}$ El número de personas fallecidas por este capítulo fue de 17.432, en 2008. Dentro del mismo destaca el creciente peso de las muertes por enfermedad de Alzheimer, prácticamente el $60 \%$ de todos los fallecimientos por este capítulo en la actualidad, cuya evolución entre 1981 y 2008 es calificada de espectacular por Regidor et al (2011:16): en 1981, se produjeron 21 muertes por esta causa; en 2008, 
año 2007 se convierte en la quinta gran causa de mortalidad desplazando a las causas externas al sexto lugar, y por los trastornos mentales y del comportamiento ${ }^{101}$.

De forma más concreta, en el Cuadro 4.5. se recoge la evolución de diez de las causas de mortalidad que produjeron el mayor número de fallecidos en $2008^{102}$. Para poder comparar en el tiempo evitando el efecto de la estructura por edad, se han considerado las tasas de mortalidad ajustadas por edad, o <<Tasas estandarizadas de mortalidad por causa de muerte $>>{ }^{103}$, utilizando la distribución por edad estándar de la población europea (Regidor et al, 2011:74).

provocó 10.402. Otra causa de muerte cada vez más significativa dentro de este capítulo es la enfermedad de Parkinson; en 2008, fallecieron 2.633 personas por ella, conformándose como la decimoquinta causa concreta que más fallecimientos provocó en ese año (Regidor et al, 2011:14).

${ }^{101}$ La mortalidad por este capítulo asimismo está creciendo en los últimos años y se aproxima en términos absolutos y relativos a la mortalidad por causas externas. Una de las razones de esta aproximación es su ligazón al envejecimiento del organismo y, más concretamente, al aumento de las demencias con la edad: de las 12.879 muertes por este capítulo, en 2008, 11.973, el 92,96\%, se produjeron por demencia.

${ }^{102}$ Si bien en el año 2008, las enfermedades cardiovasculares provocaron el 31,7\% del total de los fallecimientos y los tumores el 26,9\%, en el Cuadro 4.5. se recoge la evolución de las dos causas que provocan el $60 \%$ de la mortalidad por enfermedades cardiovasculares (enfermedades isquémicas del corazón y enfermedades cerebrovasculares) y, en el caso de los tumores, sólo se recoge la correspondiente a los tumores malignos (cánceres).

${ }^{103}$ Para el cálculo de las mismas se estiman previamente las Tasas de Mortalidad Específicas por Edad y Causa que son los cocientes, para una causa dada, entre el número de decesos en un grupo de edad determinado, en un año dado, y la población a mediados de año en ese grupo de edad. Aceptando que el volumen de población a mitad de año es una estimación que no difiere demasiado de la población media expuesta al riesgo de morir durante el año considerado, estas tasas reflejarían la probabilidad media de morir por una causa que tiene un individuo de la población en un año determinado. Es decir, facilitan el establecimiento del lugar relativo que cada una de las causas ocupa en el conjunto de mortalidad en una edad o grupo de edades considerado. Una vez calculadas estas tasas se emplea el método de la población tipo o estandarización directa para estimar las tasas estandarizadas. Es importante tener en cuenta que estas tasas son "virtuales", es decir, no miden los riegos reales en cada población, ya que cambian al cambiar la población tipo, y sólo sirven para efectuar comparaciones. 


\section{CUADRO 4.5.: PRINCIPALES CAUSAS DE MUERTE EN ESPAÑA. TASA DE MORTALIDAD AJUSTADA POR EDAD POR 100.000 HAB. Y PORCENTAJE DE CAMBIO. ESPAÑA. 1981, 2000 Y 2008}

\begin{tabular}{|l|c|c|c|c|c|}
\hline & \multicolumn{3}{c|}{$\begin{array}{c}\text { Tasas de mortalidad } \\
\text { ajustadas por edad }\end{array}$} & \multicolumn{2}{c|}{ Porcentaje de cambio } \\
\cline { 2 - 6 } & $\mathbf{1 9 8 1}$ & $\mathbf{2 0 0 0}$ & $\mathbf{2 0 0 8}$ & $\mathbf{2 0 0 8 / 1 9 8 1}$ & $\mathbf{2 0 0 8 / 2 0 0 0}$ \\
\hline \multicolumn{1}{|c|}{ Todas las causas } & 804,8 & 611,5 & 519,7 & $-35,4$ & $-15,0$ \\
\hline Cáncer & 162,3 & 170,3 & 154,6 & $-4,7$ & $-9,2$ \\
\hline Enferm. isquémica del corazón & 78,5 & 65,4 & 47,3 & $-39,7$ & $-27,7$ \\
\hline Enferm. cerebrovasculares & 132,3 & 56,0 & 38,2 & $-71,1$ & $-31,7$ \\
\hline Accidentes y causas externas & 35,9 & 26,6 & 18,8 & $-47,6$ & $-29,3$ \\
\hline $\begin{array}{l}\text { Enferm. pulmonar } \text { obstructiva } \\
\text { crónica }\end{array}$ & 22,7 & 25,5 & 18,1 & $-20,2$ & $-29,0$ \\
\hline Enferm. de Alzheimer & 0,1 & 7,8 & 11,2 & 11.100 & 43,6 \\
\hline Diabetes mellitus & 19,2 & 14,4 & 12,3 & $-35,9$ & $-14,6$ \\
\hline Neumonía e influenza & 31.5 & 12,7 & 10,9 & $-65,4$ & $-14,2$ \\
\hline Eferm. crónica del hígado y cirrosis & 23,3 & 10,8 & 8,4 & $-63,9$ & $-22,2$ \\
\hline Suicidio & 4,6 & 7,3 & 6,5 & 41,3 & $-10,9$ \\
\hline
\end{tabular}

Fte: Elaboración propia a partir de (Regidor et al, 2011)

Entre el año 2000 y el 2008 la tasa de mortalidad ajustada por edad para todas las causas de muerte se redujo en un $15 \%$, descenso construido por la disminución de la mortalidad en todas las causas de muerte importantes. Con oscilaciones en alguna de ellas, esa tendencia descendente es continuación de una de más larga data observable en algunos países, desde los años sesenta o setenta para las enfermedades cardiovasculares, y desde los noventa para el cáncer y para otras enfermedades crónicas (enfermedad pulmonar obstructiva crónica, diabetes mellitas, neumonía e influenza y enfermedad crónica del hígado y cirrosis hepática) (Regidor et al, 2011.17). A esta evolución descendente de las enfermedades hay que añadir la dinámica asimismo favorable de la mortalidad por causas externas de traumatismos y envenenamientos, desde el inicio de la década de 1990, y de la muerte por suicidio, desde el año 2003, que rompe con la tendencia estable mantenida por esta causa entre finales de los ochenta y comienzos del siglo XXI, después del intenso crecimiento experimentado por la misma en la década de $1980^{104}$. En sentido contrario, hay que resaltar asimismo la evolución de la sexta causa de muerte en 2008, la enfermedad de Alzheimer, que provocó el 2,67\% del total de muertes de ese año y cuyo riesgo de muerte se ha incrementado un 43,6\%, desde el año 2000 , y un $11.100 \%$ desde 1981. En conjunto, desde el año 1981 hasta el 2008, la mortalidad se ha reducido en un $35,4 \%$.

\footnotetext{
${ }^{104}$ La evolución descendente de las defunciones por accidente de tráfico (incluidas en causas externas), más rápida que la de suicidio, ha situado a éste como la primera causa de muerte externa en 2008.
} 
Por otra parte, cabe recordar que, según Olshansky y Ault (1986), la cuarta etapa de la transición epidemiológica, a la que denominan de las "enfermedades degenerativas tardías", no se diferencia de la anterior tanto por las causas de muerte que la caracterizarían como por una sustitución en las edades de muerte, que tenderían a incrementarse al hilo del proceso de envejecimiento. Dado que el perfil de mortalidad por edad para cada causa es distinto, existen diferencias en las edades medias de fallecimiento por causa. En el Cuadro 4.6. se comprueba la tendencia general ascendente en la edad media de muerte desde la década de 1980, tanto para el conjunto de causas como para cada uno de los grupos de causas con mayor peso relativo. Las edades medias de muerte más altas corresponden a los trastornos mentales y del comportamiento, y a las enfermedades de los sistemas respiratorio, circulatorio y nervioso, todas ellas estrechamente ligadas al envejecimiento del organismo. Por su parte, el calendario de los tumores y de las enfermedades del sistema digestivo es más precoz que en el caso de las causas anteriores por lo que la edad media de fallecimiento por estas causas es inferior al de aquéllas. Asimismo, la distribución de las causas externas es más equilibrada a lo largo de todo el ciclo vital por lo que, dejando al margen las muertes por embarazo, parto y puerperio y las derivadas de malformaciones congénitas, la edad media de deceso por este grupo de causas es la menor de todo el conjunto de causas de muerte. Se aprecia además el importante crecimiento en la edad media de deceso por enfermedades infecciosas y parasitarias, 16 años desde comienzos de los ochenta, ligado asimismo al incremento de los riesgos inherentes al envejecimiento por la mayor vulnerabilidad de las personas de más edad ante el ataque de organismos patógenos ${ }^{105}$.

\footnotetext{
${ }^{105}$ La septicemia es la causa de muerte más importante dentro de las enfermedades infecciosas. En 2008, provocó más muertes que los suicidios, 4.136 decesos, muertes que se distribuyen crecientemente con la edad. Así, en ese año, la tasa de mortalidad por esta causa (en tantos por cien mil) entre los menores de 1 año fue de 2,6; entre la población de 15-24 años, la tasa fue de 0,2; entre los de 45-54 años, su valor fue de 2,1; y, a partir de los 65 años la tasa crece exponencialmente, 15,5, entre los de 65-74 años, 53,5, entre los de 75-84 años, y 162,0, entre los de más de 85 años.
} 


\begin{tabular}{|c|c|c|c|c|}
\hline & $\begin{array}{c}\text { (Media anual) } \\
1980-82\end{array}$ & $\begin{array}{c}\text { (Media anual) } \\
1990-92\end{array}$ & 2000 & 2008 \\
\hline Enferm. infecciosas y parasitarias & 55,09 & 53,94 & 64,01 & 71,95 \\
\hline Tumores & 66,99 & 69,23 & 71,36 & 72,62 \\
\hline Enferm. del sistema circulatorio & 76,04 & 78,68 & 80,14 & 81,47 \\
\hline Enferm. del sistema respiratorio & 74,1 & 77,53 & 80,78 & 82,29 \\
\hline Enferm. del sistema digestivo & 67,03 & 71,12 & 74,66 & 76,32 \\
\hline Enferm. del sistema nervioso & 59,03 & 67,12 & 76,41 & 79,88 \\
\hline Trastornos mentales y del comport. & 67,34 & 81,02 & 84,94 & 85,95 \\
\hline Causas externas & 48,06 & 46,39 & 51,23 & 58,68 \\
\hline Todas las causas & 69,96 & 72,78 & 75,68 & 77,57 \\
\hline
\end{tabular}

Fte: Instituto de Salud Carlos III, Base de datos de Mortalidad: Mortalidad por Capítulos y sexo 1999-2008 (http://www.isciii.es/htdocs/centros/epidemiologia/mortalidad.jsp).

\title{
4.2.2.2. RELACIÓN ENTRE MORTALIDAD Y MORBILIDAD
}

\begin{abstract}
"Hay razones para afirmar que cada uno de nosotros es una fábrica destinada a la producción de $\mathrm{CO}_{2}$ y que, creando muerte, vivimos”.
\end{abstract}

T. Volk

La transición epidemiológica/sanitaria se caracteriza, además de por el cambio mostrado en la estructura de la mortalidad por causa, por el tránsito desde una situación en la que predomina la mortalidad a otra situación en la que impera la morbilidad, generándose en esta última fase la aparente paradoja de una mortalidad decreciente combinada con una morbilidad creciente, o mejor dicho, de una mortalidad cada vez más controlada junto con una morbilidad en expansión. Las razones de esta paradoja ya han sido expuestas más arriba y tienen mucho que ver con el mayor nivel de desarrollo alcanzado por una sociedad. En cualquier caso, el hecho de que en la fase actual de la transición sanitaria la relación morbilidad/mortalidad no tenga efectos inmediatos, por la letalidad diferida de las enfermedades crónico-degenerativas, o que sea imprecisa, ya que una buena parte de la morbilidad es inmedible $0<<$ inventada $>>{ }^{106}$ y

\footnotetext{
106 Como resalta Segura (2004:290), el incremento de la morbilidad en la actual fase de la transición sanitaria está relacionado con el inevitable proceso de envejecimiento demográfico, los nuevos trastornos derivados de los estilos de vida modernos o de las transformaciones medioambientales, a los que "se suma un aumento considerable de las expectativas de salud, lo que disminuye el umbral de aceptación de los padecimientos, incluso de aquellos que en rigor no son problemas médicos y no tienen, pues, solución asistencial”, como "el malestar derivado de conflictos familiares, laborales o sociales". A lo que hay que añadir las nuevas enfermedades fomentadas por la industria farmacéutica -calvicie, menopausia masculina, timidez, osteoporosis, la hiperactividad, etc.- fenómeno analizado exhaustivamente por Blech (2004), y del que periódicamente se informa en los medios de comunicación: “Así se vendió la `píldora de la timidez"”, EL PAÍS (22/07/01:30); “Recetas inducidas por la publicidad”, EL PAÍS (10/05/05:31);
} 
no existen datos fiables sobre ella, no significa que no exista algún tipo de correlación entre las desigualdades sociales que se observan en la mortalidad humana con las desigualdades en la morbilidad, y sobre todo con la morbilidad hospitalaria (que es más importante y medible que el resto de la morbilidad) (Caïs et al, 1993:71-72) ${ }^{107}$.

El número total de personas fallecidas en España en 1980 fue de 289.344, cifra que se incrementó hasta alcanzar las 360.131, en 2001, y las 386.324, en 2008; es decir, un aumento del 23,7\% entre 1980 y 2001, y del 7,3\% entre 2001 y 2008. En esos mismos periodos de tiempo el número de pacientes hospitalizados ${ }^{108}$ aumentó a mayor ritmo que el número de decesos: un 34,9\% entre 1980 y 2001; un 8,9\%, entre 2001 y 2008 ${ }^{109}$ (Cuadro 4.7.). El crecimiento desde los 3.275.386 pacientes hospitalizados en 1980 hasta los 4.420.030, de 2001, y los 4.814.039, en 2008, certifica en una primera aproximación el creciente "dominio” de la morbilidad sobre la mortalidad a medida que la sociedad española avanzaba en la cuarta fase de su transición sanitaria. Obviamente este tránsito está relacionado con el crecimiento demográfico español durante ese periodo, con la extensión de la cobertura de la población por parte de la Seguridad Social y con la mayor disponibilidad de recursos médico-sanitarios, pero también con un incremento de la morbilidad misma, como se colige de la evolución de la tasa Número de Pacientes Hospitalizados por cada 10.000 habitantes que también creció un 23,5\% entre 1980 y 2001. En este año, el número de pacientes hospitalizados por cada 10.000 habitantes fue de 1.082,1, es decir, prácticamente 11 de cada 100 personas fueron tratadas de un episodio de hospitalización ${ }^{110}$. Cifra ligeramente superior a la de 2008, que no reflejaría un

“Osteoporosis, ¿una epidemia inventada?”, EL PAÍS (25/04/06:31); “Vendo enfermedades a la carta. Y remedios", EL PAÍS (09/10/08:28-29), en el que se denuncia lo que Ray Moynihan denomina "tráfico de enfermedades" que consiste en "la ampliación de las fronteras de lo patológico, a fin de abrir mercados para quienes venden y administran los tratamientos", y del que se extraen los siguientes párrafos: "Las compañías están detrás de informes cocinados para crear necesidades”, "El uso de estadísticas sesgadas desvirtúa los estudios", "Las personas sanas son el objetivo de las campañas de mercadotecnia”, "La osteopenia o la disfunción sexual femenina están en el punto de mira”,...

107 "Las relaciones entre las tasas de morbilidad globales y las de mortalidad son peculiares, y no necesariamente correlacionan positivamente. Sin embargo, las desigualdades sociales que se observan en la mortalidad provienen de desigualdades muy similares en la morbilidad" (Caïs et al, 1993:71-72).

${ }^{108}$ En España, los datos sobre morbilidad hospitalaria son obtenidos a través de la Encuesta de Morbilidad Hospitalaria elaborada anualmente por el INE. En esta encuesta se recoge información por muestreo del $75 \%$ de los hospitales españoles y su objetivo principal es "conocer las características demográfico-sanitarias de los enfermos dados de alta que hayan ingresado en un centro hospitalario en régimen de internado, así como disponer de información a nivel estatal sobre la frecuentación y utilización de los recursos hospitalarios en un año de referencia” (INE).

${ }^{109}$ A efectos del argumento que se quiere desarrollar, se considera más adecuado trabajar con los dos subperiodos señalados, en lugar de realizar los cálculos para el periodo total 1980-2008, porque en el denominador de las tasas de hospitalización del 2008 se refleja el importante incremento de la población española debida a la llegada de población inmigrante joven y adulta-joven desde el año 2000. El ritmo de crecimiento más intenso de la población respecto al del crecimiento del número de hospitalizaciones determina por sí mismo una caída en los indicadores de hospitalización relativos a la población total.

${ }^{110}$ Obviamente, existen importantes diferencias por edad en la distribución de las hospitalizaciones. Así, en el año 2001, el orden de mayor a menor hospitalización por grupos de edad fue el siguiente: 65-74 años (16,9\%); $25-34$ años (14,7\%); 75-84 años (13,8\%); 55-64 años (11,7\%); 85 y más años $(5,2 \%)$. 
cambio de dirección en la evolución de la morbilidad, sino que, aunque entre 2001 y 2008 el número de pacientes hospitalizados aumentó en términos absolutos, el mayor incremento de la población en ese periodo (del 9,9\%) determina que las tasas totales de hospitalización por 10.000 habitantes se redujeran un 2,4\%. Para evitar la interferencia de ese importante crecimiento de la población, por la llegada de población joven inmigrante, el análisis se centra preferentemente en el periodo 1980-2001.

El análisis desagregado de los pacientes hospitalizados por las causas de muerte más relevantes aporta más datos que corroboran el incremento de la morbilidad. En el Cuadro 4.7. se puede observar que las tasas de hospitalización en todas esas causas han crecido entre 1980 y 2001 excepto en las enfermedades infecciosas, que prácticamente permanecen constantes durante ese periodo en poco más de 20 pacientes hospitalizados por cada 10.000 habitantes. El crecimiento, sin embargo, fue especialmente intenso en las principales enfermedades crónicas y degenerativas, por lo que se puede aventurar que en gran medida estuvo relacionado con el envejecimiento de la población y con la incidencia de los "estilos de vida" en un número cada vez mayor de organismos cada vez más envejecidos. Así, por ejemplo, el número de pacientes hospitalizados con enfermedades del aparato circulatorio por cada 10.000 habitantes pasó de 54, en 1980, a 138, en 2001, constituyendo la primera causa de hospitalización, mientras que en el caso de los pacientes hospitalizados por algún tipo de tumor, las tasas pasaron entre esos dos años de 36 a 74,2 $2^{111}$. Esta más que duplicación de las tasas de hospitalización por estas dos enfermedades entre 1980 y 2001 -un incremento del 155,4\% en el primer caso y del 106,1\% en los tumores-, fue muy superior al incremento medio del $35 \%$ para todas las causas de hospitalización durante ese periodo.

Desde otra perspectiva, en ese año, requirieron hospitalización una de cada diez personas de 55-64 años, dos de cada diez de 65-74 años y tres de cada diez de 75 y más años (INE (2003): Encuesta de Morbilidad Hospitalaria 2001).

${ }^{111}$ La distribución por causa de hospitalización varía por sexo, así, entre las mujeres la primera causa de hospitalización son las enfermedades obstétricas directas (embarazo, parto y puerperio) que, en 2001, constituyeron el 21,6\% del total de hospitalizaciones de mujeres, porcentaje que aumentó hasta el 24,5\%, en 2008, en consonancia con el incremento del número de nacimientos en la primera década del siglo XXI (INE (2008): Encuesta de Morbilidad Hospitalaria 2008, pp.2); la segunda causa de hospitalización de las mujeres, en el año 2001, fue las enfermedades del sistema circulatorio, $10,5 \%$ del total, causa que permanece en esa posición, en 2008, al mantenerse estable su peso relativo, 10,6\%. Entre los hombres, la primera causa de hospitalización en 2001 fue las enfermedades del aparato circulatorio, 15,2\% del total, seguida de las enfermedades del aparato digestivo, 13,9\%. Posiciones que se mantienen en 2008: 15,4\% y $14,6 \%$, respectivamente. 


\begin{tabular}{|c|c|c|c|c|c|c|c|c|}
\hline \multicolumn{9}{|c|}{$\begin{array}{r}\text { CUADRO 4.7.: EVOLUCIÓN DE LA MORBILIDAD } \\
\text { DIAGNÓSTICO, 1980-2008 }\end{array}$} \\
\hline \multirow{2}{*}{$\begin{array}{l}\text { DIAGNÓSTICO } \\
\text { DEFINITIVO }\end{array}$} & \multicolumn{4}{|c|}{$\begin{array}{l}\text { PACIENTES HOSPITALIZADOS } \\
\text { POR 10.000 HABITANTES }\end{array}$} & \multicolumn{4}{|c|}{$\begin{array}{c}\mathrm{N}^{\circ} \text { DE FALLECIMIENTOS POR } \\
1000 \text { HOSPITALIZADOS DE } \\
\text { CADA DIAGNÓSTICO }\end{array}$} \\
\hline & 1980 & 1989 & 2001 & 2008 & 1980 & 1989 & 2001 & 2008 \\
\hline Enf. Infecc. & 23 & 22 & 21,5 & 17,4 & 21 & 18 & 41,1 & 82,9 \\
\hline Tumores & 36 & 56 & 74,2 & 92,7 & 79 & 90 & 100,5 & 105,2 \\
\hline Enf. Mentales & 20 & 24 & 26 & 25,5 & 23 & 21 & 16,6 & 16,0 \\
\hline Enf. Circulat. & 54 & 76 & 137,9 & 135,2 & 99 & 92 & 58 & 66,3 \\
\hline Enf. Respirat. & 63 & 72 & 100,4 & 113,2 & 22 & 32 & 45,5 & 63,6 \\
\hline Enf. Digestiv. & 100 & 101 & 127 & 125,4 & 19 & 21 & 25,5 & 28,5 \\
\hline Causas extern. & 80 & 77 & 90,2 & 88,9 & 16 & 14 & 20,7 & 25,7 \\
\hline Total & 876 & 950 & 1082,1 & 1055,9 & 29,2 & 29,7 & 31,2 & 37,9 \\
\hline Número & 3.275 .386 & 3.694 .445 & 4.420 .030 & 4.814 .039 & 95.670 & 109.820 & 137.804 & 182579 \\
\hline
\end{tabular}

Fte: Años 1980 y 1989, (Caïs et al, 1993: 48-49). Años 2001 y 2008, elaboración propia a partir de INE (2001 y 2008): Encuesta de Morbilidad Hospitalaria, INEbase.

Sin embargo, las hospitalizaciones por las dos causas seleccionadas en el Cuadro 4.7. con una incidencia más directa y/o inmediata de los factores sociales, las enfermedades mentales y las causas externas, se han incrementado por debajo de la media total en el periodo de análisis. Las hospitalizaciones por enfermedades mentales, por ejemplo por "psicosis", por el “síndrome de la dependencia del alcohol” o por la "adicción a las drogas”, crecen ligeramente durante la década de 1980 y prácticamente se estabilizan en los años noventa, incrementándose un total del 30\% entre 1980 y 2001. Esta peculiar evolución está probablemente relacionada con el hecho de que cada vez son más las personas con enfermedades mentales, muchas de las cuales están ligadas al envejecimiento biológico, como la demencia, atendidas en centros no hospitalarios especializados en personas ancianas o/y en todo tipo de drogodependencias. Las hospitalizaciones por causas externas, por su parte, han evolucionado erráticamente disminuyendo durante los años ochenta y aumentado en los noventa, especialmente al final de los mismos, incrementándose en todo el periodo un 11\%. La explicación de esta evolución requeriría un análisis más pormenorizado dado que son muchas las causas incluidas en este epígrafe y probablemente, sobre un fondo común de mayor prevención y control, la heterogeneidad de sus influencias impide identificar en la agregación de las mismas una tendencia dominante para todas ellas. Así, por ejemplo, las hospitalizaciones por fracturas y traumatismos, originados en accidentes de tráfico de vehículos a motor, que por diversas circunstancias aumentaron durante la década de los años ochenta, han reducido su incidencia desde la década de 1990 al hilo de la mayor sensibilización social derivada de las sucesivas campañas de educación vial. Un efecto también reductor han tenido asimismo las campañas de 
sensibilización para la prevención de los accidentes en el hogar. Por el contrario, la introducción de nuevas tecnologías en los procesos de producción, y los mayores recursos dedicados a la prevención de los accidentes laborales no han logrado compensar el efecto negativo de la precariedad laboral y de la subcontratación que hace de España el país con mayor siniestralidad laboral durante los últimos años.

El crecimiento absoluto y relativo del número de pacientes hospitalizados en las tres últimas décadas ha venido acompañado por un aumento absoluto del 90,8\% en el número de fallecimientos de pacientes hospitalizados en ese tiempo: 95.670, en 1980; 137.804, en 2001, y; 182.579, en 2008. En términos relativos, la evolución de la tasa Número de Fallecimientos por cada 1.000 Pacientes Hospitalizados de Cada Diagnóstico creció desde los 29,2 fallecimientos por cada 1000 pacientes hospitalizados, en 1980, hasta los casi 38, de 2008. Desagregando los fallecimientos en hospitales para las distintas causas de muertes seleccionadas se puede apreciar que en el caso de las enfermedades infecciosas, que habían disminuido durante los años ochenta, crecen desde los noventa y en especial al final de los mismos, cuando mueren 41 de cada 1000 pacientes hospitalizados por esa causa. Además de la importante letalidad por septicemia, el motivo fundamental del incremento de este indicador en el año 2001 fue la inclusión, desde el año 1999, de las infecciones por VIH/SIDA entre las enfermedades infecciosas.

Entre todos los diagnósticos de pacientes hospitalizados, los tumores son los de mayor letalidad hospitalaria: desde principios de este siglo, algo más de uno de cada diez pacientes hospitalizados por algún tipo de cáncer fallece en el hospital. Esta tasa de fallecimientos entre enfermos hospitalizados por tumores se incrementó en un 27,2\% durante las dos décadas finales del siglo XX, muy por debajo del aumento observado en la tasa de hospitalizaciones por tumores por cada 10.000 habitantes. Es decir, cada vez se hospitalizan más enfermos de cáncer, pero también mueren más, aunque a un ritmo menos intenso que el de la hospitalización. Las razones de esta evolución pueden estar relacionadas, por un lado, y como ya se ha señalado, con la elevada letalidad de esta enfermedad y con el incremento de su incidencia, en parte ligado al envejecimiento demográfico en parte fruto biográfico de estilos de vida arriesgados, y con una mayor dotación de recursos médico-sanitarios en general y hospitalarios en particular para hacer frente a una enfermedad que, en la actualidad, constituye para la sociedad, y para sus científicos, un reto similar al de las enfermedades infecciosas en el pasado. Por otro lado, las mejoras en la detección precoz de los tumores en chequeos ordinarios, por ejemplo, que conllevan mejores pronósticos de curación, o los avances científicos que garantizan un elevado porcentaje de curación en determinados tipos de tumores, no pueden impedir, sin embargo, que otros tumores sean de muy difícil detección o que tengan muy bajos índices de curación aunque sean detectados incluso en sus primeras fases. Desde otra perspectiva, el cáncer es la enfermedad que 
mayores temores provoca en la población española. En un estudio mediante encuesta de la Sociedad Española de Oncología Médica (2007) sobre la Percepción del Cáncer, el 64\% de las personas entrevistadas consideraba que esta enfermedad era la que más miedo le daría que le diagnosticaran, por delante del SIDA (14\%), Alzheimer (7\%) y las patologías coronarias (4\%). Las razones de este temor eran: para el 36\%, porque la relaciona con la muerte; para el $27 \%$, porque la considera una enfermedad incurable o de difícil curación, y para el 25\%, porque produce dolor. En términos generales, el 76\% consideraba el tabaquismo como un factor de riesgo para contraer cáncer; el 29\%, señalaban también la exposición al sol, sin embargo, no percibían como factores de riesgo la obesidad y el sedentarismo. Respecto al riesgo de padecerlo personalmente, el 11\% de las personas encuestadas consideraba que su riesgo era alto; riesgo que estaba relacionado para un 57\%, por tener antecedentes familiares; para un 33\%, por ser fumadora; para un 15\%, por la exposición a la contaminación y; para un 9\%, por su avanzada edad.

Paradójicamente, la tasa de fallecimiento entre los pacientes hospitalizados por la principal causa de muerte, las enfermedades del aparato circulatorio, disminuyó un 41,4\% entre 1980 y 2001. En este año, fallecieron aproximadamente 7 de cada cien enfermos hospitalizados por esta causa, y es la segunda causa por la que más enfermos hospitalizados mueren. Entre las razones que explican este descenso en la mortalidad hospitalaria de las enfermedades cardíacas están la menor letalidad, en relación a los tumores, de algunas de las enfermedades incluidas en esta causa de muerte, los cambios en los estilos de vida una vez detectadas y los avances médico-sanitarios que permiten una detección precoz y mejores tratamientos de las mismas, especialmente en el ámbito de la cirugía cardiovascular.

Este breve repaso a las relaciones entre mortalidad y morbilidad hospitalaria ha permitido poner de manifiesto las peculiaridades de las mismas en el momento actual. En efecto, las relaciones entre la morbilidad y la mortalidad no afectan demasiado a la esperanza de vida de la población: el incremento de las tasas generales de hospitalización y de mortalidad hospitalaria durante las dos últimas décadas del siglo XX no ha impedido que la e(0) se incrementara durante ese periodo en 3,28 años. Además, existen desigualdades significativas en la morbilidad hospitalaria por diagnóstico que no se corresponden con la importancia relativa de cada enfermedad, ni con su letalidad, sino con las diferentes posibilidades de tratamiento, curación y paliación, o con la rapidez en la atención sanitaria.

Por último, una de las creencias más extendidas entre la población española en relación a la mortalidad hospitalaria es la de que la mayoría de las muertes actuales se producen en centros hospitalarios. De hecho, en la encuesta elaborada para esta Tesis dos de cada tres 
personas así lo afirman, mientras que una de cada cinco contestó que la gente moría mayoritariamente en casa. Pues bien, para el caso de España, esta creencia era errónea, al menos en el momento de realizar la encuesta como se muestra a continuación. En efecto, aunque el número total de fallecimientos anuales en España ha crecido durante las últimas tres décadas (289.344 decesos, en 1980; 324.796, en 1989; 360.391, en 2000; 386.324, en 2008), hasta el año 2000 la proporción de fallecidos dentro de hospitales respecto al total de fallecidos en España prácticamente no se incrementó, situándose alrededor de uno de cada tres decesos, porcentaje que sí se ha elevado notablemente en la primera década del siglo XXI, aproximándose a la mitad del total de fallecidos en el años 2008, 47,26\% (Cuadro 4.8.).

\section{CUADRO 4.8. EVOLUCIÓN DE LA MORTALIDAD Y DE LA MORTALIDAD HOSPITALARIA TOTAL. ESPAÑA. 1980, 1989, 2000 Y 2008}

\begin{tabular}{|l|c|c|c|c|}
\hline & $\mathbf{1 9 8 0}$ & $\mathbf{1 9 8 9}$ & $\mathbf{2 0 0 0}$ & $\mathbf{2 0 0 8}$ \\
\hline Fallecimientos & 289.344 & 324.796 & 360.391 & 386.324 \\
\hline $\begin{array}{l}\text { Fallecimientos en } \\
\text { hospital }\end{array}$ & 95.670 & 109.820 & 118.945 & 182.579 \\
\hline \% sobre el total & 33,06 & 33,81 & 33,00 & 47,26 \\
\hline Fte: Años 1980 y 1989, (Caïs et al, 1993: 48-49). Años 200’ y 2008, INE(2000 y 2008): Encuesta de Morbilidad Hospitalaria,.. \\
\hline
\end{tabular}

\subsubsection{ESTRUCTURA ETAREA DE LA MORTALIDAD}

“Es exactamente igual como uno muera. Dura mucho. ¡Mamá!”

En todo momento la esperanza de vida al nacer, e(0), es un indicador que sintetiza la actuación conjunta de los vectores "fuerza de la mortalidad", es decir, de la probabilidad de fallecer a una edad ${ }^{112}$ determinada. Esta probabilidad no es idéntica en todas las edades, sino que se distribuye de forma bimodal con un máximo secundario en el primer año de vida y el principal en las edades más avanzadas. Asimismo, y por esta razón, la evolución de la e(0) se construye sobre las de los vectores fuerza de la mortalidad, cuyas dinámicas son diferentes entre

112 Dados los objetivos de este trabajo, en el mismo se emplea la variable “edad” en su acepción demográfica de "edad en años cumplidos”: número entero de años de la persona cumplidos en su último cumpleaños (Pressat, 1987:53). Así, la utilización de expresiones del tipo “grupo de edad” tiene un carácter más taxonómico, equivalente a "categoría de edad”, que esencialista, como sinónimo de un caso particular del concepto sociológico "grupo social”. Una crítica a esta segunda acepción de los “grupos de edad” puede verse en Pérez Díaz (2002: cap.5) y Requena (1992:993-1.008). Por otra parte, dado que en un buen número de enfermedades crónicas y tumores, con un componente etiológico medioambiental, existe un desfase temporal entre la primera exposición al agente causal y la aparición clínica de la enfermedad, los datos de mortalidad y morbilidad por edad de un año concreto en realidad lo que hacen es reflejar exposiciones a los riesgos producidas hace años. Para evitar los errores de análisis inducidos por este desfase temporal causa/efecto se han desarrollado métodos, que no se emplean en el presente trabajo, centrados en el efecto de la cohorte de nacimiento. Un buen ejemplo de este tipo de análisis es el monográfico de López-Abente et al (2002). 
sí. En consecuencia, al analizar el incremento de la longevidad media en una población, resulta imprescindible determinar qué grupos de edad han contribuido de manera diferencial y decisiva al mismo.

La existencia, por tanto, de una mortalidad diferencial por edad convierte a ésta en un factor de riesgo, que incide en los niveles de mortalidad general y, especialmente, en la morbimortalidad por causas. A diferencia de otros factores que asimismo actúan sobre los niveles de mortalidad, la edad no es un factor prevenible o evitable en la lucha contra la muerte. La imposibilidad de un control directo, que dota de un cierto carácter determinista a la edad en su incidencia sobre la muerte, podría, en principio, restar interés al estudio de la mortalidad por edad, al menos desde el punto de vista de la lucha contra la muerte. Sin embargo, y dado que la mortalidad diferencial por edad puede estar en el origen, como causa, o puede ser el reflejo de las diferencias de mortalidad motivadas por otros factores sobre los que sí se puede establecer algún tipo de control o de actuación (sanitaria, educativa, redistributiva, etc.), se hace preciso conocer en sí mismo el efecto que la edad ejerce sobre el nivel de mortalidad general.

En 1840 el actuario inglés Gompertz estableció la ley que lleva su nombre. En esencia, en ella se indica que la mortalidad durante el primer año de vida es alta, cae a su nivel más bajo durante la niñez y adolescencia (cinco años a catorce años) y asciende gradualmente durante la tercera y cuarta décadas de la vida. Después de los 35 o 40 años, el aumento de la mortalidad con la edad tiende a ser exponencial hasta el final de la vida, de forma que el aumento relativo de la mortalidad en cada categoría de edad sucesiva (de igual tamaño) es más o menos constante: después de los 15 años, el riesgo de morir se duplica aproximadamente cada diez años ${ }^{113}$. Independientemente de cuál sea el número de años en los que se duplica el riesgo de morir, de ser cierta la existencia de una "ley de mortalidad" supondría, como muy bien resaltan Olshansky y Carnes (2001:98-103), la constatación empírica de dos procesos que hasta hace muy pocas fechas se consideraban obvios y que en los últimos tiempos, al hilo de los avances tecno-científicos de la Biología y la Genética, han sido puestos en entredicho. Primero, significaría que existen causas biológicas que hacen que los organismos se vuelvan viejos y que la muerte tenga lugar en un momento determinado. Segundo, supondría que la duración de la

\footnotetext{
${ }^{113}$ El problema de cotejar si existe una ley de mortalidad como la propuesta por Gompertz es la existencia de causas extrínsecas además de las que supuestamente son responsables de la ley. Utilizando procedimientos matemáticos que eliminaran la influencia de esas causas extrínsecas, Olshansky y Carnes, (2001:101-102), comprobaron que la ley de Gompertz se cumplía tanto en seres humanos como en perros y ratones: "para cada especie, tenía correlación con el periodo de tiempo reproductivo". No obstante, "nadie sabe a qué se debe la casi universalidad de la ecuación de Gompertz que es totalmente empírica y no se deriva de ningún principio fundamental ni de ninguna teoría gerontológica” (Klarsfeld y Revah, 2002:43-44).
} 
vida humana tiene límites y, por tanto, establecería hasta qué punto puede aumentar la e(0) sin intervención de la medicina ${ }^{114}$.

La representación gráfica de la mortalidad real por edades para cualquier país facilita una imagen en la que contrastar lo establecido por Gompertz. Para el caso de España, esta evolución queda reflejada en el Gráfico 4.4. ${ }^{115}$ en el que se constata, por un lado, la desigual incidencia etárea de la muerte, con sustanciales diferencias de intensidad entre los distintos grupos de edad; por otro lado, que las mayores probabilidades de defunción se concentran en los extremos de la distribución por edad de la población, mientras que las frecuencias bajas se localizan en la niñez y adolescencia; finalmente, se aprecia una evolución en la distribución de la fuerza de la mortalidad desde una curva con forma de "U", en 1900, a otra con forma de "J", a finales del siglo XX.

Por otra parte, la evolución de las curvas de la mortalidad por edad permite sugerentes comparaciones que revelan la profundidad del cambio en la mortalidad por edad vivido por la sociedad española a lo largo del siglo XX. Así, el elevado nivel de la mortalidad general a comienzos del siglo XX se construía sobre una intensa fuerza de la mortalidad en todas las edades pero que incidía sobre todo en los extremos de la distribución etárea. Una buena muestra de la situación de subdesarrollo demográfico de la población española en ese periodo de tiempo lo constituye el hecho de que hasta 1920 el riesgo de fallecer entre 1 y 4 años fuera superior incluso al ya de por sí elevado de los recién nacidos antes de cumplir un año de vida. Asimismo, en el año 1900 la probabilidad que tenía un recién nacido de fallecer antes de cumplir un año de edad era superior a la que tenía una persona de 60 años de cumplir 65 años. A finales del siglo XX, con unas probabilidades de morir mucho más reducidas en todas las edades, se ha invertido la dirección de esa comparación hasta tal punto que esta última probabilidad de muerte decuplica a la de los recién nacidos.

El perfil actual de la distribución por edad de la mortalidad presenta un calendario claramente moderno desde el punto de vista demográfico. Las probabilidades de deceso máximas en 1998/99 se localizan en las edades más avanzadas y en el máximo secundario de la infancia, aunque en este caso se ha reducido notablemente su intensidad y sólo afecta ya al

\footnotetext{
${ }^{114}$ Esta cuestión se analiza con más detenimiento en el apartado 4.3.2. de este capítulo.

${ }^{115}$ Habitualmente se utilizan como indicadores de la mortalidad por edad las Tasas de Mortalidad Específicas por Edad (T.M.E.E.) que representan la relación de fallecimientos a una edad dada respecto a los efectivos poblacionales a esa edad en un año de calendario, es decir, el número de decesos por persona-año. A partir de las T.M.E.E. se calculan los Cocientes de Mortalidad o Probabilidades de Muerte $\left({ }_{n} q_{\mathrm{x}}\right)$, indicador que se emplea en este trabajo, y que representa la proporción de personas vivas al comienzo de un intervalo de edad, que fallecen en el mismo y no alcanzan a cumplir el siguiente aniversario.
} 
primer año de vida. Por su parte, las probabilidades de fallecer mínimas se detectan progresivamente en un mayor número de grupos de edad, siendo muy reducidas entre 1 y 30 años de edad. El mínimo absoluto se desplaza del grupo 10-14 años, tradicionalmente el de menor mortalidad, al grupo de 5-9 años de edad, "la mejor edad actuarial”, siguiendo una tendencia igualmente observada entre otros países europeos consistente en el desplazamiento de la fuerza de la mortalidad mínima a edades cada vez menores ${ }^{116}$.

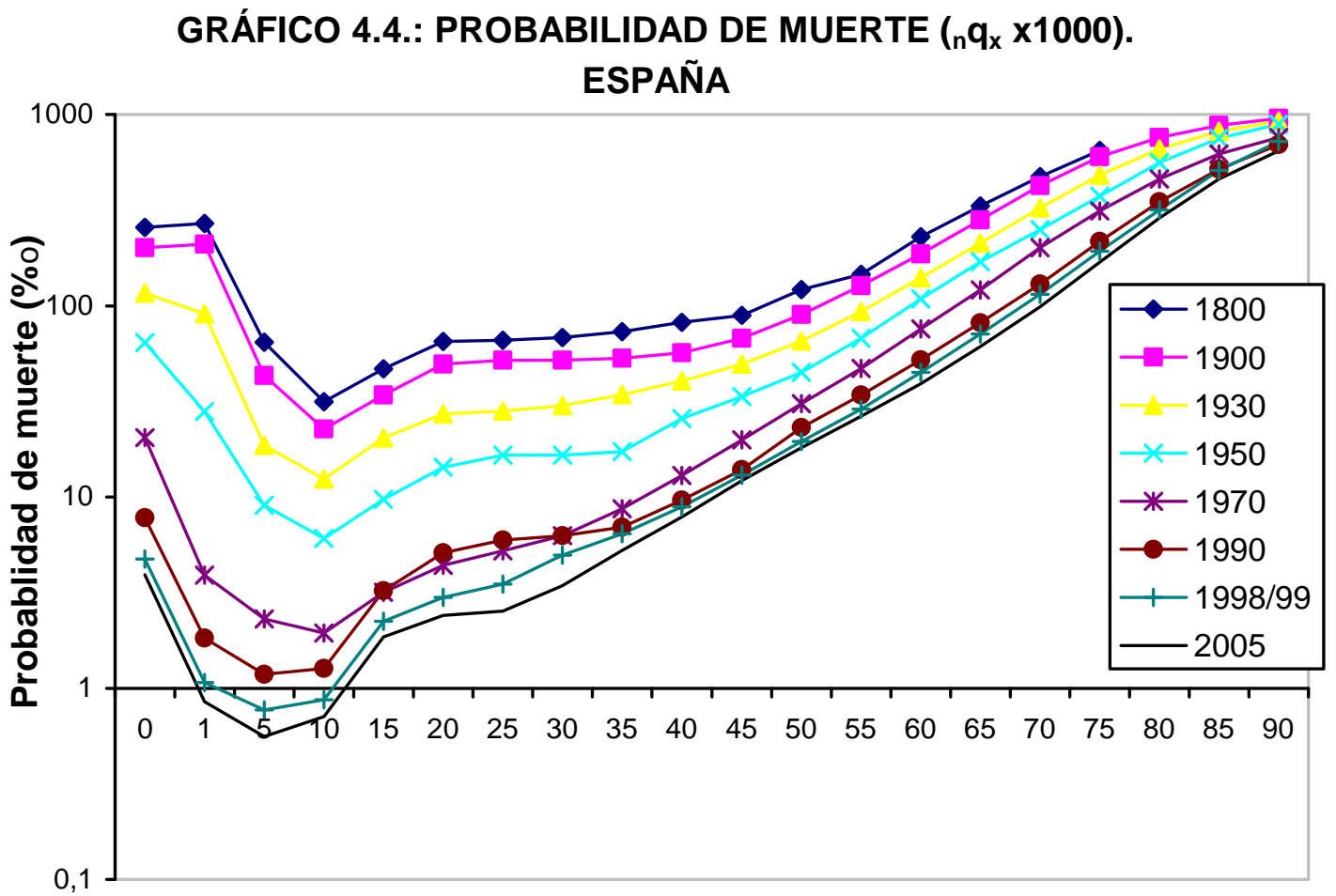

Edad

Fte: Año 1800, estimaciones teóricas de Livi-Bacci (1968): "Fertility and Nupciality Changes in Spain from the late $18^{\text {th }}$ to early $20^{\text {th }}$ Century”, en Population Studies, XXII, pp.1 y 2. Resto de años, INE: Tablas de Mortalidad de la Población Española.

En todas las curvas recogidas en el Gráfico 4.4. se observa que es a partir de los 45 años, final de la edad de reproducción, cuando las probabilidades de muerte empiezan a ser significativas. Por su parte, en las edades más avanzadas se ha producido asimismo una continua reducción de la mortalidad a lo largo del siglo XX aunque, obviamente, los descensos relativos de la misma han sido menos intensos, sobre todo a medida que se consideran los grupos de más edad. No obstante, a comienzos del siglo XXI, a una persona que cumpla los 65 años aún le queda casi una cuarta parte de su curso vital (Abellán y Puga, 2005:64). Además, y en sintonía con lo que se ha observado en otros países desarrollados, en los últimos veinte años

116 "En realidad, la mejor edad actuarial se sitúa en torno a los siete años de edad. A esa edad, la probabilidad de vivir otro día, mes o año es más elevada que en ninguna otra época de la vida. Como envejecer se define a veces como un incremento en la fuerza de la mortalidad, algunos gerontólogos argumentan que el envejecimiento comienza a partir de esa edad” (Hayflick, 1999:304). 
el incremento de la mortalidad con la edad no sigue una senda de crecimiento exponencial en las edades más avanzadas, tal como pronostica la ley de Gompertz, sino que la curva de las probabilidades de fallecimiento alcanza un punto de inflexión, alrededor de los 80 años, ralentizando a partir de esa edad su incremento, alejándose progresivamente de la senda exponencial.

Los cambios producidos en el nivel y en la estructura por edad de la mortalidad se detectan igualmente en los valores de la esperanza de vida, $\mathrm{e}(\mathrm{x})^{117}$, que, para un grupo de edad concreto, sintetiza la suma de las fuerzas de la mortalidad de ese grupo y de sus mayores. En el Cuadro 4.9. se recogen los valores de la esperanza de vida de los grupos de edad quinquenales en 1900, 1950 y 1998/99, que resumen todo lo expuesto hasta ahora: a) desigual incidencia etaria de la muerte, que se traduce en una menor esperanza de vida a medida que se avanza en la edad; b) evolución descendente de la fuerza de la mortalidad en el tiempo, que se manifiesta en un aumento de la esperanza de vida en todos los grupos de edades en el siglo pasado; c) subdesarrollo demográfico de la población española principios del siglo XX reflejado en una e(0) y e(1) inferiores a e(5), como consecuencia de los elevados niveles de mortalidad en la primera infancia. En 1900, un recién nacido tenía una esperanza de vida 14,56 años menor que uno que hubiera cumplido 5 años. Incluso aquellos que habían superado el primer año de vida podían esperar vivir de media 7 años menos que los que habían cumplido 5 años; d) transición de la mortalidad muy avanzada a mediados del siglo XX, pero aún sin finalizar. En 1950, la e(0) era todavía 3,21 años menor que la e(1); e) modernización demográfica actual expresada en una e(0) que ha más que duplicado a la de 1900 y es una de las más elevadas del mundo; f) mayor descenso de los riesgos relativos de mortalidad en los grupos de edad más jóvenes respecto al resto de grupos, que da cómo resultado un mayor incremento relativo de la e(x) en aquéllos; g) vidas medias más largas para los más mayores como fenómeno claramente reciente, y; h) mayor mortalidad en los varones que en las mujeres. En los tres periodos y en todos los grupos de edad la e(x) de las mujeres es sistemáticamente superior a la de los varones.

\footnotetext{
${ }^{117}$ La esperanza de vida a la edad $x$,e(x), mide la expectativa de vida futura de un individuo de edad $x$ que por el resto de su vida estuviera sujeto a las tasas de mortalidad especificadas por edades más allá de la edad registrada en algún periodo determinado (N.U., 1982:2).
} 


\begin{tabular}{|c|ccc|ccc|cccc|}
\hline \multicolumn{7}{|c|}{ CUADRO 4.9. ESPERANZA DE VIDA (años). ESPAÑA } \\
\hline \multirow{2}{*}{ EDAD } & \multicolumn{3}{|c|}{$\mathbf{1 9 0 0}$} & \multicolumn{3}{|c|}{$\mathbf{1 9 5 0}$} & \multicolumn{3}{c|}{$\mathbf{1 9 9 8 / 9 9}$} \\
\cline { 2 - 10 } & Total & Varones & Mujeres & Total & Varones & Mujeres & Total & Varones & Mujeres \\
\hline $\mathbf{0}$ & 34,76 & 33,85 & 35,70 & 62,10 & 59,81 & 64,32 & 78,71 & 75,25 & 82,16 \\
$\mathbf{1}$ & 42,38 & 41,74 & 43,01 & 65,31 & 63,18 & 67,32 & 78,08 & 74,64 & 81,52 \\
$\mathbf{5}$ & 49,32 & 48,60 & 49,99 & 63,16 & 60,99 & 65,19 & 74,16 & 70,71 & 77,61 \\
$\mathbf{1 0}$ & 46,45 & 45,66 & 47,19 & 58,72 & 56,57 & 60,73 & 69,22 & 65,78 & 72,65 \\
$\mathbf{1 5}$ & 42,47 & 41,60 & 43,29 & 54,06 & 51,91 & 56,08 & 64,28 & 60,84 & 67,70 \\
$\mathbf{2 0}$ & 38,87 & 37,93 & 39,78 & 49,57 & 47,44 & 51,56 & 59,42 & 56,03 & 62,78 \\
$\mathbf{2 5}$ & 35,76 & 34,93 & 36,56 & 45,25 & 43,18 & 47,17 & 54,59 & 51,27 & 57,87 \\
$\mathbf{3 0}$ & 32,59 & 31,86 & 33,28 & 40,97 & 38,97 & 42,82 & 49,77 & 46,53 & 52,96 \\
$\mathbf{3 5}$ & 29,24 & 28,52 & 29,92 & 36,61 & 34,69 & 38,39 & 45,00 & 41,85 & 48,09 \\
$\mathbf{4 0}$ & 25,74 & 25,02 & 26,43 & 32,21 & 30,36 & 33,90 & 40,28 & 37,22 & 43,25 \\
$\mathbf{4 5}$ & 22,14 & 21,49 & 22,76 & 27,99 & 26,22 & 29,60 & 35,62 & 32,66 & 38,47 \\
$\mathbf{5 0}$ & 18,56 & 18,04 & 19,05 & 23,87 & 22,23 & 25,34 & 31,05 & 28,21 & 33,75 \\
$\mathbf{5 5}$ & 15,13 & 14,77 & 15,47 & 19,87 & 18,43 & 21,12 & 26,62 & 23,95 & 29,09 \\
$\mathbf{6 0}$ & 11,96 & 11,74 & 12,17 & 16,11 & 14,93 & 17,11 & 22,32 & 19,89 & 24,52 \\
$\mathbf{6 5}$ & 9,12 & 9,00 & 9,23 & 12,75 & 11,83 & 13,48 & 18,25 & 16,11 & 20,09 \\
$\mathbf{7 0}$ & 6,67 & 6,61 & 6,72 & 9,82 & 9,16 & 10,32 & 14,44 & 12,66 & 15,85 \\
$\mathbf{7 5}$ & 4,74 & 4,71 & 4,78 & 7,24 & 6,81 & 7,56 & 10,96 & 9,59 & 11,94 \\
$\mathbf{8 0}$ & 3,40 & 3,38 & 3,42 & 5,06 & 4,81 & 5,24 & 7,95 & 7,02 & 8,52 \\
$\mathbf{8 5}$ & 2,46 & 2,45 & 2,47 & 3,47 & 3,33 & 3,56 & 5,45 & 4,91 & 5,72 \\
$\mathbf{9 0}$ & 1,78 & 1,76 & 1,79 & 2,37 & 2,30 & 2,42 & 3,56 & 3,36 & 3,65 \\
$\mathbf{9 5}$ & 1,17 & 1,10 & 1,07 & 1,63 & 1,59 & 1,65 & 1,99 & 1,99 & 1,99 \\
\hline
\end{tabular}

Fte : INE: Tablas de Mortalidad de la Población Española.

A lo largo del siglo XX, por tanto, se observa que en la evolución de la fuerza de la mortalidad se ha reducido la intensidad de la misma en todas las edades, sin embargo, el ritmo de descenso no ha sido constante en todo momento y tampoco todos los grupos de edad han contribuido de forma equiproporcional al aumento de la esperanza de vida al nacer. En lo relativo al ritmo temporal de descenso, en el Cuadro 4.10. se recoge la distribución por subperiodos, entre 1900 y 1998, de la ganancia de la esperanza de vida a distintas edades para el total de la población española. En el mismo se constata que el grueso de las ganancias en la esperanza de vida en todas las edades tuvo lugar entre 1940 y 1970; así, por ejemplo, en ese sub-periodo la e(0) se incrementó en 22,26 años, el 50, 65\% de su crecimiento total entre 1900 y 1998, 43,95 años. Asimismo, se confirma otro hecho muy significativo ya reseñado arriba: que a lo largo del siglo XX se ha producido un cambio significativo en las mejoras de la e(x) por edad, de tal forma que si en la primera mitad del siglo las mejora de las esperanzas de vida de los más jóvenes fueron importantes, siendo relativamente mucho menores las de las edades 
avanzadas, en la segunda mitad, y en especial desde 1970, ocurre al revés (Goerlich y Pinilla, 2005:15) ${ }^{118}$.

\begin{tabular}{|c|c|c|c|c|c|c|c|}
\hline \multicolumn{8}{|c|}{$\begin{array}{r}\text { CUADRO 4.10.: AÑOS DE e(x) GANADOS A CADA EDAD Y SU DIS } \\
\text { POR SUB-PERIODOS. TOTAL. ESPAÑA, 1970-1998 }\end{array}$} \\
\hline \multirow{2}{*}{ Edad } & \multirow{2}{*}{$\begin{array}{c}\text { Total } \\
1900- \\
1998\end{array}$} & \multicolumn{3}{|c|}{ Años de $e(x)$ ganados } & \multicolumn{3}{|c|}{ \% sobre el total a cada edad } \\
\hline & & $\begin{array}{l}1900- \\
1940\end{array}$ & $\begin{array}{c}1940- \\
1970\end{array}$ & $\begin{array}{c}1970- \\
1998\end{array}$ & $\begin{array}{c}1900- \\
1940\end{array}$ & $\begin{array}{r}1940- \\
1970\end{array}$ & $\begin{array}{r}1970- \\
1998\end{array}$ \\
\hline 0 & 43,95 & 15,34 & 22,26 & 6,35 & 34,90 & 50,65 & 14,45 \\
\hline 1 & 35,70 & 13,15 & 17,33 & 5,22 & 36,83 & 48,54 & 14,62 \\
\hline 15 & 21,81 & 5,4 & 11,90 & 4,87 & 23,11 & 54,56 & 22,33 \\
\hline 30 & 17,18 & 3,18 & 9,30 & 4,70 & 18,51 & 54,13 & 27,36 \\
\hline 45 & 13,48 & 2,06 & 6,90 & 4,52 & 15,228 & 51,19 & 33,53 \\
\hline 65 & 9,13 & 1,84 & 3,74 & 3,55 & 20,15 & 40,96 & 38,88 \\
\hline 80 & 4,55 & 0,96 & 1,93 & 1,66 & 21,10 & 42,42 & 36,48 \\
\hline
\end{tabular}

Fte: (Goerlich y Pinlilla, 2005:15)

Respecto a la contribución de los distintos grupos de edad en el incremento de la esperanza de vida al nacer, en el Cuadro 4.11. se recoge la descomposición de esa contribución para los tres sub-periodos considerados y para el conjunto del periodo. En el mismo se comprueba, efectivamente, que la contribución de cada grupo de edad no ha sido equiproporcional. Así, en la última columna, se puede constatar que el 70\% de la ganancia de la e(0) a lo largo del siglo XX se ha producido por la reducción de la mortalidad en las edades más jóvenes, menores de 15 años, concentrándose además la mitad de esa mejora de la supervivencia de los menores de 1 año; mientras, la contribución de los grupos de más de 65 años apenas ha superado el 5\% de la ganancia total de la e(0) en todo el siglo XX. Por otra parte, al comparar las contribuciones en los distintos sub-periodos, se observa que las ganancias de la e(0) derivadas de la contribución de los grupos más jóvenes se han producido fundamentalmente durante la primera mitad del siglo XX; así, en el sub-periodo 1900-1940, el 80\% de la esa ganancia se produjo por mejoras en la supervivencia de los menores de 15 años, resaltando que solo la reducción de la mortalidad en el grupo 1-14 años logró la mitad de la misma. La ganancia de la e(0) en el sub-periodo 1940-70 se produce también por mejoras en la supervivencia de los más jóvenes, el 57,51\%, pero los grupos de edad intermedia (15-64 años) tienen una contribución mucho más significativa que en el sub-periodo inicial (35,34\%, en

\footnotetext{
${ }^{118}$ En un trabajo más reciente, centrado en el periodo 1975-2006, en el que considera los sub-periodos 1975-90 y 1990-2006, Goerlich ha constatado que los incrementos en las esperanzas de vida se han distribuido en los mismos de forma equilibrada en las edades jóvenes pero no así en las más altas en las que, siguiendo la dinámica marcada desde 1970, han crecido más en el último sub-periodo (Goerlich, 2009:42-43).
} 
1940-70, frente a 16,25\%, en 1900-40). En el último sub-periodo, 1970-1998, la contribución de los más jóvenes, 25,48\%, se ha reducido a menos de la mitad de la del sub-periodo anterior y son las mejoras en la supervivencia de las personas de más edad las que más están contribuyendo en esta fase al incremento de la longevidad media: el 43,65\% del mismo se originó por la reducción de la mortalidad en los mayores de 65 años ${ }^{119}$ (Goerlich y Pinilla, 2005: 17-19).

Centrando el análisis de manera más específica en la evolución de la e(0) desde la década de 1970 hasta hoy, diversas investigaciones han confirmado que el incremento de la misma en este periodo se ha debido fundamentalmente a las mejoras en la supervivencia de los más mayores Goerlich (2009), Blanes (2007), Gómez Redondo (2005, 1998, 1995) y Viciana (1998). Asimismo, otro hecho resaltado por estos estudios en este último periodo es la evolución errática de la mortalidad de los jóvenes y adultos-jóvenes entre 1970 y 2001. Así, en el sub-periodo 1970-1990 el incremento de la e(0) se ha visto frenado por la evolución desfavorable de esa mortalidad, sobre todo entre los varones, lo que ha supuesto una "sangría" de años jóvenes perdidos para la vida del conjunto de la población española. Si bien la cantidad aminorada no ha sido muy significativa en términos cuantitativos, sí lo es cualitativamente: primero, porque se ha producido entre los jóvenes (fundamentalmente en los varones); segundo, porque ha sido fruto, básicamente, de causas de muerte sociales y de comportamiento de riesgo, como accidentes con vehículos de motor, toxicomanías, siniestralidades, violencias, etc., lo que permite situar claramente a la transición de la mortalidad española en "la inesperada cuarta etapa de la historia epidemiológica” (Gómez Redondo, 1995: 94). Por su parte, en el subperiodo 1991-2001, desaparece ese freno, esas “muertes a contracorriente” y "los hombres jóvenes recuperan su potencial de vida perdido en la década anterior” (Gómez Redondo y Boe, 2004:121 y 129).

\footnotetext{
${ }^{119}$ Considerando todo el siglo XX, pero con diferentes distribuciones de los sub-periodos, Blanes (2007) y Viciana (1998) constatan asimismo ese desplazamiento, desde la infancia hacia las más elevadas, en las aportaciones por edad al incremento de la longevidad media.
} 


\begin{tabular}{|c|c|c|c|c|c|c|c|c|}
\hline \multicolumn{9}{|c|}{$\begin{array}{l}\text { CUADRO 4.11. AÑOS DE VIDA GANADOS EN LA e(0) POR GRUPOS DE EDAD. } \\
\text { TOTAL. ESPAÑA, 1970-1998 }\end{array}$} \\
\hline \multirow{2}{*}{$\begin{array}{l}\text { Grupos } \\
\text { de edad }\end{array}$} & \multicolumn{4}{|c|}{ Años de e(x) ganados por edad } & \multicolumn{4}{|c|}{ \% sobre el total en cada sub-periodo } \\
\hline & $\begin{array}{c}1900- \\
1940\end{array}$ & $\begin{array}{c}1940- \\
1970\end{array}$ & $\begin{array}{c}1970 \\
1998\end{array}$ & $\begin{array}{c}1900- \\
1998\end{array}$ & $\begin{array}{c}1900- \\
1940\end{array}$ & $\begin{array}{c}1940- \\
1970\end{array}$ & $\begin{array}{c}1970- \\
1998\end{array}$ & $\begin{array}{c}1900- \\
1998\end{array}$ \\
\hline$<1$ & 4,83 & 6,92 & 1,24 & 15,43 & 31,52 & 31,08 & 19,47 & 35,11 \\
\hline 1-14 & 7,53 & 5,88 & 0,38 & 15,65 & 49,09 & 26,43 & 6,01 & 35,60 \\
\hline 15-29 & 1,34 & 2,63 & 0,22 & 4,05 & 8,74 & 11,83 & 3,52 & 9,21 \\
\hline $30-44$ & 0,74 & 2,32 & 0,29 & 2,96 & 4,81 & 10,42 & 4,61 & 6,74 \\
\hline $45-64$ & 0,41 & 2,91 & 1,44 & 3,47 & 2,70 & 13,09 & 22,75 & 7,90 \\
\hline 65-79 & 0,44 & 1,36 & 2,15 & 2,19 & 2,87 & 6,10 & 33,80 & 4,99 \\
\hline$>80$ & 0,04 & 0,23 & 0,63 & 0,20 & 0,27 & 1,04 & 9,85 & 0,45 \\
\hline Total & 15,34 & 22,26 & 6,35 & 43,95 & 100,00 & 100,00 & 100,00 & 100,00 \\
\hline
\end{tabular}

Fte: (Goerlich y Pinlilla, 2005:18)

En consecuencia, los cambios de la mortalidad iniciados en el siglo XIX han conformado a lo largo del siglo XX una modificación radical en la edad de fallecimiento fruto de los distintos ritmos en la evolución de los cocientes de mortalidad. Durante este periodo de tiempo las mayores reducciones de la mortalidad han ido trasladándose desde las edades más tempranas hasta edades cada vez más avanzadas que tomaban el relevo a medida que se agotaban las "vetas” de mortalidad, conformándose progresivamente, como se ha señalado más arriba, “una nueva edad de la muerte” situada en la vejez (Caselli et al., 1995:15-20; Viciana, 2003:90). La desigual disminución del riesgo de fallecer en todas las edades, especialmente intensa en la infancia y juventud, ha significado que un número mayor de personas llegue a edades más avanzadas, en otras palabras, que con el tiempo se haya incrementado el número de supervivientes en todas las edades.

Una forma de comprobar este proceso se deriva de las tablas de mortalidad del momento, y consiste en observar, en distintas fechas, los efectos de la mortalidad en una hipotética población de 100.000 nacidos vivos sometida a los riesgos específicos de mortalidad por edad del momento (Cuadro 4.12.). La simple comparación permite constatar que también en España se ha producido una evolución hacia una nueva edad de la muerte. En el año 1800, una cohorte de 100.000 nacidos, con las pautas de mortalidad de ese año, perdía un cuarto de sus efectivos antes de cumplir un año, la mitad (lo que se denomina "vida probable" o edad mediana de fallecimiento) antes de los 15 años y el 75\% antes de llegar a los 60 años. En el año 1900, la situación se había modificado ligeramente, se perdía un cuarto de los efectivos alrededor de los dos años de edad, la vida probable era de 33 años y la cohorte quedaba reducida a un cuarto de sus efectivos poco después de cumplir los 65 años. Estos datos, que ilustran el 
statu quo de una situación secular, son claves para visualizar la incidencia de la mortalidad en las estrategias familiares hasta los inicios del siglo XX: en el año 1900, entre el 43\% y el 46\% de los recién nacidos no llegaron a cumplir los 20-25 años, es decir, no tuvieron la oportunidad, al menos potencial, de formar una familia; de los que pudieron hacerlo, un cuarto de ellos no llegaron a los cincuenta años, fin de la vida reproductiva de las mujeres. Esta mediatización desaparece a la par que transcurre la transición de la mortalidad, llegándose a la situación actual en la que con las pautas de mortalidad del año 2000 la cohorte ficticia inicial de 100.000 nacidos pierde un 25\% de sus efectivos a los 73,6 años, su vida probable se sitúa ligeramente por encima de los 82,6 años de edad y queda reducida a un cuarto poco después de cumplir los 89 años de edad. En términos de la vida fértil de una persona potencialmente casadera esto supone que, a finales del siglo XX, el 99\% de los recién nacidos pueden aspirar a ello, y que de los que alcancen los 20-25 años, sólo un 4\% no cumplirá los cincuenta años: la madurez de las masas, en expresión de Pérez Díaz (2002).

En resumen, se ha pasado de una situación en la que lo "normal” era morir de niño -en el año 1900, la probabilidad para un recién nacido de cumplir un año de edad era del 79,9\%, la de cumplir 5 años era del 63,1\%, la de llegar a 10 años del 60,4\%, la de alcanzar los 65 años del 26,2\%, y de sólo 4,3\% y 1,0\% de cumplir 80 y 85 años, respectivamente- $-{ }^{120}$, a una situación en la que lo habitual es morir de anciano. En el año 1998/99, las probabilidades para un recién nacido de llegar a su primer aniversario eran de 99,5\%; la de alcanzar el quinto, 99,4\%; la del décimo, 99,3\%; la del sexagésimo quinto, 86,5\%; la de llegar a octogenario 57,4\%; y la de cumplir su 85 cumpleaños, 39,2\%. Las condiciones de mortalidad del año 1998/99 permitían a un recién nacido ese año llegar a cumplir con más probabilidad 75 años de edad (71,1\%) que las existentes a principios del siglo XX para los recién nacidos de alcanzar los 5 años (63,1\%). Por otro lado, la evolución del número de supervivientes, permite comprobar cómo la probabilidad de alcanzar la supervivencia hasta una edad determinada está aumentando también en las edades más altas. Así, la probabilidad de alcanzar los 90 años de edad teniendo 85 años ha pasado del 12,2\%, en 1900, al 25,1\%, en 1950, siendo del 48,86\% en el año 1998/99, es decir, mientras que a principios del siglo XX de cada diez personas que cumplían 85 años sólo una llegaba a cumplir su nonagésimo aniversario, a finales del siglo XXI casi la mitad de los que cumplen 85 años llegarán a cumplir 90 años.

Los datos reales de mortalidad proporcional confirman la existencia de una tendencia de concentración de los decesos en las edades avanzadas para el conjunto de la población española

${ }^{120}$ El cálculo de la probabilidad de sobrevivir hasta una edad determinada desde otra edad se realiza empleando la columna del número de supervivientes en las tablas de mortalidad, dividiendo el número de supervivientes a la edad más alta, por ejemplo a 1 año (99.526, en 1998/99) entre el número de supervivientes a la edad de la que se parte, 0 años (100.000) (Cuadro 4.11.). 
(Gráfico 4.5.). En el año 1930, el peso relativo del número de fallecidos antes de llegar a cumplir los 5 años (32,4\%) era ligeramente inferior al del conjunto de decesos de más de 60 años (37,1\%). En el año 2000, sin embargo, la proporción de muertes antes de los cinco años es mucho menor que la de los fallecidos de más de 60 años, 0,6\% frente a 86,4\%. De hecho, en el año 2000 sólo el número defunciones de las personas que ese año cumplieron 60 años de edad, 2.863, fue superior al total de fallecidos menores de 10 años de edad, 2.793, (INE: MNP), o, “el número de centenarios fallecidos supera ya la media de todos los fallecidos de 40-49 años, y en los últimos veinte años casi se ha duplicado” (Abellán y Puga, 2005:66). La transición de la mortalidad, en definitiva, implica un continuo aumento de la proporción de defunciones de ancianos en el total de decesos. Se confirma, por tanto, que el descenso de la mortalidad ha venido acompañado de un cambio en el calendario de la misma, de tal forma que la muerte es cada vez más cosa de “viejos”.

\begin{tabular}{|c|c|c|c|c|c|c|c|}
\hline \multicolumn{7}{|c|}{ CUADRO 4.12. SUPERVIVIENTES EN LOS DISTINTOS ANIVERSARIOS. ESPAÑA } \\
\hline EDAD & $\mathbf{1 8 0 0}$ & $\mathbf{1 9 0 0}$ & $\mathbf{1 9 3 0}$ & $\mathbf{1 9 5 0}$ & $\mathbf{1 9 7 0}$ & $\mathbf{1 9 9 8} / \mathbf{9 9}$ & $\mathbf{2 0 0 5}$ \\
\hline $\mathbf{0}$ & 100.000 & 100.000 & 100.000 & 100.000 & 100.000 & 100.000 & 100.000 \\
$\mathbf{1}$ & 74.300 & 79.887 & 88.347 & 93.601 & 97.960 & 99.526 & 99.575 \\
$\mathbf{5}$ & 54.300 & 63.115 & 80.335 & 90.974 & 97.578 & 99.419 & 99.516 \\
$\mathbf{1 0}$ & 50.800 & 60.384 & 78.837 & 90.148 & 97.353 & 99.342 & 99.461 \\
$\mathbf{1 5}$ & 49.200 & 59.020 & 77.856 & 89.600 & 97.163 & 99.255 & 99.383 \\
$\mathbf{2 0}$ & 46.900 & 57.004 & 76.273 & 88.727 & 96.854 & 99.033 & 99.186 \\
$\mathbf{2 5}$ & 43.900 & 54.181 & 74.193 & 87.457 & 96.428 & 98.737 & 98.948 \\
$\mathbf{3 0}$ & 41.000 & 51.367 & 72.109 & 86.009 & 95.295 & 98.390 & 98.692 \\
$\mathbf{3 5}$ & 38.200 & 48.703 & 69.936 & 84.589 & 95.322 & 97.902 & 98.339 \\
$\mathbf{4 0}$ & 35.400 & 46.111 & 67.540 & 83.132 & 94.495 & 97.272 & 97.801 \\
$\mathbf{4 5}$ & 32.500 & 43.491 & 64.808 & 80.994 & 93.272 & 96.409 & 96.999 \\
$\mathbf{5 0}$ & 29.600 & 40.511 & 61.604 & 78.286 & 91.420 & 95.153 & 95.765 \\
$\mathbf{5 5}$ & 26.000 & 36.907 & 57.576 & 74.779 & 88.608 & 93.297 & 93.961 \\
$\mathbf{6 0}$ & 22.200 & 32.200 & 52.189 & 69.773 & 84.444 & 90.615 & 91.374 \\
$\mathbf{6 5}$ & 17.100 & 26.181 & 44.886 & 62.170 & 78.069 & 86.559 & 87.655 \\
$\mathbf{7 0}$ & 6.000 & 18.843 & 35.328 & 51.618 & 68.609 & 80.405 & 82.035 \\
$\mathbf{7 5}$ & 2.100 & 10.848 & 23.843 & 38.708 & 54.812 & 71.174 & 73.489 \\
$\mathbf{8 0}$ & & 4.322 & 12.318 & 24.205 & 37.664 & 57.455 & 60.388 \\
$\mathbf{8 5}$ & & 1.043 & 4.180 & 10.621 & 20.317 & 39.202 & 42.116 \\
$\mathbf{9 0}$ & & 127 & 768 & 2.668 & 7.702 & 19.158 & 21.913 \\
$\mathbf{9 5}$ & & 6 & 59 & 291 & 1.869 & 5.291 & 7.245 \\
\hline
\end{tabular}

Fte: Año 1800, estimaciones teóricas de Livi-Bacci (1968): "Fertility and Nupciality Changes in Spain from the late $18^{\text {th }}$ to early $20^{\text {th }}$ Century”, en Population Studies, XXII, pp. 1 y 2. Resto de años, INE: Tablas de Mortalidad de la Población Española. 


\section{GRÁFICO 4.5. MORTALIDAD PROPORCIONAL POR GRUPOS DE} EDAD (\%). 1930, 2000. ESPAÑA.

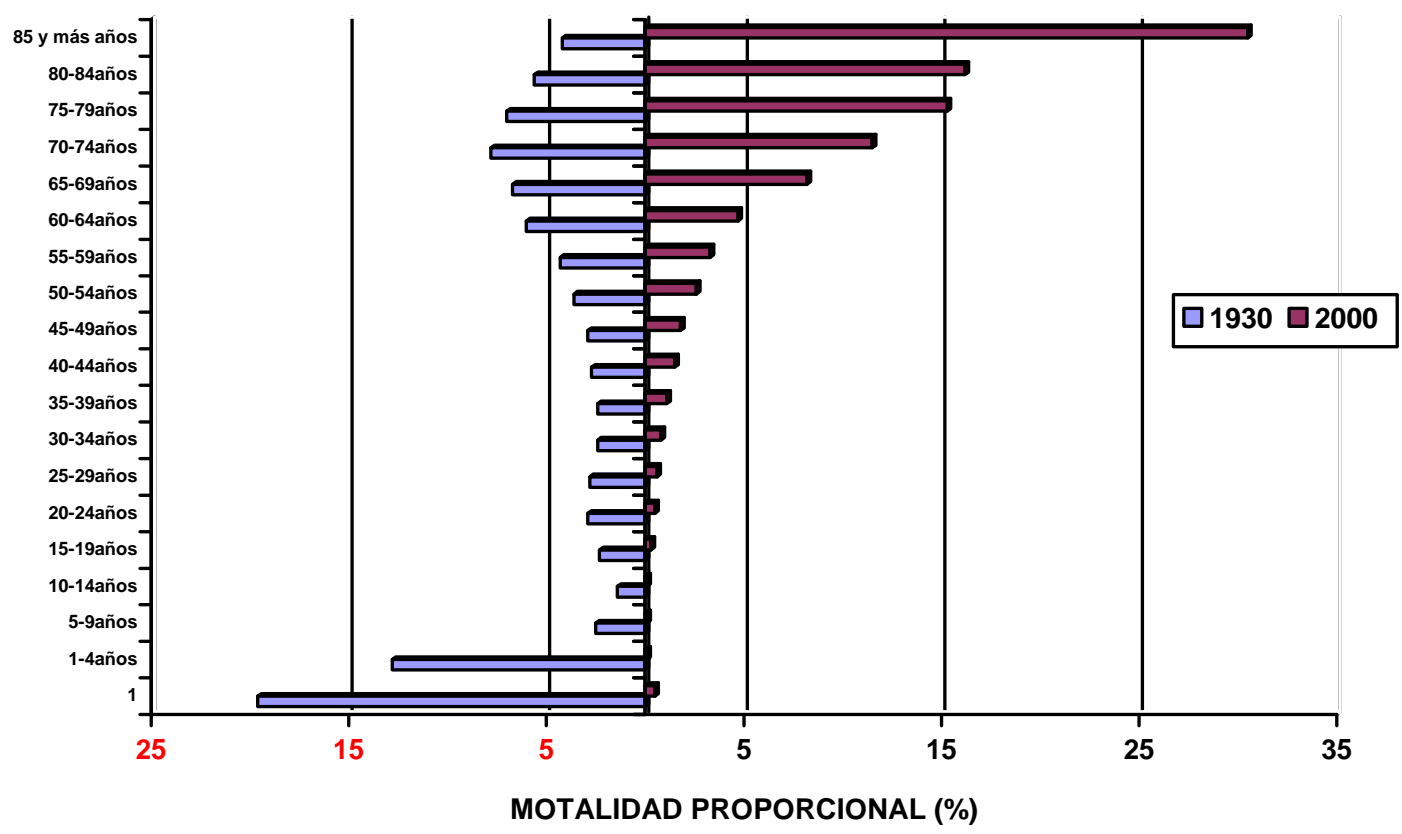

Fte: Elaboración propia a partir de INE: MNP.

Todos estos cambios ligados a la transición de la mortalidad han afectado a la vida familiar cotidiana, y más concretamente, a la experiencia directa que supone vivir la muerte de un ser próximo. El contraste entre la situación habitual durante cientos de años, característica de las sociedades premodernas, en las que la mortalidad de los “párvulos” podía suponer el 50\% de la mortalidad general (Pérez Moreda, 1980:161), en las que la experiencia de una vida biológicamente completa (infancia-juventud-madurez-vejez) estaba vedada para la mayoría de la población, y la situación actual es bien elocuente. Aunque, obviamente, los cambios de la mortalidad en la segunda mitad del siglo XX han acentuado ese contraste, no deja de ser diáfana la comparación expuesta por Fourastié (1959): “a finales del siglo XVII, la vida de un padre de familia medio, casado por primera vez a los 27 años, podía resumirse del siguiente modo: nacido en una familia de 5 hijos, sólo vio a la mitad de ellos alcanzar la edad de 15 años; él mismo tuvo 5 hijos (...) de los cuales 2 ó 3 vivían a la hora de su muerte.

Este hombre, que vivió una media de 52 años (...) ha visto morir en su familia directa (sin hablar de tíos, sobrinos y primos hermanos) una media de nueve personas, entre las que se encontraba sólo uno de sus abuelos (pues los otros habían fallecido antes de que él naciera), sus dos padres y tres de sus hijos.

Hoy la situación del hombre que tiene 50 años es la siguiente: pertenece a una familia de 3 hijos, se casó a los 26 años con una joven de 24 años. Sus únicos duelos fueron los de sus 4 
abuelos. Y este hombre a los 50 años tiene una posibilidad sobre dos de vivir todavía 26 años más.

Ayer, en un caso sobre dos, la muerte arrebataba a los niños pequeños antes que a su padre, y el resto veía morir a su padre antes de alcanzar la mayoría de edad. La edad media de los niños, cuando por primera vez moría uno de sus progenitores era de unos 14 años. Mañana el hijo "medio" tendrá 65 o 60 años cuando muera su padre; el fondo hereditario del patrimonio familiar estará casi siempre en manos de hombres y mujeres de más de 60 años, casi la mitad de la fortuna privada de una nación pertenecerá a ancianos mayores de 70 años”.

En definitiva, se ha pasado de unas sociedades en las que la muerte, omnipresente e impredecible, estaba situada en el centro de la vida misma a otras, las sociedades desarrolladas, en las que se ha perdido esa "familiaridad” íntima con la muerte y se la percibe sujeta de alguna manera al control humano, ocupando cada vez más un lugar marginal en la experiencia vital de los individuos. Se ha estimado, por ejemplo, que frente a su cotidianeidad pretérita, en la actualidad el período de tiempo durante el cual puede esperarse que en una familia no haya ocurrido ninguna muerte es el de una generación, aproximadamente veinte-treinta años (Fulton, 1965:79). En esta profunda mutación, que en último término también es existencial, ha tenido una importancia determinante el que el factor de riesgo <<edad $>>$ incida sobre todo en las personas de edades más avanzadas. El hecho de que en estas edades se concentren la mayoría de los fallecimientos en la actualidad ha construido en el imaginario social una poderosa identificación: vejez igual a edad de la muerte.

\subsubsection{MORTALIDAD, SEXO, GÉNERO}

"Yo he vivido sola, así que dejadme morir también sola, dejadme morir sola"

D. Pattison

En su Diccionario ideológico feminista Victoria Sau (1990:137) mantiene que cuando "el sexo deje de ser un factor estructurante quedarán las diferencias funcionales pertinentes y los dos géneros desparecerán”. Hace referencia con ello a tres cuestiones básicas: por un lado, a que en el caso específico de las poblaciones humanas el sexo no es sólo soporte de diferencias biológicas, sino que fundamenta además desigualdades psicológicas, económicas y socioculturales: de género. Alude, por otro lado, a que si el sexo es un factor unidimensional, inherente a la especie humana, estático, y del que pocos cambios cabe esperar, no ocurre lo mismo con el género, factor multidimensional, construcción social estructurada sobre el sexo, 
dinámico en el tiempo, y variable entre culturas diferentes ${ }^{121}$. Se refiere, por último, al prejuicio patriarcal históricamente asentado que identifica sexo con género y justifica mediante las diferencias fisiológicas inherentes al primero desigualdades que sólo pertenecen al ámbito del segundo y que, aunque han sido interesadamente naturalizadas, no son naturales y pueden ser transformadas.

Esta controversia sexo/género, que inunda numerosas facetas de la vida social humana, se reproduce a la hora de interpretar las diferencias entre sexos ${ }^{122}$ observadas en el continuo salud/enfermedad/muerte, cuando se constata que hombres y mujeres tienen patrones distintos a la hora de enfermar y morir. No obstante, a diferencia de otros ámbitos en los que las consecuencias de la discriminación por sexo han sido directas y diáfanas, en este caso la controversia adquiere tintes menos vehementes dadas las circunstancias aparentemente contradictorias con que emergen las diferencias entre sexos. En efecto, es posible que la muerte homogeneice a hombres y mujeres después de que ha ocurrido, pero desde luego no antes. Las estadísticas demográficas son claras a este respecto: la longevidad media y las causas inmediatas de mortalidad varían claramente entre hombres y mujeres de tal forma que la fuerza de la mortalidad es menor en éstas y, en consecuencia, sus esperanzas de vida en todas las edades son superiores a las de los varones ${ }^{123}$. Simultáneamente, las tasas de morbilidad e incapacidad de las mujeres son asimismo mayores que las de los varones. En resumen, las mujeres mueren después que los varones de sus mismas cohortes, pero enferman más que ellos.

Hasta hoy no se conocen a ciencia cierta las causas últimas de estos procesos diferenciales dado que no ha sido posible deslindar la influencia exacta en los mismos de los factores propiamente biológicos -sexo- entre las de todo el conjunto de factores que intervienen en ellos -género. Es decir, admitiendo que la incidencia de los factores biológicos conforma al sexo como un factor de riesgo per se, no se ha delimitado aún en qué grado lo es. No obstante, y como ha ocurrido en el examen de otras desigualdades sociales, el avance en múltiples áreas de conocimiento, junto con las innovaciones tecnológicas y el desarrollo de nuevos instrumentos

\footnotetext{
${ }^{121}$ Puleo (2000:29) define el <<género〉> como "la construcción cultural que toda sociedad elabora sobre el sexo anatómico y que va a determinar, al menos en alguna medida, y según la época y cultura de que se trate, el destino de la persona, sus principales roles, su estatus y hasta su identidad en tanto identidad sexuada”.

${ }^{122}$ De acuerdo con Verbrugge (1985:157), en este trabajo se empleará el concepto “sexo” en el sentido demográfico, es decir, para denotar categorías de población, sin ninguna presunción sobre las causas de cualquier diferencia observada entre ellas. Desde el punto de vista analítico, no obstante, se asume la perspectiva de género.

${ }^{123}$ Conviene recordar que la duración de la vida, o potencial de longevidad máxima, es una característica de la especie. Por tanto, el tiempo de envejecimiento de la misma es prácticamente independiente de las condiciones de vida, no existiendo diferencias entre hombres y mujeres. Es decir, las mujeres viven más no porque envejezcan más lentamente, sino porque su mortalidad es inferior a la de los varones en todas las edades, incluso durante la concepción (Klarsfeld y Revah, 2002:48-49; Hayflick, 1999:157; Austad, 1998:64).
} 
de análisis, han permitido precisar someramente las áreas de influencia de los distintos factores causales. Junto a ello, hay que resaltar el acicate que ha supuesto la labor ideológica, y de sensibilización, realizada desde la década de 1960 por los movimientos feministas que, en su permanente denuncia del sistema patriarcal en general, han reivindicado la necesidad de introducir la perspectiva de género en la agenda pública para poder comprender, entre otras cosas, la paradoja que aflora al contrastar las dinámicas de la morbilidad y la mortalidad por sexo. Las desigualdades observadas en éstas no son ajenas a las peculiaridades con que el sistema sexo/género define en cada cultura lo que es "ser un hombre" y "ser una mujer", sobre la base del principio de la primacía de la masculinidad (Bourdieu, 2000), determinando con ello, junto a otros factores, la división sexual del trabajo, la separación de los ámbitos público (masculino) y privado (femenino), estilos de vida y formas de estructurar el tiempo personal diferenciados por sexo (Artazcoz et al, 2002; Bourdieu, 2000; Durán, 2000, 1992, 1988, 1986; Ramos, 1990). En última instancia, estos condicionantes vitales impuestos socialmente a hombres y mujeres inducen, en el ámbito de la salud, conductas diferenciales que explican las desigualdades por sexo en salud/morbilidad/mortalidad.

En efecto, los análisis tradicionales de las desigualdades en mortalidad, y especialmente en morbilidad, por sexo adolecen de un <<sesgo de género $>{ }^{124}$ que impide la comprensión global de esas desigualdades al no recoger la contribución de todas las dimensiones del sistema social $^{125}$ (Valls Llobet, 2001:16). Este sesgo se concreta en la práctica, por ejemplo, en que, tomando la parte por el todo se reduce la población objeto de estudio a la población de varones y se equipara el concepto de normalidad en la salud con lo que es "normal” en los varones, obviando con ello que "las mismas causas pueden producir efectos distintos en las mujeres

\footnotetext{
${ }^{124}$ Los "sesgos de género" limitan la investigación de los factores de riesgo para la salud, condicionando con ello la propia promoción de la salud. Entre estos sesgos en la investigación médica, Valls Llobet (2002; 2001) resalta los siguientes: a) los estereotipos de género: que presuponen que hombres y mujeres tienen iguales riesgos y problemas para la salud, cuando no es así. De esta forma, los factores de riesgo para la salud detectados en los hombres se extrapolan directamente a las mujeres; b) los sesgos en investigación: derivados de lo anterior, muchos ensayos clínicos se realizan sólo para hombres, suponiendo implícitamente que los resultados pueden aplicarse automáticamente a las mujeres. Así, se obtienen datos de laboratorio sin base científica asentados en un "paradigma reduccionista de etiologías o en cruces incorrectos de causa/efecto"; c) la no valoración de las condiciones de vida y trabajo: en las encuestas de salud, por ejemplo, no se incluyen preguntas sobre las condiciones de vida y diferencias en sobrecarga de trabajo, así como sobre la doble jornada; d) la organización sanitaria androcéntrica: no sólo en la investigación de los factores de riesgo, sino también en la conducta de los "proveedores de salud": numerosas investigaciones han mostrado que "los médicos/as aprecian a menudo que las demandas de los pacientes varones son más serias y también es más probable que valoren un componente psicosomático si la paciente es del sexo femenino"; f) los sesgos en prevención y promoción de la salud: asentados en diagnósticos previamente condicionados.

${ }^{125}$ En este sentido, según Valls Llobet (2001:18), para lograr una comprensión completa, al menos desde la perspectiva epidemiológica, de las desigualdades por sexo en salud/enfermedad sería necesario añadir "al tradicional triunvirato de agente, huésped y medio ambiente una cuarta influencia... desde la perspectiva de género que es la contribución desde el sistema social como las políticas de reembolso de los gobiernos, las prioridades organizativas y la variable de conducta de los proveedores de salud".
} 
debido a su distinta posición social de género y a su propia biología diferencial” (Carranza y Puleo, 2001:32). Además, al centrar el análisis en los condicionantes que explican la salud, enfermedad y muerte de los varones hace invisibles aspectos esenciales para la interpretación de la salud, enfermedad y muerte de las mujeres como son el trabajo doméstico ${ }^{126}$ y la doble jornada laboral ${ }^{127}$. Es decir, históricamente se ha prestado más atención al examen de las conductas de riesgo físico socialmente masculinizadas, que se manifiestan en la etapa media de la vida y provocan muertes prematuras, y se ha abordado menos las conductas socialmente determinadas de las mujeres que "tienen una marcada influencia en la salud, y suelen generar problemas crónicos, físicos y mentales, que se extienden a lo largo de toda la vida sin producir la muerte prematura, pero sí limitaciones de larga duración” (Rohlfs et al, 2000:146). Para evitar todas estas consecuencias introducidas por el "sesgo de género", por tanto, es por lo que se hace necesaria la inclusión en el análisis del género como variable sustantiva, más que de control, ya que juega un papel determinante al estar interrelacionada con los factores biológicos, sociales, medio ambientales, y el sistema sanitario y, por ello, evidencia desigualdades que antes eran tratadas como meras diferencias en los estudios basados sólo en el sexo (Rohlfs, 2002:209; Valls Llobet, 2001:20).

Por otra parte, al ser un constructo social, el género es además un producto histórico que cambia en el tiempo. Se hace preciso, en consecuencia, tener en cuenta la evolución de los condicionantes vitales diferenciales entre sexos, y más en la fase actual del proceso de modernización caracterizada ente otros rasgos por el avance en la consecución de la igualdad de oportunidades por sexo, el igualitarismo formal, la exacerbación del individualismo, la ruptura del modelo dicotómico tradicional público/ privado y, sobre todo, la creciente permeabilidad en los estilos de vida que en parte son asumidos indistintamente por ambos sexos en las generaciones de jóvenes y de adultos-jóvenes. Esta des-diferenciación en la construcción de las

\footnotetext{
126 "Un concepto integral de salud debería incorporar no sólo la prevención de los riesgos en la actividad laboral, sino los derivados del trabajo doméstico" (Barañano, 1992:33). Dadas las características alienantes de éste (trabajo desvalorizado, aislado, de escasa cualificación, rutinario, repetitivo, depreciado socialmente, sin promoción al tener un techo natural) comporta importantes problemas para la salud que afectan casi en exclusiva a las mujeres al ser ellas las que tienen adscrito en el sistema patriarcal, como la forma de "ser una mujer”, el “destino inexorable”del trabajo doméstico (Carranza y Puleo, 2001).

${ }^{127}$ La doble jornada laboral consiste en el desarrollo diario de trabajo productivo fuera del hogar y trabajo reproductivo dentro de éste (trabajo en casa, socialización, cuidado de los miembros de la familia, apoyo emocional, mantenimiento de las redes familiares). El contenido específico y diferencial de los roles sexuales establecidos en el sistema sexo/género determina que, al menos en la sociedad española, la doble jornada recaiga mayoritariamente en las mujeres configurando una división asimétrica del tiempo entre hombres y mujeres. De esta forma, se establecen "relaciones no-recíprocas que conducen a la desigualdad", al asignar hombres y mujeres un "tiempo distinto a la realización de las mismas actividades, creando situaciones de vida también distintas” que, en última instancia, repercuten diferencialmente en la preservación de la salud (Barañano, 1992:28; Ramos, 1990). Un análisis empírico sobre la relación entre doble jornada/género/clase social/estado de salud aplicado a Andalucía, Cataluña y País Vasco, puede consultarse en Artazcoz et al (2002).
} 
identidades sexuales está repercutiendo en la evolución de las desigualdades por sexo en el continuo salud/enfermedad/muerte en la cuarta fase de la transición epidemiológica/sanitaria ${ }^{128}$.

La relativa mayor longevidad media de las mujeres ya fue detectada por John Graunt en 1662, pero no va a ser hasta principios del siglo XX cuando se explicite con el sorprendente agrandamiento de las desigualdades ante la muerte por género a la par que transcurría la transición de la mortalidad. Si en la primera mitad del siglo XIX la esperanza de vida de hombres y mujeres era aproximadamente igual (Hart, 1989:109), a principios del siglo XXI una mujer media de la Unión Europea puede esperar vivir algo más de seis años más que un hombre medio de la misma cohorte y origen geográfico: según estimaciones del Eurostat, en 2002, la esperanza de vida al nacer de las mujeres de la Unión Europea es de 81,6 años y la de los hombres 75,5 años (Eurostat, 2003:6). Este proceso, además, no es privativo de los países desarrollados que han vivido una profunda modificación de sus pautas demográficas inserta en el proceso de modernización general de los dos últimos siglos; con menor intensidad, la sobremortalidad masculina ha emergido y/o aumentado asimismo en la práctica totalidad de los países menos desarrollados que han iniciado o tienen ya muy avanzada su transición demográfica $^{129}$ (Cuadro 4.13.).

La emergencia de la sobremortalidad masculina se ha abordado en numerosas investigaciones al objeto de desentrañar qué factores actúan en el diferencial de mortalidad por género, cuál es el peso relativo de cada uno de ellos en dicho diferencial y cómo han incidido en el incremento del mismo a lo largo del siglo XX. Existe prácticamente unanimidad a la hora de admitir la existencia de una superioridad biológica en las mujeres respecto a los hombres de cara a la supervivencia ${ }^{130}$. Superioridad que Pressat (1973) estimó en 2 años en la e $(0)^{131}$. Una

\footnotetext{
${ }^{128}$ Obviamente, los efectos de la incorporación de las mujeres a ocupaciones antes masculinizadas, así como de la asunción de determinados comportamientos de riesgo (consumo de bebidas alcohólicas o de tabaco), no tienen efectos inmediatos en la salud de las mismas y tendrán que pasar algunos años para que esos efectos se manifiesten con la prevalencia con que lo hacen en los varones. No obstante, en 1985, Verbrugge ya advertía que estos cambios en la forma de vida de las personas estaban repercutiendo en las diferencias de salud entre sexos y que, específicamente en la población estadounidense, se evidenciaba que esas diferencias en algunas causas importantes de muerte estaban disminuyendo. En concreto, se refería al cáncer de pulmón sobre el que ya existen evidencias claras de cambio: mientras en 1950 el número de mujeres muertas por cáncer de pulmón en Estados Unidos era el más bajo de los cuatro principales cánceres que afectan a las mujeres, desde 1986, año en el que superó al cáncer de mama, pasó a ser la causa principal de muerte por cáncer entre las mujeres. Algo similar ocurre en Dinamarca, donde la prevalencia del consumo de tabaco por parte de las mujeres es aproximadamente del $40 \%$ desde la década de 1950, y donde las tasas de mortalidad por cáncer de pulmón se acercan a las de la mortalidad por cáncer de mama en la década de 1990 (Comisión Europea, 1995:15).

${ }_{129}$ De los 194 países analizados en el Informe sobre Desarrollo humano 2009, (PNUD, 2009:195-199), en 2007, sólo en dos (Afganistán y Swazilandia) hay sobremortalidad femenina.

${ }^{130}$ Según Cockerham (2002:47), la debilidad fisiológica de los hombres respecto a las mujeres "está demostrada" porque las tasas de mortalidad de aquéllos son más altas que las de las mujeres en los periodos prenatal, neonatal y posteriores de la vida: "a pesar de que los porcentajes pueden variar algo de un año a otro, las probabilidades de morir durante la fase prenatal son aproximadamente un 12 por ciento
} 
prueba irrefutable de esa superioridad, de que la mujer "por su constitución biológica se beneficia de mayores probabilidades de supervivencia” (Vallin, 1985:63), lo constituye el hecho de que la sobremortalidad masculina es norma general en todas aquellas sociedades inmersas en procesos de modernización socioeconómica. Con independencia de niveles y estructuras económicas y sociales y de tradiciones culturales, la ventaja física innata de las mujeres, medida en términos de mortalidad, se manifiesta claramente a medida que se eleva el nivel de vida de una sociedad. A partir de este consenso inicial las interpretaciones difieren dependiendo de dónde se sitúe cada autor en el continuo naturaleza/cultura.

\begin{tabular}{|c|c|c|c|}
\hline \multicolumn{4}{|c|}{$\begin{array}{c}\text { CUADRO 4.13.: DIFERENCIAS EN LA ESPERANZA DE VIDA AL NACER ENTRE } \\
\text { MUJERES Y HOMBRES (Años). 2005-2010 }\end{array}$} \\
\hline & MUJERES & HOMBRES & DIFERENCIA \\
\hline Total & 69,8 & 65,4 & 4,4 \\
\hline Países de alto ingreso & 80,5 & 73,6 & 6,9 \\
\hline Suiza (2007) & 84,1 & 79,2 & 4,9 \\
\hline España (2007) & 84,0 & 77,5 & 6,5 \\
\hline Países en desarrollo. Todos & 67,4 & 63,9 & 3,5 \\
\hline Países menos adelantados & 57,2 & 54,7 & 2,5 \\
\hline Swazilandia (2007) & 44,8 & 45,7 & $-0,9$ \\
\hline
\end{tabular}

Fte: Datos de 2005-2010, NU (2009:14); datos de 2007, PNUD (2009): Informe sobre Desarrollo Humano 2009, pp.195-199.

Retherford (1975), por ejemplo, sitúa este determinismo biológico en un marco más amplio cuando constata que el diferencial de longevidad media por sexo no es privativo de la especie humana sino que está presente “en todo el reino animal”. De esa constatación deriva que si sólo fueran las mujeres las que tienen una mayor e(0) que los varones podría suponerse que en ese diferencial únicamente actúan factores culturales que condicionan distintos comportamientos por sexo. Sin embargo, la extensión del mismo a todas las especies animales hace poco verosímil esta hipótesis y sugiere que en "todo el reino animal las hembras viven más tiempo que los machos, (por) la existencia de una básica inferioridad biológica en la capacidad de sobrevivir de éstos respecto de aquéllas”. Se han propuesto diversos factores para explicar las causas de esta superioridad biológica de las hembras en general, y de las mujeres en particular, sin embargo, de momento la evidencia empírica existente no ha aportado respuestas concluyentes sobre el peso relativo de cada uno de ellos. En un plano general se la ha

mayores entre los hombres que entre las mujeres y un 130 por ciento mayores durante el periodo neonatal... Asimismo, los hombres nacidos son más propensos a ciertos trastornos circulatorios de las arterias pulmonares y aórticas y a infecciones bacteriales más graves. Las mujeres son menos propensas a tener leucemia infantil y tienen una mayor probabilidad de supervivencia cuando la sufren”.

${ }^{131}$ Pressat (1973) lo justifica señalando que, al menos en Occidente, no existiendo influencias externas en el primer año de vida, el exceso de mortalidad de los niños respecto a las niñas en esa edad es del $25 \%$ al $30 \%$, y que esa diferencia se mantiene a lo largo de toda la vida resultando en una diferencia aproximada de 2 años en la e(0). 
relacionado con los dos cromosomas $\mathrm{X}$ de las hembras, frente a los cromosomas $\mathrm{X}$ e $\mathrm{Y}$ de los machos, que dotarían a las primeras de mayor poder inmunorregulador (Kirkwood, 2000:198202; Waldron, 1983:321-333). Por ejemplo, Vallin (2006:177-179) señala que, dado que más de 1.000 enfermedades están relacionadas con el cromosoma X, si una mutación afectara a uno de los cromosomas $\mathrm{X}$ de las mujeres podría no causar enfermedad o desórdenes en muchos casos al compensar el otro cromosoma $\mathrm{X}$ la pérdida de función del primero, cosa que no podría ocurrir en un varón. Asimismo, se ha relacionado la superioridad biológica de las mujeres con ciertas funciones específicas de las mismas para cuyo cumplimiento requieren de mayor protección frente a las enfermedades degenerativas y el envejecimiento biológico, ante los que los hombres son menos resistentes. Kirkwood (2004:306), por ejemplo, lo vincula a que las mujeres son las garantes de la reproducción por lo que su soma sería menos desechable que el de los varones, que cumplen un papel mínimo en la reproducción y, por tanto, son más prescindibles. También con la mayor capacidad de las mujeres para almacenar alimento, para el embarazo y la lactancia, y su capacidad para eliminar las reservas de alimentos acumuladas sin daño les permite afrontar fácilmente cambios en las condiciones de vida (Seely, 1990). Por otra parte, se señalan la tasa metabólica más elevada en los varones, la ratio peso del cerebro/peso corporal superior en las mujeres (Hayflick, 1999:158), o también la cantidad y diferencia de las hormonas sexuales, concretamente la dotación genética de muchos estrógenos y poca testosterona que harían más susceptibles a los varones de contraer enfermedades cardiovasculares, aunque no explicaría la mayor incidencia en ellos de los tumores o la neumonía $^{132}$ (Bernis, 2004:10; Kirkwood, 2000: 205-207; Austad, 1998:65). Además, se resalta el papel jugado por el par de cromosomas XX defendiendo más eficazmente al cuerpo contra las lesiones por oxidación causadas por los radicales libres, al tener mayor capacidad para reparar encimas que un único cromosoma X (Vallin, 2006:178). En cualquier caso, diversos autores han resaltado que la mayor longevidad media de las hembras no es en modo alguno universal, ya que existen diversas especies animales, como los conejillos de Indias, en las que los machos viven más que las hembras (Hayflick, 1999:158).

Para otros autores, la incidencia de los factores biológicos no sólo es la clave en la explicación del diferencial de mortalidad entre géneros, sino también de su ensanchamiento, ante el que poco puede hacerse. Madigan (1957:202-223) en su estudio ya clásico de las diferencias de mortalidad entre religiosas y religiosos católicos dedicados a la enseñanza en

132 Según Bernis (2004:10), "la mujer, a igual edad cronológica, tiene desde su nacimiento una edad fisiológica más avanzada, menor tamaño, diferente composición (más grasa y menos músculo) y, por tanto, menores requerimientos nutricionales excepto durante el embarazo y el periodo de lactancia. Las mujeres son más longevas, tienen los telómeros más largos y, mientras mantienen su capacidad reproductora, presentan un perfil hormonal con elevada concentración de estrógenos”. Estos tienen un efecto cardio-protector ya que "estimulan la síntesis de la telomerasa lo que reduce la velocidad de atrición del telómero”, permitiendo conservarlos más tiempo en su sistema vascular. 
Estados Unidos, comprobó, una vez controladas las variables socioculturales ${ }^{133}$, que las diferencias entre sexos en la esperanza de vida a las distintas edades seguían una trayectoria similar a la del conjunto de la población de Estados Unidos. En consecuencia, para él, la explicación del diferencial se asentaba más en los factores biológicos (sexo) que en los sociales (género). Madigan resaltó, además, que en igualdad de condiciones las mujeres no son más resistentes que los hombres a las enfermedades infecto-contagiosas y que "las ganancias que las mujeres han hecho a lo largo de este siglo pueden estar principalmente relacionadas con una superior resistencia constitucional a las enfermedades degenerativas”.

Madigan, no obstante, dejó sin responder una cuestión básica: ¿por qué el diferencial sólo se había manifestado en el siglo XX? Este hecho es el que lleva a otros autores a admitir la existencia de una dotación biológica favorable a las mujeres, pero no a considerarla responsable del diferencial global de mortalidad entre géneros, y mucho menos de su ensanchamiento. En efecto, los factores biológicos se encuentran lejos de explicar la totalidad del exceso de mortalidad de los hombres y en estos momentos no generan la parte principal del diferencial. Dos características de la desigualdad de mortalidad por sexo permiten constatarlo. En primer lugar, que la sobremortalidad masculina tienda a convertirse en norma general no implica que sea un proceso universal en el espacio ni en el tiempo. En efecto, en algunas sociedades de África y Asia existe sobremortalidad femenina en las edades jóvenes y en las de procrear, lo que se traduce en una $\mathrm{e}(0)$ de la mujeres inferior a la de los hombres ${ }^{134}$. Asimismo, la

\footnotetext{
${ }^{133}$ Madigan suponía que controladas las variables socioculturales emergería la actuación de los factores biológicos aislados. Para ello eligió como sujeto de estudio a un colectivo de población que llevaba una vida al margen de la sociedad corriente de Estados Unidos, y que le permitió eliminar cinco grandes diferenciales de estrés entre géneros: a) el servicio en las fuerzas armadas de los hombres; b) "la mayor libertad de los hombres para la disipación”; c) los roles disimilares de marido y esposa; d) el empleo masculino en ocupaciones temporales y/o peligrosas; y e) el empleo de hombres y mujeres en actividades heterogéneas. Además de la mortalidad maternal en las mujeres.

${ }^{134}$ El resultado de esta sobremortalidad femenina se manifiesta en unas anormales proporciones totales de mujeres sobre hombres en Sudáfrica, Asia Occidental, norte de África y China, que varían entre 0,93 y 0,96, en contraste con el 1,05 de Europa y América del Norte (Sen, 1995:141). Aplicando a la India la relación de masculinidad de África $(1,02)$, a mediados de los ochenta se habrían contabilizado 20 millones más de mujeres que las observadas hacia mediados de los años ochenta. Sobre la misma base, el número de "mujeres ausentes" en China sería de 40 millones (Sen, 1995:141). En un intento por comprender este fenómeno Sen (1998:13) señala que "he tratado de anotar tanto (1) las influencias sociales de convenciones y prejuicios establecidos, y (2) las influencias económicas de las oportunidades dispares que los hombres tienen vis-à-vis con las mujeres,... La importancia de la cooperación hace que un hecho de la vida familiar (un argumento basado en la eficiencia) pueda ser usado en una situación de asimetría social y prejuicio para que la cooperación de las mujeres se produzca en términos muy desiguales (con gran injusticia). Este es un problema general que se aplica aún en Europa y Norte América en una variedad de campos (tales como las división de las tareas familiares, la provisión de apoyo a los mayores, y otros), pero en los países pobres, las desventajas de las mujeres pueden aplicarse aún a campos básicos de los cuidados de salud, apoyo nutricional, y educación elemental. El olvido de niñas e infantas puede estar, en general, relacionado con el menor estatus social de las mujeres". Recientemente, el Programa de Naciones Unidas para el Desarrollo ha actualizado los datos de "mujeres desaparecidas" y ha estimado en "134 millones de mujeres desaparecidas en 2010, casi un tercio más que en estimaciones anteriores” (PNUD, 2010:85-86).
} 
sobremortalidad masculina tampoco ha sido un proceso universal en el tiempo. En la primera mitad de siglo XX la distribución de los cocientes de mortalidad por género fue sustancialmente distinta a la actual en todos los países europeos. Así, la intensidad de la sobremortalidad masculina no ha resultado nunca antes tan intensa como en las últimas décadas, para ningún grupo de edad; además y fundamentalmente, hasta la década de 1940 se detectan sobremortalidades de las mujeres en algunos grupos de edad. Este fenómeno fue común en todos los países europeos en el pasado afectando a las mujeres más jóvenes y a las que se encontraban en edad de procrear (mortalidad materna). En el primer caso, el menor valor social de la mujer, derivado en parte de la preferencia como asalariados de los hombres (Harris y Ross, 1991:170) desembocaba en el <<infanticidio aplazado>>; en el segundo caso, las malas condiciones higiénicas y la ausencia de control médico y sanitario determinaba que cualquier embarazo supusiera un serio riesgo para la vida de las mujeres ${ }^{135}$. Ambas sobremortalidades femeninas desaparecen con el lento proceso de modernización al elevarse el estatus de las mujeres y con el desarrollo de toda una serie de mejoras (médicas, sanitarias, alimentarias, etc.) que aminoraron sustancialmente los riesgos durante el embarazo, parto y puerperio.

La segunda característica actual de la sobremortalidad masculina que permite constatar la incidencia de otros factores, además de los biológicos, consiste en que diversos países desarrollados con niveles casi idénticos de mortalidad femenina presentan discrepancias significativas en los niveles de mortalidad masculina. Es el caso, por ejemplo, de Suiza y España que en 2007 tenían una esperanza de vida similar para las mujeres, 84,1 y 84,0 años, respectivamente, y sin embargo la longevidad media de los hombres españoles era 1,7 años inferior a la de los hombres suizos (Cuadro 4.13.). Salvo que se admita una superioridad biológica en los varones suizos respecto a los españoles, cabe presumir la presencia de otros factores contextuales distintos de los biológicos como causantes de ese diferencial. En este sentido, todo parece indicar que, de igual forma que cada sociedad ha tenido sus rasgos peculiares en la transición de la mortalidad, otro tanto cabe afirmar en el progresivo ensanchamiento del diferencial de mortalidad entre géneros.

${ }^{135}$ La Organización Mundial de la Salud define la “muerte materna” como “aquella muerte de una mujer
embarazada o durante los 42 días que siguen a la terminación del embarazo, independiente de la duración
y la localización del mismo, provocada por cualquier causa relacionada con o agravada por el embarazo o
su asistencia, pero no por causas accidentales o incidentales” (O.M.S, 1977:763-64). La mejora en todos
los ámbitos relacionados con el embarazo, parto y puerperio se ha traducido, por ejemplo, en España en
una reducción del número de mujeres fallecidas a consecuencia del parto por cada 100.000 partos:
\begin{tabular}{|c|c|c|c|c|c|c|c|}
\hline 1900 & 1930 & 1960 & 1965 & 1970 & 1975 & 1980 & $1990-98$ \\
\hline 558 & 342 & 72 & 51 & 32 & 21 & 10 & 6 \\
\hline
\end{tabular} Fte: Datos hasta 1970, (De Miguel, 1982:29); dato de 1980, Banco Mundial (1992): Informe sobre el Desarrollo Mundial 1992, pp. 277; dato de 1990, PNUD (2000): Informe sobre Desarrollo Humano 2000, pp.186. 
La ventaja física innata de las mujeres ha quedado, por tanto, históricamente enmascarada por el peso de los factores sociales, económicos y culturales. Los profundos cambios que en estos ámbitos se han producido en el siglo XX han invertido la situación permitiendo que por primera vez se revelara explícitamente la superioridad biológica de las mujeres. No obstante, como señala Hart (1989:121), “aún si la comparación física de las mujeres ayuda a estructurar desigualdades en las posibilidades de vida al comienzo del período de vida, no es suficiente explicación del ensanchamiento del diferencial en la longevidad en la vida adulta”.

Distintas investigaciones empíricas han intentado explicar los motivos del ensanchamiento en el diferencial de mortalidad por sexo. En general, todo parece indicar que el proceso de modernización socioeconómica que ha conllevado el control de las enfermedades infecciosas, las mejoras en la tecnología médica (como el empleo de sulfamidas para controlar las enfermedades puerperales, y las transfusiones de sangre que contribuyeron a una notable reducción de la mortalidad maternal), así como en la producción y distribución de alimentos, en sanidad, en el hogar, la elevación del nivel general de vida, han tenido un resultado neto más favorable para las mujeres que para los varones. En efecto, si bien ambos sexos han obtenido igual provecho de los factores positivos asociados a la creciente abundancia de recursos, la incidencia de los aspectos negativos de la misma se ha acumulado en mucha mayor proporción en los hombres. Además, los procesos de industrialización y de urbanización han reducido al mínimo el valor diferencial entre hijos e hijas para la economía familiar, disipándose con ello el favoritismo para con los hijos varones, que ha dejado de tener consecuencias para la mortalidad diferencial por sexo.

Por otro lado, el asentamiento de comportamientos reproductores modernos ha incidido en el diferencial de mortalidad por sexo. El descenso de la fecundidad ha tenido un efecto directo sobre la reducción de los riesgos derivados de la mortalidad maternal, al disminuir el número de embarazos. A la par, ha incidido indirectamente al reducirse el desgaste físico y psicológico conexo. Si se admite con Hart (1989:128) que la constitución de la mujer es más fuerte porque el rol reproductivo así lo requiere, “cuando éste disminuye, la ventaja natural genética puede ser realizada en mejoras de la longevidad”. A la reducción de la mortalidad materna ha contribuido, asimismo, la utilización de métodos anticonceptivos modernos que han permitido a muchas mujeres evitar embarazos no deseados durante edades relativamente peligrosas por debajo de los 19 años y por encima de los 40 años (Ortmeyer, 1979:128).

A través de la comparación de la mortalidad por sexo en países con distintos niveles de desarrollo, Preston (1976:120-162) demostró que el diferencial de longevidad media entre 
géneros se incrementaba significativamente con el desarrollo económico. Asimismo, demostró que el diferencial aumentaba con la mejora del estatus relativo de las mujeres al removerse las barreras que impedían su participación en el mercado laboral. El acceso a éste les abría la posibilidad de obtener no sólo recursos económicos propios, con lo que esto conlleva, sino también de integrarse en una red de vínculos sociales más extensa. Todo ello eliminaba la discriminación histórica que inhibía la potencial ventaja biológica de las mujeres. Pampel y Zimmer (1989) denominan a este proceso <<hipótesis discriminatoria >>. No obstante, estudios posteriores sobre esta cuestión, centrados asimismo en el incremento de la participación de las mujeres en la fuerza de trabajo, han disentido de las interpretaciones de Preston y planteado otras hipótesis explicativas, lo que ha dado lugar a una fértil discusión que se prolonga hasta la actualidad. En síntesis, se observan tres hipótesis que interpretan de forma diferente la causalidad en las desigualdades en la mortalidad por sexo relacionadas con el incremento del estatus laboral de las mujeres y que conducen, en consecuencia, a distintas predicciones sobre la evolución del mismo (Pampel y Zimmer, 1989:281-304):

A) La de quienes, en la línea de Preston, señalan que las mejoras en educación, la incorporación al mercado de trabajo y el mayor estatus ocupacional de las mujeres han incrementado su esperanza de vida y parcialmente el crecimiento del diferencial de mortalidad por sexo (hipótesis discriminatoria).

B) La de quienes sugieren que el menor estatus social de las mujeres les ha protegido históricamente frente a los riesgos laborales y de estilo de vida que sí han afectado negativamente a los varones, <<hipótesis protectora >>. Negando su acceso al poder por el sistema patriarcal, históricamente las mujeres fueron también preservadas de los peligros inherentes a la guerra y a la caza (Vallin, 2006:187). Sin embargo, la convergencia en la actividad laboral y en los roles sociales de hombres y mujeres disipará las diferencias en el comportamiento sesgado ante la mortalidad y el diferencial tenderá a estrecharse.

C) La de quienes afirman que el estatus laboral de las mujeres no está relacionado con el diferencial de mortalidad por sexo, explicándose éste fundamentalmente por las diferencias de clase en la mortalidad entre los "hombres". Dado que las mujeres, independientemente de su estatus, tienen unos niveles de mortalidad similares a los de los hombres de estatus alto, las diferencias de mortalidad por sexo se originan en el peso relativo con que la mortalidad de los hombres de estatus bajo arrastra al total de mortalidad masculina, <<hipótesis nula $>{ }^{136}$ (Nathanson y López, 1987).

\footnotetext{
${ }^{136}$ Es evidente que la incorporación de las mujeres al mercado de trabajo puede tener un efecto de bienestar, como se ha comprobado en numerosas ocasiones, en la percepción subjetiva de la salud, pero en general no produce consecuencias inmediatas en términos de mortalidad. Éstas se pueden manifestar pasados unos años, por lo que para testarlas se requieren estudios que tengan en cuenta ese gap temporal. En un estudio con datos agregados de 18 países y con 8 observaciones para cada uno, Pampel y Zimmer (1989) han examinado las tres hipótesis y los resultados obtenidos mostraban evidencias sobre la
} 
No obstante, las tres hipótesis anteriores se enfrentan al problema que supone realizar inferencias causales sobre el comportamiento individual desde datos agregados. Aunque este análisis macro proporciona evidencias de asociación entre algunas condiciones sociales y las diferencias en mortalidad por sexo en, y entre, países, obviamente, no se recogen en el mismo la incidencia de otros muchos factores que incluso pueden llegar a influir con más intensidad que el propio estatus laboral de las mujeres. Por esta razón, Kitagawa y Hauser (1973) advirtieron que la investigación de los factores causales de las diferencias de mortalidad por sexo es intrínsecamente epidemiológica ${ }^{137}$. De ahí, la necesidad de centrarse en las evidencias aportadas por estudios empíricos sobre las inferencias causales de los factores ambientales inmediatos. En este sentido, los trabajos de la socióloga estadounidense Lois M. Verbrugge $(1989,1985,1976)$ son una referencia inexcusable a la hora de analizar las diferencias en mortalidad y en morbilidad entre sexos. Centrando sus análisis en las personas adultas, dado que es en éstas en las que es más probable que se manifieste la incidencia de factores sociales y psicológicos, esta autora intenta encontrar las razones de la paradoja más arriba mencionada: en las sociedades más desarrolladas, los riesgos de muerte son mayores en los hombres que en las mujeres, en todas las edades y en la mayoría de las causas que conducen a la muerte. Simultáneamente, las mujeres tienen mayor morbilidad que los varones para las enfermedades agudas, crónicas nofatales, y tienen también más incapacidades a corto plazo y usan en mayor medida los servicios médicos y farmacéuticos ${ }^{138}$.

hipótesis discriminatoria: los países con mayores niveles relativos de fuerza laboral femenina (y mayor nivel educativo de las mujeres) tenían relativamente más diferencial por sexo en la longevidad media. Asimismo, comprobaron que si se incluía la desigualdad en la renta se incrementaba consistentemente el diferencial, al recoger las desigualdades en mortalidad entre varones de distintas clases sociales. Por lo que dedujeron que una parte del diferencial por sexo se ajustaba a la hipótesis nula. No obstante, el estudio de Pampel y Zimmer se realizó a finales de la década de 1980, desde entonces, y aunque el diferencial total entre sexos ha continuado creciendo, distintos estudios han resaltado que las diferencias de mortalidad entre sexos para algunas causas concretas han disminuido a medida que las mujeres han ido accediendo a ámbitos sociales que anteriormente tenían vedados y, sobre todo, han asumido comportamientos, hasta hace poco masculinizados, que comportan mayores riesgos para su salud (hipótesis protectora).

${ }^{137}$ Vaquero (1992:62-63) define a la epidemiología como "el método de estudio de la presentación de la enfermedad en los colectivos humanos, así como el análisis y determinación de las causas y factores que motivan o condicionan tal presentación, para intervenir sobre ellos”. Es pertinente en nuestro caso resaltar el hecho de que a diferencia de la medicina clínica que se centra en el individuo aislado, la epidemiología aborda a las personas como conjuntos estimables estadísticamente. Esto la ha permitido adquirir una "situación privilegiada como ciencia puente entre los fenómenos sociales (causas) y los biológicos (efectos)" para "identificar dentro de los complejos procesos sociales, componentes específicos susceptibles de ser modificados: contaminación ambiental, dieta, riesgos laborales, hábitos, etc..” (García Benavides, 1992:6).

${ }^{138}$ En el caso de España, las sucesivas Encuestas Nacionales de Salud, realizadas por el $\mathrm{M}^{\mathrm{o}}$ de Sanidad, Política Social e Igualdad, en 2006, y el Mº de Sanidad y Consumo en los años 2003, 2001, 1997, 1995, 1993, 1987, y otras encuestas realizadas por CC.AA., Ayuntamientos, etc., además de los datos sobre morbilidad, han permitido constatar las desigualdades de hombres y mujeres en salud, mostrando repetidamente la peor salud subjetiva de las mujeres, sus mayores tasas incidencia de enfermedades agudas, mayores tasas de prevalencia de condiciones crónicas no fatales, días de incapacidad, visitas a 
Según Verbrugge (1985:162-163), no existe tal paradoja y las estadísticas lo único que hacen es reflejar que las mujeres enferman o se incapacitan más, pero con problemas de salud "menos serios", que no amenazan sus vidas. Por el contrario, los varones enferman o se incapacitan menos, pero con riesgos más amenazantes para sus vidas, que les provocan más incapacidades permanentes o muertes más tempranas. Es decir, tanto las estadísticas de mortalidad como las de morbilidad reflejan que son los varones los que tienen problemas de salud más graves. Verbrugge sintetiza en cinco categorías la explicación de las diferencias por sexo en salud/enfermedad/muerte:

a) Riesgos biológicos: diferencias fisiológicas intrínsecas a los sexos que, como se ha señalado anteriormente, confieren riesgos diferenciales de morbilidad.

b) Riesgos adquiridos: riesgos de enfermar y accidentarse ligados a los roles en el trabajo y en las actividades de ocio, al estilo de vida, a los hábitos de salud, al estrés psicológico y al medio social.

c) Aspectos psicosociales de síntomas y cuidados de salud: cómo perciben las personas los síntomas de la enfermedad, cómo se valora la gravedad de los síntomas, cuál es la voluntad de aliviar o curar los problemas de salud y cuál es la habilidad para hacerlo.

d) Comportamientos para expresar la salud: cómo y cuánto hablan las personas de sus síntomas.

e) Cuidados preventivos de la salud: qué acciones terapéuticas se eligen para uno mismo, cuál es el nivel de autocuidados, cuál es el nivel de cuidados médicos. Influyen en el curso de la enfermedad y en la incidencia de potenciales enfermedades.

La revisión de la evidencia empírica de estas explicaciones conduce a Verbrugge (1985:173) a señalar que "las principales razones de las desigualdades por género en salud son epidemiológicas -el resultado de riesgos adquiridos desde los roles, estrés, estilos de vida y a largo plazo de prácticas preventivas de salud-”. Algunos de estos riesgos adquiridos son más comunes entre los hombres (consumo de tabaco y de bebidas alcohólicas, riesgos laborales, conducción de vehículos a motor, ocio más arriesgado), pero otros condicionantes y comportamientos implican mayores riesgos para la salud de las mujeres (medio social, desempleo, trabajo doméstico, doble jornada, inactividad, sobrepeso, estrés, infelicidad). Los "factores biológicos" tendrían, por su parte, un rango próximo pero indeterminado y globalmente dan ventajas a las mujeres. Los “factores psicosociales”, asimismo, tienen un rango próximo de influencia. Son aspectos importantes a la hora de enfrentarse a la enfermedad y, si

servicios médicos, etc. (Gómez Redondo et al, 2002; Gómez Redondo 2001; Gómez Redondo et al, 2001; Jiménez Aboitiz et al, 2001, Rolhfs et al, 2000; Valls-Llobet, 2001; Instituto de la Mujer, 2002, 2001; Instituto Universitario de Estudios de la Mujer, 2001; Onís y Villar, 1992). 
bien no existe evidencia empírica irrefutable, se considera que hasta ahora favorecen a las mujeres. Los "cuidados preventivos de la salud" constituyen una causa de rango medio, y existen evidencias diáfanas de que son claramente desfavorables para los hombres en términos de salud y longevidad media ${ }^{139}$. Finalmente, los “comportamientos para expresar la salud" inciden mínimamente en el diferencial.

Análisis posteriores a los de Verbrugge han profundizado en la discriminación de estos cinco grupos de factores como constructores de las diferencias por sexo en morbilidad y mortalidad. Si bien, parece claro que alguno de ellos -los "comportamientos para expresar la salud" -, tiene escaso peso relativo, y que las desigualdades por sexo actuales responden menos a la influencia de los factores biológicos que a la de los ligados de una manera general al estatus de las mujeres y al nivel de desarrollo socioeconómico y sanitario de una población, la indeterminación de la influencia exacta de éstos y otros factores recomienda eludir posiciones reduccionistas de corte biofisiológico o de perfil sociológico, con el objetivo de no desenfocar las investigaciones y evitar con ello alcanzar conclusiones erróneas sobre un proceso tan complejo (Vallin, 2006; Valls Llobet, 2002; McKinlay, 1996). Esta estrategia, además, entronca perfectamente con el esquema interpretativo de la teoría de la transición sanitaria. Con estas premisas, se desarrolla a continuación el análisis de las diferencias por sexo en España centrándolo exclusivamente en el ámbito de la mortalidad ${ }^{140}$.

El incremento de la esperanza de vida al nacer de la población española desde 1900 ha venido acompañado por un ensanchamiento continuo del diferencial de longevidad media entre mujeres y hombres, siempre favorable a las primeras ${ }^{141}$. Esta evolución, desde los 1,8 años de diferencia en 1900 hasta los 6,8 años en 2000, se ha producido con un crecimiento medio del diferencial de medio año de vida por década. Hay que resaltar, no obstante, la quiebra producida en la segunda mitad de la década de 1990 cuando, alcanzado el diferencial máximo en las tablas de mortalidad de 1996, se observa un cambio en la tendencia y el diferencial por sexo comienza a declinar, tendencia que continúa hasta hoy. Así, frente a un crecimiento significativo del

\footnotetext{
${ }^{139}$ Son mayoritariamente las mujeres las que acuerdan las citas familiares con los servicios médicos, las que apremian a sus familiares a reconocer síntomas de enfermedad y solicitar ayuda médica, las que compran y reponen las medicinas de la familia. En definitiva, las mujeres se cuidan y cuidan de los otros en mayor medida que los varones. Un ejemplo concreto de las consecuencias que se derivan del mayor hábito de las mujeres a la hora de frecuentar los servicios médicos y de preocuparse por su salud lo aportan Caselli et al (1995:46) al observar que el diagnóstico precoz de los tumores de cuello de útero con ocasión de las visitas ginecológicas ha constituido la causa principal de reducción de la mortalidad por cáncer de útero.

${ }^{140}$ Para un análisis detallado de las diferencias en salud y morbilidad por sexo en la sociedad española pueden consultarse (Regidor et al, 2011, Instituto de la Mujer, 2002; Instituto Universitario de Estudios de la Mujer, 2001; Onís y Villar, 1992)

${ }^{141}$ Este proceso ha discurrido paralelo al incremento general de la esperanza de vida y, sin embargo, por los datos que se dispone para distintos países, se puede afirmar que no hay relación evidente entre ambos procesos (Vallin, 1985:67).
} 
diferencial de 1 año en la década de 1980, en la última década del siglo XX el diferencial se reduce en 0,27 años ${ }^{142}$.

Si bien en la práctica no se ha acometido un examen que determine los factores subyacentes en el diferencial de mortalidad por sexo en España, sí que se puede realizar una aproximación al mismo a través de las causas inmediatas de muerte. Se hace preciso, en consecuencia, dirigir la atención hacia aspectos más concretos de la diferencia de longevidad media entre mujeres y hombres al objeto de perfilar mejor la incidencia de la naturaleza y el contexto socio-histórico en la mortalidad y, sobre todo, detectar indicios sobre cuál puede ser su evolución futura. Dos cuestiones son relevantes en este sentido; en primer lugar, identificar en qué grupos de edad se genera la diferencia de esperanza de vida entre hombres y mujeres, así como el incremento de la misma; en segundo lugar, qué causas de muerte inmediatas contribuyen en mayor medida a la evolución del diferencial de longevidad media entre sexos.

Respecto a la primera de las cuestiones, en España, como en el resto de los países desarrollados, no sólo la longevidad media de las mujeres es superior a la de los varones, sino que en todas las edades la mortalidad de éstos es sistemáticamente mayor que la de aquéllas. En el Cuadro 4.14. se recoge la evolución de la razón de sobremortalidad entre sexos, $r_{x}{ }^{143}$, verificándose que en la actualidad sus valores superan la unidad en todos los grupos de edad. Se constata, asimismo, que no sólo los riesgos de deceso son superiores en todas las edades para los hombres, sino que además la sobremortalidad masculina varía notablemente con la edad. Así, la distribución de la $\mathrm{r}_{\mathrm{x}}$, como ocurre en la mayor parte de los países europeos, es bimodal. Comienza con unos valores ligeramente superiores a la unidad en las edades infantiles, alcanza un primer máximo alrededor de la veintena, cuando la probabilidad de fallecer de los varones casi triplica a la de las mujeres, desciende durante las edades adultas medias, aunque con niveles todavía elevados ( $\mathrm{r}_{\mathrm{x}}$ superior a 2), alcanza un segundo máximo en las edades cercanas a la jubilación y tiende hacia la unidad en las edades más avanzadas ${ }^{144}$.

\footnotetext{
${ }^{142}$ En sus Proyecciones de la Población de España a Largo Plazo, 2009-2049, el INE (2010) estima una evolución positiva de la e $(0)$ tanto para hombres como para mujeres durante los próximos cuarenta años, si bien la evolución será más favorable en aquéllos que en éstas: en los primeros, la e(0) crecerá 6,3 años entre 2009 (78,01 años) y 2048 (84,31años); en las segundas, crecerá 5,52 años en ese periodo de tiempo (de 84,37 años, en 2009, a 89,89 años, en 2048). Como resultado de esta proyección el diferencial por sexo descenderá continuamente desde los 6,36 años, en 2009, hasta los 5,58 años, en 2048.

${ }^{143}$ La diferencia entre las esperanzas de vida de mujeres y hombres es un indicador que por su carácter sintético proporciona una visión resumida de las diferencias de mortalidad por sexo, pero su carácter general no facilita el análisis de las causas de dicho diferencial. Se hace preciso, por tanto, descender a un nivel más desagregado que permita este análisis. Para ello se emplea la "razón de mortalidad entre sexos" o "razón de sobremortalidad masculina" en un intervalo de edad dado, $\left(\mathrm{r}_{\mathrm{x}}\right)$, que es un indicador que expresa la diferencia relativa de mortalidad entre hombres y mujeres a través del cociente entre la probabilidad de deceso de los hombres y la de las mujeres para cualquier grupo de edad.

${ }^{144}$ Es esta la razón por la que la diferencia por sexo en la esperanza de vida al nacimiento disminuye paulatinamente a medida que se consideran grupos de edad más avanzada, siendo prácticamente
} 


\begin{tabular}{|c|c|c|c|c|c|c|c|}
\hline \multicolumn{8}{|c|}{$\begin{array}{l}\text { CUADRO 4.14.: EVOLUCIÓN DE LA RAZÓN DE SOBREMORTALIDAD } \\
\text { MASCULINA }\left(r_{\mathrm{x}}\right) . \text { ESPAÑA }\end{array}$} \\
\hline EDAD & 1900 & 1930 & 1950 & 1970 & 1990 & 1998/99 & 2005 \\
\hline $\mathbf{0}$ & 1,02 & 1,13 & 1,16 & 1,29 & 1,20 & 1,18 & 1,25 \\
\hline 1 & 1,01 & 1,03 & 1,03 & 1,20 & 1,23 & 1,01 & 1,15 \\
\hline 5 & 0,97 & 1,08 & 1,16 & 1,39 & 1,48 & 1,61 & 1,33 \\
\hline 10 & 0,88 & 0,91 & 1,04 & 1,55 & 1,45 & 1,47 & 1,61 \\
\hline 15 & 0,93 & 1,10 & 1,19 & 2,19 & 2,73 & 2,46 & 2,62 \\
\hline 20 & 1,17 & 1,08 & 1,32 & 2,26 & 3,68 & 3,31 & 2,98 \\
\hline 25 & 1,17 & 0,97 & 1,33 & 2,09 & 3,33 & 3,10 & 2,83 \\
\hline 30 & 1,06 & 1,06 & 1,37 & 1,82 & 3,03 & 2,87 & 2,48 \\
\hline 35 & 1,04 & 1,17 & 1,46 & 1,70 & 2,46 & 2,64 & 2,41 \\
\hline 40 & 1,17 & 1,33 & 1,38 & 1,73 & 2,47 & 2,31 & 2,23 \\
\hline 45 & 1,26 & 1,47 & 1,54 & 1,80 & 2,42 & 2,36 & 2,27 \\
\hline 50 & 1,26 & 1,51 & 1,72 & 1,79 & 2,39 & 2,55 & 2,49 \\
\hline 55 & 1,19 & 1,45 & 1,71 & 1,88 & 2,40 & 2,66 & 2,60 \\
\hline 60 & 1,11 & 1,35 & 1,54 & 1,85 & 2,35 & 2,61 & 2,56 \\
\hline 65 & 1,05 & 1,25 & 1,38 & 1,71 & 2,21 & 2,44 & 2,42 \\
\hline 70 & 1,02 & 1,16 & 1,27 & 1,50 & 1,91 & 2,10 & 2,11 \\
\hline 75 & 1,01 & 1,09 & 1,17 & 1,32 & 1,59 & 1,76 & 1,79 \\
\hline 80 & & 1,05 & 1,09 & 1,17 & 1,31 & 1,43 & 1,46 \\
\hline 85 & & 1,02 & 1,04 & 1,10 & 1,17 & 1,21 & 1,22 \\
\hline
\end{tabular}

Fte: Elaboración propia a partir de INE: Tablas de Mortalidad de diversos años.

Este perfil de la sobremortalidad masculina en la población española no ha sido perenne; de hecho, en la primera mitad del siglo XX la distribución de la $\mathrm{r}_{\mathrm{x}}$ era sustancialmente distinta a la que se observa a finales de siglo. Así, se aprecia que, por una parte, la sobremortalidad masculina hasta 1950 no era tan intensa, para ningún grupo de edad, como en la actualidad; y, por otra parte, y fundamentalmente, hasta la década de 1940 existía sobremortalidad femenina en algunos grupos de edad. Este fenómeno era común a todos los países europeos y afectaba sobre todo a las mujeres jóvenes y a las que se encontraban en edad de procrear. La disminución de la fecundidad, junto con la lenta mejoría de las condiciones ambientales y sanitarias, además del avance en la transición epidemiológica ${ }^{145}$, propiciaron la reducción de las causas específicas de sobremortalidad femenina durante la primera mitad del siglo XX (Blanes, 2007:214). Así, a partir de los años cincuenta, se constata la desaparición de todo rasgo de sobremortalidad femenina en la población española, caracterizándose la evolución creciente de la sobremortalidad masculina por un acrecentamiento de la misma en todos los

insignificante a partir del noventa aniversario. Según Hayflick (1999:157) esta convergencia tiene su origen en que los varones más vulnerables son eliminados antes que las mujeres previamente a la senescencia, de tal forma que sólo los varones tan "robustos” como las mujeres llegan a esas edades.

${ }^{145}$ Aunque las enfermedades infecciosas atacaban a toda la población, eran más desfavorables para las mujeres, en especial en las edades jóvenes y en las edades reproductivas, por lo que su declive desde finales del s.XIX las beneficia relativamente más (Vallin, 2006:191). 
grupos de edad. Se detecta la emergencia progresiva del máximo situado en las edades jóvenes que se explica fundamentalmente por la accidentalidad, más intensa en los hombres que en las mujeres debido a la mayor peligrosidad laboral y al aumento de los decesos en accidentes de tráfico de vehículos de motor, además de las consecuencias negativas derivadas de los estilos de vida más arriesgados de los varones jóvenes (drogodependencias, SIDA): la $<<$ mortalidad a contratiempo>>, en expresión de Gómez Redondo y Boe (2004:121). A finales de la década de 1980 y principios de la de 1990, este máximo resultó el principal de la distribución, de tal forma que entre los 20 y 34 años de edad el riesgo de muerte de los varones más que triplicó al de las mujeres. Esta sobremortalidad masculina en las edades jóvenes y adultos-jóvenes, no obstante, se ha atemperado desde entonces al producirse una reducción de la misma en la década de 1990, fruto de la mayor disminución de la fuerza de la mortalidad masculina que la de las mujeres durante esa década. Asimismo, se aprecia en el Cuadro 4.14. la consolidación, durante la segunda mitad de siglo XX, de otro máximo secundario en las edades maduras derivado de la reducción más temprana de la mortalidad cardiovascular entre las mujeres y la mayor incidencia de los tumores entre los hombres (Blanes, 2007:216).

A pesar de la importancia relativa de la sobremortalidad masculina entre los 20-34 años, el hecho de que en estas edades las probabilidades de deceso sean de las más bajas del ciclo vital (inferiores al 10 por mil) determina que la misma incida mínimamente en el diferencial de longevidad entre sexos, frente a sobremortalidades masculinas menos intensas en edades más avanzadas en las que sin embargo el riesgo de deceso es más elevado. En efecto, distintos estudios realizados para la población española muestran la desigual contribución de los distintos grupos de edad en la evolución del diferencial de mortalidad por sexo (Goerlich, 2009; Blanes, 2007; Gómez Redondo y Boe, 2005, 2004, Gómez Redondo, 1998, 1995). Así, analizando datos entre 1975 y 2006, Goerlich (2009) ha estimado que ese diferencial se construye fundamentalmente por las diferencias en las tasas de mortalidad a las edades más avanzadas como se puede comprobar en el Cuadro 4. 15. 


\section{CUADRO 4. 15: CONTRIBUCIONES POR EDAD A LA DESIGUALDAD EN LA e(0)} ENTRE MUJERES Y HOMBRES. Años de vida y porcentaje

\begin{tabular}{|l|c|c|c|c|c|c|}
\hline \multirow{2}{*}{$\begin{array}{c}\text { Grupos de } \\
\text { edad }\end{array}$} & \multicolumn{3}{c|}{ Periodo (Años de vida) } & \multicolumn{3}{c|}{ Porcentaje en cada periodo } \\
\cline { 2 - 7 } & $\mathbf{1 9 7 5}$ & $\mathbf{1 9 9 2}$ & $\mathbf{2 0 0 6}$ & $\mathbf{1 9 7 5}$ & $\mathbf{1 9 9 2}$ & $\mathbf{2 0 0 6}$ \\
\hline Menos de 1 & 0,33 & 0,12 & 0,08 & 5,69 & 1,65 & 1,17 \\
\hline $\mathbf{1 - 1 4}$ & 0,13 & 0.06 & 0,05 & 2,21 & 0,88 & 0,79 \\
\hline $\mathbf{1 5}-\mathbf{2 9}$ & 0,49 & 0,80 & 0,35 & 8,46 & 10,96 & 5,49 \\
\hline $\mathbf{3 0 - 4 4}$ & 0,56 & 0,98 & 0,50 & 9,61 & 13,57 & 7,78 \\
\hline $\mathbf{4 5 - 6 4}$ & 2,13 & 2,36 & 2,15 & 36,51 & 32,63 & 33,48 \\
\hline $\mathbf{6 5 - 7 9}$ & 1,90 & 2,37 & 2,43 & 32,46 & 32,74 & 37,73 \\
\hline Más de 80 & 0,30 & 0,55 & 0,87 & 5,07 & 7,57 & 13,56 \\
\hline Total & 5,84 & 7,25 & 6,43 & 100,00 & 100,00 & 100,00 \\
\hline
\end{tabular}

Fte: (Goerlich, 2009:44)

En este cuadro se constata que en todo momento más del $70 \%$ del diferencial de mortalidad por sexo se genera por las diferencias de mortalidad entre hombres y mujeres a partir de los 45 años. Se observa además que ese porcentaje ha crecido en el tiempo, de tal forma que de los 6,43 años del diferencial de longevidad media entre sexos en 2006, 5,45 años, el 84,77\%, se originan entre los mayores de 45 años. Es asimismo significativa la evolución creciente en la aportación en el grupo de más edad (mayores de 80 años) que se acerca al año en 2006, casi la séptima parte del total de ese año (13,56\%). Llama asimismo la atención el poco peso específico de los fallecimientos de los menores de 15 años y que, además, su contribución tienda a diluirse con el tiempo, de tal forma que sólo aportan 13 centésimas de año al diferencial en $2006^{146}$. Este dato es de gran importancia por dos razones; en primer lugar, porque, dada la igualdad de trato a los recién nacidos y a los infantes en la sociedad española actual, parece que el diferencial de mortalidad a esas edades manifiesta sólo la desigual capacidad biológica de lucha contra la muerte; en segundo lugar, porque su escasa cuantía y evolución descendente pueden considerarse un indicio del peso real de los factores biológicos en la sobremortalidad masculina.

La desigual incidencia etarea de la mortalidad por sexo se refleja asimismo en el número de supervivientes al comienzo de cada grupo de edad, como se puede comprobar para la población española en 2000 y en 2009, Gráfico 4.6. En este gráfico se muestran los dos aspectos señalados arriba, por una parte, la sobremortalidad masculina en todas las edades se traduce en que el número de mujeres supervivientes en cada grupo de edad es siempre superior al de los varones; por otra parte, el máximo principal de sobremortalidad masculina entre los jóvenes

${ }^{146}$ Especialmente significativa es la escasa contribución de la mortalidad infantil (la de los menores de un año) 8 centésimas de año en 2006 (1,17\%) que contrasta con la que se vivía a principios de siglo XX, cuando la mortalidad infantil era muy elevada y la sobremortalidad masculina del primer año de vida provocaba ella sola la mitad de la diferencia en la esperanza de vida entre sexos (Caselli et al., 1995:43). 
apenas se refleja en el diferencial de supervivientes entre sexos, todo lo contrario que el máximo secundario de los adultos-adultos que sí genera importantes aportaciones al mismo. De hecho, sólo a partir de los 45 años las diferencias por sexo entre el número de supervivientes empiezan a ser significativas. Estas diferencias se hacen máximas al rededor de los 80 años cuando, por ejemplo en el año 2000, el número de mujeres supervivientes de una cohorte ficticia inicial de 100.000 quedaba reducida a 70.668, mientras que en el caso de los hombres sólo sobrevivirían 47.3117 hasta esa edad (INEbase). En términos relativos, esto significa que, en ese año, en tanto la cohorte de mujeres no perdió un cuarto de sus efectivos hasta los 78,38 años; la mitad hasta los 85,47 años; y quedó reducida a un cuarto a los 90,82 años; en el caso de los varones las edades correspondientes a esos procesos fueron 69,41 años, 79,19 años y 86,47 años, respectivamente. En última instancia, la desigual mortalidad por sexo se traduce, por tanto, en la feminización de la población anciana.

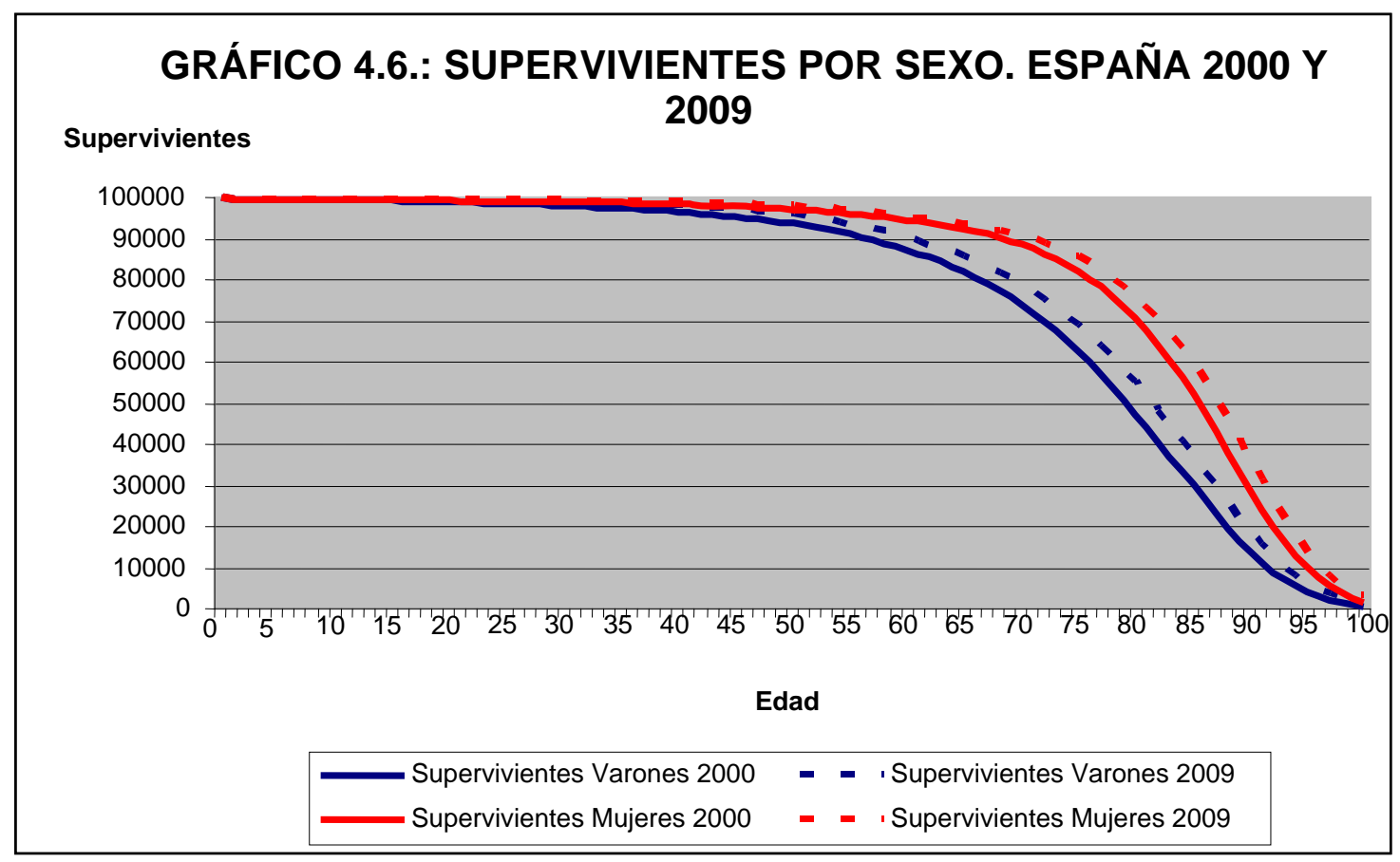

Fte: Elaboración propia a partir de INEbase.

Para responder a la segunda de las cuestiones, qué causas de muerte inmediatas contribuyen en mayor medida a la evolución del diferencial de longevidad media entre sexos, se utiliza inicialmente un indicador que permite medir el riesgo de morir por una causa ${ }^{147}$ : la

${ }^{147}$ La utilización de este indicador para la comparación entre poblaciones no permite aclarar si las diferencias entre dos grupos en relación con la enfermedad $\mathrm{X}$ se deben a la desigualdad en el riesgo global de muerte (denominadores), a desigualdades en el riesgo de muerte por la causa X (numeradores) o a ambas causas (Martínez, 1989:99). 
$<<$ Tasa Específica de mortalidad por causa de muerte $>>^{148}$. No obstante, este es un indicador que por su construcción no permite comparaciones entre poblaciones ${ }^{149}$. Para subsanar estas limitaciones se recurre a la $<<$ Tasa estandarizada de mortalidad por causa de muerte $>>$. En el Cuadro 4.16., se recogen ambas tasas para los hombres y mujeres españoles en el año 2008. Se puede apreciar en dicho cuadro cuáles son los grandes grupos de causas (tumores, enfermedades de los sistemas circulatorio, respiratorio, digestivo y nervioso, y causas externas) que más muerte provocan en ambos sexos en ese año: el 86,71\%, en los hombres, y el 80,41\%, en las mujeres; asimismo, se puede constatar que en todas ellas, excepto en la mortalidad por enfermedades del sistema circulatorio, la intensidad es mayor en los hombres que en las mujeres ${ }^{150}$. Al margen de las muertes por causas externas, las provocadas por los otros cinco grandes grupos son muertes por enfermedades degenerativas y crónicas, propias de la cuarta fase de la Transición Sanitaria, y que están muy relacionadas en su génesis con el envejecimiento del organismo y con los comportamientos ligados a los estilos de vida de la población. Por ejemplo, con el consumo de tabaco que está en el origen del crecimiento observado en buena parte de los tumores que afectan a los hombres, y en menor medida hasta ahora en los de las mujeres, aunque entre éstas la situación empeorará en el futuro cuando, como ya ha ocurrido en los países donde las mujeres empezaron a fumar antes, emerjan con fuerza los cánceres relacionados con el tabaquismo y en especial el cáncer de pulmón ${ }^{151}$ (Regidor et al, 2011, 2009; López-Abente, 2000; Fernández et al, 2003 y 2000).

\footnotetext{
${ }^{148}$ La Tasa específica de mortalidad por una causa es el resultado de dividir el número de decesos para una causa concreta, en un año dado, por la población media durante este año y multiplicado por 100.000.

${ }^{149}$ Esta tasa, como la TBM en general, es un indicador imperfecto ya que se encuentra condicionada por la estructura de edad de la población y, en consecuencia, no refleja sólo los riesgos de deceso para una causa dada, sino que varía generalmente con la edad y con frecuencia de forma sustancial.

${ }^{150}$ Considerando las dos causas más importantes, en 2008, los tumores fueron la principal causa de muerte entre los hombres, provocando el $32,41 \%$ de sus decesos, mientras que la segunda causa de muerte entre ellos fue las enfermedades del sistema circulatorio, 27,28\% de los decesos. Entre las mujeres el orden se invierte: los tumores originaron el $21,28 \%$ de los decesos, y las enfermedades del sistema circulatorio el 35,90\%.

${ }^{151}$ La mortalidad por cáncer de pulmón entre las mujeres españolas, siendo siempre reducida, ha disminuido hasta fechas muy recientes. Sin embargo, las crecientes tasas observadas desde 1995 "pueden estar mostrando el inicio de la epidemia de cáncer de pulmón en mujeres en nuestro país” (López-Abente, 2000). Lo que de alguna forma se confirma con datos más recientes: entre 2000 y 2008, la tasa de mortalidad ajustada por edad de cáncer de pulmón ha descendido el $7 \%$ entre los hombres y ha aumentado el 44\% en las mujeres (Regidor et al, 2011:19).
} 


\begin{tabular}{|c|c|c|c|c|c|c|}
\hline \multicolumn{7}{|c|}{ 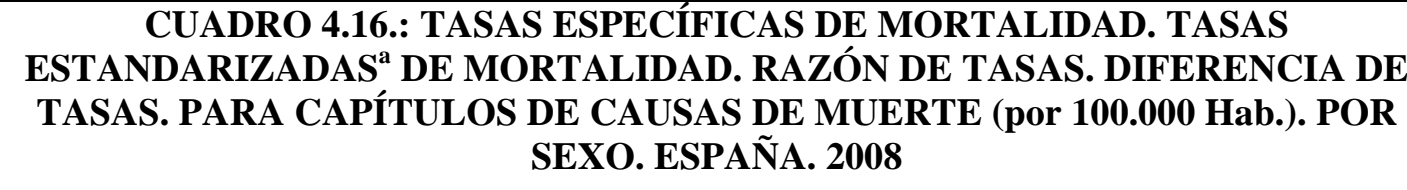 } \\
\hline \multirow{2}{*}{$\begin{array}{c}\text { Causas de } \\
\text { muerte }\end{array}$} & \multicolumn{2}{|c|}{ Tasas Específicas } & \multicolumn{2}{|c|}{ Tasas Estandarizadas } & \multirow{2}{*}{$(1) /(2)$} & \multirow{2}{*}{$(1)-(2)$} \\
\hline & Varones & Mujeres & Varones (1) & Mujeres (2) & & \\
\hline I. & 17,82 & 15,84 & 14,19 & 8,22 & 1,73 & 5,97 \\
\hline II. & 285,23 & 171,57 & 227,27 & 105,52 & 2,15 & 121,75 \\
\hline III. & 2,45 & 3,39 & 1,88 & 1,62 & 1,16 & 0,26 \\
\hline IV. & 22,21 & 31,66 & 16,43 & 14,25 & 1,15 & 2,18 \\
\hline V. & 19,63 & 37,36 & 13,74 & 14,23 & 0,97 & $-0,49$ \\
\hline VI., VII., VIII. & 30,13 & 46,28 & 21,79 & 20,61 & 1,06 & 1,18 \\
\hline IX. & 244,66 & 289,47 & 181,18 & 121,73 & 1,49 & 59,45 \\
\hline $\mathrm{X}$. & 112,62 & 80,96 & 79,92 & 33,91 & 2,36 & 46,01 \\
\hline XI. & 45,44 & 39,59 & 36,1 & 18,97 & 1,90 & 17,13 \\
\hline XII. & 1,59 & 3,69 & 1,1 & 1,47 & 0,75 & $-0,37$ \\
\hline XIII. & 4,82 & 9,99 & 3,42 & 4,17 & 0,82 & $-0,75$ \\
\hline XIV. & 22,13 & 24,18 & 15,5 & 9,99 & 1,55 & 5,51 \\
\hline $\mathrm{XV}$. & & 0,1 & & 0,1 & 0,00 & $-0,1$ \\
\hline XVI. & 2,38 & 1,72 & 3,35 & 2,63 & 1,27 & 0,72 \\
\hline XVII. & 2,04 & 1,97 & 2,52 & 2,46 & 1,02 & 0,06 \\
\hline XVIII & 21,86 & 28,07 & 17,34 & 12,16 & 1,43 & 5,18 \\
\hline $\mathrm{XX}$ & 45,03 & 20,4 & 39,25 & 13,12 & 2,99 & 26,13 \\
\hline Todas & 880,03 & 806,22 & 674,97 & 385,15 & 1,75 & $293,24^{b}$ \\
\hline
\end{tabular}

I. Enferm. infecciosas y parasitarias; II. Tumores; III. Enferm. de la sangre y trastornos de la inmunidad; IV. Enferm. de las glándulas endocrinas, de la nutrición, del metabolismo; V. Trastornos mentales y del comportamiento; VI VII. y VIII. Enferm. del sistema nervioso y de los órganos de los sentidos (ojo y oído); IX. Enferm. del aparato circulatorio; X. Enferm. del aparato respiratorio; XI. Enferm. del aparato digestivo; XII. Enferm. de la piel y tejido subcutáneo; XIII. Enferm del sistema osteomuscular y del tejido conjuntivo; XIV. Enferm. del sistema genitourinario; XV. Complicaciones del embarazo, parto y puerperio; XVI. Ciertas afecciones originadas en el periodo perinatal; XVII. Anomalías congénitas; XVIII. Signos, síntomas y estados morbosos mal definidos; XX. Causas externas.

a Tasas estandarizadas por edad según población estándar europea.

b Esta cifra se obtiene sumando los valores absolutos de V-M, sin considerar el signo.

Fte: Instituto de Salud Carlos III, Base de datos de Mortalidad: Mortalidad por Capítulos y sexo 1999-2008 (http://www.isciii.es/htdocs/centros/epidemiologia/mortalidad.jsp).

Si las tasas específicas de mortalidad por causa informan de los riesgos reales de morir por cada causa en cada sexo en el año considerado, las tasas estandarizadas permiten la comparación de riesgos entre sexos. A partir de estas últimas se ha calculado la $<<$ Razón de Tasas de Mortalidad $>{ }^{152}$ entre sexos, que puede interpretarse en términos de lo que en epidemiología se denomina “riesgo relativo". La razón de mortalidad entre hombres y mujeres

${ }^{152}$ La razón de tasas de mortalidad es un indicador que permite conocer, para una causa determinada: a) la dinámica temporal de la desigualdad entre las tasas de mortalidad de dos categorías de una variable de persona o lugar; b) la existencia o no de relación entre el hecho de pertenecer a una determinada categoría y la mortalidad por una causa (por ejemplo, sexo masculino y cáncer de pulmón); y c) el grado y dirección de la relación, si es que existe. 
para el conjunto de causas de muerte en 2008 alcanza un valor de 1,75, lo que significa que en ese año el riesgo de muerte de los varones españoles fue un $75 \%$ mayor que el de las mujeres españolas. Asimismo, este indicador es mayor que la unidad en casi todos los capítulos de causas de muerte y desde luego entre los grupos de causas de muerte más importantes, incluido el de la mortalidad por enfermedades del aparato circulatorio que, al estandarizar la tasa, se invierte y, a efectos comparativos, se torna mayor en los hombres que en las mujeres. Así, se observan los mayores riesgos relativos entre los hombres por las causas externas, capítulo en el que el riesgo de muerte de estos casi triplica al de las mujeres (2,99); ese riesgo es más del doble en la mortalidad por las enfermedades del sistema respiratorio $(2,36)$ y los tumores $(2,15)$, y se acerca al doble en las enfermedades del sistema digestivo $(1,90)$. En el resto de grupos de causas la razón entre tasas es inferior a la media del conjunto de causas $(1,75)$, siendo reseñable que en la mortalidad por enfermedades del sistema circulatorio el riesgo de muerte de los varones supera en casi el 50\% al de las mujeres. Por otra parte, en el año 2008 sólo en tres grupos de causas de muerte entre todos los que afectan a ambos sexos -los trastornos mentales, las enfermedades de la piel y las enfermedades osteomusculares-, se aprecia una ligera sobremortalidad femenina. En cualquier caso, hay que tener en cuenta que la existencia de todas estas sobremortalidades ayuda a identificar grupos de alto riesgo, sin embargo, no permite concluir que la pertenencia a un sexo concreto sea en sí mismo un factor de riesgo, o, alternativamente, la pertenencia al otro sexo sea un factor protector. La multidimensionalidad de la variable sexo, y la distribución irregular entre los dos sexos de las distintas influencias, impide ser taxativo al establecer las relaciones sexo/riesgos. Además, dentro de cada capítulo de causas no todas actúan en la misma dirección, como puede comprobarse en el Gráfico 4.7. en el que se representa el índice de sobremortalidad masculina ${ }^{153}$ para las causas de muerte concretas más significativas que provocan las sobremortalidades más importantes en un sentido u otro. Destaca la sobremortalidad por cáncer de traquea, bronquios y pulmón, cuyo riesgo entre los varones casi septuplica al de las mujeres; en sentido contrario, la mortalidad de las hombres por Alzheimer es un $24 \%$ menor que la de las mujeres.

\footnotetext{
153 Índice de sobremortalidad calculado como el cociente de las tasas de mortalidad por causa ajustadas por edad sobre la distribución por edad de la población estándar europea (Regidor et al, 2011)
} 


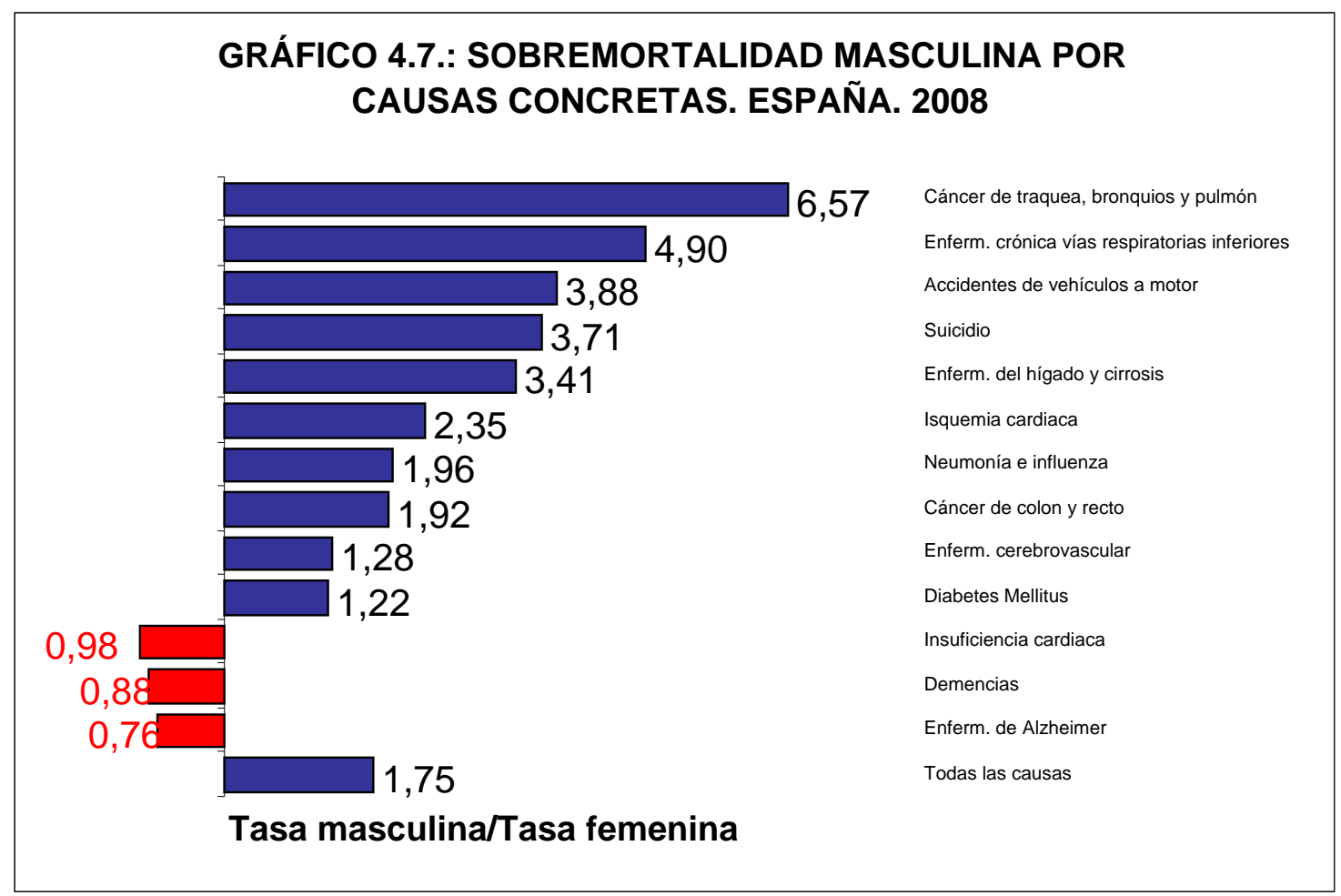

Fte: Elaboración propia a partir de Instituto de Salud Carlos III, Base de datos de Mortalidad: Mortalidad por Capítulos y sexo 2008 (http://www.isciii.es/htdocs/centros/epidemiologia/mortalidad.jsp).

La "Diferencia de tasas" es un otro indicador derivado de las tasas (estandarizas) que expresa el exceso o el déficit de mortalidad que se puede atribuir al hecho de pertenecer a un determinado grupo de población. Este indicador resulta muy útil a la hora de determinar la contribución relativa de determinadas causas de muerte a la diferencia de mortalidad total, obtenida como sumatorio de las diferencias parciales sin tener en cuenta su sentido o signo (Vallin, 1985:67-68). Sus valores representan la porción de mortalidad que se podría imputar, en sentido amplio, al hecho de ser varón; es decir, los desvíos absolutos incluyen tanto las diferencias debidas a factores biológicos como las derivadas de la condición masculina, con todas las connotaciones socioculturales que ello comporta. El análisis de las diferencias de tasas, Cuadro 4.16., muestra que las muertes por tumores provocan el 41,3\% $(121,75 / 293,24)$ de la diferencia global de mortalidad entre sexos; las enfermedades del sistema circulatorio, el 20,27\%; las enfermedades del sistema respiratorio, el 15,69\%; las causas externas, el 8,91\%; y, las enfermedades del sistema digestivo, el 5,84\%. Porcentajes que aplicados a la diferencia en la e(0) entre sexos significa que, por ejemplo, de los 6,10 años de diferencia en 2008, 2,52 años se originaron por la sobremortalidad masculina por tumores y 1,24 años fueron la contribución diferencial de las enfermedades del sistema circulatorio.

La utilización conjunta de las tasas específicas de mortalidad por grupos de edad y grupos de causas de muerte permite, finalmente, lograr un análisis más preciso de las 
desigualdades en la mortalidad por sexo. En el Gráfico 4.8. se han representado las razones de sobremortalidad masculina en todos los grupos de edad para el total de causas y para los cinco grupos de causas de muerte que más diferencia de mortalidad por sexo originan en el año 2008. En ese gráfico se observa, en primer lugar, la existencia de sobremortalidad masculina en todos los grupos de edad para el conjunto total de causas. Además, se constata la presencia de perfiles de sobremortalidad masculina significativamente diferentes para cada una de las causas de deceso. Así, las causas externas constituyen el grupo de causas con mayores niveles de sobremortalidad hasta los sesenta años de edad. Un análisis desagregado del mismo permite certificar, como es sabido, que esta sobremortalidad está motivada fundamentalmente por los accidentes de tráfico con vehículos a motor, los accidentes laborales, los envenenamientos y los suicidios que, con menos importancia absoluta que los accidentes de tráfico hasta 2008, tienen asimismo un mayor peso relativo entre los varones. Estas causas concretas de muerte constituyen un fiel reflejo de las diferencias en los roles masculino y femenino al sedimentar en mayor medida en los varones la exposición a los riesgos de deceso relacionados con la movilidad espacial, las profesiones, y más ampliamente con el modo de vida. En las edades avanzadas la sobremortalidad masculina por causas externas se aproxima a la correspondiente a la producida por las principales enfermedades. Esta evolución tiene su razón de ser en dos circunstancias: por un lado, a esas edades los individuos son más vulnerables a otro tipo de afecciones y, por otro lado, los varones ancianos se encuentran expuestos a menores riesgos externos que en edades más jóvenes ${ }^{154}$.

La sobremortalidad masculina para cada uno de los principales grupos de enfermedades resulta, en principio, más débil que la correspondiente a las causas externas e, incluso, se producen submortalidades en algunos grupos de edad y para algunas causas; por ejemplo, entre 1 y 4 años, por enfermedades de los sistemas digestivo y circulatorio; entre 5 y 14 años, por enfermedades respiratorias; entre 35-44 años, por tumores, y; entre los mayores de 85 años, por enfermedades del sistema circulatorio. El análisis profundo de estos hechos, que pueden tener carácter coyuntural, sólo puede realizarse a partir de un estudio dinámico pormenorizado de

\begin{tabular}{|c|c|c|c|c|c|c|c|c|}
\hline \multicolumn{9}{|c|}{$\begin{array}{l}154 \text { Obviamente, a edades avanzadas no sólo el modo de vida es menos “arriesgado” que a edades más } \\
\text { tempranas, sino que también la salida del mercado laboral y la menor movilidad espacial contribuyen a } \\
\text { una reducción de los riesgos relativos entre los hombres -caso de los accidentes de tráfico y de los } \\
\text { accidentes en general-, o a una reducción con equiparación de los riesgos entre sexos -caso de los } \\
\text { envenenamientos o las caídas. Por el contrario, con la edad aumentan tanto las tasas de suicidio en ambos } \\
\text { sexos, como la razón de mortalidad entre ellos, como puede observarse en la siguiente tabla elaborada a } \\
\text { partir de lo datos tomados de http://www.isciii.es/htdocs/centros/epidemiologia/mortalidad.jsp } \\
\text { TASAS ESPECÍFICAS DE MORTALIDAD POR SUICIDIO, EDAD Y SEXO. RAZÓN DE } \\
\text { SOBREMORTALIDAD MASCULINA. ESPAÑA. 2008. Por } 100.000 \text { hab. }\end{array}$} \\
\hline & $15-24$ & $25-34$ & $35-44$ & $45-54$ & $55-64$ & $65-74$ & $75-84$ & 85 y más \\
\hline HOMBRES (1) & 5,15 & 9,43 & 13 & 14,8 & 15,17 & 19,24 & 30,75 & 41,07 \\
\hline MUJERES (2) & 1,22 & 2,35 & 3,79 & 3,82 & 5 & 5,8 & 6,47 & 7,03 \\
\hline RAZÓN (1)/(2) & 4,22 & 4,01 & 3,43 & 3,87 & 3,03 & 3,32 & 4,75 & 5,84 \\
\hline
\end{tabular}


cada uno de los grupos de causas considerados, lo que, por otra parte, se sitúa lejos del alcance del presente trabajo ${ }^{155}$. Esto no impide, sin embargo, mencionar a las causas concretas más importantes sobre las que se asienta buena parte de la mortalidad diferencial por sexo en el año 2008: a) entre las enfermedades del sistema circulatorio, el infarto agudo de miocardio y otras enfermedades isquémicas del corazón, en las que existe sobremortalidad masculina en todas las edades. En las muertes causadas por enfermedades cerebrovasculares existe sobremortalidad masculina hasta los ochenta años, mientras que es mayor la mortalidad de las mujeres en las edades más avanzadas; b) entre los tumores, excepto los cánceres ligados específicamente a la fisiología de las mujeres, todos los demás cánceres inciden en mayor medida en los varones en todas las edades. Esta sobremortalidad masculina es especialmente significativa en los cánceres que afectan a los aparatos digestivo y respiratorio y, dentro de ellos, sobre todo en los cánceres de estómago y de tráquea, bronquios y pulmón; c) entre las enfermedades del sistema respiratorio, tanto en las muertes por neumonía como en las producidas por bronquitis las tasas de mortalidad masculina son muy superiores a las de las mujeres en todos los grupos de edad; d) entre las enfermedades del sistema digestivo, las muertes causadas por úlcera gástrica, a partir de los 40 años, y sobre todo las producidas por cirrosis hepática, desde los 25 años, son el origen principal de la sobremortalidad masculina.

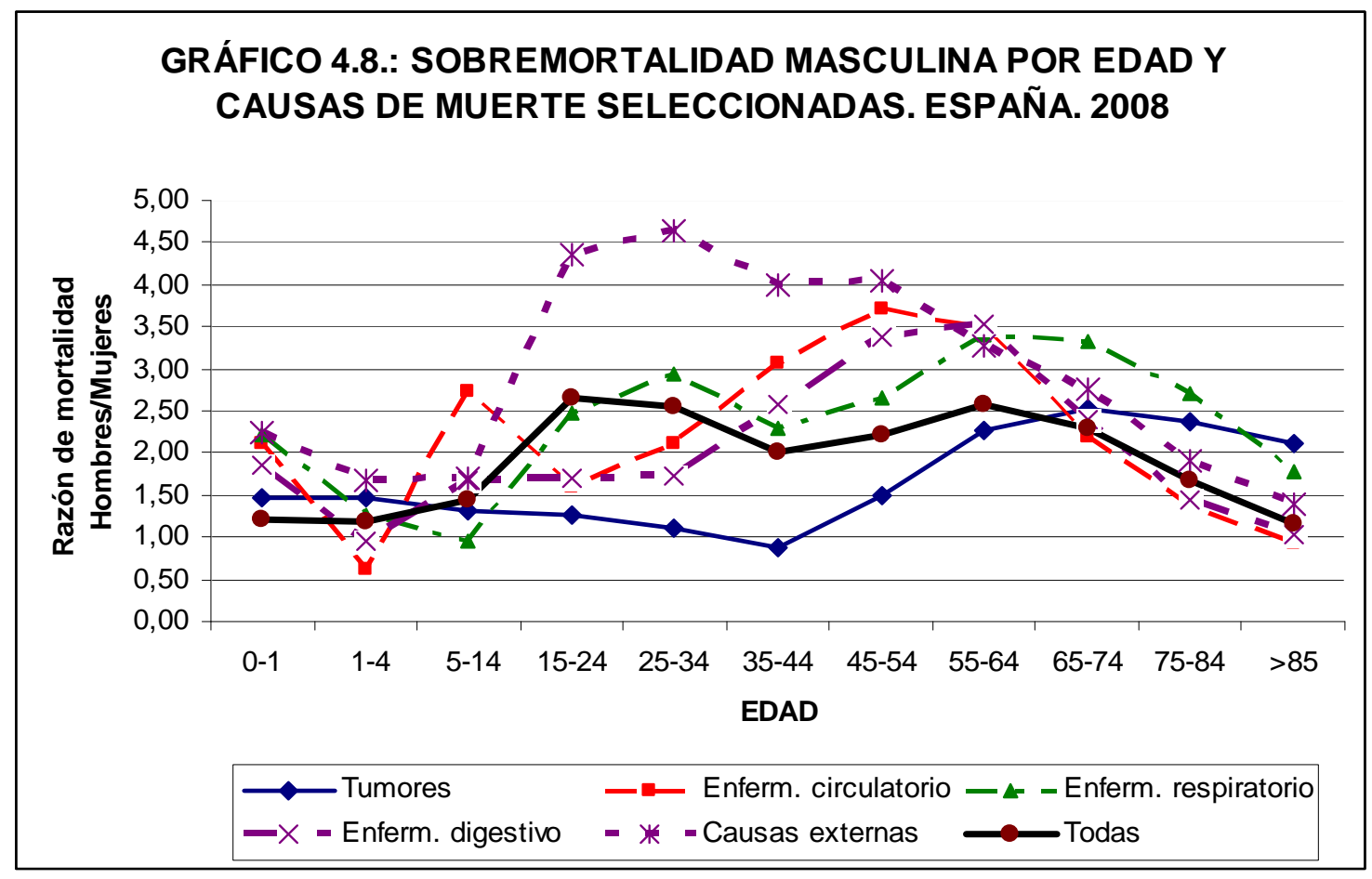

155 Para abordar un tipo de análisis desagregado en el que se examine la evolución de la mortalidad española por edad, sexo y causas de muerte individualizadas, pueden consultarse, por ejemplo, Regidor et al (2011); Blanes (2007); López-Abente et al (2002, 1996), y; Onís y Villar (1992). 
Fte: Elaboración propia a partir de Instituto de Salud Carlos III, Base de datos de Mortalidad: Mortalidad por Capítulos y sexo 2008 (http://www.isciii.es/htdocs/centros/epidemiologia/mortalidad.jsp).

El análisis conjunto por edad y causa de muerte, en consecuencia, muestra que el grueso de las desigualdades por sexo en la mortalidad se concentra en las enfermedades degenerativas en los adultos mayores y ancianos y en la mortalidad ligada al comportamiento en los jóvenes y adultos menores de 50 años. En línea con lo planteado por Verbrugge (1989, 1985, 1976), el perfil por edad y causas de muerte descrito remite a los factores sociales como las causas subyacentes más significativas en la generación de la desigualdad por género ante la muerte. Bien es cierto que, dado que hombres y mujeres comparten un medio socioeconómico prácticamente idéntico, con condiciones de vida similares, resulta difícil explicar el diferencial de longevidad exclusivamente en los términos tradicionales de posición en la pirámide social (renta, ocupación, educación). Sí que puede ser explicada, en cambio, si se tiene en cuenta el efecto generación observado y la etiología de las principales causas de muerte, sobre la base de los estilos de vida, es decir, de los comportamientos individuales socialmente determinados (Jiménez Aboitiz y Gómez Redondo, 1997:67-70) ${ }^{156}$.

Las causas de muerte que generan sobremortalidad masculina, están relacionadas sobre todo con los estilos de vida que han emergido con el proceso de modernización de las sociedades. De tal forma que, en un marco general caracterizado por profundos cambios estructurales en el nivel de riqueza, en la estratificación social, en la estructura ocupacional y en los mecanismos de redistribución, los estilos de vida contemporáneos se han ido conformando sobre distintas actitudes y comportamientos, algunos de los cuales tienen efectos nocivos sobre la salud de mujeres y hombres. Así, a la par que se ha producido una tendencia general hacia el descenso de la mortalidad, esos comportamientos nocivos, que conllevan riesgos relativamente inocuos a corto plazo pero que pueden ser letales si se prolongan en una biografía durante muchos años, han incidido de forma diferencial en las tasas de mortalidad de determinadas causas de muerte en hombres y mujeres. La invisibilidad social/pública de éstas, recluidas en el ámbito familiar/privado, característica de las sociedades tradicionales determinó que en las primeras fases de la modernización se conformaran estilos de vida diferenciados por sexo sobre la base de una distribución asimétrica de esos comportamientos de riesgo. Éstos se difundieron

\footnotetext{
${ }^{156}$ El reflejo de la incidencia de los estilos de vida, y de sus cambios, sobre la mortalidad se pone de manifiesto al comprobar la evolución histórica de la mortalidad por causas. En efecto, si en un momento determinado las diversas causas de deceso construyen con distinto peso relativo la mortalidad total, su contribución en el descenso de ésta también ha diferido a lo largo del tiempo. Así, unas causas han añadido años de vida por presentar una evolución favorable (descendente), mientras que otras han frenado el incremento en la esperanza de vida al aumentar su incidencia. En Viciana (1998) se puede consultar unas estimaciones sobre las contribuciones absolutas y relativas de las principales causas de muerte al incremento medio anual de la e(0) durante tres subperiodos que cubren casi todo el siglo XX: 1907-1935; 1935-1977 y 1977-1990. En Blanes (2007) se recogen además las estimaciones hasta 2001.
} 
en mucha mayor medida entre los hombres, mientras que las mujeres no los han asumido hasta fechas más recientes, por lo que los riesgos adquiridos se han manifestado con más antelación entre los varones. La dilación de la población femenina en incorporarse a ese tipo de "modernidad" la ha beneficiado ante la muerte, al menos hasta el presente, y explica en gran medida las diferencias de mortalidad por sexo en la población de más de 50 años que, como se ha señalado arriba, es en la que más se ha reforzado la desigualdad por sexo ante la muerte en la población española ${ }^{157}$ (Gómez Redondo, 1995:103).

De acuerdo con la hipótesis protectora, la convergencia en la actividad laboral y en los roles sociales por parte de las mujeres y hombres de las generaciones de jóvenes y de adultosjóvenes actuales, “democratiza” esos comportamientos lo que probablemente en el futuro, y para esas causas concretas de muerte, diluya en gran medida los sesgos por sexo en la mortalidad estrechándose el diferencial entre ellos ${ }^{158}$. Sin embargo, no conviene olvidar que el proceso es mucho más complejo y que, por una parte, aunque los comportamientos hayan llegado a ser similares en hombres y en mujeres, no son idénticos, y que es un hecho comprobable que los hombres fuman y beben más que las mujeres, conducen vehículos más que ellas y tienen mayores tasas de actividad en sectores económicos que conllevan más riesgos (Vallin, 2006:186-187). Por otra parte, junto a esos comportamientos nocivos, los estilos de vida actuales se conforman además sobre actitudes y comportamientos que ayudan, si no a aumentar, sí a mantener el stock de salud de las personas. En este sentido, distintos estudios han mostrado que, aunque también los varones participan de esta actitud positiva, son las mujeres las que la asumen en mucha mayor medida (Regidor et al, 2011; Vallin, 2006, 1988; Gómez Redondo y Boe, 2005, 2004; Gómez Redondo et.al, 2002, 2001; Caselli et al, 1995:41-46). La existencia de una mayor predisposición por parte de éstas a asumir cuidados preventivos de la salud (prevención, auto-cuidados, selección y utilización de cuidados médicos y acciones terapéuticas), o su mayor percepción de los aspectos psicosociales de síntomas y cuidados de salud (percepción de la enfermedad, valoración de la gravedad de los síntomas, cuidado cuando

${ }^{157}$ De forma complementaria, Goerlich (2009:42) señala que la reducción del diferencial de longevidad por sexo desde la década de 1990 sólo se puede atribuir a un acercamiento entre las tasas de mortalidad de hombres y mujeres menores de 65 años.

${ }^{158}$ Un ejemplo claro de este tipo de comportamiento lo constituye el consumo de tabaco, que es un factor de riesgo en el cáncer de traquea, bronquios y pulmón, las enfermedades del sistema respiratorio y en las enfermedades vasculares. En la actualidad, el tabaquismo produce muchas más muertes entre los hombres que entre las mujeres ya que aquéllos fuman desde hace más tiempo y con mayor intensidad. No obstante, el efecto generacional ya se empieza a detectar en algunos países, así en Dinamarca, donde aproximadamente el $40 \%$ de las mujeres fuman desde el decenio de 1950, las tasas de mortalidad por cáncer de pulmón se están incrementando y se acercan a las de mortalidad por cáncer de mama (Comisión Europea, 1995:15). Puede preverse, en consecuencia, un efecto similar en la población española a medida que la asunción de esos comportamientos empiece a pasar factura entre las mujeres que los fueron asimilando desde la década de los sesenta. Para un análisis de la prevalencia del consumo de tabaco y sus consecuencias en las mujeres españolas pueden consultarse Regidor et al (2011, 2009); Blanes (2007); Becoña y Vázquez (2000), y; Joossens et al (1999). 
se ha enfermado), resulta decisiva en un contexto en el que el papel del individuo se revela crucial en la promoción de su propia salud. En ese sentido, refiriéndose a la relación diferencial con el propio cuerpo y con la propia salud entre hombres y mujeres, Vallin (2006:188) señala: "para el cuerpo humano, la cultura de la feminidad es una obligación muy diferente de la que impone la exaltación de la virilidad. A riesgo de caricaturizar, se podría decir que la búsqueda de la belleza se opone a la de la fuerza y de la potencia. En el primer caso, el cuerpo debe permanecer joven y sano el más largo tiempo posible, en el segundo, al contrario es sometido muy pronto a la prueba y al riesgo. Es que la mujer parece estar siempre, mucho más que el hombre, a la escucha de su cuerpo y de sus necesidades de salud. Ella recurre cada vez más a los servicios sanitarios”. Una muestra de ese comportamiento diferencial son, por ejemplo, los siguientes datos del año 2008 extraídos de la base de datos del INCLASNS (Mํo de Sanidad y Política Social, 2010): a) la frecuentación registrada en medicina en Atención Primaria por persona asignada/año: 4,99 en los hombres, 6,56 en las mujeres; b) la frecuentación registrada en enfermería en Atención Primaria por persona asignada/año: 2,55 en los hombres, 3,21 en las mujeres; c) la frecuentación declarada a consultas especializadas por habitante/año. 2,32 en los hombres, 2,96 en las mujeres; d) la frecuentación declarada de ingreso hospitaliario por 1.000 habitantes/año. 111,34 en los hombres, 121,74 en las mujeres, y; e) la frecuentación declarada a urgencias por 1.000 habitantes/año: 489,62 en los hombres, 603,97 en las mujeres.

En la actualidad, por tanto, los individuos construyen sus biografías sobre un escenario que en el caso de la sociedad española ha experimentado rápidas y profundas mutaciones en un corto espacio de tiempo. Su proceso de modernización se ha desarrollado en la práctica desde la década de 1960, y si bien en el mismo se han producido importantes avances que han permitido una convergencia de la sociedad española hacia el grupo de países más avanzados existen aún, comparativamente con éstos, importantes déficits que han condicionado, por ejemplo vía recursos insuficientes en el sistema de atención sanitaria, la posibilidad de lograr una evolución más favorable de la mortalidad. No obstante, el esfuerzo realizado ha permitido incrementar la esperanza de vida de la población española hasta alcanzar valores, tanto en los hombres como sobre todo en las mujeres, que superan incluso a los de las poblaciones de algunos países que, según distintos indicadores objetivos, tienen un nivel de desarrollo mayor que el de la sociedad española. Esta situación paradójica, que ya en otro momento histórico -la larga post-guerra española-, y con otras dimensiones, había producido perplejidad y desconfianza entre los analistas internacionales, como se comentó más arriba, pone de manifiesto la presencia de otros factores, además de los estrechamente relacionados con la disponibilidad de recursos materiales, como determinantes próximos de los niveles de salud/enfermedad/mortalidad y como generadores de las diferencias por sexo en los mismos. 
En efecto, asumiendo una mejora generalizada en el sistema de atención sanitaria español desde la década de 1960, no se puede olvidar que el mismo no cubre la totalidad de las necesidades sanitarias de la población, que en buena medida son cubiertas informalmente por las mujeres ${ }^{159}$. No existe evidencia empírica de que estas circunstancias tengan efectos sobre la mortalidad diferencial, por lo que son otros determinantes -las condiciones de vida; las condiciones de trabajo; los estilos de vida- (Frenk et al, 1991) los que pueden condicionar en mayor medida la evolución futura del diferencial de mortalidad entre sexos en la población española.

En lo relativo al primero de estos factores, las condiciones de vida, que definen la situación material objetiva de los distintos grupos sociales, los "derechos de intercambio" individuales y familiares que lo conforman pueden ser obtenidos por concesión pública (Educación y Seguridad Social) o adquiridos en el mercado (Alimentos y Vivienda). En el primer caso, la oferta actual de bienes y servicios públicos en España, al menos formalmente, no discrimina por sexo. En el segundo caso, la discriminación existe pero está más relacionada con las posibilidades económicas, individuales y familiares, que con el sexo ${ }^{160}$. En ambos casos, sin embargo, las condiciones de vida actuales de los individuos son también los estuarios en los que desembocan sus biografías, acumulación de afluentes cuyos cursos están en gran medida dibujados previamente. Así, los determinantes sociales de la salud y de los procesos de enfermedad han mediatizado históricamente las biografías de los individuos y esa mediatización no ha sido homogénea, democrática, como reiteradamente se ha denunciado desde la perspectiva de género. Y, como corroboran un buen número de investigaciones que muestran de forma inequívoca cómo en la sociedad española actual, al igual que en otras sociedades desarrolladas, a pesar del avance indudable en el terreno de la igualdad de oportunidades por género, el reparto de poder y de oportunidades sigue haciendo más vulnerables a las mujeres a situaciones de pobreza y de exclusión social y, por tanto, comprometiendo en mayor medida su salud que en el caso de los varones (Instituto de la Mujer, 2002; 2001; Instituto Universitario de Estudios de la Mujer, 2001; Barañano (comp.), 1992). De cara al futuro, la crisis del Estado de Bienestar puede tener consecuencias directas más negativas en la salud de las mujeres que en la de los hombres. En efecto, según Marset y Sáez (2002:83), el desmantelamiento del Estado de Bienestar, iniciado teóricamente con la crisis de los años setenta y acelerado después de la caída del muro de Berlín, conlleva, entre otras consecuencias, la reducción y la privatización de un

\footnotetext{
159 "La socialización de las mujeres como proveedoras y cuidadoras del bienestar familiar, madre, esposa e hija al servicio de los demás, las convierten efectivamente en <<agentes de salud $>>$ pero no en $<<$ sujetos de salud $>>$. La mayor parte de las enfermedades leves y de patologías agudas son atendidas en el seno de las familias y, en muchas ocasiones, sin ningún contacto con el sistema sanitario institucional” (Rohlfs et al, 2000:150).

${ }^{160} \mathrm{~A}$ modo de ejemplo, no parece razonable pensar que el vivir en una determinada vivienda o tomar una determinada alimentación afecten por sí mismas de forma diferencial a los miembros de una familia.
} 
buen número de servicios públicos lo que desfavorece en mayor medida a las condiciones de vida de las mujeres ${ }^{161}$. En última instancia, este proceso puede constituir un pequeño freno a la evolución ascendente de la longevidad media y un factor que en alguna medida haga converger las esperanzas de vida entre sexos.

Respecto al segundo determinante próximo, las condiciones de trabajo, la progresiva apertura de la economía española a los mercados internacionales ha dado lugar a múltiples transformaciones en todas las esferas de la vida económica y laboral, que se están acelerando en un mundo que avanza de forma imparable hacia la globalización económica. Al hilo de este proceso, las relaciones laborales internacionales, y por tanto las nacionales, se mueven en un marco general caracterizado por la flexibilización y la precarización del trabajo, la destrucción de empleo estable y a tiempo completo y su sustitución por empleo eventual y a tiempo parcial, la reducción de plantillas y procesos de deslocalización espacial de la producción, además de una imparable laminación de derechos laborales, sindicales y salariales históricamente adquiridos. Dado que la investigación empírica ha demostrado la existencia de intensas relaciones entre mala salud y desempleo, esta evolución del sistema capitalista posmoderno puede provocar importantes consecuencias negativas en la salud de hombres y mujeres. En términos agregados, no obstante, estas consecuencias son difíciles de anticipar dado que los estudios realizados hasta ahora confirman que por razones culturales la situación de desempleo es soportada peor por los varones ${ }^{162}$; por otra parte, certifican que son los jóvenes y las mujeres quienes se ven abocados en mayor medida a situaciones laborales de precariedad, inseguridad, discriminación (también salarial) y paro; por último, constatan, tal y como se ha señalado arriba, que la creciente participación de las mujeres en la actividad económica se concentra mayoritariamente en el sector servicios por lo que, globalmente, se enfrentan a muchos menos riesgos laborales que los amenazan a los varones desde sectores más diversificados. En cualquier caso, no se puede descartar que la influencia futura de este determinante en el ámbito de la mortalidad se mueva previsiblemente, aunque de forma más atenuada, en la misma dirección que la señalada para las condiciones de vida.

\footnotetext{
${ }^{161}$ Según Marset y Sáez (2002:83), el desmantelamiento del Estado de Bienestar tendrá a lo largo de este siglo dos graves consecuencias para las mujeres de los países desarrollados que acabarán afectándoles en su salud: a) al eliminarse servicios que favorecen la presencia de las mujeres en el mercado de trabajo, no sólo se dificulta esta presencia, sino que se incrementan las cargas de las mujeres que, en mayor medida que los hombres, asumen necesidades no cubiertas socialmente (por ejemplo, atención a las personas envejecidas); b) la eliminación de esos servicios públicos propios del Estado de Bienestar, en gran medida feminizados laboralmente, aumentará la tasa de paro femenina.

${ }^{162}$ La incidencia de la situación laboral sobre la salud de las personas y su diferente distribución por sexo está ampliamente documentada. En el caso concreto del desempleo, diversos estudios resaltan el mayor impacto del mismo en la salud de los varones respecto a la de las mujeres, por la centralidad del trabajo en los roles masculinos. En el caso de las mujeres, distintos estudios han mostrado que las que trabajan tienen mejor salud que las paradas y éstas tienen a su vez mejor salud que las que están fuera del mercado de trabajo (Marset y Sáez, 2002; Rolhfs, 2002; Rohlfs et al, 2000; Verbrugge, 1985).
} 
Finalmente, parece mucho más clara en estos momentos la incidencia del tercero de los determinantes próximos, los estilos de vida, en el diferencial de longevidad media entre sexos. Y no sólo porque las causas concretas de muerte, que provocan los mayores diferenciales de mortalidad entre hombres y mujeres, estén estrechamente relacionadas, como se ha señalado más arriba, con los estilos de vida emergentes en el proceso de modernización, sino porque estos estilos de vida representan la forma en que hombres y mujeres trasladan su situación objetiva a patrones de comportamiento. Así, históricamente han emergido "riesgos de comportamiento" para unos individuos que se hallan inmersos en una dinámica, acelerada a principios del siglo XXI, que entremezcla la impotencia ante el aumento de los "riesgos sociales” con la novedad, el efecto imitación, la información, y la reflexividad conexa a ésta. Suma de riesgos medioambientales, sociales e individuales que condicionan la "susceptibilidad individual” ante la enfermedad y la muerte.

En este sentido, conviene tener en cuenta la influencia del $<<$ efecto generación $>>$ toda vez que la sociedad española actual está constituida por más de cien generaciones con experiencias vitales imposibles de equiparar. Por tanto, no cabe identificar un único estilo de vida masculino, como no cabe referirse a sólo un estilo de vida femenino, $y$, en mucha menor medida, tampoco se puede afirmar que estos estilos de vida sean, además, homogéneos, pétreos y estancos. De esta forma, si bien se ha podido hablar hasta ahora genéricamente de dos construcciones sociales de la salud por sexos, que se pueden representar en dos imágenes: $<<$ la fuerza $>>$ frente a $<<$ la resistencia $>>$, de cara al futuro estos modelos parece que continuarán teniendo sentido en las generaciones actuales de adultos-adultos y de ancianos, pero no está tan claro que sean aplicables a las generaciones de adultos-jóvenes y jóvenes cuyos relatos biográficos se escriben en guiones para ser representados en un escenario social que, al menos formalmente, apuesta por la des-diferenciación de roles por sexo. Así, hasta ahora, las consecuencias de los "vicios masculinos", acompañadas por los beneficios de las "virtudes femeninas”, arrojan un saldo desfavorable en la evolución de la mortalidad de los hombres respecto a la de las mujeres (Caselli et al, 1995:46). De cara al futuro, y parafraseando a Victoria Sau, siempre existirá una mortalidad diferencial entre sexos de origen biológico, pero la evolución global de la mortalidad diferencial dependerá sobre todo de los comportamientos asumidos por hombres y mujeres. En este sentido, algunos autores resaltan la incipiente "feminización" de los comportamientos masculinos en algunos sectores sociales, de momento minoritarios, en los que, como consecuencia de ello, ya empieza a percibirse ganancias en la mortalidad por enfermedades cardiovasculares, todas las relacionadas con el tabaquismo y en los accidentes de vehículos a motor (Gómez Redondo y Boe, 2005, 2004; Pérez Díaz, 2002, 2000). Mucho más palpable es el proceso de "masculinización" de los comportamientos 
femeninos observado en las últimas décadas del siglo XX por el que, parece inevitable, que en un periodo no lejano la población femenina sufra las consecuencias de su mimetismo hacia algunos hábitos del estilo de vida masculino, con su correspondiente coste indeseable en salud, y se genere en consecuencia una convergencia en la evolución de las esperanzas de vida de hombres y mujeres, que la estabilización de ese diferencial durante la década de 1990 anticipa (Gómez Redondo, 2005:121; Jiménez Aboitiz y Gómez Redondo, 1997:70).

\title{
4.3. EVOLUCIÓN FUTURA DE LA MORTALIDAD
}

\begin{abstract}
"A medida que el hombre se eleva sobre la condición de las bestias, la población se restringe por miedo a las privaciones, más bien que por las privaciones en sí”
\end{abstract}

Parafraseando a Mill se puede afirmar que, en general, las actitudes y los comportamientos de los seres humanos se refieren no tanto a lo que los hechos son en sí, sino a las expectativas que las personas se crean sobre los mismos. Expectativas que son conformadas por una mezcla situacional de información, conocimiento adquirido, saber popular y estado de opinión, y que en muchas ocasiones no se corresponden con la realidad objetiva de los hechos. Es el denominado por Merton <<teorema de Thomas >: "si los individuos definen las situaciones como reales, son reales en sus consecuencias". Sin embargo, es función de la Sociología desvelar las apariencias para descubrir tras ellas la esencia de las cosas, y así mostrar las inconsistencias de estados de opinión muy generalizados, del `sentido común ${ }^{\prime 163}$. Cualidad del análisis sociológico que se torna más perentoria aún a la hora de examinar las sociedades más desarrolladas en las que su "mundo" está constituido "más por su imagen que por la realidad y por ello el pensamiento está parasitado por poderosos prejuicios” ideológicos, estereotipos, imágenes heredadas o clichés previos acerca de la realidad (Lamo de Espinosa, 2004:110). Inconsistencias que son especialmente relevantes en un ámbito tan esencial para los

\footnotetext{
${ }^{163}$ De hecho, el propio Merton para evitar los posibles excesos idealistas que se podrían derivar de una lectura unilateral del teorema de Thomas ("la profecía que se autocumple" o "la profecía que se autoniega") propuso posteriormente un complemento al teorema: "aunque los hombres no definan las situaciones como reales, éstas siguen, sin embargo, siendo reales en sus consecuencias” (Ramos, 1998:783).
} 
seres humanos como es el del enfrentamiento con la muerte. De hecho, puede considerase paradigmático en este sentido el contraste entre las percepciones asumidas por la mayoría de la población respecto al enfrentamiento con la muerte en la actualidad, así como el que se prevé en el futuro, y el estado real de los conocimientos científicos relativos al tema de la muerte. En efecto, una vez que se ha descrito el status quo de la mortalidad en la población española actual, interesa ahora planear sobre las aportaciones realizadas por investigadores de distintas ramas del conocimiento respecto a lo que consideran más probable que ocurra en la evolución futura de la mortalidad y de la longevidad, a la luz de los conocimientos científicos actuales.

Para abordar el análisis prospectivo de la mortalidad se utiliza como referencia inicial las actas del Congreso sobre Salud y Mortalidad, organizado conjuntamente por Naciones Unidas y la Organización Mundial de la Salud (NU y OMS, 1999), celebrado en Bruselas en 1997, en el que se abordaron las principales cuestiones que centran las investigaciones y los debates científicos sobre la situación actual y las perspectivas de futuro tanto de la evolución de la relación salud/enfermedad/mortalidad como la de la longevidad humana. Sobre el marco de la teoría de la Transición Sanitaria, que subyacía en todas las intervenciones, se discutieron, entre otras, tres cuestiones relevantes sobre la evolución futura de la mortalidad: 1) la transición sanitaria en el futuro; 2) las longevidades máxima y media alcanzables por los seres humanos, y; 3) la calidad de vida conexa al incremento de la esperanza de vida.

\subsubsection{LA TRANSICIÓN SANITARIA EN EL FUTURO: ¿CONTRATRANSICIONES?}

"Tengo en la lengua el sabor de la muerte. Siento algo que no es de este mundo" W. A. Mozart

La transición sanitaria (transición epidemiológica (transición demográfica (transición de la mortalidad))) no es un proceso lineal y de sentido único, en el que no quepan movimientos de contraflujo. Es decir, no existe ninguna razón intrínseca al concepto de transición que obligue a pensar que la evolución deba de ir forzosamente por la dirección que han seguido los países desarrollados y, lo que es más importante para este trabajo, tampoco existen garantías de que las mejoras alcanzadas hasta ahora con la transición sean definitivas y puedan mantenerse de forma indefinida (Chamie, 1999:2). Centrando el análisis en esta segunda dimensión, en el citado Congreso se alertó sobre la reversibilidad de la transición sanitaria en un contexto en el que no sólo no se contempla tal reversibilidad, sino que, por el contrario, en la opinión pública domina la percepción de que fruto de los avances científico-técnicos sólo cabe progresar en la 
consecución de una vida más sana, saludable, fácil y cómoda ${ }^{164}$. Cabe recordar en este sentido que, con la presentación en el año 1997 de la oveja clónica Dolly y el anuncio por parte de un físico estadounidense en 1998 de su intención de clonar seres humanos, a finales del siglo XX las investigaciones de la biogenética saltaron a los medios de comunicación y penetraron en las conversaciones de la vida cotidiana proyectándose una imagen social ambivalente respecto a dichas investigaciones (Sánchez Morales, 2001). En efecto, en términos generales, se recibía con una alta valoración a las mismas por las expectativas optimistas que prometían, siendo especialmente relevante el apoyo abierto y con pocas fisuras de la mayoría de la opinión pública a la aplicación de algunas de esas innovaciones científico-tecnológicas en los seres humanos, sobre todo las relacionadas con el trasplante de órganos, la biotecnología y la ingeniería genética en los tratamientos médicos de algunas enfermedades (diagnósticos genéticos y terapia génica) ${ }^{165}$.

No obstante, junto a esa percepción positiva de que "el hombre posee el $<<$ secreto $>>$ de la herencia y de la vida”, surgían dudas e inquietudes sobre la implementación concreta de algunas de estas tecnologías ya que "modificarán las concepciones de nuestra cultura” y "son potencialmente un instrumento de generación de sujetos genéticamente perfeccionados”, lo que crea inquietud y que su aceptación no sea unánime en todos los sectores sociales, como se ha

\footnotetext{
${ }^{164}$ En las investigaciones que, desde 1995, realiza el Grupo de Estudio sobre Tendencias Sociales (GETS) se persigue analizar la evolución de la opinión pública española y grupos de expertos sobre la percepción de los procesos de cambio tecnológico. Como marco general, el director del GETS, Tezanos (2003:310-311) resalta que, a diferencia de otros cambios históricos, los relacionados con la revolución tecnológica desde finales del siglo XX son vividos por la mayoría de la población como si se trataran de un proceso natural, lógico, prácticamente inevitable y que no requiere reflexión, una especie de determinismo que en buena medida lleva aparejado la insuficiente concienciación sobre los impactos sociales y los riesgos que las nuevas tecnologías acarrean. Así, entre 1995 y 2002, una creciente mayoría de la opinión pública, el 66,4\% de las personas encuestadas en 2002, percibía que en los próximos años se iban a producir grandes cambios sociales y económicos ligados a la revolución tecnológica. Cambios que sobre todo se iban a circunscribir a innovaciones en los ámbitos más visibles (ordenadores, robots, etc.) y en los más cercanos (trabajo, ocio). Como contraste, las percepciones proyectadas por los expertos en los Estudios Delphi se centran en "la convicción de que nos encontramos inmersos en un gran ciclo de cambios” que girará en "una gran explotación de las posibilidades de la biogenética” (Tezanos, 2003:319, 322-323).

${ }^{165}$ En un estudio realizado Atienza y Luján (1997), cercano en el tiempo al trabajo de campo de la encuesta de esta Tesis, se analizó la percepción y opinión de la población española respecto a los nuevos avances científico-técnicos y sus aplicaciones. Algunos de los resultados más significativos recogidos en el mismo son: $1^{\circ}$ ) el $94 \%$ de los encuestados opinaban que los trasplantes de órganos contribuían bastante o mucho a mejorar la calidad de vida de las personas; $2^{\circ}$ ) el 92,7\% de los encuestados estaba bastante 0 muy de acuerdo en que se utilizase la ingeniería genética para curar enfermedades genéticas graves; $3^{\circ}$ ) el $90,2 \%$ estaba bastante o muy de acuerdo en que se utilizase la ingeniería genética para impedir que los niños heredasen enfermedades genéticas graves; $4^{\circ}$ ) el $69,6 \%$ estaba dispuesto a someterse a un tratamiento genético que le corrigiera los genes defectuosos. Paradójicamente, menos de tres de cada diez encuestados se consideraba bastante o muy informado sobre los descubrimientos científicos (26,2\%) o sobre los avances tecnológicos (28,2\%), y el $80,9 \%$ creía que "las decisiones sobre la ciencia y la tecnología es mejor dejarlas en manos de los expertos".
} 
podido comprobar con el temor a su uso en prácticas eugenésicas, o con la polémica sobre la utilización de las células madre embrionarias ${ }^{166}$ (Sánchez Morales, 2001:465-466) ${ }^{167}$.

La llegada del siglo XXI ha venido acompañada por una serie de novedades epidemiológicas que plantean dudas sobre el discurrir de la transición epidemiológica en los países desarrollados. Bernabeu Mestre (2010) resume dichas novedades en: a) el regreso de las epidemias ${ }^{168}$; b) el agravamiento de los problemas de salud asociados al desarrollo, y; c) la emergencia de problemas de salud asociados al fenómeno de la globalización o a los conflictos entre desarrollo y medio ambiente (degradación antropogénica). En lo relativo a la primera de las cuestiones, numerosos estudios empíricos muestran que en muchos países la declinación de la mortalidad por la lucha contra un amplio número de enfermedades infecciosas y parasitarias no ha sido irreversible y definitiva en todos los casos, produciéndose pequeñas o amplias $<<$ contratransiciones >>; bien es cierto, como señala Frenk (1994), que el resurgimiento en muchas de ellas ha ocurrido con tasas de letalidad considerablemente menores que en el pasado. Así, por una parte, han emergido nuevas enfermedades infecciosas (por ejemplo, VIH/SIDA en 1970; virus Ébola en 1976; Legionella en 1976; virus Hanta en 1977; enfermedad de Creutzfeldt-Jackob (CJD) en 1979; Hepatitis D en 1980; Encefalopatía espongiforme bovina, 1986; Hepatitis C en 1989; fiebre hemorrágica venezolana en 1991 (Pearson, 2002:28-29); "síndrome respiratorio agudo y severo" -SRAS-, en 2002; Escherichia coli -E coli-, en $2011)^{169}$. Por otra parte, enfermedades transmisibles conocidas han reaparecido con nuevas cepas, algunas de ellas más virulentas y otras menos controlables (tuberculosis, paludismo, malaria, dengue). Asimismo, otras enfermedades conocidas, han saltado desde los animales a los seres humanos, como ocurrió en enero de 2004 con el virus de la gripe aviar H5N1 en Vietnam, lo que provocó un estado de alerta permanente en el mundo ante el temor a su

\footnotetext{
${ }^{166}$ En Macip (2008:cap. 2) se abordan las técnicas de clonación y de células madre, sus limitaciones, así como las implicaciones éticas que rodean su utilización.

${ }^{167}$ En los Estudios del CIS no 2.412, de marzo de 2001, y n ${ }^{\circ} 2.652$, de septiembre de 2006, en los que se encuesta a la población española sobre los riesgos y beneficios del desarrollo científico-tecnológico se constata de nuevo la ambivalencia señalada: percepción de su carácter beneficioso (aumento del bienestar social y de la calidad de vida, ayuda a la superación de enfermedades), a la par que un número creciente de personas encuestadas consideran que traerán más riesgos.

168 Bernabeu Mestre (2010) amplia el concepto tradicional de epidemia (enfermedad infecciosa, accidental y transitoria, que afecta a un gran número de personas de un territorio o de una región determinadas) incluyendo la extensión de hábitos con efectos nocivos para la salud ("epidemias del tabaquismo o de la obesidad").

${ }^{169}$ En relación con la mayor movilidad espacial de la población en un mundo interconectado, las "enfermedades infecciosas no sólo pueden propagarse más deprisa, sino que parecen estar surgiendo con más rapidez que nunca. Desde los años setenta, se han identificado nuevas enfermedades al ritmo sin precedentes de una o más al año. Hoy en día existen al menos 40 enfermedades que se desconocían una generación atrás. Además, en los últimos cinco años la OMS ha verificado más de 1.100 eventos epidémicos... Sería pecar de gran ingenuidad y exceso de confianza suponer que no surgirá tarde o temprano otra enfermedad como el SIDA, la fiebre hemorrágica del Ébola o el SRAS” (OMS, 2007:6-8).
} 
mutación y transmisión entre humanos, proceso que podría generar una pandemia de consecuencias devastadoras.

Horiuchi (1999:65-66) menciona diversas razones por las que se ha producido la emergencia o la reemergencia de enfermedades infecciosas-contagiosas: a) algunas enfermedades con gran prevalencia en el pasado, que fueron puestas bajo control con medicamentos, han desarrollado nuevas cepas patógenas resistentes a los fármacos esenciales (nueva cepa de salmonella aparecida en 1988; nueva cepa de cólera en 1992). Esta aparición de bacterias letales está relacionada en gran medida con la utilización negligente, por defecto o por exceso, de los antibióticos, como denunció, en el año 2000, la OMS al presentar un estudio sobre enfermedades infecciosas con el elocuente título Contengamos la resistencia microbiana $^{170}$ (OMS, 2000). La conclusión más importante del mismo es que si no se tomaban medidas urgentes al respecto muchas enfermedades que hoy son tratables se volverán incurables en pocos años, con lo que este proceso amenaza con devolver al mundo a la era anterior al descubrimiento de la penicilina ${ }^{171}$; b) el desarrollo tecnológico y los cambios socioeconómicos ligados a la globalización han facilitado que se acelere más rápidamente la expansión de las enfermedades de transmisión antes circunscritas a ámbitos locales y que ahora, gracias al

\footnotetext{
${ }^{170}$ La negligencia en los países desarrollados consiste en la utilización masiva de antibióticos cuando no se requieren. Por ejemplo, sólo el $20 \%$ de las infecciones respiratorias necesitan ser tratada con antibióticos, sin embargo, éstos también son recetados para el 80\% restante, como en el caso de catarros y gripes que, además, son enfermedades de origen vírico, que no responden a los antibióticos y contra las que sólo son eficaces las vacunas. Junto a este exceso por prescripción, existe el exceso derivado de la automedicación y el originado por la adición de antibióticos en la alimentación de animales de granja. Además, no sólo las bacterias mutan para hacerse más resistentes, sino que la resistencia puede transmitirse de unas bacterias a otras y una misma bacteria puede hacerse resistente a varios fármacos. Por otra parte, Ho (1998) añade la contribución de otro factor nuevo que puede estar acelerando la resistencia microbiana: la utilización masiva de la ingeniería genética en aplicaciones comerciales desde mediados de la década de 1990. Según el informe de la OMS (2000), el 70\% de las infecciones respiratorias son ya resistentes a los antibióticos más comunes, y el $60 \%$ de las infecciones hospitalarias son multirresistentes, es decir, no responden a dos, tres o más antibióticos. En el caso de Francia, por ejemplo, más del $40 \%$ de los enfermos infectados por el Streptococcus pneumoniae, principal causa de la neumonía, son resistentes a la erytromicina y cerca del 5\% a la penicilina. En el caso de España, las resistencias a esos antibióticos son del 22\% y del 9\%, respectivamente (EUROSTAT (2008): Eurostat Yearbook 2008:197).

${ }^{171}$ Posibilidad cada día más cierta tal como subrayan distintos expertos españoles en enfermedades infecciosas entrevistados por M. Pérez Oliva (2008). Por ejemplo, Rafael Cantón, jefe del Servicio de Microbiología del hospital Ramón y Cajal de Madrid, afirma que "Sí, es posible que muramos de enfermedades que creíamos totalmente controladas... Cada vez nos encontramos con más casos de organismos resistentes, no a uno, sino a varios antibióticos, de manera que las opciones terapéuticas son muy limitadas, y en algunas ocasiones, nulas”. Así, uno de cada 100 pacientes muere por infecciones contraídas dentro del hospital. Es el caso de la Escherichia coli (E coli), bacteria cuyas infecciones se combatían con antibióticos de uso común pero cuya evolución ha hecho que el 8\% de las cepas no sólo sean resistentes a ese tipo de antibiótico sino también a los de amplio espectro, por lo que en esos casos "las alternativas son ya pocas". El problema se agrava además porque las bacterias "invulnerables" no sólo provocan la muerte de 50.000 personas en Europa por infecciones contraídas dentro de los hospitales, sino que han salido fuera de éstos generando un "nuevo escenario" de infección: en 2007, el 45\% de las infecciones por Staphylococcus aureus fueron resistentes a varios fármacos, el $8 \%$ de las mismas se contrajeron fuera del hospital.
} 
comercio de alimentos, bienes o animales, al turismo o a los movimientos migratorios, hacen posible "una epidemia global en un espacio de tiempo corto" ${ }^{172}$. De forma similar a lo ocurrido en la desaparición de poblaciones indígenas durante la colonización de América, las migraciones masivas y el turismo ponen en contacto a grandes grupos de individuos procedentes de entornos muy distintos, a los que durante generaciones se han adaptado sus organismos, haciéndoles más vulnerables a microbios para los que sus organismos no han desarrollado defensas; c) la desorganización ecológica que acompaña al desarrollo económico facilita la invasión por los seres humanos de nuevos nichos ecológicos, bien por ocupación de nuevos espacios o por establecimiento de nuevas interacciones con otras especies, que puede ayudar a la aparición de nuevas enfermedades al provocar que los seres humanos entren en contacto con gérmenes patógenos con los que anteriormente no habían contactado. Es el caso, por ejemplo, de enfermedades infecciosas conocidas que son transmitidas por la alimentación y los mosquitos, como el paludismo, el dengue y el cólera, y para las que se estima que, como consecuencia del calentamiento global, en el año 2030 “el clima se habrá desplazado 150 millas hacia el Norte y estas enfermedades podrían alcanzar Europa” (Pearson, 2002:28). Es el caso, asimismo, de las nuevas enfermedades infecciosas aparecidas en los últimos años derivadas de las alteraciones ecológicas introducidas por el ser humano que han permitido que algunos virus puedan infectar a especies distintas del huésped normal y pasar, por ejemplo, al ser humano. Un ejemplo claro, reciente y próximo a la población española, de este "salto de virus entre especies”, ha estado originado en la inclusión de despojos de ovejas infectadas en la alimentación de ganado bovino en Gran Bretaña que originó la llamada enfermedad de las "vacas locas”, y que posteriormente "saltó” a los seres humanos. Ejemplos similares son los del SIDA, virus importado desde los chimpancés; el virus del Hanta, que salta de los roedores a los seres humanos; el Ébola, que proviene de un animal, aunque todavía no se sabe de cuál; el nuevo virus de la gripe detectado en 1997, que previamente sólo había sido observado en aves; su variante, la "gripe del pollo", detectada a finales de 2003, así como el SARS (Ortín, 2003:16).

A los factores hasta ahora señalados hay que añadir los peligros para la salud derivados de, por un lado, las prácticas desarrolladas para el incremento de la producción de alimentos y, por otro lado, de la incidencia del medio ambiente. En el primer caso, se menciona la incertidumbre derivada del uso masivo de fertilizantes y pesticidas en las explotaciones

\footnotetext{
${ }^{172}$ Un ejemplo de “exportación” de bacterias resistentes, con origen en España, tuvo lugar en el año 2000. Una bacteria de neumonía resistente a los antibióticos y localizada originariamente en España, fue detectada en pocos días en países de cuatro continentes: Estados Unidos, México, Chile, Argentina Sudáfrica, Singapur, Corea del Sur Filipinas, entre otros (EL PAíS, 13/06/00:32). Más reciente aún es el caso del SARS (neumonía asiática) en 2003, que en apenas tres meses se extendió por el sureste asiático y llegó a Norteamérica.
} 
agrícolas, o del arsenal químico utilizado para lograr mayores rendimientos (“dopaje”) en las explotaciones ganaderas, y de la introducción de los alimentos con componentes modificados genéticamente $^{173}$ (Bernabeu Mestre, 2010). Respecto a los peligros relacionados con el medio ambiente, se suelen clasificar en dos categorías (NU, 2001; OMS, 1997): a) los <<peligros tradicionales $>>$ que, en general, van unidos a la falta de desarrollo y la pobreza ${ }^{174}$, y que amplifican su incidencia en situaciones de catástrofe. Así, por ejemplo, un informe de Naciones Unidas preparado para la Conferencia Mundial para la Reducción de Desastres de enero de 2005, estimó que, entre 1994 y 2003, habían fallecido 609.638 personas por catástrofes naturales, el 95\% de las cuales vivía en países en desarrollo, y que al menos 2.700 millones se habían visto afectadas por terremotos, inundaciones, tsunamis, temperaturas extremas, sequías, incendios, etc. (EL PAÍS, 02/01/05:Domingo:1-3); b) los <<peligros modernos $>>$ derivados del desarrollo cuando no se toman medidas de protección. En efecto, los propios procesos de desarrollo vienen acompañados de riesgos, a modo de "polizones indeseables”, cuyos efectos pueden acarrear una reversión en la evolución descendente de la mortalidad. Señala Mir que "la probabilidad de accidentes improbables crece con el tiempo y con el número de macrotecnologías implantadas” (EL PAÍS, 4/10/01:33); de esta forma, toda una serie de riesgos globales (ecológicos, nucleares, químicos y genéticos) ${ }^{175}$, algunos de ellos intangibles, acechan crecientemente a todas las sociedades humanas y de manera especial a las sociedades más desarrolladas. Dejando al margen los efectos de las catástrofes ecológicas localizadas geográficamente, como las de Seveso (1976), Bophal (1984), Chernobil (1986) o Fukuyama

\footnotetext{
${ }^{173}$ Sobre la inocuidad para el consumo humano o, al contrario, sobre los efectos por la ingesta diaria de determinados aditivos alimentarios y contaminantes de los alimentos se pueden consultar Porta et alt (2009); VV.AA. (2008); Corinne (2008), y; FAO/OMS (1999).

${ }^{174}$ En 1986, el Informe Brudtland de la Comisión Mundial sobre el Medio Ambiente y el Desarrollo, CMMAD, (1987), afirmaba que "la pobreza es la causa y efecto de los problemas mundiales del medio ambiente..., ya que un mundo donde la pobreza es endémica estará siempre propenso a ser víctima de la catástrofe ecológica. La pobreza es entonces la causante de la desaparición de ciertos recursos ecológicos y no los desprovistos de tierra y otros bienes, quienes no tienen otra opción que violentar principios básicos de la ecología para sobrevivir”. Por ejemplo, según el estudio más amplio realizado por la OMS (2006) para analizar las causas ambientales de las enfermedades, el 24\% de la morbilidad mundial se debe a la exposición a riesgos ambientales evitables y "cada año se registran 13 millones de defunciones provocadas por causas ambientales prevenibles. De las 102 principales enfermedades -grupos y traumatismos- conocidas, 85 tienen relación con el medioambiente, siendo la diarrea la de mayor vinculación, 1'7 millones de defunciones anuales y una carga de morbilidad de 58 millones de DALYs. La segunda enfermedad más ligada al medio ambiente es la infección de las vías respiratorias inferiores, 1'5 millones de muertes y 37 millones de DALYs al año". Un DALY, en español AVAD -años de vida ajustados en función de la discapacidad- es el número de años que habría podido vivir una persona, perdidos por su defunción prematura, y los años de vida productiva perdidos por discapacidad.

${ }^{175}$ Sobre las variadas consecuencias y el incremento de riesgos, también para la salud, inherentes al proceso de desarrollo puede consultarse Riechmann (2004 y 2000). De forma más específica, sobre las repercusiones sociales, políticas y económicas de la ingeniería genética, y desde un planteamiento multidisciplinar, Durán y Riechmann (1998) coordinan un texto en el que se sintetizan los debates actuales sobre la incidencia de la "revolución biotecnológica" no sólo como fuente de "seductoras promesas de bienestar, salud y riqueza”, sino también de "amenazadores peligros para los ecosistemas, las poblaciones humanas y sus derechos fundamentales. Sobre las consecuencias en la salud de los riesgos ecológicos y químicos ver Sunyer et al (2002; NU, 2001a:cap.V); Sempere y Riechmann (2000:caps. 10 y 12); tercera parte del Informe SESPAS 2000: El Medio Ambiente Saludable, y; OMS (1998).
} 
(2011), desde la segunda mitad del siglo XX multitud de estudios ha tratado de, primero, evaluar la influencia de los seres humanos en el medio ambiente en el que desarrollan sus actividades, segundo, medir la acumulación de sustancias contaminantes generadas en esas actividades y para las que el medio ambiente no tiene capacidad de absorción, descomposición o transformación y, tercero, analizar los riesgos derivados de la contaminación en la salud y su reflejo en los niveles de morbilidad y mortalidad de las poblaciones humanas. El espectro de estos últimos estudios abarca desde las consecuencias del cambio climático ${ }^{176}$ hasta las derivadas de la calidad del aire que respira una población concreta.

En lo relativo a los efectos del cambio climático sobre la salud humana, éstos pueden venir mediados a través de complejas interacciones de factores físicos, ecológicos y sociales. La emisión masiva de dióxido de carbono, metano y otros gases, derivada de la utilización de combustibles fósiles -carbón, gas natural, petróleo- desde los inicios de la industrialización, está alterando la composición química de la atmósfera y provocando el calentamiento de la misma, el llamado <<efecto invernadero >>. Un calentamiento rápido del planeta pondrá en peligro numerosos sistemas de los que dependen las sociedades humanas, generará problemas graves de adaptación y se convertirá en el caldo de cultivo que alimentará continuos conflictos de todo tipo; de hecho, por sus efectos, ha sido comparado con los efectos de una guerra nuclear (Sempere y Riechmann, 2000:cap.12). De forma más concreta, estos autores resaltan que, además de a través de otros efectos ${ }^{177}$, el cambio climático repercute directamente en la salud humana por el incremento de los riesgos derivados de exposiciones a temperaturas extremas (enfermedad/mortalidad cardiovascular, cerebrovascular y respiratoria), por los cambios en la distribución de las aguas superficiales, incrementándose los riesgos de inundaciones o de escasez de agua (enfermedades diarreicas, cólera), por el incremento de riesgos ligados a cambios de los vectores de enfermedad -tasas de reproducción y maduración de patógenos-,

\footnotetext{
${ }^{176}$ Además de los efectos sobre la salud, y en un contexto más amplio, la reducción de la diversidad, la crisis energética, el deterioro y escasez de los recursos no renovables, todos ellas dimensiones del deterioro ecológico provocado por el cambio climático, llevarán aparejadas previsiblemente un incremento de la conflictividad por el control de los recursos naturales, lo que incidirá negativamente en las condiciones de vida de la población. Un lúcido análisis de esa conflictividad puede verse en Welzer (2010); también en los diferentes artículos recogidos en el número monográfico del Boletín ECOS, ${ }^{\circ} 15$. La conflictividad que viene, junio-agosto, 2011, Madrid, CIP-Ecosocial.

${ }^{177}$ Sempere y Riechmann (2000:270-277) destacan entre los riesgos derivados de un calentamiento rápido de la atmósfera los siguientes: a) <<daños a los ecosistemas >>, con la extinción acelerada de especies animales y vegetales; b) <<subida del nivel del mar >>, con la anegación de una tercera parte de las tierras de cultivo del mundo y los hogares de 1.000 millones de personas; c) <<impredecibilidad climática y hambre>>, con abundancia de fenómenos meteorológicos extremos, enfriamientos en algunas regiones y calentamiento en otras, aumento del número de parásitos que amenazarán a la agricultura mundial, reducción del margen de seguridad del sistema alimentario mundial y riesgo serio de grandes hambrunas; d) <<daños a los asentamientos humanos e infraestructuras $>>$, al resultar inadecuadas a las nuevas condiciones climáticas construcciones que fueron pensadas para otras temperaturas; e) <<incremento de las catástrofes "naturales” >, con mayor frecuencia de sequías, maremotos, olas de calor extraordinarias y huracanes devastadores.
} 
que como ya se ha señalado puede extender a las partes templadas del planeta enfermedades hoy confinadas a las zonas tropicales (paludismo, malaria, peste bubónica, leismaniosis, dengue, entre otras), o por la estacionalidad e incidencia de infecciones relacionadas con la alimentación (cólera). La OMS (2002:72) estima que, en el año 2000, el cambio climático causó 150.000 muertes en todo el mundo y fue el responsable del 2,4\% de las enfermedades diarreicas, del 6\% de la malaria en todo el mundo y del 7\% del dengue en algunos países industrializados.

Respecto a las consecuencias de la contaminación en la salud, por razones metodológicas ${ }^{178}$ los resultados obtenidos han sido siempre controvertidos, aunque "la asociación entre contaminación atmosférica y aumento de la morbimortalidad, encontrada de forma constante en diferentes tipos de población y áreas geográficas, parece indudable” (Ramos Delgado y Barrueco, 1995:510). De hecho, no existen dudas acerca de los efectos patológicos inmediatos (a corto plazo) de la contaminación, aunque la unanimidad sobre sus efectos a medio y largo plazo es menor ${ }^{179}$. Por otro lado, esas evidencias sobre los efectos de la contaminación en la salud no se refieren a tendencias nacionales de la mortalidad globalmente consideradas, sino a las de ámbitos geográficos limitados, fundamentalmente concentraciones urbanas. En este sentido, estudios epidemiológicos ${ }^{180}$ han demostrado que la contaminación atmosférica (humos

\footnotetext{
${ }^{178}$ Ciertamente, no es fácil observar en muchos casos la relación directa causa-efecto. Por otra parte, en los trabajos experimentales resulta difícil extrapolar los resultados del laboratorio a la población en general. En los trabajos epidemiológicos la dificultad deviene de cribar aquellos factores o variables ajenas a la investigación como el tabaco o la exposición laboral y que podrían alterar los resultados y las conclusiones (Ramos Delgado y Barrueco, 1995:510).

${ }^{179}$ En lo relativo, por ejemplo, a la incidencia de la contaminación ambiental en la dieta y sus posibles efectos nocivos sobre la salud, José Luis Domingo Roig, director del Laboratorio de Toxicología y Salud Medioambiental de la Universidad Rovira i Virgili, señala que se desconoce "el impacto real de los contaminantes a través de la dieta". Domingo ha coordinado un estudio en el que se ha analizado el contenido de distintos contaminantes en la cesta de la compra de un ciudadano medio en Cataluña. Los resultados del mismo son extrapolables al conjunto de España y los datos más significativos son: a) toda una serie de tóxicos, orgánicos e inorgánicos, están presentes en la comida diaria aunque en concentraciones y con grados de toxicidad distintos. Los niveles de los cuatro metales pesados, arsénico, mercurio, plomo y cadmio, están por muy por debajo de los niveles de ingesta máxima tolerable, lo que no supone un riesgo importante. Y, mientras que el nivel de ingesta de algunos compuestos orgánicos (hidrocarburos aromáticos, por ejemplo) tampoco es alto, la de otros, dioxinas, PCB, PCN, compuestos de bromo y éteres policlorados, a través de algunos alimentos supera los limites recomendados por la OMS; b) de todos los alimentos, el pescado y el marisco son, con diferencia, los que tienen mayor concentración de tóxicos, lo que es lógico ya que "todos los contaminantes acaban en el mar, y allí entran en la cadena trófica y acaban llegando a nosotros”; c) aunque su ingesta no tiene efectos a corto plazo, el organismo humano los va acumulando y pueden acabar causando enfermedades como el cáncer. Dado que se conoce con certeza el efecto cancerígeno de algunos de los contaminantes estudiados, el estudio ha estimado, por ejemplo, que la cantidad de dioxinas detectadas en la comida estaría provocando un aumento en la probabilidad de padecer cáncer de 1.360 casos sobre un millón, es decir, extrapolando los datos a España, unos 750 cánceres anuales, alrededor del 0,5\% de los cánceres nuevos que se producen al año (Diario de la seguridad alimentaria, consumaseguridad.com 10/06/04; EL PAÍS, 2/03/04:42).

${ }^{180}$ Entre los estudios epidemiológicos que han analizado la relación contaminación atmosférica/salud/ mortalidad en España destaca el Proyecto EMECAM y su sucesor el Proyecto EMECAS. En ambos proyectos se han utilizado los datos de quince ciudades, y mientras el primero de ellos estudió la asociación de la mortalidad con varios contaminantes atmosféricos, el segundo examina la incidencia de estos contaminantes en la salud. En la Revista Española de Salud Pública, v.73, nº 2, de 1999, se recogen
} 
negros, partículas en suspensión, dióxido de azufre, dióxido de nitrógeno, monóxido de carbono y ozono) está directamente relacionada con el aumento de las urgencias por diversas enfermedades agudas y crónicas, dependiendo de la composición del aire contaminado, y con un porcentaje de las muertes de sus habitantes -mortalidad cardiovascular, mortalidad respiratoria, cáncer de pulmón, mortalidad en infecciones respiratorias agudas en los niños-, aún en aquellas ciudades, como las españolas, con niveles medios de contaminación por el humo del tráfico, calefacciones y, en menor medida, por el industrial o el procedente de incineradoras de residuos. La OMS (2002:69) estimó que en el año 2000 la contaminación del aire urbano provocó la muerte de 800.000 personas en todo el mundo. Por su parte, la UE alertó en el año 2005 de que si no se tomaba ninguna medida "dentro de 15 años habría 290.000 muertes prematuras debidas a la contaminación atmosférica” (Jano-on line, 22/09/05). En el caso de España, el Atlas municipal de mortalidad por cáncer en España 1898-1998, elaborado por el Centro Nacional de Epidemiología (2007), muestra claramente que, al margen de la dotación genética, de la predisposición familiar y de los hábitos saludables o insanos, el área geográfica de residencia influye en la mayor o menor probabilidad de padecer los distintos tipos de cáncer, las enfermedades cardiovasculares, la diabetes, la tuberculosis o el Parkinson y el Alzheimer. En la presentación del trabajo, el director del mismo, Gonzalo López Abente, señaló que "los genes no explican estos patrones de distribución. Hay claras desigualdades ambientales”, y refiriéndose a los distintos tipos de tumor añadió: "se observa que los casos siguen el patrón de la industrialización en España, con una concentración en polos como Asturias, Huelva, Cataluña o País Vasco” (El PAÍS, 31/08/07:28-29). M. Porta, catedrático de Salud Pública de la UAB, resumió gráficamente los polémicos resultados de este informe: "El cáncer no es una lotería. Si lo fuese el mapa (de la distribución de cada tipo de cáncer en España) aparecería repartido homogéneamente. Pero la realidad es que unos tienen más probabilidades que otros en función de su lugar de residencia” (El PAÍS, 01/09/07:28).

Junto a estos riesgos globales los individuos de las sociedades desarrolladas viven asimismo con una "cesta de micropeligros" que producen efectos igualmente devastadores en la sociedad (Mir, 2001). Las llamadas “enfermedades de la sociedad”, es decir, las producidas por los efectos perversos de hábitos insalubres o arriesgados incrementan su incidencia con el proceso de modernización. La mayor rapidez y disponibilidad de productos para capas cada vez más amplias de la población ha afectado a los estilos de vida de las mismas facilitando un aumento del consumo de tabaco, bebidas alcohólicas, dietas hipercalóricas y ricas en grasas y

toda una serie de estudios con los resultados generales, y para cada una de las ciudades participantes, de los análisis realizados en el marco del Proyecto EMECAM. 
del sedentarismo, con consecuencias negativas sobre la salud y la longevidad media ${ }^{181}$. Una estimación de la expansión de las enfermedades relacionadas con el estilo de vida a nivel mundial cifra el incremento del número total de muertes por esas causas desde 49 millones de fallecimientos en 1990 hasta 68 millones en 2020. Este aumento en términos absolutos supone, además, el aumento del peso relativo de esas defunciones sobre el total de muertes, que pasará de ser el 55\%, en 1990, al 73\%, en 2020 (Pearson, 2002:30). Otro ejemplo diáfano de micropeligro, sorprendentemente "naturalizado" por las sociedades de todo el mundo, es el derivado de los accidentes de tráfico. Las consecuencias de los mismos constituyen un gran problema de salud a nivel mundial, como se colige de las estimaciones para cada año realizadas por la OMS: en el año 2002, por ejemplo, 1,2 millones de muertos y 50 millones de heridos, de los que 5 millones podrían quedar incapacitados permanentemente. De cara al futuro, según las estimaciones de esta organización, los traumatismos por accidentes de tráfico pasarán de ser la novena causa concreta más frecuente de enfermedad en 1990, a la tercera en 2020. Sobre el supuesto de que no se introdujeran medidas de prevención se produciría un incremento del 60\% en las cifras de muertos y heridos por accidente de tráfico hasta el 2020.

A pesar de las sombras que todos los factores de riesgo señalados arrojan sobre la evolución futura de la mortalidad, lo cierto es que las proyecciones de población elaboradas por los principales organismos nacionales e internacionales prevén un crecimiento de la esperanza de vida a lo largo de toda la primera mitad del siglo $\mathrm{XXI}^{182}$. Obviamente, ese crecimiento no va

\footnotetext{
${ }^{181}$ En un estudio dirigido por Jay Olshansky y publicado en The New England Journal of Medicine, se estimaba que, si continuaba la tendencia observada en el incremento de la obesidad, la e(0) de EE.UU. se reducirá en cinco años en el 2050 (EL PAÍS, 05/04/05:38). Los datos de la e(0) de ese país en 2008 han reflejado por primera vez una reducción en ese indicador, descenso motivado por el incremento de la mortalidad en las capas sociales más desfavorecidas y que algunos autores han relacionado con los hábitos nocivos pero sobre todo con el sobrepeso y su incidencia enfermedades como la hipertensión, la diabetes y los problemas cardiacos (EL PAÍS, 14/01/11:30-31). Sobre la relación entre dieta, nutrición y enfermedad se puede consultar FAO/OMS (2003). Una interesante reflexión sobre los cambios en la dieta humana en los últimos tiempos, y las razones por las que la epidemia de obesidad se extiende fundamentalmente entre las clases bajas de la población, puede verse en Aguirre (2007).

${ }^{182}$ Como se sabe, desde la perspectiva demográfica las proyecciones de población a largo plazo, e incluso a medio plazo como las de 2025-30, carecen de fiabilidad y no dejan de ser un mero entretenimiento matemático en el que, todo lo más, se puede prever el estado de la cuestión en un momento temporal determinado bajo la asunción de determinadas hipótesis que, por otra parte, nadie puede garantizar que se cumplan. Si, por definición, siempre ha sido imposible predecir con certeza total nada, esa imposibilidad lo es en mayor medida aún en una época tan compleja como la actual en la que, a pesar del nivel de desarrollo alcanzado hasta ahora, no hay ninguna garantía de que lo conseguido pueda mantenerse, de que los riesgos observados puedan controlarse, y de que otros riesgos larvados y aún no detectados o nuevos riesgos por surgir emerjan trastocando todas las hipótesis previstas. Por tanto, los datos proyectados se deben tomar con toda clase de prevenciones. En todo caso, la razón fundamental por la que se hace referencia a las proyecciones a largo plazo es porque la difusión de ese tipo de datos en los medios de comunicación ayuda a conformar un estado de opinión sobre cómo será la evolución futura de la mortalidad. Algo que se pudo comprobar en el caso de España cuando en Febrero de 2001, con gran repercusión en los medios de comunicación, se presentó públicamente la síntesis de los resultados del informe de NU (2001): World Population Ageing 1950-2050, siendo un tema central de conversación durante varios días, y, en especial, el hecho de que, fruto entre otros procesos del descenso de la
} 
a tener para el conjunto de la población mundial la intensidad del experimentado durante la segunda mitad del siglo XX, bien por el elevado nivel que la e(0) ha alcanzado ya en muchos países, bien porque algunos factores de riesgo, como el VIH/SIDA, frenan, cuando no retraen, la evolución ascendente de la e(0) en otros países. Day (1991) critica el excesivo “optimismo” de las proyecciones de población centrándose en las hipótesis que subyacen en las mismas para los países más desarrollados. Según este autor el incremento de la longevidad que unánimemente se predice para Europa se asienta en tres supuestos: 1) una continuación casi mecánica de las tendencias descendentes actuales de la mortalidad; 2) la consecución de mejoras en la prevención de las enfermedades y de las lesiones y accidentes; y 3) mejoras en todas las fases de los tratamientos terapéuticos ${ }^{183}$. Estos supuestos se asientan a su vez en tres hipótesis: a) habrá mayores progresos en la ciencia y en su aplicación, b) se producirán mejoras en el acceso a los servicios y en los cuidados de la salud, y c) habrá cambios favorables en los estilos de vida. Admitiendo que esos cambios favorables se han producido ya en el pasado (avances indudables de la Medicina en el tratamiento de algunas enfermedades; mejora en el acceso a los servicios médicos por la extensión general de la cobertura de los seguros de salud; cambios en los estilos de vida ligados al incremento de los niveles de vida y educativo), Day cuestiona sin embargo estas tres hipótesis por considerarlas sobreestimadas ya que, en su opinión, se dejan fuera de las proyecciones toda una serie de factores que pueden "contrabalancearlas” en el futuro.

En efecto, las investigaciones de las futuras declinaciones de la mortalidad están concentradas principalmente en el factor medioambiental enfatizando las mejoras continuas tanto en la prevención de la enfermedad como en la terapia a aplicar. Cabe, sin embargo, un empeoramiento general de las condiciones medioambientales (cambio climático, radioactividad, lluvia ácida, deterioro de la capa de ozono, contaminación del aire, del agua y de la tierra), frente al que no se hayan arbitrado medidas de prevención. Es posible, también, un cambio en la virulencia de organismos infecciosos, o la aparición de nuevos patógenos, para los que la ciencia médica no tenga una respuesta inmediata, como ha ocurrido con el VIH/SIDA -surgido en África, en 1970, y descrito el primer caso en Estados Unidos, en 1981-, para el que no se ha conseguido aún una vacuna y no se logró desarrollar un tratamiento eficaz contra el mismo hasta 1995. Además, en el supuesto de que existieran tratamientos médicos eficaces, es posible que por sí mismo eso no garantice que dichos tratamientos estén al alcance de todos los

mortalidad, España “perdería el 22\% de su población en 50 años”, y que, con una edad media de 55 años, llegaría a ser el país “más viejo" del mundo en el año 2050 (EL PAÍ́S, 28/02/01:28).

${ }^{183}$ A los innegables beneficios aportados por los avances en la atención médico-sanitaria hay que contraponer, como subraya Segura (2004:291) los perjuicios que provoca: la iatrogenia, que "se ha convertido en una causa principal de mortalidad y morbilidad". Según este autor, que hace referencia a distintos informes, en EE.UU. se estima que "los errores médicos provocarían más muerte que el SIDA, el cáncer de mama y los accidentes de trabajo, llegando a ser la tercera causa de defunción”. 
ciudadanos, como ha sucedido históricamente ${ }^{184}$. Este desfase, según Day (1991:121), se incrementará en el futuro por el auge de las políticas y doctrinas económicas neoliberales que han convertido a la salud en una mercancía más, que se puede comprar y por la que hay que pagar en el mercado. El incremento de la desconfianza hacia lo público, hacia la sanidad pública, que esa línea de pensamiento lleva pareja, no hace más que servir de coartada ideológica a la progresiva restricción de los accesos a bienes y servicios básicos. Es decir, el paraguas de los avances médicos no ha cubierto, no cubre y no cubrirá nunca, de la misma forma a toda la población, incluso en los países desarrollados. Situación que se ha agravado desde el inicio de la crisis económica en 2007, y la solución aplicada de reducción de los Estados de Bienestar y el recorte de gastos sociales como respuesta a la misma, lo que ha reforzado el proceso de dualización social en un contexto de creciente empobrecimiento, como se ha comentado en el Capítulo 3 de esta Tesis. Por otra parte, en lo relativo a los cambios en los estilos de vida, Day (1991:122) considera improbable la adquisición voluntaria automática de nuevos hábitos más saludables por cuanto las personas pueden ignorar la influencia negativa de sus hábitos; pueden pensar que para ellas es imposible o muy costoso mejorar sus hábitos; pueden estar sujetas de la presión de sus iguales contra esos cambios; o pueden creer que escaparán de las consecuencias negativas de comportamientos insalubres, consecuencias que, en todo caso, se perciben lejanas en el tiempo.

Además de la emergencia de factores que puedan contrabalancear la evolución ascendente de la e(0), Day (1991:124-126) añade un factor generacional que en su opinión va a frenar el incremento futuro de la longevidad en los países occidentales: dado que, en estos momentos, las ganancias en la e(0) se están produciendo por la evolución favorable de la mortalidad en las edades más altas, una vez extinguidas las actuales generaciones de mayores, que son únicas, dentro de “una o de dos décadas” la mortalidad de esas edades comenzará a incrementarse $^{185}$.

\footnotetext{
${ }^{184}$ Matizando la satisfacción y el optimismo con el que con frecuencia se evalúa al sistema de salud español, J. Benach (2000; Benach y Urbanos, 2000) incide en la falta de equidad y en el peso de las desigualdades sociales existentes en el mismo, por lo que señala que "la ampliación y mejora de la atención sanitaria no garantiza que todos los ciudadanos tengan igual accesibilidad y calidad en los servicios sanitarios, ni mucho menos que la salud y calidad de vida sea equitativa. Por un lado, porque acceder a un nivel básico de servicios no significa que exista un nivel homogéneo en cuanto a prestaciones y calidad; y por otro, porque el nivel de salud del que disfrutan los ciudadanos no depende en gran parte de los servicios sanitarios disponibles", ya que "cualquier estudiante de salud pública sabe que el impacto del sistema sanitario de un país sobre la salud y la calidad de vida de los ciudadanos, aun siendo relevante, es relativamente menor en comparación con el conjunto de factores sociales de tipo económico, laboral, ambiental y cultural que afectan a una determinada población”.

${ }^{185}$ Day argumenta su posición sobre dos grupos generales de factores: 1) diferencias entre la actual generación de gente mayor y las que la sucederán. Las personas mayores de ahora son supervivientes biológicos de mayores niveles de mortalidad en la infancia, juventud, y temprana adultez, es decir, están más seleccionados y son más resistentes a la enfermedad. Comparada con la generación que la sucederá, la presente generación de personas mayores ha estado, además, menos expuesta a ciertas condiciones
} 


\subsubsection{LA LONGEVIDAD HUMANA EN EL FUTURO}

"Si hubiese un hombre que no pudiese morir, si fuera real la leyenda del judío errante, ¿cómo habríamos de titubear en declararlo el más infeliz de todos?”

S. Kierkegaard

Una segunda cuestión que acapara la atención y provoca intensos debates entre demógrafos, gerontólogos, epidemiólogos, biólogos y actuarios es la de si son esperables nuevos incrementos de la longevidad humana en el futuro. La investigación sobre este tema se torna clave desde un punto de vista político dadas las consecuencias sociales derivadas del creciente proceso de envejecimiento demográfico ${ }^{186}$ de las sociedades desarrolladas y, en especial, las que se relacionan con el futuro de los sistemas de seguridad social y de servicios de salud. En efecto, los cambios pretéritos en la mortalidad, en especial desde la década de 1970 cuando los mayores descensos de la misma se empiezan a conseguir a partir de su evolución en las edades adultas, se están haciendo sentir ya en los países desarrollados con el progresivo envejecimiento por la cúspide de sus poblaciones. Esto supone el aumento de la esperanza de

medioambientales deletéreas, las consecuencias insalubres de las cuales se manifiestan sólo después de años de exposición: fumar, asbestos, monóxido de carbono, contaminación atmosférica, materiales agrícolas tóxicos, etc. También han estado menos expuestas a ciertos tipos de estrés emocional asociados con la ruptura familiar y los nuevos roles y estatus esperados de las mujeres. Muchas de ellas han pasado gran parte de su vida en el medio rural; 2) La distribución de recursos sociales. La presente generación de mayores se ha beneficiado asimismo de la redistribución de recursos públicos que, entre otras cosas, les ha permitido acceder a servicios médico-sanitarios que han reducido efectivamente la morbilidad y la mortalidad en las edades más altas. Esto ha sido posible, en parte, por su menor número y por constituir una proporción relativamente pequeña del total de la población. Es posible que el creciente envejecimiento de las poblaciones occidentales modifique las condiciones asistenciales a las generaciones de mayores que les sucedan. De hecho, hay expertos en bioética y economistas que han planteado la necesidad de abrir un debate sobre la fijación de límites a la asistencia sanitaria de las personas mayores de 65 años y la posibilidad de restringir e incluso excluir del uso de la alta tecnología a las mismas. El bioético D. Callahan (2004), de forma provocativa y para animar la reflexión sobre esta cuestión, afirmaba: "Se debe limitar la búsqueda y el desarrollo así como las innovaciones tecnológicas tendentes a la conservación de la vida, y no dar tratamiento de esta naturaleza a las personas mayores de 75 años”. Para una revisión crítica de estos planteamientos ver Ortega (2001).

${ }^{186}$ Se define el envejecimiento de la población como el aumento relativo de la población anciana -la población de 65 o más años. Este cambio en la distribución por edad de una población es fruto, por un lado, de la reducción de la mortalidad, que al incrementar el número de supervivientes en todas las edades la envejece por la cúspide, y, por otro lado, de la disminución de la fecundidad, que al reducir las entradas de los nacimientos la envejece por la base. Las consecuencias del progresivo envejecimiento de la población en las sociedades desarrolladas constituye uno de los temas sociodemográficos sobre el que más se ha debatido en los últimos años. Las implicaciones sociales, económicas y políticas son múltiples e inundan prácticamente todos los ámbitos, presentes y futuros, de la vida social. Una síntesis general de todas estas cuestiones puede verse en Binstock y Shanas (1985). Sobre el envejecimiento demográfico de la población española puede consultarse el Portal Mayores del IMSERSO (http://imsersomayores.csic.es/ documentos) en el que se facilita el acceso a un amplio número de informes y estudios sobre todos los aspectos relativos a la vejez, a la salud y al envejecimiento demográfico, además de Gómez Redondo et al (2010 y 2007); Salvà y Ribero (2007); Abellán y Puga (2005 y 2004); Zamora (2003); Puga (2002; Pérez Díaz (varios años); Cabré y Pérez Díaz (1995); sobre las implicaciones económicas y financieras en el gasto social pueden consultarse el n ${ }^{\circ} 104$ de Papeles de Economía Española, CECA (2005), en el que se abordan las consecuencias del envejecimiento demográfico en el sistema educativo, el mercado de la vivienda, el ahorro, la inversión y el consumo agregados, etc.; asimismo, Pérez Ortiz (2005, 1997); Pérez Díaz (2003); Loriaux (1995); $\mathrm{M}^{\mathrm{a}}$ de Trabajo y SS (1995). 
vida en las edades más avanzadas ${ }^{187}$ y un continuo incremento del número absoluto de ancianos que, en el caso de España, se ha acelerado en las últimas décadas del siglo XX: si en 1900 el número de personas censadas con 65 o más años fue de 967.754, uno de cada veinte habitantes, en 1970 fue de 3.290.800, una de cada diez, y en el Censo de Población y Viviendas de 2001 el número de ancianos se ha más que duplicado respecto a 1970 y se ha más que septuplicado respecto a un siglo antes, 6.964.267, es decir, una de cada seis personas censadas (INE, 2003). Crecimiento absoluto de la población anciana que según todas las proyecciones se va a intensificar en las próximas décadas; así, durante los primeros años del siglo XXI, cada mes, han cumplido 65 años aproximadamente 30.000 personas y la cifra de personas que cumplan esa edad se elevará a 50.000 cada mes dentro de dos décadas, “algo más de 600.000 al año" (Abellán y Puga, 2005:57).

Este proceso, además, se ha producido en interacción con la evolución del resto de los fenómenos demográficos, y fundamentalmente, también desde la década de 1970, con el descenso de la fecundidad que se ha situado por debajo de los niveles de reemplazo poblacional y lo ha acelerado ${ }^{188}$ (Robles, 2010:42; Puga, 2002:23). Como resultado, todas las sociedades que han finalizado su transición demográfica experimentan una situación demográfica inédita con profundas repercusiones en todos los ámbitos de la vida social, y sobre la que no existe experiencia histórica previa: el proceso irreversible e ineludible del envejecimiento demográfico. Por primera vez en la historia de la humanidad algunas sociedades van a estar constituidas por poblaciones con la mitad de sus efectivos superando los 40 años de edad y más de un cuarto por encima de los 60 años. Es el caso de la población española en la que, dada la rapidez con la que se ha desarrollado su transición demográfica, ese proceso de envejecimiento está siendo además especialmente acelerado desde que finalizó ésta, como muestra la evolución de su Edad Media, que ha crecido en casi 12 años durante el siglo XX: en 1900, 28,3 años; en 1975, 33,21 años; en 2001, 39,95 años, y; en 2009, 40,93 años (INEbase; Goerlich, 2010). Más gráfica aún es la evolución de su Índice de Envejecimiento, es decir, del número de personas ancianas (65 o más años) por cada 100 jóvenes (menores de 15 años): en 1900, existían 15,52 personas ancianas por cada 100 jóvenes; en 1950, ese número subió hasta 27,58; en 1981, alcanzó el valor de 43,7; durante la década de 1990, el número de jóvenes y de ancianos en España se igualan; en 2001, se situó en 117,63; en 2010, bajó ligeramente hasta 115,13 ancianos

\footnotetext{
${ }^{187}$ A principios del siglo XX, la e(65) era de 9,12 años, la e(75) de 4,74 años y la e(85) de 2,46 años. En el año 2000, la evolución señalada de la mortalidad ha desembocado en que esas Esperanzas de Vida son de 18,76 años, 11,44 años y 5,93 años, respectivamente. En 2009, esos datos son: 20,17 años, a los 65 años; 12,45 años, a los 75 años; 6,48 años, a los 85 años (INEbase: Tablas de mortalidad de España, distintos años).

${ }^{188}$ Sobre los efectos, desde la década de 1990, de la inmigración en el envejecimiento demográfico de la población española, en su caso como freno del mismo, pueden consultarse entre otros Izquierdo et al (2006); Jiménez-Ridruejo et al (2006), y; León Salas (2004).
} 
por cada 100 jóvenes y a partir de la segunda década del siglo XXI, si no ocurren contingencias inesperadas y por las razones que se señalan abajo, el valor de este índice se acelerará hasta los 173,86, en 2030, y los 233,20 mayores de 65 años por cada 100 menores de 15 años, en 2050 (IMSERSO, 2008:33-34).

En su dimensión poblacional, el envejecimiento demográfico significa en esencia: a) un incremento notable en números absolutos de la población anciana, como se ha señalado arriba para el caso de España; b) este aumento se acelerará, en términos absolutos y relativos, durante la primera mitad del siglo $\mathrm{XXI}^{189}$; c) un envejecimiento de la población activa ${ }^{190}$; d) un

${ }^{189}$ El envejecimiento por la cúspide se producirá en todos los países del mundo pero sobre todo en los países más desarrollados, que son los que tienen su transición de la mortalidad más avanzada y a los que, en muchos casos, además, va a afectar el efecto estructural de la llegada de generaciones voluminosas, las del "baby-boom" de postguerra, a la edad de jubilación. Si a este hecho se añade la baja fecundidad en esos países, es decir, la entrada de pocos efectivos en la base de la distribución por edad, el envejecimiento se incrementará en términos relativos. En el caso de España, el envejecimiento demográfico se ralentiza en la primera década del siglo XXI, al llegar a los 65 años las generaciones reducidas de la guerra civil y la postguerra, y se relanzará a partir de la segunda década y sobre todo de la tercera década cuando lleguen a los 65 años las nutridas generaciones nacidas entre 1957 y 1977. De esta forma, en sus proyecciones a largo plazo para la población española, el INE (2010) estima que el número de mayores de 65 años en el año 2010 ha sido de 7,7 millones (16,8\% del total de la población), en el 2020 será de 9,1 millones (19,3\%), en el 2030 subirá hasta los 11,2 millones de ancianos (23,5\%) y en el 2040 ese valor alcanzará los 13,7 millones (28,7\%). Por otra parte, Naciones Unidas (NU, 2007) estima que, de no producirse grandes cambios en las tendencias, algo por otra parte imposible de desechar, mientras la edad mediana del total de la población mundial en 2005 ha sido de 28 años, en el año 2050 subirá hasta los 38,1 años. En el caso de la población española, NU estiman que ese indicador aumentará desde los 38,8 años, de 2005, hasta los 49,1 años, en 2050.

${ }^{190}$ La evolución señalada de la mortalidad ha significado, asimismo, un aumento de las probabilidades de, una vez cumplidos los 15 años, llegar a la edad de jubilación. Así, si en el año 1900, la probabilidad de cumplidos los 15 años llegar a los 65 años era de 44,3\%, en el año 2000 ha sido de 87,7\%. Es decir, si a comienzos del siglo XX casi 6 de cada 10 potenciales trabajadores no llegaban a la edad de jubilación, esa ratio se reducía a poco más de 1 de cada 10 en 2000 (INEbase). Desde otro ángulo, el envejecimiento de la población activa se puede medir a través del índice de estructura de la población activa, IS, obtenido dividiendo las 25 generaciones adultas más mayores (40-64 años) entre las 25 más jóvenes (25-39 años) (Livi-Bacci, 1993:89-90). La evolución de este indicador a lo largo del siglo XX, y sobre todo en su tramo final, no deja lugar a dudas sobre el avance del envejecimiento demográfico de la población activa española: en 1900, hubo 63,8 personas de las generaciones adultas-mayores por cada 100 de las adultasjóvenes; en 2001, ese índice fue de 76,7 (Zoido y Arroyo, 2003:29). 
envejecimiento de la propia población anciana ${ }^{191}$; y, e) la feminización de la población anciana ${ }^{192}$ derivada de la sobremortalidad masculina en todas las edades.

Desde las perspectivas política, económica, social o cultural esos cambios demográficos no son inocuos, sino que socavan la lógica de las adaptaciones sociales previas y presionan para que las sociedades modifiquen sus instituciones tradicionales y se acomoden a la nueva situación en la que se han modificado profundamente las necesidades relativas de y entre las distintas generaciones, a la par que han cambiado las relaciones de poder entre ellas. En definitiva, está emergiendo un nuevo escenario social sobre las ruinas desbordadas de unas estructuras seculares que se están quedando obsoletas para hacer frente a las "mareas crecientes” de necesidades sanitarias, asistenciales, financieras, de protección, de comunicación y relación, por parte de un número cada vez más elevado de personas de edad. Como alerta M.A. Durán (2005:6), “llevamos mucho tiempo hablando de la vejez y del envejecimiento, pero todavía no ha calado en nosotros la revolución que significa ser una sociedad vieja... todavía no hemos inventado una estética de la vejez, y pasamos muchos más años siendo viejos que siendo jóvenes”. Todo ello constituye, por tanto, un reto sin precedentes para la propia organización y funcionamiento de la vida social, ya que "en una sociedad envejecida no es el anciano el que debe adaptarse a la sociedad, sino las estructuras establecidas las que deben adaptarse a sus necesidades” (Puga, 2002:9). Además, esta profunda mutación del escenario social se ha ido produciendo a la par que otros intensos cambios sociales cuyas consecuencias, sobre todo en el caso de España, van a amplificar los efectos del envejecimiento demográfico; concretamente, las profundas transformaciones en las estructuras y funcionamiento familiares ${ }^{193}$ anticipan una

\footnotetext{
191 "El aumento de la esperanza de vida, que históricamente había sido un factor de rejuvenecimiento se ha convertido en un factor de envejecimiento, porque son las edades más avanzadas las que registran la reducción más importante de la frecuencia relativa de las defunciones” (Puga, 2002:29). En efecto, el incremento de las probabilidades de sobrevivir hasta edades muy avanzadas ha conllevado un aumento del número de personas que llegan a octogenarias, nonagenarias e incluso a centenarias. Según la OCDE la población mayor de 80 años es la que está aumentando con mayor rapidez dentro de la población anciana. Así, si en el año 1980, en los países de la OCDE, el porcentaje de mayores de 80 años era el $18,2 \%$ de los mayores de 65 años, en 1990 era el 21,7\% y se estima que en el 2020 sea de alrededor del 25\%. En el caso de España, el número de personas con 80 años o más se ha multiplicado por doce entre 1900, cuando había 115.365, el 0,6\% del total de la población censada, y 2001, cuando su número fue de 1.633.040, el 4\% de la población; se estima que para el 2050 llegarán a ser 5.923.000, el 11,1\% de la población (IMSERSO, 2008:44).

${ }^{192}$ Según el Censo de Población y Vivienda 2001, en ese año había un millón cien mil mujeres más que hombres entre la población anciana censada: 4.027 .953 mujeres y 2.930 .563 hombres. Este desequilibrio es aún mayor en los grupos de edad más avanzada; así, dos de cada tres octogenarios son mujeres: 1.048.317 mujeres, 532.005 hombres (INE, 2004:55). El ralentizamiento del envejecimiento en la primera década del siglo XXI se ha traducido en que, en 2010, esa proporción se haya reducido ligeramente, según los datos estimados por el INE (INEbase): 1.202.348 mujeres octogenarias; 716.313 hombres octogenarios. El proceso de feminización de la vejez tiene importantes consecuencias sociales. Un análisis de las mismas referido a la población española puede consultarse en Pérez Díaz (2002:cap.6; 1999; 1995)

${ }^{193}$ Un ejemplo de las múltiples transformaciones relacionadas con el envejecimiento demográfico lo refiere Segura (2004:296) cuando resalta que el crecimiento del gasto sanitario actual no está relacionado
} 
crisis futura del sistema de cuidados informales ${ }^{194}$. Por todo ello, resulta perentorio prever cuál puede ser la evolución futura de todos estos cambios demográficos y sus consecuencias.

Las incertidumbres sobre la evolución futura del proceso de envejecimiento enlazan, en última instancia, con la incertidumbre sobre la naturaleza general de los límites biológicos de la longevidad humana ${ }^{195}$. Por esta razón, antes de abordar la cuestión de dónde reside el finisterre de la esperanza de vida, es decir, del envejecimiento poblacional, conviene recordar brevemente lo señalado en el Capítulo 1 sobre el por qué se producen el envejecimiento y la muerte de los individuos desde la perspectiva global de las teorías evolucionistas. En esencia, estas teorías consideran que, aunque existen evidencias de que, de alguna forma, la longevidad, el envejecimiento y la muerte están inscritas en el patrimonio hereditario de cada individuo, la Naturaleza tiene un papel neutral en esos procesos, no existiendo una programación activa y deliberada de los mismos, sino que la fuerza que empuja a la selección natural es la continuidad de la línea germinal. No se trata de que los individuos sobrevivan por sobrevivir, sino de que sobrevivan adaptándose a un entorno ecológico dado hasta reproducirse y criar la prole de acuerdo a unas formas de reproducción determinadas en cada especie; lo que sucede después no tiene importancia ya que una vez cumplido con su papel reproductor los individuos son desechables. De esta forma, los genes que producían efectos deletéreos en edades avanzadas han encontrado poca o nula oposición por parte de la selección natural y, en consecuencia, se han propagado en el acervo genético (Rose, 2000:62). Es decir, los seres humanos no están diseñados para ser inmortales y el envejecimiento y la muerte natural han surgido como efecto secundario de la propia selección natural, cuya fuerza decrece con la edad: los continuos y crecientes desequilibrios moleculares acumulados con la edad ("hipótesis del lastre mutacional”) dan lugar a mermas fisiológicas o a una reducción de la eficacia del sistema inmunitario que comprometen el equilibrio homeostático de los organismos pluricelulares. De esta forma, surge el proceso de envejecimiento por el que aumenta la vulnerabilidad de los individuos, que pierden capacidad de adaptación y de respuesta fisiológica ante las incidencias y transformaciones medioambientales.

sólo con el aumento lógico de las necesidades asistenciales al incrementarse el deterioro corporal, sino “con el papel vicariante que los servicios de atención médica juegan en unas sociedades en las que se han debilitado los vínculos familiares y las redes de cooperación comunitarias, de manera que buena parte de la utilización de tales servicios viene a sustituirlos”.

194 "Nos enfrentamos en el umbral del siglo XXI, con un modelo de bienestar familiarista a extinguir, al menos en las formas y magnitudes en que lo conocemos. Esta situación hace surgir la necesidad de organizar colectivamente lo que hasta ahora se resolvía en el ámbito de lo doméstico: el cuidado de los mayores dependientes... La Comisión de las Comunidades Europeas ha llegado a afirmar que $<<$ estamos en medio de una redefinición de las funciones del Estado, la empresa y la familia, tal como sucedió en la revolución industrial>>” (Puga, 2002:10).

${ }^{195}$ Una exposición, con perspectiva histórica, de las aportaciones en el campo de la Demografía sobre esta cuestión puede verse en Vallin y Berlinguer (2006). 
Estos cambios orgánicos característicos, denominados conjuntamente $<<$ senescencia $>>$, son en gran medida el legado genético heredado de los antepasados, forjado en la interacción con entornos hostiles para la vida, y que en el caso de los seres humanos se ha ido conformando desde hace 130.000 años hasta aproximadamente 100 años (Olshansky y Carnes, 2001:86-87). Son procesos biológicos básicos que afectan por igual a todos los individuos de la especie humana, son inevitables, y por tanto no están sujetos a intervenciones efectivas. No obstante, el envejecimiento individual es un proceso biodemográfico, es decir, además de biológico depende también de las calidades de los medio ambientes ecológico y social en los que los individuos gastan la mayor parte de sus energías y que pueden ser más o menos favorables a que éstos realicen su potencial de longevidad (Robine, 2001:899). Es evidente el papel adaptativo que la cultura juega en este sentido; de hecho, los efectos de su evolución han compensado, o incluso superado, a los de la evolución como especie al permitir a los seres humanos trascender ampliamente sus limitaciones biológicas. Como resalta Viciana (2003:11): “Si bien una larga vida, más allá del periodo reproductivo, no aumenta la probabilidad de transmisión de la carga genética propia, al facilitar el proceso de acumulación y transmisión cultural, mejora las posibilidades de supervivencia de hijos, nietos y familiares, que al fin y al cabo son los que seguirán transmitiendo la carga genética que recibieron de sus ascendentes”.

Conviene diferenciar, por tanto, entre los procesos insitos en la senescencia y los efectos derivados de las distintas biografías que se materializan en enfermedades que con mayor probabilidad afectan a algunas personas al envejecer y sobre las que en principio sí cabe algún tipo de intervención. Como gráficamente afirma Kirkwood, "envejecer no es enfermar, sino acumular errores y daños”. Es decir, las enfermedades están relacionadas con el proceso de envejecimiento pero no dependen de él, no forman parte del proceso de envejecimiento mismo, sino que al aumentar la edad se reduce la capacidad de los cuerpos humanos para rechazarlas y tienden a revelarse cada vez en mayor medida (“basurero genético”). Al envejecer se ponen de manifiesto los "eslabones débiles" de los organismos que incluyen "un sistema cardiovascular que se obstruye y está sometido a desgaste natural (enfermedades cardíacas y apoplejía), un sistema inmunológico debilitado (enfermedades infecciosas), un ADN que acumula desperfectos (cáncer), un sistema esquelético que se vuelve más frágil a edades avanzadas (osteoporosis) y sistemas sensoriales deteriorados (menos capaces para ver u oír). Nuestros ancestros estaban sometidos a los mismos procesos de degradación, pero la mayoría no vivió el tiempo suficiente para experimentarlos”196 (Olshansky y Carnes, 2001:85).

\footnotetext{
${ }^{196}$ De forma más precisa, Horiuchi (1999:60), a partir del análisis de las tasas de mortalidad de aquellas causas que crecen al aumentar la edad, distingue tres modelos de mortalidad: $1^{\circ}$ ) el de la mayoría de los cánceres, las tasas de deceso crecen de forma abrupta en las edades medias, pero su ritmo de crecimiento decelera marcadamente en las edades más elevadas: "realmente, se ha observado que los cánceres son bastante raros entre centenarios"; $2^{\circ}$ ) las tasas de las muertes debidas a enfermedad isquémica del corazón
} 
La diferenciación entre senescencia y patología se torna esencial a la hora de hacer previsiones sobre la evolución futura de la longevidad humana por cuanto es el punto en el que se materializa la bifurcación de las dos grandes hipótesis presentes en el debate, por otra parte insoluble, de si existe o no un límite intrínseco, y por tanto fijo, a la duración máxima de la vida humana ${ }^{197}$. Debate teórico que subyace a otro debate empírico mucho más relevante como es el de determinar cuáles son los límites a los incrementos futuros de la esperanza de vida. En ambos casos, tanto si se trata de la longevidad máxima como de la e(0), y cualquiera que sea el nivel alcanzado en una u otra, el deseo de aumentarlo continuará. La cuestión es, como señala Vallin (1995c:3), "hasta dónde puede ir el progreso y dónde comienza la pura ilusión. ¿Cuáles son los límites que el principio de realidad impondrá al principio del deseo?”. En esencia, las líneas fundamentales en la argumentación de esas dos grandes perspectivas son las siguientes:

1) Hipótesis de la duración de vida limitada: Esta perspectiva, denominada “tradicional” por Manton (1991), asume la existencia de un límite biológico fijo a la longitud máxima de la vida humana. A través de la senescencia, proceso intrínseco en todas las células somáticas, y que es un proceso no-tratable, se fija genéticamente la longevidad máxima para cada especie, cuya duración apenas ha variado durante miles de años. Dado que las probabilidades de enfermar aumentan con la edad, las tasas de mortalidad se incrementan exponencialmente con ella hasta una edad máxima a partir de la cual no pueden existir supervivientes. Desde esta perspectiva, la distinción senescencia/patología es diáfana y es la que permite atribuir los incrementos logrados históricamente en el promedio de longevidad (esperanza de vida) exclusivamente a la eficacia de las intervenciones frente a las enfermedades. Es el $<<$ tiempo manufacturado $>>{ }^{198}$, en expresión de Olshansky y Carnes (2001). Mientras que, hasta ahora, los avances científico-técnicos, las políticas sanitarias y los cambios en los estilos de vida han permitido controlar, reducir y retrasar la incidencia de las enfermedades, consiguiendo que cada vez más individuos sobrevivieran hasta edades cercanas al límite máximo de la vida humana, es decir, han incrementado la esperanza de vida, no hay constancia

y a infarto cerebral tienden a incrementarse con la edad a un ritmo relativamente constante con altas tasas, aunque eventualmente el aumento tiende a decelerar en las muy altas edades; $3^{\circ}$ ) las tasas de muerte de algunas enfermedades crecen lentamente en las edades medias, pero aceleran marcadamente en las edades últimas. En estas enfermedades se incluyen la neumonía, la gripe, la bronquitis, gastroenteritis, fallo cardiaco. "Las muertes a muy altas edades debidas a estas últimas enfermedades o sin causa específica pueden ser consideradas manifestaciones directas de senescencia”. Por otra parte, las variaciones de edad entre individuos en la incidencia de estas enfermedades se produce porque hay un componente de azar que determina cuándo, dónde y cuánto deterioro acumulan los cuerpos (Olshansky y Carnes, 2001:85).

${ }^{197}$ Como ocurre con la medida de la inteligencia (Coeficiente de Inteligencia), no es posible observar el valor máximo de la duración de la vida humana y tampoco resulta posible inferir estadísticamente ese valor a partir de la variable estado observada: empíricamente, todo lo más que se puede afirmar es que se ha alcanzado un valor máximo sólo cuando el anterior ha sido superado.

198 "Los días adicionales vividos como resultado de una intervención médica en una enfermedad que podía se mortal” (Olshansky y Carnes, 2001:140). 
de que esos factores hayan tenido incidencia alguna en el proceso mismo de senescencia, es decir, de que hayan incrementado en alguna cuantía la longevidad humana máxima ${ }^{199}$. En esta perspectiva se sitúan biólogos ${ }^{200}$ como Hayflick (1999), o Walford (1985), médicos como Fries (1989, 1980), demógrafos como Olshansky (Olshansky et al, 2001, 2001a, 1993) o Duchene y Wunsch $^{201}$ (1991).

Aunque no es una prueba suficiente ${ }^{202}$ de la existencia de un límite fijo en la duración de la vida humana, se suele asociar con esta perspectiva lo que se denomina proceso de $<<$ rectangularización de la supervivencia/comprensión de la mortalidad >> consistente en la reducción de la variabilidad de la distribución por edad de los fallecimientos a la par que se incrementa la esperanza de vida (Fries, 2002, 1989, 1980). Admitiendo la existencia de un límite biológico fijo cercano a los 100 años, según esta hipótesis se estaría asistiendo en los países más desarrollados a una “concentración” de los fallecimientos alrededor de la esperanza de vida, una edad próxima a los 85 años, lo que conlleva longevidades muy homogéneas: así, el

199 Los resultados obtenidos en algunos estudios realizados en Estados Unidos sobre poblaciones concretas, fundamentalmente grupos religiosos preocupados por la salud, muestran que algunas de ellas tienen muchas menos probabilidades de morir en diversas edades, comparadas con los promedios de la población estadounidense, como se puede ver en el siguiente cuadro. No obstante, salvo el compartir un estilo de vida saludable, "nadie ha identificado nada específico que estos grupos puedan tener en común y que explicara su supervivencia superior a la de la población general” (Hayflick, 1999:412).

\begin{tabular}{|l|c|c|c|cc|c|}
\hline \multicolumn{2}{|c|}{ ESPERANZA DE VIDA DE GRUPOS COMPARADOS CON LA POBLACIÓN GENERAL DE EE.UU. } \\
\cline { 2 - 7 } & $\mathrm{e}(0)$ & $\mathrm{e}(65)$ & $\mathrm{e}(85)$ & $\mathrm{e}(0)$ & $\mathrm{e}(65)$ & $\mathrm{e}(85)$ \\
\hline Sacerdotes mormones (1980-1988) & 86,5 & 25,5 & 12,7 & 86,5 & 24,9 & 11,0 \\
\hline $\begin{array}{l}\text { Condado de Alameda, California, con estilo } \\
\text { de vida mormón (1974-1988) }\end{array}$ & 92,4 & 30,4 & 16,4 & 87,5 & 25,7 & 11,6 \\
\hline Mormones asegurados (1980-1988) & 85,7 & 24,8 & 12,2 & 88,1 & 26,3 & 12,0 \\
\hline Dallas, Texas, población selecta (1989) & 88,4 & 27,0 & 13,8 & 98,1 & 35,0 & 19,0 \\
\hline Adventistas del Séptimo Día (1960) & 80,5 & 20,8 & 9,0 & - & - & - \\
\hline Población general de EE.UU. (1989) & 71,8 & 15,2 & 7,1 & 78,6 & 18,7 & 9,0 \\
\hline
\end{tabular}
Fte: Tomado de (Hayflick, 1999:412).

200 Como se ha señalado en el Capítulo 1, Hayflick (1999:112) reconoce que la incidencia de la investigación médica moderna, y la influencia de ciertos estilos de vida, han ayudado a incrementar la esperanza de vida, pero niega que hayan desacelerado el ritmo de envejecimiento o influido en el mecanismo que indirectamente determina la longevidad máxima. Para él, "no hay pruebas de que la duración máxima de la vida sea distinta de la que era hace cien mil años. Se sitúa en torno a los ciento quince años”. En la misma línea, Walford (1985) sitúa el máximo de supervivencia, para todas las generaciones y sin diferencias entre sexos, entre los 110-120 años.

${ }^{201}$ Duchene y Wunsch (1988), utilizando los conocimientos existentes en esos momentos sobre biología, envejecimiento y senescencia, proyectaron a finales de los años ochenta unas tablas de mortalidad al objeto de determinar un hipotético límite de vida humana. Según estos autores, el límite de vida máximo en los seres humanos es de 115 años, pero la actuación tanto de factores externos (enfermedades, accidentes) como los procesos intrínsecos de envejecimiento forzaba a que la edad media "natural" de muerte se situara entre los $90+5$ años.

${ }^{202}$ Reconociendo que en algunos momentos ambas hipótesis pueden ser consistentes, Wilmoth (1997) sin embargo, las analiza separadamente por cuanto considera que una reducción en la variabilidad de las edades de muerte no es prueba suficiente de la existencia de límites en la mortalidad. De hecho, nada impide que pueda darse una situación en la que simultáneamente la distribución por edades de muerte pueda estar más y más comprimida mientras que se traslada más y más hacia la derecha, hacia edades más elevadas. 
66\% de los fallecimientos se producirían entre los 81 y 89 años, y el 95\% entre los 77 y los 93 años. Proceso en el que se asume que las causas exógenas de mortalidad habrían sido eliminadas y la variabilidad de la edad de la muerte estaría ligada a la actuación de los factores genéticos implicados en la senescencia (Fries, 1980). Es decir, la rectangularización de la superviviencia equivaldría al envejecimiento del calendario de la mortalidad (Muñoz Pradas, 2003:143). Los dos motores del mismo serían (Kannisto, 2000): por un lado, la disminución del número de decesos prematuros, que desplaza las muertes hacia edades más avanzadas provocando una redistribución de las muertes en éstas; por otro lado, la menor capacidad del ser humano para alargar su vida con la edad, lo que conlleva que la creciente incidencia de las enfermedades crónico-degenerativas impide el desplazamiento hasta edades más avanzadas de los mayores riesgos de muerte, como si existiera un muro invisible. Así, a los 70 años casi toda la población está viva y a los 100 años de edad casi todos han fallecido (Fries, 1989).

El proceso de rectangularización de las curvas de supervivencia ha sido observado en los países desarrollados según avanzaban en su transición sanitaria y se reducía su mortalidad comprimiéndose la mayor parte de la misma en un intervalo estrecho de edad (Kannisto, 2000:11). En el Gráfico 4.9. puede comprobarse para el caso de España cómo a medida que la e(0) se alejaba de los bajos valores de principios del siglo XX el número de supervivientes en cada edad se ha ido incrementado, lo que se refleja en el proceso de horizontalización de la curva de supervivencia hasta edades elevadas. Asimismo, el rápido crecimiento de las probabilidades de fallecimiento a partir de los 60-70 años, provoca caídas abruptas de las curvas de supervivencia en la parte final de la distribución, y la progresiva concentración de los decesos en las edades más avanzadas se refleja en que las curvas de supervivencia tienen cada vez una pendiente mayor. 
GRÁFICO 4.9. SUPERVIVIENTES EN LOS DISTINTOS ANIVERSARIOS. ESPAÑA. 1800-2009

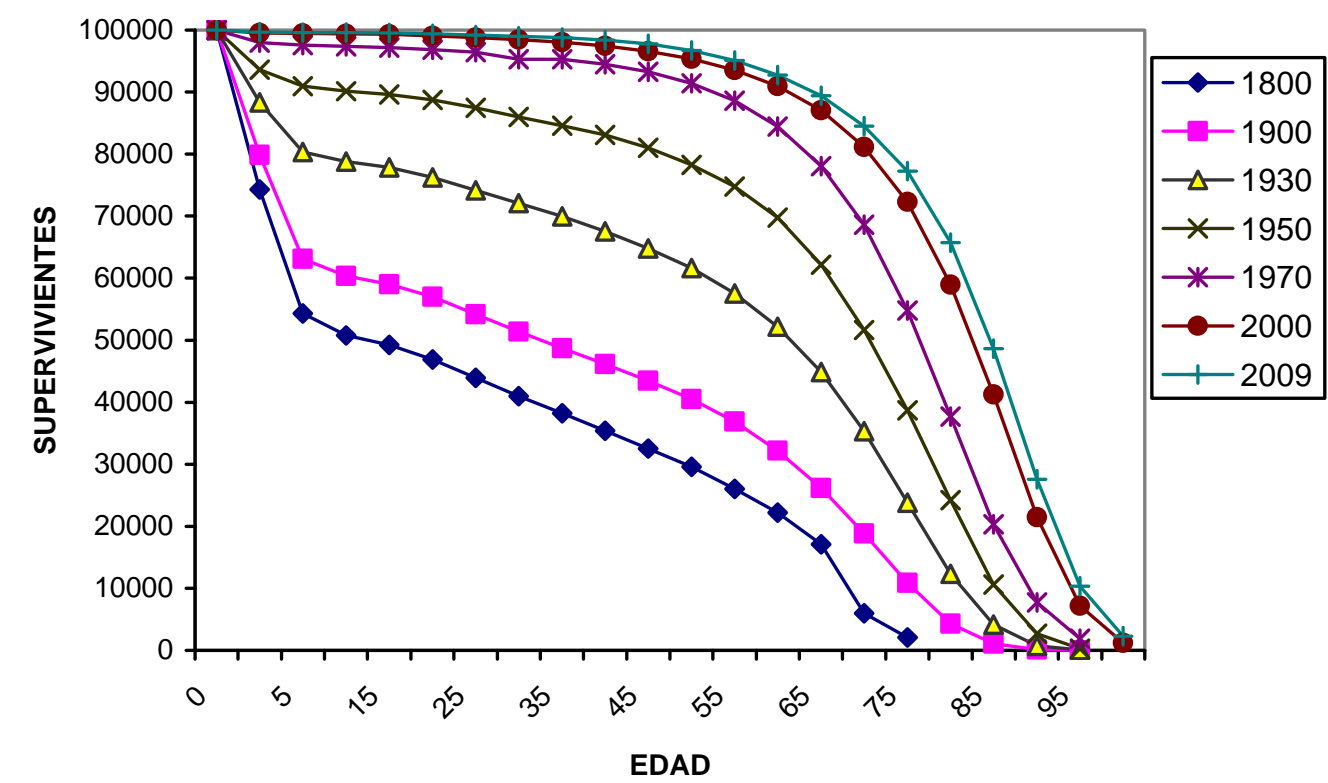

Fte: Año 1800, estimaciones teóricas de Livi-Bacci (1968): "Fertility and Nupciality Changes in Spain from the late $18^{\text {th }}$ to early $20^{\text {th }}$ Century”, en Population Studies, XXII, pp. 1 y 2. Resto de años, INE: Tablas de Mortalidad de la Población Española.

2) Hipótesis de la duración de vida sin un límite fijo: Desde esta perspectiva, denominada "prolongevista” por Olshansky y Carnes (2001), se considera que la hipótesis “tradicional” es excesivamente pesimista y conservadora, ya que niega todo progreso futuro en la longevidad humana, además de escasamente intuitiva por cuanto sugiere que es posible sobrevivir hasta alguna edad máxima $w$ pero no hasta el día w+1 (Wilmoth, 1997:60). Para esta perspectiva, el proceso de envejecimiento orgánico es multifactorial es decir, es un proceso homeostático en el que múltiples dimensiones fisiológicas actúan sinérgicamente entre ellas para compensar la pérdida parcial de función de un órgano del sistema; sólo de un fallo total o de la pérdida de un sistema orgánico necesario podría sobrevenir la muerte. No obstante, conscientes de la difícil discriminación entre mortalidad endógena (la derivada de la degeneración de las fuerzas vitales internas) y exógena (la provocada por factores externos), los partidarios de esta perspectiva consideran que esa sinergia está mediatizada además por la interacción con el entorno ya que, como señalan Vallin y Berlinguer (2006:107), la longevidad humana no es una característica biológica taxativamente determinada por la herencia biológica, sino que es el balance efímero entre el potencial de esa herencia y las constricciones medioambientales. Por ello, rechazan por arbitraria e irreal la distinción senescencia/patología y la atribuyen a las limitaciones de los conocimientos científicos actuales para identificar las propiedades de los cambios etiquetados como senescentes. A medida que nuevas dimensiones de la senescencia sean conocidas, identificadas y caracterizadas, como ha ocurrido con el 
“representante arquetípico de un proceso senescente”, el cáncer, las muertes atribuidas a deterioros de las funciones corporales normales o al debilitamiento del sistema inmunológico dejarán de ser muertes "naturales" y pasarán a ser etiquetadas como procesos patológicos o “estados” enfermos, conformándose como un problema que incentivará la investigación de su tratamiento y control (Manton et al, 1999; Manton,1991:99; Horiuchi ${ }^{203}$, 1999). Por este motivo Manton denomina "empírica” a esta perspectiva, ya que considera que la evolución del conocimiento/ tratamiento del cáncer, así como de otras enfermedades crónicas que "parecen tener componentes inmunológicos”, avalan a esta hipótesis ${ }^{204}$.

Así, es posible que el nivel mínimo de mortalidad se pueda reducir más en el futuro no sólo por intervenciones medioambientales, químicas, terapéuticas o por el desarrollo de comportamientos individuales y sociales saludables que reducirían la incidencia de las enfermedades -que no alterarían el potencial genotípico para la longevidad pero sí tenderían a maximizar el potencial fenotípico-, como está ocurriendo hasta ahora, sino por la modificación de las características de la propia senescencia como resultado de la selección natural, la deriva genética, o la manipulación consciente (educación selectiva o ingeniería genética) (Manton et al, 1999:337; Horiuchi, 1999:60; Wilmoth, 1997:53). Esto supondría la entrada en una nueva etapa de la transición sanitaria, de la que ya hay indicios, y en la que se abordaría el control "del proceso intrínseco de degradación del organismo", creando las bases para una nueva “expansión”, similar a la ocurrida con la revolución pasteuriana, las vacunas y los antibióticos, que proporcionaría un “dominio del reloj biológico” y abriría las puertas al aumento de la e(0) hasta edades mucho más avanzadas ${ }^{205}$ (Vallin, 1995c). Cambio histórico en el concepto de salud

\footnotetext{
${ }^{203}$ Frente a la hipótesis "tradicional", Horiuchi (1999:60-61) ve perfectamente posible que a través de la investigación gerontológica, que está investigando los mecanismos fundamentales de la senescencia, se llegue a resultados que puedan eventualmente materializarse en nuevos tipos de tecnologías médicas que retrasen el proceso de senescencia. Se apoya para ello en las investigaciones en las que se ha conseguido extender significativamente la longitud de vida de otras especies con ciertas manipulaciones como restricción calórica, intervención genética, radiación, calor, etc. "estos mecanismos pueden indicar que en el curso de la evolución, los animales han desarrollado ciertos mecanismos para incrementar su habilidad para resistir el estrés y/o reparar daños bajo circunstancias especiales. Estos mecanismos están inactivos en el curso habitual de la vida, pero son activados por algunos estímulos durante la experimentación. Aunque estos resultados de laboratorio no son directamente aplicables a los seres humanos, están emergiendo teorías que sugieren que los procesos de senescencia en el organismo humano pueden ser retrasados activando una capacidad latente que también esté presente en el cuerpo humano”.

204،"Es por tanto, incorrecto asumir que los mecanismos genéticos de una persona son fijos y no alterables por intervención externa. De forma similar, el sistema inmune puede ser alterado por exposición a factores externos y ha crecido la evidencia sobre el hecho de que las infecciones bacterianas o virales podrían ser la causa principal de ciertas enfermedades crónicas” (Manton et al, 1999:340).

${ }^{205}$ Una exposición clara y pedagógica sobre conceptos, técnicas y problemas de implementación relativos a los avances experimentados por la Biología Molecular y a su aplicación en Medicina, así como del alcance real y realista de lo logrado hasta ahora en ese ámbito, puede verse en el magnífico de texto divulgativo de Macip (2008). A partir de unas definiciones accesibles de los principales conceptos manejados en el ámbito de la biomedicina, expone, en el capítulo 1, la importancia real y las posibilidades derivadas del Proyecto Genoma Humano, las bondades y peligros de la manipulación genética y los límites en la aplicación de la terapia génica. En el capítulo 3 aborda el tema del cáncer, esa <<expresión
} 
por el que "la biología, entendida como la dotación genética básica, ya no es destino, sino punto de partida” (Beck y Beck-Gernsheim, 2003:255). En esta perspectiva optimista se sitúan demógrafos como Gómez Redondo (Gómez Redondo et al, 2010, 2007, 2004), Robine (Robine, 2001, 2000a, 2000b; Robine et al, 2004, 2003, 1998, 1995), Caselli y Vallin (Caselli y Vallin, 2001; Vallin, 1995c: 12-14; Caselli, 1993c), o Vaupel (1997), economistas como Guijarro y Peláez (2008), gerontólogos como De Grey (2005, 2004), Kirkwood (2004, 2000), Manton (1999, 1991), Horiuchi (1999) y Wilmoth (1997), o biólogos como Collins (2007), Morata (2005, 2005a) y Rose (2000, 1997).

Optimismo que en la mayoría de los casos se puede calificar de atemperado (Macip, 2008:234), como cuando Rose (2000:62), reconociendo la posibilidad de retrasar el envejecimiento, ya que no es un objetivo de todo o nada, “como poner un hombre en la Luna”, afirma que queda mucho camino aún por recorrer hasta que esa posibilidad se materialice, aunque para él lo más difícil ya se ha conseguido: "se ha resuelto un misterio todavía más básico: por qué apareció el envejecimiento. Merced a tal respuesta, se ha elaborado una estrategia de investigación racional para descubrir las vías bioquímicas cuya manipulación nos podría traer años de vigor”. No obstante, en otros casos, las perspectivas abiertas con el avance de la biología molecular y la utilización de la medicina regenerativa ${ }^{206}$ les lleva a que en su optimismo no perciban ningún límite en la extensión de la longevidad máxima y consideren factible la posibilidad de alcanzar la inmortalidad. Es el caso del Premio Príncipe de Asturias de Investigación Científica y Técnica de 2007, G. Morata, para quien "lo fundamental es que para el hombre la evolución ha dejado de existir. La evolución nos ha creado, pero ya ha dejado de existir. Nosotros dominamos el medio ambiente. Nos afecta cada vez menos. Y no sólo eso: con las nuevas tecnologías genéticas el hombre podrá modificarse a sí mismo. Lo que el hombre vaya a ser en el futuro va a depender de la tecnología que se aplique sobre sí mismo... Puede parecer inconcebible. Pero es cierto. El futuro biológico de la especie humana será un asunto social. El hombre podrá decidir ser más alto, más bajo, más inteligente, más...”. Sobre ese marco general, en el caso específico del envejecimiento y de la muerte afirma que, al no ser biológicamente inevitables, “ya es concebible” aspirar a la inmortalidad, “sólo se trataría de

clonal >> de una célula "sin que nadie la pueda detener", además de la descripción de las distintas técnicas actuales, y de las que se plantean de cara al futuro, que intentan controlarlo. Finalmente, en el capítulo 4 analiza el proceso de envejecimiento, expone las distintas líneas de investigación sobre el mismo, valora críticamente las ofertas de diversas <<píldoras de la inmortalidad >> por la industria farmacéutica para cubrir la creciente demanda de productos antienvejecimiento en la sociedad y concluye reconociendo que "actualmente no disponemos de ninguna estrategia que ejerza un efecto importante sobre el envejecimiento de las células o del cuerpo" (Macip, 2008:252).

${ }^{206}$ La medicina regenerativa es la "rama de la medicina que estudia la posibilidad de sustituir tejidos envejecidos o dañados por otros nuevos, sobre todo mediante el uso de células madre” (Macip, 2008:271). 
manipular en nuestro beneficio los genes que controlan el envejecimiento”, deteniéndolo ${ }^{207}$. En esta línea, el Premio Príncipe de Asturias de Investigación Científica y Técnica de 2001, F. Collins, anticipa que dentro de unas décadas, "la cuestión más urgente a resolver por los humanos quizás no sea <<¿cuánto podemos vivir?>>, sino <<¿cuánto tiempo queremos vivir?>>. Un caso más extremo es el del polémico biogeróntologo A. De Grey, que no sólo persigue frenar el envejecimiento si no suprimirlo a través de procedimientos de bioingeniería que permitan renovar lo que la edad desgasta: "Si detenemos la degeneración de las células no hay motivo por el que nuestro cuerpo no pueda seguir funcionando indefinidamente”. De lo que colige que “viviremos mil años” 208 (De Grey, 2004).

Independientemente de la existencia o no de un límite fijo en la duración máxima de la vida humana, lo cierto es que desde las perspectivas demográfica y sociológica, el debate teórico sobre la idea de la longevidad máxima tiene en sí mismo una importancia secundaria y puramente relacional por cuanto remite a otro debate empírico socialmente más relevante, sustantivo, real y próximo, ya que afecta no sólo a unos pocos individuos “privilegiados” sino a toda la población: el incremento de la longevidad media. En efecto, registrar la mayor longevidad alcanzada por una persona permite hacerse una idea de la longevidad potencial que, al menos teóricamente, podrían alcanzar todos los seres humanos si desapareciesen las causas de muerte prematuras. Si la francesa Jeanne Calment (21/02/1825 - 04/08/1997) murió a la edad de 122 años y 5 meses, eso significa que, en principio, la dotación genética de la especie humana no impide que sus organismos puedan alcanzar esa edad. No obstante, la duración máxima de vida documentada se ha incrementado continuamente a lo largo del tiempo porque sólo puede moverse en una dirección: hacia arriba; por ejemplo, en el caso de Suecia la edad máxima al fallecimiento ha aumentado aproximadamente cinco años durante el periodo 1980-1990 (Robine, 2000a:145). Además, a medida que aumente el tamaño de la población aumentará el

\footnotetext{
207 "La medicina moderna, el dominio de las condiciones ambientales, etc., han alterado las reglas clásicas del juego evolutivo. Además, las nuevas tecnologías biológicas van a permitir en un plazo no muy largo, 100 ó 200 años o quizá menos, que nuestra especie se modifique genéticamente a sí misma. Esto abre unas posibilidades inmensas, ya que podemos dirigir a voluntad el proceso de cambio biológico" (Morata, 2005a).

${ }^{208}$ De Grey, presidente de la Methuselah Foundation, trabaja en el desarrollo del proyecto "Estrategias para la Ingeniería de la Senescencia Insignificante” (SENS), que intenta prevenir y curar el envejecimiento a partir de estrategias combinadas de bioingeniería que reparen la senescencia. De Grey ha identificado siete tipos de daños (pérdida de células, acumulación de células, mutaciones en el núcleo celular, mutaciones en la mitocondria, acumulación de basura dentro y fuera de la célula y acumulación de conexiones químicas indebidas en el material que sostiene a las células) en los tejidos causados por el envejecimiento que deben ser reparados médicamente para lograr el objetivo de incrementar la longevidad. En (De Grey, 2005) se explican algunos de esos daños y el grado de desarrollo de las tecnologías que pueden combatirlos. Admitiendo que la propuesta de De Grey ha permitido afrontar el tema del envejecimiento sin cerrar de antemano ningún camino, la mayoría de los/as investigadores/as la considera, en el mejor de los casos, simplista, cuando no seudo-científica o ciencia-ficción. De forma corrosiva, J.M. Ribera Casado, catedrático de Geriatría de la U.C., se refiere a ella señalando que "hasta ahora lo único que frena la vejez es la muerte” (EL PAÍS, 24/02/08:47).
} 
récord de longevidad, aunque no se modificasen en absoluto los factores biológicos que determinan la senescencia. De esta forma, aunque parece difícil que a corto plazo se supere el record actual no es imposible y, de hecho, las probabilidades de que se supere aumentan, ceteris paribus, en poblaciones en las que cada vez más gente alcanza edades cada vez más elevadas ${ }^{209}$. Asimismo, como señala Wilmoth (1997:61), probar o no la existencia de límites biológicos que desmientan la experiencia actual no es hoy una cuestión prioritaria; cuando se trata de poblaciones y no de individuos aislados, lo política y socialmente relevante es "si nos aproximamos al límite biológico de la longevidad, no si tal límite existe”. Es decir, ¿tiene la longevidad humana límites a la vista?, y ¿cuántas personas podrán acercarse a dichos límites?.

El récord de longevidad máxima es una promesa de futuro, que hasta hace relativamente poco tiempo se consideraba que estaba determinado sólo por las características genéticas de la especie humana. El debate reseñado entre los partidarios de la hipótesis "tradicional” y los de la emergente hipótesis "prolongevista”, que creen en la modificación de la senescencia por intervención humana, refleja las profundas divergencias existentes al respecto entre ambas perspectivas; diferencias que asimismo se trasladan a la hora de prever la evolución futura de la longevidad media de la población. Sin embargo, en este caso las discrepancias, aunque esenciales, no son tan radicales ya que desde ambas perspectivas se asume que lograr mayores incrementos en la duración media de la vida humana va a depender de la evolución futura de un conjunto de múltiples factores en interacción. Es este complejo escenario el que hace irrelevante la duración máxima de la vida humana para las propias vidas de los individuos, ya que las duraciones de éstas son el resultado final de biografías construidas sobre la diversidad de la dotación genética, la variedad de los factores medioambientales, la desigualdad de los factores estructurales, y la mezcla de los estilos de vida, lo que en conjunto "garantiza" que la inmensa mayoría de la población morirá antes de batir o siquiera aproximarse al record de longevidad. El hecho de que la especie humana sea una especie heterogénea, junto con la incidencia de entornos asimismo heterogéneos, es lo que conlleva que la duración máxima de vida alcanzable sea siempre, por definición, mayor que la duración media efectiva ${ }^{210}$.

\footnotetext{
${ }^{209}$ Olshansky y Carnes (2001:231) muestran gráficamente su escepticismo ante una respuesta afirmativa a la cuestión “¿podemos todos vivir ciento veinte años?” cuando señalan que "cada billete de lotería tiene un número único y cada persona tiene un potencial genético único de longevidad... Aunque alguien algún día llegara a superar el récord actual de ciento veintidós años de vida, las probabilidades de poseer la combinación ganadora de genes, entorno y suerte como para batir ese récord son aún menores que las de ganar la lotería”. Más gráfico es aún Austad (1998:31) cuando afirma, refiriéndose concretamente al caso de Jeanne Calment, que "incluso con todos los progresos de la medicina actual, se tiene más probabilidades de ser alcanzado por un rayo que de vivir hasta los ciento diez años, por no hablar de los ciento veinte o más... si la duración máxima de la vida humana está aumentando, lo hace al paso de un glaciar".

${ }_{210}$ Robert P. Wadlow (Estados Unidos, 1918-1940), el hombre más alto del que se tiene noticia médica 2,72 m), y Manute Bol (Sudán, 1962-2010), el jugador más alto que ha pasado por la liga de baloncesto norteamericana (2,32 m), constituyen dos ejemplos de la altura potencial máxima a la que podría llegar la
} 
El consenso existente respecto a que los límites de la e(0) no están impuestos sólo por la estructura misma del organismo humano desaparece a la hora de prever la evolución futura de la duración promedio de la vida humana. Para los partidarios de la hipótesis "tradicional”, la existencia de un tope máximo a la duración de la vida determina que, como mucho, la e(0) pueda incrementarse hasta esa edad máxima. No obstante, dadas las circunstancias señaladas, asumen como más probable un incremento moderado de la e $(0)^{211}$ siempre que se produzcan mejoras en el tratamiento de las enfermedades, haya cambios estructurales y/o medioambientales que permitan el acceso a mejores condiciones de vida a un número mayor de personas, o se produzcan cambios generalizados entre la población hacia estilos de vida más saludables $^{212}$. Por su parte, los “prolongevistas” ironizan con el “estatus casi mítico” otorgado tanto a la creencia de una duración de la vida humana con obsolescencia incorporada (a los 120 años), como a la creencia sobrevenida de una e(0) con duración igualmente tasada (en 85 años) (Wilmoth, 1997:45). Asumen que si no hay un plan biológico de senescencia y los individuos no están programados para morir, las intervenciones en la base genética y molecular de la enfermedad -incluido el proceso de senescencia- que posibiliten aumentar la duración máxima de la vida son las mismas que permitirán a un número creciente de personas vivir hasta edades más avanzadas, por lo que asimismo la e(0) se incrementará. No obstante, dado el alcance real de los conocimientos actuales sobre los procesos bio-moleculares, del nivel conseguido en el desarrollo de tecnologías bio-médicas eficaces, así como del tiempo necesario para que éstas surtan efectos, los partidarios de esta perspectiva, con prudencia, consideran que sólo cabe

especie humana. Personalidades como Goethe, Mozart o Einstein, tuvieron un Coeficiente de Inteligencia muy elevado, y por tanto son una muestra de la capacidad potencial alcanzable por los seres humanos en ese ámbito. Al margen de la necesidad de investigar ambos procesos para poder obtener información y extender a aquellas personas que lo deseen esas cualidades (altura e inteligencia), ¿cabe pensar en la generalización de las mismas a todas las personas independientemente de sus condiciones genéticas, ambientales, socioeconómicas, etc.?. De igual forma, no hay razones objetivas que permitan suponer una potencial longevidad máxima al alcance de todos los individuos.

211 "No creo que dispongamos pronto de la capacidad de manipular lo que parece ser la duración de la vida humana fijada en unos ciento quince años. Incluso si concediéramos que, a una escala de tiempo evolutiva, la duración de la vida humana aumentara de manera natural, el incremento sería imperceptible a lo largo de varios milenios. Si el pasado sirve de guía, podrían pasar diez mil años o más antes de que la duración máxima de la vida humana llegara tan sólo a los ciento veinte años. Soy muy pesimista en cuanto a que, en el siglo próximo, sepamos lo suficiente sobre evolución humana para ser capaces de acelerar los procesos que controlan nuestra vida en aumento” (Hayflick, 1999:422).

${ }^{212}$ Un ejemplo diáfano de que es posible lograr mejoras en la e(0), aplicando los tratamientos terapéuticos disponibles en la actualidad, lo ofrecen los estudios pormenorizados de la mortalidad por cánceres en España realizados bajo la dirección de López-Abente: "El cáncer es más frecuente en unas áreas que en otras y, en términos teóricos, es posible hacer descender la mortalidad hasta los niveles de las áreas de menor riesgo. El reto está en encontrar las razones de esas desigualdades demostrándolas científicamente” (López-Abente et al, 1996:2). 
esperar incrementos moderados de la e(0) a corto o, incluso, a medio plazo ${ }^{213}$ (Macip, 2008; Rose, 2000; Manton et al, 1999:341).

Al margen de las incertidumbres temporales existentes sobre cuándo llegarán los nuevos avances biomédicos y cuándo empezarán a notarse sus efectos, lo cierto es que, dada la multidimensionalidad de los procesos de salud/enfermedad/muerte, su incidencia en los límites de la longevidad humana está mediatizada, y puede ser frenada, por constricciones societales, económicas y ecológicas, además de estar condicionada por la provisión de cuidados de salud (Ispisúa, Rasskin y Raya, 2002b). Es decir, por un lado se verá influida por el previsible mantenimiento de las desiguales condiciones estructurales actuales lo que impediría, como ha ocurrido hasta ahora, que todos los individuos pudieran beneficiarse en igual medida de los efectos de esas nuevas biotecnologías ${ }^{214}$. Esto podría suceder, según Eurostat (1998:12), porque su elevado coste haría de ellas un bien escaso e inaccesible para los estratos más desfavorecidos de la pirámide social; porque determinados tratamientos que incluyeran recursos limitados, como órganos o "nuevos órganos" para trasplante, obligaría a la selección de personas para recibir tratamiento, o; porque las características de algunos tratamientos los hagan técnicamente inadecuados para ser aplicados en personas ancianas ${ }^{215}$. Por tanto, aún en el supuesto de que se

\footnotetext{
213 “A corto plazo no todas las enfermedades se beneficiarán mucho de las mejoras en los servicios de salud y de mejoras en el conocimiento médico y en los estilos de vida saludables. Parece, por ejemplo, que sólo se podrá alcanzar una reducción moderada y gradual de la mortalidad por cáncer... Muchos expertos piensan que la terapia génica para muchas enfermedades afectará positivamente la longevidad de cohortes que nacerán después de 2020. En 2050 estas generaciones tendrán 30 años y estarán en una etapa de la vida en que las tasas de muerte aún son muy bajas, lo que no afectará a corto plazo muy intensamente a la e(0). Por supuesto, la salud de las cohortes más ancianas también se mejorará a través de progresos médicos, pero puede esperarse que como en el pasado esto será un proceso muy gradual y las reducciones de la mortalidad no serán muy grandes en las próximas décadas” (Eurostat, 1998:12-13).

${ }^{214}$ En una entrevista en la que se refería a esta cuestión, Valentí Fuster, uno de los cardiólogos más reputados a nivel mundial, no sólo mostraba su escepticismo respecto a la rapidez y extensión social de la aplicación de la "revolución genómica", sino que denunciaba el absurdo, a la par que alertaba sobre sus graves consecuencias, que las constricciones sociales de todo tipo estaban generando: "Vivimos entre dos paradojas. La primera es que la tecnología nueva es muy cara, y sin embargo no estamos empleando el dinero suficiente en una prevención eficaz de la enfermedad cardiovascular, que por eso esta creciendo de manera epidémica (se avecina una trágica epidemia cardiovascular global. La enfermedad cardiovascular aumentará un 30\% en los próximos 15 años en Occidente, y un 100\% en los países en desarrollo. Es una epidemia adquirida, una enfermedad de las sociedades de consumo, que se genera por la obesidad, por la diabetes, por la hipertensión arterial, por el tabaquismo, etc., y todos esos factores están aumentando globalmente). La segunda paradoja es que la investigación va tantas millas por delante de su aplicación que por mucho que descubramos, no podemos aplicarlo clínicamente. ¿cómo vamos a individualizar la medicina cuando no somos capaces de manejar cosas tan globales como la hipertensión, el colesterol, la diabetes, la obesidad o el tabaquismo?... Sólo la prevención podrá frenar la epidemia global... Hay factores sociológicos y culturales importantísimos que hacen que fumemos o comamos en exceso. Es una de las razones por las que veo muy difícil que la enfermedad cardiovascular llegue a vencerse" (EL PAÍS, 22/07/03:25).

${ }^{215}$ Parece razonable contemplar que si en algún momento se llegara a descubrir un sistema para alargar la vida sería caro y, al menos al principio, sólo sería accesible para las personas más adineradas. Lo que reforzaría la dualización del modelo social, además de perpetuarla puesto que las personas más adineradas tendrían más tiempo para incrementar su fortuna (Macip, 2008:237). La utilización de los antibióticos y
} 
dispusiera de los conocimientos necesarios para lograr maximizar la duración de la vida humana, las constricciones señaladas limitarían el acceso a los mismos, por lo que, incluso con el supuesto irreal de que todos los individuos fueran genéticamente homogéneos, las desigualdades ante la muerte entre categorías sociales frenarían notablemente el aumento del promedio de la duración de vida ${ }^{216}$. Por otro lado, existe un intenso debate sobre las implicaciones económicas de la extensión de la longevidad y la conveniencia de la misma. Se señala, por ejemplo, la incidencia sobre la eficiencia en la actividad productiva, la necesidad de ampliar los puestos de trabajo para ocupar a una población mucho más voluminosa, las tensiones en el mercado de trabajo con la población joven y, sobre todo, las graves consecuencias que puede tener para los Estados y su creciente necesidad de recursos para realizar adecuadamente sus funciones (pensiones, asistencia, etc.). Asimismo, se alerta sobre los problemas de sostenibilidad ecológica derivados de añadir un número creciente de personas mayores en un mundo ya superpoblado. Finalmente, los esfuerzos por detener el envejecimiento pueden verse frenados también por consideraciones éticas desde posiciones ideológicas conservadoras, al identificarlos con procesos que van en contra del $<<$ orden natural $>>$ de las cosas, o desde posiciones religiosas, al verlos como un intento de $<<$ jugar a ser Dios $>>^{217}$ (Macip, 2008:235-238).

A estos frenos estructurales y culturales en la evolución de la e(0) se suma actualmente otro poderoso freno demográfico resaltado por Olshansky y Carnes (2001:94-118; Olshansky, Carnes y Cassel, 1993), la <<entropía de la tabla de vida>>, que explica por qué la e(0) para los seres humanos no aumentará pronto hasta los cien o más años. En el fondo de la misma subyace la idea de que la duración de la vida, como la capacidad de correr, "es un fenómeno de la herencia biológica que está sometido a limitaciones impuestas por programas genéticos de crecimiento, desarrollo y reproducción ${ }^{218}$. Si la duración de la vida de los individuos tiene

de los tratamientos del SIDA son dos ejemplos diáfanos de desigual acceso social a los avances científicos.

216 "Si se tratase en efecto de una simple mutación tecnológica, comparable a la que se conoció con la revolución pasteuriana, las vacunas y los antibióticos, en resumen la puesta a punto de un medio simple, eficaz y barato de dominio del envejecimiento biológico, se podría imaginar, mutatis mutandis, una nueva fase de progreso sanitario rápida y desbaratando todas las fronteras socioeconómicas y culturales. En un primer tiempo favorecería necesariamente a los provistos, pero ulteriormente, se podría esperar que se extienda el beneficio a todos. $\mathrm{Si}$, al contrario, y lo que sucede hoy me incita a dar más credibilidad a esta hipótesis, el dominio del envejecimiento celular responde más todavía que hoy la lucha contra las enfermedades cardiovasculares y los cánceres, a una cooperación en todos los instantes entre el paciente y las estructuras sanitarias, con gran acompañamiento de medios tecnológicos costosos y sofisticados, esto difiere a mucho más tarde, y quizá hasta las calendas griegas, la igualación de oportunidades ante la muerte" (Vallin, 1995c:13-14).

${ }^{217}$ Lo que no deja de ser irónico, puesto que todos los avances médicos han perseguido precisamente incrementar la longevidad. La investigación de las causas del envejecimiento "no va más en contra de los principios divinos que intentar curar el cáncer” (Macip, 2008:236).

${ }^{218}$ Olshansky y Carnes (2001:110-111) utilizan el símil de la capacidad de correr para mostrar que las limitaciones impuestas por el diseño de un cuerpo genéticamente determinado impide reducir 
limitaciones biológicas, a nivel colectivo tiene que haber también límites biológicos a la esperanza de vida de las poblaciones de las que forman parte”. Por ello, no se puede pronosticar la evolución futura de la e(0) sin tener en cuenta las restricciones biológicas que limitan la duración de la vida de todos los individuos. Así, la entropía de las tablas de vida consiste en que a medida que la e(0) crezca más allá de los niveles actuales (80 años y más), las tasas de mortalidad tendrían que disminuir a un ritmo cada vez más acelerado para lograr tan siquiera pequeños incrementos en la e(0). En efecto, los grandes incrementos de la e(0) durante el siglo XX se lograron "explotando una gran reserva de años de vida a edades tempranas"; sin embargo, las tasas de mortalidad en esas edades son tan bajas en la actualidad que se puede considerar que ese filón de edad para la e(0) está casi agotado. De esta forma, sólo se puede producir un incremento notable en la $\mathrm{e}(0)$ si existen reservas en otras edades, y la única disponible, en principio, es la de las grandes edades. No obstante, esta reserva de edad también tiene dos limitaciones importantes en estos momentos, por un lado, la fuerza de la mortalidad es tan elevada en las edades avanzadas que la veta de e(0) aprovechable es insignificante en comparación con la que estaba disponible a principios del siglo XX; por otro lado, su explotación "será extremadamente difícil porque los que llegan a la vejez han acumulado a lo largo de su existencia considerables daños en los genes, células y tejidos, deterioros complejos que plantean un enorme desafío al tratamiento biomédico”.

La entropía de la tabla de vida significa, por tanto, que a medida que crece la e(0), ésta se hace menos sensible a las reducciones de las tasas de mortalidad en las edades avanzadas. $\mathrm{O}$ dicho de otra forma, que es mucho más difícil añadir 30-40 años a la vida de un octogenario en la actualidad, y conseguir una e(0) de110-120 años, que lo que resultó añadírselos a un recién nacido español desde 1900 hasta la actualidad ${ }^{219}$. De hecho, según las estimaciones realizadas por el grupo de Olshansky ${ }^{220}$, una e(0) de 100 años requiere la reducción o supresión drástica de

ilimitadamente "el récord mundial de la carrera de la milla", ya que llegaría un momento que "alguien correría la milla a velocidades que son biomecánicamente imposibles para el cuerpo humano".

${ }^{219}$ En unas proyecciones de población a muy largo plazo, NU (2004): World Population in 2300, Naciones Unidas asume un crecimiento constante de la e(0) hasta el 2300. En este marco, el país con mayor e(0) al final del periodo de proyección sería Japón con una esperanza de vida de 108 años para las mujeres y de 104 años para los hombres. La población española, por su parte, tendría una e(0) de 107 años entre las mujeres y 104 años entre los hombres, en 2300. Estos datos parecen contradecir la hipótesis de una duración máxima fija de la vida humana y, en efecto, la asunción de la no existencia de un límite superior a la e(0) con la que se ha realizado la proyección así lo confirma. Sin embargo, en la propia exposición de la metodología utilizada se resalta el carácter puramente especulativo y voluntarista de ese supuesto ya que "en estos momentos no existe evidencia empírica de que puedan alcanzarse probabilidades verosímiles de muerte a las edades más elevadas” como las empleadas (NU, 2004:21).

${ }^{220}$ Con un planeamiento muy práctico, las estimaciones realizadas por Olshansky, Carnes y Cassel (1993) se realizan de acuerdo con la siguiente metodología: "más que predecir los límites inferiores de la mortalidad, nos preguntamos qué calendarios de mortalidad, o tasas específicas de mortalidad por edad, se necesitarían para elevar la esperanza de vida desde los niveles actuales hasta varios objetivos de edad comprendidos entre los 80 y los 120 años”. Un ejemplo diáfano de lo que significa la entropía de la tabla de vida es el hecho de que cuando la e(0) es de 50 años se estima que es necesario una reducción del 4,1\% 
casi todas las causas de muerte que existen hoy, lo que se sitúa claramente fuera de la realidad, y más cuando en estos momentos la mortalidad por algunas de estas causas está aumentando. Aún en el supuesto de que esa hipótesis fuera factible, las estimaciones indican que pasaría un siglo antes de que la esperanza de vida subiera de los ochenta a los cien años. En suma, las limitaciones demográficas derivadas de la entropía de la tabla de vida, reflejo de las restricciones orgánicas individuales, les lleva a concluir que "en ausencia de revoluciones científicas que modifiquen la tasa básica de envejecimiento, es improbable que la esperanza de vida exceda de los 85 años” (Olshansky, Carnes y Cassel, 1993:11).

Uno de los instrumentos teóricos empleados para explorar la posible evolución de la e(0) es el evaluar la ganancia que cabe esperar en ésta cuando se suprime alguna causa de muerte, para ello se construye una tabla de mortalidad en ausencia de una o varias causas de muerte (Livi-Bacci, 1993:177-184; Pressat, 1985:42-46; Monnier y Nizard, 1985:119-122). El cálculo de esta tabla se basa en la teoría de los riesgos competitivos, es decir, en la independencia entre la causa eliminada y el conjunto de las otras causas, y es precisamente esta hipótesis, poco realista en la mayoría de las ocasiones, su mayor debilidad y la fuente principal de las críticas que recibe este método ${ }^{221}$. En este sentido, como resalta Livi-Bacci (1993:179), "la hipótesis de la independencia es un concepto abstracto, aceptable solamente como un primera aproximación al problema y sólo a causa de nuestro desconocimiento de las interrelaciones reales existentes entre las causa de muerte”. Así, adoptando las máximas cautelas, su utilización, como ocurre con otras metodologías igualmente “artificiales” -las tablas de mortalidad del momento; las proyecciones de población-, puede servir como referencia de lo que probablemente ocurriría si se dieran determinados supuestos. Concretamente, la comparación de la vida media resultante de una tabla de mortalidad en ausencia de una causa y la que se deriva de una tabla de mortalidad general permite evaluar la importancia relativa de la

de las tasas de mortalidad por edad para incrementar un año la esperanza de vida. Sin embargo, para incrementar la e(0) de 80 a 81 años se requiere que esa reducción de las tasas de mortalidad sea del 9,1\%. 221 "Este razonamiento presupone una independencia de los componentes humanos (de los órganos, por ejemplo) muy difícil de admitir. Y de hecho, dicha independencia no existe, puesto que es evidente que la <<duración >> de cada componente individual está condicionada por el modo de funcionamiento de los otros, y que el funcionamiento inadecuado (enfermedad) de un órgano puede someter a esfuerzos a otros órganos y comprometer su duración... Es probable que la causa de muerte eliminada A afecte preferentemente a individuos portadores de ciertas características, a su vez correlacionadas también con la causa de muerte B; por tanto, la eliminación de A podría hacer aumentar la incidencia de B. También puede ocurrir el caso contrario, que la eliminación de la causa de muerte $\mathrm{Z}$ provoque una reducción de la incidencia de todas las demás causas de muerte” (Livi- Bacci, 1993:179). En el plano puramente empírico resulta imposible delimitar, aislar y estimar el efecto neto de cada uno de los factores de riesgo asociados a cada causa de muerte. Así, los factores que determinan la reducción de la mortalidad actúan "no sobre un conjunto reducido y delimitado de causas, sino sobre grupos de conjunto causales con fronteras borrosas y amplias interrelaciones entre ellos (Viciana, 1998:206). 
causa suprimida al estimar el efecto de su eliminación en la reducción de la fuerza de la mortalidad $^{222}$ (Monnier y Nizard, 1985:120).

En todos los países desarrollados las tasas de mortalidad de los menores de 50 años son comparativamente tan bajas en la actualidad (7,7\% del total de decesos en España) que la eliminación completa de todas las muertes antes de esa edad no incrementaría más que mínimamente la e $(0)^{223}$. En el año 1995, por ejemplo, se estimó que la eliminación completa de la mortalidad infantil de la Comunidad Europea, algo imposible por otra parte, elevaría sólo 0,6 años la e(0). Este incremento sería de 1,2 años si se eliminaba toda la mortalidad entre 1 y 34 años, y de 4,1 años y 3,3 años en el caso del control de todas las causas de muerte en los grupos de edad 35-64 años y 65-74 años, respectivamente (Comisión de las Comunidades Europeas, 1995:39). Obviamente, la eliminación de las defunciones por una causa de muerte determinada no significa que las personas que habrían fallecido por ella eviten los riesgos referidos al resto de causas y vivan eternamente, sino que están expuestos a padecer y morir por ellos. Esta es la razón por la que la eliminación de causas de muerte importantes comporta prolongaciones modestas de la e(0). Por ejemplo, la eliminación de los tumores, mayoritariamente padecidos por personas adultasadultas o ancianas, implica padecer otras enfermedades con riesgos muy altos en esas edades, por lo que la ganancia media de vida no será muy elevada. Otro caso distinto son las muertes por accidentes de tráfico, causa que sí que es independiente del resto de causas de muerte y que afecta principalmente a la población joven. Por ello, y aunque el peso absoluto de esta causa en la mortalidad total no es muy elevado, la eliminación de la misma genera una ganancia relativa de la e(0) más elevada (Livi-Bacci, 1993:181-182).

No obstante lo anterior, desde la perspectiva prolongevista se afirma que, de acuerdo a la experiencia acumulada hasta ahora, no necesariamente existe un tope de vida máximo fijo y tampoco existe un tope que limite a la esperanza de vida. En efecto, bajo un proceso general de concentración de la mayoría de los fallecimientos en las edades más elevadas, es decir, de rectangularización de las curvas de supervivencia, los datos más recientes sobre la evolución de la distribución de las muertes en esas edades evidencian un continuo desplazamiento hacia la derecha en la distribución de la mortalidad, sin visos de que, al menos por el momento, exista

\footnotetext{
${ }^{222}$ En relación con algunos conceptos que se desarrollan en el epígrafe siguiente, Robine y colaboradores señalan lo siguiente respecto a la utilización de esta metodología: "gracias al cálculo de las mejoras en la esperanza de salud resultantes de la eliminación de enfermedades concretas, es posible determinar la prioridades de salud pública en relación con los efectos previstos en la esperanza de vida, la esperanza de vida sin discapacidades y el tiempo de vida con discapacidades” (Robine et al, 1999:106).

${ }^{223}$ Por ejemplo, con datos de principios de la década de 1990, Hayflick (1999:147-152) estimó que la eliminación de todas las muertes de los menores de 50 años sólo incrementaría la e(0) de la población de Estados Unidos en 3,5 años.
} 
un tope infranqueable (Gómez Redondo, Génova y Robles, 2007:55; Blanes, 2007:145; Puga, 2002:35; Oeppen y Vaupel, 2002:1029).

Para dilucidar empíricamente esta cuestión para el caso español en la actualidad, se toma como referencia a Muñoz Pradas ${ }^{224}$ (2003:144-146), quien considera que el proceso de $<<$ reordenamiento >> de la mortalidad en las sociedades más avanzadas está conformado por dos fenómenos cuya vinculación es indeterminada: la reducción de la mortalidad y la rectangularización. Por ello, aconseja analizarlo abordando por separado ambos fenómenos, utilizando indicadores de tendencia central para analizar los cambios en el nivel de mortalidad (las edades media -o la e(0)-, mediana y modal ${ }^{225}$ de los decesos del año), e indicadores de dispersión para examinar las mutaciones en la distribución de los decesos (la desviación estándar de la edad de los fallecimientos, el recorrido intercuartílico entre el 75 y el 25 por ciento de los decesos). En el Cuadro 4. 17. ${ }^{226}$ se recogen los datos correspondientes a algunos de esos indicadores para el conjunto de la población española desde 1975 hasta 2009. Los tres indicadores de tendencia central incluidos en el mismo experimentan un crecimiento ininterrumpido a lo largo del periodo de análisis, lo que reflejaría claramente que las fuerzas de la mortalidad tienden a desplazarse hacia edades cada vez más elevadas, moviendo hasta ellas la supervivencia. Así, en el periodo analizado la media de edad de los fallecidos se incrementó en más de 10 años; la edad mediana o percentil 50, es decir, la edad que divide en dos la distribución por edad de las personas fallecidas en cada año, se elevó en 8 años; finalmente, la edad modal, la que mide cuál es la duración más común de la vida, lo hizo en 7 años. Es decir, las muertes se producen a edades cada vez más altas, más de la mitad de los fallecimientos ocurren después de los 80 años, y la edad en la que se concentra el mayor número de decesos es asimismo cada vez más elevada. $\mathrm{Y}$, a pesar de que esas tres medidas de tendencia central se localizan en etapas cada vez más avanzadas de la vida, el número de supervivientes a las mismas es cada vez mayor (Blanes, 2007:137).

\footnotetext{
${ }^{224}$ En su análisis de la rectangularización de las curvas de supervivencia en España, Muñoz Pradas (2003) constata la existencia de dos etapas diferenciadas, antes de 1960 y después de esa década, con un periodo de tránsito intermedio, los años sesenta. Como consecuencia de la evolución descendente de la mortalidad a lo largo del siglo XX, el proceso de rectangularización fue intenso hasta la década de 1960 y más atemperado desde los años ochenta.

${ }^{225}$ El hecho de que en la actualidad la mejora de la longevidad se asiente en la reducción de la mortalidad en las edades adultas y avanzadas, limita la capacidad analítica de la esperanza de vida (o de la edad media de los fallecimientos), al ser ésta muy dependiente del nivel de riesgos en las edades tempranas, y aconseja emplear la edad modal, que "expresa mejor los avances (o retrocesos) en la duración de la vida a lo largo del siglo XX” (Muñoz Pradas, 2003:147 y 152).

${ }^{226}$ Los datos de este cuadro se han calculado sobre la base de la vida media vivida por las personas que fallecen en cada intervalo de edad. Para los años 1975 y 1981, se ha estimado este indicador aplicando la metodología del INE para la elaboración de las tablas de Mortalidad (INEbase) a la información sobre las tablas de mortalidad de esos años obtenida en www.ivie.es (Francisco Goerlich e Ivie). Para 1991, 2000 y 2009, se han utilizado los datos sobre ese indicador aportados directamente por el INE en las tablas de mortalidad correspondientes a esos años.
} 
Por su parte, la evolución descendente de la desviación típica, y del coeficiente de variación, certificaría la cada vez mayor concentración de los decesos en las edades más altas. Dado que, además, las edades media, mediana y modal de deceso siguen un lento proceso de convergencia cabe sugerir que, con el tiempo, la distribución de los fallecimientos por edad podría aproximarse hacia una curva normal -“normalización” o "simetrización” alrededor de la moda- en las últimas etapas de la vida (Muñoz Pradas, 2003:144). Lo que lleva a este autor a considerar la existencia de un margen de mejora potencial en el reordenamiento de la mortalidad, con mayor concentración de la mortalidad y, por tanto, de aumento de la longevidad (Muñoz Pradas, 2003:157). No obstante, en su análisis para contrastar la misma en el caso español, considera que esa tendencia se ha estancado a finales del siglo XX (Muñoz Pradas, 2003:155-156). Sobre ese margen de mejora potencial, Blanes (2007:140), al comparar los datos de mortalidad de las mujeres ancianas españolas y japonesas, constata que el proceso de concentración no es irreversible como lo demuestra el que la desviación típica de los decesos a partir de la edad modal entre las japonesas es más alta que la de las españolas, a pesar de situarse su moda por encima de la de éstas.

CUADRO 4.17.: INDICADORES DE MORTALIDAD EN ESPAÑA. 1975, 1980, 1991,
\begin{tabular}{|l|c|c|c|c|c|} 
2000 Y 2009 & $\mathbf{1 9 7 5}$ & $\mathbf{1 9 8 0}$ & $\mathbf{1 9 9 1}$ & $\mathbf{2 0 0 0}$ & $\mathbf{2 0 0 9}$ \\
\hline & 67,33 & 69,47 & 72,74 & 75,56 & 77,78 \\
\hline Edad media de deceso (años) & 73,10 & 74,48 & 77,35 & 79,02 & 81,44 \\
\hline Edad mediana de deceso (años) & 79,34 & 79,90 & 83,03 & 85,92 & 86,33 \\
\hline Edad modal de deceso (años) & 21,63 & 19,75 & 17,80 & 16,18 & 15,31 \\
\hline Desviación típica & 0,32 & 0,28 & 0,24 & 0,21 & 0,20 \\
\hline Coeficiente de variación
\end{tabular}

Fte: Elaboración propia a partir del MNP y Tablas de Mortalidad de 1991, 2000 y 2009 (INEbase) y Tablas de Mortalidad de 1975 y 1980 elaboradas por Francisco Goerlich (www.ivie.es)

El análisis de la mortalidad del conjunto de la población española, a partir de los datos recogidos en el Cuadro 4.17., no difiere demasiado de lo avanzado por Muñoz Pradas (2003) o, más recientemente, por Gómez Redondo et al (2007, 2004) y Blanes (2007), y no sólo certifica el proceso de rectangularización/compresión de la mortalidad, sino que, efectivamente, constata el desplazamiento hacia la derecha de la distribución de la mortalidad, como queda reflejado en el Grafico 4.10. Por tanto, dado que las edades media, mediana y modal de muerte siguen aumentando, si existe un tope de vida máximo no se ha alcanzado, y desde luego es más elevado que el establecido por Fries. 


\section{GRÁFICO 4.10.: DISTRIBUCIÓN DE LAS DEFUNCIONES OCURRIDAS ENTRE CADA DOS EDADES EXACTAS. ESPAÑA. 1985-86, 1990-91, 2000-01 Y 2008-09}

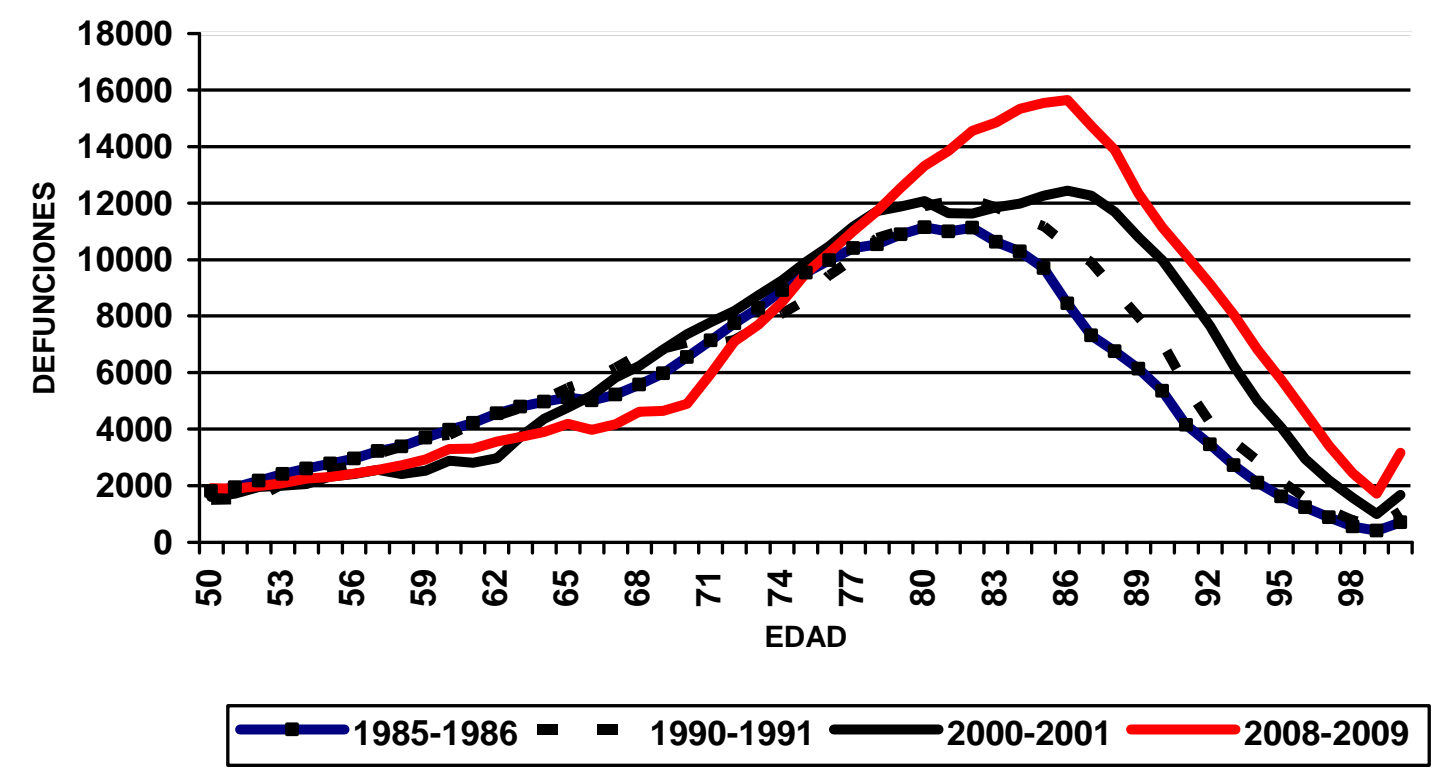

Fte: Elaboración a partir de INE: Tablas de Mortalidad de la Población Española,

Cabe destacar dos hechos relevantes del proceso de rectangularización/concentración de la mortalidad en las edades elevadas: la población española en la actualidad, al igual que la del resto de los países desarrollados, muere más vieja (mayor edad media de muerte) y además muere más envejecida (mayor concentración de decesos, reflejado en un menor coeficiente de variación). Como consecuencia de estas tendencias, distintas investigaciones han centrado su atención en la evolución de la mortalidad de los grupos de edad más elevada, que hasta hace relativamente poco tiempo apenas eran considerados en los estudios demográficos. Así, por ejemplo, con los datos recientes recabados en diversos estudios, bien en laboratorio experimentando con otras especies, bien de los seres humanos una vez que se ha podido medir la mortalidad a edades muy elevadas, se ha constatado que, en contra de lo asumido por la perspectiva "tradicional” y como se señaló más arriba, aunque las tasas de mortalidad crecen entre los muy mayores su ritmo de crecimiento desacelera con la edad y lo hacen por debajo de la senda exponencial; concretamente, entre los seres humanos, una vez superados los 80-85 años de edad, el ritmo de crecimiento de la mortalidad con la edad tiende a desacelerarse ${ }^{227}$ (Robine y Vaupel, 2002; Wilmoth, 1997; Vaupel, 1997; Rose, 1997; Mésle, 1995, Vaupel et al, 1992). Robine (2001) señala que este resultado cambia tres conceptos centrales de la biología y la

\footnotetext{
${ }^{227}$ Vaupel (1997) y Wilmoth (1997) resaltan que si fuera cierta la teoría evolucionista del envejecimiento, las tasas de mortalidad de la especie humana crecerían exponencialmente con la edad (Ley de Gompertz), como se había admitido mayoritariamente hasta hace muy poco. La desaceleración de la mortalidad en las edades más avanzadas, que ha constituido una sorpresa y un "shock" para los biólogos y los gerontólogos, junto con otras observaciones empíricas llevan a Vaupel (1997) y a Carey y Gruenfelder (1997) a rechazar que los mayores sean insignificantes desde el punto de vista de la evolución.
} 
gerontología del envejecimiento: 1) que la senescencia puede ser operacionalmente definida y medida por el incremento continuo en las tasas de mortalidad al aumentar la edad; 2) que el patrón básico de mortalidad de las edades adultas en casi todas las especies sigue el mismo patrón unitario descrito por el modelo Gompertz (incremento exponencial) ${ }^{228}$; 3) que las especies pueden ser caracterizadas por sus duraciones de vida específicas de especie. Este cambio conceptual quedaría explicado por la heterogeneidad genética de las poblaciones humanas, es decir, porque los individuos tienen distintos atributos para la supervivencia (características persistentes, innatas o adquiridas, que afectan a sus probabilidades de supervivencia), que juegan un papel creciente al aumentar la edad. Según Finch (1998), estos atributos, además, pueden ser tales que algunos individuos experimenten distintos grados de senescencia en diferentes medio ambientes; a lo que este autor denomina $<<$ plasticidad del envejecimiento>>.

De ahí, del incremento de la longevidad, la “explosión” reciente de centenarios observada en todos los países desarrollados, especialmente entre las mujeres, y la aparición de los "supercentenarios", aquellas personas que alcanzan los 110 años de vida ${ }^{229}$. Según los cálculos realizados por Robine y Vaupel (2002, 2001), en aproximadamente 20 años, desde 1980 a 2000, la edad máxima a la muerte documentada se ha incrementado en 10 años desde los 112 a los 122 años, siendo la probabilidad anual de muerte a los 110 años en 2000 de 0,52, un nivel similar al de los 114 años, lo que certificaría que la mortalidad en las edades más avanzadas no crece de acuerdo con la curva de Gompertz, sino que parece que se sitúa en una meseta entre los 110-115 años. Estos resultados son para Robine (2001; 2000a:138) una muestra inequívoca de que la idea de una longevidad fija "ha comenzado a hacer agua por todos los lados”, aunque tampoco aportan una evidencia empírica clara de un incremento en longevidad potencial de la especie humana, simplemente, "no tenemos argumentos para predecir que bajo

\footnotetext{
${ }^{228}$ Desde la Biología se ha explicado esta "violación"de la ley de Gompertz por los efectos de la selección genética a partir de una edad elevada, edad que sólo alcanzarían los individuos genéticamente más fuertes, de tal forma que los supervivientes de la parte más alta de la pirámide de edad son cada vez menos representativos de la población en general: "la eliminación precoz de los individuos más frágiles, que son la mayoría, que envejecerían más rápido, y la supervivencia de una minoría más robusta que envejecería más lentamente. Cada una de estas dos subpoblaciones sigue una ley de Gompertz, con unos parámetros distintos. El envejecimiento parece ralentizarse cuando la mayoría frágil casi ha desaparecido y la población está compuesta en su mayoría por supervivientes robustos” (Klarsfeld y Revah, 2002:222223; Kirkwood, 2000:46).

${ }^{229} \mathrm{El}$ aumento del número de centenarios es un fenómeno relativamente reciente que se inicia alrededor de 1800, y que "explota" a partir de la década de 1950, estando bien documentado para Europa y Japón. Los supercentenarios comenzaron a surgir alrededor del año 1960 y su número se ha incrementado de forma regular desde mediados de los setenta. La prevalencia actual de supercentenarios recogida por el Internacional Database on Longevity (IDL) es aproximadamente 10 veces la de mediados de la década de 1970. En la década de 1990 se han validado cinco casos de personas (cuatro mujeres y un hombre) que han superado los 115 años de edad (Robine y Vaupel, 2002; Robine, 2000a:144).
} 
las condiciones medioambientales de mañana, el rendimiento humano en longevidad no será mucho mejor".

En el caso de España, el número de centenarios se multiplicó por 6 entre 1973 y 2004, de los cuales, en conjunto, 8 de cada 10 eran mujeres (Gómez Redondo y García González, 2008). Según los datos definitivos del Censo de Población de España, en 1991 vivían en España 2.959 centenarios (2.231 mujeres, el 75,40\%, y 728 hombres, el 24,60\%); en 2001, esa cifra aumentó hasta los 4.218 (3.310 mujeres, el 78,47\%, y 908 hombres, el 21,53\%), (Cuadro 4.18.). A 1 de enero de 2010, la cifra de centenarios estimada por el INE casi se había incrementado en un 70\% en la última década, 7.155, de los cuales el 74,16\% eran mujeres, 5.306, y el 25,84\% hombres, 1.849 (INE, 2010). En sus proyecciones a largo plazo el INE (INE, 2010) estima además que el número de centenarios continuará creciendo en la primera mitad del siglo XXI hasta multiplicarse por más de 15 el número correspondiente a 2001 (Cuadro 4.18.). Por otra parte, Gómez Redondo y García González (2010a) en un exhaustivo trabajo han verificado los datos de edad correspondientes a los supercentenarios españoles que murieron entre enero de 1987 y abril de 2007, recogidos en el IDL, y cifran el número de los mismos en 28, de los cuales tres (dos mujeres y un hombre) han llegado a celebrar su 114 aniversario.

\begin{tabular}{|c|c|c|c|c|c|}
\hline $\begin{array}{l}\text { CUADI } \\
\text { DISTR }\end{array}$ & $\begin{array}{l}\text { 8.: } E V \\
\text { N POF }\end{array}$ & $\begin{array}{l}\text { IÓN DE } \\
\text { D. ESPAÑ }\end{array}$ & $\begin{array}{l}\text { POBLA } \\
1-2049\end{array}$ & CENTEN & $\begin{array}{lll} & \text { DE } & S\end{array}$ \\
\hline & Total & Hombres & Mujeres & \% Hombres & \% Mujeres \\
\hline 1991 & 2.959 & 728 & 2.231 & 24,60 & $\begin{array}{l}75,40 \\
\end{array}$ \\
\hline 2001 & 4.218 & 908 & 3.310 & 21,53 & 78,47 \\
\hline 2010 & 7.155 & 1.849 & 5.306 & 25,84 & 74,16 \\
\hline 2020 & 14.442 & 4.101 & 10.341 & 28,40 & 71,60 \\
\hline 2030 & 28.977 & 8.845 & 20.133 & $\begin{array}{l}30,52 \\
\end{array}$ & $\begin{array}{l}69,48 \\
\end{array}$ \\
\hline 2040 & 40.429 & 12.707 & 27.722 & 31,43 & 68,57 \\
\hline 2049 & 64.841 & 20.578 & 44.263 & 31,74 & 68,26 \\
\hline
\end{tabular}

Fte: datos de 1991 y 2001, INE: Censos de Población y Vivienda de 1991 y 2001. Resultados definitivos. Datos de 2010 a 2049, (INE, 2010)

A partir de sus estudios con nonagenarios y centenarios, Perls (1998) ha sugerido una hipótesis de <<supervivencia selectiva>> como explicación de la "explosión" de centenarios: "por la razón que sea, algunas personas oponen particular resistencia a las enfermedades que discapacitan y matan a la mayoría antes de los 90 años. En virtud de esa resistencia, no sólo sobreviven, sino que se desenvuelven relativamente libres de achaques... Estos individuos parecen seleccionados para sobrevivir largo tiempo porque poseen rasgos que les capacitan para 
evitar o retrasar las enfermedades que suelen acompañar al envejecimiento”230. Esta versión peculiar de la supervivencia del mejor adaptado viene acompañada, además, de un resultado sorprendente al que Perls denomina <<cruzamiento de género >>: a partir de los 90 años se produce un giro por el que los hombres tienen mejor salud que las mujeres fruto de su mayor y mejor adaptación física y mental ${ }^{231}$. Es ésta, quizá, una de las razones por la que, a pesar de que la mayor longevidad de las mujeres determina que en la actualidad el número de centenarias case triplique al de los varones coetáneos, la tendencia futura de ese número proyectada por el INE sea descendente hasta poco más que duplicarse en el año 2049 (Cuadro 4.18).

El desplazamiento del límite de longevidad media va a constituir, de cara al futuro, el mayor desafío para unas sociedades cada vez más envejecidas. El hecho de que si, por ejemplo, la e(0) llegase a los 91 años significaría que, de cada 100.000 nacidos vivos, 63.000 personas alcanzarían la edad de 90 años y 12.5000 llegarían a centenarios. Esto supondría una profunda modificación de las estructuras demográficas, que, al alterar las condiciones de cohabitación entre las generaciones, aceleraría el motor del cambio social con consecuencias no del todo previsibles en las fases del ciclo vital -al probablemente transformarse el ciclo biológico-, en el conflicto entre las obligaciones de la vida profesional y de la vida familiar - al atenuarse por la posibilidad de disociarlas en el tiempo-, en la transmisión patrimonial -al coincidir y/o convivir en el mismo hogar dos generaciones de personas jubiladas cuidándose mutuamente-, etc. (Loiraux, 1995a). Desafío en el que una de sus dimensiones más importantes es la incertidumbre sobre el discurrir futuro de la calidad vida ligada a la salud en las edades más avanzadas.

\subsubsection{AÑADIR AÑOS A LA VIDA VERSUS AÑADIR VIDA A LOS AÑOS}

"La sociedad se verá pronto obligada a reconocer que la muerte ya no es su principal adversario”

S. J. Olshansky, B.A. Carnes y Ch. K. Cassel

\footnotetext{
${ }^{230}$ Perls (1998:100) utiliza la enfermedad de Alzheimer como ejemplo para demostrar la "hipótesis de la supervivencia selectiva": "la probabilidad de que los varones que sobreviven hasta la segunda mitad de los noventa desarrollen la enfermedad de Alzheimer va disminuyendo a medida que pasan los años. Además, el estado mental del varón medio de esa edad es mejor que el del varón medio octogenario. Quizás esas pautas sean consecuencias de que los hombres susceptibles de padecer enfermedad de Alzheimer suelen fallecer de la afección cuando tienen ochenta y tantos o al poco de entrar en los noventa. Estas tendencias se explicarían si el grupo de varones que alcanza el siglo lo formaran casi exclusivamente individuos insensibles a la enfermedad de Alzheimer y que, por tanto, conservaran sus facultades mentales”.

231 "Sexagenarios y septuagenarios se muestran más proclives que las mujeres a padecer accidentes cerebrovasculares y paros cardíacos. El retraso de estas afecciones permite a las mujeres vivir más que los varones, quienes tienen que afrontar la enfermedad en etapas tempranas. En cifras absolutas, hay bastantes más mujeres de 95 años; en términos de salud mental y física media, los hombres toman entonces la delantera. Los varones sanos que han esquivado las enfermedades demuestran una ventaja: aunque los hombres constituyen sólo el 20\% de los centenarios, el 40\% de los que llegan a 105 años son varones" (Perls, 1998:100-101).
} 
Una tercera cuestión que concita el interés de los investigadores en la relación salud/enfermedad/muerte es la de la calidad de vida conexa al incremento de la longevidad media. Independientemente de cuál sea la longevidad máxima de la vida humana, el continuo crecimiento de la longevidad media -medido a través de la e(0)- que caracteriza a la transición de la mortalidad se ha producido en sus últimas fases como una combinación de una mortalidad decreciente y una morbilidad creciente, modificándose el estado medio de salud de las poblaciones. Es decir, se ha retrasado la edad de muerte, con lo que cada vez sobrevive una proporción mayor de individuos hasta edades cada vez más avanzadas, pero esto no garantiza que los años de vida que se ganan se vivan en completa salud. Como se ha expuesto anteriormente, los incrementos de la e(0) en las dos últimas décadas se han logrado precisamente por reducciones de la mortalidad en las edades más avanzadas. Se sabe que la edad es un factor de riesgo, y que al envejecer un individuo aumentan tanto sus posibilidades de fallecer como las de padecer enfermedades crónicas o las de sufrir algún tipo de discapacidad. Salvo para una minoría "privilegiada" de personas que mueren ancianas "sin haber tenido un catarro en su vida”, para la mayoría de los individuos a partir de una cierta edad `empiezan a aparecer las piteras' por las que se escapa la salud, siendo cada vez más frecuentes los achaques derivados de enfermedades crónicas y/o discapacidades que erosionan su calidad de vida, aumentan su fragilidad y vulnerabilidad, y reducen su autonomía e independencia.

Dado que el estado de salud es un determinante clave de la calidad de vida ${ }^{232}$, la dinámica demográfica descrita ha llevado, inevitablemente, a interrogarse sobre la evolución del balance cantidad de vida/calidad de vida entre la población anciana de los países más desarrollados. Este debate sobre la calidad de los años añadidos de vida se asienta en la resolución de toda una serie de importantes dilemas: ¿es el incremento de la supervivencia un bien primario en sí mismo?, ¿el vivir más años significa que se intercambia calidad de vida por cantidad de vida?, ¿se “disfrutan” o se "sufren” esos años ganados a la muerte?, ¿más años de vida para qué? Dilemas que no son nuevos pero que desde la década de 1960 saltaron al primer plano de las preocupaciones político-sociales como una dimensión a tener muy en cuenta en la evolución futura del Estado de Bienestar. En efecto, el aumento de la e(0), la reducción de la mortalidad, los incrementos de las prevalencias de enfermedades crónicas y de discapacidades,

${ }^{232}$ Cummins (1997) define la "calidad de vida" como un "constructo universal, definido tanto objetiva como subjetivamente, donde los dominios objetivos comprenderían medidas culturalmente relevantes de bienestar objetivo, y los dominios subjetivos comprenderían la satisfacción con las diferentes dimensiones ponderadas por su importancia para el individuo". Concepto multidimensional y complejo sobre el que, sin embargo, no se ha llegado a un acuerdo respecto a los componentes a incluir en estudios globales, lo que ha canalizado el enfoque hacia la perspectiva individual, es decir, hacia las interpretaciones que los propios individuos realizan sobre aquellos aspectos que consideran esenciales en su vida. Entre éstos, tradicionalmente destaca el papel otorgado a la salud (Fernández-Mayorales et al, 2007: 2-5). 
desde finales de esa década, y sobre todo las evoluciones más recientes de la mortalidad y de la morbilidad en las edades más avanzadas, han incrementado el peso de las enfermedades en una sociedad cada vez más envejecida haciendo imprescindible conocer cuál es su impacto presente y prever el futuro sobre la demanda y las necesidades en diversos servicios sociales y de cuidados de salud (Robine, Romieu y Jee, 1998). Como resalta Viciana (1998:8-9), la OMS resumió bien todas estas preocupaciones, sobre el impacto de las previsibles ganancias en la e(0) en la evolución de la salud de las poblaciones, al considerar entre los objetivos promovidos en su estrategia de <<Salud para Todos >> tan importante añadir "más años a la vida" (incrementar la longevidad), como añadir “más vida a los años” (fomentar la participación, relación e intercambio en actividades sociales, culturales). De momento, además, estos dilemas tienen difícil solución ya que, por un lado, la relativa novedad de algunos de los procesos determina que desde el plano empírico no existan series de datos amplias y comparables que permitan extraer conclusiones generales consistentes, fiables y unívocas; en especial respecto a los procesos más recientes como son los derivados de la emergencia de una población muy mayor y frágil: los centenarios y los “supercentenarios”. Por ello, no existe una perspectiva única, clara y compartida por todos los investigadores de tal forma que el análisis agregado del estado de salud/morbilidad referido al mismo proceso de envejecimiento está siendo interpretado de forma diferente por aquéllos. Por otro lado, junto a estas dificultades de interpretación, y condicionándolas en buena medida, se encuentran toda una serie de problemas metodológicos como son los derivados de que la medida de la salud no es fácil ya que la buena salud, de acuerdo a la definición de la OMS, no se puede estimar sólo en términos de ausencia de enfermedad o discapacidad, o, como son los emanados de las insuficiencias que en la práctica tienen los indicadores utilizados hasta ahora para medir todas las dimensiones de la salud en el proceso de envejecimiento.

En lo relativo a la diversidad de interpretaciones sobre la evolución del balance salud/morbilidad/mortalidad en el proceso de envejecimiento demográfico, se asume unánimemente que el incremento de la supervivencia no equivale forzosamente a lograrlo con buena salud, sino que lo más probable es que conlleve la degradación del estado de salud ${ }^{233}$. Más allá del consenso impuesto por esta evidencia florecen, sin embargo, distintas perspectivas que intentan explicar la evolución de dicho balance y que, en esencia, se pueden reagrupar en

\footnotetext{
${ }^{233}$ En términos agregados, y con la utilización de los indicadores que se definen más adelante, el análisis comparativo entre países (EHEMU, 2007 y 2005), o entre CC.AA. (Gispert et al, 2007), muestra que la variabilidad entre los distintos ámbitos demográficos es menor en el caso de la esperanza de vida que entre el indicador de expectativa de salud elegido (en buena salud percibida; libre de discapacidad), lo que significa que, aunque en general una mayor expectativa de salud se corresponde con una mayor esperanza de vida, no siempre es así. Por ejemplo, si se comparan los datos, en 1999, de las mujeres Castilla y León, cuya e(0) era la más alta -83,87 años-, con los de las mujeres de La Rioja, cuya e(0) era de 82,4 años, se observa que el número de años que las castellanoleonesas podían esperar vivir sin discapacidad en esa fecha fue de 72,07 años, frente a los 76,73 años de las riojanas (Gispert et al, 2007:158).
} 
tres escenarios teóricos de salud diferenciados por la evolución de cuatro aspectos: la prevalencia, la incidencia, la letalidad y el ritmo de progresión de las enfermedades (Puga, 2002:11-13):

a) Teoría de la <<comprensión de la morbilidad $>>$. Formulada por Fries (2002, 1989, 1980), y estrechamente dependiente de la hipótesis de la rectangularización de la curva de superviviencia/comprensión de la mortalidad, prevé una mejora en el estado de salud: bajo el supuesto de la existencia de un límite biológico infranqueable de 85 años para la e(0), sostiene que la mejora de la calidad de vida derivada de cambios hacia estilos de vida saludables y de la aplicación de innovaciones tecno-médicas pospondrían la aparición y desarrollo de afecciones no mortales, a la par que reducirían las tasas de mortalidad provocadas por enfermedades mortales. Es decir, que la edad media a la primera enfermedad crónica podría ser retrasada, haciendo que la curva de morbilidad fuera cada vez más rectangular y, simultáneamente, que la expansión del vigor de los adultos hasta el límite máximo de la longevidad humana comprimiría la senescencia cerca del final de la vida. De esta forma, junto a la comprensión de la mortalidad, se prevé una comprensión aún más rápida de la morbilidad en un estrecho registro de edades antes de que la vida "se cerrase”, con lo que no sólo se añadirían más “años de vida” sino también la posibilidad de más "vida en los años". Teoría optimista para unos, e ingenua para otros, dado que, como se ha señalado en el sub-epígrafe anterior, no hay evidencia empírica de que exista un límite absoluto en la longevidad máxima, ni en la e $(0)^{234}$, aunque el número de ancianos frágiles con enfermedades no mortales no ha dejado de crecer en las tres últimas décadas.

b) Teoría de la <<expansión de la morbilidad >>. Formulada inicialmente por Gruenberg (1977), está relacionada con la hipótesis de expansión de la mortalidad: rechaza la idea de la existencia de un límite biológico en la e(0), y aunque admite que los cambios en el estilo de vida y las innovaciones tecno-médicas pueden seguir reduciendo las tasas de mortalidad provocadas por enfermedades crónicas y degenerativas, sostiene sin embargo que esa reducción continuada en las tasas de mortalidad, con el consiguiente incremento de la $\mathrm{e}(\mathrm{x})$, no tiene porqué venir acompañada de una reducción de la incidencia de esas enfermedades, o de una ralentización de su ritmo de progresión, con lo que se incrementará el número de personas que experimentarán una degradación de la calidad de vida en su dilatada vejez al reforzarse la frecuencia de los

\footnotetext{
${ }^{234}$ En la práctica, la hipótesis de que la esperanza de vida permanezca constante no se ha materializado por lo que habitualmente se suele considerar que se cumple la teoría de la comprensión de la morbilidad cuando la evolución de la esperanza de vida libre de discapacidad aumenta a mayor ritmo que la esperanza de vida, disminuyendo de esta forma el periodo de discapacidad en el curso de la vida (Gutiérrez-Fisac, Regidor y Alfaro, 2010; EHEMU, 2007, 2005; Génova y Pereira, 2003; Olshansky y Carnes, 2001; Robine, 2001; Vallin, 1995).
} 
estados crónicos más severos (Kramer, 1980) ${ }^{235}$. De esta forma, aumentará la prevalencia de enfermedades crónicas y de discapacidades, es decir, se expandirá la morbilidad, ya que el hecho de que la muerte provocada por enfermedades letales se retrase no significa que el proceso morboso subyacente sufra un retraso similar. Visión pesimista, que la gerontóloga Lois Verbrugge (1984) resume gráficamente al señalar que lo que se está consiguiendo es “obtener una vida más larga a cambio de una salud que empeora”,236.

c) Teoría del <<equilibrio dinámico>>. Formulada por Manton (1982), plantea que la reducción de las tasas de mortalidad iría acompañada por la ralentización del ritmo de progresión de las enfermedades crónicas, aunque no necesariamente de una reducción de su incidencia. Esta teoría entraña en cierta forma una especie de "estatus quo" del estado de salud de la población: "la parte de años vividos sin discapacidad es constante, cualquiera que sea el aumento de la esperanza de vida” (Puga, 2002:12-13). Así, la disminución de la mortalidad conllevaría un incremento de la prevalencia, al aumentar el número de personas con enfermedades crónicas que no fallecen, pero las minusvalías y discapacidades serían por término medio menos graves. Es decir, el aumento de la e(0) no irá acompañado por un incremento simultáneo de los años vividos con una minusvalía grave o una discapacidad severa, pero sí puede estarlo con una discapacidad leve o moderada (Manton, 1982), y en el peor de los casos incluso podría haber una pandemia de discapacidades o minusvalías ligeras (Robine et al, 1999:109) ${ }^{237}$.

Para dilucidar cuál de las tres teorías es más verosímil, Robine y Michel (2004) reivindican la necesidad de "una armonización mundial de medidas de declinación funcional”, lo que remite a los problemas metodológicos relativos a la medida y comparación de la salud en

\footnotetext{
${ }^{235}$ En el límite, a fuerza de incrementar la e(0), todos los supervivientes llegarían a padecer algún tipo de demencia, enfermedad y/o discapacidad, por lo que se habla incluso de $<<$ pandemia de los problemas mentales, las enfermedades crónicas y las discapacidades $>>$ (Kramer, 1980).

${ }^{236}$ Olshansky y Carnes (2001:202) resaltan precisamente el papel ambiguo que está jugando en este sentido la tecnología médica que puede mantener viva más tiempo a una persona que padece una enfermedad, incluso en el caso extremo de que su cerebro no funcione: "La tecnología médica podría estar convirtiendo las enfermedades mortales en enfermedades no mortales, particularmente al final de la vida, cuando los riesgos de padecer debilidad y discapacidad son más altos”.

${ }^{237}$ Escenario compartido, en principio, por Vallin (1995:18), quien, sin embargo, dada "la carrera de velocidad entre el <<rejuvenecimiento biológico > (individual) y el <<envejecimiento demográfico >” aconseja no descartar la sucesión en cuatro fases propuesta por Myers y Lamb (1993), en la que se integran los tres hipotéticos escenarios de salud de la población: "En un primer momento, el retroceso de la mortalidad debida a las enfermedades de degeneración entrañaría una pandemia relativa de incapacidades. Esto demandaría el desarrollo de técnicas nuevas de cuidados y de prevención de estas incapacidades, lo que permitiría detener la pandemia y conducir a una suerte de equilibrio dinámico. En una tercera fase, las ganancias en la esperanza de vida sin discapacidad igualarían a las ganancias en e(0), se asistiría a una comprensión relativa de la morbilidad. Por último, siendo las ganancias en la e(0) cada vez más débiles, la esperanza de vida sin discapacidad progresaría finalmente más deprisa que la e(0) y habría comprensión absoluta de la morbilidad”.
} 
el proceso de envejecimiento. En efecto, los conceptos "salud”, “enfermedad”, “discapacidad”, “dependencia”, y “calidad de vida” son social y culturalmente variables (Lupton, 1994), por lo que existen dificultades para desarrollar métodos estandarizados que permitan medirlos idénticamente en los distintos países. Así, como un aspecto puramente metodológico de este debate, se asiste desde hace tres décadas por un lado a una creciente contestación sobre la idoneidad de seguir utilizando indicadores de mortalidad -e(0), TMI- como los principales indicadores del nivel de salud de una población que envejece, y, por otro lado, a la búsqueda de indicadores que permitan medir las expectativas de salud de una población, es decir, estimar el número medio de años que una persona puede esperar vivir en un estado de salud determinado. En el fondo de este debate metodológico se encuentra la sospecha, justificada, de que el incremento de la esperanza de vida puede ser el elemento más fácilmente perceptible del guión, pero no es el único y, sobre todo, no narra toda la historia ${ }^{238}$.

Distintas razones técnicas justifican, en principio, la utilización de datos de mortalidad en la evaluación, estática y dinámica, de las condiciones de salud/morbilidad de una población: “1) universalidad de su registro, 2) estabilidad relativa a lo largo del tiempo de los criterios de clasificación y codificación, 3) calidad de la información sobre la causa de muerte para un gran número de rúbricas, y 4) disponibilidad de datos” (López-Abente, et al., 2002:7). La aplicación de indicadores universales de mortalidad a estas series de datos homogéneas permite además realizar comparaciones objetivas entre poblaciones sin gran dificultad. Sin embargo, la utilización de los indicadores de mortalidad como indicadores de salud homogeneiza a todos los individuos en términos de salud al imponer una mirada digital -vivo/muerto-, en un ámbito esencialmente analógico -gradiente pérdida de la salud. Así, a efectos del cálculo de la e(0) contribuyen en igual medida una persona que practique deporte de élite, una persona ciega, otra tetrapléjica e, incluso, una que esté en coma, si son todas de la misma edad. Obviamente, todas ellas forman parte indistintamente del stock de vivos que se utiliza como denominador en las tasas de mortalidad necesarias para el calcular la e(0), pero el relato de sus biografías particulares está construido de forma muy diferente y en el ámbito concreto de la salud/enfermedad la ausencia en el primer caso de problemas de salud o los prolongados problemas de salud por enfermedades crónicas y/o discapacidades en los otros casos determinan que sus percepciones, necesidades y demandas sean claramente distintas entre sí: la e(0) estima

\footnotetext{
${ }^{238}$ En la base de esta cuestión se encuentra la importancia del tiempo como principal recurso (económico) de los individuos y la sociedad (Viciana, 2003:13). Según este autor, al ser la longitud de la vida limitada, "existe una clara competencia en su empleo (del tiempo) entre usos alternativos, cada uno con su correspondiente coste de oportunidad". Sin embargo, "no todo el tiempo tiene necesariamente el mismo valor", ya que no es lo mismo disponer plenamente de tiempo para disfrutar o para producir, que pasarlo enfermo o lesionado. Por todo ello, considera que la medición de la calidad de vida de una población debe de ir más allá de la simple agregación de los tiempos sintetizada en la e(x), y ser expresada por una suma de tiempos de vida ponderados por su calidad.
} 
la salud de la población, con información sobre la última consecuencia del deterioro de la salud, es decir, sobre la ausencia completa de salud, pero no proporciona una estimación de cómo está de sana la población cuando está viva (Génova y Pereira, 2003:515; Ahn et al, 2002:9). Es decir, al incluir en su valor periodos de tiempo vividos en enfermedad y/o discapacidad, la esperanza de vida sobreestima la salud global de la población (Goerlich, 2009:10).

Se hace necesario, en consecuencia, poder medir con mayor sensibilidad las expectativas o esperanzas de salud de la población y, en especial, conocer cómo serán de saludables los últimos años de la vida, es decir, mirar más a la calidad que a la cantidad de vida $^{239}$. Así, se han elaborado distintos indicadores, variantes de la e(0), que en lugar de cuantificar el tiempo restante hasta el instante final que acaba en la muerte, utilizan como referente temporal el periodo en el que comienza a declinar la salud, se pierde autonomía en la vida cotidiana y/o se pasa a depender de los cuidados de los demás. Por diversas razones no son indicadores tan objetivos y universales como los de mortalidad pero en alguna medida palian la incapacidad de éstos para cubrir todas las dimensiones del estado de salud de una población. Su necesidad es evidente no sólo en términos analíticos o desde la implementación de políticas ${ }^{240}$, sino también, como resalta Hayflick (1999:139), desde el conocimiento individual: "para muchos de nosotros ser capaces de prever el comienzo de la dependencia en el último recorrido de la vida es tan importante como prever la hora del desenlace final”.

En efecto, los cambios demográficos que han acelerado el proceso de envejecimiento poblacional han propiciado, asimismo, la emergencia de indicadores sintéticos que intentan medir, además de la longitud de vida, las “expectativas de salud” de la población, esto es, el estado funcional y la vitalidad, el nivel de discapacidad y la calidad de vida en la misma (Robine, Romieu y Jee, 1998a:1). Así, a través de la medición de tres dimensiones básicas: la esperanza de vida activa, la esperanza de vida sin discapacidad y la esperanza de vida sana, se puede estimar el tiempo medio, en años, que una persona puede esperar vivir en un estado de salud determinado. Frente a la unidimensionalidad de la e(0), la multiplicidad de perfiles que componen la estimación de las expectativas de salud constituye su mayor riqueza pero también

\footnotetext{
${ }^{239}$ Existen dos grandes familias de medidas sintéticas de salud de las poblaciones: las "expectativas de salud" y los "diferenciales de salud". En el presente trabajo se van a considerar indicadores correspondientes a la primera de las familias (esperanza de vida en buena salud -EVBS-, esperanza de vida libre de discapacidad -EVLD). Puede consultarse en Gènova, Álvarez y Morant (2006) la utilización de indicadores de la segunda de las familias (años de vida ajustados por discapacidad -EVAD o DALY) al caso español.

${ }^{240}$ Además de comprobar si el incremento de la esperanza de vida se "gasta" en buena salud o con enfermedad, los indicadores de expectativas de salud son usados para examinar "las desigualdades en salud dentro de los países y entre ellos, orientar los recursos para la promoción de la salud, evaluar las políticas sanitarias y son crecientemente usados para informar sobre la planificación a largo plazo de las políticas sanitarias, sociales y fiscales” (EHEMU, 2007:3).
} 
su principal debilidad por cuanto hace difícil su utilización en la comparación entre poblaciones: por un lado, existen varios procedimientos para su cálculo y, por otro lado, no hay una única manera de evaluar el estado de salud de una población. En efecto, normalmente, los datos de salud percibida y de discapacidad necesarios para estimar las esperanzas de salud se obtienen de encuestas nacionales de salud cuyas características específicas (significado de los conceptos, formulación de las preguntas, tasas de respuesta, características de la muestra, etc.), dificultan realizar comparaciones entre países e, incluso, la comparación diacrónica dentro de un mismo país ${ }^{241}$. De aquí, la importancia de cuál sea el instrumento de medida empleado en la medición (Génova y Pereira, 2003:516; Robine, Romieu y Jee, 1998a:2).

La noción de "esperanza de salud” fue elaborada inicialmente en los Estados Unidos por Sanders, 1964, mientras que posteriormente Sullivan, 1971, propuso el primer método para calcularla ${ }^{242}$. Desde entonces, y a propuesta de organismos internacionales como la OCDE, el BM y la OMS, distintos grupos de investigadores han elaborado diferentes indicadores, expresados en términos de esperanzas de vida, para estimar simultáneamente los cambios en la mortalidad, la morbilidad y la discapacidad, y determinar si estos indicadores varían de la misma manera que la esperanza de vida (Robine, 2000:136). Admitiendo la variedad de consecuencias de las enfermedades crónicas, no obstante se otorga un lugar central en los cálculos realizados a la discapacidad (incapacidad), al considerarla no sólo un indicador de la severidad del estado mórbido, sino también de la calidad de vida. Además, la distinción dentro de la esperanza de vida entre los años que se vivirán con y sin discapacidad permite discernir en cuál de los escenarios de salud señalados arriba se encuentra con más probabilidad las poblaciones analizadas (EHEMU, 2005:3).

\footnotetext{
${ }^{241}$ En efecto, por un lado, las medidas de las expectativas de salud pueden cambiar en el tiempo aunque la salud no lo haga, simplemente al modificar las preguntas de las encuestas que se realizan, y con ello las respuestas que se utilizan para realizar los cálculos de los indicadores. También porque las percepciones individuales de la propia salud pueden cambiar, al variar el entorno, aunque la salud propiamente no se haya modificado. Por ejemplo, "si para el conjunto de la población la salud ha mejorado probablemente pueden tolerar menos sus problemas de salud e informar más sobre ellos sistemáticamente cuando podrían no haberlo hecho en el pasado". Además, cambios en la situación de las personas con discapacidad pueden influir en cómo se sienten más que en cómo están. Por otra parte, pueden surgir problemas comparativos según el grado de cobertura de la población encuestada, al omitirse por ejemplo entre ésta a la población institucionalizada, buena parte de la cual es mayor y está institucionalizada precisamente por necesitar cuidados por sus mayores problemas de salud y de discapacidad (EHEMU, 2007:4).

${ }^{242}$ El método Sullivan denominado <<método de la tabla de prevalencia observada de la longevidad >> el más simple, y el más utilizado, de todos los desarrollados, combina, para un periodo dado, los datos de mortalidad de una cohorte ficticia derivados de una tabla de mortalidad del momento con la prevalencia a cada edad de los estados de salud/enfermedad y discapacidad obtenidos generalmente a partir de una encuesta nacional de salud. Con este método se pueden calcular esperanzas de vida con o sin discapacidad o enfermedad, y esperanzas de vida con distintos niveles de salud o de discapacidad.
} 
El análisis de las expectativas de salud en la población española, incluida la comparación con otros países, puede abordarse a partir de la información aportada por diferentes organismos e instituciones nacionales e internacionales ${ }^{243}$. Dada la variedad de indicadores de expectativas de salud, en el presente trabajo se limita su utilización a una pequeña selección de los mismos extraída de publicaciones nacionales. Es necesario resaltar la importancia de estos indicadores para la presente Tesis, por cuanto en su cálculo se utilizan datos obtenidos de encuestas nacionales que pueden servir como un marco de referencia general de las circunstancias y las percepciones subjetivas más extendidas entre la población en las que encuadrar los datos de la encuesta realizada para este trabajo. En el Cuadro 4.19., por ejemplo, se recogen las estimaciones realizadas por el grupo de trabajo conformado por Regidor, Gutiérrez-Fisac, y Alfaro (2010, 2009) para el Mº de Sanidad, Política Social e Igualdad sobre la evolución de las <<esperanzas de vida en buena salud percibida $>>(E V B S)^{244}$. Considerando el total de la población española, una persona nacida en el año 2007 podría esperar vivir de media 81,1 años, de los cuales el 68,3\%, es decir 55,4 años, serían de buena salud. Por su parte, una persona de 65 años podía esperar vivir de media 20 años más, de los cuales, 7,9 años (el 39,5\%), serían en buena salud. Para calibrar la importancia real de estos datos se hace necesario considerar dos dimensiones recogidas en el Cuadro 4.19.: la evolución en el periodo 1987-2007 y las diferencias entre mujeres y hombres.

\footnotetext{
${ }^{243}$ Por ejemplo, la OMS (2002) aportó datos comparativos sobre la Esperanza de vida ajustada por salud (HALE) para el año 2001; datos que reflejaban que la población española no sólo tenía una de las e(0) más elevadas, sino que también su HALE al nacimiento era de los más elevados del mundo. Por su parte, Eurostat ha elaborado estadísticas comparativas para la Unión Europea sobre los Años de vida saludable utilizando primero datos del Panel de Hogares de la Unión Europea (ECHP), hasta el 2003, y más recientemente, rompiéndose la serie, con datos de la Encuesta de Ingresos y Condiciones de Vida (SILC). Puede consultarse una revisión amplia de las principales fuentes de datos, los principales indicadores y las limitaciones de ambos, aplicables al análisis de las esperanzas de salud en España en (INEbase, EDAD-2008; Gènova y Pereira, 2002) y en la web del $\mathrm{M}^{\mathrm{o}}$ de Sanidad y Política Social: www.msps.es/estadEstudios/ estadisticas/docs/informeEVLI.pdf. Más ampliamente, puede consultarse la tipología de expectativas de salud elaborada por REVES (Red Internacional de Investigación sobre la Esperanza de Vida en Salud): http://reves.site.ined.fr/en/home/about_reves/.

244 "La EVBS a una determinada edad x representa el número medio de años que, en buena salud, restan por vivir a una persona de esa edad hasta su fallecimiento". Mide el efecto de la prevalencia de los problemas de salud percibidos, es decir, es una evaluación del impacto sobre la calidad de vida de la presencia subjetiva de la enfermedad (Regidor, Gutiérrez-Fisac y Alfaro, 2009:22). En el caso de España, para su elaboración, siguiendo el método Sullivan, se aplican a los datos de mortalidad y población procedentes del INE los de autovaloración del estado de salud procedentes de las Encuestas Nacionales de Salud, realizadas por el $\mathrm{M}^{\circ}$ de Sanidad. Concretamente, se emplea la agregación de las respuestas a "muy bueno" y "bueno" obtenidas de la siguiente pregunta incluida en dichas encuestas: "En los últimos doce meses, ¿diría que su estado de salud ha sido muy bueno, bueno, regular malo o muy malo?”.
} 
CUADRO 4.19.: ESPERANZA DE VIDA (e(x)), ESPERANZA DE VIDA EN BUENA SALUD PERCIBIDA (EVBS), PORCENTAJE DE EVBS/e(x) Y DIFERENCIAS POR SEXO. España. 1987, 1997 y 2007

\begin{tabular}{|l|c|c|c|c|c|c|c|c|c|}
\hline & \multicolumn{3}{c|}{$\mathbf{e}(\mathbf{x})$} & \multicolumn{3}{c|}{ EVEVBS/e(x) } \\
\hline & $\mathbf{1 9 8 7}$ & $\mathbf{1 9 9 7}$ & $\mathbf{2 0 0 7}$ & $\mathbf{1 9 8 7}$ & $\mathbf{1 9 9 7}$ & $\mathbf{2 0 0 7}$ & $\mathbf{1 9 8 7}$ & $\mathbf{1 9 9 7}$ & $\mathbf{2 0 0 7}$ \\
\hline Al nacer & 77,0 & 78,8 & 81,1 & 53,2 & 54,6 & 55,4 & 69,1 & 69,3 & 68,3 \\
\hline Total & 73,6 & 75,2 & 77,8 & 54,4 & 55,2 & 57,3 & 73,9 & 73,4 & 73,7 \\
\hline Hombres & 80,3 & 82,3 & 84,3 & 52,1 & 54,3 & 53,5 & 64,9 & 66,0 & 63,5 \\
\hline Mujeres & 6,7 & 7,1 & 6,5 & $-2,3$ & $-0,9$ & $-3,8$ & & & \\
\hline Muj. - Homb. & & & & & & & & & \\
\hline \\
A los 65 años
\end{tabular}

Fte: (Gutiérrez-Fisac, Regidor y Alfaro, 2010:25-27)

Respecto a la primera de esas dimensiones, se constata que las evoluciones de la e(x) y de la EVBS, aunque crecientes ambas, han diferido notablemente en el periodo comprendido entre 1987 y 2007. Así, la EVBS al nacimiento en 2007 fue 2,2 años más elevada que veinte años antes, mientras que durante ese periodo el crecimiento de la e(0) fue mayor, 4,1 años, lo que determina que el porcentaje de años vividos en buena salud se haya reducido desde el 69,1\%, en 1987, al 68,3\%, de 2007. De hecho, si en lugar de considerar la EVBS se estima su complementaria, la <<expectativa de mala salud subjetiva >>, (diferencia entre e(x) y EVBS), se comprueba que el número de años esperados en mala salud al nacimiento para el conjunto de la población aumentó desde los 23,8 años, en 1987, a los 25,7 años, en 2007. Otro tanto ocurre si se consideran la e(65) y la EVBS a los 65 años. Mientras que la primera creció 2,5 años entre 1987 y 2007, el crecimiento de la segunda fue menor, 1 año, hasta alcanzar los 7,9 años en 2007. Si se estima la expectativa de mala salud subjetiva a los 65 años se constata asimismo que el número de años esperados en mala salud también ha aumentado durante el periodo considerado pasando de 10,6 años, en 1987, a 12,1 años, en 2007. Es decir, entre 1987 y 2007, han aumentado las esperanzas de vida al nacimiento y a los 65 años, también han aumentado en términos absolutos las EVBS y las expectativas de mala salud al nacimiento y a los 65 años, pero el peso relativo de estas últimas en las $\mathrm{e}(\mathrm{x})$ ha variado reduciéndose la proporción correspondiente a las EVBS, lo que significa "que una buena parte de los años de vida ganados son vividos en mala salud percibida” (Gutiérrez-Fisac, Regidor y Alfaro, 2010:30). 
A diferencia del ligero descenso observado en el porcentaje de EVBS/e(x) al nacimiento, ese indicador a los 65 años se ha mantenido estable entre 1987 y 2007, situándose cercano al 40\%. Este equilibrio, sin embargo, oculta las tendencias divergentes entre mujeres y hombres, la segunda dimensión a considerar. En efecto, en el año 2007, las EVBS al nacimiento y a los 65 años fueron mayores para los hombres que para las mujeres, en 3,8 años y 1,4 años respectivamente, al contrario de lo que ocurre con los valores de las esperanzas de vida a esas edades que son superiores en las mujeres: 6,5 años, al nacimiento, y 4,1 años, a los 65 años. Además, esas diferencias se han ido incrementando en el periodo 1987-2007, y lo han hecho a mayor ritmo que las diferencias en las esperanzas de vida. Así, el diferencial de EVBS al nacimiento entre hombres y mujeres, siempre superior en los hombres, se ha incrementado en 1,5 años, mientras que el diferencial de e(0), favorable a las mujeres, se reducía en 0,2 años; por su parte, el diferencial de EVBS a los 65 años se ha incrementado en 1,1 años, a la par que la diferencia favorable a las mujeres en la e(65) lo hacía en 0,6 años. Es decir, las mujeres viven más años que los hombres pero lo hacen con peor salud percibida, percepción diferencial que además se ha incrementado en el tiempo ${ }^{245}$. Lo que se constata de forma más diáfana si se consideran las expectativas en mala salud percibida: si en 1987 el número de años de vida esperados al nacimiento con mala salud percibida era de 19,2 años para los hombres y 28,2 años para las mujeres, en 2007 esos valores se han incrementado hasta los 20,5 años y los 30,8 años, respectivamente. Por su parte, en ese periodo de tiempo, la expectativa de mala salud a los 65 años ha pasado de 8,6 años a 9,2 años, para los hombres, mientras que para las mujeres los valores de ese indicador se han elevado desde los 12,4 años, en 1987, hasta los 14,7 años, en 2007. Confirmándose que, en el periodo 1987-2007, se ha producido un crecimiento en el diferencial por sexo de las expectativas en mala salud hasta alcanzar, en 2007, los 10 años más de mala salud al nacimiento y 5,5 años más de mala salud a los 65 años en las mujeres respecto a los hombres (Gráficos 4.11. y 4.12.).

Como resultado de esta evolución, las proporciones EVBS/e(x) para los dos sexos han divergido erráticamente en el periodo de análisis (Cuadro 4.19.). En el caso de los hombres, esas proporciones se han mantenido estables entre los recién nacidos, alrededor del 74\%, y se han incrementado a los 65 años, desde el 44,9\%, en 1987, hasta el 48,3\%, en 2007. Por su parte, en el caso de las mujeres, la evolución de ese indicador ha sido decreciente en ambas edades, aunque la mayor reducción se ha producido a los 65 años que ha pasado de 35,1\%, en 1987, a 32,9\%, en 2007. Así, en 2007, mientras un varón recién nacido puede esperar vivir casi tres cuartas partes de su vida en buena salud (73,7\%), una recién nacida sólo puede esperar hacerlo

${ }^{245}$ Al margen de la presencia real de enfermedad o de discapacidad, Gènova y Pereira (2002:523) consideran que esta aparente contradicción puede ser debida a que las mujeres pueden tener una percepción más sensibilizada sobre su propia salud que los hombres, lo que las hace estar más pendientes de los servicios de salud y más receptivas a los consejos preventivos sobre la misma. 
en menos de dos tercios de su vida (63,5\%). Proporciones que, obviamente, son mucho más reducidas a los 65 años de edad: los hombres de 65 años pueden esperar vivir casi la mitad de los años de vida que les quedan en buena salud (48,3\%), mientras que las mujeres de esa edad lo harán en menos de un tercio de su vida restante (32,9\%).

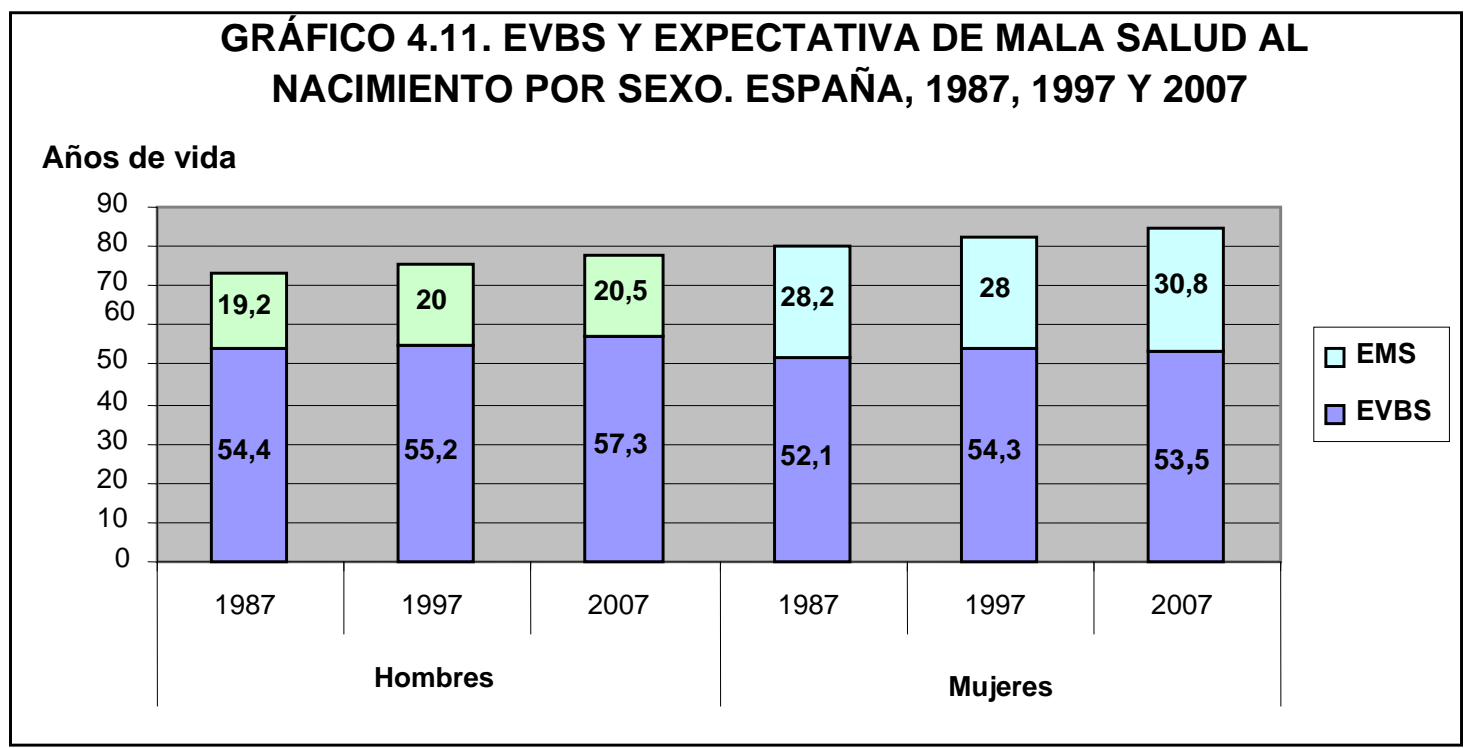

Fte: Elaboración propia a partir de (Gutiérrez-Fisac, Regidor y Alfaro, 2010:25-27)

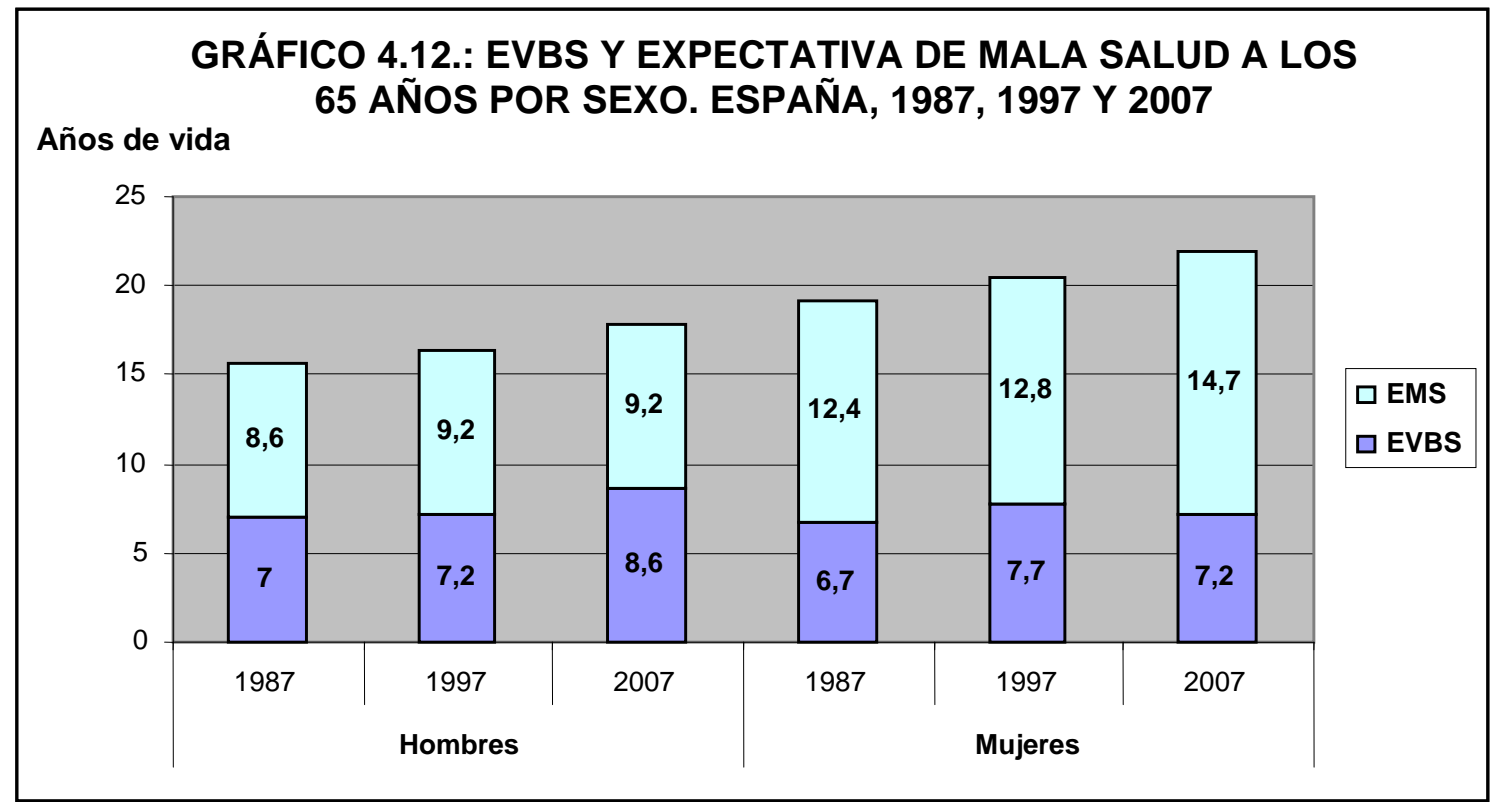

Fte: Elaboración propia a partir de (Gutiérrez-Fisac, Regidor y Alfaro, 2010:25-27)

Como se ha señalado, en los cálculos de las expectativas de salud se otorga un lugar central a la presencia de la discapacidad (incapacidad), puesto que conforma en mayor y mejor medida que la percepción subjetiva del estado de salud la evaluación de la calidad de vida: "la esperanza de vida en salud será, sobre todo, esperanza de vida sin discapacidad” (Puga, 
2002:13). Además, la comparación en la evolución entre las e(x) y las esperanzas de vida sin discapacidad desvela si una determinada población se encuentra en un escenario de comprensión de la morbilidad (cuando las segundas crecen más que la primera y, en consecuencia, el tiempo que viven los individuos en buena salud aumenta), expansión de la morbilidad (cuando es la $\mathrm{e}(\mathrm{x})$ la que crece más que las esperanzas de vida sin discapacidad, por lo que el tiempo que los individuos viven en mala salud aumenta) o de equilibrio dinámico (cuando el incremento de la e(x) "no se ve acompañado simultáneamente de un aumento del tiempo vivido con discapacidad severa, pero sí de discapacidad leve o moderada”) (Gènova y Pereira, 2002:515-516).

Las sucesivas encuestas realizadas por el $\operatorname{INE}^{246}$ para evaluar el fenómeno de la discapacidad $^{247}$ entre la población española han confirmado que a medida que se avanza en el ciclo de vida de una persona se incrementa el peso, el número y el grado de severidad de la misma ${ }^{248}$. Así, por ejemplo, según la última encuesta realizada por este organismo, EDAD2008, el número de residentes en España con alguna discapacidad en ese año era de 3,85 millones, lo que significa una tasa de prevalencia de la discapacidad de 85,45 por 1.000 habitantes. Al desagregar por edad se constata la incidencia de ésta ya que, mientras entre los 6 y los 64 años la tasa de incidencia fue de 44,76\%, a partir de esa edad el crecimiento de la misma se acelera hasta alcanzar el 223,4\%o, en el grupo de 65-74 años, y el 514,56\%o, en el de los mayores de 80 años (en este último grupo, los mayores de 90 años tenían una tasa de discapacidad de 751,47\%o). En lo que respecta al número de discapacidades, la codiscapacidad, aunque no es privativa de las edades más avanzadas, sí que tiene más incidencia en ellas; así, por ejemplo, si el 26,5\% de las personas encuestadas tenían once o más discapacidades, el 45\%

\footnotetext{
${ }^{246}$ Encuesta sobre Deficiencias, Discapacidades y Minusvalías, de 1986; Encuesta sobre Discapacidades, Deficiencias y Estado de Salud (EDDES), de 1999, y; Encuesta sobre Discapacidades, Autonomía personal y situaciones de Dependencia (EDAD), de 2008. Las tres encuestas fueron dirigidas al conjunto de personas que residen en viviendas familiares principales, quedando excluida de las muestras la población residente en establecimientos colectivos, lo que, como se ha señalado más arriba, implica una subestimación del peso real de los fenómenos analizados.

247 "La OMS define las discapacidades como las consecuencias de las deficiencias desde el punto de vista del rendimiento funcional y de la actividad del individuo; las discapacidades representan, por tanto, trastornos a nivel de la persona. Las deficiencias hacen referencia a las anormalidades de la estructura corporal y de la apariencia, y a la función de un órgano o sistema cualquiera que sea su causa; en principio las deficiencias representan trastornos a nivel de órgano". A efectos de las encuestas, "se entiende por discapacidad toda limitación grave que afecte o se espere que vaya a afectar durante más de un año a la actividad del que la padece y tenga su origen en una deficiencia. Se considera que una persona padece una discapacidad aunque la tenga superada con el uso de ayudas técnicas externas. Se hace una excepción, recogiendo también las discapacidades que no tienen su origen en una deficiencia claramente delimitada, sino que más bien obedecen a procesos degenerativos en los que la edad de la persona influye decisivamente" (INE; 2000:7-9).

${ }^{248}$ En términos generales, "el proceso de aparición de problemas de salud es gradual. En primer lugar aparecen las enfermedades crónicas, que conllevan una posterior autopercepción de un mal estado de salud general. Más tarde aparecen las limitaciones en la realización de actividades, es decir, se presenta el fenómeno de la discapacidad; por último, surgen las discapacidades más severas, las que necesitan ayudas y las que hacen referencia a las actividades domésticas y de autocuidado” (INE, 2003:16).
} 
de ellas eran mayores de 80 años. Asimismo, la severidad de la discapacidad se incrementa con la edad, como se comprueba con la distribución porcentual de los datos por edad de las personas con discapacidad total que precisan ayuda: el 10,20\%, de 6 a 44 años; el 12,25\%, de 45 a 64 años; el 29,34\%, de 65 a 79 años, y; el 48,2\%, mayores de 80 años. Además de la edad el sexo también influye por cuanto el 59,8\% de las personas discapacitadas, según la EDAD-2008, eran mujeres. Éstas no sólo son más, sino que, a partir de los 45 años, sus tasas de discapacidad son más elevadas, tienen más procesos de codiscapacidad y el grado de severidad es más intenso en ellas que entre los varones (INEbase: EDAD-2008).

Los datos aportados por las encuestas elaboradas por el INE para medir la discapacidad son utilizados para estimar, con el método Sullivan, distintos gradientes complementarios en las expectativas de salud: la <<esperanza de vida libre de discapacidad >> (EVLD) ${ }^{249}$; la $<<$ esperanza de vida libre de discapacidad severa $>>(E V L D S)^{250}$; la <<esperanza de vida libre de enfermedad crónica $>>(E V L E C)^{251}$; además de esperanzas de vida libres de tipos concretos de discapacidad ${ }^{252}$. En el Cuadro 4.20. se recoge una estimación del primero de estos indicadores, al nacimiento y a los 65 años, para la población española en los años 1986, 1999 y 2007, realizada por Gutierrez-Fisac, Regidor y Alfaro (2010) ${ }^{253}$. La EVLD al nacimiento en 2007 fue de 72,6 años para el conjunto de la población española, mientras que a los 65 años fue de 13,5 años, niveles inferiores a las e(0) y e(65), respectivamente, evidenciando que al ajustar por calidad se reducen notablemente las esperanzas de vida (Goerlich, 2009:50). Las evoluciones de ambos indicadores desde 1986 han sido más intensas que las de sus correspondientes e(0) y e(65), respectivamente. En efecto, mientras la e(0) ha crecido durante ese periodo de tiempo 4,7 años, la EVLD al nacimiento lo ha hecho con mayor intensidad, 5,9 años; por su parte, la EVLD a los 65 años se ha incrementado un poco más $-3,2$ años-, que la

\footnotetext{
${ }^{249}$ Algunos autores también la denominan <<esperanza de vida libre de incapacidad > (EVLI), es "el número medio de años que un individuo puede esperar vivir libre de incapacidad si los patrones actuales de mortalidad e incapacidad continúan en el futuro” (Robine, Romieu y Jee, 1988:33).

${ }^{250}$ En su cálculo se emplea "la tasa de personas con alguna discapacidad o limitación severa o total (categorías 3 "Con severidad grave” y 4 "No puede realizar la actividad" de la variable severidad sin ayudas en alguna discapacidad)” (INE, 2003:48).

${ }^{251}$ Construida a partir de la "tasa de personas con al menos una enfermedad crónica” (INE, 2003:48).

${ }^{252}$ Como por ejemplo la <<esperanza de vida libre de discapacidad de visión $>>$ o la <<esperanza de vida libre de discapacidad para realizar tareas del hogar $>>$. Por otra parte, las esperanzas de vida calculadas permiten estimar sus complementarias. "Así, por ejemplo, la diferencia entre la EV y la EVLD mide la esperanza de vida con discapacidad (EVCD); la diferencia entre EVLD y EVLEC mide la esperanza de vida con al menos una enfermedad crónica pero sin discapacidad" (INE, 2003:14).

${ }^{253}$ Estos autores (Gutierrez-Fisac, Regidor y Alfaro, 2010:9-11), a partir de un proceso de depuración de datos, han eliminado las dificultades que impedían hasta ahora la comparación con la Encuesta sobre Deficiencias, Discapacidades y Minusvalías de 1986, logrando de esta manera una serie de datos comparativa más amplia sobre las EVLD. En su cálculo, los datos de las tres encuestas se han aplicado respectivamente a las tablas de mortalidad del INE para los dos primeros periodos y a una tabla de mortalidad elaborada por el Instituto de Información Sanitaria para el año 2007. Las estimaciones obtenidas para los dos últimos periodos, en general, no difieren de las realizadas por otros autores u organismos.
} 
e(65) -3,1 años. Como consecuencia de estas evoluciones, el porcentaje de las EVLD sobre las e(x) ha sido creciente en las dos edades; así, en 2007, un ciudadano medio español podía esperar al nacer que el $89,5 \%$ de su vida fuera sin discapacidad, mientras que a los 65 años ese porcentaje representaría algo más de los dos tercios de la vida esperada, el 67,5\%. Por tanto, para el conjunto de la población española, y a diferencia de la evolución de las EVBS, entre 1986 y 2007 los años de vida ganados lo han sido con menor discapacidad. Lo que se confirma por otra vía si se calcula el complementario de la EVLD, las <<expectativas de incapacidad >> (EI), (diferencia entre e(x) y EVLD). En efecto, el número esperado, al nacer, de años de vida con incapacidad se ha reducido en 1,2 años (9,7 años de expectativa de incapacidad, en 1986; 8,5 años, en 2007), y también se han reducido ligeramente a los 65 años en 0,1 años (6,6 años de expectativa de incapacidad a los 65 años, en 1986; 6,5 años, en 2007).

CUADRO 4.20.: ESPERANZA DE VIDA (e(x)), ESPERANZA DE VIDA LIBRE DE DISCAPACIDAD (EVLD), PORCENTAJE DE EVLD/e(x) Y DIFERENCIAS POR SEXO. España. 1986, 1999 y 2007

\begin{tabular}{|c|c|c|c|c|c|c|c|c|c|}
\hline & \multicolumn{3}{|c|}{$e(x)$} & \multicolumn{3}{|c|}{ EVLD } & \multicolumn{3}{|c|}{$\% E V L D / e(x)$} \\
\hline & 1986 & 1999 & 2007 & 1986 & 1999 & 2007 & 1986 & 1999 & 2007 \\
\hline \multicolumn{10}{|l|}{ Al nacer } \\
\hline Total & 76,4 & 79,4 & 81,1 & 66,7 & 70,7 & 72,6 & 87,3 & 89,0 & 89,5 \\
\hline Hombres & 73,2 & 76,1 & 77,8 & 64,8 & 69 & 71,3 & 88,5 & 90,7 & 91,6 \\
\hline Mujeres & 79,6 & 82,8 & 84,3 & 68,6 & 72,4 & 73,8 & 86,2 & 87,4 & 87,5 \\
\hline Muj. - Homb. & 6,4 & 6,7 & 6,5 & 3,8 & 3,4 & 2,5 & & & \\
\hline \multicolumn{10}{|l|}{ A los 65 años } \\
\hline Total & 16,9 & 18,8 & 20 & 10,3 & 12,2 & 13,5 & 60,9 & 64,9 & 67,5 \\
\hline Hombres & 15 & 16,7 & 17,8 & 9,7 & 11,7 & 13,2 & 64,7 & 70,1 & 74,2 \\
\hline Mujeres & 18,4 & 20,6 & 21,9 & 10,8 & 12,6 & 13,7 & 58,7 & 61,2 & 62,6 \\
\hline Muj. - Homb. & 3,4 & 3,9 & 4,1 & 1,1 & 0,9 & 0,5 & & & \\
\hline
\end{tabular}

Fte: (Gutiérrez-Fisac, Regidor y Alfaro, 2010:12-25)

En el Cuadro 4.20. se aprecia asimismo la existencia de diferencias en el interior de la población española al desagregarla por sexo. Así, en 2007, si se mantienen las condiciones de mortalidad e incapacidad del momento, una española recién nacida en ese año tendría mayor esperanza de vida (6,5 años) y, a diferencia de lo que ocurre con la EVBS, mayor esperanza de vida libre de discapacidad que un varón español coetáneo, 2,5 años, (71,3 años entre los hombres y 73,8 años entre las mujeres). Es decir, la amplia diferencia entre sexos en la e(0) favorable a las mujeres se reduce a menos de la mitad en el caso de la EVLD al nacer, lo que significa que aquella diferencia está conformada sobre un número mayor de años vividos en discapacidad por ellas (Regidor, Gutiérrez-Fisac y Alfaro, 2009:21). Por otra parte, la evolución 
creciente de la EVLD al nacer entre 1986 y 2007 ha sido mayor en términos absolutos entre los hombres (6,5 años frente a los 5,2 años de aumento entre las mujeres) lo que ha conllevado que el diferencial entre sexos haya evolucionado de forma descendente pasando de 3,8 años, en 1986, a 2,5 años, en 2007. Como resultado de estas evoluciones, el porcentaje de años vividos sin discapacidad en la vida esperada al nacer se ha incrementado en ambos sexos, siendo este ligeramente mayor entre los hombres en 2007 (91,6\% frente al 87,5\% de las mujeres). En términos complementarios, estos datos cristalizan en el descenso entre 1986 y 2007 del número de años que se espera vivir con incapacidad al nacimiento en ambos sexos (Gráfico 4.13.).

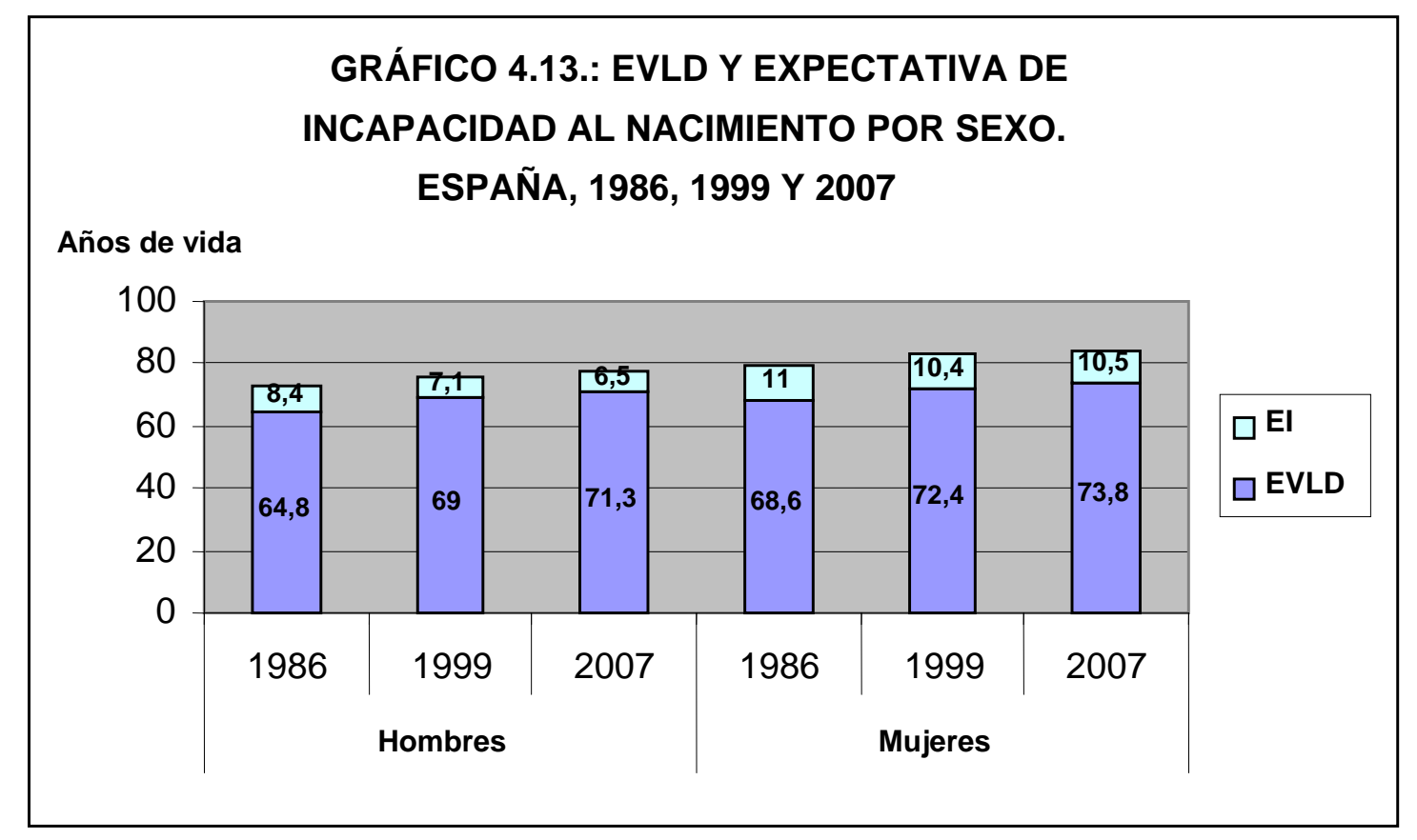

Fte: Elaboración propia a partir de (Gutiérrez-Fisac, Regidor y Alfaro, 2010:16)

Una situación similar se observa al examinar la evolución por sexo de la EVLD a los 65 años. En efecto, siendo mayor en las mujeres en todo momento, ese indicador ha crecido durante el periodo considerado en ambos sexos aunque en mayor cuantía entre los varones (3,5 años frente a los 2,9 años de las mujeres), reduciéndose en consecuencia el diferencial entre sexos hasta los 0,5 años en 2007. En términos relativos respecto a la e(65), la evolución ha sido también creciente, de tal forma que, en 2007, un varón de 65 años podía esperar vivir casi tres cuartos de su vida media sin discapacidad (el 74,2\%), mientras que en el caso de una mujer de esa edad ese indicador era inferior a dos tercios de su vida restante (62,6\%). Complementando el análisis con las expectativas de incapacidad se comprueba que, mientras que entre los hombres de 65 años se han reducido los años vida esperables con incapacidad, entre las mujeres se han incrementado en 0,6 años (Gráfico 4.14.). 
En resumen, de media, las mujeres viven más años que los hombres, pero esos adicionales lo viven con peor salud, tanto en términos absolutos, como relativos.

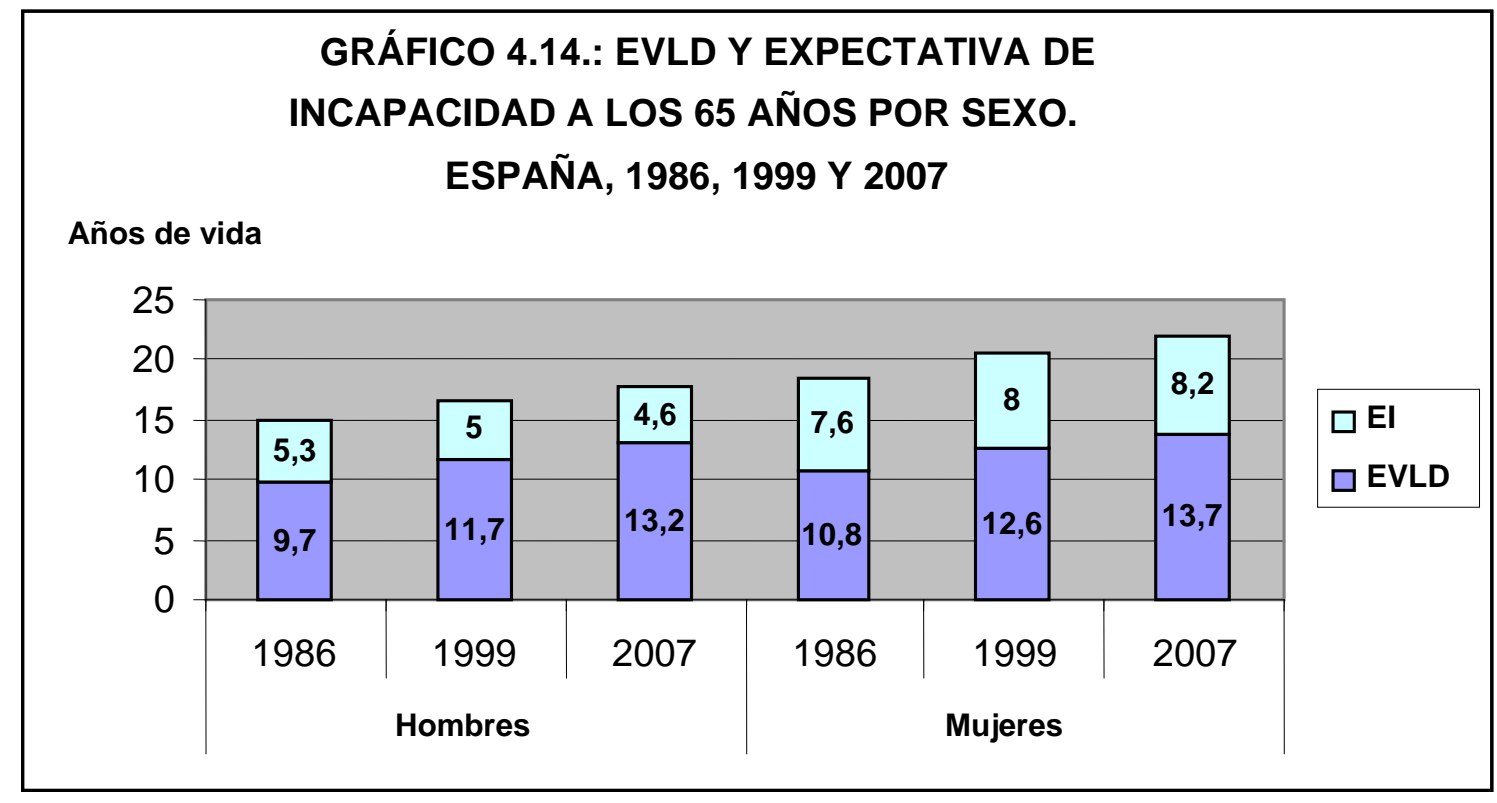

Fte: Elaboración propia a partir de (Gutiérrez-Fisac, Regidor y Alfaro, 2010:20-22)

A efectos de concretar el tipo de hipótesis teórica sobre la expansión o comprensión de la morbilidad, el mayor incremento de la EVLD al nacer respecto al de la e(0) "sugiere la existencia de un efecto comprensión de la morbilidad hacia edades más avanzadas”, es decir, que los años de vida ganados entre 1986 y 2007 habrían sido en su mayor parte años sin discapacidad (Gutiérrez-Fisac, Regidor y Alfaro, 2010:28). Este patrón, sin embargo, no está tan claro a los 65 años por cuanto aunque en conjunto la EVLD a esa edad ha crecido más que la e(65), no ha ocurrido así en los dos sexos. En efecto, mientras que entre los hombres la EVLD a los 65 años creció (3,5 años) en mayor medida que la e(65), 2,9 años, lo que sugiere un ligero efecto de comprensión de la morbilidad entre ellos, en el caso de las mujeres ocurrió al contrario (2,9 años de aumento de la EVLD; 3,5 años de crecimiento en la e(65)), lo que apunta a una suave expansión de la morbilidad entre ellas (Regidor, Gutiérrez-Fisac y Alfaro, 2009:28-29).

Para delimitar más esta cuestión conviene considerar la evolución de otros indicadores más concretos de expectativas de salud, como por ejemplo la "esperanza de vida libre de discapacidad severa” (EVLD1), cuyos valores se recogen en el Cuadro 4.21., que está construido con los datos aportados por el INE (INEbase, 2003a) a partir de la EDDES-1999 y la EDAD-2008. Como es lógico, tanto hombres como mujeres, en 1999 y en 2008, disponen de más tiempo de vida sin discapacidad severa que sin discapacidad, tanto al nacer como a los 65 años. Así, mientras que un hombre recién nacido en 2008 podía esperar vivir de media 71,27 años sin discapacidad, en ese año la EVLD1 era para él de 73,13 años, es decir, 1,86 años mayor. En el caso de las mujeres esos indicadores fueron 73,75 años y 75,95 años, 
respectivamente, con una diferencia entre ellos de 2,20 años. Otro tanto ocurre a los 65 años, en los que ese diferencial es también mayor en las mujeres, quienes pueden esperar vivir 15 años, de los 21,65 años que de media tienen por delante, sin discapacidad severa mientras que vivirían 13,6 años sin discapacidad. Por otra parte, y como se ha señalado más arriba, el hecho de que la EVLD haya crecido a mayor ritmo que la e(x), entre los hombres, y a menor ritmo, entre las mujeres, sugiere una ligera comprensión de la morbilidad entre los primeros y una suave expansión de la morbilidad entre las segundas. Sin embargo, al comparar las evoluciones de la e(x) y la EVLD1, tanto al nacer como a los 65 años, se observa que ésta ha crecido con menor intensidad que aquélla, lo que apunta a una expansión de la discapacidad severa para los dos sexos, si bien mayor en el caso de las mujeres. Es decir, el incremento de la esperanza de vida ha venido acompañado de un mayor número de años de vida esperada sin discapacidad pero, a la par, el grado de severidad dentro de ésta se ha incrementado relativamente en ambos sexos. Lo que se puede certificar si se consideran los datos complementarios correspondientes a la expectativa de incapacidad, que ha disminuido ligeramente entre los hombres e incrementado suavemente entre las mujeres, y a la expectativa de incapacidad severa, que se ha incrementado para ambos sexos, pero sobre todo en el caso de las mujeres, quienes pueden esperar vivir algo más de un año con incapacidad severa que en 1999, tanto al nacer como a los 65 años.

En resumen, de las series cronológicas de datos examinadas se colige que, en España, hay que diferenciar por sexo no sólo la evolución relativa de las e(x), sino también de las diferentes expectativas de salud. En este sentido, la evolución de la EVLD y la EVLD1 y de su relación respecto a la evolución de la e(x) sugieren la existencia de una expansión de la morbilidad y de la discapacidad severa entre las mujeres, mientras que entre los hombres se ha producido una ligera comprensión de la morbilidad pero con una expansión interna de la discapacidad severa ${ }^{254}$. Procesos que además son relativamente más marcados a los 65 años que al nacimiento ${ }^{255}$.

\footnotetext{
${ }^{254}$ Sin entrar a considerar las variaciones por grado de discapacidad, en EHUME (2005:13-15) se describe el caso de Finlandia entre 1996 y 2001 -o, con menos intensidad, el de Holanda, entre 1995 y 2001-, como ejemplo de población que durante ese periodo vivió una comprensión de la discapacidad entre los hombres a la par que una expansión de la discapacidad entre las mujeres.

${ }^{255}$ Por ejemplo, en el caso de los hombres, la reducción en 0,2 años observada en la expectativa de incapacidad a los 65 años supone el 4,18\% del valor inicial, 4,78 años, en 1999, y es más intensa que el decremento en 0,27 años de la expectativa de incapacidad al nacer que constituye el 3,99\% del valor de 1999, 6,77 años. En el caso de las mujeres, cabe comparar el incremento de 1,06 años de expectativa de incapacidad severa a los 65 años, lo que significa un aumento del 18,96\% respecto a los 5,59 años de 1999, con los 1,29 años de aumento en la expectativa de incapacidad al nacer, que significan el $18,77 \%$ de los iniciales 6,87 años.
} 


\begin{tabular}{|c|c|c|c|c|c|c|}
\hline $\begin{array}{l}\text { CUADRO } 4 . \\
\text { DISCAPACII } \\
\text { SEVERA } \\
\text { INCAPACID } \\
\text { SEXO. Españ }\end{array}$ & $\begin{array}{l}\text { : } \\
\text { ESPER } \\
D \quad(E V L \\
\text { LD1), I } \\
(E I) \text { Y } \\
\text { (E99 y } 20\end{array}$ & $\begin{array}{r}\text { EAA DE } \\
\text { ESPE } \\
\text { ERENCI } \\
\text { PERANZ }\end{array}$ & $\begin{array}{l}\text { DA (e(x } \\
\text { NZA D } \\
\text { EVLD1 } \\
\text { CON II }\end{array}$ & $\begin{array}{l}\text { ESPERA } \\
\text { VIDA I } \\
\text { EVLI } \\
\text { PACIDA }\end{array}$ & $\begin{array}{l}\text { A DE V } \\
2 E \text { DIS } \\
\text { ESPERA } \\
\text { SEVERA }\end{array}$ & $\begin{array}{l}\text { LIBRE } \\
\text { ACIDAD } \\
\text { A } \quad \text { CON } \\
\text { IS) } \text { POR }\end{array}$ \\
\hline & & Hombres & & & Mujeres & \\
\hline & $1999(1)$ & $2008(2)$ & (2) - (1) & $1999(1)$ & $2008(2)$ & (2) - (1) \\
\hline e(x) & & & & & & \\
\hline Al nacer & 75,29 & 77,77 & 2,48 & 82,31 & 84,11 & 1,8 \\
\hline A los 65 años & 16,17 & 17,68 & 1,51 & 20,25 & 21,65 & 1,4 \\
\hline EVLD & & & & & & \\
\hline Al nacer & 68,52 & 71,27 & 2,75 & 72,12 & 73,75 & 1,63 \\
\hline A los 65 años & 11,39 & 13,1 & 1,71 & 12,39 & 13,6 & 1,21 \\
\hline EVLD1 & & & & & & \\
\hline Al nacer & 71,07 & 73,13 & 2,06 & 75,44 & 75,95 & 0,51 \\
\hline A los 65 años & 13,09 & 14,16 & 1,07 & 14,66 & 15,00 & 0,34 \\
\hline$\%$ EVLD/e(x) & & & & & & \\
\hline Al nacer & 91,01 & 91,64 & 0,63 & 87,62 & 87,68 & 0,06 \\
\hline A los 65 años & 70,44 & 74,10 & 3,66 & 61,19 & 62,82 & 1,63 \\
\hline \%EVLD1/e(x) & & & & & & \\
\hline Al nacer & 94,40 & 94,03 & $-0,36$ & 91,65 & 90,30 & $-1,36$ \\
\hline A los 65 años & 80,95 & 80,09 & $-0,86$ & 72,40 & 69,28 & $-3,11$ \\
\hline EI & & & & & & \\
\hline Al nacer & 6,77 & 6,5 & $-0,27$ & 10,19 & 10,36 & 0,17 \\
\hline A los 65 años & 4,78 & 4,58 & $-0,2$ & 7,86 & 8,05 & 0,19 \\
\hline EIS & & & & & & \\
\hline Al nacer & 4,22 & 4,64 & 0,42 & 6,87 & 8,16 & 1,29 \\
\hline A los 65 años & 3,08 & 3,52 & 0,44 & 5,59 & 6,65 & 1,06 \\
\hline
\end{tabular}

Fte: Elaboración propia a partir de (INEbase e INE, 2003a)

De cara al futuro, Robine y Michel (2004) han reivindicado la necesidad de elaborar "una teoría general sobre el envejecimiento poblacional”, a la par que reconocían la dificultad de tal empresa dada la complejidad de las interacciones entre los distintos factores (mortalidad, longevidad, morbilidad, discapacidad), y sus determinantes, que inciden en el envejecimiento poblacional, lo que dificulta prever si la evolución futura de éste se dirigirá hacia un envejecimiento saludable o hacia una pandemia de discapacidades. Cuál sea esta evolución va a depender del peso relativo que en el futuro tengan los siguientes cuatro elementos que coexisten en el escenario actual del envejecimiento poblacional: “1) un incremento en las tasas de supervivencia de personas enfermas, que podrían explicar la expansión de la morbilidad, 2) un control de la progresión de las enfermedades crónicas, que podrían explicar un equilibrio sutil 
entre el descenso de la mortalidad y el incremento de la incapacidad, 3) una mejora del estatus de salud y de los comportamientos saludables de las nuevas cohortes de gente mayor, que podría explicar la comprensión de la morbilidad, y eventualmente 4) una emergencia de poblaciones muy mayores y frágiles, que podría explicar una nueva expansión de la morbilidad” (Robine y Michel, 2004:590).

Desde una perspectiva más general, las tres cuestiones planteadas, reversión de la transición sanitaria, incrementos en las longevidades humanas máxima y media y calidad de vida conexa al incremento de la cantidad de vida, remiten al ámbito político de las posibles intervenciones a implementar para condicionar con sus efectos, alentado o retrayendo, la evolución futura de la relación salud/enfermedad/muerte. Al margen de la hipotética aparición de nuevas enfermedades o patologías, la transición sanitaria explica los incrementos de la e(0) y los previsibles en el futuro-, como fruto, además de la actuación del "estado sanitario" extensión de los tratamientos versus persistencia de las desigualdades en el acceso a los recursos sanitarios-, de la implicación activa de cada individuo en la lucha contra la enfermedad modificando comportamientos y estilos de vida, permitiendo con ello reducir la mortalidad evitable. Si bien éstos, los estilos de vida, están mediatizados socialmente se asiste en las sociedades desarrolladas, como se ha analizado en los capítulos anteriores, al crecimiento de un individualismo utilitarista que "contempla al ser humano cortado de sus raíces pretéritas y de sus prolongaciones futuras” (Sempere y Riechmann, 2000:14), a la par que reduce a un mínimo interesado las relaciones con los otros. En este sentido, la dialéctica elección individual/responsabilidad social se torna más compleja y conflictiva y no tiene fácil discurrir. En efecto, el desarrollo de comportamientos o prácticas de riesgo ligadas al individualismo desborda en muchos casos el ámbito personal de quien los practica y afecta negativamente a terceras personas -es el caso, por ejemplo, de los fumadores pasivos-, o traslada a las administraciones públicas la cobertura de gastos derivada de sus consecuencias negativas. Como resultado de estas dinámicas se ha generado una creciente presión social hacia los Gobiernos para que tomen medidas que, por un lado, fomenten culturas menos tolerantes ante determinados comportamientos de riesgo y los desalienten a la par que, por otro lado, protejan a sus ciudadanos, en especial a los más jóvenes, de esos efectos deletéreos no buscados conscientemente (OMS, 2004 ${ }^{256}$, 2002; N.U., 1999).

\footnotetext{
${ }^{256}$ En la página Web de la OMS (http://www.who.int) pueden consultarse toda una serie de informes elaborados para describir, analizar y proponer las actuaciones necesarias para reducir o eliminar la incidencia de los distintos factores de riesgo, que han sido elevados a los países miembros para ser implementados por los gobiernos e instituciones. Un ejemplo reciente es el informe OMS (2004): Global strategy on diet, physical activity and health, elaborado para la "55 Asamblea Mundial de la Salud".
} 
Esta demanda pública para lograr el control de los riesgos de la salud es un buen ejemplo, según Giddens (1997:155-160), de reflexividad respecto al riesgo externo y a la interacción entre los expertos, que identifican, definen y analizan los peligros de los riesgos, y los profanos. Fruto de esa reflexividad, de esa toma de conciencia, el pensar en términos de riesgos y de su evaluación, “es una práctica más o menos de carácter imponderable” en las condiciones de la alta modernidad (Giddens, 1997:159). Esto, en principio, podría suponer una mayor sensibilización de la población sobre los riesgos que asume y que afectan a su salud, lo que significaría avanzar en la transición sanitaria lográndose nuevas reducciones de la mortalidad. Sin embargo, el propio Giddens, escéptico, advierte sobre lo limitado de esta posibilidad. En efecto, parece ilusorio pensar, no ya en la desaparición, incluso en una reducción sustantiva de los riesgos para la salud derivada del control voluntario de hábitos y comportamientos insanos por parte de los individuos. La libertad de éstos para elegir su modo de vida es una de las señas de identidad de las sociedades más avanzadas, por lo que, en principio, imponer conductas supondría adentrarse en un terreno de gran sensibilidad social con consecuencias difíciles de prever.

No obstante, hay un ámbito concreto en el que hasta ahora predomina el control social sobre las decisiones individuales y que, según evolucione esa dialéctica, podría también incidir en la evolución de la mortalidad. En efecto, a la hora de hablar de muerte y de mortalidad se parte de un supuesto previo aparentemente universal e innegociable: el carácter absoluto de la vida y, en consecuencia, la necesidad de hacer todo lo posible para extender la misma todo lo que sea posible. Este supuesto, dominante en la mayoría de las sociedades, al menos retóricamente, aplicado a los propios ciudadanos tiene consecuencias perversas si se lleva al límite, porque pierde su funcionalidad y llega a convertirse en un corsé sobre aquellos a los que dice proteger. Es decir, se puede producir, y de hecho diariamente se produce, un choque entre lo aparentemente bueno para la sociedad -basado en el carácter absoluto de la vida- y el enfrentamiento particular de la muerte, de la mala muerte en realidad. En este sentido, el control tecnomédico de la muerte puede frenar otras opciones más individualistas ligadas a los valores posmodernos, que reivindican la muerte como espacio de realización. Estas posiciones sobre la vida y la muerte pueden afectar a la evolución de la mortalidad, ya que, por ejemplo, la percepción de la mala calidad de vida en los años finales, con todos los costes que implica para la persona afectada y sus familiares y amigos, puede incidir en las reivindicaciones de los individuos sobre su propia muerte (control y no prolongación de la vida). Así, podría ocurrir que la asunción de la muerte como parte integrante de la vida, por individuos cada día más concienciados frente a las promesas que se derivan de una investigación genética de la que no se sabe aún qué efectos tendrá sobre la prolongación de la vida, pero que todavía se imagina menos 
qué consecuencias mismas tendrá sobre las condiciones y calidades de esa vida, limite la expansión de la investigación médica y atempere el descenso de la mortalidad.

Con este marco de fondo, resulta necesario conocer cómo percibe de forma más concreta el ciudadano medio su situación en el ámbito del control de la propia muerte y detectar en sus opiniones si, y cómo, vislumbra por dónde pueden evolucionar los acontecimientos. Es decir, obtener respuestas a cuestiones como: ¿creen que la vida tiene carácter absoluto?, ¿merece la pena vivirla indefinidamente?, ¿̇se sienten protagonistas de su vida y de su muerte?, ¿a quién corresponde decidir?, ¿qué alcance tiene el paradigma médico?, ¿creen en la inmortalidad?, ¿qué lugar ocupa la muerte en su pensamiento?, ¿cómo les gustaría morir?, ¿son partidarios de la eutanasia?, etc. Las respuestas a estos y otros interrogantes que se abordan en el siguiente capítulo de esta Tesis y que pueden ayudar a comprender no sólo el modelo de muerte dominante en la sociedad española actual, sino que también pueden aportar luz sobre la predisposición o el rechazo de la opinión pública hacia las actuaciones tecnomédicas, lo que incidiría en la evolución futura de la mortalidad. En última instancia, se plantea la cuestión de si, como ocurrió con la segunda Transición Demográfica ${ }^{257}$ cuando se redujo la fecundidad por razones culturales y por la necesidad de un control individual sobre la propia vida, ¿'existe ya o puede generarse un caldo de cultivo cultural en el que se extienda ese control individual también a la propia muerte?.

257 Lesthaeghe y Van de Kaa (1986; Lesthaege, 1998; Van de Kaa, 1987), señalan la existencia de una segunda transición demográfica que, a diferencia de la primera en la que los procesos determinantes fueron el descenso de la mortalidad seguido del de la natalidad, tendría como rasgos característicos los cambios en la conducta marital y reproductiva ocurridos en los países de Europa occidental desde mediados de la década de 1960, y que han supuesto un descenso de los niveles de fecundidad por debajo del nivel de reemplazo poblacional. Esos cambios en la fecundidad (aumento del número de divorcios, descenso de la fecundidad y su relación con la utilización de métodos anticonceptivos, cambios en la legislación del aborto, incremento de la soltería, decrecimiento de la nupcialidad, auge de las uniones consensuales, aumento de los hogares nucleares monoparentales y aumento de los hijos extramatrimoniales), que obedecen a las conductas y decisiones individuales, son sin embargo esencialmente sociales. Concretamente, están relacionados con las transformaciones estructurales del Estado de Bienestar, con los avances tecnológicos -difusión espacial rápida de innovaciones, especialmente los vinculados con la contraconcepción-, y sobre todo con los cambios culturales asentados en los procesos de secularización e individualización (Herrera Ponce, 2007). 
CAPÍTULO 5.- LA “MUERTE VIVIDA” CUANDO

ESTÁ LEJANA: CREENCIAS, ACTITUDES,

VALORES Y COMPORTAMIENTOS ANTE LA

MUERTE Y EL MORIR 

CAPÍTULO 5.- LA “MUERTE VIVIDA” CUANDO ESTÁ LEJANA: CREENCIAS, ACTITUDES, VALORES Y COMPORTAMIENTOS ANTE LA MUERTE Y EL $\underline{\text { MORIR }}$

"La ironía de la condición humana consiste en la necesidad más profunda de verse libre de la ansiedad de la muerte y la aniquilación, pero es la propia vida la que la despierta”

E. Becker

Si históricamente el "discurso de la muerte" y la "muerte sufrida" se han transformado, parece razonable pensar, en consecuencia, que con mayor o menor calado igualmente se han producido mutaciones en lo que Vovelle denomina la "muerte vivida", es decir, tanto lo que sería la "envoltura formal" (red de gestos y ritos que acompañan el recorrido de la última enfermedad a la agonía, a la tumba y al más allá), como la "sensibilidad” a la muerte (Vovelle, 1985:103).

Como se ha señalado en el Capítulo 3, en un contexto en el que coexisten distintos modelos de muerte, no obstante se observa la presencia de unas claves básicas que conforman en la actualidad un modelo de muerte dominante en Occidente caracterizado por la negación de la misma -la muerte invertida. Este modelo, fruto de profundas y continuas mutaciones producidas en las sociedades desarrolladas, no incide por igual en todos sus miembros lo que da lugar a que incluso en cada uno de éstos no exista una respuesta única ante la muerte. Además, al hecho de que "en las sociedades complejas a menudo coexistan supervivencias de varias mentalidades” (Bouthoul, 1971:10), se añade la existencia de desigualdades sociales en la percepción de la muerte lo que condiciona actitudes y comportamientos diferenciales frente a ella entre las distintas categorías sociales.

En el presente Capítulo se realiza una aproximación a la relación sociedad/muerte en la población española actual desde el ámbito de la muerte vivida. Inicialmente, se justifican los conceptos empleados y se presentan la metodología y técnicas utilizadas en el análisis; asimismo, se describen la composición de la muestra utilizada para la encuesta implementada en este trabajo, el cuestionario, y las características de las entrevistas semi-estructuradas y del grupo de discusión para la obtención de información cualitativa complementaria. Posteriormente, y sobre el marco de fondo de los valores axiológicos dominantes, se realiza el análisis de la muerte vivida entre la población encuestada a partir de un esquema estructurado en siete apartados: a) muerte y vida cotidiana; b) muerte y planes de vida; c) ritos funerarios; d) interacción en el ámbito hospitalario; e) imágenes de la muerte; f) multidimensionalidad del miedo a la muerte, y; g) la muerte como dimisión de la vida. 


\subsection{METODOLOGÍA, TÉCNICAS, INSTRUMENTOS Y DATOS PARA EL ANÁLISIS DE LA MUERTE VIVIDA}

“¿Dónde está la vida que hemos perdido en el vivir? ¿Dónde está la sabiduría que hemos perdido en el conocimiento? ¿Dónde está el conocimiento que hemos perdido en la información? ¿Dónde está la información que hemos perdido en los datos?”

T.S. Elliot

Al menos desde Platón (<<mito de la caverna >>), son bien conocidos los problemas epistemológicos subyacentes a la construcción del pensamiento humano. Resulta pertinente destacar entre ellos, dado que se refiere a la esencia misma de esos problemas, la necesidad de tener clara la distinción y el vínculo entre datos, información, conocimiento y sabiduría. Como señala Lorente (2002), de la agregación estructurada de los datos se construye la información, de la aprehensión de la información el conocimiento, y de la sublimación de éste la sabiduría ("logos”). En este discurrir hay continuas fugas que Lorente ejemplifica con los versos citados de T.S. Elliot.

Esta limitación general del proceso de conocer, en gran medida insalvable, se materializa en problemas metodológicos y técnicos específicos en las diversas fases del mismo. Así, históricamente, en la construcción de los conceptos “creencia”, "actitud” y "valor” ha estado presente la polémica ligada a su propia naturaleza 'escurridiza': qué contenidos se incluyen en los mismos y cuáles no, y “a qué tipo de elementos empíricos se hace referencia” en cada uno de ellos (Gimeno, 2001:14) ${ }^{1}$. De ahí, las múltiples definiciones elaboradas sobre cada uno de esos conceptos tanto en la tradición sociológica como en la psicológica. Refiriéndose concretamente a los valores, González Blasco (1994:15) recuerda que adentrarse en ellos es tarea inabarcable y en gran medida inaccesible para el análisis al tener que enfrentarse a horizontes desconocidos. Estas dificultades han determinado que las definiciones de esos conceptos tengan en gran medida un carácter operativo y estén asentadas en decisiones subjetivas arbitrarias sobre ideas preconcebidas de lo que, por ejemplo, debe ser una actitud o sobre la presunción, asimismo arbitraria, de que el contendido de la misma pueda recogerse en su totalidad mediante cuestionario y ser cuantificado (Blumer, 1982:70).

Por ello, el análisis de las creencias, actitudes, valores, opiniones y comportamientos de una población encuestada sobre la muerte y el morir requiere que, previamente y de forma sintética, se expliciten la acepción y el sentido en que tales conceptos son empleados en este

\footnotetext{
${ }^{1}$ A la diferenciación conceptual ligada a la construcción intrínseca de los conceptos se añade la derivada del enfoque teórico adoptado en el análisis de los mismos ("conductista, cognitivista, funcional, el del interaccionismo simbólico de G.H. Mead o de la acción razonada"), que valoran de forma muy diferente el papel desempeñado por lo social (Bergere, 1998:9).
} 
trabajo. Para ello se toma como referencia el modelo teórico elaborado por Rokeach (1975) ${ }^{2}$. Este autor afirma que "un adulto tiene probablemente decenas de millares de creencias, varios centenares de actitudes, pero sólo unas decenas de valores” (Rokeach, 1975:19). Su modelo, por tanto, tiene carácter piramidal, y su unidad básica, la célula del mismo, es la creencia, a la que define como "una proposición simple, consciente o inconsciente, inferida de lo que una persona dice o hace, que puede ir precedida de la frase <<Yo creo que...>>” (Rokeach, 1975:15). El contenido de una creencia consta de tres componentes (Rokeach, 1975:16):

a) el que describe un objeto o situación como verdadero o falso (componente cognitivo);

b) el que lo evalúa como bueno o malo (componente afectivo); y

c) el que recomienda o no actuar (componente conativo-conductual).

En general, por tanto, una creencia constituye "un estado de adhesión firme e indudable, una convicción que se funda, no sobre un saber lógico y sujeto a verificación, sino sobre un sentimiento que reconoce el carácter práctico de una acción o el valor absoluto de unos principios” (Prades, J. A., 1998:158). No obstante el carácter multidimensional de las creencias, la intrínseca e íntima relación entre los tres componentes facilita, según Rokeach, que importe poco cuál de ellos se emplee para clasificar a las personas respecto a las mismas. Este hecho, unido a la imposibilidad empírica de medir directamente algunas variables o de aislar los tres componentes, y a que, como resalta Rokeach (1975:16), en algunas ocasiones el componente afectivo no esté activado ${ }^{3}$, ha determinado que históricamente se asimile el concepto de creencia con su componente cognitivo. Así, en la práctica sólo se ha medido éste, justificando esta estrategia en que las creencias "tienen que ver con pensamientos e ideas más que con sentimientos y emociones” (Harding et al., 1986:5). Fruto de este proceso, las creencias han quedado reducidas e identificadas como el elemento cognitivo de las actitudes ${ }^{4}$ (Assael, 1984). En cualquier caso, resulta paradójica esta asimilación reduccionista de las creencias con su componente cognitivo dada la evolución conceptual acumulativa de las actitudes, de las que las creencias son su materia prima, en la que se han incorporado aspectos estructurales hasta llegar

\footnotetext{
${ }^{2}$ Como destacan Requena y Benedicto (1988:13), este modelo se caracteriza por su claridad conceptual y por reflejar estructuradamente un sistema global -sistema de creencias- en el que los referidos conceptos (creencias, actitudes, valores) aparecen interrelacionados y jerarquizados y cuyas inter-conexiones configuran subsistemas que aseguran la consistencia y la coherencia funcional.

${ }^{3}$ Rokeach (1975:16) cita como ejemplo la ausencia de discusión -se hable a favor o en contra- sobre la forma de la Tierra al existir un amplio consenso al respecto. Éste sería un caso típico en el que no se activa el componente afectivo de la creencia. No obstante, "hay que suponer que el componente afectivo está ahí, y de hecho, se activa cuando dicha creencia es objeto de controversia... Toda creencia dada por supuesto, por muy impersonal que sea, tiene la propiedad de provocar reacciones afectivas siempre que su validez es puesta en duda... Todos tenemos interés en que nuestras creencias sean correctas; la verdad es buena y la mentira es mala".

${ }^{4}$ Morales et al (1994:508) señalan que existen actitudes que no surgen de un proceso consciente ni del cálculo previo de los benéficos y costes y que, al carecer de "un elenco amplio de creencias que las acompañan y sustentan, tienen un fuerte componente afectivo".
} 
a la situación actual en la que domina una visión sistémica de las mismas y se resalta su carácter multidimensional.

Una actitud, según Rokeach (1975:15), es “una organización relativamente duradera de creencias en torno a un objeto o situación, que predispone a reaccionar preferentemente de una manera determinada”. Las actitudes, aprendidas en el proceso de socialización, constituyen un juicio evaluativo bipolar (positivo-negativo; favorable-desfavorable, acercamiento-alejamiento) sobre cualquier objeto actitud. Éste puede ser algo o alguien concreto: “el yo, los demás, cosas, acciones, sucesos o ideas” (Smith y Mackie, 1997:266), los problemas sociales y/o las situaciones sociales (Morales et al, 1994:497). La evaluación, por su parte, se entiende como "el afecto que despierta (el objeto), las emociones que moviliza, el recuerdo emotivo de las experiencias vividas, incluso las creencias acerca de la capacidad del objeto para conseguir metas deseadas” (Morales et al, 1994:497). Esta concepción amplia de la evaluación del objeto de actitud, como integrada por los tres componentes (cognitivo, afectivo, y conativoconductual), no es óbice para resaltar que la parte más relevante de la misma, por ser la que predispone al individuo a dar una respuesta preferencial, es su componente afectivo ${ }^{5}$ (Robins, 1996:180; Rokeach, 1975:18).

En la estructura de las actitudes de las personas se integran tanto la estructura de las actitudes individuales como la estructura de los sistemas de actitudes sociales, además de las interacciones con otros sistemas de la persona (Bergere, 1998:8). Las actitudes, por tanto, no surgen de la nada o por azar ni se encuentran aisladas, sino que proceden de la estructura de la personalidad del individuo ${ }^{6}$ y de su entorno social, son dinámicas, pudiendo modificarse e incluso desaparecer. En efecto, las actitudes cumplen distintas funciones destacando entre ellas la función de ajuste social, cuyo objetivo es adecuarse al entorno social en el que se encuentran los individuos, para lo que deben de responder apropiadamente a las exigencias de los grupos de referencia en cada situación (Morales, et al, 1994:511-512) ${ }^{7}$.

\footnotetext{
${ }^{5}$ Obviamente, esto no significa minusvalorar el componente conativo-conductual de las actitudes, ni mucho menos asumir que algunas de ellas carezcan del mismo, ya que, como matiza Rokeach (1975:20), es imposible descubrir una predisposición que no lleve a dar alguna respuesta: "ninguna preferencia hacia el objeto de una actitud puede ocurrir en el vacío".

${ }^{6}$ Si bien algunas actitudes son innatas, por ejemplo, la preferencia del placer sobre el dolor, la mayoría de las actitudes son aprendidas: a través de los "otros" se construyen representaciones cognitivas de los objetos de actitudes. Estas representaciones del objeto se componen de información cognitiva (lo que las personas saben -hechos y creencias- sobre él), afectiva (lo que las personas sienten -sentimientos y emociones- hacia el mismo) y conativo-conductual ("conocimientos sobre el pasado, presente o futuro de las interacciones de las personas con el objeto”) asociada al objeto (Smith y Mackie, 1997: 270-271).

${ }^{7}$ Otras funciones de las actitudes son, por una parte, la de la evaluación del objeto -función de conocimiento-, que orienta sobre las características del objeto de actitud y el modo más eficaz para tratar con él. A través de un proceso selectivo de la información más relevante sobre un objeto de actitud, la actitud "toma vida propia” y llega a ser "un sustituto práctico de lo que sabemos y de cómo nos sentimos con respecto al objeto de actitud" (Smith y Mackie, 1997:272-273). De esta forma, la actitud se constituye
} 
Desde el punto de vista analítico, a la hora de examinar cualquier realidad social concreta se han de considerar tres aspectos esenciales de la relación actitud/conducta. Por un lado, el hecho de que todo objeto de actitud se halla inserto en una situación acerca de la cual los individuos también mantienen una actitud, es decir, siempre se activan simultáneamente dos actitudes en interacción: una, referida al objeto de la actitud, y la otra, a la situación (Rokeach, 1975:20). Por tanto, a la hora de analizar cualquier conducta social, por ejemplo referida a la muerte, se ha de tener en cuenta que ésta no viene determinada por una sola actitud, sino que depende siempre, como mínimo, de dos tipos de actitudes, una activada por el objeto y otra activada por la situación, por el contexto histórico concreto. En otro caso, puede resultar difícil comprender la conducta al observarse una falta de correspondencia entre ésta y la actitud. Por otro lado, dada la complejidad de la relaciones entre actitudes y comportamientos, relaciones que están mediatizadas por múltiples factores (sociales, institucionales, personales, etc.), a efectos analíticos se ha de considerar asimismo el nivel de generalidad en el que están planteadas las actitudes y las conductas a la hora de establecer cuáles son las relaciones entre ellas. En efecto, de la misma forma que no basta una conducta concreta para afirmar o desmentir una actitud general, no cabe lo contrario, es decir, no parece razonable intentar pronosticar un comportamiento específico a partir de una actitud genérica. Por ejemplo, de la no asistencia a un funeral de un familiar próximo (conducta muy específica en lo que se refiere a la acción concreta a realizar, el objeto hacia el que se dirige la acción, el contexto en que tiene lugar y el momento en que ocurre), no se colige una actitud general de indiferencia, de aceptación, o de temor hacia la muerte. $\mathrm{Y}$ al revés. Se ha de tener en cuenta, por tanto, el $<<$ principio de compatibilidad >> por el que "sólo cabe esperar relaciones entre actitudes y conductas cuando ambas están planteadas al mismo nivel de generalidad” (Morales et al, 1994:513-515). No obstante, sí es más factible esperar que cuanto más específica sea la actitud que se está midiendo y más específica sea la identificación del comportamiento, mayor será la probabilidad de que se pueda mostrar una relación entre ambos. Finalmente, un tercer aspecto esencial a considerar en el análisis de la relación actitud/conducta es la incidencia de la presión social o de las restricciones sociales sobre el comportamiento: la $<<$ norma social subjetiva $>>$. En efecto, en un individuo pueden presentarse discrepancias entre las actitudes y el comportamiento debido al poder excepcional que pueden ejercer sobre él las presiones sociales que recibe para que se comporte de determinada manera (Robins, 1996:186; Morales et al, 1994:516). Por ejemplo, las

en un marco de referencia que organiza el conocimiento, ahorra tiempo, y que, dado su carácter dialéctico con el mundo real, tiene inscrita dentro de sí misma la potencialidad del cambio ante la aparición de nuevos datos. Por otra parte, las actitudes ayudan a mantener la identidad social -función expresiva de valor-, "al expresar las personas su yo real, hacer escuchar sus convicciones, mostrar lo que sustentan y afirmar sus relaciones significativas” (Smith y Mackie, 1997:270). Únicamente, por tanto, se construyen aquellas actitudes que "reflejan, expresan y comunican adecuadamente los valores fundamentales... ajustados a lo que internamente se considera correcto” (Morales, et al, 1994:511-512). 
presiones o los condicionantes sociales pueden explicar que una persona con marcadas actitudes antirreligiosas asista a un funeral religioso.

Junto a estas prevenciones analíticas generales, a la hora de examinar las actitudes ante un fenómeno social tan "sensible” y complejo como es el de la muerte, se torna inexcusable, además, precisar cuáles de esas actitudes serán objeto de examen. En esta Tesis, y como se ha señalado en la Introducción, se parte del hecho básico de que la muerte es abstracta mientras que el morir es concreto, y de que la forma y/o proximidad del morir condiciona la concepción de la muerte. De ahí que, siguiendo a C. Castilla del Pino (1995), sea necesario diferenciar dos tipos de actitudes ante la muerte entre las que no cabe equiparación y, por tanto, conviene examinar por separado: las actitudes relacionadas con la experiencia directa del morir propio, cuando ya no queda tiempo y todo lo que había sido y es la vida cotidiana se difumina al aproximarse, inexorablemente, el fin del Yo (<<actitud ante la muerte $>>)$, y las derivadas de la experiencia vicaria del morir de los demás que, sí, aporta información sobre lo que será en el futuro, pero que no impide seguir con la vida diaria esquivando el enfrentamiento con la muerte (<<actitud ante la expectativa de nuestra muerte>>). En este capítulo se analiza este segundo tipo de actitudes entre la población española actual, es decir, lo que los miembros de ésta que no han tenido contacto directo con la muerte en los últimos años se imaginan que es o será la muerte. 'Actitud ante la expectativa de muerte' que es la que está presente durante la mayor parte de la biografía de esos individuos en las sociedades occidentales.

En la práctica, y a diferencia de los objetos físicos que pueden ser observados y medidos con diversos instrumentos, las actitudes no son directamente observables en sí mismas. De esta forma, se dice que una actitud es una "variable latente" que emerge, por ejemplo, "al ser inferida de ciertas respuestas mensurables y que refleja, en última instancia, una evaluación global positiva o negativa del objeto de la actitud” (Morales et al., 1994:497). Así, por la vía de las expresiones de las actitudes, éstas pueden ser 'medidas' directamente (opiniones ${ }^{8}$ a través, por ejemplo, de "escalas de actitudes" ${ }^{9}$, u observando comportamientos) o indirectamente (técnicas de medida fisiológicas) (Smith y Mackie, 1997:266-270).

En la cima del esquema piramidal propuesto por Rokeach (1975:19), y que toma como unidad básica a la creencia, se encuentran los valores, entendiendo por $<<$ valor $>>$ "un tipo de

\footnotetext{
${ }^{8}$ Por “opinión” se entiende la "expresión verbal de alguna creencia, actitud, valor” (Rokeach, 1975:19). El "comportamiento", por su parte, refleja la predisposición a la acción.

${ }^{9}$ Una <<escala de actitudes >> "es una serie de preguntas que se hace a la gente para ver en qué medida están de acuerdo o no, favorecen o se oponen, aceptan o rechazan un determinado objeto de actitud" (Smith y Mackie, 1997:267). El posicionamiento de las personas encuestadas en escalas de actitudes hace que éstas sean "más objetivas" que otros instrumentos a la hora de interpretar los resultados (Gutiérrez Vega y Martínez Daza, 1991:119).
} 
creencia, localizada en el centro del sistema total de creencias de una persona, acerca de cómo se debe o no se debe comportar o acerca de algún objetivo en la existencia que vale o no vale la pena conseguir". Los valores, por tanto, son convicciones básicas y profundas, ideales abstractos, de que "algo" -“un modo específico de conducta o estado final de existencia” - es mejor o peor, bueno o malo, deseable o no, respecto a "otra cosa -el modo opuesto o contrario de conducta o estado final de existencia-” (Beltrán, 1998:811; Robins, 1996:174).

Las diferencias entre las actitudes y los valores son diáfanas. Mientras que las primeras hacen referencia a un objeto o una situación concretos, los segundos se orientan hacia la generalidad. Así, los valores son patrones de deseabilidad que traspasan la especificidad de lo concreto, gobiernan las acciones, los juicios, las actitudes y las opiniones y, en consecuencia, las actitudes están subordinadas a ellos (Requena y Benedicto, 1988:16). En definitiva, los valores constituyen el "substrato básico" que permite comprender las actitudes y las motivaciones, a la par que influye en las percepciones de las personas (Robins, 1996:174). A esta diferencia de competencias entre actitudes y valores se suma el distinto ritmo de cambio en unas y otros. Aunque ambos son dinámicos, los valores son mucho más resistentes al cambio, es decir, más relativamente estables y permanentes ${ }^{10}$ que las actitudes (Robins, 1996:175).

Los valores son sociales en su origen y naturaleza. Aunque son los individuos quienes en última instancia los portan, no debe olvidarse que, en todos los sentidos, son actores sociales mediatizados. Esto significa, según Andrés Orizo (1991:15), que el talante, el humor e incluso el tono vital de los individuos reflejan los de la sociedad en la que viven, ya que "la estructura social en la que están inmersos se registra en su misma persona: es el 'nosotros' insito en la interioridad de los sujetos”. De esta forma, los individuos no se inventan sus valores, sino que, a través de la influencia, condicionamiento o, incluso, determinación de los grupos en los que se hallan integrados, eligen entre los valores que encuentran en el contexto histórico-cultural en que viven (Beltrán, 1998:811-81). Es en este contexto social en el que se definen y dotan de contenido a los valores, así como donde se conforma el marco social en el que adquieren plena significación para los individuos. Esto implica que, si bien a efectos de análisis puede diferenciarse, por ejemplo, entre valores personales (lo que se desea) y morales (lo que se debe desear) resulta imposible separar del todo ambos componentes (Requena y Benedicto, 1988:17). En efecto, en el proceso de socialización de los individuos la "concepción de lo deseable" socialmente se incrusta en ellos e influye en su "comportamiento selectivo" (Williams, 1975:610). Para algunos autores, incluso, las actitudes individuales no cuentan, ya que al formar

\footnotetext{
${ }^{10}$ Robins (1996:175) resalta como principal razón de la mayor estabilidad de los valores la forma en que se aprenden durante los primeros años de la vida. Concretamente, el carácter absoluto de un aprendizaje "en blanco o negro", sin áreas intermedias entre lo deseable o lo indeseable.
} 
parte de una estructura social "lo que interesa son las vigencias en esta dimensión de la vida, aquellas que cada individuo encuentra y que ejercen su presión sobre él, sea cualquiera su posición personal” (Marías, 1993:371). En todo caso, y al margen de su convencionalismo o arbitrariedad, desde el punto de vista sociológico lo realmente relevante es el grado en que se comparten los valores por más o menos gente (“algo es valioso porque es preferido por muchos”), y los mecanismos sociales implícitos en las transformaciones de los mismos (Beltrán, 1998: 811-812).

Resulta pertinente, en consecuencia, a la hora de examinar los valores de las personas ante la muerte, adoptar en el análisis una posición matizada como la planteada por González Blasco (1994). Este autor, sobre la base de una revisión selectiva de la bibliografía filosófica ${ }^{11}$ y sociológica relativa a la consideración y utilización de los valores por las distintas tendencias y teorías, señala las peculiaridades y limitaciones del análisis sociológico en este ámbito y extrae algunas conclusiones de interés. Cabe destacar entre las peculiaridades y limitaciones, su afirmación de que la aproximación sociológica, a diferencia de la filosófica, se refiere a valores más en sentido relativo que absoluto. En Sociología no se plantea una axiología pura de los valores en cuanto a su esencia, no se plantea la realidad o irrealidad de los valores, sino que, admitiendo la existencia de una realidad social denominada valores, se asume una <<postura pragmática >> de análisis por la que "todo lo más que captamos son prioridades que nos pueden llevar a ciertos tipos de seres, pero no a lo que pasaría fundamentalmente a los seres, si consideramos a los valores como tales” (González Blasco, 1994:18-19, 40). En este sentido, y como ocurre con las actitudes, dado que los valores no pueden observarse y medirse directamente, al ser procesos internos de los individuos, la Sociología accede a su identificación y análisis "por vía de razón, cognitiva e intelectual” cuantificándolos en comparación, es decir, buscando no tanto su significación en términos absolutos, sino su importancia relativa (González Blasco, 1994:18-19).

\footnotetext{
${ }^{11}$ En el ámbito filosófico, González Blasco toma como referencia la entrada “valor” del Diccionario de Filosofía abreviado de Ferrater Mora (1976:424-426). Según este autor algunas de las características que se atribuyen a los valores son las siguientes: 1) "El valer... La característica del valor es el ser valente, a diferencia del ser ente... Su forma de realidad no es el ser ideal ni el ser real, sino el ser valioso... 2) Objetividad. Los valores son objetivos, no dependen de las preferencias individuales, sino que mantienen su forma de realidad más allá de toda apreciación y valorización... La objetivación del valor es sólo la indicación de su autonomía con respecto a toda estimación subjetiva y arbitraria... 3) No independencia.... Esta dependencia no debe entenderse como una subordinación del valor a instancias ajenas, sino como la necesaria adherencia del valor a las cosas... 4) Polaridad. Los valores se presentan siempre polarmente, porque no son entidades indiferentes como las otras realidades. Al valor de la belleza se contrapone siempre el de la fealdad; al de la bondad, el de la maldad... 5) Cualidad. Los valores son totalmente independientes de la cantidad y por eso no pueden establecerse relaciones cuantitativas entre las cosas valiosas. 6) Jerarquía. El conjunto de valores se ofrece en una tabla general ordenada jerárquicamente”.
} 
Entre las conclusiones extraídas por González Blasco, la de mayor calado para este trabajo es la que sostiene que "en sociología no podríamos hablar netamente de que lo que estudiamos son valores, sino más bien lo que hacemos es análisis de las opciones o sistemas de opciones preferenciales, que los sujetos de una colectividad, socializados en su respectivo contexto -sobre todo cultural- eligen mayoritariamente”. El objeto del análisis sociológico será por tanto más bien las "visiones del mundo" de los sujetos analizados que propiamente los valores interiorizados por tales individuos y que no son captados por la analítica (González Blasco, 1994:41).

Por otra parte, los valores tienen dos atributos, uno de contenido por el que se establece si “algo" es importante, y otro de intensidad, por el que se especifica qué tan importante es ese “algo”. Este segundo atributo permite a cada individuo establecer una especie de jerarquía valorativa de acuerdo a la importancia relativa que concede a cada valor (Robins, 1996:174). Sobre la base del propio sistema de valores cada persona ordena y elige entre las distintas opciones alternativas que se le presentan en su vida. No obstante, esa elección está mediatizada socialmente como muestran de forma diáfana los trabajos empíricos que revelan la existencia de regularidades en las valoraciones de los miembros de toda comunidad sociocultural. Así, cabe identificar en cada una de éstas, como agregado que relaciona los diferentes conjuntos de valores individuales y de los grupos, un <<sistema cultural de valores $>>$, es decir, un sistema de criterios por el que se juzga la conducta, otorgando reconocimiento o aplicando sanciones, que representa lo que socialmente se prevé o se espera, lo que se exige o se prohíbe ${ }^{12}$ (Albert, 1975:611). Estos sistemas de valores han permitido elaborar diferentes tipologías de valores y observar las diferencias existentes en ese ámbito entre distintas categorías sociales.

En este sentido, los sistemas de valores son imprescindibles a la hora de analizar el "valor" que una sociedad otorga a la muerte, por cuanto resulta totalmente insuficiente examinar aisladamente ese valor sin considerar a otros valores con los que se encuentra en estrecha interrelación y lo condicionan, cuando no lo determinan. En el caso de la sociedad española actual, por tanto, hay que situar el 'valor de la muerte' en un marco más amplio de valores y, en especial, hay que relacionarlo con los cambios que se han producido en los mismos fruto de las transformaciones estructurales ligadas al proceso de modernización desarrollado durante el siglo XX, explicadas en el Capítulo 2 de esta Tesis. Desde esta perspectiva, y siguiendo a Requena y

\footnotetext{
12 "Un sistema cultural de valores es operacionalmente, el conjunto de criterios de valoración, de base inductiva y con una ordenación lógica, construido a partir de los juicios de valor explícitos y de las inferencias de conductas no explícitas relacionadas con los valores. Teóricamente, es el conjunto de criterios estructurados, explícitos e implícitos, por referencia a los cuales se hace inteligible la conducta valorativa. Funcionalmente, es el conjunto de principios por el que se rige y regula la conducta y una guía para los individuos y el grupo social” (Albert, 1975:611).
} 
Benedicto (1988:23-24), resulta imprescindible aludir al conjunto de valores genéricos que, aún no circunscritos a parcelas concretas de la vida social, conforma el marco de referencia axiológico básico sobre el que los individuos estructuran su vida cotidiana. Razón por la que analíticamente es importante identificarlos, ya que, aunque por sí mismos pueden no incidir directamente en el contenido y orientación de las actitudes y en los comportamientos relativos a ámbitos específicos de la realidad social, aportan información relevante sobre los criterios subyacentes en las evaluaciones, las preferencias valorativas y la toma de decisiones de los individuos cuando actúan en esos ámbitos concretos. Por ello, además de la información primaria, resulta pertinente consultar fuentes de datos que, como las Encuestas Mundiales de Valores, aportan información secundaria sobre los valores centrales o básicos situados en la cúspide del sistema de valores en un momento determinado. Obviamente, en la presente investigación no interesa conocer cuál es el statu quo de toda la cúspide del sistema de valores en la sociedad española actual, sino sólo la de aquellos más genéricos que puedan condicionar las actitudes ante la muerte. En este sentido, cabe recordar lo ya destacado en el Capítulo 2 sobre el ascenso de los valores postmaterialistas, el proceso de (de)secularización y, conexo a ambos, el incremento del relativismo moral.

En el análisis de las creencias, actitudes y valores hacia la muerte, en consecuencia, se han de tener en cuenta estas dificultades conceptuales genéricas y algunas más que le son específicas al propio objeto de la investigación. De hecho, según algunos autores, serían estas 'complicaciones adicionales' relacionadas con la complejidad y multidimensionalidad de la realidad de la muerte, las que, por su calibre, al inscribirse en planos muy distintos del ser humano, desaconsejan la realización de un análisis sociológico tradicional mediante encuesta dado que lo dejarían sin validez por su nula fiabilidad. Es el caso de Rodríguez Rioboo (1993:7), quien sintetiza gráficamente su rechazo al análisis demoscópico de la muerte señalando que no es lo mismo preguntar qué se piensa sobre el sistema de partidos propio de la democracia, que preguntar qué se piensa sobre la muerte ${ }^{13}$. Es obvio que en el presente trabajo no se abrazan posiciones tan extremas, aunque sí se reconoce la importancia de los problemas específicos ligados al objeto de análisis "muerte” en los estudios mediante encuesta como se comenta a continuación. Desde el punto de vista conceptual el más relevante de esos problemas, como señala Kalish (1985:152), es la asunción implícita de que las personas al ser interpeladas

13 Para Rodríguez Rioboo (1993:7-8), encuestar sobre la muerte es un procedimiento mucho más nebuloso que preguntar sobre temas más concretos y específicos de la vida social. Básicamente, porque aunque la muerte se asienta en el nivel de la "conciencia expresa” de los seres humanos, lo que les permite manifestar sus opiniones sobre ella identificándola como "neumonía y cáncer y radiaciones... Y muerte es putrefacta y luego pestilente descomposición. Y muerte es esperanza para algunos, el no ser para siempre para otros. Y es eternidad tremebunda para los que cabalgan entre la aprehensión y el pecado, vida eternal y excelente para otros...”, también reside en el plano de la fantasía, “escondida la mayoría de las veces en el tupido bosque de los universos simbólicos”, y en el más inaccesible e "inquietante mundo del inconsciente". 
sobre la muerte dicen de la misma lo que realmente significa para ellas. Así, si una persona afirma que su actitud ante la muerte es de ausencia de temor se asume que, efectivamente, no tiene temor a la muerte. Se admite, implícitamente, que lo manifestado por esa persona es una síntesis de su posición en las tres dimensiones de toda actitud. No obstante, suele ocurrir con frecuencia que haya individuos que no manifiesten temor a la muerte en el nivel consciente y, sin embargo, se les detecte en otros niveles de consciencia. También cabe la posibilidad de que las respuestas manifestadas se aparten conscientemente de lo que se piensa o se siente en el fuero interno por querer dar una imagen determinada de sí mismo. Además, es posible que las respuestas aportadas estén mediatizadas por otros determinantes diferentes de la propia actitud, sin que exista el propósito explícito de distorsionar la respuesta (Feifel y Nagy, 1981).

Un segundo problema relevante es la dificultad de definir operativamente los diversos conceptos, lo que puede llevar a una utilización conceptual inadecuada de los términos o a la confusión conceptual si se etiqueta de forma inapropiada en las escalas de medida de la muerte (Kalish, 1985:153). Así, se suelen medir como un único factor, por ejemplo, temor/no temor a la muerte, lo que en realidad es la síntesis de una combinación de dos o más factores de muy difícil delimitación: “temor, ansiedad, elusión, negación, no querer morir”. Cabe además la posibilidad de que en algunas de las personas encuestadas coexistan actitudes contradictorias (aceptación-rechazo). A lo que hay que añadir un tercer problema de difícil solución como es el de detectar si las escalas están midiendo realmente las actitudes habituales (generales) ante la muerte de las personas encuestadas o si es su aplicación cuando se las interroga la que hace aflorar actitudes que están larvadas y no son usuales en la vida cotidiana de dichas personas. Cuestión metodológicamente “trascendente”, como alerta Durán (2004) quien, en su examen sobre la calidad de la muerte a través del análisis de los datos aportados por doce encuestas (CIS, CIRES, ASEP), ilustra la cuestión con lo ocurrido en el espacio del año que medió entre los Estudios del CIS n ${ }^{\circ}$ 2.244, de abril de 1997, y n 2.279 , de marzo de 1998. En ambos se preguntaba a la población, mayores de 18 años, en el primero, y mayores de 65 años, en el segundo, sobre una batería concreta de preocupaciones que pudieran afectar a las personas mayores. La batería de cuestiones era la misma salvo que en el segundo de los estudios se eliminaron tres ítems (“Muerte”, "Inactividad” y "Deterioro físico”) y se añadieron otros tres ("Pérdida de amigos”, "Pérdida de cónyuge o compañero” y “Otras causas”). A raíz de los resultados obtenidos, Durán comenta y se interroga lo siguiente: “después de que desapareciese explícitamente la respuesta relativa a la muerte como causa de preocupación, nadie pareció sentir la necesidad de tal respuesta, y <<otras causas $>>$ sólo obtuvo un 2,5\% del total de respuestas. Parece como si lo que no se menciona en el cuestionario se olvidase. ¿O lo que sucede no es que se olvide, sino solamente que no se responde?” Durán (2004:18). 
Finalmente, otros problemas a los que se enfrenta el análisis sociológico mediante encuesta de las actitudes ante la muerte son los derivados de la renuencia de muchas personas a hablar de la muerte, lo que puede traducirse en un número elevado de no respuestas a determinadas preguntas, o en una alteración de la sinceridad de las personas encuestadas en sus respuestas para ajustarse a lo políticamente correcto. Como ocurre con el resto de las encuestas, esto puede plantear problemas de validez y fiabilidad de los datos obtenidos.

Teniendo en cuenta todas las dificultades anteriormente señaladas, el análisis de las creencias, actitudes, valores, comportamientos y opiniones ante la muerte de la población encuestada para esta Tesis se ha estructurado según diferentes áreas temáticas, Tabla 5.1. Con esa distribución se ha buscado cubrir el mayor número posible de dimensiones en las que examinar las <<actitudes ante la expectativa de nuestra muerte>>, es decir, las actitudes en la vida cotidiana de las personas para las que la muerte es un acontecimiento que se experimentará en el futuro.

En lo relativo a las técnicas e instrumentos de análisis aplicables en la fase de obtención de datos, dado que, como se ha señalado más arriba, en sí mismos los valores y las actitudes son inconmensurables, con un criterio pragmático, y por tanto limitado, la aproximación sociológica a los mismos habitualmente se realiza desde el componente cognitivo y fundamentalmente con el objetivo de establecer relaciones comparativas, mientras que la aproximación psicológica, que tentativamente se aborda al final de este capítulo al examinar la multidimensionalidad del miedo a la muerte, se centra en la dimensión afectiva de las actitudes. Entre los instrumentos más empleados a este fin se encuentra el entrevista a personas, solicitándoles sus opiniones con preguntas cuestionario de respuestas estandarizadas, o que manifiesten su actitud respecto a un objeto actitudinal situándose en escalas de medida de actitudes. Obviamente, para que los datos recabados de esa forma sean fiables se requiere por parte de las personas entrevistadas, entre otras actitudes y aptitudes, interés y predisposición para proporcionar información, comprensión de las preguntas, capacidad de análisis, y sinceridad (Gimeno, 2001:13). 


\begin{tabular}{|c|c|}
\hline \multicolumn{2}{|c|}{ TABLA 5.1. ÁREAS TEMÁTICAS OBJETO DE LA INVESTIGACIÓN } \\
\hline ÁREAS TEMÁTICAS & CONTENIDO \\
\hline MUERTE Y VIDA COTIDIANA & $\begin{array}{l}\text { ¿Piensa la gente frecuentemente en la muerte?, ¿habla sobre } \\
\text { ella?, ¿en qué etapa del ciclo vital comienza la muerte a ser una } \\
\text { cuestión importante?, ¿bajo qué circunstancias tienden los } \\
\text { individuos a pensar en, o hablar sobre, la muerte?, ¿qué tan } \\
\text { fuerte es esa preocupación?, ¿es más fuerte la preocupación por } \\
\text { la muerte que otras preocupaciones diarias?, ¿cómo se } \\
\text { relacionan esas preocupaciones? }\end{array}$ \\
\hline MUERTE Y PLANES DE VIDA & $\begin{array}{l}\text { ¿En qué medida está la gente inclinada a hacer planes relativos a } \\
\text { su muerte?, ¿qué tipo de planes?, ¿qué tipo de gente hace qué } \\
\text { género de planes? }\end{array}$ \\
\hline RITOS FUNERARIOS & $\begin{array}{l}\text { ¿Qué opinión se tiene sobre los ritos funerarios?, ¿cuál es nivel } \\
\text { y frecuencia de uso?, ¿están obsoletos, desgastados, se han } \\
\text { reinventado con otros formatos? }\end{array}$ \\
\hline $\begin{array}{l}\text { INTERACCIÓN CON EL ÁMBITO } \\
\text { HOSPITALARIO }\end{array}$ & $\begin{array}{l}\text { ¿Confianza en la ciencia?, ¿'hasta dónde deben llegar las } \\
\text { innovaciones tecnológicas?, ¿tratamientos selectivos según } \\
\text { recursos económicos?, ¿eugenesia social?, ¿eugenesia etaria?, } \\
\text { ¿medicalización de la muerte?, ¿los hospitales como nidos de } \\
\text { muerte?, ¿los hospitales ocultan la muerte? }\end{array}$ \\
\hline IMÁGENES DE LA MUERTE & $\begin{array}{l}\text { ¿Qué tipos de imágenes tiene la gente sobre la muerte?, ¿esas } \\
\text { imágenes tienden a referirse a uno mismo o comprometen } \\
\text { también a otros?, ¿es una imaginería morbosa o tranquilizadora? }\end{array}$ \\
\hline $\begin{array}{l}\text { MULTIDIMENSIONALIDAD DEL } \\
\text { MIEDO A LA MUERTE }\end{array}$ & $\begin{array}{l}\text { Miedo a la muerte, aceptación de acercamiento, evitación de la } \\
\text { muerte, aceptación de escape, aceptación neutral, aceptación } \\
\text { natural. }\end{array}$ \\
\hline $\begin{array}{l}\text { LA MUERTE COMO DIMISIÓN } \\
\text { DE LA VIDA }\end{array}$ & $\begin{array}{l}\text { ¿Cuáles son las actitudes ante el derecho a poner fin a la propia } \\
\text { vida?, ¿y ante la eutanasia? }\end{array}$ \\
\hline
\end{tabular}

Fte: Encuesta 2000. Elaboración propia.

No obstante las limitaciones epistemológicas señaladas hasta ahora, en la presente investigación se realiza una aproximación a la construcción social de la muerte utilizando como instrumento básico de análisis una encuesta en la que se ha recogido información sobre las creencias, opiniones, actitudes, valores y comportamientos de las personas entrevistadas respecto a los diferentes núcleos temáticos ligados al objeto de estudio recogidos en el Tabla 5.1. Se asume que la utilización de estos "procedimientos estandarizados de medida, donde las actitudes se desglosan en indicadores cuantificables", presupone "que existen regularidades observables en la suma de actitudes individuales” (Gimeno, 2001:15). Si bien este proceder 
conlleva el riesgo de incurrir en los conocidos problemas inherentes a la técnica de encuesta ${ }^{14}, y$ en especial en su incapacidad para alcanzar una compresión profunda de la muerte como fenómeno social ${ }^{15}$, no es menos cierto que, de acuerdo al objetivo central de la investigación, la información obtenida con ella permite conocer lo socialmente aceptable, lo que la sociedad valora ideológicamente, en ese ámbito social. Además, y para paliar en alguna medida esta limitación, el análisis se ha complementado con el examen de los discursos ideológicos subyacentes sobre los mismos núcleos temáticos de las actitudes ante la expectativa de la muerte recogidos en cuatro entrevistas semi-estructuradas y un grupo de discusión.

En lo relativo a la construcción de la encuesta, y con una concepción integral de la relación sociedad/muerte, se ha utilizado un cuestionario muy amplio, 73 preguntas tipo cuestionario y escala ${ }^{16}$ y 165 variables, con las que se buscaba abordar la mayoría de los

\footnotetext{
${ }^{14}$ Las limitaciones más significativas de las encuestas son: 1) Sólo permiten hacer una descripción superficial de la heterogeneidad de la realidad social; como con el resto de las técnicas cuantitativas, no basta por sí sola para alcanzar un conocimiento global de aquélla. 2) La encuesta estadística precodificada se aplica de manera tecnocrática y fría. De esta forma las respuestas a la misma no recogen su contexto de producción ni "exploran causalidades que, aunque se pudieran demostrar matemáticamente, ignoran el papel que ese discurso tiene en la vida social realmente, los usos que tienen esos discursos actitudinales en el entramado de la vida cotidiana, su necesidad y función" (Gimeno, 2001:15). 3) Se puede producir una interpretación semántica errónea al confundir el dato con el hecho. Así, por ejemplo, si la mayoría de la población encuestada afirmara que, en estos momentos, el número de incineraciones supera al de inhumaciones, esto no tendría por qué ser lo que ocurre en la realidad. 4) En las manifestaciones inmediatas las personas tienden a la racionalización. De esta manera, por un lado, no se pueden proporcionar respuestas precisas que lleguen del subconsciente, y, por otro lado, se pueden ocultar al mundo exterior valores, impulsos emocionales, etc. 5) El cuestionario impone un lenguaje (el de quien lo ha elaborado) a la realidad cotidiana. Así, se pierde la polisemia de las palabras, que se transforman en denotativas. 6) Es posible que las personas entrevistadas no respondan a ciertas preguntas sobre temas sensibles. 7) Las respuestas recogidas son respuestas de individuos. Su agregación, por tanto, no es más que un agregado de respuestas de individuos, no representan la opinión de grupos sociales, en el sentido sociológico del término, sino que son la expresión de las categorías sociales elaboradas por la persona que investiga.

${ }^{15}$ Siguiendo el esquema propuesto por Báez y Pérez de Tudela (2007), se pueden identificar en todo individuo tres niveles de conciencia: a) el "consciente": cuando obra con conciencia, sabiendo lo que hace y el valor y el significado de ello. Produce un comportamiento premeditado, intencionado; b) el "preconsciente": cuando obra sin que su quehacer sea percibido por la conciencia, pero las razones de este obrar afloran con relativa facilidad cuando se indaga en ello, y; c) el "inconsciente": cuando desarrolla una actividad independiente de su voluntad y no percibida por su conciencia. Su comportamiento es "involuntario", no deliberado, ocurre sin que el hacedor "sepa" que ocurre. Mientras los dos primeros niveles son accesibles mediante encuesta, al tercero sólo se puede llegar tentativamente interpretando los datos obtenidos mediante metodología cualitativa. Así, mediante las encuestas se pueden obtener datos relativos a: 1) Hechos (nivel consciente): tienen un carácter externo, material y relativamente objetivo; 2) Percepciones (niveles consciente y preconsciente): incluye enunciados de lo que los individuos saben -o creen saber- sobre el mundo e imágenes o representaciones mentales de una cosa; c) Opiniones (nivel consciente): son internas, mentales, subjetivas, enunciados de las preferencias o creencias de la gente sobre determinados eventos y objetos; d) Actitudes (nivel preconsciente): evaluaciones relativamente estables de eventos, objetos e ideas, y orientaciones sobre los mismos, y; e) Comportamientos (nivel consciente): declaraciones en las que la gente expresa su manera de actuar.

${ }^{16}$ El tipo de escala utilizado es el Likert que añade una medida de intensidad en el grado de acuerdo con las afirmaciones planteadas en los ítems. Se utilizan cinco posiciones: Muy de acuerdo (1), Bastante de acuerdo (2), Indiferente (3), Poco de acuerdo (4), Nada de acuerdo (5).
} 
componentes de esa relación (el cuestionario se recoge en el Anexo $1^{17}$ ). En la construcción del cuestionario, además de las preguntas sociodemográficas de control que son de uso común en todos los cuestionarios, y de las nuevas creadas al efecto, se han utilizado completas o parcialmente otras preguntas recogidas de estudios sociológicos o psicológicos sobre el morir y la muerte ${ }^{18}$. La estructura del cuestionario está configurada por grupos de preguntas correspondientes a cada área temática contemplada que, en general, se suceden en el discurrir de la lectura del cuestionario. Sólo existe una salvedad, el análisis factorial empleado para el área temática de la multidimensionalidad del miedo a la muerte ha requerido la utilización de ítems correspondientes a diferentes preguntas dispersas a lo largo del cuestionario. En cualquier caso, en el análisis realizado se resalta en todo momento a qué número de pregunta del cuestionario se hace referencia en cada cuestión examinada. Por otra parte, y al objeto de identificar y delimitar el papel de las diferentes dimensiones de la estructura social como ejes vertebradores de las actitudes ante la muerte, si bien inicialmente se había contemplado cruzar las variables dependientes con todas las variables de control incluidas en el cuestionario, finalmente se ha limitado este análisis a las variables género, edad, nivel de estudios y religiosidad. Además, las variables edad y nivel de estudios se han recodificado en las siguientes categorías sociales: Edad (Jóvenes: 16-19 + 20-29 años; Adultos: 30-39 + 40-49 + 50-59 años; Ancianos: > 60 años); Nivel de estudios (Básicos: sin estudios + estudios básicos; Medios: estudios secundarios + formación profesional; Universitarios: universitarios grado medio + universitarios grado superior). Por su parte, la variable religiosidad también ha sido reformulada mediante un análisis factorial tal como se justifica en el apartado 5.2.

La gran extensión del cuestionario, que requería alrededor de una hora para ser cubierto en su totalidad, ha dificultado que la muestra sea más amplia, especialmente entre las personas de mayor edad. Entre éstas, sólo las que recibieron ayuda en la cumplimentación del cuestionario lo finalizaron, mientras que una parte importante de las que lo rellenaron en solitario, a pesar de que se les explicó lo que se requería de ellas, cubrieron sólo la primera y la última página, por lo que fueron desechados. Además de estos cuestionarios fallidos, de la revisión individual de cada cuestionario recogido sólo en dos se apreciaron contradicciones intensas entre las diferentes respuestas por lo que asimismo fueron desechados. Así, la muestra inicial de 600 entrevistas (200 jóvenes; 200 adultos; 200 ancianos), ha quedado reducida

\footnotetext{
${ }^{17}$ En el Anexo 1, CD adjunto, se recoge asimismo la ficha técnica de la encuesta y la base de datos creada con las respuestas obtenidas.

${ }^{18}$ Entre los estudios e informes sociológicos consultados están: CIS: Estudios y encuestas, $\mathrm{n}^{\text {os }} 11$ (1988); 16 (1989); 20 (1990) y Estudio de Población no 1.841 (1989); Riley (1970); Shibles (1974); I.F.O.P.Société de thanatologie (1979); Kalish (1985); Orizo (1991); Fericgla (1992); De Miguel, A. (1994); Walter (1994). Entre los estudios psicológicos de la muerte se han extraído preguntas e ítems de: Neimeyer (1997); Lester (1997); Wong et al (1997); Gutiérrez Vega y Martínez Baza (1991), y Urraca (1981).
} 
finalmente a 430, una vez descartadas las defectuosas y las que, por diferentes motivos, no llegaron a cumplimentar y/o entregar el cuestionario.

\begin{tabular}{|c|c|c|c|c|c|c|c|}
\hline \multicolumn{8}{|c|}{ CUADRO 5.1.: DISTRIBUCIÓN POR SEXO Y EDAD DE LA MUESTRA. (\%) } \\
\hline EDAD & TOTAL & HOMBRE & MUJER & EDAD & TOTAL & HOMBRE & MUJER \\
\hline 16-19 años & $\begin{array}{c}17 \\
(4,0)\end{array}$ & $\begin{array}{c}6 \\
(3,6)\end{array}$ & $\begin{array}{c}11 \\
(4,2)\end{array}$ & \multirow[b]{2}{*}{ JÓVENES } & \multirow{2}{*}{$\begin{array}{c}199 \\
(46,0)\end{array}$} & \multirow{2}{*}{$\begin{array}{c}79 \\
(39,4)\end{array}$} & \multirow{2}{*}{$\begin{array}{c}120 \\
(60,6)\end{array}$} \\
\hline 20-29 años & $\begin{array}{c}182 \\
(42,3) \\
\end{array}$ & $\begin{array}{c}73 \\
(43,2) \\
\end{array}$ & $\begin{array}{c}109 \\
(41,8) \\
\end{array}$ & & & & \\
\hline 30-39 años & $\begin{array}{c}41 \\
(9,5) \\
\end{array}$ & $\begin{array}{c}16 \\
(9,5) \\
\end{array}$ & $\begin{array}{c}25 \\
(9,6) \\
\end{array}$ & \multirow{3}{*}{ ADULTOS } & \multirow{3}{*}{$\begin{array}{c}142 \\
(33,0)\end{array}$} & \multirow{3}{*}{$\begin{array}{c}60 \\
(57,7)\end{array}$} & \multirow{3}{*}{$\begin{array}{c}82 \\
(57,7)\end{array}$} \\
\hline 40-49 años & $\begin{array}{c}48 \\
(11,2)\end{array}$ & $\begin{array}{c}23 \\
(13,6)\end{array}$ & $\begin{array}{c}25 \\
(9,6)\end{array}$ & & & & \\
\hline 50-59 años & $\begin{array}{c}53 \\
(12,3)\end{array}$ & $\begin{array}{c}21 \\
(12,4)\end{array}$ & $\begin{array}{c}32 \\
(12,3)\end{array}$ & & & & \\
\hline 60 y más & $\begin{array}{c}89 \\
(20,7)\end{array}$ & $\begin{array}{c}30 \\
(17,8)\end{array}$ & $\begin{array}{c}59 \\
(22,6)\end{array}$ & ANCIANOS & $\begin{array}{c}89 \\
(20,7)\end{array}$ & $\begin{array}{c}30 \\
(17,8)\end{array}$ & $\begin{array}{c}59 \\
(22,6)\end{array}$ \\
\hline TOTAL & $\begin{array}{c}430 \\
(100,0)\end{array}$ & $\begin{array}{c}169 \\
(100,0)\end{array}$ & $\begin{array}{c}261 \\
(100,0)\end{array}$ & TOTAL & $\begin{array}{c}430 \\
(100,0)\end{array}$ & $\begin{array}{c}169 \\
(100,0)\end{array}$ & $\begin{array}{c}261 \\
(100,0)\end{array}$ \\
\hline \multicolumn{2}{|c|}{ TOTAL POR SEXO } & $(39,3)$ & $(60,7)$ & & & & \\
\hline
\end{tabular}

Fte: Encuesta 2000. Elaboración propia

Por otra parte, la imposibilidad material y logística de abordar un muestreo probabilístico, es decir, aquel en el que los sujetos de la población-diana fueran elegidos siguiendo las leyes del azar (todos los individuos tienen la oportunidad de ser incluidos y todos ellos lo son con la misma probabilidad), eliminaba cualquier intento de búsqueda de representatividad estadística para el conjunto de la población española en el trabajo a realizar. En consecuencia, se ha optado por un muestreo intencional similar al empleado en el análisis cualitativo en el que las unidades de muestreo se toman, no al azar, sino de acuerdo a otros criterios. Es el caso del muestreo opinático, en el que se selecciona los elementos de la muestra según criterios estratégicos, por ejemplo, por ser los de más fácil acceso. Es el caso asimismo del muestreo teórico, cuyo objetivo es que la búsqueda de datos permita generar teorías a quien investiga, que "más que preocuparse por el número correcto (de informantes) o de su selección al azar se preocupa de recoger la información más relevante para el concepto o teoría buscada” (Ruiz Olabuénaga, 1996:64). Así, tomando como fondo el de la estructura socio-demográfica de la sociedad española de entre siglos, se aborda el examen de la muerte vivida con una muestra de personas que no trabajan/estudian en el sector sanitario y no han vivido un proceso de morir(se) o muerte de otros cercano en el tiempo. Muestra centrada en la provincia de Valladolid y adyacentes y que, como se describe a continuación, era la más accesible para la investigación (muestreo opinático) y ha sido elegida para realizar una aproximación a las percepciones de la clase media de la misma (muestreo teórico). No obstante, la no representatividad estadística de la muestra no impide que, tal como ha sido reclutada, se puedan 
realizar inferencias sociológicas aproximativas sobre el nicho de población elegido. En este sentido, en el análisis realizado más que buscar diferencias entre categorías sociales, que también se realiza, lo que se enfatiza es la intensidad del fenómeno resaltando los valores más elevados en los casos promedio y en los casos modales.

El tamaño final de la muestra es de 430 personas (169 hombres y 261 mujeres) en diferentes fases temporales del ciclo vital: 198 jóvenes (78 hombres y 120 mujeres), 142 adultos/as (60 hombres y 82 mujeres), y 90 ancianos/as (31 hombres y 59 mujeres), Cuadro 5.1. La mayoría de la población joven es universitaria (89,9\%); asimismo, la adulta en su mayoría es universitaria (52,1\%) o con estudios medios (31,0\%); la anciana, en su mayoría tiene estudios básicos $(53,3 \%)$ y sólo una minoría (16,0\%) tiene estudios universitarios, Cuadro 5.2. Por último, la mayoría de la población encuestada se declara católica, 75,8\%; el 12,3\%, no creyente (agnóstico/a o ateo/a); el 8,1\%, indiferente; el resto, de otras religiones, no han sido considerado en los análisis cruzados por religiosidad, Cuadro 5.3.

El trabajo de campo se desarrolló entre los meses de marzo y mayo del año 2000. Inicialmente, se solicitó la colaboración de estudiantes de la Universidad de Valladolid tanto para ser sujetos muestrales como para que actuaran como encuestadores entre sus familiares y amigos. Con esta estrategia se perseguía reclutar una población lo más homogénea posible desde el punto de vista socioeconómico con el objetivo de aprehender lo que la mayoría de la sociedad, la clase media, valora ideológicamente sobre la muerte. Esta muestra inicial, localizada en las capitales y provincias de Segovia, León, Palencia, Zamora y sobre todo Valladolid, se complementó con entrevistas a ancianos/as en núcleos rurales de esas mismas provincias. En todos los casos se requirió las dos condiciones mencionadas arriba: no trabajar/estudiar en el sector sanitario y no haber vivido un proceso de morir(se) o muerte de otros cercano en el tiempo. Para lograr la mayor fiabilidad posible de los datos recabados se informó a las personas inicialmente interesadas sobre cuáles eran los objetivos de la investigación, como es obvio se les garantizó el anonimato de sus respuestas, y se les solicitó que su colaboración fuera voluntaria y sincera para alcanzar tal fin. Desde aquí agradezco la colaboración desinteresada de todas las personas que me han facilitado datos sobre su visión de la muerte. 


\begin{tabular}{|l|c|c|c|c|}
\hline \multicolumn{5}{|c|}{ CUADRO 5.2.: DISTRIBUCIÓN POR EDAD/NIVEL DE ESTUDIOS Y SEXO/NIVEL } \\
\hline & $\begin{array}{c}\text { ESTUDIOS } \\
\text { BÁSICOS }\end{array}$ & $\begin{array}{c}\text { ESTUDIOS } \\
\text { MEDIOS }\end{array}$ & $\begin{array}{c}\text { ESTUDIOS } \\
\text { UNIVERSIT. }\end{array}$ & TOTAL \\
\hline \multirow{2}{*}{ JÓVENES } & 0 & 21 & 178 & 199 \\
& $(0)$ & $(10,1)$ & $(89,9)$ & $(100,0)$ \\
\hline \multirow{2}{*}{ ADULTOS } & 24 & 44 & 74 & 142 \\
& $(16,9)$ & $(31,0)$ & $(52,1)$ & $(100,0)$ \\
\hline \multirow{2}{*}{ ANCIANOS } & 47 & 28 & 14 & 89 \\
& $(53,3)$ & $(31,1)$ & $(15,6)$ & $(100,0)$ \\
\hline \multirow{2}{*}{ TOTAL } & 71 & 93 & 266 & 430 \\
& $(16,7)$ & $(21,4)$ & $(61,9)$ & $(100,0)$ \\
\hline \multirow{2}{*}{ HOMBRE } & 20 & 38 & 111 & 169 \\
& $(11,8)$ & $(22,5)$ & $(65,7)$ & $(100,0)$ \\
\hline \multirow{2}{*}{ MUJER } & 51 & 55 & 155 & 261 \\
& $(19,9)$ & $(20,7)$ & $(59,4)$ & $(100,0)$ \\
\hline
\end{tabular}

Fte: Encuesta 2000. Elaboración propia

\begin{tabular}{|l|c|c|c|c|c|}
\hline \multicolumn{7}{|c|}{ CUADRO 5.3.: DISTRIBUCIÓN POR EDAD/RELIGIOSIDAD Y } \\
\hline & SEXO/RELIGIOSIDAD DE LA MUESTRA. (\%) & \\
\hline & CATÓLICO & INDIFERENTE & NO CREYENTE & OTROS & TOTAL \\
\hline \multirow{2}{*}{ JÓVENES } & 138 & 22 & 29 & 10 & 199 \\
& $(69,7)$ & $(10,6)$ & $(14,7)$ & $(5,0)$ & $(100,0)$ \\
\hline \multirow{2}{*}{ ADULTOS } & 105 & 10 & 22 & 5 & 142 \\
& $(73,9)$ & $(7,0)$ & $(15,5)$ & $(3,5)$ & $(100,0)$ \\
\hline \multirow{2}{*}{ ANCIANOS } & 82 & 4 & 2 & 1 & 89 \\
& $(92,2)$ & $(4,4)$ & $(2,2)$ & $(1,1)$ & $(100,0)$ \\
\hline \multirow{2}{*}{ TOTAL } & 325 & 36 & 53 & 16 & 430 \\
& $(75,8)$ & $(8,1)$ & $(12,3)$ & $(3,8)$ & $(100,0)$ \\
\hline \multirow{2}{*}{ HOMBRE } & 114 & 21 & 29 & 5 & 169 \\
& $(67,4)$ & $(12,4)$ & $(17,2)$ & $(3,0)$ & $(100,0)$ \\
\hline \multirow{2}{*}{ MUJER } & 211 & 15 & 24 & 11 & 261 \\
& $(81,2)$ & $(5,4)$ & $(9,1)$ & $(4,2)$ & $(100,0)$ \\
\hline
\end{tabular}

Fte: Encuesta 2000. Elaboración propia

Los datos primarios de encuesta se han complementado con la información cualitativa obtenida de 4 entrevistas semi-estructuradas y de 1 grupo de discusión. En todos los casos las personas entrevistadas o las que conformaron el grupo de discusión cumplían las mismas restricciones que las encuestadas: no haber vivido recientemente un proceso de muerte cercano. Los rasgos sociodemográficos básicos de las mismas son: a) Entrevista 1 (E1): hombre, 23 años, estudiante, católico no practicante; b) (E2): mujer, 26 años, estudiante, no creyente; c) (E3): mujer, 33 años, trabajadora del sector servicios, muy creyente -católica practicante; d) (E4): hombre, 53 años, trabajador del sector industrial, indiferente en términos religiosos. Respecto a esta última variable y a partir del análisis factorial que se realiza en el siguiente apartado estas cuatro personas entrevistadas estarían ubicadas en las siguientes categorías de religiosidad: E1, “Creyente”; E2, “No creyente”; E3, “Crédula”, y E4, “Incrédula”. Las entrevistas tuvieron lugar 
en la primavera del año 2000. Respecto a la composición del grupo de discusión (GD1), estuvo conformado por 3 hombres de 77, 70 y 65 años, los tres jubilados, y 4 mujeres de 78, 69, 61 y 53 años, las tres primeras jubiladas ${ }^{19}$.

El tratamiento estadístico de los datos de encuesta se ha realizado con el paquete estadístico SPSS, bajo licencia de la UVa. Entre los módulos incluidos en SPSS, se ha utilizado el módulo SPSS BASE. La mayor parte del análisis realizado en este trabajo tiene carácter descriptivo, para lo que se han empleado programas estadísticos de dicho módulo que permiten observar las frecuencias absolutas y relativas, así como calcular diversas medidas de dispersión (media, moda, varianza, etc.). Asimismo, se ha utilizado el programa "Tablas de contingencia" para contrastar la independencia/ asociación entre variables a través del test de la "chi cuadrado", y el grado de asociación con el coeficiente "V" de Cramer. Por otra parte, de la opción “Clasificar” se ha utilizado el programa “Conglomerados” para la realización de análisis cluster que permite la búsqueda de grupos similares de individuos o de variables que se van clasificando en grupos lo más homogéneos posibles -conglomerados- (Pérez, 2001:465). Finalmente, se ha empleado una opción de análisis multivariante, el análisis factorial, que permite la reducción del número de variables obteniendo otras que son combinaciones lineales de las antiguas y a las que se denomina componentes principales o factores, variables a las que posteriormente se han aplicado otros procedimientos estadísticos.

\subsection{DIMENSIONES AXIOLÓGICAS GENERALES}

"Vivir la vergüenza de la vida y callar: tal es el logro más grande"

I. Kertész

Antes de abordar el análisis de las creencias, actitudes, valores y comportamientos de la población encuestada sobre la muerte, se hace necesario realizar un acercamiento empírico al marco axiológico general en el que todo ello se sustenta. Como se ha señalado más arriba, en la cúspide del sistema cultural de valores de toda sociedad existen una serie de valores básicos que, aún no incidiendo directamente en las actitudes y comportamientos concretos, de forma subyacente actúan transversalmente impregnando toda la vida social. En este sentido, se señalaba que el ascenso de los valores postmaterialistas, el proceso de (de)secularización y el incremento del relativismo moral en la sociedad española de entre siglos eran algunos de esos valores esenciales a tomar en consideración por su influencia en la vivencialidad de la muerte. Con el objetivo de identificar otros valores básicos o de matizar/complementar los señalados, en

\footnotetext{
${ }^{19}$ En el Anexo 2, CD adjunto, se recogen las fichas técnicas y las trascripciones de las entrevistas y del grupo de discusión.
} 
la encuesta se ha realizado esa aproximación a las prioridades valorativas personales a través de dos preguntas (las números 12 y 14) que pueden servir como marco de referencia indicativo, aunque parcial, en este ámbito. Obviamente, con estas preguntas no se persigue determinar los porcentajes exactos de personas encuestadas con una determinada adscripción valorativa, sino poner en evidencia la complejidad del escenario axiológico en el que aquéllas viven. En efecto, lejos de moverse en un escenario caracterizado por la simplicidad y la homogeneidad de posiciones, entre las personas encuestadas, autocalificadas como de clase media, existe una gran diversidad de posiciones valorativas entre las que se puede ubicar a individuos con una adscripción claramente identificable con los valores tradicionales, o con los modernos o con otra ligada a los valores postmodernos y, junto a ellos, a un porcentaje importante de la muestra que mantiene posiciones mixtas, híbridas de las anteriores ${ }^{20}$.

\subsubsection{TRANSMISIÓN DE VALORES}

"La vida tiene un valor si creemos en los valores, si no creemos, es mejor morir de inmediato"

R. Levi Montalcini

De forma proyectiva se pueden identificar las preferencias valorativas para una persona al inquirirla sobre cuáles son, según ella, las cualidades más importantes que deberían inculcarse durante la infancia (pregunta 12). Esta medición indirecta de los valores no sólo refleja lo que cada individuo valora como importante para sí en esta vida, a través de lo que desearía que sucediese en el proceso de socialización primaria, sino que también informa, en parte, sobre cuáles son los valores que de hecho se están transmitiendo en el proceso de socialización familiar (Andrés Orizo, 1991:71). Así, conocer las preferencias axiológicas de los individuos permite configurar una imagen aproximada de los principios valorativos fundamentales subyacentes en el comportamiento evaluativo de la sociedad analizada (Requena y Benedicto, 1988:24).

En este trabajo se ha realizado una aproximación de este tipo a los estándares morales predominantes a través de una pregunta en la que se solicitaba a las personas encuestadas que eligieran, entre un conjunto de dieciséis ${ }^{21}$, las dos cualidades más importantes que a su juicio deberían inculcarse durante la infancia. El grupo de cualidades empleado es una derivación de la batería de <<valores instrumentales $>>$ que propuso Rokeach (1973) en la "Encuesta de Valores

\footnotetext{
${ }^{20}$ Según los datos de la Encuesta Mundial de Valores y del Estudio Europeo de Valores, en el año 2000, la distribución de la población española según sus valores básicos era la siguiente: valores materialistas, 26\%; valores posmaterialistas, 17\%; valores mixtos, 57\% (Inglethart et al, 2004:23).

${ }^{21}$ Inicialmente se consideró también el valor “autocontrol”, sin embargo, la revisión de los cuestionarios recomendó su exclusión puesto que se detectaron problemas de interpretación semántica en una proporción atípica de personas ancianas.
} 
Rokeach”, y que ha sido replicada en numerosas investigaciones posteriores ${ }^{22}$. Los valores instrumentales, según Rokeach, son las maneras de ser o los modos de comportamiento más adecuados para alcanzar los $<<$ valores terminales $>>$, es decir, las metas o estados terminales de existencia que a una persona le gustaría alcanzar durante su vida ${ }^{23}$.

Si bien el sesgo muestral de este trabajo, centrado sobre todo en los jóvenes y en las personas con estudios universitarios, invalida cualquier comparación con los resultados obtenidos con muestras representativas del conjunto de la población, la jerarquía de valores obtenida en el mismo se halla sin embargo en sintonía con las que han puesto de manifiesto otras investigaciones sobre la sociedad española (Pérez Agote y Santiago García, 2005; Campo Ladero, 2002; Andrés Orizo, 1991). Esta similitud en las pautas valorativas predominantes no es más que el reflejo del progresivo asentamiento y estabilidad de las mismas en la sociedad española actual. En el Cuadro 5.4. se puede comprobar por ejemplo que, con una ordenación ligeramente diferente, las prioridades axiológicas de la población encuestada son similares a las obtenidas por el CIS para el conjunto de la sociedad española en el 2002, fecha próxima a la de la realización del trabajo de campo para el presente trabajo. En ambos casos, cuatro 'virtudes' destacan sobre las demás en las preferencias valorativas de los individuos: "tolerancia”, "honestidad”, “responsabilidad” y "buena educación”. En efecto, al menos una de cada cuatro personas encuestadas cita alguna de esas cualidades como una de las dos más importantes a inculcar en el proceso de socialización primaria. Del resto de cualidades, sólo la "generosidad" es citada por algo más del 10\% de la población encuestada, mientras que las demás no llegan a esa proporción; algunas, incluso, sólo fueron citadas por menos de una de cada cien personas encuestadas (“ahorro”, “paciencia”, “laboriosidad” y “liderazgo”).

\footnotetext{
${ }^{22}$ Por ejemplo, para el caso de España ha sido utilizada por el CIS en sus Estudios $n^{\circ} 2442$, de 2002, y ${ }^{\circ}$ 1703, de 1987. Asimismo, se han determinado los principales valores instrumentales para la sociedad española en la Encuesta sobre los Sistemas Europeos de Valores de 1981 y en la Encuesta Europea de Valores de 1990, patrocinadas por el EVSSG (European Value Systems Study Group).

${ }^{23}$ Entre los valores instrumentales Rokeach incluye: Alegría (felicidad), Ambición (trabajar arduamente, aspirar), Afectividad (ternura), Atención (cortesía), Autocontrol (autodisciplinado), Capacidad (competencia, eficacia), Generosidad (trabaja para el bienestar de otros), Honradez (sinceridad), Imaginación (audacia, creatividad), Indulgencia (disposición al perdón), Intelectual (inteligencia, reflexividad), Limpieza (aseo), Lógica (consistencia, racionalidad), Mente abierta, Obediencia, Perseverancia (defensor de sus creencias), Responsabilidad (confiable). Entre los valores terminales incluye: Amor maduro (intimidad sexual y espiritual), Armonía interior (sin conflictos internos), Felicidad (contento), Igualdad (fraternidad, igual oportunidad para todos), Libertad (independencia), Placer (una vida que se disfruta, sin prisas), Reconocimiento social (respeto, admiración), Respeto a sí mismo (autoestima), Sabiduría (una comprensión madura de la vida), Salvación (a salvo, vida eterna), Seguridad familiar (cuidado de los seres amados), Seguridad nacional (protección contra los ataques), Un mundo de belleza ( (belleza de naturaleza y las artes), Un mundo en paz (libre de guerra y conflicto), Una sensación de logros (contribución permanente), Una vida cómoda (vida próspera), Una vida emocionante (estimulante, activa), Verdadera amistad (compañerismo cercano). (ROKEACH, M. (1973): The Nature of Human Values, Nueva York, Free Prees, citado en Robins (1996:176-177)).
} 


\begin{tabular}{|lr|c|c|}
\hline \multicolumn{3}{|c|}{ CUADRO 5.4. PREFERENCIAS VALORATIVAS (\%) } \\
\hline & & ENCUESTA (2000) & CIS (2002) \\
\hline Honestidad & & 41,4 & 31,5 \\
& Tolerancia & 41,7 & 41,5 \\
& Lealtad & 6,7 & 3,7 \\
Fe religiosa & Generosidad & 12,3 & 4,1 \\
Limpieza & & 4,8 & 2,3 \\
Laboriosidad & 5,1 & 2,2 \\
Perseverancia & 0,5 & 6,1 \\
Buena educación & 6,0 & 2,6 \\
Obediencia & Liderazgo & 3,1 & 54,0 \\
Paciencia & Responsabilidad & 0,2 & 4,4 \\
& Imaginación & 0,7 & 0,2 \\
Ahorro & & 34,9 & 1,5 \\
& Independencia & 5,3 & 34,7 \\
& & 1,0 & 0,9 \\
\multicolumn{2}{|r|}{} & 3,9 & 1,6 \\
\hline
\end{tabular}

Fte: CIS (2002): Estudio n n 2442 y Encuesta 2000. Elaboración propia.

Los resultados obtenidos muestran, en primer lugar, que las preferencias valorativas de la población encuestada tienen una dimensión colectiva diáfana, ya que se han elegido sobre todo aquellas cualidades que socializan al individuo en su relación con el otro. Siguiendo a Andrés Orizo (1991:71-74), la elección de la “tolerancia” y la “responsabilidad” responderían a una demanda de disciplina interior en relación con los demás, mientras que la de la "honestidad" y la "buena educación” no serían más que una demanda de orden social y de recuperación de las formas. Frente a este dominio de las virtudes "soft", las virtudes "hard" ocupan un lugar secundario en la jerarquía de valores de la población encuestada. Efectivamente, a comienzos del siglo XXI se apreciaba una profunda desafección hacia los valores dirigidos a la consecución de los intereses más específicos para los propios individuos, como son los relativos a la promoción de la disciplina material (“ahorro”), la fortaleza interior (“paciencia”, "laboriosidad”) o las creencias personales (“fe religiosa”). Desafección que se torna en rechazo para el caso del "liderazgo". A la vista de estos datos, cabe aplicar también a la muestra seleccionada en este trabajo la conclusión extraída por Orizo (1991:251) en la Encuesta Europea de Valores de 1990 para el conjunto de la sociedad española: prudente ante un mundo de incertidumbre, que desconfía de los lejanos pero que es tolerante, moderada, y que remite a las ámbitos de la libertad (de pensamiento) y del imperio de la razón: "una sociedad $<<$ desapasionada $>>$. 
Por otra parte, la agrupación de los valores instrumentales de acuerdo a la distribución propuesta por Harding (1986) en <<valores tradicionales >> (lado izquierdo de la primera columna del Cuadro 5.4.) y <<valores post-tradicionales $>>$ (lado derecho de la primera columna del Cuadro 5.4.), permite realizar una primera, y simplificadora, aproximación al contraste entre valores tradicionales, los que priman el orden social, y valores modernos, los que priman la autonomía y la iniciativa individual, en la población encuestada. Así, para el conjunto de la sociedad española se constata, por ejemplo, que en el año 2002 existía un cierto equilibrio valorativo entre ambas orientaciones aunque con un ligero predominio de las preferencias valorativas tradicionales: el peso relativo de la suma de estas últimas superaba ligeramente al de las preferencias valorativas post-tradicionales (valores tradicionales/valores post-tradicionales = 1,16). Por el contrario, en la población encuestada para este trabajo, las preferencias valorativas innovadoras superaban en conjunto a las tradicionales (valores tradicionales/valores postradicionales $=0,84)$. Obviamente, este último dato está marcado por el sesgo de la muestra utilizada, sesgo que está potenciado además por la incidencia especial de dos variables discriminatorias claves en este ámbito como son la edad y el nivel educativo, para las que existen diferencias estadísticamente significativas ${ }^{24}$. En efecto, basta comparar los Cuadros 5.4. y 5.5. para apreciar el sesgo introducido en la muestra total por la sobre-representación en la misma de jóvenes y de personas con estudios universitarios.

La desagregación por edad y nivel de estudios, Cuadro 5.5., permite comprobar la existencia de notables diferencias en las preferencias valorativas según las distintas categorías sociales en las que ambas variables discriminan entre la población encuestada. Así, se puede observar que a medida que se incrementa la edad son mayores las preferencias por los valores tradicionales: la "buena educación”, seguida de la "honestidad”, son las virtudes preferidas entre la población anciana, mientras que la "tolerancia" seguida de la "honestidad" son las cualidades preferidas entre la población joven y adulta. Entre estas dos poblaciones, además, se prefiere en mayor medida el sentido de la "responsabilidad” que la socialización en la "buena educación”, y se eligen en mayor proporción otros valores post-tradicionales, o se citan menos al resto de valores tradicionales, que entre la población anciana.

\footnotetext{
${ }^{24}$ La variable "religiosidad” es asimismo estadísticamente significativa. En su caso, no obstante, el dato más relevante es que incluso las personas que se declaran católicas otorgan una posición secundaria a la socialización de la "fe religiosa": sólo cinco de cada cien encuestados que se declaran católicos señala esa opción como una de las dos cualidades a inculcar en la infancia.
} 


\begin{tabular}{|c|c|c|c|c|c|c|}
\hline \multicolumn{5}{|c|}{ CUADRO 5.5. PREFERENCIAS VALORATIVAS POR EDAD Y NIVEL DE ESTUDIOS (\%) } \\
\hline & \multicolumn{3}{|c|}{ EDAD } & \multicolumn{3}{c|}{ NIVEL DE ESTUDIOS } \\
\cline { 2 - 7 } & JÓVENES & ADULTOS & ANCIANOS & BÁSICOS & MEDIOS & UNIVER \\
\hline Honestidad & 41,9 & 43,3 & 35,3 & 23,9 & 49,4 & 42,9 \\
Tolerancia & 45,9 & 44,2 & 25,4 & 26,8 & 39,1 & 46,0 \\
Lealtad & 8,6 & 5,7 & 3,8 & 6,0 & 8,0 & 6,4 \\
Generosidad & 11,1 & 15,8 & 10,1 & 10,4 & 12,6 & 12,9 \\
Fe religiosa & 5,0 & 5,7 & 2,6 & 4,5 & 5,7 & 4,5 \\
Limpieza & 4,0 & 5,0 & 7,6 & 7,5 & 2,3 & 5,3 \\
Laboriosidad & - & 0,7 & 1,3 & 1,5 & 1,1 & - \\
Perseverancia & 6,5 & 5,7 & 5,1 & 6,0 & 8,0 & 5,3 \\
Buena educación & 24,8 & 17,9 & 39,3 & 43,3 & 26,4 & 20,1 \\
Obediencia & 1,5 & 2,2 & 8,9 & 7,5 & 3,4 & 1,9 \\
Liderazgo & 0,5 & - & - & - & - & 0,4 \\
Paciencia & - & 1,4 & 1,3 & 4,5 & - & - \\
Responsabilidad & 35,8 & 35,2 & 31,6 & 32,8 & 25,3 & 38,4 \\
Imaginación & 8,6 & 3,6 & - & - & 6,9 & 6,1 \\
Ahorro & - & 0,7 & 3,8 & 4,5 & 1,1 & - \\
Independencia & 4,0 & 5,0 & 1,3 & 1,5 & 2,3 & 5,0 \\
\hline (N) & 198 & 140 & 79 & 67 & 87 & 263 \\
\hline
\end{tabular}

Fte: Encuesta 2000. Elaboración propia.

Estas tendencias están más marcadas aún si se considera la distribución por nivel de estudios, en la que se observa una preferencia por los valores post-tradicionales a medida que aumenta el nivel formativo de las personas encuestadas. Así, la jerarquía en las preferencias valorativas difiere entre las tres categorías educativas examinadas de la siguiente forma: entre las personas con estudios universitarios, la cualidad más importante es la "tolerancia”, seguida de la "honestidad", la "responsabilidad" y la "buena educación”; entre las población con estudios medios, se prefiere en primer lugar la "honestidad", seguida por la "tolerancia”, la “buena educación” y la "responsabilidad”; entre la población con estudios básicos, claramente el valor de socialización más importante es la "buena educación”, seguido de la “responsabilidad” que es mucho más preferido que la "tolerancia” y la "honestidad”.

Desde otra perspectiva, las tendencias señaladas no ocultan una cierta hibridación en las preferencias valorativas entre buena parte de la población encuestada, en sintonía con las propuestas teóricas realizadas por Inglehart. Es decir, si bien desde el punto de vista analítico parece adecuada la consideración de dos polos valorativos en los que situar a las personas encuestadas, esta opción no deja de ser una simplificación de la realidad por cuanto supone una visión digital de las preferencias valorativas, ya que cada uno de los valores instrumentales considerados sólo puede estar en uno de los polos y, además, porque a cada uno de los valores situados en uno de los polos se le otorga la misma carga valorativa. En este sentido, parece claro 
que, por ejemplo, la "buena educación” y la “obediencia” pueden ser considerados como valores tradicionales, o, que la "tolerancia”, la "responsabilidad” y la "imaginación” son valores característicos de la modernidad; sin embargo, otros valores como la "honestidad”, la "lealtad" y la "perseverancia” tienen una carácter transversal y antes que ser rasgos identificadores de uno de los dos polos valorativos parece más adecuado entenderlos como valores híbridos (mixtos) situados entre ellos.

\subsubsection{CREENCIAS RELIGIOSAS}

"Son las Iglesias las que se erigen en supremos gestores de esta vida elevada a patrimonio sagrado. De esa abdicación ante la muerte forzosa extraen ellas su poder”

A. Arteta

Como se ha señalado en el Capítulo 2 de esta Tesis, las creencias religiosas constituyen un ámbito privilegiado en el que poder identificar la matriz de valores dominantes en una sociedad por cuanto pertenecen al género de las creencias básicas y esenciales del individuo, que las manifiesta sin mediación. De acuerdo con Andrés Orizo (1991:116), la intensidad y firmeza de las mismas determina en buena medida los códigos morales, las prácticas y los rituales imperantes en una sociedad. Obviamente, esa determinación es sólo parcial en las sociedades occidentales en las que, fruto del proceso de secularización vivido a lo largo del siglo XX, el factor religioso ha quedado reservado al reducto de las conciencias personales, se ha privatizado. Como se ha señalado más arriba, los avances en el conocimiento científico y el poder de la razón entraron en competencia con la cosmovisión religiosa del mundo, cercenando su secular posición hegemónica como única vía de conocimiento capaz de interpretarlo, provocando con ello la desacralización del mundo y de la vida, pero sobre todo la obsolescencia de los dogmas de fe y la aminoración de la influencia de las instituciones religiosas. Relativización gráficamente expresada por uno de los componentes del grupo de discusión:

- "Yo creo que eso de la religión,..., es un problema de geografía, si tú en vez de nacer aquí naces en Japón tendrás otra religión, si naces en Madagascar, otra; y si naces en África o América, otra. O sea, es un problema geográfico” (GD1:28).

Implosión de la matriz religiosa que deriva en que la religión ha perdido prestigio social, como “dosel sagrado”, en la jerarquía de valores de las sociedades más desarrolladas. Para el caso de España, por ejemplo, esta evolución puede ser observada de forma diáfana en las series temporales del CIS en las que se constata cómo la religión, junto con la política, reducen paulatinamente su importancia en las preferencias axiológicas hasta ocupar las dos últimas posiciones en la jerarquía de valores de la sociedad española actual. Este cambio de valores es el resultado de una progresiva diferenciación de los ámbitos de vida en los que participan los 
individuos, diferenciación marcada, además, por la primacía de los intereses personales más cercanos y/o inmediatos sobre cualquier otra consideración. Así, fruto del creciente predominio de los valores individuales, privados y laicos, sobre los valores colectivos, públicos y religiosos, "la religión en sí, como institución, se encuentra muy desvalorizada” desde el punto de vista de la importancia personal (Pérez Agote, 1990:31).

Los procesos concomitantes de “desdogmatización”, “desritualización”, “despolitización” y “desnacionalización” de la religión, que caracterizan la dinámica secularizadora de las sociedades occidentales, no implican, sin embargo, que se haya producido el vaciado o el desecamiento total de los sentimientos religiosos en ellas. Como señala Andrés Orizo (1991:116), en las sociedades más desarrolladas permanece todavía una reserva de creencias religiosas básicas que, si bien no determinan la totalidad de la vida de los individuos, sí constituye un referente de buena parte de sus valores y actitudes centrales. Afirmación que ha sido corroborada empíricamente en diferentes estudios ${ }^{25}$ y también en éste, en el que se ha constatado que con distinta intensidad las personas encuestadas creen actualmente en algunos de los dogmas de fe de la religión católica, Cuadro 5.6. De hecho, están especialmente extendidas entre la población encuestada las creencias en la existencia de $\operatorname{Dios}^{26}$ y en la existencia del alma.

\begin{tabular}{|c|c|c|c|c|}
\hline \multicolumn{5}{|c|}{ CREENCIAS RELIGIOSAS. ESPAÑA. 2002 (\%) } \\
\hline & SÍ & NO & NO SABE & N.C. \\
\hline Dios & 69,4 & 21,7 & 7,5 & 1,5 \\
\hline El alma & 52,0 & 33,0 & 13,6 & 1,5 \\
\hline El pecado & 42,6 & 45,8 & 9,9 & 1,6 \\
\hline El Cielo & 39,5 & 47,5 & 11,7 & 1,4 \\
\hline Vida después de la muerte & 37,1 & 41,2 & 20,2 & 1,5 \\
\hline El demonio & 24,1 & 63,3 & 11,2 & 1,4 \\
\hline La reencarnación & 20,4 & 60,5 & 17,4 & 1,7 \\
\hline El infierno & 23,6 & 63,9 & 11,2 & 1,3 \\
\hline
\end{tabular}

Fte: CIS (2002): Estudio n ${ }^{0} 2442$.

${ }^{26} \mathrm{Al}$ no ser éste un trabajo sobre sociología de la religión sólo se interrogó por la creencia en la existencia de Dios sin precisar a qué concepción del mismo se estaba haciendo referencia. Esta consideración es relevante para poder entender algunos de los resultados que se exponen más adelante. No obstante, para minimizar en parte el efecto de esta limitación se pueden tomar como referencia los resultados de otros trabajos en los que sí se ha matizado esta cuestión. Así, los datos aportados por dos estudios del CIS (2002), el citado 2442 y el 2443, Actitudes y creencias religiosas, permiten comprobar cuál era a comienzos del siglo XXI el peso relativo de las distintas concepciones de Dios en la sociedad española. En el primero de esos estudios, el 56\% de los encuestados estudiados manifestó firmemente creer en un Dios, en el sentido de la tradición católica: omnipotente, todopoderoso, Padre y Juez, revelado por las Sagradas Escrituras, y personal (González Blasco, 2004); el 16,1\% dijo creer en la existencia de "una fuerza suprema”; el 12,5\% señaló que no sabía realmente en lo que creía; y el 12,4\% afirmó "no creer en nada, ni en Dios ni en una fuerza suprema”. En el segundo, se pudo comprobar que "la idea de que existe un Dios personal que se ocupa del ser humano en concreto está afirmada y negada por igual entre los españoles” (Pérez Agote y Santiago García, 2005:36). En efecto, el 39,6\% estaba de acuerdo con dicha idea frente al $37,9 \%$ que la rechaza, mientras que al 17,2\% le es indiferente. 
Casi 3 de cada 4 personas entrevistadas manifestaron creer en la existencia de Dios, mientras que 2 de cada 3 declararon que creían en la existencia de alma. Por el contrario, 1 de cada 10 mostró su incredulidad total en ambas creencias, mientras que un significativo porcentaje de población, alrededor de 1 de cada 5, respondió “no sabe”, es decir, manifestó no tener opinión, o se mostró “indiferente” según expresión de Bericat (2003a:282) ante estas dos creencias religiosas.

Frente al consenso observado en ambas creencias, existen otras tres para las que se aprecia un disenso positivo, es decir, una polarización de la población entre creyentes y no creyentes con mayor presencia de los primeros. En efecto, se puede observar en el Cuadro 5.6. que, aunque en menor proporción que las dos creencias anteriores, están asimismo muy extendidas entre la población las creencias en la existencia del "pecado”, el “Cielo” y de "vida después de la muerte”; creencias que son compartidas entre el $40 \%$ y el $50 \%$ de las personas encuestadas. Frente a esas proporciones de creyentes, las de los que no creen en ellas, aunque menores, son asimismo significativas y varían notablemente según cuál sea la creencia de que se trate; así, 1 de cada 4 personas no cree en el "Cielo” y 1 de cada 6 no cree en la "existencia de vida después de la muerte”. Entre las personas que rechazan estas creencias, una de las componentes del grupo de discusión lo argumentó de la siguiente manera:

- "No, pacté con mi padre que viniera a contármelo y no ha venido... Si crees que no hay nada. No ha venido nadie a contarlo todavía” (GD1:22).

Respecto al "pecado", 1 de cada 3 personas encuestadas no cree en él y entre los componentes del grupo de discusión, unos creyentes, otros incrédulos y algunos agnósticos, ninguno cree en el pecado en el sentido de la doctrina católica, como se comprueba en algunos fragmentos del verbatim:

- “...El pecado, según quién lo tenga que juzgar. Porque yo, a lo mejor, cojo estas llaves, y voy a la cárcel porque dicen que he hecho un verdadero robo. Sin embargo, éste que se ha llevado un castillo, pues como lo tiene que juzgar aquél, dice "no, es que es una cosa que la he tomado de momento para volverla a dejar". El pecado es una cosa que no... que no le veo la cosa yo por ningún lado. Según quién lo juzgue, pues es más pecado o menos pecado" (GD1:11).

- “... El pecado es una cosa que se han inventado cuatro listos. Crean el pecado, y luego ellos son los intermediarios para quitar ese pecado. Es el negocio. En todas las religiones, eh...

- Intentan dominar a la gente.

- Claro. Es un dominio. Además de sentirte mal, encima tienes que pagar para que ese pecado te lo quite otro intermediario" (GD1:11).

Por otra parte, existe un disenso negativo en la creencia sobre la "resurrección de los muertos” ya que el porcentaje de no creyentes está próximo al 40\% de las personas encuestadas, mientras que el de los creyentes supera ligeramente el 30\%. Esta proporción, además, es similar 
a la de los indiferentes, lo que sumado a los no creyentes significa que en conjunto existe una clara desafección respecto a este dogma de la fe católica: 2 de cada 3 encuestados no creen, no les interesa o les es indiferente la resurrección de los muertos. Más alejamiento aún se aprecia en relación a otros tres dogmas religiosos incluidos en el Cuadro 5.6. respecto a los que existe un claro consenso negativo. Algo más de la mitad de la población encuestada no cree en la existencia del "demonio", en la "comunicación extra-sensorial con los muertos" o en la “reencarnación”. Parece lógico que, al no pertenecer a la tradición católica, estos dos últimos dogmas no reúnan demasiadas adhesiones entre la población encuestada; sin embargo, el hecho de que algo más de 1 de cada 10 personas encuestadas se adhieran a las mismas ofrece asimismo una pista reveladora de la emergencia de sensibilidades religiosas que fluyen al margen de la religión católica. Por su parte, la relativamente baja proporción de creyentes respecto a la existencia del demonio, dogma secularmente utilizado como instrumento de control social junto al "infierno”, es una prueba clara de "racionalización” de las creencias que, junto con los datos relativos al resto de los dogmas, permite perfilar algunas de las claves de la religiosidad de la población encuestada: carencia de una matriz religiosa omnicomprensiva, alejamiento de la religiosidad institucional, dominio de una religiosidad existencial, espiritual, emocional, experiencial, personal e íntima.

\begin{tabular}{|l|ccc|c|}
\hline \multicolumn{5}{|c|}{ CUADRO 5.6.: CREENCIAS RELIGIOSAS (\%) } \\
\hline & Sí & NO & NO SABE & $(\mathrm{N})$ \\
\hline Dios & 72,4 & 10,8 & 16,8 & $(414)$ \\
El alma & 67,9 & 10,1 & 21,0 & $(405)$ \\
El pecado & 47,5 & 35,5 & 16,3 & $(406)$ \\
El Cielo & 44,2 & 27,9 & 26,4 & $(405)$ \\
Vida después de la muerte & 48,0 & 17,7 & 33,7 & $(406)$ \\
La resurrección de los muertos & 30,4 & 38,1 & 29,7 & $(404)$ \\
La comunicación extra-sensorial con los & 12,7 & 51,1 & 35,5 & $(403)$ \\
muertos & 19,9 & 53,2 & 25,9 & $(402)$ \\
El demonio & 14,9 & 51,6 & 32,8 & $(403)$ \\
La reencarnación & & & & \\
\hline
\end{tabular}

Fte: Encuesta 2000. Elaboración propia.

Aunque no se incluyen datos sobre la desagregación de las creencias según las distintas variables discriminatorias, los resultados de ese análisis no difieren de los obtenidos por otros autores sobre este tema y que resaltan sobre todo la importancia del proceso de cambio intergeneracional como proceso secularizador (Pérez Agote y Santiago García, 2005; González Blasco, 2004; Bericat, 2003; CIS, 2002; Campo Ladero, 2002; Inglehart, 1998; Andrés Orizo, 1991, Pérez Agote, 1990). En efecto, existe una relación directa entre la credulidad sobre los dogmas de fe de la religión católica con la edad de tal forma que son las personas ancianas las 
que creen en mayor proporción en los mismos y las jóvenes las que menos. No ocurre así con los otros dogmas religiosos no católicos como la "reencarnación", en la que creen en mayor medida los jóvenes (17,2\%) que los ancianos (11,9\%), y la “comunicación extra-sensorial con los muertos” en la que sí que creen algo más de 1 de cada 6 jóvenes $(17,2 \%)$, pero no los ancianos (1,5\%). Estrechamente relacionado con el cambio generacional, el nivel de estudios alcanzado conforma, asimismo, perfiles diferenciales ante las creencias religiosas al existir una relación inversa entre dicha variable y la credulidad en las mismas. En lo relativo a todos los dogmas de fe católicos las personas con estudios básicos son con diferencia las más creyentes mientras que las que tienen estudios universitarios son las que menos creen; las que tienen estudios medios, por su parte, son relativamente las más indecisas/indiferentes ante esos dogmas, excepto en la creencia en el "demonio" en la que las mayores proporciones de indecisos se observan entre las que declaran estudios básicos. Asimismo, son éstas, también con diferencia, las más incrédulas respecto a la existencia de la "reencarnación” o de la “comunicación extra-sensorial con los muertos”. Respecto a estos dos dogmas apenas existen diferencias entre las que tienen estudios medios o universitarios, ya que aproximadamente la mitad de ambos grupos se muestran incrédulas ante las mismas y una proporción importante de ellas, una de cada tres, se manifiesta indecisa/indiferente.

En el perfil diferencial de las personas creyentes se observa, como también han puesto de manifiesto otros trabajos, la existencia de diferencias por género, de tal forma que las mujeres creen en mayor proporción que los hombres en todos los dogmas religiosos citados, aunque en la muestra de esta encuesta esas diferencias sólo son estadísticamente significativas en los casos de la existencia de "Dios” y en la del "alma”. La mayor credulidad relativa de las mujeres es una manifestación más de la mayor religiosidad que hasta ahora han mostrado cuando se las considera como un conjunto; no obstante, dada la progresiva equiparación entre géneros y el proceso de desaparición de la mentalidad religiosa tradicional, cabe esperar que con ello las diferencias en las creencias por género desaparezcan (Pérez Agote, 1990:32). De hecho, tales diferencias se reducen notablemente o incluso desaparecen entre las personas con estudios universitarios de ambos sexos.

Lógicamente, las personas que se auto-identifican como católicas son las que en mayor medida manifiestan creer en todos los dogmas católicos citados. No obstante, un análisis más pormenorizado de esa categoría social muestra la existencia de una especie de "frontera" entre aquéllas que se declaran católicas practicantes y las que se identifican como católicas poco o nada practicantes. Mientras que las primeras asumen sin muchas dudas todos los dogmas católicos, excepto el de la existencia del "demonio", en el que se observan los mismos porcentajes de creyentes, no creyentes e indiferentes, las que se declaran católicas poco o nada 
practicantes sólo asumen mayoritariamente la existencia de "Dios”, y en menor medida la del “alma” (65\%), a la par que se hallan claramente alejadas del resto de los dogmas católicos, entre los que en ningún caso existen más del 50\% de creyentes en esta subcategoría. Este salto cualitativo entre católicos practicantes y católicos poco o nada practicantes se observa asimismo a la hora de asumir la existencia de la "reencarnación” y la de la “comunicación extra-sensorial con los muertos”: si bien en ambas subcategorías se muestran mayoritariamente incrédulos respecto a esas dos creencias, los católicos practicantes lo son con mayor rotundidad. Estos resultados ponen de relieve que la auto-identificación en términos de catolicidad no conlleva necesariamente la asunción íntegra y plena de todos los dogmas de fe de la religión católica. Lo que significa que el proceso de secularización en el que ha estado, y está, inmersa la sociedad española no sólo ha supuesto una progresiva reducción de la proporción de adeptos de la religión católica, sino que además entre los que se auto-identifican como católicos también se ha producido un cierto proceso secularizador, es decir, que para ellos la religión (católica) cada vez es menos importante como elemento definidor de su escala de valores. En última instancia, por tanto, y como señala Pérez Agote (1990:32), hay que diferenciar entre una secularización que supone el abandono definitivo de la religión y otra secularización en la que se produce una pérdida de influencia en el homo religiosus de la religiosidad institucionalizada, manteniéndose sin embargo un poso de espiritualidad religiosa íntima, privada.

Dado que la religión es un sistema de creencias básico en el condicionamiento de las actitudes ante la muerte, interesa conocer tanto el grado de integración entre las mismas como el modo en que están integradas (Bericat, 2003a:282-289). Para ello se ha aplicado un análisis Cluster, mediante la técnica “conglomerados no jerárquicos de K medias” (Pérez López, 2001:cap.14), por el que las personas encuestadas han quedado agrupadas en cuatro conglomerados $^{27}$, dos de los cuales, con una alta correlación interna, recogen las posiciones extremas, mientras que los otros dos, con una correlación moderada, se sitúan entre los anteriores. Manteniendo la terminología empleada por Bericat, en el Cuadro 5.7. se muestra la distribución de la población encuestada de acuerdo a su agrupación en una tipología de conglomerados denominados ${ }^{28}$ :

a) <<crédulos >>, aquellas personas encuestadas que manifiestan creer en todas y cada una de las creencias dogmáticas de la fe católica aunque con diferente intensidad en cada una de ellas. Su

\footnotetext{
${ }^{27}$ Los centros de los conglomerados finales, el número de casos por conglomerado, así como una tabla intermedia que traduce el significado de las respuestas dadas y ayuda a la interpretación de los conglomerados puede consultarse en el Anexo 4 incluido en el CD adjunto.

${ }^{28}$ Sobre una muestra de datos representativa del conjunto de la población española (CIS (2002): Estudio 2.443), Bericat (2003a) obtiene la siguiente distribución de la población encuestada de acuerdo a la misma tipología: a) <<crédulos >>, el 23,5\%; b) <<incrédulos >>, el 26,9\%; c) <<creyentes >>, el 33\%; y, d) $<<$ no creyentes $>$, el 16,3\%.
} 
sistema de creencias es coherente y se mueve en unos porcentajes de creencias que superan como mínimo el 68\% -caso de la creencia en la "resurrección de los muertos"-, salvo en la existencia del "demonio" que sólo lo admiten el 43,7\% de los crédulos, mientras que el 14\% duda. Al ser un tipo muy integrado de creencias, rechazan sin paliativos los dogmas religiosos que no pertenecen a su tradición. Casi cuatro de cada diez personas encuestadas pertenecerían a esta categoría social. No obstante, por las respuestas recabadas en este trabajo, se podría estimar que algo menos de la mitad de esa categoría, en torno al 10-15\% del total de la muestra, constituye lo que cabe denominar como el "núcleo duro o integrista" del mismo, es decir, el constituido por las personas más profundamente religiosas que consideran que la vida humana es sagrada y no pertenece al propio individuo, ya que está por encima de todo interés de él, sino que pertenece a Dios, que es quien decide sobre ella. Por lo que consideran el aborto, la eutanasia y el suicidio como inmorales y los identifican con crímenes, al vulnerar el valor intrínseco y sagrado de la vida y atentar contra la naturaleza (Argumento de la ética de la santidad de la vida). Por ejemplo, interrogada sobre qué es lo que ocurre cuando una persona muere, la mujer crédula entrevistada respondía:

- "Yo lo veo desde el punto de vista religioso, entonces desde ese punto de vista el alma se separa del cuerpo y el cuerpo se queda aquí y el alma a donde tenga que ir. Es Dios quien determina ese paso" (E3:1).

Dios omnipotente que da sentido a la vida, determinándola en todas sus dimensiones:

- "V: Para mí sí, porque sale de la voluntad de Dios no de la del hombre. De hecho, hay quien quiere tener hijos y no los puede tener.

$\mathrm{E}:$ ¿Cómo lo relacionas?

$V$ - Hombre, son cuestiones biológicas o físicas, la gente se lo toma así, pero yo no lo veo asî" (E3:8).

b) <<incrédulos >>, las personas encuestadas que asimismo con mucha coherencia, y en oposición a los crédulos, manifiestan no creer en las creencias dogmáticas religiosas. Los porcentajes de no creencia varían según cuál sea el dogma sobre el que se les interpela, siendo superior al 90\% en aquellos dogmas, como el de la existencia del "demonio", en los que incluso tampoco creen los crédulos. Cabe resaltar dos resultados muy relevantes en relación a este tipo; por un lado, aunque ninguno de los incrédulos cree en "Dios", el 41,3\% de ellos duda o le es indiferente su existencia; por otro lado, la mayoría de los incrédulos, el 57,1\%, manifiestan creer en la existencia del “alma”. Probablemente, la explicación de estos dos resultados paradójicos esté en razones semánticas, en el sentido de que los encuestados conciban a Dios o al alma con otros parámetros distintos de los definidos por la tradición católica. Como se comprueba en los siguientes fragmentos de la entrevista al varón incrédulo y de uno de los componentes del grupo de discusión:

- “¿En el alma? Es algo que... es que es algo tan inconcreto, que la verdad no tengo, digamos un conocimiento muy fuerte como para poder hablar del alma. $O$ sea, es algo que, bueno, es algo que se ha puesto nombre a una cosa y no la veo 
por ningún sitio. El alma, no lo sé. El alma es el soplo de la vida por llamarlo de alguna forma. El alma es algo muy inconcreto. No estoy yo capacitado para hablar del alma. No tengo ni idea" (E4:5).

- "Para mí, Dios es una palabra que se ha inventado a través de los siglos, y la gente cree pues en su Dios. Unos en el sol, los otros en una imagen, en Mahoma.. para mí es una cosa etérea que no.., ¿el alma?, pues es la dignidad de la persona. Según los sentimientos que tengas, pues eso se suele llamar el alma. Quien tiene muchos sentimientos, pues llamémoslo que tiene alma" (GD1:11).

A este otro tipo extremo pertenecen aproximadamente una de cada seis personas encuestadas. En su caso, consideran fundamental que sea la propia persona quien tome las decisiones que la afectan, en especial las referidas al cuándo y cómo del final de su vida (Argumento de la autonomía de la persona):

- “¿La vida es sagrada, un derecho irrenunciable?, derecho... es que esto no es... aquí no se trata de derechos irrenunciables. Naces por un proceso, no sé si es químico o físico, y nada más. No es ningún derecho, ni... ninguna historia. O sea, naces y punto... Uno tiene todo el derecho del mundo a suicidarse. Creo yo, vamos... Es que si uno dice "yo aquí sobro y lo estoy pasando fatal y no tengo nada que me una a esta vida que llevo", pues si decide irse al otro barrio, pues me parece correcto. No soy yo quién para decirle que no, eso lo tengo claro también" (E4:8).

c) $<<$ creyentes $>>$, es un tipo intermedio, próximo a los crédulos, que está integrado por las personas encuestadas que se inclinan a creer pero que a la vez tienen dudas sobre algunas de las creencias religiosas. En efecto, sus incertidumbres no se manifiestan en las creencias en "Dios" y en el “alma”, que asumen unánimemente, pero sí en el resto de las creencias religiosas entre las que domina sobre todo la indecisión o la indiferencia. De hecho, incluso la creencia en el Dios católico se tiene con matices diferenciales, como resaltan el joven creyente entrevistado y algunos componentes del grupo de discusión:

- "Puede ser que sea el mismo Dios, no desde la perspectiva de tener un temor o de que pueda ocurrir algo malo si tú en la vida, en la tierra haces algo malo. No tengo esa perspectiva tan negra del demonio. Sé que existe el pecado que puede ser malo, pero quizás no dejando de ser lo que es la mala acción del pecado en sí. Me gusta pensar que si existe Dios es para algo bueno. No que tenga que existir, aparte de Dios, el demonio también para que en contrapartida creas en Dios, no sé, es una fe un poco descafeinada. Sui géneris” (E1:5).

- "- Creo en una cosa que... no sé, que se llame como se llame, pero... pero no un Dios... no un Dios como el Dios que nos han enseñado.

- El Dios que te han educado a ti desde niño, porque yo me acuerdo que las misiones... aquello era terrible. Empezaban a hablarte, y cuando llegabas al purgatorio y al infierno, ¡vamos!, es que ya se caía el mundo. Te abrasabas" (GD1:8).

El 22,5\% de las personas encuestadas pertenecen a este tipo. En términos generales, identifican el derecho a la vida como el primero y más importante de todos los derechos, un 
valor superior a todo lo demás. Derecho que, al ser anterior a la libertad de la persona, conlleva un deber, puesto que la vida no es algo que la propia persona haya creado sino que le ha sido dado, por lo que debe actuar con responsabilidad en todo lo relativo a ella (Argumento del derecho a la vida) (Silva Alarcón, 1999). En el caso del joven creyente entrevistado percibe la vida:

- "Vamos, que esto es único. Es un don, una facultad de los seres vivos que no se puede cambiar por nada, yo creo. Veo a gente que lo está pasando muy mal y por el hecho de seguir vivo sigue luchando. Hay muchas situaciones que dan pena, que la gente tenga que vivir así. Por eso pienso en mi situación en sí, pero por lo que veo en otras personas, lo que luchan por vivir, me imagino que esas situaciones que merecerá la pena” (E1:6).

d) $<<$ no creyentes $>>$, es el otro tipo intermedio, en su caso próximo a los incrédulos, que está constituido por aquellas personas encuestadas que mayoritariamente tienden a no creer pero con muchas dudas y entre las que, incluso, sin ser mayoritarios se observan porcentajes importantes de aceptación de algunas creencias concretas como por ejemplo la creencia en "Dios", que asumen el $44,7 \%$ de ellas. El porcentaje de no creyentes entre las personas encuestadas es similar al de creyentes (Cuadro 5.7.). En algunos casos, los no creyentes lo son a su pesar, como la joven no creyente entrevistada que al interrogarla sobre la batería de creencias (Dios, el pecado,...) comenta:

- "A lo mejor cuando era pequeña sí pero ahora ojala me dijeran algo porque les tengo envidia a los que creen que hay vida después de la muerte, que bien que morirte y seguir viviendo porque encuentran un sentido, reconforta más” (E2:4).

Para esta categoría social el valor de la vida humana no es un absoluto, sino que varía según la calidad de la misma, siendo necesario por ello respetar el deseo de vivir o de morir de una persona (Argumento de la ética de la calidad de vida). Como afirma la joven no creyente entrevistada:

- "La vida es sagrada, un derecho irrenunciable; no, no estoy de acuerdo. A cualquier persona que no le gusta la vida que tiene y cualquier derecho se puede renunciar a él, creo yo. No tienes por qué vivir obligatoriamente. Si no puedes disponer de tu vida, es lo último que nos queda" (E2:6).

La importancia sociológica de esta tipología estriba, como resalta Bericat, en que revela empíricamente la emergencia de grupos híbridos definidos por una religiosidad contemporánea y posmoderna en un entorno en el que, al menos analíticamente, hasta hace poco la mayoría de las miradas sólo contemplaban la existencia de los dos grupos “modernos" extremos. En efecto, frente a la coherencia interna, cierre categórico y resistencia al cambio de éstos dos grupos, "vestigios cristalizados de una cultura pasada, la de la lucha del laicismo de la modernidad contra la religiosidad tradicional”, un 45\% de las personas encuestadas, integradas en los dos grupos intermedios, manifiestan su escepticismo en las creencias religiosas, su "falta de 
convicción o voluntad religiosa”, la debilidad de sus vínculos institucionales con la religión, que se traducen en la práctica en una baja participación en los actos religiosos. Estas “carencias”, no obstante, no son indicativas de incoherencia o debilidad religiosa, sino que, por el contrario, expresan "los nuevos signos del tiempo" caracterizados por nuevas demandas de religiosidad imposibles de ser cubiertas con la actual oferta religiosa institucional: son "los rasgos de la verdadera religiosidad contemporánea, una religiosidad adaptada a los cambios sociales y culturales de las sociedades avanzadas, hipermodernas o posmodernas” (Bericat, 2003a:286287).

La complejidad de la situación religiosa actual se manifiesta de forma explícita al cruzar la tipología de creyentes con las variables sociodemográficas básicas, como se recoge en el Cuadro 5.7. Si bien existen diferencias estadísticamente significativas en todos los cruces, dos de ellos son especialmente relevantes. Por un lado, la distribución por edad muestra la profundidad del cambio intergeneracional de valores: no se trata sólo de que, como se ha señalado arriba, a medida que aumenta la edad es mayor el peso relativo de los crédulos, dos de cada tres personas ancianas lo son, sino sobre todo de que entre los jóvenes, aún siendo mayoría los crédulos, los pesos relativos de las dos posiciones híbridas intermedias, creyentes y no creyentes, son similares al de aquéllos. En efecto, más de la mitad de las personas jóvenes entrevistadas están adscritas, a partes iguales, a uno de los dos tipos intermedios.

Estos datos son indicativos más de un cambio generacional que de un mero efecto edad; cambio que producirá en el futuro, a medida que las cohortes jóvenes releven a las ancianas, una sustitución de la mentalidad religiosa tradicionalista asentada en la omnipotencia de un ser superior, en la necesidad de reglas absolutas, en la maximización de la predectibilidad para minimizar incertidumbres, por otra mentalidad religiosa posmoderna, más ambigua y permisiva, poco condicionada por la autoridad religiosa, en la que se cuestiona el significado y el sentido de la vida, en la que se admiten reglas flexibles y en la que predomina la ética situacional como fruto de la auto-expresión individual (Inglehart, 1998:cap. 1). 


\begin{tabular}{|l|ccccc|}
\hline \multicolumn{5}{|c|}{ CUADRO 5.7.: TIPOLOGÍA DE CREYENTES (\%) } \\
\hline & CRÉDULO & INCRÉDULO & CREYENTE & NO CREYENTE \\
\hline Total & 39,1 & 16,3 & 22,5 & 22,0 \\
$(\mathrm{~N})$ & $(151)$ & $(63)$ & $(87)$ & $(85)$ \\
\hline Hombres & 32,9 & 21,5 & 20,3 & 25,3 \\
Mujeres & 43,4 & 12,7 & 24,1 & 19,7 \\
\hline Jóvenes & 30,1 & 19,2 & 25,9 & 24,9 \\
Adultos & 41,7 & 16,7 & 18,2 & 23,5 \\
Ancianos & 62,3 & 6,6 & 21,3 & 9,8 \\
\hline Est. básicos & 58,2 & 5,5 & 27,3 & 9,1 \\
Est. medios & 33,8 & 16,3 & 16,3 & 33,8 \\
Est. universitarios & 36,7 & 18,7 & 23,5 & 21,1 \\
\hline Católicos & 49,5 & 4,5 & 27,3 & 18,7 \\
Indiferentes & 6,5 & 48,4 & 6,5 & 38,7 \\
No creyentes & 2,0 & 66,0 & 4,0 & 28,0 \\
\hline
\end{tabular}

Fte: Encuesta 2000. Elaboración propia.

Por otro lado, el cruce entre la tipología de creyentes y la autodefinición religiosa permite constatar la heterogeneidad interna existente en las tres categorías concretadas según la auto-definición religiosa ${ }^{29}$. Así, por ejemplo, en la categoría más amplia, la de los que se declaran católicos, se encuentran tanto individuos que creen en todos los dogmas religiosos crédulos-, o que tienden a creer en ellos -creyentes-, como individuos cuya declaración de catolicidad es más bien retórica o formal, en el sentido de que expresan con ello únicamente el hecho de haber sido bautizados, ya que manifiestan una importante desafección o indiferencia hacia las creencias dogmáticas católicas -no creyentes. Dados estos resultados, en el resto del trabajo se empleará como variable de religiosidad la distribución de la población encuestada según la tipología de creyentes porque se considera que identifica con mayor fiabilidad la religiosidad de cada individuo que la distribución según la autodefinición religiosa.

\subsection{MUERTE Y VIDA COTIDIANA}

"Un golpe de ataúd en tierra es algo perfectamente serio”

A. Machado

Como se ha comentado hasta ahora, la adquisición de la conciencia de muerte por el ser humano, que es naturalmente ciego a ella, es un proceso por el que éste "se ve forzado sin cesar

\footnotetext{
${ }^{29}$ En el Cuadro 5.7. se constata además la existencia de un número reducido de respuestas incongruentes Por ejemplo, trece personas que inicialmente se declaran católicas y, sin embargo, manifiestan no creer en ninguno de los dogmas religiosos, o, una persona que se identifica como atea y que a la vez cree en todos los dogmas católicos.
} 
a reasumirla” (Morin, 1974a:62). Sin embargo, y a pesar de la experiencia vicaria de la muerte, el ser humano de las sociedades desarrolladas vive despreocupadamente como si nunca fuera a morir, dejando obsoleta la advertencia de Machado de evitar acostumbrarse a la muerte, todo lo contrario. Morin (1974a:62-65) afirma que la principal razón por la que la muerte no está presente en la vida cotidiana en las sociedades occidentales, por la que no se piensa en la muerte, es que los individuos de las mismas están centrados en el presente, en sus hábitos, trabajos, actividades, etc., rechazando todo lo que no sea esto, lo que implica una ceguera de la muerte. Actitud por la que el ser humano vuelve a la ignorancia animal de que va a morir, "es decir está dotado de vida”. Así, esta "animalidad es la vida misma, y, en ese sentido, la obsesión de la muerte es una <<diversión>> de la vida”. Para comprobar el alcance de esa <<diversión>> de la vida entre la población encuestada, a continuación se examinan las actitudes de la misma en lo relativo al pensamiento, comunicación, experiencia y conocimiento personal de la muerte.

\subsubsection{PENSAR EN LA MUERTE}

"Siempre que no pienso en la muerte tengo la impresión de trampear, de engañar a alguien dentro de mí”

E.M. Cioran

La reflexión sobre la muerte no forma parte de los pensamientos cotidianos de la gente. Según López Aranguren (1981:298-302) esta actitud de no pensar, de no preocuparse por la muerte, en definitiva de eludirla, es la más habitual entre los individuos de las sociedades desarrolladas, aunque la muerte se mantiene en la penumbra de la semiconsciencia. La muerte no se puede evitar, pero el pensamiento sobre ella, que paraliza y perturba la vida, sí. Un tercio de las personas encuestadas afirma pensar con frecuencia en la muerte, entre ellas sólo un 10\% lo hace muy a menudo o diariamente, mientras que un 67\% no piensa sobre ella ${ }^{30}$ (pregunta 16), Cuadro 5.8. En este cuadro se constata que es mayor la proporción de mujeres que piensan en la muerte que la de los hombres (37,3\% frente a 27,1\%), y además que ellas lo hacen con más frecuencia -muy a menudo o diariamente- (11,4\% frente a 7,2\%). Durán (2004:13-14) vincula la mayor reflexión sobre la muerte entre las mujeres no sólo a su mayor longevidad, sino también a las razones culturales y estructurales por las que: a) se vinculan más que los varones en los procesos de enfermedad, morir y muerte de familiares y amigos (en mayor medida que los hombres proporcionan cuidados en la enfermedad, vejez y agonía, se encargan de la organización del funeral, enterramiento, etc.); b) al depender más de los ingresos de sus compañeros, que al revés, desde un punto de vista social y económico se ven más afectadas que aquéllos por el fallecimiento de su pareja, y; c) dado que en general las mujeres están

\footnotetext{
${ }^{30}$ Como se comenta más adelante, el $41,3 \%$ de la población encuestada declara que su actitud de no pensar en la muerte es voluntaria, ya que “evito totalmente pensar en la muerte” (pregunta 73k).
} 
emparejadas con varones mayores que ellas, tienen más probabilidad que sus cónyuges de experimentar el fallecimiento de su pareja.

Si existe asociación entre el pensamiento sobre la muerte y el género, el vínculo entre ese pensamiento y la edad es aún mayor. En efecto, como se constata en el Cuadro 5.8., entre las edades más avanzadas el pensamiento sobre la muerte está más extendido y es más frecuente: el 44,5\% de los ancianos piensa a menudo en la muerte, frente al 27,8\% de los jóvenes; el 14,4\% de los ancianos lo hacen muy a menudo o diariamente frente al 10,6\% de los jóvenes, o el 5,7\% de los adultos. Asociación clara derivada, por un lado, de que al avanzar en la edad son mucho más probables las experiencias vicarias de muerte, primero las de los progenitores y poco a poco las de los amigos y coetáneos, y, por otro lado, de que el declive fisiológico, una vez superada la edad de procreación, hace que a partir de los 45 años emerjan lentamente problemas de salud que se van incrementando a medida que las personas envejecen y se aproximan a su final. Causalidades que se reflejan en los siguientes extractos de las entrevistas realizadas y del verbatim del grupo de discusión:

- "Pero es un tema que trato de evitar. Pensar en la muerte propia pues tampoco, porque creo que me pilla tan lejos" (E1:2).

- "La verdad es que no. Pienso en cuanto a lo que pueda ocurrirles a los cercanos a mí, pero en el caso mío no demasiado. No es algo que me preocupe" (E4:6).

- “- Yo todos los días.

- Pues yo, de pequeña mucho. Y lloraba porque decía "¿por qué me tengo que morir?, ¿por qué se tiene que morir mi abuela?” Luego ha habido una temporada que no he vuelto a pensar en ello "si es así, tiene que ser". Y ahora vuelvo a pensar en ello otra vez.

- Claro porque, cuando eres pequeño, nadie te dice ni te lleva al entierro de un familiar, auque sea de un abuelo. Te dejan un poco apartado. ¿Cuándo empiezas a pensar? Cuando ya lo vas viendo tú un poquitín más palpable. Cuando llegas a cierta edad...

- Cuando te das cuenta de que es inminente la muerte, que es una cosa segura.

- Sí, pero yo, por ejemplo, a mis 65 años, ya pienso que muchos no me pueden quedar. Por otro lado, digo "cuando me llegue ya me llegará". ¿Para que voy a pensar yo ahora?, ¿que me puedo morir, ahora o mañana, o dentro de un segundo?

- Yo nunca pienso en lo que me puede quedar. Pero si no lo sabe nadie. Es una cosa que la tengo presente.

- En el ambiente que te vas moviendo... vas viendo que se muere el compañero, el amigo.. y no sé si os pasará una cosa: por inercia, coges el periódico, y vas a las esquelas, y miras la edad...

- La edad, sí que es verdad.

- ...y la comparas con la tuya...

- ...y dices "poco me queda"...

- ...y dices "pues a lo mejor yo soy especial y me paso", pero estamos ahí.

...- Yo miro las esquelas y digo "por ahí si te quedan 10 años..." Con lo rápida que pasa la vida, estamos ya abocados...

- Pero tú eres muy egoísta, tú piensas que te quedan 10 años” (GD1:13-14). 
Por otra parte, el análisis realizado a la muestra seleccionada mediante el test de la "chi cuadrado" revela que no existe asociación entre el pensamiento sobre la muerte y el nivel de estudios alcanzado, y tampoco entre aquél y la religiosidad ${ }^{31}$.

\begin{tabular}{|l|c|c|c|c|c|}
\hline \multicolumn{5}{|c|}{ CUADRO 5.8.: FRECUENCIA CON QUE SE PIENSA EN LA MUERTE (\%) } \\
\hline & CADA DÍA & $\begin{array}{c}\text { MUY A } \\
\text { MENUDO }\end{array}$ & A MENUDO & MUY POCO & NUNCA \\
\hline TOTAL & 1,2 & 8,6 & 23,5 & 58,0 & 8,8 \\
\hline HOMBRES & 1,2 & 6,0 & 19,9 & 60,8 & 12,0 \\
MUJERES & 1,2 & 10,2 & 25,9 & 56,1 & 6,7 \\
\hline JÓVENES & 1,0 & 9,6 & 17,2 & 64,1 & 8,1 \\
ADULTOS & 0,0 & 5,7 & 28,6 & 56,4 & 9,3 \\
ANCIANOS & 3,6 & 10,8 & 30,1 & 45,8 & 9,6 \\
\hline EST. BÁSICOS & 4,2 & 6,9 & 22,2 & 52,8 & 13,9 \\
EST. MEDIOS & 1,1 & 11,4 & 26,1 & 53,4 & 8,0 \\
EST. UNIVERS. & 0,4 & 8,0 & 23,0 & 60,9 & 7,7 \\
\hline CRÉDULOS & 0,7 & 6,6 & 26,5 & 57,6 & 8,6 \\
CREYENTES & 1,1 & 13,8 & 18,4 & 62,1 & 4,6 \\
NO CREYENTES & 0,0 & 10,7 & 20,2 & 61,9 & 7,1 \\
INCRÉDULOS & 4,8 & 6,3 & 20,6 & 54,0 & 14,3 \\
\hline
\end{tabular}

Fte: Encuesta 2000. Elaboración propia

Estos resultados, que con poca variación concuerdan con los obtenidos en otras investigaciones (Pérez Agote y Santiago García, 2005; Durán, 2004; Bericat, 2003; Campo Ladero, 2002; Marí-Klose y Rodríguez, 2000; Inglehart, 1998; Orizo, 1991, Pérez Agote, 1990), llevan a interrogarse sobre cuáles son las razones por las que los individuos reflexionan poco sobre un fenómeno tan crucial en su existencia. En este sentido, se han planteado diversas hipótesis plausibles, no excluyentes, que intentan aportar las razones que expliquen esta concreción práctica de la negación psicológica de la muerte.

Por una parte, se ha aludido al progresivo asentamiento de la muerte como tabú a lo largo del siglo XX en las sociedades desarrolladas, es decir, a que la muerte "inspira miedos o respetos superiores a la contingencia física” y, en consecuencia, a que provoca en la mayoría de los individuos actitudes de elusión o negación ante ella. La muerte constituiría un estímulo

\footnotetext{
${ }^{31}$ Con un formato distinto en los ítems, el Estudio 2.442 del CIS (2002) interrogó a una muestra de 2.493 personas mayores de 18 años entre otras cosas sobre esta misma cuestión, la frecuencia del pensamiento sobre la muerte. Los resultados obtenidos son similares a los de la presente encuesta: a) la mayoría de la población no piensa mucho en la muerte (el 14,1\%, piensa muy frecuentemente; el 41,7\%, algunas veces); b) el pensamiento sobre la muerte está muy relacionado con la edad (aumenta con la misma); c) mayor proporción de mujeres, y con más frecuencia, que la de los hombres piensan en la muerte (el 44,9\% de las mujeres piensa en la muerte, frente al 38,3\% de los hombres; el 17,5\% de las mujeres lo hacen frecuentemente, frente al 10,4\% de los hombres), y; d) no se observa asociación entre el pensamiento sobre la muerte y el nivel de educación.
} 
aversivo que convoca respuestas de huída al representar una amenaza directa o indirecta contra la propia supervivencia (Kastenbaum, 1984; Urraca, 1982). No pensar en la muerte sería uno de los síntomas de esas actitudes, que podría sintetizarse gráficamente con una versión en negativo del Principio de Thomas: "No pienso en ella, luego no es real, no existe”.

Una segunda hipótesis relaciona el grado de reflexión sobre la muerte -y el sentido de la vida - con la religiosidad y con el grado de integración en las instituciones religiosas. Se afirma que cuando éstos son altos, las propias convicciones religiosas aportan explicaciones sobre el sentido de la vida y de la muerte y, en consecuencia, el grado de reflexión sobre estos temas es menor. La sacralidad, la devoción y el respeto absoluto inherentes a la religión hacen que las legitimaciones últimas sobre la vida que aquélla determina deriven en un proceso de autocomprensión de una realidad intocable e incuestionable. No cabe especular sobre el absoluto dado. Por el contrario, cuando fruto del proceso de secularización la religiosidad y/o el grado de integración religiosa institucional son menores, se vuelve más acuciante para las personas buscar respuestas al sentido de su existencia, al no estar cubiertas por el paraguas protector de una cosmogonía religiosa. Desde esta perspectiva, aquellos individuos y grupos sociales más reacios a admitir soluciones religiosas al problema del sentido de la propia existencia serían los más inclinados a pensar en la muerte (Requena y Benedicto, 1988:95-98). A pesar de las diferencias que se observan entre las categorías por religiosidad, Cuadro 5.8., como se ha señalado éstas no son estadísticamente significativas, por lo que para el caso de la población encuestada no parece confirmarse esta segunda hipótesis: religiosidad y activación e intensidad del pensamiento en la muerte son independientes. No parece, por tanto, que en la práctica la ilusión que ofrece la religión para aliviar "la pesadumbre de sabernos mortales” con la promesa de un mundo celestial en el que seremos "intrínsecamente inmortales" (Castilla del Pino, 1995:256) tenga efectos balsámicos distintos a los de otras interpretaciones seculares.

Por otro lado, una tercera hipótesis se asienta en la funcionalidad económica que la denegación de la muerte tiene para los individuos y la sociedad. Estos han de enfrentarse con inmediatez a los problemas de la vida cotidiana y necesitan hacerlo de forma adecuada. Si quieren ser operativos en su vida diaria, no verse paralizados por la angustia ante la muerte, precisan apartar de su pensamiento la fuente principal de su temor. Así, como señala Castilla del Pino, si en la realidad social, construida y constituida por los otros, domina una actitud denegadora de la muerte, se hace posible que el individuo se olvide de que ha de morir, se sienta inmortal aquí, y haga aquí y ahora: la expulsión de la muerte de la vida social logra la expulsión de la muerte en los individuos y, así, éstos pueden entregarse de lleno a vivir la vida. Como comenta la joven no creyente entrevistada: 
- "No pienso que sea un tema que haya que prepararlo, que sea un acontecimiento; siempre lo pienso como una amenaza, pero prefiero no pensar en ello, no pienso con gusto en ello. A veces te asaltan esos pensamientos pero no premeditadamente, no es que lo busque" (E2:1).

La fuerza de esta tercera hipótesis parece confirmarse con los datos recogidos en diferentes estudios relativos a las condiciones de vida de la sociedad española. En los mismos se constata que los aspectos relativos a los ámbitos de relación primaria y a los de carácter instrumental -trabajo, familia, salud, bienestar-, constituyen los ejes esenciales alrededor de los cuales giran los intereses cotidianos de la población española. La centralidad de esos ejes es tal, que inevitablemente las amenazas hacia los mismos filtran las percepciones con que se percibe a lo “otro” y al mundo exterior, y constituyen las principales, y más habituales, preocupaciones en la sociedad española. Esto mismo se observa en los individuos de la población encuestada en este trabajo, que al ser interrogados (pregunta 13) por su grado de preocupación actual sobre diversas cuestiones responden que, en lo que atañe a sí mismos, lo que más les preocupa es enfrentarse a aquellas situaciones que comprometan su posición `aquí y ahora’ o les genere incertidumbre en un futuro cercano: su situación económica futura, su situación económica actual, caer gravemente enfermos. Por el contrario, la inseguridad sobre su propia vida en abstracto les preocupa en menor medida y las cuestiones religiosas, ir al infierno o perder la fe, apenas les inquietan (Cuadro 5.9.).

En las entrevistas realizadas, al mostrar la tarjeta en la que se incluían las distintas situaciones recogidas en el Cuadro 5.9., se constató, efectivamente, la primacía de las preocupaciones más inmediatas:

- "Las que ahora más estoy pensando es sobre el trabajo y mi situación, no tanto económica, pero sí en la situación relacionada con el trabajo... Luego hay otras que, claro, nunca te gustan como ser victima de un atraco o que alguien ligado a mí muera o le suceda algo malo... pues perder la Fe o ir al infierno pues bastante poco me preocupa. Creo que para ir al infierno hay que morir y como no me preocupaba.., no sé, en ese sentido no tengo una especial preocupación” (E1:5).

- "En mi vida diaria ¿lo que más pienso de todo esto? Pues ahora mismo en el trabajo. También me preocupa una crisis ecológica pero ahora mismo mi prioridad soy yo. A lo mejor cuando tenga trabajo también pensaré en otras cosas, pero ahora mismo es ya prácticamente una obsesión" (E2:3).

- "Ahora en este momento me preocupa muchísimo más la muerte de alguien cercano a mí que el hecho de caer yo gravemente enfermo, me preocupa mucho más... Me preocupa caer gravemente enfermo más que estar sin trabajo o ser víctima de un atraco criminal, porque el atraco se puede solucionar favorablemente... ¿Lo de la incertidumbre sobre mi propia vida?; no tengo ningún tipo de incertidumbre sobre mi vida, no me planteo grandes cosas sobre mi propia vida, la verdad es que no" (E4:4). 
CUADRO 5. 9.: GRADO DE PREOCUPACIÓN ACTUAL POR LAS SIGUIENTES SITUACIONES... (\%)

\begin{tabular}{|c|c|c|c|c|c|c|c|}
\hline & A & B & C & D & $\mathbf{E}$ & $\mathbf{F}$ & G \\
\hline TOTAL & 63,8 & 41,9 & 17,0 & 71,7 & 69,1 & 59,5 & 88,7 \\
\hline HOMBRES & 65,0 & 33,4 & 19,1 & 70,7 & 57,8 & 58,8 & 83,6 \\
\hline MUJERES & 62,9 & 47,9 & 15,6 & 72,4 & 76,8 & 60,0 & 92,1 \\
\hline JÓVENES & 79,3 & 35,0 & 8,6 & 81,8 & 62,1 & 54,0 & 90,1 \\
\hline ADULTOS & 57,9 & 37,3 & 16,8 & 69,0 & 67,8 & 63,3 & 82,3 \\
\hline ANCIANOS & 29,8 & 71,0 & 43,1 & 47,0 & 90,6 & 67,6 & 97,0 \\
\hline EST. BÁSICOS & 35,5 & 69,3 & 32,2 & 58,0 & 70,9 & 61,3 & 95,3 \\
\hline EST. MEDIOS & 57,3 & 51,2 & 27,5 & 69,5 & 80,2 & 71,1 & 90,5 \\
\hline EST. UNIVERS. & 72,6 & 32,3 & 10,1 & 75,7 & 60,0 & 55,4 & 86,5 \\
\hline CRÉDULOS & 55,0 & 50,0 & 29,5 & 69,2 & 67,2 & 56,1 & 89,2 \\
\hline CREYENTES & 74,1 & 43,6 & 13,8 & 75,5 & 73,2 & 66,6 & 89,6 \\
\hline NO CREYENTES & 67,1 & 35,7 & 8,4 & 76,5 & 68,3 & 54,8 & 83,9 \\
\hline \multirow[t]{2}{*}{ INCRÉDULOS } & 66,7 & 21,0 & 1,6 & 71 & 61,3 & 66,1 & 91,7 \\
\hline & $\mathbf{H}$ & I & $\mathbf{J}$ & \multirow{14}{*}{\multicolumn{4}{|c|}{$\begin{array}{l}\text { A.- Estar sin trabajo } \\
\text { B.- Ser víctima de un atraco criminal } \\
\text { C.- Ir al infierno } \\
\text { D.- Su situación económica actual } \\
\text { E.- Caer gravemente enfermo } \\
\text { F.- Una crisis ecológica generalizada } \\
\text { G.- La muerte de alguien muy próximo } \\
\text { H.- La incertidumbre sobre su propia vida } \\
\text { I.- Perder la fe } \\
\text { J.- Su situación económica futura }\end{array}$}} \\
\hline TOTAL & 61,1 & 30,1 & 73,0 & & & & \\
\hline HOMBRES & 53,4 & 24,3 & 70,7 & & & & \\
\hline MUJERES & 66,5 & 34,3 & 74,7 & & & & \\
\hline JÓVENES & 73,3 & 21,8 & 89,4 & & & & \\
\hline ADULTOS & 47,4 & 25,6 & 65,4 & & & & \\
\hline ANCIANOS & 53,8 & 63,8 & 41,2 & & & & \\
\hline EST. BÁSICOS & 55,8 & 57,2 & 59,6 & & & & \\
\hline EST. MEDIOS & 56,6 & 40,9 & 68,6 & & & & \\
\hline EST. UNIVERS. & 63,9 & 20,2 & 77,7 & & & & \\
\hline CRÉDULOS & 62,9 & 46,0 & 69,8 & & & & \\
\hline CREYENTES & 63,9 & 31,7 & 77,0 & & & & \\
\hline NO CREYENTES & 69,4 & 14,4 & 81,0 & & & & \\
\hline INCRÉDULOS & 41,9 & 9,7 & 68,3 & & & & \\
\hline
\end{tabular}

Fte: Encuesta 2000. Elaboración propia

Obviamente, estos resultados para el conjunto de la población encuestada están sesgados por la composición de la muestra utilizada en este trabajo. Se hace necesario, en consecuencia, observar las diferencias entre las distintas categorías sociales y especialmente las relacionadas con el ciclo vital, que en buena medida son similares a las del nivel de estudios. En este sentido, se puede apreciar en el Cuadro 5.9. una evolución cruzada en el grado de preocupación por edad que, para las cuestiones “materiales” socialmente más relevantes, es máximo entre las personas jóvenes, llegando a duplicar o incluso triplicar al de las ancianas, mientras que en las cuestiones trascendentales ocurre a la inversa. No obstante, también entre éstas lo que más les preocupa es el "aquí y ahora” concretamente aquello que pueda alterar su seguridad física: caer gravemente enfermo, ser víctima de un atraco criminal. Si se considera la distribución por género, las mujeres muestran mayor nivel de preocupación que los hombres en 
todas las dimensiones excepto en la de estar sin trabajo y en la de ir al infierno ${ }^{32}$. Por otra parte, y como parece obvio, excepto las preocupaciones relacionadas con cuestiones religiosas, el resto son independientes de la religiosidad y transversales a toda la población encuestada. Incluso entre la propia población más religiosa, los crédulos, las dos cuestiones de carácter religioso planteadas no preocupan ni a la mitad de ella, quizá por la seguridad con que se mantienen las creencias, como señala la mujer crédula entrevistada:

- “...perder la fe no, la tengo muy arraigada y no creo que jamás la perdiera. Y lo de ir al infierno por supuesto que sí, pero creo que de momento no he hecho méritos, no me preocupa” (E3:4).

Al objeto de clarificar en mayor medida el ordenamiento de la jerarquía de preocupaciones, se han transformado las variables originales en unos pocos factores incorrelacionados entre sí ${ }^{33}$. Se ha aplicado para ello un análisis factorial de componentes principales $^{34}$ cuyos resultados se recogen en el Cuadro 5.10. En el mismo se observa que las principales preocupaciones de la población encuestada pueden agruparse en tres factores que en conjunto explican el $62,22 \%$ de la varianza: Factor 1) "Económico-laborales": las preocupaciones e incertidumbres relativas a los aspectos instrumentales y materiales como la de estar sin trabajo, su situación económica actual y futura, y la incertidumbre sobre la propia vida (30,28\% de la varianza explicada); Factor 2): “Amenazas para la salud y la vida”: las preocupaciones derivadas de las amenazas, concretas o abstractas, que puedan comprometer la salud y la vida, propia o de las personas próximas como la de ser víctima de un atraco, caer gravemente enfermo, la muerte de un ser querido, y la posibilidad de una crisis ecológica generalizada (20,34\% de la varianza explicada); Factor 3: "Religiosas y existenciales": las preocupaciones e incertidumbres personales en las cuestiones trascendentales como perder la fe o ir al infierno (11,60\% de la varianza explicada).

Resulta fácil colegir de estos datos que los individuos están tan pendientes de su quehacer cotidiano que apenas tienen tiempo para pensar en algo en lo que además no quieren pensar. No obstante, es necesario matizar que debajo de esa actitud en la que aparentemente a

\footnotetext{
${ }^{32}$ En el análisis realizado por Durán (2004:15-16) sobre el Estudio n ${ }^{\circ} 2244$ del CIS (1997) en el que se interrogaba a la población en general sobre una batería cerrada de potenciales preocupaciones entre los mayores, se comprueba que la "Muerte" no es una preocupación proyectada entre la población general (13,3\%), ni tampoco entre los más mayores (12\%). La "Enfermedad" es el segundo motivo más proyectado entre la población general como preocupación de la población anciana (38,1\%), lo que se certifica más intensamente entre la propia población anciana (45\%). Tanto entre la población general (76,9\%) como para los más mayores $(71,0 \%)$, la principal preocupación que inquieta a la población anciana es la "Soledad".

${ }^{33}$ Dado que los KMO (Kaiser-Meyer-Olkin) tienen un valor de 0,729, y que el test de Barlett tiene un valor de 1.002,342 y un grado de significación $\mathrm{p}=0,000$, resulta adecuado la aplicación del análisis factorial (Visauta, 1998:224-225).

${ }^{34}$ De acuerdo al "criterio de raíz latente", se han extraído los tres factores con autovalores iguales o mayores que 1 (Hair et al, 2000:92).
} 
los encuestados les preocupan más los problemas de la vida que los de la muerte, hay "indicios claros de una ambivalencia latente y subyacente" (Riley, 1979:174). En efecto, como puede apreciarse en el Cuadro 5.9., en la cima de las preocupaciones más importantes existe una inquietud, exógena a los individuos, a la que probablemente no se enfrenten de continuo, pero que recurrentemente les asalta: el temor, y por tanto el pensamiento, de la muerte de alguien muy próximo. Esta preocupación es, además, máxima en todas las categorías sociales: entre 8 y 9 de cada 10 encuestados.

\begin{tabular}{|l|c|c|c|}
\hline \multicolumn{3}{|c|}{ CUADRO 5.10.: PRINCIPALES PREOCUPACIONES } \\
\hline & \multicolumn{3}{|c|}{ Componente } \\
\cline { 2 - 4 } & 1 & 2 & 3 \\
\hline a.- Estar sin trabajo & $\mathbf{0 , 6 7 4}$ & 0,25 & $-0,267$ \\
\hline b.- Ser víctima de un atraco criminal & $-0,005$ & $\mathbf{0 , 7 1 3}$ & 0,308 \\
\hline c.- Ir al infierno & 0,007 & 0,131 & $\mathbf{0 , 8 1 5}$ \\
\hline d.- Su situación económica actual & $\mathbf{0 , 8 0 0}$ & 0,033 & 0,049 \\
\hline e.- Caer gravemente enfermo & 0,096 & $\mathbf{0 , 7 7 7}$ & 0,258 \\
\hline f.- Una crisis ecológica generalizada & 0,024 & $\mathbf{0 , 7 5 6}$ & $-0,187$ \\
\hline g.- La muerte de alguien muy próximo & 0,157 & $\mathbf{0 , 6 2 9}$ & 0,263 \\
\hline h.- La incertidumbre sobre su propia vida & $\mathbf{0 , 6 5 1}$ & 0,138 & 0,358 \\
\hline i.- Perder la fe & 0,013 & 0,227 & $\mathbf{0 , 7 9 6}$ \\
\hline j.- Su situación económica futura & $\mathbf{0 , 8 5 2}$ & 0,083 & 0,032 \\
\hline
\end{tabular}

a Matriz de componentes rotados. Método de extracción Análisis Factorial de Componentes Principales. Método de rotación Varimax con Kaiser. La rotación ha convergido en 4 iteraciones.

Fte: Encuesta 2000. Elaboración propia

Otros datos corroboran, en cierta medida, esa matización. En efecto, interrogados sobre las siguientes cuestiones “¿Cuándo se imagina usted que la gente piensa más sobre la muerte?” (pregunta 20) y “¿Cuándo ha pensado usted más sobre la muerte?” (pregunta 21), las respuestas aportadas son independientes del sexo de las personas encuestadas pero no de su edad, ya que se observan divergencias significativas en las mismas ligadas a su ubicación en las distintas fases del ciclo vital, Cuadro 5.11. Divergencias menores en lo relativo a la primera cuestión, en las que de fondo se aprecia una proyección que identifica vejez con muerte, probablemente por la proximidad entre ambas. Divergencias de más calado en las respuestas a la segunda cuestión, lógicas en algunos casos, por ejemplo en el de las personas jóvenes que, obviamente, sólo pueden responder a ese interrogante en la adolescencia y/o en la juventud, nunca en la edad adulta o en la vejez, pero que, sin embargo, reflejan que entre las adultas y las ancianas la realidad de la muerte no es una completa desconocida de sus pensamientos en el presente ni en el pasado. En el caso de estas últimas, su proximidad más inmediata a la muerte les hace buscar el significado de la misma, lo que impacta en todos los ámbitos de su vida diaria. Conciencia de 
finitud que, además de la edad, se construye por el estado de salud percibida y la supervivencia de los más próximos, y en especial de los coetáneos (Urraca, 1982:69), como se refleja de forma cristalina en el fragmento del grupo de discusión mostrado más arriba, y como es percibido por la joven no creyente entrevistada:

- "Y, sí, creo que es la gente mayor. Aparte ya tienen en menos cosas que pensar porque ya han hecho su vida y ya han hecho su familia, los que la hayan hecho, su carrera profesional... Entonces te quedan menos cosas en las que pensar, además que eso lo ves más cercano, es lógico. Aparte ya de los que tengan problemas de salud, que es ya una amenaza más firme todavía” (E2:5).

CUADRO 5.11.: ¿CUÁNDO SE IMAGINA USTED QUE LA GENTE PIENSA MÁS SOBRE LA MUERTE? (\%)

\begin{tabular}{|c|c|c|c|c|c|}
\hline & $\begin{array}{c}\text { EN LA } \\
\text { ADOLESCENCIA }\end{array}$ & $\begin{array}{c}\text { EN LA } \\
\text { JUVENTUD }\end{array}$ & $\begin{array}{l}\text { EN LA VIDA } \\
\text { ADULTA } \\
\end{array}$ & $\begin{array}{l}\text { EN LA } \\
\text { VEJEZ }\end{array}$ & SIEMPRE \\
\hline TOTAL & 1,2 & 0,2 & 11,6 & 78,6 & 8,3 \\
\hline HOMBRES & 0,0 & 0,0 & 12,0 & 80,2 & 7,8 \\
\hline MUJERES & 2,0 & 0,4 & 11,4 & 77,8 & 8,7 \\
\hline JÓVENES & 1,5 & 0,5 & 10,1 & 76,3 & 11,6 \\
\hline ADULTOS & 1,4 & - & 17,0 & 73,8 & 7,8 \\
\hline ANCIANOS & - & - & 6,1 & 92,7 & 1,2 \\
\hline \multicolumn{6}{|c|}{ ¿CUÁNDO HA PENSADO USTED MÁS EN LA MUERTE? (\%) } \\
\hline & $\begin{array}{c}\text { EN LA } \\
\text { ADOLESCENCIA }\end{array}$ & $\begin{array}{c}\text { EN LA } \\
\text { JUVENTUD }\end{array}$ & $\begin{array}{c}\text { EN LA VIDA } \\
\text { ADULTA }\end{array}$ & $\begin{array}{l}\text { EN LA } \\
\text { VEJEZ } \\
\end{array}$ & SIEMPRE \\
\hline TOTAL & 15,9 & 28,0 & 34,3 & 11,3 & 10,9 \\
\hline HOMBRES & 16,1 & 26,5 & 36,8 & 7,7 & 12,9 \\
\hline MUJERES & 15,7 & 28,9 & 32,6 & 13,6 & 9,1 \\
\hline JÓVENES & 28,9 & 56,7 & 4,4 & & 10,0 \\
\hline ADULTOS & 7,4 & 6,6 & 72,8 & 1,5 & 11,8 \\
\hline ANCIANOS & 1,2 & & 35,8 & 53,1 & 9,9 \\
\hline
\end{tabular}

Fte: Encuesta 2000. Elaboración propia

\subsubsection{HABLAR DE LA MUERTE}

“...hablar entre las mudas soledades, pedir prestada sobre la fe paciencia, y en lo que es temporal llamar eterno; creer sospechas y negar verdades, es lo que llama en el mundo ausencia; fuego en el alma, y en la vida infierno"

Lope de Vega

No resulta extraño, por tanto, que dado el bajo grado de reflexión sobre la muerte, la comunicación entre los individuos sobre este tema sea extraordinariamente limitada. Así, la proporción de personas encuestadas que hablan sobre la muerte (pregunta 17) con alguna asiduidad, menos del 15\%, es inferior a la de los que en algún momento piensan en ella, Cuadro 5.12. El no hablar de la muerte es otro síntoma de la negación de la misma. De hecho, con una 
lógica social imperante en la que se deniega la muerte, se considera de mal gusto, una "notoria impertinencia”, hablar a los demás sobre la muerte. Rechazo que se hace manifiesto en las entrevistas:

- “...yo creo que hablar de la muerte desilusiona, entonces no es decir todo el tiempo: vas a morir, morir por esto, por lo otro... yo creo que estamos en la vida para disfrutarla, no vas a estar pensando en que la vida se acaba. Sí es verdad que la vida se acaba pero que sea lo más tarde posible. Por eso no me gusta hablar de la muerte porque parece que se está recordando algo que espero me quede muy lejos" (E1:6).

- "No me gusta. A lo mejor si me hablaran de una manera que me ayudara a entenderlo mejor pues sí me gustaría, pero como de la manera que me han hablado hasta ahora no puedo buscarle una lógica, pues no me gusta hablar del tema" (E2:2).

- “... no es un tema de sobremesa, ni que hable con amigos... Porque no deja de ser un drama la muerte. Gusta más hablar de otros temas, no tan tristes” (E3:2).

No obstante, al igual que con el pensamiento sobre la muerte, se aprecian en esta actitud de silencio posiciones ambiguas y contradictorias. Si bien los individuos reconocen que no hablan habitualmente de la muerte, en distintos estudios se ha comprobado que tanto la población general, como sobre todo aquellos individuos que tienen más próximo el morir, las personas ancianas, agradecen profundamente el poder hablar sobre este tema (Wong et al, 1997; Ponce de León, 1997; Humphry y Wickett, 1989; Kubler-Ross, 1989; Kalish, 1974; Hinton, 1974) ${ }^{35}$. Esta aparente contradicción refleja que, en el fondo, la realidad social construida sobre la negación de la muerte constituye en buena medida una eficaz ficción que permite que en su conjunto la vida social no se paralice, pero que choca para cada individuo aislado, que vive su realidad concreta, con la certeza intelectual y emocional de la muerte de los demás. En este choque entre lo general y lo particular, entre lo heterónomo y lo autónomo, entre lo social y lo individual, se pueden quebrar las cadenas que ligan al individuo con la sociedad a través de las normas sociales interiorizadas y éste entonces manifiesta sus temores, preocupaciones, deseos, sobre la muerte. No obstante, como en otros aspectos relacionados con el morir y la muerte, esa ruptura sólo puede ser circunstancial y sobre todo ha de hacerse en privado. Corroborando lo señalado, en el Cuadro 5.12. se aprecia la existencia de diferencias significativas por edad entre la población encuestada a la hora de hablar sobre la muerte, de tal forma que son los ancianos los que con mayor frecuencia lo hacen, 1 de cada 3, frente a los adultos, 1 de cada 5, y los jóvenes, 1 de cada 10. Así, entre los componentes del grupo de discusión:

-“- Hay mucha gente a la que no le gusta hablar...

\footnotetext{
${ }^{35}$ En el estudio realizado por J. De Miguel (1995), a través de entrevistas en profundidad, comenta las grandes dificultades a las que se enfrentaron los entrevistadores para plantear cuestiones relativas a la muerte.
} 
- No les gusta, pero yo creo que el hablar no puede influir en tu vida normal, en tu vida cotidiana...

- Si lo pensáramos un poco para bien.

- ... yo que sé, pues como cuando hablas de otra cosa.

... - Bueno, pues igual que hablas de las vacas locas...

- Es un tema como otro cualquiera.

- Debería ser... pero yo a mí mujer no le puedo hablar de este tema.

- Ah, pues yo no tengo ningún problema.

- Ni yo a mi marido. Mi marido es blandurrio para esto. No puede. Como se muera un amigo...

- Para mí es un tema más... lo hablan mis hijas.

... - A mí no me importa hablar... como si tengo que hablar todos los días, porque yo pienso que, como me va a llegar, no sé cuándo (cuanto más lejos, mejor).

- Es que, yo creo que deberíamos pensar más en la muerte, porque no hay cosa que tengamos más segura que eso. Y todo el mundo lo rehúye” GD1:15).

Es posible, asimismo, como señala la mujer crédula entrevistada, que para evitar la desazón entre sus familiares los ancianos incluso hablen de la muerte en menor medida de lo que lo desearían:

- "La gente mayor lo ve más próximo. Pero de ahí a que lo hablen, no lo sé. Creo que lo piensan más pero lo interiorizan. Por ejemplo mi padre, y que a veces la ha tenido cerca, no habla de ello... Pero él ve que si no es un problema es otro. Pero a nosotros no nos lo dice" (E3:3).

Igualmente, se observan diferencias significativas por nivel de estudios, de tal forma que casi 9 de cada 10 personas con estudios universitarios habla poco o nada sobre la muerte, mientras que entre las personas con estudios básicos esa relación es de 7 sobre 10 . Por el contrario, la distribución de esta variable es independiente del género, y también de la religiosidad. 


\begin{tabular}{|l|c|c|c|c|c|}
\hline \multicolumn{6}{|c|}{ CUADRO 5.12.: FRECUENCIA CON QUE SE HABLA DE LA MUERTE (\%) } \\
\hline & CADA DÍA & $\begin{array}{c}\text { MUY A } \\
\text { MENUDO }\end{array}$ & A MENUDO & MUY POCO & NUNCA \\
\hline TOTAL & 0,5 & 4,0 & 13,8 & 72,2 & 9,5 \\
\hline HOMBRES & 0,6 & 3,0 & 12,6 & 74,3 & 9,6 \\
MUJERES & 0,4 & 4,7 & 14,6 & 70,9 & 9,4 \\
\hline JÓVENES & 0,5 & 2,5 & 8,6 & 79,3 & 9,1 \\
ADULTOS & 0,0 & 1,4 & 17,7 & 71,6 & 9,2 \\
ANCIANOS & 1,2 & 12,2 & 19,5 & 56,1 & 11,0 \\
\hline EST. BÁSICOS & 1,4 & 5,6 & 22,5 & 60,6 & 9,9 \\
EST. MEDIOS & 1,1 & 9,0 & 16,9 & 61,8 & 11,2 \\
EST. UNIVERS. & 0,0 & 1,9 & 10,3 & 78,9 & 8,8 \\
\hline CRÉDULOS & 0,7 & 4,0 & 17,2 & 65,6 & 12,6 \\
CREYENTES & 0,0 & 5,7 & 8,0 & 81,6 & 4,6 \\
NO CREYENTES & 0,0 & 3,5 & 11,8 & 78,8 & 5,9 \\
INCRÉDULOS & 1,6 & 1,6 & 12,7 & 71,4 & 12,7 \\
\hline
\end{tabular}

Fte: Encuesto 2000. Elaboración propia

El choque entre lo social y lo individual señalado arriba se pone de manifiesto al interrogar a la población encuestada sobre si la gente debería hablar más de la muerte, pregunta con la que emerge y se hace patente una manifiesta disonancia entre el deseo (pregunta 19) y la realidad. En efecto, contrastando los datos del Cuadro 5.12. con los del Cuadro 5.13., se aprecia una situación ambigua y contradictoria entre lo que se dice que se hace y la gran predisposición que se manifiesta a que la gente hable de la muerte, no sólo cuando ocurren acontecimientos extraordinarios (29\%), sino a que lo haga habitualmente con naturalidad (2 de cada 3). Opinión que, aparentemente, trasluce la frustración ante algo que se desea y no se hace, pero que también puede no ser más que una respuesta políticamente correcta ante una pregunta que, porque no compromete, permite ser respondida compensando la evidencia ya manifestada de que no se piensa ni se habla frecuentemente de algo tan esencial, y que tanto atemoriza, como es la muerte. Como se colige de la respuesta a esta cuestión por parte de la joven no creyente:

- "Yo no pienso que me moriré siendo vieja, lo que pienso es cómo me puede afectar la muerte ahora siendo joven y con las cosas que te quedan por hacer y te gustaría hacer. A largo plazo ya no es tanto una amenaza, es el fin de la vida, no puedes hacer otra cosa, es algo inevitable pero a una edad temprana lo ves de otra manera. Desde luego con la mayoría de la gente no es un tema del que se trate, a no ser con los muy amigos o cuando te toca una muerte de cerca de alguien joven sí que hablas del tema pero con frecuencia, no.” (E2:1).

De hecho, cuando al avanzar en el cuestionario se les interroga sobre si consideran que entre los planes a realizar en previsión de la muerte uno de ellos debería ser hablar de la propia 
muerte con otras personas (pregunta 33d), sólo un tercio de las personas encuestadas responden afirmativamente, mientras que el $40 \%$ rechazan tal posibilidad y un cuarto no saben a qué atenerse.

CUADRO 5.13.: ¿CREE USTED QUE LA GENTE DEBERÍA HABLAR DE LA MUERTE? (\%)

\begin{tabular}{|l|c|c|c|c|}
\hline & SÍ, MUCHO & $\begin{array}{c}\text { SÍ, CON } \\
\text { NATURALIDAD }\end{array}$ & $\begin{array}{c}\text { EN ALGUNA OCASIÓN } \\
\text { ESPECIAL }\end{array}$ & NUNCA \\
\hline TOTAL & 1,2 & 66,1 & 28,9 & 3,8 \\
\hline HOMBRES & 1,2 & 61,7 & 31,7 & 5,4 \\
MUJERES & 1,2 & 69,0 & 27,1 & 2,7 \\
\hline JÓVENES & 0,5 & 66,2 & 29,8 & 3,5 \\
ADULTOS & 1,4 & 73,0 & 24,1 & 1,4 \\
ANCIANOS & 2,4 & 54,2 & 34,9 & 8,4 \\
\hline
\end{tabular}

Fte: Encuesta 2000. Elaboración propia

A la hora de hablar de la muerte con otra persona (pregunta 18), a más de la mitad de la población encuestada le gustaría hacerlo con un/a amigo/a (51,7\%), a casi tres de cada 10 con un familiar (29,1\%), a casi 1 de cada 10 con un sacerdote (9,7\%), y a sólo el 2,2\% con un/a médico/a. Estos dos últimos datos, en especial el sorprendente último, son dos de los que mejor permiten visualizar la ambigüedad de la relación de la población encuestada con la muerte. Quizá por no estar o no haber estado próximos a ella, las personas encuestadas entienden esa conversación como un ejercicio intelectual sobre la muerte en abstracto, similar al que pueden desarrollar sobre cualquier otro tema con las personas que les son más próximas, a quienes también prefieren para ello. Probablemente, si la pregunta se hubiera referido al morir, y más concretamente, al morirse, el orden de preferencias tendría otra composición muy distinta. Cabe también la posibilidad de que el bajo aprecio mostrado por los/as médico/as, cuya imagen está ligada a la enfermedad y a la muerte, como contertulios para hablar de la muerte, no sea más que otra manifestación del Principio de Thomas: "si no se habla con los médicos, es que hay salud y la muerte está lejana”. No es el caso sin embargo del varón incrédulo entrevistado, para quien la muerte no es un tabú y siente curiosidad por ella, por lo que justifica la elección de su hipotético interlocutor relacionándole con la satisfacción de esa curiosidad:

- "Yo creo que nadie puede hablarme de la muerte, podría hablar con personas cercanas al hecho de que la gente muere, pues serían los médicos... En todo caso con un médico, que son los que más cerca están al hecho de que la gente se muera. Pero tampoco me podría decir mucho, él me podría hablar de los temas mecánicos que puedan afectar al hecho de que una persona se muera o no. Pero de la muerte es que no me puede hablar nadie" (E4:6). 


\subsubsection{EXPERIENCIA CON LA MUERTE}

"En las iglesias y en las clínicas vi columnas de luz y uñas de acero y resistí asido a las manos de mi madre

Ahora aparto crespones y cánulas hipodérmicas: busco las manos de mi madre en los armarios llenos de sombra”

A. Gamoneda

Se suele relacionar la a-reflexión y el silencio alrededor de la muerte con el hecho de que, a diferencia de épocas pretéritas, en la actualidad no se ve con proximidad física la muerte, no se "toca” el proceso de morir de los otros. No es el caso de la población encuestada, entre quienes el 90\% ha visto algún cadáver humano en algún momento de su vida (pregunta 31). Independientemente del género y de la religiosidad, la experiencia de ver un cadáver sí que está relacionada con la edad ya que, en términos generales, al aumentar ésta existen más probabilidades de ello y, además, por razones generacionales las personas de más edad tienen una socialización más tradicional y por tanto más pegada a la naturaleza. En sentido contrario, obviamente quienes menos experiencia tienen en este aspecto son los jóvenes, y a pesar de ello 8 de cada 10 han visto algún cadáver, Cuadro 5.14. En este cuadro se puede apreciar asimismo que un tercio de los encuestados han rechazado ver, en algún momento, el cadáver de un ser querido, en mayor medida las mujeres que los hombres y los jóvenes que los adultos y ancianos (pregunta 32). Rechazo que no se ve afectado por la religiosidad pero sí por el nivel de estudios que, por su vínculo con la edad, es menor entre las personas con estudios básicos que en las otras dos categorías de estudios. La razón principal aducida en tres de cada cuatro casos, y en todas las categorías sociales, es que se quería mantener el recuerdo de la persona fallecida como cuando estaba viva:

- "No me gusta, la verdad. No me gusta la costumbre de ponerles ahí de exposición me parece tétrico y desagradable. No me gusta" (E3:11).

- "No por el hecho de que me cree un trauma terrible el ver ese cadáver, sino que la consabida frase que se dice muchísimo: "Es que prefiero recordarle en vida". Sí, pero también por el hecho de que si puedo evitar una cosa que no tiene más trascendencia en el caso de un conocido, pues bueno, me da igual, no le veo" (E4:14). 


\begin{tabular}{|c|c|c|c|c|c|c|}
\hline \multicolumn{7}{|c|}{$\begin{array}{l}\text { CUADRO 5.14.: ¿HA VISTO USTED ALGÚN CADÁVER HUMANO? ¿HA RECHAZADO } \\
\text { USTED LA POSIBILIDAD DE VER EL CADÁVER DE ALGÚN SER QUERIDO?, ¿POR } \\
\text { QUÉ? (\%) }\end{array}$} \\
\hline & \multirow[b]{3}{*}{$\begin{array}{l}\text { HA VISTO } \\
\text { UN } \\
\text { CADÁVER }\end{array}$} & \multicolumn{5}{|c|}{ RECHAZAR VER CADÁVER } \\
\hline & & \multirow[b]{2}{*}{ Sí } & \multicolumn{4}{|c|}{ PORQUE } \\
\hline & & & $\begin{array}{c}\text { NO PODÍA } \\
\text { SOPORTARLO }\end{array}$ & $\begin{array}{l}\text { TENGO } \\
\text { MIEDO A } \\
\text { LA } \\
\text { MUERTE }\end{array}$ & $\begin{array}{l}\text { QUERÍA } \\
\text { MANTENER } \\
\text { EL } \\
\text { RECUERDO }\end{array}$ & OTRAS \\
\hline TOTAL & 90,0 & 32,5 & 11,1 & 5,2 & 74,8 & 8,9 \\
\hline HOMBRES & 90,9 & 25,3 & 14,3 & 2,4 & 73,8 & 9,5 \\
\hline MUJERES & 89,5 & 37,3 & 9,7 & 5,2 & 74,8 & 8,9 \\
\hline JÓVENES & 79,7 & 39,6 & 9,3 & 4,0 & 72,0 & 14,7 \\
\hline ADULTOS & 98,6 & 27,0 & 7,7 & 7,7 & 82,1 & 2,6 \\
\hline ANCIANOS & 100,0 & 25,3 & 23,6 & 5,2 & 74,8 & \\
\hline EST. BÁSICOS & 100,0 & 22,2 & 6,3 & 6,3 & 87,5 & \\
\hline EST. MEDIOS & 93,1 & 36,4 & 12,9 & 3,2 & 71,0 & 12,9 \\
\hline EST. UNIVERS. & 86,3 & 34,1 & 11,4 & 5,7 & 73,9 & 9,1 \\
\hline CRÉDULOS & 89,4 & 33,3 & 8,0 & 6,0 & 76,0 & 10,0 \\
\hline CREYENTES & 87,3 & 22,6 & 9,7 & 0,0 & 87,1 & 3,2 \\
\hline NO CREYENTES & 94,3 & 35,6 & 20,7 & 3,4 & 62,1 & 13,8 \\
\hline INCRÉDULOS & 89,3 & 36,5 & 13,3 & 13,3 & 60,0 & 13,3 \\
\hline
\end{tabular}

Fte: Encuesta 2000.Elaboración propia

El 36,5\% de la población encuestada vio por primera vez un cadáver en la infancia, el 32,7\% en la adolescencia, y el 30,8\% cuando ya habían cumplido 18 años (pregunta 31a). Es decir, para casi 7 de cada 10 encuestados la experiencia de ver por primera vez un cadáver fue temprana. Cadáver que muy mayoritariamente correspondía a un familiar, el 72,6\%, al que se vio en una capilla ardiente en casa, el 64,3\%, y en menor medida en un tanatorio, el 23,3\% (preguntas 31b y c). La reacción declarada ante esa visión es mayoritariamente de sentir pena, el 46,6\%, sobre todo entre las mujeres y los más mayores, mientras que una de cada cinco personas encuestadas lo afrontó con tranquilidad y otro quinto declara que sintió miedo (pregunta 31d).

En consecuencia, la falta de reflexión y el mutismo sobre la muerte de la población encuestada no se puede atribuir a la inexistencia de algún tipo de experiencia con la muerte que haya cortocircuitado y enmudecido a los individuos. Tampoco se puede aducir una parálisis ligada a un miedo incontenible a la misma; esa circunstancia como mucho la alegan un 5\% de los que rechazaron ver un cadáver. Parece, de nuevo, que es el apego a la vida (mantener vivo el recuerdo, sentir pena) lo que subyace en el desapego hacia la muerte. 


\title{
5.3.4. SABER DE LA MUERTE
}

\author{
"Cada vez que considero \\ que me tengo que morir, \\ tiendo la capa en el suelo \\ y no me harto de dormir" \\ Copla popular
}

En efecto, la muerte actúa como un límite a la experiencia vital, que es lo único realmente real para los individuos. Los individuos saben que existe esa frontera y que en algún momento tendrán que traspasarla. Mientras tanto, y al contrario que en la copla popular, deciden seguir su vida sin pensar en ella, o más exactamente, sin dejarse mediatizar por un conocimiento radical que la condicione. Siete de cada diez encuestados manifiestan su acuerdo (bastante + mucho) con que el saberse mortal no le afecta en su conducta diaria (pregunta 73n), Cuadro 5.15. Sólo se observan diferencias significativas en la distribución por edad en la que los jóvenes, porque tienen su vida por hacer y ven la muerte lejana, y los ancianos, por lo contrario, son los que más de acuerdo están con esa idea, mientras que, por el contrario, un cuarto de los adultos admite que el saberse mortales les afecta en su vida cotidiana. La joven no creyente entrevistada, por ejemplo, afirma no sentirse condicionada por el saberse mortal, aunque implícitamente lo está:

- "Sí que estoy de acuerdo, porque como es algo que está presente siempre, no es algo de lo que me haya enterado ahora de que me vaya a morir, siempre he actuado de la misma manera, a lo mejor si supiera que no me iba a morir no me tomaría las cosas, me las tomaría con más calma, las haría más despacio, y no estaría preocupada por hacer las cosas rápido porque se me acaba el tiempo" (E2:23).

Esta actitud de obviar, mientras sea posible, la muerte llega hasta el punto de que prácticamente la totalidad de las personas encuestadas no quieren conocer la fecha en la que van a morir (pregunta 69), Cuadro 5.15. Quizá porque la muerte deja de ser una extraña a partir de cierta edad, parece observarse de nuevo una cierta influencia del ciclo vital de tal forma que, a medida que se avanza en el mismo, se vive más con ella y preocupa menos conocer la fecha de su llegada. No obstante, esa querencia por saber la fecha del propio fallecimiento también es minoritaria entre las personas ancianas. 


\section{CUADRO 5.15.: GRADO DE ACUERDO/DESACUERDO CON LA IDEA: “TENER LA SEGURIDAD DE QUE MORIRÉ NO AFECTA A MI CONDUCTA EN LA VIDA”. ¿DESEARÍA CONOCER LA FECHA EN QUE VA A MORIR? (\%)}

\begin{tabular}{|c|c|c|c|c|c|}
\hline & \multicolumn{3}{|c|}{$\begin{array}{l}\text { SEGURIDAD MORIR/ } \\
\text { CONDUCTA VIDA }\end{array}$} & \multicolumn{2}{|c|}{$\begin{array}{c}\text { CONOCER FECHA DE } \\
\text { MORIR }\end{array}$} \\
\hline & ACUERDO & INDIFERENTE & DESACUER. & SÍ & NO \\
\hline TOTAL & 70,9 & 10,3 & 12,8 & 6,7 & 93,3 \\
\hline HOMBRES & 72,7 & 10,3 & 17,0 & 8,4 & 91,6 \\
\hline MUJERES & 69,8 & 10,4 & 19,9 & 5,6 & 94,4 \\
\hline JÓVENES & 74,1 & 9,1 & 16,7 & 4,1 & 95,9 \\
\hline ADULTOS & 62,6 & 11,5 & 25,9 & 6,5 & 93,5 \\
\hline ANCIANOS & 78,6 & 11,4 & 10,0 & 13,1 & 86,9 \\
\hline EST. BÁSICOS & 78,4 & 13,3 & 8,4 & 9,4 & 90,6 \\
\hline EST. MEDIOS & 69,8 & 11,6 & 18,7 & 4,4 & 95,6 \\
\hline EST. UNIVERS. & 69,6 & 9,2 & 21,2 & 6,8 & 93,2 \\
\hline CRÉDULOS & 69,6 & 9,5 & 21,0 & 7,5 & 92,5 \\
\hline CREYENTES & 72,2 & 11,5 & 16,1 & 8,2 & 91,8 \\
\hline NO CREYENTES & 64,7 & 12,9 & 22,4 & 4,8 & 95,2 \\
\hline INCRÉDULOS & 76,2 & 6,3 & 17,4 & 7,9 & 92,1 \\
\hline
\end{tabular}

Fte: Encuesta 2000. Elaboración propia

En general, por tanto, tener la seguridad de que se va a morir en un futuro indeterminado no afecta a la conducta diaria de la gente que, además, prefiere que su vida siga funcionado así, como si no existiera el límite temporal que marca la muerte. Esa homogeneidad manifestada sobre la conducta de la gente sin embargo se altera cuando ese límite se vislumbra a corto plazo, a seis meses vista (pregunta 29), y el principio de realidad, anteriormente mencionado, pierde su capacidad social conformadora. Aún dentro de ciertos límites, se observa la emergencia de actitudes individuales “des-socializadas” como manifestación de que, cuando ya no es el propio individuo el que rompe las cadenas que le unen al grupo sino que éstas se rompen al margen de la propia voluntad por un imponderable externo, el individuo percibiría su soledad ante lo inevitable y que los “otros” no podrían hacer nada por él, con lo que se expresa de forma más autónoma buscando lo que considera esencial en el plano ya sólo personal. Así, en los casos de las personas entrevistadas:

- "En principio me sentiría muy mal pero trataría de aprovechar los días que me quedaran, si de verdad es así por cualquier motivo como una enfermedad, pues si pudiera aprovechar los seis meses de vida pues intentaría pasar el mayor tiempo posible con la gente que quiero y aprovechar para hacer un montón de cosas que hasta ahora no he tenido esa urgencia en hacer; intentar visitar un montón de países... Desde luego trabajar no, no tendría tiempo para trabajar” (E1:7). 
- "Si me quedaran seis meses de vida con el ánimo que tengo ahora, haría muchas cosas, pero claro si me lo dijeran cambiaría totalmente y no tendría el mismo ánimo que tengo ahora. Pero si no conociera la fecha no podría aprovechar esos seis meses que me quedan. Eso es un dilema así que me lo he planteado muchas veces, es bastante difícil. Yo creo que trataría de sobreponerme y aprovechar lo que me queda... Como lo que más me gusta es viajar, viajaría a todos los sitios y estar con la gente que más quiero, sobre todo eso" (E2:14).

Aflora de esta forma un abanico de conductas que comprende desde las de los que no harían cambios en sus vidas, uno de cada cinco, hasta las de los que se encuentran perplejos sin saber qué hacer, uno de cada tres. Mientras, el 30\% apuraría la copa de la vida todo lo que pudiera y poco más de uno de cada diez orientaría existencialmente la última etapa de su vida, Cuadro 5.16. No obstante, este catálogo de conductas está influido por el ciclo vital, de tal forma que las mismas no se reflejarían con igual intensidad en los diferentes grupos de edad. Más de la mitad de los jóvenes trataría de exprimir la vida que les quedase y un tercio estaría desorientado sin un rumbo por el que decidirse, mientras que los ancianos son los menos indecisos, un tercio de ellos seguiría su vida y otro tercio se prepararía para morir; la mayoría de los adultos se mueven entre la indecisión (40\%) y la continuidad (30\%). Como el varón entrevistado:

- "En este momento no lo sé pero no creo que hiciera grandes cosas. Por supuesto dedicar más tiempo a estar, en la medida de lo posible, con mi familia. Y siempre que te hablo de mi familia te estoy hablando de mi mujer y mis dos hijas, que es mi familia cercana. Y luego intentar hacer cosas que me gustan hacer y que están dentro de mis posibilidades hacerlas y si no, pues nada más. Así, nada más” (E4:13).

Por su parte, otra variable que incide claramente en las respuestas que se darían en la hipotética situación del morirse a corto plazo es la religiosidad. Y no tanto en lo que se refiere a la parálisis que generaría, entre un 30 y un $40 \%$ de indecisos en las distintas categorías religiosas, como sobre todo en la indiferencia por la búsqueda de placebos existenciales por parte de los no creyentes e incrédulos, y las marcadas actitudes de éstos por apurar la vida, no hartándose de dormir, sino, al contrario, haciendo honor a otra expresión popular: “iQue me quiten lo bailao!”. Como manifiesta el adulto entrevistado:

- "El sentido de la vida es tratar de obtener lo mejor de ella, desde luego. Por supuestísimo. Yo estoy convencido de que hay que vivir lo mejor que se pueda, y lo demás son historias, porque voy a vivir una vez, nada más. Entonces, eso lo tengo muy claro" (E4:7). 
CUADRO 5.16.: ¿QUÉ HARÍA SI SUPIERA QUE LE QUEDAN SEIS MESES DE VIDA? (\%)

\begin{tabular}{|l|c|c|c|c|}
\hline & $\begin{array}{c}\text { ME } \\
\text { PREPARARÍA } \\
\text { PARA MORIR }\end{array}$ & $\begin{array}{c}\text { TRATARÍA DE } \\
\text { EXPERIMENTAR } \\
\text { TODO LO QUE } \\
\text { PUDIERA }\end{array}$ & $\begin{array}{c}\text { NO HARÍA } \\
\text { CAMBIOS EN MI } \\
\text { VIDA }\end{array}$ & NO SABE \\
\hline TOTAL & 12,5 & 30,9 & 22,8 & 33,8 \\
\hline HOMBRES & 12,7 & 25,5 & 25,5 & 36,4 \\
MUJERES & 12,3 & 34,5 & 21,0 & 32,1 \\
\hline JÓVENES & 2,6 & 51,0 & 12,8 & 33,7 \\
ADULTOS & 15,0 & 14,3 & 30,7 & 40,0 \\
ANCIANOS & 32,1 & 11,1 & 33,3 & 23,5 \\
\hline EST. BÁSICOS & 27,1 & 15,7 & 28,6 & 28,6 \\
EST. MEDIOS & 17,2 & 24,1 & 23,0 & 35,6 \\
EST. UNIVERS. & 6,9 & 37,3 & 21,2 & 34,6 \\
\hline CRÉDULOS & 18,9 & 25,0 & 27,0 & 29,1 \\
CREYENTES & 9,2 & 32,2 & 18,4 & 40,2 \\
NO CREYENTES & 4,7 & 40,0 & 15,3 & 40,0 \\
INCRÉDULOS & 1,6 & 44,4 & 22,2 & 31,7 \\
\hline
\end{tabular}

Fte: Encuesta 2000. Elaboración propia

Estas actitudes ante la muerte propia, marcadas en gran medida por la indecisión, se reflejan especularmente en las opiniones contradictorias que la población encuestada tiene sobre la vida en abstracto y el vivir concreto. En efecto, interrogada sobre el grado de acuerdo con que la vida es sagrada, un derecho irrenunciable (pregunta 22d), el 70,3\% se muestra muy o bastante de acuerdo con esa afirmación, mientras que el 17,7\% se declara poco o nada de acuerdo con ella. Afirmación que es asumida en mayor medida al ascender en la distribución de edad, el 93,3\% de los ancianos están de acuerdo, o entre los que tienen estudios básicos, el 91,4\%, además de entre los que se declaran religiosos, por ejemplo entre el $83 \%$ de los crédulos. Sin embargo, e independientemente de cuál sea la variable de control elegida, para la práctica totalidad de las personas encuestadas, el 96\%, no es tan importante vivir muchos años, como que los que se vivan sean de calidad (pregunta 28). Es decir, en la práctica, a la hora de vivir la vida, ésta pierde su sacralidad, no es ya un absoluto, y tampoco es forzoso vivirla por tenerla, cabe decidir sobre ella, sobre su calidad. Este dato tiene gran trascendencia sociológica, y sobre todo política, por cuanto no sólo corrobora la hipótesis funcional señalada arriba (adecuación al principio de realidad), y que es exógena a los individuos, sino que en éstos se puede identificar larvada una actitud endógena proclive a dicha hipótesis. Es decir, no es tanto que el principio de realidad se imponga desde fuera a unos individuos, inermes, inertes y pasivos, cuanto que sean 
los propios individuos los que colaboren activamente en la construcción y asentamiento del mismo, incluso radicalizando su trascendencia: se complementa el `no pensar en la muerte para poder vivir' con el 'no se trata de vivir por vivir'. Esta actitud se muestra diáfana, como se resalta más adelante, al constatar que la mayoría de las personas encuestadas consideran que existen situaciones ligadas a la vida peores que la propia muerte, lo que para muchas de ellas justificaría la aplicación de la eutanasia. Así pues, independientemente del género, de la edad y también de la religiosidad, de estos datos se colige que las personas encuestadas no valoran la vida en sí misma como un absoluto, sino que lo que la gente valora realmente es que esa vida sea de calidad. Enmienda mayoritaria a la sacralidad de la vida, con algunos matices dentro del grupo de discusión:

- "Mejorar la calidad de vida, sí, en cuanto a buscar solución o remedio a enfermedades mortales o enfermedades degenerativas. Pero lo de alargar la vida así porque así... cuando pienso en eso me acuerdo en estos viejos que parecen momias y me da un poco de mal rollo. No me atrae mucho eso, a lo mejor cuando tenga setenta años diré: "sí, sí". Pero ahora mismo lo de la conservación de la vida, no, a pesar de que te estoy diciendo que no me quiero morir" (E2:12).

- "Yo quiero vivir un número determinado de años en buenas condiciones. Si me dicen: vas a vivir diez años más pero ya vas a estar fastidiadito, pues mira, no hijo, yo quiero vivir bien y en el momento en que deje de vivir bien ya no quiero estar aquí. Eso lo tengo claro" (E4:12).

- “- Yo para mí calidad de vida.

- Calidad de vida.

- Calidades

- Eso no se duda.

- Muchas veces hemos dicho que tendríamos que vivir bien hasta el momento que te canses y después cortar. Todo el mundo tener una buena muerte y no dar guerra a nadie, eso es lo que pedimos

...- Para vivir cien años mal mejor vivir ochenta.

- Pero ; coño; a la vida se agarra todo el mundo cuando hay cierta calidad de vida. Hay personas que cuando llegan a la hora de la muerte, por ejemplo nosotros estamos hablando tranquilamente ahora de la muerte, pero hay personas que cuando llega esa hora se agarran a la vida, se aferran, que por todos los medios que les hagan tal o cual...Y, sí, cuando nos llegue no sabemos lo que vamos a hacer, desde luego" (GD1:21). 
CUADRO 5.17.: ELECCIÓN ENTRE CALIDAD DE VIDA Y CANTIDAD DE VIDA (\%)

\begin{tabular}{|l|c|c|}
\hline & CALIDAD DE VIDA & CANTIDAD DE VIDA \\
\hline TOTAL & 95,8 & 4,2 \\
\hline HOMBRES & 93,7 & 6,3 \\
MUJERES & 97,2 & 2,8 \\
\hline JÓVENES & 96,4 & 3,6 \\
ADULTOS & 95,7 & 4,3 \\
ANCIANOS & 94,4 & 5,6 \\
\hline EST. BÁSICOS & 92,2 & 7,8 \\
EST. MEDIOS & 98,8 & 1,2 \\
EST. UNIVERS. & 95,8 & 4,2 \\
\hline CRÉDULOS & 98,0 & 2,0 \\
CREYENTES & 92,6 & 7,1 \\
NO CREYENTES & 96,4 & 3,6 \\
INCRÉDULOS & 96,7 & 3,3 \\
\hline
\end{tabular}

Fte: Encuesta 2000. Elaboración propia

\subsection{PLANES DE VIDA EN RELACIÓN A LA MUERTE}

"El feto González. Sus padres no le olvidan" Inscripción en un nicho del cementerio de Vallehermoso (Madrid)

Las actitudes mostradas en el apartado anterior pueden inducir comportamientos concretos por parte de los individuos a la hora de enfrentarse a la muerte. Por ejemplo, que anticipen y hagan planes en previsión de que la muerte les alcance. La predisposición a desarrollar o no estos comportamientos, y el llevarlos a la práctica, pueden ser consideradas como otra dimensión más en la que se aprecie el grado de renuencia a interactuar con la muerte. Aporta, además, información valiosa sobre la organización del “viaje” hacia la misma y el sistema de “autoridad” deseado (Walter, 1994: Cap4). En principio, la mayoría de la población encuestada no se muestra esquiva a tratar con la muerte y manifiesta su predisposición a la gestión de algunas medidas preventivas ante su contingencia (pregunta 33), Cuadro 5.18. Mayoritariamente se considera necesario hacer testamento, 86\%, hacerse donante de órganos para trasplante, 77\%, y rellenar un testamento vital, 55,7\%. En menor medida (menos de la mitad de la muestra) se suscriben la necesidad de hacerse un seguro de vida, 47,2\%, y hacerse donante de órganos para investigación, 43,8\%. Hay que resaltar además que en algunos de esos planes preparatorios ante la propia muerte el porcentaje de indecisos es muy elevado. En efecto, 
más de 3 de cada 10 personas encuestadas no saben si deberían hacerse o no donantes de órganos para investigación, 31,6\%, o hacer un testamento vital, 30,2; por otra parte, más de un cuarto de ellas no sabe si debería hacerse un seguro de vida, 26,3\%, y; el 15,8\%, no sabe si debería hacerse donante de órganos para trasplante.

$\mathrm{Si}$, por razones históricas, el hacer testamento es un comportamiento que se inserta en los tres modelos de muerte -tradicional, moderno y neomoderno-, identificados por Walter (1994), el resto de las medidas preparatorias sólo pueden corresponder a los dos últimos modelos. Así, de los datos relativos a los planes para hacer frente a la muerte se puede afirmar que la población encuestada se sitúa en el modelo moderno con ligeros indicios de inicio de tránsito hacia el modelo neo-moderno. El primero se infiere de la gran confianza mostrada en la racionalidad de la organización social de la muerte que garantiza seguridad económica (testamento, seguro de vida) y tecnológica (trasplantes). El segundo, el reconocimiento de la individualidad como valor fundamental y, por tanto, del Yo, el self, como máxima autoridad en la etapa final de la vida se vislumbra a través de la aceptación del testamento vital. Éste es un documento en el que la persona que lo firma declara de forma explícita cómo desea ser tratada en las etapas finales de su vida y sobre todo renuncia a ser objeto de tratamientos médicos que prolonguen su vida innecesariamente, es decir, es un "reconocimiento de que la calidad de muerte es un derecho humano del que nadie debería despojar a otro, y que la muerte debería de ser tan humana y buena como la propia vida” (Durán 2004:29). No obstante, resulta más esclarecedora de la situación real de tránsito entre modelos de muerte el resultado paradójico, si se tiene en cuenta la resaltada posición favorable al testamento vital, el que la población encuestada se reparta entre los que son y no son partidarios de que los individuos arreglen las disposiciones necesarias respecto al propio funeral y entierro, es decir, de que piloten su último (propio) viaje. La ligera mayoría de no partidarios, además del 19,9\% de indecisos sobre este particular, es indicativa de que el “yo hice mi camino”, aspecto básico del modelo neo-moderno de muerte, no está consolidado en toda su amplitud ni siquiera en el ámbito de las creencias. 
CUADRO 5.18.: ¿CREE USTED QUE TODA PERSONA DEBERÍA HACER COMO PREVISIÓN A LA MUERTE...? (\%)

\begin{tabular}{|c|c|c|c|c|c|c|}
\hline & \multicolumn{2}{|c|}{ TESTAMENTO } & \multicolumn{2}{|c|}{ SEGURO DE VIDA } & \multicolumn{2}{|c|}{$\begin{array}{l}\text { DISPONER EL PROPIO } \\
\text { FUNERAL Y ENTIERRO } \\
\end{array}$} \\
\hline & Sí & NO & SÍ & NO & SÍ & NO \\
\hline TOTAL & 86,0 & 5,4 & 47,2 & 26,5 & 38,2 & 41,9 \\
\hline HOMBRES & 86,3 & 5,6 & 51,6 & 23,2 & 36,4 & 41,6 \\
\hline MUJERES & 85,8 & 5,3 & 44,2 & 28,8 & 39,5 & 42,1 \\
\hline JÓVENES & 81,7 & 7,6 & 43,9 & 25,5 & 32,8 & 45,6 \\
\hline ADULTOS & 86,7 & 3,7 & 50,0 & 28,5 & 36,9 & 43,1 \\
\hline ANCIANOS & 96,1 & 2,6 & 51,6 & 25,8 & 58,1 & 27,4 \\
\hline EST. BÁSICOS & 95,5 & 3,0 & 36,2 & 37,9 & 52,5 & 30,5 \\
\hline EST. MEDIOS & 91,6 & 3,6 & 59,7 & 26,0 & 36,4 & 53,2 \\
\hline EST. UNIVERS. & 81,9 & 6,6 & 45,8 & 24,1 & 35,5 & 41,0 \\
\hline CRÉDULOS & 87,2 & 6 & 47,5 & 31,9 & 39,3 & 42,9 \\
\hline CREYENTES & 88,4 & 2,3 & 56,4 & 29,1 & 36,0 & 37,2 \\
\hline NO CREYENTES & 84,3 & 4,8 & 49,4 & 18,1 & 39,8 & 43,4 \\
\hline \multirow[t]{3}{*}{ INCRÉDULOS } & 80,0 & 8,3 & 47,5 & 18,0 & 39,3 & 42,6 \\
\hline & \multicolumn{2}{|c|}{$\begin{array}{c}\text { DONAR ÓRGANOS } \\
\text { PARA } \\
\text { TRASPLANTES }\end{array}$} & \multicolumn{2}{|c|}{$\begin{array}{c}\text { DONAR ÓRGANOS } \\
\text { PARA } \\
\text { INVESTIGACIÓN }\end{array}$} & \multicolumn{2}{|c|}{ TESTAMENTO VITAL } \\
\hline & Sí & NO & SÍ & NO & Sí & NO \\
\hline TOTAL & 77,0 & 7,1 & 43,8 & 24,6 & 55,7 & 14,1 \\
\hline HOMBRES & 76,8 & 6,5 & 51,9 & 21,4 & 56,0 & 10,7 \\
\hline MUJERES & 77,2 & 7,6 & 38,4 & 26,7 & 55,5 & 16,4 \\
\hline JÓVENES & 82,6 & 4,1 & 47,4 & 21,6 & 57,7 & 12,4 \\
\hline ADULTOS & 75,8 & 8,3 & 42,3 & 23,8 & 54,4 & 16,9 \\
\hline ANCIANOS & 63,1 & 13,8 & 35,5 & 35,5 & 52,2 & 13,4 \\
\hline EST. BÁSICOS & 66,7 & 10,0 & 32,8 & 37,9 & 41,7 & 25,0 \\
\hline EST. MEDIOS & 78,5 & 6,3 & 45,0 & 21,3 & 58,8 & 8,2 \\
\hline EST. UNIVERS. & 79,1 & 6,7 & 46,0 & 22,6 & 57,9 & 13,5 \\
\hline CRÉDULOS & 74,6 & 10,6 & 39,9 & 27,5 & 53,1 & 18,9 \\
\hline CREYENTES & 79,1 & 4,7 & 37,2 & 29,1 & 48,8 & 14,0 \\
\hline NO CREYENTES & 73,5 & 3,6 & 46,3 & 17,1 & 56,5 & 9,4 \\
\hline INCRÉDULOS & 82,3 & 8,1 & 62,3 & 19,7 & 70,5 & 9,8 \\
\hline
\end{tabular}

Fte: Encuesta 2000. Elaboración propia

Obviamente, la deseabilidad de hacer estos planes no se distribuye de forma homogénea en la población, detectándose diferencias significativas entre las distintas categorías sociales. Así, aunque las distribuciones de todos los planes sobre los que se ha interrogado son independientes del género, se observa una mayor predisposición, no estadísticamente significativa, entre los hombres a la hora de suscribir un seguro de vida o de donar órganos para investigación. En la distribución por nivel de estudios son significativas las diferencias observadas a la hora de hacer testamento y de disponer del propio funeral (más partidarios entre los de estudios básicos), así como de hacerse un seguro de vida y un testamento vital (mayor 
proporción entre los de estudios medios). El nivel de religiosidad sólo incide en la opción de donar órganos para investigación, mayoritariamente suscrita por las personas incrédulas, 6 de cada 10, mientras que no se contempla por una mayoría de población crédula, casi 4 de cada 10, a la par que más de 3 de cada 10 personas de esta categoría se muestran indecisas ante esa tesitura. Por otra parte, puede observarse que en todos los planes existe una relación directa o inversa con el ciclo vital, algunas de las cuales son además muy relevantes desde el punto de vista sociológico. Así, los jóvenes, quienes ven alejada su muerte, son los menos partidarios de hacer testamento, disponer del propio entierro y funeral y hacerse un seguro; por contra, son los más predispuestos para donar órganos y hacer testamento vital. Los ancianos, que ven más próxima la muerte, y que por razones generacionales tienen mayor poso de valores tradicionales, son por ello los más partidarios de los planes que permitan dejar "atados los cabos” de la realidad concreta en que viven. Análisis que se corrobora en las entrevistas realizadas:

Testamento:

- "Bueno, lo de hacer el testamento a cierta edad yo creo que es una cosa útil. Es un instrumento de cierta utilidad para los herederos y para la familia. Yo creo que es una cosa bastante útil porque debe evitar bastantes problemas" (E1:10).

- "A: Testamento creo que sí, porque con las disputas que hay luego al respecto sí que...

E: Y eso ¿̇a qué edad?

A- Pues eso llegando a jubilarte o llegando a ser bastante mayor. Creo que sí pero llegando a una edad avanzada. Conozco a gente con cuarenta años ya hace el testamento, pero yo en mi caso no creo que preocupase eso a esa edad y que tampoco tuviera mucho que dejar a lo mejor" (E2:14).

- "El testamento no me lo planteo ahora mismo. Creo que sí hay que hacerlo porque luego vienen las disputas familiares, acaba todo el mundo tirándose los trastos a la cabeza y eso lo he visto cantidad de veces" (E3:12).

- "Hombre, hacer testamento es que es volviendo a lo mismo, si tienes una situación familiar y que tienes cierto apego a tus familiares y a tus descendientes pues es ilógico y ridículo no hacerlo" (E4:14).

Seguro de vida:

- “... me parece un producto financiero, una cosa más para venderte y agarrándose a los sentimientos más primarios. Yo ahora mismo el problema no me lo planteo, si tuviera hijos y dijera: "anda, que si me muero y les dejo aquí sin un duro", pues a lo mejor sí me lo hacía pero ahora mismo nunca se me había ocurrido, así como testamento pues sí, sabes que piensas hacer testamento a ver a quién dejo pero en un seguro de vida no había pensado nunca” (E2:15).

Arreglar las disposiciones respecto al propio funeral y entierro:

- “... no sé, depende de las circunstancias, si vas a morir o eres ya muy mayor, pues sí, bueno. Pero la propia persona en la juventud yo creo que no tiene... yo esto lo veo muy tétrico. No veo que una persona joven hiciera algo de esto...No sé, 
pero yo esto del funeral y entierro yo creo que son las personas que se dejan las que se deben de encargar. Es que encargarse la misma persona, aunque sí es verdad que puede ser mayor o se ve sola y sí tiene que encargarse de su entierro, pero lo veo algo muy triste” (E1:10).

- "Bueno, para la gente que es importante ese acontecimiento pues sí; la boda, el bautizo... La muerte es otro acontecimiento más y aunque la gente no esté presente ni conscientemente allí pues sí que le gustaría que se celebrase en determinadas condiciones. Pero hoy por hoy no me preocupa, vamos, que una vez muerta ya me da igual lo que hagan conmigo, o quien venga" (E2:15).

Donación de órganos para trasplantes:

- "Hacerse donante de órganos para transplantes, esto es una cosa que veo interesante y hasta un cierto punto yo mismo me lo he planteado, no muy seriamente, pero cuando ves que hay gente que dona sus órganos... Pero tengo consciencia que es muy lamentable para los familiares y para la gente que dejas, saber que te haces tú donante vale, pero la familia tiene que aceptar los inconvenientes y los trastornos que eso conlleva. Pero, vamos, es el acto más generoso que puede hacer una persona” (E1:10).

- “... sí que me parece importante, a mí sí que me gustaría hacerlo, vamos, y está en mis manos ahora mismo y es una cosa que sí que te gustaría hacerlo, luego por dejadez o porque tienes otras cosas más importantes en qué pensar no lo haces, pero sí que me parece una buena acción y si puedes ayudar a otra gente, pues fenomenal” (E2:16).

Donación de órganos para investigación:

- "Hacerse donante para investigación también es interesante, pero menos, porque la investigación puede tener resultados pero no se sabe. El donante sabe que le puede salvar la vida, que puedes ayudar a otra persona" (E1:10).

- “... es un poco más morboso, eso de que te estén ahí, diseccionando (risas), pero, bueno, tampoco.., no sé, prefiero donarlos para ayudar a otras personas que no que estén ahí.., haciendo experimentos” (E2:16).

Testamento vital:

- “... sí, pero yo sólo en el caso de que me viera en esa situación, pues eso, de que me diagnosticaran una enfermedad, no sé, de que dijeran que tengo un principio de Alzheimer o..., igual sí que diría... a mí me parece que es un tema que si no te afecta de cerca, no me parece que sea conveniente, porque luego además cambian mucho las opiniones, porque lo que piensas ahora luego, estás en el caso, y ya no piensas lo mismo y dices "pues, mira, si llego a tal situación quiero... que me pongáis ahí retirado del mundo”, y luego llega el momento y a lo mejor eres más feliz, aunque no estés consciente, o no tengas tus facultades" (E2:16).

Dado que en muchos ámbitos no existe una relación directa causa-efecto entre creencias y conductas las primeras pueden no ser predictoras de las segundas. De hecho, al ser fruto de procesos externos (valores sociales básicos) y factores situacionales (normas, costumbres, etc.), pueden en muchas ocasiones no constituir estímulos con la suficiente fuerza como para lograr la motivación interna que mueva a la actuación. Quizá por ello, la información recogida en el Cuadro 5.19. muestra la existencia de una disonancia entre creencias y comportamientos frente 
a la muerte en la gestión de las medidas preparatorias de ésta. Se comprueba que, de hecho, no existe una actuación anticipatoria de la muerte tan extendida como la que los datos sobre la predisposición a hacer planes sobre la misma parecían prever. En efecto, si el 86\% de las personas encuestadas creía necesario hacer testamento, sólo un cuarto de ellas lo tiene hecho (pregunta 34). Si el 47\% creía necesario hacerse un seguro de vida, sólo un $17 \%$ lo ha suscrito (pregunta 35). Y lo que es más significativo, algo más de un tercio de la población encuestada no ha pensado hacer testamento y un $63 \%$ no ha pensado suscribir un seguro de vida.

Las diferencias entre las categorías sociales, no obstante, son muy significativas. Así, el porcentaje de mujeres que ha hecho testamento casi duplica al de los hombres, mientras que la proporción de éstos que han suscrito un seguro de vida supera en casi 8 puntos porcentuales al de las mujeres que tienen seguro de vida. No obstante, y como es lógico, destacan sobre todo las diferencias relacionadas con el ciclo vital. Muy marcadas entre población joven y anciana en tener un testamento, ya que sólo un 1\% de la primera manifiesta tenerlo, frente a 3 de cada 4 personas ancianas; a lo que hay que añadir que más de la mitad de la población joven no ha pensado sobre esa opción. Plan preventivo cuya resolución perciben lejana en el tiempo y para el que probablemente, dada la situación económica de la mayoría de esa población, no tengan mucho que dejar en testamento. No obstante, para casi la otra mitad de la población joven hacer testamento sí constituye un desideratum: no lo tiene pero lo hará. En lo relativo a la suscripción de un seguro de vida, las diferencias más marcadas son las existentes entre población joven y adulta. Si casi un tercio de la población adulta tiene seguro de vida, esa proporción baja a menos de 1 de cada 20 entre la población joven. En ambas la intención de suscribirlo es minoritaria. Además, y quizá por las razones señaladas para el testamento, 2 de cada 3 personas jóvenes ni siquiera se ha planteado esta cuestión. Mientras, sólo 1 de cada 5 ancianos tienen seguro, y 3 de cada 4 no han pensado sobre ello. En este caso, parece lógico que, si no lo han suscrito en etapas anteriores, las abultadas primas a pagar que se solicitan a partir de cierta edad no animen a su suscripción y, por tanto, ¿’para qué pensar sobre ello? 


\begin{tabular}{|c|c|c|c|c|c|c|}
\hline \multicolumn{7}{|c|}{ CUADRO 5.19.: ¿TIENE USTED HECHO...? (\%) } \\
\hline & \multicolumn{3}{|c|}{ TESTAMENTO } & \multicolumn{3}{|c|}{ SEGURO DE VIDA } \\
\hline & Sí & $\begin{array}{l}\text { NO, PERO } \\
\text { LO HARÉ }\end{array}$ & $\begin{array}{c}\text { NO HE } \\
\text { PENSADO } \\
\text { EN ELLO }\end{array}$ & Sí & $\begin{array}{l}\text { NO, PERO } \\
\text { LO HARÉ }\end{array}$ & $\begin{array}{c}\text { NO HE } \\
\text { PENSADO } \\
\text { EN ELLO }\end{array}$ \\
\hline TOTAL & 24,2 & 38,3 & 36,1 & 16,7 & 19,6 & 63,2 \\
\hline HOMBRES & 21,0 & 41,3 & 34,7 & 21,8 & 23,7 & 53,3 \\
\hline MUJERES & 39,4 & 36,2 & 40,0 & 13,3 & 16,9 & 69,8 \\
\hline JÓVENES & 1,0 & 46,7 & 50,8 & 4,1 & 28,1 & 67,9 \\
\hline ADULTOS & 26,8 & 40,9 & 31,0 & 32,9 & 16,4 & 50,0 \\
\hline ANCIANOS & 75,6 & 13,3 & 9,7 & 19,5 & 3,9 & 75,4 \\
\hline
\end{tabular}

Fte: Encuesta 2000. Elaboración propia

Por otra parte, interrogada la población encuestada sobre su preferencia, una vez fallecida, por el enterramiento o la incineración (pregunta 37), la distribución de sus respuestas se reparte prácticamente de forma equilibrada en tres tercios entre esas dos opciones más la de las personas que se declaran indiferentes ante esa tesitura, Cuadro 5.20. Distribución que está muy asociada a las variables de control, especialmente a la edad y el nivel de estudios, y en menor medida a la religiosidad. En efecto, se constata, por un lado, una ligera asociación con el género, las mujeres se muestran más partidarias de la inhumación, mientras que a los hombres les es más indiferente una u otra opción. Como afirma el varón incrédulo entrevistado:

- "Me da exactamente igual. Si hay problemas de sitio ya saben lo que tienen que hacer. Es verdad, me da igual. Si he pensado alguna vez en algo de esto es por mis cercanos pero en mi caso me da exactamente igual" (E4:15).

Por otro lado, frente a un evidente equilibrio en las tres opciones entre los jóvenes, con una ligera preferencia por la incineración, ésta es la elección más escogida entre los adultos, mientras que la opción mayoritariamente preferida por los ancianos, 3 de cada 4, es el enterramiento. La asociación con el nivel de estudios se refleja en que a medida que éste sube, suben las preferencias por la incineración y bajan las del enterramiento, y al revés. Jupp (1996) relaciona las preferencias por la incineración con la movilidad social en el sentido de que permite borrar los signos de las raíces sociales a las personas que han ascendido socialmente. Respecto a la asociación con el nivel de religiosidad, con una proporción similar en las cuatro categorías de religiosidad por la opción de la indiferencia, alrededor del $30 \%$, a medida que aumenta el nivel de religiosidad se prefiere en mayor medida la inhumación, mientras que entre las personas menos religiosas la opción más escogida es la incineración. Así, casi la mitad de los crédulos, el 46,3\%, desean ser enterrados frente al 57,1\% de los incrédulos que prefieren se incinerados. Entre los componentes del grupo de discusión existe una predisposición favorable 
hacia la cremación y, aunque alguno/a lo tenía decidido y hablado con la familia, preferían no obstante dejar que fueran los deudos quienes tomasen la decisión:

- "- A mí me da igual que me incineren o me entierren. Yo a mis hijas...

- Yo no quiero ser pasto de los gusanos, yo polvo.

- A mí me da igual, que si quieren incinerarme que me quemen, que si quieren enterrarme que me entierren, me tiene sin cuidado. Lo que no quiero es que empiecen a decir; ay qué buena madre... yo ir a un entierro y oír esas bobadas me pongo mala. Si he sido buena o he sido mala se acabó.

- Ahí se ha terminado ya.

- Efectivamente.

- Con eso de la incineración yo tengo una póliza de esas de los vivos porque los muertos ya no pagan y hemos puesto incinerar y no sé cuanto, y mis padres se incineraron, mi padre ya hace muchos años...

- Yo si quieren hacer una cosa que la hagan, que quieren hacer otra que la hagan” (GD1:24-25).

\begin{tabular}{|l|c|c|c|}
\hline \multicolumn{4}{|c|}{ CUADRO 5.20.: PREFERENCIA POR LA... (\%) } \\
\hline & INHUMACIÓN & INCINERACIÓN & INDIFERENTE \\
\hline TOTAL & 35,5 & 34,3 & 30,2 \\
\hline HOMBRES & 29,9 & 34,2 & 36,0 \\
MUJERES & 39,2 & 34,4 & 26,4 \\
\hline JÓVENES & 27,6 & 37,2 & 35,2 \\
ADULTOS & 25,5 & 41,8 & 32,6 \\
ANCIANOS & 74,0 & 13,0 & 13,0 \\
\hline EST. BÁSICOS & 71,6 & 11,9 & 16,4 \\
EST. MEDIOS & 38,4 & 32,6 & 29,1 \\
EST. UNIVERS. & 25,3 & 40,6 & 34,1 \\
\hline CRÉDULOS & 46,3 & 22,1 & 31,5 \\
CREYENTES & 34,1 & 37,6 & 28,2 \\
NO CREYENTES & 26,1 & 39,3 & 34,5 \\
INCRÉDULOS & 12,7 & 57,1 & 30,2 \\
\hline
\end{tabular}

Fte: Encuesta 2000. Elaboración propia

Es interesante asimismo la información aportada por la población encuestada sobre las razones principales de su elección en este ámbito (preguntas 37a y 37b). Así, entre las personas que optaron por el enterramiento, y sin que existan diferencias estadísticamente significativas en ninguna de las variables de control, las dos razones fundamentales aducidas son la tradición social, 37,2\%, y la tradición familiar, 24,3\%, mientras que las creencias religiosas sólo son las más importantes para el 7,4\%. Elección por tanto más social que religiosa, hasta el punto de que incluso entre los crédulos sólo mencionaron las creencias religiosas el 11,6\% de los mismos. Según Basterra (1996:269), la preferencia de las personas creyentes por la inhumación y la sepultura puede estar relacionada con la gestión del cuerpo y su futura resurrección. Respecto a 
la incineración, las razones principales citadas para su elección son el constituir el procedimiento más higiénico y eficaz, 27,7\%, el que los muertos están en la memoria no siendo necesario ubicarlos espacialmente, 22,7\%, el miedo a la descomposición del cuerpo, 18,4\%, y porque es más cómodo, 16,3\%. No obstante, en este caso sí que existen diferencias significativas respecto algunas de las variables de control, como el género. Por ejemplo, 1 de cada 4 mujeres señala como motivo principal el que le angustia que su cuerpo se descomponga. Mientras, entre los hombres, las dos razones principales de su opción por la incineración son, en un $27,7 \%$ cada una, la comodidad, por un lado, y la higiene, sencillez y eficacia del proceso, por otro. En el caso concreto de la joven no creyente su elección se justifica por:

- "A mí, que me incineraran, porque, es una chorrada (risas), sí que pienso a veces en gente que los entierran vivos y me da.., bueno, sí, se me ponen los pelos de punta, sólo pensar en la posibilidad., estos enfermos de catalepsia, que luego.., resucitan, ¿no?, por lo menos si te incineran ya sabes que de ahí ya no te saca nadie, que no te despiertas" (E2:16).

Finalmente, a la hora de analizar los planes de vida vinculados a la muerte se interrogaba asimismo a la población encuestada sobre su grado de acuerdo con dos prácticas tanáticas concretas que, ligadas a los avances tecnológicos, han emergido desde la década de 1960 la primera de ellas, y desde la de 1990 la segunda (preguntas 52 y 55). Se trata en el primer caso de la criogenización, es decir, de la versión extrema de la negación de la física de la muerte, que persigue hacer realidad el mito de la contingencia de la muerte mediante la congelación de la persona fallecida hasta que en una fecha futura se encuentre el remedio a la enfermedad que la había matado y poder "resucitarla". El segundo caso se refiere a los “cementerios virtuales”, geografías inmateriales en las que "enterrar” a un ser querido, preservar así su memoria por tiempo ilimitado, y dar la posibilidad de que sea homenajeado por todas aquellas personas que lo deseen, cuando deseen y desde donde deseen.

En lo relativo a la criogenización, se constata el rechazo mayoritario por algo más de 3 de cada 4 personas encuestadas, el 76,7\%, pero también, y no deja de ser llamativo que casi 1 de cada 4 personas está dispuesta a someterse a ese proceso Cuadro 5.21. Entre las razones principales que se aducen para oponerse esta práctica curiosamente no está la de la imposibilidad de su materialización técnica, cosa que sólo menciona el 16\% de la muestra, sino que 1 de cada 3 personas encuestadas señalan que la muerte es necesaria para entender la vida, y un porcentaje similar argumenta que al reanimarle no conocería a nadie. Por su parte, entre las personas que sí que estarían dispuestas a ser criogenizadas la razón principal para ello es que hay que aprovechar todos los avances aportados por la ciencia, el 31,7\% de ellas. La distribución de esta variable está asociada significativamente con el género y la religiosidad. En el primer caso, se comprueba la mayor predisposición de los hombres, 3 de cada 10, mientras 
que algo más de 8 de cada 10 mujeres rechazan esa práctica, rechazo que está motivado sobre todo porque al reanimarlas no conocerían a nadie. Respecto a la religiosidad, a medida que se incrementa el nivel de ésta, aumenta la oposición, que en este caso está vinculado sobre todo a razones existenciales como la pérdida del sentido de la vida. En el caso de la joven no creyente entrevistada las razones de su rechazo son:

- “... no lo utilizaría, y vale muchísimo dinero, yo creo que no, me encontraría en un mundo totalmente desconocido, igual es como una segunda oportunidad. Es que no creo que cuando te descongelen vuelvas a vivir, yo es que no creo, aparte de encontrarte con una nueva vida, no conocer a nadie, sentirte como un extraño, no creo que cuando te despierten puedan arreglar eso porque si estás muerto estás muerto, yo creo que una vez que se para el corazón, es que yo creo que eso es un invento para timar a cuatro ricos que quieren vivir eternamente" (E2:26).

\begin{tabular}{|l|c|c|c|c|c|}
\hline \multirow{2}{*}{} & \multicolumn{5}{|c|}{ CUADRO 5.21.: UTILIZARÍA... (\%) } \\
\cline { 2 - 6 } & NO & SÍ & NO & SÍ & NO SABE \\
\hline TOTAL & 76,7 & 23,3 & 74,0 & 6,3 & 19,7 \\
\hline HOMBRES & 68,3 & 31,7 & 73,2 & 7,3 & 19,5 \\
MUJERES & 82,2 & 17,8 & 74,6 & 5,6 & 19,8 \\
\hline JÓVENES & 71,0 & 29,0 & 64,6 & 10,8 & 24,6 \\
ADULTOS & 80,9 & 19,1 & 84,1 & 2,9 & 13,0 \\
ANCIANOS & 83,5 & 16,5 & 79,7 & 1,3 & 19,0 \\
\hline EST. BÁSICOS & 86,4 & 13,6 & 82,1 & 1,5 & 16,4 \\
EST. MEDIOS & 77,0 & 23,0 & 81,6 & 1,1 & 17,2 \\
EST. UNIVERS. & 74,1 & 25,9 & 69,4 & 9,3 & 21,3 \\
\hline CRÉDULOS & 84,2 & 15,8 & 79,1 & 7,4 & 13,5 \\
CREYENTES & 78,2 & 21,8 & 69,8 & 8,1 & 22,1 \\
NO CREYENTES & 65,9 & 34,1 & 72,9 & 5,9 & 21,2 \\
INCRÉDULOS & 63,9 & 36,1 & 65,6 & 4,9 & 29,5 \\
\hline
\end{tabular}

Fte: Encuesta 2000. Elaboración propia

Respecto a la segunda práctica, la mayoría de la población encuestada se posiciona en contra de la utilización de los “cementerios virtuales", 3 de cada 4, mientras que un quinto de ella está indecisa, Cuadro 5.21. El 55\% de las que rechazan esta práctica lo justifica por preferir el sistema tradicional de entierro, mientras que para el resto no es más que una frivolidad y un sinsentido. Por su parte, el 92\% de los que sí utilizarían los cementerios virtuales lo harían porque consideran que sí que es un buen sistema para inmortalizar a un ser querido. La distribución de esta variable está asociada con la edad y el nivel de estudios, así, mientras adultos y ancianos tienen unos altos porcentajes de rechazo, alrededor del $80 \%$, y muy bajos niveles de aceptación, entre los jóvenes su rechazo es menor, 2 de cada 3, y se muestran más 
indecisos, 1 de cada 4. Asociación que está ligeramente más equilibrada en lo relativo al nivel de estudios, con los menores porcentajes de rechazo entre las personas con estudios universitarios y los mayores entre las de estudios básicos. En el trasfondo de estos datos habría que situar el mayor acceso de la población joven, y universitaria, a la "realidad virtual” y a la promesa implícita en ésta de un mundo sin los límites de la "realidad real”.

\subsection{RITUALES FUNERARIOS}

"Los ritos sociales crean una realidad que, sin ellos, no sería nada"

M. Douglas

Algunos autores consideran que el desarrollo en las sociedades occidentales de actitudes favorables a la incineración ${ }^{36}$, con la consiguiente ‘desmaterialización' del cadáver, o a la predisposición a donar el cuerpo a la ciencia no hacen más que confirmar el descrédito con el que en las mismas se percibe al cuerpo muerto (Marí-Klose y De Miguel, 2000; Jupp, 1996; Ariès, 1983). Actitudes que, junto a la medicalización de la muerte, contribuyen al deterioro de la imagen de la persona muerta como epítome de la negación de la muerte (Thomas, 1985). Por ejemplo, en el caso concreto de la incineración, al estar huérfana de toda simbología o justificación metafísica, como la que tenía en el pasado en algunas culturas, sólo se justifica socialmente por criterios en los que prima la eficacia técnica sobre cualquier otra consideración, de tal forma que ha quedado reducida en el imaginario colectivo a un simple procedimiento técnico que acelera la eliminación del cadáver, es higiénico, de bajo coste relativo y deja espacio para los vivos.

Criterios pragmáticos que, sujetos a la lógica del beneficio, la productividad y la eficiencia que caracteriza al sistema capitalista, impulsan el proceso de desocialización de la muerte en las sociedades avanzadas y que, junto a otros factores, están asimismo modificando profundamente los rituales funerarios en las mismas. Si, con carácter general, los ritos son construcciones sociales universales creadas para enfrentarse a lo incontrolado y aleatorio, es decir, si su función principal es aportar seguridad y amortiguar las angustias provocadas por la incertidumbre ante lo desconocido e incrementar la cohesión social, esa auténtica "necesidad vital” para individuos y grupos que son los ritos sociales se torna más perentoria aún cuando de lo que se trata es del enfrentamiento a la muerte (Thomas, 1985). En efecto, siguiendo a este autor, la "NADA" inconcebible, el no-sentido, que constituye el cadáver para el imaginario colectivo ha sido universalmente conjurada a través de la creación de ritos, creencias y prácticas funerarias que reparan el desorden introducido en la vida por la muerte. Paliativos que buscan

\footnotetext{
${ }^{36}$ En el ámbito de la ideología católica, Juan XXIII levantó la prohibición de la incineración en 1963.
} 
dejarla atrás, dominarla en sí misma y a través del control de los “enlutados”, pero que sobre todo tienen la función terapéutica de que los vivos puedan controlar el estremecimiento que les provoca la muerte, desculpabilizándoles, reconfortándoles, revitalizándoles (Thomas, 1985:120125).

Por tanto, los rituales de muerte en realidad lo son de vida, y sin embargo, y paradójicamente, están perdiendo esas funciones tanáticas en una sociedades avanzadas centradas sobre todo en el corto plazo, en el aquí y ahora, en la vida que niega la muerte. La dedicación, el tiempo, el espacio, la organización que requerían tradicionalmente los rituales funerarios chocan con las necesidades de rentabilidad, confort, velocidad, eficiencia, que dominan en esas sociedades, quedando en buena medida obsoletos en su configuración tradicional. Como se ha señalado en el Capítulo 2 de esta Tesis, diversos cambios estructurales han modificado la percepción y el enfrentamiento ante la muerte en las sociedades occidentales desde hace dos siglos, cambios que inevitablemente también han transformado las prácticas funerarias introduciendo efectos desritualizadores en las mismas.

En efecto, a la hegemonía de los criterios pragmáticos, señalados arriba para la incineración, fruto de la racionalización, la burocratización y la mercantilización en casi todas las parcelas de la vida (social), se añaden, por un lado, los efectos de la progresión del individualismo exacerbado que reivindica el Yo como contrapeso al anonimato que esos mismos procesos generan en las sociedades de consumo, pero que como contrapartida conlleva aislamiento y soledad. Por otro lado, se ha de tener en cuenta la incidencia de una "urbanización invasora" que limita en la práctica el desarrollo de buena parte de los "actos prescritos" en los rituales funerarios en sentido estricto ${ }^{37}$. A lo que hay que añadir además los efectos del proceso de secularización, con la consecuente pérdida de potencial redentor de los ritos religiosos ${ }^{38}$, y los de la medicalización de la muerte, con el aislamiento espacial de las personas moribundas y la consiguiente limitación material del acompañamiento antes, durante y después de su muerte como mucho a su círculo más próximo, en el mejor de los casos. Finalmente, y en especial, hay que considerar la incidencia de los avances científicos-técnicos, tanto en el ámbito práctico del desarrollo de tecnologías cada vez más sofisticadas en el tratamiento del cadáver, que ya no amenaza tanto, como sobre todo en el de las mentalidades, ya que el saber aportado por la

37 Thomas (1985:12) señala que, en sentido estricto, un rito es "una ceremonia reglada, un conjunto de actos prescritos por una liturgia para esperar, con el apoyo de los símbolos, un fin determinado”. El reducido tamaño de los pisos, la extensión de las ciudades, los problemas circulatorios, etc., si no impedirían sí limitarían prácticas como el amortajamiento y el velatorio en el hogar, el cortejo fúnebre, etc.

${ }^{38}$ Función terapéutica que "alcanza su más alto grado de eficacia cuando es garantizada por creencias religiosas que suponen la adhesión incondicional a la simbología subyacente... andamiajes de seguridad para paliar la angustia existencial bajo todas sus formas: gracia o poder sobrenatural atribuido a los ritos conjuratorios, propiciatorios, expiatorios,...” (Thomas, 1985:13). 
ciencia se ha constituido en el centro de la reflexión, ahogando a cualquier otro tipo de conocimiento, en el principal suministrador de soluciones eficaces para todos los problemas, también los del tránsito hacia la "otra realidad”, y lo hace además de forma aparentemente neutra, sin aspavientos, despojándolas de cualquier carga simbólica, tal y como se ha mostrado en el Capítulo 1 de esta Tesis. Racionalidad, control, asepsia, rapidez y cumplimiento de la normativa de seguridad e higiene. Deriva global que llevó a la queja de Thomas (1985:16): "Nuestra civilización, con evidencia, está al pairo de lo simbólico y los comportamientos repetitivos que jalonan nuestra vida proceden más a menudo de un comportamiento vacío de sentido que de una conducta ritual”. En definitiva, cambios estructurales que han desembocado en un proceso de desritualización caracterizado por la recolocación de los rituales funerarios desde el ámbito comunitario al privado, por su simplificación, aceleración y neutralización afectiva (Littewood, 1993; Thomas, 1985). Por ello, cabe preguntarse si, una vez dejada en las manos de la ciencia y la técnica el dominio de la muerte, los rituales funerarios siguen cumpliendo con su función terapéutica de reintegración de los vivos o si se han transformado simplemente en unos mecanismos sociales rutinarios movidos por la conformidad y carentes de toda significación simbólica. Tal y como lo perciben dos de las personas entrevistadas, y con mucha ironía en el grupo de discusión al comentar las novedades en el terreno de la oferta de ataúdes:

- "Es que son actos sociales como una boda, como una primera comunión, ya algunos actos ya no tienen sentido para celebrar el hecho de la muerte, sino que es un acontecimiento social y se hace sin pensarlo y es una manera de encontrarse la gente, que aunque no tenga sentido, que aunque se haya perdido el sentido, que a lo mejor tenía en un principio, se sigue haciendo; entonces, igual que pienso que no me gustan otros actos sociales que se hacen ahora tampoco les encuentro sentido a algunos de estos, relacionados con la muerte" (E2:24).

- "J: Sí., la situación ha cambiado mucho, la situación no tiene nada que ver con aquello. Aquello era demasiado, y lo de ahora es un trámite... es una situación social, en un momento determinado, como ir a una comunión, como ir... esto es así... aquello era muy trágico todo.

E: Pero, ¿qué función crees que cumplía socialmente aquello, el que las cosas se hicieran de esa forma?

$\mathrm{J}$ : La misma que ahora, lo que pasa es que antes era distinta, antes se exageraba demasiado la nota y ahora no se exagera casi nada la nota, también depende de casos, antes yo creo que era demasiado, bueno en las sociedades, de nosotros para atrás era mucho más trágico todo, creo. Eso de estar toda una santa noche, ahí delante del cadáver, rezando rosarios, eso me parece una barbaridad, me parece una burrada, ¿para qué?, y llorar, bueno, de todo esto, no, no lo veo necesario para nada" (E4:25).

- “- Por lo exótico que es en Valencia hace poco en la feria última de los ataúdes... - Ah, sí...

- Fíjate tú qué horterada con luz de neón que estaba allí y digo ¿para qué necesitarán la luz?

- Porque le pasarán la prensa diaria.

- Unas cosas, pero bueno... Eso sí que es surrealismo ¿eh? 
- Para que lea el alma.

- Y es que además te entierran en una caja y ¿qué más da que sea de pino que de ébano? Pero te mueres, te entierran y punto. Había cajas con espejos, con el raso de no sé cuántas calidades. Ahora ya se llevaba la seda pero seda sintética, de importación... una bobada...

- Son unos ritos..., es para los vivos no para los muertos, para los que quedan. Para satisfacerse" (GD1:29).

Así, al objeto de comprobar el alcance del aprecio/desafección hacia los rituales funerarios entre la población encuestada, se le pidió que manifestara sus opiniones sobre los rituales tanáticos más habituales en la sociedad española (pregunta 57); asimismo, para conocer el nivel de uso/desgaste de dichos rituales se le interrogó sobre su participación en ellos (preguntas 58), Cuadro 5.22. La información recogida en este cuadro es una aproximación exploratoria a la percepción de la necesidad o no de esos rituales y a la práctica efectiva de los mismos. Lo primero que se observa en dicho cuadro es que existe una clara disonancia entre opiniones y comportamientos en este ámbito, ya que en 10 de los 11 rituales sobre los que se pedía información las personas entrevistadas los han practicado en mayor medida de los que los consideran necesarios; de hecho, más de la mitad de la población encuestada ha practicado en alguna ocasión 8 de los 11 ritos, cuando sólo 5 de ellos son considerados necesarios por más de la mitad de la población. Datos que, por un lado, confirman inicialmente la vigencia de algunas de esas prácticas y la obsolescencia clara de otras, y que, por otro lado, anticipan cambios futuros hacia su desuso toda vez que, como se señala más adelante, los mayores niveles de desafección corresponden a las generaciones más jóvenes, que son asimismo las que declaran menores niveles en su práctica efectiva. Distanciamiento respecto a algunos de los rituales que se transforma en una enmienda a la totalidad a los mismos entre dos de las personas entrevistadas:

- "En este tema por un lado se puede convertir muy fría la muerte, la forma de llevarlo ahora comparado a cómo era antes o como en otras culturas, pero los ritos y ceremonias a mí no me gustan. Tampoco quiere decir que la gente de antes lo viviera y lo sufriera más porque estuvieran más tiempo o porque lo hicieran de otra manera, podrían ser igual de hipócritas que la gente que va ahora a un funeral" (E3:15).

- "Esto me da igual todo... Para nada, el velatorio, nada, el luto, menos, el funeral, puaf, me da igual” (E34:24).

Entre los rituales que se consideran necesarios, y que son los más practicados, destacan dos de los vinculados al acompañamiento de los 'enlutados': el funeral, el 85,8\% de las personas encuestadas lo perciben como tal y el $97,0 \%$ ha participado en alguno, y el dar el pésame, el 77,6\% lo ve necesario y el $95,5 \%$ ha dado alguna vez las condolencias. Thomas (1985:64-69) señala que estas dos prácticas, la participación en las exequias y el dar las condolencias, han sido durante mucho tiempo obligaciones sociales a las que las personas no se 
podían sustraer, no sólo porque reforzaran la cohesión social al mostrar solidaridad con los “enlutados”, sino porque la no participación se interpretaba como una especie de rebeldía y se corría el riesgo de caer en la marginación respecto al grupo. Entre la población entrevistada se reconoce la necesidad del primero:

- "Lo del funeral pues sí lo veo una costumbre pues natural de, vamos, la sociedad en general también es verdad que se le da distinta importancia y, bueno, puede que haya cambiado, pero para mí sí que lo considero una cosa pues necesaria" (E1:17).

- "El funeral, bueno, sí, el funeral aunque no sea religioso es una manera de hacer un último homenaje, o de juntarse la gente allegada, que tenía relación, bueno pues sí es otro, eso sí que me parece que tiene más sentido" (E2:24).

Sin embargo, se observa algún tipo de rebeldía respecto al segundo rito entre los más jóvenes, quizá porque, como señala Elias (1987:33-39), no se socializa a las nuevas generaciones inculcándolas formas de expresión estereotipadas, comportamientos estandarizados que, aunque pueden "aliviar la fuerte carga emotiva que conllevan” determinadas situaciones, las personas encuentran embarazoso utilizarlas por considerarlas vacías y triviales. Situación que se refuerza con el "empuje informalizador" vivido por las sociedades desarrolladas, desde la segunda mitad del siglo XX, por el que las personas, sobre todo las de las generaciones más jóvenes, se muestran muy reticentes a utilizar fórmulas preestablecidas en el pasado ${ }^{39}$ :

- "Dar el pésame, eso no, es que me parece un rollo, absoluto, no me gusta nada, encima en los pueblos, mis padres que son de un pueblo, cada vez que hay un entierro, es que se presenta casi todo el pueblo y les da igual que sea uno que casi no te hablaba que casi uno que no te conociera de nada, vamos, eso que yo no me he visto en el caso de tener que recibirlo yo directamente, pero, vamos, me parece un rollo absoluto, que en esos momentos que estás... lo que menos te apetece tener que estar aguantando los besos de la gente" (E2:25).

Asimismo, se perciben como rituales necesarios, con menor intensidad que los anteriores pero también con niveles de participación muy mayoritaria, otros también relacionados con el acompañamiento de los `enlutados', pero que sobre todo simbolizan el homenaje y reconocimiento a la persona fallecida: la participación en la comitiva de conducción del cadáver, 2 de cada 3 personas encuestadas lo juzgan necesario y el 85,5\% ha participado en algún cortejo fúnebre, y el velatorio del cadáver, valorado como necesario por el 57,9\% y que en algún momento ha realizado el 78,9\%. Las opiniones divergentes respecto al velatorio entre las personas entrevistadas quedan patentes en estos fragmentos de las mismas:

\footnotetext{
${ }^{39}$ Más allá de los rituales de muerte, el análisis de Elias (1987:38-39) se refiere especialmente a las dificultades de comunicación durante el proceso de morir. En este sentido, comenta: "la situación de tránsito hacia la muerte carece en nuestra sociedad de forma en medida considerable: es un espacio en blanco en nuestro mapa social. Los rituales seculares se han vaciado en gran parte de sentimiento: a las fórmulas seculares tradicionales les falta poder de convicción”.
} 
- “... el velatorio yo lo veo como una cosa, como una despedida, yo creo que las personas que se ven afectadas por una muerte, pues creo que, lo veo algo útil, algo como el último adiós, que se dice, pues sí, una cosa que hay ciertas personas que lo..,como que casi es imprescindible, a mí me parece hasta de... de propia educación, ¿no?. Si un ser querido muere pues, el velarle” (E1:16).

- "El velatorio, vamos, me parece absurdo porque es que yo pienso estar en esa situación y lo que menos me apetecería es que vinieran ahí, bueno, todavía en las ciudades a lo mejor que viene la gente más allegada, pero en los pueblos que se presenta allí todo el pueblo, hay gente que no conoces de nada y que..., es que me parece tan absurdo, vamos, no, no me gustaría que lo hicieran cuando me muriese" (E2:24).

Por último, más de la mitad de la población encuestada considera necesario, dentro de la ceremonia general que es el funeral, la comunicación de los fallecimientos mediante un procedimiento neutro, estandarizado, a la vez que identificador de la persona fallecida como es la esquela; no obstante, y por razones obvias, la proporción de personas que han puesto una esquela es menor que la que lo considera necesario ${ }^{40}$. Percepción de su utilidad manifestada asimismo en las entrevistas:

- "poner una esquela, bueno, si la persona que fallece pues tiene pues relaciones públicas o tiene contacto con mucha gente, pues bueno, de cara a que lo conozcan lo del fallecimiento, es claro, lo más lógico” (E1:17).

Así pues, estas cinco prácticas funerarias persisten en la sociedad actual, lo que puede significar un mantenimiento efectivo de esos rituales por el momento, aunque no queda aclarado si es por motivaciones afectivas de fidelidad y respeto o si simplemente es el resultado de la estandarización de las relaciones sociales construidas sobre la repetición de gestos y la conformidad.

Por el contrario, hay otras prácticas que concitan mucho rechazo, siendo éste especialmente relevante en las relacionadas con el duelo. En efecto, este término, como recuerda Thomas (1985:71), abarca tres procesos: a) el "estar en duelo" (bereavement), que denota el estatus de las personas que han perdido a un/a allegado/a; b) el "hacer su duelo" (grief), conjunto de estados afectivos que conforman el proceso de tránsito psicológico hasta que los 'enlutados' asumen la pérdida, recuperan el tono vital y se reincorporan plenamente a la vida social, y; c) el luto (mourning), la exteriorización de la pérdida, la marca de haber sido tocado por la muerte. Respecto a este último, el rechazo es mayoritario, ya que casi 9 de cada 10 personas encuestadas lo consideran innecesario y sólo un quinto, las de más edad, lo han llevado a cabo en algún momento. Dinámica que, como ya se ha comentado en el Capítulo 3 de esta

\footnotetext{
${ }^{40}$ Poner una esquela es el único ritual que la gente ha practicado en menor medida que lo que considera necesario. Dado que para poner una esquela sólo se requiere la presencia de una persona que se desplace a una empresa de servicios funerarios para contratar ese servicio, entre otros, no es extraño que esa sea la práctica menos realizada entre las que se consideran necesarias.
} 
Tesis, está en consonancia con el ocultamiento de la muerte, ya que se considera que la exteriorización de la misma acaba reforzándola, además de que su exhibición no es socialmente bien recibida, lo que es acorde también con la privatización de las emociones en las sociedades modernas. Como reflejan los comentarios de los jóvenes entrevistados:

- "Yo creo que el dolor se lleva por dentro, no en la forma de vestir" (E1:16).

- "Luto, vamos, es que me parece de película de risa, nada, vamos, eso, fuera, y eso que si se lo digo a mi abuela (risas), que ya hasta la gente mayor ya se está... quitando ese lastre de encima" (E2:24).

Rechazo al luto compartido por la población de más edad componente del grupo de discusión, aunque en su caso, además de la disfuncionalidad del mismo, añaden como motivo la discriminación por género que tradicionalmente comportaba, es decir, el tipo de control social que suponía para las mujeres, y sólo para ellas, una especie de muerte social cada vez que se producía un fallecimiento entre sus familiares:

- “- Y luego no te digo nada, que te tocaba el luto. Que había gente que se pasaba de luto toda la vida...

- Ahora el luto no se lleva.

- ... por mi abuelo luego seis meses por mi suegro. Las medias negras, madre, como lo llevaba de mal, a mí que no me gustan ni en invierno las medias.

- Que las teñían y se rompían todas.

- Aquí los únicos que van ahora de luto son los gitanos.

- Aquello era la España profunda.

- Óyeme una cosa, el luto lo llevábamos las mujeres porque el hombre o una corbata negra o el botón. Y las mujeres, oye, para todo, es que...

- El hombre se iba a jugar la partida. Las mujeres no podíamos ni ir al cine.

- Y la mujer no podía ni poner la radio. Nada. Y ahora la gente lo lleva como más natural.

- Es normal, mueres y sigue la vida.

- En aquellos momentos también era una hipocresía en la mayoría de los casos.

- Pues en Andalucía era aún más extremado. Yo me acuerdo de ver a mis tías, yo me vine para León cuando tenía ocho o nueve años, pero yo tengo vivencias de mi tierra que me han marcado mucho. Ver a mis tías y a mi abuela con aquellos mantos negros...

- Como cuervos.

- ... Se murió mi abuelo, cinco años; se murió mi abuela, otros cinco años; se murió otro hermano en la guerra, otros cinco años. Se pasaban toda la vida de luto las pobres...

- Pero ellas, no ellos.

- ... No, no, ellos no.

- El sentimiento lo tenían y tendrían igual un hijo que una hija, pues no señora, la que cargaba con el mochuelo era la hija, hombre, ipor favor!.

- Mi madre se casó de negro que están las fotos que parece... hacía tres años que se había muerto mi abuelo.

- Con aquello tan riguroso de antes hubo gente que se pasó cuarenta años de luto" (GD1:34).

Aunque en este largo fragmento del verbatim se recoge el rechazo explícito a la manifestación externa del duelo, al luto, también se puede apreciar en el mismo un cierto 
malestar a lo que implicaba para algunas personas el desarrollo del duelo mismo, por lo que no sorprende tanto el rechazo hacia la puesta a distancia voluntaria que significa el duelo, trabajo socio-psicológico que los psicólogos consideran inexcusable para la adecuada reincorporación a la vida social y que, sin embargo, sólo ven necesario 1 de cada 3 personas encuestadas. Dado que la mitad de éstas ya ha pasado por un proceso de duelo, y que por tanto no desconocen lo que significa, parecería como si se hubiera producido una pérdida de sensibilidad ante los efectos que en uno mismo tiene la muerte de una persona allegada, "un aplanamiento del yo consciente”, en expresión de Thomas (1985:103), para actuar como si la muerte no existiera. Una reducción del espacio y el tiempo de la muerte para que perturbe lo mínimo al espacio y el tiempo de la vida. Lógica de reproducción del sistema plenamente integrada en las actitudes de la mayoría de las personas encuestadas. Tal como lo perciben los jóvenes entrevistados:

- "Bueno, yo creo que es una señal de respeto y consideración hacia quien ha tenido.., quien lo está pasando mal al fin y al cabo, se supone, entonces, bueno el duelo yo lo veo algo, una forma de acompañar y de respetar el sentimiento que puedan tener esas personas, ¿no?, entonces lo veo lógico y normal que por una temporada.., tampoco vas a estar de duelo toda la vida, pero siempre cuando son muertes de gente muy cercana pues que se respete un duelo siempre tiene esa consideración" (E1:16).

- “... sí, no salen.., sí, bueno, a mí eso siempre que sea sincero, si la gente lo hace porque lo siente y porque no le apetece salir y porque están muy dolida, pues, sí, bueno, eso hay que respetarlo. No vas a hacer salir por ahí a alguien que se le ha muerto alguien allegado porque eso del duelo está pasado de moda, eso cada uno, pero si es por guardar las apariencias, eso me parece absurdo, claro, es que eso me cuentan mis padres y mis abuelos que había gente que se quedaba sin juventud porque se le moría el padre o la madre, bueno, es que me parece atroz, es que es totalmente alucinante" (E2:24).

Otras prácticas tanáticas que no son percibidas como necesarias, y que de momento no están en desuso, son el dar o recibir recordatorios y el sustituto vergonzante de las condolencias (Thomas, 1985:69), el firmar en el libro de firmas ${ }^{41}$, ambas consideradas innecesarias por más de 7 de cada 10 personas encuestadas y que alrededor de la mitad ha practicado en algún momento. No obstante, la impersonalidad, y sobre todo la ausencia de relación personal directa que estas dos prácticas comportan, pueden ser bien valoradas por parte de la población, como ocurre con la joven no creyente:

- “... hombre, mejor que el pésame y esto, sí, si la gente quiere.. no es lo que tú quieras es lo que la gente que está a tu alrededor, aunque tú no quieras que haya pésame y no sé qué, es que la gente se pone burra "que quiero ir a darte el

\footnotetext{
${ }^{41}$ Thomas (2985:69) comenta a este respecto que la práctica relativamente reciente de la firma en el libro de firmas no es más que la sustitución de las condolencias tradicionales motivada, por un lado, por la necesidad de no ser demasiado expansivo en la exteriorización de las emociones que caracteriza a la muerte negada, y, por otro, porque el proceso de desocialización de la muerte hace que no se sepa qué decir en esos momentos, por lo que se considera más conveniente la rapidez, comodidad y menor tensión implícita en la inscripción del nombre que en dar el pésame.
} 
pésame”, así que me parece cómodo, pones un libro y el que quiera que firme, ya queda bien con su conciencia, y ya está" (E2:24).

Finalmente, también se considera innecesaria por la mayoría de la población uno de los rituales tanáticos más mediáticos y al que todos los años todos los medios de comunicación dedican varios reportajes alrededor de la fecha de esa onomástica, la visita al cementerio en el Día de Difuntos, que es rechazado por el 56,2\% de la muestra, aunque más de 3 de cada 4 lo hayan practicado en algún momento:

- “- Yo creo que el cementerio el día de los Santos es una romería porque no van en todo el año y van allí a lucirse

- Pero fíjate...

- Para que los vean" (GD1:37).

\begin{tabular}{|l|c|c|c|c|}
\hline \multicolumn{5}{|c|}{ CUADRO 5.22.: OPINIONES Y COMPORTAMIENTOS RESPECTO A RITUALES } \\
\hline \multirow{2}{*}{$\begin{array}{l}\text { FUNERARIOS (\%) } \\
\text { LELATORIO }\end{array}$} & \multicolumn{3}{|c|}{ RITOS FUNERARIOS } & LO HA \\
\cline { 2 - 4 } & NECESARIO & INNECESARIO & NO SABE & PRACTICADO \\
\hline FUNERAL & 57,9 & 31,5 & 10,7 & 78,9 \\
\hline DUELO & 9,3 & 87,0 & 3,7 & 22,3 \\
\hline $\begin{array}{l}\text { ACOMPAÑAR } \\
\text { CONDUCCIÓN DEL } \\
\text { CADÁVER }\end{array}$ & 85,8 & 9,7 & 4,5 & 97,0 \\
\hline $\begin{array}{l}\text { ENVIAR CORONA } \\
\text { FLORES }\end{array}$ & 32,4 & 43,2 & 24,4 & 50,0 \\
\hline LIBRO DE FIRMAS & 39,4 & 23,5 & 9,1 & 85,5 \\
\hline RECORDATORIOS & 17,9 & 48,8 & 12,1 & 64,7 \\
\hline DAR PÉSAME & 16,7 & 71,8 & 10,3 & 46,1 \\
\hline ESQUELA & 77,6 & 74,3 & 9,0 & 55,1 \\
\hline VISITA DÍA DIFUNTOS & 33,9 & 17,9 & 4,5 & 95,5 \\
\hline
\end{tabular}

Fte: Encuesta 2000. Elaboración propia

La distribución de las opiniones sobre cada uno de estos rituales está asociada a algunas de las variables de control. No es el caso del género, que en ninguna de ellas presenta asociaciones estadísticamente significativas, pero sí lo es para las otras tres variables, excepto en las distribuciones relativas a dar el pésame en las que no se aprecia ninguna asociación. En términos generales se constata el peso de la tradición en este ámbito, de tal forma que a mayor edad, menor nivel de estudios, y mayor religiosidad, mayor es la percepción de necesidad de 
cada uno de los rituales considerados, y al revés. Así, por ejemplo, en el caso del funeral, mientras que el 94,2\% de los ancianos, o el 95,1\% de los crédulos, lo consideran necesario, sólo lo perciben de esta forma el 76,5\% de los adultos o el 63,5\% de los incrédulos. O, en el caso del ritual más denostado, el luto, frente al 32,0\% de los ancianos sólo lo consideran necesario el $5,6 \%$ de los jóvenes. Algunas de las asociaciones más significativas son las que se aprecian entre velatorio y religiosidad (necesario para el 69,0\% de los crédulos frente al 37,1\% de los incrédulos); dar recordatorios con edad (necesario para el 44,0\% de los ancianos frente al 9,1\% de los adultos); poner esquela con edad (necesario para el 62,7\% de los ancianos frente al 38,3\% de los adultos), y visitar el cementerio el Día de Difuntos con edad y religiosidad ( necesario para el 73,1\% de los ancianos frente al 25,5\% de los jóvenes; necesario para el 46,1\% de los crédulos frente al $11,1 \%$ de los incrédulos).

El hecho de que en alguna ocasión, a pesar de no tener una opinión favorable a ello, se haya practicado alguno de los rituales tanáticos hace que en las distribuciones de participación efectiva en ellos sí que se observe alguna asociación significativa con el sexo; concretamente, tanto en la distribución relativa a dar un recordatorio como en la de ir al cementerio el Día de Difuntos se aprecia que las mujeres encuestadas lo han practicado en mayor medida que los hombres -8 de cada 10 mujeres declaran que han ido al cementerio ese día, frente a 7 de cada 10 hombres-. Por lo demás, excepto en las distribuciones de acudir a un funeral o en la de dar el pésame, en el resto se aprecian distintos grados de asociación con las otras tres variables de control en la línea señalada para las opiniones sobre los diferentes rituales. No obstante, y como parece lógico, las distribuciones en relación con la edad se extreman más en este caso aunque sólo sea porque el tener más edad implica tener más probabilidades de haberse enfrentado al fallecimiento de una persona allegada. Así por ejemplo, mientras entre los ancianos el 100,0\% de ellos ha acompañado en la conducción del cadáver, el 95,8\% ha estado en un velatorio, el $87,7 \%$ ha puesto una esquela, o el $65,2 \%$ ha seguido el luto, entre los jóvenes esos porcentajes han sido $72,5 \%, 62,1 \%, 22,9 \%$ y 4,7\%, respectivamente. Por su parte, en lo relativo a las asociaciones con la religiosidad, además del factor ideológico ya detectado en las opiniones sobre los distintos rituales, se puede especular para alguno de los rituales con la incidencia de otro factor que también aumenta la asociación como es la necesidad de expresar la propia autenticidad, la independencia de espíritu que libera de los formalismos sociales, por parte de las personas menos religiosas que las lleva a tener una menor necesidad de cumplir con toda la parafernalia social conexa a los rituales funerarios. Basten, como ejemplos, la visita al cementerio el Día de Difuntos, practicada por el 82,3\% de los crédulos frente al 54,8\% de los incrédulos, el envío de coronas, realizado por el 74,7\% de los crédulos frente al 59,7\% de los incrédulos, o la firma en el libro de firmas, ritual que ha sido practicado por más de la mitad de los crédulos, 54,1\%, y por poco más de 1 de cada 3 incrédulos, el 37,7\%. 
Por otra parte, se interrogaba a la población encuestada sobre su predisposición a utilizar "paquetes funerarios", es decir, a que todo el proceso relacionado con el "último adiós" -tratamiento del cadáver, exposición, funeral, traslado, inhumación/incineración, etc.- quedara en manos de organizaciones especializadas en esas tareas (pregunta 62). La mayoría de la población, 7 de cada 10, se muestra dispuesta a la utilización de esos servicios, mientras que sólo el $10 \%$ se opone a ello y 1 de cada 5 está indecisa, Cuadro 5.23. No existen diferencias significativas entre sexos pero sí por edad, nivel de estudios y religiosidad. Diferencias que se observan en las distribuciones de las que los rechazan y las indecisas, y no tanto entre las que se muestran favorables a su utilización que como mínimo superan el $60 \%$ en todas las categorías. Nuevamente el peso de la tradición, es decir, el factor generacional más que propiamente la fase del ciclo vital, incide en el mayor rechazo por parte de las personas de más edad, y también de las que tienen menor nivel de estudios, 1 de cada 4 en cada una de esas categorías. En lo relativo a la religiosidad, son las personas crédulas las que menos dudas tienen en este ámbito y las que más rechazan la utilización de los "paquetes funerarios", mientras que sólo un 3,5\% de las creyentes rechazan los “paquetes funerarios”. La principal razón que se aduce para el rechazo de este tipo de servicio es la preferencia por la tradición, 7,8\% del total de la población encuestada, mientras que los dos principales motivos para utilizarlo son la comodidad para la familia y la higiene y organización, 40,7\% y 29,0\% de la muestra, respectivamente. Cabe colegir, en consecuencia, no sólo la inserción de las distintas ceremonias y prácticas tanáticas en el circuito económico como un producto comercial más, sino sobre todo la aceptación mayoritaria del mismo por parte de la población encuestada. Como se constata en las opiniones favorables, por su comodidad, manifestadas en las entrevistas, aunque no gusten a todas las personas entrevistadas:

- "Hombre, es un negocio como otro cualquiera, que me imagino que será gente profesional y que se dedican a ello, que harán de tripas corazón para realizar su trabajo, y que, bueno, que cada vez está más extendido y que ofrecen más servicios. $Y$, no sé, también ha avanzado con la sociedad, la gente cada vez quiere más comodidad y quiere tener más.., no sé, que con sufrir ya la muerte de una persona cercana ya es bastante como para tener que encargarte de un montón de cosas, entonces me imagino que estas empresas pues tendrán sus departamentos y su personal adecuado para en el momento adecuado pues saber ofrecer un montón de servicios sin molestia para los familiares. Me parece bien, me parece que es una cosa más y cada uno elige luego lo que su forma del funeral y todo eso" (E1:18).

- "Pues, sí, es que es muy cómodo... pero lo que no me parece bien es que te vendan el paquete que te ponen las flores, que te ponen la música, y te ponen el vestido, si te gusta y de verdad lo sientes, te tendrás que comprometer con ello, y encargarte tú, pero es que es un acto social como otro cualquiera, hala lo compro, me desentiendo, quedo bien y ya está, a mí, no, es para gente cómoda que además que no, gente cómoda y que sólo quiere, que se preocupa por las apariencias, porque si eres cómodo y no te quieres preocupar, pues para qué haces eso, no sé 
es un poco contradictorio, yo no lo veo bien, pero como no veo bien lo de las bodas las comuniones y todo eso que te lo venden todo ya" (E2:25-26).

- "Ahorrarte trámites o preocupaciones, pero vamos, que es una forma de sacarte dinero y tampoco me gusta... Eso es una forma de evitarte problemas, de que te den hecho lo desagradable. Gastas un dineral en los ataúdes, esos coches para ir para allá y para acá. Hacer un negocio de la muerte, pues no, vamos que es así, pero no me encanta la idea. A parte de que luego es sólo un trámite del cuerpo y poco más, porque el resto lo que da más trabajo es el papeleo y eso no te lo quita nadie" (E3:13-14).

- "A mí particularmente no me crea ningún problema, pero el hecho.., me parece una buena idea lo de los tanatorios, en una palabra, o sea, no me parece mala idea. Teniendo en cuenta que lo principal es que se te ha muerto alguien, lo demás es todo secundario y bueno es más cómodo para la generalidad, para el resto, para todo el mundo es más cómodo, pues bueno, pues vale, me parece bien, me parece una buena idea, es un negocio, por supuesto, y se inventó como negocio no como... beneficio público pero, no me parece mala idea, porque está bien, no pasa nada. Antes se nacía en las casas, ahora se nace en los hospitales, antes se moría en las casas, ahora se muere en los tanatorios, vamos te instalan en un tanatorio, no tiene mayor importancia" (E4:26).

Por su parte, los componentes del grupo de discusión en un doble discurso asumen, por una parte, que es una moda importada que como tal no les gusta porque les parece artificial en comparación con la naturalidad con la que se vivía ese proceso en el pasado, pero, por otra, reconocen que constituye un rasgo más de la evolución de la sociedad, rasgo que supone una mayor comodidad para todo el mundo al que no van a poder ni querer renunciar:

- “-Es que antes teníamos más relación con la muerte y más directa. Yo me acuerdo cuando era pequeña que en mi pueblo, un poco más allá un poco más acá, siempre había una persona muerta. Iba todo la gente a verlo y si la abuela te decía pues "cuando me muera... Pues le tocará como le ha tocado al abuelo de esa otra".

- Pero es la sociedad la que ha cambiado porque acordaos cuando veíamos en las películas de los americanos que los llevaban a los tanatorios o que les maquillaban y toda esa parafernalia que hacen lo americanos y ahora lo estamos haciendo nosotros. O sea, que como es el imperio pues nos coloniza a todos, digo yo. Y ahora la gente en casa no porque menudo engorro...

- Se vivía más de cerca y más natural la muerte.

- También se vivían los nacimientos, acordaos qué mujer no paría en casa.

- Las cosas relacionadas con la vida estaban más cercanas.

- Era más normal.

- Hoy ni naces en casa ni mueres en casa. Es así.

- Es comodidad. Te quita trabajo, te quita sufrimiento, ahora te lo hacen todo allí en el tanatorio" (GD1:31).

- "Con estas casas modernas... hay que entender que tenías que desarmar una habitación y dejar allí al muerto.

... - Una muerte como antes en casa tenías que ir pidiendo sillas a la vecina.

- Una habitación lo primero.

- Y si era en mi tierra, yo vivía de pequeña en mi tierra, yo era de un pueblo la provincia de Sevilla. ¡Madre mía como la muerte fuera en verano!, andaba toda la 
gente cerrando allí todo en oscuro para que no hiciera calor dentro de la casa y no había ventiladores ni nada..

- Yo tengo el olor de la muerte de mi abuelo metido aquí metido.

- ..Al rato no entraba nadie a la habitación del muerto. Si moría en un puente y era una persona que se había medicado mucho, a las pocas horas olía aquello...

- Era antihigiénico.

- Es que ahora dan la una de la mañana o las dos de la noche, cierran el tanatorio y se va toda la familia y descansa. Además, estaban hechos polvo" (GD1:33).

\begin{tabular}{|l|c|c|c|}
\hline \multicolumn{3}{|c|}{ CUADRO 5.23.: UTILIZARÍA “PAQUETES FUNERARIOS” (\%) } \\
\hline \multicolumn{1}{|c|}{ TOTAL } & NO & SÍ & NO SABE \\
\hline HOMBRES & 10,5 & 69,7 & 19,8 \\
MUJERES & 9,7 & 67,9 & 22,4 \\
JÓVENES & 11,0 & 71,0 & 18,0 \\
ADULTOS & 6,2 & 61,7 & 32,1 \\
ANCIANOS & 7,9 & 80,6 & 11,5 \\
\hline EST. BÁSICOS & 25,6 & 70,5 & 3,8 \\
EST. MEDIOS & 25,0 & 69,1 & 5,9 \\
EST. UNIVERS. & 12,9 & 69,4 & 17,6 \\
\hline CRÉDULOS & 5,8 & 70,0 & 24,1 \\
CREYENTES & 17,0 & 67,3 & 15,6 \\
NO CREYENTES & 3,5 & 71,8 & 24,7 \\
INCRÉDULOS & 3,6 & 75,9 & 20,5 \\
\hline
\end{tabular}

Fte: Encuesta 2000. Elaboración propia

Los datos relativos a opiniones, creencias y comportamientos efectivos correspondientes tanto a los planes de vida en relación a la muerte como a los rituales funerarios ponen de manifiesto que, ante las exigencias de las "jaulas de hierro" de la racionalidad en las que se encuentran atrapados los individuos de las sociedades desarrolladas, aunque se mantienen vivas actitudes tradicionales respecto a los mismos se constata la emergencia y asentamiento de nuevas actitudes favorables a su transformación. Actitudes de cambio a las que hay que añadir además las actitudes de rechazo frente a algunas prácticas que han quedado obsoletas. Así, por ejemplo, la incineración avanza rápidamente a costa de la inhumación, los velatorios o los funerales se mantienen pero con un perfil profesionalizado ${ }^{42}$ ante la imposibilidad e

\footnotetext{
${ }^{42}$ En la conmemoración del quinto aniversario de los atentados del 11-M, M.A. Sánchez-Vallejo publicó un artículo periodístico en EL PAÍS (23/03/09:30-31) titulado "La cultura del luto vive su propia revolución”, en el que afirmaba que "la sociedad demanda cada vez más ayuda para afrontar la pérdida de seres queridos" toda vez que "el tabú de la muerte se ha reforzado" en la sociedad española. Haciendo referencia a las muertes masivas de ese atentado y de catástrofes aéreas, que habían incrementado la
} 
incomodidad de hacerlos en el propio hogar y desde las propias capacidades, y el luto está en desuso por anticuado e impúdico. Es decir, en la actualidad, se mantienen las prácticas funerarias pero en gran medida se han perdido los ritos funerarios que las envolvían, la simbología que los daba sentido, prácticas pragmáticas que traslucen actitudes prosaicas en la línea de la negación de la muerte. Por otra parte, la desagregación según las distintas variables de control, en especial la edad, permite aventurar, por un lado, una aceleración en esa dinámica transformadora a medida que se vaya produciendo la renovación generacional, ya que son los jóvenes los que muestran mayores niveles de rechazo o de incomprensión hacia algunos de los rituales funerarios, pero, por otro lado, los datos recabados no permiten especular con que ese cambio conllevará una especie de renovación existencial de las actitudes, que seguirán marcadas por el pragmatismo, como se constata, por ejemplo, en la baja predisposición de los jóvenes a "pilotar" el propio entierro y funeral, lo que permite prever un estancamiento a medio plazo en el avance hacia las posiciones características del modelo neo-moderno de muerte. $\mathrm{O}$, en todo caso, que éste sólo pueda ser desarrollado en todas sus dimensiones por una minoría de la sociedad.

\subsection{INTERACCIÓN CON EL ÁMBITO HOSPITALARIO}

\footnotetext{
“¿Tiene uno que dar a luz a su propia muerte sin anestesia?”
} J.M. Coetzee

Fruto de los avances científico-técnicos y de la progresiva burocratización de la vida social, una de las tendencias más relevantes entre las que caracterizan a las sociedades desarrolladas en el ámbito del proceso de morir es el incremento relativo del número de fallecimientos en centros especializados (hospitales ${ }^{43}$, residencias de ancianos, hospices). Las consecuencias de este proceso, ya comentadas en los capítulos 2 y 3 de esta Tesis, han alertado a numerosos autores que han expresado diversas críticas al mismo presentándolo no como lo que se quiere hacer ver, el triunfo de los avances tecno-médicos, sino como lo contrario, como una muestra evidente de su impotencia y sobre todo, y paradójicamente, como paradigma de la irracionalidad que caracteriza a la voluntariamente asumida jaula de hierro hospitalaria. En

demanda de ayuda profesional especializada para superar el duelo y fomentado la creación de grupos de auto-ayuda, certificaba la orfandad de la población española en ese ámbito. El duelo, que no el luto como ella afirma, "de décadas pasadas se ha sustituido por una forzada normalización que pretende darle carpetazo al dolor en tiempo record. Y en vez de la paulatina asunción de la pérdida, que según los expertos dura entre 12 y 18 meses -nunca menos de 6 meses-, se recurre a los ansiolíticos, a la ayuda médica, cuando sólo el $2 \%$ de los duelos deriva en psicopatología”.

${ }^{43}$ En el caso de España, y como se recoge en el Capítulo 4 de esta Tesis, a pesar de la evolución creciente del número absoluto de personas fallecidas, durante las décadas de 1980 y 1990 se mantuvo constante el número relativo de las que morían en centros hospitalarios; así, en el año 2000, esa proporción fue del $33 \%$. Sin embargo, en la primera década del siglo XXI sí que se ha producido un aumento constante de la misma, aproximándose a la mitad del total de muertes en 2008 (47,26\%). 
efecto, reconociendo las indudables ventajas que el proceso de modernización ha aportado al control y tratamiento de la muerte y el morir (control y reanimación, atenuación y/o supresión del dolor, rapidez de actuación, etc.), centran no obstante su atención en los también innegables inconvenientes que ha conllevado. Así, y con carácter más general, se resalta que, a diferencia de épocas pretéritas, cada vez más el morir no tiene lugar en sociedad, no implica a ésta como un todo, sino que se produce en entornos sociales restringidos. En éstos, por un lado, se despoja a la muerte y el morir de cualquier significado social, afectando a lo sumo al grupo cada vez más restringido de allegados (Abad Márquez, 1994). Por otro lado, y como crítica más específica, la racionalización que caracteriza a las estructuras burocráticas que gestionan esos entornos implica que en última instancia se persigan en éstos metas incompatibles con el proceso de morir, por lo que, a semejanza de la producción mecanizada de cualquier producto, “los individuos que mueren están en el centro de una fábrica de valores y prácticas” (Rosel, 1978:54) que produce ambigüedad, incomunicación, anonimato, despersonalización, masificación, alienación, y que, en última instancia, les sustrae la última etapa de su vida. Crítica a la que se acompaña la denuncia de que, de hecho, una buena parte de las personas que mueren en las sociedades occidentales viven ese proceso inconscientemente, de forma parcial y superficial, y no como el fenómeno total que debería ser (Pacheco, 1987:30).

Esta limitación existencial se materializa además en un entorno social en el que la muerte y el morir, como se ha constatado en los datos hasta ahora mostrados del trabajo empírico realizado, se viven socialmente de una forma alejada, discreta, muda, casi clandestina, y en el mejor de los casos, con indiferencia, es decir, como que no existieran. Se subraya, además, que esta situación se retroalimenta con la inexistencia de un proceso socializador anticipatorio, lo que impide cualquier tipo de aprendizaje sobre lo que ocurre en las instituciones donde se muere. Éstas no socializan, no enseñan los roles adecuados a la situación, ni a los que mueren ni a muchos de los que interactúan con ellos, y no sólo a los allegados, sino también a muchos/as profesionales que trabajan en esas instituciones. De tal forma que los individuos se enfrentan al morir desprotegidos y aislados. A esto se añade, como señala Abad (1994), una “complicidad de silencio”, achacable también a las Ciencias Sociales, que contribuye "no sólo a la deshumanización del acto de morir, sino también, y con frecuencia, a un flagrante desprecio hacia los derechos fundamentales de los pacientes terminales. La preocupación por garantizar los derechos humanos en la vida social parece detenerse en el umbral de la muerte”. Obviamente, y para el caso de España, esta crítica de Abad ha perdido formalmente vigencia desde la entrada en vigor de la "Ley 41/2002 reguladora de la autonomía del paciente"; sin embargo, a efectos de este trabajo conviene seguir tomándola en consideración porque, por un lado, en el momento de realizar la encuesta para esta Tesis no existía tal Ley, y, por otro lado, porque, como ocurre con todas las leyes, su entrada en vigor no 
ha comportado su aplicación práctica efectiva, por ejemplo, por parte de algunos profesionales médicos obsesionados ideológicamente con la sacralidad de la vida ${ }^{44}$.

Interesa, en consecuencia, contrastar éstas y otras críticas recurrentes a la medicalización de la muerte y hacer un “diagnóstico” sobre la percepción de la misma, y más específicamente aún sobre la muerte hospitalaria, a partir de las opiniones que las personas encuestadas expresan sobre todo ello. Así, inicialmente se delimitan las percepciones que esas personas tienen sobre las distintas dimensiones de la medicalización de la vida y de la muerte, y, sobre esa base, posteriormente se examinan las preferencias de la población encuestada en lo relativo a cómo desearía que se produjese el proceso de morir en su caso y qué elementos consideraría necesarios que intervinieran en el mismo.

\subsubsection{MEDICALIZACIÓN DE LA VIDA Y DE LA MUERTE}

“Como enferma de cáncer, estoy viviendo simultáneamente en dos sociedades. Por lo que se refiere a la relación con la técnica, vivo en una sociedad moderna. Pero por lo que se refiere a la muerte, vivo y padezco los restos de una sociedad arcaica... a los que van a morir les obligan a someterse a códigos de conducta antiguos, ya caducos. No les dejan ser ciudadanos libres, mayores de edad, sino súbditos sin voluntad propia”

M.A. Durán

Dada la complejidad del proceso de medicalización de la vida y de la muerte, en este apartado se analizan las siguientes cuestiones entrelazadas: a) confianza en si la ciencia tiene capacidad para eliminar el proceso de muerte; b) adscripción a los valores dominantes cuando se relacionan con la muerte; c) medicalización de la muerte y; d) valoración global de los hospitales como nidos de muerte.

\footnotetext{
${ }^{44}$ Un ejemplo paradigmático de ello, en el que, entre otros factores, se han mezclado ideología religiosa fundamentalista, política neoliberal en contra de la sanidad pública, celos profesionales y afán de controlar el poder en la organización, ha sido el de las denuncias falsas, entre los años 2000 y 2005, por sedaciones excesivas con el objetivo de matar, en concreto a 400 personas, en las Urgencias del Hospital de Leganés. En este caso, y ya estando en vigor la "Ley de autonomía del paciente", el derecho de las personas moribundas y de sus familiares a decidir sobre el final de sus vidas fue la última preocupación para las personas que anónimamente realizaron las denuncias, para algunos de los/as profesionales del propio hospital que en el mejor de los casos actuaron con calculada ambigüedad, y que posteriormente ascendieron en la estructura de la organización, y, sobre todo, para los/as máximos responsables de la Consejería de Sanidad de la Comunidad de Madrid, en especial para el inefable Manuel Lamela, que utilizaron las falsas denuncias en su labor de zapa contra la sanidad pública (Montes y Güell, 2008). Como resultado de este disparate, y según se ha recogido reiteradamente en los medios de comunicación, no solo en dicho hospital, sino también en el resto de los de esa Comunidad Autónoma, el personal médico aplica desde entonces menores dosis de sedación a las personas moribundas para evitar denuncias; es decir, las personas que están muriendo han perdido su derecho a una muerte digna sin dolores y sufrimientos.
} 


\title{
5.6.1.1. CONFIANZA EN LA CIENCIA: ELIMINACIÓN DE LA MUERTE; INMORTALIDAD
}

\begin{abstract}
"Uno no puede eludir el conocimiento de lo que le aguarda dentro de poco. El silencio que le rodeará para siempre. Por lo demás, todo es lo mismo. Por lo demás uno es inmortal mientras vive”
\end{abstract}

P. Roth

Una de las consecuencias derivadas del proceso de secularización desarrollado en las sociedades occidentales ha sido el progresivo alejamiento de las explicaciones teológicas sobre la vida, y su sustitución por las desarrolladas desde el conocimiento centífico-tecnológico. Este cambio ha afectado también a la construcción social de la muerte y el morir, de tal forma que la ciencia ha sustituido a la religión en la búsqueda de la mayor utopía de la historia de la humanidad, es decir, en "la materialización de la esperanza ancestral de omnipotencia e inmortalidad del hombre” (Abad, 1994). A modo de ejemplo, y como una concreción desde la ciencia de esta universal utopía secular, Castells (1997:485-489) menciona que el sistema tecnológico, al permitir dilatar la separación entre la vida y la muerte, alimenta la creencia en esa separación, y en su ampliación, emergiendo con ello en el imaginario la idea de que se puede alcanzar "la eternidad en nuestro lapso vital".

En un contexto social en el que, como se ha comentado en capítulos anteriores de esta Tesis, aunque poco a poco van surgiendo dudas por los riesgos derivados de los avances científico-técnicos, la mayoría de la población no obstante se muestra confiada y favorable a dichos avances, por su contribución de hecho y potencial al incremento de la calidad de vida y, sobre todo, a la superación de las enfermedades; sin embargo, no perciben que dichos avances puedan llegar al punto de eliminar la muerte. Al menos eso es lo que declara la mayoría de la población encuestada, 8 de cada 10, que no cree que se pueda alcanzar la inmortalidad física con el concurso de la ciencia, frente a un 8\% que sí lo cree posible (pregunta 24e), Cuadro 5.24. No existen diferencias estadísticamente significativas por sexo ni por religiosidad, pero sí por edad. En este caso no parece que sea el ciclo vital sino el efecto generación el determinante de las mismas. Paradójicamente, la proporción de ancianos que creen en esa posibilidad, casi 2 de cada 10, triplica al de los otros dos grupos de edad. Por su parte, los adultos son los que más en desacuerdo se muestran con esa posibilidad, 9 de cada 10. Estas diferencias, no obstante, se entienden mejor si se tienen en cuenta los datos de la distribución por nivel de estudios. A medida que se incrementa éste, es decir, a medida que se está más informado y se es más consciente de, y crítico con, las posibilidades reales de la ciencia, más en desacuerdo se está con la posibilidad de que ésta elimine la muerte. Entre las personas entrevistadas, además de mostrar su escepticismo ante esa posibilidad, sobre todo no la consideran deseable, aunque en unos 
casos pensando en aprovechar al máximo la vida presente y en otros casos seducidos por las promesas de la otra vida:

- "Perdería un poco de sentido la vida, porque si ahora no aprovechamos el tiempo como algo extraordinario entonces si las personas no murieran cambiaría mucho todo. Si por ejemplo murieran a los ciento cincuenta años y en buenas condiciones de salud, desde luego no es lo mismo. Ahora, una persona que a los treinta años es joven $y$, antes, a los treinta ya era bastante mayor; en esta circunstancia a los ochenta serías joven... Cambiaría toda la perspectiva del tiempo y creo que a eso no se va a llegar, a evitar la muerte, yo creo que por muchos avances que haya así en un siglo vista, creo que no" (E1:9).

- "Eso es para los vampiros sólo" (E2:12). "El humano es mortal por naturaleza" (E2:14).

- "No, porque si después hay una vida mejor por muy feliz que sea ésta, siempre es una vida ajetreada y de sufrimiento. Siempre hay que trabajar y siempre hay enfermedades aunque se superen y siempre hay dramas. Lo de después se supone que es una vida mejor" (E3:11).

- J: "Es un proceso de vida y de muerte, nada más. Naces y desapareces. $Y$ en el reino animal y en el vegetal... El ciclo natural. O sea, no concibo una vida sin muerte. Eso no... además no me gusta... Porque sería aburridísimo. Y llegaría un momento en que dirías "ya se acabó; ya estoy hasta el gorro de estar aquí". Creo yo, vamos..

E: ..Lo de la inmortalidad entonces ¿no te parece una buena idea ser inmortal?..

J: ..No, no. En absoluto. Estoy totalmente convencido de ello. Para nada, vamos. En absoluto. Hombre, me gustaría una larga vida, pero no una larguísima vida" (E4:8).

Por otra parte, interrogada la población no ya sobre la inmortalidad del cuerpo si no la del alma (pregunta 30), el 30\% no cree en ella por considerarlo algo ilógico, mientras que un $70 \%$ sí que cree en la inmortalidad, Cuadro 5.24. No obstante, hay que señalar que en los ítems del cuestionario se recogían distintas posibilidades dentro de esa creencia, que en el cuadro aparecen reagrupadas en dos bloques. De un lado, la de aquellas personas que entienden la inmortalidad como proyección en los otros (“permaneciendo en la memoria de los otros”), lo que en sentido estricto no debe considerarse como tal, y, de otro lado, la de aquellas otras personas, algo más de 4 de cada 10, que consideran que no todo se acaba al morir, sino que el alma en sí misma continúa existiendo como tal después de la muerte, en el cielo o en el infierno, como energía vital o reencarnándose. 
CUADRO 5.24.: GRADO DE ACUERDO O DESACUERDO RESPECTO A SI EL SER HUMANO SERÁ CAPAZ DE ELIMINAR COMPLETAMENTE LA MUERTE A TRAVÉS DE LOS AVANCES CIENTÍFICOS. ¿CREE USTED EN LA INMORTALIDAD DEL ALMA? (\%)

\begin{tabular}{|l|c|c|c|c|c|c|}
\hline & \multicolumn{3}{|c|}{ ELIMINACIÓN DE LA MUERTE } & \multicolumn{3}{c|}{ INMORTALIDAD } \\
\cline { 2 - 7 } & ACUERDO & INDIFEREN & DESACUER & NO & SÍ* & SÍ** \\
\hline \multicolumn{1}{|c|}{ TOTAL } & 8,3 & 8,8 & 82,9 & 30,1 & 27,6 & 42,3 \\
\hline HOMBRES & 10,2 & 8,4 & 81,3 & 35,8 & 24,7 & 39,5 \\
MUJERES & 7,0 & 9,1 & 83,9 & 26,2 & 29,6 & 44,3 \\
\hline JÓVENES & 6,0 & 10,1 & 83,8 & 31,9 & 30,9 & 37,2 \\
ADULTOS & 6,3 & 3,5 & 90,1 & 34,8 & 26,5 & 38,6 \\
ANCIANOS & 18,6 & 17,7 & 65,8 & 16,7 & 20,8 & 62,5 \\
\hline EST. BÁSICOS & 12,7 & 15,9 & 71,5 & 25,4 & 20,6 & 54,0 \\
EST. MEDIOS & 11,8 & 8,2 & 80,0 & 28,9 & 26,5 & 44,5 \\
EST. UNIVERS. & 6,1 & 7,3 & 86,6 & 31,7 & 29,7 & 38,5 \\
\hline CRÉDULOS & 8,6 & 8,0 & 83,3 & 16,1 & 16,8 & 67,1 \\
CREYENTES & 6,8 & 12,9 & 80,4 & 27,2 & 34,6 & 38,2 \\
NO CREYENTES & 5,9 & 9,4 & 84,7 & 50,0 & 37,5 & 12,5 \\
INCRÉDULOS & 12,7 & 4,8 & 82,5 & 38,3 & 33,3 & 28,4 \\
\hline
\end{tabular}

*Sí, permaneciendo en la memoria de los otros; ** Sí, el alma continúa viviendo (en el cielo, reencarnándose, etc). Fte: Encuesta 2000. Elaboración propia

Centrando el análisis sobre esta segunda concepción de la inmortalidad, existen diferencias notables entre las categorías sociales sobre esta cuestión. Se ha señalado más arriba que el $67,8 \%$ de la población encuestada cree en la existencia del alma, y aunque no se ha mencionado, esa creencia está relacionada con las cuatro variables de control. Las mujeres, las personas ancianas, las de estudios básicos, y las crédulas y creyentes son las que más creen en la existencia del alma. Y, por ello, esas personas son las que más creen en una de las características esenciales atribuidas al alma: su inmortalidad. Así, por ejemplo, a medida que se incrementa el nivel de educación formal, se aprecia un incremento del escepticismo sobre esa creencia: más de la mitad de la población con estudios básicos la asume, el 54\%, frente al 38,5\% de los que tienen estudios universitarios. Por otra parte, y como es lógico, las diferencias más importantes se producen en las distribuciones por edad y religiosidad. En este sentido, el peso de las religiones, y sobre todo de la doctrina católica, es determinante en la asunción de esta creencia, al menos para dos tercios de los más creyentes. No obstante, en esa distribución se aprecian resultados que, si bien no cuestionan la influencia real de la religiosidad, sí que requieren alguna matización, concretamente el que casi 3 de cada 10 incrédulos la mantengan. La explicación de esta aparente paradoja está en que buena parte de las personas incluidas en esa categoría identifican el alma con una "energía vital que no se destruye cuando morimos". 
Finalmente, la influencia del nivel educativo y de la religiosidad se plasma en la distribución por edad, en la que se observa que entre los ancianos son mayoría los que creen en la inmortalidad, 6 de cada 10, y relativamente pocos los que no creen en ella (16\%). Las distribuciones de jóvenes y adultos son similares entre sí y en ambas son mayoría, relativa, los que creen en la inmortalidad, casi 4 de cada 10.

\subsubsection{ADSCRIPCIÓN A LOS VALORES DOMINANTES: “AGEISMO”}

"El aspecto caricaturesco de la vida aparece siempre que se consume la embriaguez de la ilusión”

A. Nin

La modernización iniciada hace dos siglos supuso un cambio global respecto a las sociedades tradicionales, proceso en el que emergieron, hasta hacerse hegemónicos, toda una serie de nuevos valores centrados en la importancia del logro económico, a la par que se diluían los valores comunitarios. De tal forma que fueron interiorizándose por la población hasta convertirse en lo "normal", o incluso lo "natural", de toda interacción social valores individualistas como responsabilidad, racionalidad instrumental, cálculo, previsión, rentabilidad, aspiración de éxito, competencia, esfuerzo, disciplina, aplicación y dedicación (Tezanos, 2001). Valores que auparon a la cúspide de los valores sociales a la Vida, la Libertad, la Actividad, la Utilidad, el Pragmatismo, el Consumo, y..., la Juventud. Valores que inevitablemente desembocaron, por ser su antítesis, en un cambio de actitudes hacia los ancianos, "que constituyen una suma de pérdidas irreversibles y de anormalidades” (Thomas, 1992:155), y especialmente hacia los moribundos, a los que se ha desplazado hacia la periferia de la vida social: la Muerte Social denunciada por Thomas, Ariès, Elias o Rice.

En el epicentro de esos valores está situada, por tanto, la creciente mercantilización de la vida social por la que se reducen las relaciones sociales a la unidimensionalidad de las relaciones económicas. Este proceso, como no podía ser de otra forma, ha incidido asimismo en los ámbitos de la salud, la enfermedad y la muerte. Así, por ejemplo, desde el último cuarto del siglo XX han proliferado propuestas muy agresivas para contrarrestar el temor provocado por la aceleración del envejecimiento demográfico, o se han desarrollado actuaciones discriminatorias de política sanitaria bajo la excusa de escasez de recursos, que ponen de manifiesto de manera explícita y radical la hegemonía de esos valores dominantes.

\footnotetext{
${ }^{45}$ Concepto acuñando en 1969 por el gerontólogo R. Butler para denunciar la elaboración de estereotipos y la discriminación sistemática contra las personas de edad avanzada.
} 
Ya se ha mencionado la identificación de la población encuestada con el principio de realidad. Sin embargo, resulta interesante cotejar la identificación y extensión de esos valores dominantes entre dicha población a partir de su opinión sobre diversos aspectos en los que esos valores pueden incidir en el proceso de morir y muerte. En su conjunto, mayoritariamente la población encuestada no se identifica, entre 8 y 9 de cada 10, con la primacía y exclusividad de los criterios más extremos (básicamente económicos) como reguladores de la vida social en la fase final de la vida de los individuos, Cuadro 5.25. Así, se rechaza la selección de enfermos por criterios pragmáticos de eficiencia económica ${ }^{46}$ (pregunta 24a), o, por lo mismo, el que no se dediquen recursos públicos para el tratamiento de personas que desarrollan actividades que pueden comportar riesgos para la propia salud (deportes de riesgo, fumar, beber alcohol, etc.) (pregunta 24c). En el primer caso, no existen diferencias significativas entre las categorías sociales, aunque se aprecia que el rechazo no es absoluto ya que un $15 \%$ de las personas encuestadas se muestra favorable a la selección de enfermos, lo que indica la existencia de un germen social que se identifica con esa lógica. Como en el caso del varón incrédulo entrevistado quien, reconociendo que no le gustaría ser quien tomara las decisiones, admite que podrían ser necesarias:

- "Posiblemente en un momento determinado sí habría que decidir, pero son situaciones límite... Para mí eso es decidir sobre quién tiene que vivir. Yo no entro ahí. Para mí es muy complicado. Yo no puedo aceptar el hecho de que, porque este señor sea alcohólico, pues ; hala!, está en pecado y tiene que morir por ello, y este señor que no es alcohólico, que es buena persona y es buen chico, tiene que vivir... Pues es que no lo sé, como yo no me he visto en ese caso no tengo opinión. Hombre, si la situación económica no lo permite no puedes hacer otra cosa, creo yo, en un momento determinado. En la situación de esa gente tendrían que buscar los recursos necesarios, pero si no los tienen, pues no hay tu tía. Así de rotundo. Es que no lo sé. Es que no podrían... ¿seleccionar? Seleccionar... al que le toque, tela" (E4:10).

En el segundo caso, en el que el rechazo es aún mayor, superando el 90\% en algunas categorías sociales, la población relativa que se muestra favorable es menos de la mitad que en la cuestión anterior. En este caso, además, sí que existen diferencias sociales relevantes, ya que los hombres, las personas ancianas y las que tienen estudios básicos rechazan en mayor medida la utilización de recursos públicos en el tratamiento de enfermos o accidentados por desarrollar actividades de riesgo. Por el contrario, las mujeres, los jóvenes y los que tienen estudios universitarios se manifiestan más favorables a ello. Resultados sobre los que cabe especular algún tipo de explicación dado que, además, cada categoría social otorga a esas actividades de

${ }^{46}$ Desde la década de 1990 se han producido diversas situaciones en diferentes países europeos, especialmente en Reino Unido, en las que se ha negado tratamiento o la posibilidad de trasplante de órganos a determinados enfermos alegando criterios de eficacia ante la falta de disponibilidad de recursos para todos. Así, se ha negado ese tipo de tratamiento a personas obesas, alcohólicas, fumadoras o de edad. 
riesgo distintos grados de importancia en su vida (pregunta 15) ${ }^{47}$. Así, parece lógica la posición de los ancianos (la mayoría de ellos con estudios básicos), puesto que desarrollan en menor medida ese tipo de actividades de riesgo, pueden percibir que dedicar recursos públicos escasos a tratamientos para paliar los efectos de esas actividades supone mermar lo que se dedica a la atención de las personas mayores, además de que entre sus prioridades axiológicas están la honestidad y la responsabilidad, es decir, la asunción de las consecuencias de los propios actos, por lo que sería una manifestación aleccionadora con afán de ejemplaridad. No piensan así sin embargo los componentes del grupo de discusión quienes, reconociendo que esas actividades de riesgo constituyen un placer para la vida, y que pueden comprometer la vida de otras personas, están de acuerdo con que se dedique dinero público al tratamiento de esas personas, pero con condiciones:

- “- De hecho se están muriendo... para ellos tiene que ser un placer grande porque si no, no se expondrían.

- Si no, no se haría, porque lo hacen voluntariamente de una manera... además lúdica, para pasarlo bien.

- Ellos se exponen la vida porque es un placer para ellos y otros exponen la vida, como los de las pateras, para sobrevivir.

- Sí, y otros exponen la vida fumando, o bebiendo.. o haciendo deporte, porque mucha gente se ha muerto haciendo deporte.

$\ldots$

- A mí lo que más rabia me da de estos que van a la nieve, de antes de Navidad y de ahora, es que luego el gasto que suponen los rescates esos.

- Y el riesgo que tiene, porque van a rescatar a unos al Naranjo de Bulnes, acordaros, y se estrelló el avión.

- Es que se ponen en riesgo personas... los voluntarios, los bomberos, los del helicóptero.., toda ésa gente que interviene ahí supone un gasto enorme enorme para la sociedad.

...

- Hombre, el Estado tiene que estar... salir a todo. El Estado no puede decir "tú, a ti no te...".

- Sí, pero a esa gente que hace un deporte de riesgo, que además vale mucho dinero, cuando van a sacar.. yo sería partidaria de esta cosa: cuando van a sacar la licencia, cobrarles un extra.

- Hacerles un examen.

- Que pagaran un canon del riesgo que corren. Oye, yo, sí” (GD1:4-5).

La asunción de valores postmaterialistas en mayor medida entre los jóvenes, junto a la propia situación económica, puede explicar en parte la opinión de éstos (y buena parte de los que tienen estudios universitarios). Más complicado es encontrar explicaciones para la diferencia por género, salvo que esté asentada en una mayor tolerancia y empatía de las mujeres, y en la mayor identificación con los valores modernos dominantes por parte de los hombres, en

\footnotetext{
${ }^{47}$ Entre la población encuestada las consideran bastante o muy importantes en su vida los hombres, $63,5 \%$, los jóvenes, $70,9 \%$, y los de estudios universitarios, $67,4 \%$, mientas que esa importancia es menor entre mujeres, $56,2 \%$, ancianos, $37 \%$, y los que tienen estudios básicos, $33 \%$.
} 
especial con la competitividad y la necesidad de autoafirmación ${ }^{48}$. Por ejemplo, en el caso del joven varón entrevistado se observa su tolerancia al desarrollo de actividades de riesgo en general, sean deportes de riesgo o el fumar, a la par que recalca la necesidad de asumir la responsabilidad sobre los propios actos:

"Pero aún así hay gente aquí en España que consume tabaco y saben que es perjudicial y no se lo pueden quitar. Cada uno es libre, juega con su vida de una manera, y hay quién prefiere matarse fumando un cigarrillo que no conduciendo. Somos así de malos con nosotros mismos” (E1:4).

“... creo que cada persona tiene que ser consciente de lo que está haciendo con su vida y el consumo de estos productos y deportes de riesgo pues, cada persona tiene que ser consciente de lo que se está jugando y lo que la sociedad le pide de responsabilidad a esa persona. Quien más pierde es la propia persona” (E1:9).

Por su parte, la joven no creyente entrevistada muestra su rechazo a la retirada de recursos públicos sanitarios por razones fiscales:

- "Yo no estoy de acuerdo con eso, porque en el caso del tabaco y la bebida yo también estoy pagando esos impuestos, hay que asumirlo. El Estado no puede excusarse porque también ha estado recaudando dinero a costa suya... Si fuera una guerra y hubiera un hospital que sólo se pudiera operar a gente que tuviera posibilidades de sobrevivir, pues ahí cambiaría el tema porque es una situación extrema. Pero lo que es un sistema de sanidad pública como el que tenemos, no me parece admisible" (E2:9).

Mientras que el adulto incrédulo también muestra su rechazo pero en su caso por solidaridad interesada:

- "Es algo que ves frecuentemente y lo ves algo normal, desde luego lo que a mí no me importa es que lo que yo pueda producir en cuanto a dinero se refiere vaya a parar a un determinado señor que se le ha cruzado la neura y se ha pegado un galletón con el coche, yo por lo menos no retiro mi parte de ese dinero que al final es esto para que este señor se muera por gilipollas, pues no, que se le cure... En el caso del alcohol; pues un gilipollas también. Y en el caso del tabaco; somos otros gilipollas” (E4:11).

El rechazo de las personas encuestadas es aún más intenso ante propuestas discriminatorias contra la población anciana-ageismo-, Cuadro 5.26. Entre estas propuestas se incluyeron las formuladas por R. Launm, gobernador de Colorado (USA): "Las personas de edad afectadas por enfermedades mortales tienen el deber de desaparecer y dejar su lugar a la otra sociedad, la de los niños” (pregunta 24b), y la realizada con el propósito de epatar y provocar debate sobre las consecuencias futuras del envejecimiento demográfico, como ya se ha comentado, por el profesor de ética D. Callahan: "Se deben limitar la búsqueda y el desarrollo

${ }^{48}$ Sobre la satisfacción de esa necesidad de autoafirmación a través de las prácticas de riesgo, Morin (1974a:75-78) afirma que las "participaciones en actividades de riesgo poseen en sí mismas una fuerza extraordinaria,..., el individuo que se entrega a ellas se olvida de sí mismo y de su muerte... Porque ante el riesgo de muerte afronta el horror de la muerte y se encuentra capaz de vencerla. Porque entonces se trata, no ya de una abdicación del individuo, sino de una autoafirmación heroica. Autoafirmación tanto más rica cuanto que el héroe nunca se ha sentido tan vigorosamente <<el mismo >> como en el momento del riesgo, sintiéndose vivir <<intensamente>>, sintiéndose íntimamente ligado a una realidad que le supera". 
así como las innovaciones tecnológicas tendentes a la conservación de la vida, y no dar tratamiento de esta naturaleza a las personas mayores de 75 años” (pregunta 24f). En ambos casos, nueve de cada diez encuestados estaban en desacuerdo.

CUADRO 5.25.: GRADO DE ACUERDO O DESACUERDO CON LAS SIGUIENTES IDEAS (\%).

\begin{tabular}{|c|c|c|c|c|c|c|}
\hline & \multicolumn{3}{|c|}{$\begin{array}{l}\text { La escasez de recursos económicos } \\
\text { públicos obliga a seleccionar, para su } \\
\text { tratamiento, sólo a aquellos enfermos } \\
\text { que tengan perspectivas ciertas de } \\
\text { sobrevivir }\end{array}$} & \multicolumn{3}{|c|}{$\begin{array}{l}\text { Las personas que desarrollan } \\
\text { comportamientos de riesgo para su vida } \\
\text { no tienen derecho a que se dediquen } \\
\text { parte de los recursos públicos escasos } \\
\text { para su tratamiento cuando enferman o } \\
\text { se accidentan }\end{array}$} \\
\hline & ACUERDO & INDIFER. & DESACUER & ACUERDO & INDIFER. & DESACUER \\
\hline TOTAL & 15,0 & 4,9 & 80,1 & 7,2 & 4,7 & 88,2 \\
\hline HOMBRES & 13,8 & 4,8 & 81,3 & 10,8 & 5,4 & 83,7 \\
\hline MUJERES & 15,6 & 4,9 & 79,4 & 4,6 & 4,2 & 91,3 \\
\hline JÓVENES & 16,3 & 6,1 & 77,7 & 4,0 & 4,5 & 91,4 \\
\hline ADULTOS & 11,5 & 3,6 & 85,0 & 7,9 & 4,3 & 87,7 \\
\hline ANCIANOS & 18,0 & 4,2 & 77,8 & 14,3 & 5,7 & 80,0 \\
\hline EST. BÁSICOS & 14,1 & 6,3 & 79,7 & 15,3 & 6,8 & 77,9 \\
\hline EST. MEDIOS & 18,6 & 4,7 & 76,8 & 10,5 & 4,7 & 84,9 \\
\hline EST. UNIVERS. & 13,9 & 4,6 & 80,3 & 4,2 & 4,2 & 91,6 \\
\hline CRÉDULOS & 14,2 & 4,7 & 81,1 & 6,1 & 0,7 & 93,3 \\
\hline CREYENTES & 13,7 & 5,7 & 79,7 & 6,9 & 2,3 & 90,8 \\
\hline NO CREYENT. & 14,1 & 3,5 & 82,3 & 2,4 & 7,1 & 90,6 \\
\hline INCRÉDULOS & 14,3 & 4,8 & 80,9 & 9,5 & 4,8 & 85,7 \\
\hline
\end{tabular}

Fte: Encuesta 2000. Elaboración propia

No obstante, la homogeneidad no es absoluta apreciándose diferencias estadísticamente significativas por sexo, edad y nivel de estudios, no así por religiosidad, ya que el rechazo/aceptación a ambas proposiciones es independiente de ella. Como en las dos afirmaciones anteriores, ante estas dos proposiciones los hombres muestran nuevamente mayor grado de acuerdo con las mismas que las mujeres, quizá por los mismos motivos que se adujeron para aquéllas. También por las mismas razones que las señaladas en las anteriores afirmaciones para los jóvenes, y estudiantes universitarios, se puede explicar que sean las categorías sociales que más rechazan la propuesta eugenésica de necesidad de renovación generacional. A esas razones, y su lejanía de los 75 años, cabe achacar que sean una de las dos categorías sociales, junto con los incrédulos, que menos rechazan y más indiferentes se muestran ante el control de la investigación médica para los más ancianos. Por otra parte, siendo lógico el rechazo de la población anciana a la eliminación de la investigación y de los tratamientos para las personas de edad, sorprende que más de 1 de cada 10, y casi el 15\% de los 
que tienen estudios básicos, se muestren de acuerdo a la proposición de eugenesia etaria. Cabe especular en este caso, por un lado, con razones ligadas al ciclo vital como la percepción de la proximidad inevitable del cierre del mismo, junto con, por otro lado, razones ligadas a factores generacionales, concretamente, su mentalidad más tradicional y comunitaria, más pegada a la naturaleza. Como cuando Orín, en La balada de Narayama (Shohei Imamura, 1983), va a cumplir sesenta años y, rompiéndose los dientes, fuerza a su hijo Tatsue a que le lleve a morir al monte Narayama, buscando eliminar una boca que alimentar, cumpliendo así con una tradición que había instituido esa práctica de renovación generacional.

CUADRO 5.26.: GRADO DE ACUERDO O DESACUERDO CON LAS SIGUIENTES IDEAS (\%).

\begin{tabular}{|l|c|c|c|c|c|c|}
\hline & \multicolumn{3}{l|}{$\begin{array}{l}\text { “Se debe limitar la búsqueda y el } \\
\text { desarrollo así como las innovaciones } \\
\text { tecnológicas tendentes a la conservación } \\
\text { de la vida, y no dar tratamiento de esta } \\
\text { naturaleza a las personas mayores de 75 } \\
\text { años” }\end{array}$} & $\begin{array}{l}\text { "Las personas de edad afectadas por } \\
\text { enfermedades mortales tienen el deber } \\
\text { de desaparecer y dejar su lugar a la otra } \\
\text { sociedad, la de los niños” }\end{array}$ \\
\cline { 2 - 8 } & ACUERDO & INDIFER. & DESACUER & ACUERDO & INDIFER. & DESACUER \\
\hline TOTAL & 4,4 & 5,1 & 90,4 & 6,4 & 2,9 & 90,6 \\
\hline HOMBRES & 7,3 & 4,2 & 88,5 & 7,8 & 5,4 & 86,7 \\
MUJERES & 2,4 & 5,7 & 91,8 & 5,3 & 1,2 & 93,4 \\
\hline JÓVENES & 5,1 & 8,1 & 86,8 & 4,0 & 3,5 & 92,4 \\
ADULTOS & 5,0 & 2,9 & 92,1 & 6,4 & 2,1 & 91,5 \\
ANCIANOS & 1,4 & 1,4 & 97,3 & 12,8 & 2,9 & 84,3 \\
\hline EST. BÁSICOS & 10,9 & 0,0 & 89,1 & 14,6 & 3,2 & 82,2 \\
EST. MEDIOS & 4,7 & 3,5 & 91,7 & 9,5 & 4,7 & 85,9 \\
EST. UNIVERS. & 2,7 & 6,9 & 90,4 & 3,4 & 2,3 & 94,3 \\
\hline CRÉDULOS & 3,4 & 4,0 & 92,7 & 7,5 & 5,4 & 87,1 \\
CREYENTES & 3,4 & 2,3 & 94,3 & 5,8 & 2,3 & 91,9 \\
NO CREYENTES & 3,6 & 8,3 & 88,1 & 4,8 & 7,1 & 88,3 \\
INCRÉDULOS & 11,1 & 7,9 & 81,0 & 9,5 & 3,2 & 87,3 \\
\hline
\end{tabular}

Fte: Encuesta 2000. Elaboración propia

\subsubsection{MEDICALIZACIÓN DE LA MUERTE}

“Todavía tiene el sobre en sus manos. En su interior deben de estar dos placas de tórax. Fotos azules, transparencias duras, cortantes. El cuerpo de su padre convertido en un dibujo difuso donde, sin embargo, se puede retratar la muerte con cruel nitidez"

A. Barrera Tyszka 
Como se ha comentado en el Capítulo 2 de esta Tesis, una de las dimensiones más importantes de la modernización ha sido el proceso de medicalización de la vida social en tanto que, entre otras consecuencias, ha contribuido a la construcción de la mentalidad moderna sobre la vida y la muerte. En efecto, como derivación del mismo, la comprensión de éstas se ha alejado de interpretaciones basadas en designios teocráticos para ser percibidas bajo el prisma de causalidades racionales que pueden ser explicadas científicamente. Por otra parte, una de las consecuencias más criticadas de ese proceso, en especial por la incidencia del mismo sobre el morir y la muerte, ha sido, y es, que ésta haya perdido su carácter natural e inevitable y se la perciba como una enfermedad extrema susceptible de ser controlada por la actuación médica. En el fondo de las críticas subyace el hecho cada vez más evidente de la separación del ser humano occidental de la naturaleza "para moverse en el plano artificial". A esta creciente artificialidad de la vida sólo le puede corresponder un "creciente sentir de toda muerte como muerte artificial” (López Aranguren, 1981:300).

La opinión de las personas encuestadas no corrobora esas críticas, ya que alrededor de seis de cada diez no las comparten, frente a un quinto que sí que está de acuerdo con ellas, Cuadro 5.27. Para contextualizar el análisis de estos resultados, conviene recordar de nuevo en este punto que, en el año 2000, "sólo" murieron en un hospital el 30\% del total de fallecidos en ese año en España. El análisis desagregado muestra la existencia de relaciones significativas con tres de las variables de control: sexo, edad, nivel de estudios. En efecto, casi 2 de cada 3 mujeres o jóvenes, y el $60 \%$ de los de estudios medios o universitarios, rechazan la idea de la medicalización de la muerte, frente al 50\% de los hombres, adultos o ancianos, y personas con estudios básicos.

Estos resultados son sociológicamente muy relevantes por diversos motivos: a) parece lógico el resultado correspondiente a la distribución por edad, ya que los jóvenes son los que menos contacto tienen con la muerte (ven lejos su propia muerte y apenas están socializados sobre ella), además de que son los que menos participan del cuidado de los enfermos próximos en el hogar y en los hospitales, por lo que son menos conscientes de todo lo que ocurre en ese proceso y probablemente lo tengan ya asumido como algo normal, como una sucesión dada de procedimientos de cuidado familiar, en el hogar, o técnicos, en el hospital, que no cabe cuestionar. La evolución en el ciclo vital conlleva inevitablemente un cambio de perspectiva en esta cuestión, como se observa en su mayor aceptación por parte de la población adulta, aunque no en la población anciana, entre la que 3 de cada 10 no saben que contestar; b) señala J. A. Marina que una de las razones por las que los hombres han temido históricamente a las mujeres, entre otros motivos, ha sido porque éstas trataban con los moribundos y preparaban a los muertos. En efecto, en la sociedad castellanoleonesa, como en el conjunto de la española, son 
las mujeres las que en mayor proporción se encargan del cuidado de la población anciana, también cuando está internada en instituciones hospitalarias. Quizá porque en el año 2000 la mayoría de los fallecimientos se produjeron en el propio hogar, y porque, a pesar de que los cambios funcionales producidos en esas actividades tanáticas, que han ido pasando de las mujeres a organizaciones hospitalarias y funerarias, ellas siguen atendiendo a las personas enfermas y moribundas también en los hospitales, las mujeres mantienen en mayor medida que los hombres, 10 puntos porcentuales de diferencia, la percepción de que la muerte no ha perdido su carácter natural y es tratada como una enfermedad, y c) el nivel educativo también ayuda a dilucidar sobre esta cuestión, ya que hace que se reduzca la proporción de los indecisos (No Sabe) a menos de la mitad entre las categorías extremas. En efecto, a medida que aumenta el nivel de estudios se reduce el peso relativo de los indecisos, a la par que aumenta la proporción de los que no consideran que la muerte haya de ser tratada como una enfermedad. Parece obvia la influencia de la población joven en este resultado.

En consecuencia, al margen de si el proceso de medicalización de la muerte es real o no, la población encuestada no tiene conciencia de que el mismo se esté produciendo. Además, si se proyecta este interrogante de cara al futuro, y aun con una sociedad en la que las sucesivas generaciones alcancen un mayor nivel de educación formal, se puede prever que no se desarrollará una dinámica crítica en la opinión pública favorable a cambios en este ámbito, si no son para reforzarlo. Si hay medicalización de la muerte no parece que a la gente le preocupe, al contrario. Lo que asimismo se ha constatado en las entrevistas realizadas:

- "También se mueren en los hospitales, porque se evita morir precisamente, se va al hospital para evitarlo. No sé, me parece que hay circunstancias que obligan a ello pero a mí me parece lo más correcto y lo más conveniente el que se acuda" (E1:11).

- "Yo creo que no, porque la muerte yo creo que es un proceso doloroso, entonces, todo lo que ayude a disminuir el dolor y hacerlo llevadero, me parece positivo. Hombre, lo de alargar ya la vida.., con aparatos., cuando ya no eres consciente, y demás, no, eso ya no me parece positivo, pero siempre que puedas seguir viviendo, con unas facultades mínimas, yo creo que sí, vamos, no me parece excesivo la medicalización, y en el nacimiento, igual. Si gente que antes no podía tener hijos y ahora, gracias a los avances médicos, puede hacerlo pues por qué no, simplemente el proceso está cambiando, igual que está cambiando todo en la sociedad. Ahora, lo que es alargar la vida artificialmente, no, pero ayudar en el proceso de morir sí que me parece, sí, sí, es que es otro acontecimiento de la vida y por qué no se va a tratar de mejorarlo en la medida de lo posible, es que entonces para eso pues dices "mira, es que no vamos a ir en coche a los sitios, vamos a ir andando, porque es el proceso natural”, y yo que sé, así con todo, no sé, todos los avances científicos afectan a todas las áreas de la vida" (E2:16). 
De hecho, al interrogar a la población encuestada sobre si consideraban deseable la evolución medicalizadora de la muerte (pregunta 39), se observa que lo que predomina es la indefinición, más de la mitad de la población encuestada, Cuadro 5.27. Este resultado es indicativo de que no es un tema sensible para población encuestada y, sobre todo, de que no tienen una imagen negativa del mismo. Además, 1 de cada 5 encuestados/as se muestra favorable al proceso de medicalización de la muerte, mientras que el 30\% de la población encuestada no lo considera deseable. Entre los que se muestran partidarios, aducen la mayor eficacia organizativa y la reducción de riesgos sanitarios e higiénicos como las razones que justifican su predisposición. Por otra parte, existen diferencias significativas entre las categorías por sexo, edad y nivel educativo. Quizá por ser los que menos perciben el proceso de medicalización de la muerte, las mujeres, los jóvenes y los que tienen estudios universitarios son los más indecisos al avance de ese proceso, en una proporción cercan al 60\%; mientras que los hombres, los ancianos y los que tienen menor formación académica, lo tienen más claro y simultáneamente presentan las proporciones más altas de aceptación y rechazo, siempre mayores las segundas, al proceso de medicalización de la muerte.

CUADRO 5.27.: ¿CREE USTED QUE LA MUERTE HA PERDIDO SU CARÁCTER NATURAL Y ES TRATADA MÉDICAMENTE COMO SI FUESE UNA ENFERMEDAD?. ¿DESEA USTED LA MEDICALIZACIÓN DE LA MUERTE? (\%)

\begin{tabular}{|l|c|c|c|c|c|c|}
\hline & \multicolumn{2}{|c|}{ MUERTE COMO ENFERMEDAD } & \multicolumn{3}{c|}{ DESEO DE MEDICALIZACIÓN } \\
\cline { 2 - 7 } & Sí & NO & NO SABE & Sí & NO & NO SABE \\
\hline \multicolumn{1}{|c|}{ TOTAL } & $2, .5$ & 58,6 & 19,9 & 19,2 & 29,7 & 51,1 \\
\hline HOMBRES & 30,5 & 52,7 & 16,8 & 22,7 & 35,6 & 41,7 \\
\hline MUJERES & 15,5 & 62,5 & 19,9 & 16,8 & 25,6 & 57,6 \\
\hline JÓVENES & 17,9 & 63,8 & 18,4 & 19,7 & 21,2 & 59,1 \\
ADULTOS & 30,3 & 53,5 & 16,2 & 17,5 & 34,3 & 48,2 \\
ANCIANOS & 15,0 & 55,0 & 30,0 & 21,2 & 43,6 & 35,2 \\
\hline EST. BÁSICOS & 15,9 & 49,3 & 34,8 & 22,6 & 43,5 & 33,9 \\
EST. MEDIOS & 23,9 & 60,2 & 15,9 & 16,6 & 35,7 & 47,6 \\
EST. UNIVERS. & 22,2 & 60,5 & 17,2 & 19,2 & 24,3 & 56,5 \\
\hline
\end{tabular}

Fte: Encuesta 2000. Elaboración propia

En resumen, aún no siendo las percepciones mayoritarias entre los hombres, las personas de más edad y las de estudios básicos, sí son estas tres categorías sociales las que se manifiestan en mayor medida conscientes del proceso de medicalización de la muerte y muestran mayor rechazo a la desarrollo del mismo. 


\subsubsection{LOS HOSPITALES COMO NIDOS DE MUERTE}

"Fernando Silva dirige el hospital de niños, en Managua

En vísperas de Navidad, se quedó trabajando hasta muy tarde. Ya estaban sonando los cohetes, y empezaban los fuegos artificiales a iluminar el cielo, cuando Fernando decidió marcharse. En su casa lo esperaban para festejar.

Hizo una última recorrida por las salas, viendo si todo quedaba en orden, y en eso estaba cuando sintió que unos pasos lo seguían. Unos pasos de algodón: se volvió y descubrió que uno de los enfermitos le andaba atrás. En la penumbra, lo reconoció. Era un niño que estaba solo. Fernando reconoció su cara ya marcada por la muerte y esos ojos que pedían disculpas o quizá pedían permiso. Fernando se acercó y el niño lo rozó con la mano:

- Decile a... -susurró el niño-. Decile a alguien, que yo estoy aquí.”

E. Galeano

Independientemente de la variable de control elegida, la mayor parte de la población encuestada, dos tercios de la misma, cree que la mayoría de los fallecimientos se producen en el hospital, mientras que 1 de cada 5 afirma que tienen lugar en casa (pregunta 42). Datos de peso en una creencia errónea que nuevamente certificarían que la medicalización de la muerte no es un tema especialmente polémico para la mayoría de la población encuestada, ya que, cierta o no, lo que es evidente es que no genera ningún tipo de tensión social. Por otra parte, y de forma más concreta, en los Cuadros 5.28. y 5.29. se recogen las respuestas a cuatro cuestiones que permiten esclarecer si la población encuestada (el ciudadano medio de Castilla y León) comparte los análisis que valoran negativamente el papel jugado por las instituciones hospitalarias en la etapa final de la vida de los individuos: inseguridad, alienación, deshumanización y ocultación de la muerte. La mayoría de las personas encuestadas, 8 de cada 10, están (bastante o muy) de acuerdo en que los hospitales dan seguridad porque son los únicos lugares donde se aplican los tratamientos médicos más adecuados hasta el último instante de la vida de una persona y sobre todo controlan el dolor (pregunta 44a). Así, el poder y la tecnología localizados en los hospitales hacen que la población perciba a los mismos como un "gran fetiche” y que los utilice como una especie de "lenitivo moral", puesto que acudir a ellos equivale a haber hecho todo lo posible por la persona moribunda (Basterra, 2006:62). Como resaltan la joven no creyente y el varón incrédulo:

- "Claro, hoy por hoy, sí, si te mueres de una enfermedad degenerativa, o de un cáncer o algo así, claro, es que los hospitales son los sitios más adecuados, sí que estoy de acuerdo, ahora, si te mueres de un ataque al corazón, lo mismo te da morirte en un hospital que en otro sitio. Sí, para ese tipo enfermedades sí que estoy de acuerdo" (E2:18).

- "Hombre, en cuanto que te puedan dar la seguridad de evitarte el dolor me parece lógico en un hospital... si es donde te puedan evitar el dolor, por supuesto. O por lo menos morirte de una forma más relajada, pero no necesariamente porque el hospital de la seguridad sino porque allí es donde están los medios para darte esa seguridad... Sí, a mí lo que más me joroba en esta vida es el dolor, el dolor que pueda tener uno, a mi lo que me gusta es vivir bien, si voy a vivir fastidao, mejor sea en un hospital a que sea en casa. Yo creo que te daría más seguridad un hospital, eso sí que es verdad.... O sea, que si estás en un hospital y 
te duele mucho también, te duele la misma intensidad de dolor, yo creo que estás más, te sientes más seguro en un hospital, pero porque ahí tienen los medios, los posibles medios para solucionártelo ” (E4:18).

En esta apreciación no se observan diferencias por género aunque sí son significativas las que existen por edad, nivel de estudios y religiosidad. Precisamente, son los que tienen más cercanos el momento final de la vida, los ancianos (mayoritariamente de estudios básicos y con los mayores niveles de religiosidad), los que más de acuerdo se muestran con la seguridad aportada por los hospitales en el momento de morir. Quizá porque, sea cual sea el desenlace final en caso de hospitalización, se perciba que pronto se va a necesitar ayuda para afrontar sin dolor y con la mayor y mejor atención posible el momento final de la vida, o, al contrario, porque se tenga la esperanza de que sólo en el hospital existe alguna posibilidad de retrasar ese momento final con un "milagro" médico que revierta la situación. Siendo mayoritariamente partidarias de la seguridad aportada por los hospitales, las personas que se muestran menos favorables a esa proposición son las jóvenes, con más del 10\% de indiferentes o de detractores, y las incrédulas, entre las que casi 1 de cada 4, no participan de ella.

Por otro lado, la población encuestada se muestra dividida en sus opiniones cuando se plantea la cuestión de la alienación de los moribundos, que son reducidos a meros enfermos estandarizados y forzadamente silentes (pregunta 44c). Cuatro de cada diez están de acuerdo en que los hospitales no permiten al individuo conducir la última etapa de su vida, frente a otros cuatro que están en desacuerdo con esa idea. Aunque las diferencias por sexo (los hombres están más de acuerdo que las mujeres) y religiosidad (se está más de acuerdo cuanto menor es el nivel de religiosidad) son importantes, no son estadísticamente significativas. Sí lo son, en cambio, las existentes entre las categorías etarias y las de nivel educativo. Mientras los adultos y los de estudios medios son los que más creen en la existencia de alienación en la muerte hospitalaria, alrededor de la mitad de la población en cada caso, más de la mitad de los ancianos y el 45\% de los que tienen estudios básicos rechazan esa idea. Por su parte, la distribución entre los jóvenes está más equilibrada entre las tres opciones, aunque la mayoría de ellos la rechaza, 4 de cada 10, casi 1 de cada 3 está de acuerdo y a 1 de cada 5 le es indiferente. En el caso de la joven no creyente el rechazo es explícito:

- "Si no estás en el hospital dónde estás, si estás en el hospital es porque no puedes conducir tu vida, porque ya estás muy grave y.., y ya no., los que ahora están en los hospitales antes estarían en casa, echados en la cama, o sea, que tampoco creo que haya mucha diferencia, en ese sentido, entre la gente que la meten en el hospital y empiezan a hacer pruebas y pruebas, a lo mejor ahí sí que le quitan un poco de autonomía y eso, pero si ya está, si eres un enfermo terminal te da igual estar en hospital que en la cama, no vas a poder ya aprovechar tus últimos días, no creo que sea la culpa de los hospitales” (E2:18). 
Sin embargo, el adulto incrédulo sí que está de acuerdo con que los hospitales provocan alienación ante la muerte, aunque lo relativiza porque en realidad la alienación es inherente al proceso mismo de morir, se produzca éste en casa o en el hospital:

- "Porque en el hospital ya se encargan de que estén lo más relajaditos posible, entonces tus facultades están un poco mermadas, normalmente. Estás sedao, te sedan para que no des guerra y no des trabajo. $Y$ entonces, no te enteras prácticamente de nada...Hombre, basándome en que a mí me parece importante que una persona no sufra, si se puede evitar que no sufra, hombre, si está en un hospital y no sufre, mejor, yo creo, pero si va a estar en casa va a tener, pero si está sufriendo mucho, estamos en la misma situación, está jorobado y en ese momento no tiene sus facultades, o sea, si tú estás sufriendo, tus facultades no funcionan, al 100\%, digámoslo así, aunque tu mente esté bien pero si estás sufriendo.., tú con un dolor de muelas intenso que no te pregunten, que no hagas filosofía porque no estás para filosofías, ni para decisiones en un momento determinado de decir "bueno, yo decido hacer esto", lo único que quieres es que te quiten el dolor de muelas, lo demás no te preocupa demasiado, ¿me entiendes? ” (E4:17-18).

\section{CUADRO 5.28.: EN LO RELATIVO A LAS MUERTES QUE SE PRODUCEN EN LOS HOSPITALES, GRADO DE ACUERDO O DESACUERDO CON LAS SIGUIENTES IDEAS... (\%)}

\begin{tabular}{|l|c|c|c|c|c|c|}
\hline & \multicolumn{3}{|l|}{$\begin{array}{l}\text { Los hospitales dan seguridad porque son } \\
\text { los únicos lugares donde se aplican los } \\
\text { tratamientos médicos más adecuados } \\
\text { hasta el último instante }\end{array}$} & \multicolumn{2}{l}{$\begin{array}{l}\text { Los hospitales no permiten al individuo } \\
\text { conducir la última etapa de su vida }\end{array}$} \\
\cline { 2 - 7 } & ACUERD. & INDIFER. & DESACUE. & ACUERD. & INDIFER. & DESACUE. \\
\hline TOTAL & 80,5 & 7,2 & 12,3 & 40,6 & 18,5 & 40,9 \\
\hline HOMBRES & 76,7 & 8,6 & 14,8 & 46,0 & 20,5 & 33,5 \\
MUJERES & 82,9 & 6,3 & 10,7 & 37,0 & 17,2 & 45,8 \\
\hline JÓVENES & 75,1 & 11,2 & 13,7 & 35,0 & 22,3 & 42,7 \\
ADULTOS & 80,9 & 3,5 & 15,6 & 53,3 & 12,9 & 33,8 \\
ANCIANOS & 93,5 & 3,9 & 2,6 & 40,2 & 19,0 & 50,8 \\
\hline EST. BÁSICOS & 88,5 & 2,9 & 8,6 & 35,6 & 18,6 & 45,7 \\
EST. MEDIOS & 86,9 & 2,4 & 10,7 & 48,1 & 13,6 & 38,3 \\
EST. UNIVERS. & 76,3 & 10,0 & 13,8 & 39,3 & 20,1 & 40,5 \\
\hline CRÉDULOS & 81,3 & 7,3 & 11,4 & 37,2 & 15,5 & 47,3 \\
CREYENTES & 85,0 & 8,0 & 6,9 & 36,5 & 21,2 & 42,4 \\
NO CREYENTES & 81,0 & 7,1 & 11,9 & 43,5 & 24,7 & 31,8 \\
INCRÉDULOS & 68,3 & 7,9 & 23,8 & 48,4 & 14,5 & 37,1 \\
\hline
\end{tabular}

Fte: Encuesta 2000. Elaboración propia

El rechazo es asimismo mayoritario cuando se plantea la cuestión de la deshumanización y soledad de la muerte en los hospitales (pregunta 44d). Más de la mitad de los encuestados no está de acuerdo con esa afirmación, frente a un tercio que sí la acepta. El desacuerdo es mayoritario entre las mujeres, los ancianos, los que tienen estudios básicos y los 
creyentes y crédulos, mientras que entre los hombres, aún siendo mayoritaria esa opinión, 4 de cada 10 muestran su acuerdo con ella. Por su parte, casi la mitad de los que tienen estudios medios y alrededor de 1 de cada 3 no creyentes e incrédulos aceptan que existe deshumanización de la muerte en los hospitales. En las entrevistas realizadas asimismo se observó un rechazo explícito a la deshumanización de la muerte en los hospitales:

- "Tampoco creo que sea tan trágico, hay muertes mucho peores que las de los hospitales, las muertes en la guerra, las muertes fíjate en las hambrunas, cómo podemos decir aquí a los hospitales los culpables de que la gente se muera y.., además, "muere en soledad", yo creo que la gente que quiere estar contigo en esos momentos está igual en el hospital que en casa; si estás muy enfermo y la gente de tu alrededor sabe que te vas a morir estará junto a ti aunque estés en un hospital, desde luego que es más digna la escena esa de morirte en casa, alrededor de tu familia, en tu cama, pero es que eso, sólo en las películas. Yo no creo que sea tan radical” (E2:18).

- "No, es que no es rotundo, unos casos, sí, otros, no, o sea, no es una cosa "esto es así", no, no siempre, puede estar uno en un hospital y estar humanizado totalmente, porque está la gente que le quiere y él quiere alrededor de él, y puede estar en casa y estar con una cuadrilla que está deseando que se muera, y qué, no es una cosa rotunda, depende de lo que te rodee. Se puede estar muy bien en casa, y muy mal en casa, y se puede estar muy bien en el hospital o muy mal en el hospital, no son cosas rotundas" (E4:18).

Por último, la mayoría de la población encuestada, 6 de cada 10, no percibe que la muerte en los hospitales sirva para ocultársela a la sociedad (pregunta 44e). Esta opinión mayoritaria se observa también en todas las categorías sociales, apreciándose sólo diferencias significativas en la distribución por género. Así, frente a los 5 de cada 10 hombres que suscriben el ocultamiento de la muerte, casi 7 de cada 10 mujeres rechazan esa opinión. Como la joven no creyente entrevistada y el varón incrédulo:

- "Yo creo que es al revés porque en los hospitales no sólo hay gente que va a morir, también hay mucha gente que va a curarse enfermedades, a tener niños, $o, y$ también, yo, muchas muertes no he visto, pero que he conocido ha sido por ocasiones que he estado en el hospital y han sido gente totalmente ajena a mí. Yo, por ejemplo, una vez que estuvo mi abuelo enfermo el señor que estaba con él en la habitación se murió y, claro, pues eso me afectó, claro, si ese señor no llega a estar en el hospital yo no me entero de que se ha muerto" (E2:19).

- “... la muerte no se puede ocultar, te mueras en un hospital o te mueras en casa... De antes, estoy hablando cuando se morían los abuelos, cuando se murió mi abuelo en el pueblo... pero no sé si es mejor o es peor, aquello era más tétrico eso sí que estoy seguro, vamos, o sea, la situación, o es que yo lo veo desde mi punto de vista de niño, aquello eran situaciones un poco más traumáticas, desde el punto de vista de niño, si me pilla ahora posiblemente no sería tan traumático, pero aquello pues sí, sobre todo por la fatalismo de la sociedad que era aquella, todo muy serio, todo negro, todo llantos, todo seriedad" (E4:19). 
CUADRO 5.29.: EN LO RELATIVO A LAS MUERTES QUE SE PRODUCEN EN LOS HOSPITALES, GRADO DE ACUERDO O DESACUERDO CON LAS SIGUIENTES IDEAS... (\%)

\begin{tabular}{|l|l|c|c|c|c|c|}
\hline & \multicolumn{2}{l}{$\begin{array}{l}\text { La muerte en los hospitales está } \\
\text { deshumanizada, se descuida la dignidad } \\
\text { del que fallece que, además, muere en } \\
\text { soledad }\end{array}$} & $\begin{array}{l}\text { Morir en los hospitales sirve para } \\
\text { ocultar la muerte en nuestra sociedad al } \\
\text { hacerla menos visible }\end{array}$ \\
\hline & ACUERDO & INDIFER. & DESACUE. & ACUERDO & INDIFER. & DESACUE. \\
\hline TOTAL & 34,4 & 12,8 & 52,7 & 28,7 & 10,9 & 60,3 \\
\hline HOMBRES & 40,6 & 13,9 & 45,5 & 36,8 & 14,7 & 48,4 \\
MUJERES & 30,2 & 12,0 & 57,7 & 23,3 & 8,3 & 68,4 \\
\hline JÓVENES & 27,1 & 19,9 & 53,1 & 24,4 & 11,7 & 63,9 \\
ADULTOS & 43,6 & 6,4 & 50,0 & 34,6 & 8,6 & 56,8 \\
ANCIANOS & 37,2 & 5,7 & 57,2 & 29,9 & 13,4 & 56,7 \\
\hline EST. BÁSICOS & 30,7 & 4,8 & 64,5 & 30,7 & 12,9 & 56,4 \\
EST. MEDIOS & 49,4 & 7,1 & 43,6 & 25,6 & 8,5 & 65,9 \\
EST. UNIVERS. & 30,5 & 16,6 & 52,9 & 29,3 & 11,2 & 59,4 \\
\hline CRÉDULOS & 30,8 & 8,7 & 60,5 & 27,0 & 8,1 & 64,8 \\
CREYENTES & 29,7 & 13,1 & 57,1 & 33,0 & 7,1 & 60,0 \\
NO CREYENTES & 35,3 & 21,2 & 43,5 & 30,6 & 15,3 & 57,1 \\
INCRÉDULOS & 38,1 & 15,9 & 46,0 & 26,9 & 12,7 & 60,3 \\
\hline
\end{tabular}

Fte: Encuesta 2000. Elaboración propia

El conjunto de la población encuestada, por tanto, no participa, al menos de forma explícita, de los análisis que diagnostican una pérdida de naturalidad de la muerte, que es tratada médicamente como una enfermedad curable o un accidente reparable, en un proceso deshumanizado y solitario, que aliena existencialmente a la persona moribunda sustrayéndole la vivencia de la última etapa de su vida y que, como fruto de una estrategia premeditada acorde al principio de realidad, sirve para ocultar la muerte en nuestra sociedad. De hecho, la contundencia de los resultados obtenidos permite afirmar lo contrario, como se aprecia en el siguiente comentario resumen de la joven no creyente al ser preguntada si creía que la muerte está recluida en los hospitales:

- "Sí, pero no creo que sea por deseo de nadie en particular, o que se quiera hacer menos visible, es lo que te he dicho antes de que las muertes porque sean más cómodas en los hospitales, es que es el proceso natural, es que la gente que está enferma pues está en el hospital, y es lo más normal que se muera allí, tampoco creo que sea para hacerla menos visible, es que es por el proceso natural, por la evolución de la sociedad hasta este punto, entonces, no creo ni que se haga deliberadamente, el querer ocultarla, ni que además se oculte, porque, yo ya te digo, en lo poco que he vivido en los hospitales, pues es eso, he estado más cerca de la muerte en esos momentos que he visitado los hospitales que en cualquier otro 
momento, porque tú estás cerca de la muerte de tus allegados, pero de otra gente que te es totalmente ajena?, en los hospitales, sí, si no vas allí no lo ves” (E2:19).

Existe por tanto una profunda confianza, muy extendida en el universo estudiado, en el sistema hospitalario como nido de muerte. Para los demás. En efecto, entre las personas que no están, o no han estado últimamente, en contacto directo con la muerte, y que sólo se preocupan por vivir, como es el caso de las encuestadas para esta Tesis, la situación de los que están en estos momentos muriendo en los hospitales les resulta tan lejana como la de los niños nacidos (o los no nacidos) en África y que morirán sin tardanza: no forman parte de su realidad inmediata, ni siquiera de su realidad mediática. Es decir, no les pasa a ellos. Es evidente, por tanto, que las opiniones recogidas sobre esta cuestión están mediatizadas por esa lejanía y por las urgencias contingentes de la vida diaria. Además, otros cambios estructurales ligados a la modernización, aparte de la ya citada profesionalización de las actividades tanáticas, han favorecido el incremento de ese distanciamiento hasta generar dos geografías prácticamente aisladas entre sí, la de la vida y la de la muerte. La frontera entre ambas es cada vez menos permeable al tránsito, por razones de eficiencia organizativa y de higiene, pero también por la mayor comodidad de los familiares de los moribundos. Al menos eso opina más de la mitad de la población encuestada, 51,4\%, frente a un tercio que está en desacuerdo con la afirmación de que muchas muerte se producen en los hospitales porque son más cómodas para las familias (pregunta 44b). Las personas adultas, $60 \%$, y las creyentes, 58,8\%, son las que están más de acuerdo en que la derivación de los enfermos terminales a los hospitales se asienta en que de esa forma las familias se desentienden de sus responsabilidades. Las personas no creyentes, 40\%, y las jóvenes, 43,1\%, son las que están menos de acuerdo con esa afirmación. En el caso de la joven no creyente entrevistada comparte la afirmación por:

- "Pues también, sí, sí, porque también hay gente que cuando tienen una persona enferma, y saben que se va a morir, intentan prolongar la estancia en el hospital para que se muera allí, por lo menos eso he oído... Vamos, creo yo que., muchas veces las personas mayores que viven con su familia les meten en el hospital y casi se olvidan de ellos, van a los turnos que les tocan y de mala gana y, pero eso no es la culpa del hospital, eso es culpa de la familia.., a veces también de los padres que no, porque a veces las personas mayores se quejan del trato que les dan pero hay que ver también el trato que ellos han dado cuando cuando tenían ocasión de estar en la posición de más autoridad, no sé, yo creo que eso no es la culpa de los hospitales" (E2:19).

Entre esos cambios estructurales destacan el aumento de la movilidad espacial de la población, el incremento de la actividad femenina fuera del hogar, la evolución hacia una arquitectura funcional (para la vida), etc. Todos ellos han favorecido la progresiva desaparición de la costumbre secular de morir en casa. Ésta implicaba, llegado el caso, dedicar un espacio físico dentro de la misma al proceso de morir y sobre todo que varias personas, fundamentalmente las mujeres de la familia, se dedicaran intensamente al cuidado de la persona 
moribunda. Obviamente, una sociedad urbanizada funcionalmente, con familias nucleares espacialmente cada vez más dispersas, con una creciente proporción de mujeres incorporadas al mercado de trabajo, hace cada vez más difícil, humana y materialmente, afrontar desde la propia familia ese proceso y, en consecuencia, mantener aquéllas prácticas, como ocurre con los ritos funerarios. En este sentido, una de las componentes del grupo de discusión utiliza el parto en el que tuvo a su hijo como ejemplo comparativo de la lógica inherente en el desplazamiento de los fallecimientos en los hospitales:

- "- Con estas casas modernas... hay que entender que tenías que desarmar una habitación y dejar allí al muerto. Y ya no sólo con lo muertos, te pasa también con lo vivos. Yo he dado a luz a mi hijo, que tiene cuarenta y tres años, en casa y al hospital de Río Ortega sólo se podía ir si venía mal, si había peligro y eso pero si no, tenías que dar a luz en casa. Tenía que ir el marido con toda la placenta y esas historias a tirarlo por ahí, a ver dónde lo metías.

- Al río en una caja de botas..

- ... Tú fíjate qué tinglado, y tú vas al hospital y te olvidas de todo. ¡Tenías que ir a enterrarlo!" (GD1:33).

Además, cuando incluso las actividades familiares lúdicas se exportan fuera del hogar los cumpleaños infantiles se macdonalizan, por ejemplo-, para evitar deterioros y molestias, parece difícil que se esté dispuesto a dedicar un espacio dentro del hogar que temporalmente quede marcado por la muerte. Sobre todo si existen organizaciones eficaces que permiten evitarlo. No es extraño por tanto, que se considere a los hospitales como un buen refugio al que enviar a morir a los otros; no es extraño tampoco que sean las mujeres las que se muestren más predispuestas a ello. Motivación práctica que justifica la idoneidad de los hospitales como espacios donde esperar la muerte, pero que no elimina la sospecha fundada de que la razón de fondo para esa preferencia sea el deseo de no interactuar con la muerte, es decir, su negación. Como se contrasta a continuación en el sub-epígrafe siguiente.

Antes de abordar ese análisis, conviene contrastar las percepciones de la población encuestada con los resultados obtenidos en dos de los pocos estudios realizados sobre la calidad de la agonía y la muerte en los hospitales de España. En el primero de ellos, desarrollado en el Hospital General de Especialidades de Almería, entre 1999 y 2000, y dirigido por N. Marín Gámez (2002), se realizó un estudio clínico observacional y prospectivo del proceso de la muerte en 56 pacientes asistidos -“en tiempo real y a la cabecera de la cama”. De la propia labor de observación desarrollada por el equipo médico éste obtuvo resultados tan reveladores como los siguientes: sólo 4 pacientes conocían su situación, tampoco conocían la situación terminal de los pacientes el $42,9 \%$ de las familias. Ni siquiera el propio personal de enfermería estaba avisado de proximidad de la muerte en todos los casos, sólo de la del 51,7\% de los pacientes. El 70\% de los pacientes agonizó sin ayuda médica suficiente, con dolor no controlado, disnea, angustia vital, vómitos, miedo o agotamiento. El 30\% no recibió 
sedación/analgesia alguna y un 40\% recibieron algún tipo de analgesia/sedación, pero limitadas, no centradas en el paciente. "Morían extenuados" ${ }^{49}$. Aunque la disnea afectó a todos, sólo se suplementó oxígeno en el 76,8\% de los casos. A pesar de lo inevitable de la muerte, se documentó la orden de "no reanimar" en el 51,7\% de los casos, "por lo que se llevaron a cabo tres reanimaciones cardiopulmonares, ciertamente prescindibles por intempestivas e inútiles”. Sobre esta base, el equipo de Marín Gámez concluye que a "la vista de los datos aportados, opinamos que el conocimiento científico sobre el hecho de morir es tan escaso como nuestra compasión demostrada a la cabecera del enfermo que muere”, por lo que la "asistencia al moribundo es claramente mejorable. En la mayoría de los casos, la autonomía es usurpada por un paternalismo "bien intencionado". La información proporcionada al paciente fue casi nula e imperó el secretismo. Los pacientes deseaban alivio y se les ofreció tecnología invasiva. Detectamos una actitud “neutral”, abandono o cierta indiferencia ante el último y mayor sufrimiento humano. Invocamos un cambio de actitud entre los clínicos” ${ }^{50}$.

El otro estudio, realizado mediante entrevistas telefónicas a familiares de fallecidos en el Hospital de Navarra durante el año 2006 muestra en principio unos resultados cuantitativos más alentadores por cuanto en las seis áreas sobre las que se interrogó a la muestra final de 327 personas se obtuvieron, sobre una escala de 10, unos resultados medios positivos o muy positivos en: a) calidad de comunicación con médicos, enfermeras y demás personal que cuidaba al paciente: 7,61; b) respeto a los deseos del paciente: 7,74; c) control de los síntomas: 7,78; d) morir con dignidad, tal como el paciente hubiera deseado: 7,79; e) apoyo emocional al paciente y a la familia: 6,08, y f) atención general recibida en la última semana: 7,91. Sin embargo, en la propia entrevista se incluyó una última pregunta abierta con la posibilidad de que añadieran "algo más” obteniéndose una gran diversidad de respuestas que matizaban mucho los buenos resultados cuantitativos obtenidos y ayudaban a detectar problemas no previstos inicialmente (Osés et al, 2007). Así, frente a valoraciones positivas, hubo quejas sobre la comunicación (“La información se nos dio de la forma más fría que se pueda usted imaginar, sin ningún cariño", "En el pasillo en vez de en un despacho donde pudiéramos preguntar”), sobre la imposición del criterio de los médicos sobre el del paciente o de los familiares (“Ni nos escucharon cuando les dijimos que a él no le hubiera gustado que le pusieran aquello de

49 "El soporte tecnológico invasivo continuado, pese a la ausencia de expectativas vitales, contrastó con el minimalismo analgésico o sedativo... Creemos que las diferencias detectadas en las prescripciones de analgésicos y sedantes entre facultativos reflejaron la variabilidad de hábitos y no, justamente, las preferencias expresadas por los pacientes” (Marín Gámez et al, 2002).

50 "El reduccionismo biotecnológico dominante simplifica en un varón o una mujer a un cuerpo que muere. Es la expresión de un totalitarismo médico, un cierto despotismo «técnico ilustrado», fruto de una visión escasa del enfermar humano y producto de la fría mirada del paradigma de mercado, que enfatiza la futilidad: seres humanos rabiosamente individuales, con historicidad exclusiva, rebajados a meras estructuras biopatológicas que se extinguen. Hay, tal vez, un cierto abandono o indiferencia respecto al sufrimiento final del agonizante” (Marín Gámez et al, 2002). 
respirar", "No nos preguntaron nada de nada. Lo hacían todo ellos sin consultarnos para nada y eso no está bien”, "No había forma de que pararan. Ellos iban a lo suyo y nosotros no podíamos ni decirles”), sobre el control del dolor ("Le pusieron muy poca anestesia. Se murió consciente y muy angustiado. Nosotros queríamos que le pusieran más pero se negaron”, "Las enfermeras nos dijeron que para el dolor le habían recetado cada 8 horas y que ellas no podían hacer más”, “Al parecer al médico se le olvidó escribir lo del dolor y por más que pedimos no le dieron nada"), sobre el morir con dignidad, en especial a lo relativo a la intimidad de la situación ("Fue horroroso. Mi padre muriéndose mientras el enfermo de la cama de al lado se comía la merienda", "Fue una agonía larga y toda ella la vivimos ella, nosotros y la otra enferma y su familia que se quedaron destrozados", "Es increíble que todavía haya que compartir habitación y que ni siquiera puedas llorar y despedirte de tu madre con un poco de intimidad”), sobre la asistencia religiosa o la ausencia de psicólogos/as (“El cura tardó mucho en llegar. Nos dijo que estaba diciendo misa pero no sé...”, "Me dijeron que no había pero yo sé que en lo del cáncer sí hay. Y no sé por qué para los demás enfermos no...”, "Nosotros necesitábamos ayuda psicológica y nos dijeron que no había"), y, finalmente, sobre la valoración global de la atención recibida ("Se creen dioses y no se dan cuenta del sufrimiento de las personas", "Son como témpanos. Menos mal que hay algunas enfermeras que son todo lo contrario”, “¿Sabe qué le digo?, que recibió un trato muy malo. Y nosotros también”).

\title{
5.6.2. PREFERENCIAS ANTE LA PROPIA MUERTE: <<CANON $>>$ DE LA MUERTE
}

\begin{abstract}
"Ese mes la vi afrontar la muerte una y otra vez, y por eso creo que ver afrontar la muerte con dignidad y valor no confiere una cosa ni la otra, sino sólo lástima, desamparo y miedo"
\end{abstract}

R. Ford

A partir del análisis realizado, entre 1993 y 1998, mediante entrevistas en profundidad (86), grupos de discusión (12) y seis muestras diferentes de población a las que se planteó que redactaran en un papel su respuesta a la pregunta “¿cómo le gustaría morirse?”, M. Marí-Klose y J. de Miguel (2000) elaboraron un canon de la muerte de la población española actual, es decir, un modelo idealizado de la muerte resultante de los deseos anticipados sobre la misma manifestados mayoritariamente entre aquélla. Este modelo ideal de muerte dominante entre la población estudiada se construye y queda definido por las siguientes seis “pautas normales”: a) morir sin dolor y sin sufrimiento; b) morir durmiendo o inconsciente; c) morir de forma rápida; d) morir rodeado de familiares y amistades íntimas; e) morir en edad avanzada, y; f) morir en casa. Pautas que, como resaltan estos autores, sintetizan el hecho de que "se vive como se muere sin pensar en la muerte”, como si ésta viniera desde el exterior y no estuviera inserta en la 
propia persona -“la muerte es otro yo”-, es decir, pautas que reflejan una negación de la muerte. Así, el canon de la muerte en las sociedades avanzadas en realidad es más bien un canon de la no-muerte ${ }^{51}$.

En el presente trabajo se ha preguntado a la población encuestada sobre sus preferencias ante la propia muerte obteniéndose unos resultados que no difieren demasiado de los reseñados; concretamente, y tal como se desarrolla a continuación, se asumen mayoritariamente cuatro de las seis pautas identificadas por Marí-Klose y de Miguel. En efecto, las opiniones manifestadas por las personas encuestadas cambian cuando se trata del morir propio. Puestos hipotéticamente en esa situación ya se ha señalado que las conductas cotidianas de las personas encuestadas cambiarían ante la cercanía de su muerte. Interrogadas sobre dónde desearían morir si pudieran elegir (pregunta 43), la mitad desearía hacerlo en casa, frente a sólo un 12,8\% que querría morir en el hospital ${ }^{52}$, Cuadro 5.30. No obstante, es muy significativo que más de un tercio de ellas esté indecisa al respecto. Apenas existen diferencias por género en esta cuestión, pero sí por el resto de las variables de control. Entre las categorías de edad, los ancianos son los que tienen una opinión más perfilada y mayoritariamente desean como refugio para su morir su casa, 64,9\%; simultáneamente, son los que en mayor proporción desean morir en el hospital, 18,3\%. En las otras etapas del ciclo vital también el morir en casa es la opción más deseada, sin embargo, el porcentaje de indecisos es elevado, cercano al 40\%. Por su parte, la distribución de preferencias está asociada al nivel de estudios, siendo reseñables en este caso el que menos del $40 \%$ de la población con estudios medios desea morir en casa, pero no porque desee hacerlo en el hospital, sino porque casi la mitad de ella se muestra indecisa. Respecto a la distribución por religiosidad, los crédulos son los que tienen más claro que desean morir en su casa, casi 6 de cada 10, mientras que los incrédulos son los que menos desean morir en el hospital, 6,3\%. No obstante, aunque la preferencia por morir en casa es diáfana no dejan de asaltar las dudas, como comenta la joven no creyente:

\footnotetext{
${ }^{51}$ El canon de la muerte es un modelo ideal que no explica la muerte real, más bien "se refiere a los tropos, simbolismos, metáforas, e imaginario asociados a ella... El canon es el retrato de la muerte ideal, una muerte para seres inmortales que no han pensado antes sobre la muerte” (Marí-Klose y De Miguel, 2000:117-122). En su estudio estos autores no detectan la existencia de un modelo alternativo al dominante pero sí de lo que llaman "contranormas", es decir, de pautas deseables para ciertos individuos que manifiestan su oposición a alguno de los seis factores normales pero que asumen todos los demás.

${ }^{52}$ Otra de las posibilidades incluida entre los ítems de esa pregunta son los hospices, opción sólo contemplada por el 2,1\% de la población encuestada. Bien es verdad, que es un tipo de organización de la que sólo el 14,6\% de la muestra sabe de su existencia (pregunta 40), y que, aunque 1 de cada 4 personas encuestadas le parece bien como alternativa a los hospitales, más de la mitad no tiene opinión sobre la idoneidad de esa alternativa (pregunta 41). En un estudio más reciente, CIS (2009:10), representativo del conjunto de la población española se ha interrogado sobre esta cuestión observándose en los resultados obtenidos la inclusión entre las respuestas, con un peso relativo importante, de los hospices: el 45,5\% deseaba morir en su casa, el 17,8\% en el hospital y el 31,9\% en un centro especializado en enfermedades terminales.
} 
- "En casa. Yo creo que a poca gente le gustaría morir en un hospital... Ya, claro, es que también depende de qué tipo de muerte que sea porque si necesitas asistencia médica, en casa no la puedes tener, y si te he dicho antes que estoy a favor de que se medicalice el proceso de la muerte y te digo ahora que no., que me gustaría morirme en casa, es una contradicción, hombre, si me muriese por una enfermedad y tuviera que tener asistencia, preferiría en un centro de esos (hospice), antes que en un hospital sí que preferiría en un centro de esos, ahora si me dices ahora “¿dónde prefieres morirte?”, pues en casa, porque, vamos, me parece que es más íntimo que delante ahí de todo el mundo” (E2:17-18).

Asimismo, en algunos casos la indecisión no está tanto relacionada con ausencia de conocimiento sobre cuál sería la mejor opción, cuanto con la indiferencia porque lo que se quiere realmente no se puede conseguir:

- "Bueno, frialdad según están establecidos en este momento, pero si hubiese unos habitáculos para... (morir en los hospitales), pero, claro, si es que vuelvo otra vez a lo mismo, todo depende de las personas, hay personas que darán toda su vida por morirse en la cama de su casa, si es su ilusión pues, bueno, él contestará otra cosa, a mí es que me da igual yo lo que quiero es no morirme ahora, si me tengo que morir qué más me da morirme en un sitio que en otro, si es que me da igual. No quiero morirme, sencillamente. Esto es como si "me encantan los percebes", qué más me da que sea un plato de porcelana que sea un plato de barro cocido, si es que me da igual, lo que me interesan son los percebes" (E4:16-17).

Respecto a cómo les gustaría vivir los últimos instantes de su vida si pudieran elegir (pregunta 65), las respuestas obtenidas clarifican la extensión real de los dominios de cada uno de los modelos de muerte. Frente a la consciencia inevitable en el estoico modelo tradicional ${ }^{53}$ y la consciencia reivindicada de los planteamientos existenciales del modelo neo-moderno, se manifiesta mayoritariamente, de nuevo, una notable adhesión al principio de realidad: la vida o nada. Es decir, si ya nada se puede hacer se desea anticipadamente la muerte, el "no ser". Llegado, ipor fini el examen final, que se sabe se va a suspender, pero al que tampoco se le han dedicado grandes esfuerzos en la preparación, se prefiere afrontar el mal trago sin consciencia, 6 de cada 10, sin dolor, 9 de cada 10 y lo más rápidamente posible, 7 de cada 10. En definitiva, como afirman Marí-Klose y De Miguel (2000:117-121), un morir de espaldas a la muerte: higiénico, sin que la muerte se manifieste ni muestre síntomas de morbilidad ${ }^{54}$; pasivo y anestesiado, sin que constituya una experiencia individual que dote de sentido y coherencia a la

\footnotetext{
${ }^{53}$ En su análisis de la muerte entre los Vaqueiros de Alzada (habitantes en el oeste de Asturias), M. Cátedra (1988:157-205) demuestra que no en todas las sociedades tradicionales se percibe como positiva la consciencia en el enfrentamiento a la muerte. En efecto, la población vaqueira distingue entre: a) buena muerte, caracterizada por ser repentina, y si además es indolora e inconsciente se la denomina muerte feliz, muerte bonita o guapa-; también denominan buena muerte a la muerte natural que se produce en la vejez; b) mala muerte, si es por enfermedad crónica o por accidente pero no inmediatamente mortal, es decir, dolorosa y dilatada en el tiempo, sin esperanza de curación y siendo consciente de ello, y; c) muerte desgraciada, el negativo de la muerte natural, una desagradable sorpresa para los que se quedan provocada por agentes externos o accidentales -accidentes mortales-, o por un agente humano -asesinato o suicidio.

${ }^{54}$ Citando a Ivan Illich, Marí-Klose y De Miguel (2000:119) califican a "nuestra sociedad de analgésica e incapaz de soportar dolores o de gestionarlos, dado que no poseen valor de redención”.,
} 
vida, una "especie de resignación autista" que prefiere no vivirse; fugaz e inesperado, sin que haya que prepararse especialmente para afrontarlo:

- "Yo he pedido una horita corta, como los partos" (GD1:21).

Estas tres características del morir moderno, ligadas a la hegemonía de los valores dominantes que rechazan como indeseables la enfermedad, la degeneración física y el dolor, se desean más entre las mujeres que entre los hombres, y entre los jóvenes que entre los ancianos; entre éstos, un tercio desea ser conscientes de esa fase vital (Cuadro 5.30). Quizá por las razones que apunta la joven no creyente entrevistada:

- “A lo mejor cuando eres mayor, y has estado pensando mucho en la muerte, a lo mejor no te importa ser consciente del proceso, porque al fin y al cabo son tus últimos momentos, a lo mejor prefieres.., pero yo ahora mismo cuanto menos me enterase mejor" (A2:21).

La distribución del grado de consciencia en el morir por nivel de estudios muestra que en esta cuestión no existe ligazón con la de la edad, por cuanto son los de estudios básicos los que en mayor medida desean un morir inconsciente, 7 de cada 10 . Si se considera la religiosidad, los crédulos son los más partidarios de un morir consciente, 1 de cada 3, mientras que los incrédulos son los más partidarios de lo contrario, el 63,5\%. En lo relativo a la distribución del grado de dolor en el proceso de morir, no existen diferencias significativas por nivel de estudios y de religiosidad. Sí que se aprecia sin embargo una diferencia relevante en lo relativo al tiempo del proceso de morir entre las categorías extremas de religiosidad: 8 de cada 10 incrédulos desean que ese tiempo transcurra lo más rápido posible, mientras que 1 de cada 5 crédulos es favorable a que el tiempo sea el que requiere ese proceso. La influencia de la moral tradicional y católica en este último caso parece evidente.

Los datos sobre cómo se quiere morir permiten, asimismo, explicar por qué la mayoría de la población encuestada no considera que la muerte haya perdido su carácter natural y esté medicalizada. En realidad, se teme y se rechaza la muerte natural tradicional, el proceso natural de morir, de la misma forma que, salvando las distancias, un número creciente de mujeres huyen del parto natural y solicitan anestesia cuando van a dar a luz. Es evidente que para satisfacer los deseos de una muerte inconsciente, indolora y concentrada en el tiempo, es necesario que el proceso de morir esté controlado, lo que requiere el concurso de profesionales de la sanidad. Por eso a la población en términos generales no le importa, más bien al contrario, la medicalización de la muerte. De hecho, esa es la naturaleza de la muerte moderna. 
CUADRO 5.30.: EN CASO DE PODER ELEGIR ¿DÓNDE LE GUSTARÍA MORIR? ¿CON QUÉ GRADO DE CONCIENCIA PREFERIRÍA MORIR? ¿Y DE DOLOR? ¿DURANTE CUÁNTO TIEMPO? (\%)

\begin{tabular}{|c|c|c|c|c|c|c|}
\hline & \multicolumn{3}{|c|}{ MORIR EN CASA } & \multicolumn{3}{|c|}{ GRADO DE CONSCIENCIA } \\
\hline & HOSPITAL & CASA & NO SABE & CONSCIENTE & INCONSCIENTE & NO SABE \\
\hline TOTAL & 12,8 & 50,8 & 34,2 & 24,6 & 58,6 & 16,8 \\
\hline HOMBRES & 10,3 & 50,9 & 35,8 & 31,4 & 53,3 & 15,4 \\
\hline MUJERES & 14,5 & 50,8 & 33,2 & 20,1 & 62,2 & 17,7 \\
\hline JÓVENES & 11,2 & 47,7 & 38,6 & 21,2 & 61,6 & 17,2 \\
\hline ADULTOS & 12,0 & 47,2 & 38,7 & 22,7 & 57,4 & 19,9 \\
\hline ANCIANOS & 18,3 & 64,6 & 15,9 & 35,7 & 53,6 & 10,7 \\
\hline EST. BÁSICOS & 18,3 & 56,3 & 22,5 & 19,1 & 69,1 & 11,8 \\
\hline EST. MEDIOS & 12,5 & 39,8 & 47,7 & 25,6 & 55,6 & 18,9 \\
\hline EST. UNIVERS. & 11,5 & 53,1 & 32,8 & 25,7 & 57,0 & 17,4 \\
\hline CRÉDULOS & 14,7 & 58,0 & 24,7 & 33,3 & 52,7 & 14,0 \\
\hline CREYENTES & 18,6 & 39,5 & 38,4 & 14,9 & 64,4 & 20,7 \\
\hline NO CREYENTES & 10,6 & 42,4 & 45,9 & 14,1 & 64,7 & 21,2 \\
\hline \multirow[t]{3}{*}{ INCRÉDULOS } & 6,3 & 50,8 & 41,3 & 25,4 & 63,5 & 11,1 \\
\hline & \multicolumn{3}{|c|}{ DOLOR } & \multicolumn{3}{|c|}{ TIEMPO } \\
\hline & $\begin{array}{c}\text { SIN } \\
\text { DOLOR }\end{array}$ & $\begin{array}{c}\text { CON EL } \\
\text { RELATIVO A LA } \\
\text { SITUACIÓN }\end{array}$ & NO SABE & RÁPIDAMENT & $\begin{array}{l}\text { CON EL TIEMPO } \\
\text { QUE REQUIERE } \\
\text { EL PROCESO }\end{array}$ & NO SABE \\
\hline TOTAL & 89,4 & 7,8 & 2,8 & 73,2 & 15,4 & 11,4 \\
\hline HOMBRES & 87,0 & 9,5 & 3,6 & 70,8 & 16,7 & 12,5 \\
\hline MUJERES & 90,9 & 6,7 & 2,4 & 74,7 & 14,6 & 10,7 \\
\hline JÓVENES & 90,0 & 7,6 & 1,5 & 76,3 & 13,1 & 10,6 \\
\hline ADULTOS & 87,2 & 7,8 & 5,0 & 73,6 & 12,9 & 13,6 \\
\hline ANCIANOS & 89,3 & 8,3 & 2,4 & 65,1 & 25,3 & 9,6 \\
\hline EST. BÁSICOS & 89,7 & 5,9 & 4,4 & 72,1 & 19,1 & 88,8 \\
\hline EST. MEDIOS & 84,6 & 12,1 & 3,3 & 66,7 & 18,9 & 14,4 \\
\hline EST. UNIVERS. & 90,0 & 6,8 & 2,3 & 75,7 & 13,3 & 11,0 \\
\hline CRÉDULOS & 86,0 & 9,3 & 4,7 & 69,1 & 21,5 & 9,4 \\
\hline CREYENTES & 95,4 & 4,6 & 0,0 & 78,2 & 11,5 & 10,3 \\
\hline NO CREYENTES & 92,9 & 3,5 & 3,5 & 77,6 & 7,1 & 15,3 \\
\hline INCRÉDULOS & 87,3 & 11,1 & 1,6 & 81,0 & 9,5 & 10,5 \\
\hline
\end{tabular}

Fte: Encuesta 2000. Elaboración propia 


\subsection{IMÁGENES DE LA MUERTE}

"Para una persona, la educación significa afrontar su impotencia natural y la muerte"

L.L. Miller

El hecho de que la mayoría de la población encuestada no piense, ni hable, ni haya hecho planes anticipatorios sobre la muerte no significa, más bien al contrario, que no sepa que existe ni que no lleve consigo distintas imágenes sobre ella. No está claro si esas imágenes de la muerte que acompañan a las personas son previas o posteriores, o más probablemente una mezcla, a la forma en que viven su vida. Es decir, si componen, a modo de superestructura, un marco de referencia exógeno que los individuos socializados al efecto toman como modelo y al que adecuan su periplo vital. O, si constituyen precisamente los frutos de un periplo vital individual, para unos cosecha lógica de una vida vivida con coherencia y plenitud (visión existencial), para otros, argumento (auto)justificativo de un periplo vital que no se ha gobernado en su totalidad (visión determinista).

Entre esas posibles imágenes de la muerte, hay una históricamente muy asentada en la que se la equipara con sufrimiento, más concretamente, en la que se identifica al proceso de morir con una especie de tortura insufrible. Interrogada la población encuestada sobre esta cuestión concreta sólo 1 de cada 5 personas encuestadas considera que "morir es sufrir", mientras que casi 6 de cada 10 rechazan esa imagen dramática del morir (pregunta 63a), Cuadro 5.31. Este dato revela un cambio sustancial respecto a la imagen trágica, en sentido físico, dominante en la historia de la humanidad. Es evidente que este cambio está relacionado con los avances tecno-médicos que, como se ha señalado arriba, potencialmente permiten una muerte a la carta. No se teme, o por lo menos no se teme tanto, aquello que se sabe va que a producirse en las condiciones que se desean. Es el caso de la joven no creyente entrevistada:

- "Depende del tipo de muerte, si es por una enfermedad, pues sí, si es por un accidente o algo que no te enteras, pues no, es pasar de un estado a otro, sí de un estado consciente a otro que a saber cómo será, a un estado mineral" (E2:21).

No obstante, si para el conjunto de la muestra esa imagen tortuosa ya no es dominante, se pueden observar algunas diferencias entre las categorías sociales, lo que indicaría que el poso de la misma es aún importante en alguna de ellas. Es el caso de las diferencias observadas en el ciclo vital, de tal forma que a medida que aumenta la edad es mayor la proporción de los que identifican muerte con sufrimiento, hasta el punto de que uno de cada tres ancianos así lo manifiesta. Su proximidad a la muerte, y su carácter tradicional, explicarían en buena medida ese dato. 
Por otra parte, el menor dramatismo con el que se percibe el morir convive con algunas imágenes atemperadas y tranquilizadoras de la muerte como es la de su equiparación a un largo sueño (pregunta 63b). El 38,2\% de la población encuestada suscribe esta afirmación frente al 30,7\% que la rechaza, Cuadro 5.31. Como ya comprobó Riley (1979) para el caso de Estados Unidos, la distribución de esta variable está asociada a la edad y al nivel de estudios siendo las personas de más edad y las de menor nivel de estudios, más del $50 \%$ en cada caso, quienes muestran un mayor grado de acuerdo con la misma. Del mismo modo, son estas dos categorías, ancianos y estudios básicos, las que, muy por encima de la media del total de la población, 45,1\%, muestran mayor acuerdo, por razones obvias, con que la muerte siempre viene muy pronto, alrededor de 7 de cada 10 (pregunta 63c). Resulta llamativa asimismo la tranquilidad con la que jóvenes y adultos muestran su desacuerdo con esa afirmación, 1 de cada 3 adultos y más del $40 \%$ de los jóvenes consideran que la muerte llega en el momento adecuado, o quizá tarde, Cuadro 5.31. Es el caso de los dos jóvenes entrevistados:

- “... hombre, hay quien cuando le ha llega la muerte ha aprovechado muy bien la vida, tampoco es que le llegue pronto, más ahora yo creo que es como un.. "que no llegue pronto", eso de que llegue pronto, hombre, todos querríamos vivir más, siempre que se pueda aprovechar, claro" (E1:14).

- "Eso, quién dice que es pronto o no, cuánto es pronto y cuánto es tarde, depende, hay personas que aunque les venga la muerte con 90 años a lo mejor es pronto porque todavía tiene muchas cosas que hacer, y hay gente que con 40 años ya no van a hacer nada más en su vida, entonces eso de pronto es muy relativo” (E2:21).

Es evidente también la asociación con el nivel de religiosidad, de tal forma que, paradójicamente, cuanto mayor es éste, mayor es la percepción de que la muerte llega antes de tiempo, al contrario de las personas menos o nada religiosas, los incrédulos, que en su mayoría, $55,6 \%$, muestran su templanza ante la llegada de la muerte, que llega cuando tiene que llegar.

Como un espejo, la muerte devuelve la imagen de lo que se es, mortal, pero sobre todo resalta lo que no se es, lo que está fuera de alcance: ser inmortal. Imposibilitados para alcanzar la inmortalidad, y escépticos incluso con la inmortalidad del alma, los individuos optan por vivir lo que son, que saben es lo único que es. Desde esta perspectiva, y en consonancia con los resultados de otros estudios (Pérez Agote y Santiago García, 2005; Bericat, 2003; Campo Ladero, 2002; Inglehart, 1998; Orizo, 1991, Pérez Agote, 1990), las personas encuestadas para este trabajo están más interesadas en el sentido de la vida, el "ser", que en el de la muerte, el "no ser” (pregunta 22a). Hasta el punto de que, sin diferencias significativas entre las categorías sociales, ni siquiera las construidas sobre la religiosidad, muy mayoritariamente la población encuestada, el 94\%, afirma que el sentido de la vida es obtener lo mejor de ella, Cuadro 5.32. 


\begin{tabular}{|c|c|c|c|c|c|c|}
\hline \multicolumn{7}{|c|}{$\begin{array}{c}\text { CUADRO 5.31.: PROPORCIÓN DE PERSONAS QUE ESTÁN DE ACUERDO CON } \\
\text { LAS SIGUIENTES AFIRMACIONES (\%) }\end{array}$} \\
\hline & \multicolumn{2}{|c|}{ Morir es sufrir } & \multicolumn{2}{|c|}{$\begin{array}{l}\text { La muerte es como un } \\
\text { largo sueño }\end{array}$} & \multicolumn{2}{|c|}{$\begin{array}{l}\text { La muerte viene siempre } \\
\text { muy pronto }\end{array}$} \\
\hline & ACUERDO & DESACUE. & ACUERDO & DESACUE. & ACUERDO & DESACUE. \\
\hline TOTAL & 21,4 & 58,2 & 38,2 & 30,7 & 45,1 & 35,9 \\
\hline HOMBRES & 19,2 & 63,0 & 32,1 & 35,2 & 42,6 & 36,4 \\
\hline MUJERES & 23,0 & 54,9 & 42,4 & 30,1 & 46,9 & 35,5 \\
\hline JÓVENES & 17,2 & 61,4 & 35,0 & 29,4 & 34,5 & 42,6 \\
\hline ADULTOS & 20,9 & 58,2 & 35,8 & 36,6 & 51,1 & 33,6 \\
\hline ANCIANOS & 34,8 & 48,5 & 52,2 & 22,4 & 66,1 & 19,4 \\
\hline EST. BÁSICOS & 24,1 & 51,7 & 54,2 & 22,0 & 72,7 & 10,9 \\
\hline EST. MEDIOS & 25,6 & 56,1 & 45,8 & 28,9 & 45,7 & 39,5 \\
\hline EST. UNIVERS. & 19,4 & 60,3 & 32,0 & 33,2 & 39,0 & 40,2 \\
\hline CRÉDULOS & 19,6 & 62,2 & 41,7 & 32,6 & 50,4 & 35,3 \\
\hline CREYENTES & 25,3 & 53,3 & 38,1 & 31,0 & 45,2 & 34,5 \\
\hline NO CREYENTES & 20,3 & 50,0 & 29,4 & 28,2 & 40,2 & 28,0 \\
\hline INCRÉDULOS & 19,3 & 67,7 & 34,9 & 34,9 & 28,6 & 55,6 \\
\hline
\end{tabular}

Fte: Encuesta 2000. Elaboración propia

Así, si uno ha vivido su existencia plenamente, la imagen especular proyectada por la muerte no es tan trágica, sino relativamente tranquilizadora: la muerte constituye en ese caso el punto de descanso natural (pregunta 22b). Dos de cada tres personas encuestadas así lo creen, Cuadro 5.32. No obstante, se aprecian divergencias muy importantes por edad (y nivel de estudios) y religiosidad. Diferencias que están generadas en el primer caso tanto por la ubicación en el ciclo vital en el que se encuentra esa persona, como por el efecto generación (relacionado asimismo con el nivel de formación) y la adscripción diferencial a valores tradicionales, modernos o postmodernos. Cabe añadir también, en el caso de las personas de más edad, una interpretación especulativa de carácter más psico-sociológico como es la de la necesidad de querer cerrar la propia vida con la sensación de plenitud y control sobre la misma, ya que, como señalaban Berger y Luckmann (1972), la muerte plantea un problema clave para la legitimación de la biografía ${ }^{55}$. Así, mientras el 85\% de los ancianos están de acuerdo, el 12\% es indiferente y el 3\% está en desacuerdo con esa afirmación, cifras que contrastan notablemente con las correspondientes a los jóvenes, que son 49\%, 27\% y 24\%, respectivamente. Diferencias que, aunque no en tanta cuantía, también son grandes entre las

${ }^{55}$ Según la teoría psicosocial del desarrollo de Erikson, en la última fase de la vida las personas se enfrentan al dilema integridad versus desesperanza. Quien ve su vida en esta fase como un todo significativo, resolverá positivamente la crisis, en caso contrario la persona percibirá su vida como un fracaso y mostrará un alto miedo a la muerte (Tomer, 1997:31). 
personas con estudios básicos (mayoritariamente ancianas) y las que tienen estudios universitarios (mayoritariamente jóvenes). En lo relativo a la religiosidad, resalta sobre el resto de categorías el que casi 7 de cada 10 crédulos suscriben la identificación de la muerte como punto de descanso natural para una vida realizada. Es obvio que este dato está relacionado con lo señalado para la población anciana, y sobre todo con la asunción del argumento de la santidad de vida, como comenta la mujer crédula entrevistada:

- "No sé hasta qué punto el ciclo natural, es lo normal, pero hay gente que vive muchísimo y gente que vive poco. Cada uno tiene un papel en la vida y depende de las circunstancias. Como yo lo veo desde el punto de vista espiritual, pues uno ha vivido su existencia cuando a Dios le parece, tenga veinte años o tenga ochenta" (E3:6).

CUADRO 5.32.: PROPORCIÓN DE PERSONAS QUE ESTÁN DE ACUERDO CON LAS SIGUIENTES AFIRMACIONES (\%)

\begin{tabular}{|l|c|c|c|}
\hline & $\begin{array}{c}\text { El sentido de la vida es } \\
\text { obtener lo mejor de } \\
\text { ella }\end{array}$ & $\begin{array}{c}\text { Si uno ha vivido su existencia, } \\
\text { la muerte es el punto de } \\
\text { descanso natural }\end{array}$ & $\begin{array}{c}\text { Hay situaciones peores } \\
\text { que la propia muerte }\end{array}$ \\
\hline \multicolumn{1}{|c|}{ TOTAL } & 93,9 & 62,9 & 84,8 \\
\hline HOMBRES & 92,6 & 64,1 & 85,0 \\
MUJERES & 94,6 & 62,1 & 84,6 \\
\hline JÓVENES & 96,4 & 48,7 & 85,4 \\
ADULTOS & 90,7 & 72,1 & 82,3 \\
ANCIANOS & 92,9 & 85,0 & 87,8 \\
\hline EST. BÁSICOS & 95,0 & 81,4 & 83,1 \\
EST. MEDIOS & 95,4 & 74,1 & 81,8 \\
EST. UNIVERS. & 93,0 & 55,0 & 86,3 \\
\hline CRÉDULOS & 94,0 & 68,1 & 82,0 \\
CREYENTES & 93,1 & 56,3 & 86,5 \\
NO CREYENTES & 97,7 & 55,3 & 83,5 \\
INCRÉDULOS & 93,7 & 51,9 & 87,3 \\
\hline
\end{tabular}

Fte: Encuesta 2000. Elaboración propia

Parece, por tanto, que, al menos en el plano cognitivo, y en la distancia (del morir y de la muerte), no está instalada en el imaginario de la población encuestada una imagen trágica de la muerte, ni en lo físico ni en lo existencial. De hecho, la mayoría de esa población, el 85\%, y sin grandes diferencias entre las distintas categorías sociales, considera que hay situaciones peores que la propia muerte (pregunta 23), Cuadro 5.32. Un muestrario de esas potenciales situaciones certifica de modo paradigmático lo señalado hasta ahora sobre que a la población encuestada mayoritariamente sólo le interesa la vida, y que en ésta lo importante es la calidad más que la cantidad. El 27\% de las personas encuestadas que piensan que hay situaciones peores que la muerte señalan como una de ellas al dolor y al sufrimiento de la enfermedad, el 11,4\% 
mencionan que la agonía es otra de esas situaciones, mientras que un cuarto de ellas temen por encima de su muerte el quedarse imposibilitados y depender completamente de otras personas. (pregunta 23a). Resulta asimismo muy relevante el que una de cada cuatro personas encuestadas obvie la decadencia o el sufrimiento físico propio y señale que mucho peor que la propia muerte es la muerte de un/a hijo/a. Opinión manifestada por ejemplo por el adulto incrédulo entrevistado y por varios componentes del grupo de discusión, quienes además reconocen que el sufrimiento que acompañaría a la muerte de un ser querido les lleva, por egoísmo, a desear la anticipación de la propia muerte para no vivirlo:

- "Lo he dicho varias veces: que pudiera pasar algo a mis cercanos...que se muriera cualquiera de mis cercanos, para mí sería peor que mi propia muerte" (E4:9-10).

- “- Es que con respecto a la muerte de un hijo, siempre piensas que ellos te van a sobrevivir. Que por ley natural, te van a sobrevivir. Piensas en eso y, sin embargo, todos sabemos que hay gente que se le ha muerto, no uno, sino incluso varios hijos, por accidente o por lo que sea. $Y$ entonces es distinto, porque debes sentir un dolor grandísimo. Lo que estaba diciendo antes Goya de que se quiere morir antes, yo creo que ella incluso es egoísta, porque no quiere pasar el dolor de perder a Mario. En ese momento está pensando "si yo me voy antes..."

- Quieres evitar el sufrimiento.

- Efectivamente. Lo que estás evitando es el sufrimiento

... - Claro. Y de hecho, tenemos más miedo al dolor que a la muerte. La muerte la tenemos segura" (GD1:16).

Como parece lógico, la influencia del ciclo de vida en esta cuestión hace que la distribución de situaciones peores que la propia muerte esté muy asociada con la de la edad. Así, mientras que para el 33,1\% de la población joven el dolor y el sufrimiento de la enfermedad es la peor alternativa a la propia muerte, entre la población adulta se señala a la pérdida de un/a hijo/a, 1 de cada 3, proporción idéntica a la mencionada para el mismo temor por la población anciana; no obstante, en ésta sobre todo temen su deterioro y tener que depender de terceras personas, el 39,4\%. Algo en lo que estaban de acuerdo todos los componentes del grupo de discusión, con el añadido de que tanto en los familiares como en la propia persona afectada subyacen una profunda desazón por sentimientos de culpabilidad:

- “- Y yo digo, bueno, si una persona mayor con una vida como se lleva ahora con el trabajo que van a trabajar los hijos, las nueras, todos, pues vaya un incordio que sería tener a una persona ahí, y como está la vida, porque antes la gente mayor no estorbaba.

- Es que no puede salir, una persona tiene que estar con ella en casa.

- Y yo no quiero con cinco hijos estar con ninguno ¿a quién le doy el coñazo de los cinco? A ninguno. En mi casa lo que pueda y cuando no pueda, si ya no puedo valerme y la cabeza me funciona me voy a una residencia, y si no me funciona haced conmigo lo que queráis.

... - Luego estas cosas te crean problemas de conciencia, si tú deseas una cosa o la otra, porque yo cuando mi madre tenía ochenta y seis años y le dio un derrame cerebral y se quedó de la cintura para abajo que no andaba y la cabeza bien, al ver que a ella no podía y ella lloraba y decía; yo no puedo, no puedo, y dejadme 
tranquila. Pesaba ciento y pico kilos y además como no sentía la columna pues se hacía pis, caca, se hacía de todo. Veía a mi madre que iba a salir del hospital y el conflicto que teníamos porque éramos cuatro hijas, la única que vive cerca de ella tiene un hijo deficiente que era un problema para ella para poder atenderla encima. Yo cuando veía a mi madre en el hospital y la veía que lloraba tanto, qué sufrimiento que ya no podía andar, yo en fondo decía: "pero bueno, para vivir así ¿qué va a vivir un año o dos más? Mejor se moría, Dios la tenía que recoger”... Le volvió a repetir o lo que sea y duró un mes y diez días en el hospital aquel. Pero de verdad te lo digo, como ya ha pasado un año y pico pero al principio yo decía: "ay Dios..." a la vez yo deseaba, no la muerte sino que no sufriera.

- Entonces es una muerte piadosa lo que tú pedías.

- Yo pedía... ella aquí no perdió nada, ella lloraba; y “yo, ¿para qué voy a comer? si ya no valgo nada, no me limpiéis a ver si me muero", decía, fíjate; “¿cómo te vamos a dejar sucia? Venga mama come, haz un esfuerzo, come un yogurt”. "Dejadme, si no me dais de comer igual me muero antes". Ese sufrimiento que ella tenía era un conflicto entre la parte de su cuerpo que había quedado bien y la que estaba mal porque le pinchaban en las piernas y todo... Luego duró un mes y pico pero que el haberla llevado para la residencia-hospital aquella, como ella la cabeza la tenía bien, como que estaba triste, decía: “¿para qué me habéis traído para aquí? Para que ahora encima os deje sin dinero".

- Ella también tendría un conflicto.

- Era un tira y afloja" (GD1:20).

Aunque no existen diferencias significativas por religiosidad en este punto, precisamente la posesión de un fuerte sentimiento religioso puede explicar la minusvaloración de la muerte frente a otras situaciones que se consideran más trágicas, como puede comprobarse en el caso de la mujer crédula entrevistada:

- "Sí, quedarse paralítico o ciego, cosas de esas... Mucho más. La muerte por supuesto, pero sería una transición, algo momentáneo, pero quedarte ciego o tetrapléjico sería horrible” (E3:9).

Otra forma de constatar el papel secundario y paradójico que nuestra sociedad otorga a la muerte, a la que se valora no en sí misma, sino como ruptura de la experiencia vital, se observa cuando la mayoría de la población está de acuerdo en que el impacto social de la muerte depende de la edad de las personas que fallecen (pregunta 25). En una sociedad en la que gracias al control sobre las enfermedades no sólo se han alcanzado altos niveles de esperanza de vida, sino que se ha racionalizado la sucesión de generaciones, asentándose y regularizándose el ciclo vital, se valora más la vida en potencia de la población joven que la vida casi amortizada de la población anciana. El poder disruptor de la muerte es menor en el caso de esta última ya que, fruto de la racionalización demográfica, está cristalizada entre la población una visión temporal normalizada de la muerte por la que se asume la muerte de los más mayores como final de ciclo -es considerada como la "muerte natural" (Cátedra, 1988)-, sin embargo no ocurre así con la muerte antes de tiempo, a contracorriente, de los más jóvenes que rompe esa lógica "naturalizada” de la misma. No es extraño, por tanto, que el 95,2\% de las personas encuestadas crean que la sociedad, los demás, valoran como menos trágica la muerte de un 
anciano que la de un niño, Cuadro 5.33. Interrogados sobre cuál era su opinión al respecto (pregunta 26), se aprecian algunas diferencias respecto a lo que dicen que valora la sociedad, sin embargo, la mayoría, el 80\%, manifiestan que ellas también opinan así. Como opinan la joven no creyente entrevistada y componentes del grupo de discusión:

- "Hombre, a mí me da menos pena que se muera una persona mayor que no un joven o un niño... porque cuando ves una esquela en el periódico y tiene noventa años, pues dices: este hombre ya tenía edad suficiente, sí lo comenta todo el mundo. O cuando se muere algún personaje famoso, pues hombre sí, como Rafael Alberti, te daba pena pero como ya han vivido la vida tampoco van a ser eternos. No te da tanta pena como cuando a una persona se le trunca su vida y todavía no le ha dado tiempo. Yo creo que sí es un sentimiento general” (E2:9).

- “... si el que se marcha es una persona joven o es una persona, como dice este compañero, de noventa años. No hay color. Hay también que situarse de que sea un hombre de cuarenta años, o una mujer, una persona joven a que sea una persona de noventa años que incluso si tienen la cabeza bien se dan cuenta de que se quieren ir. Yo lo entiendo así, es completamente distinto” (GD1:19).

En el Cuadro 5.33 se recogen, asimismo, unos datos que aparentemente contradicen lo señalado hasta ahora. Pasados ya los tiempos en que la muerte de una persona afectaba e implicaba a toda la sociedad y que, al alimón del auge del imperio del individualismo, lo importante es el Yo, es decir, vivir la propia vida, resultaría congruente pensar que interrogadas las personas encuestadas, las cuales mayoritariamente transitan en esa lógica o en sus aledaños, sobre para quién es fundamentalmente una pérdida la muerte de una persona respondieran que para sí misma (pregunta 27). Sin embargo, no es así, la mayoría de ellas, 3 de cada 4, creen que es una pérdida para los familiares y amigos, mientras que 1 de cada 5 opina que lo es para sí misma, y menos del 3\% que es, como se contempla en el modelo tradicional, una especie de catástrofe social. Esta aparente contradicción, que ya fue señalada por Riley (1960), está muy correlacionada con el nivel de estatus. En el presente trabajo se aprecia en las distribuciones por edad y por nivel de estudios, y refleja que a la hora de pensar en la muerte la mayoría de la población piensa en la muerte de los otros, que es la que conoce y que es para la que le resulta más fácil imaginar sus consecuencias y a quién o a quiénes afecta en la realidad que conoce. Quizá por ello, son los jóvenes (mayoritariamente con estudios universitarios), los que ven más alejada su muerte y, por tanto, menos se la imaginan, los que en menor medida consideran que la muerte es sobre todo una pérdida para la propia persona que muere. Quizá también, en este caso por el papel desarrollado hasta hace poco tiempo por los hombres como principales proveedores de recursos económicos para la familia y por su mayor actuación en el espacio público, sean ellos los que consideran, relativamente menos que las mujeres, la muerte de una persona como pérdida para la propia persona. Como opina el adulto entrevistado:

- "Pensando como pienso yo, yo creo que para sus familiares. Yo estoy hablando ya con mis cincuenta y tres años y pasada la vida, a lo mejor me lo preguntas a 
los veinte y no opino lo mismo. Ahora, en la vida que tengo yo vuelvo a decir lo mismo; me preocupa más la muerte de mis familiares" (E4:12).

En todo caso, la respuesta a esta cuestión está también relacionada con la propia percepción de lo que se produce en el proceso de muerte, como apuntan la joven no entrevistada y en el grupo de discusión:

- "Creo que para sus familiares y la gente próxima al muerto, porque el que muere sufre una pérdida de lo que le pudiera quedar de vida pero ya no es una pérdida consciente. Cuando te mueres ya no puedes valorarlo, no es como cuando pierdes otra cosa que piensas: "qué bien estaba antes y ahora...”" (E2:12).

- “- A quién le importa la muerte es a los familiares que quedan, que lo sufren. El que se muere, pues sí, pero ya no siente nada” (GD1:18).

En lo que sí que hay consenso es en lo irrelevante que se considera la pérdida en términos sociales:

- “- Yo pienso que en estos casos a quién menos le interesa es a la sociedad. La sociedad, normalmente, dice "que cada uno con su problema se apañe" y así la cosa globalizada no creo que le importe la muerte de los demás” (GD1:18).

Estos resultados, por otra parte, no son más que el reflejo de una relación ambivalente con la muerte, en la que conscientemente no se la percibe de forma trágica pero que, sin embargo, inspira un temor ancestral que emerge cuando uno la percibe en la cercanía, es decir, cuando se pasa de las actitudes ante la expectativa de la propia muerte a las actitudes ante la muerte. Socialmente se la deniega, se vive como si no existiera ni fuera a venir, hasta que no queda más remedio que enfrentarse a ella. Mientras tanto se la recluye en una geografía muy delimitada por la que, como se ha señalado más arriba, no hay ningún interés en transitar. Si esto es así para los adultos es fácil imaginar que socialmente no exista ningún interés en acercar la muerte real a los/as niños/as, sino más bien al contrario. Actitud protectora que censura la visión de la misma de la que son partidarias más de la mitad de las personas encuestadas que afirman que no hay que dejar ver la muerte a los/as niños/as (pregunta 24d), cuando paradójicamente la visión de la muerte virtual está desplegada de forma casi pornográfica desde todos los medios de comunicación al alcance de los menores de edad, Cuadro 5.33. 


\section{CUADRO 5.33.: PROPORCIÓN DE PERSONAS QUE ESTÁN DE ACUERDO CON LAS SIGUIENTES AFIRMACIONES (\%).}

\begin{tabular}{|c|c|c|c|c|c|}
\hline & \multirow{2}{*}{$\begin{array}{c}\text { Los niños deben } \\
\text { ser protegidos de } \\
\text { ver la muerte } \\
\text { siempre que sea } \\
\text { posible } \\
\end{array}$} & \multirow{2}{*}{$\begin{array}{c}\text { La sociedad } \\
\text { considera menos } \\
\text { trágica la muerte de } \\
\text { los ancianos que la } \\
\text { de los jóvenes } \\
\end{array}$} & \multicolumn{3}{|c|}{$\begin{array}{c}\text { La muerte de una persona es una } \\
\text { pérdida para... }\end{array}$} \\
\hline & & & sí misma & $\begin{array}{l}\text { familiares y } \\
\text { amigos }\end{array}$ & $\begin{array}{c}\text { toda la } \\
\text { sociedad }\end{array}$ \\
\hline TOTAL & 52,0 & 95,2 & 20,7 & 76,5 & 2,6 \\
\hline HOMBRES & 50,3 & 95,2 & 17,5 & 77,7 & 4,8 \\
\hline MUJERES & 53,2 & 95,3 & 22,7 & 75,7 & 1,2 \\
\hline JÓVENES & 44,9 & 94,4 & 14,7 & 81,2 & 4,1 \\
\hline ADULTOS & 49,3 & 96,5 & 26,8 & 71,1 & 2,1 \\
\hline ANCIANOS & 76,7 & 95,1 & 24,4 & 74,4 & 0,0 \\
\hline EST. BÁSICOS & 76,5 & 94,3 & 28,2 & 69,0 & 1,4 \\
\hline EST. MEDIOS & 56,4 & 93,3 & 25,8 & 71,9 & 2,2 \\
\hline EST. UNIVERS. & 44,6 & 96,2 & 16,9 & 80,1 & 3,1 \\
\hline CRÉDULOS & 50,7 & 95,4 & 22,7 & 74,0 & 3,3 \\
\hline CREYENTES & 50,5 & 96,6 & 19,5 & 78,2 & 1,1 \\
\hline NO CREYENTES & 52,9 & 92,6 & 16,5 & 83,5 & 0,0 \\
\hline INCRÉDULOS & 52,4 & 95,2 & 20,6 & 71,4 & 7,9 \\
\hline
\end{tabular}

Fte: Encuesta 2000. Elaboración propia

Existen, no obstante, diferencias significativas ligadas al ciclo vital. Tres de cada cuatro ancianos está de acuerdo con ese tipo de censura mientras que menos de la mitad de los adultos y de los jóvenes la comparten. En las entrevistas realizadas se constata la disparidad de posiciones al respecto:

- “... yo creo que más que protegidos a los niños hay que educarles y tienen que saber que la vida no es eterna y que existe la muerte, tampoco se les va a estar amargando, pero cada momento tiene su parte adecuada para enseñar unas cosas. Tampoco hay que protegerles de ver la muerte" (E1:9).

- "Sí, que es un tema bastante impactante cuando eres pequeño y creo que se debe evitar. Son situaciones que te pueden generar traumas. Tampoco evitar hablar del hecho de la muerte, de manera natural, por eso luego le pasa a la gente lo que me pasa a mí, que no lo sabemos afrontar. Pero el hecho de ver imágenes de violencia en la televisión, eso sí creo que se debería evitar, pueden crear sentimientos contradictorios a los niños. Por lo menos si lo tienen que ver que estén preparados para ello, que no sea algo que les surja de repente... Yo sí recuerdo cuando era pequeña que las imágenes de muertos, en televisión no en películas, en informativos sí me impactaba mucho y luego pensaba mucho y he tenido pesadillas" (E2:11).

- "No sé, se le puede llevar y al niño le queda ahí un trauma para toda su vida. No lo sé, no tengo ni idea. Sé que todo el mundo lo hace y si me tocase imagino que haría lo mismo, lo evitaría" (E3:11). 
- "Es que no hay ninguna necesidad de que los niños vayan a ver el cadáver. El abuelo se ha ido, pues santas pascuas. Tampoco creo que sea tan importante que vean al cadáver. Es un trago en el que los críos lo podrían pasar muy mal, y ¿para qué? No tiene ningún sentido bajo mi punto de vista. ¿Por qué tiene que ver el niño al abuelo muerto? Estamos hablando de esta sociedad en que vivimos, en algunos casos se tienen que adaptar y ver las cosas que ocurren pero como no es algo que sea necesario, si puede evitarse yo considero que es mejor que se evite” (E4:12).

\title{
5.8. MULTIDIMENSIONALIDAD DEL MIEDO A LA MUERTE
}

\begin{abstract}
“ESTOY DESPROVISTO DE FE y no puedo, pues, ser dichoso, ya que un hombre dichoso nunca llegará a temer que su vida sea un errar sin sentido hacia una muerte cierta”
\end{abstract}

S. Dagerman

El análisis sociológico de las actitudes ante la expectativa de la muerte ha tendido a primar, tradicionalmente, una única expresión de esas actitudes, el miedo, obviando a las demás. De esta forma, se ha reducido a una única dimensión el miedo a la muerte cuando en realidad éste es un cúmulo de actitudes complejas en interacción, mezcla de conductas evasivas, esperanzadoras, conflictivas y de adaptación que se compensan entre sí, como han mostrado por su parte los análisis psicológicos ${ }^{56}$. Los resultados de la encuesta realizada permiten precisamente poner de manifiesto esa multidimensionalidad de la relación individuo/sociedad/ muerte. Si hasta ahora se han examinado toda una variedad de dimensiones aisladas de esa relación, relativas unas a la muerte propia (pensar en la muerte, hablar sobre ella, la pérdida del yo, lo desconocido y al más allá, consecuencias para los allegados, ruptura de un proyecto vital, etc.), otras a la muerte de los otros (muerte de alguien próximo, ver o no el cadáver de conocidos, etc.), además de la referidas al morir propio (en casa, indoloro, inconsciente, mínimo, etc.), o al morir de los demás (medicalización, hospitalización, etc.),..., dimensiones que todas ellas apuntan a la existencia de un miedo más o menos difuso hacia la muerte, se hace necesario traspasar ese tope analítico con el que tradicionalmente se conforma el análisis sociológico para contemplar, más allá del mismo y de forma integrada, un abanico más amplio de actitudes ante la muerte que, además del miedo a la misma, abarque otras dimensiones igualmente significativas que aportan luz sobre la relación individuo/sociedad/muerte.

\footnotetext{
${ }^{56}$ Además de artículos teóricos sobre psicología de la muerte, en el texto compilado por Neimeyer (1997) puede encontrarse toda una serie de artículos sobre trabajos empíricos en los que se examinan las actitudes hacia la muerte con perspectiva multidimensional; asimismo, incluye artículos técnicos en los que se exponen los instrumentos (escalas, protocolos, etc.) como los habitualmente se utilizan en ese tipo de análisis. En Lonetto y Templer (1988) se pueden ver aplicaciones de esos instrumentos en Estados Unidos. Instrumentos que también son presentados y analizados, a la par que aplicados para el caso de España, en Urraca (1982).
} 
En este sentido, conviene diferenciar entre ansiedad ante la muerte, temor o miedo a la muerte y preocupación ante la muerte. Si la primera hace referencia a una amenaza difusa y general que pueda comprometer la supervivencia personal, siendo su función precisamente alertar frente a ese peligro difuso, el miedo a la muerte es, según la definición de Hoelter (1979:996), una "reacción emocional que implica sentimientos subjetivos de desagrado y preocupación basados en la contemplación o anticipación de cualquiera de las diferentes facetas relacionadas con la muerte", es decir, un tipo de reacción emocional ante un estímulo específico, localizado e identificado (el final de todo lo que se conoce, la pérdida de control, las consecuencias de la muerte sobre las personas allegadas, etc.). Estímulo que se percibe como un castigo y que, también con la función de mantener la supervivencia del individuo ${ }^{57}$, puede provocar en éste reacciones de evitación, huída o eliminación del mismo. Es decir, "el miedo a la muerte no se refiere a aspectos especulativos de la misma (propios de la ansiedad ante la muerte)” (Urraca, 1982:92 y 103-104). Por su parte, la preocupación ante la muerte es la “contemplación consciente de la realidad de la muerte y una evaluación negativa de esa realidad” (Dickstein ${ }^{58}$, 1972:565). Cabe suponer que una persona que esté preocupada por la muerte se muestre asimismo ansiosa ante ella, como cabe admitir que si en un entorno social domina la negación de la muerte, la reacción social políticamente correcta en él sea la de rechazar la preocupación por la muerte (Urraca, 1982). En el examen realizado hasta ahora en este trabajo no se ha diferenciado entre las tres actitudes y se han incluido todas las actitudes analizadas como si fueran dimensiones aisladas dentro de la gran actitud de miedo a la muerte, como las uvas de un sólo racimo que es a la vez la parra. Para perfilar la estructura de ésta y mostrar que efectivamente en ella existen distintos racimos que, aunque alimentados por la misma savia, no todos ellos son idénticos, es decir, que las tres actitudes ante la muerte, ansiedad, miedo y preocupación, son multidimensionales, y se cruzan transversalmente entre ellas, se procede a analizar en primer lugar un ejemplo de preocupación ante la muerte para a continuación abordar las distintas dimensiones que se detectan en el miedo a la muerte entre la población encuestada.

Fruto quizá de la complejidad de esa relación con la muerte, la mayoría de las personas encuestadas, 52,2\%, no se sienten preparadas a día de hoy para afrontar su propia muerte, mientras que algo menos del 30\% de ellas afirman estarlo (pregunta 73j), Cuadro 5.34. Esas

\footnotetext{
${ }^{57}$ Existe un debate centrado en si el miedo a la muerte es connatural al ser humano, es decir, si nace o no con él. Debate en el que algunos autores consideran que es el sistema de muerte, es decir, la sociedad, la que crea dicho miedo para someter a los individuos, mientras que otros autores, como Becker (2003:4350) afirman que el mismo es, en realidad, una expresión del instinto de conservación que "funciona como un aliciente constante para asegurar la vida y dominar los peligros que la amenazan”. Si no fuera así, si el miedo a la muerte no estuviera inscrito en el funcionamiento biológico normal del ser humano y fuera sólo una actitud consciente, permanentemente activada, "seríamos incapaces de funcionar con normalidad" por el continuo gasto de energía psicológica que conllevaría.

${ }^{58}$ Citado en (Urraca, 1982:151).
} 
actitudes de preocupación ante la muerte están muy asociadas con las diferentes variables de control. Así, mientras un tercio de los hombres admiten estar preparados ante su muerte, a la par que a un cuarto de ellos les es indiferente esa preocupación, casi 6 de cada 10 mujeres señalan no estar preparadas, frente al 26,9\% que afirman lo contrario. Asimismo, se observa una clara vinculación de las respuestas a esta pregunta con la fase del ciclo vital en la que se encuentra la persona encuestada. Las razones señaladas hasta ahora para las diferentes edades explican que las personas ancianas (mayoritariamente de estudios bajos) se sientan más preparadas que las de los otros dos grupos etarios; de hecho, son las dos únicas categorías, ancianos y estudios bajos, en las que más de la mitad de la población afirma estar preparada para afrontar su muerte. La variable religiosidad influye sobre todo entre los que se declaran más religiosos, de los que 4 de cada 10 asumen ese enfrentamiento; no obstante, incluso entre esta categoría, la de los crédulos, es mayoritaria la posición de rechazo, 44,6\%. Posición mayoritaria también, aunque con mucha más intensidad, entre los no creyentes o incrédulos, casi 6 de cada 10.

CUADRO 5.34.: GRADO DE ACUERDO/DESACUERDO CON LA IDEA: “ME SIENTO PREPARADO PARA AFRONTAR MI MUERTE” (\%)

\begin{tabular}{|l|c|c|c|}
\hline & ACUERDO & INDIFERENTE & DESACUERDO \\
\hline TOTAL & 29,1 & 18,7 & 52,2 \\
\hline HOMBRES & 32,3 & 25,0 & 42,7 \\
MUJERES & 26,9 & 14,3 & 58,8 \\
\hline JÓVENES & 19,8 & 21,3 & 58,8 \\
ADULTOS & 29,2 & 16,1 & 54,7 \\
ANCIANOS & 55,9 & 16,2 & 27,9 \\
\hline EST. BÁSICOS & 56,9 & 10,3 & 32,7 \\
EST. MEDIOS & 27,0 & 17,6 & 55,3 \\
EST. UNIVERS. & 23,6 & 20,8 & 55,6 \\
\hline CRÉDULOS & 41,2 & 14,2 & 44,6 \\
CREYENTES & 26,4 & 16,1 & 57,5 \\
NO CREYENTES & 19,1 & 22,6 & 58,3 \\
INCRÉDULOS & 19,4 & 22,6 & 58,1 \\
\hline
\end{tabular}

Fte: Encuesta 2000. Elaboración propia

Estas diferencias en la preocupación ante la propia muerte, sobre todo las ligadas a la edad, certifican que no existe un único y compacto miedo a la muerte inyectado, a modo de veneno existencial, en la misma cantidad en todos los individuos. Si así fuera, la proporción de los que se sienten preparados sería nula en todas las categorías sociales y, en caso de no ser nula, al menos debería ser idéntica en todas ellas. Por tanto, la "actitud universal miedo a la muerte” (Becker, 2003) no es un todo cerrado, homogéneo y monolítico, comparable en todas las sociedades, sino que al ser una construcción social difiere en sus perfiles entre las diferentes 
culturas, y entre las distintas categorías sociales. Por ejemplo, Long (1985-86) en un análisis sobre el miedo en la cultura islámica comprobó que el temor a lo desconocido o el miedo a ser destrozado no estaban tan extendidos en ella como en la cultura cristiana occidental.

$\mathrm{Al}$ objeto de indagar sobre las diferentes dimensiones del miedo a la muerte entre la población encuestada se ha realizado un análisis factorial ${ }^{59}$ de componentes principales ${ }^{60}$ cuyos resultados se recogen en el Cuadro 5.35. Análisis factorial que inicialmente abarcaba 26 variables, pero que finalmente se circunscribió a las 19 que tenían una comunalidad superior a $0,50^{61}$. La formulación de estas variables fue tomada directamente o ligeramente retocada de los protocolos e instrumentos empleados en diferentes investigaciones, en unos casos, de los cuestionarios de encuestas más generales, como la Encuesta Mundial de Valores -EMV-, en otros, de los protocolos de estudios dirigidos específicamente a detectar y medir la multidimensionalidad del miedo a la muerte, como el Perfil Revisado de Actitudes hacia la Muerte -PRAM- (Wong et al, 1997), o la Escala Revisada de Ansiedad ante la Muerte ERANM- (Thorson y Powell, 1997), además del cuestionario utilizado por Riley (1979) en su encuesta sobre la muerte. El origen de la formulación de cada item concreto se recoge en los acrónimos incluidos en cada fila de la primera columna del Cuadro 5.33. Este análisis ha permitido identificar combinaciones lógicas de variables para comprender mejor las relaciones entre ellas. Como resultado del mismo, para el conjunto de la población encuestada se extraen seis factores que en conjunto explican el 63,19\% de la varianza común ${ }^{62}$. El Cuadro 5.33. recoge la matriz de componentes rotados, y a partir del mismo se constata de forma diáfana cómo lo que globalmente se suele considerar como miedo a la muerte en realidad es la suma de múltiples actitudes que se contrabalancean entre sí. Así, junto al temor a la muerte en sí se observan distintos tipos de aceptación de la misma, además de la evitación y renuencia a interactuar con ella. Dado que cuatro de los seis factores implican algún tipo de aceptación de la muerte, pero con distinta raíz, antes de identificarlos conviene delimitar de forma genérica dichas actitudes. Siguiendo a Wong et al (1997:134-135), la aceptación de la muerte "se puede definir ampliamente como estar psicológicamente preparado para la salida final”, es decir, es una actitud en la que por un lado se acepta conscientemente la propia mortalidad y, por otro, se

\footnotetext{
59 Dado que los KMO (Kaiser-Meyer-Olkin) tienen un valor de 0,727, y que el test de Barlett tiene un valor de 1.801,389 y un grado de significación $\mathrm{p}=0,000$, resulta adecuado la aplicación del análisis factorial (Visauta, 1998:224-225).

60 De acuerdo al "criterio de raíz latente", se han extraído los tres factores con autovalores iguales o mayores que 1 (Hair et al, 2000:92).

61 Siguiendo a Anderson (2.000:101), se han desechado 7 variables que mostraban una comunalidad inferior a 0,50 por ser carentes de explicación suficiente.

${ }^{62}$ Siguiendo el criterio de Hair et al (2000:93), constituye un porcentaje satisfactorio toda vez que en ciencias sociales es normal considerar como tal una solución que represente un $60 \%$ de la varianza total.
} 
reacciona emocionalmente de forma positiva ante las consecuencias de esa certeza. Los factores identificados en el análisis realizado son $^{63}$ :

a) Factor 1 (explica el 18,25\% de la varianza): Miedo a la muerte.- Es una actitud universal $^{64}$ por la que se reacciona emocionalmente con rechazo ante algo específico relacionado con la muerte. Para algunos autores, seguidores de la psicología de los constructos personales de Kelly, las personas construyen de forma activa su realidad para poder relacionarse con otras y con el entorno; aquellas que en la estructura de su esquema vital prevén anticipadamente su muerte, tendrán menos miedo a la muerte que las que la han dejado fuera y han organizado su mundo como si su muerte no fuera un hecho real personal (Neimeyer, 1997b; Urraca, 1981). Otros autores, desde una perspectiva existencial, relacionan el miedo a la muerte con la búsqueda de significado personal a la propia vida; del fracaso en esa tarea emergería el miedo a la muerte (Wong, et al, 1997; Frankl, 1981). Propuesta psicológica que enlaza con la pirámide de necesidades de Maslow y la motivación para la autorrealización, de tal forma que los individuos más autorrealizados se aceptan más, tienen una ansiedad más baja y "un miedo a la muerte más bajo” (Tormer, 1997:22). Entre la población encuestada este miedo está relacionado sobre todo con que la muerte supone el final de su vida (la disolución del Yo), con la pérdida de control sobre "mis cosas después de morir" (la pérdida del Yo), y con la incertidumbre e inseguridad sobre lo que vendrá después de la muerte. Así, el 44,5\% de dicha población manifiesta sentirse asustada porque la muerte signifique el final de todo, tal como lo conoce (pregunta 73f), a la par que el 38\% se muestra muy preocupada por no saber lo que pueda existir después de la muerte (pregunta 73l). Como en el caso del adulto incrédulo entrevistado:

- " $<<$ Me asusta el hecho de que la muerte signifique el final de todo tal y como lo conozco>>, no es que me asuste, me desagrada la situación de separarme de mis allegados, pero asustarme tampoco, me fastidiaría tener que irme y dejarlo todo, pero nada más. $<<$ La perspectiva de mi propia muerte despierta mi ansiedad >>, hombre, una cierta ansiedad sí que te despierta, no es algo que pienses todos los días pero si alguna vez lo piensas no es algo agradable de lo que digas "coño, estoy encantado de que venga esto", no" (E4:24).

\footnotetext{
${ }^{63}$ El análisis realizado buscaba, con algunas variaciones en los instrumentos de medida y en las variables empleadas, replicar para la población media lo realizado por Wong et al (1997) en Estados Unidos, empleando la Perfil Revisado de Actitudes hacia la Muerte. Los resultados obtenidos difieren ligeramente al de aquellos. Así, y empleando su terminología a la hora de denominar los factores, los cuatro primeros factores sí coinciden (Miedo a la muerte; Aceptación de acercamiento; Evitación de la muerte; Aceptación de escape), mientras que el quinto y último factor de su análisis (Aceptación neutral) se desdobla en el presente análisis (Aceptación neutral; y al que se ha denominado Aceptación natural).

${ }^{64}$ Reacción universal cuya ausencia puede reflejar la negación de la muerte (Becker, 2003). Aunque no siempre es así, como resaltan Wong et al (1997:134), cuando, tras realizar estudios con personas ancianas comprobaron que muchas de ellas tenían una ansiedad baja ante la muerte, las gustaba hablar sobre su muerte, la anticipaban para "liberarse finalmente de la esclavitud y del peso de un cuerpo frágil", es decir, que su actitud estaba más marcada por la aceptación que por el temor.
} 
Sin embargo, en algunos casos, como en el de la mujer crédula entrevistada, el miedo a morir no está relacionado con el final de esta vida ni con la pérdida del control de las cosas que se poseen, tampoco con la incertidumbre de lo que vendrá, que se tiene muy claro, sino con si se alcanzará o no la meta deseada para después de la muerte, es decir, si se superará el "examen” del "juicio final". En el siguiente extracto de la entrevista se aprecia el papel determinante jugado por el sentimiento de culpa, inoculación característica de la socialización católica, en la generación de ese miedo:

- “M: Miedo, sí, miedo siempre.

E: Pero con ese dominio que planteas de protección espiritual, y convicciones religiosas fuertes...

V: Pero la duda, precisamente, la tienes ahí, y creo que a no ser que seas una maravilla de persona... miedo, vamos, yo siempre tendría miedo porque se te plantea el problema de si te vas a morir y qué pasa con lo que has hecho en esta vida, si lo que has hecho lo has hecho bien o mal. A no ser que seas un santo siempre te quedará la duda. Desde ese punto de vista después te van a pedir cuentas. Y ¿quién no tiene miedo? Pues hay que pasar el examen... Aparte que entre esas creencias está el tema del purgatorio y entonces no lo vas a pasar precisamente bien, si te fueras directamente al cielo estupendo. Luego dicen que hay distintos grados de felicidad, te toca el que te hayas merecido y como es eterno... pues siempre hay... eso suponiendo que te vayas al cielo" (E3:6).

b) Factor 2 (explica el 14,79\% de la varianza): Aceptación de acercamiento.- Es una actitud que de manera sutil niega la muerte al reducir su trascendencia y transformarla en un simple pasaje que hay que atravesar para conseguir la recompensa de una vida posterior. De esta forma se está preparado psicológicamente para la salida final porque la posibilidad de una vida feliz después de la muerte mitiga los temores a ésta. Marías ${ }^{65}$ (1993:375) la denomina actitud trasmundana inconexa, basada en una firme creencia en la inmortalidad del alma, en que la muerte no es un muro, sino un paso, una puerta hacia "la <<otra vida $>>$ que aparece asegurada por el cumplimiento de ciertas condiciones en la vida terrena”. Entre la población encuestada, casi la mitad, el 47\%, está de acuerdo con esta mezcla de deseo (necesidad) y ficción y se ilusiona ${ }^{66}$ con la creencia de que hay una vida después de la muerte (pregunta73h), mientras que alrededor de un tercio se muestra de acuerdo con que la muerte trae la promesa de una vida nueva y gloriosa (pregunta 73e), el 22,9\%, o con que la muerte es la unión con Dios y la gloria

\footnotetext{
${ }^{65}$ A la hora de caracterizar los factores hallados en este análisis resulta interesante compararla con la tipología planteada por Julián Marías (1993:370-381) en su “perspectiva de las ultimidades”. Tipología construida por un lado según se considere a la muerte conectada a la vida (conexa) o no conectada (inconexa), y, por otro, según esté en el lado de acá, de la vida (cis), o del otro lado (trans).

${ }^{66}$ Entre las teorías psicológicas que buscan explicar las actitudes ante la muerte, están las teorías de la negación y las de las ilusiones positivas. Ambos grupos resaltan el papel de los sistemas culturales, los $<<$ sistemas de muerte >>, como amortiguadores ante un "mundo real (que) es sencillamente demasiado terrible para aceptarlo; (que) le dice al ser humano que es un animal insignificante y tembloroso que morirá y se descompondrá” (Becker, 2003:201). Para ello prometen la ilusión de la inmortalidad, $<<$ simbólica >> $0<<$ real $>>$, para que el ser humano parezca importante, "esencial para el universo" (Tomer, 2007:27-28).
} 
eterna (pregunta 73m), el 35,8\%. Entre las posiciones críticas a esta actitud está la del joven varón entrevistado:

“<<La muerte trae la promesa de vida nueva y gloriosa $>>$, pero ¿para qué queremos?, o sea, ponerse a pensar que hay otra vida y no aprovechar ésta, me da igual, también, porque, sí es una vida nueva gloriosa, porqué no, puede serlo, ¿y ésta qué?, ¡estaremos aquí para algo! ¿No? Que es la que somos conscientes de que la hay y existe" (E1:15).

c) Factor 3 (explica el 9,42\% de la varianza): Evitación de la muerte.- Si no se puede eliminar la muerte al menos sí es posible no preocuparse por ella negándola. Es otra forma de actitud transmundana inconexa por la que, dado que se haga lo que se haga la muerte acabará apareciendo, lo mejor para no angustiarse por ello es desconectarla de la vida. Se elimina al estímulo que produce temor rechazando enfrentarse a la realidad de la muerte y a sus consecuencias (Wong et al, 1997:137). En sí misma no es una actitud patológica, sino un mecanismo de defensa que mantiene la muerte fuera de la consciencia ante la inaceptabilidad de la muerte personal ${ }^{67}$. En efecto, siguiendo a Becker (2003:261), la muerte "es un problema abrumador para un animal que no tiene instinto”, por lo que el ser humano sólo se puede proteger frente a ella limitándola, aislándose de su experiencia, desarrollando el olvido de sus terrores y ansiedades, en definitiva, reprimiéndola para autoprotegerse porque de lo contrario no sería capaz de actuar. Ese autoengaño se manifiesta en una desgana o falta de voluntad para estar cerca o tocar la muerte y en un rechazo a experimentar situaciones con reminiscencias a ella. En el caso de la población encuestada, el $40 \%$ intenta no tener nada que ver con la muerte (pregunta 73b) y 4 de cada 10 manifiesta que voluntariamente no quiere pensar en ella (pregunta 73k). Como gráficamente comenta el adulto entrevistado:

- "Yo creo que la gente no habla de la muerte... Por miedo a ella. No se habla de lo que se tiene miedo, creo que eso es así... Y además no gusta hablar de ella porque no es un tema que le guste a la gente. Porque es un tema muy temido por la gente en general. No se habla de lo que se teme" (E34:7).

d) Factor 4 (explica el 8,44\% de la varianza): Aceptación de escape.- La vida en su dimensión de calidad es lo único que cuenta. Para unas personas, si no se puede vivir la vida con unas condiciones mínimas no merece la pena ser vivida. Para otras, el miedo a vivir bajo ciertas condiciones puede ser más fuerte que el miedo a la muerte. Es la actitud cismundana conexa, la muerte es un muro, pero totalmente engarzado con la vida, a la que <<explica >> e interpreta: "Si se piensa que la vida termina positivamente en la muerte, que ésta le confiere

\footnotetext{
67 "Lejos de ser un acontecimiento patológico, la negación de la muerte puede representar la salud de una persona que se refugia temporalmente de una realidad caótica que no se puede adaptar a su actual sistema de significado" (Neimeyer, 1997a:269-270). De hecho, esa estrategia se convertiría en un proceso mórbido, en neurosis, si fracasan las "torpes mentiras respecto a la realidad": para algunas personas "el mundo es demasiado para ellas, y las técnicas que han desarrollado para mantenerlo a raya y hacerlo a su medida al final acaban ahogándolas” (Becker, 2003: 262).
} 
unidad y figura, la vida toda se orienta hacia el morir... La vida se orienta hacia la muerte; no en el sentido de que la busque o procure, sino en el de que la elige; la vida se convierte en una busca de una buena muerte" (Marías, 1993:374). Dados los resultados reflejados más arriba tanto en lo relativo a la disyuntiva calidad/cantidad de vida, como a la opinión muy mayoritaria de que existen situaciones peores que la propia muerte, no es extraño que casi 7 de cada 10 personas encuestadas considere que la muerte es a veces una bendición, una buena salida para una vida que no merece vivirse (pregunta 63d), o que el 44,3\% de ellas la perciba como una liberación del dolor y el sufrimiento (pregunta 22e), cuando no el fin de todas las preocupaciones, como declaran 1 de cada 3 (pregunta 73c). Como afirman el adulto incrédulo o los componentes de grupo de discusión:

- “¿La muerte es una liberación del dolor y el sufrimiento? Desde luego que sí. En muchos casos, lo es. Estoy convencido de que lo es. Yo creo que para vivir mal, es mejor no vivir. $Y$ tengo muy claro que si en un momento determinado, el tema es irreversible y la situación es fastidiada, pues claro que es una liberación. Te mueres y te quedas a gustísimo. O creo que te quedas a gusto. No lo sé. Yo creo que entre vivir muy mal y morir, es mejor morir" (E4:9).

- “- Hay quien está viviendo y está sufriendo muchísimo y entonces la muerte sí puede ser una bendición.

- Porque si pasas un sufrimiento muy grande...

- Como cuando alguien ha estado, como ese funcionario de prisiones que estuvo secuestrado tantísimo tiempo ¿tú te imaginas?.

- Lo que tiene que haber pasado.

- ..Son situaciones límite pero ese hombre, yo pienso, que tendría que estar deseando morirse porque un día y otro día, que tendrá que perder el conocimiento...

- Que les dijo: "pegarme un tiro".

- ..Sí, pero hasta entonces...

- Ahora, son situaciones límite" (GD1:47).

e) Factor 5 (explica el 6,34\% de la varianza): Aceptación neutral.- Se acepta la muerte, pero sobre todo se vive la vida, que es finita. A la muerte "ni se la teme, ni se le da la bienvenida” (Wong et al, 1997:135) ${ }^{68}$. Según Marías es la actitud cismundana inconexa, se cree en la facticidad de la muerte, que la hace inevitable. La muerte es una barrera extrínseca a la vida con la que nada tiene que ver. Así, "la vida aparece como indiferente vista desde la muerte, y ésta como <<inorgánica >>, es decir, que no se articula con la vida ni confiere ninguna articulación a ella” (Marías, 1993:373). Es la posición de N. Elias (1987:82-84) cuando afirma "la muerte no tiene nada de terrible. Se cae en sueños y el mundo desaparece, cuando todo va bien... Quizá se debería de hablar más abiertamente y claramente sobre la muerte, aunque no sea más que dejando de presentarla como un misterio. La muerte no encierra misterio alguno, no

${ }^{68}$ En una entrevista realizada a Paco Rabal antes de fallecer, al preguntarle si tenía miedo a morir recordaba un dicho popular que con frecuencia recitaba su abuela: "Todo el mundo tenemos que nacer, y todo el mundo tenemos que morir". 
abre ninguna puerta. Es el fin de un ser humano”. Una de cada cuatro personas encuestadas no aprecia intencionalidad en la muerte, no la consideran ni buena ni mala (pregunta 22f). Y más de dos de cada tres está de acuerdo en que la muerte es inevitable y que, en consecuencia, no tiene sentido preocuparse por ella (pregunta 22c). Como en el caso de la joven no creyente:

- "Es como si está lloviendo y ¿qué voy a hacer? No me voy a preocupar porque no va a dejar de llover" (E2:6).

f) Factor 6 (explica el 5,94\% de la varianza): Aceptación natural- Se percibe a la muerte como un proceso natural que forma parte de la vida. La muerte está delante de cada persona y también detrás, desde que nace hasta que muere. Al margen de las diferencias en el vivir lo cierto es que "todos acaban igual, todos mueren sin distinción”. Es la actitud transmudana conexa (Marías, 1993:376). Algo más del 90\% de las personas encuestadas perciben la naturalidad de la muerte, como parte del proceso de la vida (pregunta 22j), proceso que al finalizar, según el 85,5\% de ellas, iguala a todos los seres humanos (pregunta 63c). Así, por ejemplo, para el varón incrédulo la muerte es simplemente un acontecimiento natural, y para la joven no creyente el carácter democrático de la muerte no sólo constituye una certeza, sino también un consuelo frente a las frustraciones:

- "Es la última parte del proceso de la vida. Es el final de una vida y.. se acabó. Una planta.. le da el sol, se seca, y se acabó, nada más” (E4:9).

- "Pues, sí, estoy de acuerdo porque ahí no se libra nadie, es lo único que me consuela, cuando pienso en la muerte, bueno, mal de muchos.. Sí, porque a veces cuando te pasan cosas malas dices "jolin, cómo me ha pasado a mí esto, fíjate Fulanito qué suerte ha tenido que tal”, pasa así, lo típico, que siempre miras a la gente, o te comparas con otras personas, pero aquí pienso en la muerte y es algo que le pasa a todo el mundo, entonces, en cierta manera me consuela, dirás qué consuelo pero, bueno, sí que lo pienso a veces” (E2:22). 


\begin{tabular}{|c|c|c|c|c|c|c|}
\hline \multicolumn{7}{|c|}{ CUADRO 5.35.: PRINCIPALES PREOCUPACIONES ${ }^{\text {a }}$} \\
\hline & \multicolumn{6}{|c|}{ Componente } \\
\hline & 1 & 2 & 3 & 4 & 5 & 6 \\
\hline (p.22c) “La muerte es inevitable, no tiene sentido preocuparse por ella” (PRAM) & $-0,120$ & 0,053 & 0,211 & 0,031 & 0,789 & 0,040 \\
\hline (p.22e) “La muerte es una liberación del dolor y el sufrimiento” (PRAM) & 0,044 & 0,250 & 0,049 & 0,665 & $-0,020$ & 0,205 \\
\hline (p.22f) “La muerte no es ni buena ni mala” (PRAM) & $-0,200$ & 0,031 & $-0,226$ & 0,184 & 0,592 & 0,278 \\
\hline (p.22g) “La muerte tiene sentido sólo si crees en Dios” (EV) & $-0,060$ & 0,674 & 0,244 & 0,257 & $-0,176$ & 0,014 \\
\hline $\begin{array}{l}\text { (p.22j) “La muerte es un acontecimiento natural, simplemente una parte del proceso de vida” } \\
\text { (PRAM) }\end{array}$ & 0,009 & $-0,297$ & $-0,016$ & 0,003 & 0,386 & 0,583 \\
\hline (p.63d) “La muerte es a veces una bendición” (PRAM) & $-0,078$ & $-0,003$ & $-0,051$ & 0,749 & 0,003 & 0,103 \\
\hline (p.63c) “La muerte nos iguala a todos” RILEY & 0,004 & 0,006 & 0,105 & 0,151 & 0,007 & 0,716 \\
\hline (p.73a) “Tengo un miedo intenso a la muerte” (PRAM) & 0,604 & 0,106 & 0,237 & 0,000 & $-0,433$ & 0,004 \\
\hline (p.73b) “Intento no tener nada que ver con el tema de la muerte” (PRAM) & 0,124 & $-0,004$ & 0,809 & $-0,002$ & $-0,006$ & 0,002 \\
\hline (p.73c) “La muerte pondrá fin a todas mis preocupaciones” (PRAM) & 0,004 & 0,006 & $-0,006$ & 0,710 & 0,123 & $-0,126$ \\
\hline (p.73d) “Odio la idea de sentirme indefenso después de morir” (ERANM) & 0,691 & $-0,000$ & 0,006 & 0,104 & 0,186 & $-0,237$ \\
\hline (p.73e) “La muerte trae la promesa de una vida nueva y gloriosa” (PRAM) & 0,002 & 0,889 & 0,000 & 0,004 & 0,009 & $-0,003$ \\
\hline $\begin{array}{l}\text { (p.73f) “Me asusta el hecho de que la muerte signifique el final de todo tal y como lo conozco" } \\
\text { (PRAM) }\end{array}$ & 0,761 & $-0,002$ & 0,164 & $-0,181$ & $-0,157$ & 0,009 \\
\hline (p.73g) “La perspectiva de mi propia muerte despierta mi ansiedad” (PRAM) & 0,723 & 0,007 & $-0,004$ & 0,006 & $-0,144$ & 0,007 \\
\hline (p.73h) “Me ilusiona pensar en una vida después de la muerte” (PRAM) & 0,227 & 0,664 & $-0,291$ & 0,003 & 0,164 & $-0,105$ \\
\hline (p.73i) “Odio pensar en perder el control de mis cosas después de morir” (ERANM) & 0,573 & $-0,001$ & 0,215 & 0,156 & 0,232 & $-0,478$ \\
\hline (p.73k) ”Evito totalmente pensar en la muerte” (PRAM) & 0,114 & 0,111 & 0,856 & $-0,005$ & 0,121 & 0,002 \\
\hline (p.73l) “Me preocupa la incertidumbre de no saber qué ocurre después de la muerte” (PRAM) & 0,725 & 0,003 & 0,000 & $-0,006$ & $-0,123$ & 0,004 \\
\hline (p.73m) “La muerte es la unión con Dios y la gloria eterna” (PRAM) & 0,000 & 0,884 & 0,007 & 0,006 & $-0,005$ & 0,002 \\
\hline
\end{tabular}

a Matriz de componentes rotados. Método de extracción Análisis Factorial de Componentes Principales. Método de rotación Varimax con Kaiser. La rotación ha convergido en 7 iteraciones.

Los paréntesis que inician cada fila en la primera columna hacen eferencia a la pregunta del cuestionario.

Fte: Encuesta 2000. Elaboración propia 
Del análisis se concluye que, efectivamente, las actitudes que las personas mantienen ante la muerte son una mezcla de actitudes que se contrabalancean (negación, temor, ansiedad, aceptación, indiferencia, ira, esperanza, engaño, alienación,...). Es posible, por ejemplo, imaginar a dos personas a las que hipotéticamente se les pudiera medir exactamente sus actitudes ante la muerte, y que ambas tuvieran el mismo nivel de miedo, pero que el de aceptación de escape de la primera fuera más alto que el de la segunda, y que ésta tuviera un nivel mayor de aceptación neutral que la primera. Es posible, siguiendo con el ejemplo, que la primera, gravemente enferma, esté 'deseando' que su vida se acabe y morir, mientras que la segunda, ajena a ese tipo de deseo, anhele vivir la vida con intensidad dilatando lo más posible su encuentro con la muerte. Es decir, existe una muy amplia casuística en la conformación del miedo a la muerte de las personas. Entre las variables que pueden incidir en ese proceso se han considerado la variabilidad de las relaciones de dependencia de cada uno de los seis factores según género, edad y religiosidad ${ }^{69}$. Para analizar esas relaciones se ha aplicado un análisis ANOVA con el objetivo de detectar la existencia de diferencias significativas entre las distintas categorías sociales en cada uno de los factores. En el análisis se han empleado “escalas aditivas”70, sustituyendo en el presente trabajo cada factor por la media respecto al total de variables que cargan alto sobre el mismo. Es importante advertir en este punto que, por la construcción de las preguntas tipo escala del cuestionario ${ }^{71}$, la lectura de los valores obtenidos debe hacerse en sentido contrario a lo que el valor literal de las medias obtenidas parecería indicar. Así, si la media de una categoría social en, por ejemplo, evitación de la muerte es superior a la media de otra categoría no quiere decir que las personas incluidas en la primera eviten en mayor medida la muerte que las incluidas en la segunda, sino, al contrario, que están más en desacuerdo con la actitud evitar la muerte.

En lo relativo a la variable sexo, las $\mathrm{F}$ de las pruebas y los correspondientes grados de significación $(p)$, sólo indican diferencias significativas en lo que se refiere al primer factor, el miedo a la muerte, y en menor medida respecto a la aceptación de escape (Cuadro 3.36.). En el primer caso, el valor de la media para los hombres, 3,47, supera al de las mujeres, 3,25, es decir, son éstas las que tienen más desarrollada la actitud miedo a la muerte. Lo que se puede constatar si se consideran los porcentajes de respuesta por sexo en alguna de las variables que cargan más

\footnotetext{
${ }^{69}$ Dada la composición de la muestra, en la que gran parte de la población joven es la que tiene estudios universitarios y buena parte de la población anciana la que tiene estudios básicos, se omite el análisis para la variable estudios por ser sus resultados próximos a los de la variable edad.

${ }^{70}$ Esta técnica consiste en reemplazar cada factor por una "combinación lineal de todas las variables que cargan alto sobre el mismo, y el total -o más normalmente la puntuación media de las variables- se emplea como variable de sustitución” (Hair et al, 2000:103-107).

${ }^{71}$ En efecto, hay que recordar que el tipo de escala utilizado en este trabajo es el Likert que añade una medida de intensidad en el grado de acuerdo con las afirmaciones planteadas en los ítems. El tipo de escala utilizado identifica mayor grado de acuerdo con menor puntuación en la escala: Muy de acuerdo (1), Bastante de acuerdo (2), Indiferente (3), Poco de acuerdo (4), Nada de acuerdo (5).
} 
en el Factor1. Así, por ejemplo, 1 de cada 2 mujeres, 50,6\%, afirma estar de acuerdo (muy + bastante) con que le preocupa el que la muerte signifique el final de todo, frente a la intranquilidad que muestran algo más de un tercio de los hombres, 35,7\%, (pregunta73f). En lo relativo a la aceptación de escape, los hombres presentan una media inferior a la de las mujeres, 2,85 frente a 3,03, es decir, están más de acuerdo con esa actitud. Las respuestas por género a una de las variables incluidas en ese Factor4, concretamente, a que la muerte es a veces una bendición (pregunta 63d), confirman que los hombres están ligeramente más de acuerdo con la misma, $69,8 \%$, que las mujeres, $66,7 \%$.

\begin{tabular}{|c|c|c|c|c|}
\hline \multicolumn{5}{|c|}{ CUADRO 5.36.: ANOVAS PARA SEXO } \\
\hline & Hombres & Mujeres & $\mathbf{F}(1,399)$ & $p$ \\
\hline F1: Miedo a la muerte & $\begin{array}{l}3,47 \\
0,76 \\
\end{array}$ & $\begin{array}{l}3,25 \\
0,87\end{array}$ & 7,014 & 0,008 \\
\hline $\begin{array}{r}\text { F2: Aceptación de acercamiento } M e . \\
\text { Des. Típ. }\end{array}$ & $\begin{array}{l}3,25 \\
1,08\end{array}$ & $\begin{array}{l}3,14 \\
1,03\end{array}$ & 1,048 & 0,307 \\
\hline F3: Evitación de la muerte & $\begin{array}{l}2,99 \\
1,03\end{array}$ & $\begin{array}{l}2,89 \\
1,06\end{array}$ & 0,850 & 0,357 \\
\hline F4: Aceptación de escape & $\begin{array}{l}2,85 \\
0,93\end{array}$ & $\begin{array}{l}3,03 \\
0,88\end{array}$ & 3,375 & 0,067 \\
\hline F5: Aceptación neutral & $\begin{array}{l}2,50 \\
0,99\end{array}$ & $\begin{array}{l}2,59 \\
0,99\end{array}$ & 0,870 & 0,351 \\
\hline F6: Aceptación natural & $\begin{array}{l}1,67 \\
0,69\end{array}$ & $\begin{array}{l}1,62 \\
0,68\end{array}$ & 0,593 & 0,442 \\
\hline
\end{tabular}

Fte: Encuesta 2000. Elaboración propia

La realización de los ANOVAs por edad muestra que existen diferencias significativas entre las tres categorías etarias en cuatro de los factores (Cuadro 5.37.). Las más importantes se producen en la aceptación de acercamiento y en la de escape, en menor medida en el miedo a la muerte y en menos aún en la aceptación de la misma como un proceso natural. Así, se constata que mientras son los jóvenes los que tienen una actitud de mayor miedo a la muerte, son los ancianos los que más aceptan la proximidad de su llegada, los que están más de acuerdo en considerarla como salida de escape y los que en mayor medida la perciben como algo natural al que llegarán todas las personas. Se pueden comprobar esas diferencias por edad en las actitudes ante la muerte a partir de las distribuciones concretas en alguna de las variables incluidas en cada factor. Así, más de la mitad de la población joven, 52,7\%, acepta tener miedo a la muerte porque significa el final de la vida que conoce, de sus proyectos vitales apenas iniciados (pregunta73f), frente al 38\% de los adultos o el 34,8\% de los ancianos. El porcentaje de éstos que considera que la muerte conlleva la promesa de una vida nueva y gloriosa, 64,8\%, casi duplica al de adultos que mantienen esa actitud esperanzada, 33,6\%, y más que triplica al de jóvenes con idéntico anhelo, 20,9\%, (pregunta73e). Asimismo, casi 8 de cada 10 ancianos, 77,7\%, están de acuerdo con que la muerte a veces es una bendición (pregunta 63d), mientras 
que los porcentajes correspondientes a adultos y a jóvenes son 71,4\% y 62,5\%, respectivamente. Por último, a pesar de ser la aceptación natural la que tiene las medias más bajas y menor variabilidad en todos los grupos de edad, fruto de ser una actitud casi unánime en toda la población, se aprecian no obstante ligeras diferencias por edad, de tal forma que la casi totalidad de la población anciana, 96,1\%, suscribe el que "la muerte nos iguala a todos” (pregunta 63c), afirmación también mayoritariamente aceptada pero con menos intensidad entre la población adulta, 87,3\%, y entre la población joven, 80,2\%.

\begin{tabular}{|c|c|c|c|c|c|}
\hline \multicolumn{6}{|c|}{ CUADRO 5.37.: ANOVAS PARA EDAD } \\
\hline & Jóvenes & Adultos & Ancianos & $F(2,399)$ & $p$ \\
\hline F1: Miedo a la muerte & $\begin{array}{l}3,20 \\
0,88\end{array}$ & $\begin{array}{l}3,49 \\
0,79\end{array}$ & $\begin{array}{l}3,45 \\
0,71\end{array}$ & 5,473 & 0,005 \\
\hline $\begin{array}{r}\text { F2: Aceptación de acercamiento Me. } \\
\text { Des. Típ. }\end{array}$ & $\begin{array}{l}3,47 \\
0,89\end{array}$ & $\begin{array}{l}3,17 \\
1,11\end{array}$ & $\begin{array}{l}2,33 \\
0,96\end{array}$ & 31,722 & 0,000 \\
\hline F3: Evitación de la muerte $\begin{array}{c}\text { Me. } \\
\text { Des. Típ. }\end{array}$ & $\begin{array}{l}2,89 \\
1,03\end{array}$ & $\begin{array}{l}3,06 \\
1,10\end{array}$ & $\begin{array}{l}2,79 \\
0,94\end{array}$ & 1,744 & 0,176 \\
\hline F4: Aceptación de escape $\begin{array}{c}\text { Me. } \\
\text { Des. Típ. }\end{array}$ & $\begin{array}{l}3,19 \\
0,85\end{array}$ & $\begin{array}{l}2,83 \\
0,90\end{array}$ & $\begin{array}{l}2,42 \\
0,82\end{array}$ & 20,113 & 0,000 \\
\hline F5: Aceptación neutral & $\begin{array}{l}2,64 \\
0,95\end{array}$ & $\begin{array}{l}2,51 \\
1,08\end{array}$ & $\begin{array}{l}2,37 \\
0,88\end{array}$ & 2,117 & 0,122 \\
\hline F6: Aceptación natural & $\begin{array}{l}1,73 \\
0,69\end{array}$ & $\begin{array}{l}1,58 \\
0,73\end{array}$ & $\begin{array}{l}1,49 \\
0,48\end{array}$ & 4,091 & 0,017 \\
\hline
\end{tabular}

Fte: Encuesta 2000. Elaboración propia

De los análisis realizados con la variable religiosidad se observa que sólo existen diferencias significativas en relación al Factor2, aceptación de acercamiento, Cuadro 5.38. En efecto, la posesión de una cosmovisión religiosa se refleja sobre todo en una actitud de esperanza hacia lo que vendrá tras la muerte, especialmente entre los crédulos y, en menor medida, los creyentes. Así, por ejemplo, mientras que 2 de cada 3 crédulos o el 30,3\% de los creyentes conciben que la muerte constituye la unión con Dios y la gloria eterna (pregunta 73m), esa posibilidad no es contemplada por ningún incrédulo. 


\begin{tabular}{|c|c|c|c|c|c|c|}
\hline \multicolumn{7}{|c|}{ CUADRO 5.38.: ANOVAS PARA RELIGIOSIDAD } \\
\hline & Crédulo & Creyente & No crey. & Incrédulo & $\mathbf{F}(2,399)$ & $p$ \\
\hline 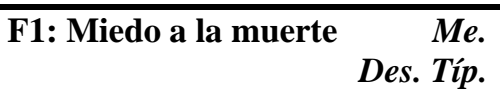 & $\begin{array}{l}3,43 \\
0,81\end{array}$ & $\begin{array}{l}3,29 \\
0,74\end{array}$ & $\begin{array}{l}3,12 \\
0,75\end{array}$ & $\begin{array}{l}3,51 \\
1,04\end{array}$ & 3,55 & 0,010 \\
\hline $\begin{array}{r}\text { F2: Acept. de acercamiento Me. } \\
\text { Des. Típ. }\end{array}$ & $\begin{array}{l}2,53 \\
0,91\end{array}$ & $\begin{array}{l}3,24 \\
0,95\end{array}$ & $\begin{array}{l}3,54 \\
0,81\end{array}$ & $\begin{array}{l}4,16 \\
0,77\end{array}$ & 56,12 & 0,000 \\
\hline $\begin{array}{r}\text { F3: Evitación de la muerte } M e . \\
\text { Des. Típ. }\end{array}$ & $\begin{array}{l}3,01 \\
1,10\end{array}$ & $\begin{array}{l}2,89 \\
1,00\end{array}$ & $\begin{array}{l}2,69 \\
0,92\end{array}$ & $\begin{array}{l}3,13 \\
1,14\end{array}$ & 2,58 & 0,052 \\
\hline $\begin{array}{r}\text { F4: Aceptación de escape } \quad \text { Me. } \\
\text { Des. Típ. }\end{array}$ & $\begin{array}{l}2,83 \\
0,96\end{array}$ & $\begin{array}{l}3,03 \\
0,90\end{array}$ & $\begin{array}{l}3,02 \\
0,87\end{array}$ & $\begin{array}{l}3,02 \\
0,88\end{array}$ & 1,27 & 0,283 \\
\hline F5: Aceptación neutral $\begin{array}{r}\text { Me. } \\
\text { Des. Típ. }\end{array}$ & $\begin{array}{l}2,50 \\
1,01\end{array}$ & $\begin{array}{l}2,60 \\
0,93\end{array}$ & $\begin{array}{l}2,65 \\
0,92\end{array}$ & $\begin{array}{l}2,54 \\
1,07\end{array}$ & 0,51 & 0,682 \\
\hline F6: Aceptación natural $\begin{array}{r}\text { Me. } \\
\text { Des. Típ. }\end{array}$ & $\begin{array}{l}1,74 \\
0,75\end{array}$ & $\begin{array}{l}1,57 \\
0,57\end{array}$ & $\begin{array}{l}1,66 \\
0,60\end{array}$ & $\begin{array}{l}1,64 \\
0,79\end{array}$ & 1,15 & 0,330 \\
\hline
\end{tabular}

Fte: Encuesta 2000. Elaboración propia

Dado que la formulación de las variables utilizadas en el análisis realizado buscaba obtener los distintos componentes de las actitudes ante la muerte en abstracto, se hace necesario ampliar ese análisis para cotejar si efectivamente, como sugiere Urraca (1982: 103-104), la dimensión que centraliza el miedo a la muerte es algo más concreto: el miedo a morir. Para ello, se aborda en segundo lugar un análisis ANOVA con el objetivo de observar la influencia del proceso de morir en el miedo a la muerte. En el mismo se han cruzado los 6 factores obtenidos con las variables recogidas en el cuestionario que sí hacen referencia al proceso de morir propio para comprobar si éstas inciden con intensidad en alguno de aquéllos.

En el Cuadro 5.39. se recogen los resultados de los ANOVAs aplicados a la variable independiente "tener la seguridad de que moriré no afecta a mi conducta en la vida" (pregunta 73n). Se observa que la incidencia de la mayor o menor ansiedad derivada del tener conciencia clara de que se producirá el morir propio, quizá porque para gran parte de la población encuestada ese hecho se percibe lejano aún y para otra parte está ya muy cercano, sólo incide de forma muy clara en la aceptación de acercamiento (F2), y en menor medida en la aceptación neutral (F5), mientras que no se observan diferencias significativas en los otros cuatro factores. Respecto a la aceptación de acercamiento, se constata que son las personas que se muestran indiferentes ante el condicionamiento con que el saber de su morir pueda afectar a su discurrir cotidiano, las que tienen un valor medio menor en ese factor, 2,97, mientras que las que no admiten ese condicionamiento son las que puntúan más alto, 3,23. Es decir, son éstas, las menos limitadas por la certeza de su morir las que menos de acuerdo se muestran con la consideración de la muerte como un mero trámite hacia una vida feliz. Asimismo, y aunque las diferencias en ese factor no son significativas, son las que menos miedo tienen a la muerte, como se puede observar en el Cuadro 5.39. 
En lo relativo a la aceptación neutral de la muerte, la media más alta corresponde a las personas que se manifiestan más condicionadas en su vida diaria por la certeza de su morir, 2,97, mientras que las que se muestran menos limitadas son las que puntúan más bajo, 2,46. Es decir, a mayor alienación vital por el saberse mortal, menor aceptación de que la muerte sea simplemente una barrera externa a la vida sin conexión con ella.

CUADRO 5.39.: ANOVAS PARA “TENER LA SEGURIDAD DE QUE MORIRÉ NO AFECTA A MI CONDUCTA EN LA VIDA”

\begin{tabular}{|c|c|c|c|c|c|}
\hline & Acuerdo & Indifern. & Desacuer. & $F(2,399)$ & $p$ \\
\hline $\begin{array}{lc}\text { F1: Miedo a la muerte } & \begin{array}{c}\text { Me. } \\
\text { Des. Típ. }\end{array}\end{array}$ & $\begin{array}{l}3,41 \\
0,86\end{array}$ & $\begin{array}{l}3,10 \\
0,64\end{array}$ & $\begin{array}{l}3,24 \\
0,79\end{array}$ & 3,20 & 0,040 \\
\hline $\begin{array}{r}\text { F2: Aceptación de acercamiento Me. } \\
\text { Des. Típ. }\end{array}$ & $\begin{array}{l}3,23 \\
1,04\end{array}$ & $\begin{array}{l}2,97 \\
0,75\end{array}$ & $\begin{array}{l}3,18 \\
1,24\end{array}$ & 384 & 0,000 \\
\hline $\begin{array}{cc}\text { F3: Evitación de la muerte } & \begin{array}{c}M e . \\
\text { Des. Típ. }\end{array}\end{array}$ & $\begin{array}{l}2,92 \\
1,08\end{array}$ & $\begin{array}{l}2,81 \\
0,85\end{array}$ & $\begin{array}{l}3,06 \\
1,03\end{array}$ & 0,86 & 0,421 \\
\hline F4: Aceptación de escape $\begin{array}{c}\text { Me. } \\
\text { Des. Típ. }\end{array}$ & $\begin{array}{l}2,96 \\
0,89\end{array}$ & $\begin{array}{l}2,93 \\
0,81\end{array}$ & $\begin{array}{l}2,96 \\
0,90\end{array}$ & 0,01 & 0,99 \\
\hline F5: Aceptación neutral & $\begin{array}{l}2,46 \\
0,96\end{array}$ & $\begin{array}{l}2,52 \\
0,78\end{array}$ & $\begin{array}{l}2,97 \\
1,12\end{array}$ & 8,03 & 0,000 \\
\hline F6: Aceptación natural & $\begin{array}{l}1,61 \\
0,64\end{array}$ & $\begin{array}{l}1,74 \\
0,71\end{array}$ & $\begin{array}{l}1,76 \\
0,82\end{array}$ & 1,73 & 0,185 \\
\hline
\end{tabular}

Fte: Encuesta 2000. Elaboración propia

Por otra parte, una cosa es afirmar que el saber de la propia muerte no afecta a la vida diaria y otra es el sentirse o no preparado en estos momentos para afrontarla (pregunta 73j). De hecho, cruzando ambas actitudes se constata que si más de la mitad de toda la población encuestada está preocupada por no hallarse preparada para afrontar su muerte, 52,2\%, y sólo 3 de cada 10 sí admiten estarlo, entre las personas que admiten que su morir les afecta en su vida esos porcentajes se extreman hasta el 68,0\% y el 24\%, respectivamente, mientras que entre las que están menos alienadas por su mortalidad se distribuyen más homogéneamente: 1 de cada 3 se declara preparada, frente al 47,9\% que no lo está. Por ello, un análisis ANOVA tomando como variable independiente al sentirse preparado o no para afrontar la propia muerte ayuda a perfilar en mayor medida la centralidad del morir en el miedo a la muerte.

Los resultados de este análisis se recogen en el Cuadro 5.40. En este caso se observan diferencias significativas en 4 factores, el miedo a la muerte, F1, la aceptación de acercamiento, F2, la aceptación de escape, F4, y la aceptación neutral, F5. Respecto al miedo a la muerte, F1, la mayor puntuación corresponde a las personas encuestadas que más preparadas se sienten para enfrentar su muerte, 3,71, y la menor a las que se declaran más indefensas, 3,09. Es decir, mientras las primeras son las que menos miedo tienen a la muerte, estas últimas, las que están 
más inermes ante ella, son las que más miedo la tienen. En el análisis relativo a la aceptación de acercamiento, F2, aquellas personas que se manifiestan menos preparadas para enfrentar su muerte, y las que se muestran indiferentes ante ello, son las que puntúan más alto, 3,36, mientras que las más preparadas son las que puntúan más bajo, 2,76. De estos resultados se colige que a menor preparación ante la muerte, menor es la aceptación de una salida feliz transmundana. Otro tanto cabe decir sobre los factores F4, aceptación de escape, y F5, aceptación neutral, que son actitudes menos presentes entre los que se sienten menos preparados ante la muerte.

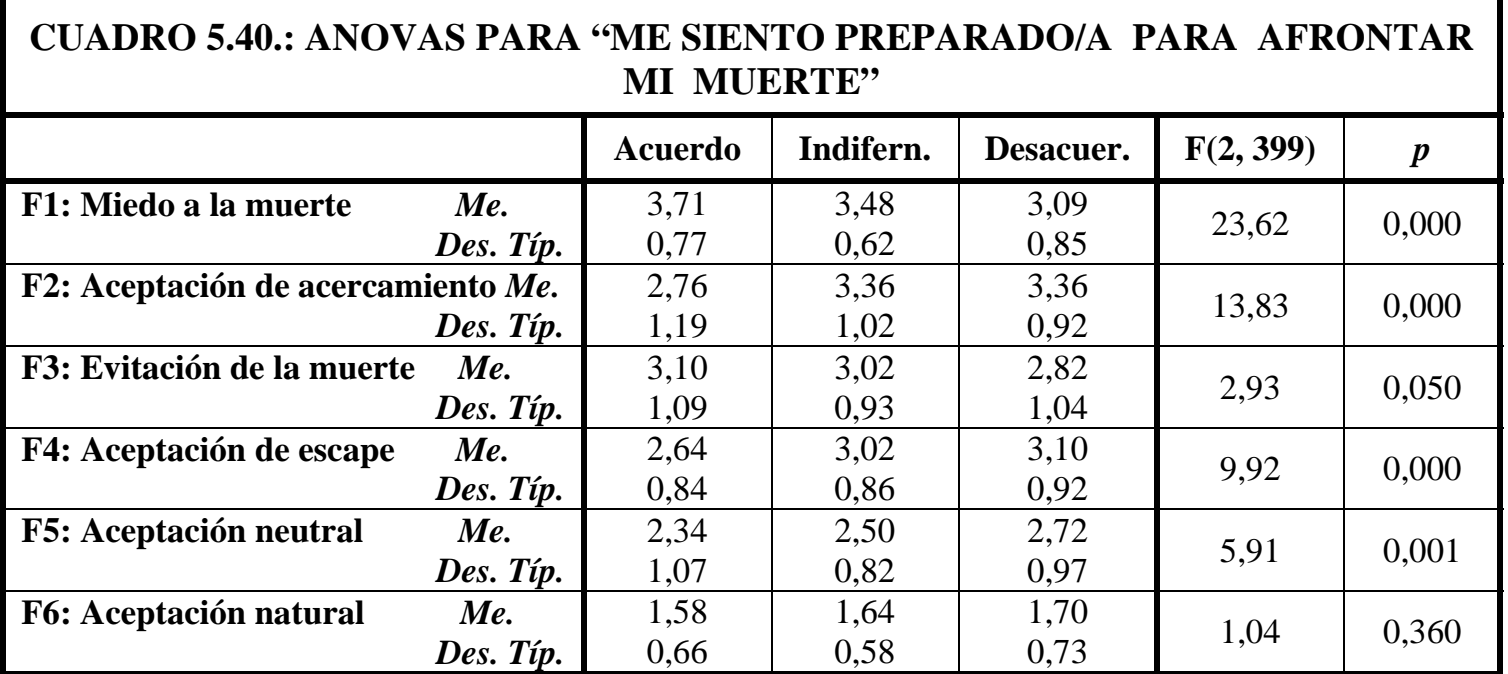

Fte: Encuesta 2000. Elaboración propia

Finalmente, una variable que refleja de forma más concreta aún el temor al morir propio, es la preocupación por lo que pueda ocurrir “con mi cuerpo” una vez que se ha fallecido (pregunta 73o). Entre la población encuestada, el 55,2\% afirma no estar preocupado por ello, al 18,8\% le es indiferente y poco más de 1 de cada 4, el 26\%, sí lo está. Tomando esta variable como independiente y realizados ANOVAs con los 6 factores, sólo existen diferencias significativas en el primero de los factores, el miedo a la muerte $(F=9,55, p=0,000)$. Así, lógicamente, mientras que la media de los que no se sienten preocupados por lo que le pase a su cadáver es la mayor, 3,50, esto es, son los que desarrollan una actitud con menos miedo a la muerte, los que sí manifiestan estar preocupados son los que más miedo tienen a la muerte, lo que se refleja en que son los que puntúan con una media más baja, 3,11.

En definitiva, aunque las distintas actitudes ante la muerte pueden estar en mayor o menor medida presentes en todas las categorías sociales consideradas, cabe confirmar, con Urraca, el papel destacado que en el miedo a la muerte juega el miedo al morir propio. Así, son las personas más vitalistas las menos condicionadas por el saber de su mortalidad y las más preparadas para afrontarlo, las que presentan unas actitudes ante la muerte más atemperadas: las 
que tienen menos miedo a la muerte, las que necesitan en menor medida recurrir a explicaciones transmundanas para justificar su vivir, las que más se concentran en éste, las que más aceptan la existencia inevitable de la muerte como cierre a su vida, y las que en mayor medida consideran que ese tope forma parte del discurrir natural de la vida.

\subsection{LA MUERTE COMO DIMISIÓN DE LA VIDA}

"Y frente a él, no intento encontrar lo que podría haber anticipado y no supe ver, como si de todo lo que intercambiamos se hubiera quedado fuera lo esencial. Más bien, ahora parto de su violenta muerte y, desde ella, miro atrás y contemplo con mayor ternura lo que se propuso hacer y lo que ofreció a los demás, mientras pudo aguantarlo”.

J. Berger

En el último apartado de este capítulo se examinan sintéticamente las creencias, opiniones y actitudes de la población encuestada en dos materializaciones concretas del proceso de morir: el suicidio y la eutanasia. Siempre presentes en la historia de la Humanidad constituyen en la actualidad dos temas centrales en los debates públicos de las sociedades más avanzadas en las que se observan contradicciones entre su retórica modernidad societal, asentada en los deberes y derechos de los ciudadanos/as como presuntos protagonistas de esa modernidad, y las limitaciones al ejercicio del derecho individual a decidir sobre la propia muerte $^{72}$, es decir, sobre la propia vida. Más cuando, como señala Jonas (1997:159) con el derecho a morir no se plantea al mundo exigencia alguna sino que, al contrario, se renuncia a toda posible pretensión. Siendo esto es así, el derecho origen de todos los demás, el derecho a vivir ¿conlleva la obligación de vivir?, ¿`se ha de escuchar otras voces además de la de la persona interesada en lo relativo a su muerte?, ¿tienen los otros, la $<<$ sociedad $>>$, no sólo "una obligación frente a mi derecho a vivir, sino también un derecho a reclamar contra mi mismo mi obligación de vivir y, por ejemplo, impedirme morir antes de lo que tengo que hacerlo, aunque yo quiera”? (Jonas, 1997:160).

\footnotetext{
${ }^{72}$ La existencia del "derecho a morir” llegó a plantearse al Tribunal Constitucional español (STC 120/90, de 27 de junio) y, según el catedrático del Derecho Penal, M. Bajo, "constatándose, al no recibir sentencias contradictorias al respecto, de que `no hay derecho a morir' en el sentido de que alguien pueda exigir a otro que le respete ese derecho a morir y, por tanto, le tenga que matar (lo que otorga el Tribunal Constitucional es, en definitiva, un derecho de elección) "hay un derecho a hacer lo que uno quiera" (OMC, 2009:34).
} 


\subsubsection{LA MUERTE COMO DESERCIÓN: EL SUICIDIO ${ }^{73}$}

"Sólo se suicidan los que creen en la vida"

L. M. Panero

Es bien conocido que en el inicio de El mito de Sísifo, ensayo sobre "la medida exacta en que el suicidio es una solución para lo absurdo”, A. Camus (1981:13) plantea que éste, el suicidio $^{74}$, es el problema "realmente serio" que el análisis filosófico debe afrontar: "Juzgar que la vida vale o no la pena de ser vivida equivale a responder a la cuestión fundamental de la filosofía”. Problema que Camus examina alejándolo del análisis social para centrarlo en el “pensamiento individual” y sus vínculos con la pérdida de sentido de la vida; problema sobre el que considera que, por tanto, la sociedad no tiene mucho que ver, ya que "el gusano se encuentra en el corazón del hombre”; problema al que equipara con una confesión ${ }^{75}$. Revelación del ser humano que se siente "extranjero" en un universo en el que no tiene nada a lo que asirse: "Es un destierro sin remedio, pues está privado de los recuerdos de una patria perdida o de la esperanza de una tierra prometida. Este divorcio entre el hombre y su vida, el actor y su decorado, es propiamente el sentimiento de lo absurdo" (Camus, 1981:15-17). Como Andrés Hurtado, el médico protagonista de El árbol de la ciencia, (Baroja, 1998:292), a quien, después de envenenarse, la "muerte había sobrevenido por parálisis inmediata del corazón.

- Ha muerto sin dolor -murmuró Iturrioz-. Este muchacho no tenía fuerza para vivir. Era un epicúreo, un aristócrata, aunque él no lo creía.

- Pero había en él algo de precursor -murmuró el otro médico”.

Otros autores, como Meyer (1983:79-86), añaden sin embargo la sospecha de que la decisión de morir por mano propia no depende exclusivamente del rechazo a la vida, ya que en algunos suicidios intervienen "las representaciones, los temores y las esperanzas en relación con la muerte”, es decir, en esos suicidios no sería tanto un rechazo, una interpelación, a la vida misma cuanto el resultado de un balance, una ponderación de su valor frente a las consecuencias de la muerte buscada, tanto para los individuos como para el conjunto de la sociedad. Por ello, el suicidio se constituye en el verdadero test de la libertad humana ya que,

\footnotetext{
${ }^{73}$ La información sobre el suicidio recogida en la encuesta utilizada en este trabajo no es muy amplia, seis preguntas de las que en cuatro se interroga sobre el grado de conocimiento de la incidencia del suicidio y sólo en las otras dos sobre actitudes ante el mismo. De ahí, el alcance forzosamente limitado del análisis empírico realizado.

74 "Se llama suicidio a todo caso de muerte que resulta directa o indirectamente de un acto positivo o negativo, llevado a cabo por la propia víctima que sabía que iba a producir ese resultado" (Durkheim, 2004:22)

75 "Es confesar que la vida nos supera o que no la entendemos. Es solamente confesar que $<<$ no vale la pena >>... Morir voluntariamente supone que hemos reconocido, aunque sea instintivamente, el carácter ridículo de esta costumbre (la de vivir), la ausencia de toda razón profunda para vivir, el carácter insensato de esa agitación cotidiana y la inutilidad del sufrimiento" (Camus, 1981:16).
} 
ignorando el instinto de conservación, los individuos buscan su reafirmación absoluta a través de la muerte absoluta (Basterra, 2006:158). Como Ramón Sampedro, como Orín en La balada de Narayama, como Jesucristo, como los kamikaces o como los terroristas suicidas.

Sin negar que el suicidio es un "acto individual que sólo afecta al individuo", cuyas motivaciones íntimas únicamente pueden ser "adivinadas desde fuera con algo más que burdas aproximaciones”, Durkheim (2004), al contrario que Camus, abordó el análisis del mismo no examinando las causas concretas de los suicidios, sino centrándose en la "tasa social de los suicidios”76, a la que identificó como un indicador global de esa patología social (Ramos, 1998:763). Así, aunque las motivaciones para el suicidio puedan ser muy variadas ${ }^{77}$ y aunque en último término sea la propia persona la que toma la decisión de suicidarse o no, según Durkheim en esta decisión privada y personal intervienen también factores sociales que subyacen en las primeras y por tanto condicionan a la segunda. En efecto, dado que, a pesar de la rotación y sustitución de los individuos particulares de una sociedad año a año, las tasas sociales de suicidio permanecen relativamente estables conservando su intensidad, eso significaba para Durkheim (2004:418) que las “causas que determinan de este modo el contingente de las muertes voluntarias en una sociedad o en una parte determinada de la sociedad, deben por tanto de ser independientes de los individuos". De ello se desprende que "la tasa social de los suicidios sólo puede explicarse sociológicamente”. Explicación que vinculó a las "corrientes sociales", es decir, a las tendencias o pasiones colectivas que son hechos sociales inmateriales objetivos que actúan sobre el individuo desde el exterior y carecen de forma cristalizada. Sobre esta base, Durkheim no sólo comparó las tasas sociales de suicido de grupos y sociedades para detectar las diferencias entre las distintas categorías sociales, diferencias obviamente motivadas por esas corrientes sociales, sino que elaboró una explicación teórica sobre el suicidio que materializó en su conocida tipología. Ésta está construida sobre las fluctuaciones en la intensidad de la integración -grado en que se comparten los sentimientos colectivos- y de la regulación -grado de constricción externo sobre las personas-, que dan lugar a cuatro tipos de corrientes suicidógenas: a) suicido egoísta ${ }^{78}$ (integración baja); b) suicidio

\footnotetext{
76 "Cada sociedad tiene por lo tanto, en cada momento de su historia, una capacidad determinada para el suicidio. La intensidad relativa de esta capacidad puede medirse comparando la cifra global de las muertes voluntarias con la población total de cualquier edad y sexo. Llamaremos a este dato numérico tasa de mortalidad-suicidio propia de la sociedad considerada" (Durkheim, 2004:29).

${ }^{77}$ Además de la subjetividad de los motivos que llevan a una persona a suicidarse, "la soledad, el abuso sexual o físico, la carencia afectiva, el rechazo familiar, la ruina económica, la marginación, la falta de autoestima y la culpabilidad son factores que se repiten con frecuencia en las biografías de los que acaban con sus propias vidas. También situaciones de crisis como el desempleo, la inseguridad, la pérdida de ingresos, la enfermedad grave o degenerativa, cualquier circunstancia que contribuya a la ruptura de lazos familiares, la emigración y el aislamiento mental y físico influyen en la conducta suicida” (Pérez Jiménez 2011:96).

78 "Las altas tasas de suicidio egoísta suelen encontrarse en aquellas sociedades, colectividades o grupos en los que el individuo no está totalmente integrado en la unidad social global. Esta falta de integración
} 
altruista $^{79}$ (integración alta); c) suicidio anómico ${ }^{80}$ (regulación baja), y; d) suicidio fatalista ${ }^{81}$ (regulación alta). Dado que las inclinaciones individuales al suicido derivan de la inclinación propia de cada grupo social hacia el mismo, y no al revés, según sean en cada momento las intensidades de esas cuatro "causas suicidógenas", que penetran en los individuos y "los determinan a matarse”, así se conformará la intensidad de la tasa social de suicidio (Durkheim, 2004:406-407).

Al margen de cuál sea la motivación personal o el condicionamiento social que empuje a los individuos a suicidarse, lo cierto es que una buena parte de la sociedad lo percibe con incomprensión y/o con rechazo. En efecto, si bien Camus (1981:16-17) afirmaba que "todos los hombres sanos han pensado en el suicidio", es decir, en la ausencia de sentido en la vida y en su lazo directo con "la aspiración a la nada”, también reconocía que eran mayoría los que se interrogaban sin llegar a una conclusión. Es por esto, por la incomodidad de interrogarse sobre el sentido de la (propia) vida, por lo que a esa mayoría de la población le resulta imposible integrar en sus esquemas mentales una lógica que niega valor a la vida. De ahí su incomprensión de las razones subjetivas del suicidio, ya que, con sinceridad, o por conformidad, o como autojustificación por no ser 'hombres sanos', "nos resistimos a aceptar que una persona se haya quedado sin alternativas, queremos creer que siempre hay otra solución, y pensamos que otro individuo en idénticas circunstancias, no haría lo mismo” (Pérez Jiménez, 2011:96). Como señalaba el joven varón entrevistado:

- "Que hay situaciones de gente que les llevan a esa situación y es difícil. A mí me parece que no sirve para nada, no soluciona ningún problema, es más, cualquier

produce un sentimiento de vacío y falta de significado en los individuos... Cuando estas corrientes sociales son débiles, los individuos pueden fácilmente sobrepasar la conciencia colectiva y hacer lo que desean... Este egoísmo no reprimido suele desembocar en una gran insatisfacción personal, debido a que no todas las necesidades pueden satisfacerse y las que quedan insatisfechas simplemente generan más y más necesidades; en última instancia, conducen al total descontento y, en algunos casos al suicidio... Las familias, los grupos religiosos y las entidades políticas fuertemente integradas actúan como agentes de la conciencia colectiva y evitan las tendencias suicidas” (Ritzer, 1993:221).

79 "El suicidio altruista es más probable que se realice cuando la integración social es demasiado fuerte. El individuo se ve literalmente obligado a suicidarse”, justifica el sacrificio de un individuo por el bien del grupo (Ritzer, 1993:221).

80 "Es el principal tipo de suicidio para Durkheim, cuya probabilidad aumenta cuando dejan de actuar las fuerzas reguladoras de la sociedad. Esta interrupción suele crear insatisfacción en los individuos: sus pasiones apenas están controladas, y son libres de iniciar una salvaje persecución del placer... Cualquier tipo de interrupción en estas fuerzas reguladoras hace que la colectividad sea temporalmente incapaz de ejercer su autoridad sobre los individuos. En estos cambios se producen situaciones en las que las viejas normas dejan de observarse, desarrollándose otras nuevas. Los períodos de interrupción liberan corrientes de anomía -actitudes desarraigadas y desreguladas- y estas corrientes conducen a un aumento de las tasas de suicidio anómico... Esto ocurre, por ejemplo, en el caso de una depresión económica, en la que el individuo se ve desorientado e incapaz de sentir el efecto regulador de su empresa y su trabajo... Apartado de estas estructuras o de otras (por ejemplo, la familia, la religión y el estado), el individuo es muy vulnerable a los efectos de las corrientes de anomia" (Ritzer, 1993:222).

${ }^{81}$ El suicidio fatalista es más fácil que ocurra cuando la regulación es excesiva, y actúa sobre "personas cuyo futuro está implacablemente determinado, cuyas pasiones están violentamente comprimidas por una disciplina opresiva". Caso de la esclavitud (Ritzer, 1993:222). 
otra solución, es que no es solución de nada. Así que cualquier otra solución puede ser mejor, es que lo pierdes todo, pierdes la vida” (E1:6).

Además, como señala Morin (1974a:49-50), el "suicidio consagra la total dislocación entre lo individual y lo cívico", es decir, el que se produzca un suicido no sólo supone la constatación del fracaso de la sociedad, del sistema de muerte, como fuente de sentido que ahuyenta la muerte al proporcionar a los individuos oportunidades para trascenderla y tomar gusto por la vida, sino que también significa que "ella misma ha sido derrotada, negada: ya nada puede hacer por y contra la muerte del hombre”. Cada suicidio sería así un espejo en el que la imagen reflejada de la sociedad se desvanece, una especie de crimen contra la sociedad que ésta no puede tolerar. A la incomprensión y rechazo general hay que añadir también el que una parte de la población perciba al suicidio además como un atentado contra la propia esencia de la vida, un acto contra natura, o un crimen contra Dios, y, en consecuencia, no sólo lo rechaza sino que lo hace con desagrado. Obviamente, no es ajena a esta percepción la influencia de la Iglesia católica, que siempre ha condenado el 'pecado mortal' del suicidio sobre la base de que el ser humano es un simple usufructuario de su cuerpo pero no su propietario, como se puede comprobar en algunos de los párrafos dedicados al suicidio en el Catecismo de la Iglesia Católica (2003:410): “Cada cual es responsable de su vida delante de Dios que se la ha dado. Él sigue siendo su soberano dueño. Nosotros estamos obligados a recibirla con gratitud y a conservarla para su honor y para la salvación de nuestras almas. Somos administradores y no propietarios de la vida que Dios nos ha confiado. No disponemos de ella” (párrafo 2280). "El suicidio contradice la inclinación natural del ser humano a conservar y perpetuar su vida. Es gravemente contrario al justo amor de sí mismo. Ofende también al amor del prójimo porque rompe injustamente los lazos de solidaridad con las sociedades familiar, nacional y humana con las cuales estamos obligados” (párrafo 2281).

Percepción pecaminosa y criminal del suicidio, del que se responsabiliza al propio actor del mismo, y que dominó hegemónicamente en Occidente hasta finales del siglo XVIII, percepción que le excomulgaba y condenaba al infierno, mientras que también se castigaba a su familia confiscando legalmente sus bienes (Pérez Jiménez, 2011:63). Desde entonces, ha emergido otra concepción del suicidio que poco a poco se ha ido imponiendo, sin eliminar a la anterior cuyo poso de rechazo persiste, y que lo identifica con locura, exculpando de toda responsabilidad al actor. Así, como denunciaba Szasz (1991:75), en su crítica a la prevención del suicidio por el Estado ${ }^{82}$, "las personas prefieren hoy descartar el problema del suicidio alegando concebirlo <<científicamente>>, mediante una imagen que combina no sólo los rasgos

\footnotetext{
82 "La creencia de que es una función legítima del Estado coaccionar a las personas porque podrían matarse es una idea característicamente moderna, cuasi terapéutica, que satisface al mismo tiempo nuestras ansias de dependencia y omnipotencia” (Szasz, 1991:80).
} 
del pecado, la enfermedad y el crimen, sino también irracionalidad, incompetencia e insania mental”. Por lo que, en la actualidad, el suicidio no sólo sigue siendo el problema central de la filosofía, sino que se ha convertido en un problema de salud pública, como reiteradamente ha afirmado la Organización Mundial de la Salud. Y más concretamente, en un problema de salud mental, ya que, según esta organización, el 90\% de las personas que se suicidan padecen algún tipo de enfermedad mental. Según las últimas estimaciones colgadas en la página web de la OMS, abril de 2011, en el año 2008 se suicidaron en todo el mundo 782.014 personas, lo que representa una tasa social de suicidios de 11,6 suicidios por 100.000 habitantes, el 1,4\% del total de muertes en el mundo, casi 2.150 suicidios diarios, a los que hay que añadir 20 intentos de suicidio por cada uno materializado. En el caso de Europa, el número de suicidios, en el año 2008, fue de 125.875, 18.000 muertes más que las provocadas por accidentes de tráfico. Además, los datos aportados por la OMS muestran una tendencia al continuo crecimiento del número de suicidios en los últimos 50 años.

La cuantía de estos datos hace que algunos autores consideren que el debate sobre la legitimidad del suicidio haya quedado obsoleto y planteen la necesidad trasladar la discusión a la forma de abordar el sufrimiento psíquico, antesala en muchos casos del suicidio, como paso necesario para prevenirlo y combatirlo por el Estado (Pérez Jiménez, 2011:70). Control y prevención con el que se muestran críticos otros autores, quienes consideran que hay que avanzar eliminando el estigma y el tabú que cubre al suicidio, ya que en una sociedad libre lo realmente deseable es "otorgar al suicidio el estatus de un derecho humano básico (en su estricto significado político-filosófico)” (Szasz, 1991:79). Derecho inalienable a decidir sobre su propia muerte $^{83}$. Derecho reivindicado durante treinta años por Ramón Sampedro (1998:178-179) quien, en la parte final de una de sus Cartas desde el infierno titulada "La dignidad y la muerte”, expone de forma diáfana esta postura sobre el suicidio:

"En una verdadera cultura de la vida, el derecho de la muerte como un acto de libertad de conciencia es la conducta moral positiva.

Se dice que vivir en sociedad conlleva deberes y derechos. Sí, pero una parte es la que impone las normas, a la otra sólo le queda el deber de la obediencia y el derecho al pataleo estéril como única forma de discrepancia. Eso no es respeto sino paternalismo.

Cuando a alguien se le niega un derecho cuyo ejercicio efectivo resulta esencial para que se cumpla su voluntad, y con ello el respeto por sí mismo como ser humano libre, a esa persona sólo le queda el deber de la humillante resignación. Esa esclavitud de la conciencia es la

83 "El derecho a la propia muerte nació históricamente de la conciencia de la autodisponibilidad del hombre que se instauró con la Ilustración” (Meyer, 1983:15). El primer país en el que desaparecieron las sanciones contra el suicidio de su código penal fue Francia, en 1791 (Pérez Jiménez, 2011:67). 
verdadera cultura de la muerte.

Sin el derecho a ser dueño y señor de toda su persona, el ser humano no disfruta de plenos derechos.

No puede haber dignidad posible ni libre albedrío sin libertad plena.

Si no tiene el derecho a renunciar a su vida nadie es dueño de ella.”

Más de la mitad de la población encuestada considera que las personas tienen derecho a quitarse la vida, mientras que algo más de 1 de cada 3 rechaza ese derecho (pregunta 66), Cuadro 5.41. Existen diferencias significativas por edad, nivel de estudios y religiosidad, de tal forma que a medida que las personas están en una fase más avanzada del ciclo vital, tienen menos nivel de estudios o mayor es su religiosidad, mayor es el rechazo mostrado. Así, frente a 2 de cada 3 jóvenes, sólo 1 de cada 4 ancianos acepta ese derecho; por otra parte, el rechazo de éstos es el mayor, cuadruplica al de los jóvenes, 73,4\% frente a 16,5\%; además, los ancianos tienen las ideas más claras en este ámbito ya que sólo 3,7\% de ellos estaban indecisos frente al 17,5\% de los jóvenes. Esquema que se repite, como en variables anteriores, en la distribución del nivel de estudios. En el caso de los componentes de grupo de discusión, la mayoría ancianos/as, perciben el suicidio como resultado de una patología mental -una desgracia-, o como un acto heroico; ambos, de momento, les son ajenos, sin embargo, no sólo no lo rechazan sino que en determinadas situaciones, a las que no quisieran llegar, les parece la actuación más lógica:

- "- Lo que pasa es que cuando una persona se suicida es porque tiene un problema grave. Un problema que no puede resolver o bien porque tenga una depresión. Habrá muchas razones.

- Es un estado mental.

- Habrá muchas razones entonces la gente coge y adiós.

... - Es que lo de los suicidios es algo que no tengo muy claro; o tienes mucho miedo o tienes mucho valor.

... - Yo pienso, hablando del suicidio, creo que tienen mucho miedo y a la vez mucho valor, las dos cosas juntas. En realidad ellos se practican la eutanasia, no tienen que dar el incordio a nadie. Todos nos acordamos de aquel chico de Galicia, todos nos acordamos, que él no podía hacer nada. Es terrible. Claro, efectivamente.

- Eso es más...

- No tenía cuerpo, no tenía nada” (GD1:26-27).

Respecto a la religiosidad, se observa claramente la influencia de la educación tradicional (religiosa) en el trasfondo de las diferencias, ya que el rechazo se incrementa con el nivel de religiosidad, más de la mitad de los crédulos lo rechazan frente al 6,3\% de los incrédulos, y al revés, cuanto menor es el nivel de religiosidad mayor es la afirmación del derecho al suicidio, hasta el punto de que el 90,5\% de los incrédulos lo apoyan frente al 31,9\% de los crédulos. Dato este último que es por sí mismo significativo: casi 1 de cada 3 personas 
más religiosas entre las encuestadas admiten el derecho al suicidio. No obstante, todos estos datos se refieren a la existencia de un derecho al suicidio en abstracto y probablemente serían muy distintos si se hubiera interrogado por el ejercicio de ese derecho por parte de una persona muy próxima, como apunta el adulto incrédulo entrevistado:

- "No es que sea partidario del suicidio, digo que si uno decide irse para otro barrio, iallá cuidaos!... (en caso de un familiar próximo) No me agradaría, y lo tengo muy claro. Volvemos a lo mismo, una cosa es muy distinta a la hora de opinar cuando es en general o cuando es algo muy allegado, porque es que ahí los problemas son otros, porque tu parte de culpabilidad en ese caso, ya influyen otras cosas, entonces ya no puede ser lo mismo de objetivo en un caso que en otro. Quiero decir, que si en un momento determinado alguien te dice "oye, que se ha suicidado...”, vale, lo ha decidido, yo, ni entro ni salgo. Pero en este caso, si entro y salgo, porque formo parte de la vida de esa persona, son situaciones totalmente distintas, entonces, la opinión no puede ser la misma, entonces, claro, en el caso de un familiar la cosa sería distinta, el trauma sería totalmente distinto, como todo" (E4:22).

\begin{tabular}{|l|c|c|c|}
\hline \multicolumn{3}{|c|}{ CUADRO 5.41.: DERECHO A QUITARSE LA VIDA (\%) } \\
\hline & NO & SÍ & NO SABE \\
\hline \multicolumn{1}{|c|}{ TOTAL } & 35,5 & 51,9 & 12,6 \\
\hline HOMBRES & 28,9 & 57,8 & 13,3 \\
MUJERES & 39,9 & 48,0 & 12,1 \\
\hline JÓVENES & 16,5 & 66,0 & 17,5 \\
ADULTOS & 39,9 & 49,3 & 10,9 \\
ANCIANOS & 73,2 & 23,2 & 3,7 \\
\hline EST. BÁSICOS & 72,3 & 24,6 & 3,1 \\
EST. MEDIOS & 40,0 & 45,6 & 14,4 \\
EST. UNIVERS. & 24,7 & 61,0 & 14,3 \\
\hline CRÉDULOS & 52,8 & 31,9 & 15,3 \\
CREYENTES & 29,4 & 54,1 & 3,2 \\
NO CREYENTES & 19,0 & 66,7 & 16,5 \\
INCRÉDULOS & 6,3 & 90,5 & 14,3 \\
\hline
\end{tabular}

Fte: Encuesta 2000. Elaboración propia

Resulta asimismo relevante la información obtenida en la otra pregunta sobre actitudes incluida en la encuesta: 21 de las personas entrevistadas han pensado en suicidarse durante el año anterior a la realización de la encuesta (pregunta 68). Es una cifra que en términos relativos, el 5\% de la población encuestada, es menos de la mitad de lo que se estima que ocurre entre la población adulta de occidente, que en un $11 \%$ ha deseado darse muerte en algún momento de su vida (Pérez Jiménez, 2011:94). Cifra que en todo caso parece confirmar la sospecha de Camus sobre la escasez relativa de "hombres sanos", aunque en este caso sería más correcto hablar de “mujeres sanas” pues si bien fueron 12 mujeres y 9 hombres quienes pensaron en suicidarse, la 
proporción sobre el total de las mujeres era menor que la correspondiente a la de los hombres. En relación a la edad, ese pensamiento se reduce al aumentar la misma entre la población encuestada, ya que es entre la población joven en la que un mayor número de personas declara haber pensado en ello: 15 jóvenes, 5 adultos y 1 anciano.

Dada la conformación de la muestra, la distribución por nivel de estudios es paralela a la de edad, así, el mayor número de personas que han pensado en suicidarse tienen estudios universitarios, 18, 2 estudios medios y 1 estudios básicos. Respecto a la religiosidad, aunque no se tiene información de si el poseer o no ese tipo de ideología ha contribuido a no materializar el pensamiento de suicidarse, lo cierto es que éste es transversal y está presente en las cuatro categorías sociales de religiosidad. De hecho, el número mayor, en términos absolutos y relativos de personas que declaran haber pensado en suicidarse son crédulas, 5 , y creyentes, 11 , frente a 1 no creyente y 3 incrédulas.

Al margen de la propia inclinación al suicidio, éste no es del todo desconocido y probablemente no ha estado muy alejado de una parte de la población encuestada, ya que un porcentaje de la misma, el 13,4\%, sin diferencias significativas en ninguna de las variables de control, conoce a alguien que se ha suicidado en el último año (pregunta 67). En la encuesta no se profundiza sobre esta cuestión, por lo que ese alguien puede ser una persona allegada, algún conocido, o un personaje público o anónimo cuyo suicidio fuera informado a través de los medios de comunicación. En todo caso, lo que sí que parece sugerir esa baja proporción de personas que conocen a otra que se ha suicidado recientemente es que, al menos en el ámbito espacial en el que se mueve la población encuestada, el problema de salud pública (mental) suicidio no tiene la intensidad que en otras zonas del mundo, ni tampoco la de otras causas de muerte. Deducción que por otra parte se asienta en las cifras oficiales sobre suicidio aportadas por el INE: en el caso de España, y para el año 2008, 3.421 suicidios, es decir, 7,5 personas suicidadas por cada 100.000, cifra inferior a los 11,6 suicidios por 100.000 habitantes del total mundial en ese año. En el caso de Castilla y León, esos indicadores en el momento de realizar la encuesta en el año 2000 daban unas cifras de 241 suicidios, es decir, de 9,7 suicidios por 100.000 habitantes. En el año 2008, los datos correspondientes fueron 218 suicidios y 8,52 suicidios por 100.000 habitantes, respectivamente.

Por otra parte, interrogada la población encuestada sobre su percepción del alcance del suicidio en la población española, es decir, dónde creían que se producían más suicidios (medio rural versus mundo urbano), si entre hombres o entre mujeres, en qué edades (jóvenes, adultos, ancianos) y si creían que el número de suicidios actuales era mayor que el de hace 20 años (preguntas 70, 71 y 72), la mayoría de la población encuestada manifiesta desconocer el alcance 
de esas diferencias, hasta el 59\% en el caso de las diferencias por sexo, y los que optan por dar una respuesta concreta tienen creencias erróneas sobre dos de las cuestiones planteadas, Cuadro 5.42. En efecto, la percepción de que se suicidan más los jóvenes que en las otras dos edades no es cierta en términos absolutos, la mayor proporción de suicidios se produce en los grupos de edades adultas, ni tampoco en términos relativos ya que las tasas de suicidio entre los ancianos más que sextuplican a las de los jóvenes. Así, en el año 2000, año de la encuesta, la tasa de suicidio por 100.000 habitantes de 85-89 años fue de 28,66, para el conjunto de la población de ese grupo de edad, 67,83, para los hombres, y 10,24, para las mujeres; en ese año, las tasas de suicidio correspondiente al grupo de edad 20-24 fueron 5,66, 9,56 y 1,58, respectivamente. Al estar el medio rural muy envejecido, resulta lógico que las tasas de suicidio en ese medio sean mayores que en el medio urbano. Probablemente, esas dos percepciones erróneas estén motivadas por la residencia urbana de buena parte de la población encuestada y por la mayor repercusión mediática de los suicidios entre la población joven. No es el caso de la joven no creyente entrevistada, que acertó en sus respuestas porque:

- “... quizá en el medio rural porque se conocen más, vamos, porque cuando voy al pueblo de mis padres pues cuando alguien.. Yo, aquí, no, a lo mejor puedo tener noticia de un suicido si es alguien relativamente cercano, alguien que conoces o alguien conocido de un conocido tuyo, pero en un pueblo cuando alguien se suicida lo sabe todo el pueblo, y claro parece que se suicidan más en los pueblos... ... Yo creo que los ancianos, porque son los que más solos están, ¿no?, pero no tengo ni idea...

... No sé, quizá conozco más casos de hombres, pero no tengo ni idea, no creo que tengamos tendencia por ser de un sexo o de otro" (E2:22).

El adulto incrédulo entrevistado, por su parte, afirmó que había un mayor número de suicidios en el medio rural y entre los hombres por las siguientes razones:

- "En el medio rural, no me preguntes porqué, bueno sí, porque están más en contacto con, tampoco lo sé, al estar más en contacto con la naturaleza se ve la vida y la muerte de una forma más natural,..., pienso que lo ven de una forma más natural, es más trágico el hombre del medio rural, en todo el sentido de la palabra, así, sin analizar, es más trágico...Los hombres, yo creo que sí, los hombres,..., la mujer es más dura, más sufrida, aguanta más las penalidades que el hombre" (E423). 


\begin{tabular}{|c|c|c|c|c|c|c|}
\hline \multirow{2}{*}{} & \multicolumn{5}{|c|}{ EN EL MEDIO } & \multicolumn{3}{c|}{ AHORA O HACE 20 AÑOS } \\
\cline { 2 - 7 } & RURAL & URBANO & NO SABE & AHORA & ANTES & NO SABE \\
\hline TOTAL & 4,7 & 58,8 & 36,5 & 51,2 & 2,2 & 46,1 \\
\hline & ENTRE HOMBRES O MUJERES & & \multicolumn{3}{c|}{ POR EDAD } \\
\hline TOTAL & HOMBRES & MUJERES & NO SABE & JÓVENES & ADULTOS & ANCIANOS \\
\hline & 27,4 & 13,1 & 59,0 & 30,7 & 21,0 & 7,1 \\
\hline
\end{tabular}

Fte: Encuesta 2000. Elaboración propia

Sin embargo, la población encuestada acierta en que los hombres se suicidan más que las mujeres: en el año 2000, las tasas de suicido de hombres y mujeres fueron 13,05 y 3,98 por 100.000, respectivamente; en el año 2008, esos valores fueron 11,88 y 3,38 por 100.000 . También aciertan las personas que afirman que en la actualidad se producen más suicidios que hace 20 años: en el año 1980 se suicidaron en España 1.652 personas; veinte años después, en el 2000, lo hicieron 3.393, un 105,4\% más. Esta tendencia en el crecimiento del número de suicidios es general en el mundo, como ha denunciado la OMS, y, para el caso de Occidente, ha sido relacionada por la suicidóloga R Menahem (1974:186) con el desarrollo de "una enfermedad de la civilización contemporánea, que ha edificado una mitología fundada en la negación de la realidad de la muerte. La lucha contra el suicidio sólo dará sus frutos cuando el miedo a la muerte sea desmitificado”.

\subsubsection{LA MUERTE COMO DESCANSO PROHIBIDO: EUTANASIA}

“El fuego termina por apagarse bajo la ceniza” H. Roorda

Otra de las cuestiones más debatidas entre la opinión pública de las sociedades desarrolladas es la de la legalización/despenalización o no de la eutanasia, en la que, al igual que en el caso del suicidio, se observa un gradiente de actitudes entre dos posiciones extremas, la del sostenimiento de la vida a cualquier precio y la de la libertad personal. Un mismo acto que es percibido en un extremo de la opinión pública como criminal y en el otro extremo como un deber de solidaridad humana (De Miguel, 1974:252). Sin embargo, y a diferencia del suicidio, el derecho a morir expresado tanto en la eutanasia como en el suicidio asistido requiere del concurso de al menos otra persona para que quien quiera ejercer ese derecho pueda consumarlo. 
Presencia y colaboración de un "otro" que transforma la materialización de ese derecho en un acto social, lo que lleva a cuestionar la primacía del principio de autodeterminación de la persona sobre su propia vida en la ejecución efectiva de la eutanasia ${ }^{84}$ (Casado y Royes, 2003:9; Fernández Buey, 1998:13). En mayor medida aún cuando la petición de ayuda para ejercer el derecho a morir viene acompañada por la de limitación del dolor y el sufrimiento, lo que asimismo requiere la posesión de conocimiento especializado por el "otro", que tendrá que prescribir fármacos y administrarlos correctamente para que se pueda conseguir que el morir sea tranquilo e indoloro, por lo que, en la mayoría de las ocasiones, la persona enferma es hospitalizada, es decir, es traslada a un ámbito público donde queda sometida a las normas y controles de éste (Jonas, 1997:166).

Por tanto, el derecho a morir asistido médicamente no corresponde sólo a la esfera individual y, en consecuencia, colisiona con la misión encomendada a los poderes públicos de proteger la vida, y más concretamente con lo sancionado mediante ley sobre el derecho a recibir tratamiento médico. En esta tesitura se plantea el problema social de qué cabe pedir moral ${ }^{85} \mathrm{y}$ legalmente al personal médico en aquellas situaciones en las que las personas enfermas demandan que se les aplique eutanasia o se las ayude a suicidarse. Ciertamente, no está justificado que el paciente deba ser forzado a vivir por parte del personal médico, pero éste sí que puede verse forzado a propiciar "tal condición, en parte por la ética de la profesión y en parte por la ley vigente y la jurisprudencia predominante” (Jonas, 1997:173). Como gráficamente señala este autor, al ser hospitalizado un paciente, sometido a tratamiento y/o conectado a maquinaria de mantenimiento vital, el personal médico "está por así decirlo enjaulado con él y ya no es alguien que opera libremente desde fuera”. Situación incómoda para el personal médico que se ha visto potenciada en las últimas décadas por la incidencia de tres procesos sociales: a) el establecimiento de una nueva definición de muerte, que como se ha examinado en el Capítulo 2 de esta Tesis, ha complicado en algunos casos incluso el mero acto

\footnotetext{
${ }^{84}$ En un artículo titulado "Una muerte tan dulce” (EL PAÍS, 29/04/99:15-16), M. Vargas Llosa no tiene dudas sobre qué derecho debe primar, por ello afirma que "la legalidad que proclama una universal "obligación de vivir”" (constituye) "un atropello intolerable a la soberanía individual y una intrusión del Estado reñida con un derecho humano básico". En ese artículo realiza un panegírico del doctor Jack Kevorkian, al que califica como un "auténtico héroe de nuestro tiempo" por haber ayudado a morir, violando la ley, a 130 "desdichados", y critica precisamente "la maraña de hipocresías, paradojas y prejuicios que rodean al debate sobre la eutanasia" en las sociedades occidentales: "Sólo quienes no están en condiciones físicas de poder llevar a cabo su voluntad de morir -pacientes terminales reducidos a grados extremos de invalidez-, es decir, a quienes más tormento físico y anímico acarrea la norma legal, se ven obligados a acatar la prohibición burocrática de morir por mano propia... (en el tema de la eutanasia, la civilización occidental arrastra todavía... un considerable lastre de barbarie). Porque no es menos inhumano privar de la muerte a quien lúcidamente la reclama ya que la vida se le ha vuelto un suplicio, que arrebatar la existencia a quien quiere vivir”.

85 "La defensa moral de la eutanasia se basa en la consideración de que la obligación de aminorar los sufrimientos de una persona está por encima de la obligación de preservar la vida en general” (Fernández Buey, 1998:12).
} 
de identificar la aparición del cadáver; b) los avances tecnológicos que permiten prolongar considerablemente el mantenimiento artificial de la vida humana, frente a los que en determinadas circunstancias algunas personas se rebelan, y; c) la emergencia en muchos países de asociaciones que reivindican no sólo la moralidad de la eutanasia sino también su despenalización (Fernández Buey, 1998:9).

Dado que, ni moral ni legalmente, es lo mismo "matar" que "dejar morir", el debate sobre la eutanasia y el suicidio asistido ha discurrido con una gran proliferación de términos con los que se buscaba dilucidar conceptualmente la casuística de actuaciones médicas concretas en este ámbito. Entre estos conceptos cabe destacar los siguientes tomados de (Cuenca, 2006):

\begin{tabular}{|c|c|}
\hline \multicolumn{2}{|c|}{ TABLA 5.2. CONCEPTOS RELACIONADOS CON LA EUTANASIA } \\
\hline CONCEPTO & DEFINICIÓN \\
\hline Eutanasia: & $\begin{array}{l}\text { "acción u omisión directa o indirecta dirigida a procurar la } \\
\text { muerte de una persona que padece una enfermedad avanzada o } \\
\text { terminal, bajo su petición expresa y reiterada de aquella". }\end{array}$ \\
\hline Eutanasia Activa o positiva: & $\begin{array}{l}\text { "acción que provoca la muerte de un paciente que sufre de } \\
\text { manera intolerable". }\end{array}$ \\
\hline Eutanasia Pasiva u occisita: & $\begin{array}{l}\text { "omisión o suspensión de las medidas terapéuticas que prolongan } \\
\text { la vida de un paciente en fase terminal”. }\end{array}$ \\
\hline Eutanasia Voluntaria: & "la que se realiza a petición expresa del paciente". \\
\hline Eutanasia Involuntaria: & $\begin{array}{l}\text { "conducta consistente en provocar la muerte de un paciente en } \\
\text { contra de su voluntad explícita, o sin su consentimiento ya que } \\
\text { no se puede conocer si desearía morir". }\end{array}$ \\
\hline Eutanasia Directa: & $\begin{array}{l}\text { "conducta médica que tiene por objeto y resultado principal la } \\
\text { muerte del paciente (se considera sinónimo de eutanasia activa)". }\end{array}$ \\
\hline $\begin{array}{l}\text { Eutanasia Indirecta (Sedación } \\
\text { terminal): }\end{array}$ & $\begin{array}{l}\text { "conducta del médico que no tiene como fin principal la muerte } \\
\text { del paciente sino que ésta es un efecto secundario de la auténtica } \\
\text { intención, que es la de aliviar del dolor y aplacar la agonía } \\
\text { insoportable (doble efecto)". }\end{array}$ \\
\hline Suicidio asistido: & $\begin{array}{l}\text { "conducta o actuación en la que la persona misma que sufre una } \\
\text { enfermedad irreversible pone fin a su vida con la ayuda de otra } \\
\text { persona que coopera proveyendo los medios para ello". }\end{array}$ \\
\hline Encarnizamiento terapéutico: & $\begin{array}{l}\text { "adopción de medidas médicas carentes de ningún otro sentido } \\
\text { que el de alargar innecesariamente la vida de un paciente que está } \\
\text { abocado irremediablemente a la muerte”. }\end{array}$ \\
\hline $\begin{array}{l}\text { Limitación terapéutica } \\
\text { (Eutanasia pasiva): }\end{array}$ & $\begin{array}{l}\text { "actuación de limitar, retirar o no iniciar una medida de soporte } \\
\text { vital aunque ésta pretendiese retrasar el momento de la muerte". }\end{array}$ \\
\hline Morir dignamente: & $\begin{array}{l}\text { "concepto ambiguo y subjetivo ya que depende de los deseos de } \\
\text { cada persona, aunque podría objetivarse el mismo incluyendo el } \\
\text { morir sin dolor físico ni psíquico innecesario, con conocimiento } \\
\text { de la situación, con la posibilidad de tomar decisiones o que se } \\
\text { respeten las voluntades expresadas previamente, y en un entorno } \\
\text { y ambiente acogedor y positivo". }\end{array}$ \\
\hline
\end{tabular}

Fte: Elaboración propia a partir de Cuenca (2006) 
Esta proliferación de conceptos han enmarañado ${ }^{86}$ el debate de la eutanasia desplazando en muchas ocasiones el foco de atención de los hechos para dirigirlo a cuestiones puramente nominales (Júdez, 2007:138), por lo que desde distintas instancias se ha solicitado la eliminación de los adjetivos que califican a la palabra eutanasia ${ }^{87}$ y la fijación del mismo en las dos actuaciones concretas más problemáticas: la eutanasia activa y el suicidio asistido. Toda vez que, además, las otras opciones están admitidas legalmente y se asumen entre el personal médico porque se considera que se ajustan a las buenas prácticas médicas ${ }^{88}$. En efecto, no tiene sentido debatir sobre eutanasia indirecta ni sobre eutanasia pasiva, "el desenchufar", ya que ambas conductas están despenalizadas en el Código Penal desde 1995 y se aplican desde hace tiempo en los hospitales; no así la acción directa que busca acabar con la vida del paciente, "la inyección letal” (“la bomba”), que se considera inmoral y legalmente punible. Así, mientras que en el artículo 143.2 del Código Penal se castiga con "una pena de 2 a 5 años de prisión, la cooperación necesaria al suicidio de otro", en el artículo 143.4 se describe el <<contexto eutanásico>> vigente en España delimitando las conductas que se penalizan y las no punibles: "El que causare o cooperare activamente con actos necesarios a la muerte de otro, por la petición expresa, seria e inequívoca de éste, en el caso de que la víctima sufriera una enfermedad grave que condujera necesariamente a su muerte, o que produjera graves padecimientos permanentes y difíciles de soportar, será castigado con la pena inferior en uno o dos grados a las señaladas en los números 2 y $3^{89}$ de este artículo”. En un informe elaborado por la Comisión Jurídica de la Asociación Derecho a Morir Dignamente (Montes y Casares, 2008; Montes y Soler, 2008; DMD, 2003) se exponen las insuficiencias de esta regulación, entre ellas

\footnotetext{
${ }^{86}$ Una buena muestra de cómo la discusión se aleja de los hechos para centrarse en el matiz de los conceptos es el documento Ética de la sedación en la agonía, elaborado por la Organización Médica Colegial de España (2009), que en su justificación señala: “"Sedación en la agonía” es el término que debe utilizarse en vez de "sedación terminal", ya que la palabra "terminal" puede hacer creer que se trata de una eutanasia encubierta, cuando en realidad no es así. Quienes no conocen las indicaciones y la técnica de sedación o carecen de experiencia en medicina paliativa, pueden confundirla con una forma encubierta de eutanasia; sin embargo la sedación en la agonía debe considerarse hoy día como un tratamiento adecuado para aquellos enfermos que, en los pocos días y horas que preceden a su muerte, son presa de sufrimientos intolerables que no han respondido a los tratamientos adecuados". En el apartado 17.2 de ese documento se recoge: "Es un deber deontológico abordar con decisión la sedación en la agonía, incluso cuando de ese tratamiento se pudiera derivar, como efecto secundario, una anticipación de la muerte".

${ }^{87}$ Por ejemplo, ante los datos aportados para diferentes países, incluido España, en los que se constataba el apoyo mayoritario de la opinión pública a la eutanasia activa, en un Seminario jurídico internacional sobre la Eutanasia organizado en 1994 por el Instituto Andaluz Interuniversitario de Criminología, (Boletín Criminológico, n5, I.A.I.C., Universidad de Málaga, p.4) entre las conclusiones se recomendó que "2. Sería aconsejable eludir la terminología de eutanasia activa y pasiva, pues tiende a poner erróneamente el énfasis en el carácter activo u omisivo del comportamiento de la tercera persona interviniente cuando lo verdaderamente decisivo son las diferentes situaciones clínicas en las que se encuentra el paciente."

88 "El criterio médico que justifica esas decisiones encuentra amparo tanto en las normas deontológicas de la profesión como en la Ley básica 41/2002 de Noviembre, reguladora de la autonomía del paciente y de derechos y obligaciones en materia de información y documentación clínica” (Casado y Royes, 2003:8).

${ }^{89}$ En el artículo 143.3 del Código Penal se castiga con una pena de 6 a 10 años de prisión la prestación de una ayuda "que llegara hasta el punto de ejecutar la muerte".
} 
que, al delimitar como hechos punibles los actos necesarios y directos, deja fuera del tipo penal el facilitar un veneno letal a una persona que hubiera podido conseguirlo sin ayuda complicidad como ayuda no necesaria- (art. 29), y, sin embargo, penaliza a quien se lo facilita a una persona impedida que no puede acceder por sí sola al mismo (art. 28).

La distinción entre eutanasia activa y eutanasia pasiva es asimismo contemplada, con ambigüedad y cierta confusión, en el apartado dedicado a la eutanasia en el Catecismo de la Iglesia Católica (2003:409). Si bien en principio se condena todo tipo de eutanasia: "Cualesquiera que sean los motivos y los medios, la eutanasia directa consiste en poner fin a la vida de personas disminuidas, enfermas o moribundas. Es moralmente inaceptable. Por tanto, una acción o una omisión que, de suyo o en la intención, provoca la muerte para suprimir el dolor, constituye un homicidio gravemente contrario a la dignidad de la persona humana y al respeto del Dios vivo, su Creador...” (párrafo 2.277). A continuación se admite la eutanasia pasiva o limitación terapéutica: "La interrupción de tratamientos médicos onerosos, peligrosos, extraordinarios o desproporcionados a los resultados puede ser legítima. Interrumpir estos tratamientos es rechazar el "encarnizamiento terapéutico". Con esto no se pretende provocar la muerte; se acepta no poder impedirla...” (párrafo 2.278). Y, finalmente, se consiente el doble efecto de la eutanasia indirecta (sedación terminal): “Aunque la muerte se considere inminente, los cuidados médicos ordinarios debidos a una persona enferma no pueden ser legítimamente interrumpidos. El uso de analgésicos para aliviar los sufrimientos del moribundo, incluso con riesgo de abreviar sus días, puede ser moralmente conforme a la dignidad humana si la muerte no es pretendida, ni como fin ni como medio, sino solamente prevista y tolerada como inevitable. Los cuidados paliativos constituyen una forma privilegiada de la caridad desinteresada...” (párrafo 2.279).

La recurrente apelación a los cuidados paliativos como fórmula mágica que, debidamente desarrollada e implementada por personal especializado, solucionaría todas las peticiones de eutanasia no es tal, al menos hasta ahora, como ha apuntado el propio secretario general del Consejo General de Colegios Oficiales de Médicos, J.J Rodríguez Sendín, en varias ocasiones. Así, en una ilustrativa mesa redonda sobre: "Eutanasia: ¿sabemos de lo que hablamos?”, organizada por la Organización Médica Colegial (OMC) en 2009, afirmó que “el problema es que muchas veces no hay posibilidad de hacerse, no se tiene acceso a ese tipo de cuidados, con lo cual la inequidad en este sentido es bastante llamativa... No deja de ser llamativo que nos movamos en un 'blanco o negro’ extraordinariamente extremo. Por un lado, tenemos gente que se muere sola con infinitos dolores, sin garantías de que se les vaya a tratar en condiciones, pero sin ganas de terminar con su vida, y, por otro, que haya que acabar activamente con la vida de alguien, cuando no tenemos garantizado que, obligatoriamente, 
poner los remedios que tenemos (sic). Y es que para un caso de éstos, tenemos miles de los primeros a los que me he referido" (OMC, 2009:32). Por otra parte, en la presentación de la Declaración sobre "La atención médica al final de la vida", documento elaborado por la OMC, Rodríguez Sendín declaró su voluntad “de impulsar los cuidados paliativos, un tipo de atención que está en un estado "francamente deficiente en España... Hay muchísimo margen de mejora $^{90, ", ~(E L ~ P A I ́ S, ~ 7 / 10 / 09) . ~}$

Paradójicamente, tanto en la mesa redonda como en el acto de presentación de la Declaración, se utilizó, combinado con las insuficiencias de los cuidados paliativos, otro argumento recurrente para oponerse a la legalización de la eutanasia activa: "los casos reales de eutanasia activa son muy escasos”91. O lo que es lo mismo, no cabe legislar para tan pocos casos concretos cuando lo prioritario, en estos momentos, es que la "demanda de eutanasia baje al mínimo posible" haciendo que "todo el mundo tenga acceso" a los mismos ${ }^{92}$. Bucle médicoburocrático fantasioso (la insuficiencia de cuidados paliativos cierra el paso a cualquier demanda de eutanasia, porque si estuvieran adecuadamente desarrollados esas demandas no se producirían, serían "absolutamente esporádicas”) en el que, según los datos aportados por la propia OMC en la presentación de la Declaración, se encontrarían atrapados el 1\% de los enfermos terminales, incluidos los atendidos en unidades de cuidados paliativos, que solicitan a sus médicos se les aplique la eutanasia, es decir, como mínimo unas 2.000 personas al año en España $^{93}$.

Sin embargo, y tal como se reconoce en el punto 6 de la Declaración de Santander para la despenalización de la eutanasia ("El suicidio asistido, y la eutanasia van más allá de los

\footnotetext{
${ }^{90}$ Efectivamente, en un reciente informe comparativo internacional sobre la calidad de los cuidados paliativos, elaborado por el grupo de estudio The Economist Intelligence Unit, vinculado al semanal The Economist, se sitúa a España en el puesto 26 de 40 en el Índice de Calidad de la muerte con una nota global de 4,2 sobre 10. Índice en el que se combinan una serie de variables como: provisión de unidades de cuidados paliativos, acceso a tratamientos analgésicos, existencia de políticas y fondos públicos para estos cuidados, percepción social de la muerte, etc. En la clasificación, España aprueba en calidad de la atención ofrecida y en el entorno sanitario alrededor del final de la vida, pero suspende, con un 2,3 sobre 10, en número de unidades de cuidados paliativos necesarias (hay 400, y se necesitarían 200 más) (EL PAÍS, 16/08/10:24).

${ }^{91}$ Argumento que utilizó en la mesa redonda organizada por la OMC el catedrático de geriatría J.M. Ribera Casado para afirmar que los casos de eutanasia activa en realidad constituyen "un problema falso" (OMC, 2009:32).

${ }_{92}$ En una entrevista para EL PAÍS (16/04/00:Domingo:2), el presidente de la Sociedad Española de Cuidados Paliativos, M. Gómez Sancho, mostraba de forma diáfana su punto de vista sobre la eutanasia: "El que un país que no atiende correctamente a los enfermos candidatos a solicitar la eutanasia intente legalizar la forma de acabar con ellos me parece una frivolidad".

${ }^{93}$ Datos complementados en la presentación de la Declaración por el presidente de la Comisión Central de Deontología de la OMC, M. Gómez Sancho, con estos otros: reconociendo que no obstante la situación había mejorado respecto a tiempos pretéritos, en la actualidad "más de la mitad de las personas mueren con dolor, un 24\% recibe reanimación cardiaca aunque sean terminales, y un 55\% tiene puesta todavía la sonda nasogástrica cuando fallecen” (EL PAÍS, 7/10/09).
} 
cuidados paliativos, aun cuando estos estuvieran bien implantados en todo ámbito de la sanidad pública estatal. Los cuidados paliativos no resuelven todos los problemas relacionados con el dolor y el sufrimiento físico, psíquico y existencial”) (Montes y Casares, 2008), en algunas situaciones el dilema sobre la aplicación de la eutanasia persiste, como así lo reconocen parte de los propios profesionales que trabajan en el ámbito de los cuidados paliativos ${ }^{94}$; entonces, para esos casos: ¿qué hacer cuando la enfermedad conducirá en breve a la muerte, el paciente manifiesta explícitamente su deseo de no querer seguir viviendo, se halla en un estado de sufrimiento y dolor insoportable (por fracaso de los cuidados paliativos o por su inaccesibilidad), o en un estado comatoso profundo y no podrá tener ya una existencia “normal”? Dilema que se enmarca más ampliamente en el debate entre dos posiciones éticas, la de la $<<$ santidad de la vida $>>{ }^{95}$, de raíz religiosa, y la de la $<<$ calidad de vida $>>{ }^{96}$ (junto con la de la $<<$ autonomía de la persona $>>$ ), de carácter laico, pero que para algunos autores, al margen de las posiciones morales de partida, es un dilema que lo que sobre todo pone de relieve es lo difuso y arbitrario de la línea que separa la eutanasia activa de la pasiva en las sociedades tecnológicamente avanzadas, y que en realidad esa distinción no es más que la salvaguarda

\footnotetext{
${ }^{94}$ Según datos de una encuesta realizada durante el $6^{\circ}$ Congreso Nacional de la Sociedad Española de Cuidados Paliativos (CP), en junio de 2006, de los 175 profesionales de CP interrogados sobre si “¿Apoyaría una ley que despenalizase la eutanasia? Un 30\% respondió afirmativamente y un 21\% dijo que probablemente sí. Dudaban un 17\% y entre el "probablemente no" y el "no" se definió un 32\%”, lo que según Barbero y Díaz (2007:83) eran datos no habituales "en el ámbito de los paliativistas, históricamente muy reacio a admitir dicha despenalización”, es decir, si "los profesionales entendieran que los CP resuelven todos los problemas de las personas al final de la vida no sería congruente una respuesta así".

${ }_{95}$ Entre los argumentos empleados para defender la ética de la santidad de vida se incluyen los siguientes tomados de Cuenca (2006:13-14): 1) el fin del médico es sanar y proteger la vida humana; 2) las decisiones autónomas de los pacientes tienen límites legales, éticos y morales; 3) el coste psíquico, económico y social relacionados con algunos pacientes no es razón suficiente para practicar conductas eutanásicas; 4) el dolor y el sufrimiento insoportable no es argumento suficiente para practicar la eutanasia; 5) el concepto de "dignidad humana" no implica conductas conducentes a la práctica de la eutanasia, sino todo lo contrario; 6) la práctica de la eutanasia conlleva un riesgo para los más débiles, distorsionando la confianza del enfermo hacia el sistema sanitario; 7) el argumento de la "pendiente resbaladiza" que deduce que una vez legalizada la eutanasia podrían practicarse acciones eutanásicas a personas inconscientes y/o incapaces de expresar su posición; 8) hay casos en los que después de situaciones clínicas complejas (p.e., estados vegetativos producidos por coma) se puede salir de ellas; 9) se puede aceptar en la praxis médica las prácticas de doble efecto y/o la no aplicación o renuncia a tratamientos desproporcionados.

${ }^{96}$ Entre los argumentos recogidos por Cuenca (2006:14-15) respecto a la ética de la calidad de vida destacan: 1) los derechos fundamentales de la persona, autonomía, dignidad, libertad, etc., permiten la libre disposición de la vida en su final; 2) la voluntad de los pacientes debe ser considerada principio fundamental para la eutanasia y el suicidio asistido; 3) el coste y la carga social deben ser tomados en cuenta a la hora de considerar la eutanasia libremente aceptada; 4) el dolor y el sufrimiento físico y psíquico de un paciente terminal debe ser tenido en cuenta y es argumento para que un paciente pueda solicitar la eutanasia y/o el suicidio asistido; 5) el afrontamiento de la muerte desde la libertad del individuo a decidir cuándo y cómo finalizar su vida pertenece al ámbito de morir dignamente; 6) en un contexto legal y jurídico positivos, las prácticas eutanásicas garantizan la buena praxis médica en un sentido general; 7) el encarnizamiento terapéutico es irracional, inhumano y un atentado contra la libertad (adulto que ha decidido) como contra la dignidad de la persona (incapacitados que no han decidido); 8) los médicos que acepten las prácticas eutanásicas y/o de suicidio asistido deben realizarlas bajo determinados criterios, y deben estar legalmente protegidos.
} 
legal, que no moral, de las actuaciones de la clase médica. En efecto, desde un punto de vista lógico, y para algunos autores también desde un punto de vista moral (Montes y Soler, 2008; DMD, 2003; Casado, 1996; Singer, 1984), si de lo que se trata es de dar "buena muerte”, en determinados casos el "desenchufar” puede suponer más tiempo de sufrimiento y dolor que el aplicar una "inyección letal” (“la bomba”), siendo, en el sentido de moral señalado arriba, peor “dejar morir” que “matar”, o, como afirma Fernández Buey (1998:12), en este caso “lo mejor (desde el punto de vista ético) es enemigo de lo bueno". Siguiendo a este autor, se argumenta además que, con la tecnología actual, "la eutanasia pasiva no es realmente pasiva" ya que no hay nada de pasividad, sino pura actividad que afecta a otro, en el hecho de desconectar una máquina de mantenimiento vital. Siendo ésta otra de las insuficiencias del <<contexto eutanásico>> español recogidas en el Código Penal de 1995 y denunciadas en el informe de los servicios jurídicos de la Asociación DMD (2003:117-118): la desigualdad con la que se trata a personas que están en la misma situación pero que recibirán o no satisfacción a sus demandas por estar penalizadas las conductas activas y directas y no ser punibles las pasivas y omisivas, cuando, de hecho, "la desconexión tiene un componente activo de retirada de soporte vital desde el punto de vista físico" ${ }^{97}$. Argumento que cuestiona la distinción moral eutanasia activa/pasiva, y que evidenciaría que lo que en realidad se persigue con la misma es blindar legalmente al personal médico para evitar acusaciones de homicidio. En cualquier caso, no sería la satisfacción de los intereses de los pacientes lo que primaría en esa distinción.

Por otra parte, la necesaria legalmente, que no imprescindible, participación del personal médico en la aplicación de la eutanasia y el suicidio asistido ha conllevado, como denuncia V. Méndes en su artículo “Mar adentro y tierra por medio”, (EL PAÍS, 16/11/04:35), que tanto parte del personal médico como "los expertos en bioética reclamen el privilegio de conformar a su gusto el debate sobre la eutanasia”. Es decir, que las personas no especializadas en la materia, sean pacientes o no, están cautivas, de nuevo en temas relacionados con la muerte, de quienes sí poseen ese conocimiento experto. Y no sólo cautivas, también infantilizadas, ya que, según Gómez Sancho, presidente de la Comisión Central de Deontología de la OMC, ni siquiera cabe considerar en este ámbito las opiniones de la ciudadanía favorables mayoritariamente a la eutanasia, simplemente porque esas personas encuestadas no están próximas a la muerte: “no es lo mismo opinar cuando se ve la muerte como algo muy lejano que

97 Por ello, Montes y Soler (2008) van incluso más allá, y comparando eutanasia pasiva y suicidio asistido, señalan que es "muy difícilmente comprensible que se tenga el derecho a decidir la propia muerte mediante la desconexión por un tercero de un respirador (el caso de Inmaculada Echeverría) y no se tenga el de pedir que se le administre a uno un fármaco letal al que tampoco se puede acceder sin ayuda (como Ramón Sampedro). Se podrán emplear cuantos tecnicismos legales se quieran, pero los ciudadanos de a pie no entendemos cómo es posible que en iguales circunstancias de rechazo de la vida, que ambos consideraban una condena, sólo uno tuviera el derecho legal de conseguirlo”. 
cuando se es ya una persona mayor y se ve la situación como más cercana” (EL PAÍS, 6/10/09). Quizá haya que esperar a envejecer para tener derecho a opinar sobre este tema, pero, al margen de la sospecha sobre la opinión pública que esta opinión conlleva (ignorancia en el mejor de los casos, eugenesia en el menos favorable), y del papel que se otorga al personal médico de salvaguarda y protector de los intereses de esa opinión pública (que por sí sola actuaría contra sí misma), parece claro entonces que salvo las personas que están próximas a la muerte, por razones obvias, y el personal médico especializado, por su conocimiento experto, el resto de la ciudadanía no tiene nada que decir sobre un tema al que se puede enfrentar inesperadamente de forma directa ("Y de repente la nada"), o con alguna o bastante frecuencia de forma vicaria a partir de una edad muy provecta.

En todo caso, no queda claro entonces cuál es la posición y el papel desarrollado por una parte significativa del estamento médico que parece contradecir con su actuación y con sus opiniones lo manifestado por la cúpula de la OMC. En efecto, por un lado, el 15\% de los médicos entrevistados en una encuesta realizada por la OCU en el año 2000, manifestó que había participado activamente en al menos una eutanasia activa ${ }^{98}$. Es decir, "si miramos los números, sólo en la categoría médicas se habrían producido en los últimos veinte años más de quince mil eutanasias activas” (DMD, 2003:118). Datos que llevan a Eulalia López Imedio, jefa de enfermería de la Unidad de Cuidados Paliativos del Hospital Gregorio Marañón de Madrid a denunciar que la eutanasia activa siga practicándose de forma oculta en España, “como sucedía con el aborto hace años. Si se legalizara no iba a practicarse más, sino que dejaría de hacerse en condiciones penosas" (EL PAÍS, 16/04/00:Domingo:2). Por otra parte, 6 de cada 10 médicos entrevistados por el CIS, en 2002, se manifestaron partidarios de legalizar la eutanasia activa y el suicidio asistido para pacientes terminales ${ }^{99}$, frente a un $31,4 \%$ que se oponía a esa legalización (CIS, 2002:7), mientras que en el caso de los pacientes con enfermedades incurables pero no terminales el número de partidarios de la legalización se reducía hasta el 26,4\%, frente a 2 de cada 3 que se oponían a ella (CIS, 2002:5). Otros resultados significativos de esta interesante encuesta, ya que permiten contextualizar y ser contrastados con la opinión de la población encuestada no especializada para el presente trabajo, son los siguientes:

\footnotetext{
${ }^{98}$ Además, el 21\% de los 477 médicos encuestados (una tercera parte de ellos trabajando en cuidados paliativos) afirma conocer que se practica la eutanasia activa por otros y el $65 \%$ dice haber recibido él mismo la petición de aplicarla. Petición que se eleva al 85\% en el caso de las 63 enfermeras entrevistadas, todas ellas trabajando en cuidados paliativos. De forma más específica, el 10,8\% de los médicos encuestados ha tomado medidas activas a petición de la persona enferma; el 9,9\%, a petición de la familia; el 14,7\%, por iniciativa propia, y; el 2,6\% ha realizado suicidio asistido a petición de la persona enferma (OCU-Salud, 2000, $\mathrm{n}^{\circ}$ 33, diciembre).

${ }^{99}$ Desagregados como sigue: el $41,5 \%$ sí que se mostraba partidario de legalizar la eutanasia activa y el suicidio asistido "pero sólo para enfermos terminales que conserven todas sus facultades mentales", mientras que otro 18,4\% consentía que fuera "para pacientes que conserven todas sus facultades mentales, independientemente de que su enfermedad sea terminal o crónica (grave e irreversible)”.
} 
- El 57,6\% de los médicos encuestados ha recibido a lo largo de su vida peticiones (de pacientes y/o familiares) de eutanasia pasiva, el 19,5\% de eutanasia activa y el 7,8\% de suicidio asistido. En el último año antes de la encuesta, el 6,8\% había recibido petición de practicar eutanasia activa o suicidio asistido por parte de los pacientes, y el 25,5\% por parte de familiares de pacientes (CIS, 2002:3-4). Datos que, siendo minoritarios en el caso de la eutanasia activa y el suicidio asistido, no dejan de ser relevantes y en todo caso muestran que es una experiencia relativamente extendida entre el personal médico, más cuando una parte de éste incluida en la muestra no trabaja en el ámbito de los cuidados paliativos ni con enfermos terminales.

- Interrogados, en pregunta multirrespuesta, por cuáles creían que eran los principales motivos que llevan a un enfermo a pedir que se acabe con su vida sus respuestas fueron: el dolor insoportable, 74,7\%; el miedo a tener que depender de los demás, el 38,5\%; el sentirse que es una carga personal para su familia, el 34,5\%; el miedo al deterioro físico, el 33,1\%, y; la depresión, el 33,5\% (CIS, 2002:1). Lo que implica que no sólo cuenta el dolor físico, sino que también se percibe que otras circunstancias que provocan sufrimiento pueden ser determinantes en la petición de eutanasia.

- Pese al apoyo mayoritario a la legalización de la eutanasia, ante una petición de eutanasia activa por parte de un paciente con dolor intenso, depresión, abandono, etc., el 69,8\% considera que lo más adecuado es controlarle el dolor y los síntomas, el 12,4\% darle apoyo emocional, el 6,3\% proporcionarle lo que pide (eutanasia) y el 2,5\% darle el coktail lítico (CIS, 2002:4). Es decir, la mayoría de ellos no estaría dispuesto a practicar la eutanasia activa ni el suicidio asistido.

- En lo relativo a las razones que según el personal médico encuestado constituyen las mayores dificultades para la legalización de la eutanasia (pregunta multirrespuesta), sitúan en primer lugar la vulneración de los derechos de las personas en situación de fragilidad, el 58,9\%; seguida de la mala utilización, el 57,0\%; a continuación de razones de carácter ético, el 52,1\%, y; por último, el rechazo social, el 11,6\% (CIS, 2002:8). Dato este último que supone un reconocimiento de que sus opiniones están en sintonía con las de la mayoría de la población española cuando se solicita la legalización de la eutanasia activa: no perciben que el rechazo social a la misma sea importante en extensión ni tampoco en intensidad.

- Respecto a los cuidados paliativos en abstracto, el 84,6\% no cree que un correcto empleo de los mismos resuelva todas las situaciones de eutanasia, frente a un 13,1\% que sí lo cree. Para el caso concreto de España, y en el hipotético supuesto de que existiese un buen sistema universal de cuidados paliativos, sólo el 3,3\% cree que se acabarían todas las peticiones de eutanasia, el 85,5\% que lo harían la mayoría o algunas de las peticiones de eutanasia, mientras un 9,4\% piensa que no cambiaría el número de peticiones de eutanasia (CIS, 2002:7).

- En cuanto a la valoración del estado real de los cuidados paliativos en España, en una batería de preguntas tipo escala, en la que 1 significa totalmente en desacuerdo y 10 totalmente de 
acuerdo, algunas de las medias obtenidas fueron las siguientes: "La infraestructura hospitalaria existente en España es suficiente para atender las necesidades de cuidados paliativos", 3,2; "La atención a los pacientes de cuidados paliativos cuenta con una buena asistencia de enfermería”, 5,8; "La atención a los pacientes de cuidados paliativos cuenta con una buena asistencia médica”, 5,8; "Los programas de cuidados paliativos ofrecen un buen tratamiento del dolor", 6,9; "Existe un buen apoyo psicológico para los familiares o allegados de pacientes de cuidados paliativos”, 3,4 (CIS, 2002:9). Datos que si se equiparan a `notas' equivaldrían a suspensos o aprobados 'raspados', es decir, que certifican las carencias, insuficiencias e ineficacia de los cuidados paliativos en España a ojos de los que trabajan directa, o próximamente a ellos.

- En otra batería de preguntas tipo escala con el formato de la anterior se obtuvieron las siguientes respuestas medias que certifican el reconocimiento y asunción de la eutanasia pasiva y la sedación artificial como buena práctica médica: “Algunas veces es una decisión acertada suspender (o no iniciar) un tratamiento de prolongación de la vida con muy mala calidad”, 8,4; "Es una práctica médica aceptada, incrementar la dosis de un analgésico para un enfermo terminal, con el objetivo de aliviar el sufrimiento, siendo consciente de que podría acelerar el final de su vida", 8,4; "Desconectar el respirador artificial de un enfermo terminal es un asesinato inaceptable”, 3,2. Por otra parte, si bien se reconoce el derecho de los pacientes terminales a solicitar la eutanasia activa o el suicidio asistido, "Los enfermos terminales que conservan totalmente sus facultades mentales, tienen derecho a decidir sobre la finalización de su vida”, 7,1; ese derecho no se percibe que tenga que conllevar la obligación de satisfacerlo por parte del personal médico: "La autonomía del enfermo no puede llegar hasta el punto de exigir el suicidio asistido o la eutanasia activa”, 5,0. De hecho, se rechaza que la eutanasia activa forme parte de las obligaciones del personal médico: "Proporcionar una dosis letal a petición del enfermo terminal, es acorde con la función médica de aliviar el dolor y sufrimiento”, 4,4; y no están dispuestos a practicarla: "Nunca recetaría/proporcionaría una dosis letal a un enfermo", 6,2. Finalmente, una pregunta clave, que por otra parte es la que más acuerdo concita, es la relativa a las implicaciones profesionales y legales derivadas de la aplicación de la eutanasia: "Proporcionar una dosis letal a un enfermo, puede crear serios problemas profesionales o legales al médico que lo haga”, 8,9 (CIS, 2002:10).

Estos resultados, no obstante, dejan al menos una cuestión muy relevante pendiente de resolver: si existe una predisposición general favorable por parte del personal médico al cambio legislativo sobre la eutanasia activa y el suicidio asistido, ambos médicamente apoyados, y si en el plano de las actuaciones concretas se considera que no hay obligación por parte del personal médico de desarrollar esas tareas y mayoritariamente no lo harían nunca, dado que legalmente es ese personal el único autorizado a ello, ¿quiénes lo practicarían?. Quizá por su experiencia vivida en primera persona, M.A. Durán (2004:30), al denunciar el conflicto que se vive en la 
sociedad española con este tema, aporta una reflexión clave que sirve de respuesta a ese interrogante: dadas las carencias reconocidas en el sistema de cuidados paliativos en España, las limitaciones impuestas por la legislación y los riesgos que comportan para el personal médico determinadas actuaciones si son conocidas y se hacen públicas, el hecho de que las horas finales de los enfermos terminales dependan del "azar del equipo o personal sanitario al que corresponda atenderles”, parece como si para la mayoría del personal médico lo más adecuado fuese que todo siguiese como hasta ahora, dejar que las cosas sigan igual confiando en que el equipo sanitario concernido, llegada la ocasión, “tomará las medidas oportunas sin ruido y sin necesidad de manifestar abiertamente su conducta”. Es decir, práctica de la eutanasia sin practicarla legal y abiertamente, llegando a acuerdos 'bajo cuerda' con los familiares, si se constata unanimidad de posiciones entre éstos y garantizan que no habrá denuncias, por ejemplo, a la hora de aplicar "la bomba”, evitándose con ello problemas con la Ley, y con otros colegas. Actitud esquizofrénica por cuanto corren riesgos innecesarios cuando sólo tienen obligación en sus comportamientos de ajustarse a lo legalmente establecido. Actitud "ocultista" cuya eficacia, según Durán (2004:30), queda desmentida precisamente por la insatisfacción y cierto sentimiento de culpa que los datos de la encuesta del CIS transmiten.

A pesar de lo señalado hasta ahora, diversidad de posiciones morales y de perspectivas teóricas, delgada e interesada línea legal de demarcación entre eutanasia activa y pasiva, papel de Gran Hermano en una parte de la cúpula del estamento médico, lo cierto es que los estudios empíricos realizados entre la población general muestran que en la práctica, como tal, no hay debate sobre la eutanasia entre la opinión pública, sino que la discusión se centra en la disputa entre el ejercicio de la libertad personal y las normas del sistema muerte que, al menos hasta ahora en la sociedad española, impiden ese ejercicio. En efecto, como se analiza a continuación la mayoría de la población encuestada cuando se la interroga al respecto tiene muy clara su posición a favor de las distintas formas de eutanasia y aboga abiertamente por la legalización de la eutanasia activa bajo ciertas circunstancias ${ }^{100}$.

De hecho, ya a finales de la década de 1980 el CIS (1989), interrogó por primera vez sobre esta cuestión, y los resultados mostraron que globalmente la población encuestada (2.498 entrevistas representativas del conjunto de la población española) tenía un "grado de apoyo muy

\footnotetext{
${ }^{100}$ En el estudio sobre la calidad de la muerte citado más arriba, en el que se sintetiza la información recogida hasta ese momento en una docena de estudios de diversas instituciones españolas (CIS; CIRES, ASEP), a la hora de examinar las posiciones de la población española sobre la eutanasia, Durán (2004:9) afirma que la conclusión principal que se podía extraer al respecto es que "las opiniones y actitudes de la sociedad española en este tema son mucho más abiertas que lo reconocido por la legislación vigente”; y, a partir de los cambios legales para la legalización de la eutanasia producidos en algunos países europeos (Holanda y Bélgica) además del Estado norteamericano de Oregón, pronostica que probablemente "el siglo XXI conocerá cambios similares en las actitudes respecto a la muerte de los que vivió el siglo XX respecto al nacimiento" (Durán, 2004:12).
} 
considerable a una idea general que podría resumirse como el derecho de los individuos a tener una muerte digna, con una insistencia significativa en la inutilidad de alargar los sufrimientos en el momento en que no existen fundadas esperanzas de curación para un enfermo” (CIS, 1989:101). En los datos obtenidos en las cinco preguntas de la encuesta referidas a la eutanasia el nivel de indefinición era muy moderado al plantear el tema, lo que significaba que ya entonces era un problema muy presente en la opinión pública española. Un análisis global de los datos revelaba además que existía "una valoración muy positiva de la eutanasia", siendo la homogeneidad y la consistencia de las respuestas notable, lo que demostraba "que la sociedad española está preparada para aceptar una posible legislación que regule los casos y las condiciones en los que se practique la eutanasia” (CIS, 1989:112). Por su parte, los estudios realizados por A. de Miguel en la primera mitad de los años noventa sobre la sociedad española contenían una pregunta sobre la eutanasia y en los mismos se confirma el apoyo a la eutanasia, y especialmente a la eutanasia activa (De Miguel, 1994:253-255). En la encuesta realizada para esta Tesis el número de preguntas sobre la eutanasia ha sido también reducido, 7, y, en términos generales, con gran consistencia entre las respuestas y bajo nivel de indefinición en todas las preguntas excepto una, se observa asimismo un intenso apoyo a la eutanasia, activa y pasiva. Más recientemente, un estudio específico del CIS (2009), con 39 preguntas relacionadas con el tema, el n $n^{\circ}$ 2.803: Atención a pacientes con enfermedades en fase terminal, muestra nuevamente que en términos generales la opinión pública española sobre el tema de la eutanasia está muy definida y cristalizada, es muy consistente y sobre todo diáfana en su apoyo a la eutanasia activa.

Con el objetivo de obtener una información más amplia que el mero posicionamiento a favor o en contra de la eutanasia entre la población encuestada para el presente trabajo, se la ha interrogado planteándola diversas situaciones concretas para determinar si existían diferencias notables en su posicionamiento respecto, entre otras cosas, a la eutanasia pasiva y la activa, obviamente sin mencionarlas como tales. Asimismo, dado que en la ejecución de eutanasia es crucial la figura del personal médico se intentaba indagar el papel que las personas encuestadas le otorgan en el mismo. El grado de responsabilidad médico fue precisamente una de las cuestiones más publicitadas del estudio del CIS (1989), ya que según este estudio las actitudes favorables a la eutanasia se elevaban cuando el sujeto activo que debía tomar la decisión final era el personal médico, y no tanto el propio paciente. En el presente trabajo, y en el estudio $\mathrm{n}^{\circ}$ 2.803 del CIS (2009), se comprueba que la situación se ha invertido en buena medida y mayoritariamente se considera al paciente como el actor que debe llevar las riendas del final de su vida, y no tanto al personal médico. 
Entre las cuestiones concretas que se planteaban a las personas encuestadas estaba la de que se proyectaran en una hipotética situación en la que tuvieran una enfermedad grave y si ante ello estarían interesadas en conocer el diagnóstico o no de la misma (pregunta 45), Cuadro 5.43. La mayoría de la población, 3 de cada 4, sí deseaba ser informada de las malas noticias, mientras que el resto optaba por delegar en su familia, $13,2 \%$, o se mostraba indecisa. Hay que destacar que en ningún caso la población encuestada era partidaria de que la información se quedase entre el personal médico, sino que necesariamente tenía que ser transmitida siempre. Como manifiestan las personas entrevistadas:

- "Me gustaría que me lo comunicaran, pero quizás no precisamente el doctor. Creo que las personas más indicadas serían mis familiares, mis padres, no el doctor que parece que es más... También es difícil pensar que quién más te quiere te tenga que decir que te vas a morir. La verdad es que es una noticia... sí que me gustaría que no me lo ocultaran, que lo supieran otras personas y no me lo hubieran comunicado a mî" (E1:12).

- "Prefiero saberlo, aunque sea más fastidioso, digámoslo así, pero yo creo que sí, que tengo derecho a saberlo, que tengo derecho a saber qué me pasa a mí" (E4:19).

A grandes rasgos, en la distribución de esta variable no existe asociación por género pero sí por las otras tres variables de control. En lo relativo a la edad (y al nivel de estudios) se observa que los que reclaman más sinceridad son los jóvenes (y los de estudios universitarios), 8 de cada 10, mientras que los que menos desean ser informados de su situación son los más mayores (y los de estudios básicos) quienes, en un proceso de delegación de responsabilidades, prefieren que se comunique las malas noticias a su familia, casi 3 de cada 10. Resultado de la distribución por edad que, como los obtenidos para otras de las preguntas en el análisis realizado, matiza y devalúa en buena medida la afirmación comentada más arriba del presidente de la Comisión Central de Deontología de la OMC, Gómez Sancho, respecto a que en todo caso sólo se tendrían que tomar en consideración las opiniones sobre la eutanasia de las personas cuando se están aproximando a la muerte. Por otra parte, es asimismo significativa la influencia de la religiosidad en este ámbito, ya que tanto las personas muy creyentes, las crédulas, como su antítesis, las incrédulas, son las que tienen más clara la decisión a tomar, tanto en que se lo comuniquen a ellas mismas o en que se lo transmitan a su familia, mientras que las dos categorías intermedias se muestran mucho más indecisas. 
CUADRO 5.43.: SINCERIDAD EN LA TRANSMISIÓN DE MALAS NOTICIAS POR EL PERSONAL MÉDICO EN UNA ENFERMEDAD GRAVE (\%)

\begin{tabular}{|l|c|c|c|c|}
\hline & $\begin{array}{c}\text { Que fueran } \\
\text { sinceros y me } \\
\text { informaran }\end{array}$ & $\begin{array}{c}\text { Que se lo } \\
\text { comunicaran a mi } \\
\text { familia }\end{array}$ & $\begin{array}{c}\text { Que no me } \\
\text { informaran }\end{array}$ & No sabe \\
\hline \multicolumn{1}{|c|}{ TOTAL } & 76,1 & 13,2 & 1,9 & 8,9 \\
\hline HOMBRES & 78,8 & 13,3 & 1,2 & 6,7 \\
MUJERES & 74,3 & 13,0 & 2,4 & 10,3 \\
\hline JÓVENES & 80,2 & 7,6 & 2,5 & 9,6 \\
ADULTOS & 76,6 & 12,1 & 0,7 & 10,6 \\
ANCIANOS & 65,0 & 28,8 & 2,5 & 3,8 \\
\hline EST. BÁSICOS & 64,7 & 27,9 & 1,5 & 5,9 \\
EST. MEDIOS & 69,3 & 15,9 & 3,4 & 11,4 \\
EST. UNIVERS. & 81,3 & 8,4 & 1,5 & 8,8 \\
\hline CRÉDULOS & 79,2 & 14,8 & 1,3 & 4,7 \\
CREYENTES & 74,7 & 9,2 & 0,0 & 16,1 \\
NO CREYENTES & 71,8 & 9,4 & 5,9 & 12,9 \\
INCRÉDULOS & 82,5 & 12,7 & 0,0 & 4,8 \\
\hline
\end{tabular}

Fte: Encuesta 2000. Elaboración propia

Como se ha señalado, una de las cuestiones clave en el tema de la eutanasia es el papel que se otorga al personal médico, más teniendo en cuenta que sin él legalmente la eutanasia no podría realizarse. En el Cuadro 5.44. se recogen los datos sobre esta cuestión fundamental: la opinión de las personas encuestadas respecto a quién debe tomar las decisiones sobre los cuidados médicos en el momento final de la vida de un/a enfermo/a (pregunta 46). Se puede observar que para el conjunto de la población encuestada la distribución es más heterogénea que en la cuestión anterior, existiendo una mayoría relativa, el 43,5\%, que reclaman que esas decisiones en última instancia las debe tomar la persona afectada; por su parte, casi 3 de cada 10 consideran que debería ser una especie de decisión colegiada entre personal médico, familia y persona enferma; 1 de cada 5 opina que debe ser una decisión tomada por el paciente junto a su familia, y; el 8,2\% se inhibe y hace dejación de su responsabilidad derivando la decisión en exclusiva al personal médico ${ }^{101}$. Heterogeneidad de opiniones que asimismo se manifiesta en varios momentos del grupo de discusión en los que, por un lado, se reconocen las capacidades técnicas del personal médico pero, por otro, se reivindica la autonomía del propio individuo o, si está inconsciente, de la familia, para decidir:

${ }^{101}$ En una pregunta similar del Estudio 2.803 del CIS (2009:8) se interrogaba, con otra redacción y sólo dos items de respuestas, sobre esta cuestión: si una persona mayor de edad padece una enfermedad muy grave con riesgo para su vida, es informada de ello y decide no someterse a tratamiento, “¿con cuál de estas opiniones está más de acuerdo?: a) Debe respetarse la decisión del paciente por encima de la del médico, 74,3\%; b) Debe respetarse la decisión del médico por encima de la del paciente. 18,8\%”. 
- “- Estamos hablando ya que cuando una persona de treinta o cuarenta años, ique le ponga lo que sea!, la esperanza es lo último que se pierde...

- Claro, por eso la última palabra la tienen que decir, lógicamente, los médicos.

- Efectivamente.

- Pero los médicos tienen la obligación o el deber de poner los remedios hasta que sea la familia o la propia persona misma la que tiene que decidir.

- Los cuidados paliativos, "te vamos a sedar para que estés más tranquilo”...

... - " tiene que ser un médico democrático para curar a las personas.. pero ahora trate, porque usted no es Dios y tendremos que morirnos, a ver si usted me lo hace lo más llevadero posible"” (GD1:21).

- “- El médico te tiene que decir: "mira, aquí ya no hay nada que hacer”.

- Exactamente. A tenor de...

- Y entonces en el informe médico... el médico no puede decidir, el médico te tiene que informar de la situación que es.

- Pero yo creo que una vez informada la familia por ejemplo que sea una madre y tenga tres hijos y dos estén a favor..

- Que haya discrepancias.

- ..Dos a favor y uno que no y empiecen ahí con la discrepancia.

- Pues entonces tendría que haber un consenso como en las decisiones políticas.

- Yo pienso que el equipo médico tendría que imponer su criterio.

... - Que un médico que venga y te diga: "hay esto señores. Pues si se acuerda todo. Hasta aquí hemos llegado y no podemos hacer más".

- Y si la familia se opone que los médicos puedan tomar una decisión.

- No pueden tomarla. Yo creo que lo médicos no pueden tomarla” (GD1:40).

Como en la cuestión anterior, no existe asociación por género pero sí por el resto de categorías sociales. En lo relativo a la edad, las personas más mayores se inhiben en mayor medida en la toma de la decisión, y son las que con más peso relativo dejarían tomar la decisión sólo al personal médico, el 11,1\%, o mejor, que fuera decidida entre éste y la familia, el 44,4\%; mientras que 3 de cada 10 ancianos, frente por ejemplo a 1 de cada 2 adultos, son partidarios de que sea el propio enfermo quien tome las decisiones. Así, entre las personas entrevistadas señalan las siguientes opiniones mediatizadas por diferentes circunstancias:

- "Creo que el médico, porque es la persona que más objetivamente se podría comportar, me tendría que explicar bien los pros y los contras de una u otra elección o las consecuencias que puede acarrear una decisión u otra. Pero yo creo que él no sería en una situación tan crítica (estando inconsciente) no debería ser él el que eligiera, aunque él pudiera aportar más información de qué puede ser lo mejor o no, pero dejar la decisión en los familiares” (E1:12).

- "Hombre, yo creo que primero la persona, siempre que esté en facultades de hacerlo, claro, porque si tiene todas sus facultades será consciente de lo que quiere, entonces, tiene que ser el que decida si quiere alargar su vida al máximo, si quiere acabar con ella, o cómo quiere que sea ese proceso. Claro, si la persona no es consciente, si es una enfermedad como el Alzheimer o degenerativa yo creo que son los familiares, porque los familiares son los que mejor conocen a esa persona y supongo que sabrán., serán los que más se acerquen al deseo de esa persona, siempre, claro, que respeten sus decisiones, porque, claro, eso nunca se sabe, porque si los familiares piensan de forma diferente, estás apañao, o alguien muy allegado que, claro, respetando las decisiones de esa persona. Yo creo que los especialistas serían los últimos en decidir porque es que es algo.., hombre, tendría 
que ser algo en conjunto pues primero plantear las perspectivas, pero una vez que se plantean tiene que ser el individuo el que decida" (E2:20).

- "Hombre, siempre la decisión la tiene que tomar uno mismo, ¿no? pero, claro en el momento que implicas a otro, la decisión tuya se la trasladas a otro, claro, y le creas un problemón al otro, es un problemón muy serio" (E4:19).

En cuanto al nivel de estudios, a medida que se tienen más estudios se reivindica mayor protagonismo para el propio enfermo o, en todo caso, que la decisión sea una decisión colegiada. Respecto a la distribución por religiosidad, se comprueba que aquellas personas menos religiosas, las incrédulas son las que en mayor medida, 6 de cada 10, opinan que las decisiones son individuales e intransferibles, es decir, que la persona enferma es la responsable, o la protagonista, de sus últimos momentos de vida; además, comparativamente con las otras tres categorías religiosas, otorgan un protagonismo más reducido no sólo al personal médico sino incluso a la propia familia. En el polo opuesto, el 33,1\% de las personas crédulas afirman que la decisión corresponde al propio paciente, pero otro porcentaje similar, el 33,8\%, consideran que deber ser una decisión consensuada entre todos los actores a una, mientras que casi 1 de cada 4 afirman que es un asunto entre la familia y el personal médico. CUADRO 5.44.: QUIÉN DEBE TOMAR LAS DECISIONES SOBRE LOS CUIDADOS
MÉDICOS EN EL FINAL DE LA VIDA DE UNA PERSONA ENFERMA (\%)

\begin{tabular}{|l|c|c|c|c|}
\hline & $\begin{array}{c}\text { Mejor dejárselo a } \\
\text { los médicos }\end{array}$ & $\begin{array}{c}\text { Los médicos deben } \\
\text { consultar con la } \\
\text { familia }\end{array}$ & $\begin{array}{c}\text { Los pacientes } \\
\text { tienen la última } \\
\text { palabra }\end{array}$ & $\begin{array}{c}\text { Todas las personas } \\
\text { implicadas }\end{array}$ \\
\hline \multicolumn{1}{|c|}{ TOTAL } & 8,2 & 20,4 & 43,5 & 27,9 \\
\hline HOMBRES & 9,6 & 19,3 & 44,6 & 26,5 \\
MUJERES & 7,2 & 21,2 & 42,8 & 28,8 \\
\hline JÓVENES & 5,2 & 12,9 & 44,8 & 23,4 \\
ADULTOS & 10,6 & 17,0 & 48,9 & 13,6 \\
ANCIANOS & 11,1 & 44,4 & 30,9 & 26,1 \\
\hline EST. BÁSICOS & 13,2 & 38,2 & 36,8 & 32,7 \\
EST. MEDIOS & 8,0 & 26,1 & 39,8 & 33,8 \\
EST. UNIVERS. & 6,9 & 13,8 & 46,5 & 29,4 \\
\hline CRÉDULOS & 9,5 & 23,6 & 33,1 & 24,7 \\
CREYENTES & 7,1 & 20,0 & 43,5 & 22,2 \\
NO CREYENTES & 8,2 & 15,3 & 51,8 & 60,3 \\
INCRÉDULOS & 7,9 & 9,5 & & \\
\hline
\end{tabular}

Fte: Encuesta 2000. Elaboración propia

En el Cuadro 5.45. se recoge la información estándar utilizada en las encuestas cuando se desea conocer la opinión respecto a los tipos de eutanasia legalizados y considerados como 
buenas prácticas médicas: eutanasia pasiva e indirecta. En el primer caso se solicitaba a la población encuestada su grado de acuerdo con que, no existiendo esperanza de curación de una persona enferma, se prolongara artificialmente la vida de la misma (pregunta 47), es decir, su valoración sobre el encarnizamiento terapéutico y la limitación terapéutica. En el segundo caso, se quería saber si estaban de acuerdo o no sobre la administración de medicamentos para calmar el dolor a una persona con una enfermedad incurable, aun cuando el tratamiento acortase la vida de esa persona (pregunta 48), es decir, sus actitudes hacia la sedación terminal.

La población encuestada se manifiesta mayoritariamente en contra del encarnizamiento terapéutico, el 71,5\%, no obstante, 1 de cada 10 son partidarias de la prolongación del tratamiento, y casi 1 de cada 5 se muestra indecisa ${ }^{102}$. Cabe especular con las razones por las que ese $10 \%$ de la población encuestada es partidaria de prolongar el tratamiento; por un lado, podría corresponder a una parte de los que en la muestra suscriben una concepción de santidad de la vida, aunque quizá también, por otro lado y como se ha aducido, sea el temor a una mala praxis médica en la que se sospechen intencionalidades eugenésicas. En la distribución de esta variable, no existe asociación con el género pero sí con la edad; así, casi 1 de cada 4 jóvenes no tienen opinión formada sobre ello, mientras que son precisamente los ancianos los menos indecisos y los que, por tanto, tienen más perfiladas sus opiniones, especialmente la de rechazo a la prolongación artificial de la vida. Rechazo detectado en todos los componentes del grupo de discusión, quienes manifiestan tener muy claro lo que en términos fisiológicos implica la muerte cerebral; no obstante, reconocen que podría suponer problemas de conciencia para las personas implicadas:

- “- Y verle allí con cincuenta aparatos.

- Yo pienso que una persona joven hasta última hora... yo creo que una persona que está ya en esas condiciones ¿cómo vas a alargarle la vida?

- Pero Goyo, si una persona joven está en muerte cerebral es como siendo mayor, es irrecuperable ya ¿por qué se la vas a alargar? ¿Por qué cumple veinte años o veintisiete?

- Todos los medios...

- Pero es que no hay medios. Hay que partir de la base de que no hay medios para recuperar una muerte cerebral...

- Sí, pero si tiene un problema de conciencia...

- Pero el problema de conciencia a lo mejor lo tienes que tener igual. Hay que poner un límite...

- Un problema de conciencia religioso...Dios lo prohíbe” (GD1:22).

${ }^{102}$ En el siguiente cuadro se recoge la comparación de los resultados de esta pregunta con las encuestas del CIS (1989) y CIS (2009):

\begin{tabular}{|c|c|c|}
\hline $\begin{array}{l}\text { NO CREEN QUE LOS MÉDICOS DEBAN PROLONGAR UNA VIDA SIN ESPERANZA DE } \\
\text { CURACIÓN ARTIFICIALMENTE (\%) }\end{array}$ \\
\hline CIS (1989) & ENCUESTA (2000) & CIS (2009) \\
\hline 58 & 71,5 & 81,2 \\
\hline
\end{tabular}


El nivel de estudios también está asociado con las opiniones sobre esta cuestión. Así, son las personas con estudios básicos las que se manifiestan más en contra de la prolongación artificial de la vida, más de 8 de cada 10, mientras que las que tienen estudios universitarios son las más indecisas, 1 de cada 5, y las más proclives al encarnizamiento terapéutico, el 11,9\%. Como a priori podía preverse, existe una asociación significativa con el nivel de religiosidad de tal forma que a medida que aumenta éste aumenta el peso relativo de las personas partidarias de la prolongación artificial de la vida. Obviamente, entre las personas religiosas que asumen los postulados de la Iglesia Católica, y en especial entre las crédulas, al ser la vida una concesión de Dios, su dueño, no cabe interrumpirla. De ahí que el 16,1\% de los crédulos sean partidarios de la prolongación artificial de la vida; sin embargo, quizá por la ambigüedad señalada respecto al tratamiento de la eutanasia en el Catecismo de la Iglesia Católica, incluso 2 de cada 3 crédulos se muestran partidarios de la interrupción del mismo. Por el contrario, a medida que las personas tienen menores niveles de religiosidad, es mayor el rechazo a la prolongación artificial de la vida, hasta el punto de que el 85,5\% de los incrédulos rechazan dicha prolongación. No deja de ser significativo asimismo que casi 1 de cada 4 personas creyentes o no creyentes manifiesten no tener opinión sobre el tema; aunque en todo caso, en esas dos categorías, como entre los crédulos, 2 de cada 3 se muestran partidarias de suspender los tratamientos inútiles. El adulto incrédulo entrevistado no tiene dudas en este sentido:

- "Yo estoy de acuerdo en que si una persona está irreversible totalmente, y los médicos creo que lo saben en un $98 \%$ de los casos, lo saben, yo estaría en que no se hiciera demasiado por alargar esa vida" (E4:19).

Respecto a la sedación terminal, la población encuestada es muy mayoritariamente favorable, casi 9 de cada 10, a la aplicación de los medios necesarios para reducir el dolor aunque ello tenga el doble efecto del acortamiento de la vida, mientras que el porcentaje de indecisos en esta cuestión se reduce respecto al encarnizamiento terapéutico, aunque todavía lo constituyen casi 1 de cada 10 personas encuestadas ${ }^{103}$. Se ha apuntado a que la reducción en el porcentaje de indecisos en este caso puede estar motivada porque al interrogar sobre el encarnizamiento terapéutico no se habla de dolor o de padecimiento físico de la persona, sino que se plantea simplemente el mantenimiento de la vida de un enfermo terminal (CIS, 1989:103). No existe asociación estadísticamente significativa con el género y el nivel de estudios, pero sí con la edad y sobre todo con la religiosidad. En el caso de la edad, la distribución de adultos y ancianos es similar y la única categoría discordante nuevamente son

${ }^{103}$ En el siguiente cuadro se recoge la comparación de los resultados de esta pregunta con las encuestas del CIS (1989) y CIS (2009):

PARTIDARIOS DE QUE LOS MÉDICOS ADMINISTREN DROGAS PARA CALMAR EL DOLOR A UN ENFERMO INCURABLE AUNQUE ACORTE SU VIDA (\%)

\begin{tabular}{|c|c|c} 
CIS (1989) & ENCUESTA (2000) & CIS (2009) \\
\hline
\end{tabular}

67

88,8

82,6 
los jóvenes, pero no tanto porque se opongan sino porque es mayor la proporción de indecisos, el 15,5\%. En lo relativo a la religiosidad, los datos muestran que el contraste entre las distintas categorías sociales no es lineal, sino que son las posiciones extremas, crédulos e incrédulos, las que tienen las opiniones más perfiladas y seguras, mientras que las dos categorías intermedias se muestran más indecisas. En cualquier caso, el dato más reseñable por sus implicaciones sociológicas y políticas es que entre las personas encuestadas más de 8 de cada 10 creyentes, el 83,7\%, y sobre todo más de nueve de cada 10 crédulas, el 93,1\%, se muestran favorables a la denominada eutanasia indirecta.

\begin{tabular}{|l|c|c|c|c|c|c|}
\hline \multicolumn{7}{|c|}{ CUADRO 5.45.: CONFORMIDAD O NO CON QUE... (\%) } \\
\hline & $\begin{array}{l}\text { el personal médico debe prolongar } \\
\text { artificialmente la vida de un enfermo, sea } \\
\text { cual sea su edad, cuando no existe } \\
\text { esperanza de curación }\end{array}$ & $\begin{array}{c}\text { el personal médico debe administrar } \\
\text { drogas para calmar el dolor a un } \\
\text { enfermo incurable, aunque acorte su } \\
\text { vida }\end{array}$ \\
\cline { 2 - 8 } & Sí & NO & NO SABE & Sí & NO & NO SABE \\
\hline \multicolumn{1}{|c|}{ TOTAL } & 10,8 & 71,5 & 17,7 & 88,8 & 1,9 & 9,2 \\
\hline HOMBRES & 10,8 & 70,5 & 18,7 & 86,1 & 3,0 & 10,8 \\
MUJERES & 10,7 & 72,2 & 17,1 & 90,7 & 1,2 & 8,1 \\
\hline JÓVENES & 12,2 & 64,8 & 23,0 & 82,5 & 2,1 & 15,5 \\
ADULTOS & 7,9 & 77,9 & 14,3 & 96,4 & 1,4 & 2,2 \\
ANCIANOS & 12,2 & 76,8 & 11,0 & 91,1 & 2,5 & 6,3 \\
\hline EST. BÁSICOS & 8,7 & 81,2 & 10,1 & 90,9 & 3,0 & 6,1 \\
EST. MEDIOS & 9,1 & 72,7 & 18,2 & 86,4 & 4,5 & 9,1 \\
EST. UNIVERS. & 11,9 & 68,6 & 19,5 & 89,1 & 0,8 & 10,1 \\
\hline CRÉDULOS & 16,1 & 67,1 & 16,8 & 93,1 & 2,1 & 4,8 \\
CREYENTES & 10,5 & 66,3 & 23,3 & 83,7 & 0,0 & 16,3 \\
NO CREYENTES & 8,2 & 68,2 & 23,5 & 83,5 & 4,7 & 11,8 \\
INCRÉDULOS & 4,8 & 85,5 & 9,7 & 90,3 & 1,6 & 8,1 \\
\hline
\end{tabular}

Fte: Encuesta 2000. Elaboración propia

En lo relativo a la eutanasia activa, es decir, a que los médicos suministren un producto que ponga fin a la vida de un enfermo incurable (pregunta 50), los resultados obtenidos varían según quién sea la(s) persona(s) que realice(n) la petición, Cuadro 5.46. Dado que mayoritariamente se rechaza que sea la familia quien haga la petición o que se tome según el criterio del personal médico, se centra el análisis cuando es la propia persona enferma quien hace la petición. En este caso, 2 de cada 3 encuestados se muestran partidarios de la eutanasia 
activa, el $16,5 \%$ se opone y el $15,3 \%$ se muestra indeciso ${ }^{104}$. No se observan diferencias significativas por sexo ni por nivel de estudios, pero sí por edad y religiosidad. En lo relativo a la edad, el porcentaje de indecisos es muy similar en las tres categorías, alrededor del 15-16\%, observándose un disenso notable entre jóvenes y ancianos en las posiciones a favor y en contra. Así, mientras más de 3 de cada 4 jóvenes se muestran partidarios de la eutanasia activa y sólo el $8,2 \%$ se oponen a ella, entre los ancianos son partidarios de la misma menos de la mitad y el $33,3 \%$ se muestra contrario. Respecto a la religiosidad, como al interrogarles sobre las eutanasias pasiva e indirecta, nuevamente son los incrédulos los que se muestran más partidarios de la eutanasia activa, siendo insignificante el porcentaje de éstos que la rechaza. Los mayores porcentajes de rechazo corresponden a los crédulos, el 31,3\%, aunque más de la mitad de ellos la apoyan. En alguna medida, esta disonancia respecto a la eutanasia activa entre los crédulos queda muy bien reflejada en el siguiente fragmento de la entrevista realizada a la mujer crédula, cuando comenta el suicido asistido de Ramón Sampedro:

- "V: Sí, eso me parece horrible. Es un dilema, el dilema de ver a alguien sufrir y es suicidarse o ayudar a matar. Yo si estuviera en su lugar también me querría morir y querría suicidarme.

E: ¿Pero entonces...?

V: No, pero eso no quiere decir que lo hiciera. Según la teoría de la iglesia católica es un pecado mortal atentar con la vida de uno, con lo cual se supone que si te suicidas después tendrías que ir al infierno. No lo sé, porque dicen que Dios es misericordioso a lo mejor en el último momento te arrepientes, si te has puesto una inyección o te has tomado lo que sea para morirte y en el último momento te arrepientes pero ya no lo evitas y quizás ahí Dios te perdona porque te has arrepentido, pero teóricamente no estaría bien” (E3:7).

${ }^{104}$ En el siguiente cuadro se recoge la comparación de los resultados de esta pregunta con las encuestas del CIS (1989) y CIS (2009):

\begin{tabular}{|c|c|c|}
\hline $\begin{array}{c}\text { PARTIDARIOS DE QUE LOS MÉDICOS ADMINISTREN DROGAS PARA ACABAR CON LA } \\
\text { VIDA DE UN ENFERMO INCURABLE SI ÉL LO PIDE (\%) }\end{array}$ \\
\hline CIS (1989) & ENCUESTA (2000) & CIS (2009) \\
\hline 60 & 68,5 & 80,5 \\
\hline
\end{tabular}




\begin{tabular}{|c|c|c|c|c|c|c|c|c|c|}
\hline & \multicolumn{3}{|c|}{ si el enfermo lo pide } & \multicolumn{3}{|c|}{ si lo pide la familia } & \multicolumn{3}{|c|}{$\begin{array}{c}\begin{array}{c}\text { si el médico lo considera } \\
\text { conveniente }\end{array} \\
\end{array}$} \\
\hline & sí & NO & $\begin{array}{l}\text { NO } \\
\text { SABE }\end{array}$ & Sí & NO & $\begin{array}{l}\text { NO } \\
\text { SABE }\end{array}$ & sí & NO & $\begin{array}{l}\text { NO } \\
\text { SABE }\end{array}$ \\
\hline TOTAL & 68,5 & 16,3 & 15,3 & 13,1 & 63,2 & 23,7 & 13,7 & 67,5 & 18,8 \\
\hline HOMBRES & 71,9 & 13,8 & 14,4 & 12,4 & 59,1 & 28,5 & 12,6 & 68,9 & 18,5 \\
\hline MUJERES & 66,3 & 17,9 & 15,8 & 13,5 & 66,0 & 20,5 & 14,5 & 66,5 & 19,0 \\
\hline JÓVENES & 76,5 & 8,2 & 15,3 & 12,6 & 61,0 & 26,4 & 11,0 & 69,2 & 19,8 \\
\hline ADULTOS & 66,7 & 19,3 & 14,1 & 15,2 & 67,6 & 17,1 & 17,5 & 70,9 & 11,5 \\
\hline ANCIANOS & 49,3 & 33,3 & 17,4 & 10,0 & 62,0 & 28,0 & 16,0 & 54,0 & 30,0 \\
\hline EST. BÁSICOS & 56,1 & 24,6 & 19,3 & 11,1 & 64,4 & 24,4 & 20,5 & 50,0 & 29,5 \\
\hline EST. MEDIOS & 66,3 & 19,1 & 14,6 & 9,1 & 68,2 & 22,7 & 16,9 & 72,3 & 10,8 \\
\hline EST. UNIVERS. & 72,0 & 13,4 & 14,6 & 14,6 & 61,5 & 23,9 & 11,5 & 69,5 & 19,0 \\
\hline CRÉDULOS & 51,4 & 31,3 & 17,4 & 12,6 & 70,9 & 16,5 & 15,2 & 70,4 & 14,4 \\
\hline CREYENTES & 70,9 & 11,6 & 17,4 & 13,2 & 55,3 & 31,6 & 11,7 & 62,3 & 26,0 \\
\hline NO CREYENTES & 80,5 & 6,1 & 13,4 & 7,2 & 58,0 & 34,8 & 11,8 & 67,6 & 20,3 \\
\hline INCRÉDULOS & 88,7 & 1,6 & 9,7 & 19,2 & 61,5 & 19,2 & 13,5 & 69,2 & 17,3 \\
\hline
\end{tabular}

Fte: Encuesta 2000. Elaboración propia

Por otra parte, la población encuestada reconoce el papel clave jugado por el personal médico en la ejecución de la eutanasia activa hasta el punto de que una gran mayoría, el 70,8\%, le exonera de cualquier responsabilidad legal y considera que no debe de ser castigado por ello, frente a un $11,5 \%$ que afirma que sí que debe serlo ${ }^{105}$ (pregunta 49), Cuadro 5.47. En la distribución de esta variable no existe asociación con el género pero sí con las otras tres variables de control. En el caso de la edad, el porcentaje de los que consideran que no se ha de penalizar al personal médico supera la mitad en las tres categorías, si bien en el caso de los ancianos por un margen muy estrecho; de hecho, 1 de cada 5 ancianos es partidario de que sí reciban un castigo, frente alrededor del 10\% en adultos y jóvenes. Una distribución similar a la de edad, pero más atenuada, es la correspondiente al nivel de estudios en la que también son poco más de la mitad de los que tienen niveles básicos los que rechazan el castigo a los médicos, y sobre todo casi 1 de cada 3 de integrantes de esa categoría se muestra indeciso. En la distribución por nivel de religiosidad se observa la incidencia de la ideología religiosa en la

${ }^{105}$ En el siguiente cuadro se recoge la comparación de los resultados de esta pregunta con las encuestas del CIS (1989) y CIS (2009):

\begin{tabular}{|c|c|c|}
\hline $\begin{array}{l}\text { (\%) DE PARTIDARIOS DE QUE NO SE CASTIGUE A LOS MÉDICOS QUE ADMINISTRAN } \\
\text { DROGAS PARA ACABAR CON LA VIDA DE UN ENFERMO INCURABLE SI ÉL LO PIDE }\end{array}$ \\
\hline CIS (1989) & ESTE TRABAJO (2000) & CIS (2009) \\
\hline 66 & 70,8 & 75,7 \\
\hline
\end{tabular}


categoría de los crédulos quienes, aunque más de la mitad no son partidarios del castigo a los médicos, el 23\%, el dato más elevado de todas las categorías, sí que suscriben la aplicación del mismo. Dos ejemplos de actitudes diferentes respecto a la penalización o no de la persona que ayude a morir a otra son, primero, la contundencia en su repuesta del adulto incrédulo y, segundo, la indecisión que se observa en la secuencia de la entrevista al joven varón creyente quien al plantearle la cuestión inicialmente de forma abstracta, impersonal, duda en la respuesta, pero cuando, a continuación, se le recuerda el nombre de Ramón Sampedro no sólo se muestra partidario de la no persecución a la persona que le ayudó a morir, sino que incluso expone las dudas existenciales que sobre sus propias convicciones católicas le provoca ese tipo de situaciones:

- “No, no, en absoluto, condenar a nadie, no, ningún organismo oficial tiene derecho a nada de eso... No estoy de acuerdo, yo en cuanto a la ley, no estoy de acuerdo salvo en el caso de que el uno no quiere y el otro sí, y te le mandas para el otro barrio, por supuesto. Pero, en el caso de que te lo pida y llega el otro y le ayude, la cosa está entre dos personas, nada más, y si están de acuerdo los dos, nada que objetar, y desde luego la ley no es quien para tomar ningún tipo de medidas... No, la ley no tiene ningún derecho a meterse ahí, yo creo que las leyes no tienen ningún derecho a opinar sobre ese tema" (E4:21).

- "Es que no sé, el médico está para salvar vidas, pero ¿esa vida es salvable? ¿Sirve de algo otro tratamiento? Prolongar una enfermedad de esa manera... El destino muchas veces tiene esas cosas y claro, ¿es ético mantener a esa persona en esa situación porque los avances, la medicina y los sanitarios, permitan tenerla en esa situación? Si esa persona nace en otro país en que no hay esos tratamientos, moriría. En una sociedad como la nuestra hay tratamientos para prolongar la vida y para dejarle que muera. Yo aquí tengo mis dudas, no sabría decir pues sí o no" (E1:13).

- "Pues es difícil, quizás ahí si hay justicia tampoco es justo dejar a una persona así, porque la persona se encuentra, me imagino, desamparada. Y si hay justicia, ésta no tiene que perseguir a quien le haya ayudado a morir y fue así como sucedió. Creo que la justicia tiene que ser justa y no perseguir a las personas, personas de buena fe. Aunque eligiera morir, creo que cualquier persona lo que quiere es vivir, y si eliges morir de esa manera e incluso pedir ayuda para morir es que se tienen que ver muy mal. Que se puede hacer de cierta manera que no sea tan evidente que esa persona le ha ayudado. Es que no sé, si existe Dios ¿por qué tiene que haber esas situaciones? ¿Por qué tiene que hacer a esa gente vivir así? Pero no me parecería justo que a la persona que le ha ayudado a morir... yo a esa persona no la veo como un asesino" (E1:13). 
CUADRO 5.47.: CONFORMIDAD O NO CON QUE SE CASTIGUE A LOS MÉDICOS QUE ADMINISTREN ALGÚN PRODUCTO PARA PONER FIN A LA VIDA DE UN ENFERMO INCURABLE, SI ÉSTE SE LO PIDE (\%)

\begin{tabular}{|l|c|c|c|}
\hline & SÍ & NO & NO SABE \\
\hline \multicolumn{1}{|c|}{ TOTAL } & 11,5 & 70,8 & 17,7 \\
\hline HOMBRES & 13,2 & 74,8 & 11,9 \\
MUJERES & 10,3 & 68,2 & 21,5 \\
\hline JÓVENES & 7,9 & 74,3 & 17,8 \\
ADULTOS & 11,8 & 76,5 & 11,8 \\
ANCIANOS & 20,3 & 51,4 & 17,7 \\
\hline EST. BÁSICOS & 13,6 & 54,5 & 31,8 \\
EST. MEDIOS & 11,1 & 77,8 & 11,1 \\
EST. UNIVERS. & 11,0 & 72,8 & 16,1 \\
\hline CRÉDULOS & 23,0 & 56,1 & 20,9 \\
CREYENTES & 3,6 & 75,9 & 20,5 \\
NO CREYENTES & 6,0 & 79,8 & 14,3 \\
INCRÉDULOS & 4,9 & 88,5 & 6,6 \\
\hline
\end{tabular}

Fte: Encuesta 2000. Elaboración propia

Finalmente, se interrogó a la población encuestada sobre cuál sería su actuación, no en abstracto, sino en una situación concreta y cercana, dramática en sí misma, cuando a la enfermedad incurable de un familiar próximo se añade la tensión de la solicitud por parte de éste de ayuda personal para morir (pregunta51), Cuadro 5.48. En este caso, los datos recabados muestran que las personas encuestadas se enfrentan a una situación insostenible para la que no tienen recursos que ofrecer y en su mayoría no sabrían que hacer, el 62\%. Por su parte, 1 de cada 5 le ayudaría personalmente como fuere, y un 6,6\% pediría que un médico le ayudara a morir. Algo más de 1 de cada 10, el 11,9\%, se opondría a cualquier medida que acelerase el proceso $^{106}$. Se detectan asociaciones significativas por género, edad y religiosidad, no por nivel de estudios. Entre géneros, las diferencias más relevantes se observan en que los hombres estarían mucho más dispuestos a complacer los deseos del familiar que las mujeres, 26,4\% frente a 14,9\%, quienes se muestran mucho más perplejas por la situación, 2 de cada 3 frente al $56,4 \%$ de los hombres. Por edad, la indecisión vuelve a ser mayoritaria entre los jóvenes, 2 de cada 3 no saben qué harían, aunque esa actitud es mayoritaria en todos los grupos de edad; por su parte, los ancianos son los que más se opondrían a cualquier final anticipado, 1 de cada 4. En casi esa proporción, los adultos son los que más complacerían al familiar enfermo. La

\footnotetext{
${ }^{106}$ En una pregunta similar del Estudio 2.803 del CIS (2009:14) se interrogaba sobre cuál sería el comportamiento de la persona entrevistada ante una petición reiterada de ayuda a morir por parte de un familiar cercano: el 21,4\% aseguraba con rotundidad que contribuiría personalmente a adelantar el final de la vida, y otro 21,4\% también respondía afirmativamente pero con dudas.
} 
religiosidad de las personas encuestadas también condiciona la distribución de las distintas actitudes en este caso. En efecto, se puede comprobar que cuanto mayor es el grado de religiosidad mayor es la oposición a buscar atajos, haciendo bueno el precepto católico de que hay que sufrir para ganarse el cielo. Los incrédulos, por su parte, son la categoría social que tiene más claras sus actitudes ante ese dilema, no sólo son la única categoría en la que menos de la mitad están indecisos ante la situación, sino que son los que en mayor medida, directamente o a través de la ayuda de un médico, complacerían al enfermo, el 49,2\%. La indecisión ante la situación hipotética planteada se constata en los siguientes fragmentos de las entrevistas realizadas, indecisión motivada en todos los casos por la disonancia entre la lógica y el deseo, la racionalidad y la emoción:

- “... al fin y al cabo si esa persona te está diciendo que hagas eso por él tiene que encontrarse en una situación, digamos, que sin vuelta de hoja, digamos que sería la única salida. Si fuera una situación como la de este hombre, Sanpedro, pues, yo creo que mi consciencia aunque no me permitiera hacer eso, igual en esa situación me dejaría llevar. La verdad es que esa sería una de las decisiones más difíciles que le puede tocar a una persona" (E1:13).

- "Yo, sí, claro, me pongo en el lugar de que yo fuera la persona afectada, claro. Si me lo pidieran a mí, que fuera yo la persona que se lo administrara, ya se me plantearían más dudas, sobre todo si es alguien muy allegado. Yo, egoístamente, desde mi punto de vista de que yo fuera el afectado, sí estaría de acuerdo, claro. Ya ahí sería muy difícil a quién eliges para... Hombre, yo ahora mismo digo que sí, claro, pero hay que estar en la situación, es que ese tema es muy delicado, es como el aborto, puedes estar a favor o en contra, pero hasta que no se te plantea en tus propia carnes no sabes lo que harías, porque no es un hecho aislado, tiene consecuencias, y entonces.., hombre, yo ahora mismo te diría que sí, pero a lo mejor dependiendo luego de quién fuera cambiaba de opinión, por las consecuencias que te puede traer y todo..” (E2:21).

No obstante, la mayor indecisión entre las personas entrevistadas se observó en el varón incrédulo quien, dada su concepción de la vida como única posesión y certeza, y el papel esencial jugado en ella por su familia más cercana, no puede evitar en última instancia olvidarse de la demanda solicitada y apurar su propio deseo, como se observa en dos fragmentos de la entrevista:

- "Yo creo que nadie sabe qué haría, digo, fuera de ese problema nadie puede contestar a no ser una persona que tuviera las ideas muy claras, que yo no tengo, sabría qué hacer en ese momento, no lo sé, es algo tan.. a mi me parece tan.. tan brutal en un momento determinado, no lo sé, no sabría qué hacer... diría "pues nada, este hombre que viva lo mejor lo que le queda", pero claro, en el caso de un hijo, la situación es totalmente distinta... Bueno, sí, creo que intentaría por todos los medios que mi hija no sufriera" (E4:20).

- "(en el caso de la demanda de ayuda por una hija) En ese caso, no, no quisiera que se muriera mi hija, aunque respetaría... Que estuviera en la cama... Ya, pero la tienes, leche, la tienes, posiblemente estaría pegándome con ella todo el día de que no se muriese, pero, claro, vuelvo a decirlo, las situaciones no son las mismas... Pero, claro, tú no la estás viendo en una situación que esté sufriendo 
físicamente, a lo mejor está sufriendo.., intentarías por todos los medios que no estuviera.., es que son situaciones muy complicadas y muy serias, y tampoco, en un momento determinado, ahora, así de una manera fría puedes opinar muy convencido de lo que estás diciendo, son.., es que es distinto por completo, no habrá nadie que te pueda contestar, creo que no, fríamente es muy difícil, no, no puedo contestar a eso, porque no estoy en la situación y porque son situaciones muy distinta" (E4:23).

CUADRO 5.48.: SI UN FAMILIAR CON UNA ENFERMEDAD INCURABLE LE MANIFESTASE SU DESEO DE MORIR... (\%)

\begin{tabular}{|l|c|c|c|c|}
\hline & $\begin{array}{c}\text { se opondría a } \\
\text { acelerar su muerte }\end{array}$ & $\begin{array}{c}\text { pediría a un } \\
\text { médico que le } \\
\text { ayudara a morir }\end{array}$ & $\begin{array}{c}\text { le complacería } \\
\text { como pudiera }\end{array}$ & no sé que haría \\
\hline \multicolumn{1}{|c|}{ TOTAL } & 11,9 & 6,6 & 19,5 & 62,0 \\
\hline HOMBRES & 11,0 & 6,1 & 26,4 & 56,4 \\
MUJERES & 12,5 & 6,9 & 14,9 & 65,7 \\
\hline JÓVENES & 7,7 & 6,1 & 18,9 & 67,3 \\
ADULTOS & 10,2 & 8,0 & 23,4 & 58,4 \\
ANCIANOS & 25,6 & 5,1 & 14,1 & 62,5 \\
\hline EST. BÁSICOS & 20,0 & 1,5 & 23,1 & 63,6 \\
EST. MEDIOS & 10,2 & 10,2 & 17,0 & 63,4 \\
EST. UNIVERS. & 10,5 & 6,6 & 19,4 & 73,3 \\
\hline CRÉDULOS & 19,3 & 4,1 & 13,1 & 64,7 \\
CREYENTES & 7,0 & 3,5 & 16,3 & 44,4 \\
NO CREYENTES & 5,9 & 8,2 & 21,2 & 33,3 \\
INCRÉDULOS & 6,3 & 15,9 & & \\
\hline
\end{tabular}

Fte: Encuesta 2000. Elaboración propia

En resumen, se constata que entre la mayoría de la población encuestada para este trabajo existe una posición claramente favorable a la eutanasia activa y al suicidio asistido. Ambos procesos además han de estar medicalizados, por ello se requiere la legalización de los mismos con el fin de evitar consecuencias penales al personal médico que los realizara. Cabe complementar estos resultados con algunos de los datos más significativos que en la misma dirección se han obtenido en el Estudio 2.803, Atención a pacientes con enfermedades en fase terminal, del CIS (2009). Así, por ejemplo, entre las personas encuestadas:

- El 77,3\% está muy o bastante de acuerdo con que cada "persona es dueña de su propia vida y de elegir cuándo y cómo quiere morir” (2009:12).

- El 50,1\% sabe que existe en la actualidad alguna ley en España que regula los derechos y deberes de los pacientes (2009:7).

- El 73,6\% opina que debería regularse por Ley la eutanasia y el 52,7\% el suicidio asistido (2009:19). 
- El 50,9\% es partidaria de la legalización del suicidio asistido médicamente para el caso de una persona que tiene una enfermedad en fase terminal que le causa grandes sufrimientos y de la que morirá en poco tiempo (2009:13).

- El 46,7\% considera que la razón más importante para que una persona enferma solicite ayuda para morir es sentir un dolor físico insoportable; el 19,5\% cree que es la situación de dependencia para satisfacer las necesidades más básicas; el 11,9\%, la perdida de autonomía y libertad como persona; y el 10,9\% el sentirse una carga para la familia. (2009:13).

- El 33,1\% cree sí que debería castigarse a un médico que practica el encarnizamiento terapéutico, por contra, el 52,0\% se opone al castigo en ese caso (2009:15).

- El 47,6\% considera que al sistema sanitario público le faltan algunos medios o no los tiene para realizar la labor de cuidados paliativos (2009:9).

El hecho de que ninguna de las personas encuestadas, entrevistadas o de las que han formado parte del grupo de discusión haya vivido recientemente, en algunos de los casos nunca, una experiencia próxima, directa o indirecta, en la que una persona conocida padeciera una enfermedad incurable en fase terminal determina la conformación de los discursos sociales sobre la eutanasia obtenidos. La ausencia de esta experiencia vital, y de la del conexo enfrentamiento al dilema petición/aplicación de la eutanasia, se concreta ciertamente en una visión limitada en este ámbito por parte de las personas encuestadas y entrevistadas, pero ello no es menoscabo para que se minusvaloren sus opiniones comparándolas con las de las personas que están próximas a la muerte y sobre todo con las del personal médico. Al contrario, como ocurre en otros ámbitos de la vida pública, por ejemplo con el terrorismo en sus múltiples vertientes, o con situaciones conflictivas de toda índole -robos, accidentes laborales, de tráfico, etc.-, no parece adecuado legislar tomando en consideración sólo las opiniones de las víctimas, o haciéndolo ad hoc a medida que se suceden los casos, como tampoco parece adecuado fiarlo todo a las soluciones técnicas del personal experto. Por todo ello, se valora en la parte final de este sub-apartado el peso social de los discursos sobre la eutanasia obtenidos ubicándolos, primero, en el contexto general de las distintas concepciones de la muerte presentes en las sociedades más desarrolladas en la actualidad, para a continuación, situarlos en el marco ideológico del continuo <<integrista-progresista >> extraído de otras investigaciones más amplias en las que se han implementado varios grupos de discusión ${ }^{107}$.

En este sentido, al margen del reconocimiento de la importancia que para cada una de las personas participantes pueda tener la religión en ese ámbito, los rasgos del discurso sobre la

\footnotetext{
${ }^{107}$ Agradezco en este punto el material facilitado por el profesor Javier Callejo, producido en el curso de Postgrado "Praxis de la Sociología del Consumo. Teoría y práctica de la investigación de mercados. 1992-1993”, en especial el trabajo presentado por Ana Muro Pascual, que ha sido la base fundamental y necesaria para poder construir la Tabla 5.3.
} 
muerte dominante se corresponden prácticamente en su totalidad con las características del modelo Muerte Moderna arriba referidas. Incluso en la mujer crédula entrevistada se aprecia la importancia otorgada a efectos prácticos al personal médico, más allá de su concepción teocrática de la vida y de la muerte (Muerte Tradicional). En el otro extremo, la reivindicación de la autonomía de la persona como fuente de derecho irrenunciable frente a la vida y la muerte, manifestada por el varón incrédulo y algunos de los componentes del grupo de discusión, que deja traslucir tímidamente alguna de las características esenciales del incipiente y minoritario modelo de Muerte Neo-moderna, no oculta que esas mismas personas reconozcan el papel esencial jugado por el personal médico en todo lo referido a las últimas horas de la vida de una persona.

Por otra parte, en los análisis realizados en otras investigaciones se observa la existencia de cuatro posiciones ideológicas básicas respecto a la eutanasia. Puntos de vista que se mueven entre las dos posiciones extremas, Integrista y Permisivo-Progresista, mucho más definidas y con las ideas más claras, y las dos posiciones centrales, Conservadora y Pragmático-Tolerante, con perfiles llenos de dudas y permeabilidad entre ellas. En todos ellos se observa cierta desinformación sobre la situación legal de la cuestión. Hay que tener en cuenta en este sentido la fechas de realización del trabajo de campo, alrededor del año 2000, cinco años después de la despenalización de la eutanasia pasiva, dato que desconocían buena parte de las personas encuestadas o entrevistadas.

En la Tabla 5.3. se recogen las características básicas de esas posiciones ideológicas en relación a la eutanasia (pasiva y activa), a su legalización, así como al suicidio asistido. El grupo de Integristas estaría conformado por el "núcleo duro" de los crédulos, los que asumen en su integridad el argumento de la santidad de vida, por lo que tienen una concepción de la naturaleza como plan divino en el que los seres humanos no tienen ningún derecho a interferir. Así, y al igual que con el aborto, no cabe legalizar la eutanasia ya que es una violación de las "leyes de la naturaleza”, es decir, un crimen contra ésta y un desafío a Dios. No obstante el dominio esencial que en este grupo tiene la autoridad tradicional religiosa, es obvio que ello no les lleva a repudiar a la autoridad médica moderna para los problemas de salud terrenales, lo que significa que en alguna medida el modelo moderno de muerte está presente en su concepción de la vida y de la muerte.

El grupo de Conservadores estaría conformado por el resto de los crédulos y aquella parte de los creyentes que suscriben el argumento del derecho a la vida, es decir, aquellos para los que la vida es un "don" otorgado y por ello hay que conducirse en la misma con responsabilidad. Esto no significa que la doten de un carácter absoluto, sino que asumen que 
puede haber determinadas situaciones en las que sea muy difícil querer seguir viviendo, especialmente en las situaciones límites e irreversibles próximas a la muerte. Situaciones en las que, obviamente, juega un papel esencial la autoridad del personal médico (Muerte Moderna). Por ello, para evitar el encarnizamiento terapéutico, son partidarios de la interrupción de los procedimientos que prolongan la vida artificialmente; asimismo, para no prolongar situaciones irreversibles no controladas con cuidados paliativos son también partidarios de la sedación terminal. No obstante, la legalización de la eutanasia pasiva habría de hacerse con una regulación estricta que evitase problemas de todo tipo a pacientes y médicos; por un lado, limitando su aplicación exclusivamente a pacientes terminales y, por otro, extremando todos los controles de la práctica médica para así eliminar la posibilidad de imposición de su criterio por parte de personal médico integrista o permisivo. En este grupo, como en el de los pragmáticotolerantes y en parte del permisivo-progresista, se observan muchas dudas sobre la eutanasia, en especial las que surgen al ser conscientes de que no es lo mismo opinar fuera de situación, aunque se tengan unas actitudes muy asentadas al respecto, que estando en ella viviendo el problema. Dudas que se manifiestan de forma diáfana y concreta en la comprensión mostrada incluso con el suicidio asistido de Ramón Sampedro.

Por su parte, en el grupo de Pragmático-Tolerantes se ubicarían parte de los creyentes y otra parte de los no creyentes. Comparten con los componentes del grupo anterior algunas características, entre ellas su desconcierto e indecisión si se tuvieran que enfrentar a una situación real de petición/aplicación de la eutanasia, dada la complejidad, sobre todo de sentimientos, con que perciben la gestión de la misma. Las diferencias más importantes respecto a los conservadores devienen de la primacía que otorgan al propio individuo en la toma con libertad de las decisiones que afecten al final de su vida (argumento de la calidad de vida). Consideran que deben de regular la eutanasia pasiva pero también la activa ya que lo esencial es evitar que las personas mueran con dolor y sufrimiento, es decir, son partidarios de extender la eutanasia a otros pacientes y no sólo a los enfermos terminales e irreversibles. No obstante, dado que la aplicación de la eutanasia implica necesariamente la participación de un "otro" con conocimientos médicos, y que este otro tiene sus propios valores que en determinadas circunstancias podrían hacerle inhibirse de participar, consideran que la eutanasia no tendría que aplicarse en todas las situaciones sino sólo en aquellas que fueran acordes a un protocolo objetivo de actuación legalmente establecido. Es decir, se trataría de evitar peticiones arbitrarias o caprichosas de la eutanasia que provocaran el rechazo moral por parte de la mayoría del personal médico.

Por último, el cuarto grupo, los Permisivo-Progresistas, está formado por los incrédulos y el resto de los no creyentes. Son partidarios del argumento de la autonomía de la 
persona, es decir, consideran la libertad personal e individual por encima de todo. Sin embargo, aunque una parte de ellos dotan a esa libertad de un carácter absoluto y por tanto no sujeta a leyes, también en lo relativo a la propia muerte (muerte neomoderna), otra parte de ellos, y por razones prácticas obvias, mantienen además una concepción moderna de la muerte en la que el personal médico juega un papel esencial también en los momentos finales de la vida. Son partidarios de la legalización de la eutanasia activa y del suicidio asistido para poder satisfacer todas las peticiones de ayuda a morir dignamente, independientemente de las características objetivas o subjetivas que definan su situación. Basta con que la persona lo quiera y lo pida. En definitiva, para ellos la eutanasia es una llave para la liberación. Tal como lo perciben algunos de los componentes del grupo de discusión:

- “- A quién le importa la muerte es a los familiares que quedan, que lo sufren. El que se muere, pues sí, pero ya no siente nada.

- Según casos. Porque por eso es morir con dignidad. Y ¿qué es morir con dignidad? Daos cuenta, por ejemplo ponemos la cantidad de sacrificios que hemos hecho cuando han estado enfermos, y te quieren entrañablemente pero cuando llegas a la vejez y empiezas a decaer y ya necesitas una atención continua, los mismos que te han querido y has querido están deseando que te mueras. Están pensando ¿cuándo se muere?..

- Están hartos

- ..Y para mí esa es la dignidad de la muerte, Cuando ya ha llegado ese momento que no debe llegar nunca pues mejor desaparecer. Y eso es para mí morir con dignidad. Porque lo otro, los propios feudos, los que te quieren, los que te han amado están esperando que te mueras. ¿Cuándo se va este hombre o esta mujer? Eso es muy normal..

- Yo he visto casos de enfermedades largas y dolorosas que termina la familia agotada.

-..Y yo no quisiera...

- Ildefonso, tú propones que sea como lo elefantes que se marchan a un cementerio cuando piensan que van a morirse.

- ..No, pero para eso es el caso éste, la eutanasia.

- Efectivamente. Que presienten que se acaba ya el ciclo y se retiran.

- Exactamente, con dignidad, sabiendo salir" (GD1:18-19). 
TABLA 5.3.: POSICIONES IDEOLÓGICAS BÁSICAS RESPECTO A LA LEGALIZACIÓN DE LA EUTANASIA ACTIVA

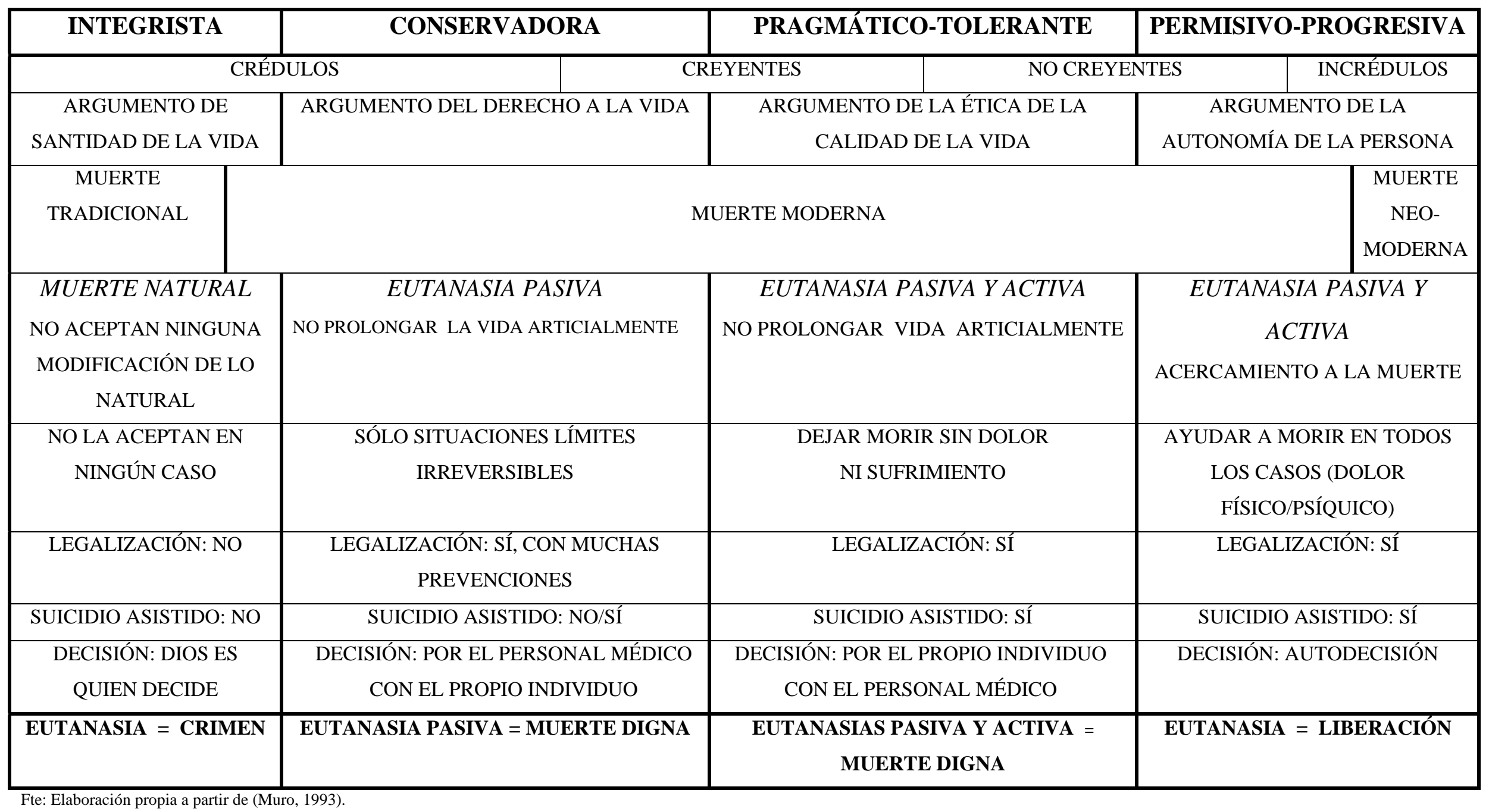


El análisis empírico de la Muerte Vivida confirma que en el caso de la población examinada el modelo de muerte dominante es el de Muerte Moderna, con el imperio del discurso médico sobre todos los demás. No obstante, se constata la persistencia, sobre todo entre la población de más edad, de residuos del modelo de Muerte Tradicional, a la par que se aprecia brotes puntuales y localizados en algunos estratos concretos de la población de pautas que se corresponden a las características del modelo de Muerte Neo-Moderno. Asimismo, no parece que la muerte constituya un tabú para la mayoría de la población analizada, sino que más bien se la mantiene alejada para que no perturbe el desarrollo de la vida diaria, como se comprueba en el siguiente extracto del verbatim del grupo de discusión:

“- Os cuento el cuento de la muerte: un pastor, un pastor joven que está en el campo con las ovejas y se le aparece la muerte y le dice: "Vengo a buscarte". "¡Ay, que es muy pronto!, deja pasar unos años”. Y dice la muerte: "Bueno, te dejaré pasar unos años". "Pero antes avísame para estar yo preparado", dice el pastor. "Bueno, si quieres que te avise, te avisaré". Y pasan los años, pasan los años y cuando ya es mayor y la muerte le dice: "Ya estoy aquí". El pastor le comenta: "Hicimos un pacto y tú me tenías que avisar cuándo vendrías a por mí". Y la muerte le dice: "Es que te he avisado... El pelo no lo tienes, los dientes no los tienes, andas con un bastón... Todas esas señales son las que te he estado enviando para que supieras que iba a llegar".

- Exacto.

- La primera dentadura, la segunda, el sonotone...

- Que pareces un hombre como un mecano.

- Mi consuegra como está tan deprimida dice: "es que tengo arrugas". Y le digo: "coño, con setenta años ¿qué quieres tener? Vete haciéndote a la idea que las gafas... estamos con la segunda dentadura, a punto del sonotone..."

- Esos son los avisos.

- Pues claro, y hay que llevarlos con alegría...” (GD1:48). 

CONCLUSIONES 



\section{CONCLUSIONES}

“Que los amigos aplaudan. La comedia se ha acabado”

L. van Beethoven

El análisis sobre la construcción social de la muerte en la sociedad española actual, realizado a través de los discursos de la muerte, la "muerte sufrida" y la "muerte vivida", confirma la hipótesis central de partida de la investigación desarrollada: la preeminencia del modelo de Muerte Moderna, sobre cualquier otro. Es decir, la hegemonía del discurso médico sobre la muerte, su `secuestro' o reclusión en espacios reservados, junto al predominio de actitudes individuales hacia la muerte dominadas por actitudes de denegación: negación consciente y rechazo emocional. Escenario general que corrobora la centralidad de la muerte en la vida social actual, en la que constituye un fenómeno social total paradójicamente a pesar de su ocultamiento. Escenario del que se pueden extraer numerosas conclusiones parciales, como se detalla a continuación siguiendo el esquema de los cinco objetivos secundarios propuestos en la investigación:

A) Identificación de los componentes básicos de la construcción social de la Muerte en el contexto de las sociedades occidentales:

La revisión teórica realizada ha identificado el aparato conceptual básico sobre el que asentar el análisis sociológico de la muerte. Una vez constatado que ésta es una construcción social que va más allá del mero proceso biológico hasta encubrirlo con mitos sobre su contingencia, y que su influencia es determinante en la propia construcción de la sociedad, en esencia, ese análisis puede quedar definido por:

$1^{\circ}$ ) Si bien cabe formular múltiples enunciados sobre la vida del ser humano, no cabe plantear ninguno concreto sobre su muerte. La grieta absoluta que ésta abre impide cualquier tipo de experiencia sobre ella, por lo que el ser humano no sabe lo que es estar muerto. Como no se vive la muerte, no existe un conocimiento cierto, racional y radical sobre ella. Así, la idea de la propia muerte propiamente dicha es una idea sin contenido. La muerte es inefable.

$2^{\circ}$ ) Esto no significa que el ser humano no haya aprehendido nada sobre la muerte. La experiencia vicaria de la muerte ajena le enseña que también es mortal, le permite de alguna forma 'anticipar' que su vida tarde o temprano cesará, que debe morir. No obstante, ese morir, acontecimiento biológico que les ocurre a todos los organismos desde que nacen, no puede equipararse al morirse, a la propia experiencia individual e intransferible de ese acontecimiento 
por parte del sujeto. En este sentido, la muerte no es un concepto objetual, sino relacional, en tanto que no puede concebirse sin su opuesto, la vida: al saber que va a morir la vida del ser humano queda cualificada por la muerte futura; en cuanto que vive, todavía no ha muerto, pero ya es mortal. Así, el ser humano sabe 'qué es estar muriendo' y al enfrentarse a ese morir construye la muerte.

$3^{\circ}$ ) De la emergencia de la conciencia humana de la muerte brota antropológicamente la conciencia. Más allá de su función profiláctica, el inicio de los enterramientos buscaba asegurar la desaparición de los muertos y conjurar la amenaza que comportaban, lo que denota la existencia de unas creencias en un más allá en el que los individuos sobrevivirían después de muertos. Así, la irrupción de la muerte entre los antepasados del ser humano conllevó el desarrollo de una capacidad autoconsciente de reflexión sobre la vida, la muerte y el mundo, y también propició la reflexión sobre sí mismo. La toma de conciencia de la muerte acompaña a la individualización humana, entendida ésta como constitución de individualidades singulares.

$4^{\circ}$ ) Al hecho antropológico de ser mortal y de saberse mortal se le une de forma indisociable otro hecho antropológico indiscutible: al ser humano le resulta insoportable el pensamiento de que va a morir. Como la muerte constituye la disolución absoluta e irremediable de su conciencia, su extinción completa, le horroriza, ya que supone el fin de su individualidad.

$5^{\circ}$ ) Paradójicamente, al imponer la muerte al ser humano la conciencia traumática de la finitud de sus vidas, le empuja a la acción y a la elección entre diferentes posibilidades, es decir, da significado a su vida: al fijar un límite a la existencia humana, instaura una discontinuidad, instituye el tiempo, confiere un lugar y un sentido a cada instante de vida, da unicidad a cada acto, lo que en la duración social indistinta distingue y otorga significado a cada vida: la muerte instaura la libertad. Sin ese límite el ser humano estaría disuelto en la indiferencia.

$\left.6^{\circ}\right)$ La muerte tiene la virtualidad inmediata de desvelar la interconexión de la vida social, el juego de las dependencias mutuas que mediatiza las elecciones y permite a los individuos construir su identidad, porque con suma potencia muestra no sólo la contingencia de las cosas, sino la de los propios individuos. Así, la muerte deja ver a éstos que su vida no les pertenece completamente pero que, sin embargo, se vuelve suya en la medida en que la comparten. Revelación paradójica, a la par de dependencia y de libertad: el ser humano es un ser estructuralmente social, obtiene la personalidad de los otros y sólo puede ser persona en tanto que es libre para comprometerse con ellos. Por todo ello, aunque la muerte no está inscrita en la necesidad de la conciencia aparece para ésta como una necesidad de tipo existencial. 
$7^{\circ}$ ) Por otra parte, la emergencia de la conciencia humana de la muerte supuso un salto cualitativo en el conocimiento consciente del homo sapiens, que vino acompañado de un creciente grado de su complejidad. Al ser la muerte un tránsito de una realidad a otra provocó la emergencia de nuevas formas de percepción de la realidad -lo imaginario- y que se desarrollaran nuevas visiones del mundo -el mito-, que "se convertirán a un mismo tiempo en productos y coproductores del destino humano". Es decir, por primera vez en la historia coexistía en el pensamiento de los antepasados del homo sapiens sapiens la dualidad objeto/sujeto, fruto de la brecha abierta en su conciencia por la muerte. Brecha antropológica indicativa de que desde ese estadio el homo sapiens se disocia de su destino natural (la especie) y de que entra en un nuevo desarrollo de la individualidad caracterizado por el impulso de la autoconciencia y el fortalecimiento de las relaciones sociales como respuesta a la propia mortalidad. Brecha de la que germinan todas las culturas en el intento de integrar la idea de la muerte, elaborando para ello todo tipo de mitos sobre su contingencia. Así, la muerte humana dimana de la cultura tanto como de la naturaleza.

$8^{\circ}$ ) Entre los mitos de la contingencia de la muerte existe uno especialmente extendido en la mayoría de las culturas: la creencia en la inmortalidad. Creencia por la que los individuos reaccionan frente a la muerte que provoca su disolución afirmándose como seres supervivientes más allá de ella, negando con ello el carácter definitivo de la muerte. De esta forma, la muerte que es irremediable, el fin de todo, y que, por tanto, no es contingente, es concebida sin embargo como tal. Ya no sería una finalización, sino una expiración, el tránsito de una realidad a otra, de mundo a otro. Así, paradójicamente, para el homo sapiens la toma de conciencia de la muerte conlleva la pérdida de conciencia de la misma (homo demens).

$9^{\circ}$ ) Este proceso ‘neurótico', por el que los seres humanos desarrollaron creencias sobre lo invisible extramundano -en el más allá, en Dios, etc.- para hacer frente a la muerte, implicó dejar de creer realmente en ella (como aniquilación final), lo que a su vez conllevó la desvalorización de la vida terrenal. Dilema que fue resuelto en muchas culturas diferenciando entre cuerpo y alma, distinción que quedó definida por la naturaleza temporal del primero y el carácter imperecedero de la segunda. Dilema que además se conformó identificando la verdadera vida con la vida eterna del alma, mientras que la vida terrenal no sería más que un ensayo crucial para acceder a aquélla. En efecto, según cuál fuera el desarrollo de la vida terrenal sería posible alcanzar, o no, la felicidad en la vida después de la muerte, lo que revalorizó a la vida.

$10^{\circ}$ ) Por todo ello, además de estar en el origen de la humanidad, la conciencia humana de la muerte se constituyó en uno de los principios activos clave en el propio proceso de la 
construcción histórica de la sociedad, al estar éste íntimamente ligado con el desarrollo de la individualidad. La inadaptación individual a la muerte sólo puede superarse, parcialmente, en sociedad, ya que ésta se constituye en el único refugio frente a la misma. Arrogándose la mayoría de los atributos de la especie, a modo de <<segunda naturaleza >>, la sociedad adapta al individuo a la muerte. Esa dialéctica inadaptación/adaptación se libera a partir de la inadaptación a la especie, lo que hace posible las adaptaciones humanas, sean éstas mágicas, religiosas o de otro tipo, como la que caracteriza a las sociedades modernas: la deconstrucción de la mortalidad. O dicho de otro modo, la sociedad es continuamente conformada por la muerte.

$11^{\circ}$ ) Por todo ello, la vida llega a hacerse transparente sobre el fondo de la muerte ya que ésta actúa como un catalizador que precipita las expectativas, preocupaciones y creencias básicas de las personas. Las relaciones de los individuos con la muerte ponen de manifiesto aspectos básicos y esenciales del funcionamiento de una sociedad. La muerte, por tanto, es un principio estructurador de la vida social. Es decir, se confirma la primera de las hipótesis básicas de la investigación.

$12^{\circ}$ ) Entre todas las especies animales, la vida de los seres humanos está permanentemente calificada por la muerte. Son los únicos que de verdad mueren. Y no sólo mueren en algún momento, sino que son siempre mortales.

$13^{\circ}$ ) La labor de mediación de la sociedad para proteger a sus individuos ante el espanto que les provoca su propia muerte no mitiga la necesidad última de conocer si la muerte biológica es inevitable y necesaria. Interesa por tanto conocer las razones por las que se produce ésta según las ciencias de la vida: aunque existen evidencias de que, de alguna forma, la longevidad, el envejecimiento y la muerte están inscritas en el patrimonio hereditario de cada individuo, la Naturaleza tiene un papel neutral en esos procesos, no existiendo una programación activa y deliberada de los mismos, sino que la fuerza que empuja a la selección natural es la continuidad de la línea germinal. No se trata de que los individuos sobrevivan por sobrevivir, sino de que sobrevivan adaptándose a un entorno ecológico dado hasta reproducirse y criar la prole de acuerdo a unas formas de reproducción determinadas en cada especie; lo que sucede después no tiene importancia ya que una vez cumplido con su papel reproductor los individuos son desechables. De esta forma, los genes que producían efectos deletéreos en edades avanzadas han encontrado poca o nula oposición por parte de la selección natural y, en consecuencia, se han propagado en el acervo genético. Es decir, los seres humanos no están diseñados para ser inmortales y el envejecimiento y la muerte natural han surgido como efecto secundario de la propia selección natural, cuya fuerza decrece con la edad: los continuos y crecientes 
desequilibrios moleculares acumulados con la edad dan lugar a mermas fisiológicas o a una reducción de la eficacia del sistema inmunitario que comprometen el equilibrio homeostático de los organismos pluricelulares. De esta forma, surge el proceso de envejecimiento por el que aumenta la vulnerabilidad de los individuos, que pierden capacidad de adaptación y de respuesta fisiológica ante las incidencias y transformaciones medioambientales.

$14^{\circ}$ ) En el ámbito biológico, la muerte de todos los seres pluricelulares es un proceso irremediable, incondicional y `natural’ -inherente biológicamente a su existencia. De ahí que la deconstrucción de la mortalidad humana sea otro mito más.

\section{B) Caracterización del $<<$ Sistema de Muerte $>$ :}

La concepción de la muerte en una sociedad compromete globalmente a todo su sistema cultural. La gestión del proceso de morir, el tratamiento de los muertos o el desarrollo de los rituales relacionados con la muerte conforman una mirada concreta sobre ésta, pero también informan sobre la realidad social en su conjunto y sobre la relación de esa sociedad con el resto del mundo. El elemento clave en esos vínculos es el Sistema de Muerte, marco social en el que se delimitan las relaciones entre el enfrentamiento a la muerte y la vida social en cualquier sociedad. Centrado el análisis en las sociedades desarrolladas, a continuación se resumen la funcionalidad de este sistema y de las mutaciones acaecidas, derivadas de la evolución de algunos factores estructurales y culturales durante los tres últimos siglos. Transformaciones que resultan especialmente relevantes para una adecuada identificación y definición de la muerte en esas sociedades:

$1^{\circ}$ ) El ser humano, originariamente ciego a la muerte, toma conciencia de ella a partir de un saber individual mediatizado culturalmente. Socialización que se realiza a través del Sistema de Muerte.

$2^{\circ}$ ) La función del Sistema de Muerte es integrar la muerte y controlarla para reducir su poder ‘anomígeno', es decir, <<legitimarla>> para amortiguar el terror que provoca y evitar así la paralización de la vida social cotidiana. Este encauzamiento de la inadaptación individual hacia la adaptación social se realiza por distintas vías: otorgando significado supraindividual al acontecimiento de la muerte, recordando a los individuos su común mortalidad, ayudando a los individuos a sobrevivir a sus contemporáneos, y proporcionando a los individuos oportunidades para trascender sobre la muerte, ligando el significado de la temporalidad de su vida a la permanencia y duración de la sociedad. 
$3^{\circ}$ ) Al ser productos socioculturales, los Sistemas de Muerte varían entre sí y en el tiempo. Diferencias y transformaciones que se sustentan en dos grupos de factores: los "factores realidad" (la "exposición a la muerte" y la "esperanza de vida”) y los "factores teóricos” (el "control percibido sobre las fuerzas de la naturaleza" y la "percepción de qué significa ser persona").

$4^{\circ}$ ) El juego entre estos cuatro grupos de factores ha propiciado que históricamente se haya generado una muy variada casuística de soluciones culturales para enfrentar la muerte y los problemas sociales y personales que concita. En el caso de las sociedades occidentales, el papel disruptor de la muerte ha sido modelado por sucesivos cambios estructurales y culturales interrelacionados, iniciados hace tres siglos, que han modificado profundamente las experiencias del morir y la muerte. Además de las derivadas de la evolución del sistema capitalista, que se comenta más adelante, y de las transformaciones en la institución familiar o por la creciente importancia de los medios de comunicación de masas, cabe destacar entre las transformaciones sociales que más han alterado el enfrentamiento a la muerte las siguientes: a) Modernización demográfica; b) Pacificación interna de esas sociedades; c) Burocratización; d) Desarrollo del conocimiento científico-técnico; e) Medicalización de la vida social; f) Cambios en las preferencias valorativas; g) Secularización; h) Nuevos perfiles en el proceso de individualización.

$5^{\circ}$ ) Un aspecto clave en cualquier Sistema de Muerte es la identificación y definición social de la muerte, ya que, cuando una persona es etiquetada como muerta, toda una serie de procesos sociales, culturales, políticos, económicos y éticos entran en juego alrededor de ella.

$\left.6^{\circ}\right)$ La muerte humana es ante todo una construcción social, un concepto. Concepto que, como todo producto histórico-social, es dinámico y multidimensional, por tanto, complejo. Complejidad que se ha extremado en las sociedades más desarrolladas en las que las constantes innovaciones científico-técnicas aplicadas al campo de las ciencias de la salud han ampliado el proceso de morir conduciendo a un creciente número de seres humanos hacia una situación en la que, con ayuda mecánica o no, mantienen sus constantes vitales -están vivos biológicamente-, pero han perdido de forma irreversible, al tener su cerebro muy dañado, toda capacidad de relación humana -están muertos humanamente. 
$7^{\circ}$ ) En el contexto histórico actual, el debate público sobre la muerte se concentra sobre el proceso de morir y en el diagnóstico de la muerte. Así, por razones pragmáticas, es la dimensión médica de la muerte humana la más importante a la hora de determinarla. De ahí el claro proceso de medicalización y tecnificación en la identificación social de la muerte, sobre todo desde que, en el segundo cuarto del siglo XX, en algunos países se empezó a llevar a la gente a morir a los hospitales. Actuando como fedatario público, el estamento médico es el único habilitado legalmente para certificar la defunción de personas e identificar la muerte clínica, permitiendo con ello la desconexión a máquinas y, si el caso, el transplante de órganos.

$8^{\circ}$ ) Desde un punto de vista biológico el cambio radical que supone pasar de estar vivo a estar muerto no tiene carácter digital, no se produce en un instante, sino que es un proceso que se prolonga en el tiempo. Sólo el personal médico puede determinar en qué momento un sujeto dejó de vivir. Tarea para la que disponen de protocolos de actuación pero que se torna difusa en la actualidad al coexistir cuatro definiciones y criterios alternativos de muerte que marcan diferentes puntos posibles de no retorno en ese proceso. El análisis de los pros y contras de las cuatro definiciones muestra que todas contienen problemas conceptuales y de implementación práctica. Paradójicamente, a pesar de la utilización de tecnologías cada vez más sofisticadas, lejos de identificar de forma taxativa y neutra cuándo se produce la muerte se ha creado una nebulosa de criterios que han desembocado en que la toma de decisiones sobre esta trascendental cuestión se halle cautiva de los sucesivos avances técnicos, es decir, sea dependiente, incompleta e inestable. Así, hoy la "ciencia médica no puede descubrir el momento en que se dice que se produce la muerte, sino que más bien lo debe elegir”.

$10^{\circ}$ ) La definición de muerte dominante en la mayoría de los países - la muerte encefálica- fue introducida con una finalidad muy concreta que iba más allá de la función tradicional de identificar la aparición del cadáver, ya que, en una dinámica al servicio del pragmatismo reinante, se utiliza para satisfacer otros intereses. Por ello, para algunos autores surgen dudas razonables sobre si con la definición de muerte cerebral lo que realmente se ha buscado ha sido una definición de muerte ad hoc tamizada por la necesidad de conseguir órganos para trasplantes. Dudas que han propiciado un intenso debate en el que se plantea desde la vuelta a la utilización sólo de la definición tradicional de muerte (parada cardio-respiratoria), hasta la propuesta de la aplicación del criterio más específico de delimitación de la parte del cerebro que debe estar dañada definitivamente (la neocorteza cerebral), aunque el resto del cerebro siga funcionando.

$11^{\circ}$ ) La asimilación del enfoque médico de carácter meramente pragmático en la definición de muerte se constata en la evolución de la norma en el caso de España. En el régimen jurídico 
español no existe una Ley General que recoja todos los aspectos relativos al proceso de morirmuerte-cadáver, ni tan siquiera una ley exclusivamente dedicada a definir como tal a la muerte. De hecho, se la define de forma subsidiaria, es decir, como elemento instrumental al servicio de un ámbito social específico que se quiere regular, concretamente, el de los transplantes de órganos. Además, como en otros países, se ha producido una evolución de la norma en la que se han ido admitiendo nuevos criterios para determinar la muerte de una persona al hilo de la acumulación de conocimientos derivados de los avances científico-técnicos. Incluso la norma más reciente, el Real Decreto 2070/1999, contempla la necesidad de su propia actualización a medida que se sucedan “avances en la materia”. El citado Real Decreto define el diagnóstico de muerte como sigue: “el diagnóstico y certificación de la muerte de una persona se basará en el cese irreversible de las funciones cardiorrespiratorias o de las funciones encefálicas, conforme establece el artículo 10 (el que regula la extracción de órganos de fallecidos”. Al margen de las posibilidades de dar vida que implican los transplantes de órganos, la lectura de la documentación aportada por la Organización Nacional de Transplantes y por otras organizaciones de índole similar no deja lugar a la duda sobre el carácter marcadamente utilitario del diagnóstico de muerte clínica basado en el criterio de la muerte encefálica: no se perjudica a los pacientes con muerte cerebral y se beneficia a todos los demás, a los vivos. Con todo ello se comprueba la segunda de las hipótesis básicas planteadas.

\section{C) Análisis de las características y de los dominios del(os) Discurso(s) sobre la Muerte:}

En términos generales, las formas de morir y de enfrentar la muerte en una sociedad en un momento histórico dado revelan, asimismo, la forma de vida concreta que la caracteriza. No obstante, por debajo de la particular implementación social de las experiencia de morir y muerte que caracterizaría a cada contexto histórico concreto, subyacen a lo largo de la historia concepciones de largo recorrido temporal sobre cómo vivir y morir que se retroalimentan con aquéllas. En el caso de la muerte, Vovelle denomina a esas representaciones permanentes de la misma <<discursos sobre la muerte >>, una especie de residuo psicológico irreductiblemente estable, común a los individuos de una sociedad, conformado por ideas, juicios, conceptos y creencias. Sobre la base, primero, de los estudios históricos de Ariès, y, después, de la propuesta para las sociedades contemporáneas de Walter, se resumen a continuación los discursos sobre la muerte presentes hoy en las sociedades desarrolladas:

$1^{\circ}$ ) Ariès, construye un itinerario sobre la evolución de la idea de la muerte en las culturas cristianas occidentales desde la temprana Edad Media, siglo V, hasta aproximadamente la década de 1970. Tomando como referencia cuatro elementos psicológicos -la conciencia de sí 
mismo; los otros como defensa de la sociedad contra la naturaleza salvaje; la creencia en la sobrevida, y; la creencia en la existencia del mal-, plantea la existencia de cinco modelos sucesivos de muerte en las sociedades occidentales a medida que por diferentes razones se iban produciendo modificaciones en alguno de esos cuatro parámetros: la Muerte Domada, la Muerte Propia, la Muerte Lejana y Próxima, La Muerte del Otro, y la Muerte Invertida.

$2^{\circ}$ ) Mientras en los cuatro primeros modelos de muerte, entre el siglo V y el siglo XIX, la población europea se enfrentaba abiertamente a la muerte de forma habitual, defendiéndose de su amenaza por medio de fuerzas sociales tradicionales como la comunidad, la espiritualidad y el ritual, en el siglo XIX emerge un nuevo modelo general de enfrentamiento a la misma, la Muerte Invertida, que modifica incluso un rasgo que se había mantenido en todos los modelos anteriores: la percepción de la muerte como hecho social y público. Modelo que se consolida durante el siglo XX y que está en la base de la multiplicidad de actitudes ante la muerte características de las sociedades occidentales en la actualidad.

$3^{\circ}$ ) Con este modelo de muerte, la familiaridad y el enfrentamiento abierto y público a ella dejan paso a las actitudes vergonzantes, de ocultación y silencio, características de los tabúes. Por ello, la muerte debía ser evitada y, a ser posible, conquistada: negación individual y colectiva de la muerte. El progresivo proceso de individualización, junto a la medicalización de la muerte, consolidó la ‘indiferencia’ social por la pérdida de uno de los miembros del grupo y la percepción de que el enfrentamiento a la muerte era más un problema personal que social.

$4^{\circ}$ ) Asimismo, los progresos científicos y técnicos en el ámbito de la medicina contribuyeron a un cambio mental fundamental en las actitudes ante la muerte: una persona enferma ya no se enfrentaba con su angustia existencial inerme e inerte ante la muerte, sino que luchaba contra la enfermedad que la aquejaba con ayuda del personal médico. La tecnología médica se convirtió en el nuevo instrumento para domesticar a la mortalidad sustituyendo en esa función a la religión. En la vida cotidiana del hogar ya no era necesario defenderse de la muerte salvaje, incomprensible y sucia, sino que al quedar ésta bajo control médico se la aparta de la vida diaria recluyéndola en hospitales y más tarde también en geriátricos.

$5^{\circ}$ ) Sobre la "variedad de sedimentos históricos" analizados por Ariès, Walter examina los discursos sobre la muerte presentes a finales del siglo XX en las sociedades contemporáneas. En su propuesta cabe diferenciar tres modelos sucesivos de muerte: La Muerte Tradicional, la Muerte Moderna y la Muerte Neo-Moderna. 
$6^{\circ}$ ) Desde el punto de vista de los discursos dominantes en cada uno de los tres modelos de muerte propuesto por Walter se puede concluir:

$6^{\circ}$.1) El modelo de Muerte Tradicional es un modelo mediatizado por una concepción religiosa sobre la naturaleza y esencia del mundo y del ser humano de la que, inevitablemente, se deriva una visión determinista y de impotencia absoluta frente a la muerte, ante la que nada cabe hacer. Discurso dominante: el religioso;

$\left.6^{\circ} .2\right)$ El modelo de Muerte Moderna es fruto de los cambios estructurales ligados al proceso de modernización de los tres últimos siglos; en especial, del desarrollo del conocimiento científicotécnico y de su aplicación al ámbito médico-sanitario. El papel activo jugado por el conocimiento científico-médico ha permitido la construcción de una nueva visión estandarizada sobre la muerte, la muerte "natural", que ocurre al final de una larga vida. Se han desplazado con ello la mayoría de las muertes hasta la vejez, conformando a su vez, como un dato básico de la condición humana en las sociedades modernas, el que los individuos perciban que la muerte está controlada y que cabe enfrentarse a ella. Discurso dominante: el científico-médico;

$\left.6^{\circ} .3\right)$ Fruto de las ambigüedades y de los efectos negativos del modelo moderno de muerte sobre la esfera privada de la persona moribunda y de sus allegados (alienación, ocultamiento, etc.), emerge en el último tercio del siglo XX un nuevo modelo de muerte, Muerte Neo-moderna, en el que, como conclusión lógica del individualismo imperante, la muerte es controlada (pilotada) por el propio individuo, el yo individual (el self): la buena muerte es ahora la que el propio individuo elige. Discurso dominante: el psicológico.

$7^{\circ}$ ) El análisis de la muerte en cualquier sociedad desarrollada permite reconocer algunos de los rasgos señalados en los tres modelos de muerte siendo imposible, sin embargo, identificar netamente a una sociedad con un único tipo de muerte. Además de otras circunstancias, el mero hecho de que, en la actualidad, las poblaciones de esas sociedades estén constituidas por más de cien generaciones determina que por el "efecto generación" coexistan en su seno los tres modelos de muerte. De esta forma, la cultura de la muerte no sería tanto el agregado de tres culturas estancas cuanto una cultura transversal de ellas. No obstante, en la mayoría de las sociedades desarrolladas, y particularmente en el caso de la sociedad española, como se ha comprobado empíricamente en esta investigación, sí cabe hablar, en la actualidad, de una implantación hegemónica del modelo denominado Muerte Moderna.

$8^{\circ}$ ) Aunque la muerte es inevitable, históricamente se ha acabado convirtiendo en una institución social esencial para el propio funcionamiento de la sociedad. Por ello, el temor a la muerte constituye un factor de cohesión en la organización de la sociedad, es decir, de control social. La <<racionalidad >> de la cultura occidental exige la exclusión intencionada de la muerte, que se la niegue socialmente (modelo tabú de la muerte). Desde el siglo XVI toda la 
cultura occidental ha sido un enorme esfuerzo para disociar la vida de la muerte, beneficiando a la primera (la vida como valor, como acumulación) en detrimento de la segunda (la muerte como vencimiento). El objetivo último perseguido ha sido claro: abolir la muerte. Inicialmente, con una intencionalidad de control existencial de la supervivencia y la eternidad por parte de las religiones; después, con la de fomentar la productividad y la acumulación para la economía por parte de los Estados.

$9^{\circ}$ ) El proceso por el que se niega la muerte tiene sin embargo una funcionalidad social y económica evidente en el desarrollo del sistema capitalista. Los individuos han de enfrentarse con inmediatez a los problemas de la vida cotidiana y necesitan hacerlo de forma adecuada. Si quieren ser operativos en su vida diaria precisan apartar de su pensamiento la fuente principal de su temor. Así, si en la realidad social, construida y constituida por los otros, domina una actitud denegadora de la muerte, se hace posible que el individuo se olvide de que ha de morirse, se sienta inmortal, y actúe aquí y ahora: la expulsión de la muerte de la vida social logra la expulsión de la muerte en los individuos. La denegación de la muerte va a permitir al individuo ser práctico.

$10^{\circ}$ La expulsión social de la muerte coincide históricamente con la afirmación de la individualidad, lo que conlleva que el individuo se enfrente en solitario a la muerte. Sin soportes, obligado a enfrentarse cara a cara con su vida y su muerte, responde con la percepción de su alejamiento, como si no existiera. Este extrañamiento de la muerte corre parejo al extrañamiento del "otro", al aislamiento social respecto a los otros, de ahí la soledad de los moribundos. De ahí también que en el imaginario de las sociedades desarrolladas esté asentado firmemente el vínculo muerte/vejez, vínculo que ayuda a conjurar en la vida cotidiana la idea misma de la muerte, y que se refuerza tomando distancia respecto de los que están asociados a ella, las personas ancianas.

$11^{\circ}$ ) Las transformaciones derivadas de los avances científico-médicos, que en su búsqueda de la verdad intrínseca de la naturaleza, de su lógica causal, lejos de atemperar las angustias de los individuos ha desembocado en una paradójica situación: la concepción moderna de la muerte como "natural”, profana e irreversible entra en "contradicción aguda con los principios de la racionalidad burguesa”, al cuestionar la hegemonía de los valores individuales, al reconocer de hecho un límite al progreso ilimitado de la ciencia y, por tanto, a la capacidad real de ésta para dominar la naturaleza. Así, por un lado, la `deconstrucción’ analítica de la mortalidad, y la segregación etárea, espacial e institucional de la muerte, han contribuido a alimentar una “conspiración del silencio” en torno a ella. La muerte, como hecho inevitable de la naturaleza, ha sido deconstruida en diferentes procesos contingentes de muerte privada, cada uno con su 
propia causa evitable. De esta forma, la muerte ha dejado de ser inherente a la naturaleza humana y se la percibe como extraña a la misma, como algo que adviene de fuera para acabar con ella. Pero, por otro lado, paradójicamente esa `deconstrucción’ de la mortalidad en lugar de reducir la conciencia de mortalidad ha incrementado el terror a la muerte haciéndola omnipresente en la vida diaria. Como un alien espectral diseminado por todos los lados, su recuerdo constante forma parte integral de todas las funciones de la vida (trabajo, familia, ocio, alimentación, etc.) y está detrás de todas las decisiones que se toman en ella.

$12^{\circ}$ ) La utilización de la muerte como instrumento de control social no sólo ha perseguido favorecer el funcionamiento cotidiano de la vida social, sino que ha ido más allá y se ha buscado además aprovechar el terror hacia la muerte para acumular poder social -Death Power. En los dos últimos siglos, los sistemas políticos -los Estados- habrían reemplazando a las religiones en este ámbito convirtiéndose en las más poderosas agencias sociales de la muerte. Ejercicio del poder por parte de los Estados que no consiste en las sociedades desarrolladas tanto en la capacidad de dar muerte a los individuos, sino en lo contrario, en la capacidad de retrasársela. La reivindicación de una justa duración de vida, como la de un salario justo, se convierte en derecho, en un <<contrato de vida >> implícito con la sociedad, un nuevo contrato social en el que ésta se responsabiliza de la muerte de cada individuo, pero que como contrapartida de ese contrato impone el deber de muerte natural, la obligación de vivir hasta el final. En última instancia, esto significa que los individuos han sido desposeídos de su muerte, se les prohíbe elegir cuándo quieren o cómo quieren morir: control y neutralización de la vida que pierde su dimensión cualitativa y queda reducida a cantidad de vida.

$13^{\circ}$ ) Desde finales del siglo XX se han ido sucediendo una serie de cambios estructurales y culturales que han reforzado la orfandad de los individuos en su enfrentamiento a la muerte. Así, además de la profundización en el proceso de individualización, el avance de las nuevas tecnologías, las nuevas formas de organización de la producción, la revolución de la comunicación (INTERNET) y el proceso de globalización, han propiciado una nueva reorganización del tiempo y del espacio tanto en los ámbitos de la vida social como de la privada, provocando profundas mutaciones en las instituciones modernas (trabajo, Estado, familia, pareja, democracia, iglesias, etc.), que ya no cumplen muchas de las funciones para las que estaban destinadas. La pérdida de influencia de estos suministradores modernos de sentido ha conformado un escenario en el que se abandona a su suerte a los individuos quienes, por un lado, se han de hacer responsables de sí mismos, pero, por otro lado, cada vez son más dependientes de condiciones que no comprenden ni controlan. Escenario ambivalente, inestable e incierto, en el que la realidad social se desmorona en manos de los individuos escapando a su comprensión -modernidad líquida. 
$14^{\circ}$ ) Este contexto lleva a los individuos a encerrarse en el universo de su vida personal y de las relaciones interpersonales. Al desaparecer los anclajes sociales pretéritos, la identidad personal tiene que ser continuamente creada y recreada de acuerdo al estilo de vida que se elige, recreación de la identidad que se hace cada vez más compleja en el mundo desbocado que se ha conformado hoy. La fragmentación social derivada de unas condiciones sistémicas de <<apertura>> social y continuamente cambiantes hace que los individuos construyan su identidad personal, no de forma única y unitaria, sino que crean y recrean varias identidades sociales de carácter microscópico y laxo adaptadas a las pautas culturales y sistemas de valores de los diferentes escenarios sociales en los que se mueven.

$15^{\circ}$ ) Aunque los individuos tienen una libertad de elección sin precedentes históricos para hacer su vida, sin embargo, como no controlan las condiciones de su elección, se ven involucrados en continuos conflictos por las múltiples decisiones que han de tomar, por lo que enfocan la construcción de sus identidades y proyectos de vida con inseguridad y desconfianza ante el porvenir. Como resultado de esta precarización vital, ya no son necesarios los mecanismos de control heterónomo de la etapa moderna, sino que las responsabilidades se insertan entre las tareas a desarrollar por los propios individuos como componentes necesarios e imprescindibles para la creación/recreación de sus identidades. Si tienen consecuencias negativas, sólo cabe achacárselas a una inadecuación del yo. Así, el individuo percibe sus fracasos como resultado de su incompetencia o de sus limitaciones, y no por fallos del sistema.

$16^{\circ}$ ) Y también en el caso de la muerte. Los procesos de secularización e individualización han eliminado todos los puentes sociales entre la vida y la inmortalidad que ayudaban a los individuos a 'saltar' la muerte. Ésta queda fuera de toda posibilidad de control, por lo que ante la imposibilidad de abolirla la vida propia se concentra en enfrentarse y metabolizar algo que el yo sí experimenta desde muy pronto: la "amenaza ubicua” que es el morir. Sobre éste sí que se puede actuar, por un lado, desplazándolo hasta que la medicina deja de ser eficaz y, por otro lado, evitando todo pensamiento sobre la muerte.

$17^{\circ}$ ) La conciencia de muerte, específicamente humana, determina que el enfrentamiento al miedo a la muerte sólo pueda realizarse con herramientas construidas por los propios seres humanos. Los mitos de la contingencia de la muerte utilizados para ello se han construido sobre tres estrategias: denegación y deconstrucción de la muerte, las correspondientes a las sociedades tradicionales y modernas, y banalización de la muerte, la propia de la modernidad líquida. Las tres son estratagemas que buscan transformar un hecho natural en un hecho cultural, la primera ignorando la muerte mediante la sustitución de la transitoriedad de la vida 
por la duración de la eternidad, mientras que las otras dos, renegando de esa estrategia, buscan desactivarla despreocupándose de lo duradero para concentrarse sólo en lo transitorio, en la propia vida.

$18^{\circ}$ ) Son diversas las tácticas empleadas dentro de la estrategia general de banalización de la muerte. La más utilizada en las sociedades posmodernas, y la más acorde con la personalidad tipo de esas sociedades, la personalidad narcisista, es la de su trivialización por continua repetición, la <<hipervisibilización >> de la muerte, con lo que se persigue devaluarla, comercializarla, quitarla toda su carga simbólica y transformarla en algo inofensivo. La asunción de los valores materialistas, consumistas, hedonistas, etc., que caracterizan a esas sociedades avala la hiperexaltación de la vida (del yo como sagrado e `inmortal’) y exige la eliminación social de la muerte. Aunque minoritaria, otra táctica de banalización es la llamada $<<$ cultura de lo extremo >>, en la que los individuos que la practican no devalúan la muerte para así poder consumir sólo vida, sino que, al contrario, la tienen siempre virtualmente presente y flirtean constantemente con ella para tener la sensación de control y de estar vivos.

$19^{\circ}$ ) En el contexto actual es significativo y paradójico el papel disruptor que se atribuye a la muerte que, según algunos autores sigue siendo tabú, para otros está secuestrada en la privacidad víctima de una conspiración de silencio y según otros aflora al ser reivindicada. Diversas circunstancias, como por ejemplo, la creciente bibliografía académica sobre la muerte y el morir, junto con la multiplicación de artículos periodísticos relacionados con ella, además de la proliferación de representaciones de todo tipo sobre la muerte en los mass-media, cuestionan su carácter de tabú. Por ello, se resalta la conveniencia de diferenciar en este tema los procesos sociales de los psicológicos. En el primero de esos ámbitos, las recientes transformaciones estructurales han provocado mutaciones en las respuestas culturales a la muerte que hacen que sea más apropiado hablar de muerte escondida que de, propiamente, una negación social de la muerte (modelo muerte secuestrada). En el plano psicológico, la subjetivación de los significados torna crecientemente frágil la seguridad ontológica de los individuos, por lo que el abandono del espacio público para quedar forzosamente ubicada en el privado transforma a la muerte en una amenaza intensa y constante para ellos. De ahí que resulte inevitable la negación individual de la muerte, renuncia necesaria para la construcción de un proyecto vital viable. Así, se ha reforzado la denegación de la misma por parte de los individuos al ser un límite difícil de aceptar tanto para las personas que están próximas a ella (denegación por horror), como para las que la perciben lejana (denegación moderna; denegación por narcisismo; (denegación por aventura). Lo que permite constatar la tercera de las hipótesis básicas de esta investigación. 


\section{D) La Muerte Sufrida:}

La demografía de una población es un elemento esencial en la ordenación de la vida social. En el caso concreto de la mortalidad, sus características determinan el enfrentamiento a la muerte, es decir, constituyen un elemento estructural del Sistema Muerte en cualquier sociedad. El análisis demográfico realizado, tomando como referencia el marco teórico de la Transición Demográfica, ha permitido cuantificar toda una serie de aspectos relativos a la evolución histórica de la contabilidad de la muerte en España. En el análisis se han utilizado asimismo otros modelos teóricos que explican, por un lado, la evolución descendente de la mortalidad hasta fechas recientes a partir de la evolución de la mortalidad por causas Transición Epidemiológica (Omran)-, y, por otro, permiten contextualizar esa evolución como parte de un proceso multidimensional -Transición Sanitaria (Lerner). En esencia, los resultados obtenidos sobre la evolución pretérita de la mortalidad en España, y la hipotética evolución futura de la misma, son los siguientes:

$1^{\circ}$ ) España es uno de los países desarrollados que más tarde inician su transición demográfica. $\mathrm{Al}$ igual que el resto de esos países, en lo que se refiere a la evolución de su contabilidad de la muerte (Transición de la Mortalidad) los rasgos básicos observados son: a) pronunciado descenso del nivel de la mortalidad; b) reducción de la variabilidad de la misma de un año a otro; c) notable incremento de la longevidad media. Lo que no significa necesariamente que se haya incrementado el límite biológico máximo de la vida humana, sino que un número mayor de personas viven hasta edades avanzadas; d) alteración sustancial en la distribución relativa de los decesos según las distintas estructuras identificables en una población. Dos estructuras básicas en este sentido son: d1) la estructura por edad, cuya composición relativa se altera por la cúspide conformando, junto al descenso de la fecundidad, la dinámica del envejecimiento demográfico y en la que ha tenido lugar una profunda modificación del calendario de la mortalidad, generándose una <<nueva edad >> de la muerte ubicada en la vejez, y; d2) la estructura por género, en la que, durante todo el siglo $\mathrm{XX}$, se ha producido una creciente divergencia entre las longevidades medias de hombres y mujeres, aunque los últimos datos muestran una atenuación en ese diferencial.

$2^{\circ}$ ) La transición de la mortalidad observada en la sociedad española a lo largo del siglo XX ha sido consecuencia del proceso modernizador acaecido en la misma, pero también causa de él. La reducción de las probabilidades de fallecer, con el consiguiente incremento de la longevidad media, y el ordenamiento del ciclo vital han permitido mitigar incertidumbres de todo tipo ligadas a la muerte e instaurar un marco estable de seguridad en el que concebir proyectos 
vitales de futuro. La incidencia en este sentido abarca múltiples dimensiones de la vida social: institución familiar, relaciones intergeneracionales, organización del trabajo, del ocio, promoción del ahorro, creación del sistema de Seguridad Social, diversificación de valores culturales, etc. Asimismo, ha favorecido el desarrollo del individualismo, al reducir el sentimiento de fragilidad y aminorar las dependencias respecto a terceros.

$3^{\circ}$ ) El análisis de la mortalidad por causas permite situar al conjunto de la población española en la cuarta fase de la transición epidemiológica caracterizada por: a) una cada vez más amplia separación entre una morbilidad creciente y una mortalidad decreciente; b) un progresivo dominio de las enfermedades endógenas (degenerativas y crónicas) como causa de muerte; c) la importancia relativa de las muertes accidentales y violentas provocadas por "patologías” ligadas a prácticas sociales de riesgo (accidentes, suicidios, drogadicción, tabaquismo, etc.), y; d) la incidencia acumulada del comportamiento, del estilo de vida, en las edades más avanzadas con un mayor peso de las enfermedades degenerativas a esas edades. Conviene matizar que en ese dominio de las enfermedades endógenas existen tendencias dispares entre ellas, al haberse promocionado desde distintos frentes el desarrollo de estilos de vida más saludables y así lograr un cierto control de las mismas. Es el caso, por ejemplo, de la reducción observada en la primera década del siglo XXI en el peso relativo de la mortalidad provocada por las enfermedades del sistema circulatorio.

$4^{\circ}$ ) El proceso de medicalización de la muerte en la sociedad española es diáfano. En este sentido los indicadores evidencian un crecimiento absoluto y relativo en el número de pacientes hospitalizados en las tres últimas décadas. Evolución acompañada por un aumento absoluto en el número de fallecimientos de pacientes hospitalizados en ese tiempo, que casi se ha duplicado. A diferencia de la creencia dominante en la sociedad española, el porcentaje de la población que fallece en los hospitales no es el mayoritario, no llega a la mitad del total de decesos. Por otra parte, entre todos los diagnósticos de pacientes hospitalizados, los tumores son los de mayor letalidad hospitalaria: desde principios de este siglo, algo más de uno de cada diez pacientes hospitalizados por algún tipo de cáncer fallece en el hospital. El cáncer es la enfermedad que mayores temores provoca en España; buena parte de esos temores provienen del vínculo imaginario con el que la sociedad española enlaza cáncer con muerte.

$5^{\circ}$ ) A lo largo del siglo XX se observa que en la evolución de la fuerza de la mortalidad se ha reducido la intensidad de la misma en todas las edades, sin embargo, el ritmo de descenso no ha sido constante en todo momento y tampoco todos los grupos de edad han contribuido de forma equiproporcional al aumento de la esperanza de vida al nacer: si en la primera mitad del siglo las mejoras de las esperanzas de vida de los más jóvenes fueron importantes, siendo 
relativamente mucho menores las de las edades avanzadas, en la segunda mitad, y en especial desde 1970, ha ocurrido al revés. De hecho, los incrementos recientes en la esperanza de vida en la población española se han producido sobre todo por la evolución decreciente de la mortalidad en las edades más avanzadas.

$6^{\circ}$ ) La longevidad media y las causas inmediatas de mortalidad varían claramente entre hombres y mujeres de tal forma que la fuerza de la mortalidad es menor en éstas y, en consecuencia, sus esperanzas de vida en todas las edades son superiores a las de los varones. Simultáneamente, las tasas de morbilidad e incapacidad de las mujeres son asimismo mayores que las de los varones. Hasta hoy no se conocen a ciencia cierta las causas últimas de estos procesos diferenciales dado que no ha sido posible deslindar la influencia exacta en los mismos de los factores propiamente biológicos -sexo- entre las de todo el conjunto de factores socioculturales que intervienen en ellos -género. No obstante, si bien existe prácticamente unanimidad a la hora de admitir la existencia de una superioridad biológica en las mujeres respecto a los hombres de cara a la supervivencia, el análisis empírico muestra que las principales razones de las desigualdades por género en salud son epidemiológicas -el resultado de riesgos adquiridos desde los roles, estrés, estilos de vida y a largo plazo de prácticas preventivas de salud. Por ello, las causas de muerte que generan sobremortalidad masculina están relacionadas sobre todo con los estilos de vida que han emergido con el proceso de modernización. La convergencia en la actividad laboral y en los roles sociales por parte de las mujeres y hombres de las generaciones de jóvenes y de adultos-jóvenes actuales, “democratiza” esos comportamientos lo que probablemente en el futuro, y para causas concretas de muerte, diluya en gran medida los sesgos por sexo en la mortalidad estrechándose el diferencial entre ellos.

$7^{\circ}$ ) Respecto a la evolución futura de la mortalidad y la longevidad, existen intensos debates científicos respecto al rumbo hacia el que pueden dirigirse. Dado que muchas de las aportaciones de esos debates se vuelcan en los medios de comunicación, y acaban finalmente influyendo en la construcción del imaginario sobre la muerte de la población general, es necesario recoger las más significativas en ese sentido. En líneas generales, las perspectivas de futuro de la mortalidad vienen marcadas por:

$\left.7^{\circ} .1\right)$ La transición sanitaria no es un proceso lineal y de sentido único, en el que no quepan movimientos de contraflujo. No existe ninguna razón intrínseca al concepto de transición que obligue a pensar que la evolución deba de ir forzosamente en una dirección de mejora continua, tampoco existen garantías de que los logros alcanzados hasta ahora sean definitivos y puedan mantenerse de forma indefinida. Lo cierto es que existe toda una serie de fuentes amenazadoras que pueden provocar procesos de contratransición: a) el regreso de las epidemias; b) el agravamiento de los problemas de salud asociados al desarrollo, y; c) la emergencia de 
problemas de salud asociados al fenómeno de la globalización o a los conflictos entre desarrollo y medio ambiente (degradación antropogénica). Junto a estos riesgos globales las llamadas “enfermedades de la sociedad”, es decir, las producidas por los efectos perversos de hábitos insalubres o arriesgados producen efectos igualmente devastadores en los niveles de salud de la población.

$7^{\circ}$.2) Un tema especialmente polémico desde la óptica científica es el de si son esperables nuevos incrementos de la longevidad humana en el futuro, cuestión clave por las importantes consecuencias sociales derivadas del creciente proceso de envejecimiento demográfico, por lo que conviene diferenciar en primer lugar las distintas hipótesis respecto a la existencia o no de un límite fijo en la duración máxima de la vida humana. Mientras que para unos autores el proceso de senescencia es un proceso intrínseco, no tratable, que impone genéticamente una duración de vida determinada en cada especie, otros autores rechazan esa determinación y consideran que los avances en el conocimiento científico permitirán domesticar los procesos senescentes y con ello ampliar la longevidad máxima de la vida humana. Este debate remite a otro debate empírico socialmente mucho más relevante como es el del incremento de la longevidad media. En este caso, la multidimensionalidad de los procesos de salud/enfermedad/ muerte mediatizan de forma más compleja la consecución de avances en la longevidad media que, de hecho, pueden verse frenados por constricciones societales, económicas y ecológicas, y también por los estilos de vida desarrollados por los propios individuos. En todo caso, el análisis empírico realizado certifica que, de momento, continua el desplazamiento hacia la derecha en la distribución de la mortalidad por edad, es decir, que las edades media, mediana y modal de muerte siguen aumentando sin que a día de hoy se vislumbre la existencia de un tope que impida esa evolución. Incremento de la longevidad media que se ha traducido en la "explosión” reciente de centenarios e, incluso, de supercentenarios en los países desarrollados, fenómeno que también se ha observado en España.

$\left.7^{\circ} .3\right)$ La cuarta fase de la transición sanitaria se caracteriza por la combinación de una mortalidad decreciente y una morbilidad creciente, modificándose con ello el estado medio de salud de las poblaciones. Con el retraso en la edad de muerte sobrevive una proporción mayor de individuos hasta edades cada vez más avanzadas, pero esto no garantiza que los años de vida que se ganan se vivan en completa salud. De hecho, en ese balance calidad de vida/cantidad de vida entre la población anciana se asume que lo más probable es que conlleve la degradación del estado de salud. La cuestión que se debate en este caso es si la evolución futura de ese balance estará marcada por una comprensión, una expansión o un equilibrio dinámico de la morbilidad. El análisis empírico sobre esta cuestión está muy mediatizado por el tipo de indicador utilizado para su medición; asimismo, las diferencias en morbilidad y mortalidad entre hombres y mujeres recomiendan realizar un examen discriminado por sexo. Los resultados más significativos obtenidos en este trabajo son: a) una buena parte de los años de vida ganados son 
vividos en mala salud percibida; b) las mujeres viven más años que los hombres pero lo hacen con peor salud percibida, percepción diferencial que además se ha incrementado en el tiempo; c) para el conjunto de la población española, los años de vida ganados lo han sido con menor discapacidad; d) la diferencia por sexo en la esperanza de vida, mayor entre las mujeres, está conformada sobre un número mayor, absoluto y relativo, de años vividos en discapacidad por ellas; e) el incremento de la esperanza de vida ha venido acompañado de un mayor número de años de vida esperada sin discapacidad pero, a la par, el grado de severidad dentro de ésta se ha incrementado relativamente en ambos sexos, y; f) el análisis diacrónico sugiere la existencia de una expansión de la morbilidad y de la discapacidad severa entre las mujeres, mientras que entre los hombres se ha producido una ligera comprensión de la morbilidad pero con una expansión interna de la discapacidad severa.

$8^{\circ}$ ) El análisis demográfico ha permitido confirmar que la baja intensidad y el calendario tardío de la mortalidad conforman un escenario en el que existe una baja probabilidad de vivenciar la muerte, lo que verifica la cuarta de las hipótesis básicas de esta investigación.

\section{E) Muerte Vivida:}

El análisis realizado a través de una amplia encuesta, cuatro entrevistas semiestructuradas y un grupo de discusión, ha permitido una aproximación sociológica (valores en sentido relativo más que absoluto; medida de la dimensión cognitiva de los valores; sistemas de preferencias mayoritarios) a la idea de la muerte en la vida cotidiana de la población de clase media. Análisis en el que se ha centrado el foco de atención cuando la muerte no está próxima en el tiempo (se ha estudiado a personas que no trabajan/estudian en el sector sanitario y a personas que no han vivido un proceso de morir(se) o muerte cercano en el tiempo). En el examen realizado se han utilizado como variables independientes la edad, el sexo, el nivel de estudios y la religiosidad, mientras que las variables dependientes se han agrupado en siete grandes áreas temáticas. Entre las múltiples conclusiones obtenidas las más significativas son:

$\left.1^{\circ}\right)$ Muerte y vida cotidiana: A pesar de la trascendencia de la muerte, la reflexión sobre ella es infrecuente; no obstante, se observa un vínculo de esta variable con la edad y el sexo: el pensamiento sobre la muerte es más frecuente y más intenso entre las personas ancianas y las mujeres. Las razones fundamentales de esa despreocupación son de tipo utilitario: el dedicarse al quehacer cotidiano y los problemas materiales conexos al mismo; sin embargo, sí que se piensa con frecuencia en el fallecimiento de una persona próxima. En última instancia, se asume que la gente piensa más en la muerte durante la vejez. En consonancia, un manto de silencio 
cubre a la muerte, de la que apenas se habla, aunque se cree que la gente debería hablar de ella con naturalidad. Despreocupación y silencio que no están vinculados a la falta de contacto con la muerte, experiencia vicaria que ha tenido la mayoría de las personas encuestadas, que en algún momento de su vida han visto al menos un cadáver. Tener seguridad de que se va a morir no afecta a la conducta diaria, pero saber que a uno le quedan seis meses de vida sí que la alteraría notablemente, proyectándose como respuestas diferentes conductas muy vinculadas al ciclo vital y a la religiosidad. Estos datos, entre otros, confirman la quinta hipótesis de esta investigación: no es lo mismo morir que morirse. Como fondo, el hecho de que la mayoría de la población encuestada no valora a la vida en sí misma, como un absoluto, sino que opta por la calidad de vida frente a la cantidad de vida.

$2^{\circ}$ ) Planes en relación a la muerte: Ante la muerte en el horizonte se considera necesario realizar algunos planes de actuación. Por ejemplo, hacer testamento, hacerse donante de órganos para trasplante y rellenar un testamento vital. En menor medida se suscribe la necesidad de cubrir un seguro de vida y hacerse donante de órganos para investigación. Resultados que confirman el dominio del modelo moderno de muerte $\mathrm{y}$, aunque se perciben indicios del modelo neo-moderno a través del apoyo al testamento vital, el bajo aprecio mostrado a que sea el propio individuo quien realice las disposiciones sobre su entierro y funeral prueba que este modelo no está consolidado ni siquiera en el ámbito de las creencias. En todos los planes sobre los que se ha interrogado, se observa una relación con el ciclo vital. No obstante, se aprecia una disonancia entre lo que se considera necesario y la práctica efectiva en varios de los planes: así, la mayoría tiene adquirida una sepultura, pero no tiene testamento o seguro de vida. En conjunto, no existe una predisposición favorable hacia la inhumación o hacia la incineración, aunque sí que se observan diferencias según la fase del ciclo vital, siendo las personas ancianas mayoritariamente partidarias del enterramiento. Se rechazan las nuevas prácticas fanáticas ligadas a los avances tecnológicos: criogenización y “cementerios virtuales”.

$\left.3^{\circ}\right)$ Rituales funerarios: Existe una clara disonancia entre las opiniones y los comportamientos en este ámbito, ya que, de hecho, más de la mitad de la población encuestada ha practicado en alguna ocasión 8 de los 11 ritos sobre los que se pedía información, cuando sólo 5 de ellos son considerados necesarios. Datos que, por un lado, confirman la vigencia de algunas de esas prácticas (funeral, dar el pésame, acompañar la conducción del cadáver, velatorio, esquela) y la obsolescencia clara de otras (luto, recordatorios, libro de firmas, visita Día de Difuntos, enviar corona, duelo), y que, por otro lado, anticipan cambios futuros hacia su desuso toda vez que los mayores niveles de desafección corresponden a las generaciones más jóvenes. Por otra parte, se observa una predisposición favorable a la utilización de los "paquetes funerarios", es decir, a que todo el proceso relacionado con el "último adiós" -tratamiento del cadáver, exposición, 
funeral, traslado, inhumación/incineración, etc.- quede en manos de organizaciones especializadas. Los dos principales motivos para optar por esta opción son la comodidad para la familia y la higiene y organización. El motivo principal para rechazarla es la tradición, por lo que son las personas de más edad las que en mayor medida se oponen a ello.

$4^{\circ}$ ) Interacción con el ámbito hospitalario: La mayoría de la población encuestada no cree que se pueda alcanzar la inmortalidad física con el concurso de la ciencia. Asimismo, mayoritariamente se rechaza la utilización de criterios económicos extremos como reguladores de la vida social en la fase final de la vida de los individuos. Sea el caso, por ejemplo, de la selección excluyente de enfermos por criterios pragmáticos de eficiencia económica, o de todas aquellas propuestas discriminatorias contra la población anciana -ageismo. Por otra parte, el conjunto de la población encuestada no participa de los análisis que diagnostican que su “hospitalización” supone una pérdida de naturalidad de la muerte, que aliena existencialmente a la persona moribunda sustrayéndole la vivencia de la última etapa de su vida. Más bien, la contundencia de los resultados obtenidos permite afirmar lo contrario. En otro orden de cosas, la población encuestada suscribe mayoritariamente las dimensiones fundamentales del <<canon>> de la muerte elaborado en otras investigaciones: muerte inconsciente, rápida, indolora y en casa.

$\left.5^{\circ}\right)$ Imagen de la muerte: Al menos en el plano cognitivo, no está instalada en el imaginario de la población encuestada una imagen trágica de la muerte, ni en lo físico ni en lo existencial. No se percibe mayoritariamente, aunque sí entre los de más edad, que el morir sea sufrir. De hecho, buena parte de la población convive con una imagen tranquilizadora de la muerte, como si de un largo sueño se tratara. En todo caso, se la considera como el punto de descanso natural de una vida que se debe vivir plenamente. Quizá por ello, concentrada en el vivir, la mayoría de la población considera que hay situaciones peores que la propia muerte, las que afectan a la calidad de vida física (dolor provocado por enfermedad, agonía) o a la calidad de vida psicológica (dependencia, y sobre todo muerte de un/a hijo/a). Por otra parte, se asume que el impacto social de la muerte depende de la edad de las personas que fallecen: se valora como menos trágica la muerte de un anciano que la de un niño. Asimismo, y en sintonía con el modelo moderno de muerte, se opina que la muerte de una persona es una pérdida sobre todo para la familia y los amigos, y no tanto para la propia persona fallecida ni para la sociedad.

$\left.6^{\circ}\right)$ Multidimensionalidad del miedo a la muerte: Los resultados empíricos obtenidos permiten poner de manifiesto la multidimensionalidad de la relación individuo/sociedad/ muerte. En efecto, si el análisis sociológico de las actitudes ante la expectativa de la muerte tiende a primar una única dimensión en esas actitudes, el miedo a la muerte, el análisis factorial realizado ha 
permitido identificar seis factores que en conjunto explican el 63,19\% de la varianza común. Estos factores son por orden de importancia:

$6^{\circ}$.1) Miedo a la muerte: Es una actitud universal por la que se reacciona emocionalmente con rechazo ante algo específico relacionado con la muerte.

$\left.6^{\circ} .2\right)$ Aceptación de acercamiento: Es una actitud que de manera sutil niega la muerte al reducir su trascendencia y transformarla en un simple pasaje que hay que atravesar para conseguir la recompensa de una vida posterior.

$\left.6^{\circ} .3\right)$ Evitación de la muerte: Si no se puede eliminar la muerte al menos sí es posible no preocuparse por ella negándola.

$\left.6^{\circ} .4\right)$ Aceptación de escape: La vida en su dimensión de calidad es lo único que cuenta. Para unas personas, si no se puede vivir la vida con unas condiciones mínimas no merece la pena ser vivida. Para otras, el miedo a vivir bajo ciertas condiciones puede ser más fuerte que el miedo a la muerte.

$\left.6^{\circ} .5\right)$ Aceptación neutral: Se acepta la muerte, se cree en su facticidad, que la hace inevitable, por eso se vive la vida, que es finita.

$\left.6^{\circ} .6\right)$ Aceptación natural: Se percibe a la muerte como un proceso natural que forma parte de la vida.

Del análisis se concluye que, efectivamente, las actitudes que las personas mantienen ante la muerte son una mezcla de actitudes que se contrabalancean (negación, temor, ansiedad, aceptación, indiferencia, ira, esperanza, engaño, alienación,...). Asimismo, aunque las distintas actitudes ante la muerte pueden estar en mayor o menor medida presentes en todas las categorías sociales consideradas (por edad, sexo, etc.), cabe confirmar el papel destacado que en el miedo a la muerte juega el miedo al morir propio. Esto es, son las personas más vitalistas las menos condicionadas por el saber de su mortalidad y las más preparadas para afrontarlo, las que presentan unas actitudes ante la muerte más atemperadas: las que tienen menos miedo a la muerte, las que necesitan en menor medida recurrir a explicaciones transmundanas para justificar su vivir, las que más aceptan la existencia inevitable de la muerte como cierre a su vida, y las que en mayor medida consideran que ese tope forma parte del discurrir natural de la vida.

$7^{\circ}$ ) La muerte como dimisión de la vida: En este apartado se han examinado las creencias, opiniones y actitudes de la población encuestada sobre dos materializaciones concretas del proceso de morir: el suicidio y la eutanasia. Los resultados más relevantes de ese análisis son:

$7^{0} .1$ ) La mayoría de la población considera que las personas tienen derecho a quitarse la vida, aunque una parte significativa de ella rechaza tal derecho. Son las personas de las generaciones más provectas, las que tienen menos estudios y las de mayor religiosidad, es decir, las más tradicionales, las que se oponen en mayor medida a ello. Por otra parte, la baja proporción de 
personas encuestadas que conocen a otra que se haya suicidado recientemente sugiere que, al menos en el ámbito espacial en el que se mueve la población encuestada, el problema de salud pública (mental) suicidio no tiene la intensidad que en otras zonas del mundo, ni tampoco la de otras causas de muerte. Quizá sea esta la razón por la que al ser interrogadas sobre el alcance del suicidio en la población española (diferencias entre medio rural/urbano, por edad, por sexo) manifiestan mayoritariamente su desconocimiento sobre el grado de esas diferencias, y entre las que responden de forma concreta una buena parte lo hacen erróneamente.

$7^{\circ}$.2) Al margen de la diversidad de posiciones morales y de perspectivas teóricas, y de la delgada e interesada línea legal de demarcación entre eutanasia activa y pasiva, la mayoría de la población encuestada tiene muy clara su posición a favor de las distintas formas de eutanasia y aboga abiertamente por la legalización de la eutanasia activa bajo ciertas circunstancias. De forma más concreta: a) la mayoría de la población desea ser informada con sinceridad sobre el alcance de un diagnóstico de gravedad propio; b) existe una heterogeneidad de opiniones sobre quién debe tomar las decisiones sobre los cuidados médicos en el momento final de la vida de una persona enferma. El espectro de opiniones abarca desde una mayoría relativa que considera que debe ser la propia persona afectada, hasta una minoría inferior al $10 \%$ que delega la decisión en el personal médico. Dato este último muy relevante por cuanto supone una relativización muy importante de la autoridad médica en este ámbito; c) la población encuestada se manifiesta mayoritariamente en contra del encarnizamiento terapéutico, es decir, favorable a la limitación del esfuerzo terapéutico (eutanasia pasiva); d) respecto a la sedación terminal, la población encuestada es muy mayoritariamente favorable a la aplicación de los medios necesarios para reducir el dolor aunque ello tenga el doble efecto del acortamiento de la vida (eutanasia indirecta); e) En lo relativo a la eutanasia activa, los resultados obtenidos varían según quién sea la(s) persona(s) que realice(n) la petición. Mayoritariamente se rechaza que se realice a petición de la familia o a criterio del personal médico, y se acepta cuando es la propia persona enferma quien lo solicita; f) se reconoce el papel fundamental del personal médico en la realización de la eutanasia activa, se le exonera de cualquier responsabilidad legal y se considera que no debe ser castigado por ello; g) interrogada la población encuestada sobre cuál sería su conducta personal ante la petición de suicidio asistido por parte de un familiar, los datos recabados muestran que las personas encuestadas se enfrentarían a una situación insostenible para la que no tienen recursos que ofrecer y en su mayoría no sabrían que hacer, y; h) Por último, se han sintetizado los discursos en relación a la eutanasia y al suicidio asistido de acuerdo a cuatro posiciones ideológicas: 1) Integristas estaría conformado (asumen en su integridad el argumento de la santidad de vida); 2) Conservadores (suscriben el argumento del derecho a la vida); 3) Pragmático-Tolerantes (asumen el argumento de la calidad de vida), y; 4) Permisivo-Progresistas (partidarios del argumento de la autonomía de la persona). 
Como consecuencia de todo lo anterior, se puede afirmar que es cierta asimismo la última de las hipótesis básicas consideradas por cuanto el examen de las relaciones individuo/sociedad/muerte muestra que esas relaciones se refieren también y sobre todo a la propia vida social. Es decir, tiene gran capacidad explicativa para las ciencias sociales en general, y para la Sociología en particular.

Finalmente, y a modo de recomendación, el análisis realizado detecta como una necesidad el fomento de la educación para la muerte. El gran contraste existente entre la actitudes ante las expectativas de muerte, como las examinadas en este trabajo, y las circunstancias tan especiales que concurren cuando el morir propio o de una persona próxima está cercano, recomienda cubrir esa necesidad. En efecto, al morir una persona, ella misma, además de sus familiares y allegados, interrelacionan en un proceso sumamente complejo, subjetivamente "irrepetible", y sobre el que apenas han sido socializados. Esta ausencia de vivencias "prácticas" sobre el morir llega a ser especialmente relevante por cuanto todas esas personas implicadas se hallan impactadas por el golpe que supone un diagnóstico fatal, bloqueadas, incrédulas ante lo que ocurre, paralizadas por el miedo, desoladas, desprotegidas y técnicamente analfabetas, sin respuestas ni soluciones para una situación inesperada y sobre la que no se habían preparado mínimamente y para la que en general tienen poco tiempo de actuación. Por tanto, aunque las proyecciones que pueda aportar la educación sobre el morir y la muerte sean un mero paliativo de lo que ocurrirá en la realidad pueden tener, sin embargo, y como ocurre en otros ámbitos pedagógicos del entrenamiento social, la virtud de provocar la reflexión, ampliar los conocimientos, imaginar situaciones, anticipar soluciones, y familiarizar con la discusión sobre toma de decisiones en unos procesos inevitables, esencialmente dramáticos y profundamente emotivos como son los del morir y la muerte. 


\section{BIBLIOGRAFÍA}





\section{BIBLIOGRAFÍA:}

ABAD MÁRQUEZ, L. (1994): "La construcción social de la muerte. Muerte y estructura social”, en SISTEMA, n ${ }^{\circ} 122$.

ABADI, M. et al. (1973): La fascinación de la muerte, Buenos Aires, Paidós.

ABELLÁN, A. y PUGA, M.D. (2005): “Una España que envejece”, en LEAL MALDONADO, J. (coord.): Informe sobre la situación demográfica en España, Madrid, Fundación Fernando Abril Martorell, pps. 57-75.

AGUIRRE, P. (2007): Ricos flacos y gordos pobres. La alimentación en crisis, Buenos Aires, Capital Intelectual S.A.

AHN, A.; GÈNOVA, R.; HERCE, J.A. y PEREIRA, J. (2002): Life expectancy and morbidity in Europe (AGIR proyect . WP1 on "Biodemography"), Madrid, FEDEA y ENEPRI.

ALBERT, E.M. (1975): "Sistemas de valores”, en Enciclopedia Internacional de las Ciencias Sociales, Madrid, Aguilar, pp. 611-614.

ALBERDI, I. Y ESCARIO, P. (1988): Estudio sociológico sobre las viudas en España, Madrid, Siglo XXI.

ALBIAC, G. (1996): La muerte, Barcelona, Paidós.

ALONSO, L.E. (2000): Trabajo y posmodernidad: el empleo débil, Madrid, Fundamentos.

ALLUÉ, M. (1981): “La muerte y las ciencias sociales: acerca de una bibliografía”, en Actas del

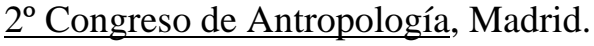

ÁLVAREZ, A. (1999): “La investigación sobre tabaquismo en España”, en Rev. Esp. Salud Pública, vol. 73, nº 3, mayo-junio, versión electrónica.

ÁLVAREZ RODRÍGUEZ, J Y DEL BARRIO YESA, R. (1999): “Donantes a corazón parado”, Curso de Postgrado: El proceso de donación y trasplante de órganos y tejidos, Universidad de Alicante, http://donacion.organos.ua.es/ proceso/corazon-parado.htm.

AMÉRY, J. (1999): Levantar la mano sobre uno mismo, Valencia, Pre-Textos.

ANDRÉS ORIZO, F. (1996): Sistemas de valores en la España de los 90, Madrid, CIS y Siglo XXI, colección “Monografías” n” 150.

ANDRÉS ORIZO, F. (1991): Los nuevos valores de los españoles, Madrid, Fundación Santa María.

ANDERSON et al. (2000): Análisis Multivariante, Madrid, Prentice Hall.

ANDRÉS ORIZO, F. (1991): Los nuevos valores de los españoles, Madrid, Fundación Santamaría.

ARANGO, J. (1980): “La Teoría de la Transición Demográfica y la experiencia histórica”, en R.E.I.S., Madrid, CIS, nº 10, pp. 169-198.

ARGULLOL, R. (2001): Davalú o el dolor, Barcelona, RBA. 
ARIÈS, P. (2000): Historia de la muerte en Occidente, Barcelona, El Acantilado, versión original 1975.

ARIÈS, P. (1987): El niño y la vida familiar en el Antiguo Régimen, Madrid, Taurus.

ARIÈS, P. (1983): El hombre ante la muerte, Madrid, Taurus, versión original 1977.

ARMSTONG, P. (1987): "Silence and Truth in Death and Dying", en Social Science and Medicine, vol. 24, nº 8, pp. 651-657.

ARNEY, W.R.; BERGEN B.J. (1984): Medicine and the Management of Living: Taming the Last Great Beast. Chicago, University of Chicago Press.

ARON, R. (1998): “Introducción”, en WEBER, M.: El político y el científico, Madrid, Alianza, pp.7-77., (v.o.1959).

ARREGUI, J. V. (1992): El horror de morir, Barcelona, Tibidabo.

ARRIOLA PALOMARES, J. (2003): “¿La globalización? ¡El poder!”, en Cuadernos Bakeaz, nº 57, Bilbao, Bakeaz.

ARROYO MÉNDEZ, Millán (2004): “Hacia una espiritualidad sin Iglesia”, en TEZANOS, J.F. (ed.): Tendencias en identidades, valores y creencias. Séptimo Foro sobre Tendencias Sociales, Madrid, Sistema, pp.409-436.

ARTAZCOZ, L.; GARCÍA, M.M.; ESNAOLA, S.; BORRELL, C.; SÁNCHEZ, J.J.; RAMOS, J.L.; MERINO, J.; DAPONTE, A.; ANITUA, C.; ROHLFS, I. y CABRERA, A. (2002): "Desigualdades de género en salud: la conciliación de la vida laboral y familar", en Informe SESPAS 2002: Invertir en salud. Prioridades para la salud pública y los servicios sanitarios, Granada, Escuela Andaluza de Salud Pública, pp. 73-90.

ARTETA, A. (1995): “Última voluntad”, en EL PAÍS, 30/01/95, pp. 14.

ARTIEDA, K. (1979): “El espectáculo de la muerte”, en El Viejo Topo, nº 30, pp. 67.

ASSAEL, H. (1984): Consumer Behavior and Marketing Action, Boston, Kent Publishing Company.

ATIENZA, J. y LUJÁN, J.L. (1997): La imagen social de las nuevas tecnologías biológicas en España, Madrid, CIS, colección Opiniones y Actitudes, $n^{\circ} 14$.

ATKINS, P. (2003): El dedo de Galileo. Las diez grandes ideas de la ciencia, Madrid, Espasa Calpe.

AUSTAD, S. (1998): Por qué envejecemos. Qué está descubriendo la ciencia sobre la transformación del cuerpo a través de la vida. España, Paidós Contextos.

BÁEZ Y PÉREZ DE TUDELA, J. (2007): Investigación cualitativa, Madrid, ESIC.

BAIRD, R.M. Y ROSENBAUM, J. (1992): Eutanasia: los dilemas morales, Barcelona, Alcor.

B.M. (1993): Informe sobre el Desarrollo Mundial 1993, Washington, Banco Mundial.

B.M. (1990): Informe sobre el Desarrollo Mundial 1990, Washington, Banco Mundial. 
B.M. (1984): Informe sobre el Desarrollo Mundial 1984, Washington, Banco Mundial.

BARAÑANO, M. (1992): “Introducción”, en BARAÑANO, M. (comp.): Mujer, Trabajo, Salud, Madrid, Ed Trotta, pp. 13-43.

BARBA, C. (1994): “Modernidad tardía y cambios en la teoría social”, en Espiral, vol. 1, nº 1, Guadalajara -México-, Universidad de Guadalajara, pp. 14-19.

BARBERO, J. y DÍAZ, L. (2007): “Diez cuestiones inquietantes en cuidados paliativos”, en An. Sist. Sanit. Navar., vol.30 (supl. 3), pp.71-86.

BARLEY, N. (2000): Bailando sobre la tumba, Barcelona, Anagrama.

BAROJA, P. (1998): El árbol de la ciencia, Madrid, Cátedra, v.o. 1911.

BARRERA TYSZKA, A. (2006): La enfermedad, Barcelona, Anagrama.

BASTERRA PÉREZ, Á. (2006): la muerte a través del discurso del personal sanitario. El caso de las instituciones hospitalarias de Alicante, Tesis doctoral, Alicante, Universidad de Alicante.

BARTHES, R. (2009): Diario de duelo, Barcelona, Paidós.

BAUDOUIN, J-L y BLONDEAU, D. (1995): La ética ante la muerte y el derecho a morir, Barcelona, Herder.

BAUDRILLARD, J. (1991): La transparencia del mal. Ensayos sobre los fenómenos extremos, Barcelona, Anagrama.

BAUDRILLARD, J. (1980): El intercambio simbólico y la muerte, Caracas, Monte Ávila.

BAUMAN, Z. (2011): 44 cartas desde el mundo líquido, Barcelona, Paidós.

BAUMAN, Z. (2007): Miedo líquido. La sociedad contemporánea y sus temores, Barcelona, Paidós.

BAUMAN, Z. (2003): Modernidad líquida, México, FCE.

BAUMAN, Z. (2001): La sociedad individualizada, Madrid, Cátedra.

BAUMAN, Z. (1997): Modernidad y Holocausto, Madrid, Sequitur.

BAUMAN, Z. (1995): Life in Fragments: Essays in Postmodern Morality, Oxford, Blackwell.

BAUMAN, Z. (1992): Mortality and Inmortality and Other Life Strategies, Cambridge, Polity Press.

BEAUVOIR, S. DE (1982): Una muerte muy dulce, Barcelona, Edhasa.

BECK, U. (2002): La sociedad del riesgo global, Barcelona, Siglo XXI.

BECK, U. (1998): ¿Qué es la globalización?. Fala-cias del globalismo, respuestas a la globalización, Barcelona, Paidós.

BECK, U. (1994): Risk Society, Londres, Pollity Press. 
BECK, U. Y BECK-GERNSHEIM, E. (2003): La individualización. El individualismo institucionalizado y sus consecuencias sociales y políticas, Barcelona, Paidós.

BECK, U. Y BECK-GERNSHEIM, E. (1998): El normal caos del amor, Barcelona, El Roure Editorial.

BECK, U.; GIDDENS, A. y LASH, S. (1994): Reflexive Modernization, Londres, Polity Press.

BECKER, E. (2003): La negación de la muerte, Barcelona, Cairos, v.o. 1973.

BECOÑA, E. y VÁZQUEZ, F.L. (2000): "Las mujeres y el tabaco: características ligadas al género”, en Rev. Esp. Salud Pública, vol. 74, nº 1, enero-febrero, versión electrónica.

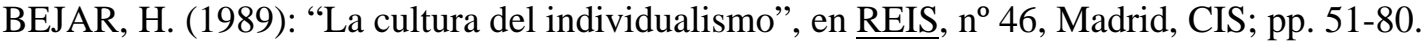

BELTRÁN, M. (2002): “A vueltas con los <<terremotos>> demográficos en España”, R.E.I.S., $\mathrm{n}^{\circ}$ 100, Madrid, CIS, pp.83-102.

BELTRÄN, M. (1998): "Valor”, en GINER, S.; LAMO DE ESPINOSA, E. y TORRES, C. (eds.): Diccionario de Sociología, Madrid, Alianza, pp. 811-812.

BELTRÁN, M. (1992): “Terremotos en los cimientos de la estructura social española”, en VV.AA.: Escritos de Teoría sociológica en homenaje a Luis Rodríguez Zúñiga, Madrid, C.I.S., pp.135-144.

BELL, D. (1976): El advenimiento de la sociedad postindustrial. Un intento de prognosis social, Madrid, Alianza.

BENACH, J. (2000): “La desigualdad daña la salud de los españoles”, en EL PAÏS, 14/11/00, pp.42.

BENACH, J. y URBANOS, R.M. (2000): “Objetivo 1: lograr equidad en salud”, en ÁLVAREZ, C Y PEIRÓ, S. (eds.): Informe SESPAS 2000: La salud pública ante los desafíos de un nuevo siglo, Granada, Escuela Andaluza de Salud Pública.

BENAVENTE FARÍAS, C.A. (2005): La rebelión contra el cuerpo, Tesis de grado en artes, Santiago de Chile, Universidad de Chile, Facultad de Artes.

BENJAMIN, B. (1987): "Consecuencias de los niveles y diferenciales de mortalidad y morbilidad para los planes de seguros y de pensiones”, en N.U.: Consecuencias de las tendencias y diferenciales de la mortalidad, Nueva York, Naciones Unidas, pp.176-185.

BERGER, J. (1996): Páginas de la herida, Madrid, Alfaguara, colección Visor de Poesía.

BERGER, P. (1999): El dosel sagrado. Por una teoría sociológica de la religión, Barcelona, Kairos, $3^{\mathrm{a}}$ ed. (v.o. 1967).

BERGER, P., BERGER, B. Y KELLNER, H. (1974): The Homeless Mind: modernization and consciousness, Londres, Penguin. Citado en Walter (1994:54).

BERGER, P. y LUCKMANN, T. (1972): La construcción social de la realidad, Buenos Aires, Amorrortu, $2^{\mathrm{a}}$ ed.

BERGERE, J.A. (1998): “Actitud”, en GINER, S.; LAMO DE ESPINOSA, E. y TORRES, C. (eds.): Diccionario de Sociología, Madrid, Alianza, pp. 8-9. 
BERICAT, E. (ed.) (2003): El conflicto cultural en España. Acuerdos y desacuerdos entre los españoles, Madrid, CIS y Siglo XXI, colección “Monografías” nº 202.

BERICAT, E. (2003a): “¿Existe riesgo de una nueva guerra cultural en España?”, en BERICAT, E. (ed.) (2003): El conflicto cultural en España. Acuerdos y desacuerdos entre los españoles, Madrid, CIS y Siglo XXI, colección “Monografías” n 202, pp. 1-52.

BERICAT, E. (2003b): "La religiosidad contemporánea: entre la secularización moderna y la espiritualidad posmoderna”, en BERICAT, E. (ed.) (2003): El conflicto cultural en España. Acuerdos y desacuerdos entre los españoles, Madrid, CIS y Siglo XXI, colección “Monografías" n 202, pp. 268-327.

BERICAT, E. (2003c): “Anexo. Diseño teórico y metodológico de la investigación”, en BERICAT, E. (ed.) (2003): El conflicto cultural en España. Acuerdos y desacuerdos entre los españoles, Madrid, CIS y Siglo XXI, colección “Monografías” n² 202, pp. 1-52, pp. 387-400.

BERICAT, E. (2003d): “Fragmentos de la realidad social posmoderna”, en Reis, $\mathrm{n}^{\circ}$ 102, pp.945.

BERNABEU MESTRE, J. (2010): Sesiones 5/6 Un epílogo incierto: población y salud en el marco de la globalización y de una nueva revolución epidemiológica, material repartido en el Master en Salud Pública, Escuela Nacional de Sanidad.

BERNABEU MESTRE, J. Y ROBLES, E. (2000): “Demografía y problemas de salud. Unas reflexiones críticas sobre los conceptos de transición demográfica y transición sanitaria”, en Política y Sociedad, Madrid, ${ }^{\circ}$ 35, pp. 45-54.

BERNABEU MESTRE, J. (1994): Enfermedad y población, Valencia, Seminari d’Estudis sobre la Ciencia, Monografías, $n^{\circ} 5$.

BERNAT, J.L. (1997): Repensar la vida y la muerte. El derrumbe de nuestra ética tradicional, Barcelona, Paidós.

BERNAT, J.L. (1992): "How much of the brain must die on brain death?”, en Journal of Clinics Ethics, 3, pp. 21-26.

BERNIS, C. (2004): "Envejecimiento, poblaciones envejecidas y personas ancianas", en Antropo, 6, pp. 1-14, www.didac.ehu.es/antropo.

BINSTOCK, R.M. y SHANAS, E. (ed.)(1985): Handbook of Aging and the Social Sciences, Nueva York, van Nostrand Reinhold Company ( $2^{\mathrm{a}}$ ed.).

BIÒETICA \& DEBAT (10/03/05a): Posición de la Academia Americana de Neurología sobre el EVP, documento electrónico http://www.bioetica-debat.org/article.php?storyid=11.

BIÒETICA \& DEBAT (10/03/05b): Diagnóstico del EV: aspectos clínicos y éticos, documento electrónico http://www.bioetica-debat.org/article.php?storyid=12.

BLANCK-CEREIJIDO, F. Y CEREIJIDO, M. (1996): La vida, el tiempo y la muerte, México, FCE.

BLANES LLORENS, A. (2007): La mortalidad en la España del siglo XX. Análisis demográfico y territorial, Barcelona, Tesis doctoral Departamento de Geografía, Facultad de Filosofía y Letras, Universidad Autónoma de Barcelona. 
BLASCO, M. (2008): “¿Se puede detener la máquina del tiempo del organismo?”, en EL CULTURAL, 18/12/08, pp.44-45.

BLAUNER, R. (1966): “Death and Social Structure”, en Psychiatry, $\mathrm{n}^{\circ}$ 29, pp.378-394, citado en (Walter, 1991).

BLECH, J. (2004): Los inventores de enfermedades. Cómo nos convierten en pacientes, Barcelona, Destino.

BLOCH, M.; PARRY, J. (eds) (1982): Death and the Regeneration of Life, Cambridge, Cambridge University Press.

BLUMER, H. (1982): El interaccionismo simbólico: perspectiva y método, Barcelona, Ed. Hara.

BOND, J.; COLEMAN, P.; PEACE, S.M.( eds) (1993): Ageing in Society. An Introduction to Social Gerontology, Londres, SAGE.

BONGAARTS, J. (2006): “How Long will we live?”, en Population and Development Review, vol. 32, no 4 , pp. 605-628.

BOTKIN, J.R. Y POST, S.G. (1993): "Confusion in the Determination of Death: Distingnishing Philosophy from Physiology”, en Perspectives in biology and Medicine, ${ }^{\circ}$ 36, pp. 129-138.

BOULDING, K. (1978): Ecodynamics. A new Theory of Societal Evolution, Bervely Hills, Londres, Sage P., citado en FERNÁNDEZ BUEY, F. (1998): Sobre el nacer y el morir. Controversias contemporáneas acerca del aborto y la eutanasia”, en Ética y filosofía política A, Tema 6, http://www.upf.es/iuc/buey/etica-a/tema6.htm.

BOURDIEU, P. (2002): Lección sobre la lección, Barcelona, Anagrama, (v.o. 1982).

BOURDIEU, P. (2000): La dominación masculina, Barcelona, Anagrama.

BOURDIEU, P. (1998): “Neoliberalismo: La lucha de todos contra todos”, edición electrónica http://www.rebelion.org/hemeroteca/sociales/bordieu260302.htm.

BOUTHOUL, G. (1982): Las Mentalidades, Barcelona,

BOWKER, J. (1996): Los significados de la muerte, Cambridge, Cambridge University Press.

BUSTELO, F. (1985): “La población española del siglo XIX: un crecimiento preindustrial”, en Información Comercial Española, $n^{\circ}$ 623, julio.

Brzezinski, Z. ()

CABRÉ, A. y PÉREZ DÍAZ, J. (1995): “Envejecimiento demográfico en España”, en SECOT: Las actividades económicas de las personas mayores, Madrid, Central Hispano, pp. 33-60.

CACABELOS, R. (2001): Trascripción de la entrevista al Director del Centro de Investigación Biomédica Euroespes en el programa de televisión ㅌDES, nº 191, 25/02/01.

CAÏS, J.; CASTILLA, E.J. y DE MIGUEL, J-M. (1993): "Desigualdad y morbilidad”, en I Simposio sobre igualdad y distribución de la renta y la riqueza, vol. VIII: El impacto de las políticas sociales: educación, salud y vivienda, Madrid, Fundación Argentaria, pp. 65-112. 
CALDWELL, J.C. (2001): "Population health in transition”, en Bulletin of The World Health Organization, 79(2), pp. 159-170.

CALDWELL, J.C. (1996): "Health Transition", en KUPER, D. y KUPER, J.: The Social Science Enciclopedy, Londres, Routledge, pp. 357-358.

CALDWELL, J.C. (1991): "Mayor new evidence on health transition and its interpretation”, en Health Transition Review, vol. 1, pp. 221-229.

CALDWELL, J.C. (1987): "La función de la declinación de la mortalidad en las teorías de la transición social y demográfica”, en N.U.: Consecuencias de las tendencias y diferenciales de la mortalidad,..., pp. 261-387.

CALDWELL, J.C. (1981): “The mechanisms of demographic change in historical perspective”, en Population Studies, 1.

CALDWELL, J.C. (1979): "Education as a Factor in Mortality Decline An Examination of Nigerian Data”, en Population Studies, vol. 33, nº 3, pp. 395-413.

CALLAHAN, D. (2004): Poner límites. Los fines de la medicina en una sociedad que envejece, Madrid, Triacastela, (v.o. 1995).

CAMPO, S. DEL (1988): "Demografía Mundial”, en CAMPO, S. DEL (ed.): Tratado de Sociología, vol. 1, Madrid, Taurus, pp. 191-235.

CAMPO LADERO, M.J. (2002): Relaciones interpersonales: Valores y actitudes de los españoles en el nuevo milenio, Madrid, CIS, Colección “Opiniones y Actitudes”, nº 46.

CAMPS, V. (2001): Una vida de calidad. Reflexiones sobre bioética, Barcelona, Crítica.

CAMUS, A. (1981): El mito de Sísifo, Madrid, Alianza, v.o. 1942.

CANDWELL, J.C. Y SANTOW, G. (2001): Selected Readings in the Cultural, Social and Behavioural Determinants of Health, NCEPH, Health Transitions Series Book ${ }^{\circ} 1$.

CANETTI, E. (2000): Masa y poder, Barcelona, Muchnik Editores S.A. (v.o. 1960).

CAREY, J.R. Y GRUENFELDER, C. (1997): "population Biology of the Elderly", en WACHTER, K.W. Y FINCH, C.E. (eds.): Between Zeus and the Salmon. The Biodemography of Longevity, Washington, National Academy Press, pp.127-160.

CARMONA FERNÁNDEZ, F.J. (2005): “La Religión”, en IGLESIAS ET AL.: Leer la sociedad, Madrid, Tecnos, pp. 475-503.

CARPINTERO, M.C. (1987): “El impacto tecnológico sobre el concepto de muerte”, en VÁZQUEZ, J.M. (dir.): Antropología de la vida cotidiana, Madrid, Instituto de Sociología Aplicada, pp. 109-116.

CARRANZA, M.E. y PULEO, A. (2002): "Influencia de la doble jornada en la salud de las mujeres”, en GARCÍA COLMENARES, C.; PULEO, A. y CARRANZA, M.E.: El trabajo y la Salud de las mujeres. Reflexiones para una sociedad en cambio, Palencia, Ayuntamiento de Palencia y Ediciones Cálamo, pp. 13-49. 
CARSE, J.P. (1987): Muerte y existencia. Una historia conceptual de la mortalidad humana, México, F.C.E.

CASADO, M. y ROYES, A. (coords.) (2003): Documento sobre la disposición de la propia vida en determinados supuestos: declaración sobre la eutanasia, Barcelona, Observatori de Bioètica i Dret.

CASADO, M. (1996): "La controversia sobre la eutanasia”, en VV.AA.: En el límite de los derechos, Barcelona, EUB, pp. 165-186.

CASELLI, G. Y VALLIN, J. (2001): “Une démographie sans limite?”, en Population, vol. 56, no 1-1, pp. 51-84.

CASELLI, G.; MESLÉ, F. y VALLIN, F. (1995): Le triomphe de la médicine. Évolution de la mortalité depuis le début dus siècle, París, INED, Dossier et Recherches, nº 45.

CASELLI, G. y EGIDO, V. (1995): "Nuevas formas de supervivencia: la duración y la calidad de vida", en $\mathrm{M}^{\circ}$ de TRABAJO Y S.S.: El capital humano en el umbral del siglo XX, Madrid, Colección Seguridad Social, pp. 217-258.

CASELLI, G. (1993a): “L'évolution à long terme de la mortalité en Europe”, en BLUM, A. y RALLY, J-L.: European populatio. Demographie dynamics, París, INED, pp. 111-164.

CASELLI, G. (1993b): "Future longevity Among The Elderly: Causes of Death and Survival at the Down of The $21^{\text {st }}$ Century: An International Perspective”, en N.U.; Conference on Health and Mortality Trends among Elderly Populations: Determinants and Implications, Japón, Naciones Unidas.

CASELLI, G. (1993c): “Nacional Differences in the Health Transition in Europe”, ponencia presentada en The History of Registration of Causes of Death Conference, Indiana University, Noviembre 11-14.

CASELLI, G.; DUCHENE, J. y WUNSCH, G. (1988): Une methodologuie pour l'analyse comparative de la mortalite differentielle, Working Paper, $\mathrm{n}^{\circ} 140$, Departement de Démographie, U.C.L., Lovaina la Nueva, 14 pp.

CASTELLS, M.; TUBEDA, I.; SACHO, T. y ROCA, M.(2007): La transición a la sociedad red, Barcelona, Ariel.

CASTELLS, M. (1997): La era de la información. La sociedad red, vol. I, Madrid, Alianza

CASTILLA DEL PINO, C. (1995): Celos, locura, muerte, Madrid, Ediciones Temas de Hoy.

CASTILLA DEL PINO, C. (1974): “Experiencia y expectativas ante la muerte”, prólogo a la edición española de HINTON, J.: Experiencias sobre el morir, Barcelona, Ariel.

CATEDRA, M. (1988): La Muerte y otros Mundos, Madrid, Jucar.

CAUCHARD, P. (1960): La Muerte, Buenos Aires, Paidós.

CECA (2005): Papeles de Economía Española. Transformaciones demográficas, raíces y consecuencias, $\mathrm{n}^{\circ}$ 104, Madrid, CECA.

CEPAL (2002): Vulnerabilidad sociodemográfica: viejos y nuevos riesgos para comunidades, hogares y personas, Documento electrónico LC/W.3. 
CIORAN, E.M. (1995): Del inconveniente de haber nacido, Madrid, Taurus.

CIPOLLA, C.M. (1980): Historia económica de la población mundial, Barcelona, Crítica.

CIRES (1993): Actitudes sociales hacia la Ciencia y la Tecnología.

CIS (2009): Atención a pacientes con enfermedades en fase terminal, Madrid, CIS, Estudio ${ }^{\circ}$ 2.803 .

CIS (2002): Actitudes y opiniones de los médicos ante la eutanasia, Madrid, CIS, Estudio $\mathrm{n}^{\circ}$ 2.451 .

CIS (1990): Estudios y Encuestas, nº 20, Madrid, CIS.

CIS (1989): Encuesta general de población, Madrid, CIS.

CIS (1989a): Problemas sociales: Actitudes y opinión de los españoles ante la natalidad, el aborto y la eutanasia, Madrid, CIS, colección Estudios y Encuestas, nº 16.

CLARK, D. (2002): "Between hope and acceptance: the medicalisation of dying”, en sw, vol.324, 13/04/02, pp.905-907.

CLARK, D. (ed.) (1993): The Sociology of Death: Theory, Culture, Practice, Oxford, Blackwell Publishers.

CLELAND, J.; HILL, A.G. (eds) (1991): The Health Transition: Methods and Measures, Camberra, Health Transition Centre for Epidemiology.

COETZEE, J.M. (2003): La edad de hierro, Barcelona, Mondadori.

COLLINS, F. (2007): Entrevista de J. López Rejas en EL CULTURAL, 24/05/07, pp.79-81.

COMAS ARNAU, D. (2004): "La transición religiosa en España: catolicismo, secularización y diversidad”, en TEZANOS, J.F. (ed.): Tendencias en identidades, valores y creencias. Séptimo Foro sobre Tendencias Sociales, Madrid, Sistema, pp.317-352.

COMELLES, J.M. Y MARTÍNEZ HERNÁEZ, A.M. (1993): Enfermedad, cultura y sociedad. Un ensayo sobre las relaciones entre la Antropología Social y la Medicina, Madrid, Eudema.

COMISIÓN CIENTÍFICA DE ESTUDIOS DE LAS DESIGUALDADES SOCIALES EN SALUD EN ESPAÑA -CCEDSSE (1996): Desigualdades Sociales en Salud en España, Madrid, $\mathrm{M}^{\mathrm{o}}$ de Sanidad y Consumo.

COMISIÓN DE LAS COMUNIDADES EUROPEAS (1995): Informe sobre la situación de la salud en la C.E., Bruselas, COM(95)357final.

CONSEJO DE EUROPA (1991): The second demographic transition: fact or fiction, Estrasburgo, Population Studies, $\mathrm{n}^{\circ} 23$.

CORDERO, C. Y DÍEZ RAMOS, M.A. (1988): “La extemporaneidad social de la muerte”; en SISTEMA, nº 82, pp.101-115.

CORINNE, G. (2008): Peligro: los aditivos alimentarios: la guía indispensable para que no te envenenen más, Barcelona, Obelisco. 
CORTÉS, ALCALÁ, L. (1998): “Urbanización”, en GINER, S.; LAMO DE ESPINOSA, E. Y TORRES, C. (eds.): Diccionario de Sociología, Madrid, Alianza, p. 807.

CORTINA, M. y DE LA HERRÁN, A. (2011): Pedagogía de la Muerte a través del cine, Madrid, Universitas.

COUCEIRO, A. (ed.) (2004): Ética en cuidados paliativos, Madrid, Triacastela.

COUCEIRO, A. (2003): "La sedación de los enfermos terminales en el contexto de los cuidados paliativos”, en VV.AA.: Ética y sedación al final de la vida, Barcelona, Fundació Víctor Grífols i Lucas, Cuadernos de la Fundación, nº 9, pp.29-58.

CRICK, F. (1994): La búsqueda del alma. Una revolucionaria hipótesis para el siglo XXI, Madrid, Debate.

CUENCA, J.A. (2006): Intuiciones sobre el final de la vida: "Yo", eutanasia y suicido asistido, Curso "Master en Bioética”, Instituto Borja de Bioética, Universidad Ramón Llull.

CUENDE, N. y DE LA ROSA, G. (2008): "Programas de calidad en la donación de órganos”, en MATESANZ, R. (ed.): Modelo Español de Coordinación y Trasplantes, Organización Nacional de Trasplantes y Aula Médica Ediciones, cap. 10.

CUENDE, N.; SÁNCHEZ, J.; CAÑÓN, J.F.; ÁLVAREZ, J.; ROMERO, J.; MARTÍNEZ, J.; MACÍAS, S. y MIRANDA, B. (2004): "Mortalidad hospitalaria en unidades de críticos y muertes encefálicas según los códigos de la Clasificación Internacional de Enfermedades”, en Med. Intensiva, 28(1), pp. 1-10.

CUMMINS, R.A. (1997): Comprenhensive Quality of life Scale-Adult: Manual, Melburne, School of Psychology, Deakin University, citado en FERNÁNDEZ-MAYORALAS, G. et al. (2007:2).

CHAMIE, J. (1999), “Introducción”, en N.U. y OMS: Health and Mortality Issues of Global Concern. Proceedings of the Symposium on Health and Mortality. 1997, Nueva York, Naciones Unidas, pp. 1-2.

CHESNAIS, F. (1988): La revancha del Tercer Mundo, Barcelona, Planeta.

DAGERMAN, S. (2007): Nuestra necesidad de consuelo es insaciable..., Logroño, Pepitas de calabaza ed., v.o. 1952.

DAWKINS, R. (2004): "Los genes y el pasado”, en PUNSET, E.: Cara a cara con la vida, la mente y el Universo. Conversaciones con los grandes científicos de nuestro tiempo, Barcelona, Destino, cap. X No evolucionamos hacia algo mejor y más grande, pp.258-263.

DAWKINS, R. (2000): El gen egoísta. Las bases biológicas de nuestra conducta, Barcelona, Salvat Ciencia (v.o. 1976).

DAY, L. (1991): “Upper-Age Longevity in Low-Mortality Countires: a Dissenting Wiew”, en LUTZ, W. (ed.): Future demographic trends in Europe and North America. What can we Assume Today?, Londres, Academic Press Limited, pp. 117-128.

DE GREY, A. (2005): Trascripción de la entrevista realizada por E. Punset en el programa de TVE REDES, nº 365, 20/09/05, 4 pp. 
DE GREY, A. (2004): Entrevista en BBCMundo, 05/12/04. Accesible en http://axxon.con.ar/145/c-1450033.htm.

DE LA HERRÁN, A. y CORTINA, M. (2006): La muerte y su didáctica. Manual para Educación Infantil, Primaria y Secundaria, Madrid, Universitas.

DE MIGUEL, A. (1994): La sociedad española, 1993-94, Madrid, Alianza.

DE MIGUEL, A. (1987): España cíclica. Ciclos económicos y generaciones demográficas en la sociedad española contemporánea, Madrid, Fundación Banco Exterior.

DE MIGUEL, A. (1982): Diez errores sobre la población española, Madrid, Tecnos.

DE MIGUEL J. (1995): “<<El último deseo>>: Para una sociología de la muerte en España”, en R.E.I.S., $n^{0}$ 71-72, pp. 109-156.

DI NOLA, A. (2007): La muerte derrotada. Antropología de la muerte y el duelo, Barcelona, Belacqva.

DI NOLA, A. (2006): La negra señora. Antropología de la muerte y el luto, Barcelona, Belacqva.

DICKENSON, D. y JOHNSON, M. (comp.) (1993): Death, Dying and Bereavement, Londres, Sage.

DIEZ NICOLAS, J. e INGLEHART, R. (eds.) (1990): Tendencias mundiales de cambios en los valores sociales y políticos, Madrid, Fundesco.

DMD (2003): “La punibilidad de los comportamientos eutanásicos”, en Archipiélago, $\mathrm{n}^{\circ}$ 56, pp.116-118.

DOMINGO-RODRIGO, M. (1997): El primate excepcional. El origen de la conducta humana, Barcelona, Ariel.

DOPICO, F. y REHER, D-S. (1998): El declive de la mortalidad en España, 1860-1930, Huesca, Asociación de Demografía Española, Monografías, nº 1.

DUCHEME, J. y WUNSCH, G. (1988): Population Aging and The Limits to Human Life, Lovaina, Universidad Católica de Lovaina, Working Paper, n 146.

DUKE, R.C.; OJCIUS, D.M. y YOUNG, J. D-E. (1997): "Suicidio celular, en la salud y en la enfermedad”, en Investigación y ciencia, Febrero, pp. 44-52.

DURÁN, M.A. (2005): Entrevista en EL PAÍS. Domingo, 25/09/05, pp.6-7.

DURÁN, M.A. (2004): “La calidad de muerte como componente de la calidad de vida”, en REIS, no 106, Madrid, CIS, pp. 9-32.

DURÁN, M.A. (2003): Diario de una batalla. Mi lucha contra el cáncer, Madrid, Aguilar.

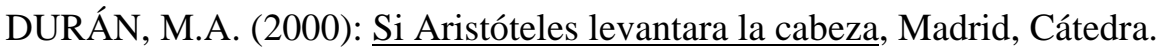

DURÁN, M.A. (1992): “Salud y sociedad: Algunas propuestas de investigación”, en BARAÑANO, M. (comp.): Mujer, Trabajo, Salud,..., pp. 57-79. 
DURÁN, M.A. (1988): De puertas adentro, Madrid, Mº Asuntos Sociales.

DURÁN, M.A. (1986): La jornada interminable, Barcelona, Icaria.

DURÁN, M.A. (1985): "Las bases biológicas de la estructura social”, en CAMPO, S. DEL (ed.): Tratado de Sociología, vol. 1, Madrid, Taurus, pp. 97-117.

DURAN, M.A. (1983): Desigualdad social y enfermedad, Madrid, Tecnos.

DURÁN, A. y RIECHMANN, J. (coords.)(1998): Genes en el laboratorio y en la fábrica, Madrid, Trotta y Fundación $1^{\circ}$ de Mayo.

DURKHEIM, E. (2004): El suicidio, Madrid, Losada, v.o. 1897.

DURKHEIM, E. (1993): Las formas elementales de la vida religiosa, Madrid, Alianza.

EHEMU (2007): Interpreting health expectancies. Technical report 1, Junio, http://www.ehemu.eu/pdf/Report_year_3/Technical report_2007_1.pdf.

EHEMU (2005): Are we living longer, healthier lives in the EU?. Disability-Free Life Expectancy (DFLE) in EU Countries from 1991 to 2003 based on the European Community \begin{tabular}{llllll}
\hline Household & Panel & (ECHP). & Technical & report & Julio,
\end{tabular} http://www.ehemu.eu/pdf/EHEMU_Technical_Report_2005_2.pdf.

EHRENREICH, B. (2011): Sonríe o muere. La trampa del pensamiento positivo, Madrid, Turner.

ENCICLOPEDIA BRITÁNICA (1987): “Death”, en MACROPEDIA, vol. 16, pp. 1030-1042.

ELIAS, N. (1987): La soledad de los moribundos, México, F.C.E..

ELLIOT, G. (1973): El libro de los muertos del siglo XX, Barcelona, Dopesa.

EPICURO (1999): Obras completas, Madrid, Cátedra.

EPSTEIN, H (1999): "Vida y muerte en la escala social", en Revista de Occidente, nº 215, pp. 19-46.

ESCALANTE, J.L. (1996): “La definición de muerte”, en GAFO, J. (ed.): Transplantes de órganos: problemas técnicos, éticos y legales, Madrid, Universidad Pontificia Comillas, pp. 5374.

ESCUDERO, D.; MATESANZ, R.; SORATTI, C.A. y FLORES, J.I. (2009): “Consderaciones generales sobre la muerte encefálica y recomendaciones sobre las decisiones clínicas tras su diagnóstico”, en Med. Intensiva, doi:10.1016/ j.medin.2009.06.004.

ESCUDERO, D. (2008): “La Muerte Encefálica. Exploración clínica y métodos diagnósticos instrumentales”, en MATESANZ, R. (ed.): Modelo Español de Coordinación y Trasplantes, Organización Nacional de Trasplantes y Aula Médica Ediciones, cap. 8.

EUROSTAT (1999): Demographic statistics. Data 1960-99, Luxemburgo, Comisión Europea.

EUROSTAT (1998): Long-term mortality scenarios for the countries of European Economic Area, (3/1998/E/n $\left./ \mathrm{n}^{\circ}\right)$. 
FAO/OMS (2003): Informe sobre dieta, nutrición y prevención de enfermedades crónicas, Ginebra, Organización Mundial de la Salud.

FAO/OMS (1999): $49^{\circ}$ Informe del Comité Mixto FAO/OMS de Expertos en Aditivos Alimentarios, Ginebra, Organización Mundial de la Salud.

FEATHERSTONE, M.; HEPWORTH, M.; TURNER, B. (eds) (1991): The Body: Social Process and Cultural Theory, Londres, SAGE.

FEIFEL, (1959): The meaning of death, Nueva York, McGraw-Hill, p. 128, citado en (WONG, P.T.; REKER, G.T. Y GESSER, G., 1997:138).

FERICGLA, J.M. (1992): Envejecer, Barcelona, Anthropos.

FERNÁNDEZ, E.; SCHIAFFINO, A.; BORRÀS, J.M.; SHAFEY, O; VILLALBÍ, J.R. Y LA VECCHIA, C. (2003): "Prevalence of cigarette smoking by birth cohort among males and females in Spain, 1910-1990”, en European Journal of Cancer Prevention, n 12, pp.57-62.

FERNÁNDEZ, E.; BORRÀS, J.M.; LEVI, F.; SCHIAFFINO, A.; GARCÍA, M. y LA VECCHIA, C. (2000): “Mortalidad por cáncer en España, 1955-1994”, en Medicina clínica, vol. 114, n 12 , pp.449-451.

FERNÁNDEZ-MAYORALAS, G.; MARTÍNES, P.; ROJO, F.; FORJAZ, J., PRIETO, M.E.; FRANDES, B.; LEÓN, B. Y GARCÍA, C. (2007): El significado de la salud en la calidad de vida de los mayores, Madrid, Portal Mayores, Informes $n^{\circ} 74$.

FERNÁNDEZ BUEY, F. (1998): “Tema 6: Sobre el nacer y el morir. Controversias contemporáneas acerca del aborto y la eutanasia”, Curso Ética y Filosofía Política A, Universidad Pompeu Fabra, accedido a través de http://www.upf.es/iuc/buey/etica-a/tema6.htm, pp. 9-13.

FERRATER MORA, J. (1988): El ser y la muerte, Madrid, Alianza.

FIELD, D. (1989): Nursing the Dying, Londres, Routledge.

FINCH, C.E. (1998): "Variations senescence and longevity include the possibility of negligible senescence” en Journal Gerontology A Biolo. Science Medi. Science, nº 53, pp. 235-239.

FLINN, M.W. (1989): El sistema demográfico europeo, 1500-1820, Barcelona, Crítica.

FLOREY, CH. (1992): “De la Epidemiología a la Salud Pública”, ponencia presentada en el II Encuentro Marcelino Pascua, Madrid, 12/07/92.

FOESSA (1994): V Informe sociológico sobre la situación social en España, Madrid, Fundación Foessa.

FOESSA (1976): Estudios sociológicos sobre la situación social de España 1975, Madrid, Ed. Euroamericana.

FOGEL, R.W. (1997): "New findings on secular trenes in nutrition and mortality. Some implications for population theory", en ROZENWEIG, M.R. y STARK, O. (eds.): $\underline{\text { Handbook of }}$ Population and Family Economics, vol.1A, Amsterdam, Elsevier, pp. 434-481.

FOLTA, R. Y DECK, E.F. (1974): “Reconstrucción Social Después de la Muerte”, en VV.AA.: Sociología de la Muerte, Madrid, Tribuna Médica. 
FORD, R. (2010): Mi madre, Barcelona, Anagrama.

FOSSSEY, D. (1988): Gorilas en la niebla, Barcelona, Biblioteca Científica Salvat, nº 2.

FOUCAULT, M. (1978): Historia de la sexualidad, 1. La voluntad de saber, Madrid, Siglo XXI, pp. 161-194.

FOURSTIÉ, J. (1954): "De la vie tradidionelle á la vie tertiaire ", en Population , julio-sept., citado en PRESSAT, R. (1985) : Introducción a la Demografía, Barcelona, Ariel, pp.70.

FOUTS, R. (1999): Primos hermanos, Barcelona, Ediciones B.

FOX, N. (1993): Postmodernism, Sociology and Health, Buckingham, Open University Press.

FRANKL, V.E. (1981): El hombre en busca de sentido, Barcelona, Herder.

FRENK, J. (1994): “La dinámica de la salud”, en FRENK, J.: La salud de la población. Hacia una nueva salud pública, México D.F., F.C.E. y CONACYT, cap. III.

FRENK, J.; BOBADILLA, J.L.; STERN, C.; FREJKA, T. y LOZANA, R. (1991): "Elements for a theory of the health transition”, en Health Transition Review, vol.1, n 1 , pp. 21-38.

FREUD, S. (1990): El malestar en la cultura, Madrid, Alianza.

FRIES, J.F. (2002): "Reducing disability in older age”, en JAMA, vol. 288, n 24, pp. 31643166.

FRIES, J.F. (1989): “The comprensión of mortality: near or far?”, en The Milbank Quarterly, vol. 67, pp. 208-232.

FRIES, J.F. (1980): “Aging, natural death, and the comprenssion of morbidity”, en The New England Journal of Medicine, vol. 303, n 3, Julio, pp. 130-135.

FROMM, E. (1980): ¿Tener o Ser?, Madrid, F.C.E.

FULD, W. (2004): Diccionario de últimas palabras, Barcelona, Seix-Barral.

FULTON, R. (1965): Death and Identity, Nueva York, John Wiley and Sons Inc.

FUNDACIÓN BBV (1993): El proyecto Genoma Humano: Ética, Bilbao, Fundación BBV.

FUNDACIÓ VÍCTOR GRÍFOLS i LUCAS (2003): Ética y sedación al final de la vida, Barcelona, Cuadernos de la Fundació Víctor Grífols i Lucas, no 9

GALEANO, E. (2008): El libro de los abrazos, Madrid, Siglo XXI.

GAMONEDA, A. (2003): Arden las pérdidas, Barcelona, Tusquets.

GARCÍA BARRENO, P. (2001): “La vejez transparente”, en EL CULTURAL, 21/03/01, PP.64-65.

GARCÍA BARRENO, P. (1998): “Muerte celular programada”, en ABC Cultural, 10/12/98, pp. 60. 
GARCÍA BENAVIDES, F. (1992): "La Epidemiología $<<$ moderna $>>$ y la $<<$ nueva $>>$ Salud Pública”, ponencia presentada en II Encuentro Marcelino Pascua, Madrid, 12/06/92.

GARCÍA BENAVIDES, F.; SEGURA, A. y GODOY, C. (1991): "Estadísticas de mortalidad en España. Pequeños problemas, grandes perspectivas”, en Revisiones en Salud Pública, nº 2.

GARCÍA DÜTTMANN, A. (1995): La discordia del sida. Cómo se piensa y se habla acerca de un virus, Madrid, Anaya \& Mario Muchnik.

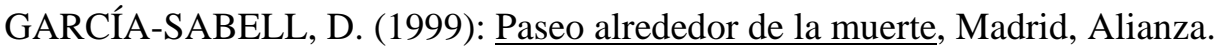

GARRIDO MEDINA, L. (1996): “La revolución reproductiva”, en CASTAÑO, C. Y PALACIOS, S. (eds.): Salud, dinero y amor. Cómo viven las mujeres españolas de hoy, Madrid, Alianza, pp. 205-238.

GEE, E.M. Y VEEVERS, J.E. (1977): “Accelerating Sex Differentials in Mortality: An Analisis of Contributing Factors”, en Social Biology, vol. 30, nº 1, pp. 75-85.

GÈNOVA, R., ÁLVAREZ, E. Y MORANT, C. (2006): “Carga de enfermedad y tendencias de morbilidad de la población española”, en PUYOL, R. Y ABELLÁN, A. (coord.): Envejecimiento y Dependencia. Una mirada al panorama futuro de la población española, Madrid, Mondial Assitance, pp.91-108.

GÈNOVA, R. Y PEREIRA, J. (2003): “Las expectativas de salud”, en IMSERSO: Las personas mayores en España. Informe 2002, Madrid, Observatorio de Portal Mayores del Imserso, pp.513-547.

GÈNOVA, R. (1994): “Estudio de la mortalidad”, en VINUESA, J. (ed.): Demografía. Análisis y Proyecciones, Madrid, Síntesis, cap. 3.

GIDDENS, A. (2002): Sociología, Madrid, Alianza.

GIDDENS, A. (2000): Un mundo desbocado. Los efectos de la globalización en nuestras vidas, Madrid, Taurus.

GIDDENS, A. (1997): Modernidad e identidad del yo, Barcelona, Península.

GIDDENS, A. (1993): Consecuencias de la mordernidad, Madrid, Alianza Universidad.

GIL ALONSO, F. Y CABRÉ, A. (1997): “El crecimiento natural de la población española y sus determinantes”, en PUYOL, R. (ed.): Dinámica de la población en España, Madrid, Síntesis, pp. 64-91.

GIL VILLA, F. (2011): La derrota social de la muerte, Madrid, Abada Editores.

GILDER, S.S.B. (1968): “Twenty-second World Medical Assembly”, en British Medical Journal, 3, pp. 493-494.

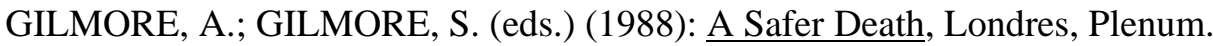

GIMENO, L. (2001): Actitudes hacia la inmigración. Relación entre las investigaciones cualitativas y cuantitativas, Madrid, CIS, Opiniones y Actitudes, $\mathrm{n}^{\circ} 34$.

GINER, S.; LAMO DE ESPINOSA, E. y TORRES, C. (eds.): Diccionario de Sociología, Madrid, Alianza. 
GIRARD, A. (1986): El hombre y la masa. Consecuencias de la revolución demográfica, Madrid, Espasa-Universidad.

GISPERT, R.; RUÍZ-RAMOS, M.; ARÁN, M.; VIVIANA, F. Y CLOT-RAZQUIN, G. (2007): "Diferencias en la esperanza de vida libre de discapacidad por sexo y comunidades autónomas en España”, en Revista Española de Salud Pública, nº 81, pp. 155-165.

GLAZER, W.H. (1973): “The Task of Medicine”, en Scientific American, n² 228(4), pp.13-17.

GOERLICH, F. Y PINILLA, R. (2009): Tablas de mortalidad de España y sus regiones: 19752006. Esperanzas de Vida Libres de Discapacidad por sexo y Comunidad Autónoma: 20042006. Base de datos y principales resultados, Valencia, Ivie.

GOERLICH, F. Y PINILLA, R. (2006): Esperanza de vida en España a lo largo del siglo $\underline{X X}$.Las Tablas de mortalidad del INE, Valencia, Ivie.

GOERLICH, F. Y PINILLA, R. (2005): "Esperanza de vida y potencial de vida a lo largo del siglo XX en España”, en Revista de Demografía Histórica, XXIII, II, pp.79-109.

GÓMEZ, P. y DE SANTIAGO, C. (2008): “La entrevista familiar. Técnica y resultados”, en MATESANZ, R. (ed.): Modelo Español de Coordinación y Trasplantes, Organización Nacional de Trasplantes y Aula Médica Ediciones, cap. 7.

GÓMEZ, R.D. (2001): "La transición en epidemiología y salud pública: ¿explicación o condena?”, en Rev. Nac. Salud Pública, 19(2), pp.57-74.

GÓMEZ MARINERO, S. et al. (1994): “Obtención del consentimiento familiar para la donación. Relación de ayuda”, en ORGANIZACIÓN NACIONAL DE TRANSPLANTES: Revista Española de Transplantes, $n^{\circ} 1$.

GÓMEZ REDONDO, R. Y GARCÍA GONZÁLEZ, J.M. (2010): “Longevidad y salud a edades avanzadas”, en GÓMEZ REDONDO, R. (DIR.): Salud, Demografía y Sociedad en la Población Anciana, Madrid, Alianza Editorial, pp. 57-81.

GÓMEZ REDONDO, R. Y GARCÍA GONZÁLEZ, J.M. (2010a): "Emergence and verification of supercentenarians in Spain”, en MAINER, H., GAMPE, J., JEUNE,, D. ROBINE, J.M. Y VAUPEL, J.W. (eds.): Supercentenaians, Berlín, Demographic Research Monographs, Springer, pp. 151-171.

GÓMEZ REDONDO, R. Y GARCÍA GONZÁLEZ, J.M. (2008): “The emergence of oldest-old in Spain”, presentación para EAPS Conference, Barcelona.

GÓMEZ REDONDO, R.; GÉNOVA, R. Y ROBLES, E. (2007): Envejecimiento, Longevidad y Salud. Bases demográficas en España”, en BALLESTEROS, S. (ed.): Envejecimiento Saludable: Aspectos biológicos, psicológicos y sociales, Madrid, Universitas-UNED, cap. 2.

GÓMEZ REDONDO, R. Y BOE, C. (2005): "Descomposition análisis of Spanish life expectancy at birth. Evolution and changes in the components by sex anda ge", en Demographic Research, 13(20), pp. 521-546.

GÓMEZ REDONDO, R. Y BOE, C. (2004): “Tendencias de mortalidad en la población española: longevidad creciente, juventud recuperada y hacia la convergencia por sexo”, en CEDA Papers, Berkeley, Center for the Economics and Demography of Aging. 
GÓMEZ REDONDO, R. y ROBLES, E. (2003): "Contrastes, excepciones y frenos en las tendencias de la mortalidad mundial”, en SISTEMA, $\mathrm{n}^{\circ}$ 175-176, Tendencias demográficas, Madrid, Fundación Sistema, Septiembre, pp. 113-139.

GÓMEZ REDONDO, R.; JIMÉNEZ ABOITIZ, R.; CALLEJO, J Y ROBLES, E. (2002): “Ocupación y salud: un análisis de la desigualdad social”, en SISTEMA, No 168-169, pp. 195220.

GÓMEZ REDONDO, R.; JIMÉNEZ ABOITIZ, R.; CALLEJO, J Y ROBLES, E. (2001): "Diferencias socioeconómicas en la salud en la última etapa de la transición sanitaria", ponencia presentada en el VII Congreso Español de Sociología, Salamanca, 20-22 de septiembre.

GOMEZ REDONDO, R., (2001): "Mortalidad, salud y desigualdad”, en DURÁN, M.A. et al. (coords.): Estructura y cambio social. Homenaje a Salustiano del Campo, Madrid, CIS, pp. 159184.

GOMEZ REDONDO, R., (1998): “Tendencias en la desigualdad ante la muerte y sus consecuencias demográficas”, en TEZANOS, J.F. Y SÁNCHEZ MORALES, R. (eds.): Tecnología y Sociedad en el Nuevo Siglo, Madrid, pp..

GOMEZ REDONDO, R., (1995): "Vejez prolongada y juventud menguada: tendencias en la evolución de la esperanza de vida de la población española, 1970-1990”, en R.E.I.S., n ${ }^{\circ}$ 71-72, Julio-Diciembre, pp. 79-108.

GÓMEZ REDONDO, R. (1992): La mortalidad infantil española en el siglo XX, Madrid, CIS, Monografías, $\mathrm{n}^{\circ} 123$.

GÓMEZ SANCHO, M. (2006): El Hombre y el Médico ante la muerte, Madrid, Arán Ediciones.

GONZÁLEZ BLASCO, P. (2004): "Las creencias religiosas de los jóvenes españoles", en TEZANOS, J.F. (ed.): Tendencias en identidades, valores y creencias. Séptimo Foro sobre Tendencias Sociales, Madrid, Sistema, pp. 3181-393.

GÓNZALEZ BLASCO, P. (1994): reflexiones Sobre los valores y su uso en Sociología”, en KAIERO, A. (ed.): Valores y estilos de vida, Bilbao, Universidad de Deusto, pp.15-42.

GOODALL, J. (1986): En la senda del hombre. Vida y costumbres de los chimpancés, Barcelona, Biblioteca Científica Salvat, $\mathrm{n}^{\circ} 23$.

GORER, G. (1965): Death, Grief and Mourning in Contemporary Britain, Londres, Cresset.

GOULD, S.J. (2004a): Obra esencial, Barcelona, Crítica.

GOULD, S.J. (2004b): La estructura de la teoría de la evolución, Barcelona, Tusquets.

GOULD, S.J. (1994): El pulgar del panda, Barcelona, Crítica (v.o. 1980).

GOVE, W.R. (1995): “Sex, Marital Status, and Mortality”, en American Journal of Sociology, vol. 79, n 1, pp. 45-67.

GRACIA, D. (2004): Como arqueros al blanco. Estudios de bioética, Madrid, Triacastela. 
GRACIA, D. (1996): “Historia del transplante de órganos”, en GAFO, J. (ed.): Transplantes de órganos: problemas técnicos, éticos y legales, Madrid, Universidad Pontificia Comillas, pp. 1332.

GRACIA, D. (1990): “Historia de la Eutanasia”, en GAFO, J. (ed.): La eutanasia y el arte de morir, Madrid, Universidad Pontificia Comillas, pp. 13-32.

GREYSON, B. (1992): "Reduced death treat in near-death experiences”, en Death Studies, vol. 16, pp. 523-536.

GRIMEAU, H. (1992): Demographie, vol. 1, Bruselas, Press Universitaires de Bruxelles.

GUIJARRO, M. Y PELÁEZ, Ó. (2008): “La longevidad globalizada: un análisis de la esperanza de vida en España (1900-2050)”, en Scripta Nova. Revista electrónica de Geografía y Ciencias Sociales, Universidad de Barcelona, vol. XII, $\mathrm{n}^{\circ}$ 260, 1 de marzo [disponible on line en: http://www.ub.es/geocrit/sn/se-260.htm].

GUILLÉN, M.F. (1990): Estructura social y salud. Análisis del acceso a la asistencia sanitaria y los niveles de salud a partir de la Encuesta Nacional de Salud, Madrid, CIS, Estudios y Encuestas, $\mathrm{n}^{\circ} 22$.

GUTIÉRREZ VEGA, J. Y MARTÍNEZ BAZA, P. (1991): Enfermo Terminal y eutanasia desde el punto de vista del personal sanitario, Valladolid, Universidad de Valladolid.

GUTIÉRREZ-FISAC, J.L.; REGIDOR, E. Y ALFARO, M. (2010): Esperanzas de vida en salud en España 1986-2007. Esperanza de vida libre de incapacidad y esperanza de vida en buena salud en España y sus comunidades autónomas, Madrid, $\mathbf{M}^{\mathrm{o}}$ de Sanidad, Política Social e Igualdad.

HAINES, M.R. (2002): “The Great Mortality Transition”, reelaboración de la ponencia presentada en el encuentro anual de Social Science History Association 1999, Texas, For Worth, Noviembre.

HAIR, J.H.; ANDERSON, R.E.; TATHAM, R.L. y BLACK, W.C. (2000): Análisis multivariante, Madrid, Prentice Hall.

HARDING, S. et al (1986): Contrasting Values in Western Europe. Unity, Diversity and Change, Londres, McMillan Press LTD, citado en REQUENA, M. y BENEDICTO, J.: Las relaciones interpersonales,..., pp.14.

HART, N. (1989): "Sex, gender and survival: inequalities of life chances between European men and women”, en FOX (ed.): Health Inequalities in European Countries, Aldershot, Gower, pp. 109-141.

HARVEY, J. (1996): “Achieving the indeterminate: accomplishing degrees of certainty in life and death situations”, en Sociological Review, vol. 44, n 1 pp.78-98.

HAYFLICK, L. (1999): Cómo y por qué envejecemos, Barcelona, Herder.

HAYFLICK, L. (1998): "Biología celular del envejecimiento humano”, en Investigación y Ciencia, Temas 11, pp. 64-72.

HEIDEGGER, M. (1974): El ser y el tiempo, México, F.C.E.

HENNEEZEL, M. de (1996): La muerte íntima, Barcelona, Plaza y Janés. 
HERTZ, R. (1990): La muerte y la mano derecha, Madrid Alianza Universidad (v.o. 1906).

HERRERA PONCE, M.S. (2007): Individualización social y cambios demográficos: hacia una segunda transición demográfica?, Madrid, CIS, Monografías nº 236.

HINTON, J.M. (1974): Experiencias sobre el morir, Barcelona, Ariel.

HOCKEY, J. (1990): Experiences of Death: An Anthropological Account, Edimburgo, Edimburgo University Press.

HOELTER, J.W. (1979): “Multidimensional treatment of fear of death”, en Journal of Consulting and Clinical Psychology, n 47, pp. 996-999.

HOFFMAN, Y. (ed.), (2000): Poemas japoneses a la muerte, Barcelona, Editorial DVD.

HORIUCHI, S. (1999): "Epidemiological Transitions in Human History", en N.U. y OMS (1999): Health and Mortality Issues of Global Concern. Proceedings of the Symposium on Health and Mortality. 1997, Nueva York, Naciones Unidas, pp. 54-71.

HUMPHREY, G.M. Y ZIMPFER, D.G. (1996): Counselling for Grief and Bereavement, Londres, SAGE.

HUMPHRY, D. Y WICKETT, A. (1989): El derecho a morir. Comprender la eutanasia, Barcelona, Tusquets.

HYFLICK, L. (1999): Cómo y por qué envejecemos, Barcelona, Herder.

I.F.O.P.-SOCIETE DE THANATOLOGIE (1979): Les Français et la mort, París.

ILLICH, Ivan (1975): Némesis Médica. La expropiación de la salud, Barcelona, Barral.

IMAIZUMI, Y. (1987): "Consecuencias genéticas y biológicas de los cambios de la mortalidad”, en N.U.: Consecuencias de las tendencias y diferenciales de la mortalidad,..., pp. 71-82.

IMBERT, G. (2010): La sociedad informe. Posmodernidad, ambivalencia y juego con los límites, Barcelona, Icaria.

IMBERT, G. (2004): La tentación de suicidio, Madrid, Tecnos.

IMSERSO (2008): Informe 2008. Las personas mayores en España, Madrid, $\mathbf{M}^{\mathrm{o}}$ de Sanidad, Política Social e Igualdad, Observatorio de Portal Mayores del Imserso.

IMSERSO (2002): Envejecer en España, II Asamblea Mundial sobre el envejecimiento 2002, Madrid, $\mathrm{M}^{\mathrm{o}}$ de Trabajo y Asuntos Sociales.

INE (distintos años): Anuario Estadístico de España, Madrid, INE.

INE (distintos años): Tablas de Mortalidad de la Población Española, Madrid, INE.

INE (2010): Proyecciones de la Población de España a Largo Plazo, 2009-2049, Madrid, INE. 
INE (2009): Panorámica de la discapacidad en España. Encuesta de Discapacidad, Autonomía personal y situaciones de Dependencia. 2008. Cifras INE, Madrid, INE, Boletín informativo del INE, $\mathrm{n}^{\circ} 10$.

INE (2003): La sociedad española tras 25 años de la Constitución, Madrid, INE.

INE (2003a): Esperanza de vida en salud, Madrid, INE.

INE (2001a): Proyecciones de la población de España, versión electrónica.

INE (2001b): Proyecciones de la población de España calculadas a partir del Censo de Población de 1991. Evaluación y revisión, Madrid, INE.

INE (2000): Encuesta sobre Discapacidades, Deficiencias y Estado de Salud 1999. Datos básicos, Madrid, INE.

INE (1994): Panorámica Social de España, Madrid, INE.

INGLEHART, R. Y WELZEL, CH. (2006): Modernización, cambio cultural y democracia: la secuencia del desarrollo del desarrollo humano, Madrid, CIS, Monografías n ${ }^{\circ} 231$.

INGLEHART, R.; BASÁÑEZ, M.; DÍEZ-MEDRANO, J.; HALMAN, L. y LUIJKX, R. (2004): Human Beliefs and Values, a cross-cultural sourcebook base don the 1999-2002 values surveys, México D.F., Siglo XXI editores.

INGLEHART, R. (1998): Modernización y posmodernización. El cambio cultural, económico y político en 43 sociedades, Madrid, CIS, Monografías, nº 161.

INSTITUTO DE LA MUJER (2002): La salud de las mujeres: hacia la igualdad de género en salud, Madrid, Instituto de la Mujer.

INSTITUTO DE LA MUJER (2001): La salud mental de las mujeres, Madrid, Instituto de la Mujer.

INSTITUTO UNIVERSITARIO DE ESTUDIOS DE LA MUJER (2001): Salud y género: La salud de la mujer en el umbral del sigo XXI. XII Jornadas de Investigación Interdisciplinaria, Madrid.

ISPISÚA, J.C.; RASSKIN, D. y RAYA, Á. (2002): "Los secretos de la vida. 6. El Sexo. Donde la biología y la cultura se confunden”, en EL PAÍS. Domingo, 18/08/02, pp. 12-13.

ISPISÚA, J.C.; RASSKIN, D. y RAYA, Á. (2002a): "Los secretos de la vida. 9. La evolución. De las sopa primitiva al gazpacho andaluz”, en EL PAÍS. Domingo, 8/09/02, pp. 12-13.

ISPISÚA, J.C.; RASSKIN, D. y RAYA, Á. (2002b): “Los secretos de la vida. 10. El futuro. La lucha por desterrar la enfermedad”, en EL PAÍS. Domingo, 15/09/02, pp. 14-15.

IZQUIERDO, A. (dir.) (2006) Demografía de los extranjeros. Incidencia en el crecimiento de la población, Bilbao, Fundación BBVA.

JAMENSON, F. (1991): El posmodernismo o la lógica cultural del capitalismo avanzado, Barcelona, Paidós.

JANKÉLÉVITCH, V. (2002): La muerte, Valencia, Pre-textos (v.o. 1966). 
JENNETT, B. (1986): High Technology Medicine: Benefits and Burdens, Oxford, Oxford University Press.

JIMÉNEZ ABOITIZ, R. Y GÓMEZ REDODNDO, R. (1997): "El género como criterio de desigualdad ante la muerte”, en Temas para el Debate, ${ }^{\circ}$ 37, pp. 67-70.

JIMÉNEZ LARA, A. (2010): “La esperanza de vida libre de discapacidad”, en Boletín del Real Patronato sobre Discapacidad, $n^{\circ} 71$, diciembre, Madrid, BRPD.

JIMÉNEZ-RIDRUEJO AYUSO, Z.; BORONDO ARRIBAS, C.; LÓPEZ DÍAZ, J.; LORENZO LAGO, C. y RODRÍGUEZ SUMAZA C. (2006): El efecto de la inmigración en la sostenibilidad a medio y largo plazo del sistema de pensiones en España. M $^{\circ}$. Trabajo y Seguridad Social. Secretaría de Estado de la Seguridad Social (Disponible en: http://www.segsocial.es/prdi00/groups/public/documents/binario/ 100618.pdf).

JOHNSON, J.; SLATER, R. (eds.) (1993): Ageing and Later Life, Londres, SAGE.

JONAS, H. (1998): Pensar sobre Dios y otros ensayos, Barcelona, Herder.

JONAS, H. (1997): Técnica, medicina y ética. Sobre la práctica del principio de responsabilidad, Barcelona, Paidós.

JOOSSENS, L.; SASCO, A.; SALVADOR, T. y VILLALBÍ, J.R. (1999): "Las mujeres y el tabaco en la Unión Europea”, en Rev. Esp. Salud Pública, vol. 73, n 1, enero-febrero, versión electrónica.

JOURNAL OF THE AMERICAN MEDICAL ASSOCIATION (1968): Report of the Hoc Committee of the Harvard Medical School to examinate the Definition of Brain Death" en J.A.M.A., vol. ccv, $\mathrm{n}^{\circ} 6$.

JUAN, M. y RODRÍGUEZ, J.A. (1994): "El cuerpo humano y las nuevas tecnologías. Hacia una redefinición del principio y el fin”, en $\underline{\text { REIS }}$, n 68, Madrid, CIS, pp. 173-196.

JÚDEZ, J. (2007): "Suicidio asistido y eutanasia: un debate clásico y trágico, con pronóstico reservado”, en An. Sist. Sanit. Navar., vol. 30 (supl. 3).

JUPP, P. (1993): “Cremation or burial? Contemporary choice in city and village”, en CLARK, D. (ed.): The Sociology of Death: Theory, Culture, Practice, Oxford, Blackwell Publishers, pp. 169-197.

KALISH, R.A. (1985): “The social context of Death and Dying”, en BINSTOCK, R.H.; Shanas, e. (EDS): Handbook of Aging and The Social Sciences, New York, Van Mostrand Reinhold.

KANNISTO, V. (2000): “Measuring the Compression of Mortality”, en Demographic Research, vol. 3, art. 6, sep.

KANNISTO, V. (1994): Development of oldest-old mortality 1950-1990: evidence from developed countries, Odense, Odense University Press, citado en VALLIN, J. (1995c): “Espérance de vie: quelle quantité pour quelle qualité de vie?”, p. 8.

KASTENBAUM, R. (1984): Entre la vida y la muerte, Barcelona, Herder.

KASTENBAUM, R. Y AISENBERG, R. (1972): The psychology of death, Nueva York, Springer Publishing company 
KEARL, M. (1989): Endings: A Sociology of Death and Dying, Oxford, Oxford University Press.

KELLEHEAR, A. (1984): “Are We a Death Defying Society? A Sociological Review”, en Social Science and Medicine, vol. 18(9), p.714 citado en (Moller, 1996:279).

KERTÉSZ, I. (2004): Liquidación, Madrid, Alfaguara.

KEYFITZ, N. (1977): Applied Mathematical Demography, Nueva York, Wiley, citado en SANTOW, G.: "The mortality, epidemiological and health transitions...

KIELEY, M. (1997): "El sentido de la vida: cómo enfrentarse a la aflicción, el dolor y la muerte", en TORRE, I. de la (coord.): El sentido de la vida, Madrid, Universidad Autónoma.

KIRK, D. (1996): “Demographic transition theory”, en Population Studies, vol. 50, pp. 361-387.

KIRKWOOD, T. (2004): “Antienvejecimiento (I)”, en PUNSET, E.: Cara a cara con la vida, la mente y el Universo. Conversaciones con los grandes científicos de nuestro tiempo, Barcelona, Destino, cap. XII Lo que viene I: la biología de la inmortalidad, pp. 293-307.

KIRKWOOD, T. (2000): El fin del envejecimiento. Ciencia y longevidad, Barcelona, Tusquets.

KLARSFELD, A. Y REVAH, F. (2002): Biología de la Muerte, Madrid, Ed. Complutense.

KÜBLER-ROSS, E. (1998): Preguntas y respuestas a la muerte de un ser querido, Barcelona, Martínez Roca.

KÜBLER-ROSS, E. (1991): Vivir hasta despedirnos, Barcelona, Luciérnaga.

KÜBLER-ROSS, E. (1989): Sobre la muerte y los moribundos, Barcelona, Grijalbo.

KULA, W. (1977): Problemas y métodos de la historia económica, Barcelona, Península, $3^{\text {a }}$ edición.

KÜNG, H. y JENS, W. (1997): Morir con dignidad. Un alegato a favor de la responsabilidad, Madrid, Trotta.

KITAGAWA, E.N. y HAUSER, P.M. (1973): Differential Mortality in the United Status. A Study in Socioeconomic Epidemiology, Cambridge, Harvard University Press.

KUSAK, E. (2001): La muerte cerebral y sus implicaciones sociales, conferencia pronunciada en el Ateneo de Valladolid, 14/02/01.

LAMBOY, B. (1989): La mort réconciliée, La Varenne-Saint-Hilaire, Sereyrat.

LAMO DE ESPINOSA, E. (2004): Bajo puertas de fuego. El nuevo desorden internacional, Madrid, Taurus.

LAMO DE ESPINOSA, E. (1995): “¿Nuevas formas de familia?”, en CLAVES de la Razón Práctica, $n^{\circ}$ 50, pp. 50-55.

LAMO DE ESPINOSA, E. (1990): La sociedad reflexiva, Madrid, CIS. 
LANDSBERG, P-L. (1995): Ensayos sobre la Experiencia de la Muerte. El problema moral del suicidio, Madrid, Caparrós.

LAPLANCE, J. Y PONTALIS, J-B. (1979): Diccionario de Psicoanálisis, Barcelona, Labor.

LE BOURG, É (2001): “A mini-review of the evolutionary theories of aging. Is it the time to accept them?, en Demographic Research, vol. 4, art.1, Febrero.

LEGUINA, J. (1981): Fundamentos de demografía, Madrid, Siglo XXI.

LEÓN SALAS, B. (2004) "La inmigración: ¿una opción ante el envejecimiento de la población?”. Estudios sobre la Economía Española nº 182, FEDEA, Abril.

LEPP, I. (1967): Psicoanálisis de la muerte, Buenos Aires, Carlos Lohlé.

LERNER, M., 1973, Modernization and health: a model of the health transition, Reunión anual de la American Public Health Association, San Francisco.

LESTER, D. (1997): "Escala de Miedo a la Muerte de Collett-Lester", en NEIMEYER, R.A. (comp.): Métodos de evaluación de la ansiedad ante la muerte, Barcelona, Paidós, pp. 57-72.

LESTHAEGHE, R. (1998): "On theory development: applications to the study of family formation”, en Population and Development Review, vol. 24, nº 1.

LESTHAEGHE, R. (1992): “The Second Demographic Transition in Western Countries: An Interpretation”, en Seminar on Gender and Family Change in Industrializaed Countries, Roma, IUSSP Comitee on Gender and Population.

LEY 41/2002, de 14/11/02: Ley básica reguladora de la autonomía del paciente y de derechos y obligaciones en materia de información y documentación clínica, BOE, 15/11/02.

LEY 42/1988, de 28 de diciembre: De donación y utilización de embriones y fetos humanos o de sus células, tejidos u órganos, BOE, 314, 31/12/88.

LEY 35/1988, de 22 de noviembre: Sobre técnicas de reproducción asistida, BOE, 282, 24/11/88

LEY 30/1979, de 27 de octubre: Sobre extracción y trasplante de órganos, BOE, 266, 06/11/79.

LEWIS, C.S. (1997): Una pena en observación, Barcelona, Anagrama.

LINDESMISH, A.R.; STRAUSS, A.L. Y DENZIN, N. (2006): Psicología social, Madrid, CIS, Monografías $n^{\circ} 228$.

LITTLEWOOD, J. (1993): "The denial of death and rites of pasaje in contemporary societies", en CLARK, D. (ed.): The Sociology of Death: Theory, Culture, Practice, Oxford, Blackwell Publishers, pp.69-84.

LITTLEWOOD, J. (1992): Aspects of Grief: Bereavement in Adult Life, Londres, Routledge.

LIVI-BACCI, M. (1993): Introducción a la demografía, Barcelona, Ariel, caps. 6-8.

LIVI-BACCI, M. (1990): Historia mínima de la población mundial, Barcelona, Ariel. 
LIVI-BACCI, M. (1988): Ensayo sobre la historia demográfica europea. Población y alimentación en Europa, Barcelona, Ariel.

LIVI-BACCI, M. y DEL PANTA, L. (1990): La cuestión demográfica, Barcelona, Oikus-Tau.

LONETTO, R. y TEMPLER, D.I. (1988): La ansiedad ante la muerte, Barcelona, Temis.

LONG, D.D. (1985-86): “A cross-cultural examination of death among Suudi Arabians”, en Omega, $n^{\circ} 16$, pp.43-50.

LÓPEZ, A.D.; COLLISHAW, E.N. y PIHA, T. (1994): "A descriptive model of the cigarette epidemic in developed countries”, en Tabacco Control, no3, pp. 342-347.

LÓPEZ ARANGUREN, J.L.[1958] (1981): Ética, Madrid, Alianza Universidad Textos, pp.298308.

LÓPEZ, A. y CRUIJSEN, H. (1995): "Mortalidad en la Comunidad Europea. Tendencias y perspectivas”, en $\mathrm{M}^{\mathrm{o}}$ de TRABAJO Y S.S.: El capital humano en el umbral del siglo XX,..., PP. 53-80.

LÓPEZ-ABENTE, G.; POLLÁN, M.; ARAGONÉS, N.; PÉREZ, B.; LLÁCER, A.; PÉREZ, J.; MEDRANO, M.J.; BOIX, R.; DÍEZ, M.; GONZÁLEZ, P.; NAVAS, A.; ALMAZÁN, J.; JIMÉNEZ, M.T. Y PEDRO, J. (2002): Tendencias de la mortalidad de España, 1952-1996. Efecto de la edad, de la cohorte de nacimiento y del periodo de muerte, Madrid, $\mathrm{M}^{\mathrm{o}}$ de Sanidad y Consumo, Instituto de Salud Carlos III, Centro Nacional de Epidemiología.

LÓPEZ-ABENTE, G. (2000): “Objetivo 10: Lograr el control del cáncer”, en ÁLVAREZ, C Y PEIRÓ, S. (eds.): Informe SESPAS 2000: La salud pública ante los desafíos de un nuevo siglo, Granada, Escuela Andaluza de Salud Pública.

LÓPEZ-ABENTE, G.; POLLÁN, M.; ESCOLAR, A.; ERREZOLA, M. Y ABRARIRA, V. (1996): ATLAS de la mortalidad por cáncer y otras causas en España 1978-1992, Madrid, M $^{\circ}$ de Sanidad y Consumo, Instituto de Salud Carlos III, Centro Nacional de Epidemiología.

LÓPEZ-GIL, M. Y REGNASCO, M.J. (1996): “MORIN, Edgard”, en LOIZAGA, P. (dir.): Diccionario de pensadores contemporáneos, Barcelona, EMECË, pp. 255-259.

LORIAUX, M. (1995): “El envejecimiento de la sociedad europea”, en $\mathrm{M}^{\mathrm{o}}$ de TRABAJO Y S.S.: El capital humano en el umbral del siglo XX, Madrid, Colección Seguridad Social, ${ }^{\circ} 13$, cap. XXI.

LORIAUX, M. (1995a): "Les conséquences de la révolution d'mographique et du vieillissement sociétal: restruturation des âges et modification des rapports entre génerations”, en Sociologie et société, 2(XXVII), pp.9-26.

LUTZ, W. (ed.) (1991): Future demographic trends in Europe and North America. What can we Assume Today?, Londres, Academic Press Limited.

LYNGE, E. (1984): Socio-economic differences in mortality in Europe. Newly emerging trends in Mortality, Estrasburgo, Consejo de Europa, Population Studies, $n^{\circ} 9$.

LLEDÓ, E. (1995): El Epicureísmo, Madrid, Taurus, $3^{\mathrm{a}}$ ed.

MACINNES, J. Y PÉREZ DÍAZ, J. (2008), "La tercera revolución de la modernidad: la reproductiva", en $\underline{\text { REIS }}, n^{\circ} 122$, pp. 89-118. 
MACIP, S. (2008): Inmortales y perfectos. Cómo la medicina cambiará radicalmente nuestras vidas, Barcelona, Destino.

MACKLIN, R. (1987): Mortal Choices: Ethical Dilemmas in Modern Medicine, Boston, Houghton Mifflin Company.

MADIGAN, F.C. (1957): “Are sex mortality differences biologically caused?”, en The Milbank Memorial Fund Quarterly, pp. 202-223.

MAFFESOLI, M. (2004): "Postmodernidad. Las criptas de la vida", en Espacio Abierto. Cuaderno Venezolano de Sociología, vol. 13, nº 3, pp. 471-482.

MAFFESOLI, M. (1990): El tiempo de las tribus, Barcelona, Icaria.

MALTHUS, T.R. (1983): Primer ensayo sobre la población, Madrid, SARPE.

MANTON, K.G.; STALLARD, E. y CORDER, C.S. (1999): "The Limits of longevity and their implications for health and mortality in developed countries”, en N.U. y OMS: Health and Mortality Issues of Global Concern. Proceedings of the Symposium on Health and Mortality. 1997, Nueva York, Naciones Unidas, pps. 324-343.

MANTON, K.G.; STALLARD, E. y CORDER, C.S. (1997): "Changes in the age dependence of mortality and disability: cohort and other determinants", en Demography, vol 34, pp. 135158.

MANTON, K.G. (1991): "New Biotechnologies and the Limitis to Life Expectancy”, en LUTZ, W. (ed.): Future demographic trends in Europe and North America, Londres, Academic Press Limited, cap.6.

MARCUSE, H. (1986): Ensayos sobre política y cultura, Barcelona, Planeta-Agostini, Colección Obras Maestras del Pensamiento Contemporáneo, $\mathrm{n}^{\circ} 55$.

MARDONES, José María (2004): "La valores religiosos y los valores laicos en la sociedad actual”, en TEZANOS, J.F. (ed.): Tendencias en identidades, valores y creencias. Séptimo Foro sobre Tendencias Sociales, Madrid, Sistema, pp.395-408.

MARGARIT, J. (2002): Joana, Madrid, Hiperión.

MARGULIS, L. (2000): "Una prueba concluyente de las fusiones húmedas en la eterna absorción”, en GRFFITHS, S. (comp.): Predicciones, Madrid, Taurus, pp. 208-210.

MARGULIS, L. Y SAGAN, D. (1998): ¿Qué es el sexo?, Barcelona, Tusquets.

MARÍ-KLOSE, M.; SÁNCHEZ BENNASAR, J.; RIERA, P. y DE MIGUEL, J. (2004): “El futuro de la muerte: Cambio de valores en el canon”, en PENSANDO EUROPA, IV Congreso de Sociología para el futuro, Universidad de Barcelona.

MARÍ-KLOSE, M. y DE MIGUEL, J. (2000): “El canon de la muerte”, en Política y Sociedad, $\mathrm{n}^{\mathrm{o}}$ 35, Madrid, pp. 115-143.

MARÍN GÁMEZ, N.; KESSEL, H.; BARNOSI, A.C.; RODRÍGUEZ, M-; LAZO, A.M. y COLLADO, A.. (2002): “Cincuenta y seis muertes”, en Rev. Esp. Geriatr Gerontol, vol. 37 (n5), pp. 244-248.

MARÍAS, J. (1993): La estructura social, Madrid, Alianza. 
MARSET, P. Y SÁEZ GÓMEZ, J.M. (2002): “Mujeres y salud a lo largo de la historia”, en INSTITUTO DE LA MUJER: La salud de las mujeres: hacia la igualdad de género en salud, Madrid, pp. 65-85.

MARTIN-FUGIER, A. (1992): "Los ritos de la vida privada burguesa”, en ARIÈS, P. y DUBY, G. (dirs.): Historia de la vida privada. Tomo 7. La Revolución francesa y el asentamiento de la sociedad burguesa, Madrid, Taurus, pp. 199-268.

MARTÍNEZ GIL, F. (1993): Muerte y sociedad en la España de los Austrias, Madrid, siglo XXI.

MARZANO, m. (2010): La muerte como espectáculo. La difusión de la violencia en Internet y sus implicaciones éticas, Barcelona, Tusquets.

MATESANZ, R. (ed.): Modelo Español de Coordinación y Trasplantes, Organización Nacional de Trasplantes y Aula Médica Ediciones.

MAY, C. (1992): “Individual Care Power and Subjectivity in Therapeutic Relationships”, en SOCIOLOGY, vol. 26, nº 4, pp. 589-602.

McCARTNEY, S. (1994): Defying the Gods: Inside the New Frontiers of Organ Transplants, Nueva York, Macmillan.

McKEOWN, T. (2006): Los orígenes de las enfermedades humanas, Madrid, Ed. Triacastela, (v.o. 1988).

McKEOWN, T. (1978): El crecimiento moderno de la población, Barcelona, Antoni Bosch.

McKINLAY, J.B. (1996): "Some contribution from the social system to gender inequalities in heart disease”, en Journal Health Social Behaviour, n 37, pp. 1-26.

McNICOLL, J. (1987): “Adaptación de los sistemas sociales a los cambios en los regímenes de mortalidad”, en N.U.: Consecuencias de las tendencias y diferenciales de la mortalidad,...., pp.13-20.

MEAD, M. et al (1972): El derecho a vivir. Medicina moderna y futuro humano, Buenos Aires, Editorial La Aurora.

MEIL, G. (2011): Individualización y solidaridad familiar, Barcelona, Obra Social "la Caixa”, Colección Estudios Sociales, $n^{\circ} 32$.

MENAHEM, R. (1974): “El suicidio”, en VV.AA.: Sociología de la muerte, pp. 177-186.

MELLOR, P. (1993): "Death in High Modernity: The Contemporary Presence and Absence of Death”, en CLARK, D. (ed.): The Sociology of Death: Theory, Culture, Practice, Oxford, Blackwell Publishers and The Sociological Review.

MELLOR, P.; SHILLING, C. (1993): "Modernity, Self-Identity and the Sequestration of Death”, en SOCIOLOGY, vol. 27, $\mathrm{n}^{\circ}$ 3, pp. 411-431.

MENÉNDEZ, E.L. (1998): "Estilos de vida, riesgos y construcción social. Conceptos similares y significados diferentes”, en Estudios Sociológicos, nº 46, pp. 37-64. 
MESLÉ, F. Y VALLIN, J. (2006): “The Health Transition: Trends and Prospects”, en Demography: Analysis and Synthesis, vol 2, cap.57, pp.247-259.

MESLÉ, F. (1995): “La mortalité en France: le recul se poursit”, en Population, vol. 50, no 3, pp. $745-778$.

MEYER, J.E. (1983): Angustia y reconciliación de la muerte en nuestro tiempo, Barcelona, Herder.

$M^{\circ}$ DE SANIDAD Y POLÍTICA SOCIAL (2010): Indicadores Clave del Sistema Nacional de Salud, Madrid, (INCLASNS-BD).

$\mathrm{M}^{\mathrm{o}}$ de TRABAJO Y S.S.: El capital humano en el umbral del siglo XX, Madrid, Colección Seguridad Social, $n^{0} 13$.

MIR, N. (2001): Informe sobre los riesgos que afectan a los ciudadanos en Cataluña, Barcelona, ESADE, citado en EL PAIS, 4/10/01, pp.33.

MOLLER, D.W. (1996): Confronting Death. Values, Institutions \& Human Mortality, Oxford, Oxford University Press.

MONNIER, A. Y NIZARD, A. (1995): "Les méthodes d'analyse de la mortalité par cause ", en PRESSAT, R. (dir.) (1985): Manuel d'analyse de la mortalité, París, INED, pp. 115-122.

MONOD, J. (1970): El azar y la necesidad, Barcelona, Ediciones Orbis.

MONSERRAT, J. Y RODRÍGUEZ, J. (1994): "El cuerpo humano y las nuevas tecnologías médicas. Hacia una redefinición del principio y el fin”, en R.E.I.S., nº 68, pp.173-196.

MONTERO, E. (1999): "El derecho a la autonomía en el debate sobre la legalización de la eutanasia voluntaria”, en Universidad de Navarra, pp. 28, www.muertedigna.org/textos/euta65.htm

MONTES, L. y CASARES, M. (2008): Declaración de Santander para la despenalización de la eutanasia, Santander, Presentada en el marco de un curso de verano de la Universidad Internacional Menéndez Pelayo el 11 de Julio de 2008.

MONTES, L. y GÜELL, O. (2008): El caso Leganés, Madrid, Aguilar.

MONTES, L. y SOLER, F. (2008): “La voluntad inequívoca de morir”, en EL PAÍS, 30/09/08.

MORA, F. (2003): “Ambioma, ¿Diana contra la vejez?”, en EL Cultural, 15/05//03, pp.48-49.

MORALES, J.F.; REBOLLOSO, E. Y MOYA, M. (1994): Sección X: Actitudes, en VV.AA.: Psicología Social, Madrid, ; McGraw-Hill, pp. 495-624.

MORATA, G. (2005): Entrevista de A. Espada en EL PAÍS. Domingo, 28/08/05.

MORATA, G. (2004): Entrevista de J. López Rejas en EL CULTURAL, 28/08/05, pp.55-56.

MORGAN, J.D. (1995): "Living Our Dying and Our Grieving; Historical and Cultural Attitudes”, en WASS, H. Y NEIMEYER, A. (eds.): Dying. Facing the Facts, Washington D.C., Taylor \& Francis, pp. 25-46. 
MORIN, E. Y JAY GOULD, S. (1997): “¿Un futuro para la especie?”, resumen de los Encuentros del s. XXI: ¿Qué futuro para la especie humana?, $1^{a}$ serie, EL PAÍS, 13/10/97, pp.27.

MORIN, E. (1974a): El Hombre y la Muerte, Barcelona, Kairós.

MORIN, E. (1974b): El paradigma perdido: el paraíso perdido, Barcelona, Kairós.

MOSTERÍN, J. (1995): Los derechos de los animales, Madrid, Debate.

MULKAY, M. (1993): "Social death in Britain”, en CLARK, D. (ed.): The Sociology of Death: Theory, Culture, Practice, Oxford, Blackwell Publishers, pp. 31-49.

MUÑOZ PRADAS, F. (2003): "Rectangularización y evolución de la mortalidad en la población española del siglo XX”, en SISTEMA, $\mathrm{n}^{\circ}$ 175-176, Tendencias demográficas, Madrid, Fundación Sistema, Septiembre, pp. 141-160.

MURO PASCUAL, A. (1993): "Eutanasia: alternativa para una muerte digna”, trabajo final para el Curso de Postgrado "Praxis de la Sociología del Consumo" (1992/93), Madrid.

MURRAY, C.J.L. y LOPEZ, A.D. (1996): The Global Burden of Disease: a comprehesive assesment of mortality and disability from diseases, injuries, and risk factors in 1990 and projected to 2020, Cambridge Mass, OMS; BM; Harvard School of Public Health.

MYRDAL, A. Y KLEIN, V. (1973): La mujer y la sociedad contemporánea, Barcelona, Península.

NADAL, J. (1992): Bautismos, desposorios y entierros. Estudios de historia demográfica, Barcelona, Ariel.

NADAL, J. (1976): La población española siglos XVI-XX, Barcelona, Ariel.

NATHANSON, C. A. y LOPEZ, A. D. (1987): "The future of sex mortality differentials industrialized countries: A structural hypothesis", en Population Research and Policy Review, vol. 2, n², pp.123-136.

NAVARRO, P. (1997): “La metáfora del <<Holograma Social >>”, accesible en http://www.netcom.es/pnavarro/Publicaciones/HologramaSocial.html.

N.U. (2009): World Population Prospects. The 2008 Revision, Nueva York, Naciones Unidas.

N.U. (2007): World Population Prospects. The 2006 Revision, Nueva York, Naciones Unidas.

N.U. (2003): World Population Prospects: The 2002 Revision, Nueva York, P.N.U.D., cap II: Past and Future Trends in Mortality”.

N.U. (2001): World Population Prospects: The 2000 Revision, vol. III: Analytical Report, Madrid, Naciones Unidas.

N.U. (2001a): Población, medio ambiente y desarrollo, Nueva York, Naciones Unidas.

N.U. (1999): World Population Prospects: The 1998 Revision, Nueva York, N.U.

N.U. (1987): Consecuencias de las tendencias y diferenciales de la mortalidad, Nueva York, Naciones Unidas. 
N.U. (1982): Niveles y tendencias de la mortalidad a partir de 1950, Nueva York, Naciones Unidas.

N.U. y OMS (1999): Health and Mortality Issues of Global Concern. Proceedings of the Symposium on Health and Mortality. 1997, Nueva York, Naciones Unidas.

NEIMEYER, R. A. (comp.) (1997): Métodos de evaluación de la ansiedad ante la muerte, Barcelona, Paidós.

NEIMEYER, R. A. (1997a): "Las actitudes hacia la muerte en la vida adulta: epílogo”, en NEIMEYER (comp.)(1997), pp.267-280.

NEIMEYER, R. A. (1997b): “El Índice de Amenaza y otros métodos relacionados”, en NEIMEYER (comp.)(1997), pp.73-112.

NEIMEYER, R. A. y MOORE, M.K. (1997): "Validez y fiabilidad de la Escala Multidimensional de Miedo a la Muerte”, en NEIMEYER (comp.)(1997), pp.113-131.

NIZARD, A. (1985): "La classification internationale des maladies traumatismes et causes de décès (CI.M.)”, en PRESSAT, R. (dir.): Manuel d'analyse de la mortalité, París, INED, pp.100114.

NULAND, S. B. (1995): Cómo morimos: Reflexiones sobre el último capítulo de la vida, Madrid, Alianza.

OEPPEN, J. Y VAUPEL, J.W. (2002): “Broken Limits to Life Expectancy”, en Science, n 296, pp. 1029-1031.

OLSHANSKY, S.Y. Y CARNES, B.A. (2001): En busca de la inmortalidad. Ciencia y esperanza de vida, Barcelona, Grijalbo.

OLSHANSKY, S.Y.; CARNES, B.A. Y BUTLER, R.N. (2001a): “Anatomía de larga vida”, en Investigación y Ciencia, Mayo, pp. 44-49.

OLSHANSKY, S.Y.; CARNES, B.A. Y CASSEL, C.K. (1993): "Envejecimiento de la especie humana”, en Investigación y Ciencia, Junio, pp. 8-15.

OLSHANSKY, S.J. y AULT, A.B. (1986): “The fourth stage of the Epidemiologic Transition: the Age of Delayed Degenerative Diseases”, en The Milbank Quarterly, vol. 64, n 3, pp. 355391.

OMC (2009): "Eutanasia: ¿sabemos de lo que hablamos?, en OMC. Revista Oficial del Consejo General del Colegio de Médicos de España, n 10, Marzo-Abril.

OMRAN, A.R. (1982): "Epidemiological Transition: Theory”, ” en Ross, J.A. (ed.), International Encyclopedia of Population, vol. 1, Londres, The Free Press, pp. 172-183.

OMRAN, A.R., (1971): "The epidemiologic transition: a theory of the epidemiology of population change”, en Milbank Memorial Fund Quarterly, n 29, pp. 509-538.

OMS (2007): Informe sobre la salud en el mundo 2007. Un porvenir más seguro. Protección de la salud pública mundial en el siglo XXI, Ginebra, OMS.

OMS (2007a): Las amenazas para la salud no tienen fronteras, Ginebra, OMS. 
OMS (2006): Ambientes saludables y prevención de enfermedades. Hacia una estimación de la carga de morbilidad atribuible al medio ambiente, Ginebra, OMS.

OMS (2003): Cambio climático y salud humana. Riesgos y respuestas, Ginebra, OMS.

OMS (2002): The World health report 2002. Reducing risks, promotion healthy life, Ginebra, OMS.

OMS (2001): Hombres, envejecimiento y salud, Ginebra, OMS.

OMS (2000): Contengamos la resistencia microbiana, Ginebra, OMS.

OMS (1997): Health and Enviroment in Sustainable Development: Five years alter the Eart Summit, Ginebra, OMS.

OMS (1990): Health Promotion. A ResurceBook, Copenhague, OMS-EURO.

OMS (1977): Definitions and Recommendations: Manual of the International Statistical Classification of Diseases; Injures, and Causes of Death, vo.1, Génova, OMS.

ORGANIZACIÓN NACIONAL DE TRASPLANTES (2011): Guía de Buenas Prácticas en el Proceso de Donación de Órganos, Madrid, ONT,

ORGANIZACIÓN NACIONAL DE TRASPLANTES (2010): Programa de Garantía de Calidad del Proceso de donación. Memoria de resultados de la Autoevaluación Año 2009, Madrid, ONT, disponible en http://www.ont.es/infesp/DocumentosCalidad/ memcal9809.pdf.

ONÍS, M. Y VILLAR, J. (eds.) (1992): La mujer y la salud en España. Informe básico. 4 tomos, Madrid, Instituto de la Mujer.

ORTEGA, F. (2001): “¿Por qué no se debe excluir del uso de la alta tecnología sanitaria a los ancianos?”, en EL PAÍS, 6/03/01/, pp. 35.

ORTÍN, J. (2003): "El reto de las nuevas enfermedades infecciosas. Salto de virus entre especies”, en EL PAÍS, 27/04/03, pp.16.

ORTMEYER, L.E. (1979): "Female's Natural Advantage? Or, The Unhealthy Environment of Males?. The Status of sex Mortality Differentials”, en Women and Health, vol. 4(2), pp. 121133.

ORTÚN, V. (2000): “Desigualdad y salud”, en Política y Sociedad, nº 35, Madrid, pp.65-71.

OSÉS, I.; MARTINEZ, K. y DÍAZ, A. (2007): "Estudio de la calidad de la asistencia al moribundo en un hospital”, en An. Sist. Sanit. Navar. vol. 30 (suplemento 3), pp. 177-188.

PAMPEL, F.C. Y ZIMMER, C. (1989): "Female labour force activity and sex differential in mortality: comparisons across developed nations, 1950-1980", en European Journal of Population I, pp. 281-304.

PARDO, A. (1998): "Muerte cerebral y ética de los trasplantes”, Universidad de Navarra, Dpto. De Humanidades Biomédicas, www.unav.es/humbiomedicas /mcindice.html.

PARSONS, T. (1984): El sistema social, Madrid, Alianza Universidad, cap.10 (v.o. 1951). 
PARSONS, T. (1975): “The sick role of the physician reconsidered”, en Milbank Memorial Fund Quarterly, n 53, pp. 257-278.

PATTINSON, E.H. (1977): The Experience of Dying, New Jersey, Prentice-Hall.

PEARSON, I. (ed.) (2002): Atlas del Futuro, Madrid, Akal.

PERA, C. (2003): El cuerpo herido. Un diccionario filosófico de la cirugía, Barcelona, El Acantilado.

PÉREZ AGOTE, A. y SANTIAGO GARCÍA, J.A. (2005): La situación de la religión en España a principios del siglo XXI, Madrid, CIS, Colección Opiniones y Actitudes, nº 49.

PÉREZ AGOTE, A. (1990): Los lugares sociales de la religión: la secularización de la vida en el País Vasco, Madrid, CIS, Colección “Estudios y Encuestas”, nº 20.

PÉREZ DÍAZ, J. (2005): “Consecuencias sociales del envejecimiento demográfico”, en Papeles de Economía. Transformaciones demográficas. Raíces y consecuencias, ${ }^{\circ}{ }^{0} 104$, Madrid, pp. 210-226.

PÉREZ DÍAZ, J. (2003): “¿Cómo ha mejorado tanto la vejez en España?”, en Políticas Demográficas y de Población, Zaragoza, Gobierno de Aragón, pp. 81-107.

PÉREZ DÍAZ, J. (2002): La Madurez de las Masas, Barcelona, $\mathrm{XV}^{\mathrm{o}}$ Premio "Dr Rogeli Duocastella” de Investigación en Ciencias Sociales, Fundación “La Caixa”.

PÉREZ DÍAZ, J. (2000): Envejecimiento y esperanza de vida en salud, ponencia presentada en el $23^{\circ}$ Congreso de la Sociedad Española de Geriatría y Gerontología, Barcelona, 8/06/02.

PÉREZ DÍAZ, J. (1998): “La Demografía y el envejecimiento de las poblaciones”, en STAAB, A.S. Y HODGES, L.C.: Enfermería Gerontológica, México D.F., McGraw-Hill, pp. 451-463.

PÉREZ DÍAZ, J. (1996): La situación social de la vejez en España desde una perspectiva demográfica, Madrid, Fundación Caja de Madrid.

PÉREZ DÍAZ, J. (1995): “Las mujeres ancianas, la auténtica vejez de la España actual”, en Papers de Demografía, nº 99, Barcelona, Centre de Éstudis Demografícs.

PÉREZ GÁLVEZ, J.F. (1997): El sistema funerario en el Derecho Español, Pamplona, Ed. Aranzadi.

PÉREZ JIMÉNEZ, J.C. (2011): La mirada del Suicida. El enigma y el estigma, Madrid, Plaza y Valdés.

PÉREZ MOREDA, V. (1988): "Hambre, mortalidad y crecimiento demográfico en las poblaciones de la Europa preindustrial”, en Rev. Historia Económica, nº 3, pp. 709-735.

PÉREZ MOREDA, V. (1987): "La modernización demográfica, 1800-1930. Sus limitaciones y cronologías", en SÁNCHEZ-ALBORNOZ, N. (comp.): La modernización económica de España. 1830-1930, Madrid, Alianza Universidad, pp. 25-62.

PÉREZ MOREDA, V. (1984): "Evolución de la población española desde finales del Antiguo Régimen”, en Papeles de Economía Española, nº 20, pp. 20-38. 
PÉREZ MOREDA, V. (1980): Las crisis de la mortalidad en la España interior, siglos XVIXIX, Madrid, Ed. Siglo XXI.

PÉREZ OLIVA, M. (2008): “La rebelión de las bacterias se cobra vidas”, en EL PAÍS, 326/11/08, pp. 32-33.

PÉREZ ORTÍZ, L. (2005): La estructura social de la vejez en España. Nuevas y viejas formas de envejecer, Madrid, IMSERSO.

PÉREZ ORTÍZ, L. (1995): Las necesidades de las personas mayores. Vejez, economía y sociedad, Madrid, IMSERSO.

PÉREZ PÉREZ, R.M.; BARDLET, N. y SOLER, N. (2006): "Diagnóstico de muerte y trasplante de órganos: Implicaciones jurídicas y medicolegales”, en Med Clin (Barc), 126(18), pp.707-711.

PERLS, T. Y FRETTS, R. (1998): Why woman live longer than men”, en Sci. Am. Press, Junio, pp. 100-107.

PERROW, CH. (1984): Normal Accidents: Living with High-Risk Technologies, Nueva York, Basic Books.

PICÓ LÓPEZ, J. (1998): "Postmodernismo, postmodernidad" voz en GINER, S.; LAMO DE ESPINOSA, E. Y TORRES, C. (eds.): Diccionario de Sociología, Madrid, Alianza, p. 590-592.

PINO ARTACHO, J. DEL y BERICAT ALASTUEY, E. (1998): Valores sociales en la cultura andaluza. Encuesta Mundial de Valores. Andalucía 1996, Madrid, CIS y Siglo XXI, colección "Monografías" n 156.

PNUD (2010): Informe sobre el Desarrollo Humano 2010, Madrid, Mundi-Prensa.

PNUD (2009): Informe sobre el Desarrollo Humano 2009, Madrid, Mundi-Prensa.

PNUD (1999): Informe sobre el Desarrollo Humano 1999, Madrid, Mundi-Prensa.

PNUD (1998): Desarrollo Humano en Chile 1998: las paradojas de la modernización, Santiago de Chile.

PNUD (1987): Consecuencias de las tendencias y diferenciales de la mortalidad, Nueva Cork, NU.

POLLARD, J.H. (1988): "On the Decomposition of Changes in Expectation of Life and Differentials in Life Expectancy”, en Demography, n 25, pp. 265-276.

PONCE DE LEÓN, O. (1997): El médico enfermo, Madrid, CIS.

POPULATION REFERENCE BUREAU (2002): Las mujeres de nuestro mundo 2002, Washington, Measure Communication.

PORTA, M.; PUIG, E. Y DOMENECH, F. (eds.) (2009): Nuestra contaminación interna. Concentraciones de compuestos tóxicos persistentes en la población española, Madrid, Los libros de la Catarata.

PRADES, J.A. (1998): “Creencia”, en GINER, S.; LAMO DE ESPINOSA, E. y TORRES, C. (eds.): Diccionario de Sociología, Madrid, Alianza, pp. 158-159. 
PRESSAT, R. (1987): Diccionario de Demografía, Barcelona, Oikus Tau.

PRESSAT, R. (dir.) (1985): Manuel d'analyse de la mortalité, París, INED.

PRESSAT, R. (1973): “Surmortalité biologique et surmortalité sociale”, en Revue Francaise de Sociologie, vol. 14, pp. 103-110.

PRESTON, S. H. (1976): Mortality Patterns in National Populations, Nueva York, Academic Press.

PRESTON, S. H. (1975): "The Changing Relation between Mortality and Level of Economic Development”, en Population Studies, vol. 29, pp. 231-248.

PRIOR, L. (1989): The Social Organisation of Death, Londres, Macmillan.

PUERTA LÓPEZ-CÓZAR, J.L. Y MAURI, A. (1995): "La pendiente resbaladiza en las decisiones médicas concernientes a la eutanasia”, en URRACA, S. (ed.): Eutanasia hoy. Un debate abierto, Madrid, Ed. NOESIS, PP. 183-203.

PUGA, M.D. (2002): Dependencia y necesidades asistenciales de los mayores en España, una previsión a 2010, Madrid, Ed. Pfizer.

PUGA, M.D. Y ABELLÁN, A. (2004): El proceso de discapacidad. Un análisis de la Encuesta sobre discapacidades, deficiencias y estado de salud, Alcobendas, Fundación Pfizer.

PUIGPELAR, F. (1998): Clonación y Dignidad humana, Texto para discusión de la Assocciació de Bioètica i Pret (20/20/98), documento electrónico www.ub.es/fildt/edc15.htm.

PULEO, A. (2000): Filosofía, género y pensamiento crítico, Valladolid, UVA.

QUINT BENOLIEL, J. Y DEGNER, L.F. (1995): "Institutional Dying: A Convergente of Cultural Values, Technology, and Social Organization”, en WASS, H. Y NEIMEYER, A. (eds.): Dying. Facing the Facts, Washington D.C., Taylor \& Francis, pp. 117-141.

QUINTANA, O. (1997): Por una muerte sin lágrimas. Problemas éticos al final de la vida, Barcelona, Flor del Viento.

RAMOS TORRE, R. (1999): "Prometeo y las flores del mal: el problema del riesgo en la sociología contemporánea”, en RAMOS TORRE, R. Y GARCÍA SELGAS, F. (eds.): Globalización, riesgo, reflexividad. Tres temas de la teoría social contemporánea, Madrid, CIS, PP. 249-274.

RAMOS TORRE, R. (1998): “Teorema de Thomas”, en GINER, S.; LAMO DE ESPINOSA, E. y TORRES, C. (eds.): Diccionario de Sociología, Madrid, Alianza, pp. 783.

RAMOS TORRE, R. (1990): Cronos dividido. Uso del tiempo y desigualdad entre hombres y mujeres en España, Madrid, Instituto de la Mujer.

RAMOS DELGADO, E. y BARRUECO, M. (1995): "Efectos de la contaminación atmosférica en la salud”, en Formación Médica Continuada en Atención Primaria, vol. 2, no 9, noviembre, Madrid, Sociedad Española de Medicina de Familia y comunitaria, pp. 505-514.

RAMOS, E. Y SÁNCHEZ, A. (2002): "Investigación, acción, participación (IAP) en la promoción de la salud de las mujeres”, en INSTITUTO DE LA MUJER: La salud de las 
mujeres: hacia la igualdad de género en salud. I Congreso Nacional, Madrid, Instituto de la Mujer, pp. 213-220.

REGIDOR, E.; GUTIÉRREZ-FISAC, J.L. Y ALFARO, M. (2011): Patrones de mortalidad en España, 2008, Madrid, M $^{\circ}$ de Sanidad, Política Social e Igualad.

REGIDOR, E.; GUTIÉRREZ-FISAC, J.L. Y ALFARO, M. (2009): Indicadores de salud 2009. Evolución de los indicadores de estado de salud en España y su magnitud en el contexto de la Unión Europea, Madrid, $\mathrm{M}^{\mathrm{o}}$ de Sanidad, Política Social.

REGIDOR, E.; GUTIÉRREZ-FISAC, J.L. Y RODRÍGUEZ, C. (1994): Diferencias y desigualdades en salud en España, Madrid, Díaz-Santos.

REHER, D-S. (2003): “Transformación demográfica y modernización de la sociedad española durante el siglo XX”, en SISTEMA, n 175-176, Tendencias demográficas, Madrid, Fundación Sistema, Septiembre, pp. 35-49.

REHER, D-S. (1996): La familia en España, pasado y presente, Madrid, Alianza Universidad.

REQUENA, M. (2008): “Religión y sociedad: la secularización de la sociedad española”, en GONZÁLEZ, J.J. y REQUENA, M. (eds.): Tres Décadas de Cambio Social en España, Madrid, Alianza, $2^{a}$ ed., cap.11.

REQUENA, M. (1992): "Secularización, clases de edad y generaciones. El caso de la sociedad española”, en MOYA, C.; PÉREZ AGOTE, A.; SALCEDO, J. y TEZANOS, J.F. (eds.): Escritos de teoría sociológica en homenaje a Luis Rodríguez Zúñiga, Madrid, CIS, pp. 9931018.

REQUENA, M. Y BENEDICTO, J. (1988): Relaciones interpersonales: actitudes y valores en la España de los ochenta, Madrid, C.I.S., Estudios y Encuestas n ${ }^{\circ} 11$.

RESÉNDEZ, L. (2007): "La muerte y Michel Vovelle como representante de la Historia de las Mentalidades a través de su obra Ideologies and Mentalities”, Comunicación presentada al Primer Congreso Internacional de Historia Social, Monterrey, Febrero.

RETHERFORD, R.D. (1975): The Changing Sex Differentials in Mortality, Westport, Greenwood Press.

RIBERA, J.M. (1982): Reflexiones sobre la propia muerte, Madrid, Mezquita.

RICE, F.P. (1997): Desarrollo Humano. Estudio del Ciclo Vital, Madrid, Prentice-Hall.

RIDLEY, M. (2000): Genoma. La autobiografía de una especie en 23 capítulos, Madrid, Taurus.

RIECHMANN, J. (2004): Gente que no quiere viajar a Marte. Ensayos sobre Ecología, Ética y Autolimitación, Madrid, Los Libros de la Catarata.

RIECHMANN, J. (2000): Un mundo vulnerable. Ensayos sobre Ecología, Ética y Tecnociencia, Madrid, Los Libros de la Catarata.

RIESMAN, D.; GLAZER, N. y DENNEY, R. (1981): La muchedumbre solitaria, Barcelona, Paidós Ibérica.

RIFKIN, J. (1996): El fin del trabajo, Barcelona, Paidós Ibérica. 
RILEY, J.W. Jr. (1979): "What People Think About Death?", en BRIM, O.G.; FREEMAN, H.E.; LEVINE, S. y SCOTCH (eds.): The Dying Patient, Nueva York, Russell Sage Foundation, pp.30-41.

RILEY, J.W. Jr. (1979a): “Muerte y duelo”, en SILLS, D.L. (dir.): Enciclopedia Internacional de las Ciencias Sociales, Madrid, Aguilar, vol.7, pp. 274-280.

RITZER, G. (1993): Teoría Sociológica Clásica, Madrid, McGraw-Hill.

ROBLES, E.; GARCÍA BENAVIDES, F. y BERNABEU MESTRE, J. (1996): "La Transición Sanitaria en España desde 1900 a 1990”, en Rev. Esp. Salud Pública, 70, pp.221-233.

ROBINE, J-M. (2001): “A new biodemographic model to explain the trajectory of mortality”, en Experimental Gerontology, vol. 36, Abril, pp. 899-914.

ROBINE, J-M. (2000a): "Prolongación de la vida de los seres humanos: longevidad y calidad de vida”, en Encuentro Latinoamericano y Caribeño sobre las Personas de Edad, Santiago, CELADE, Serie Seminarios y Conferencias, nº 2, LCIL.1399-P, pp. 135-170.

ROBINE, J-M. (2000b): “Freedom and quality of life”, editorial de Journal of Epidemiology and Community Health, vol. 54, Agosto, pp. 564.

ROBINE, J-M. Y MICHEL, J.P. (2004): "Looking forward to a general theory on population aging”, en Journal Gerontology A Biolo. Science Medi. Science, vol. 59(6), Junio, pp. 590-597.

ROBINE, J-M.; SAITO, Y. Y JAGGER, G. (2003): “The emergence of extremely old people: the case of Japan”, en Experimental Gerontology, vol. 38, Julio, pp. 735-739.

ROBINE, J-M.; COURNIL, A.; HENON, N. Y ALLARD, M. (2003a): "Have centenarians had younger parents than the others?”, en Experimental Gerontology, vol. 38, Julio, pp. 361-365.

ROBINE, J-M. Y VAUPEL, J.W. (2002): "Emergence of supercentenarians in Low-Mortality Countries”, en North American Actuarial Journal, vol. 6, Julio, pp. 54-63.

ROBINE, J-M. Y VAUPEL, J.W. (2001): "Supercentenarians: slower ageng individuals or senile elderly?”, en Experimental Gerontology, vol. 36, Abril, pp. 915-930.

ROBINE, J-M.; JAGGER, C. Y ROMIEU, I. (2001a): "Disability free life expectancies in the European Union countries: calculation and comparisons”, en Genus, LVII, n 2, pp.89-101.

ROBINE, J-M.; ROMIEU, I. Y CAMBOIS, E. (1999): “Indicadores de la esperanza de salud”, en Boletín de la Organización Mundial de la Salud. Recopilación de artículos, ${ }^{\circ} 1$, OMS, pp.106-110.

ROBINE, J-M. Y ROMIEU, I. (1998): "Healthy active: Healthy expectancies at age 65 in the different parts of world”, en REVES, Mayo, paper n 318.

ROBINE, J-M.; ROMIEU, I. Y LEE, M. (1998a): "Healthy Expectancies in OCDE countries”, en REVES, Abril, paper n ${ }^{\circ} 317$.

ROBINE, J-M.; ROMIEU, I.; JAGGER, C. Y EGIDI, V. (1998b): "Health expectation in the European Union. The European Community household panel: data analysis", en REVES, papers $\mathrm{n}^{\mathrm{o}} 320$. 
ROBINE, J-M.; ROMIEU, I.; CAMBOIS, E.; VANDEWATER, H.P.A.; BOSHUIZEN, H.C. Y JAGGER, C. (1995): "Global Assesment in Positive Health. Contribution of the Network on Health Expectancy and the Dissability Process to the World Health Report 1995”, en REVES, papers $\mathrm{n}^{\circ} 19$.

ROBINS, S.P. (1996): Comportamiento organizacional. Teoría y práctica, México, PrenticeHall Hispanoamericana S.A., $7^{\text {a }}$ ed.

ROBLES, E. (2010): El envejecimiento de la población: aspectos demográficos”, en GÓMEZ REDONDO, R. (DIR.): Salud, Demografía y Sociedad en la Población Anciana, Madrid, Alianza Editorial, pp. 39-56.

ROBLES, E.; GARCÍA BENAVIDES, F Y BERNABEU, J. (1996): "La transición sanitaria en España desde 1900 a 1990”, en Rev. Esp. Salud Pública, nº 70, pp.221-233.

ROCHE, J.A. (2005): “La construcción cultural de la realidad social en la Modernidad”, en Papers, $n^{\circ} 77$, pp. 11-42.

ROCHE, J.A. (2002): "El alejamiento de la realidad en la cultura, el arte y la sociedad modernas”, comunicación al VII Congreso de Sociología, Salamanca.

RODRÍGUEZ, P. (2002): Morir es nada. Cómo enfrentarse a la muerte y vivir en plenitud, Barcelona, Ediciones B.

RODRÍGUEZ, J. (1988): “El reparto del bienestar: salud y desigualdad social en España”, en SISTEMA, nº 83, Marzo.

RODRÍGUEZ, J. (1987): Salud y sociedad: Análisis sociológico de la estructura y la dinámica del sector sanitario español, Madrid, Tecnos.

RODRÍGUEZ, J. Y DE MIGUEL, J. (1990): Salud y poder, Madrid, C.I.S.

RODRÍGUEZ, J. Y GARCÍA, J.A. (1996): “Psicología social de la salud”, en ALVARO, J.L.; GARRIDO, A. Y TORREGROSA, J.R. (coords.): Psicología Social Aplicada, Madrid, McGraw-Hill, pp. 351-380.

RODRÍGUEZ DEL POZO, P. (1993): "La determinación de la muerte: historia de una incertidumbre”, en JANO, XLIV, pp. 71-77.

RODRÍGUEZ LÓPEZ, J. (2002): “La última lección”, en Archipiélago, n 51, pp. 111-113.

RODRÍGUEZ RIOBOO, F. (1993): La idea de la muerte en la sociedad española actual, Madrid, Universidad Complutense, Tesis doctoral.

ROGER CIRUANA, E. (1995): Edgar Morin. Introducción al pensamiento complejo, Valladolid, Tesis doctoral, Uva.

ROGERS, R.G. y HACKENBERG, R., (1987): "Extending Epidemiologic Transition Theory: A New Stage”, en Social Biology, vol. 34, n 3-4, pp. 234-243.

ROHLFS, J. (2002): "Desigualdades de género y salud”, en INSTITUTO DE LA MUJER: La salud de las mujeres: hacia la igualdad de género en salud. I Congreso Nacional, Madrid, Instituto de la Mujer, pp. 207-211. 
ROHLFS, J.; BORRELL, C.; ANITUA, C.; COLOMER, C.; ESCRIBÁ, V.; GARCÍACALVENTE, M.; LLACER, A. MAZARRASA, L.; PASARÍN, M.I.; PEIRÓ, R. y VALLS LLOBET, C. (2000): "La importancia de las perspectivas de género en las encuestas de salud", en Gaceta Sanitaria, 14(2), pp. 146-155.

ROKEACH, M. (1975): "Naturaleza de las actitudes”, en Enciclopedia Internacional de las Ciencias Sociales, Tomo I, Madrid, Aguilar, pp.15-29.

ROMEO CASABONA, C.M. (1996): "Tendencias legales sobre los transplantes de órganos", en GAFO, J. (ed.): Transplantes de órganos: problemas técnicos, éticos y legales, Madrid, Universidad Pontificia Comillas, pp. 101-136.

ROMERO CASABONA, C.M. (1993): "Estudio específico del problema de la muerte en el donante cadáver a la vista de las innovaciones científicas y tecnológicas ocurridas en las ciencias biomédicas”, en Revista General de Derecho, pp. 6127-6128.

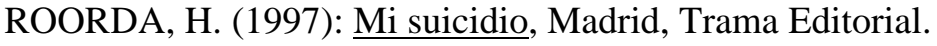

ROSE, M.R. (2000): “¿Podemos retardar el envejecimiento?”, en Investigación y Ciencia, Enero, pp. 60-65.

ROSE, M.R. (1997): “Toward and Evolutionary Demography”, en WACHTER, K.W. Y FINCH, C.E. (eds.): Between Zeus and the Salmon. The Biodemography of Longevity, Washington, National Academy Press, pp.96-107.

ROSEL, N. (1978): “Toward a Social Theory of Dying”, en OMEGA, vol9(1), pp. 49-55.

ROSENBERG, J.F. (1983): Thinking clearly about death, Nueva Jersey, Prentice hall, citado en (ARREGUI, 1992: 78-81).

ROSNAY, J. DE; SERVAN-SCHREIBER, J-L.; CLOSETS, F. DE Y SIMONNET, D. (2006): Una vida extra. La longevidad: un privilegio individual, una bomba colectiva, Barcelona, Anagrama.

ROTH, P. (2002): El animal moribundo, Madrid, Alfaguara.

RUBIO, A. (1983): "La muerte no es (la) sino (nos)", en Muerte, Ámbit Maria Corral d’investigació i difussió.

RUDIKOFF, S. (1981): “Los problemas de la euthanasia”, en FULTON, R. (ed.): La muerte y el morir, Puerto Rico, Fondo Educativo Interamericano Incorporado.

SÁDABA, J. (1991): Saber morir, Madrid, Ediciones Libertarias.

SAFRANSKI, R. (2004): ¿Cuánta globalización podemos soportar?, Barcelona, Tusquets.

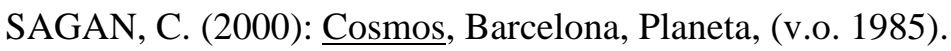

SALVÀ, A. Y RIVERO, A. (2007): Evolución del proceso de envejecimiento de la población española y análisis de sus determinantes, Madrid, Fundación Pfizer.

SAMPEDRO, J. (2002): “La mejor idea”, en EL PAÍS, Babelia, 12/01/02, p. 3.

SAMPEDRO, J. (2001): “Un salto evolutivo en el darwinismo”, en EL PAÍS, 14/03/01, p. 31. 
SAMPEDRO, R. (1998): Cartas desde el infierno, Barcelona, Planeta.

SÁNCHEZ MORALES, M.R. (2001): “Biogenética y Sociedad”, en RODRÍGUEZ CAAMAÑO, M.J.: Temas de Sociología II, Madrid, Huerga y Fierro editores, pp. 443-468.

SANTOW, G. (1999): "The mortality, epidemiological and health transitions: their relevance for the study of health and mortality”, en N.U. y OMS: Health and Mortality Issues of Global Concern, Nueva York, NU, pp.39-53.

SARTRE, J.P. (1976): El ser y la nada, Buenos Aires, Losada.

SAU, V. (1990): Diccionario ideológico feminista, Barcelona, ICARIA.

SAVATER, F. (2007): La vida eterna, Madrid, Ariel.

SAVATER, F. (1999): "La muerte antropomorfa”, en CLAVES de Razón Práctica, n 100, pp. 10-12.

SCHOFIELD, R. y REHER, D. (1991): “The decline of mortality in Europe”, en SCHOFIELD, R.; REHER, D. y BIDEAU, A. (eds.): The Decline of Mortality in Europe, Oxford, Clarendon Press, pp. 1-17.

SCHOPENHAUER, A. (1976): El mundo como voluntad y representación. Antología, Barcelona, Labor.

SCHOPF, W. (2002): “La evolución en 24 horas”, en EL CULTURAL, 17/10/02, pp.56.

SEALE, C.F. (1998): Constructing Death. The sociology of Dying and Bereavement, Cambridge, Cambridge University Press.

SEALE, C.F. Y CARTWRIGHT, A. (1994): The year before Death, Aldershot, Avebury.

SEALE, C.F. Y CARTWRIGHT, A. (1990): The Natural History of a Survey: An Account of the Methodological Encountered in a Study of Life Before Death, Londres, Kings Fund.

SEELY, S. (1990): “The gender gap: why do women live longer than men?”, en International Journal of Cardiology, vol. 29(2), pp. 113-119, citado en (Vallin, 2006:178).

SEGURA, A. (2004): "Demografía y Salud”, en LEAL MALDONADO, J. (coord.): Informe sobre la situación demográfica en España, Madrid, Fundación Fernando Abril Martorell, pps. 298-314.

SEMPERE, J. y RIECHMANN, J. (2000): Sociología y medio ambiente, Madrid, Síntesis.

SEN, A. (1998): "Mortality as an Indicator of Economic Succeses and Failure", en The Economic Journal, vol. 108, nº446, Enero, pp. 1-25.

SEN, A. (1995): Nuevo examen de la desigualdad, Madrid Alianza.

SEN, A. (1993): "La vida y la muerte como indicadores económicos", en Investigación y Ciencia, Julio, pp. 6-13.

SEN, A. (1989): "More than a 100 million women are missing”, en New York Review of Books, Dic., pp. 61-66. 
SEN, A. (1981): Poverty and Famines: An Essay on Entitlement and Deprivation, Oxford, Clarendon Press.

SENNETT, R. (2000): La corrosión del carácter, Barcelona, Anagrama.

SESPAS (2000): Informe SESPAS 2000: La salud pública ante los desafíos de un nuevo siglo, Granada, Escuela Andaluza de Salud Pública. Accesible en http://www.sespas.es/ind_lib04.html

SERRANO RUÍZ-CALDERÓN, J. M. (2001): Eutanasia y vida dependiente, Madrid, Ediciones Internacionales Universitarias.

SETHI, D. y ZWI, A. (1999): “Accidents and other injuries”, en N.U. y OMS: Health and Mortality Issues of Global Concern,..., pp.412-441.

SHANN, F. (1991): "The cortically dead infant who breathes”, en SANDERS, K. Y MOORE, B. (comps.): Anencephalics, Infants and Brain Death Treatment Options and the Issue of Organ Donation, Melbourne, Law Reform Commission of Victoria.

SHIBLES, J.W. (1974): Death. An interdisciplinary analysis, Wisconsin, The Language Press.

SHIVA, V. (2001): Biopiratería. El saqueo de la naturaleza y el conocimiento, Barcelona, Icaria.

SHREENIWASS, S. (1994): “La población en su contexto social”, en R.I.C.S., n 140, pp. 295314.

SIMMEL, G. (2001): El individuo y la libertad, Barcelona, Península (v.o. 1917).

SIMÓN, P. (2004): "El consentimiento informado; alianza y contrato, deliberación y decisión”, en COUCEIRO, A. (ed.) (2004): Ética en cuidados paliativos, Madrid, Triacastela, pp. 79-108.

SINGER, P. (2002): Una vida ética. Escritos, Madrid, Taurus.

SINGER, P. (1997): Repensar la vida y la muerte. El derrumbe de nuestra ética tradicional, Barcelona, Paidós.

SINGER, P. (1984): Ética práctica, Barcelona, Ariel.

SMITH, E.R. Y MACKIE, D.M. (1997): Psicología Social, Ed. Médica Panamericana.

SOLÉ, C. (dir.): (1998): Medio Ambiente: Prevención y Control de Residuos Sólidos Urbanos, Bilbao, Fundación BBV.

SOLÉ, C. (1990): Nuevas Tecnologías y Modernización, Barcelona, Oikos-Tau.

SONTAG, S. (1989): El SIDA y sus metáforas, Barcelona, Muchnick Editores.

SONTAG, S. (1984): La enfermedad y sus metáforas, Barcelona, Muchnik Editores.

SOTTO, A. Y OBERTO, V. (1986): Más allá de la muerte, Madrid, edad.

SPECTOR, R.E. (2003): Las culturas de la salud, Madrid, Prenctice may.

STOETZEL, J. (1946): “Sociologie et Demographie”, en Population, INED, nº 1, pp.79-89. 
SUDNOW, D. (1971): La organización social de la muerte, Buenos Aires, Ed. Tiempo Contemporáneo.

SUNYER, J.; KOGEVINAS, M. y ANTÓ, J.M. (2002): “Medio Ambiente y Salud”, en Informe SESPAS 2002: Invertir en salud. Prioridades para la salud pública y los servicios sanitarios, Granada, Escuela Andaluza de Salud Pública, pp. 209-224.

SUTCLIFFE, B. (1999): “Desarrollo Humano y muerte”, ponencia presentada en el Congreso "Análisis de 10 años de desarrollo humano. Límites y potencialidades para una estrategia de desarrollo”, Bilbao, 18-20 Febrero.

SÜSKIND, Patrick (2006): Sobre el amor y la muerte, Barcelona, Seix Barral.

SZASZ, T. (1991): “El pleito contra la prevención del suicidio”, en Claves de Razón Práctica, $\mathrm{n}^{\mathrm{o}} 14$, pp. $74-80$.

TAPIA GRANADOS, J.A. (2011): "La mejora de la salud durante las crisis económicas: un fenómeno contraintuitivo", en Papeles de relaciones ecosociales y cambio global, $n^{\circ} 113$, pp. 121-137.

TAPIA GRANADOS, J.A. (2007): "Salud, economía y libertad: 40 años de crecimiento económico, transición política y condiciones de salud en España”, en Medicina Cínica, no 128 (12), pp. 463-467.

TAPIA GRANADOS, J.A. (2005): "Economía y Mortalidad en las Ciencias Sociales: del Renacimiento a las Ideas sobre la Transición Demográfica”, en SALUD COLECTIVA 1 (3), Buenos Aires, pp. 285-308.

TARONGÍ, S.; BARCELÓ, M.I.; BARCELÓ, A. y MOLINA, F.J. (2003): “Muerte encefálica y donación de órganos: Revisión a la luz de la legislación española”, en Revista de Neurología, vol. 36, no 8 , pp.771-780.

TERCEIRO, J.B. (1996): Sociedad digital, Madrid, Alianza.

TEZANOS, J.F. (2006): La explicación sociológica: una introducción a al Sociología, Madrid, UNED.

TEZANOS, J.F. (2003): “Tendencias y previsiones en innovación cinético-tecnológica y sus impactos sociales”, en TEZANOS, J.F.; TORTOSA, J.M. y ALAMINOS, A.: Tendencias en desvertebración social y en políticas de solidaridad. Sexto Foro sobre Tendencias Sociales, Madrid, Sistema, pp. 301-333.

TEZANOS, J.F. (2001): La sociedad dividida. Estructura de clases y desigualdades en las sociedades tecnológicas, Madrid, Biblioteca Nueva.

THOMAS, L.V. (1992):”Actitudes colectivas hacia los ancianos: problema de civilización”, en VV.AA.: La cuestión del envejecimiento. Perspectivas psicoanalíticas, Madrid, Biblioteca Nueva, pp.133-173.

THOMAS, L.V. (1991): La muerte. Una lectura cultural, Barcelona, Paidos Ibérica.

THOMAS, L.V. (1985): Rites de mort, París, Fayard.

THOMAS, L.V. (1983): Antropología de la muerte, México, F.C.E. 
THORSON, J.A. y POWELL, F.C. (1997): “Escala Revisada de Ansiedad ante la Muerte”, en NEIMEYER (comp.), pp.45-56.

TIPLER, F.J. (1996): La física de la inmortalidad, Madrid, Alianza.

TIZÓN, J.L. (2004): Pérdida, pena y duelo. Vivencias, investigación y asistencia, Barcelona, Paidós.

TOCQUEVILLE, A. (1984): La democracia en América, vol. II, Madrid, SARPE (v.o. 1835).

TOHARIA, J.J. (1989): La mitad de la explosión, Madrid, Fundación Banco Exterior.

TOLSTOI, L. (1981): La muerte de Iván Ilich, Barcelona, Bruguera.

TÖNNIES, F. (1979): Comunidad y asociación, Barcelona, Península.

TORMER, A. (1997): "La ansiedad ante la muerte en la vida adulta: perspectivas teóricas”, en NEIMEYER (comp.)(1997), pp.19-42.

TORNOS, A. (1990): “Sobre antropología de la muerte”, en GAFO, J. (ed.): La eutanasia y el arte de morir, Madrid, U.P.C., pp. 33-45.

TORTELLA, G. (1994): El desarrollo de la España contemporánea. Historia económica de los siglos XIX y XX, Madrid, Alianza.

TOYNBEE, A. (1989): "El interés del hombre en la vida después de la muerte”, en TOYNBEE, A.; KOESTLER, A. et al: La vida después de la muerte. COMPLETAR

TOURAINE, A. (2006): Crítica a la modernidad, México, FCE.

TOURAINE, A. (1971): La sociedad postindustrial, Barcelona, Ariel.

TREAS, J. (1999): “Older Americans in the 1990s and Beyond”, en DICKINSON, G.E.; LEMMING, M.R. y MERHANN: Dying, Death and Bereavement,., pp. 71-80.

TRUEBA, J.L. (2007): “La muerte clínica: un diagnóstico y un testimonio”, en An. Sist. Sanit. Navar., vol. 30, Suplemento 3, pp.57-70.

TRUOG, R.D. (1999): “Is it Time to Abandon Brain Death?”, en DICKINSON, G.E.; LEMING, M.R. Y MERMANN (eds.): Dying, Death, and Bereavement, McGraw-Hill, pp. 4451.

TURNER, B.S. (1989): El cuerpo y la sociedad. Exploraciones en teoría social, México, F.C.E.

UGALDE, A.C. (1983): "Sociología de la salud y sociedad post-industrial”, en EUSKO JAURLARITZA: Sociología de la salud, Primeras Jornadas, Vitoria, Servicio Central de Publicaciones del Gobierno Vasco, pp. 57-73.

URRACA, S. (ed.) (1995): Eutanasia hoy. Un debate abierto, Madrid, NOESIS.

URRACA, S. (1995a): “Introducción”, en Eutanasia hoy. Un debate abierto, Madrid, NOESIS, pp. 27-40. 
URRACA, S. (1995b): "Eutanasia: concepto y contexto”, en Eutanasia hoy. Un debate abierto, Madrid, NOESIS, pp. 43-66.

URRACA, S. (1982): Actitudes Ante la muerte (preocupación, ansiedad, temor) y religiosidad, Madrid, U.C.M., Tesis Doctoral.

URREIZTIETA, M.T. (2004): “La sociología interpretativa: globalización y vida cotidiana”, en Espacio Abierto. Cuaderno venezolano de Sociología, vol. 13, nº 3, pp. 457-470.

VAIL, C. (1974): “Los problemas de la Muerte”, en VV.AA.: Sociología de la Muerte, Madrid, Tribuna Médica, pp.

VALENT, M. (1999): "Eutanasia: el <<suicidio asistido>> de Occidente”, en ARBIL, $\mathrm{n}^{0}$ 57, www.muertedigna.org/textos/euta623.htm.

VALLIN, J. (2006): “Mortality, Sex, and Gender”, en Demography. Analysis and Synthesis, vol. 2, cap. 53, pp. 177-194.

VALLIN, J. (1995a): La población mundial, Madrid, Alianza Universidad.

VALLIN, J. (1995b): La demografía, Madrid, Alianza Universidad.

VALLIN, J. (1995c): “Espérance de vie: quelle quantité pour quelle qualité de vie?”, París, CEPED \& INED.

VALLIN, J. (1995d): “Evolution de la mortalité: hypothése pour les annes futures”, en Risques, $\mathrm{n}^{\circ}$ 5, pp. $15-36$.

VALLIN, J. (1988): Évolution sociale et baisse de la mortalité : conquete on reconquête d'un avantage féminin, París, INED, Dossiers et Recherches, $\mathrm{n}^{\circ} 17$.

VALLIN, J. (1985): “La mortalité différentielle”, en PRESSAT, R.: Manuel d'analyse de la mortalité, París, INED, pp. 61-97.

VALLIN, J. Y BERLINGUER, G. (2006): "From Endogenous Mortality to the Maximum Human Life Span”, en Demography. Analysis and Synthesis, vol. 2, cap. 48, pp. 95-115.

VALLS LLOBET, C. (2002): Promoción de la salud desde la perspectiva de género”, en INSTITUTO DE LA MUJER: La salud de las mujeres: hacia la igualdad de género en salud. I Congreso Nacional, Madrid, Instituto de la Mujer, pp. 199-205.

VALLS LLOBET, C. (2001): “Desigualdades de género en salud pública”, en INSTITUTO DE LA MUJER: Género y salud. I Jornadas de la red de médicos y profesionales de la salud, Madrid, Instituto de la Mujer, Documentos no 30, pp. 15-21.

VAN DE KAA, D.J. (1987): “Europe`s Second Demographic Transition”, en Population Bulletin, vol. 42, $\mathrm{n}^{\circ}$ 1, Nueva York.

VAQUERO, J.L. (1992): Manual de Medicina Preventiva y Salud Pública, Madrid, Pirámide.

VAUPEL, J.M. (1997): “Trajectories of Mortality at Advanced Ages”, en WACHTER, K.W. Y FINCH, C.E. (eds.): Between Zeus and the Salmon. The Biodemography of Longevity, Washington, National Academy Press, pp.17-36.

VAUPEL, J.M.; CAREY, J.R.; LIEDO, P. Y OROZCO, D. (1992): "Slowing of mortality rates at older ages in lage medfly cohorts”, en Science, Oct 16; 258(5081), pp. 457-61. 
VEATCH, R.M. (1995): “The Definition of Death: Problems for Public Policy”, en WASS, H. Y NEIMEYER, R.A. (eds.): Dying: Facing the Facts, Londres, Taylor \& francis, $3^{\mathrm{a}}$ ed., pp. 405432.

VEATCH, R.M. (1989): Death, Dying, and the Biological Revolution, Yale University Press.

VERA BOLAÑOS, M. (2000): "Revisión crítica de la teoría de la transición epidemiológica”, en Papeles de POBLACIÓN, nº 25, CIEAP/UAEM.

VERBRUGGE, L.M. (1989): "The twain meet: Empirical explantions of sex diferences in health and mortality”, en Journal of Health and Social Behaviour, vol. 30, pp. 282-304.

VERBRUGGE, L.M. (1985): “Gender and Health: An Update on Hypotheses and Evidence” en Journal of Health and Social Behaviour, vol. 26, pp. 156-182.

VERBRUGGE, L.M. (1976): "Females and Ilness: recent trends in sex diferences in the United States”, en Journal of Health and Social Behaviour, vo. 17, pp. 387-403.

VICIANA, F. (2003): "Mortalidad”, en ARROYO, A. (coord.): Tendencias demográficas durante el siglo XX en España, Madrid, INE, pp. 78-118.

VICIANA, F.; GARCÍA GIL, C.; FERNÁNDEZ CORDÓN, J.A. (1999): Divergencias regionales de mortalidad en el fin de siglo. El caso de Andalucía, Instituto Andaluz de Salud, documento electrónico, 14 pp.

VICIANA, F. (1998): La transición demográfica y sanitaria en Andalucía en el siglo XX, Tesis doctoral, Departamento de Ciencias Sociosanitarias, Universidad de Sevilla.

VILA-MATAS, E. (2007): Exploradores del abismo, Barcelona, Anagrama.

VILLALVÍ, J.R. (2002): “El tabaco como problema de Salud Pública”, en Informe SESPAS 2002: Invertir en salud. Prioridades para la salud pública y los servicios sanitarios, Granada, Escuela Andaluza de Salud Pública, pp. 113-129.

VILLALÓN OGÁYAR, J.J. (2002): “Las identidades sociales básicas de los españoles-2010”, en TEZANOS, J.F. (ed.): Clase, estatus y poder en las sociedades emergentes. Quinto Foro sobre Tendencias Sociales, Madrid, Sistema, pp.401-421.

VILLAR, F. Y BANEGAS, J.R. (2000): "Objetivo 9: Reducir las enfermedades cardiovasculares”, en ÁLVAREZ, C Y PEIRÓ, S. (eds.): Informe SESPAS 2000: La salud pública ante los desafíos de un nuevo siglo, Granada, Escuela Andaluza de Salud Pública.

VISAUTA, B. (1998): Análisis estadístico con SPSS para Windows. Tomo I, Estadística básica. Tomo II, Estadística multivariante, Madrid, McGraw-Hill.

VOLK, T. (2011): Muerte, Barcelona, Kairós.

VOVELLE, M. (1985): Ideologías y mentalidades, Barcelona, Ariel.

VV.AA. (2008): Observatorio DKV de Salud y Medio Ambiente en España 2008. Alimentación, medio ambiente y salud, Madrid, DKV Seguros.

VV.AA. (2000): La muerte. Una antología, Madrid, Valdemar. 
VV.AA. (1986): La pulsion de mort, París, PUF.

VV.AA. (1974): Sociología de la Muerte, Madrid, Tribuna Médica.

WACHTER, K.W. (1997): "Between Zeus and the Salmon: Introduction” en_WACHTER, K.W. Y FINCH, C.E. (eds.): Between Zeus and the Salmon. The Biodemography of Longevity, Washington, National Academy Press, pp.1-16.

WACHTER, K.W. Y FINCH, C.E. (eds.) (1997): Between Zeus and the Salmon. The Biodemography of Longevity, Washington, National Academy Press.

WALDRON, I. (1983): "Sex differences in human mortality: the role of genetic factors", en Soc. Sci. Med., vol 17, nº 6, pp. 321-333.

WALDRON, I. (1976): “Why do women live longer than men?”, en Soc. Sci. Med., vol 10, pp.349-362.

WALFORD, R. (1983): Maximum Life Span, Nueva York, W.W. Norton and Company.

WALTER, T.; LITTLEWOOD, J. Y PICKERING, M. (1995): “Death In The News: The Public Invigilation of Private Emotion”, en SOCIOLOGY, vol. 29, nº 4, pp. 579-595.

WALTER, T. (1994): The Revival of Death, Londres, Routledge.

WALTER, T. (1993): “Sociologists Never Die. British Sociology and Death”, en CLARK, D. (ed.): The Sociology of Death, Oxford, Blackwell.

WALTER, T. (1992): “Modern Death: Taboo or not Taboo?”, en SOCIOLOGY, vol. 25, n 2, pp. 293-310.

WASS, H. y NEIMEYER, R.A. (eds.) (1995): Dying. Facing the Facts, Washington, Taylor \& Francis.

WATSON, J.D. Y BERRY, A. (2003): AND. El secreto de la vida, Madrid, Taurus.

WEBER, M. (1998): El político y el científico, Madrid, Alianza, (v.o. 1918).

WELZER, H. (2010): Guerras climáticas. Por qué mataremos (y nos matarán) en el siglo XXI, Madrid, Katz Editores.

WICK, G.; BERGER, P.; JANASEN-DÜRR, P. Y GRUBECK-LOEBENSTEIN, B. (2002): “A Darwinian-evolutionary concept of age-related diseases”, en Experimental Gerontology, $\mathrm{n}^{\circ}$ 38, pp. 13-25.

WILBER, K. (1995): Gracia y coraje, Madrid, GAIA.

WILMOTH (1997): "In search of Limits", en WACHTER, K.W. Y FINCH, C.E. (eds.): Between Zeus and the Salmon. The Biodemography of Longevity, Washington, National Academy Press, pp. 38-64.

WILLIAMS, R. (1975): “Concepto de Valores”, en Enciclopedia Internacional de las Ciencias Sociales, Madrid, Aguilar, pp. 607-610. 
WONG, P.T.P.; REKER, G.T. y GESSER, G. (1997): "Perfil revisado de Actitudes hacia la Muerte: Un instrumento de medida multidimensional", en NEIMEYER, R.A. (comp.): Métodos de evaluación de la ansiedad ante la muerte, Barcelona, Paidós, pp. 131-158

WRIGLEY, E.A. (1985): Historia y población. Introducción a la demografía histórica, Barcelona, Crítica.

YOURCENAR, M. (1983): Memorias de Adriano, Barcelona, Edhasa.

YOUNGER, S.J. (1992): “Definition Death: A Superficial and Fragile Consensus”, en $\underline{\text { Archives }}$ of Neurology, $\mathrm{n}^{\circ}$ 49, pp. 570-572.

ZARRANZ, J.J. (1994): “Propuesta de una ley única de declaración de muerte”, en Quadern Caps, 20.

ZAMORA, F. (2003): “¿Quién teme al envejecimiento?”, en SISTEMA, n 175-176, Madrid, pp. 201-214.

ZAMORA, F. (1997): “El futuro de la población española”, en PUYOL, R. (ed.): Dinámica de la población en España, Madrid, Síntesis, pp. 378-381.

ZIEGLER, J. (2006): El imperio de la vergüenza, Madrid, Taurus.

ZIEGLER, J. (1976): Los vivos y los muertos, Madrid, Siglo XXI.

ZOIDO, F. Y ARROYO, A. (2003): “La población en España”, en INE: Tendencias demográficas durante el siglo XX en España, Madrid, INE, pps. 19-75. 



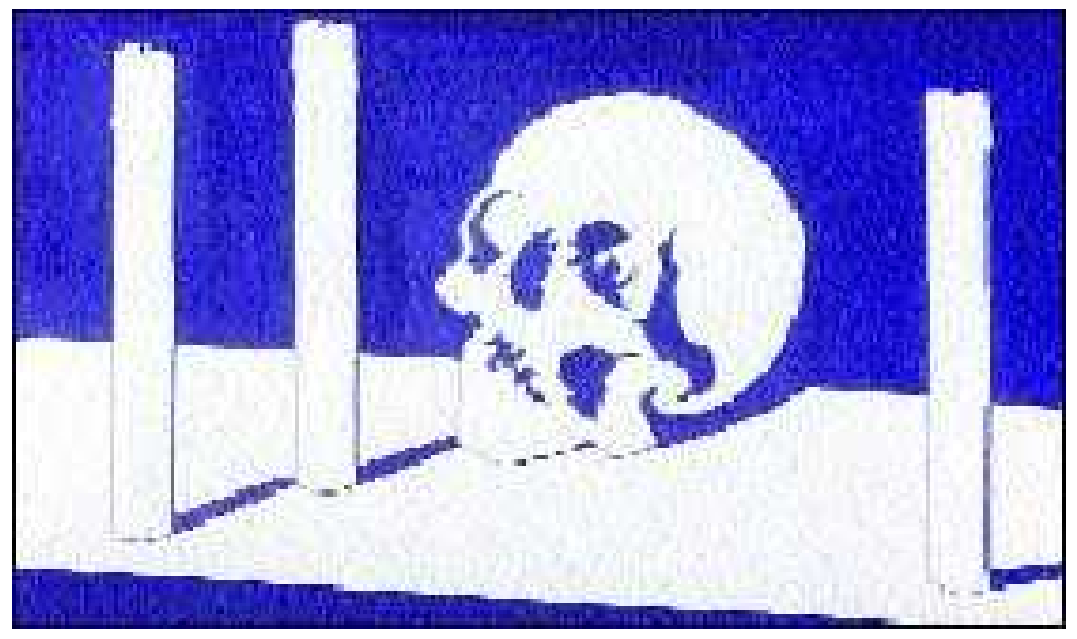

Crâne et bougies (Luis Fernández, 1966) 